

\section{Gesammelte Schriften}

von

\section{Ernst Troeltsch}

Dr theol, phil, jur.

Erster Band

\section{Die Soziallehren der christlichen Kirchen und Gruppen}

Dritte, photo-mechanisch gedruckte Auflage

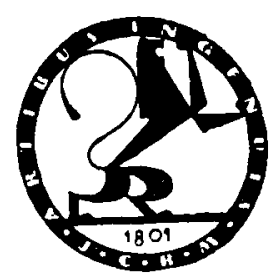

Tübingen

Verlag von J. C. B. Mohr (l'aul Siebeck)

1923 


\section{Die Soziallehren}

\section{der christlichen Kirchen}

\section{und Gruppen}

von

\section{Ernst Troeltsch}

Dr theol, phil, jur.

Dritte, photo-mechanisch (gedruckte Auflage

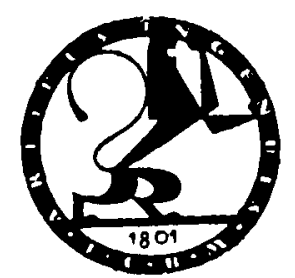

Tübingen

Verlag von J. C. B. M o hr (Paul Sicbeck) 
Whe limlutung, sowie die Kapitel I-III 2 sind ein veränderter Abdruck aus den linden 26-30 des s Archivs für Sozialwissenschaft und Sozialpolitik «.

Copyright 1912 by J. C. B. Mohr (Paul Siebeck), Tübingen.

Alle Rechte vorbehalten.

Druck von Omnitypie-Ges., Nachfl. L. Zechnall, Stuttgart. 
Der hohen philosophischen Fakultät

$$
\text { zu Greifswald }
$$

\author{
und \\ Der hohen juristischen Fakultät \\ zu Breslau
}

in tiefster Dankbarkeit und Ehrerbietung gewilmet. 



\section{Vorwort.}

Eigenen und fremden Wünschen folgend sammle ich hiermit meine zerstreuten Untersuchungen. Meine bisherige Arbeit hat - abgesehen von der großen Darstellung des Protestantismus in der Kultur der Gegenwart - in monographischen, methodischen und skizzierenden Untersuchungen bestanden, die sich über sehr verschiedene Stoffe erstreckten. Indem sie nun hier gesammelt zu Tage treten, wird sich zeigen, daß sie trotz aller scheinbaren Zersplitterung doch einem einheitlichen Plane entspringen. Darüber seien hier ein paar Worte gesagt.

Der Zusammenhang ist leicht erkennbar. In der Schule Ritschls ausgebildet, empfand ich frühzeitig, daß in der eindrucksvollen Lehre dieses energischen und großen Gelehrten zweierlei verbunden war: eine bestimmte Auffassung der dogmatischen Ueberlieferung, vermöge deren sie den modernen Bedürfnissen und Fragestellungen entgegen kam, und eine ebenso bestimmte Auffassung der modernen geistigen und religiösen Lage, vermöge deren diese zur Aufnahme und Fortsetzung der in Ritschls Sinn verstandenen Tradition befähigt schien. Daraus entstand naturgemäß die Frage, ob mit jenem ersten die dogmatische Tradition in ihrem eigentlichen historischen Sinn getreu verstanden und ob in jenem zweiten die gegenwärtige Lage in ihrer wirklichen Verfassung ergriffen sei. Da wurde klar, daß hier von beiden Seiten her Angleichungen vollzogen waren, die der Sachlage nicht entsprachen und die den wirklichen Gegensatz nicht voll zur Geltung kommen ließen. So ergab sich für mich naturgemäß die doppelte Aufgabe, die kirchlich-dogmatische Tradition des Protestantismus in ihrem eigenen historischen Sinn und die geistig-praktische Lage der Gegenwart in ihren wahren Grundbestrebungen mir deutlich zu machen. Daraus entstand die Doppelseitigkeit meiner Untersuchungen, die Analyse des Altprotestantismus und die Analyse 
der modernen Welt. Freilich sollte all das nur der Lösung der systumatischen Aufgabe dienen, nun selbständis mit rückhaltloserem Eingehen auf die moderne Welt die christliche Ileen- und Lebenswelt zu durchdenken und zu formulieren. Das führte zu methodologischen und religionsphilosophischen Untersuchungen, auf denen sich erst cine christliche Glaubens- und Lebenslehre erbauen kann. Je mehr ich aber hicrbei gerade auf die modernen Problemstellungen einging, um so mehr verschab sich mir das Schwergewicht nach der Seite der Ethik. Ist das Christentum vor allem Praxis, so liegen seine Hauptfragen auf praktischem Gebiet, und eben aus diesem erheben sich heute die allerschwierigsten Verwickelungen und Gegensätze segen die christliche Lebenswelt. Insbesondere gegenüber den Anforderungen der heutigen Sozialethik ist die Ethik der Kirchen veraltet. Ging ich aber dem weiter nach, so kam ich auf die Frage, wic denn ein derartig neu sich bildender Begriff der christlichen Lebenswelt zu ihren alten Organisationen, den Kirchen, sich verhalte, ob sich eine solche neue Erfassung überhaupt auf die alten (Orsanisationen aufpfropfen lasse, und wenn nicht, welche Möglichkeit der Gemeinschaftsbildung und des Anschlusses eine solche Neubilcluns überhaupt habe.

Aus diesen Erwägungen gingen die Lntersuchungen hervor, die in diesem ersten Bande vreinigt sind. Sie gewannen leicht ein Einheitsband, wenn auf die gesamte Geschichte des Christentums überhaupt die soziologische liragestellung übertragen wurdc. Sie erleuchtete mit Einem Bicdcutung und Wesen der religiösen Gemeinschaftsbildungen, die Grundzüge des christlichen Ethos in seinem Verhältnis zu den ethischen Problemen und Aufgaben des außerreligiösen Lebens und die innere Bezichung jeder dogmatischen Gedankenbildung auf einen ihr vorschwebenden Gemeinschaftskreis. Leberdies entstand damit zugleich eine eigentümliche Auffassung vom Wesen des Christentums, seiner Geschichte und seinen Beziehungen auf die allsemeine Kulturgeschichte, damit ein Fortschritt in meiner Gesamtbegründung der theologischen Aufgabe überhaupt. Die Ergebnisse sind in der Schlußabhandlung zusammengefaßt. Sie sind wirkliche Frgebnisse, die aus der Untersuchung herausspringen, nicht Thesen, zu deren Erweis das Buch geschrieben worden wäre. IJarum stehen sie auch am Schluß und nicht am Anfang. Doch kann der Leser die Sache sich erleichtern durch Vorwegnahme des Schlusses, wenn er nicht lieber selber 
aus dem ausgebreiteten Sachzusammenhang sich die Folgerungen crwachsen zu lassen vorzieht.

I)as l3uch ist nun freilich mit seinen ungefähr 1000 Seiten recht massiv geworden. Insbesondere erforderte der Text eine hüchst umfangreiche Unterkellerung durch Anmerkungen. Das ließ sich nicht ändern, wenn ich moine Begründungen vorlegen und dic Auseinandersetzung mit der bisherigen fiorschung vollziehen wollte. Ungefähr zwei Drittel waren bereits im Archiv für Sozialwissenschaft und Sozialpolitik veröffentlicht, die Kapitel über Calvinismus, Sektentypus und Mystik sind vïlligr neu hinzugekommen. Die vorauserehenden Kapitel wurden nach der Veröffentlichungr im Archiv noch einmal überarbeitet und crweitert, dann aber aus dem Satz genommen. l)araus erklärt sich, daß einige neueste literarische Erscheinungen nicht mehr verwertet sind.

Fin Lmstand tröstet mich über die Dicklcibigkeit dieses Bandes, der Umstand, daß er dadurch imstande ist, die Last und Weihe ciner Doppclwidmung zu tragen. Die philosophische Fakultät zu Greifswald hat mir im Jahre 1903 bei Gelegenheit ihrer Jubelfeier die hohe Ehre erwiesen, mich zum Doctor philosophiac honoris causa zu promovicren. Die Ehre bezog sich in erster Linie auf meine damals soeben crschiencne Gesamtdarstellung des Protestantismus. Im laufenclen Jahre I9I I hat mir dic juristische lakultät zu Breslau aus Anlaß ihrer Zentennarfeier die Würde eines Ioctor juris honoris causa übertragen. Die Begründung bezog sich wesentlich auf den bereits im Archiv veröffentlichten Teil dieses Buches. Da. nun aber dieses vorliegende Buch mit dem erstcn sich nahe berührt und zu vielen seiner Sätze erst die eingehenden Beweise liefert, so darf ich für das Wagnis der Doppelwidmung mich außer der stofflichen S.chwere dieses Buches auch auf die Einheitlichkeit der Beziehungen berufen, welche beide Promotionen zu seinem geistigen Inhalt haben.

Es ist nicht $\mathrm{zu}$ leugnen und ist auch durch diese beiden Promotionen mittelbar angedcutet, daß meine Arbeit keine besonderen theologischen, insbesondere keine christlichen, Methoden der Forschung anerkennt. Allein ich bin gewiß und sehe es auch durch diese Arbeit als bezeugt an, daß dabei die christliche Lebenswelt an Größc und innerer Bedeutung nichts verliert.

$\mathrm{Heidelberg,} \mathrm{I.} \mathrm{November} \mathrm{IgII.}$

Ernst Troeltsch. 
. 


\section{Inhaltsübersicht.}

\section{EINLEITUNG UND METHODISCHE VORFRAGEN.}

Ausgangspunkt von den sozialethischen Fragen der Gegenwart I-4. Begriff der soziologischen Selbstgestaltung des Christentums 4-6. Begriff der profanen sozialen Bildungen 6-9. Herstellung eines beide überwölbenden und irgendwie von der religiösen Idee bestimmten soziologischen Grundschemas 9-10. Stellung der religiösen Ethik zu den sozialen Hauptbildungen des Staates, der Familie, der Wirtschaft innerhalb dieses Grundschemas 10-14. Gewinnung der Kategorien für den Stoff aus diesen Erörterungen I4-I 5 .

\section{KAPITEL.}

\section{DIE GRUNDLAGEN IN DER ALTEN KIRCHE.}

I. DAS EVA NGELIUM.

Unabhängigkeit des ältesten Christentums von allen direkten Einflüssen der sozialen Bewegungen der Spätantike und der Kaiserzeit I6-25. Hervorgang aus der religiösen Gesamtbewegung der Spätantike 25-29. Mittelbarer Zusammenhang mit der Sozialgeschichte 29-33.

Der ethische Grundgedanke der Predigt Jesu 34-38. Soziologischer Charakter und Bedeutung dieser Grundgedanken 39-45. Stellung zu den sozialen Werten des Staates, der Wirtschaft, der Familie, der Gesellschaft 45-52.

Religiöse und soziologische Parallelbildung in der Stoa $52-58$.

2. PAULUS.

Die Entstehung einer neuen Kultgemeinde und soziologische Wirkung dieses Vorgangs 54-6o. Entwickelung eines soziologischen Grundschemas von der Kirche her; Gleichheit und Ungleichheit; Patriarchalismus 60-69. Stellung zu Familie, Staat, Gesellschaft, Wirtschaft $69-72$. Konservative und revolutionäre Elemente in der neuen Religionsgemeinschaft $72-78$. Wahlverwandtschaft des Christentums mit gewissen Kulturformen. Ausblick auf die kommende Entwickelung 78-83.

3. DER FR ÜHKATHOLIZISMUS.

Bildung der Kirche und ihrer Verfassung 83-92. Auseinandertreten von Kirche und Welt als Folge davon 93-95. Die Askese 95-105. Die aus diesem Gegensatz entwickelte und ihn überbrückende Ethik der Kirche I06-109. Rege- 
lung der vizialen Probleme in der Kirche und durch die Kirche als Staat im Strate $1(1)-11$ :

I) lichit: 113-117. Die Alheit 117-120. licrufe und Stände 120-127.

Der Ilandel 127-120. Die Familie 121)-132. I lic Sklaverei 132-134. Die I.telich tigkeit 134-139. Dic Entstehun: eines neuen Standes 139-143. Die Wissenschaft und dic Rezcption der stoischen Ethik 144-147.

1):i- Verhältnis zum Staat 1.48-155. Gewinnung eincr positiven Staatsethik durch Rezeption der stoischen Lehre vom sittlichen Naturgesetz 156-165. Theokratische duffassung der kaiserlichen Gewalt 165-170. Entscheidende Bedeutung der Lex naturae für das Ganze einer christlichen Kulturethik $I_{7} I-I 74$. Ergebnisse der Entwickelung in der alten Kirche $175^{-1}-18$.

II. K.IPITEL.

\section{DER MITTELALTERLICHE KATHOLIZISMUS.}

I. DAS PROBLEM.

Der Begriff der christlichen Finheitskultur und das Mittelalter i78-I85. Dialektik der Iujec und Zufall 185 -I ist.

2. ANSAT\%にFC̈R DIE MITTELALTERLICHE EINHEITSK UIT UR.

Der Ausbau der, kirchlichen Verfassung und stockender Abschluß im Osten 187 - 195.

3. DII: LANDÉSKIRCIILICHE PERIODE DES FRÜH MIT T EL A L T ERS.

Das gcrmanische Landeskirchentum 195-198. Bedeutung dieses Landeskirchentums für die christliche Kultur 199-206.

4. DIE UNIVERSALKIRCHLICHE REAKTION UND DIE KATHOLISCHE EINHEITSKULTUR.

Die zentralistisch-papalistische Reaktion 206-209. Der Ertrag dieser Reaktion: Papalidee, Freiheit der Kirche, Sakraments- und Gnadendogma 209-22I. Die kirchliche Einheitskultur auf diesen Grundlagen $221-226$.

5. DIE BEDELTUNG DER ASKESEIM SYSTEM DES MIT TELALTERLICHEN LEBENS.

Die asketische Idee und ihre Vereinigung mil dem Weltleben 226-230: Verkirchlichung des Mönchtums 230-234. Relativer Sinn der Askese 234-238.

6. RELATIVE ANNAHERUNG DER TATSÄCHLICHEN SOZIALEN LEBENSFORMEN AN DAS KIRCHLICHE IDEAL.

Die Sozialgeschichte des Mittelalters 238-245. Günstige und ungünstige Dispositionen der mittelalterlichen Gesellschaft für die christliche Ethik 246-249. Die Bedeutung der Stadt für die Verchristlichung der Kultur 249-252. 
7. DIE TIIEORE'TISCHE DURCHLEUCHTUNG DER KIRCHLICHEN EINIEITSKULTUR IN DLR THOMISTISCHEN I: T H I K.

Vermittelungscharakter der thomistischen Ethik 252-254. Fortbildung des Begriffs der lex naturae als des Werkzeugs der Vermittelung 255-262. Gedanke der ethischen Stufenfolge und der Entwickelung von der Natur zur Gnade 263-272. Verbleibende Gegensätze innerhalb dieses Stufenbaus 272-276. Die besondere Art des hier ausgebildeten Entwickelungsgedankens 276-282. Klassische Bedeutung des Thomismus für die katholische Ethik und Sozialphilosophie 283-285.

8. DIE MITTELALTERIICIIE SOZIALPHILOSOPHIE NACH DEN GRUNDSATZEN DES THOMISMUS.

Jetzt erst vorhandene Möglichkeit einer umfassenden christlichen Sozialphilosophie 286-291. Gewinnungr eines soziologischen Grundschemas: Patriarchalismus und Organismus 292-jII. Ausarbeitung des Grundschemas zu dem Begriff eines Kosmos der Berufe 3II-3I3. Innere Widersprüche und Antinomien in dem Grundschema 314-324. Keine Sozialreform sondern Karität 324-328. Das katholische Naturrecht 328-329. Rückblick und Ausblick 330-336.

Die Sozialethik der Familie, des Staates, der Gesellschaft, der Wirtschaft 337 -348. Leitung dieses Kosmos durch die Obergewalt der Kirche 348-351.

Bedingtheit der katholischen Sozialphilosophie durch die allgemeine Kulturgeschichte und umgekehrte Frage nach ihrem Einfluß auf sie $352-358$.

9. DAS ABSOLUTEGOTTES-UND NATURRECHT UND DIE $S E K T E N$.

Wiederauftauchen des alten Gegensatzes gegen den kirchlichen Kompromiß 358-360. Der Sektentypus im Unterschied vom Kirchentypus 360-377. Radikale Gestaltung des Naturrechts im Sektentypus und weitere dogmatische Eigentümlichkeiten $377-383$.

Ausgangspunkt der Sektenbildung von der gregorianischen Kirchenreform 383 -389. Waldenser 389-390. Franziskaner 390-393. Die Wilkliffie 393-401. Der Hussitismus 40I-4IO. Bauernaufstände 4IO-4II. Die Literatur der Volkssouveränetät $41^{12-4} \mathbf{1}^{16}$. Naturrechtliche Elemente in der konziliaren Reformtheorie 417-418. Die städtische Kultur und der Individualismus, die Mystik 418-422. Abschluß und Vorausblick 422-426.

\section{KAPITEL.}

\section{DER PROTESTANTISMUS.}

\section{DAS SOZIOLOGISCHE PROBLEM DES PROTESTAN-} T I S M U S.

Der Protestantisimus als neuer Typus der soziologischen Selbstgestaltung der christlichen Idee 427-430. Ausgangspunkt in der Originalität Luthers und Verhältnis $z u$ den Klassenbewegungen der Zeit $43 \mathrm{I}-434$. Die religiöse Idee Luthers $434-448$. Soziologische Konsequenzen dieser Idee 448. Der neue Kirchenbegriff 448-458. Folgerungen aus diesem Kirchenbegriff: r. Der absolute Wahrheitsbegriff. 2. Das 


\section{XIV}

Amt der Wortverkündigung als Mittel der Organisation. 3. Das Landeskirchentum und die Zuangsherrschaft der Kirche 459-472. Die dem kirchenbegriff entsprechende Kompromiß-Ethik 473-490. Sondercharakter der protestantisch-kirchlichen Ethik: die 7entralstellung des Dekalogs, die doppelte Moral des Amtes und de: Person 491-500. Rückblick und Vorblick 506-512.

2. DAS LUTHERTUM.

Kirchenbegriff und kirchliche Organisation des Luthertums 5I2-52I. Dic staatlich-kirchliche Lebenseinheit der christlichen Gesellschaft 521-523. Die Ethik des Luthertums 524-53I. Das lutherische Naturrecht $532-548$.

Das soziologische Grundschema des Luthertums 549-555. Die Familie 555 -559. Der staat 560-570. Die Wirtschaft 571-580. Die Gesellschaftsgliederung und die Berufe $581-584$. Sozialpolitik, Sozialreform und Karität 585-593.

Schlußfrage nach Zusammenhang des Luthertums mit der allgemeinen deutschen Kulturlage und Rückwirkung jenes auf diese 594-602. Bedeutung des Luthertums für die deutsche politische und soziale Lage 603-605.

\section{DER CALVINISMUS.}

Ueberflügelung des Luthertums durch den Calvinismus. Linterscheidung des primitiven und des Neu-Calvinismus. Ursprünglicher Ausgang des Calvinismus vom Luthertum 607-6r2.

Religiös-ethische Besonderheit des primitive n Calvinis mus 613-68I. 1. Prädestinationslehre 615-621;2. Der calvinistische Individualismus 622-624; 3. Die heilige Gemeinde und Analogien mit dem Täufertum 6i5-642; 4. Die calvinisti-che Ethik. Die Askese. Die Berufsidee. Das natürliche Sittengesetz 625 -666; 5. Das soziologische Grundschema. Gleichheit und Ungleichheit. Chrisllicher Sozialismus $667-679$.

Der Kinfluß der Genfer kulturellen Lage auf den primitiven Calvinismus 68 I -728. 1. Her demokratisch-konstitutionelle Zug des Calvinismus. Genfer Zustände. bita. Staatslehre. Die hugenottisch-monarchomachische Staatslehrc. Die schottische Staatslehre. Cromwell. Althusius. Grotius. Locke. Hobbes. Pufendorf 681-703. 2. Der kapitalistische Zug in der Wirtschaftsethik des Calvinismus. Calvinismus und Kapitalismus. Einschränkungen des Kapitalismus durch christliche Forderungen. Aussihnun 3. Politische Intcrnationalität des Calvinismus. Das Kriegsproblem. Dic Interventionspolitik $723-728$.

Die eigentümlichen reformierten Soziallehren. Der Kirchenbegriff. Gescllschaftsund Familienbegriff $725-733$.

Der Uebergang zum Neucalvinismus im Freikirchentum und Pietismus als Folge der Uebertragung der Maßstäbe der heiligen Gemeinde auf große Volkskulturen $733-737$.

Das Freikirchentum 738-773. Der Brownismus unc Barrowismus 741-744. Der Kongurationalismus $745-74 \mathrm{~S}$. Der englische Independentismus $749-755$. Findringen des Freikirchenprinzips in den echten Calvinismus $755-757$. Die To- 
leranz 758-76r. Naturrechtlicher und liberaler Charakter des freikirchlichen Neucalvinismus $762-772$.

Puritanismus, Präzisismus und Pietismus 773-789. Der erglische Puritanismus 774-780. Der niederländische Präzisismus 78I-787. Der Pietismus am Niederrhein und in der Schweiz 788-789.)

Die Ethik des Neu-Calvinismus und ihre Verschmelzung mit der Ethik des verbürgerlichten Sektentypus. Entstehung der Gesamtgruppe des a s k t is che n Protestantis mus aus dieser Verschmelzung 790-794.

\section{SEKTENTYPUS UND MYSTIK AUF PROTESTANTI- SCHEM BODEN.}

Komplementärbewegung der Sekten und der Mystik neben dem protestantischkonfessionellen Landeskirchentum und ursprüngliche Eingeschlossenheit beider in die reformatorische Ideenwelt $794-797$.

Das Täufertum und die protestantischen Sekten 797-848.

Anknüpfungspunkte des Täufertums bei den Reformatoren 797-800. Verselbständigung des Sektenmotivs im organisierten Täufertum. Allgemeine Charakteristik des Täufertums 800-804. Herkunft des Täufertums 805-809. Verschiedene Stellung des Sektenmotivs im Katholizismus und Protestantismus 809-812.

Züricher Täufertum und erste Ausbreitung 8I2-8I4. Mennoniten 8I4-8I5. Englische Täufer und Entstehung der General Baptists 815-817. Das radikale Täufertum in der englischen Revolution 817-819. Die Leveller 820-821. Die Diggers 822-824. Die Millenarier 825-826. Der Pietismus 827-831. Die Hermhuter $832-835$. Der Methodismus $836-840$. Der Labadismus $84 \mathrm{I}$. Moderne Sekten $84 \mathrm{I}-843$. Der christliche Sozialismus $843-846$. Tolstoi $847-848$.

Die Il ystik und der Spiritualismus $848-940$.

Das religiöse Wesen der Mystik überhaupt 849-851. Die Mystik im Neucn Testament $852-853$. Die religionsphilosophisch unterbaute Mystik 853-858. Der Spiritualismus 858-859. Der protestantische Spiritualismus 860-862. Unterschied von den Täufern $863-865$. Soziologischer Charakter des Spiritualismus 865-868. Wirkungen auf das Dogma 868-874. Ethik des Spiritualismus 875-877.

Thomas Münzer 878-879. Karlstadt 879-880. Schwenkfeld 88I-885. Seb. Franck 886-888. Castellio 889-89o. Coornheert 891-893. Die Collegianten 8144 -895. Spiritualistische Theologen aus dem Täufertum 895-897. Naturphilosophen 897-898. David Joris 899-900. Heinrich Nikläs 901-902. Labadie 902-903. Niederländische Mystik des 17. Jh. 903-906. Englische Mystik des 17. Jh. 907 -910. Die Quäker 9II-9I6. Methodismus und Pietismus 9I7-92I. Herrnhutertum 922-925. Die moderne Religionsphilosophie des Idealismus 926-928. Die Romantik 929-932. Die moderne Theologie 933-935. Soziologische Folgen des modernen Spiritualismus 936-940.

Die Soziallehren der Mystik und des Spiritualismus 940-942. Die der aggressiven Sekten 943-946. Die duldende Sekte und ihre Verschmelzung mit dem Neucalvinismus; nochmals der asketische Protestantismus 946-948. Das soziolo- 
gische (irundichem. des asketischen Protestantismus 949-951. Dic Sexualethik 951-1952. I lic politische lithik 953-955. Die Wirtschaftscthik 955-958. Stellung des anketischen Puntertantismus in der (ieschichte der christichen lithik $950-901$.

rhlulfinge nach Wechselbeeintlussung der allgemeinen Kultur und der geschilderten Gruppen 960-963. Bedeutung des asketischen Protestantismus in der Gegenwart ofi.

$$
\text { SCHLUSS. }
$$

Die neue Lage der christlichen Soziallehren seit dem i8. Jahrh. 965-966. Ergebnine. I. Die drei IIaupttypen der soziologischen Selbstgestaltung der christlichen Idee. 2. Die soziologische Bedingtheit des Dogmas und der Theologie. 3. Wahrheitsbegriff und Toleranz. 4. Die Entwickelungsgeschichte der christlichen Ethik. 5. Die Bedeutung der Marxistischen Methode für die Theologie. 6. Der bleibende ethische Gehalt des Christentums. 7. Die zweckmäßigstc Organisation des christlich-religiösen Lebens in der Gegenwart. 8. Das Christentum und das moderne soziale Problem 967-986.

Sachregister $987-999$ I.

Namenregister $992-994$. 


\section{Einle it ung}

und methodische Vorfragen.

In den sozialen Kämpfen der Gegenwart, die teils von den modernen Riesen- und Einheitsstaaten, ihrer Demokratisierung und dem Kampf der Gruppen um die Beeinflussung des Staatswillens, teils von der modernen Industrialisierung, der Bildung des Proletariats und der Emanzipation der internationalen Massen ausgehen, erheben neben den politischen Parteien, den ökonomisch-soziologischen Fachwissenschaften und den modern autonomen Kulturphilosophen auch die auf uralte historische Kräfte begründeten Kirchen ihre Stimme. Zugleich verwenden sie ihre beträchtliche Organisationskraft mit zur Lösung dieser Probleme. Großenteils fallen sie dabei mit den Parteien zusammen wie das bei Zentrum, Konservativen und antisemitischen Mittelständlern mehr oder minder der Fall ist, und erleiden dann freilich auch starke Rückwirkungen durch die in jenen wirkenden politischen und Klasseninteressen; teils suchen sie in der Weise des Evangelisch-sozialen Kongresses und mit den Mitteln einer wissenschaftlichen Literatur eine parteilose geistige und praktische Einwirkung; teils finden sie in den halb-kirchlichen Vereinen und Organisationen der "Innern Mission « und verwandter Bestrebungen ihre Wirksamkeit. Jedenfalls haben diese kirchlichen und religiösen Gruppen, seit und soweit sie anerkannt haben, daß ihrer Lebensregelung von der modernen sozialen Lage her neue Voraussetzungen und Aufgaben gestellt sind, sich in diese Probleme praktisch und theoretisch vertieft und unter Anschluß an die bestehende wissenschaftliche Literatur eine eigentümlich christliche Staats-, Gesellschafts- und Wirtschaftslehre zu entwerfen oder abzugrenzen gesucht, wobei die wachsende Einsicht in die Bedeutung des ökonomischen Unterbaues für alle höhere geistige Kultur auch sie stark zur Beschäftigung mit ökonomischen Dingen gezwungen hat. Auch sind manche Nationalökonomen und manche Vertreter der politischen Wissenschaft ihnen darin entgegenge- 
kommen. Daßs die leitenden Persönlichkeiten der Regierungen sich auf solche Gedanken gerne berufen und daß das insbesondere Bismarck in merkwürdigem Gegensatz zu seinem sonstigen politischen Realismus und Naturalismus nachdrücklich getan hat, ist bekannt. Ein solches Unternehmen ist an sich auch wohl verständlich und in der Ordnung, da die Gesellschaftslehre in der Tat rein aus sich die letzten Werte und Normen nicht zu erzeugen vermag, da auch die ökonomische Lehre in Bezug auf die letzte Wertung der von ihr behandelten Güter und auf die von ihr vorauszusetzenden komplizierten sozialen, politischen und sittlichen Kräfte an außerhalb der Fachwissenschaft liegende Instanzen gewiesen ist ${ }^{1}$ ). Die Frage kann daher nicht sein, ob das Unternehmen kirchlicher und religiös bestimmter Soziallehren überhaupt berechtigt sei, sondern nur die, ob von ihnen etwas für die moderne Lage Brauchbares und Wertvolles mit geleistet worden sei. Lm diese Frage aber zu beantworten, bedarf es vor allem der Kenntnis dieser Bestrebungen.

Eine solche Aufgabe ist freilich sehr kompliziert. $\mathrm{Zu}$ beurteilen, was die kirchliche Sozialpolitik und Gesellschaftslehre praktisch geleistet hat, ist eine derart umfangreiche Sache, daß ihr nur ein diesen Fragen sich widmender Fachmann mit nationalökonomischer und politischer Schulung gewachsen ist. Darüber kann ich mir hier kein Urteil erlauben. Aber ein anderes, theoretisch noch wichtigeres Interesse liegt nach der Seite der dogmenge s chichtlichen Frage, wie die Kirchen prinzipiell ihre Lehre begründen, von ihrem ganzen Grundwesen aus prinzipiell sich zu dem modernen sozialen Problem stellen und nach ihren Ideen stellen müssen. Diese Frage ist umsomehr von Bedeutung, als es gerade einer der besonderen Vorzüge der kirchlichen Soziallehre ist, prinzipielle, metaphysisch begründete Ueberzeugungen $\mathrm{zu}$ besitzen. Darin sind sie mit den Sozialdemokraten einig, und darum haben das sozialpolitische Zentrum, die patriarchalischen Konservativen und die revolutionären Sozialdemokraten die stärkste suggestive Macht, während der in individuelle Besonderheiten, praktische Kom-

1) Das veranschaulicht mit bew̄underungswürdiger Breite der Kenntnisse und Feinfühligkeit für die Zusammenhänge Schmollers „Grundrif der Volkswirtschaft «, der freilich ebenso deutlich für die Selbständigkeit aller Beurteilungsnormen zeugt. Denn für die Gewinnung dieser hat Schmoller nur den historisch-psychologischen Kausalzusammenhang zur Verfügung, aus dem er Normen und gültige Werte teils gar nicht, teils nur durch Erschleichung gewinnt. 
promisse und bürgerliche Gelehrsamkeit sich relativistisch auflösende Liberalismus diese Kraft nicht oder nicht mehr besitzt, nachdem sein individualistischer Grundgedanke sich mindestens vorläufig erschöpft hat. Eine derartige dogmengeschichtliche Studie ist in erster Linie Sache des Theologen und Religionshistorikers oder doch wenigstens des mit diesen Kenntnissen Vertrauten. Denn hier stößt man schon beim ersten Versuch immer wieder auf die Grundtatsache, daß die Kirchen und das Christentum als vor allem historische Mächte in allen Stücken bedingt sind durch ihre Vergangenheit, durch das Evangelium, das mit der Bibel stets von neuem seine Einflüsse geltend macht, und durch die das soziale Leben und das Kulturganze betreffenden Dogmen. In Zustimmung und Gegensatz, in Abhängigheit und Umdeutung sind alle modernen kirchlichen Soziallehren von hier aus bestimmt; und, wie ihre seelische Kraft nur durch dieses Bewußtsein eines uralten und weltweiten Zusammenhangs der Glaubenstradition zu Stande kommt, so ist auch ihr Inhalt nur aus diesem Zusammenhang zu verstehen. Aus der Geschichte der christlichen Ethik und sozusagen ihren Grunddogmen müßten sie verstanden werden, wenn es eine solche gäbe, die das christliche Ethos in seinem inneren Zusammenhang mit der allgemeinen Kulturgeschichte darzustellen wüßte ${ }^{2}$ ). Da

$\left.{ }^{2}\right)$ Geschichten der christlichen Ethik von Luthhardt I888/93 (lutherischkonfessionell: die christliche Ethik ist im Evangelium und im Ideal die Durchdringung des Systems der weltlichen Berufe mit dem Geist des Gottvertrauens und der Nächstenliebe), Gaß I88I (viel Stoff und wenig Ordnung: Versöhnung und Durchdringung des Christlich-Supranaturalen und Human-Natürlichen). Ziegler 1886 (Theorie von der Selbstauflösung des christlichen Dualismus in moderne Immanenz und Autonomie). Hier ist überall die christliche Ethik wesentlich unter den Gesichtspunkt gestellt, daß sie Gnadenhilfe für die sündige Schwachheit oder Unfähigkeit sei und daher wesentlich die Gnadenlehre behandelt. Die Frage nach dem inhaltlichen Sondercharakter des christlichen Ethos und nach der Verbindung seines Inhaltes mit den übrigen, inhaltlichen sittlichen Normen und Gütern der Kulturmenschheit kommt daher immer nur nebenbei in Betracht. Das gilt auch von der Berücksichtigung der christlichen Ethik, die Jodl in seiner lehrreichen -Geschichte der Ethik \& ${ }^{2}$ I 906 gibt. Sie ist ihm mit Stoa und Platonismus zusammen der Typus der spiritualistischen, metaphysischen und dualistischen Ethik, die, auf religiösen Illusionen beruhend, wesentlich die Gnadenhilfe und mit ihr den extremen Dualismus bis zur Askese behauptet, im übrigen aber im Gegensatz gegen Stoa und Platonismus die Züge barbarischer Unwissenschaftlichkeit trägt, ja vielleicht in ihrem Besten nur eine Barbarisierung und populäre Mythisierung der stoisch-platonischen Lehre ist. In all diesen Fällen fehlt es an einer genügenden Analyse 
es cine solche nicht oder kaum gibt, muß man gerade für die hier aufgeworfene Frage selbst sich den Weg bahnen zum Verständnis der Soziallehren des Evangeliums, der alten Kirche, des Mittelalters, der nachreformatorischen Konfessionen bis zur Bildung der neuen Lage in der modernen Welt, wo die alten Theorien nicht mehr ausreichen und daher aus Altem und Neuem, bewußt oder unbewußt, eingestanden oder uneingestanden, neue Theorien aufgebaut werden.

Es muß also versucht werden, von diesen historischen Grundlagen ein Bild $z u$ gewinnen, und gerade eine möglichst kurze Darstellung ist geeignet, hier die entscheidenden Linien hervortreten zu lassen, die in ausführlichen Darstellungen allzuleicht von den krausen und bei der spinösen Ausbildung der kirchlichen Dogmen besonders verwirrenden Einzelheiten verdeckt werden. lier liegt nun aber bereits in der ersten Fragestellung eine große

der ethischen (irundideen des Evangeliums, und daher auch an einer solchen der su/iologischen Eigenkonstitution und der sozialen Beziehungen des Christentums. Einc wertvolle, den Zusammenhang mit dem allgemeinen, namentlich wirtschaftlichen. Leben am meisten betonende, aber naturgemäß nicht erschöpfende Darstellung der christlichen Ethik ist Uhlhorn $\gg$ Die christliche Liebestätigkeit * $\mathrm{I}^{2}$ I882, II 1884, III 1890 . Die Auffassung im ganzen ist lutherisch-konfessionell. Aehnlich bei $A$. Ritschl, $\gg$ Geschichte des Pietismus «, I88o/84/86, wo die Ethik eines modernisierten, $>$ weltoffenen Luthertums klassisch entwickelt ist. - Ganz entgegengesetzt sind die kulturgeschichtlichen Auffassungen, die die in vielen Gedanken verwandten, aber freilich auch vielfach dann wieder auseinandergehenden Basler Jakob Burkhardt, Franz Overbeck und Friedrich Nietzsche andeutend entwickelt haben. Ihnen erscheint die christliche Ethik wie den Katholiken wesentlich als Askese, nur daß die rom Katholizismus stets daneben betonte Einbeziehung des Natürlich-Innerweltlichen dabci abgestoßen wird. In der Tat ist das Problem der Askese ein Hauptproblem in diesem ganzen Zusammenhang. Aber die Auffassung deś Evangeliums rein als Askese ist eine Verkennung seines religiösen Grundgedankens und damit auch eine Unterschätzung der ron diesem religiösen Grundgedanken ausgehenden soziologischen Kräfte, wie denn alle drei heftige Gegner der Masse und des "Sozialen* sind und chendaher für diese Seite des Gegenstandes kein Interesse oder nur Polemik haben. IV ̈̈re das Christentum reine Askese, dann wäre über seine Soziallehren überhaupt nur zu sagen, dafs es konsequent das Mönchtum und inkonsequent ein Halbmönchtum als Anpassung an die Welt hervorgebracht habe. Es liegt aber auf der Hand, daf das den Sachverhalt nicht erschöpft und jedenfalls noch andres in ihm enthalten sein mußs. - Auch Renan in den »Origines du Christianisme « hat gelegentlich Dcrartiges geäußert, aber in seiner schillernden Weise dann auch wieder sehr icl weitergehende ethische und soziologische Gehalte anerkannt. 
Schwierigkeit und Dunkelheit. Was heißt überhaupt das "Sozialc * im Verhältnis zu den Kirchen und dem Christentum? Angesichts der Verworrenheit, die die meisten mit dem so gestellten Problem sich beschäftigenden Schriften erfüllt, ist vor allem von vornherein schon in dieser Fragestellung selbst Ordnung zu schaffen. Sieht man sich eine der typischen Arbeiten, etwa das in dritter Auflage vorliegende Buch von Nathusius »die Mitarbeit der Kirche an der Lösung der sozialen Frage « I904 an, so gewahrt man ein Doppeltes in einander gewirrt, dessen Verwirrung die Unverständlichkeiten und Irrtümer des Buches offenkundigg bewirkt. Es ist hier nämlich einmal die Rede von einer aus der religiösen Idee selbst hervorgehenden Gemeinschaft, von einem »sozialen Charakter des Christentums « überhaupt. Das aber ist bei näherer Ueberlegung etwas ganz Selbstverständliches, es ist nichts anderes als die von dem religiösen Objekt aus sich ergebende, besondere religiöse Gemeinschaft, die soziologische A uswirkung des religiösen $\mathrm{Phänomens,} \mathrm{geradeso}$ wie jedes beliebige andere Phänomen, etwa der Geschlechtstrieb, die Kunst, die Wissenschaft, die Gewinnung des Lebensunterhalts, oder auch jede Liebhaberei und jede flüchtige $Z$ wecksetzung ihre soziologische Wirkung hat, ihren größeren oder kleineren, dauernderen oder flüchtigeren, so oder so in der Lagerung seiner Glieder konstituierten soziologischen Kreis um sich zieht ${ }^{3}$ ). Mit dem "Sozialen « im gewöhnlichen Sinn des Wortes hat das gar nichts zu tun, vielmehr lehrt jede soziologische Ueberlegung die kolossale Verschiedenheit in Begründung und Struktur, in Funktion und Verknüpfung mit anderen Kreisen kennen, die je nach dem die Beziehung hervorbringenden Objekt zwischen diesen Gebilden besteht. Aber bei Nathusius ist deutlich, wie hier der Gebrauch des Wortes »sozial « für diese soziologische, aus der christlichen Idee hervorgehenden Gesellung alles verwirrt. Im Handumdrehen wird aus dem Christentum wegen dieses seines "sozialen " Charakters ein Prinzip des sozialen Lebens überhaupt, und, da dieses nach dem Verfasser in den natürlichen Beziehungen des Geschlechts, Alters u. s. w., in den natürlichen wirtschaftlichen Bedürfnissen, in den davon ausgehenden Gliederungen, dem Eigentum und einer menschlichen Völkergemeinschaft seinerseits be-

$\left.{ }^{8}\right)$ Hierzu vergl. die verschiedenen, äußerst belehren,'u soziologischen Abhandlungen Simmels; der oben ausgesprochene Gedanke in "Suziologie der Ueberund Unterordnung«, Band XXIV (1907) dieses Archivs. 
steht, so wird das soziale Prinzip des Christentums eo ipso zum Prinzip auch aller dieser Dinge. Nun kann man sich nicht mehr wundern, wenn es schlankweg heißt, daß nicht nur im allgemeinen dem Christentum ein s o z i a l e r Geist innewohnt, eine die Menschen zusammenführende Macht, sondern daß auch (eben damit) gewisse Grundsätze aufgestellt sind für die natürliche Gliederung der Menschen, die Geschlechts- und Altersverhältnisse, Lebensbedingungen, von deren Einhaltung ihre gesunde Entwicklung abhängt « ! (S. 307). Hier fehlt jeder Gedanke daran, ob nicht vielleicht der soziologische, aus der christlichen Idee hervorgehende, Kreis von den aus jenen anderen $Z$ wecken soziologisch hervorgehenden Kreisen innerlich und wesentlich verschieden sei; um der bloßen formalen Gleichheit willen, daß sie assoziierende Mächte (S. 307) sind, werden sie auch inhaltlich zusammengeworfen und eins aus dem anderen bestimmt.

Das ist aber gar nicht die einzige verhängnisvolle Verworrenheit in diesem Gedankengang. Die zweite ergibt sich bei der Frage nach dem Begriff der Gesellschaft oder des "Sozialen ", das so mit dem soziologischen Kreis der christlichen Idee zusammengeworfen worden ist. $\mathrm{Er}$ ist nichts weniger als selbstverständlich und bedeutet keineswegs den Inbegriff soziologischer Beziehungen, die neben dem soziologischen Kreis des Christentums vorhanden und möglich sind. Wenn Nathusius dem Christlich-Soziologischen alle andere Gesellung als eine Einheit gegenüberstellt und nun beide Einheiten wie Vernunft und Offenbarung, die ja auch in der Wurzel d. h. in Gott eins sind, auf einander reduziert, so wirkt darin zunächst die apologetische Gewohnheit der christlichen Dogmatiker, dem absolut gemachten Christentum alles Uebrige als eine Einheit gegenüberzustellen und es dann mit ihm zusammen irgendwie auf eine gemeinsame Wurzel zurückzuführen und dadurch die Gegensätze auszugleichen, ein Irrtum, den jede rein historische Betrachtung auflöst. Aber in dieser Denkweise liegt doch ein noch viel weiter greifender Irrtum, eine Weitschichtigkeit und Allgemeinheit im Gebrauch des Begriffs des Sozialen, die jede bestimmte und klare Fragestellung unmöglich macht und die auch. den nicht-theologischen Dogmatikern, den Vertretern des naturwissenschaftlichen Gesellschaftsbegriffes, sehr geläufig ist. Der Begriff des Sozialen bedeutet weder den Inbegriff der s natürlichen. Gesellung im Unterschied von der *übernatürlich* bewirkten Vergesellschaftung, noch den Inbegriff menschlicher 
Vergesellschaftung überhaupt, unter den als Allgemeinbegriff jedes soziologische Phänomen als Einzelfall fiele und durch den es dann damit erklärt und begriffen wäre. $\mathrm{Da}$ entsteht dann von der entgegengesetzten Seite her die gleiche Verwirrung wie bei Nathusius, statt der Auflösung des Sozialen in das ChristlichSoziologische die Auflösung des letzteren in den angeblich klaren und eindeutigen Begriff des Sozialen. Hier steht dem theologischen Dogmatiker als Beispiel der sozialistische Dogmatiker gegenüber, wie man etwa aus Kautskys Programmschrift "Die Sozialdemokratie und die katholische Kirche* (2. Aufl. 1906) ersehen kann ${ }^{3 a}$ ).

Der Begriff des „Sozialen* bedeutet vielmehr in dem heute geläufigen Sinn einen ganz bestimmten und eng begrenzten Ausschnitt aus den allgemeinen soziologischen Phänomenen,

3.) Hier wird die Kirche von vornherein lediglich als ökonomisches Phänomen aufgefaßt, da sie als soziologisches Phänomen eo ipso auch ein wesentlich ökonomisches sein muß. Im Gegensatz zur Demokratie und Priesterlosigkeit aller urwüchsigen, mit der Gesellschaft als solcher noch zusammenfallenden Religion ist die christliche Religion als Verfailsprodukt eine neue eigene Vergesellschaftung kommunistischer Art. Bei der Ausbreitung in der Masse differenziert dieser Kommunismus jedoch wieder eine Herrenschicht aus sich heraus, den Klerus, und die weitere Entwickelung bringt nur die Festigung der politischen und ökonomischen Herrenstellung des Klerus, der damit teils zum Konkurrenten, teils zum Komplizen der jeweiligen politisch-ökonomischen Herrenschicht überhaupt wird. Von einer aus einem spezifisch religiösen Motiv folgenden religiös-soziologischen Bildung ist also hierbei überhaupt nicht die Rede und die Kirche lediglich in die allgemeine ökonomisch-soziale Bewegung aufgelöst, innerhalb deren sie anfangs eine kommunistische Klassenbewegung der Armen darstellt und in ihrer religiösen Liebesidee sich ihren ökonomisch-kommunistischen Sinn verhüllt. Daher dann auch die Kirchenpolitik des heutigen Proletariats; es akzeptiert die kommunistische, religiös verhüllte Tendenz und schont darum die religiösen Ideen durch die Proklamierung der Religion zur Privatsache und sichert sich die Sympathieen der Katholiken durch Bekämpfung aller Ausnahmegesetzgebung, z. B. gegen die Orden. Gleichzeitig soll freilich die Trennung von Staat und Kirche, die Verweisung der Religion aus der Schule und die Bekämpfung der religiösen Idee durch die sozialistische Wissenschaft die Macht des Klerus brechen. In dieser widerspruchsvollen Kirchenpolitik, die Schonung und Vernichtung der Religion zugleich ist, kommt dann freilich der wirkliche Sachverhalt zum Ausdruck, daß in der Kirche noch etwas anderes enthalten ist als ein ökonomisch-klassenkämpferisches Phänomen, daß in der ideologischreligiösen Verhüllung « ein selbständiges Interesse steckt. Aber diese wohl mehr diplomatische als aufrichtige Anerkennung bleibt ohne jede tiefere Wirkung auf die Auffassung des Problems selbst, das von dem dogmatischen Allgemeinbegriff der , Gesellschaft a aus überhaupt nicht lösbar ist. 
nämlich dic ron der staatlichen Regulierung und dem politischen Interesse freigelassenen oder nur sekundär berührten soziologischen Beziehungen, die sich aus dem wirtschaftlichen 1.eben, der Bevölkerungsspannung, der Arbeitsteilung, der Ständegliederung und einigen anderen nicht direkt als politisch zu charakterisierenden Interessen ergeben, die aber tatsächlich das staatliche Gesamtleben aufs stärkste beeinflussen und seit der Ausbildung des modernen Rechtsstaates sich von ihm deutlich geschieden haben, so daf das s soziale Problem « recht eigentlich in dem Verhältnis der politischen Gemeinschaft zu diesen in der Wurzel unpolitischen, aber politisch überaus wichtigen soziologischen Erscheinungen besteht. So hat Lorenz ron Stein aus der Beobachtung der französischen Entwicklung heraus den Begriff der „Gesellschaft " neben den des Staates gestellt und das soziale Problem der Gegenwart angekündigt. So hat Rodbertus, der andere Prophet des »sozialen Problems \&, die Gesellschaft bezeichnet als den „personifizierten Inbegriff der peripherischen Lebenstätigkeiten, die von unten, von den individuellen Vielheiten aus, auf den ihnen (vom Staat) freigelassenen Teilen des sozialen Lebens sich äußern " ${ }^{4}$ ). Bei dieser engeren Bedeutung des Wortes "Gesellschaft" und »sozial", wie es durch die gegenwärtige Lage besonders akzentuiert ist, muß man aber bleiben. Denn von der Gesellschaft als dem Inbegriff aller großen, kleinen und kleinsten soziologischen Kreise und ihrer gegenseitigen Verschlingungen und Beeinflussungen kann man als von etwas Uebersehbarem und wissenschaftlich Brauchbarem überhaupt nicht reden; die ist in der Unendlichkeit ihrer Bildungen und der für jede Betrachtungsweise beliebig vornehmbaren Verknüpfung der Phänomene etwas überhaupt Unausdenkbares, ein Abstraktum wie Kultur oder Geschichte überhaupt, von denen auch nur die Dilettanten immer im Ganzen reden; in Wahrheit ist jedes Denken über sie ein Herausgreifen irgend eines interessierenden Momentes, bei dem dann jedesmal seine soziologischen Nachbarbeziehungen freilich mit in das Gesichtsfeld treten, aber auch für den schärfsten, anschauungs- und abstraktionsfähigsten Denker nach allen Seiten in die Unendlichkeit der ron beliebigen anderen Gesichtspunkten ausgehenden soziologischen Gliederungen verlaufen. Es gibt keinen naturwissen-

4) Vgl. Gothein, Artikel , Gesellschaft im HWB. der Staatswissenschaften. L. von Stein, >Der Sozialismus und Kommunismus des heutigen Frankreichs 1842. Dietzel, , Rodbertus II I 888 , S. 46. 
schaftlichen Begriff der Gesellschaft, wie es einen solchen der Mechanik gibt, mit dem dann allc Einzelphänomene gedeckt wären, sondern der Begriff der Gesellschaft ist ein historischer, der aus einer unendlichen Füllc individueller soziologischer Gestaltungen nur stets einige herausgreifen und in ihren Beziehungen verfolgen kann; auch wenn er dic für das I eben wichtigsten herausgreift und damit naturgemäß auch auf cine äußerst reiche Verwickelung soziologischer Kreise stößt, so erschöpft er doch nie den allgemeinen Begriff der Gesellschaft übcrhaupt ${ }^{5}$ ). Das aber bedeutet für unseren Fall, daß die „Gesellschaft " und das "Soziale * im Sinne des heutigen Problems nur ein besonders wichtiges heute durch die Lage stark betontes Stück des allgemeinen soziologischen $\mathrm{Zu}-$ sammenhanges ist, nicht dieser selbst. Ein Verhältnis des Christentums zu den sozialen Problemen kann nur das Verhältnis zu diesen bestimmten, von der heutigen Lage besonders betonten, immer aber vorhanden gewesenen Größen der »Gesells chaft im engeren, Stein'schen Sinne des Wortes bedeuten. So widersinnig, wie es ist, um des soziologischen assoziierenden Charakters willen das Christentum mit allen anderen soziologischassoziierenden Phänomenen zusammenzuwerfen, ebenso verkehrt ist es, mit der Gesellschaft und dem Sozialen, das ihm gegenübersteht, die Gesellschaft überhaupt $z u$ meinen. Ja, auch der Steinsche Begriff der Gesellschaft, der alles vom modernen Rechtsstaat Freigelassene umfaßt, ist noch zu weit; dic moderne Wissenschaft denkt bei der »Gesellschaft « mit Recht in erster Linie an die aus den ökonomischen Phänomenen sich ergebenden Lebenszusammenhänge. Es kann also zunächst nur die arbeitsteilige, Klassen-Stände bildende, Güter produzierende und tauschende, vom wirtschaftlichen Existenzbedürfnis aus organisierte Gesellschaft samt ihren mannigfachen Komplikationen gemeint sein.

Gewiß bedeutet nun freilich eine von so allgemeinen Ideen ausgehende soziologische Grundanschauung, wie die christliche Ordnung des Verhältnisses von Individuum und Gemeinschaft, überhaupt ein soziologisches Grundschema, das auf

5) Es ist deutlich erkennbar, daß hier die Belehrungen durch Simmel, -Probleme der Geschichtsphilosophie ${ }^{3}$ « 1907 , Rickert, „Die Grenzen der naturwissenschaftlichen Begriffsbildung « 1902, Kistiakowski, „Gesellschaft und Einzelwesen* I899, Max Weber, »Stammlers \Ueberwindung $₫$ der materialistischen Geschichtsauffassung « (Band XXIV (1907) dieses Archivs), G. Jellinek, »Recht des modernen Staates $I^{2} 1905$, S. I $-9,24-32$ zugrunde liegen. 
alle Lebensbeziehungen irgendwie wirken wird. Aber es wirkt nur bald stärker bald schwächer, bald reiner bald gebrochener auf sie, und ist nie mit ihnen identisch. Es ist hier immer nur möglich von Fall zu Fall, von Lebenskreis zu Lebenskreis, die etwaige Einwirkung des Grundschemas aufzudecken. Denn alle diese Lebenskreise haben selbständige Organisationstriebe, und es kann sich immer nur darum handeln, wie weit das religiössoziologische Grundschema in sie einzudringen und diese Kreise sich zu assimilieren vermocht hat. Wo und soweit es geschieht, wird es den verschiedenen Kreisen gegenüber sehr verschieden erreicht werden; insbesondere die ökonomisch-arbeitsteilige »Gesellschaft * bleibt immer ein selbständiges Phänomen mit eigenen soziologischen Grundlagen gegenüber der aus religiösen Ideen geleiteten Gemeinschaftlichkeit. Dazu kommt ein Weiteres. Die Frage nach der inneren Wirkung des Christentums auf die Selbstempfindung der Persönlichkeit und auf die ethische Wechselbeziehung als solche, ist gewiß ungeheuer wichtig, aber sie ist so im allgemeinen unbeantwortbar und unfaßbar. Sie kann gerade nur dadurch beantwortet werden, daß man die konkrete Einwirkung auf die verschiedenen Lebenskreise untersucht. Dabei werden freilich so große Gebiete, wie das ökonomisch-soziale, ein entsprechend starkes Licht auf die allgemeine Grundtendenz der christlichen Soziologie zurückwerfen und Rückschlüsse auf den allgemeinen Charakter und die prinzipielle Kulturwirkung der christlich-soziologischen Prinzipien erlauben. Es wird das ein Gewinn sein, der bei der Frage nach dem Verhältnis der christlichen Idee zum "Sozialen « sich mit ergibt. Aber man muß dann wissen, daß man damit eine ganz konkrete Verengung, eine Stellvertretung des allgemeinen durch ein besonderes Problem vornimmt. Das Soziale in einem faßbaren Sinn ist eben nicht die "Gesellschaft * überhaupt und erst recht nicht das ethische Leben überhaupt, sondern ein Ausschnitt; und alle Beleuchtung der soziologischen Kulturwirkungen des Christentums von dem "Sozialen" her ist nur die Beleuchtung von einem besonders wichtigen Kulturgebiete her, nicht aber eine Enthüllung seiner soziologischen Gesamtwirkung auf das Kulturganze überhaupt.

Das führt aber auf einen weiteren wichtigen Punkt. Staat und Gesellschaft sind erst unterschieden von unserem modernen Sprachgebrauch, und das Charakteristische der »Gesellschaft * entsteht erst durch den Gegensatz gegen den modernen, formal-rechtlichen 
Staatsbegriff, aus welchem Gegensatz heraus überhaupt erst der ganze Begriff sein Licht und seinen konkreten Sinn erhält. Nun ist es aber ein ganz neues und ganz besonderes Problem, wenn diese zunächst nur in ihrer Trennung und Verschiedenheit vom Staat charakterisierte Gesellschaft zu der Kirche oder den Kirchen in Beziehung gesetzt wird. Sie gewinnt in dieser Kontrastierung ganz offenkundig einen neuen Sinn. Es wird dann der Gegensatz eines von dem religiösen Gedanken der Gottes- und Menschenliebe aus organisierten soziologischen Kreises zu den aus sehr weltlichen $Z$ wecken heraus organisierten soziologischen Mächten. Das moderne soziale Problem ist eben ein zunächst am Staatsgedanken orientiertes und wird bei der Orientierung an der Kirche zu dem ganz andersartigen Problem des Verhältnisses der religiösen Kräfte zu den ökonomisch-gesellschaftlich-politischen. Das ist das Wahrheitsmoment in der Unterscheidung, die die theologischen Dogmatiker zwischen dem religiösen Lebenskreis und der gegenüberstehenden Einheit der nichtreligiösen Lebenskreise machen; aber der Unterschied ist nicht der des "Natürlichen « und "Uebernatürlichen ", sondern der zwischen einer aus dem religiösen Zweck hervorgehenden Vergesellschaftung und den wichtigsten, aus den innerweltlichen Zwecken hervorgehenden Gesellungen. Nicht der Allgemeinbegriff des $» \mathrm{Na}-$ türlichen * und auch nicht der des "Sozialen überhaupt * kommt dann in dem Letzteren zur Geltung, sondern die beiden kraftvollsten und eingreifendsten soziologischen Bildungen neben dem religiösen Lebenskreis und deren beiderseitige Begründung in einem innerweltlichen Beziehungspunkt, während die Kirchen einen religiösen und das heißt überweltlichen Beziehungspunkt sich zuschreiben. Dabei rückt dann aber der Staat wie der mit den ökonomis chs ozialen Problemen zusammen, und die Soziallehren der Kirche, abgesehen von der Selbstanschauung ihres eigenen soziologischen $\mathrm{W}$ esens, werden $\mathrm{zu}$ der Lehre ihres Verhältnisses zu Staat und Gesellschaft zusammen, die die wichtigsten weltlichen ihr gegenüberstehenden Mächte sind ${ }^{6}$ ). So ist auch in der wirk-

-) Von Wissenschaft und Kunst ist dabei abgesehen, die bei einer einigermaßen festen Begrenzung des $>$ Sozialen eben nicht zu ihm gehören, so wichtige Bestandteile des allgemeinen soziologischen Systems sie auch sind und so wichtig namentlich die erstere für eine Religion der Erkenntnis und des Glaubens ist. Allein das muß der Dogmen- und Kunstgeschichte vorbehalten bleiben. Immerhin sei auf die interessante Parallele verwiesen, die hier das Verhältnis zur $*$ Welt $<$, das heißt zu den nicht direkt religiös bedingten Gebilden, mit der in politisch- 
lichen Geschichte von Anfang an alle Soziallehre des Christentums eine Lehre über Staat und Gesellschaft zugleich gewesen. Dabei ist für seine vom Persönlichen ausgehende Denkweise stets die Familie zugleich die Voraussetzung beider. also mit dazu gehörig. So erweitert sich nun doch wieder der Begriff des »Sozialen , indem für eine religiöse Gemeinschaftslehre Familie, Staat und ökonomische Gesellschaft als eng verbundene soziologische Formationen zusammentreten. Sie erschöpfen nicht den allgemeinen Begriff der Gesellschaft überhaupt, aber sie sind die großen Objekte, die der religiöse Gesellschaftsbau sich $\mathrm{zu}$ assimiliren suchen muß, während er anderes sich selber überlassen kann. Seine Soziallehre ist eine Lehre über die wichtigsten außerreligiösen, aus selbständigen Wurzeln erwachsenden soziologischen Gebilde, oder in seiner Sprache gesprochen, von seinem Verhältnis zu den mächtigsten Formationen der »Welt ". Erkennt man an, daß Staat und Gesellschaft neben unzähligen anderen doch die formenden Hauptkräfte der Kultur sind, so ist das letzte Problem das, wie die Kirche mit diesen Hauptkräften zu einer Einheit der Kultur zusammengehen kann. Die Frage nach der Stellung der Kirchen zum sozialen Problem umfaßt also die nach der Stellung zum Staat zugleich; und jene moderne Trennung des politischen und des gesellschaftlichen Gedankens, die ihrerseits nur möglich war, weil man die bis dahin beiden übergeordnete Kirche beiseite drängte und ignorieren lernte, macht nun gerade die modernen Soziallehren der Kirchen so überaus schwierig, weil sie es in Wahrheit mit Staat und Kirche zugleich zu tun haben und doch unter der Herrschaft des Schlagwortes »sozial sich in ihrem christlich-sozialen Eifer nur auf das isolierte *soziale « Problem stürzen. So hat auch Nathusius den Staat in seiner Lehre ganz vergessen, als ob nicht der Staat selbst das brennendste Interesse an dem sozialen Problem hätte und als ob er den Kirchen erlauben würdc, es nach ihren, von seinem Interesse oft ganz abweichenden Gesichtspunkten zu lösen. Und so war umgekehrt in alten vormodernen Zeiten den Kirchen die Art ihrer Lösung des sozialen Problems nur darum möglich, weil sie mit der Gesellschaft zugleich den Staat in einer selbstverständlichen Abhängigkeit von sich hielten, weil Staat und Gesellschaft zusammen willig und über-

sozialer Hinsicht erfolgenden Verweltlichung zeigt. Sie ist auch in Wissenschaft und Kunst eine sehr bedingte. 
haupt sich dem Glauben beugten und der Staat sich der Kirche für die Verwirklichung ihres Ideals zur Verfügung stellte. An diesem Punkte liegt heute noch der charakteristische Unterschied katholischer und protestantischer Soziallehren: die ersteren verlangen heute noch Herrschaft über den Staat, um das Sozialproblem kirchlich lösen zu können, die letzteren sind bei ihrer Freilassung des Staates unsicher und wollen bald den christlichen Staat, bald eine rein kirchlich-soziale Tätigkeit neben dem Staat. Andrerseits ist heute der Staat vielfach geneigt, die Kirchen als freie Assoziationen privater Interessen zu betrachten und sie so $\mathrm{zu}$ der von ihm unterschiedenen »Gesellschaft « zu rechnen ${ }^{7}$ ).

Die dankenswerte Grobschlächtigkeit der Ausführungen von Nathusius beleuchtet aber nur eine Verwirrung, die auch in feinerer Form von Unzähligen begangen wird ${ }^{7 a}$ ). Man glaubt mit

$\left.{ }^{7}\right)$ Interessant ist hier die Entwickelung Friedrich Naumanns, der von seinem christlichen Sozialismus durch realistische Erkenntnis der Sachlage immer mehr auf den Staat geworfen wurde, bis er das soziale Problem fast nur mehr vom Staate aus angreift und Kirche wie Christentum wieder in das Element des rein persönlichen und ethischen Lebens zurückverweist. (Wenck, »Geschichte der NationalSozialen« 1905.) Umgekehrt fordert die katholische Sozialpolitik in erster Linie die Unterstellung des Staates unter kirchliche Gesichtspunkte. Vgl. Theod. Meyer, >Die christlich-ethischen Sozialprinzipien«, 1904. Das heißt dann die sorganische $d$ d. i. theokratisch vereinheitlichte Theorie. Das Unterscheidende der christlichen Soziallehre sliegt darin, daß die christliche Idee des gesellschaftlichen Organismus jede absolutistische Willk ür des zentralen Prinzips (d. h. des Staates) naturgemäß und organisch a us schließt, während die nichtchristliche Idee dieselbe ebenso naturgemäß und wesentlich einschließt $\propto$. Das geht gegen den Absolutismus nicht der Regierungsform, sondern des Staatsprinzips selbst. Ebenso kommen umgekehrt die Konservativen zu keiner energischen Sozialpolitik, weil sie in der politischen Passivität des Luthertums nicht wagen den Staat zur Reform zu nötigen, abgesehen davon, daß ihr eigenes politisches Interesse großenteils mit dieser Passivität zusammenfällt. Ueber die Zuweisung der Kirchen zur ¿Gesellschaft « als Konsequenz des modernen Staatsbegriffes vgl. Troeltsch, >Die Trennung von Staat und Kirche $\ll$, I907, S. 23-48.

70) Z. B. von dem christlichen Sozialismus St. Simons, der dio jedem positiven Sozialsystem nötige metaphysisch-religiöse Grundlage in dem christlichen Gemeinschaftsgedanken proklamierte, dabei übrigens sich darüber klar war, daß sein nouveau christianisme dann auch wirklich ein neuer, das heißt die Werte des Weltlebens viel offener anerkennender sein müsse. (v. Stein, Sozialismus und Kommunismus, S. I74.) Immerhin aber fließt auch so die christliche Brüderlichkeit mit dem sehr unbestimmten Egalitätsprinzip als dem sozialen Prinzip überhaupt zusammen. Die Geschichtswidrigkeit gerade dieser Identifikation wird das Folgende deutlich zeigen. 
dem sozialen, d. h. soziologischen Wesen der Kirche schon soziale d. h. dem Leben der Gesellschaft und des Staates angehörende Probleme gelöst zu haben, mit der Liebesorganisation einer aus Gott quellenden und zu ihm zurückkehrenden Liebe schon die menschlichen Gemeinschaften überhaupt zu umfassen. Davon kann aber keine Rede sein; ja jede solche Meinung wird das Verständnis der wirklichen geschichtlichen Bedeutung des Evangeliums und seiner Entwickelungsgeschichte verdunkeln, und all die häufigen Reden vom *sozialen Geiste des Christentums * enthalten diese Zweideutigkeit auch für die Gegenwartsprobleme. Sie sind nicht notwendig falsch, aber vieldeutig und irreführend.

Damit sind für unsere Untersuchung die Richtlinien gegeben. Wir werden überall zuerst zu fragen haben nach der eig e $\mathrm{n}$ e $\mathrm{n}$ soziologischen Idee des Christentums und deren $A$ usbau und Organisation. In ihr wird dann immer ein über đie Grenzen der eigentlich religiösen Gemeinschaft oder Kirche hinausstrebendes Ideal von einem allgemeinen Grundschema menschlicher Lebensbeziehungen überhaupt enthalten sein; aber das Problem ist dann erst, wie weit dieses Grundschema in andere Verhältnisse eindringt, wie es auf sie wirkt, wie es von ihnen rückwirkend seinerseits beeinflußt wird, und wie weit in alledem eine innere Einheitlichkeit des Lebens zu Stande kommt und zu Stande kommen kann. Wir werden daher dann weiter zu fragen haben nach dem Verhältnis dieser soziologischen Bildung zum Sozialen, d. h. zu Staat, ökonomisch-arbeitsteiliger Gesellschaft und F a mili e. Selbstverständlich wird in der geschichtlichen Wirklichkeit das letztere stets vom ersteren aus behandelt und reguliert, aber die Probleme liegen dann eben immer gerade darin, welches die wirklichen Einwirkungen des soziologischen religiösen Grundschemas auf andere Lebenskreise waren, welche Einflüsse damit tatsächlich von den Kirchen auf soziale Phänomene ausgegangen sind und welche Einwirkungen umgekehrt die religiöse Gemeinschaft von den politisch-sozialen Bildungen erfahren hat $\left.^{8}\right)$, wie weit schließlich dabei eine innere Berührung und Duici.

$\left.{ }^{8}\right)$ Ein glänzendes Beispiel für die letztere Fragestellung mit besonderer $\mathrm{Zu}$ spitzung auf das ökonomische Gebiet ist Max Webers bekannte Abhandlung -Die protestantische Ethik und der Geist des Kapitalismus\&, Jg. 1903/04 dieses Archivs, die Andeutung eines Beispiels für die erstere desselben Gelehrten Aufsatz: sKirchene und sSektenc in Nordamerika, Christl. Welt 1906, S. $55^{8} \mathrm{ff}$., $577 \mathrm{ff}$. 
dringung möglich gewesen und wie weit daraus eine in ne re Einheit lichkeit des Gesamtlebens hervorgegangen ist $^{9}$ ). Im Altertum ist das nie erreicht worden; im Mittelalter und in seinen reformatorischen Tochterkirchen ist es verwirklicht worden, wenigstens in Ideal und Theorie; in der modernen Welt ist der Zwiespalt wieder aufgeklafft. Aus diesen dem Blick sich unmittelbar so darbietenden Bildern von Altertum, Mittelalter und Konfessionen, und schließlich moderner Welt ergibt sich die Teilung des Stoffes. In erster Linje aber wird das Evangelium und die Bibel selbst sowie die alte Kirche zu betrachten sein; sie schaffen die dauernde Grundlegung.

I.

Die Grundlagen in der alten Kirche.

I. Das Evangelium.

Für das Verständnis der gesamten Grundrichtung des Christentums in ihrem Verhältnis zu den sozialen Problemen ist entscheidend die Erkenntnis, daß die Predigt Jesu und die Bildung der neuen Religionsgemeinde keine $\mathrm{Sch}$ öpfung einer so $z$ i a len Bew egung is t, das heißt nicht aus irgend einem Klassenkampf hervorgegangen oder auf ihn zugeschnitten ist und überhaupt nirgends direkt an die sozialen Umwälzungen der an-

9) Das sind dann die prinzipiellen Fragestellungen vom ethischen, theologischen oder kulturphilosophischen Interesse und Standpunkt aus, während die vorhin genannten Beispiele Max Webers dem rein Tatsächlichen zugewendet sind, und zwar vom Standpunkt und Interesse der Wirtschafts- und der Sozialgeschichte aus. Eine Arbeit wie die von v. Schulze-Gävernitz, \Britischer Imperialismus und englischer Freihandel « 1906 faßt beide Gruppen von Fragestellungen zusammen. Für die vorliegende Arbeit kommt es wesentlich auf die zweite Gruppe an, weil diese Fragestellung das eigentliche Grundinteresse der kirchlichen Soziallehren bildet, während die Untersuchungen über das faktische Verhalten und Wirken der christlichen Ideemächte gegenüber den politischen und ökonomischen Lebenskreisen nur als Voraussetzungen für die Beantwortung dieser prinzipiellen Frage in Betracht kommen. Meine Arbeit verfügt bezüglich jener Probleme des faktischen Verhältnisses nur in sehr beschränktem Maße über eigene Quellenforschung, am wenigsten bezüglich der alten und mittelalterlichen Kirche. Ihr etwaiges Verdienst liegt überhaupt nicht in selbständiger Quellenforschung, sondern in selbständigem Durchdenken der aus der jeweiligen Lage und Konstellation der Interessen erfolgenden Vereinheitlichung des Ganzen zu einer Theorie der Stellung des Religiösen zum Politisch-Sozialen. Doch hoffe ich für die Tatsachenfragen mich überall an die besten Darstellungen gehalten zu hat,en. 
tiken Gesellschaft anknüpft. Dic Tatsache freilich steht fest, daß Jesus wesentlich an die Gedrückten und Kleinen sich gewendet hat, daß er den Reichtum für seelengefährlich hielt und dem jüdischen Priesteradel wie der herrschenden Theologenwelt feindlich gegenüberstand, daß ebenso die beginnende Kirche ihre Gläubigen tatsächlich wesentlich in den niederen Ständen der Städte suchte und fand, daß erst seit dem zweiten Jahrhundert die soziale Obersciiicht von Bildung und Besitz langsam in sie einmündete und daß das nicht ohne starke Reibungen sowohl mit der Bildung und Wissenschaft als mit dem Reichtum von statten ging. Allein ebenso fest steht die andere Tatsache, daß die gesamte altchristliche Missions- und Erbauungsliteratur innerhalb und ausserhalb des Neuen Testamentes von einer prinzipiellen sozialen Fragestellung nichts weiß, daß im Mittelpunkt überall rein die Fragen des Seelenheils, des Monotheismus, des Lebens nach dem Tod, des reinen Kultus, der richtigen Gemeindeorganisation, der praktischen Bewährung, der strengen Heiligkeitsgrundsätze stehen, daß von Anfang an keine Klassenunterschiede gemacht, sondern diese vielmehr in der großen Frage nach dem ewigen Heil und den inneren Gütern ausgelöscht worden sind. Insbesondere arbeiten alle apologetischen Empfehlungen nicht mit einer in Aussicht stehenden Verbesserung der sozialen Lage oder einer Heilung der sozialen Schäden, sondern mit rein theologisch-philosophischen oder mit ethischen Argumenten, welche letzteren sich gerade stets auf die Nüchternheit, Zuverlässigkeit, Arbeitsamkeit, bürgerliche Brauchbarkeit der Christen beziehen. Auch die große Erlösungshoffnung des kommenden Gottesreiches, von der Jesus seinen Ausgang nimmt und die über der ganzen Gemeinde liegt, ist nirgends ein vollendeter Sozialzustand, den nur an Stelle menschlicher Kunst die Wunderkraft Gottes herbeiführte, oder die Vertröstung irdischen Gesellschaftselends auf ein glückliches, ausgleichendes oder gar umkehrendes Jenseits, das den Besitzlosen im Gegensatz zu den jetzt herrschenden Gesellschaftsmächten durch das Evangelium gesichert würde; sondern es ist überall in erster Linie der ethische und religiöse Idealzustand einer rein von Gott beherrschten Welt, wo alle wahren Werte des reinen Innenlebens zu ihrer wirklichen Geltung und Anerkennung kommen werden; und, als dann später die kommende Erlösung zurücktritt hinter der bereits im Leben und Tod des Christus vollbrachten, da zeigten sich auch hier die Güter der Erlösung als 
rein innerliche, ethische und geistige, für welche eine leidlose Seligkeit nur die selbstverständliche Vollendung ist. Das ist die Grundtatsache, von der ausgegangen werden muß ${ }^{10}$ ).

10) Vgl. hierzu im allgemeinen Uhlhorn, Christliche Liebestätigkeit in der alten Kirche ${ }^{2}$, 1882, Harnack, >Dogmengeschichte ${ }^{3}$ und Harnack, $>$ Mission und Ausbreitung des Christentums in den ersten 3 Jahrhunderten ${ }^{2}$, 1906, welches Buch die besten mir bekannten Sammlungen zur Sozialgeschichte des Christentums enthält. Außerdem Möller-v. Schubert, "Lehrbuch der Kirchengeschichte I I, 1904; Duchesne, "Historie ancienne de l'église«, 1907; Weizsäcker, „Das apostolische Zeitalter « ${ }^{3}$ 1902; Knopf, „Das nachapostolische Zeitalter «, 1905; Th. Keim, >Rom und das Christentum», 188I ; Gierke, „Das deutsche Genossenschaftsrecht «, III 1887, wo die christliche Korporationsidee ausgezeichnet entwickelt ist. - Vgl. auch die Rede A. Harnacks auf dem Ev.-sozialen Kongreß 1894, Die ev.-soziale Aufgabe im Lichte der Kirche (Reden und Aufsätze, 1904). - Die Gesamtstellung in der Antike zeichnet jetzt vortrefflich P. Wendland, „Die hellenistisch-römische Kultur«, 1907, wo jedoch die Sozialgeschichte absichtlich beiseite gelassen ist.

In allen bisher genannten Werken ist die Auffassung zugrunde gelegt, daß es sich um eine in erster Linie religiöse Bewegung handelt. Es fehlt aber auch nicht an solchen, die das Christentum zu einer rein sozialen Bewegung machen. Pöhlmann, »Gesch. d. antiken Sozialismus und Kommunismus«, I893/1901 wollte ursprünglich das Christentum als die Ausmündung des antiken Sozialismus schildern. Es stelle in seiner Gottesreichshoffnung dem sich philosophisch resignierenden und faktisch vom Imperium unterdrückten Sozialismus die psychologischen Motive und Kräfte zur Verfügung, die den rein politisch-sozialen und den philosophischen Bemühungen ausgegangen wären, II 583-617. Allein er hat es bei dieser Andeutung bewenden lassen und die Ausführung nicht unternommen, vermutlich weil die These sich als nicht so leicht durchführbar erwies. Sie beruht auf einem Mißverständnis der Gottesreichsidee, die schlechterdings keine politisch-soziale Erneuerung bedeutet, worüber weiteres später. - Die gleiche Yoraussetzung macht selbstverständlich $\mathrm{Ka}$ u t s $\mathrm{ky}$ in seinem Beitrag zu der Geschichte des Sozialismus in Einzeldarstellungen «, I 1, 1895 S. 16-40. Auf Grund der „geschichtsmaterialistischen Methode kann er im Christentum nur eine aus den Gesellschaftszuständen des römischen Reiches hervorgegangene kommunistische Bewegung sehen, eine Reaktion gegen das pauperistische Massenelend, das durch Verdrängung der Bürger aus Landbesitz und Handwerk, durch die Konkurrenz der mit Sklaven betriebenen Plantagen- und Fabrikarbeit bewirkt ist und das in der Staatsfütterung dieses deklassierten und arbeitslosen Lumpenproletariats zum öffentlichen Ausdruck kommt. Aus diesem vom antiken Kapitalismus bewirkten Elend suchten enthusiastisch veranlagte Elemente den Ausweg durch das Wunder; der Erlöser Christus sollte die ideale kommunistische Gesellschaft durch eine göttliche Welterneuerung herbeiführen, wofür besonders die Apokalypse als Beleg dient, die nur freilich gar keine kommunistischen $Z$ üge trägt, sondern nur den $\mathrm{Haß}$ gegen die sündige Welt und das Römerreich ausspricht. Aus diesem bald verblaßten chiliastischen Enthusiasmus ging Troelts ch, Gesammelte Schriften. I. 
Sic hat ihre weitere Frläutcrung und Bestätigung daran, daß auch die parallelen Kulte und religiösen Vereinsorganisationen, aber dann auch bereits fiir das Diesseits eine praktisch-kommunistische Wirkung hervor. lis ergibt sich in dem großstädtischen christlichen Proletariat, das eben damit an dic Stadtwirtschaft gebunden bleibt und auf das Privateigentum auf der erreichten wirtschaftlichen stufe noch nicht verzichten kann, ein Kommunismus lediglich der Konsumtion und Verteilung, wozu das Vorbild der Staatsfütterungen anleitete. Die Produktionsmittel werden in Genußmittel verwandelt und an die Armen verteilt. Daher der durchgehende Widerspruch in diesem Kommunismus auf der Grundlage des Privateigentums, der eben deshalb dann auch zugrunde geht und nur theoretisch in den Deklamationen der Kirchenväter fortbesteht, unter denen besonders Chrysostomus hervorgehoben wird. Das Christentum muß so die gegebene Gesellschaftsordnung bestehen lassen und vermehrt sie nur durch eine neue Herren-Klasse, den Klerus und den kirchlichen. Grundbesitz, deren Aufkommen aus der Schwächlichkeit solcher Demokratie des bloßen Enthusiasmus wohl verständlich ist. Es ist der (äsarismus der Bischöfe. In ihrem Zusammenschluß entsteht die katholische Kirche, und so wird aus einer kommunistischen Anstalt die riesenhafteste Ausbeutungsmaschine, die die Welt gesehen hat\&, S. 34. In den germanischen Vülkerwanderungsstaaten hört mit der Geldwirtschaft auch das antike Massenelend auf, und die Kirche wird im Zusammenhang mit dem Lehenswesen und dem Grofgrundbesitz eine rein poiitische Institution, der Sammelpunkt der herrschenden Schicht. Damit verschwindet auch die Liebestätigkeit des alten Kommunismus; die vurbleibende Liebestätigkeit ist nur die allen naturalwirtschaftlichen Stufen eigene Freude an der Mitteilung des Ueberflusses, den man selbst nicht aufessen kann. In dem dann im Spätmittelalter der moderne Kapitalismus entsteht und das Problem des Massenelends von neuem aufwirft, entsteht jetzt die neue kommunistische Bewegung, aber dieses Mal nicht auf dem Boden eines arbeitslosen Lumpenproletariats, sondern auf dem der für die Produktion unentbehrlichen freien Lohnarbeiterschaft. Damit ist die Rolle der Kirche als Vertreterin des Sozialismus röllig zu Ende, nur die Klöster bleiben mit dem bei solchen Institutionen üblichen Konservatismus bei den Resten des alten Kımmmi:ma und seiner Liebestätigkeit stehen. Diese Darstellung Kautskys rcrkennt frcilich gröblich dic selbständige Bedeutung religiöser Ideen, ist aber abyc rehell davon nicht ganz ohne Wert, indem sie auf sonst unbeachtete Seiten der Sache hinweist. Namentlich der geldwirtschaftliche Charakter der alten Kirche und der naturalwirtschaftliche der mittelalterlichen macht in der Tat einen wichtigen Unterschied aus, der nur anderswo liegt, als wo Kautsky ihn sieht. Darüber unten. - Aehnliche Wege geht Kalthoff, "Die Entstehung des Christentums $\propto$, 1905, nur daß seine Stellung zur Religion anders ist. Seine Voraussetzungen sind: I. die völlige Autonomie des religiösen Bewußtseins der Gegenwart, dessen Abhängigkeit von der Geschichte am radikalsten aufgehoben wird, wenn man nachweist, daß Jesus gar nicht existiert hat oder jedenfalls ein ganz obskurer iüdischer Enthusiast unter vielen seinesgleichens gewesen ist; es ist die radikale 
wie z. B. die Hauptmasse des sogenannten Gnostizismus oder die Mithrasmysterien sich nicht als soziales Klassenevangelium Vollendung der Biedermannschen Dogmatik, die hier der liberale Theologe vollzieht; 2. die Unmöglichkeit, aus den biblischen Wundergeschichten irgend einen Wahrheitskern herauszuschälen, und die Unmöglichkeit, die Verwandlung Jesu in das gottmenschliche Wesen bei Paulus zu erklären, während all das erklärbar wird, wenn es freie Dichtung des zweiten Jahrhunderts ist; 3 . die moderne kollektivistische, antiindividualistische und soziologische Geschichtsmethode, die den Ausgang solcher Bewegungen von einem oder mehreren Individuen nicht mehr glaubhaft erscheinen läßt und eine Erklärung aus sozialen Massenbewegungen verlangt. So ergibt sich die Entstehung des Christentums aus der stoischen Philosophie, den kommunistischen Klubs der Spätantike und dem messianischen Enthusiasmus der Juden, deren Mischung sich in Jesus einen Heros eponymos schuf und die biblische Literatur als Urgeschichte erdichtete. Die Leidens- und Todesspekulationen spiegeln den Leidens- und Siegesweg der Gemeinde. Die ganze Darstellung beruht auf völlig willkürlichen, zum Teil unrichtigen Voraussetzungen und ist in ihrem positiven Teil reine Phantasie. Vor allem aber ist von einer Schätzung der wirklichen Urkunden als relativ historisch-richtiger Ueberlieferungen sehr wohl zu einem verständlichen Zusammenhang zu gelangen. Der noch unaufgehellte Punkt ist nur die Entstehung der paulinischen Christuslehre, die aber doch in Wahrheit nicht ein Produkt der Kirchenbildung, sondern ihre offenkundige Voraussetzung ist. An dem Faktum ihrer Entstehung aus der Bekehrung des Paulus ist nicht zu zweifeln, was man auch sonst zu ihrer Aufhellung aus der außerchristlichen Welt noch heranziehen mag.

Allen solchen Versuchen ssozialer« Erklärung steht mit erfreulicher Klarheit gegenüber die Abhandlung von $\mathrm{O} v$ e r beck, Studien zur Geschichte der alten Kirche๔, 1875, über >das Verhältnis der alten Kirche zur Sklaverei im römischen Reiches. Es ist der Punkt, wo sich eine soziale Reformtendenz und ein Zusammenhang mit ihr am ehesten zeigen müßte. O. zeigt, wie im vollsten Gegensatze dazu die Sklaverei von Anfang an im Zusammenhang mit Staat, Gesellschaft, Wirtschaft und Familie als ein Stück der sündigen Welt gilt, die unabwendbar so ist, wie sie einmal ist. Sklaven nicht-christlicher Herren dürfen nur mit Einwilligung ihrer Herren Mitglieder werden, um jeden Zudrang von politisch und sozial Emanzipationslustigen $\mathrm{zu}$ verhindern (S. I88 und 202); ja die Sklaverei wird als zu den herkömmlichen Besitzverhältnissen gehörig vom Christentum geradezu gefestigt, wie denn später die Kirche selbst Sklaven hält und sie nicht einmal freilassen darf. Die Ueberwindung der Sklaverei ist rein innerlich und religiös, indem Herr und Sklave gleicherweise Christo zugehörig sind; beide sind religiös gleichberechtigt und die Sklaven in der Kirche am Anfang ämterfähig. Kommunistische Neigungen haben nur gnostische Sekten und werden daher stark bekämpft. Näheres unten. Aber diese ganze, mit der Möglichkeit freier Bewegung der Kirche sich eher verschärfende als mildernde rechtliche Anerkennung der Sklaverei und ihre Auffassung als wesentlicher Bestandteil der Ordnung ist eine schlagende Widerlegung. 
oder als Ueberwindung sozialer Schäden geberden, sondern als Anstalten höherer Theologie, kräftigerer Weihen, gesicherten Seelenheils ${ }^{11}$ ). Wenn unter den Gnostikern sich kommunistische Gruppen, vor allem die übrigens dem Christentum ganz fern stehenden Karpokratianer, finden, so ist auch das auf den eigenen Zirkel beschränkt und kein Programm allgemeiner sozialpolitischer Reform. Weithin richtet sich seit dem zweiten Jahrhundert der Sinn auf das Transszendente, aber der Drang organisatorischer Weltverbesserung ist ermüdet. Es ist das auch durchaus nicht verwunderlich. So tief erschütternde Klassenkämpfe die antike Welt seit dem peloponnesischen Kriege und seit der Reformbewegung der Gracchen erlebt hatte und so weitgreifende sozialpolitische, ökonomische, staatssozialistische, kommunistische und anarchistische Ideale dabei, die demokratische Politik und die philosophische Reflexion und Literatur hervorgebracht hatten ${ }^{12}$ ),

11) Vgl. Wendland; Ziebarth, „Das griechische Vereinswesen «, 1896. Die religiüse Form dieses besonders in der hellenistischen und Kaiserzeit üppig wuchernden Vereinswesens stammt davon her, daß das griechische Denken den Verein nur in der Form einer um einen Kult gruppierten dauernden Gemeinschaft denken konnte, wobei diese religiöse Form oft völlig äußerlich ist; eine religiöse Bewegung stellen sie daher an sich durchaus nicht dar. Die mit der Entnationalisierung und dem Verkehr sich steigernden, wirklich religiösen Zwecken dienenden Vereine sind teils zur Sammlung von Landsleuten in der Fremde, teils zur Aufnahme neuer Kulte bestimmt und entfalten eine soziale Bedeutung insofern, als sie einen engen familienhaften Zusammenschluß und die Aufhebung der Standesunterschiede in der Anteilnahme am Kult bedeuten, sind daher in einem Zeitalter des steigenden Individualismus auch aus diesem Grunde gesucht; aber sie lassen, genau wie die Christengemeinde, die sozialen Unterschiede außerhalb des Kultes bestehen; auch hebt Z. an diesen Kultvereinen gerade die Beteiligung der oberen Klassen hervor, $\therefore$. 2 10. Von skommunistischen Klubs «, die der Mutterboden des Christentums nach Kalthoff gewesen sein sollen, ist daner nicht die Rede; daher muß auch K. zugeben, daß in ihmen snoch soziale und religiöse Lebenstriebe in völliger Einheit zusammenleben $\star$, S. 83. Aber für Kalthoff ist die Synagoge kommunistisch, ist Johannes der Täufer kommunistisch!! Außerdem bedenke man das aufs strengste gehandhabte Verbot der Kaiser gegen alle politischen oder politisch verdächtigen Vereine und das beständige Bestreben der Christen, die politische Unschuld ihrer Vereine zu beweisen, vgl. Neumann, „Der römische Staat und die allg. Kirche», I 1890.

12) Vgl. die Darstellung bei Pöhlmann. Die verdienstliche Arbeit muß freilich, wie mich Max Weber belehrt, mit Vorsicht benützt werden. Sie arbeitet zu sehr mit modern sozialistischen Kategorien, obwohl deren Voraussetzung, eine neu 
mit den hellenistischen Reichen und dann mit dem Imperium des Cäsarismus war die fiebernde Zeit dieser Kämpfe in der ' Hauptsache beschlossen, kehrte Ordnung und Gedeihep wieder, verringerten sich die Umwälzungen und Deklassierungen, die verelendende Ausbeutungspolitik und die Unsicherheiten des Erwerbs. Die eiserne Festigkeit der Monarchie teilt sich dem ganzen Gedanken der sozialen und politischen Ordnung mit, und die freie Bewegung zieht sich auf das eigene Innenleben, die ethische und religiöse Reflexion zurück. Die Verringerung der Sklavenmärkte als Folge des Friedens läßt einen Mittelstand wieder aufkommen. Die lange so heiß gesuchte soziale Gerechtigkeit liegt in den Händen der Kaiser, und die große humanitäre Schule der Stoa, die das volle Ideal nur in der Urzeit als verwirklicht ansah, lehrt sich teils in die Lage und ihre mannigfache Beschränkung ergeben, teils beeinflußt sie die kaiserliche Gesetzgebung zu Gunsten wohltätigster Reformen ${ }^{13}$ ). Zwar ist die Sozialgeschichte der Kaiser-

sich emporkämpfende Klasse, überhaupt fehlt. Es gibt keinen Großbetrieb und keine Fabrik. Nur in der Landwirtschaft haben die Karthager und nach deren Vorbild die Römer den Großbetrieb organisiert, damit auch die Sklavenkaserne. Eine Fabrikindustrie dagegen gibt es nicht, weil eine solche mit Sklaven überhaupt nicht zu betreiben ist und der freie Handwerker sich dazu nicht hergab. So fehlen die Grundlagen einer sozialistischen Bewegung. Die Kämpfe spielen sich vielmehr innerhalb der herrschenden Schicht ab und sind mehr demokratisch als sozialistisch, wobei sich das wirtschaftliche Motiv ja von selbst versteht. Es sind stets die alten Klassen, die miteinander kämpfen, und die Macht und Besitz neu zu verteilen streben. P. überschätzt die Bedeutung der Staatsromane, und geht zu wenig auf das Praktische ein. Wenn auch Eduard Meyer in seinen viel zutreffenderen Darstellungen von „Fabrik redet, so bestreiten das die Nationalökonomen, die im übrigen den Historikern zugegeben haben, daß der Umfang der Geldwirtschaft und der freien Lohnarbeit größer war, als die Nationalc̈konomen bis dahin anzunehmen geneigt waren.

13) Wendland; Mommsen, Römische Geschichte Band V; L. Hahn, sRom und Romanismus im griechisch-römischen Osten«, Igo6; Pöhlmanı weiß hier in Wahrheit nur von der sich auf die Utopie und die Urzeit zurückziehenden sozialphilosophischen Romantik der 'Gebildeten zu berichten und fügt hinzu: >Drängt sich hier nicht ganz von selbst der Gedanke auf: Wenn schon in den gebildeten Kreisen der römischen Gesellschaft eine derartige Illusionsfähigkeit, ein solcher Utopismus möglich war, zu welchen Phantasieen mag sich dann vollends die revolutionäre Ideologie des Proletariers verstiegen haben«, II 606 I Das ist eine sehr bedenkliche Argumentation, wenn man ein solches Proletariat nicht auch zu zeigen hat; es scheinen nach S. $616 \mathrm{f}$. die Christen sein zu sollen, deren tausendjähriges Reich 
zeit noch wenig durchforscht und hat sich in ihr der Prozeß der Aufösung der antiken Gesellschaft nur verlangsamt. Allein mit den wichtigsten sozialgeschichtlichen Vorgängen der Kaiserzeit, dem Schwinden des Bauernstandes, der Verringerung des Sklaventestandes, der Verwandlung der Sklaven in Hörige, der Verlegung des Kapitals auf den Großgrundbesitz, der Zurückziehung des Schwergewichtes von den Küstenstädten in das Binnenland, der völligen Veränderung des Heerwesens und des Beamtenwesens, dem schließlichen Rückfall in die Naturalwirtschaft ${ }^{14}$ ) haben gerade die

dem sozialen Menschheitsstaat Zenos entsprechen und der $\gg$ religiösen Erscheinungsform des antiken Sozialismus angehören soll. Davon wissen aber die christlichen Urkunden selber lediglich nichts.

14) Ueber die Sozialgeschichte der Kaiserzeit vgl. Max Weber, „Agrargeschichte (Altertum)* im HWB. der Staatswissenschaften und \$Wahrheit (Stuttgart 1896) S. 57-77 Ueber die sozialen Gründe des Untergangs der antiken Kulture; Eduard Meyer, „Die wirtschaftliche Entwickelung des Altertums«, 1895, .Die Sklaverei im Altertum», 1897 und „Bevölkerung des Altertums" im HWB. d. Staatsw.; U. Wilcken, $\rtimes$ Griechische Ostraka aus Aegypten und Nubien «, I 1899 S. 664-704. Stark abweichend von diesen Darstellungen Uhlhorn, >Liebestätigkeit «, S. 93-113, 213-238. Was Weber schildert, die Entstehung und Auflösung eines auf Sklavenarbeit und -Kasernierung beruhenden großkapitalistischen Plantagen- und Grundbesitzerwesens, das zugleich von der Küste ins Binnenland sich zurückzieht, damit die bisherigen Träger der dünnen geldwirtschaftlichen Verkehrskultur verkümmern läßt und durch seine Konkurrenz ein arbeitsloses Hungerproletariat von Freien schafft, das gehört der westlichen Entwickelung an und bedeutet durch Entziehung des Verkehres auch für Griechenland das Wachstum eines solchen Proletariats. In den Kasernensklaven des Großbetriebs wird das Christentum aber wenig Möglichkeit des Eindringens gefunden haben; erst als mit dem Eintritt des Sklavenmangels der Sklave zum hörigen Kolonen gemacht und damit der Familie und dem Privateigentum zurückgegeben wird, setzt das Christentum bei ihnen ein. „Dies geht der siegreichen Entwickelung des Christentums parallel: in den Sklavenkasernen hätte es schwerlich Boden gefunden, die unfreien afrikanischen Bauern der Zeit Augustins waren bereits Träger einer Sektenbewegung « (Wahrheit 68). Die christlichen Sklaven werden daher wohl meist der nicht allzugroßen Kategorie der Haussklaven angehört haben oder auch der Kategorie derjenigen, die irgend ein Geschäft im Auftrag und mit den Mitteln ihres Herrn betreiben und so zwar rechtlich Sklaven blieben, aber ökonomisch und persönlich ein erhebliches Maßs von Selbständigkeit genossen. Ein Beispiel ist der bekannte Kalixt, dér ein solches Bankgeschäft betrieb und dann trotz seiner geschäftlichen Hallunkenstreiche es bis zum Bischof und Papst brachte; das ist nur eine andere Form des Yittelstandes. Wie es dagegen mit dem frelen Hungerproletariat (dem Lumpenproletariat Kautskys) und seinen Beziehungen zum Christentum steht, ist schwer zu sagen. 
christlichen Gemeinden des Anfangs sehr wenig zu tun, die während der ersten Jahrhunderte den unteren Schichten der Städte

Die Spuren davon müßten sich in den Nachrichten über. die Liebestätigkeit finden und hier finden wir in der Tat die Maxime, Arbeitsunfähige zu unterstützen, Arbeitslosen Arbeit zu verschaffen (Harnack, Mission I 150 f.), wobei sich das letztere auf solches Proletariat beziehen mag, übrigens aber vor allem Schutz gegen arbeitsscheue Elemente ist. Auch darf man an die Notitz denken, daß Rom ca. 250 gegen 1500 Hilfsbedürftige jährlich zu ernähren hatte (H. I I36). Aber jedenfalls bildet diese Arbeitsbeschaffung kein Zentralanliegen der Gemeinde und wäre ein Erfolg im großen Stil kaum möglich gewesen, sodaß man daraus den Rückschluß auf eine nicht allzu zahlreiche Beteiligung dieses Proletariats ziehen muß; und nirgends handelt es sich dabei um eine Ermunterung oder Vertröstung etwaiger revolutionärer Klassenhoffnungen. Ueberdies betrifft all das wesentlich nur den Westen. Zudem ist die römische Gemeinde bis Ende des zweiten Jahrhunderts wesentlich griechisch, hat also mit deklassierten italischen Bauern und Handwerkern wenig $z u$ tun. Erheblich anders liegen die Dinge im Osten, wo doch das Schwergewicht der Gemeinden, ihrer Literatur und Ideenbildung lag. Hier überwiegt die die Grenze von Stadt und Dorf nivellierende Geldwirtschaft und gibt es einen ausgedehnten kleinen Mittelstand der freien Arbeiter neben der nicht allzu ausgedehnten Haussklaverei. In den Kreisen solchen Mittelstandes wird wohl die Hauptmasse der Christen zu suchen sein, deren sozialer Charakter somit städtisch und überwiegend geldwirtschaftlich wäre, ohne daß davon die Dörfer allzuweit abstünden. Die Nachrichten über die stark in Geldzahlungen sich bewegende Liebestätigkeit lassen etwas Aehnliches übrigens auch für das Abendland erschließen (Harnack I 127-172); welche Rolle daneben die Naturalunterstützung in Gastfreundschaft, Aufnahme in Dienst und Arbeit, Darbringung von Lebensmitteln und Naturalgaben bei den Agapen (Uhlhorn I I38) gespielt hat, ist nicht zu ermitteln; sie waren schwerlich die Hauptsache. So bewegt sich das Christentum ein Jahrhundert lang in den Kreisen, die von der großen sozialen Umwälzung noch wenig herührt werden. Das Gesamtergebnis der Umwälzung, die man als Aufzehrung des Bauernstandes durch die antike Stadtkultur und Wiederauflösung dieser Stadtkultur durch die Anlage des Kapitals im Großgrundbesitz bezeichnen kann, ist dann freilich die Rückkehr zu überwiegender Naturalwirtschaft und den damit zusammenhängenden festen primitiven sozialen Gliederungen sowie zur Feudalität, wodurch im Westen das. Reich in die mittelalterliche Naturalwirtschaft übergeht, im Osten ein stark naturalwirtschaftlich bedingter, in erblichen Kasten geschlossener Beamtenstaat entsteht. Die christliche Gemeinde ist von diesem Prozeß offenkundig nicht erzeugt, höchstens durch die ihn begleitenden Empfindungen eines materiellen Niedergangs und versorgungsbedürftiger Massen gefördert. Als sie aus dem kleinen Mittelstande und der Masse zur Aufnahme auch der Oberschicht aufgestiegen war, wurde sie dann von den Folgen wie alle übrigen betroffen und hat dann den Staat und das herrschende System gestützt, ist als eine durchaus konservative Macht in die vom Staat allein nicht mehr lösbare 
und ihrem allmählich wieder beruhigten Erwerbsleben angehören, ihren Schwerpunkt in dem sozial viel weniger zerklüfteten Osten haben, mehr mittelständische als eigentlich proletarische Züge tragen und bei aller Hoffnung auf das Kommen der neuen Welt doch eifrigst für Ruhe und bürgerliche Brauchbarkeit sorgen. Ueberdies hat es im Altertum, wo die Bauern wenigstens fiktiv Bürger waren und ihre Interessenkämpfe in den bürgerlichen Parteikämpfen mit ausfochten, wo es keine Fabrikarbeit im modernen Sinne und damit keine große freie Lohnarbeiterschaft gab, zu einer großen sozialen Emanz̧ipationsbewegung, zum Aufsteigen einer neuen Klasse, gar nicht kommen können. Die Kämpfe sind stets politisch-demokratische Kämpfe und drehen sich um Landverteilung und Schulderleichterung; die Fortdauer der untersten Schicht als Sklavenschicht wird dabei von allen vorausgesetzt. Die Humanisierung des Sklavenloses hat praktisch nie. eine Emanzipation bedeutet. So fehlt auch abgesehen von

Aufgabe der Bekämpfung des Elends eingetreten. Aber das beginnt erst mit dem dritten Jahrhundert. 'Vgl. die Ergebnisse, die Harnack aus seinen statistischen Untersuchungen zieht (Mission II 276-287). „Das Christentum war Städtereligion: je größer die Stadt, desto stärker - wahrscheinlich auch relativ - die Zahl der Christen. Daneben aber war es in einer großen Anzahl von Provinzen bereits (um 300) tief in das Land eingedrungen: wir wissen das bestimmt in Bezug auf die Mehrzahl der kleinasiatischen Provinzen, ferner in Bezug auf Armenien, Syrien und Aegypten, auf Teile von Palästina und auch Nordafrika.. S. 278. Der große Unterschied der Ost- und Westhälfte des Reiches springt vor allem in die Augen. Trennt man aber gar noch Griechisch und Lateinisch, so steigt jener Prozentsatz noch höher. Die Erklärung ist einfach genug: eine griechische Christenheit hat es seit dem apostolischen Zeitalter gegeben, eine nennenswerte lateinische wahrscheinlich erst seit den Zeiten Mark Aurels\&, 282. Dabei erweisen sich die Christengemeinden überall als Träger des Hellenismus, ses ist aber nicht der ägyptische, sondern der kleinasiatische Hellenismus mit seinen bis auf die persische Kultur zurückreichenden Elementen und Erinnerungen, der die Führung übernahme, 283. Auch das zeigt, daß man nicht in erster Linie mit dem italischen Lumpenproletariat $\mathrm{zu}$ rechnen hat. - Viel interess ante Einzelheiten bei Uhlhorn, aber die Gesamtanschauung, daß die Sklavenarbeit die freie Arbeit erdrückt und den Pauperismus geschaffen habe, den das Christentum durch Liebestätigkeit und Adelung der Arbeit wieder habe überwinden wollen, daß es dann aber an der Unüberwindlichkeit des Gegensatzes gescheitert sei und darüber der Askese sich ergeben habe, trifft für die ersten Jahrhunderte nicht zu, wo im Gegenteil Besserung eintrat. Erst das vierte Jahrhundert bringt den Staatsbankerott und das steigende Elend. 
der mit dem Kaisertum eintretenden Beruhigung überhaupt eine emanzipationsbedürftige Klassenbewegung; die verschiedenen philosophischen Theorien und Staatsromane bedeuten wohl ethisch - und innerlich eine Milderung der Gegensätze, aber kein praktisches Aufsteigen einer neuen Klasse. Auch die soziale Zusammensetzung der Gemeinden schließlich darf man sich keineswegs als eine rein klassenmäßig bedingte vorstellen. Freilich bestanden die Gemeinden in der Hauptsache lange aus Sklaven, Freigelassenen und Handwerkern, wobei man aber, wie Overbeck richtig bemerkt, angesichts der überhaupt vorhandenen Sklavenzahl und angesichts der Vorsicht in der Aufnahme von Sklaven deren Beteiligung nicht übertreiben darf; jedenfalls war für Fernhaltung emanzipationslustiger Sklaven ausdrücklich gesorgt. Aber schon vom ersten Anfang an haben Mitglieder der Oberschicht nicht gefehlt, sie haben wohl hauptsächlich die nötigen Mittel und die Versammlungsmöglichkeit beschafft. Unter Domitian drang das Christentum bis in die obersten Hofkreise, und der berühmte Brief des Plinius spricht ausdrücklich von multi omnis ordinis. Seit Commodus ist dann die Beteiligung der Oberschicht in starkem Steigen. Alles das ist nicht mehr als natürlich unter der Voraussetzung, daß es sich um eine wesentlich religiöse Bewegung handelt, und ein klarer Gegenbeweis gegen die Meinung, daß es sich um eine "Klassenbewegung des Proletariats * oder um eine religiöse »Umformung des antiken Sozialismus * handele ${ }^{16}$ ).

So ist das Aufkommen des Christentums nicht aus der Sozialgeschichte, wohl aber aus der Religionsgeschichte des Altertums zu verstehen. Das religiöse Leben hat eben bei aller Verflechtung in das übrige Leben doch seine eigene Entwicklung und eigene Dialektik. Die Zertrümmerung der nationalen Religionen, die sich mit dem Verlust der nationalen Selbständigkeit von selbst ergab, die Völkermischung, die ganz von selbst auch die Kulte durcheinander würfelt, die Entstehung rein innerlicher, von Nation und Geburt unabhängiger Mysterienkulte, die Vermischungen der von ihrem alten Nationalboden gelösten Religionsfragmente, die philosophische Religion. der Bildung mit ihren

15) Ueber die soziale Zusammensetzung vgl. Keim 164, 319, Overbeck I88; bes. Harnack, Mission ${ }^{2}$ II 25 ff. und Bigelmair, Die Beteiligung der Christen am öffentlichen Leben «, 1902, S. 208-226, Knopf, >Die soziale Zusammensetzung der ältesten heidenchristlichen Gemeinden, Z. f. Theol. u. Kirche 1900 und Knopf, >Nachapost. Zeitalters, S. $64 \mathrm{ff}$. 
mannigfachen Angleichungen an die Volksreligionen, das Bedürfnis des Weltreiches nach einer universalen Weltreligion, dem der Kaiserkult doch nur sehr äußerlich genügte, die außerordentliche Vertiefung und Verinnerlichung des ethischen Denkens in einer vierhundertjährigen Geistesgeschichte von beispiellosem Reichtum an Kritik und Selbstvertiefung, die mit alledem verbundene Auflösung des Polytheismus, seines Mythus und seines Kultus und das Verlangen nach einer letzte, ewige Werte darbietenden Religiosität: das alles bedeutet als Abschluß der Antike die Heraufführung eines neuen Zeitalters religiöser Produktivität und Reizbarkeit. Das Altertum endet mit einer vielfachst begründeten, in letzter Linie aber aus der Verinnerlichung und Ethisierung des religiösen Denkens hervorgehenden Zersetzung der Volksreligionen und in einer gewaltigen, von allen Seiten zusammenströmenden religiösen Neubildung $^{16}$ ). Der letzte Grund von alledem aber ist die eigene selbständige Kausalität des religiösen Gedankens selbst. Aus diesem Zustande ist das Christentum hervorgegangen, und das Erbe dieses Zustandes hat es in das große weite Sammelbecken der Kirche aufgesammelt, indem es all das um seine leitenden Grundgedanken, so gut es ging, gruppierte.

Ist es aber derart aus der inneren religiösen Entwickelung des Altertums zu verstehen, so erklärt sich damit zugleich auch seine zuerst erwähnte $R$ ichtung a u die un teren $\mathrm{Klas}$ s e $\mathrm{n}$ und sein Hervorgehen aus diesen. Nicht aus der angeblichen Herausbildung aus einem sozialen Prozesse, sondern gerade aus dem Wesen religiöser Neubildungen erklärt sich diese Haltung. Solche Neubildungen vollziehen sich auf doppelte Weise. Sie gehen aus von den Höhen der Bildung und Reflexion und greifen um sich als Kritik und als Spekulation; sie sind um so bedeutsamer, je tiefere wirkliche religiöse Lebensgehalte in diese Formen der Kritik und Spekulation eingehüllt sind. So sind Platonismus und Stoa eine Art religiöser Neubildung. Aber sle sind im wesentlichen doch Reflexion und Vernunftbeweise und erlangen damit niemals die spezifisch religiöse Kraft eines Offenbarungsglaubens, sie bleiben im Gefühl ihrer Schwäche teils haften am alten Volksglauben, den sie nur umdeuten, teils vertrauen sie sich der Kraft

16) Vgl. Ed. Meyer, >Volkswirtsch. Entw.\& 52. \Die (religiöse) Bewegung beginnt in der Mitte des ersten Jahrhunderts v. Chr., in der Zeit, wo der Abschluß der antiken Entwickelung zunächst im Osten, dann auch im Westen sich vorbereitet, der dann durch den Staat des Prinzipats seine definitive Gestalt erhalte. 
des abstrakten Beweises an, den jeder in stiller Auseinandersetzung mit ihnen sich selbst klar machen mag. Dagegen sind die eigentlich schöpferischen, gemeindebildenden religiösen Grundlegungen das Werk der unteren Schichten. Hier allein ist die Ungebrochenheit der Phantasie, die Einfachheit des Gemütslebens, die Unreflektiertheit des Gedankens, die Urwüchsigkeit der Kraft und die Heftigkeit des Bedürfnisses vereinigt, aus denen heraus der unbedingte Autoritätsglaube an eine göttliche Offenbarung, die Naivetät der Hingabe und die Intransigenz der Gewißheit sich bilden kann. Die Bedürftigkeit einerseits und die Abwesenheit der stets relativierenden Reflexionskultur andrerseits sind nur hier zu Hause. Alle großen gemeinschaftsbildenden Offenbarungen sind je und je aus solchen Kreisen hervorgegangen, und die Bedeutung und Entwickelungsfähigkeit des so gebildeten Religionskreises war stets abhängig von der Macht und Tiefe des in solcher naiver Offenbarung erteilten Anstoßes, wie andrerseits von der Energie der diesen Anstoß verabsolutierenden und vergöttlichenden Glaubensüberzeugung. Keineswegs immer kommt freilich solchen Bildungen eine wirklich tiefe innere Kraft zu. Aber wo das der Fall ist, da ist es die Eigentümlichkeit und Ueberlegenheit der Naivetät über die Reflexionskultur, daß sie die stärksten Kräfte entwickeln und die tiefsten Erkenntnisse finden läßt; und da kann es dann auch nicht ausbleiben, daß in der weiteren Entwickelung der zuerst naiv gegebene Lebensgehalt sich verbindet und verwickelt mit allen höchsten religiösen Mächten der daneben bestehenden Reflexionskultur; andernfalls würde er von ihr wieder zerbrochen werden. Eine solche Verbindung ist im Christentum vom zweiten Jahrhundert an immer stärker eingetreten, zum deutlichen Zeichen dafür, daß es sich in ihm um eine tiefe religiöse Macht handelt, die auch der Zusammenstoß mit der Reflexionskultur nicht zerbricht, sondern befruchtet und fortentwickelt. Aber seine Anfänge zeigen die Volkstümlichkeit und die Volksgebundenheit aller naiven Religion. Daher kommt es auch, daß von ihm nicht die vielberufene Senilität der Kaiserzeit gelten kann. Jesus selbst ist ein Mann des Volkes und sein Evangelium trägt deutlich die Spur der einfachen bäuerlich-kleinhandwerkerlichen Verhältnisse Galiläas. Nur die Armen und Demütigen fassen sein Evangelium leicht, den Reichen und den Theologen wird es schwer, weil sie nicht das Gefühl ihrer Bedürftigkeit haben, weil sie in ihrer Weisheit den Wald vor lauter Bäumen nicht 
sehen, weil ihre Herzen an zu vielerlei gebunden sind, um unbedingte Opfer bringen zu können; doch ist bei Gott kein Ding unmöglich, auch der Reiche kann noch selig werden und auch der Schriftgelehrte kann nicht weit vom Reiche Gottes sein. Aus solchen Kreisen stammen seine ersten Jünger und die erste um den Glauben an den Auferstandenen gesammelte Gemeinde, die übrigens. ausdrücklich nicht als besitzlos geschildert wird ${ }^{17}$ ). Aber auch der Mann, der diesen Jesusglauben zur missionierenden Weltreligion und den Christuskult zur Grundlage einer neuen Kirche und Gottesverehrung gemacht hat, Paulus, ist eine wesentlich organisa-

${ }^{17)}$ Die sog. ebionitischen Stücke des Lukas, die die Armut an sich zu verherrlichen scheinen, sind dagegen kein Einwand. Denn einerseits setzen sie, wie die ganze sonstige Haltung des Evangeliums beweist, auch in der Meinung des Evangelisten die ethisch-religiöse Wirkung der Armut zu besserer religiöser Disposition voraus, andererseits entsprechen sie der Neigung des Verfassers, im Interesse des Erlösungsglaubens Krankheit, Schwäche, Elend und Armut zu betonen. Auch wäre es nicht verwunderlich, wenn die Tradition, aus der der Verfasser schöpft, die Armut bereits um ihrer selbst willen verherrlicht hätte. Die Neigung dazu liegt nahe genug. Aber Jesu Verkündigung vom unendlichen Wert der Seele liegt der Gedanke eines Wertes und Entschädigungsanspruchs der Armut an sich unzweifelhaft ferne. Vgl. Holtzmann, sLehrbuch der neutestamentlichen Theologie «, 1897, I 448-454, der in diesen Stücken wesentlich den Reflex der spätern populären Entwickelung sieht; diese hat ganz naturgemäß das Gottesreich als Entschädigung für irdisches Leiden und Belohnung der Entsagung betrachtet. Aber das ist eine sehr natürliche Folge und Herabziehung des Gedankens, nicht der Ausgangspunkt. Die Apokalypse des Johannes predigt nur den Haß gegen Römerreich und Kaiserkult und hat mit sozialen Gegensätzen nichts zu tun. Der aus dem Anfang des 2. Jahrhunderts stammende Jakobusbrief kämpft c 2 gegen die Reichen, aber die sind Mitglieder der Gemeinde! Die schärfere Stelle c 5, I-6 geht gegen die Reichen überhaupt, aber das ist in seiner ganz allgemein erbaulichen Haltung wohl zu beurteilen, wie die ebionitischen Stücke. Das ist der Geist der kleinen Leute. Es ist ähnlich, wie wenn das Dogma der Sozialdemokratie vom KleinLeute-Geist als $\gg$ Verteilung * und $>$ Rache an den Reichen * behandelt wird; in beiden Fällen haben dann sehr große Leute sich diese Meinung der kleinen angeeignet und darin die Offenbarung des Prinzips der Sache sehen zu dürfen gemeint; das erleichtert die Kritik. Bedeutsam ist, daß das Johannesevangelium in seiner überaus wichtigen Prägung der religiösen Ideen von alledem nichts weiß. Hier steht dem Klein-Leute-Geist der eigentlich religiöse Gedanke gegenüber. Aehnlich verhält es sich bei Paulus. Weinel, >Die Stellung des Urchristentums zum Staat \&, 1907, S. 12-17 überschätzt die ssozialradikale Unterströmunga, und, indem er sie wesentlich aus den Mahnungen zur Ruhe und Bescheidung erschließt, zeigt sich gerade im letzteren, was der eigentliche Geist ist. 
torisch schaffende, mystisch-religiöse Natur, die bei aller Reflexion in Wahrheit mehr kontemplativ ist und jedenfalls von jedem Geiste eigentlicher Wissenschaft, abwägender Kritik und höherer Weltkultur völlig fern ist. Er ist ein »unliterarischer Mensch in der unliterarischen Schicht der Kaiserzeit, aber als Pneumatiker über diese Schicht hinausragend und die Umwelt der zeitgenössischen Bildung mit überlegenem Kraftbewußtsein betrachtend. Alles Systematische, das sich in Ansätzen da und dort findet, zeigt die Grenzen seiner Begabung; im systemlos Religiösen liegt das Geheimnis seiner Größe*. Nicht minder ist dann die ganze altchristliche Literatur eine unterirdische, von der Bildungswelt lange nicht beachtete und nicht beeinflußte Volksliteratur mit allen Eigentümlichkeiten der Volksüberlieferung, in der Sprache des Volkes und auf Bedürfnisse und Phantasie des Volkes überall bezogen. Auch ihr legendärer Charakter, verbunden mit guter und sicherer Ueberlieferung, zeigt die Eigentümlichkeit der Volksüberlieferung. Von den Höhen der Evangelienschöpfung, der paulinischen Briefe und der johanneischen, bereits der Bildungswelt genäherten Mysteriosophie herabsinkend zeigt sie dann auch die Dürftigkeit der Volksliteratur, bis nach einem Jahrhundert mit den sogenannten Apologeten der Aufstieg in die literarische Oberschicht, ihre Sprach- und Gedankenwelt, beginnt. Indem hierbei die Apologeten auch ihrerseits die Einfachheit, Armut und Bildungslosigkeit der Christen betonen und daraus im Stile der Kyniker eine captatio benevolentiae machen, zeigen auch sie, wie wenig jene Richtung auf die niederen Schichten im Sinne irgend eines Klassengedankens oder eines chiliastischen Sozialismus gemeint war. Die Armut und die Einfachheit ist der Boden der Wahrheit, die eine erkünstelte und verfeinerte Bildung nicht sieht oder nicht glaubt, ganz ähnlich .wie das später Rousseau für die »natürliche Wahrheit geltend gemacht hat ${ }^{18}$ ).

Freilich kann man nun sagen, daß gerade die ganze große religiöse Wendung des Altertums selbst ein Ergebnis der sozialen Kämpfe sei, daß offenkundig die Zertrümmerung der Nationalstaaten im Orient und Occident den ganzen Vorgang einleite,

18) Diese Gesichtspunkte kräftig hervorgehoben bei Overbeck, \Ueber die Anfänge der patristischen Literatur«, Hist. Zeitschrift 1882 S. 417-472 und Deißmann, •Bibelstudien«, 1895, >Neue Bibelstudien«, 1897, Das Neue Testament und die Schriftdenkmäler der römischen Kaiserzeit` (Jahrbuch des Freien deutschen Hochstiftes 1905). 
daß die Selbstverzehrung in den großen, Jahrhunderte dauernden sozialen Kämpfen und das daraus folgende unermeßliche Elend die Gemüter für religiöse Erlösungsgedanken öffnete, daß der Verzicht auf ein eigenes Schaffen in sozialen Dingen und die Ergebung in die Weltherrschaft des Imperiums das Individuum in das eigene Innenleben und in die Verfeinerung der Privatmoral hineintreibt, die Sozialideale transszendent werden läßt und in$z$ wischen das Individuum und freie Kreise von Individuen in religiöser Erhebung Trost über die hoffnungslose Zeitlichkeit finden läßt. Das Scheitern so vieler großer Pläne an Kleinlichkeit und Selbstsucht der Massen und verbrecherischer Zügellosigkeit der Großen bringt Sündhaftigkeit und Gebrechlichkeit der Menschen zur Empfindung, und der rasende Wechsel der Geschicke verbunden mit dem Hinsinken der für die Ewigkeit gebauten und religiös geweihten Politien läßt den Wunsch nach bleibenden Werten in höheren Sphären entstehen ${ }^{19}$ ). Es sind das freilich Kämpfe, die mit den modernen Emanzipationskämpfen erst eines hörigen Bauerntums und dann einer proletarischen Lohnarbeiterschaft wenig zu tun haben. Aber es ist die Zersetzung der antiken Polis und die Auslöschung der alten Freiheit im bureaukratischen Großstaat, damit die Zerbrechung alter Lebensinteressen und mannigfacher schwerer Druck, der die Gedankien auf verinnerlichte Lebensziele lenkt. Das ist gewiß im Orient und Occident der Fall. In solcher Stimmung vollzieht sich die Nivellierung der Klassen und Stände und ihre Einigung in innerlichen und religiösen Werten. Es ist nicht $\mathrm{zu}$ bezweifeln: die große religiöse Schlußwendung der Antike ist mit die Folge ungeheurer sozialer Krisen, in denen das Sozialideal durch menschliche Arbeit und Reflexion sich als nicht erreichbar gezeigt hat und nach denen man sich der Ordnung durch den Cäsarismus gerne ergab, indem man ihm das Aeußerliche preisgab und für sich

19) S. Jodl, >Gesch. der Ethik ${ }^{2}$ I 97, II3 ff. und Zeller, $>$ Gesch. d. griech. Philos.« III ${ }^{2}$, S. $360 \mathrm{f}$. Immerhin bestimmen diese Motive mehr die gebildete vom politischen Leben abgedrängte Oberschicht. Die Unterschicht wird man $b_{1} i$ aller Beeinflussung durch die Moralpredigt und Diatribe der Kyniker und Stoiker doch weniger ermüdet und resigniert denken dürfen. Sie hat vor allem unter der wirtschaftlichen Verkümmerung gelitten. Ueber ihre Stimmungen und Dispositionen gegenüber der christlichen Bewegung gibt es $\mathrm{m}$. W. noch keine ausreichenden Dokumente oder doch wenigstens keine Sammlung und Bearbeitung, die aus Inschriften und Papyri zu gewinnen sein mag. 
die Freiheit der Seele gewann und ausbaute. Das gilt für die spätere Entwickelung des Platonismus und Stoizismus, es gilt für zahllose religiöse Neuerungen, es gilt insbesondere auch für die Durchsetzung des Christentums; es gilt auch für seine innerjüdische Vorbereitung. Und, wenn unter diesen Einwirkungen vorzugsweise die Oberschicht steht, so wirkt doch die Entwurzelung der Institutionen, das Mißtrauen gegen den alten Glauben, die ethisch-religiöse Propaganda der Weisheitslehrer auch nach unten und läßt die hier vorhandenen Energieen mit Leidenschaft neue Wege suchen. Wie oben der Boden ist für verinnerlichte und allgemein humane Theoreme, so ist unten der Boden für neue verinnerlichte und universale Kulte. Allein eine derartige sozialgeschichtliche Bedingtheit ist eben doch nur eine indirekte. Nur wer sich alle Geistesbewegungen lediglich als Wirkungen sozialer Bewegungen und insbesondere alle Religion nur als Spiegelung sozialer Verhältnisse ins Transszendente vorstellen kann, wird darin eine direkte Verursachung der religiösen Wendung sehen: In Wahrheit aber zeigt alle unbefangene Religionsforschung die relative Selbständigkeit der religiösen Idee, die eine eigene innere Dialektik und Entwicklungskraft besitzt und gerade derartige Lagen der Zertrümmerung menschlicher Hoffnungen und Anstrengungen benützt, um den frei gewordenen Raum mit ihren Ideen und Gefühlen zu beherrschen. Schon in der griechischen Auf klärungskritik und in deren Beantwortung durch neue spekulativ-monotheistische Regungen sowie in den Synkretismen der ihrer Bodenständigkeit beraubten orientalischen Religionen entfaltete sich selbständig diese Dialektik, die dann, nachdem die Zeit ihrer Vollentfaltung gekommen war, das Interesse ethischer und religiöser Erneuerung mit der Kaiserzeit immer stärker aufkeimen läßt. Und indem sie so Boden gewinnt, entfaltet sie dann eine Fülle von Konsequenzen, die nur aus ihrem eigenen Wesen stammen und die an Stelle der innerweltlichen Lebenswerte in steigendem Maße rein mystische und religiöse Werte setzen. Die Konzentrierung und Aufsammlung dieser Strebungen ist unzweifelhaft das eigentliche Werk des Christentums in der Spätantike, und darin setzt es nur den bereits begonnenen gewaltigen religiösen Prozeß fort, indem es ihm ein neues Zentrum in einer wahrhaft starken populären Religionsbildung mit neuem Kult und neuem Offenbarungsglauben gibt. Das alles aber ist doch nur eine indirekte Wirkung der sozialen Entwickelung, alles Eigentliche und Wesentliche er- 
gibt sich aus der eigenen Dialektik der religiösen Ideen. Insbesondere ist das, was die religiöse Idee bietet, nicht etwa ein bloß ins Transszendente gewandeltes Sozialideal, die Verheißung einer Welt der Gleichheit, Freiheit, Schmerzlosigkeit und Lebensbefriedigung durch göttlichen Wundereingriff, nachdem menschliche Tätigkeit zu dessen Herbeiführung sich als unzureichend erwiesen hat ${ }^{20}$ ). E Es ist vielmehr der Verzicht auf das innerirdische Sozialideal, auf die politischen und ökonomischen Werte überhaupt, und die Zuwendung zu den Gütern des religiösen Seelenfriedens, der Menschenliebe, der Gottesgemeinschaft, die für alle sein können, weil sie keinen Schwierigkeiten der Leitung und Organisation überhaupt unterliegen. Es ist eine Veränderung in den W'erten überhaupt, nicht eine Zuweisung der für Menschen nicht erreichbaren Organisation innerweltlicher Werte an die Kraft der Gottheit. Das ist ganz offenkundig im Stoizismus und in den Erlösungskulten der Fall, das ist aber auch der Sinn des christlichen' Gottesreiches. Der ganze Gedanke der Eudämonie oder das ethische Grundprinzip der Glückseligkeit, der Coincidenz von sittlicher Würde und politisch-ökonomischem Glück, hat sich verändert; es heißt nun mit dem Verse Rückerts : „Glückseligkeit zerpflück und jedem gib ein Stück, mir gib die Seligkeit und dem der will das Glück *. Die Seligkeit selbst aber wird in steigendem Maße jenseitig und eben damit das irdische Glück entbehrlicher; die Ideen einer unheilbaren Sündhaftigkeit oder einer in der Welt unüberwindlichen Stoffgebundenheit entwerten weiterhin das inner-

20) Das meint Pöhlmann II 533, der im Christentum s mit seinen ausschweifenden chiliastischen Umsturzgedanken« die gewaltigste revolutionäre Ideologie sieht. Wie wenig genau Pöhlmann in diesen Gegenständen ist, zeigt der Umstand, $\mathrm{daß}$ er diese Ideologie sgerade in Rom weiteste Verbreitung finden läßt. Der ('hiliasmus oder das Gottesreich hat nun aber mit sozialen Idealzuständen gar nichts zu tun, vgl. Wernle, Die Anfänge unserer Religionх 2, 1904 S. 38-49, 260-266. Stützen könnte sich $\mathrm{P}$. nur auf die bereits erwähnten sebionitischen \& Stücke, zu denen die altkirchliche Literatur zahlreiche Parallelen hat. Darüber ist das Nötige • bereits gesagt. Wie wenig aber auch dann noch von einer sozialen Revolution von oben oder von Gott her a geredet werden kann, zeigt der einfache Umstand, daß die Armut dabei großenteils aus dem religiösen Grunde des höheren Wertes der Opfergesinnung und der Selbstüberwindung erst künstlich durch Wegschenken herbeigeführt wird. Das Beherrschende in der Schätzung der Armut ist nicht die zu erwartende Erniedrigung des Reichen, sondern sehr bald die asketisch-religiöse Denkweise, die das Gegenteil von jedem Sozialismus ist. 
irdische Leben. So neutralisiert die religiöse Idee von sich aus die weltlichen Unterschiede, und mit der Entwertung der politisch. ökonomischen Güter hebt sie auch die Schranken der Rassen, Völker und Klassen auf. Daß sie dann damit wieder umgekehrt eine starke Anziehungskraft für alle entfaltet, die unter diesen Schranken leiden, ist selbstverständlich, und daß insbesondere das Christentum seine Anhänger unter den diesen Druck am stärksten Empfindenden in erster Linie suchen und finden mußte, versteht sich gleichfalls von selbst. Dabei ist auch der einfache Umstand nicht zu vergessen, daß eine von Hause aus an Gedankenwelt und Gefühlskreis der unteren Klassen sich wendende Volksbewegung ihre Verbindungen und Fortleitungen immer wesentlich nur in diesen Kreisen finden und nur schwer die Oberschicht erreichen kann, also auf lange die Empfänglichen wesentlich nur in diesen Kreisen wird finden können und in ihrer Apologetik aus dieser Not gerne eine Tugend macht. An Versuchen, die Gleichgesinnten der Oberschicht, deren es zahllose gab, zu erreichen, hat es von Anfang an nicht gefehlt, und schließlich wird ihnen ja auch steigender Erfolg zu teil. Ebenso einflußreich ist die einfache Tatsache, daß eine Religion, die ihre Anhänger in schroffsten Gegensatz gegen den Staatskult und gegen die die Gesellschaft beherrschenden, mit dem Kult zusammenhängenden Sitten stellt, ihre Anhänger nur ausnahmsweise aus den mit allen Institutionen verflochtenen Kreisen an Bildung und Besitz finden kann, aus dem gleichen Grund arbeitet z. B. die österreichische Los-von-Rom-Bewegung wesentlich in den unteren Klassen; sie sind weniger gebunden an das herrschende religiöse System. Insofern steht es allerdings unter einer starken indirekten Wirkung der sozialen Lage. Und diese Wirkung wird dann in dem Maße eine direkte, als es im Besitz starker Gemeindebildungen seinen Angehörigen auch etwas leisten muß über die bloße Heilspredigt hinaus, als es ihnen Heimat und Hilfe schaffen muß für die Zeit der irdischen Kämpfe. Je mehr es aber dann so selbst zu einer Gesellschaft in der Gesellschaft oder zu einem Staat im Staate wird, um so stärker spürt es dann auch seine Verflochtenheit in die konkreten Sozialprobleme und wendet auch diesen seine Aufmerksamkeit und Organisationskraft zu. Alles das aber ist erst Folge und Wirkung, nicht aber Ausgangspunkt und Wesen.

Stehen nun aber die Dinge so, dann ist es überhaupt ein Mißverständnis, an die all dem zu Grunde liegende Predigt 
I es $u$ in erster I inic , soziale * Fragestellungen heranzubringen. Sie ist ganz offenkundis cine rein religiöse Predigt und aus cinem hestimmten Gedanken ron Gott und dem göttlichen Willen mit den Menschen geflosien. Der religiöse Lebenswert ist ihn (in und alle; ; in ihm geht sein ganzes Leben und Denken auf. Dabei steht 's auch für die Wendung des Spätjudentums zum rein Religioinen ebenso wie in der Antike überhaupt: politische und soziale " 'rectzun hat die alten innerweltlichen Ideale auch hier aufsclïst und dic Wiendung nach Innen oder aufs Transszendente nahegelegt ${ }^{21}$ ). S(hr wohl aber ist es zulässig, an diese religiösen Gedankien die soziolusische Fragestellung heranzubringen, zu fragen, wie von dir.rem religiösen Gedanken aus das Verhältnis von Individuum und Gemeinschaft überhaupt sich gestalte, wie die an jedin wroken Gedanken sich anschließende soziologische Struktur von diencr religiösen Idee aus sich bilde. Und hierbei stößt man allerdings auf sehr wichtige und folgenreiche Dinge, deren Eigentümlichkeit es gerade ist, aus der Dialektik der religiösen Idee zu entspringen ${ }^{2 *}$.

Aus allen Unsicherheiten der Ueberlieferung ist der Grund"rc danke der Predigt Jesu doch einfach zu erkennen. Es handelt sich um dic Ankündigung der großen Endentscheidung, des Kommens des Gottesreiches als des Inbegriffes der vollendeten Gottesherrschaft, wo der Wille Gottes auf Erden geschieht, wie jetzt bloß im Himmel, ohne Sünde, ohne Leid und Schmerzen, und wo die wahren Werte der Gesinnung und des reinen Willens leuchten werden in der ihnen zukommenden Herrlichkeit; eben darum werden auch die ihre Sünden erkennenden Sünder und die in Leid und Armut zur Hingebungsfähigkeit und Demut Erzogenen vorangehen in das Reich Gottes vor den Satten und Gerechten wie vor den Reichen und Mächtigen. Es handelt sich aber weiterhin auch um Sammlung der Gemeinde, die des Gottesreiches harrt und die unterdes in Jesus die Bürgschaft und die Vorbereitung seines Kommens hat; zur Sammlung dieser Ge-

$\left.{ }^{21}\right)$ S. Bousset, $\gg$ Die Religion des Judentums im neutestamentlichen Zeitalter

22) Zum folgenden vergl. Holtzmann, „Neutestamentliche Theologie «, Wernle, -Anfänge und die «Reichsgotteshoffnung*, 1903, Wrede, »Predigt Jesu vom Reiche Gottes « (Vorträge und Studien 1907), vor allem Jülicher, „Gleichnisreden* II 1899, A. Harnach, \$prüche und Reden Jesu Die zweite Quelle des Matthäus und Lukas^, I907; bezüglich der evangelischen Ethik halte ich auch hier fest an den Auseinandersetzungen in Grundprobleme der Ethik , Z. f. Theol. u. Kirche 1902. 
meinde dient der engere Kreis der unmittelbaren Jünger und Gefolgsleute, denen daher auch die besonderen Pflichten der Sendboten auferlegt werden. Mit ihrer Hilfe wird das Reich überall hin gepredigt. Ueber die Beschaffenheit des Gottesreiches selbst spekuliert Jesus nicht, es ist eben der Inbegriff aller ethischen und religiösen Ideale, mit denen dann die Leidlosigkeit von selbst verbunden ist. Die einzelnen Angaben zu näherer Bestimmung sind unvollständig und unsicher. Auch über "Wie * und "Wann* des Kommens ist nur zu sagen, daß es bald kommen wird; den Zeitpunkt selbst hat er rein Gott anheimgestellt, und über das »Wie* ist aus der Ueberlieferung eine sichere Anschauung nicht mehr zu entnehmen. Das Gottesreich ist eine Gottesherrschaft auf Erden, der das Weltende und Gericht erst später folgen wird. Aber beides gehört doch so eng zusammen und die Bereitung auf das kommende Reich ist auch für das Endschicksal so entscheidend, daß über Unterschied und Verhältnis beider nichts Bestimmtes gelehrt wird. Aller Nachdruck liegt auf der Bereitung für das Gottesreich, und diese Bereitung kann eine so tiefgreifende sein, daß die des Gottesreiches harrende Gemeinde selbst schon in der Vorausnahme als Gottesreich bezeichnet werden kann. Nicht eine besondere Gruppe soll damit organisiert werden, sondern nur möglichst vielen der Weg gezeigt werden, der zum Heil führt, und der feste Felsen, auf den sie ihr Haus bauen sollen.

In dieser Forderung der Bereitung liegt die Ethik und der sie bedingende Gottesgedanke Jesu eingeschlossen, wobei die Frage nach der Neuheit gegenüber der jüdischen Umgebung hier gleichgültig ist.

Die sittliche Grundforderung ist, kurz gesagt, die Selbstheiligung in allem sittlichen Tun für Gott oder die Herzensreinheit, in der man Gott schauen wird beim Kommen des Reiches. Die sittlichen Gebote selbst werden aus der Praxis und der allgemeinen Anschauung aufgenommen, aber sie werden unter die Beleuchtung gestellt, daß in ihrer Erfüllung aus reiner innerer Anerkennung heraus das Handeln unter dem alles durchdringenden und die letzten Gesinnungswurzeln prüfenden Gottesauge steht, daß es im Gehorsam sich hingibt an Gott, um damit das eigentliche und wahre Leben, die wirkliche Seele und den ewigen Wert vor Gott zu gewinnen. Daher einerseits der Charakter der reinen Gesinnungsmoral, der Radikalismus der aufs äußerste gesteigerten Konsequenz aller sittlichen Gebote ohne jede Rück- 
sicht auf andire Motive und \%weckmäßigkeiten; daher andrerseits und $\mathrm{km}$ allem die überall durchgreifende Beziehung auf ein in dirsem Handeln zu sewinnendes Verhältnis zu Gott, auf den darin zu rwerbenden unendlichen Wert der Seele, den keine IVilt aufwiegen kann. Dic Eingewickeltheit dieses Gedankens in die Anerkinnung des jüdischen Gesetzes, der üblichen Volksmoral und in die populären lirwartungen von Lohn und Vergeltung, zugleich mit den mancherlei kritischen Ausbrüchen gegen diese Ideenmassen, können hier auf sich beruhen. Die Hauptsache. ist, daß dieses ethische Ideal absolut durchdrungen ist von dem religiösen Gedanken der den Menschen innerlich durchschauenden und im Gewissensgebot an sich heranziehenden Gottesgegenwart und von dem Gedanken eines in der Selbstopferung für Gott zu gewinnenden unendlichen und ewigen Wertes der Seele. Lauter Dinge, die der von der Sündenschuld Gedrückte leichter versteht als der Gerechte, die der nicht in die Welt und ihre Sorgen Verstrickte leichter verwirklicht als der Reiche und von tausend Rücksichten Gebundene, die auch dem Armen und Kleinen einen Weg zum Heil eröffnen, der ron dem Guten der Welt sich ausgeschlossen sieht. Ihnen entspricht, daß auch alle Wertungen des Menschenwertes bei Gott anderc sind als im Weltleben und Treiben des Tages.

Damit sind die Grundz üg e der E thik des Evangeliums gegeben. Man würde in ihr vergeblich irgend eine besondere Liste sittlicher Forderungen aufsuchen. Die Forderungen werden als selbstverständlich so aufgenommen, wie sie das jüdische Leben enthielt, und werden damit ganz selbstverständlich als allgemein menschliche angesehen. Hier gibt es im Evangelium weder irgend eine Vollständigkeit noch auch irgend eine Systematik. Aber es wäre doch irrig um deswillen die Ethik des Evangeliums für eine rein subjektivistische Gesinnungsmoral zu halten, für die bloße Forderung der autonomen Gewissensmäßigkeit des Handelns. Denn es wird völlig unbefangen vom Lohn in den Himmeln geredet, bei dem nur von keiner Aequivalenz mit der Leistung die Rede ist; der eigentliche Lohn ist das Gottesreich selbst, das Ziel einer religiösen Vollendung; und es sind ganz unverkennbar unter den aus dem allgemeinen Bewußtsein aufgenommenen Forderungen Abstufungen gemacht, die sittliche Linterweisung auf ganz bestimmte Punkte hingedrängt, so daß dic Ethik des Evangeliums nicht bloß auf die form des Willens oder das Motiv innerer Gewissensnotwendigkeit, sondern auf bestimmte, sachliche Forderungen sich bezieht. Diese 
konkrete und höchst charakteristische Richtung empfängt es durch die Stellung des Gottesgedankens im Zentrum alles sittlichen Wollens. Es ist der Herzen und Nieren prüfende, alles bis in den innersten Winkel und den feinsten Selbstbetrug hinein durchschauende Gott, der zugleich ein lebendig-tätiger Wille in der Weisc des Prophetismus ist und den von ihm im innersten Wesenskern erfaßten Menschen in sein eigenes Schaffen und Wollen hineinzieht. So werden alle Tugenden von dem religiösen Grundzweck, dem Zweck der Einigung mit dem Willen-Wesen Gottes und des Mitwirkens am Werke Gottes, aus durchgängig organisiert. Es treten diejenigen hervor und gewinnen die Leitung, in denen eine Selbstheiligung, Selbstopferung und Selbsthingebung an Gott durch Gehorsam am offenkundigsten stattfindet. In der Richtung auf die Gestaltung des eigenen Selbst sind es in erster Linie die Tugenden der völligen Lauterkeit und Wahrhaftigkeit, in denen allein eine Verbindung mit dem allwissenden Heiligen möglich ist, und daraus folgend die Gewissensmäßigkeit des Handelns; weiter sind es alle Tugenden der Demut, die, vor Gott die Kleinheit des Menschen empfindend, die Schulden der Menschen gegeneinander nicht geltend machen darf, und alle Tugenden der Selbstverleugnung, in denen die Selbstliebe, die Genußsucht, die Bequemlichkeit, die menschlichen Sympathien, der Strenge der mit Gott verbindenden sittlichen Forderungen geopfert werden müssen. $\mathrm{Er}$ fordert die Unabhängigkeit von Glück und Geld, die geschlechtliche Selbstbegrenzung, die Innerlichkeit der Gesinnung, die einheitliche Grundrichtung der Persönlichkeit. Hier geht das Evangelium bis zum äußersten Radikalismus. Es ist keine Askese, wohl aber eine alle Bedingungen der Möglichkeit und Durchführbarkeit beiseite setzende Strenge; die Harmlosigkeit der Lebensfreude selbst ist dabei in keiner Weise gebrochen. In der Richtung auf das Verhältnis zu anderen Menschen gilt ganz das Gleiche; alle sittlichen Leistungen dieser Art treten unter den Gesichtspunkt des Wirkens an Gottes Werk, der Offenbarung der in uns aufgenommenen wahren Gesinnung Gottes selbst, der Weckung des Sinnes für die wahre Gotteserkenntnis durch Offenbarung seines Wesens in unserem Handeln. Wie Gott die tätige schaffende Liebe ist und sein Licht leuchten läßt über Gute und Böse, so sollen die Gott geheiligten Menschen ihre Liebe kund werden lassen an Freunde und Feinde, an Gute und Böse, und die Feindschaft wie den Trotz überwinden durch ein Uebermaß der Liebe, 
das den andern beschämt und Verständnis für die Liebe weckt. Damit verbindet sich Milde, Vergebungsbereitschaft, Dienstbereitschaft, Gemütswärme der persönlichen Beziehungen, Dauer und Konsequenz in der Richtung auf andere Persönlichkeiten, Großherzigkeit, Bescheidenheit, Verträglichkeit. Auch hier gibt es keine Askese, die die Verkürzung des eigenen Selbst um der Mortifikation des natürlichen Menschen willen ohne konkreten Anlaß und sozusagen auf Vorrat forderte, sondern nur eine Strenge, die das fast Uebermenschliche verlangt, und einen Idealismus, der den stumpfen Widerstand der Masse und des Nützlichkeitsverstandes brechen zu können gewiß ist. Die sonstigen geselligen Lebensbeziehungen selbst bleiben unangetastet. Alle übrigen Tugenden aber, alle Forderungen der Selbstbeherrschung und Selbstbearbeitung wie alle Forderungen der Billigkeit und Gerechtigkeit und ähnliches treten zurück hinter diesen Hauptforderungen, werden nur mehr oder minder zufällig berührt. Sie mögen sich von selbst der Grundtendenz einfügen, die in dem Doppelgebote liegt, Gott zu lieben, das heißt ihm in dem Gehorsam gegen seine Gebote sich hinzugeben, und den Nächsten zu lieben, d. h. im Verkehr mit ihm die Gottesgesinnung der Liebe $z u$ offenbaren oder zu wecken ${ }^{23}$ ).

23) Mit diesen Begriffon hat man auch die Grundlagen der Geschichte der ch:istlichen Ethik. Die sittlichen Forderungen selbst werden auch später als selbstverständlich und jedem bekannt vorausgesetzt; wie bei Jesus die jüdische wird später die individualistisch-humanitäre Moral der Spätantike einfach vorausgesetzt (Harnack, Mission I I80). Alle christlichen Tugend- und Lastertafeln, die kasuistischen Einzelerürterungen und gelegentlichen Erörterungen von Forderungen sind daher mehr oder minder zufällig; auch die späteren Einpressungen der Tugenden in die platonische oder aristotelische Tugendtafel oder in stoische und Ciceronianische Kategorien sind lediglich wissenschaftlicher Scheinluxus. Die Forderungen und Ideale werden aus dem allgemeinen Bewußtsein aufgegriffen, ganz entgegenstehende Schulen wie die der Hedoniker scharf bekämpft als völlige, gar nicht ernst zu nehmende Verkehrtheit. Jeder Versuch einer wirklich wissenschaftlichen Ableitung aus den Grundprinzipien liegt ganz fern und ist überflüssig. Nur Detailfragen, wie die nach dem Verhältnis der natürlichen Kräfte und der Gnadensittlichkeit, von mehr weltgemäßer und mehr asketischer Lebenshaltung treten hervor, und, indem die Erürterungen in der Regel an der Hand der Bibelstellen verlaufen, werden sie vollends zufällig und prinziplos. Daher bei den meisten Geschichten der christlichen Ethik der Eindruck einer unendlichen Verworrenheit. In Wahrheit aber gibt es doch instinktiv ein Ausleseprinzip unter den vorausgesetzten sittlichen Lrtcilen, und zwar liegt das Prinzip schon bei Jesus in den hier angegebenen Doppeltendenzen. Freilich bringen dann das Eindringen der Askese, die die Selbst- 
Von diesen Gedanken aus ergibt sich die so $z$ i o log is che Struktur. Es ist einerseits der unbegrenzte und unbedingte Individualismus, der sein Maß rein in sich selber hat, in dem, was er als der Selbstheiligung für Gott dienend empfindet; er ist verpflichtet, bis zur radikalsten und rücksichtslosesten Konsequenz der empfundenen Forderungen zu gehen; er hat seinen Grund und sein Recht in dem Berufensein des Menschen zur Gottesgemeinschaft, oder wie es hier heißt, zur Gotteskindschaft und in dem hierin zu gewinnenden ewigen Seelenwert. Das Individuum, das Gottes Kind ist, darf sich als unendlich wertvoll betrachten, aber es kommt zu diesem Ziel nur durch Selbstopferung in rücksichtslosem Gehorsam an den heiligen Gotteswillen. Nicht an die naturhafte Individualität, sondern an einen erst in der Gottesgemeinschaft $\mathrm{zu}$ gewinnenden Wert ist gedacht. Es ist begreiflich, daß ein solcher Individualismus ein schlechthin radikaler, auch alle Naturschranken und Unterschiede durch das Ideal des religiösen Seelenwertes überwindender ist, und ebenso begreiflich, daß ein solcher Individualismus nur auf dieser religiösen Grundlage überhaupt möglich ist. Nur die Gottesgemeinschaft gibt dem Individuum diesen Wert, und nur in der über alles Irdische übergreifenden gemeinsamen Beziehung auf Gott verschwinden die Naturunterschiede. Wo solcher Individualismus Platz greift, sind zugleich in der alles befassenden und alle irdischen Unterschiede zum Nichts herabsetzenden göttlichen Allmacht und Liebesmacht alle sonstigen Unterschiede ausgelöscht und besteht nurmehr die Differenzierung in die unendlichen Wert besitzenden und ihn durch sittliches Handeln in sich schaffenden Individuen überhaupt, deren jedes mit seinem Pfund nach bestem Vermögen zu wuchern hat

\footnotetext{
verleugnung zum Selbstzweck und zur Uebung an jedem beliebigen Stoffe macht, das Uebergewicht der reinen priesterlichen Autorität, die die Kirchengebote um ihrer selbst willen zum Gesetz und den Gehorsam zu einem asketischen Werk der Demut macht, die Beziehung auf die Aequivalenz des Lohnes und der Fegfeuerstrafen, die das Handeln nicht zu Mitteln der Vereinigung mit Gott, sondern zum Mittel der Garantierung des jenseitigen Schicksals macht, und schließlich die Kasuistik, die Gebote aus Geboten herausspinnt, eine Unsicherheit in der Orientierung hervor, die äußerst verwirrend wirkt, die aber von allen innerlichen Naturen wieder siegreich durchbrochen wird. Erst spät wird der jüdische Dekalog zum Kompendium der christlichen Moral gemacht, und werden ihm die vevangelischen Ratschläge als das neue eigentlich Christliche zur Seite gestellt. Damit ist dann der wirkliche Sachzusammenhang völlig verdunkelt.
} 
und mit den Interessen und Unterschieden der Welt schlechterdings keine Kompromisse schließen darf. Ob freilich bei allen dieses Ideal auch wirklich Platz greifen wird, ist eine andere Frage. Hier hemmt die Sünde und die Welt, und angesichts des schweren Kampfes mit der widerstrebenden Welt gilt der Satz, daß viele berufen und wenige auserwählt sind. Doch tröstet sich Jesus angesichts dieser Schwierigkeiten, denen sein absoluter religiöser Individualismus begegnet, damit, daß bei Gott wohl möglich ist, was für Menschenaugen unmöglich erscheint. Es ist von Hause aus kein Massenideal. Auch ist bei der hohen Spannung der Forderungen nicht zu vergessen, daß es sich um die Endentscheidung und um die letzte Zeit eines zu Ende gehenden Weltlaufs handelt. So wenig die Forderungen aus der Erwartung des Endes selber abgeleitet werden dürfen, so sehr muß man doch bedenken, daß ihr Radikalismus und ihre Unbekümmertheit um Möglichkeit und Durchführbarkeit'nur von hier aus zu verstehen sind. Der Boden auf dem sie durchgeführt werden sollen, wird nicht lange dauern und hat keinen Wert in sich selbst.

Aber dieser absolute religiöse Individualismus, diese Aufhebung aller Differenzierungen in der bloßen Differenzierung der selbstwertigen Persönlichkeit an sich, enthält nun doch zugleich einen starken Gemeinschaftsgedanken, der auch seinerseits genau ebenso aus der spezifisch religiösen Grundidee hervorgeht. $\mathrm{Er}$ liegt nicht bloß darin, daß zu den in der Selbstheiligung für Gott befolgten Geboten die altruistischen Gebote überhaupt mit gegehören und um der Gesinnungsreinheit wie um der Selbstverleugnung willen bis zum äußersten Radikalismus zu verwirklichen sind. Er liegt vielmehr im letzten Grunde darin, daß die für Gott sich Heiligenden im gemeinsamen Ziel, in Gott, sich treffen; und da der obwaltende Gottesgedanke nicht der einer ruhenden, die Seelen in sich aufnehmenden Seligkeit, sondern der eines schaffenden Willens ist, so müssen die in Gott Geeinigten, vom Willen oder der Gesinnung Gottes erfüllt, den Liebeswillen Gottes betätigen. Daker gibt es für die Gotteskinder kein Recht und keinen $Z$ wang, keinen Krieg und Kampf, sondern nur eine restlose Liebe und eine Ueberwindung des Bösen mit Gutem, Forderungen, die die Bergpredigt an extremen Fällen verdeutlicht. Wie der absolute Individualismus aus der religiösen Idee der herzensreinen Selbsthingabe an den die Seelen suchenden und zur Kindschaft berufr: n Vaterwillen ausgeht, so wird aus der 
gleichen Grundidee heraus der absolute Individualismus zu einer ebenso absoluten Liebesgemeinschaft der in Gott Verbundenen, zu einer Betätigung der Gottesliebe auch gegen alle Fremden und Feindlichen, weil nur durch die Offenbarung der absoluten Liebe in ihnen das wahre Gottesverständnis geweckt und der Weg zu Gott geöffnet wird. Das ist überall der Hintergrund und Sinn der Bruder- und Nächstenliebe des Evangeliums. Sie ist nicht einfach Güte und Mildtätigkeit überhaupt, sondern die Verbundenheit der in Gott Geeinigten und die Offenbarung und Weckung des Verständnisses für die wahren Lebenswerte durch die Erweisung der Liebe, die Zerschmelzung irdischer Kleinlichkeit und Weltsinnigkeit in dem Feuer der göttlichen Liebe, der nichts Weltliches widerstehen kann. Diese Gemeinschaft reicht aber nur so weit, als ihre religiösen Voraussetzungen reichen. Sie ist absolut, wo diese vorhanden sind; sie sucht und wirbt, wo sie nicht vorhanden sind; aber der Weg zum Heil ist schmal, und wenige sind es, die ihn finden; und unter diesen Wenigen finden ihn die Leidenden am leichtesten. An ein Gattungs- und Menschheitsideal an und für sich ist nicht gedacht. Für die Fälle des Mißlingens in dem Werben um diese.Gemeinschaft hat das Evangelium nur die Anweisung des Leidens und Duldens, bis das Gericht die wahren Verhältnisse wieder herstellt. Auch hier ist für das Verständnis von Jesu Weisungen zu bedenken, daß diese Wiederherstellung nicht in endloser Form nach einem langen Weltleben, sondern in kurzer Frist stattfinden wird. So entsteht aus dem absoluten Individualismus ein ebenso absoluter $\mathrm{Uni}$ ve rs a lismus, beide rein religiös begründet, ihren festen Halt in dem Gedanken des heiligen göttlichen Liebeswillens besitzend und sich gegenseitig mit völliger logischer Konsequenz fordernd, wobei die Einzelfrage, wie weit Jesus die populäre Vorzugsstellung des Judentums wirklich aufgehoben hat, hier nicht weiter zu verfolgen ist. Hier interessiert nur der aus der religiösen Idee unmittelbar entspringende soziologische Doppelcharakter eines absoluten Individualismus und Universalismus. Beide fordern einander. Denn der Individualismus wird absolut nur durch die ethische Hingebung an Gott und die Erfüllung mit Gott; und wiederum im Besitz des Absoluten schmelzen die individuellen Differenzen zusammen zur unbedingten Liebe, deren Urbild der die Seelen berufende und in sich vereinigende Vatergott selbst ist. Das müssen alle lernen und tun, die ihre Seele retten wollen 
im Gericht und Teil gewinnen am Gottesreich; und die, welche es tun, sind seine Brüder und Schwestern und damit die Erstlinge des kommenden Gottesreiches ${ }^{24}$ ).

24) An diesem Punkt glaube ich Harnacks Auffassung des grundlegenden Sachverhaltes nicht ganz zustimmen zu können. H. (Reden I 28 f.) analysiert das Evangelium und findet hier drei Momente: 1. das Gottvertrauen, 2. den Erlösungsglauben, 3. die Nächstenliebe. Das erste führe gelegentlich zum Quietismus, das zweite zu heiliger Weltindifferenz oder zu radikaler Weltverbesserung, das dritte sei das sozial treibende. Man wird die Momente m. E. nicht so sondern und einfach nebeneinander stellen dürfen. Es gehört zunächst jedenfalls das Gottvertrauen und der Ersösungsglaube unbedingt zusammen; jenes bedeutet, daß der Mensch ruhig und unbedingt dem höchsten Interesse, dem des Seelenheils im Gericht, sich hingeben kann, da Gott für das Zeitliche genugsam sorgt und keine Sorgen um Zeitliches haben will; auch das Leiden, das ganz besonders zum Zeitlichen gehört, ist in solchem Vertrauen hinzunehmen als gerade dem Seelenheil dienend; dagegen ist ein ruhiges und ausdauerndes Gottvertrauen in Arbeit und Ordnung einer bestăndigen Welt erst die spezifisch lutherische Wendung des Gedanliens. Dem das Gottvertrauen in sich schließenden und bedingenden Erlösungsglauben, der eben das Prinzip des von mir charakterisierten absoluten religiösen Individualismus ist, steht nun aber die Nä ch st e n li e be nicht einfach zur Seite oder gar im Kontrast gegenüber. Sie ist ganz deutlich aus dem religiösen Grundgedanken motiviert als Bekundung der vollkommenen Gottesgesinnung, als Weckung des Verständnisses für das wahre Wesen Gottes, als Erfüllung des eigentlichsten Willens Gottes, in dessen Erfüllung gerade die Seele sich aus der Welt bejfreit und Gott übergibt. Gewiß wird swischen leiblicher und seelischer Note im Evangelium nicht unterschieden und s soll mit allen Kräften der Liebe dem Bedürftigen und Elenden geholfen werden fluß der gemeinsamen Verbundenheit aller in Gott und die Bewährung der Vollkommenheit Gottes, der seine Sonne scheinen läßt über Gerechte und Ungerechte. Gewiß ist solche Bruderliebe nicht ohne wirkliche Liebesgesinnung zu fordern möglich gewesen, aber diese Liebesgesinnung haftet mehr an dem Gedanken Gottes als der tätigen Vaterliebe und nicht an dem Gedanken der Hilfe und Förderung um ihrer selbst willen. Sonst wäre die Beschränkung auf reine Liebeserweisung und der Verzicht auf alle politisch-sozialen Reformforderungen gar nicht zu erklären. Die Liebe hat immer einigermaßen den Charakter der Selbstüberwindung oder doch einen propagandistischen der Offenbarung oder Weckung des wahren Gottesverständnisses; sie ist um Gottes willen gefordert und nicht um des Menschen willen. Das gilt für Jesus und für die ganze nächste Folgezeit. H. sagt S. 30: DDie Welt sah ein neues Schauspiel: während sich die Religion bisher an das Irdische angeschmiegt und alle Zustände willig begleitet oder sich allem entgegengesetzt und in die Wolken gebaut hatte, empfing sie nun eine neue Aufgabe: irdische Not und Elend ebenso wie irdisches Glück für etwas Geringes zu achten (im Erlösungsglauben) un d d o c h jeglicher Not zu steuern (im sozial- 
Die Bedeutung, welche für Mut und Freudigkeit solcher Selbstbereitung die Vergewisserung über Sündenvergebung und Gnadenwille Gottes schon in der Predigt Jesu hat, kann dabei hier außer Frage bleiben. Soziologisch hat sie ja erstlich nur die Bedeutung einer Verstärkung der Motive und einer Ueberwindung der bei

treibenden Motiv), das Haupt im Glauben mutig zum Himmel zu erheben und d o c h mit Herz und Mund und Hand auf dieser Erde für den Bruder zu arbeiten . Hier scheint mir das $>$ und doche unrichtig zu sein. Der Satz S. 32 *Wo der Christ klar erkennt, daß ein wirtschaftlicher Zustand zur Notlage für die Menschen geworden ist, da soll er nach Abhilfe suchen; denn er ist ein Jünger dessen, der ein Heiland war hat für die alte Kirche nie gegolten, wie am besten die Geschichte der Sklaverei zeigt, deren den Charakter gefährdende Wirkung und deren schmerzenreiches Elend der alten Kirche wohl bekannt war und auch in christlichen Haushaltungen keineswegs immer vermieden war. Ihr Idealismus und zugleich ihr Glaube an die Unveränderlichkeit der Welt, wie sie einmal ist, haben eine derartige Reflexion auf die Bedingtheit ethisch-religiöser Werte durch die Naturbasis des Lebens nie gekannt. Kann ich $H$, in all diesen Punkten nicht zustimmen, so kann ich mich eher der Charakteristik anschließen, die Schmoller (Grundriß I 79) gibt. -Sicher ist, daß diese Einseitigkeiten notwendige Begleiterscheinungen jenes moralischen Idealismus waren, der wie ein Sauerteig die Völker des Abendlandes ergriff und emporhob. Es entstand mit dieser christlichen Hingabe an Gott, mit diesen Hoffnungen auf Unsterblichkeit und ewige Seligkeit ein Gottvertrauen und eine Selbstbeherrschung, die bis zum moralischen Heroismus ging; eine Seelenreinheit und eine Selbstlosigkeit, ein Sichopfern für ideale Zwecke wurde möglich, wie man es früher nicht gekannt hatte. Die Idee der brüderlichen Liebe, der Nächstenund Menschenliebe, begann alle Lebensverhältnisse zu durch$d r$ inge $n$ und erzeugte eine Erweichung des harten Eigentumsbegriffes, einen Sieg des gesellschaftlichen und Gattungsinteresses über die egoistischen Individual-, Klassen- und Nationalinteressen, eine Fürsorge für die Armen und Schwachen, die man im Altertum vergeblich sucht $\propto$. Hier ist richtig das soziologische Prinzip selbst und seine soziale Anwendung und Wirkung unterschieden; freilich die in ne re Schwierigkeit, die der letzteren entgegenstand, ist dabei auch hier nicht genügend in Betracht gezogen. Das Unzutreffende in Harnacks Auffassung dagegen liegt meines Erachtens darin, daß er beides nicht unterschieden, sondern von vornherein in eins gezogen hat. - Uebereinstimmend mit meiner Analyse ist die Deutung des christlichen Liebesgedankens bei Augustin im ersten Kapitel seiner doctrina Christiana, auch Clemens im Protrepticus c. 9 am Schluß, und die Darstellung von Uhlhorn, S. 5 I-66, nur daß Uhlhorn dann andrerseits, die eschatologische Natur des Gottesreichs verkennend, von einem Gestalten und Zum-Organ-Machen der Welt für das Gottesreich als die in der Gottesliebe geeinigte erlöste Menschheit spricht. Das aber sind lutherische und noch mehr moderne Eintragungen. Die ganze folgende Darstellung wird zeigen, wie wenig ein derartiger Gedanke auf die alte Kirche zutrifft. 
der Verwirklichung des ldeals sich unvermeidlich einstellenden Hemmnisse und Trübungen. Zweitens gibt sie freilich dem Individualismus und Universalismus eine mit seiner religiösen Wurzel eng zusammenhängende Färbung. Nicht bloß das Hochgefühl des gotteinigen Individuums, sondern auch seine sündhafte Schwäche und geschöpfliche Gebrechlichkeit, das Bedürfnis nach Gottvertrauen und Gotteshilfe und die Zuversicht zu seiner Gnade als der Quelle alles Guten sind damit betont. Und ebenso wird der Universalismus damit aus der bloßen Verbundenheit in Gott und gemeinsamen Beziehung auf Gott eine Verbundenheit durch gemeinsame Bedürftigkeit, durch gegenseitige Vergebungsbereitschaft, durch Mitgefühl mit der Sünde und Kampf gegen die Sünde. Der Sündenvergebung bedürftig bleibt das Individuum auch im höchsten Selbstwert ein unnützer Knecht Gottes, und der Abrechnung vor Gott gewärtig muss die Bruderliebe alle menschlichen Schuldbücher, alle Rechnungen von Mensch zu Mensch vernichten. Die Gottesidee trägt, wie die Züge der alle zum höchsten Lebenswert berufenden Vatergüte, so die einer beständig in Demut erhaltenden und durch Sündenvergebung ermunternden, unendlich überlegenen und den Abstand nie aufhebenden Vollkommenheit. Eben damit aber stellt sie sich auch nicht als ein stets spontan erzeugbarer denknotwendiger Gedanke, sondern als $\mathrm{Au}-$ torität und Offenbarung dar. Der hebräische Willensgott gibt sich bei seinem Abstand von den Menschen nur in lebendiger Offenbarung kund, im Gesetz und den Propheten und in der Autorität, mit der Jesus beide deutet. Damit ist in das soziologische Gefüge der Autoritätsgedanke eingeführt. Aus dem Glauben an solche Autorität quillt das ganze geschilderte Denken, und die Sicherung dieser Autorität, dieses Quellpunktes, wird eine dauernde Aufgabe des ganzen Gefüges sein. An all diesen Punkten unterscheidet sich dieses Gefüge von dem im übrigen nahe verwandten, später zu schildernden religiös-ethischen und soziologischen Denken der späteren Stoa.

Im übrigen ist dies soziologische Gefüge eine völlig freie Gemeinschaft des Gedankens und der Erkenntnis. Seine Gläubigen sind überall untergemischt unter die Kinder der Welt und fahren fort teil zu nehmen am nationalen Kultus. Sie bereiten sich nur innerlich und durch das rechte Verhalten gegeneinander auf das Kommen des Reiches. Organisiert hat Jesus keine Gemeinde, sondern nur die Predigt, für die er Gehilfen sucht, die 
alles verlassen und alles ihm und der Sache opfern. Das ist einer der Hauptunterschiede von der Ordensstiftung der Essener, mit denen Jesu Werk immer wieder zusammengeworfen wird von Leuten, die meinen es sei durchaus die Aufgabe des Historikers klüger zu sein als seine Urkunden und alles für wahrscheinlicher und möglicher zu halten als was diese sagen. Es ist auch der Grund, weshalb der soziologische Gedanke des Evangeliums stets von neuem gegen kirchliche Verfestigungen $\mathrm{zu}$ reagieren vermocht hat.

Leicht läßt sich von hier aus verstehen, wie die Beziehungen zu den einem ganz anderen Interessenkreis angehörenden $\mathrm{s}$ o $\mathrm{z}$ i ale n $\mathrm{Problemen}$ sich gestalten müssen ${ }^{95}$ ). Sie gehören der Welt an und werden mit ihr vergehen. Wie diese überhaupt gemischt ist aus Gutem und Bösem, so sind auch jene Dinge mit ihrer Ordnung, ihrer Freude und ihrer Arbeit nicht ohne Gutes, aber reich an Gefahr und an Ablenkung von dem einen, was not tut. Jesu Predigt ist nicht asketisch; es fehlt jede Herabsetzung der Sinnlichkeit und des Genusses als solcher, auch jede Verherrlichung der Armut um ihrer selbst willen. Aber Lebensordnung und Arbeit gelten nur soweit als sie zum Leben überhaupt notwendig sind, und dann wie selbstverständlich, und tragen keinerlei eigenen ethischen Wert in sich selber. Hier liegen die Unterschiede orientalischen Volksempfindens gegenüber allen Bedürfnissen höherer Kultur und spricht der religiöse Radikalismus, der in allem nicht direkt auf religiöse Werte Beziehbaren einen ethischen Wert überhaupt nicht anzuerkennen im Stande ist. Jesu Ethik ist eher heroisch als asketisch. Sie mildert ihren Heroismus nur durch die Weichheit des religiösen Gottvertrauens und Vergebungsglaubens, aber nicht durch Kompromisse mit den Forderungen des Weltlebens und der "Natur der Dingee. So versteht sich von hier aus die Stellung zu Staat, Gesellschaft, Arbeit und Besitz von selbst. Vom $\mathrm{Sta}$ at ist nicht die Rede. Das jüdische Volkstum wird in allen seinen Hoffnungen auf das entschiedenste verleugnet, auch wenn Israel als der Kern der kommenden Welt erscheint. Jesu Gottesreich ist die Herrschaft Gottes und nicht die des jüdischen Volkes. Der Römerstaat wird mit schroffsten Worten als mit Gottes Zulassung zu recht bestehend anerkannt; man soll nur

25) Vgl. hierzu Jacoby, Neutestamentliche Ethik, 1899, wo nur die Bedeutung der Zukunft des Gottesreiches stark unterschätzt ist. 
ohne Rücksicht auf die Heiden Gott geben, was Gottes ist. Das wirtschaftliche Lebe $n$ wird mit einfachster Kindlichkeit als eine Angelegenheit des Tages betrachtet, wo man Gott für den kommenden Tag sorgen lassen soll. Im übrigen ist die opfernde und mitteilende Liebe, bei der übrigens eben deshalb Arbeit und Erwerb vorausgesetzt ist, die höchste Probe wahrer Frömmigkeit, und ist der Verzicht auf alle Güter die Bedingung des engeren Anschlusses an die eigentliche missionierende Jüngerschaft ${ }^{26}$ ). Daß Gott durch Arbeit jeden seinen Unterhalt finden

26) Bei der Frage nach den ökonomischen Lehren des Evangeliums von der Geschichte vom reichen Jüngling und den daran angefügten bekannten Worten über die Reichen (Mt. I9, I6 ff.) auszugehen, ist verkehrt. L. Brentano, >Die wirtschaftlichen Lehren des christlichen Altertums (Sitzungsberichte der phil.-hist. Klasse der Münchener Akademie 1902), hat das getan und konnte sich dabei auf die Kirchenväter allerdings berufen. Allein diese Väter stehen bereits unter dem Einfluß des Bedürfnisses, die Worte der Bibel zu dogmatisieren, und des im Kampf mit der Welt asketisch entwickelten Armutsgedankens. Da bot sich ihrer Verlegenheit das Wort Jesu sehr bequem dar, indem es einen gewöhnlichen Gehorsam und eine höhere Vollkommenheit zu unterscheiden, eben damit aber beiden Bedürfnissen, der Weltförmigkeit und der asketischen Selbstentäußerung, zu genügen schien. Die Worte über die Seelengefährlichkeit des Reichtums verstehen sich von Jesu Grundanschauung aus von selbst und enthalten keinerlei Negation des Besitzes und keine Askese überhaupt. Die Geschichte vom reichen Jüngling aber, deren Tatsächlichkeit nicht bewiesen und nicht bestritten werden kann, bedeutet jedenfalls keine Gründung eines Dogmas. Jesu Meinung über den Besitz ist auch sonst deutlich genug, nämlich am ersten nach dem Gottesreich zu trachten und nicht zu sorgen für den kommenden Tag. Der Jüngling aber will etwas Besonderes tun, und daher fordert ihn Jesus auf, in seine Missionsarbeit einzutreten und alles zu verkaufen für die Armen. Das ist nur dann anstößig, wenn man Jesus die Lehre zuschreibt, daß es keine besonderen heroischen Anstrengungen geben dürfe, sondern alles gleich pflichtgemäß sei. Allein diese abstrakte Lehre ist Jesus ganz fern; sein Prinzip ist gewahrt, wenn eine solche Anstrengung kein Verdienst begründet. Die ganze Aufopferung der Jünger und die Aufforderung zur Selbstprüfung, ob die Kraft hierzu auch zureiche, Luc. I4, 33, ist ein Zeichen, daß jener Gedanke besonderer Leistungen Jesus nicht fern liegt, wie er ja auch sehr natürlich ist. Uebrigens ist wohl möglich, daß die Geschichte ganz oder in ihrer Form $\therefore$ ist $i$ spätere asketische Gedanken beeinflußt ist. Jedenfalls aber ist sie nicht der Schlüssel zu den ökonomischen Lehren des Evangeliums, sondern nur der Schlüssel zu denen der späteren Kirche, die mit viel entwickelteren ökonomischen Verhältnissen kämpfend den Gegensatz und die Schwierigkeit viel stärker empfand. Für sie aber war dann der erste Teil, daß es genügen könne die Gebote zu halten, ebenso wichtig als der zweite. Ohne die Annahme, daß Jesus für seine Jünger 
lasse und daß im Falle der Not überall die Liebe helfen könne, das ist zusammen mit derScheu vor dem seelengefährlichen Reichtum die einzige ökonomische Lehre des Evangeliums, die ebendeshalb mit jeder realistischen Einsicht in die Spannung zwischen Bevölkerung und Möglichkeit der Bedarfsdeckung so schwer zusammenstößt. Die religiös geforderte Liebe erweist sich als das einfachste Mittel, zugleich auch die Lebensnöte zu beseitigen. Zudem sind alle Fragen des Besitzes lediglich vom Standpunkt des Konsums betrachtet, der bescheiden bleiben muß, wenn er gesund bleiben soll, und der die Mängel der Bedürftigkeit durch Mildtätigkeit deckt. Dabei ist wohl nicht zu bezweifeln, daß das Mitleid mit der Armut und dem Leiden der Predigt Jesu eine besondere Wendung auf die Armen gibt. Aber es geschieht doch immer in der selbstverständlichen Voraussetzung, daß hier das Wort am wenigsten steinigen oder dornigen Grund findet, auch in der Voraussetzung, daß Gottes Gerechtigkeit und Güte sich darin zeigt, daß gerade die scheinbar Zurückgesetzten und Enterbten es leichter haben zum Heil zu kommen als die scheinbar vor der Welt Bevorzugten. Es scheint in der Wendung zu den Armen auch ein Element der Theodizee zu liegen: Elend und Not, die die Menschen nicht begreifen können, erweisen sich in Gottes Augen als ein Weg zum Heil. Aber nicht um die Ausgleichung der Armut mit jenseitigem Lohn handelt es sich dabei, sondern um den Vorzug des Leidens für die Erkenntnis Gottes und der wahren Lebenswerte. Dabei schränkt sich die Predigt ja auch gar nicht auf die Armen ein, sondern geht an alle. Wenn Naumann, dem unter dem unmittelbaren Eindruck Palästinas alle diese Erwägungen schwer sich aufdrängten, trotzdem meint: „Sein Herz ist die Liebe zu den Armen, der Kampf gegen die Bedrücker, die Freude am Erwachen der Unmündigen; nur die Art, wie er seinem Herzen folgte, ist dem menschenfreundlichen Tun unseres Zeitalters ferner als wir dachten", so ist das schwerlich ganz richtig ${ }^{27}$ ). Vom Kampf gegen die Bedrücker ist nichts zu spüren, nur von dem gegen die falschen Seelenführer; und die Liebe zu den Armen wie die Freude am Erwachen der Unmündigen sind doch nicht das Streben nach Emporhebung und Em-

im engeren Sinne oder die Missionare und Gottesreichsboten andere Forderungen aufgestellt hat als für die Masse seiner Anhänger ist übrigens m. E. das ganze Evangelium nicht $z u$ verstehen, es fehlte ihm dann alle Konsequenz.

27) Naumann, Asia, S. II 5 . 
porentwickelung der Gedrückten und Zurückgebliebenen, sondern neben der Betätigung des eigensten Grundsatzes und Grundgefühls der Liebe doch zugleich die Aufsuchung des empfänglichsten Bodens. Alle Fragen und Schwierigkeiten des Pauperismus aber, ob nicht gerade in der Armut und in dem Mangel an geistigem und materiellem Fortschritt schwere ethische Gefahren und ernste Hindernisse geistiger Erhebung liegen können, liegen außerhalb des Horizontes des Evangeliums. Näher und inniger ist schließlich seine Stellung zur Familie. Die Familie in dem reinen und keuschen Sinn der spätjüdischen Moral gibt die Bilder für die höchsten Bezeichnungen Gottes, den Namen für das letzte religiöse Ziel, das Urbild der Jüngerschaft Jesu, den häufigsten Stoff der Gleichnisse und ist insofern eine der Grundvoraussetzungen seines Empfindens. Die Individualisierung der Personen in der monogamischen Familie und die Innigkeit des Familienbandes int in der Tat auch innerlich verwandt mit dem religiösen Individualismus und Universalismus seiner Predigt und die Schätzung des Gemütes mit dem undogmatisch-intuitiven Charakter seines (isttesglaubens. Daher die Forderung der Unlösbarkeit der Ehe und der geschlechtlichen Selbstbeschränkung auch des Mannes auf die Ehe. Auf die Keimzelle alles Gemeinschaftslebens, die Iamilie, wirkt das neue soziologische Ideal am unmittelbarsten und stärksten. Aber immerhin im Himmelreich werden die Menschen geschlechtslos sein und das Seelenheil fordert im Nutfall auch die Opferung des Familienbandes, der Missionsberuf den Verzicht auf das eheliche Leben, die Verschneidung fürs Himmelreich ${ }^{28}$ ).

So fehlt jedes Programm einer sozialen Erneuerung, an seiner Stelle steht die Forderung innerhalb der noch fortdauernden Ordnungen der Welt in der rein religiösen Gemeinschaft der Liebe und in der Arbeit der Selbstheiligung sich zu bereiten auf das Kommen des Gottesreiches. Und auch dieses Gottesreich selbst ist nicht etwa wenigstens dann seinerseits die von Gott gestiftete soziale Neuordnung. Es bringt eine neue Ordnung auf Erden, aber mit Staat, Gesellschaft und Familie hat sie nichts mehr zu tun. Wie sie im einzelnen aussehen wird, ist Gottes Sache; der Mensch hat nur auf sie sich zu bereiten. Und wenn

s8) Vgl. Marianne Weber, „Ehefrau und Mutter in der Rechtsentwickelunge,
S. $180 \mathrm{ff}$. 1907 , S. $180 \mathrm{ff}$. 
dabei von Jesus und späterhin für alle Leidenden und Armen die Trocknung der Tränen und Sättigung versprochen wird, so ist das nur natürlich bei einer wesentlich an die Armen sich wendenden Predigt, aber es ist nicht die Hauptsache. Die Hauptsache ist die dann eintretende vollständige und ungetrübte Herrschaft Gottes und die Ueberwindung der bösen Geister.

Sobald nun freilich um eine solche Predigt sich eine dauernde Gemeinschaft sammelt, ist es unausbleiblich, daß aus diesem Programm a u ch eine soziale Ordnung wird, daß die zunächst rein religiös gedachte soziologische Struktur sich in eine soziale Organisation innerhalb des übrigen Lebens umsetzt. Mindestens das Liebesgebot muß eine kleine, persönlich unter sich verbundene Glaubensgemeinde auch in ihrem ökonomischen Verhalten bestimmen und zu einem ersten Versuch seiner Verwirklichung führen, so lange ihr nicht äußere Hemmnisse entgegenstehen und sie unmöglich machen. Die Gesinnungsmäßigkeit der Liebe läßt sich ja an sich unter allen denkbaren Verhältnissen betätigen, aber so lange das Liebesgebot noch nicht durch den Zwang solcher Verhältnisse sich zur Resignation verurteilt sieht, muß es dem inneren Trieb gehorchen, der eine Organisation wenigstens des Zusammenlebens der eigenen Gemeinde nach den ökonomischen Grundsätzen dieses Gebotes verlangt. $\mathrm{Zu}$ Jesu Lebzeiten ist von einer organisierten Gemeinde nichts erkennbar. Die Folgen treten erst in der um sein Andenken gescharten Gemeinde hervor. So geschah es auch in der Urgemeinde. Aber die Neuordnung beschränkt sich auf die Gemeinde selbst und ist nicht ein Programm der sozialen Volkserneuerung überhaupt. Innerhalb der Gemeinde selbst aber, klein und denselben allgemeinen Lebensverhältnissen angehörig wie sie war, blieb dann keine andere Möglichkeit, als die der Organisation eines Kommunismus, den man im Unterschied von allem andern Kommunismus den religiösen Liebeskommunismus nennen muß. Das ist ein Kommunismus, der die Gemeinsamkeit der Güter als Beweis der Liebe und des religiösen Opfersinnes betrachtet, der lediglich ein Kommunismus der Konsumtion ist und den fortdauernden priváten Erwerb als die Voraussetzung der Möglichkeit von Schenkung und Opfer zur Bedingung hat. Ihm fehlt vor allem jede Gleichheitsidee, sei es die absolute Gleichheit der Anteile, sei es die relative der Verdienst und Leistung entsprechenden Beteiligung; das Entscheidende ist nur, daß alle opfern und daß alle Troelts c b, Gesammelte Schriften. I. 
zu leben haben; wie viel das ist beim ersten und beim zweiten, ist Nebensache. Ebenso fehlen jede technische Ueberlegung und Begründung, die vor allem eine gemeinsame Produktionsordnung verlangt hätten. Schließlich fehlt auch selbstverständlich jeder Gegensatz gegen das eigentliche Hemmnis jedes echten Kommunismus, gegen die mit der Privatwirtschaft innerlichst verbundene Familie. Dagegen hat es vermutlich Enthaltung vom Eide, Zurückhaltung von den Gerichten und allem offiziellen Wesen gegeben. In diesem Sinne wird die berühmte Erzählung der Apostelgeschichte vom urchristlichen Kommunismus zu verstehen sein, die alle innere Wahrscheinlichkeit für sich hat. $D a ß$ er nicht dauern konnte, jedenfalls nicht in die Weltmission übergehen konnte, das hat seinen sehr begreiflichen Grund in der inneren Struktur eines solchen Kommunismus, der allenfalls in einer kleinen und gleichartigen Gemeinde möglich sein mochte, der aber für eine Weltpropaganda viel zu lose gefügt und begründet war. Aber daß er in ihr sofort verschwand ohne jeden Kampf um sein Prinzip, das ist wieder nur ein Zeichen dafür, daß er nur eine Folgeerscheinung und nicht eine Grundidee war. Die Grundidee ist lediglich die des Seelenheils ${ }^{29}$ ).

Immerhin aber blieb von den Reden Jesu aus die Konsequenz des Liebeskommunismus bestehen. Die späteren Gemeindebildungen haben in Zeiten der Not ihm gewiß sich oft wieder genähert. Die theoretischen Darlegungen der späteren Kirchenväter verkündigen ihn vielfach als die eigentliche christliche Grundlehre: frei und allen gemein wie Licht, Luft und Erde, wie der Ursprung aus Gott und die Bestimmung für Gott sei allen der irdische Besitz durch die alles mitteilende Liebe. Wo man es dann später rein abstrakt wieder unternahm, Weisungen Jesu über soziale Dinge, d. h. über die absolute Opferbereitschaft der Liebe zu formulieren, da entstand stets von neuem aus der inneren Konsequenz der Sache der Liebeskommunismus. Das Mönchtum, die mittelalterlichen kommunistischen Bewegungen, die Wiedertäufer, moderne Schwärmer und Idealisten, alle sind auf dieser Spur gegangen. Es steckt ein revolutionäres Element darin; freilich an sich ohne jeden Willen zur Revolution ${ }^{30}$ ). Auch die

29) Vgl. Pfleiderer "Lrchristentums 1902, I $22 \mathrm{f}$.

so) Dieser Entwickelung geht Nathanael Schmidt sThe prophet of Nazaret New-York 1905 nach, den ich jedoch nur aus einer lesenswerten Anzeige von Wernle Theol. Lit.Ztg. 1907, 603 f. kenne. Beachtenswert ist auch die Bemerkung, 
Kirche hat diese Konsequenz sehr wohl empfunden und anerkannt. Wir werden sehen, wie sie mit der Gestaltung ihrer Na. turrechtslehre dieser Konsequenz sich entzog, indem sie sie zugleich anerkannte, nur freilich nicht für die Gegenwart, sondern für den Urstand. Für die Gegenwart aber wandert die Gemeinde schon von Paulus ab ganz andere Wege und zwar prinzipiell sozialkonservative Wege ${ }^{31}$ ).

Das Beherrschende des Gedankenganzen ist angesichts dessen jedenfalls nicht diese soziale Konsequenz, sondern der ideale, von der religiösen Idee ausgehende Gedanke der soziologischen Struktur überhaupt. Ihm ist eine ungeheure historische Mission beschieden, gleichviel ob aus ihm sozialkonservative oder sozialrevolutionäre Folgerungen gezogen werden. Zur Macht gekomdaß diese Nachahmung Jesu überall dem Zurücktreten des Dogmas vom Gottmenschen parallel geht. Das letztere rückt in der Tat die Ethik Jesu aus aller Vergleichbarkeit heraus und weist vielmehr auf den Gehorsam gegen die Kirche, deren Stiftung sein eigentliches Werk ist.

31) Merkwürdig ist, daß die kommunistisch-sozialistischen Aeußerungen der Kirchenlehrer erst in der nachkonstantinischen Zeit stark hervortreten. Das hat Harnack (Reden II, 4I f.) mit Recht hervorgehoben und geht auch aus der Stellensammlung deutlich hervor, die L. Brentano gemacht hat (*Die wirtschaftlichen Lehren des christlichen Altertumse) und auf "die auch bereits seine Rektoratsrede $\gg$ Ethik und Volkswirtschaft in der Geschichte I90I hingedeutet hatte. Brentano selbst beachtet das nicht und spricht daher auf Grund dieser spätern Kirchenlehrer von einem sstark sozialistischen Grundzug, der die christliche Eigentumslehre durchwehe S. 183. Auch Kautsky und Pöhlmann haben außer auf das Mißverständnis der Reich-Gottes-Idee und der Apokalypse auf diese späten Lehrer und vọr allem auf die Homilie XI in acta apost. des Chrysostomus sich als den Beweis des kommunistischen Charakters des Christentums berufen. Diese allerdings auffallende Predigt hat nun aber als Text, die Geschichte von Ananias und Saphira acta 4 und ist damit ganz erklärlicherweise durch den Text auf den Kommunismus gelenkt. Immerhin ist die Erscheinung auffallend. Sie erklärt sich, wie schon Uhlhorn I, $265 \mathrm{ff}$. zeigt, teils aus der sehr verschlechterten wirtschaftlichen Lage, teils aus der von den späteren Vätern ausgebildeten und unten darzulegenden Lehre vom Urstand, teils und vor allem aus dem Mönchtum, wie ja Chrysostomus selbst andeutet: "So lebt man heute in den Klöstern, wie ehemals die (jerusalemischen) Gläubigen lebten (Brentano 158). Praktisch gab die Kirche dem auch nicht die geringste Folge, wie Harnack (Reden 43), Overbeck "Sklaverei 229 und Uhlhorn I, 293 hervorheben, eher das Gegenteil. Brentanos Darstellung entbehrt jeder Vertrautheit mit dem Geist der alten Kirche, will ja auch nur die Unbrauchbarkeit der altchristlichen Ideen für eine liberale kapitalistische Wirtschaftspolitik dartun, woran ohnedies nicht zu zweifeln war. 
men, wird (r überall das soziologische Grundschema verändern, in dem sich Mensch zu Mensch empfindet. Soziale und politische Konsequenzen werden unvermeidlich sein und so oder so dem Bestehenden einen eigentümlichen Geist einhauchen. Auch ist von vorneherein klar, daß die Auseinandersetzung und Ausgleichung mit dem Politisch-Sozialen nichts weniger als leicht und einfach sein wird. Vor allem aber bedarf es, bis es dazu kommen kann, noch einer viel größeren Festigung und inneren Durcharbeitung des religiös-soziologischen Gedankens selbst, der im Evangelium nur wie ein strenges, aber wenig. bestimmtes Ideal über dem Ernst der Bereitung für das bevorstehende Gottesreich erhaben schwebt, und den keine christlich-religiöse Organisation je später so hat übernehmen und fortführen können, wie er in heroischer Größe und kindlicher Unbefangenheit vom Evangelium gepredigt worden ist.

Die Frage ist nur, ob dieser Gedanke im Christen-Evangelium völlig einzig auftritt, oder ob er nicht etwa verwandte Richtungen neben sich hat. Eine solche ist nun unzweifelhaft vorhanden in der späteren, namentlich der römischen Stoa, und ein Blick auf sie ist nicht bloß für die Analyse des Gedankens, sondern auch für das Verständnis der weiteren geschichtlichen Entwickelung von hoher Bedeutung. Auch die stoische Lehre ist in erster Linie eine religiös-metaphysische Lehre, hervorgegangen aus dem religiösen Umbildungsprozeß der Spätantike, und auch bei ihr handelt es sich dann um eine von ihrem religiösen Gedankenzentrum ausgehende allgemeine soziologische Struktur. Auch von ihrem philosophischen Monotheismus geht eine der antiken Volksreligion schlechthin entgegengesetzte religiöse Menschenbeziehung aus. Der Grundgedanke ist die Idee Gottes als des allgemeinen geistig-physischen Naturgesetzes, das alles einheitlich durchwaltet und als allgemeines Weltgesetz die Natur ordnet, die verschiedenen Positionen des Einzelnen in Natur und Gesellschaft hervorbringt und im Menschen zum Gesetz der Gott erkennenden und darum mit Gott einigen Vernunft wird. So verlangt das Naturgesetz, ein Begriff, der dann auch in der christlichen Theologie zu einer außerordentlichen Rolle berufen war, einerseits die Fügung in den harmonischen Gang der Natur und die dem einzelnen zugefallene Rolle innerhalb des sozialen Systems, andererseits die innere Erhebung über all das und die sittlich-religiöse Freiheit der mit Gott einigen und darum von keiner sinnlich-äußerlichen 
Tatsächlichkeit zu störenden Vernunftwürde. Es ist die Aufgabe des Willens, dieses Naturgesetz zu erkennen und durch diese Erkenntnis die Bändigung des äußerlichen und sinnlichen Begehrens wie die innere Hoheit und Reinheit des Willenseinklangs mit der göttlichen Weltregierung, die in Gott durch Erkenntnis geborgene Persönlichkeit, zu erarbeiten. Daraus ergibt sich auch hier ein prinzipieller Individualismus der religiös-ethischen Persönlichkeitsidee und ebenso sein unumgängliches Korrelat, ein ebenso prinzipieller Universalismus, der alle Menschen zur gleichen Gotteserkenntnis berufen weiß und sie in gemeinsamer Hingabe an das göttliche Naturgesetz ethisch verbindet. Es ist eine volle Analogie zu dem soziologischen Gedanken des Christentums. Auch fehlen die entsprechenden Rückwirkungen auf die sozialen Probleme nicht. Am deutlichsten sind sie auch hier an dem diesen Rückwirkungen zugänglichsten Punkte, bei der Familie und der Sexualethik. Die sittliche Freiheit und Gleichheit von Frauen, Kindern und Sklaven wird proklamiert auf Grund auch ihrer Berufung zur Gotteserkenntnis, und, weil es sich in der Ehe um ein Verhältnis sittlicher Persönlichkeiten handelt, wird auch vom Manne die volle persönliche Hingabe an die Frau gefordert und damit die voreheliche und außereheliche Keuschheit. Auch der Sklavenbefreiung und Sklavenbehandlung werden von hier aus neue Wege gezeigt, Armenversorgung und Anfänge öffentlicher Liebestätigkeit organisiert. Ja, ein Sozialideal wird aufgerichtet, das für alle die sittliche Freiheit und Gleichheit fordert und ohne Zwang, Staat, Krieg und Recht in der Vollkommenheit der sittlichen Gesinnung die Menschen in kommunistischer Lcidlosigkeit leben läßt. An eine Verwirklichung dieses Ideals war freilich nicht zu denken. Es wurde von den Stoikern der goldenen Urzeit zugeschrieben und als unwiederbringlich verloren betrachtet; erst ein neuer Weltlauf kann hier wieder von vorne anfangen. In seltsamem Gegensatz zu dem Grundgedanken der pantheistischen Harmonie wird die Verwirklichung des Ideals nicht bloß als dem Willen der Menschen zugewiesen betrachtet, sondern auch als durch die Schwäche und Sünde verhindert; die Menschheit ist gesunken und in der Gegenwart gibt es die Erhebung nur für den Einzelnen und im privaten Kreise. Nichtsdestoweniger versucht man aber doch auch das tatsächliche Recht möglichst diesen Humanitätsideen anzupassen. Die stoische Weltimmanenz des Naturgesetzes, die umdeutende Annahme der Volks- 
religion, die Zugehørigkeit zur herrschenden Oberschicht ermöglicht den Stoikern eine reformatorische Einwirkung auf die Welt, dic dem christlichen Dualismus und seiner Ausschließlichkeit unmöglich war. Die römischen Juristen der Kaiserzeit sind von ihren Ideen erfüllt und suchen sie mit dem positiven Recht auszugleichen. Die Gesetzgebung hat daher jene Grundsätze vielfach in die Praxis übergeführt, und vor allem hat die. Theorie der Juristen das positive Rechtsgesetz auf das allgemeine göttliche Naturgesetz zurückzuführen unternommen und aus dem $\mathrm{Na}$ turgesetz als besondere Anwendung die Idee des Natur rechts begründet, aus dem letztlich alle positiv-rechtlichen Ordnungen und damit Staat und Gesellschaft selbst hervorgehen oder dem sie doch möglichst sich anpassen sollten. Hier ist insbesondere $\mathrm{Ci}$ cero von höchster Bedeutung. Damit sind äußerst zukunftsreiche Begriffe geschaffen. Der kommunistische, dem Ideal oder Naturgesetz entsprechende Urzastand und das wenigstens relativ dem Naturgesetz entsprechende oder entsprechen sollende positive Gesetz von Staat und Gesellschaft: das sind Begriffe, die der christlichen Theologie später noch die wichtigsten Dienste leisten sollten.

Die nahe Verwandtschaft dieser Gedanken mit dem Christentum liegt auf der Hand, insbesondere da, wo, wie in der römischen Stoa und besonders bei Seneca und Epiktet, das göttliche Weltgesetz die Züge einer gütigen Vorsehung und die religiöse Stimmung dic Färbung einer persönlichen Gottesgemeinschaft annimmt. Insbesondere nach der soziologischen Seite ist die Uebereinstimmung der Folgerungen aus diesem Gottesglauben, ganz ähnlich denjenigen, die Jesus zieht; und es ist begreiflich, daß Zöglinge stoischer Ethik im Christentum dann später die gesuchte philosophische Religion wie umgekehrt die Christen eine Entlehnung aus der Bibel oder einen Stützpunkt allgemeiner natürlicher Erkenntnis bei ihnen zu finden meinten. Bei Epiktet ist in der Tat eine Mlitwirkung christlicher Einflüsse nicht ganz von der Hand zu weisen; bei Seneca verbindet sich mit der stoischen Weltregierungslehre und Theodicee die dualistische Psychologie Platons und der Glaube an die Anähnlichung der Vernunft an Gott: und bei beiden mildert die Beobachtung des Lebens den stoischen Rigorismus und die stoische Selbstgerechtigkeit durch Mitgefühl mit den Schwächen und Sünden der Menschen. Aber trotzdem liegen doch auch die Unterschiede klar zu Tage. Durch 
allen Theismus schlägt immer der urwüchsige Pantheismus wieder durch, der keinen, der Welt und Sünde entgegengesetzten und aus ihr heraus zum Kampfe und zur Gemeinde führenden Gotteswillen kennt; im Zusammenhang mit ihm werden die sittlichen Naturgesetze leicht auch zu utilitarischen Gesetzen der Weltordnung und die Gottverwandtschaft des Menschen zur Naturverwandtschaft. Schließlich ist bei der Eindeutung dieser Begriffe in die Volksreligion auch nach dieser Seite hin jede neue Religionsbildung ausgeschlossen und fehlt insbesondere jede Verkündigung eines kommenden Gottesreiches und der Welterneuerung, statt dessen die Blicke vielmehr nur auf ein für immer verschwundenes goldenes Zeitalter gerichtet sind, das auch bei einer neuen Weltperiode sich nicht lange behaupten wird; die Einheit und Schönheit der pantheistisch verstandenen Welt wird eben durch die menschliche Schwäche nicht allzutief beeinträchtigt. Vor allem aber ist es der Glaube der Oberschicht, die bei aller Konzentration auf innere Güter der Tugend doch an alle bestehenden Institutionen gebunden bleibt und daher im stoischen Ideal nur die Aussonderung Einzelner zu hoher Bildung und sittlicher Erkenntnis sieht. Zugleich damit erhält sich in ihr der aristokratisch-selbstgenügsame Geist einer nur eben aufgeklärten und ethisch vertieften Herrenschicht. Das Christentum ist demgegenüber die Bewegung der unteren Schicht, die etwas völlig Neues wollen kann und in ihrem Mythos und ihrem Heros über ganz andere massenpsychologische Kräfte verfügt. Das eine ist das religiöse und ethische Korrelat des Weltreiches und die ethische Erhaltung und Reform des Bestehenden, das andere ist die geistige Revolution, die Schaffung eines neuen Gemeinschaftsgebildes und einer neuen Zukunft von unten her.

Noch schärfer unterscheidet sich der Stoizismus dann allerdings von der paulinischen und kirchlichen Lehre, die mit ihrer Lehre von Sünde und Erlösung und ihrer Darbietung der Gnadenund Liebeshilfe durch die Wunderkräfte der Christus-Mystik Ideen in Bewegung setzt, die der stoischen Lehre ganz fremd sind, und ganz anders eine zukunftssichere Gemeinde aufzubauen im Stande sind. Selbständig geworden und in die gebildete Oberschicht eindringend wird aber diese Gemeinde dann die stoischen Gedanken für ihre Ethik und Soziologie immer stärker heranziehen, je mehr sie ihr neues Sondergut auf die Basis allgemeiner wissenschaftlicher Erkenntnisse zu stellen dann für notwen- 
dig finden wird ${ }^{32}$ ).

Alles in allem handelt es sich bei Evangelium und Stoa und bei den weiteren verwandten, von der Forschung erst aufzuhel-

s2) Vgl. Wendland; Zeller ,Gesch. d. griech. Philos. III I und III' 2 ; Overbeck ,Stellung der alten Kirche u. s. w.e; Keim S. 31-55; 308-328; Bonhöffer -Die Ethik des Stoikers Epiktete 1894; Zahn >Der Stoiker Epiktet und sein Verhultnis zum Christentum 1895; Baur sDrei Abhandlungen zur Geschichte der alten Philosophie und ihres Verhăltnisses zum Christentume 1876 ; Jodl I, 584-587, 82-108. Die universale Sozialethik gehört der Stoa allein an, und darauf beruht auch ihre außerordentliche im folgenden zu zeigende Bedeutung für das Christentum. Die vielfach nah verwandte $\mathrm{k} y \mathrm{n}$ is $\mathrm{ch}$ e Ethik und Diatribe berührt sich freilich auch nabe genug mit ihm, ist aber bei dem Mangel einer in der religiösen Idee der Gotteseinheit und der Gottesliebe begründeten Sozialethik nicht entfernt von der dauernden Bedeutung; sie wirkt mehr in der Richtung des reinen Individualismus, der Beschränkung auf innere Güter, der Askese. Von einer Bedeutung der anderen sozialethischen Großmächte der antiken Philosophenschulen ist in der alten Zeit des Christentums dann überhaupt nicht die Rede. Die a ristotel is che Sozialphilosophie mit ihrem bloß auf den staatsbildenden Vernunfttrieb beschränkten und keinerlei rechtliche Folgerungen aus ihm ableitenden Naturrecht, mit ihrem Haften am konkreten antiken Stadtstaat und ihrer bloßen philosophischen Regulierung des konkreten geschichtlichen Staates liegt auf Jahrhunderte dem christlichen Denken fern und ist später erst durch Einschmelzung in die stoische Idee vom Naturgesetz zu Bedeutung gekommen. Der seit dem zweiten Jahrhundert sich erneuernde Platon is mus ist freilich von höchster Bedeutung für das christliche Denken, aber nur durch seine religiöse Mystik und dualistische Metaphysik, nicht durch seine Sozialphilosophie. Die ist beim echten Platon ebenfalls am Stadtstaat orientiert, spezifisch hellenisch und aristokratisch, und ihr Kommunismus ist nicht aus der Liebe zu Gott und in Gott, sondern aus dem Triebe der Idee zu ihrer einheitlichen Selbstdarstellung motiviert, hat daher keine innere Verwandtschaft mit den christlichen Ideen des universalen Liebeskommunismus. Der neue Pythagoräismus und Platonismus hat im Unterschiede von dem patriotischen und sozialreformerischen Interesse des noch dem konkreten Griechentum zugewandten Plato ein alles überwiegendes religiöses Interesse in dem Sinne der Mystik, der Askese, des Unsterblichkeitsglaubens und der Sicherung des Seelenheils in innerer Wiedergeburt und Vergeistigung des Kultus, in dern dem Gläubigen göttliche Offenbarungen zuteil werden. Sozialethisch und politisch finden sie sich mit dem Imperium ab, predigen eine Ethisierung der bestehenden Einrichtungen und allgemeines Wohlwollen, aber die eigentliche Spitze des Gedankens ist nicht die einer im ethischen Gottesdienst geeinigten Menschheit, sondern die mystische, stark aristokratisch und intellektualistisch gedachte Kultgemeinschaft. Der eigentliche Ne uplat o $n$ is $m$ us vollends stellt die politischen und für die Antike damit immer eng zusamenhängenden sozial-ethischen Interessen überhaupt zurück hinter die völlig subjektive, in der Ekstase gipfelnde Religiosităt; sein Gottesbegriff enthält wohl Grundlagen der Mystik, aber keine der Sozialethik. 
lenden Bildungen des späten Altertums um eine Wandelung der Lebenswerte und um ein neues Ideal des Menschentums, wie es aus der Zerbrechung der militaristischen und polytheistischen $\mathrm{Na}$ tional- und Eroberungsstaaten hervorgeht. Dem Monotheismus entspricht die geschlossene Persönlichkeit und der universale Menschheitsgedanke. Dem verinnerlichten Gottesglauben, der im Gegensatz zu den Staat, Recht, Krieg, Gesellschaft heiligenden polytheistischen Kulten emporsteigt, entspricht eine Menschheit der inneren Freiheit und der Gesinnungsgemeinschaft ohne Macht, Recht, Krieg und Gewalt. Die Art, wie hier und dort der neue Gedanke sich begründet und durchsetzt, ist trotz aller Aehnlichkeit sehr verschieden, aber die Kräfte strömen doth zusammen und bauen gemeinsam ein neues soziologisches und dann auch sozial-politisches Ideal auf, das bleibend seine innere Spannung gegen die rein innerweltlichen Lebensformationen, gegen die aus dem Kampf ums Dasein und dessen rechtlichen Milderungen entsprungenen Institutionen, behält, auch nachdem sie ihre polytheistische Sanktion verloren haben. Die Gleichheit und Einigung aller im Besitz der Gottesvernunft dort, die Emporhebung und Verschmelzung der Seelen in der Gottesliebe hier, beides bedeutet ein auf reine religiöse Gedanken begründetes Menschheitsideal, das von den alten naturalistischen oder die Naturtriebe nur einschränkenden und ausgleichenden Idealen durch eine tiefe Kluft getrennt ist und doch immer wieder zum Versuch einer Ueberwindung dieser Kluft genötigt ist. Beide verkürzen in ihrem Idealismus die Na-

Das ist wohl höchst bedeutend für die Theorie der religiösen Erkenntnis und für die Metaphysik, für das Mönchtum und für die Stellung der Kirche gegen die Welt, aber nicht für den Gedanken einer universalen Sozialethik. Daher beziehen sich auch alle späteren Annäherungen an die Politeia Platons nur auf das Verhältnis der Kirche zur Welt, der seelenleitenden Körperschaft zu den Laien, aber nicht auf die allgemeine Sozialethik des Christentums. Zeller III, 142 f., 146-I89, 605. Von Dantes christlicher Sozialethik und Politik auf die sie bedingenden historischen Elemente zurückgehend kommt Voßler „Die göttliche Komödie« I, 2, r 907 zu ganz ähnlichen Ergebnissen, soweit die hellenistisch-römische Soziallehre und Ethik in Betracht kommt. - Ueber die außerordentliche Bedeutung Ciceros für die christliche Ethik s. auch das ausgezeichnete Buch von Thamin, St. Ambroise et la morale chrétienne au 4ème siècle 1895 . Il est un de ses ancêtres moraux et, à sa manière, lui aussi un père de l'église « 172. Ders. über Seneca 178: Jérôme le compta donc au nombres des écrivains ecclésiastiques, et pendant douze siècles ce fut une tradition incontestée. Merkwürdigerweise spielt Epiktet nicht entfernt die gleiche Rolle. 
turbasis des Lebens und haben beide mit deren beständiger Wiedergeltendmachung $\mathrm{zu}$ tun. So arbeitet sich in beiden ein neues, an Spannungen und Schwierigkeiten reiches Ethos empor, das ein dauernder Besitz der europäischen Menschheitsbildung geblieben ist, aber auch dauernd im Kampfe steht gegen die realistischen Forderungen der Naturtriebe, der materiellen Existenzbedürfnisse und gegen die politischrechtlichen Machtbildungen. Die Führung aber in dieser Herausbildung übernimmt in steigendem Maße die Organisation, die aus dem Evangelium hervorwuchs ${ }^{\text {22a }}$ ).

\section{- II.}

\section{Pa ulus.}

Wie in allen Stücken, so bedeutet auch in unserer Frage die Organisation einer vom Judentum abgelösten, auf den Christuskult begründeten und für diesen Christus missionierenden Weltkirche eine wesentliche Aenderung des Gedankens. Der Grundvorgang, die Entstehung des mystischen Glaubens an die die Gemeinde erfüllende Gegenwart des himmlischen und auferstandenen Herrn und an die hiemit bewirkte Erlösung und Befreiung auch seiner ihm eingepflanzten Gläubigen vom sündigen bisherigen Weltlauf, all das kann hier auf sich beruhen ${ }^{33}$ ); hier handelt es sich nur um seine soziologischen und sozialen Folgen. Diese sind beträchtlich genug.

Die des Gottesreiches harrende und auf sein Kommen sich bereitende, freie und fließende Gemeinde der Jesus-Gläubigen wird durch den Glauben an Jesus als den Auferstandenen, durch die Deutung Jesu als Messias und im engen Zusammenhang damit als, erlösenden göttlichen Weltprinzips, durch den neuen Christuskult und seine mystische Erlösungsidee, durch Taufe und Herrn-

32-) Hierzu s. Weinel, sStellung des Urchristentums S. 34 ff., 41 . Aehnlich, nur mit der entgegengesetzten Parteinahme zeichnet Jodl die platonische, stoische, neuplatonische und christliche Ethik als metaphysische (d. h. religiös-monotheistische) und stellt alles übrige dem als empiristische und der Natur gerecht werdende Ethik gegenüber.

s3) Vgl. Wrede sPaulus«, I905, Jülicher „Jesus und Pauluse, 1907, Wernle - Anfängee. Die Einsicht, daß der entscheidende Vorgang des Urchristentums die Entstehung eines Christus-Kultus aus dem Christus-Glauben ist und daß erst damit eine neue Religionsgemeinschaft, weil ein neuer $\mathrm{Kult}$, entsteht, verdanke ich meinem Freunde Deißmann. Ich setze hier nur die soziologischen Konsequenzen auseinander. 
mahl als Mittel der Verpflanzung in den gegenwärtigen himmlischen Christus zu einer selbständigen Religionsgemein $\mathrm{ch}$ af $\mathrm{t}$, die wenigstens im Ideal streng geschlossen und einheitlich verbunden ist. Es ist ein neuer Kult. Die Kultgemeinde ist der Leib des Christus, in den man durch die Taufe eingepflanzt wird und durch den man im Herrnmahl gespeist und getränkt wird. Die genaueren historischen Anknüpfungen, in denen sich dieser Gedanke einer neuen Kultgemeinde formt, wie weit dabei das Vorbild der Synagoge oder etwa auch Vorbilder der Mysterienkulte wirksam gewesen sein mögen, kann gleichfalls hier auf sich beruhen ${ }^{33 a}$ ). Das Entscheidende ist, daß in dieser, wie immer historisch-genetisch zu verstehenden, Form ein selbständiger, von den wesentlichen Tendenzen des Evangeliums erfüllter Strom der Ideen und Kräfte entsteht, die dann auch Synagoge und Mysterienkulten gegenüber ihre eigene spezifische Dialektik entfalten. Dabei bleiben die Grundzüge der Ethik des Evangeliums bestehen, aber als Ethik einer Kultgemeinde empfangen sie eine neue Nuancierung. Die Herzensreinheit wird zur Heiligung mit einem starken Gegensatz der durch die Taufe in Christus eingepflanzten Gläubigen gegen die Welt, wobei aber immer noch alles einbegriffen bleiben kann, »was gerecht, heilig, liebenswürdig, ehrbar, etwa eine Tugend, etwa ein Lob ist «. Die Nächstenliebe wird zur Bruderliebe und zum Liebesprinzip überhaupt, dem Paulus sein berühmtes hohes Lied gesungen hat. Mit der Betonung der Gemeinde scheint sogar das Liebesprinzip stark in den Vordergrund zu treten, und im Johannes-Evangelium ist die Liebe geradezu der einzige Inbegriff der christlichen Ethik. Allein das ist nur scheinbar, die Liebe ruht auf religiös-individualistischem Grunde, und der religiöse Individualismus ist und bleibt die Kernidee. Stärkere Veränderungen erfährt dagegen begreiflicherweise die soziologische Struktur. Die sehr allgemeine Individualitätsidee und die sehr freie und bewegliche Gemeinschaftsidee des Evangeliums bekommen eine starke Zuspitzung und eine empfindliche Verengung. Der soziologische Gedanke empfängt in dem alles durchwirkenden, mit dem Gottesgeist identischen Pneuma-Christus eine unermeßlich wirksame kultische Vergegen-

38 a) Für das erstere vgl. K. Rieker »Staat und Kirche in $\gg$ Festschrift für Emil Friedberg « 1908, für das zweite A. Dieterich „Eine Mithrasliturgie" I903. Diese ganzen Fragen sind noch sehr wenig geklärt. 
wärtigung seines Beziehungsmomentes, aber auch eine engere und dogmatisch gebundene Kn üpfung dies e r Bezie hungen selbst. Der unendliche Wert des Individuums knüpft sich nun nicht bloss an die Selbstheiligung für den väterlichen Gotteswillen, sondern an das Sein und Leben in dem mystisch durch die Gemüter ausgegossenen, in Taufe und Herrnmahl wirkenden, das eigentliche höhere Leben in dem Gläubigen bildenden Christus, der freilich in seinem jetzt enthüllten himmlisch-pneumatischen Wesen nichts anderes ist als der erlösende, die Dämonen, Gesetz und Sünde bezwingende Gottesgeist selbst. Die Gotteskindschaft als Inbegriff des absoluten religiösen Individualismus wird zum "Sein in Christo * Ganz entsprechend wird dann auch die Gemeinschaft der Gotteskinder in der Bruderliebe zur Bruderschaft nicht in Gott, sondern in Christo; in der gemeinsamen Verbindung aller Gläubigen durch das Leben in der realen mystischen Lebenssubstanz des Christus werden sie zu Gliedern am Leibe Christi. Der Universalismus ferner, der in der Liebe die Gottesgesinnung an alle Welt offenbarte und durch solche Offenbarung weckte, bleibt dies nach innen, wird aber nach aussen zur Mission und Bekehrung, die vor der Wiederkunft Christi und dem Gericht die gesamte ohne Christus verlorene Welt aufnehmen will in die crlösende Anteilnahme an Tod und Auferstehung des PneumaChristus und diese Bekehrung durch sehr viel verwickeltere Arbeit herbeiführt als durch das bloße Kundwerdenlassen der Liebe als der Gesinnung Gottes; sehr natürlich, da es sich nicht mehr um eine Predigt an die die Voraussetzung teilenden Volksgenossen handelt, wie bei Jesus, und nicht mehr bloß um Gottes Willen und Gottes Reich, sondern um die Lehre vom Seelenheil in Christo.

Mit dieser konkreten Fassung und der von da aus sich ergebenden geschlossenen praktischen Durchführung der soziologischen Grundgedanken tritt nun aber eine weitere wichtige Eigentümlichkeit hervor, die zwar im Evangelium durchaus begründet ist und auch von Jesus gelegentlich ausgesprochen ist, die aber erst bei der Bildung eines geschlossenen, seine Glieder gegenseitig auf sich anweisenden Kultkreises von Bedeutung wird. Es ist die dem christlichen religiös-soziologischen Gedanken eigentümliche Fassung des Gl ei ch heits- und Ungleich heitsproblems. Jedes derartig zugleich individualistische und universalistische System enthält naturnotwendig irgendwie den Ge- 
danken der Gleichheit, stellt alle Individuen auf den Boden eines gleichen Anspruches an den höchsten und letzten Lebenswerten oder doch einer gemeinsamen Berufung und Bestimmung für diese Werte. Das scheint mit dem Gedanken eines absoluten Wertes überhaupt gegeben. Aber da zeigt sich nun wieder sofort die eigentümliche Wirkung des religiösen Ausgangspunktes auf den ganzen soziologischen Gedanken. Wie der Individualismus nur in Gott sich begründet und voliendet und wie der Universalismus nur in der von Gottes allumfassender Liebe ausgehenden Liebesrichtung auf den Nächsten begründet ist, so ist der hier eingeschlossene Gleichheitsgedanke rein auf die religiöse Sphäre beschränkt. Es ist eine Gleichheit rein vor Gott und in Gott, lediglich in der religiösen Beziehung auf Gott als den Mittelpunkt des Ganzen. Und zwar ist diese Gleichheit zunächst gar nicht eine Gleichheit des Anspruchs, sondern eine Gleichheit des Abstandes und Gegensatzes gegen die unendliche Heiligkeit Gottes. Indem für die Missionspredigt der Gedanke einer gleichen Bedürftigkeit aller nach der Erlösung in Christo beherrschend wird, tritt auch dieses erste und wichtigste Merkmal der Gleichheit hervor: in der gemeinsamen Sündhaftigkeit und Bedürftigkeit verschwinden Gott gegenüber alle Unterschiede der Menschen. Nicht vom gleichen Anspruch, sondern von der gleichen Unwürdigkeit aller geht die Nivellierung aus. Freilich ist nun dann aber diese sozusagen negative Gleichheit nur die Unterlage für die Hingebung an das in Christo, der Gemeinde und ihren Sakramenten gegebene Heil der Gnade, die dann ihrerseits wieder allen Gläubigen das absolute Heil mitteilt. Die aber Teil haben am Absoluten und Göttlichen, sind eben dadurch nun positiv im Besitz des Absoluten gleich, da es hier kein Mehr und kein Weniger gibt. Immerhin ist diese Gleichheit in der Gnade eine ganz eigentümliche Gleichheit., Sie ist auch hier nicht begründet in einem naturgegebenen gleichen Anspruch, sondern in der Gnadenmitteilung der göttlichen Liebe, die überall, wo sie sich überhaupt mitteilt, nur ganz sich mitteilen kann, und die durch sich selbst ohne jede äußere soziale Veranstaltung und Sichtbarmachung die prinzipielle Gleichheit mitteilt trotz aller Unterschiede in menschlicher Lebensstellung, in Begabung und in ethischer Leistung. Es ist eine Gleichheit, die daher nur in der gleichen Anteilnahme aller am Kult zum Ausdruck kommt. Das Herrenmahl ist zugleich das Fest der Brüderlichkeit. Sklaven können Kultvor- 
steher sein. Ganz von selbst und rein innerlich teilt sich durch den Christuskult die Gleichheit mit, und es bedarf keiner andern Sicherstellung der Teilnahme aller am religiösen Heilsgut. Denn dies Gut ist die in sich einheitliche und in sich unendliche Liebe Gottes, die sich in keiner Mitteilung erschöpfen kann, die durch keine Teilung verringert werden kann und die sich immer als ein in sich wesentlich Einheitliches und Ganzes mitteilen muß ${ }^{34}$ ). Ihre äußere Wirkung und Sichtbarmachung, ihre Organisation und Verteilung besteht daher lediglich in der Gemeinsamkeit eines Kultus, der keine Unterschiede vor Gott kennt, und in der Liebe, die keine Ueberhebung kennt im Gefühl eigener Unwürdigkeit und die alles mitteilt im Gefühl, daß sie selbst alles erst empfangen hat.

Hierbei bleibt nun aber ein für den Gleichheitsgedanken ganz außerordentlich wichtiger Punkt noch offen. Alle sind gleich in dem Abstand von Gott, und alle sind gleich vor Gott und in Gott durch den Besitz der Gnade. Haben aber nun auch alle Menschen Bestimmung und Anspruch, aus dieser Gleichheit des Abstandes zu der Gleichheit des Gnadenbesitzes erlöst zu werden? Ist auch der Uebergang von der einen Gleichheit zur anderen Gleichheit selbst ein in gleicher Weise allen bestimmter und, da wo er nicht zustande kommt, lediglich in Wille und Schuld des Menschen, aber nicht in Wille und Wesen Gottes begründet? Es ist der wichtigste Punkt der Gleichheitsidee, und an ihm tritt im paulinischen Evangelium ein charakteristisches Schwanken ein, das für die ganze weitere Entwicklung von höchster Bedeutung ist. Es sind die berühmten großen Probleme der Prä destination einerseits, des universalen göttlichen Liebeswillens andererseits. Sie sind nicht bloß religiös-dogmatische Probleme von einer außerordentlichen Schwierigkeit geworden, sie sind vielmehr auf Jahrhunderte grundlegende Koeffizienten des soziologischen und damit auch des sozialen Denkens geworden. Dabei handelt es sich auch nicht etwa bloß um eine zufällige paulinische Lehre, die durch die Kanonisation der paulinischen Briefe dann ein historisches Schicksal der christlichen Ideenwelt geworden wäre. Vielmehr ist die paulinische Lehre selbst nur eine Auswirkung des im ganzen Gottesgedanken des Evangeliums enthaltenen Willensmomentes, das im israelitischen Gottesgedanken

34) Vgl. Simmel sDie Religione (Die Gesellschaft, Frankfurt, Bd. II) S. 47. Die kleine Schrift enthält viel Feines, aber auch viel Gesuchtes und Willkürliches uber die Soziologie der Religion. 
stets besonders stark ausgeprägt war und ihm seine Gewalt der unendlichen, das Geschöpf überragenden Allmacht verliehen hatte. Auch als heilige und gütige Vaterliebe bleibt er der Wille, dessen Heiligkeit eine Setzung seines Willens ist und dessen Liebe eine Tat der grundlosen Gnade ist. Aber es ist auch nicht bloß eine Zufälligkeit des semitischen Gottesgedankens, der hier in Jesu und Pauli Predigt erhalten geblieben und nur noch nicht völlig in sittliches Gesetz und universale Liebe aufgelöst wäre. Man braucht nur an die weitere Geschichte des Gedankens und seine philosophische Entfaltung von Augustin bis Descartes zu denken, um zu bemerken, daß darin ein wesentliches und grundlegendes religiöses und metaphysisches Problem überhaupt enthalten ist, das in jedem von religiösen Gedanken ausgehenden soziologischen Denken dieses Problem wiederkehren muß. Ist Heiligkeit und Liebe Norm für Gott selbst oder gelten sie nur durch seinen grundlosen Willen? oder anders ausgedrückt: Sind Denkgesetze und Werte gültig durch sich selbst oder durch einen sie erst setzenden Willen? ist das Allgemeingültige gültig durch seine Allgemeinheit oder folgt seine Allgemeinheit aus Setzung durch einen selbst nicht unter Allgemeingültigkeit stehenden Willen? Es sind die Probleme des Intellektualismus und Voluntarismus, die am Ende aller Erkenntnistheorie und Metaphysik liegen und die aus jedem tieferen Durchdenken des Gottesbegriffes, aus der Dialektik des religiösen Gedankens, folgen ${ }^{35}$ ). Paulus weiß nun freilich nichts von diesen weitgreifenden Gedanken, er denkt an diesem Punkte wie an so vielen anderen instinktiv und intuitiv; aber trotz seiner hilflosen, an die rabbinische Auslegungskunst sich klammernden Argumentation findet seine religiöse Genialität den dem Ganzen entsprechenden Ausweg. Gottes Güte ist Gnade und grundlose Barmherzigkeit, gleicherweise inSchöpfung und Erlösung. Daher gibt es keinen Anspruch des Geschöpfes auf gleichen Anteil aller am Heil; es bleibt Gottes Sache, die einen zu berufen und die anderen nicht zu berufen, die einen länger in der Irre zu belassen als die andern. Darin äußert sich der prädestinatianische Wille Gottes. Aber indem dieser Wille sich das Ziel der Gnade und Güte setzt, wird wohl die ungleiche Verteilung der Berufung sich nur auf die Verteilung der Geschicke im Zusammenhang der Heilsgeschichte beziehen, wird sie nur ein Früher oder Später,

35) Vgl. Kahl, Die Lehre vom Primat des Willens bei Augustin, Duns Scotus und Descartes, 1886 und meinen Aufsatz $>$ Prädestination \& in $\gg$ Christliche Welt \& 1907. 
ein längeres oder kürzeres Preisgeben an Irrtum und Sünde bedeuten und schließlich alle doch zu sich heranholen, bis Gott ist alles in allem. So legt er sich die Geschicke seines Volkes, die scheinb are Verwerfung Israels, zurecht.

Es ist ein Ausweg. Ob dieser Ausweg eine Lösung des Problems ist, kann hier auf sich beruhen. Hier interessiert nur die außerordentliche Bedeutung dieser Ideen für die Soziologie des christlichen Gedankens, für die in ihm eingeschlossene Gleichheitsidee. Der prädestinatianische Gedanke zerbricht den Nervder absoluten und abstrakten Gleich h e itsidee, der gleichen Berufung allẹ zum höchsten Werte, des Anspruchs aller auf das höchste Ziel. Trotz der Gleichheit aller in ihrer sündigen Unwürdigkeit und in ihrem Gnadenbesitz ist doch die eigentliche Gleichheit an sich, der gleiche Anspruch aller auf gleiche Anteilnahme am höchsten Lebenswert durch gleiche Auswirkung der Berufung und Bestimmung, aufgehoben. Auch wenn im letzten Endziel schließlich der auf alle gerichtete Liebeswille - Gottes sich verwirklicht, es bleibt in der Verteilung der Einzelnen auf den Weg zu diesem Ziele die unbegreifliche Willenssetzung Gottes, die es dem einen erleichtert, dem andern erschwert, die die einen lange fernhält und die andern rasch zum Ziele bringt. Bei aller Durchleuchtung der Welt mit einem absoluten religiös-ethischen Wert, bleibt in ihr ein Moment des Irrationalen in der Beteiligung an diesem absoluten Wert, und dies Moment geht zurück auf den unergründlïchen Willen Gottes. Das aber wirkt auf die soziologische Idee dahin, daß ein gleicher auf gleiche Weise zu rerwirklichender Anspruch aller an das Heil oder an das Absolute nicht unbedingt besteht, daß man sich begnügen muß an der Gleichheit des Abstandes von Gott und an der Gleichheit in der Liebe zu Gott, wo überall die letztere Wurzel gefaßt hat. Alles übrige ist Gott anheimzustellen.

Von Paulus her haben diese Gedànken überall die ganze Christenheit mehr oder minder klar durchwirkt, und es liegt auf der Hand, welcher starke Gegensatz dadurch für die christliche Gleichheitsidee gegenüber allen anderen im europäischen Kulturleben auftauchenden Gleichheitsideen gegeben ist. Vor allem ist es der Gegensatz gegen alle naturrechtlich-rationalistische Gleichheitsidee, die aus der Allgemeingültigkeit der Vernunft auch die Allcremeinheit der Vernunft und damit die Gleichheit aller in der Beteiligung an den Vernunftwerten fordert, in der Voraussetzung, 
daß um eben dieser Allgemeingiltigkeit der Vernunft willen auch in jedem die Möglichkeit zu ihrer Vollverwirklichung enthalten sei. Es wird aber auch verständlich, daß das Christentum bei aller radikalen Gleichmachung der Menschen vor Gott, bei aller Hineinwirkung dieser Empfindung in das ganze Seelenleben und alle persönlichen Beziehungen der Menschen zu einander, doch weiterhin auch sehr zurückhaltend ist gegen jede Hineintragung dieser Gleichheit in die weltlichen Beziehungen und Ordnungen, die mit dem eigentlich religiösen Grunde dieser Gleichheit nichts zu tun haben. In den großen Differenzierungen des staatlichen und sozialen Lebens wird es geneigt sein, zunächst etwas dem religiösen Interesse Fremdes zu erblicken und es wird auch hier, soweit sie nicht offenkundig auf Sünde beruhen, die Tendenz haben, darin göttliche Ordnungen und Setzungen zu sehen, die ohne Frage nach ihren Gründen hinzunehmen sind. Es wird diese Neigung doppelt groß sein in einer Zeit, wo die religiöse Propaganda und Arbeit alles aufzehrt wie im Urchristentum, und in einer Lage, wo alle politischen und sozialen Verhältnisse für die allgemeine Empfindung unwandelbar fertig sind wie im römischen Kaiserreich, in einer Missionstätigkeit, wo jeder Schein politischer Ungesetzlichkeit und Gefährlichkeit sorgfältig vermieden werden muß.

Das Christentum wird immer instinktiv sich ablehnend verhalten gegen alle Gleichheitsideen trotz seiner nahen Verwandtschaft mit ihnen, und es wird an diesem Punkt stets seine Hauptschwierigkeit in der Ausdeutung des Begriffes der Gerechtigkeit Gottes haben, die als gleiche Bestimmung aller zum gleichen Zweck zu bezeichnen es genötigt sein wird, und die es doch wiederum in dieser Bedeutung nicht wird festhalten können. Hier liegt der Gegensatz gegen das rationalistische stoische Ideal, das wenigstens für den Urstand das Prinzip der abstrakten Gleichheit aus dem Vernunftbesitz aller folgert. Andererseits aber ist es mit seiner Betonung gleicher Gebrechlichkeit aller und eines radikalen Abstandes aller von Gott, sowie mit seiner Zurückführung alles Heils auf den Gnadenwillen Gottes weit entfernt von jeder prinzipiell aristokratischen Denkweise, von der Grundlehre der Herrschaft und des Vorzugs der Wenigen auf Grund natürlicher Anlagen und geschichtlicher Auslese. Es ist der von der religiösen Idee ausgehende soziologische Gedanke eben ein völlig anderer in seiner Grundstruktur als der vom Rationalismus oder der vom Naturalismus ausgehende, so oft er sich nach beiden Seiten mit den andéren begegnet. $\mathrm{Si}$ 
duo faciunt idem, non est idem.

Damit kommen wir zu einem weiteren wichtigen Punkt, wo wicderum die Lehren des Paulus, aus dem Grundgedanken des Evangeliums schöpfend, gerade durch ihre Formulierung unendlich folgenreich und charakteristisch sind. Es handelt sich um die Ungleichheiten der Menschen in ihrem weltlichen Leben, wie sie teils durch Begabung und Anlage, teils durch soziale und politische Lage bedingt sind. Aus dem Bisherigen geht schon hervor, daß an eine Aufhebung dieser Ungleichheiten nicht gedacht wird. Aber sie werden darum doch nicht rein negativ behandelt, sie werden positiv aufgenommen in densoziologischen Grundgedanken des Wertes der Persönlichkeit und der unbedingten Liebesgemeinschaft, sie werden zu Qucllpunkten eigentümlicher ethischer Werte gemacht. In die religiösc Gleichheit wird die irdische Ungleichheit hineingewirkt als cin Stoff, von dem die erstere einen besonderen Anlaß zur Betätigrung cmpfängt. Paulus benützt hier das bekannte antike Bild vom ()rganismus und dem Verhältnis seiner edleren und unedleren Glicder zu einander, aber er meint damit etwas anderes als eine bloßs > organische "Sozialidee. Er macht dem religiösen Grundgedanken entsprechend die Ungleichheiten zu Anregung und Stoff der Licbcstätigkeit. Der gegenseitige Dienst aller an einander mit den von Gott gegebenen Gaben, die Ueberwindung des Bösen mit Gutem und die Stärkung des Guten im Kampf gegen das Böse, die Hingebung und Unterordnung wie die Leitung und l-ürsorge, die Rücksicht der Starken auf die Schwachen und die Hebung der Schwachen durch die Starken, all das begründet ein gegenseitiges Nehmen und Geben, in dem die christlichen Grundtugenden der Selbsthingebung und Demut wie der Liebe und Verantwortlichkeit für andere, überhaupt der ganze enge innere Zusammenhang eines in sich verbundenen und in allen Punkten sich gegenseitig bedingenden und durchdringenden Systems, zum Ausdruck kommt. Jede Arbeit und Leistung, auch die geringste, findet so ihre Ehre; und jede Größe und jeder Besitz findet so scine Pflicht gegen andere; und alle Demut ist keine Selbstwegwerfung wic auch alle I.ichesleistung, lüursorge und Autorität keine Ucbcrhebung ist, wcil in diesem soziologischen System es nie bloß der Mensch mit dem Menschen, sondern stets das Göttliche im cinen mit dem Grittlichen im anderen zu tun hat, weil sie alle in diesen Leistungen nur Haushalter Gottes sind und das, 
was sie tun, nicht Menschen sondern Gott oder Christus tun. $\mathrm{Daß}$ hierin ein gewisser Quietismus enthalten ist, ist unleugbar; es ist nirgends von Verbesserumg der Lebensbedingungen, sondern nur von ihrem Ertragen und Fruchtbarmachen für inneren Gewinn die Rede. Doch wirkt in solchem Quietismus auch die Erwartung des Endes mit und ist bei dauernder Einrichtung in der Welt von hier aus dann auch eine durchgreifendere Reform möglich geworden. Auch bleibt in einem solchen System bei aller Fügung und Ergebuing doch das Ziel, die gerade in dieser Nützung der Unterschiede $z u$ erreichende Gleichheit der inneren Seelenwerte, und damit die zunächst nur verdeckte revolutionäre Kraft eines wenigstens in der Richtung auf das Ziel wirkenden Gleichheitsgedankens, der schwerlich verfehlen kann, auch schon auf die Selbstempfindung vor dem erreichten Ziel zurückzuwirken. In der Tat gibt es in Christo bereits jetzt keinen Unterschied mehr von Nation und Rasse, von Sklave und Herr, von Arm und Reich, von Mann und Frau. Zugleich ist der Enthusiasmus noch groß genug, um an dieser inneren Gleichheit sich genügen zu lassen und um an die Möglichkeit einer Herstellung dieser Art von Gleichheit bei gutem Willen zu glauben. Die realistische Frage, ob es nicht Arten und Grade des Pauperismus gebe, die auch zu solcher Gleichheit aufzusteigen unmöglich imstande sind und ob nicht erst eine äußere Hebung des Lebens notwendig sei, liegt dieser Ueberzeugung von der Allmacht des guten Willens noch fern.

Damit ist nun aber wieder ein außerordentlich wichtiger soziologischer Typus geschaffen. Es ist der auf religiöse Anerkennung und religiöse Ueberwindung der irdischen Ungleichheit zugleich begründete Typus des christlichen Patriarchalismu s${ }^{35 a}$ ), der seine Vorbereitung im spätjüdischen gehabt hat, aber durch die Wärme der christlichen Liebesidee, durch den Zusammenschluß aller in dem Leibe Christi, seine besondere Färbung erhält. Hier halte man den Jesus Sirach und die Paulusbriefe zusammen, um Aehnlichkeit und Unterschied zu sehen. Seine volle Ausbildung hat er freilich erst im Mittelalter erhalten und damit auch einen spezifischen Charakter, wovon später noch die Rede sein muß. Jetzt hindert noch die Kompliziertheit und die weitgehende Atomisierung des spätantiken Lebens, vor allem der städtische Cha-

35a) Diese Doppelbegründung und Doppelrichtung treffend charakterisiert bei F. J. Stahl $\gg$ Der christliche Staat $\propto, 1858$, S. II-I3. 
rakter der Gemeinden und die relative Unbedeutendheit der sozialen l)ifferenzen innerhalb der Gemeinden seine volle Ausbildung. Aber seine Grundidee der willigen Akzeptierung der gegebenen Ungleichheiten und ihrer Fruchtbarmachung für die ethischen Werte der persönlichen Aufeinanderbeziehung ist gegeben. Alles Tun ist ein Gottesdienst und ein anvert : utes Amt, die Herrschaft wie der Gehorsam. Als Haushalter Gottes sorgen die Großen für die Kleinen und als Dicner Gottes ordnen sicl die Kleinen den Großen unter; und, indem so sich beide im Dienste Gottes begegnen, behauptet sich die innere religiöse Gleichheit und erweitert sich der ethische Besitz durch die zarten Tugenden der Haftung für andere und der vertrauensvollen Hingebung. Dieses Ideal schwebt unverkennbar dem l'aulus vor, und nur durch dieses Ideal will er von innen heraus die gegebenen Verhältnissc geistig ändern, ohne sie äußerlich anzutasten.

Derart erfährrt nun aber der allgemeine soziologische Zusammenhang cinc innere Gliederung durch Ueberordnungen und Lnterordnungen, wie sie in keinem soziologrischen System ausbleiben können ${ }^{35 \mathrm{~b}}$ ). Der radikale Individualismus und Universalismus ist an sich gliederungslos, er umschließt latter gleiche, weil unendlich wertvolle Persönlichkeiten und umfaß3t alle mit grleicher, weil ins Zentrum der Seele dringender Stärke. IVic das System bei praktischer Verwirklichung nicht einfach bei jenen hohen Idealen verharren kann, sondern im Pneuma-Christus cine es zusammenhaltende Autorität, eine Festlegung seiner Grundgedanken und ein anschaulich-suggestiv wirkendes persönliches Urbild hervorbrachte, so machen sich zwischen den beiden Polen des Individualismus und Lnivcrsalismus auch die natürlichen Differenzicrungen greltend, wie sie verschiedene Anlagen, Stellungen und l.cistungen inncrhall, des Ganzen, aber auch das Hereinragen der ron andem Virhältnissen her bereits bewirkten Differenzierungen mit sich bringen. $A$ ber diese Differenzierungen treten in inneren Lusammenhangr mit dem religiösen Gemeinschaftsgedanken selbst, inckem ie zu dlitteln der Entwickelung gerade religiös-ethischer Wert :tiit, (icsamtverantwortlichkeit und rürsorge gegenüber den jeweils L'ntcrscordneten und dic religiös motivierte Hingebung, Liebe und Gchorsamspflicht gegrenüber den jeweils Uebergeordneten be-

35 $\mathrm{b}_{\mathrm{j}} \mathrm{V} \mathrm{l}$. dic schon genannte Abhandlung von Simmel Soziologie der Ueberund Linterordnang:- (Archiv, Band XXIV, 1907), sowie meine Abhandlung $\rightarrow$ Politische Ethik und Christentume 1904. 
haupten. So entsteht eine beständige Bewegung und mit ihr selbst doch eine Ausgleichung aller Bewegung und Unterschiedlichkeit in dem allen gemeinsamen göttlichen Leben, ein soziologischer Typus, der nur auf religiöser Grundlage möglich ist, weil nur hier das Zurückgehen von jeder individuellen Verschiedenheit auf den sie hervorbringenden und zum Organ seiner Einheitszwecke machenden göttlichen Willen möglich ist. Die Individuen gehen nicht bloß mit einem Teil ihres Wesens auf das Ganze ein, wie das sonst in soziologischen Systemen der Fall ist; sondern weil sie ganz und gar, auch mit ihren Besonderheiten, von dem einheitlichen göttlichen Willen gewollt sind, gehen sie gerade mit dem Ganzen und Besonderen ihres Wesens und ihrer Lage in das Gesamtleben ein und löschen es hier nicht aus, sondern machen es zu Mitteln spezifischer ethischer Werte, zu Mitteln gerade der Herstellung des Ganzen.

Damit sind wir von dem allgemeinen religiös-soziologischen Gedanken schon auf die s o zia le n Probleme geführt ${ }^{35 c}$ j. Der soziologische Gedanke will sie von innen heraus bei äußerer Beibehaltung ihrer Form geistig verwandeln. Aber bei dieser bloß inneren Wandelung kann es nicht bleiben. Indem die Gemeinden einen eigenen Kult- und Lebenskreis zu bilden anfangen, müssen sie auch ä $\mathrm{u}$ B e r li ch gegen Staat und Gesellschaft sich abgrenzen und müssen sie im eigenen Innern, soweit es in ihrer Macht steht, bej sich selbst die sozialen Verhältnisse ordnen. Das geschieht denn auch bei'Paulus, und der Zukunft werden von ihm auch in dieser Hinsicht die wichtigsten Richtlinien gezeigt, die gegenüber dem Evangelium neu sind und die wenigstens für ${ }^{*}$ die alte Kirche den nächsten Weg bestimmen, die aber durch die Kanonisierung der Paulusbriefe auch für spätere Zeit eine vielfache dogmatische Wirkung haben. Die Kindlichkeit, Weite und Höhe des Evangeliums zieht sich schon jetzt ins Konkrete und Praktische, und der herbe Radikalismus weicht schon jetzt den Kompromissen mit einer von der Welt geforderten Verständigkeit. Immer aber bleibt bei aller. Verständigkeit doch der moderne Gedanke fern, daß gerade der Aufbau einer geistig-sittlichen Welt einen entsprechenden Unterbau der materiellen und sozialen Verhältnisse erfordere. Es sind nur äußere Anpassungen, nicht innere Verbindungen. Die Ideologie des guten Willens fühlt sich für mehr als

${ }^{35}$ ) Vgl. auch hier Jacoby *Neutestamentliche Ethik * und Weinel, >Stellung des Urchristentums «. 
ein Jahrstausend allmächtig, völlig autonom und selbstgenügsam. Wo die Naturbasis sich nicht gutwillig fügt und einpaßt, wird sie zerbrochen von der Entsagung. Das positive Verhältnis zu den sozialen Bildungen bleibt lediglich ein Aufsuchen der von selbst sich darbietenden Berührungspunkte.

So wurdc die Beiseitesetzung des $S t$ a te $s$ für eine in das geordnete Weltreich übergehende Propaganda ebenso unmöglich wie der Liebeskommunismus für ausgedehnte Gemeinwesen und Vereine, die der Ordnung und der Einpassung in das allgemeine Leben bedurften. In der Tat hat die paulinische Weltkirche im Gegensatze zu revolutionären Folgerungen, wie sie die Apokalypse zeigt, den Staat nicht bloß als von Gott zugelassen anerkannt, sondern geradezu als eine wenigstens für Recht, Ordnung und äußere Sittlichkeit sorgende Anstalt geschätzt. Er greift hier bereits nach der stoischen Lehre vom angeborenen Sittengesetz und schreibt auch den Heiden eine Erkenntnis des Guten zu, die in ihrem Staat und ihrem Recht zum Ausdruck kommt. Das Imperium trägt das Schwert mit Gottes Willen und aus Gottes Ordnung. Mit der staatlichen Ordnung wird aber auch die ganze, untrennbar ihr zugehörige gesells chaftliche Ordnung, die Vertcilung von Besitz und Stand, die ganze soziale Organisation anerkannt. Zwar sollen die Christen die staatlichen Rechtsbehörden nicht benützen ${ }^{35 d}$ ) und sollen sie von allen mit dem Heidentum befleckenden Gewerben und Berufen sich zurückhalten, auch eine mit dem heidnischen Kult in Berührung bringende Geselligkeit vermeiden. Aber im ganzen sollen die Christen die bestehenden Ordnungen achten und sie zum Guten wenden, da ihr Staat und ihre Gesellschaft ja überhaupt nicht auf Erden sondern im Himmel ist. Sie sollen sich als gute und fleißige Bürger erweisen und vor allem jeder selbst das Nötige erwerben um der Ordnung willen und als Voraussetzung der Mildtätigkeit. Darin kommt auch der Umstand zum Ausdruck, daß die religiöse Gemeinde nicht mehr den einfachen ländlichen Boden Galiläas mit der orientalischen Bedürfnislosigkeit und losen Rechtsordnung, sondern den der städtischen Welt von Sklaven und Kleinbürgern mit der verwickelteren Wirtschaft und der strengeren Rechtsordnung unter den

35 d) Paulus verweist die streitenden Christen auf die Entscheidung vor der Gemeinde oder vor Schiedsrichtern, womit Anfänge eines eigenen Gemeinderechtes gegeben sind und der Verzicht der Bergpredigt auf das Rechtsuchen überhaupt charakteristisch vergessen ist. H. Weinel, Stellung des Urchristentums, S. 32, 36 . 
Füßen hat ${ }^{36}$ ). Die Begrenzung auf solche städtische Verhältnisse nötigt die ethischen Ideen ganz von selbst zur Anpassung an diese Lage und läßt die radikale Art der Anwendung und Veranschaulichung in der Bergpredigt ganz von selbst zurücktreten. Selbstverständlich ist das konservative Verhältnis auch zur Fa mili e, die die Voraussetzung dieses ganzen geordneten Lebens ist. Die Ehe wird als das Bild für den wichtigsten Grundgedanken des Paulus, für die Einheit des Christus und seiner Gemeinde verwendet. Der vorgefundene Patriarchalismus mit der Vorherrschaft des Mannes wird als Naturordnung hingenommen und die Unterordnung unter sie ethisch gefordert, dafür aber aufs Schärfste auch vom Mann die geschlechtliche Reinheit vor der Ehe und die monogamische Treue verlangt nebst der persönlichen Gemütshingebung an Gattin und Kind; die beiden letzteren wie auch der Sklave sind religiös und sittlich dem Manne und dem Freien gleichgestellt, was faktisch, wenn auch nicht rechtlich die ganze Praxis des Familienlebens vertieft und verinnerlicht. Den Fragen der Mischehe wird bereits eine gleichfalls sehr vorsichtige und die Aufrechterhaltung der Ehe möglichst wahrende Behandlung zuteil. Wenn Paulus persönlich hierbei seine Bedenken gegen das Geschlechtsleben nicht unterdrückt und mindestens die möglichste Einschränkung fordert, um in der Geschlechtsleidenschaft keinen zu starken Wettbewerber gegen die Herrschaft des religiösen Interesses zu finden, so hat das mit der Schätzung der Familie als sozialer Institution nichts zu tun; es ist die begreifliche asketische Konsequenz eines alles beherrschenden religiösen Interesses, die dann freilich folgenreich genug werden sollte und der edleren Konsequenz des christlichen Gedankens, der Verpersönlichung, Individualisierung und Verinnigung der Familie, noch schwere Anfech-

36) Die Bemerkung Kautskys ist richtig, daß ein Kommunismus mit Beibehaltung . des Privateigentums notwendig sofort den Konsequenzen des Privateigentums wieder erliegt. Darin liegt wohl der eigentliche Grund des Verschwindens des urchristlichen Kommunismus. Weiter aber kommt hinzu, was Kautsky bei seiner Auffassung des Christentums als Proletarier-Sozialismus nicht sehen kann, die konservativ-religiöse Haltung, die mit der Weltordnung naturgemäß auch die Besitzordnung als deren integrierenden Bestandteil akzeptiert und daher auch durch die Ablehnung aller Revolution zur Aufgebung des Kommunismus genötigt ist. Ein solcher wäre ja nur durchführbar gewesen, wenn er sehr viel weiter ging als in der Urzeit und das Privateigentum überhaupt beseitigte. Daran aber dachte niemand, denn es hätte eine neue Ordnung und eine totale Revolution bedeutet. 
tungen bereiten sollte.

So ist von dieser Lehre des Paulus her der konservative Charakterdes Christentums gegenüber allem politisch-sozialen Wesen auf lanıe Zeit hinaus entschieden. Es ist die merkwürdige Ersch inung, daß das an sich völlig radikale und revolutionäre Prinzip des unbedingten Individualismus und Universalismus doch eine so durchaus sozialkonservative Haltung einnimmt. Freilich ist trotz alledem scine revolutionäre Wirkung tatsächlich nicht ausgeblieben. Die konservative Haltung beruhte eben nicht auf Liebe und Schätzung für die Institutionen, sondern auf einer Mischung von Verachtung, Ergebung und relativer Anerkennung. Es hat damit trotz aller Unterwürfigkeit den römischen Staat zerstört, indem es die Seelen seinen Idealen entfremdete, und es wirkt zer-örend auf jeden reinen Nationalismus wie auf jede rein irdische Autorität überhaupt. Aber indem sein Individualismus und sein Universalismus von der religiösen Idee ausgeht und auf religiöse IIirte sich bezieht, ist ihm eine solche konservative Haltung durchaus mïglich. Es scheinen in der Tat zweierlei soziale Konsequenzen in ihm zu liegen, entweder der idealistische Anarchismus und der Liebeskommunismus, die mit radikaler Gleichgiltigkeit oder mit Abneigung gegen die sonstigen Ordnungen der Welt im kleinen Kreise die Licbesilice verwirklichen, oder die sozialkonservative Ausbildung einer in Gottes ()rdnung und Willen sich fügenden Haltung gegenüber der Welt mit starker Selbständigkeit der nach innen ihre eigenen Angelegenheiten ordnenden Gemeinde, die bei wachsendem Umfang die Ordnungen der Welt nicht ignorieren kann, sondern sie tunlichst für ihre Aufgaben benützen muß. Von dem ersten Ideal gehen stets von ncuem sozial-radikale Pläne für kleinere oder urößere Kreise aus, von dem zweiten stets von neuem die konservativen Prinzipien des Duldens und Leidens in der Welt, deren Ordnungen durch Gottes Zulassung sind, deren Möglichkeiten die Christen für ihre Zwecke benützen und deren Bestand sie gewähren lassen, "Weil sie innerlich an ihm unbeteiligt sind. Die dritte Möglichkeit, die sozialen Ordnungen positiv als Unterlagen und Vorcormen der Erreichung des höchsten religiös-ethischen Zieles zu sestalten, liegt noch völlig außerhalb des Gesichtskreises der alten Cincicheit. Sie denkt noch nicht daran, die geistig ethischen lierte in kontinuierlichem Zusammenhang mit und in Abhängigkeit von der Naturbasis des Lebens zu verstehen. Daran denkt auch das ganze Mittelalter noch nicht, und daran denkt auch die 
religiös-metaphysische Ethik der Antike nicht; nur die empirische Ethik des Aristoteles achtet auf diese Zusammenhänge. Aus diesem Grunde vor allem wird auch das ganze Problem der Wirtschaft und des Besitzes wesentlich vom Standpunkt der Konsumtion her betrachtet und dem entsprechend wesentlich im Sinne der Genügsamkeit reguliert. Daß Reichtum und Besitz ein Mittel unbegrenzter Produktivkraft und damit der Beschaffung einer gesunden Lebensbasis für eine steigende Bevölkerungsmenge seien, das sind Gedanken, die überhaupt erst im Zusammenhang mit der Einsicht in die Abhängigkeit ethisch-geistiger Werte von der sozialen und wirtschaftlichen Organisation der modernen Welt eigentümlich sind; diese hat dann ja auch nicht verfehlt, von dem ideologischen Extrem zum geschichtsmaterialistischen überzugehen, und für sie ist das Verhältnis beider Kausalitäten doch auch noch heute ein schwieriges Problem. Tritt aber.derart die Abhängigkeit des ideologischen Ueberbaus von den wirtschaftlichen Verhältnissen zurück, so stellt sich auch Staat und Recht in einem sehr viel loseren Verhältnis zu den Lebensgrundlagen dar und erscheinen wesentlich nur als Wächter des Friedens, der öffentlichen Ordnung und der Zucht. Indem der Staat zugleich die religiöspolytheistische Weihe verliert, tritt er damit überhaupt naturgemäß in dem ethischen Interesse zurück und kommt nur mit seinen äußerlichsten und oberflächlichsten Funktionen für das christliche Interesse in Betracht. So ist es den paulinischen Gemeinden und dem Urchristentum möglich gewesen, eine sozialkonservative Stellung einzunehmen und doch dabei innerlich von dem ganzen sozialen Leben tief geschieden zu bleiben, in die Verhältnisse sich duldend $z u$ fügen und sie klug zu benützen, und doch ihnen ein völlig neues, ganz andersartiges Gemeindeleben entgegenzusetzen. Die Stellung, wie sie hier schon an der Schwelle der großen Zukunftsentwickelung der Paulinismus vorschreibt, ist Anerkennung und Benützung der sozialen Bildungen als nicht ohne Gottes Willen geworden und ein Element des Guten enthaltend, zugleich aber innere Ablehnung und Unabhängigkeit gegen sie als zur untergehenden Welt gehörend und überall mit dem Heidentum durchflochten. Damit ist wohl ein positives Verhältnis angedeutet, das weiterer Entwickelung fähig ist und eine solche auch, wie sich zeigen wird, in der alten Kirche zunehmend hervorgebracht hat, das aber auch bei einer unvergleichlich viel stärkeren Ausbreitung der christlichen Gemeinden niemals zu 
einem Programm der Sozialreform oder etwa gar einer christlichen Kultur werden konnte. Wo etwas derartiges später geschehen sollte, mußten ganz neue Verhältnisse und Gedanken ins Spiel treten.

Die sozial-konservative Wendung des Gedankens, die für uns vor allem durch die Briefe des ìalus dokumenticrt ist und durch die Aufnahme dieser Briefe in den Kanon dann zu einer dauernden autoritativen Wirkung kam, enthält derart doch zuglcich die radikalen Elemente der christlichen Idee, die rein auf dic innere Erneuerung, die religiöse Persönlichkeit und die Gemeinschaft der Persönlichkeiten untereinander, damit zugleich auf ein jenseitiges Ziel der ethisch-religiösen Vollendung gehen und daher die innerweltlichen Lebensorganisationen zu benützbaren Stützpunkten, aber doch nur zu duldenden und innerlich fremden Provisorien macht. So ist in klassischer und für lange Zeit maßgebender Weise das konservative und revolutionäre Element in der christlichen Idee vereinigt und wird eines durch das andere begrenzt; und diese Wendung ist keineswegs nur durch die Erwartung der Weltverwandelung bewirkt, wenn auch durch sie begünstigt; sie bleibt auch bei dem völligen Zurücktreten der Enderwartung im ganzen Altertum, ja sie reicht bis in das Mittelalter und den Protestantismus hinein. Es ist daher schon hier an der Schwelle der ganzen geschichtlichen Entwickelung die Frage zu erheben, ob diese Verbindung dem inneren Wesen der christlichen Idee entspricht oder eine Zufälligkeit der persönlichen Stellungnahme des Paulus und der Bedürfnisse der ältesten Gemeinden ist, ob darin ein für alle christlichen Soziallehren wesentlicher Zug aus der christlichen Idee selbst herausgebildet ist, der schon von hier aus die zukünftigen Entwickelungen erleuchtet. Die beiden entgegengesetzten sozialen Konsequenzen, von denen oben gesprochen wurde, sind dann vielleicht nicht zwei nebeneinanderliegende, gleich mögliche Anwendungen, sondern sie gehören in Wahrheit vielleicht zusammen und vereinigen sich in dem von hier ab ausgebildeten Grundgedanken selbst. Das wird um so wahrscheinlicher, wenn man bedenkt, daß einerseits der Liebeskommunismus der kleinen Urgemeinde doch im übrigen die Welt ruhig bestehen lassen will und daß der apokalyptische Fanatismus doch nicht eine politische oder soziale Reform, sondern den $\mathrm{Haß}$ gegen die Heiden und die Hoffnung auf das Wunder ausdrückt, daß andrerseits der paulinische Sozialkonservatismus doch auch von sich aus kein inneres Interesse an 
den Werten und Ordnungen der Welt in sich trägt, sondern sie nur als Gottes Setzung und Zulassung duldet und benützt. So sehr beide Konsequenzen auch manchmal auseinandergehen mögen, sie könnten vielleicht doch in einem inneren Zusammenhang und für das Große und Ganze zu einer einheitlichen Entwickelungslinie sich verbinden ${ }^{36}$ ).

86n) Als dies niedergeschrieben war, kam mir Harnacks lehrreiche Besprechung meines ersten Stückes in den Preuß. Jahrb. März 1908 zur Hand; Ueber das augenblickliche Problem dieses zweiten Stückes findet sich dort die Bemerkung : sEinerseits schwebt eine Art von »Liebeskommunismus über der sich ausgestaltenden Entwickelung der Gemeinde, der sich aus dem Radikalismus der Gottes- und Nächstenliebe von selbst ergab, andrerseits konnte nicht leicht daran gedacht werden, diesen Liebeskommunismus tatsächlich zu verwirklichen, oder es mußte doch die Verwirklichung sofort wieder aufgehoben werden. Man war nicht dafür disponiert, an den Zuständen überhaupt zu ändern. Die Folge war, daß das geschah, was in der stumpfen Welt doch das einzig Fördernde ist, - man schickte sich, ohne es zu wissen und $z u$ wollen (?), zu einer langsamen Umbildung im Rahmen des Gegebenen an oder vielmehr zu einer allgemeinen Versittlichung der Verhältnisse. Naturgemäß kam das zuerst der Familie zu gut, dann dem Verkehr in Handel, Wandel und Geselligkeit, in Treu und Glauben, in Reinheit und Frieden, in Unterstützung und Hilfe ... Alles ist freilich a uf die Gemeinden in ihrem inneren Verhältnis unter sich beschränkt, aber diese Gemeinden wurden immer größer und daneben fehlen doch auch Beispiele der Fürsorge für Andersgläubige nicht. Der gewonnene Zustand war in sozialer Hinsicht - auf die Aktionsfähigkeit gesehen - der denkbar günstigste: über den Gemeinden als Ideal der Liebeskommunismus schwebend, stark genug, um sie nicht einschlafen zu lassen, aber viel zu hoch um - unbedeutende Ausnahmen abgerechnet - zur Verwirklichung zu verführen; in den Gemeinden selbst kräftige sittliche Forderungen zur Heiligung des privaten Lebens, der Ehe, der Familie und des gesamten Verkehrs, aber angeschlossen an die wirklichen Zustände. Die neue Religion war von Anfang an oder wurde sehr bald in der Heidenkirche eine in Bezug auf die sozialen Zustände konservative Macht. ... Sie hatte und brachte neben der Ideologie ihres schwebenden Liebeskommunismus überhaupt kein ihr eigentümliches soziales Programm ..., sondern nur eine in ihren Wirkungen zweischneidige, absolute Autorität, ferner Verbesserungen, Versittlichungen, Verinnerlichungen und eine tatsächliche Hilfeleistung, die wahrscheinlich alles hinter sich ließ, was ähnliches im Reiche vorhanden war.e S. 457 f. Das ist natürlich alles richtig. Aber einmal scheint mir dabei die Fremdheit des neuen Ganzen gegen die Welt und deren ideeller Grund doch unterschätzt zu sein, andérerseits glaube ich, daß in diesem geschichtlichen Sachverhalt doch tiefere prinzipielle Konsequenzen und Untergründe enthalten sind, die der besonderen Formulierung bedürfen. Die slangsame Umbildung im Rahmen des Gegebenen enthält eine eigentümliche 
Man wird, wie ich glaube, ohne Gefahr einer allzu gewalttätigen Kon-truktion, in der Tat sagen dürfen, daß die paulinische llendung des (jedankens in Bezug auf die sozialen Dinge dem Geist und Sinne des Evangeliums entspricht und die klassische Zusammenfassung der Grundtendenzen in dieser Hinsicht darstellt bis zu dem Beyinne des modernen Lebens. Eine religiöse Lehre, die, wie der christliche Monotheismus, die Religion aus allen Inrestierungen in gegebenen Verhältnissen und Ordnungen herauszieht und sie rein zu einem ethischen Erlösungsglauben herausdifferenziert und versclbständigt, wird allem Gegebenen gegenüber den Radikalismus eines ethischen und universalen Ideals besitzen und äußern. Aber sie wird andererseits gerade als religiöser Glaube, der die ganze Welt und ihren Lauf trotz Teufel und Dämonen von Gott geleitet glaubt, als Ergebung in den prädestinierenden und I'nterschiede setzenden göttlichen Willen, niemals prinzipiell revolutionär sein können. Sie wird insofern den gegebenen sozialen Ordnungen und Institutionen, den Machtverhältnissen und l'nterschieden gegenüber immer einen konservativen Zug der Fügung und Ergebung haben. Eine prinzipiell revolutionäre Neigung wird nur auf dem Boden des abstrakten Rationalismus möglich sein, der vom Subjekt und seiner allgemeingiltigen Vernunfteinsicht her das Rationelle herstellt und das Göttliche nur in der Allgemeinheit der Vernunfteinsicht anerkennt, aber nicht im irrationalen Lauf der vom Subjekt nicht beherrschbaren Jinire. Daher ist auch erst der moderne Rationalismus der Boden einer prinzipiell revolutionären Theorie und Praxis, des Aufbaus der Gesellschaft auf Forderungen der Vernunft ${ }^{36 b}$ ). An-

Opposition gegen das Gegebene verbunden mit einer eigentümlichen Akzeptierung und stellt damit gleich am Anfang das Problem des Verhältnisses der revolutionären und der konservativen Elemente in der christlichen Idee, ein Problem, das in ihrer ganzen Geschichte immer wieder kehrt.

${ }^{36}$ b) Ueber das letztere $s$, Jak. Burkhardts Lehre über die weltgeschichtlichen Krisen und Revolutionen und den besonderen Charakter der modernen Krisen: - Weltgeschichtliche Betrachtungen», 1905, S. 132-137, I93 f., 198, 200, I28. Ueber den relativ konservativen Charakter der christlichen Ethik s. meine $\gg$ Politische Ethik und Chrisientums, 1904, wo dann freilich auch die Gegenseite betont ist. Die Beobachtung der beiden Tendenzen auch bei F. J. Stahl, der unter allen Umständen ein scharfsinniger, heute noch lehrreicher Denker ist. Vgl. sDer christliche Staats S. 8. Die christliche Gesinnung, jene Einigung von Pietät, Demut, Hingeburg mit Freiheit, Unabhängigkeit, Offenheit, der aller knechtische Sinn fremd 
dererseits aber wird jene christliche Ergebung und Fügung doch immer ihre Grenzen haben an den Werten des Innenlebens, an der religiös-ethischen Idealwelt und der ihr dienenden kirchlichen Organisation. Sie wird bald durch gleichgiltige Zurückziehung des Interesses vom Gegebenen, bald durch Unterwerfung des Gegebenen unter die allein giltigen Maßstäbe ihrer Ideale und unter ihre transszendenten Werte zerstörend, auflösend, neubildend wirken und hierbei ohne prinzipiellen Willen zur Revolution doch tatsächlich die stärksten Wandelungen bewirken und die tiefsten Eingriffe wagen ${ }^{36}$ ). Eine rein und unbedingt konservative Soziallehre wird daher niemals aus ihm entstehen können. Monotheismus, Universalismus, Erlösungsglaube und ethisch-persönliche Innerlich-

ist«. Ihre Ausgleichung ist ihm daher die konstitutionelle Monarchie; seben das, wenn gleich in minder vollkommener Form, muß auch das Grundverhältnis einer echten Republik bilden \&. >Auch historisch ist die Institution des konstitutionellen Staates ebenso wie diese politische Gesinnung aus dem Christentum hervorgegangen. Von der katholischen Kirche haben die germanischen Völker . . die erhabene, geheiligte Autorität, die Obrigkeit, die von Gott ist, empfangen, und der christlich-religiösen Bewegung der englischen Puritanier und Independenten entstammt der Gedanke der Freiheit und Selbstherrschaft des christlichen Volkes.

${ }^{36}$ c) Diese notwendige revolutionäre Wirkung der universalistisch-transszendenten religiösen Idee gegenüber allem Gegebenen in Staat, Gesellschaft und Kultur kommt in unseren Kirchengeschichten nicht genügend zum Ausdruck. Auch hier bewährt die äußerst gedankénreiche, oben erwähnte Phänomenologie der Geschichte von J. Burkhardt ihren scharfen Blick. Die Lehre von den sechs gegenseitigen Bedingtheiten des Staates, der Religion und der Kultur gegeneinander ist eine Fundgrube treffender Beobachtungen. Ueber den revolutionären Charakter des Christentums und der Universalreligion überhaupt s. S. 137-145. „Juden und Urchristentum bauten eben die Gesellschaft auf die Religion wie der Islam * S. 138. Dadurch kamen sie in schärfsten Konflikt mit der auf dem Staat aufgebauten Kultur. Daß der radikale Gegensatz auch heute noch fortdauert, wo viele nur mit Burkhardt die \Komplizität« der religiös-kirchlichen Mächte mit den durch den abstrakten Rationalismus und die freie Kulturbewegung bedrohten Staaten und konservativen Machtinteressen sehen, zeigt jeder Blick auf die fortdauernden Kämpfe der römischen Kirche mit dem Staat und der modernen Kultur, in denen nicht bloß reaktionäre Motive oder zentralistische Bedürfnisse stecken, der Zusammenstoß des religiösen Kosmopolitismus und der Friedensbewegung mit den politischen Interessen, der Gegensatz der ethischen Politik und ihres sHumanitätsduselse gegen die Prinzipienlosigkeit der Real- und Machtpolitik, der Verdacht revolutionärer Neigungen, in den jede christliche Sozialpolitik bei den Konservativen kommt, das häufige Eingreifen sozialethischer Forderungen in politische Programme von seiten der Gemeinden und Geistlichen in den kalvinistischen Ländern. 
keit enthalten einen Radikalismus und ein Einheitsstreben, die stets bloß gegebene Verhältnisse vergleichgiltigen oder aufheben und über allen nationalen und sonstigen I.ebenseinheiten auf eine ideale religiöse, geistig-innerliche Lebenseinheit dringen werden. Allerdings hat nun außerdem das Christentum unverkennbar einen $\mathrm{Zug} z \mathrm{u}$ verhältnismäßig e i $\mathrm{f} f \mathrm{c} h$ e $\mathrm{n}$ a $l \mathrm{l} \mathrm{g}$ e $\mathrm{m}$ e i $\mathrm{n}$ e $\mathrm{n}$ Lebensverhältnissen, in denen der unmittelbare Verkehr mit den Gottesgaben der Natur den Erwerb und die Lebensmöglichkeit bestimmt, die Anhänglichkeits- und Dankbarkeitsgefühle gegenüber den göttlichen Naturgaben lebendig hält, zu den kleinen, persönlich verbundenen Kreisen und Korporationen, in denen noch nicht die rechtliche und wirtschaftliche Formalisierung, Entpersönlichung und abstrakte Organisation des Gesamtlebens die rein persönlichen Beziehungen und die Entscheidungen von Fall zu Fall zurückdrängt. Aber das ist ein neuer, mit dem bisherigen noch nicht erklärten Zug des Christentums und hat an sich nichts mit dem Konservatismus des Christentums zu tun, sondern hat seinen Grund darin, daß eine so ganz auf das Persönliche gestellte und überall so radikal die innerliche Gesinnung betonende, zugleich das Recht durch Liebe und Vertrauen ersetzende Moral viel leichter in jenen einfacheren Lebensverhältnissen ausführbar ist als in den komplizierten einer rechtlich, politisch und wirtschaftlich formalisierten und abstrakt gemachten, vor allem auf Recht und unpersönlichen Institutionen und Notwendigkeiten beruhenden Kultur. Darin liegt schon der Grund, weshalb in der alten Kirche die kleinbürgerlichen und mittelständischen Kreise, in denen etwas von jener primitiveren Vertrauensund Gruppenmoral erhalten geblieben ist, sich leichter bewegt und ausbildet als in den Oberschichten. Die paulinischen Gemeinden sind überhaupt nur als kleine Gemeinden und als abliegend von dem großen rechtlichen Treiben des Massenstaates denkbar. Darin liegen aber auch weiter die Gründe, weshalb die spätere Geschichte im Hochmittelalter wie im Luthertum diese einfacheren Verhältnisse festzuhalten versucht. Mit einer sozialkonservativen Haltung hat das nur insofern zu tun, als hieraus sich ein Drängen auf einfache Verhältnisse ergibt, das mit der Konservierung älterer und unentwickelterer Verhältnisse unter Umständen zusammentrifft. Der Sinn davon ist aber dann in diesem Falle nicht die Ergebung und Fügung in das Gegebene, sondern die Aufsuchung derjenigen allgemeinen Verhältnisse, in denen die Befolgung der 
evangelischen Moral sich leichter und mit weniger Kompromissen durchführen läßt. Diesem $Z$ wecke dient ja auch ein großer Teil des späteren Mönchtums - freilich nicht das Mönchtum überhaupt und an und für sich —, indem es im kleinen Kreise, in einfacher Naturbezogenheit, in persönlicher Behandlung aller Verhältnisse und in Besitzlosigkeit das durchführt, was in dem großen Treiben der verwickelten sozialen Welt nicht oder nur eingeschränkt durchführbar ist ${ }^{36 d}$ ).

36 d) Hierzu vergl. das äußerst geistvolle Buch von Simmel $\$$ Die Philosophie des Geldes «2, 1908, das die geistig-ethischen Korrelate der Naturalwirtschaft und die der Geldwirtschaft gegeneinander überaus lehrreich kontrastiert und mir für diese Zusammenhänge gerade auch bei den verschiedenen Formationen und Krisen der christlichen Ethik die Augen geöffnet hat. Es erscheint mir von größter Wichtigkeit, daß dieser Zug der christlichen Ethik zu den einfacheren nicht formalisierten Lebensverhältnissen von der in den neueren Zeiten einge tretenen Komplizität kirchlicher und politisch-sozial-konservativer Interessen unterschieden wird. Der Konservatismus der alten Kirche und des Mittelalters hatte mit diesem Zuge nichts zu tun, da er gerade nicht ẹtwa solche Verhältnisse zu konservieren trachtete, sondern nur die Fügung und Ergebung in die gegebenen, von Gott geschaffenen und nach ihrer Art in der Sünde begründeten Machtvèrhältnisse war. Der Konservatismus der modernen Kirchen aber richtet sich auf Konservierung politisch-sozialer Machtverhältnisse, die ihrerseits durchaus nicht ohne weiteres mit jenen patriarchalischpersönlichen Lebensformen zusammenfallen, ja in der heutigen kapitalistischen Großindustrie und in den kapitalistischen landwirtschaftlichen Großbetrieben mit Saisonarbeitern aus aller Herren Ländern gar nicht mehr zusammenfallen können. Es ist das Bedenklichste an der heutigen >Christlichkeit \& konservativer Sozialethik, daß sie diesen letzteren Umstand beharrlich sich und anderen verbirgt. Dagegen ist es wohl in der Sache begründet, wenn bäuerliche und handwerkliche Politik sich auf die ethischen Maßstäbe des patriarchalisch verstandenen Christentums berufen; das ist dann aber durchaus nicht identisch mit dem konservativen Prinzip der Unterordnung unter die von Gott geschaffenen oder zugelassenen Machtverhältnisse und Autoritäten. Auch Stahl wagte jenen Trieb zu den einfacheren patriarchalischen Zuständen nicht ohne weiteres für den politisch-sozialen Konservatismus in Anspruch zu nehmen, sondern nur für »die konservative Richtung im lautersten Sinn, die keinen gezeitigten Fortschritt ausschließt \&, der Konservatismus habe ethisches Recht nur auf dieser Grundlage, S. 16. - Auf die Fortdauer der primitiveren und persönlicheren Gruppenmoral in den mittelständischen Klassen, in denen die alte Kirche vor allem sich ausbreitete, besonders in den auf persönliche Aushilfe und Sichvertragen angewiesenen Hetärieen und Eranoi des Altertums, weist Max Weber mich gesprächsweise hin. Die alten Christengemeinden sind ihnen analog und bewegen sich teilweise in ihren Lebensformen, was längst anerkannt ist. Als Aeusserung dieses Geistes bezeichnet er die 
Der so aus dem Sachverhalt zu erschließenden, inneren Aufeinanderbeziehung konservativer und revolutionärer Elemente, von denen die Paulusbriefe die ersten betonen, ohne die zweiten zu verleugnen, entspricht auch die kommende Geschichte. Das Christentum ist in der Tat bei aller konservativen Haltung ein Prinzip der ungeheuersten geistigen und, seit Zusammenschluß seiner kirchlich-theokratischen Kräfte, auch der materiellen, rechtlichen und institutionellen Revolution geworden. Es hat den antiken Geist und Staat zertrümmert; es hat in der gregorianischen Revolution das Landeskirchenrecht und die Staats- und Volksrechte zerstört; es hat in der Reformation die Kirche revolutioniert und neue politisch-kirchliche Formen geschaffen; aber es hat in alledem doch stets das Gegebene entweder geduldet und nur innerlich ausgehöhlt, oder in relativ konservativer Haltung gestützt und vergöttlicht. Prinzipiell revolutionär ist es nur geworden, wo sein Ideal, das in gleich zu zeigenden Vorgängen mit dem stoischen Naturrecht sich verschmolz, die Christianisierung und Einschränkung seines Naturrechts durchbrach und dessen rationalistische Konsequenzen sich zu eigen machte. Umgekehrt ist es prinzipiell konservativ nur geworden, wo seine religiöse Sanktionierung des Gegebenen rein im politischen Klasseninteresse verwendet wurde unter Verdunkelung oder Beseitigung seines ethischen Radikalismus.

Dabei beruht diese Aufeinanderbeziehung der konservativen und radikalen Elemente charakteristisch gerade auf dem bisher stets betonten Umstande, daß eine innere Verbindung und Kontinuität zwischen den allgemeinen politisch-wirtschaftlich-sozialen Zuständen und den Werten des persönlich-religiösen Lebens nicht gesucht und nicht gefunden wird, daß der Radikalismus der Ideologie alles von innen heraus mit Gesinnung und Willen oder von außen her mit Gesetz und Forderung machen will und daher die

Begründung des Verbotes des Zinsnehmens von Glaubens- und Vereinsgenossen mit charakteristischer Berufung auf das jüdische analoge Gesetz. Das entspreche einem allgemeinen soziologischen Tatbestand, daß im eigenen Stamm, Gemeinde oder Verein die persönlichen Billigkeits- und Rücksichtsgründe entscheiden, während dem Fremden gegenüber solche Rücksichten wegfallen und entweder Uebervorteilung oder abstrakter Rechtsstandpunkt eintritt. Indem die Christen diese Regel sich aneignen, zeigen sie, wie eng die Möglichkeit der Betätigung ihrer Moralität mit derartig mehr primitiven, die persönliche Wertung und Verbundenheit zur Grundlage machenden Verhältnissen zusammenhängt. 
Substruktionen der geistig-ethischen Welt teils sich selbst überläßt, teils geradezu ablehnt, in beiden Fällen aber als göttliche Finsetzung oder Fügung in der sündigen Welt toleriert und dadurch konserviert. Alle Reform und alle Heilung der Verhältnisse geht daher auf in Liebestätigkeit, die den Personen hilft und die $\mathrm{Zu}$ stände bestehen läßt und daher nur in kleinen übersichtlichen Kreisen and bei relativ erträglichen allgemeinen wirtschaftlichen Zuständen $z u$ ihrem Ziel gelangen kann ${ }^{36}$ ). Mit diesem Prinzip des bloßen Nebeneinanders der gegebenen Zustände und der idealen Forderung und das heißt dann auch mit dieser Verbindung des

$\left.{ }^{360}\right)$ Das ist der Unterschied zwischen Carität und Sozialpolitik. Daher weist auch Uhlhorn in seiner sGeschichte der Liebestätigkeit « beim Altertum und Mittelalter immer wieder darauf hin, es habe der Gedanke der »Prophylaxe gefehlt. Aber er hebt nicht hervor, was dieses Fehlen und dann das Eintreten des Gedankens für einen prinzipiellen Unterschied in der geistigen Gesamtverfassung bedeutet. Er bedeutet die Herstellung einer inneren Beziehung zwischen den allgemeinen $\mathrm{Zuständen} \mathrm{und} \mathrm{den} \mathrm{persönlich} \mathrm{ethischen} \mathrm{Werten,} \mathrm{damit}$ eine Wertung der allgemeinen Zustände, der sowohl eine andere Auffassung vom Zusammenhang des Geistigen und Materiellen als auch eine Rehabilitierung des Natürlichen gegen seine Versenkung in die Gleichgültigkeit und Verderbtheit des Erbsündenbereiches. Dahinter liegt im Grunde eine andere Auffassung des Verhältnisses von Gott und Welt, von Natur und Geist, von Allgemein-Zuständlichem und Persönlich-Individuellem. Eben deshalb muß ich auch Harnack (Preuss. Jahrbb. I 908 S. 455 f.) gegenüber meine Bestreitung des Satzes festhalten: »Wo der Christ klar erkennt, daß ein wirtschaftlicher $Z$ ustand zur Notlage für die Menschen geworden ist, da soll er nach Abhilfe suchen; denn er ist ein Jünger dessen, der ein Heiland warc. Die Beispiele, die Harnack dagegen anführt, sind Beispiele der Liebestätigkeit, die mit Zuständen gar nichts zu tun haben, und ich kann es nur für eine Bestätigung meines Satzes halten, wenn H. 'am Schlusse sagt: »das Auge des Christen sieht immer nur Personen, die unter wirtschaftlichen Zuständen leiden; ihnen aber soll geholfen werden«. Gewiß, aber ein solches Auge sieht dann eben auch keine Probleme der Sozialreform, sondern das Bild der sündigen Welt, in der der Christ teils mit konservativer Ergebung in ihre Verhältnisse, teils mit ethisch-radikalem Widerspruch, teils mit aufopfernder Liebestätigkeit sich einrichtet. Gewiß ist die auf die Person gehende, mit den religiösen Kräften motivierte und verbündete Liebestätigkeit bei der Ueberfülıe menschlichen Leidens und bei den seelischen Bedürfnissen des Menschen eine unentbehrliche und unersetzlich große Sache; aber aus ihr allein entsteht keine Soziallehre, keine Sozialreform und keine Sozialpolitik. Um es dazu zu bringen, muß noch anderes hinzukommea. Das allein wollte ich sagen. Die allgemeinen Einwendungen gegen meine Auffassung des Liebesgebotes Jesu finde ich dagegen allerdings teilweise überzeugend. und werden mich zu neuen Formulierungen veranlassen.

T soelt c h, Gesammelte Schriften. I. 
Konservativen und Radikalen bricht erst der Calvinismus, der die modernen wirtschaftlichen Erwerbsformen und das moderne politische Leben als Voraussetzung der Emporentwickelung eines heiligen Gemeinwesens, eines christlich-sozialen Ganzen anerkennt und ein Auge gewinnt für die materielle, äußerliche und zuständliche Bedingtheit der geistigen Werte. Daher entwickelt auch der Calvinismus eine radikale, die allgemeinen Zustände politisch und wirtschaftlich formende Konsequenz, die hier Stück für Stück den alten christlichen Konservatismus und seine Passivität überwindet, ohne daß damit die gerade hier stark ausgeprägte prädestinatianischvoluntaristische Gottesidee aufgehört hatte, zur Anerkennung und ethischen Nützung der naturgesetzten Differenzen im Sinne des Paulus zu wirken ${ }^{36 \mathrm{f}}$ ). Auf diesem Wege gefolgt sind dann dem Calvinismus die Sozialtheorien und Sozialpolitik der modernen Konfessionen, denen überall die modernen Verhältnisse und die moderne theoretisch-sozialwissenschaftliche, ökonomische und politische Einsicht die Anerkennung aufgenötigt hat, daß die ethischreligiösen Werte der christlichen Persönlichkeits- und Liebesidee an allgemeine Voraussetzungen des ökonomisch-rechtlich-politischen Unterbaus genau so gebunden sind, wie alle sonstigen geistig-ethischen Werte überhaupt.

Die ungeheure Tragweite, die die erste Zusammenziehung und Formung der soziologischen Ideen und sozialen Stellungnahmen des Evangeliums in der. ältesten Heidenkirche in sich birgt, nötigte hier vom Paulinismus aus bereits soweit die Blicke in die Zukunft schweifen zu lassen. Aber damit ist allerdings der kommender Darstellung weit vorgegriffen, und die Größe des hier sich zeigenden Bildes bringt erst recht den Kontrast in Erinnerung, in dem sich die kleinen paulinischen Gemeinden zu diesen Zukunftswirkungen befinden. Noch fehlt ihnen nicht bloß die Größe und Bedeutung, sondern auch die volle Klarheit des Prinzips und die Geschlossenheit des Organismus, aus der heraus allein erst die Klarheit des Prinzips und die Beziehung auf Gegensätze und Umgebung sich herstellen kann. Sie sind vor allem zunächst noch damit beschäftigt, die sozialrevolutionäre und die sozialkonservative Tendenz gegen einander, die radikale, jenseitig zugespitzte Heiligungs- und Liebesethik gegen die natürlichen

sof) Hierfür sei vorläufig nur verwiesen auf Choisy, >La theocratie à Genève au temps de Calvine und L'état chrétien calviniste à Genève au temps de Theodore de Bèze o. J. 
Forderungen des gesellschaftlichen Daseins, abzugrenzen und in dieser Abgrenzung vor allem das Leben der Gemeinde selbst. auszubauen, wozu die bisher erreichte Festigung und Formung des eigenen soziologischen Prinzips der Gemeinde durch den Glauben an den mystisch gegenwärtigen Christus und den von ihm ausgegossenen Geist nicht genügte.

3. Der Frühkatholizis mus.

Die soziologische Idee im Sinne Jesu hatte ihren Ausgangspunkt und ihren Rückhalt in dem Gottesglauben, wie er aus der jüdischen Bibel und dem jüdischen Volksleben heraus durch die Verkündigung des Reiches accentuiert und beleuchtet wurde, und in der Verkörperung durch die Persönlichkeit Jesu selbst. Als aber seiner inneren Konsequenz gemäß dieser Glaube sich von der alten Volks- und Kultzusammengehörigkeit löste und Jesus von seinen Anhängern geschieden war, da bedurfte es eines $\mathrm{Er}$ satzes für diesen Rückhalt, eines selbständigen Zentrums der Organisation und einer gegenwärtigen Verkörperung des Beziehungsmomentes, aus dem jener Individualismus und Universalismus immer neu hervorgehen und indem er sein, ihn bei der religiösen Grundlage festhaltendes, Maß immer wieder finden konnte. Oder vielmehr nur. weil ein solcher Haltpunkt sich darbot, konnte es zur Entfaltung und dauernden Behauptung jener Konsequenzen kommen. Dieser Haltpunkt war der Glaube an den erhöhten, gegenwärtigen, alles durchdringenden Pneuma-Christus. Dieser Glaube ist die organisierende Kraft der neuen Gemeinde: er schafft den einzigen neuen Glaubensartikel als den Glauben an den mit dem Gottesgeist identischen Christus; er schafft den neuen Kultus. durch den allein von einer neuen Religionsgemeinde die Rede sein konnte, die Anbetung Gottes in Christus, die Einpflanzung durch die Taufe in den Christus und die Speisung und Tränkung durch den erhöhten Christus; er schafft die neue Ethik als einen Zusammenschluß der Christusgläubigen gegen die Welt und als ein Sterben und Auferstehen des sündigen weltsinnnigen Menschen mit dem Christus zu dem neuen Leben im Geist, d. h. in der Selbstheiligung für Gott und in der Bruderliebe. Dabei ist Dogma, Kult und Ethik noch frei beweglich und einfach, fluissig und unfaßbar wie der ganze Gedanke des Erhöhten selbst, der die historischen Schranken von sich abgestreift hat und aus dem frei und beweglich gewordenen Bilde die mannigfaltigsten neuen Anwendungen 
und Deutungen auszustrahlen vermag. Seine eigentlichste Wirkung sind daher auch die enthusiastischen Geistwirkungen, die über gewöhnliches Menschenvermögen hinauszugehen scheinenden Leistungen der religiösen Erregung und Andacht, der theologischen Deutung und Schriftgelehrsamkeit, der missionarischen Tätigkeit und der organisatorischen Kunst, der Liebe und des Opfers, der Selbstüberwindung und Charakterveränderung. All das bedeutet fur die antike und populäre Wunderpsychologie ebensoviel Wunder.

Der Pneuma-Christus ist die objektive Gegenwart des soziologischen Beziehungsmomentes. Daß alle Theologie von da aus auf die Frage nach der Identität und trotzdem bestehenden Verschicdenheit des Pneuma-Christus und Gottes gewiesen war, versteht sich dann von selbst. So wurde die Lehre vom Vater und vom Logos zum ersten Fundamentaldogma, woraus sich dann in hier nicht zu erörternden Zusammenhängen schliesslich das Trinitïtsdogma ergab. Aber ebenso ist auch leicht einzusehen, daß dieser unfaßbare Pneuma-Christus und die Geisterscheinungen auf die Dauer nicht genügen konnten als Verkörperung und Gegenwart des soziologischen Beziehungsmomentes. Der enthusiastische Geistesglaube bedrohte durch schwärmerische Verworrenheit ebenso wie durch die unausbleibliche Ermattung den mit ihm verbundenen Christusglauben; und andererseits war die Verkörperung des Gottesgedankens in dieser Christusmystik durch die Konkurrenz und Aehnlichkeit der synkretistischen Kulte und Spekulationen der Ueberwucherung und Verflüchtigung um so mehr ausgesetzt, als er selbst nur durch theologische Deutungen zu Stande gekommen war, die mit diesen Kultideen bereits mannigfach verwandt gewesen zu sein scheinen, als er weder an der jüdischen Bibel noch an den Evangelienerzählungen eine hinreiçhend feste Fixierung seines eigentümlichen religiösen Gehalts besaß. Gerade das soziologische Bedürfnis verlangte eine stärkere Festlegung, eine gegenständlichere Anschauung, eine praktisch vollziehbare Abgrenzung, eine zusammenhängendere Durchsichtigkeit, eine folgerichtigere Deutungssicherheit für das soziologische Beziehungsmoment. Aus diesem Bedürfnis vor allem entstand das eigentümliche christliche Priestertum, der Episkopat, in engem $\mathrm{Zu}$ sammenhang mit der neuen christlichen Bibel oder dem neuen Testament, der Heraushebung einer echten durch die Bischöfe gesicherten Tradition und dem Ausbau der Sakramentsidee, die die Wunderwirkung in den neuen Kultakten festlegte und den Vollzug 
des Sakramentes nur in der rechtmäßigen Gemeinde und nur in der Hand des ordnungsmäßigen Klerus wirksam sein ließ. Es ist die Herausbildung des Frühkatholizismus, der zweiten großen Fortbildung des Evangeliums nach dem.Paulinismus. Wie weit darin auch hier, und hier ganz besonders, Entlehnungen und Angleichungen an jüdische und heidnische Institutionen stattgefunden haben, ist hier nicht weiter zu verfolgen. Die Hauptsache ist, daß irgend etwas Derartiges durch das soziologische Bedürfnis in der Tat gefordert war und daß in diesem Hauptinteresse trotz allem die Kontinuität deutlich erkennbar ist. Der Episkopat ist die Eingrenzung des Geistesbesitzes, der Fortleitung der wunderbaren Kräfte, der Autorität und des Sakramentsvollzugs auf das von den Organisationsbedürfnissen emporgetragene Gemeindeamt, das durch die tatsächliche Autorität der Ueberlieferung und des Zusammenhanges mit den ersten Gründern eine solche Heraushebung auch in der. Tat nahe legte. Er ist die Ersetzung und Materialisierung des erhöhten Christus und des Geistes, er ist der Nachfolger Christi und der Apostel, der Träger des Geistes, die Verlängerung oder Verewigung der Menschwerdung, die Sichtbar- und Faßbarmachung der göttlichen Wahrheit und Kraft, die konkrete Gegenwart des soziologischen Beziehungsmomentes ${ }^{37}$ ). Er wirkt auf das Christusbild auch dementsprechend zurück, indem er aus der Menschwerdung des frei wirkenden Geistes den Christus zum ersten Priester und Liturgen, zur Quelle priesterlicher Gnadenkräfte, imacht ${ }^{38}$ ). Dabei ist auch hier an dieser ganzen Entwicklung deutlich, wie die treibende Kraft der Organisation und ganzen Entwickelung der religiöse Gedanke und nicht etwa ein Gedanke sozialer Hilfstätigkeit ist. Das der Liebestätigkeit gewidmete Amt, das Diakonenamt, steht unter dem $\mathrm{Bi}$ schofsamt zum deutlichen Zeichen dafür, daß auch alle Liebestätigkeit nur ein Ausfluß des religiösen Gedankens ist und in seinem Dienste steht ${ }^{39}$ ). Die episkopale Sakraments- und Traditionskirche

37) Das ist einer der Hauptgedanken des berühmten und lehrreichen Bucles von Loisy, „L'évangile et l'église *, 1902.

38) Höchst interessant dargelegt auf Grund der Kultustheolugie von Thalhofer, Handbuch der katholischen Liturgik ${ }^{2}$, 1894.

39) Der Idee nach ist diese Anstalt der Hilfeleistung von Anfang an der Ausfluß der supranaturalen Idee des Christusleibes oder der Ecclesia, die in der Gegenwart Christi und im Geist überall die objektiven' anstaltlichen NLerkmale trägt, wie Sohm, Kirchenrecht« I I 892 S. 20 richtig ausführt. Gerade von der Geld. opferung heißt es in einer von Sohm zitierten Stelle aus De aleatoribus: pecuniam 
ist daher das zweite Fundamentaldogma geworden.

Das ist nun freilich eine weitere ganz außerordentliche Verengung des ursprünglichen soziologischen Gedankens eines absoluten religiösen Individualismus und Universalismus. Die religiöse Gemeinschaft ist nun nicht mehr bloß an die Christusanbetung, die Taufe und das Herrnmahl gebunden, sondern an die Gemeinde, den Bischof, die Tradition und die vom rechtmäßigen Bischof ausgeübte sakramentale Gnadenmitteilung. Allein schon bei Jesus war doch jene Idee nicht lediglich getragen von einer rein autonomen Gotteserkenntnis, sondern von einer autoritativen Ueberlieferung und von seiner eigenen Autorität. Der Episkopat ist nur die Umwandelung jener autoritativen Träger in Mächte, welche auch zur wirklichen Organisation und Ausbreitung des soziologischen Gedankens fähig sind, indem sie seinen Ausgangspunkt und seine Grundlage, die Gottesidee und Gotteskraft, festlegen in dem Amt und im Sakrament. Eben deshalb ist dieses neue christliche Priestertum doch auch e i n e ganz e i ge $n$ t'ü $\mathrm{ml}$ ic he Erscheinung. Seine Autorität beruht ausdrücklich nicht auf dem Menschen im Priester, sondern auf dem durch Tradition und Weihe ihm einwohnenden Göttlichen; nur soweit sein Handeln aus dieser Quelle fließt, ist es ein göttliches; soweit es ein menschliches ist, hat es keine andere als zu-

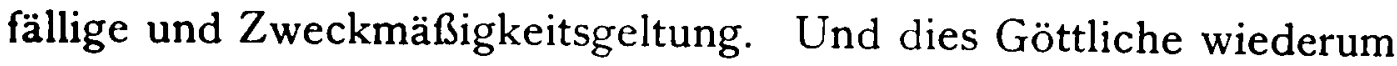
ist nicht die Stiftung großer Priestergeschlechter oder eine besondere jedesmalige wunderbare Berufung, sondern die Gegenwart des Christusgeistes, der in der Priesterweihe und Succession nur sozusagen sicher kanalisiert ist. Das Priestertum hebt die allgemeine religiöse Gleichheit und Freiheit, den reinen Gemeindecharakter aller christlichen Religionsgemeinschaft nicht auf und ordnet nicht Menschen den Menschen über; es ist nur der herausgehobene und ordnungsmäßige Träger des Christusgeistes, das Organ der Vahrheitsdarstellung und erlösenden Sakramentalkraft. Inde:.. man sich ihm unterordnet, ordnet man sich nur Gott unter, und zwar nicht besonderen nur dem Priester zukommenden Erleuchtungen, sondern der allgemeinen, der Gemeinde zukommenden Wahrheit und Gnadenkraft, die nur im Priester kenntlich lokalisiert ist. Er ist nur die Verkörperung und Kon-

tuam adsidente Christo, spectantibus angelis et martyribus praesentibus super mensam dominicam sparge. Das ergibt den richtigen Sinn für das Wort Harnacks: -Ein Tisch verband als Altar den Ausdruck der Gottes- und der Nächstenliebe S. 39. - Leber das Diakonenamt s. Uhlhorn I I54-I59. 
kretion der allgemeinen religiösen Wahrheit und auch das nur, soferne er sich in deren Auswirkung betätigt. Indem diese seine Stellung vom Kirchenrecht festgelegt wird, unterscheidet es ganz folgerichtig das jus divinum, das nur auf diese heilsverkörpernde und darum heilsvermittelnde Stellung des Priesters und deren unmittelbare Folgen sich bezieht, während die ganze übrige, organisatorisch unter Umständen viel bedeutendere Tätigkeit nur ein jus humanum, d. h. freie und veränderliche rein menschliche Zwecktätigkeit ist. In dem Maße, als der Katholizismus diesen Charakter des Priestertums betont, kann er sich als einen »religiösen und unpolitischen « Katholizismus bezeichnen; er trennt das Göttliche vom bloß Menschlichen. Aber freilich liegt der ganze organisatorische Wert der Institution darin, daß das Göttliche und Menschliche in ihr so schwer zu scheiden ist, und daß menschliche Ordnung und Zentralisation durch diese Verbindung so leicht mit dem Charakter göttlicher Autorität zu bekleiden ist. Die ganze Unterscheidung ist eine Fiktion, die den freien rein religiösen Geist und seine streng bindenden Verwirklichungsmittel ineinanderfließen läßt, und, indem sie die ursprüngliche ganz innerliche Idee behauptet, ihr doch unlösbar die strenge klerikal-sakramentale Bindung und Formung unterschiebt. Das ist die eigentliche Verweltlichung der Kirche, die Materialisierung und Veräußerlichung des religiösen Zentralpunktes, die Selbstauslieferung an die Bedingungen weltlicher Organisationskunst. Im Vergleich dazu ist die Verweltlichung auf den anderen Gebieten, der Wissenschaft, dem Staats- und Gesellschaftsleben, der Kunst viel unvollständiger durchgeführt. Ihnen gegenüber erhält sich der ursprüngliche religiös-überweltliche Charakter der christlichen Idee, und von ihnen gehen daher seit der Vollendung der soziologischen Konsequenzen des sakramentalen Priestertums teils schon im Mönchtum, teils später in der Laienreligion des sich auflösenden Mittelalters die schärfsten Reaktionen aus. Sie bedeuten dann aber auch charakteristischerweise immer tiefe Erschütterungen und Schwierigkeiten für die Soziologie der religiösen Gemeinschaft selbst.

Jedenfalls aber ist jetzt zu Anfang in dem neuen Priestertum zunächst das dringendste Bedürfnis, die kankrete Faßbarmachung des soziologischen Beziehungsmomentes, erfüllt und ordnen sich nun ihm auch alle anderen diesem. Zweck dienenden Einrichtungen ein und unter. Es ist nur der Mittel- und Anziehungspunkt für alle derartigen Entwickelungen, keineswegs 
selbst die einzige. Da ein bestimmter Gedanke von Gott das Zentrum des Ganzen ist, so wird die Sicherstellung dieses Gedankens und damit der Lehre ein Hauptanliegen. Die Sicherung, Erweisung und Ausbildung der Lehrtradition wird Sache des Klerus und dadurch bekleidet sich der Gottesbegriff, der soziologische Beziehungspunkt des Ganzen, mit einem Wahrheitsbegriff starrster Art, der dem Wahrheitsbegriff der philosophischen Schullehren formell völlig entspricht, aber auf Autorität und Offenbarung beruht. Eine eindeutige und umfassende höchste Erkenntnis ist das vom Amt getragene Zentrum, und der exklusive, alles sich und seinem Dogma unterwerfende Wa hrheitsbegriff ist dann die treibende Kraft aller Unifizierung und Zentralisierung ; er wird später der Grund des Anspruches der Kirche auf Alleinherrschaft sein über das geistige Leben und alles, was damit zusammenhängt. Ein Nebeneinander verschiedener Kirchen wird erst auf Grund eines veränderten Wahrheitsbegriffes wieder möglich sein, gerade wie ja auch die bunte Verschiedenheit des vorkatholischen Christentums mit dem Wahrheitsbegriff eines individualistischen Enthusiasmus zusammenhing ${ }^{40}$ ). Religionsgeschichtlich noch wichtiger ist, daß die von der neuen Gotteserkenntnis ausgehenden Gesinnungskräfte nicht dem rein innerlichen Wirken des Gedankens überlassen blieben, sondern als wunderbare Vorgänge an das Wunder sakramentaler Feiern vorzugsweise geknüpft wurden. Die Mysterienkulte werden in das Christentum hineingezogen, vor allem um die erlösende Kraft der neuen Gotteserkenntnis in bestimmten objektiven Vorgängen zu konzen-

40) Diese Bedingtheit der kirchlichen Organisation und ihres Verhältnisses 2u anderen Lebenskreisen durch den Wahrheitsbegriff ist der Gesichtspunkt, unter dem meine Abhandlung, Die Trennung von Staat und Kirche $\propto$, 1907, das Problem zu klären sucht. Aus diesem Grunde halte ich es auch für falsch, im Katholizismus allzusehr den Erben des römischen Reichsgedankens zu sehen; sein Zentralisationsbedürfnis und seine Ausschließlichkeit stammt aus dem Wahrheits- und Sakramentsbegriff in erster Linie, und hängt mit dem Kaiserreich nur dadurch $z \mathfrak{u}$ sammen, daß eben das Kaiserreich eine Einheitsreligion als sein Korrelat forderte. Aus dem gleichen Grunde halte ich es für falsch, den Dogmatismus und Intellektualismus, der doch nur an der Einheit und nicht an der Begreiflichkeit der Lehre hängt, ans der > Hellenisierunge und der Vermischung mit griechischer Metaphysik abzuleiten. Er erklärt sich in der Hauptsache aus der Herausbildung der Einheitsidee auch auf dem Lehrgebiet. Der Geist wirklicher griechischer Wissenschaft ist selten genug in der Dogmengeschichte und stets verdammt worden. 
trieren und sie dadurch der schwankenden, bloß menschlichen Subjektivität zu entnehmen. Auch diese ursprünglich freien Riten werden dem Klerus unterstellt. Das gewinnt nun aber dann auch eine ganz außerordentliche soziologische Bedeutung, indem die Sakramente nicht bloß der Höhe- und Sammelpunkt des Kultus werden, sondern indem sie vor allem die entscheidenden Heilsvermittler werden. Außer dem Sakrament ist kein Heil, und, da kein Sakrament - mit geringfügigen Ausnahmen - außer dem Priester ist, so ist auch außer der Kirche kein Heil. Sie hat nicht bloß allein die Wahrheit, sondern vor allem allein die sinnlich-übersinnlichen Heilsvermittelungen der Sakramente. Das völlig unsakramentale, rein ethische Evangelium nimmt damit eine auch seinen jüdischen Voraussetzungen fremde Ideenmasse auf, die aber im Grundtriebe aller naturwüchsigen Religion liegt und die von der Christusmystik her als Mittel der Herstellung der realen Substanzvereinigung sehr wohl angeeignet werden konnte ${ }^{10} \mathrm{a}$ ). Das aber ist dann auch zugleich eine Festigung des religiös-soziologischen Zusammenhangs, die der ursprünglichen Grundidee zwar sehr entgegengesetzt ist, die aber jedenfalls deren Unbestimmtheit und Lockerheit durch einen unzerreißbaren Zusammenhang ersetzt. So lange der Glaube an Priestertum, Sakrament und Einheit der religiösen Erkenntnis geteilt wird, ist er unauflöslich und führen alle Lockerungen wieder zu ihm zurück.

Mit diesen organisatorischen Mitteln aufgebaut, wird die Kirche $\mathrm{zu}$ einem eigenen Organismus, und ihr Gedanke kann schließlich nicht verfehlen, eine $\mathrm{j} u \mathrm{r}$ is $\mathrm{t}$ i s $\mathrm{c}$ h e Fassung seiner selbst hervorzubringen. Sie begründet demgemäß allmählich ein eigenes Recht, das Recht der Kirche, in dem sie von sich aus, ohne jede Rücksicht auf den Staat als die bis dahin allein mögliche Rechtsquelle, ihre eigentümliche Auffassung von dem Verhältnis zwischen Gemeinschaft und Individuum, Kirche und Welt juristisch darlegt. Die aus dem Interesse des Seelenheils sich bildende spezifische soziologische Idee schafft sich auch ein neues spezifisches Recht. Aus der ursprünglichen naiven und anschaulich unbegrifflichen Denkweise, die am sinnlichen Bilde der Gemeinde und der Christusgegenwart in der Gemeinde und dann weiter an der tat-

40a) Vgl. Heitmüller, \Taufe und Abendmahl bei Paulus 1903. Ueber die grundlegende Bedeutung des Sakramentalismus für die katholische Christlichkeit vgl. meinen Aufsatz Der Ehrhardsche Reformkatholizismus\& Christl. Welt. 1902 Nr. 20. 
sächlichen Verbindung der Gemeinden unter einander im gemeinsamen Wahrheits- und Heilsbesitze haftet, löst sich die darin unbewußt enthaltene Struktur zu begrifflicher Klarheit und juristischem Ausdruck ab. Die Rechtssubjektivität des Gesamtverbandes und der Einzelgemeinde, die Befugnissphäre der Bischöfe in der ersten und zweiten Hinsicht, die Vertretung dieser Rechtssubjektivität, die Rechte der Einzelnen gegenüber diesem objektiven Recht, der kirchliche Besitz, die religiösen Liebesanstalten, die kirchlicher Regelung zugänglichen Lebensbeziehungen vor allem im Eherecht, die Entscheidung von Streitigkeiten der Christen unter einander und die Sittenaufsicht, all das wird in steigendem Maße Gegenstand eines kirchlich-juristischen Denkens ${ }^{41}$ ). Aus diesem aber entsteht ein fester, in kirchliche Stände gegliederter Organismus, der schließlich vom Staate anerkannt und mühsam mit dem ganz andersartigen staatlichen Recht zum Kompromiß gebracht wird, der aber freilich in der alten Kirche eine darüber hinausgehende auch in die allgemeine Ordnung eingreifende Wirkung noch nicht gewinnt. Gierke hat feinsinnig den soziologischen Sinn dieses kirchlichen Rechtes im Gegensatze zu den allgemeinen Gemeinschaftsbegriffen der Antike und des Germanentums analysiert und die Bedeutung des kirchlichen Rechtsbegriffes für die Entwickelung der Gemeinschaftsidee überhaupt untersucht. Im Altertum geht das soziologische Ideal instinktiv von der Anschauung des Stadtstaates, der Bürgergemeinde und der Herrschenden aus; über alle herrscht das Gesetz, und die objektive Geltung des Gesetzes ist das Wesen der Gemeinschaft ohne Rechtssubjektivität des Ganzen und ohne solche des Einzelnen anders als sie in der Teilnahme am Gesetz des Ganzen begründet ist. Die gesetzliche Gemeinschaft selbst geht ihm aus einem zentralen Triebe der menschlichen Wesensanlage aus. Alle Religion ist Staatsangelegenheit und gehört selbst mit zu, den Gesetzen, alle Vereine sind entweder mit dem Staat identisch oder lediglich zufällige $Z$ weckverbindungen, denen das römische Recht unter Umständen die juristische Persönlichkeit als bewußte Fiktion verlieh. Dem gegenüber stellt die Kirche wie einen ganz anderen soziologischen Gedanken so auch ein ganz anderes Recht dar. IIndem eine nach Ursprung, Wesen und

4) Gass, Gesch. d. Ethik I 7 I f., 229 ff. Versuche eines kirchlichen Eherechtes schon bei Kallist, Ablehnung der Todesstrafe und Versuche sie durch geistliches Verfahren zu ersetzen; Biegelmair 92-94, Konstantin verleiht dann den bischöflichen Urteilen Rechtsgültigkeit; Weinel sStellung u. s. w.< S. 35-37. 
Bestimmung transszendente Verbandseinheit zugleich als solche zum Subjekt einer irdischen Rechtssphäre berufen wurde, trat ein bisher unbekanntes Element in den Entwickelungsprozeß der Körperschaftstheorie ein .... Wie die antike Theorie den Staat, so faßte die christliche Theologie die Kirche als lebendigen Organismus, als ein selbständiges und einheitliches Ganze auf. Allein die organische Denkweise empfing hier einen neuen religiösmystischen Gehalt. Sie führte das Bild eines beseelten Körpers in einem über verwandte Vorstellungen der antiken Philosophie weit erhobenen Sinne durch. Insbesondere war hier einerseits dem Ganzen in seinem transszendenten Mittelpunkt eine lebendige geistige Einheit beigelegt, und es war doch andrerseits jedem Gliede ein eigener Wert, eine besondere Persönlichkeit gewahrt. Hier war das Verhältnis des Ganzen zu seinen Gliedern und der Glieder zu einander als ein Verhältnis voller Gegenseitigkeit gedacht; hier waren die Prinzipien der Einheit und der Vielheit als gleich reale und gleich notwendige Elemente des allumfassenden göttlichen Seins gedacht « ${ }^{42}$ ). Indem dies göttliche Sein im Episkopat faßbar wurde, »erschien die Kirche als ein corpus mysticum, welches einerseits auf mystische Weise von Gott zur Lebenseinheit verbunden, beseelt und geleitet wurde, andrerseits aber als ein so konstituierter Körper auch ein äußeres Verbandssubjekt bildete und mit dem Anspruch auf eine rechtliche Herrschaftssphäre in die irdischen Verhältnisse eintrat*. Nach innen erscheint so die Kirche als ein Organismus, der sich teils als Anstalt für den Glauben, teils als Gemeinschaft der Gläubigen darstellt, nach außen erscheint sie als Trägerin eines vom Staat unabhängigen und eine vom Staat unantastbare Sphäre begründenden Rechtes. Es ist deutlich, daß hier das christliche Ineinander von Individualismus und Universalismus um eine juristische Fixierung ringt; und Gierke hebt die Annäherung an die germanischen Korporationsideen hervor, »die neben der Rechtssubjektivität der in ihrer Besonderheit abgeschlossenen Individuen eine Rechtssubjektivität der aus der Verbindung von Einzelwesen erwachsenden Gemeinwesen statuieren «. Innerhalb der alten Kirche blieb all das freilich auf die eigene Theorie der Kirche von sich selbst beschränkt und färbte sie auch nicht ab auf das rechtliche und sozio-

${ }^{42}$ ) Vgl. Gierke, »Genossenschaftsrecht III, 108 f., auch den interessanten Abschnitt bei Harnack, $\gg$ Mission I, 206-234, über die Selbstbezeichnung der Christen als sneues Volk und drittes Geschlecht $\propto$. 
logische Denken des Staates, aber damit sind Entwickelungen von größter Tragweite für alles politische und soziologische Denken wie für die konkreten Institutionen geschaffen ${ }^{43}$ ). Der tiefe innere Widerspruch eines aus transszendenter Quelle ausfließenden Rechtes zu dem grundlegenden Merkmal alles Rechtes, der Erzwingbarkeit, ist nur die im Recht sich zeigende Folge des allgemeinen Widerspruchs zwischen einer rein religiösen Gemeinschaft innerlichen Lebens und ihrer objektiven Faßbarmachung in Dogma, Sakrament und Amt und deutet damit nur das unter allen Formen wiederkehrende schwere Problem aller rein religiösen Gemeinschaftsbildung an ${ }^{46}$ ).

Das Bedeutsame an dieser Entwicklung ist nun aber nicht bloß die Festigung des soziologischen Zusammenhangs durch eine Autorität, die nach allen Seiten hin als supranaturale Autorität, als Inkarnation des Wunders in Priester, Bibel, Sakrament, Tradition und Recht erscheint und die den Ausgangspunkt des ganzen kirchlichen Supranaturalismus bildet, sondern ebenso wichtig ist der damit gemachte Fortschritt in der Gliederung und Differenzierung innerhalb des gemeinsamen $\mathrm{G}$ a n z e n. Es ist im Klerus eine führende und regierende Schicht emporgehoben, die durch das Bedürfnis der Organisation nach immer stärkerer Gliederung in sich selber strebt und die alten charismatischen Gaben und freien Dienstleistungen konsequent in ein aufsteigendes System priesterlicher Weihen verwandelt ${ }^{440}$ ) und dann wieder die Bischöfe und den Klerus selbst der sonstigen Gemeinde als den Laien gegenüberstellt. Es sind die Grundlagen der theokratischen Gliederung der Kirche, in der das allgemeine Priestertum und die abstrakte religiöse Gleichheit sich besondert zu tiefgreifenden und wesentlichen Differenzen. Aber im Unterschied von jeder sonstigen Aristokratie ist die regierende Schicht nur eine Konkretion und Sichtbarmachung der im Ganzen enthaltenen Heilskräfte, die nur um der Sicherung gegen Trübung und Vermenschlichung willen dieser Heraushebung bedarf und daher im Grunde

43) Gierke III I Io f., die Formeln für die germanische Korporationsidee III I f.

44) Der Ausführung dieses Gedankens dient Sohms Kirchenrecht mit seiner These, daß , Kirchenrecht ein Widerspruch in sich selbst sei. Freilich hat er bis jetzt nicht gezeigt, wie Kirche und organisierte religiöse Gemeinschaft ohne Recht möglich sei.

4.) Vgl. Harnack sUeber derı Ursprung des Lektorats und der anderen niederen Weihene (Texte und Untersuchungen III 6 ). 
immer wieder zurückgeht in das Ganze, worin freilich begründet ist, daß dieses letztere entweder zur Fiktion oder zur Einschränkung und Herabsetzung des Klerus wird. Daher wird der Gegensatz der priesterlichen Ueberordnung über die Laien mit denselben Mitteln des religiösen Patriarchalismus ethisch fruchtbar gemacht, wie wir das bereits von den sonstigen Differenzen gesehen haben: der Priester ist der Vater der Gemeinde und der Knecht der Knechte Gottes. Wie die Keime des Patriarchalismus in der religiösen Würdigung und Bewältigung der Zufallsdifferenzen liegen, so liegen in dieser theokratischen Autorität die Keime einer staffelförmigen Gliederung der ganzen Gesellschaft, die dann im Mittelalter mit dem Feudalismus sich berühren wird. In der alten Kirche kommt beides noch nicht zur Entwickelung. Das erstere wirkt lediglich zur konservativen Hinnahme der Verhältnisse, das letztere zum geschlossenen Aufbau der Kirche in sich selbst. Dabei 'sind die Bischöfe der alten Zeit noch einfache Handwerker, Kaufleute, unter Umständen auch Sklaven. Das priesterliche Amt ist nur ein Ehrenamt, neben dem der bürgerliche Erwerb hergeht. Erst allmählich dringen die intellektuell und finanziell hervorragenden Leute in das Amt wie etwa Cyprian, und erst mit dem Erwerb des kirchlichen Grundbesitzes und nach den kaiserlichen Privilegien der nachkonstantinischen Zeit werden die Bischöfe eine Herrenschicht.

Von hier aus entsteht nun die Frage, wie dieser christlichsoziologische Organismus zu den sozialen Bildungen der *Welt* sich stellt. Aber ehe diese Frage beantwortet werden kann, sind die Veränderungen und Fortentwickelungen in dem ethischen Denken und Empfinden der Christengemeinden zu verdeutlichen. Von ihnen ist die Stellung zu diesen Fragen abhängig, und besonders charakteristisch ist hierbei der Sinn, den der Begriff der Welt als Inbegriff all jener Dinge annimmt und durch den er die Stellung zu ihnen bedingt.

Jemehr nämlich so der Bereich des Heils sich zusammenschloß zur organisierten Einheit, um so stärker schloß auch umgekehrt für die mit dem Heil und dem Gottesreich beschäftigte Phantasie sich das übrige Leben zusammen im $\mathrm{B}$ e griff der W e lt. War das allgemeine Leben für Jesus trotz aller Sünde noch voll von Spuren göttlicher Güte, konnte er in Kindern, Sündern und Samaritern den naiven Naturlaut der Frömmigkeit anerkennen und lag für ihn der Schnitt nicht zwischen Welt 
und Kirche, sondern zwischen Gegenwart und Zukunft, so steht schon für Paulus das Reich Christi oder die Kirche im vollen Gegensatz zum Reiche des ersten Adams, des Fleisches, der Sünde, des Gesetzes und des bösen Geistes. Mit dem Gedanken der klerikal-sakramentalen Kirche als der civitas Dei ${ }^{44 b}$ ), um die die Engel spielen und in der der Christus-Gott thront, verstärkt sich dann auch der Gegensatz der Welt als des Satansreiches, in dem es nur Verlorenheit und sittliche Unkraft gibt. In diesem Kontrastgedanken vollendet sich erst die soziologische Geschlossenheit des christlichen Gedankens, und dieser Kontrast wird immer bedeutender für die christliche Soziallehre. Hier setzt die altchristliche Apologetik und der Angriff ein, indem um der allein erlösenden Kraft des Christusglaubens willen alle Kräfte der. Welt zum guten geleugnet oder beschränkt werden mußten. Lnd von dieser Apologetı her sind alle weiteren Gedankenbildungen und Einrichtungen bedingt. Einmal wird die Rettung aus der Welt als ein völliges sakramentales Wunder betrachtet, sei es in der Taufe, sei es in der Buße und damit die Ethik der Kirche zu der Ethik der Gnadensittlichkeit, der supranaturalen Einflößung sittlicher Kräfte, die nicht aus der Welt, sondern nur aus dem Wunder der gottmenschlichen Kirche stammen können. Ferner wird alles sittliche Handeln nun auch in seinem Inhalt dem weltlichen Handeln aufs schärfste entgegengestellt, und das was bei Jesus ein die natürlichen Lebensbedingungen gering einschätzender Heroismus war, wird unter Einwirkungen verschiedenartiger Motive, vor allem aber doch unter dem Eindruck dieser Kluft von Welt und Gottesreich zur Askese, die gegen die Natur mißtrauisch und feindlich ist und sich von der platonischen Lehre der Widergöttlichkeit aller Materie und Sinnlichkeit bezaubern läßt. Vor allem aber - und das ist für unseren $\mathrm{Zu}$ sammenhang das Wichtigste - tritt die Welt mit all ihren Ordnungen als eine geschlossene und unabänderliche Masse unter den Gesichtspunkt eines Systems der Sünde, das nur en bloc verworfen werden kann oder nur en bloc angeeignet werden kann. Das erste tut das Mönchtum und wird zur idealen Lebensregel auch des Klerus, das letztere tut die große arbeitende Masse,

4b) Der Ausdruck scivitas Deic ist nicht erst augustinisch; schon Paulus be-

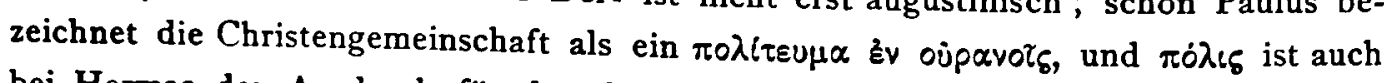
bei Hermas der Ausdruck für das Christentum im Gegensatz gegen die Stadt der Welt, Weinel sStellung u. s. w.s S. 52. 
indem sie mit der Akzeptierung der Welt sich unter die Konsequenzen der Sünde beugt. Die Begründung der Teilnahme der Christen an den weltlichen und das heißt außerkirchlichen Dingen wird von da ab stets damit begründet, daß diese Dinge, so wie sie sind, Folgen der Sünde sind und der Christ in der Teilnahme an ihnen sich unter die Folgen der gemeinsamen Sünde beugt. Er kann sie nicht ändern und darf sich unter sie nur beugen, indem er den inneren Herzenswiderspruch gegen sie nicht aufgibt und wenigstens selbst keine innere Freude und Anteilnahme hat an dem, was die Uebermacht der durch die Sünde bedingten Ordnungen auch von ihm erzwingt. Das ist in der ganzen alten Kirche so geblieben, und auch spätere Zeiten haben wenigstens im Bedarfsfall immer auf diese Argumentation zurückgegriffen. Die wichtigen Folgen hievon werden uns bei der Frage nach der sozialen Stellung und Betätiguug der Kirche entgegentreten.

In der Herausbildung jenes Gegensatzes von Welt und Kirche wurzelt nun, wie bereits angedeutet, vor allem die entscheidende Macht der alten Kirche, die Askese in der besonderen christlich-kirchlichen Form. Nichts freilich wäre verkehrter, als den Grund dieser gewaltigen und ernsten Erscheinung lediglich in dem Bedürfnis nach einem solchen Kontrast und seiner Verfestigung zu suchen. Aber die besondere Form und Wirkung der kirchlichen Askese hängt damit allerdings eng zusammen. An sich hat die Askese einen sehr viel breiteren Untergrund, freilich aber auch eine Vieldeutigkeit des Sinnes, der jedesmal erst festgestellt werden muß. Es gibt eine »Askese*, die lediglich die Folge des zu sich selbst gekommenen und nun seine ganze Tiefe entfaltenden religiösen Denkens ist. Wo Gottesgemeinschaft und Leben in Gott gesucht wird, da stellt der Gegensatz der Vergänglichkeit, der Nichtigkeit oder mindestens Unselbständigkeit aller weltlichen Werte von selbst sich ein und wird die Religion zur Erlösung. Mit der religiösen Schlußwendung der Antike tritt daher durch die innere Dialektik des Gedankens selbst auch der Erlösungsglaube und die Zurückstellung der weltlichen Werte ein. Dabei ist aber ein wirklicher Dualismus, der Glaube an ein Gott entgegengesetztes Prinzip in der Welt, keineswegs eine notwendige Folgerung. Es ist Ueberweltlichkeit, nicht Weltverneinung ${ }^{45}$ ). In diesen Zusam-

4b) Vgl. Siebeck, >Lehrbuch der Religionsphilosophie๔, I893, S. I-31, ror-156. Ein Positivist wie Bender sieht schon in jeder Metaphysik, d. h. in 
menhang gehört auch das Evangelium und die Predigt Jesu, der in der Erwartung des Gottesreiches und in dem Radikalismus der ethisch-religiösen Forderung die weltlichen Interessen mit der Forderung des Gottvertrauens und der materiellen Bedürfnislosigkeit einfach abtat, im übrigen aber schon im Zusammenhang mit dem jüdischen Schöpfungsglauben die Welt und ihre schlichten Freuden ohne weiteres gelten ließ. Die Jesus und die älteste Gemeinde erfüllende Gewißheit von einer baldigen, wunderbaren Verwirklichung des Ideals tat das ihrige dazu, um die kurze noch vorhandene Spanne der Welt zu entwerten, aber nicht im Sinne der Verneinung von Welt, Sinnlichkeit und Natur, sondern im Sinne der Gleichgültigkeit gegen das doch bald Vergehende. Es ist das mehr radikale Ueberweltlichkeit und um die irdischen Lebensbedingungen sich wenig kümmernder Heroismus als Askese im eigentlichen Sinne ${ }^{46}$ ). Erst das Eindringen der Mystik und eines akosmistischen Pantheismus macht den Erlösungsglauben zur eigentlichen Askese, weshalb dann auch das Mönchsleben als das philosophische Leben bezeichnet wird. Aber nicht nur aus der zentralen religiösen $Z$ wecksetzung, sondern zweitens auch aus dem ethischen Rigorismus des Evangeliums ging *Askese " hervor. Die reine Gesinnungsethik ohne Recht und Gewalt ist nur in ganz einfachen sozialen Verhältnissen praktisch auszuüben und setzt kleine Lebenskreise voraus. Bei dem Aufstieg in größere und verwickeltere Verhältnisse wurde den Christen die Zurückhaltung von ihnen oder die Herstellung besonderer Lebenskreise rätlich, in denen solche Praxis möglich war. Auch das ist nicht eigentliche Askese, sondern nur Zurückhaltung von den Gefahren und Verwickeltheiten des Lebens, schlug aber freilich, namentlich in Mönchskreisen leicht in solche um ${ }^{46 a}$ ). Hieran schloß sich dann

jeder Behauptung einer von der unmittelbaren Erfahrung verschiedenen, nur durch Denken faßbaren Realität, die Keime des Dualismus und mit ihm der Askese; vgl.: Metaphysik und Asketik (Archiv f. Gesch. d. Philos. VI 1888). Treffendes.

46) Hier enthalten die Ausführungen Jacobys, sNeutestamentliche Ethik \&, víel

46 a) Siehe oben S. 78 u. Harnack, DDas Mönchtum, seine Ideale und seine Geschichte،, 1907 S. 10: sIn der Nachfolge Jesu, in welcher sich das Trachtien nach dem Reiche Gottes und seiner Gerechtigkeit verwirklicht, liegt die Entäusserung von allem, was hemmend ist, beschlossen. Das Mönchtum hat aber nachmals Yersucht, der entscheidenden evangelischen Forderung $>$ Enthalte dich so gerecht zu werden, daß es den Umfang des Verzichtes ohne Rücksicht auf die individuelle 
drittens durch eine psychologisch naheliegende, aber höchst folgenreiche Verwechselung leicht die eigentliche Askese an. Indem das Merkmal der evangelischen Ethik die Selbstverleugnung und die Schwere der Anforderung war, schien umgekehrt alles was schwer, selbstverleugnend, gegen die Natur ist, ein vom Evangelium geforderter Gottesdienst. Und ähnlich wirkt eine verwandte Verwechselung, wenn die der religiösen Konzentration und der Bändigung der Sinnlichkeit dienenden Uebungen den entscheidenden Ton auf sich ziehen und zum Zweck statt zum Mittel, zur Befriedigung des Bedürfnisses nach Auszeichnung und Absonderlichkeit werden, wie das in aufgeregten Zirkeln nie ausbleibt. Während die Selbstverleugnung der evangelischen Ethik einem. positiven Zweck, der Gottesliebe und Menschenliebe, dient und damit die inneren Werte der Vereinigung mit Gott oder der Gotteskindschaft, und der Bruderliebe oder der Gemeinschaft in Gott hervorbringt, wird hier die Selbstverleugnung zum Selbstzweck, zum guten Werke, zur Büßung, zur Leistung, die um so wertvoller ist, je mehr sie gegen die natürlichen Gefühle geht und je schwerer man sie sich abringt. Im Zusammenhang mit dem Herabsinken der evangelischen Gesinnungsethik auf das Niveau der quantitativen Leistung und des Verdienstes, mit der Entwertung und Verächtlichmachung des Natürlichen durch die Sündenlehre und mit der Beziehung auf eine ausführliche Eschatologie der Belohnungen und Bestrafungen - Uebertreibungen und Gemeinwerden, wie sie bei jedem Idealismus und so auch beim altchristlichen sich einstellten - wurde daraus das dem Seelenheil und der Rettung im Gericht dienende gute Werk der Mortifikation und Humilität. Das ist wohl - neben der Virginität - die eigentlichste und häufigste Form christlicher Askese geworden, die an der zunehmenden Erbsündenstimmung und der immer weiter ausgebildeten Eschatologie ihren dauernden Nährboden empfing. In ihr liegt ein toter Punkt der Passivität, reinen Negation und ethischen Zwecklosigkeit, der sie eben darum dann auch immer als ein Hemmnis der eigentlich christlichen Ethik erscheinen läßt und mit ihren Grundtendenzen in Widerspruch bringt. Aber indem eine solche Askese doch eine außerordentliche Anstrenjung des Willens und des Enthusiasmus voraussetzt, ist sie zugleich

3eschaffenheit und den Beruf des Einzelnen bestimmte. $\times$ Das letztere wird freilich Kategorien, in denen erst das Lutherthum das Problem löste oder zu lösen meinte. Troeltsch, Gesammelte Schriften. I. 
stets oder doch sehr häufig das stärkste Belebungs- und An1":ungsmittel der christlichen Ideenbewegungen geworden; und, da sic nicht auf einem System des Akosmismus und überhaupt auf kcinem System bcruht, sondern nur außerordentliche Willensstcigrerung und eschatologisch-eudämonistische Sicherstellung ist, s) kann sie sich mit allen positiven Tendenzen zweckvoller Liebesarbcit oder nützlicher Beschäftigung völlig prinziplos verknüpfen und kann somit unter Umständen die buntesten Wirkungen, hemmende und fördernde, prinzipgemäße und prinzipwidrige ausüben, kann in allen Formen und Graden, in bloßer Selbstdisziplin und /urüchhaltung, in mönchischem Leben, in den tollsten Exzentritäten ausgeübt werden ${ }^{4 b}$ ). Einc andere Quelle der eigentlichen Askese ist dagegen der bewußte und gewollte Dualismus, der in Orient mit den sog., in ihren Ursprüngen noch sehr dunklen, gnostischen Bewegrungen auftaucht und der im Occident aus dem erneucrten Platonismus und Pythagoräismus sich entwickelt. Hier kommt es zu dem Gegensatz von Sinnlichkeit und Geist, zu dem Kampf gegen Sinnlichkeit und Materialität als solche, wobei die Verneinung der Materie bald in strengster Enthaltung, bald in libertinistischer Ignorierung zum Ausdruck kommt ${ }^{47}$ ). In die Lehre

166) Vgl. Zöckler „Kritische Geschichte der Askese « 1863, wesentlich Materialsammlurg ïber heidnische, jüdische, katholische und protestantische Askese, sowie Referat iiber die theologischen Theorien der Askese, aber gerade dadurch sehr lehrreich. Dagegen fehlt fast jede psychologische Vertiefung. In letzterer Hinsicht feinc Bemerkungen bei James , The varieties of religious experience I902. Einseitige und phantastische Erregung des religiösen Gefühls bei Zurücktreten des ethischen Elementes und bei dem Mangel der Objektivitätsgesinnung, die die wissenschaftliche Bildung ancrzieht, führt bei dazu veranlagten Individuen zu einer Fülle psychopathischer Erscheinungen. Aber auch bei höchster ethischer und wissenschaflicher 13ildung neigt der Melancholiker dazu, die religiöse Empfindung des Abstandes von Golt sowie die der Einigung mit allerhand Gewaltmitteln zu intensivieren wic Origenes und l'ascal zeigen. Uebrigens schließsen derartige Abnormitilen das Erwachsen starker und wertvoller religiöser Gehalte in diesen Formen, dic ron diesen Entstehungsbedingungen sich ablösen können, nicht aus; vgl. Hellpach, Zur Formenkunde der Beziehungen zwischen Religiosität und Abnormität, $Z$. f. Religionspsychologic 1907.

$\left.{ }^{+7}\right)$ Vgl. Anz, „Zur Frage wach dem Ursprung des Gnostizismus \& (Texte und Cintersuchungen $X_{41}$. Rohde, Psyche ${ }^{2}$, IS98. Die Forschung über diese Dinge in erat jetzt in bewegung gekommen. Namentlich sind hier auch die eschatolosischen Ileen der Spätantike daraufhin zu untersuchen, wie weit sie Askese zur Folge haben. Nur ist zu betonen, daß Eschatologie an sich noch nicht Askese bedeutet. 
les Paulus von Fleisch und Geist scheint bereits derartiges hineinzuspielen, und auch seine Fassung des Erlösungsgedankens ist von Jaher beeinflußt: nicht mehr bloß die zukünftige Erlösung im Gottesreich, sondern eine geschehene Erlösung in der Fleischesüberwindung durch den Tod des Christus bieten bei ihm sich dar. Doch hat Paulus daraus die Askese nicht gefolgert; auch ist die Sündhaftigkeit des Fleisches für ihn doch erst durch den Sündenfall d.h. den Willen der Kreatur bedingt. Aber mit dem Gnostizismus drang die dualistische Askese ein, und in ihrem Gefolge die ganze Technik der orgiastischen und ekstatischen Erregung. Hinter und unter diesen religiösen Erlösungsstimmungen und dem spekulativen Dualismus steht nun aber fünftens als allgemeinere Macht die Ermüdung einer überreifen und fertigen Kultur, deren Lebenslust und Lebenskraft ausgekostet ist und die in dumpfer Unbefriedigung an sich selbst etwas Neues sucht, über sich selbst hinaus will und darum nach all den neuen Bewegungen greift, ein ernstes und erschütterndes Schauspiel für jeden, der diese Kultur in ihrer großartigen Entfaltung bewundernd begleitet hat und jeder reifen Kultur ein ähnliches Schicksal drohend fühlt. Auch das ist nicht eigentliche Askese, das ist nur Uebersättigung, Erschöpfung und Ermüdung und greift nur leicht in den sich darbietenden asketischen Lehren und Kulten nach etwas Neuem und Höherem ${ }^{48}$ ). Weiter kommt noch hinzu, was uns besonders fremdartig ist, der von der Spätantike und ihrer religiösen Unrast neu belebte Dämonenglaube, dessen Quellen in der allgemeinen Religionsmischung die buntesten sein mögen. Ueberall wimmelt es von unreinen und gefährlichen Geistern, mit denen die Berührung vermieden werden muß. Das gibt unzählige Vorsichtsmaßregeln und $\mathrm{Ab}$ wehrmittel, die dem Leben die Unbefangenheit der Hingabe nehmen, und es bedarf nur der Identifizierung der Materie mit bösen Geistern und Weltprinzipien oder der Heidenwelt mit der Satansherrschaft, um eine Zurückhaltung gegenüber allem Weltlichen und Sinnlichen zu begründen, die aus Vorsicht lieber zu viel als zu wenig

48) Vgl. J. Burkhardt, $\gg$ Die Zeit Konstantins des Großen«, 1853. Freilich trifft eine solcbe Charakteristik mehr die Oberschicht, wie schon früher erwähnt. Aber das zerstört doch auch für, die Unterschicht die Zuversicht zur bisherigen Ordnung der Dinge und den alten Lebensnormen. Wie weit die Askese, die ja in ihren Leistungen an sich eine enorme Kraftentfaltung ist, dann etwa gerad: die ins Transszendente gewendete Naturkraft dieser Unterschichten vielfacl sein mag, ist schwer zu sagen, aber wohl zu erwägen. 
tut und damit zur Askese wird, ohne eigentlich und streng den metaphysischen Dualismus von Geist und Materie zu Grunde zu legen. Jis kann ein prinzipieller Monotheismus und die Einheit des Weltprinzips zu Grunde liegen, aber die mächtig aufschießenden und neubelebten Elemente des P'olytheismus finden in ihm dadurch Platz, daß sie als gute und böse Dämonen mit dem Guten und Bösen in Verbindung gebracht werden; und indem der Polytheismus sich in Dämonenangst verwandelt, kann er trotz prinzpiell behaupteter Güte der Welt zur Förderung der Askese wirken ${ }^{49}$ ). Vielleicht kann man schließlich auch noch eine in den unbekannten Gesetzen des Sexualle ben s begründete Ermüdung und Erschlaffung des Geschlechtstriebes, eine neuropathische Schwäche des Lebenstriebes hinzurechnen. Jedenfalls hat dieser Umstand der Kaiserzeit überaus viel zu schaffen gemacht, und, daß das Ideal der Virginität in einem so grandiosen Maße um sich greift ist aus rein sozialen und rein ideellen Gründen schwerlich zu erklären; das naturgemäße Interesse starker Religiosität, die Konkurrenz der Erotik zu beseitigen, sei es durch strenge Zucht des Geschlechtstriebes, sei es durch Verschmelzung erotischer und relisiöser Erregungen, oder auch durch die Stärke seiner Empfindung das Geschlechtsleben zu neutralisieren ${ }^{50}$ ), kann den ungeheuren Einfluß des Virginitätsideals kaum ganz erklären. Es muß etwas wie eine nervöse Kulturkrankheit $\mathrm{zu}$ Grunde liegen, die sich dann in religiösen Gedanken Reinigung und Halt sucht. Jedenfalls ist aber von dem Eindringen des Virginitätsideals aus der Askese überhaupt das Tor geöffnet, wie denn vegetarische und diätetische Lehren, Verkündigungen der Bedürfnislosigkeit und des Naturzustandes und Lobpreisungen des einsamen Lebens gleichzeitig in die Höhe schießen. Indem dieses Virginitätsideal dann auch die gesunden und kräftigen Schichten ergreift, ergeben sich aus ihm eine Fülle von körperlichen Selbstquälereien, die nur der Unterdrückung des Geschlechtstriebes dienen und in eine Art Methodik zu diesem Zweck gebracht werden. Daran schließen

49) Vgl. Weinel, $>$ Geist und Geister im nachapostolischen Zeitalter \& 1899.

$\left.{ }^{50}\right)$ Wie wenig die Virginität an sich schon aber eine negativ-asketische Haltung zum Leben bedeutet, zeigt der Apostel Paulus, bei dem die Neigung zur Virginität ein vereinzelter Punkt ist und deutlich aus der Abneigung gegen die Konkurrenz der Geschlechtsleidenschaft erklärt ist. Die in andern Kulten vor der Kultausübung vorgeschriebene Enthaltung hat teils den gleichen Grund, teils beruht sie auf Vorstellungen von Verunreinigung, die von der Art des physiologischen Vorgangs bedingt sind. 
sich dann alle Abnormitäten des irregeleiteten Geschlechtstriebes. Alle diese Dinge verschlingen sich nun in der christlichen Gemeinde. Das Evangelium Jesu und die Lehre des Paulus hat sie nicht auf die Bahn der Askese, sondern auf die eines die Naturbedingungen des Daseins gering schätzenden, nur im Mindestmaß anerkennenden und in der Enderwartung überfliegenden Heroismus gestellt, hat sie zugleich an Lebensverhältnisse von grosser Einfachheit und Intimität gewiesen. Es blieb ihr von da aus immer die Unmöglichkeit, Natur, Welt und Sinne als wesentlich und metaphysisch böse und gottfeindlich zu betrachten, eine Richtung, in der ja auch das im Kampf gegen die Gnosis siegreich behauptete alte Testament mit seinem Schöpfungsglauben, seiner Naturpoesie und seiner gesunden jüdischen Spruchmoral sie befestigen mußte. Darin hat auch die mit dem Wachstum der Gemeinde steigende Akzeptierung der Welt und die später zu zeigende Lehre von einem göttlichen Vernunftkern auch in den Ordnungen der Welt ihr inneres Recht und ihre Kontinuität mit dem Ursprung. Aber nun war einmal das $\mathrm{Ma} ß$ der damit gegebenen Anerkennung der Welt überaus unsicher; es war die Richtung auf ein Mindestmaß erteilt und war jedenfalls jede Anerkennung weltlicher Werte als Selbstzweck und Eigenwert völlig ausgeschlossen; sie waren günstigsten Falles die mit der Schöpfung gegebenen, in Gottes Willen begründeten und einfach hinzunehmenden Ordnungen. Unter diesen Umständen ist jedes positive Interesse an ihnen ausgeschlossen und führt die Herabsetzung auf das Mindestmaß leicht zur vollen Negation; dann ist man sicher, das Mindestmaß getroffen zu haben. Dazu kommen nun aber noch all die anderen genannten Einflüsse, insbesondere der Dämonenglaube, der bei allem prinzipiell festgehaltene Monotheismus und Glauben an die Güte der Welt doch die Welt per accidens so stark in Sünde und Teufelsmacht verstrikt sein lassen kann, daß die praktische Stellung auf Negation hinauskommt. Dazu kommt der spekulative Dualismus, die Kulturmüdigkeit, das Eremitentum, die Virginität, die Stimmung des Martyriums und der Kampf um die Behandlung der dem Martyrium sich Entziehenden, um die Unsicherheit voll zu machen und in die Anerkennung der Welt ein Schwanken und eine Gewissensunsicherheit zu bringen, der diejenigen, die es konnten, am besten durch Weltflucht entgingen. Auch das immer wieder von den Vätern zitierte paulinische Wort von dem Bleiben in dem Stande, in welchem man berufen war, enthielt nur Unter- 
werfung unter diese Ordnung, aber keine innere Schätzung und wurde um so schwieriger, je mehr man in die Berufe der eigentlichen großen Welt hineinwuchs. Die Haltung der Kirchenlehrer gegenüber der > Welt * ist so ein schwankender über seine Grundlage unsicherer, halber Asketismus geworden, der durch das Prinzip des Christentums zur Anerkennung eines Mindestmaßes von Berechtigung der Welt verbunden ist, aber in seiner Unsicherheit dieses Mindestmaß bald im Sinne eigentlicher und voller Askese aufhebt, bald unter dem Druck der praktischen Verhältnisse sehr umfassend erweitert ${ }^{51}$ ).

In diese Schwankungen bringt nun die oben charakterisierte Zusammenfassung der Kirche gegen die Welt, die Herausarbeitung der soziologischen Einheit der Kirche und die Auffassung der Welt als einer dem gegenüberstehenden, gleichfalls in sich zusammengefassten, Einheit eine gewisse Ordnung und Sicherheit und damit eine Einschränkung und Zuspitzung der Askese und des Weltbegriffes zugleich. Die Welt ist nicht an sich böse, sondern nur durch den Sündenfall

51) Der Uebergang vom Evangelium zur Askese vollzieht sich leicht, wenn das, was an sich Sinn und Bedeutung nur hat in Beziehung auf die zu gewinnende Gottesgemeinschaft, um seiner selbst willen eingeübt und sozusagen auf Vorrat erworben wird, um dann Gott gegenüber bereit zu stehen. So wird die Brechung des Figunwillens, der Selbst- und Weltliebe, die Dienstbereitschaft, die Demut und Liebe auch an ganz indifferenten Stoffen und Fällen eingeübt, um dann umso leichter in der cigentlichen und alleinigen Rücksicht betätigt werden zu können. Auf diesem Wege vollzieht sich psychologisch der Uebergang von dem Heroismus des Evangeliums zur Askese, und, einmal vollzogen, zieht er dann alle weiteren in der Zeit liegenden Motive der Askese an sich. Zeugnis hierfür ist der ursprüngliche Sinn und der Bedeutungswandel von $\gg$ Askese $\star$, vgl. Gass I 104; es heißt zunächst die Einübung der Tugend und bildet z. B. bei Clemens die Bedingung der höheren guostischen Vollkommenheit, Asketen sind dann die Märtyrer als »entwickelte und leidensstarke Darsteller der Nachfolge Christi๔. Von hier aus ergab sich geradlinig die Anwendung auf das Mönchtume. „Es war ebensowohl möglich, die Askese als ein Befürderungsmittel sittlicher Tätigkeit anzusehen, wie auch ihr eine Bedeutung für sich, einen Verdienstwert beizulegen. Der Unterschied war zu fein, als daß nicht das eine in das andere hätte überfließen sollen.\& Von da aus hat dann erst das Wort seinen modernen Sinn als s Mortifikation und Entwertung der Welt, Weltverneinung und Weltflucht, erhalten, während die katholische Kirchensprache es noch heute in erster Linie im Sinn von Tugendübung und Tugendmitiel gelraucht. Es ist in diesem Sinne sogar in die protestantischen Ethiken überge gangen. 
und steht unter der Macht der Dämonen nur, soweit sie sündig ist. Aber von Sünde ist sie allerdings überall durchdrungen und bildet ein in sich zusammenhängendes System der Sünde, ein soziologisches Gegenbild der Kirche. Göttlich ist in ihr nur der Geist der Ordnung und des Rechtes, der die pax terrena und damit die friedliche Arbeit der Christen sichert. Die Christen selber aber leben gar nicht unmittelbar in der Welt, sondern nur durch Vermittelung der Kirche. Sie sind in erster Linie Glieder der Kirche und leben nur als solche zugleich in der Welt, da die Kirche noch im Fleische ist als ecclesia militans. So schreibt die Kirche ihnen das Mindestmaß der Beteiligung an der Welt vor und nimmt ihnen die Verantwortung der eigenen Entscheidung ab. Sie reguliert das anzuerkennende Mindestmaß und sichert dann doch den asketischen Geist gerade durch die Fiorderung des Verhältnisses zur Kirche, des demütigen Selbstverzichtes auf eigenen Willen, der selbstentäußernden Unterwerfung unter dic sakramentale Gnade mit der allein von ihr ausgehenden Kraft zum wahrhaft Guten, der die Einheit der Kirche über alles setzenden Liebe. Unter diesen Bedingungen ist für die große Allgemeinheit de" asketische Geist zugleich gemildert und gesichert ${ }^{32}$ ). Zuglcich aber wird

${ }^{\text {02) }}$ Charakteristisch ist hier die Erklärung Augustins, De doctrina christiana I 3 ff.: er unterscheidet frui und uti, was dann zu einer Grundlehre der ganzen späteren katholischen Ethik geworden ist. Etwas „genießen heißt ctwas vlieben ; aber wahrhaft lieben soll der Christ nur Gott. Für die Welt bleibt der usus übrig. Sic ist wie das Schiff, auf dem einer in die Heimat zurückkehrt, Ergötzte man sich an den Annehmlichkeiten der Reise oder am Gang des Fahrzeugs, so daß man sich zum Genuß, statt bloß zum Gebrauch des Fahrzeuges wendet, so verliert man das Ziel aus dem Auge. Wir müssen die Welt gebrauchen und nicht genießen, damit wir so das Unsichtbare an Gott durch das erschaffent Sichtbare schauen, d. h. von den körperlichen und zeitlichen Sachen geistige und ewige ernten. Das ist höchst charakteristisch. Es ist nicht Askese im eigentlichen Finnc, sondern Aufhebung der Selbstwertigkeit aller innerweltichen füter und ihre liczichung auf den Dienst für überweltliche Güter. Darin aber fügt sich leicht die cigentliche Askese, die Mortifikation der Natur und die Vernichtung des natürlichen Willens, ein. Zwischen beiden Gedanken geh die ganze altchrisllich, und mittelalterliche Stellung zur Welt hin und her, ein deutliches Zeichen darir, daß nicht die Askese, sondern die Ueberweltlichkeit, die Setzung eines spezifisch religiösen Lebenszweckes in der Gottesgemeinschaft über allen weltichen Interessen, ihr wesentlicher Grundgedanke ist. Erst als Mittel zum Schutz gegen überstarke Konkurrenz der weltlichen Zwecke greift die Askese ein, die das Ziel dadurch sicher erreicht, daß sie das Innerirdische statt es einzuschränken lieber gleich ganz negiert. Sie ist die 
eine höhere Stufe der Vollkommenheit eröffnet, auf der die volle Askese, die Besitzlosigkeit und Virginität, ganz oder annähernd erreicht wird. Sie ist ein besonderes Charisma, das freilich der Kleriker selbst immer besitzen sollte und durch Gesetze über die Lebensführung der Kleriker unterstützt wird. Dieser Ausweg ciner doppelten und doch gleichberechtigten Moral ist dabei nicht etwa einfach eine Inkonsequenz, ein Nachlassen vom eigentlichen asketischen Grundideal. Er entspricht viel mehr einer von Hause aus in der christlichen Idee enthaltenen Doppelrichtung der die Güte Gottes in seinen Ordnungen anerkennenden relativen Innerweltlichkeit und der über die Welt zum letzten Ziel der Gotteskindschaft und der Brudervereinigung in Gott aufstrebenden Ueberweltlichkeit. Aber er ist in seiner besonderen hier angenommenen Form bedingt von allen Mächten der Zeit und insbesondere von dem Gegensatz der in sich selbst geschlossenen Heils- und Erlösungsanstalt der Kirche gegen die dem Bösen ausgelieferte Welt. Dieser Gegensatz selbst aber ist nicht etwa seinerseits bereits eine Wirkung der Askese, sondern in erster Linie eine Wirkung der apologetischen Ausschließ\}lichkeit des kirchlichen Wahrheitsbesitzes und der ihm verliehenen Wunderkraft, eine Wirkung des Supranaturalismus, mit dem die Kirche gegen die Welt sich abgesperrt hat. Dieser Supranaturalismus seinerseits hat dann erst der Askese das wichtigste Tor des Eindringens geöffnet, neben dem die paulinische Sexualethik, das mit übernommene jüdische Fasten und die jüdische Lehre vom Almosen weitere Einfallspforten bilden. Für Jesus lag der dankbare Genuss der bescheidenen Weltfreuden und die Strenge seines hohen Ideals nahe und ohne Spannungen und Schwierigkeiten bei-

via tutior, zugleich eng verbunden mit der Außerachtlaßung der Gesinnungsethik und ihrer Ersetzung durch das neue Gesetz und die beliebig zu häufenden guten Werke. Im letzteren äußert sich nur die Herabziehung aller großen Gedanken auf das Niveau der Durchschnittlichkeit und die Beziehung auf die Belohnungen und Bestrafungen im Jenseits, deren Einzelausmalung übrigens der gemeingriechischen Eschatologie angehört und mit dem Gottesreich nichts zu tun hat, vgl. A. Dieterich Nekyia 1893 und G. Anrich „Clemens und Origenes als Begründer der Lehre rom Fegfeuer (theol. Abhh., Festgabe für Holtzmann 1902). Damit wird dann freilich die Askese oft genug zum Selbstzweck; aber wo das rein der Fall ist, liegt auch immer der Abweg in ein dem christlichen Gedanken fremdes und der Kirche bedenkliches radikales Mönchtum oder in pantheistische Mystik nahe. Es ist durchaus logisch, wenn die Kirche sich gegen diese Abwege immer wieder verwahrt hat. Sie hat es freilich immer nur faktisch und instinktiv, nie mit klarer prinzipieller Begründung getan. 
sammen. Für die Kirche trat beides in dem viel komplizierten Weltleben immer weiter auseinander. Die natürliche Voraussetzung des Heroismus des Evangeliums, die Enderwartung, verschob sich; die in dem Enthusiasmus der Grundlegung und in der ländlichen Einfachheit Galiläa verständliche Ignorirung der Kulturwerte war nicht zu behaupten. So trat alles unter die Beleuchtung des Gegensatzes von Kirche und Welt. Insbesondere die religiöse Zweckbeziehung aller sittlichen Gebote auf die im Gehorsam zu gewinnende Gottesgemeinschaft wurde großenteils zur Askese oder zur Brechung des natürlichen Lebenswillens um der bloßen Brechung und um der damit zu erwerbenden Verdienste willen. $\mathrm{Da}$ vermochte die Kirche beides nur mehr zu vereinigen durch die Lehre von der Doppelstufigkeit der Moral, durch die Unterscheidung einer halbasketischen und ganz-asketischen Moral ${ }^{53}$ ).

5s) Ueber die doppelte Moral s. Uhlhorn I $200 \mathrm{ff}$. Man darf in ihr m. E. nicht einfach mit dem üblichen protestantischen Urteil eine Verlassung der ältesten und eigentlichen christlichen Moral sehen. Denn bereits diese hatte in ihrer weltindifferenten, der Vollendung zugewandten Moral von Anfang an zwar keine prinzipielle Weltverwerfung, aber auch keine Anlage zur Weltdurchdringung und Weltgestaltung. Der Montanismus bedeutet geradezu das krampf hafte Festhalten dieser alten Weltindifferenz und eschatologischen Hoffnung. Der $Z$ wang der Dinge mit der Ausbreitung der Gemeinden und dem Eindringen in das allgemeine Lebenssystem machte das erst unmöglich. U. meint: $>$ Nun stand die Kirche vor der großen Aufgabe, das sie umgebende Volksleben, Staat, Wissenschaft, Kunst, die sozialen Verhältnisse mit christlichem Geist zu durchdringen und von innen heraus umzugestalten. An dieser Aufgabe ist sie gescheitert und in falsche Bahnen gedrängt worden (S. 20I), in die Bahn der Laxheit einerseits und der Askese andererseits. Allein diese Aufgabe hat sie sich nie gestellt und konnte sie sich nie stellen bei ihrem von Anfang an grundlegenden Begriff von der Welt, und gerade auch, was sie vorfand und sich aneignete, konnte sie in der Negativität gegen die Welt nur steigern. Herrschte der geschilderte Weltbegriff, dann war gar kein anderer Ausweg möglich, als die Teilung der Aufgabe. Uhlhorns Ideal beruht auf einem anderen Begriff von der Welt, wie er dem Luthertum und noch mehr dem modernen » weltgestaltenden Luthertum eigentümlich ist. In ihm liegt die moderne Wendung zur Welt zugrunde, die Spätmittelalter und Renaissance erst vollzogen hat. Ueberhaupt ist das ganze Problem der Askese viel feiner und komplizierter als die protestantischen Ethiker in der Regel anzunehmen pflegen. - Ueberdies hat der Gedanke der doppelten Moral seine Parallele und seinen Vorgang an der Stoa, die ihr Rigorismus gieichfalls dem Leben gegenüber nötigte eine höhere und eine niedere Moral, eine vollkommene und eine mittlere Tugend, anzunehmen. Die Parallele ist nicht unbeachtet geblieben. Der Pädagog des Clemens (III I I) und die Offizien des Ambrosius I 36-37 
Unter diesen Einwirkungen verändert sich dann die ganze Ethik der Kirche überhaupt. Sie verliert ihre sichere inhaltliche Orientierung in der Doppelidee der Selbstheiligung für Gott und der Bruderliebe, und zerfließt in bunte Mischungen biblischer Einzelgebote, unbedenklicher Entlehnungen aus der stoischen und kynischen Ethik, asketischer Gebote und kirchenrechtlicher Satzungen, wirft kultische Betätigungen mit ethischen Handlungen durcheinander, bringt gute Werke, Fasten und Almosen in $\mathrm{Zu}$ sammenhang mit Verdiensten und Sicherungen des Seelenheils. Die Christlichkeit der Moral scheint geradezu nicht mehr in dem spezifischen Inhalt des Ethos, sondern in der übernatürlichen Gewirktheit des christlichen Handelns und der Unterschied gegen die heidnische Moral nicht mehr in dem Gegensatz gegen die staatlich-rechtliche und innerweltlich-eudämonistische Fassung, sondern in dem Gegensatz gegen das Hervorgehen aus natürlichen Kräften zu liegen. Seit dem augustinisch-pelagianischen Streit verschiebt sich die ganze Charakteristik vollends auf diesen formalen Unterschied. Augustins eigene berühmte und vom Mittelalter dann stets wiederholte Lehre vom Inhalt des christlichen Sittengesetzes, daß es die Beziehung alles Handelns auf den Endzweck der Gotteseinigung sei und von da aus in beschauliche Herzensreinheit und tätıge Bruderliebe sich glietere, hatte in der Kontemplation und in der Unterscheidung des kontemplativ-quietistischen und des alktivcaritativen Elementes bereits fremde und verwirrende Motive aufgenommen und diente nirgends zu einer Organisation der christlichen Ethik. Diese bestand vielmehr faktisch stets in einer überaus bunten Fülle von Anweisungen, wobei das Merkmal der Christlichkeit vorzugsweise an den durch die Gnade gewirkten und asketisch gefärbten Leistungen hängt ${ }^{53 a}$ ). Aber der soziologische Zusammen-

haben in ausdrücklichem Anschluß an die Stoa die Unterscheidung rezipiert. - Hierher gehört auch Nietzsches bekannte Lehre vom Sklavenaufstand in der Moral. Es ist sehr merkwürdig, daß Nietzsche, der sich bezüglich seiner eigenen Moral sehr wohl bewußt ist, daß sie die Konsequenz des Satzes $\gg$ Gott ist tot \&ildet, nun nicht jener Moral zubilligt, daß sie die Konsequenz des Satzes ist: „Gott ist lebendig “. In Wahrheit ist die evangelische Moral durchaus aus ihrem religiösen Motive zu verstehen, das Jesus aus dem Hebraismus zukam, den man aber seinerseits nicht wohl als im Interesse einer Erhebung der Schwachen erst konzipiert denken kann. Wenn irgend etwas Jesus charakterisiert, so ist es die Selbstverständlichkeit des Religiösen. Die Humilität an sich und um ihrer selbst willen ist aber erst ein Werk der Askese und steht in sehr viel komplizierteren Zusammenhängen, als Nietzsche annimmt. 53 4) Vgl. Gaß, Gesch. d. Ethik I 174, Liebner, Hugo v. St. Victor I832 S. 466 f. 
hang der Kirche ist bereits zu fest und enthält bereits zu klar in seinem Gefüge die ethischen Grundgedanken als daß diese Unsicherheit der Ethik ihn gefährden könnte. Er hat eine eigentliche Ethik überhaupt nicht mehr nötig und führt nun vielmehr seinerseits ihr instinktiv und unbewußt die Grundimpulse zu, die nichts anderes sind als das durch Askese, Kirchlichkeit, Verdienstlichkeit und Jenseitsbeziehung veränderte Grundgebot der Gottesliebe und Bruderliebe. Beide haben damit ihre ursprüngliche einfache religiöse Zweckbeziehung auf die Gotteskindschaft und die Liebesgemeinschaft ersetzt durch die komplizierte auf die Kirche und die Askese. Die Selbstheiligung im freien Gewissensgehorsam mit dem Ziel des unendlichen Wertes der Seele, die Herzensreinheit und Gottesliebe, wird zur Demut, zur Humilität gegenüber der Kirche, die das Opfer des Eigenwillens und der Eigenerkenntnis bringt und dann ethisch am größten ist, wenn der Verzicht am schwersten ist. Die Bruderliebe mit dem Ziel der universalen Liebesgemeinschaft wird zum kirchlichen Gemeingefühl, das jedes Opfer des Sonderwillens fordern darf und ohne das der Mensch ist wie ein vom Stamm getrenntes, verwehtes Blatt. Gerade im Gehorsam gegen die Kirche und im Opfer für die kirchliche Einheit wird die Zerbrechung des Selbst und Opferung für andere eingeübt, wird der Vorrat guter Werke gesammelt und das zukünftige Heil befestigt. Was man dem Selbst entzieht, gibt man der Kirche, und durch solche von der Kirche kontrolierte Leistung sichert man sich das jenseitige Heil, das wiederum von der Kirche verwaltet wird. Damit ergibt sich zugleich eine Verschiebung zwischen den Grundelementen der soziologischen Idee des Evangeliums. War diese vom radikalen religiösen Individualismus ausgegangen und hatte sie den Universalismus aus dem Zusammentreffen der Individuen in Gott, der Zurückwendung der in Gott Geeinigten auf die Offenbarung der göttlichen Lebensgesinnung an die Brüder, gewonnen, so ist nun die Gemeinsamkeit der Heilsanstalt übergeordnet, die Carität als Hingebung an die Kirche und als gutes Werk gegenüber dem Bruder die Hauptsache. Die asketische verdienstliche Liebe verschlingt den Individualismus, die Liebe wird zur Haupt- und Grundtugend und hat nur in der Humilität eine Voraussetzung, die mit der starken psychologischen Verinnerlichung und der Wendung des Subjekts auf sich selbst den grundlegenden Individualismus erhält und ihn freilich von hier aus stets neu hervorbrechen läßt. Das Mönchtum und die Kontemplation ist unter anderem auch 
eine Rettung des christlichen Individualismus in der jetzt allein noch möglichen Form ${ }^{54}$ ).

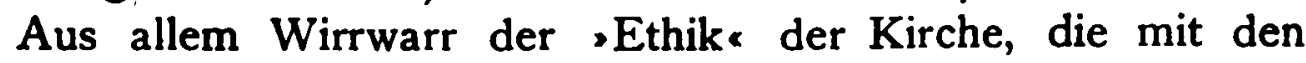
wissenschaftlichen Systemen der griechischen Moral überhaupt gar nicht zu vergleichen ist, machen sich durch die innere Logik des

34) Der einzige mir bekannte systematische Versuch einer Entwickelung der ethischen Idee aus dem Prinzip ist die bei Ziegler (Gesch. d. christl. Ethik S. 208) mitgeteilte Stelle aus den Collationes des Cassian: >Principium nostrae salutis sapientiaeque secundum scripturas timor domini est (d. h. überhaupt die Religion). de timore domini nascitur compunctio salutaris. de compunctione cordis procedit abrenuntiatio, id est nuditas et contemptus omnium facultatum. de nuditate humilitas procreatur, de humilitate mortificatio voluntatum generatur. mortificatione voluntatum extirpantur atque marcescunt universa vitia. expulsione vitiorum virtutes fructificant atque succrescunt. pullulatione virtutum $p u r$ it a s cordis acquiritur. puritate cordis apostolicae caritatis perfectio possidetur. \& Das ist freilich zunächst, wie Ziegler richtig bemerkt, Mönchsmoral. Aber es ist doch der Grundtypus der Moral in ihrem inneren Zusammenhang überhaupt; mönchisch ist nur das Absehen von der Kirche in der Bewirkung der Humilität und in der Betätigung der Carität. Im übrigen ist bemerkenswert, wie gerade die in meiner Analyse des Evangeliums herausgehobenen Grundgebote der Herzensreinheit und Bruderliebe auch hier als die beherrschenden erscheinen, und wie klar die veränderte Zweckbeziehung beider statt aus der Gottesgemeinschaft aus der Askese formuliert ist, die mit der Mortifikation des Willens auch ohne weiteres die der Laster ist und mit beidem eo ipso die Gottesgemeinschaft und die Liebe ist. Daß aus der Selbstaufgabe die Liebe entsteht, das ist freilich nur möglich, weil stillschweigend und selbstverständlich doch der Gottesbegriff des Evangeliums vorausgesetzt ist, weil die Selbstaufgabe im Grunde doch dunkel zugleich positiv als Selbsthingabe an die schaffende göttliche Tătigkeit verstanden ist. Freilich ist der dabei vorschwebende Gottesgedanke sehr unklar und darum sogar die Liebe doch wieder auch ihrerseits mehr Askese und gutes Werk oder Verdienst. Daher gebraucht man statt Liebe auch besser den Ausdruck Carität, wie er für den Katholizismus üblich geworden. Die Heraushebung von puritas cordis und caritas aus den bunten Tugend- und Lasterkatalogen - ist übrigens durch die ganze Scholastik stehend geblieben, vgl. Ziegler nach Augustin S. 230, nach Hrabanus Maurus S. 253, nach Albertus Magnus S. 387, bei den Mystikern S. 389, die Deutsche Theologie 406, Thomas a Kempis 407, Meister Eckhardt S. 399 f. Dabei wechseln die Zusammenstellungen zwischen Humilität und Carität, Gottesliebe und Carität, Herzensreinheit und Carität, Gelassenheit und Liebe. Die Filiation der Gedanken vom Evangelium her ist dabei ganz klar, sowie daß die Veränderungen im Gottesbegriff, der Askese, der Kirchlichkeit und der Verdienstlichkeit liegen. Insbesondere die mystische Analyse kommt dem Evangelium ganz nahe bis auf die Mystik und ihren akosmistischen Hintergrund, die dem hebräischen Willensgott ganz fremd sind. 
Ganzen immer wieder die beiden alten Grundgebote geltend, nur in dem durch Kirchlichkeit und Askese veränderten Sinn. Und sie bestimmen dadurch auch das soziologische Grundschema, in dem sich Mensch zu Mensch befindet, nehmen die hierarchische Gliederung in Laien, Klerus und Mönche in sich auf und gestalten mit dem christlichen Patriarchalismus das Leben, soweit es ihnen zugänglich ist, das heißt das Leben in Haus und Gemeinde. In die öffentlichen Verhältniße und das allgemeine Leben es hineintragen zu wollen, dazu ist die Kirche noch zu klein und der Welt innerlich zu fremd.

Wenn daher die Kirche von diesen Grundgedanken aus nun doch tatsächlich die sozialen Probleme regelt, so kann sie es zunächst nur für sich selber und im Kreis ihres eigenen Machtbereiches tun. Indem seit derZeit der Antonine ihre Mitgliederzahl außerordentlich wächst, muß sie nach innen tun, was sie nach außen zu fordern keine Möglichkeit hatte. Sie muß für sich selbst und vor ihrem eigenen Forum die sozialen Probleme in Angriff nehmen. Indem aber alle diese Ordnungen gegeben waren mit dem Staat, seinem Recht, seiner Besitzordnung und seinem Ständeaufbau, war damit zugleich auch nach außen eng verbunden die Stellungnahme zum Staate. Er war für die Kirche keineswegs bloß der Ausgangspunkt der Christenverfolgungen - die schrieb man den einzelnen Kaisern oder dem Volk und ihrem Mißverständnis der Christen zu -, sondern vor allem der Träger jener Ordnungen, und so war $z u$ ihm auf die Dauer kein rein negatives oder auch nur bloß indifferentes Verhältnis möglich. Eine feste Stellung zum Staat aber ist das Letzte und Späteste. Das öffentliche Leben und der Staat bot am Anfang die wenigsten direkten Berührungen bei der sozialen Zusammensetzung der Gemeinden, und lange ging man ihnen auch tunlichst aus dem Wege, um Zusammenstöße zu vermeiden. Erst als dies seit dem dritten Jahrhundert mit der sozialen Wandelung der Gemeinden unmöglich wurde, mußte auch allmählich ausdrückliche Stellung zum Staate genommen werden. Im christlichen Reich vollends wurde es unvermeidlich. So gehen die s oz i a l e n W i r k ung e n der Kirche zuerst auf den zugänglichsten Punkt, die Familie, die dann in der Folge der kirchlichen Lehre auch immer als das Fundament aller sozialen und politischen Ordnung galt, dann auf Wirtschaft und Gesellschaft, mit denen das Familienleben untrennbar verschlungen ist, schließlich auf den Staat, der die Ordnung des ganzen zusammenhält. 
Um nun aber diese sozialen Leistungen und Theorien der alten Kirche $z u$ verstehen, muß man folgende, zum Teil bereits erwähnte Punkte fest im Auge behalten. Erstli ch das Zurücktreten der Zukunftshoffnung und die Wandelung im Begriff des Gottesreiches. Das Gottesreich fließt schon in der apostolischen Zeit mit der Kirche zusammen, und dem Kommen des Reiches bleibt nur die Verherrlichung der Kirche, die Zerschlagung des irdenen Gefässes und die Befreiung des leuchtenden Schatzes von seinen Hüllen. Im übrigen tritt an Stelle des Gottesreiches die „Eschatologie «, Himmel, Hölle und Fegfeuer, die Unsterblichkeit und das Jenseits, ein Gegensatz gegenüber dem Evangelium, der von höchster Bedeutung ist. Aber auch dieser Endpunkt schiebt sich hinaus, bis zuletzt das tausendjährige Reich auf die Kirche gedeutet wurde ${ }^{55}$ ). Die Wirkung davon ist freilich ein stärkeres Eingehen auf die Welt, aber keineswegs eine wirkliche innere Anerkennung der Welt als Trägerin selbständiger ethischer Werte. Vielmehr genau in dem $\mathrm{Maß}$ als die Weltindifferenz der Reichserwartung zurücktreten mußte, wurde die asketische Weltverurteilung an deren Stelle gesetzt. So ist die Wirkung, die das Zurücktreten der Hoffnung auf das kommende Reich ausübt, eine doppelte. Das erwartete Reich war ja ein Idealzustand des Lebens auf Erden, keine Eschatologie des Himmels und der Hölle und musste insofern doch gerade zu einer Berücksichtigung des Lebens in der Welt führen. Diese Erwartung konnte die gegenwärtige Welt vergleichgültigen, aber nicht direkt asketisch wirken. Indem an Stelle der Reichserwartung die "Eschatologie * trat, war einerseits natürlich eine stärkere Anpassung an die dauernde Welt die Folge, andrerseits aber wirkte nun die abstrakte Eschatologie mit ihren bloßen Belohnungen und Bestrafungen und ihrem völlig jenseitigen Charakter erst recht entwertend auf die Welt überhaupt; nicht nur die heidnische, sondern die Welt überhaupt trat nun in Gegensatz. Erst jetzt entsteht der reine Gegensatz von Welt und Jenseits, damit die Stimmung, daß

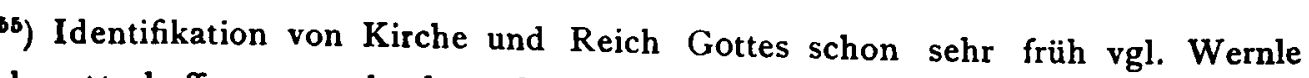
-Reichsgotteshoffnung nach den ältesten Dokumenten $\propto-$ Hippolyt gibt nocil c. 300, Laktanz 200 Jahre, Bigelmair S. 15. Mit der Ausscheidung des sog. Montanismus, d. h. der Neubelebung der Eschatologie und der ihr entsprechenden strengen Abscheidung von der Welt, ist diese Wendung entschieden. Augustin De civitate Dei XX 9,2 identifiziert das tausendjährige Reich mit der Kirche, gibt also noch ca. 600 Jahre, wie denn ja auch später im Jahre 1000 das Weltende erwartet ururde. 
es auf Rettung im Jenseits und auf gehäufte gute Werke ankommt, die man dann am besten in der wirksamsten Form, in der der Askese, häufte. So wirkt gerade die Eschatologie erst recht asketisch und sehr viel mehr asketisch als die Reichshoffnung. Besonders die Askese des Abendlandes und des Frühmittelalters ist rein eschatologisch - eudämonistisch motiviert ${ }^{65}{ }_{a}$ ). Die vom Evangelium erteilte Grundstimmung und Grundrichtung gegenüber der Welt « wurde beibehalten, nur wurde die Begründung aus dem Kommen des Reiches durch die asketische ersetzt und dadurch wiederum die Askese befördert, deren Gegensatz gegen die Motivierung des Evangeliums man sich nicht zum Bewußtsein brachte. Für die nötigen Milderungen und Anpassungen sorgte die doppelte Moral. Das z w e it e ist die Ueberzeugung von der Fertigkeit und Unveränderlichkeit der gegebenen Zustände. Sie erscheinen als ein System, wo ein Teil den andern bedingt und das nur so sein oder gar nicht sein kann ${ }^{56}$ ). Es ist die Gewöhnung des abso-

55a) Das ist die durchgängige Motivierung der Askese in der gallischen und fränkischen Kirche. S. Hauck, KG Deutschlands I 265 II 766, Harnack, Mönchtum 38.

56) Hierauf weist mit Recht vor allen Overbeck hin S. 197-201. Harnack meint Militia christiana 1905 S. 50 f., die Vorherrschaft des eschatologischen Denkens habe die Kirche zu einem \quietistischen und konservativen Prinzip gemacht; seit dessen Ermattung und der gleichzeitigen Ausdehnung in der Zeit der Antonine, womit die Kirche im Grunde schon in die Zustände des vierten Jahrhunderts hineinwachse, falle der ganze Gegensatz gegen Staat, Gesellschaftsordnung, öffentliches Leben u. s. w. den Christen erst aufs Gewissen «. \Nun brach mit voller Gewalt das Gefühl der Verantwortung herein: Wie sollen wir uns als Christen zu der Welt um uns stellen, in die wir wider unsern Willen hineingewachsen sind, weil wir auf ihren baldigen Untergang rechnend, nichts an ihr verändert habelı. Das kann sich aber, wie H's eigene Darstellung des Verhältnisses der Christen zum Heeresdienst zeigt, nur darauf beziehen, daß man bei dem Eindringen in christlich bedenkliche Berufe den Gegensatz scharf empfand und namentlich literarisch auch zum Ausdruck brachte. Dabei ist dann aber immer nur eine Zurückziehung von der Welt, nie eine Reform der Gesellschaft in Frage; und schließlich hat man sich darein gefügt, diese Dinge als zur Welt einmal gehörig und vom Staate unablösbar sich gefallen zu lassen. Die Bedenken gegen den Heeresdienst schwinden und die Synode von Arles 314 beschließt die Exkommunikation fahnenflüchtiger Soldaten, nachdem Tertullian und Origenes den Heeresdienst noch absolut verboten hatten; und auch sie hätten sich trotz der Behauptung, daß das Bluthandwerk der Soldaten absolut unchristlich ist, gefügt, hätte nicht der Heeresdienst die Christen mit dem Kaiserund Lagerkult in Beziehung gebracht. Da ist doch die nicht mehr eschatologische Kirche noch quietistischer und konservativer als die eschatologische. Sie ist es 
luten Denkens, das wie die Kirche so auch die "Welte verabsolutiert. Es äußert sich darin aber auch die eigene Empfindung des Altertums selbst, das mit dem Imperium fertig war, seine Lebensund Bildungstriebe ausgelebt hatte und trotz der gewaltigen Veränderung seiner sozialen, ökonomischen und verwaltungsrechtlichen Struktur sich doch keine andere Zukunft denken konnte als die Fortdauer des Reiches der römischen Kaiser und Beamten. Rom ist ewig. Zudem fehlt der Antike, die Politik und Oekonomik nur als Bestandteile der Ethik oder des positiven Rechtes kennt, jedes selbständige Denken über ökonomische und soziale Probleme. Das dritte ist die zunehmende Kompliziertheit der sozialen und ökonomischen Lage der Kirchenglieder. Waren die Fragen des Besitzes und der Berufe von einem kleinen Mittelstand verhältnismäßig leicht zu erledigen, so mußten sie mit dem Eintritt der gebildeten und besitzenden Schichten seit dem dritten und vierten Jahrhundert unendlich viel schwieriger werden. Nun gab es Chriauf Grund ihrer prinzipiellen Ansicht von Welt und Staat, und zieht daraus gerade mit der Verstaatlichung immer konservativere Konsequenzen, während der Radikalismus sich in das Mönchtum flüchtet. - Die Ewigkeit Roms Bigelmair 77, Cumont, l'éternité des empereurs romains (Revue de l'hist. et de litterature religieuse 1896). Lactanz betet für Rom: Roma est civitas, quae adhuc sustentat omnia, precandusque nobis et adorandus est deus coeli, ne citius quam putamus tyrannus ille abominabilis veniat, qui tantum facimus moliatur et lumen illud effodiat, zitiert nach Bigelmair 81. Das imperium ist für Barnabas, Irenäus und Hippolyt das vierte Reich der Danielvision, das dauern wird bis zum Wiederkommen Christi, eine Geschichtsphilosophie, die bis in die Reformationszeit andauert. Erst bei der Wiederkunft Christi heißt es dann mit Commodian: luget in aeternum, qui se jactabat aeterna ibid. 87 . Auch der grimmige Weltfeind Tertullian weiß es nicht anders: Christianus nullius est hostis nedum imperatoris, quem sciens a deo suo constitui necesse est, ut salvum velit cum toto Romano imperio, quo usque saeculum stabit, tamdiu enim stabit ibid. 88. Die Dauer des Reiches ist aber ebenso selbstverständlich für die großen Lehrer des 4. Jahrhunderts, vgl. Uhlhorn 22 I f. Für Ambrosius ist der von der Kaiserin Helena der Krone eingefügte angebliche Kreuznagel »der gute Nagel, der das römische Reich zusammenhälts. Alle Heimsuchungen durch die Germanen lassen den Gedanken an den Untergang des Römertums nicht aufkommen. >Der Gedanke, daß je die Barbaren dem römischen Reich und der römischen Kultur eın Ende machen könnten, fand in keines Römers, auch in keines christlichen Römers Vorstellung, Raum<. Augustin, Orosius, Salvian sahen alle Kalamitäten als Strafen Gottes an, die das Reich reinigen und bessern sollten. Die Ewigkeit Roms auch noch im Frankenreich s. Hauck KG Deutschland I 171, 231, Stelle aus Beda S. 429 : Quamdiu stat Colisäus, stat et Roma; Quando cadet Colisäus, cadet et Roma ; quando cadet Roma, cadet et mundus. 
sten, die öffentliche Aemter hatten, die im Heere dienten, die Handel trieben, die Luxusbedürfnisse hatten, die wissenschaftlichen Interessen folgten, die mit dem ganzen Getriebe von Staat und Gesellschaft verflochten waren. Es gab Aufkäufer, Monopolisten, Großgrundbesitzer, Offiziere, Beamte, Vornehme und Gelehrte, Künstler und Techniker. Das Leben dieser komplizierten Massen nach ihren Grundsätzen zu regeln war um so schwieriger, als die Grundsätze in kanonischen Schriften enthalten waren, die ihrerseits aus so unendlich viel einfacheren Verhältnissen stammten. Man darf sich über Inkonsequenzen und Sophistik nicht wundern. $\mathrm{Schlie} B \mathrm{l}$ i $\mathrm{ch}$ ist auch die ungeheure Verweltlichung im eigentlichen und schlechten Sinne des Wortes nicht zu vergessen. Dem Ernst der echten alten Christen folgt die Aeußerlichkeit der Scheinchristen, die im Grunde bleiben was sie waren. Doch kann von ihnen hier abgesehen werden. Theorie und Ideal haben ihnen sehr viel weniger Zugeständnisse gemacht als die Praxis.

Da steht an erster Stelle das Problem des Besitzes, ein für die Kirche überaus schwieriges und nur unter Schwankungen gelöstes Problem ${ }^{57}$ ). Zwar müssen alle Aeußerungen über die

$\left.{ }^{57}\right)$ Sammlungen bei Brentano $\gg$ Wirtschaftliche Lehren , Harnack $\gg$ Missionsgeschichte \& I 30 f., 253; Uhlhorn »Liebestätigkeit I 120-128, 288-299; F. X. Funk "Kirchengeschichtliche Abhandlungen und Untersuchungen II 1899, >Klemens von Alexandrien über Familie und Eigentum $445-60$, $\gg$ Handel und Gewerbe im christlichen Altertum « 60-77; sehr reichlich bei J. Seipel, Die wirtschaftsethischen Lehren der Kirchenväter (Theol. Studien der Leo-Gesellschaft I8) Wien 1907 ; ferner Ratzinger, Die Volkswirtschaft in ihren sittlichen Grundlagen $188 \mathrm{I} ; \mathrm{R}$. W. Carlyle and A. J. Carlyle -A history of mediaeval political theory in the west $\&$ I 903 das Kapitel Theory of property 132-146; Gaß, Gesch. d. Ethik I 94 ff. und 223 ff. - Die einzige dem Problem direkt gewidmete Schrift ist bekanntlich die des Clemens »Welcher Reiche kann selig werden«. Es ist eine Allegorisierung der Geschichte vom reichen Jüngling, der nicht die Güter, sondern die an den Gütern hängende Gesinnung veräußern, übrigens aber den Reichtum durch Liebestätigkeit energisch nützen soll. Es ist die dem Reichtum günstigste und dabei ökonomisch verständigste Schrift, überdies von einer feinen und zarten Frömmigkeit erfüllt. Für die Gegenwart haben die Christen den Kommunismus stets abgelehnt. Lactanz tadelt den sonst der Wahrheit so nahekommenden Plato: „Schon der Kommunismus des Besitzes widerspreche der Gerechtigkeit; aber alle Bande würden gesprengt durch den gemeinschaftlichen Besitz der Frauen und Kinder; vollends ihnen den Staatsdienst zu erschließen, wäre das größte Unglück Bigelmair 89. Die Beschränkung des Kommunismus auf die Urzeit und die strenge Festhaltung der Familienwirtschaft übersieht Brentano völlig bei seiner Behauptung eines kommunistischen Charakters der christlichen Besitzlehre. - Schwer 
Zurückführung des Privatbesitzes auf die Sünde und auf den im Paradiese herrschenden Kommunismus von vornherein ausgeschieden werden, da sie ja gerade für die Gegenwart die Fügung iı die durch die Sünde gewordene Ordnung verlangen. Sie dienen nur dazu, die Forderung der Liebestätigkeit eindrücklich zu begründen, die jenen Urzustand so wenigstens annähernd wieder herstellt. An eine Aufhebung des Privateigentums aber ist dabei nicht gedacht, und die besondere Bewandtnis, die es hierbei mit dem Urzustande hat, ist in anderem Zusammenhang zu erläutern. Auch die häufigen Aufforderungen, nichts als Eigentum zu betrachten ${ }^{58}$ ), und die Rede von der Gemeinsamkeit der Güter, die der von Licht und Luft als Gaben Gottes gleiche, ist gleichfalls nur eine Aufforderung zu energischer Liebestätigkeit. Das Privateigentum selbst ist hierbei überall vorausgesetzt. -Das Problem ist daher nicht das Privateigentum und die darauf aufgebaute wirtschaftliche Ordnung selbst, sondern das Maß und der Umfang der Liebespflicht. Es gibt kein 'ökonomisches Eigentumsproblem, sondern ein ethisch-religiöses Problem, das sich zwischen dem Radikalismus der Liebesforderung und den Rücksichten auf die Anforderungen des natürlichen Erwerbslebens hin und her bewegt. Hier lagen freilich die Dinge in den kleinen und armen Gemeinden des Anfangs einfach. Hier gab es Not und Bedürfnis in Menge, und die Liebestätigkeit mußte von selbsst soweit gehen wie möglich. Das für den einzelnen erforderliche Existenzminimum ergab sich ebenfalls von selbst: wenn ihr Nahrung und Klcidung habt, so lasset euch genügen $I \operatorname{Tim} 6,7$. Die wenigen Wohlhabenden sind ganz beschäftigt mit Fürsorgen und Opfern für die Gemeinden, wie die Paulusbriefe zeigen. Aber die Sache brauchbar ist trotz seiner Berufung auf gute Rezensionszeugnisse Somerlad, Das Wirtschaftsprogramm der Kirche des Mittelalters 1903. Hier sind in feierlichem Ernst den Vätern ökonomische Theorien aufgebürdet, jedem ein eigenes System zugeschrieben und diesen angeblichen Besonderheiten jedesmal eine umständliche Milieubegründung gegeben. So wertvoll die gesammelten Stellen sind, so wertlos sind diese Konstruktionen. Verdienstlich ist nur die Hervorhebung der urständlichkommunistischen Theorien seit dem 4. Jahrhundert. S. erklärt sie als Reaktion gegen den staatlichen Despotismus, die Bindung der Gesellschaft und die Heraushebung eines monopolistischen Reichtums, außerdem aus Einflüssen Platons. Das erstere ist müglich, statt der letzteren ist das stoische Naturgesetz zu betonen, das seit der Apologeten rezipiert ist.

${ }^{58)}$ Eine aus Acta Apost. 4, 32 (Erzählung von der Gütergemeinschaft) stammende und daher übcraus häufige Phrase. 
wird schwieriger mit der Ausbreitung und ökonomischen Differenzierung der Gemeinden. Nun entsteht das Problem ^der Reichen «. Ihnen gegenüber tritt das radikale Liebesgebot Jesu nun abstrakt hervor, es werden die Anweisungen über die Missionsnachfolge zu allgemeinen Regeln dogmatisiert und die Geschichte vom reichen Jüngling zu Grunde gelegt. Die asketische Begründung verquickt sich mit der Liebesbegruindung, und die Vergröberung der evangelischen Gesinnungsmoral zur Moral der guten Werke verherrlicht die einzelnen Opfertaten. Die Entäußerung vom Besitz wird nun die Grundforderung, sei es, daß sie mit dem Liebesgebot motiviert wird, daß niemand selbst etwas besitzen darf, so lange andere darben, sei es, daß der asketische Gedanke vorherrscht, daß jede Freude am Besitz Selbstliebe und Weltliebe ist und der Gottesliebe im Wege steht, sei es, daß die sündentilgende Kraft des Almosens betont wird ${ }^{58 *}$ ). Freilich das Privateigentum selbst bleibt dabei unangetastet, aber es wird auf das unentbehrliche Existenzminimum eingeschränkt; das Ueberflüssige soll verschenkt werden. Besitz und irdische Güter sind, wie alle Väter betonen, von Gott; aber sie sind ursprünglich für die Allgemeinheit bestimmt und erst durch Sünde und Habsucht in die gegenwärtigen drückenden Besitzdifferenzen hineingezogen worden. Das soll Liebe und Opfer nach Möglichkeit wieder ausgleichen ${ }^{58 b}$ ). Aber daran reihen sich nun selbstverständliche Schwierigkeiten. Für verschiedene Lebensstellungen ist das zugebilligte Existenzminimum ein verschiedenes; Clemens ist sogar geneigt, einen gewissen, die Grenzen des naturgemäßen Lebens einhaltenden Luxus zu billigen, während Tertullian davon nichts wissen will ${ }^{59}$ ). Auch sah man sehr wohl ein, daß mit dem Verschenken

58 a) S. Seipel 195-244. Ueber die sündentilgende Kraft, wobei doch immer auch eine Leistung der Gesinnung gefordert und nur auf die kleineren alltäglichen Sünden Bezug genommen ist, s. Seipel 219-229.

s8 b) Seipel 53-55. Für die Gegenwart kann daher als von Gott stammend nur der anständig und rechtmäßig erworbene Erwerb gelten; von daher auch die später zu schildernde Kritik der Berufe.

69) Ueber den Luxus s. die kulturgeschichtlichen Einzelheiten bei Bigelmair 23I-244; hier wird nach dem Stande sehr Verschiedenes gestattet, im ganzen eine nicht unerhebliche einfache Behaglichkeit, von wo ein Licht auf das $\$$ Existenzminimume und das Privateigentum zurückfällt, abgesehen davon, daß der Ton der Mahnreden zeigt, wie wenig selbstverständlich die Befolgung war. Wie selbstverständlich das Vermögen ist, zeigt u. a. der Umstand, daß der so rigoristische Tertullian die Mischehe von Christinnen mit Heiden widerrät, damit nicht der Mann durch Androhung einer Denun- 
allein nicht viel gewonnen war, daß es den Besitzenden nur verarme, ohne anderen zu nützen, daß der Besitz nicht bloß ein Konsumtionsmittel, sondern ein vielen anderen Unterhalt gewährendes Produktionsmittel sei, daß gerade die Liebestätigkeit das Vorhandensein von Besitz voraussetze, daß das planlose Schenken Hochmut und Selbstgerechtigkeit bei den Schenkern und Bettelhaftigkeit bei den Beschenkten bewirke, daß das eigentlich Entscheidende die Liebesgesinnung und innere Unabhängigkeit vom Besitze sei und diese Kraft durch Schenken allein weder erworben noch betätigt werde. Derartige Erwägungẻn treten steigend hervor mit der Vergrößerung der Gemeinden und ihrem Aufgehen in dem allgemeinen Wirtschaftszusammenhang. Aber andererseits fühlte man in demselben Maße, daß damit der Radikalismus des Liebesgebotes in der Lebensrichtung auf das eine, was not tut, durch Kompromisse und Relativierungen gebrochen und umgangen wurde, daß insbesondere der steigende asketische Geist dadurch am entscheidenden und wirksamsten Punkte durchbrochen wurde. So tritt diesen Kompromissen ein schroffer Radikalismus entgegen, der um so mehr rein asketisch motiviert ist, je weniger daran zu denken war, in einer großen Gesellschaft durch Liebesschenkungen wirklich alle Not aufzuheben. Das Mönchtum schreitet bis zur Einrichtung wirklichen Gemeinbesitzes fort, und den Laien wird mit gesteigerter Energie wenigstens die Pflicht des Verschenkens gepredigt. Die großen Lehrer des vierten Jahrhunderts stehen sämtlich unter dem Einfluß dieses mönchischen Ideals, können dann aber auch den Laien, die unter dem Einfluß des natürlichen Lebens stehen, milder behandeln. So ergibt sich ein doppelter Ausweg: auf der einen Seite eine Kompromißethik der relativierenden Maßstäbe, die das Privateigentum und auch den »Reichtum* anerkennt, in ihm ein Mittel des gesellschaftlichen Gedeihens billigt und nur die Mitteilung des Ueberflusses und die innere geistige I.ösung von der Freude am Besitz verlangt. Das bedeutet für den Besitz die Einschränkung auf die Ermöglichung der Existenz und die Bereitstellung der Mittel für die Liebestätigkeit. Schließlich steht es bei den Christen mit dem Besitz äußerlich und tatsächlich genau so wie bei den Nichtchristen. Auch die Kirche erwirbt Kirchenvermögen an Grundbesitz, an Sklaven, an Geld und

ziation die Frau zum Verzicht auf ihr Vermögen veranlassen könne, Bigelmair 251. Jeder praktische Einblick in die Einzelheiten des Lebens zeigt die volle Herrschaft und Selbstverständlichkeit des Eigentums, die nur in der Liebesrhetorik stark zurücktritt. 
Naturallieferungen, und tritt damit in das Besitzrecht und in die Privilegien des früheren Tempelvermögens ein. Demgegenüber betonen die Väter dann nur die andersartige innere Stellung des Christen zum Besitz und die Verpflichtung, ihn als anvertraute Gottesgabe zum Zweck der Liebestätigkeit zu betrachten. Vor allem betonen sie gegenüber einer auf den Zensus und die Vermögensdifferenzen aufgebauten Gesellschaft den wahren, die wirkliche Klassifizierung der Menschen erst bewirkenden „Reichtum “, d. h. den Reichtum an Tugenden und Frömmigkeit, die Unabhängigkeit der wahren Rangordnung von den gesellschaftlichen Unterschieden des Zensus, der die Ratsfähigkeit in den Städten, die Zugehörigkeit zu den senatorialen und amtsfähigen Geschlechtern bedingt. Hier eignen sich die Christen dann auch die verwandten stoischen Kraftworte an. Daß dieses »Haben des Besitzes, als hätte man nicht«, ebenso leicht zu einem -Haben des Christentums, als hätte man nicht * führen kann, versteht sich von selbst. Umso schärfer wird daher der andere Ausweg betont, das Mönchtum. Hier wird die Schwierigkeit durch den Fortschritt zur radikalen Aufhebung des Privateigentums gehoben, wobei dann freilich auch nicht mehr die Liebe, sondern die Askese das eigentliche Motiv ist, aber doch in der Liebe der Mönchsgemeinde und in der Fürbitte für die Weltlichen die Liebe noch zu ihrem Recht kommt. Das Prinzip der doppelten Moral, mit dem die Kirche überhaupt den Ausweg aus dem Problem des Verhältnisses von Welt und evangelischer Moral fand, ist auch der Ausweg aus dem Problem des Besitzes.

Ein zweites Problem neben dem Besitz, der, wie stets zu betonen, wesentlich als Konsumtionsmittel angesehen wird, ist die Produktion des Besitzes. Hier herrschen nur die einfachsten Vorstellungen. Das unentbehrliche, für Eigenexistenz und Liebestätigkeit vorauszusetzende Privateigentum geht hervor aus der $\mathrm{Arbeit}$, die für die alte Zeit wesentlich Handarbeit ist $\left.{ }^{60}\right)$. Mit

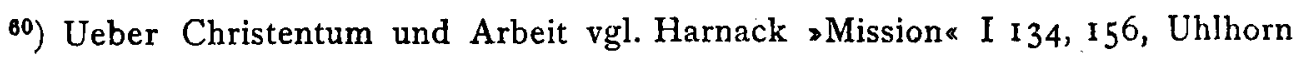
\Liebestätigkeit \& I 76-79, 129-131, Seipel 123-133; Simon Weber, Evangelium und Arbeit, Freiburg 1898; Ed. Meyer »Sklaverei* 37, Overbeck 226. Das Beispiel aus Tertullian bei Funk II 66, aus Chrysostomus bei Brentano 157, aus Augustin bei Funk II. 7o. Ueber die $>$ Adelung \& der Arbeit weiß Uhlhorn nur zu sagen: >Von Arbeit ist bei den alten Vätern nur wenig und auffallend wenig die Rede. Wo aber von ihr die Rede ist, da fühle n wir unmittelbar, daß sie ganz anders gewürdigt wird als in der heidnischen Welt ... Allerdings die 
beiden Begründungen wird daher auch die Arbeit von Anfang an nachdrücklich gefordert. Auch als Mittel der Erziehung zu Nüchternheit und Arbeitsamkeit, zur Fernhaltung bedenklicher Elemente wird sie geschätzt. Arbeitsscheue werden abgewiesen, Arbeitslose mit Arbeit versorgt. Weiterhin dient sie der Askese und Leibeszucht, in welchem Sinne sie namentlich die Mönchsethik nachdrücklich einschärft; doch ist das auch sonst ein Lieblingsthema der Kirchenväter. Im übrigen aber erscheint auch die Arbeit als Folge des Sündenfalls und als Sündenstrafe. Die Liebe zur Arbeit und zum Arbeitsprodukt darf man hier nicht suchen; sie setzt eine positivere Schätzung der Welt, als den alten Christen eigentümlich war, voraus und ist ohne Freude am Besitz gar nicht zu denken ${ }^{60}$ ). Man darf daher auch das Wort von der *Adelung der Arbeit durch das Christentum * nicht übertreiben. Die Schätzung der Arbeit ist schon durch seine Zugehörigkeit zu den unteren Schichten selbstverständlich, in denen die aristokratischen Worte des Aristoteles über die Banausen stets so wenig mit empfunden wurden als in unseren Unterschichten die Meinungen der Junker über Arbeit und Handel; auch haben bereits die Kyniker geradezu den ethischen Wert der Arbeit gepredigt. Dem handwerkerlichen Standpunkt der alten Christen, auf dem die Arbeit selbstverständlich ist, folgte dann später bei den Bildungschristen die Forderung, die Arbeit nicht zu verachten, und die Einschärfung der Liebespflicht gegen die arbeitenden Klassen. Hier schlägt immer wieder das alte politisch bedingte Ideal der Polis durch, daß der anständige Mensch von Grund- oder Geschäftsrente lebt und viel freie Zeit hat. Immerhin aber haben die Christen die Arbeitspflicht gesteigert. *Wer nicht arbeiten will, soll auch nicht essen* gilt aufs strengste. Dazu nötigte schon die Abwehr von Bettel und Mißbrauch; wer nicht arbeiten wollte, verlor das

tiefere sittliche Würdigung der Arbeit, der Begriff des Berufes, der Zusammenhang des irdischen Berufes mit dem himmlischen war der Kirche noch nicht aufgegangen .. Diè allgemeine Pflicht der Arbeit, die Bedeutung der Berufsarbeit für die Betätigung des Christenlebens und die Förderung des Gottesreiches, ist nirgends ausgesprochen. Deshalb wissen auch die apostolischen Konstitutionen von den Reichen, die keines Handwerks bedürfen, um sich zu ernähren nur zu sagen, sie sollen die Gläubigen besuchen und gottselige Gespräche mit ihnen führen ! Das heißt aber doch nur, daß eben die spätere lutherische Arbeits- und Berufsethik der alten Kirche nnbekannt war. Sie sind unbekannt, weil sie auj einem andern Geiste stammen.

60) Doch s. die Würdigung der Künste bei Origenes Seipel 159; hier spricht aber unverkennbar die griechische Bildung. 
Anrecht auf Unterstützung. Auch von den Mönchen wird Arbeit gefordert, wieweit auch von Kapitalisten und Großbesitzern steht dahin. Das eigentliche Arbeitsideal ist auch hier nur.erst im Mönchtum verwirklicht worden. Charakteristisch ist hier eine Aeußerung Augustins, der von den aus Bauern- und Arbeiterstand stammenden Mönchen Arbeit fordert mit der Begründung: Wenn schon ein arbeitsungewohnter Senator oder Grundbesitzer im Kloster arbeiten müsse, wie vielmehr verstehe sich das für einen arbeitsgewohnten Bauern und Handwerker. Ueberhaupt ist nie zu vergessen, daß die ökonomischen Anschauungen in der Antike überhaupt wenig entwickelt und bei den Christen geradezu kindlich sind. Stellungs- und erwerbslos gewordenen Christen antwortet Tertullian, daß der Hunger für den keinen Schrecken haben könne, der mit Christus in den Tod zu gehen bereit ist. Gegen die Gefahr, daß die Vergebung des Vermögens im Almosen Familie und Kinder gefährde verweist Cyprian darauf, daß Gott der beste Anwalt und Vormund der Kinder sein werde; das wird dann zu einem stehenden Thema der christlichen Moral. Derselbe leitet die wirtschaftlichen Nöte aus Uebervölkerung ab und preist als Heilmittel die Virginität; während für die Jugend der Welt das Schöpfungsgebot der Mehrung gelte, sei für das Alter der Welt der evangelische Rat der Ehelosigkeit. Einen Kaufmann, der den Handel nach streng moralischen Grundsätzen nicht vorteilhaft betreiben $\mathrm{zu}$ können meint, tröstet Augustin, daß Gott, der ihn schon bei Ungerechtigkeiten ernährt hätte, ihn noch viel mehr bei gerechtem Handeln ernähren werde. Die Bedenken, daß nach einem kommunistischen Zusammenschießen aller Vermögen in Konstantinopel schließlich nach der Verzehrung nichts mehr übrig sei, beschwichtigt Chrysostomus mit der Vorsehung Gottes, die dann schon helfen werde. Bei solchen Leuten darf man überhaupt keine tiefergreifenden ökonomischen Gedanken suchen. Die ganze moderne Volkswirtschaft und der moderne Stolz auf technische und wirtschaftliche Weltbeherrschun wäre ihnen ebenso unverständlich gewesen, wie die Sorge um wirtschaftliche und soziale Krisen. Sie leben in einer andern Welt. Doch bedeutet diese Kindlichkeit der Theorie über ökonomische Dinge, wie im ganzen Altertum, nicht die Unkenntnis der Praxis. Die Kirche, die einen mächtigen Kapital-, Sklaven- und Grundbesitz erwirbt, deren Bischöfe schließlich als große Grundherren eine politische Rolle spielen, deren Hilfe der 
seinen Aufgaben nicht mehr gewachsene Staat für Polizei, Armenversorgung, Bevölkerungskontrolle in Anspruch nahm, enthält praktisch einen außerordentlichen wirtschaftlichen Verstand. Nur wirkt er nicht oder nur ganz gelegentlich auf die Theorie zurück.

Man wird sich dann auch nicht wundern, daß die aus Arbeit und Besitz hervorgehende Gliederung der Berufe und Stände eine theoretische Aufmerksamkeit und Kritik der Christen nie hervorgerufen hat ${ }^{61}$ ). Sie nehmen auch hier das mit dem Staat gegebene, in der vordiokletianischen Zeit übrigens noch sehr wechselnde, vielfach noch der freien Konkurrenz unterliegende und von der Sozialpolitik der Kaiser nur allmählig regulierte Nebeneinander der Berufs-, Arbeits-, Besitz- und Ständegliederung hin. Große soziale Bewegungen und eine ihnen entsprechende konstruktive Kritik sozialer Verhältnisse gab es, wie bereits früher gezeigt, in dem Frieden der Kaiserzeit, bei der Erdrückung des antiken Kapitalismus durch bureaukratische Regierung, bei dem Rückgang der Sklavenmärkte und bei dem Wachstum eines aus Sklaven, Freigelassenen und Freien gemischten Kleinbürgertums überhaupt nicht; nur so war ja auch die Emporbildung einer wesentlich karitativen und nicht sozialen Bewegung, wie das Christentum es war, möglich. Die Christen heben im eigenen Kreise und in religiöser Hinsicht die Unterschiede auf und lassen sie im übrigen bestehen. Hier ist nun die Hauptsache, daß die alte Kirche wohl selbstverständlich verschiedene Geschäfte, Erwerbsarten, Standesdifferenzen kennt, aber nicht den hochmittelalterlichen und nicht den protestantischen Begriff des Berufes *. Der Grund ist durchsichtig genug. Einmal fehlt einer Ethik, die überall von der urständlichen Gleichheit und von der

$\left.{ }^{62}\right)$ Hierüber Harnack s.Missionsgeschichte \& I 25I-26I; Ders., Militia christiana; Seipel 146-16r, und Bigelmair. Die äußerst fleißige letztere Arbeit enthält eine Fülle von Material und ist überaus lehrreich. Ueber die soziale und berufliche Gliederung der Gesellschaft der Kaiserzeit s. Seipel I-48, der hauptsächlich Marquardt >Die römische Staatsverwaltung «, und »das Privatleben der Römer « (Handbuch der römischen Altertümer ${ }^{2}$ ) wiedergibt. Ueber den allgemeinen Charakter der antiken Gesellschaft und ihre Unterschiede gegen die germanisch-mittelalterlich s. den großen Artikel von Max Weber $>$ Agrargeschichte (Altertum) ${ }^{2}$ in HWB. der Staatswissenschaften 3. Aufl. bes. S. 67 , dem ein gleich wichtiger über den Kolonat folgen wird. Leber die Entstehung des Berufsbegriffes s. des gleichen Verfassers Ausführungen in Prot. Ethik u. s. w.\& Archiv XX S. 35-40. Viele Väterstellen, auf denen das oben formulierte Urteil beruht, bei Somerlad, der jedenfalls die Besonderheiten der Soziallehren des 4. Jahrhunderts mit Recht hervorhebt, aber verkennt, daß das nur die Fortbildung der stoischen Lehre vom Naturgesetz ist. 
Herbeiführung der Unterschiede durch die Sünde wesentlich ausgeht und die Arbeitsteilung höchstens als eine dem Sündenstande entsprechende zweckmäßige Fügung Gottes betrachtet, der Antrieb zu einer positiven Wertung der Berufe, nachdem am Anfang in der kleinbürgerlichen Periode der Kirche die eschatologische Erwartung und Jenseitigkeit dies verhindert hatte. Die jüdisch-handwerkerliche Stimmung, der Willenspositivismus der göttlichen Weltregierung, die Prädestination hatten anfangs die äußere Ungleichheit neben der inneren Gleichheit stark betont und zugleich die Arbeit hoch gewertet. In der Durchsetzung gegen die Welt aber trat dann die religiöse Gleichheit immer mehr als ein wesentlicher Anziehungspunkt der christlichen Lehre hervor, verschmolz sich mit dem stoischen Vernunftideal und behauptete wenigstens für den Urstand die Gleichheit überhaupt. Das aber entwertete für die Gegenwart alle Berufsdifferenzen, wenn es sie auch nicht aufhob. Andererseits bot aber auch die Gesellschaft der Kaiserzeit nicht die Unterlagen für die Bildung dieses Begriffes, die später die mittelalterliche Feudalgesellschaft und dann vor allem die zur politischen und Wirtschaftseinheit gegliederte gewerbliche Stadt darboten. Die Gesellschaft der Kaiserzeit beruht - außer in den Gebieten ägyptischer und mesopotamischer Stromkultur auf der demokratisch organisierten Stadt, auf dem gleichen Bürgerrecht aller, auf einer relativen, freilich immer mehr schwindenden Freiheit und Freizügigkeit des Erwerbs, auf den Differenzen des Vermögens und des Zensus, der die Zugehörigkeit zu den oberen Ständen bedingt, auf der Abschiebung der gewerblichen Arbeit an die Unterschicht, an kommissarisch betraute Sklaven und Freigelassene, die nicht wie die entsprechenden mittelalterlichen Arbeiter $z u$ einer selbständigen städtischen Organisation gelangen, sondern in der das alte "Ideal des Nichtinteressenten und Rentners " festhaltenden Stadt nur als Unterschicht gelten; sie beruht vor allem auf dem überall vorherrschenden Charakter der antiken Kultur als Küstenkultur, die als Organisationszentren nur die von militärischen und Handelsinteressen her konstruierte Stadt hervorgebracht hat, während die binnenländische Kultur des Mittelalters eine unendlich intensivere und reicher differenzierte agrarische und dann gewerbliche Kultur mit festen Gliederungen hervorgebracht hat. So fehlt auch von Seite der Gesellschaft her der Antrieb zur Bildung des Gedankens von einem festen, in sich gegliederten System der Berufe und der 
Arbeitsteilung. Das spiegelt sich überall in der Stellung der kirchlichen Lehrer bis in die Zeit. Konstantins, die die Berufe überall mit völliger Indifferenz als ein Los und Schicksal betrachten und sie nur kritisieren, aber nie mit positivem Interesse konstruieren. Freilich hat die antike Gesellschaft gerade in dieser Hinsicht seit dem dritten und vierten Jahrhundert im Zusammenhang mit dem langsamen Rückfall in die Naturalwirtschaft, mit dem Eintritt in binnenländische Verhältnisse, mit der Geldverminderung und dem staatlichen Reglementierungswesen, das diesen Schwierigkeiten begegnete, zu festen Bindungen geführt, zu der Erblichkeit der militärischen und amtlichen Stellungen, zu der Bildung von $Z$ wangskorporationen in den Nahrungsgewerben und zu Analogien des Feudalismus. Vermutlich ist es der Einfluß dieser Entwickelung, wenn bei den Vätern des vierten Jahrhunderts mehrfach der Gedanke einer notwendigen, gegenseitig sich ergänzenden sozialen Gliederung aufleuchtet. Aber dieser Gedanke ist bei ihnen dann stets wieder mehr als aufgehoben durch den Rückgriff auf die urständliche Gleichheit und die Wiederherstellung der Gleichheit in Liebe und Opfer und, wo das in der Welt nicht geht, im Mönchsverein. Die steigende Hochstellung des Mönchtums entspricht genau der Unmöglichkeit diese - übrigens schwierige und spannungsreiche, nicht fortschreitende sondern unter dem Druck des Rückgangs leidende soziale Welt durch den Begriff eines gottgeordneten und auf die religiösen Lebenswerte hinzielenden "Berufes $\approx \mathrm{zu}$ bewältigen. Umgekehrt werden wir sehen, daß dem Mittelalter die Eingliederung des Mönchtums, jenes Sprengstoffes für alle sozialen Systeme, nur soweit gelingt, als es das Mönchtum eingliedert unter die notwendigen, an Geeignetheit des Trägers gebundenen Berufe der christlichen Gesellschaft. An der Einsicht in diesen Umstand hängt ein großer Teil des Verständnisses für den Unterschied von altkirchlicher und mittelalterlicher und moderner Christlichkeit.

Unter dem Einfluß der eschatologischen Stimmung und der paulinisch-konservativen Haltung heißt es zunächst stets : der Christ bleibe in dem Stande, in dem er berufen ist (I. Kor. 7, 20), und bewähre hier die christlichen Tugenden. So beteiligen sich die Christen ohne weiteres an den allgemeinen Erwerbs- und Lebensverhältnissen und scheiden nur die Berufe aus, die für den Christen unmöglich waren; dadurch erwerbs- und stellungslos gewordene Christen werden von der Gemeinde versorgt. Immerhin griff in den strengen alten Zeiten diese Ausschließung sehr tief in das 
Leben ein. Ausgeschlossen waren alle Aemter und Berufe, die mit dem Götzendienst und Kaiserdienst in Beziehung brachten, die Blutvergießen und Todesurteile mit sich brachten oder die mit heidnischen Unsittlichkeiten sich berührten. Dadurch sind alle Amtsstellen im Staats- und Gemeindedienst, alle Richter- und Offiziersstellen, ja im Grunde der Soldatendienst selbst ausgeschlossen. Auch alle Beteiligung an Schauspiel, Kunst, Rhetorik ist damit verboten. Dies griff nun freilich bei der anfänglichen Zusammensetzung der Gemeinde nicht allzutief in das Leben. Sehr viel tiefer griff der Ausschluß aller Technik, Kunstarbeit und Handarbeit, die mit heidnischen Emblemen oder dem Kultusbetrieb zusammenhingen. „Die Zimmerleute, Stukkaturarbeiter, Tischler, Dachdecker, Blattgoldschläger, Maler, Bronzearbeiter, Graveure, sie alle dürfen schlechterdings nichts arbeiten, was zum Tempeldienst nötig ist, und sich an keiner Arbeit für ihn beteiligen. * Man kann die Händler mit Fleisch, Blumen und sonstigen zum Kult verwendbaren Gegenständen dazu rechnen. Magier und Astrologen sind verfehmt. Schullehrer und Lehrer der Wissenschaft kann der Christ nicht sein, da auch das mit der Idololatrie in Texten u. s. w. in Berührung bringt. Gleiche Last liegt auf dem Kunsthandwerk, das stets mit Götterbildern zu tun hat. Die sozialen Wirkungen von alledem sind bemerkbar genug. Die Christen rühmen sich dieses Gegensatzes und weisen auf ihre Macht in der Stillstellung des Geschäftslebens hin. Die Heiden bemerken die Gefahr; der berühmte Bericht des Plinius hebt die wirtschaftliche Verödung hervor, und Celsus klagt, daß bei solchen Prinzipien der Kaiser ohne Heer und Beamte bleiben und das Reich untergehen müsse. Höchst charakteristisch ist die Antwort des Origenes hierauf: „Würden alle Römer den Glauben annehmen, so würden sie durch Beten und Flehen den Sieg über ihre Feinde gewinnen, oder vielmehr, sie würden überhaupt keine Feinde mehr zu bekämpfen haben, da die göttliche Macht sie bewahren würde." „Es gibt keinen, der für den König besser streitet als wir. Wir ziehen zwar nicht mit ihm ins Feld, auch nicht wenn ers verlangt, aber wir kämpfen für ihn, indem wir ein eigenes Heer bilden, ein Heer der Frömmigkeit durch unsere Gebete an die Gottheit.* *Wenn erst einmal alle Menschen Christen geworden sind, werden auch die Barbaren zum Frieden geneigt sein. * Bei solchen Voraussetzungen liegt jede Erwägung über soziale Möglichkeiten ferne, jeder Ge- 
danke daran, daß die christliche Kritik der Gesellschaft auch eine organische Reform derselben bedeuten müsse. Dafür, daß sie auch dann noch zusammenhält, wird Gott sorgen. Es genügt die Amputation der verbotenen Berufe, das übrige wird stehen bleiben, und die Christen sind mit diesen Forderungen und ihren Leistungen, wie der Brief an Diognet meint, schon jetzt die Seele der Welt. Charakteristisch fügt der Schreiber des Briefes hinzu, »daß die Christen sich nicht durch die Umstände, in denen sie leben, von ihren heidnischen Mitbürgern unterscheiden, sondern dadurch, daß sie in den allen gemeinsamen Verhältnissen doch ein von den anderen ganz verschiedenes Leben führen. Ob sie in Griechen- oder Barbarenstädten wohnen, ist ihnen gleich. Sie fassen dies eben als ein von Gott ihnen bestimmtes Los auf. In Bezug auf Kleidung, Nahrung und die ganze übrige Lebensstellung passen sie sich ihrer Umgebung an. * Nicht vom Beruf ist dabei die Rede, sondern vom $\gg$ Los , wie es einem jeden bestimmt wurde. Das Entscheidende ist das »bewunderungswürdige und allgemein bekannte System der eigenen Politie des Christen " ${ }^{61 a}$ ). Schwieriger wird die Lage seit dem dritten Jahrhundert, als die Christen in den höheren Ständen und Berufen, im Heer und der Beamtenwelt zahlreich wurden. Da flammt an zahlreichen Stellen der Protest gegen die Teilnahme an diesen Dingen auf; andererorts fehlt es nicht an Vermittelungen und Beschwichtigungen, die die Notwendigkeit dieser Berufe für das soziale System einsehen und darum auch hier das Bleiben in dem Berufe empfehlen. Praktisch gab es eine Fülle von Mitteln des Ausweichens und Milderns, wohl auch vielfache Konnivenz der Behörden, die den Christen die Teilnahme am Kult ersparten oder erleichterten. Es gab in den Provinzen christliche Flamines des Kaiserkults, denen es möglich wurde, um die eigentliche Teilnahme am Kult sich herumzudrücken und doch die soziale Bedeutung dieser Stellungen zu genießen. Aber diese Schwierigkeiten gehören der $Z_{\text {wischenzeit }}$ wwischen der Erstarkung der Kirche und ihrer staatlichen Anerkennung an und verschwinden mit der letzteren. Nun fielen für die Christen die Berührungen mit dem Heidentum weg

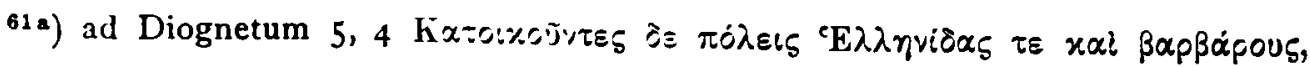

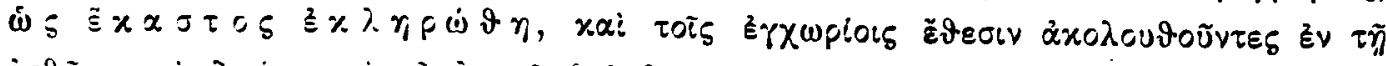

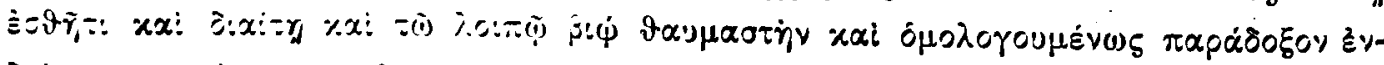
Es:หyv:x: $: \dot{r}_{1} \vee x x=\dot{x}=\tau x \sigma: \nu=\tilde{r}_{1} \sigma \varepsilon \alpha \cup \tau \tilde{\varepsilon} \alpha \pi \circ \lambda: \tau$ si $\alpha$ s.
} 
und alle Aemter wurden frei ${ }^{62}$ ). Indem man nun doppelt den inneren Zusammenhang dieser Berufe mit der Aufrechterhaltung der Staatsordnung, der pax terrena, behaupten konnte, und indem die äußeren Hindernisse der Befleckung mit dem Götzendienst wegfielen, wurde die Teilnahme an Heer und Aemtern, am allgemeinen Wirtschaftsleben völlig erlaubt. Von Sozialreform ist aber jetzt erst recht nicht die Rede. Nur die rohen Spiele, die unzüchtigen Theater und die heidnische Kunstarbeit blieben ausgeschlossen, und ihr Ausschluß wird auch von der Gesetzgebung. verlangt; auch über Kinderaussetzung, Ehe und Geschlechtssünden setzt man strengere Bestimmungen durch. Aber das System im ganzen versteht sich von selbst oder bleibt vielmehr dem Staate anvertraut, dem seine Ordnung zugehört. Hat die staatsfeindliche Kirche keine Sozialreform gekannt und gefordert, weil sie von der vergänglichen Welt überhaupt sich zurückhielt und nur das christlich Erträgliche mitmachte, so hat die. verstaatlichte Kirche sie ebensowenig gekannt, weil die Gründe zur Zurückhaltung größtenteils weggefallen waren und das bestehende System des Imperiums ihr so unabänderlich schien wie jener. Die Verweltlichung ist in vollem Gange, aber man würde sie mißverstehen, wollte man in ihr ein einfaches Eingehen in die Welt, eine Verschmelzung mit ihr sehen. Praktisch ist das natürlich massenhaft der Fall, aber den ernsten Christen und den Lehrern bleibt die. Welt mit Eigentum, Arbeit, Zwang, Gewalt, Recht, immer eine Folge der Sünde. Der Christ beugt sich in der Teilnahme an der Welt nur unter die Folgen der Sünde und bleibt in dem Stand weltlicher Ordnung, in dem er berufen ist. Die Frage ist immer nur die Erlaubtheit oder Unerlaubtheit der nun einmal bestehenden Berufs- und Geschäftsarten oder die Eingrenzung auf ein erlaubtes Maß und eine erlaubte Art. Die Berufe selbst dagegen werden fast niemals zum Gegenstand einer positiven Wertung und einer inneren Beziehung auf die religiösen Werte. Die Kirche bleibt innerlich stets geschieden von der Welt und hebt an ihrem Teil durch Liebe und Mildtätigkeit die Folgen dieser Sünde innerhalb ihres Bereiches wieder auf; und je schwieriger diese Auf-

$\left.{ }^{62}\right)$ Harnack, Militia 71 f., Bigelmair 17 I. - Noch Lactanz erklärt das Richteramt wegen des Urteils über Leben und Tod als dem Christen verboten. Bigelmair 123. Wann sich diese Bedenken gelöst haben, weiß ich nicht zu sagen. Doch vgl. Ziegler, >Gesch. d. christl. Ethik \&. 233. Jedenfalls verlangt die Kirche im donatistischen Streit gegen die Ketzer selbst Todesurteile. Gaß I 228. Aehnlich steht es mit dem Eid. 
gabe für eine in ihrer Ausdehnung mit der Welt allmählich zusammenfallende Kirche wird, um so höher steigt das Mönchtum, in dem die Korrektur der Grundsätze der Welt allein noch in voller Strenge möglich ist. Der Gedanke an eine christliche Kultur, an eine die Welt durchdringende, gestaltende und erneuernde Ordnung des Gesamtlebens liegt völlig fern und eben deshalb auch jeder Gedanke an eine von der Kirche aus zu fordernde Sozialreform. Die Gründe dafür liegen jedoch nicht bloß in der Denkweise der Kirche, sie liegen auch im Gesamtleben selbst. Hier taten die nachdiokletianischen Kaiser, was sie konnten. Aber sie konnten überhaupt nicht mehr als konservieren. Die zunehmende Knappheit der dem Staate doch unentbehrlichen Geldwirtschaft und die beständig zunehmende Rückkehr zur Naturalwirtschaft samt den vielen Nöten und Katastrophen ließ überhaupt nur den Gedanken der Erhaltung zu. Die Sozialpolitik der Kirche bestand geradezu darin, ihn darin zu unterstützen und ihren Apparat ihm zur Verfügung zu stellen. Auch wenn sie gewollt hätte, wäre ihr etwas anderes nicht möglich gewesen. Zudem hatte die alte Sitte eine ungeheure Zähigkeit, wie der Umstand zeigt, daß es der Kirche nicht einmal gelungen ist, die freie (ohne Gerichtsurteil, nur vertragsmäßig erfolgende) Scheidung der Ehe dauernd aufzuheben. So blieb die Kirche in ihrer Stellung zu den sozialen und wirtschaftlichen Gliederungen geteilt zwischen Ergebung in die durch die Sünde nun einmal gestifteten Verhältnisse und dem mönchischkommunistischen Liebesideal. Nur gelegentlich tauchen Gedanken auf, die dann das spätere Mittelalter beherrschen, daß nämlich die gegenseitige Ergänzung der Berufe und $f$ beitsgruppen von Gott gewollt sei und daher als normale göttliche Ordnung zu betrachten seien. Derselbe Chrysostomus, der diese Gedanken äußert, möchte aber dann doch Antiochien und Konstantinopel verwandeln in eine das Klosterleben nachahmende kommunistische Liebesgemeinschaft, wobei er die zuhörenden Reichen ausdrücklich beruhigt, daß das bei der Lage der Dinge ja gar nicht ausführbar sei ${ }^{62}$ ๑).

62.) O. Seipel I07-109, 131 das System der auf der Ungleichheit und dem Ergänzungsbedürfnis beruhenden Berufe. Aehnliche Stellen des Basilius bei Sommerlad $1_{3}$ I f., Theodoret $167 \mathrm{f}$. Im übrigen zeigen die von Seipel gesammelten Stellen aus Basilius, Chrysostomus, Ambrosius, Augustin, daß überall im Hintergrunde der Gedanke der ursprünglichen Gleichheit und der Zurückführung der Besitzdifferenzen auf die Sünde stand, daß daher das Ideal der mönchische Liebeskommunismus ist, daß man aber dem wirklichen Leben und seinen rechtlichen Grundlagen gegenüber das nicht durchführen zu können sich wohl bewußt ist. So wird das Ideal der 
Bei ihm und fast allen anderen Vätern schlägt gegen realistische Betrachtungen der Weltlage immer wieder die stoisch-christliche Idee der urständlichen Gleichheit durch.

Unter den Funktionen des sozialen Lebens bildet einen besonders schwierigen Punkt der $\mathrm{Handel}^{63}$ ). Unter überwiegend städtischen und das heisst geldwirtschaftlichen Verhältnissen lebend konnten die Christen nicht daran denken, den Handel aufzuheben. Sie haben ihn daher durchweg anerkannt; sogar die Klöster verhandeln ihre Produkte, und Kleriker leben bis ins vierte Jahrhundert vom Handelsgeschäft; später wird ein solches mit dem Kirchengut betrieben und genießt sogar Steuerprivilegien. Aber der Handel wurde allerdings mit starken Kautelen umgeben. Denn als Freude am Besitz und Erwerb voraussetzend war er der asketischen Gesinnung, als dem einen nehmend, was er dem andern gibt, und als sich selbst an fremdem Gut bereichernd, war er der Liebesgesinnung verdächtig. Die mit größerem Betrieb verbundene Neigung zu Monopolen, Aufkäufen, Darlehen und Zinsen, die Kalkulation und Ausnutzung der Konjunktur und die verschiedenen Neigungen zur Uebervorteilung und Unredlichkeit vermehrten die sittlichen Bedenken. Daher galt der Handel in der theologischen Theorie als die hinter Landwirtschaft und Handwerk ethisch zurückstehende Erwerbsform und wurde mit der Vorsichtsmaßregel umgeben, daß er im Preis nur die Beschaffungskosten mit dem Aufschlag des zum Leben nötigen Gewinnes verlangen dürfe. Wenn sich daraus im Zusammenhang mit der seit Diokletian einsetzenden Taxen- und Preisregulierung die Lehre von einem objektiv feststehenden gerechten Preis entwickelte, so scheint davon weniger

-Vollkommenen nicht eine kommunistische Produktionsgemeinschaft, sondern die Armut, die alles hergibt und dafür von andern sich verhalten läßt, um ihnen in kirchlichen und mönchischen Leistungen zu dienen. So wurden Augustins kommunistische Experimente zum Ideal des armen Lebens der Kleriker und zu der Duldung der allgemeinen Verhältnisse vorbehaltlich reicher Liebestätigkeit. Das aber ist kein Boden für die Berufsidee. Seipel I09-I I9.

69) Vgl. Brentano $>$ Wirtschaftl. Lehren \&, Funk >Kirchengesch. Absch. II 60 ff.৫, ,Zins und Wucher im christlichen Altertume (Tübinger Theol. Quartalschrift 1875) >Zins und Wuchere 1868, Seipel 162-182; Ratzinger, Volkswirtschaft 222-269 Endemann >Die nationalökonomischen Grundsătze der kanonistischen Lehres (Jahrb. für Nationalökonomie und Statistik 1863), Bigelmair 306-321, Die Sache ist vielfach dargestellt, ich hebe daher hier nur die prinzipiellen Hauptpunkte hervor. Brentano läßt sich auch hier von den mönchisch gesinnten Autoren zu stark beeinflussen. Außerdem s. Max Weber > Agrargeschichte (Altertum), S. 120. 
die theologische Theorie als die praktische Gestaltung der Verbältnisse die Ursache zu sein. Den Theologen kam es nur darauf an, daß der Gewinn den zum Leben nötigen Aufschlag nicht übersteige. Den Geistlichen freilich wurde in dem Maße, als das Kirchengut für ihren Unterhalt aufkommen konnte, die Beteiligung am Handel verboten. Das alles ist nun freilich nur eine Anerkennung des Kleinhandels. Der Großhandel blieb der Theorie immer verdächtig, und ebenso verbot sie das damit zusammenhängende Kredit- und Zinsgeschäft, indem sie auf das jüdische Gesetz mit seiner Beschränkung des Zinsnehmens auf Volksfremde ${ }^{63 .}$ ) und auf das Evangelium sich berief, und vor allem, weil sie in der Zinsforderung eine die Liebe verletzende Ausnützung der Not fand. Es ist in allen Aeußerungen der Standpunkt der Liebe und Kameradschaft, der in einem eng verbundenen Kreise das Zinsnehmen für unanständig und lieblos hält, wie das auch sonst s unter Brüdern * in wirtschaftlich unentwickelten Kreisen die Regel ist. Das theoretische scholastische Argument aristotelischer Oekonomik von der Unfruchtbarkeit des Geldes fehlt noch ganz ${ }^{63 b}$ ). Dabei kommt für den Eifer der großen Kirchenlehrer gegen den Wucher allerdings auch die Härte des Wucherwesens und der Schuldeintreibung in einer Zeit des Rückfalls aus der Geldwirtschaft in die Naturalwirtschaft in Betracht. Das Zinswesen der Zeit ist in der Tat lukratives Beleihen von in Not Geratenen und monopolistische Ausnützung, aber nicht Anregung eines Erzeugungsprozesses durch produktives Kapital. Gedanken der letzteren Art liegen der Kirche naturgemäß ferne. Praktisch sind diese theologischen Verbote von sehr geringer Wirkung gewesen; so lange die Geldwirtschaft dauerte, hat sie sich dagegen erfolgreich gewehrt, und man wußte den antikapitalistischen theologischen Argumentationen allerhand biblische und $Z_{\text {weckmäßigkeitsgründe }}$ entgegenzusetzen. Das *Alles ist Euer * und das "Haben als hätte man nicht * stand nicht umsonst in der Bibel. Immerhin aber sind jene Lehren prinzipiell bedeutsam genug: sie bedeuten, daß das Christentum dem natürlichen Bedürtnis nur eben so viel einräumte, als es im Minimum bedarf, und daß den alten Christen jeder Gedanke an eine die Güter unbegrenzt mehrende Produktionskraft und an deren Zusammenhang mit der allgemeinen Hebung des Lebens fehlte. Ihnen war die Welt sün-

83.) S. oben S. 79.

6s b) Sommerlad 136 glaubt bei Gregor von Nazianz eine Anspielung hierauf zu finden 
lig verderbt und gut zugleich; aber das Gute in ihr ist lediglich tie unter den von Gott zugelassenen Ordnungen stehende Befriedigung des Mindestmaßes von äußeren Lebensbedürfnissen, woJei dies Mindestmaß zwischen einer verständigen Läßlichkeit und einer asketischen Strenge sich hin und herbewegt.

Hat in allen bisherigen Dingen die Kirche nach anfänglicher scheuer Zurückhaltung die bestehenden Verhältnisse mit dem Eindringen in die Oberschicht steigend anerkannt und nur in ihren ethisch bedenklichen Spitzen reguliert, jedenfalls aber vorher wie nachher auf eine Umwandlung des sozialen Systems nie gedrungen, so ist das anders bei dem innersten Kern des Systems, der Famili e ${ }^{64}$ ). Hier ist die Gestaltung der Verhältnisse so eng mit der jeweiligen Wertung und Auffassung des persönlichen Lebens verbunden, daß hier die Durchführung des Ideals notwendig eingreifen und widerstrebende Verhältnisse umformen muß. Freilich ist auch die Familie mit der patriarchalischen Mannesherrschaft und dem $Z$ wang des Eherechtes erst eine Folge des Sündenfalles, wie alles Recht und aller Zwang, der an Stelle der vollen inneren Freiheit des. Urstandes getreten ist. Andere freilich leiten aus der Art der Erschaffung der Eva die naturnotwendige Unterordnung der Frau ab; immerhin ist doch die Herrschaft des Mannes erst durch den Fluch bei der Austreibung aus dem Paradiese begründet. Aber hier hat doch die Fügung in das mit der Welt Gewordene ihre sehr engen Grenzen. Das Ideal der Monogamie, der vorehelichen Keuschheit für Frau und

64) Vgl. Marianne Weber, „Ehefrau und Mutter «, 186-197, der ich zum Teil wörtlich folge. Das selbständige kirchliche Eherecht ist freilich hier nicht berücksichtigt. Zscharnak, Der Dienst der Frau in den ersten Jahrhunderten der Kirche, 1902, Donaldson, > Woman, her position in ancient Greece and Rome and among the early Christians \&, London 1907. Ueber die Ableitung der patriarchalischen Rechtsform aus dem Sündenfall s. Overbeck »Sklaverei๔, S. 198 nach Chrysostomus, aus der Naturverschiedenheit nach Augustin, S. 200. - Für die Stellung der Frau ist charakteristisch das $>$ Witwenamt und seine Entwickelung. Ursprünglich sind die Witwen eine Art weiblicher Presbyter, beteiligt an den Kirchenämtern und mit religiösen Funktionen der Unterweisung betraut neben Funktionen der Armenpflege. Mit der Entwickelung des Amtsbegriffes verschwinden die Witwen hinter den Diakonissen und mit der steigenden Askese hinter den Jungfrauen d. h. den Enthaltsamen. Die Frau verschwindet aus der Kirchenregierung und die Diakonisse wird eine niedere Kultdienerin. Die heilsvermittelnde Funktion des Meßopfers darf eben keine Frau vollziehen; hier gilt das (apokryphe) Herrenwort: das Schwache wird durch das starke gerettet. Uhlhorn I, I59-I7I.

Troeltsch, Gesammelte Schriften. I. 
Mann, der ehelichen Treue, der fürsorglichen ethischen und religïisen Kinderzucht, dic Verwerfung jeder Reguliarung der Be:iilicrungszahl durch Aussetzung oder künstliche Sterilisierung wird sofurt nach innen von der Gemeinde aufs strengste gefordert und wird dann nach der Verstaatlichung der Kirche nach Möglichkeit zu einer allgemeinen Grundlage auch der Gesellschaft überhaupt gemacht, teils durch kirchliche Einwirkung in kirchlichem Recht, Bußordnung und Disziplin, teils durch Beeinflussung des staatlichen Rechtes. Die monogamische Familie ist nach der von der Bibel ausgehenden Geschichtsphilosophie der Kirche der Anfang der Gesellschaft und des Staates, der aus Ausbreitung von der Familie her entstanden ist; sie ist bei den Heiden in die äußerste Verwirrung und Verkehrung der Anschauungen über sexuelles Leben geraten und wird von den Christen als Grundlage einer reinen und besseren Lebensordnung radikal gereinigt, wobei sie in die äußeren Formen des bestehenden Eherechtes nur unter fortwährenden Kämpfen sich fügen kann. Wie weit die Veränderungen des römischen Eherechtes in der byzantinischen Zeit auf christliche Einflüsse sich zurückführen, ist vielfach umstritten. Es ist »ein stetiger Kampf zwischen den höchsten Idealen desChristentums - Zulassung nur der Vollehe und nur als einer unauflöslichen Verbindung - und den Motiven der weltlichen Gesetzgebung, welche zwar an der Festigung der Familie interessiert war, aber auch auf die fest eingewurzelten Gewohnheiten der sozial herrschenden Schichten Rücksicht nehmen mußte.\& $\mathrm{Zu}$ den letzteren gehörte der römische, stets monogamische, öffentlich erklärte Konkubinat und der Vertragscharakter, damit auch die freie Löslichkeit der legitimen Vollehe. Konstantin verbietet das Pellikat, die außereheliche Verbindung eines verheirateten Mannes, erschwert das Konkubinat durch Ungültigkeitserklärung aller Schenkungen und Testamente des Konkubinanten an seine Genossin und seine Kinder. Bei den christlichen Nachfolgern treten Bestrebungen hervor, die Löslichkeit der Ehe durch Einschränkung, der Scheidungsgründe zu erschweren und durch strengere Beschränkung der Frau aufs Haus für die größere Reinheit der Ehe zu sorgen. Die Respektierung der Sklavenfamilien, deren Ausbreitung gleichzeitig durch die aus wirtschaftlichen Gründen erfolgende Umwandelung der Sklaven in Hörige und Kolonen und durch das Interesse an ihrer Vermehrung durch Fortpflanzung gefördert wird, gelingt es durchzusetzen; die Sklavenfamilien dürfen nicht beliebig aus- 
sinander gerissen werden. Die justinianeische Gesetzgebung ist Jann ein durch staatliche und wirtschaftliche Interessen stark nitbedingter Kompromiß : Gestattung des Konkubinats mit mögichster Annäherung an die legitime Ehe, Aufhebung der Standesingleichheit als Ehehindernis, Erschwerung der Ehescheidung mit nöglichster Betonung des von der Kirche allein gebilligten ScheiJungsgrundes des Ehebruchs und dadurch im Prinzip der Bruch nit der Vertragsfreiheit in Ehesachen, Erhöhung des Schutzes Jer Sklavenehe, indem Sklavenkinder bei Freilassung die Erbechte ehelicher Kinder erhalten, Einschränkung der patria potestas zu Gunsten der Vermögensfähigkeit der Hauskinder und der Fähigkeit der Frau zur Vormundschaft über ihre Kinder, besseres Erbrecht der Frau gegen den Mann und der Kinder gegen die Mutter. Ihre strenge Lehre über die Ehescheidung und ihre Verwerfung des Konkubinats hat die Kirche jedoch nicht durchgesetzt.

Neben diesen Wirkungen des kirchlichen Familiengedankens stehen dann freilich die ganz anderen der christlichen Askese und des Virginitätsideals. Diese schon bei Paulus hervortretende Zwiespältigkeit der christlichen Sexualethik führt unter der Einwirkung der Askese und des Mönchtums zu einer grotesken Hochschätzung der Geschlechtsenthaltung und zu den bekannten Lehren über die Gefährlichkeit und Minderwertigkeit der Frau, die freilich der gereizten Mönchsphantasie und nicht der Idee des Christentums entstammen. Auch ist die Kehrseite nicht zu vergessen, daß die Virginität der Frau und das Nonnenwesen andererseits auch eine Schätzung und Stellung der unverheirateten Frau, zugleich eine Wirksamkeit und einen Einfluß weiblichen Geisteslebens mit sich bringt, die wiederum der Stellung und dem Verständnis der Frau zu gute kommen. Die Wirkung jedenfalls ist eine ungeheure, die Virginität erscheint oft geradezu als das Christentum schlechthin. Methodius travestiert Platons Symposion, das hohe Lied auf die Männerliebe und die metaphysische Bedeutung des Schönen, in eine Unterhaltung enthaltsamer Jungfrauen über göttliche Dinge. Später durchdringt dann das Mönchtum geradezu alles und zieht wenigstens den Klerus unter seine Regeln, soweit es geht. Die augusteischen Strafgesetze zegen Ehelosigkeit werden zu seinen Gunsten aufgehoben. Es ist mit Sicherheit zu vermuten, daß die erschreckende und plötzliche Ausbreitung des Möchtums, z. B. in Aegypten, noch andere als bloß ideelle Gründe haben muß, und klar, daß das nicht der 
Geist des Evangeliums ist ${ }^{65}$ ). Allein für die alte Christenheit hat es doch die allgemeine Bedeutung zu zeigen, daß ihr eigentlicher Geist der der W'eltentsagung ist und nicht der der Weltreform, und daß diese Entsagung eine Umformung der Weltindifferenz des Evangeliums ist. Dabei ist aber gleich wichtig, daß die religiös geweihte Ehe vollständig gleichberechtigt und nicht etwa als Inkonsequenz daneben hergeht. Sie ruht auf den Schöpfungsbedingungen und göttlicher Einsetzung. Nicht die asketische Sexualethik, sondern eine Spaltung der Sexualethik in eine asketische und in eine die Natur heiligende Richtung nebeneinander ist das Charakteristische der christlichen Ethik bei ihrer weiteren Ausbildung. Hierin ist die Entwickelung der Sexualethik typisch für die der ganzen altchristlichen Ethik. Es ist nicht eine Konzession der ursprünglichen und wesentlichen Askese an die Natur, sondern nur in einer solchen Spaltung der Grundtriebe konnte das christliche Ethos bei Umfassung der großen Weltverhältnisse sich ausleben. Der die Naturbasis anerkennende, aber um des überweltlichen, bald eintretenden Zieles willen verkürzende Heroismus ist nur für die Zeit des ersten Kampfes und der ersten Hoffnung in kleinen weltfremden Gemeinden möglich. In den Verwickelungen des großen Gesellschaftslebens treten beide auseinander; dabei wird das eine weltförmig, das andere asketisch.

Nahe mit der Familie berührt sich die $\mathrm{Sklaverei}$ sofern es sich um die Haussklaven handelt ${ }^{66}$ ). Hier herrscht im Bereich der nahen persönlichen Beziehungen der verchristlichte und verinnerlichte Patriarchalismus des Paulus, die Verantwortung des Herrn für leibliches und seelisches Wohl der Sklaven, die Liebesund Gehorsamspflicht des Sklaven, der Gott dient und nicht den Menschen. Insofern ist innerlich die Natur des Sklavenverhält-

o5) Ueber wirtschaftliche Gründe s. Uhlhorn I, 234; es ist die Flucht in die Freiheit aus Steuerdruck, Hörigkeitszwang und erblichem Zunftzwang.

66) Vgl. hierüber Uhlhorn I 184-189, 362-375, Seipel 30-32 und die Abhandlung von Overbeck, der ich überhaupt für die ganze Auffassung und für die Nachweisung von Väterstellen sehr viel verdanke. Die richtige Anschauung, vielfache Quellenstellen und eine stärkere Betonung der inneren Wandelung des Verhältnisses als bei Overbeck gibt Carlyle I S. III-125: >Natural equality and slavery\&. Die Stellen aus Chrysostomus s: Overbeck 198, Augustin 200. Uebrigens wirft das auch ein Licht auf den $>$ Kommunismus e des Chrysostomus. Es ist ja nur ein Vorschlag, das Armenelend Konstantinopels durch Zusammenschießen des Besitzes aufzuheben und nur ein frommer durch die Apostelgeschichte nahe gelegter Wunsch. Hierüber und über ähnliche antiochenische Predigten sehr treffend Seipel 98-105. 
nisses wenigstens für die ideale Forderung aufgehoben. Aber äußerlich ist die Sklaverei. lediglich ein Stück des allgemeinen Besitzrechtes und der staatlichen Ordnung, die das Christentum hinnimmt und nicht antastet, ja im Gegenteil mit seinen moralischen Garantien festigt. Das gilt dann erst recht vom Arbeitssklaven, dessen Los freilich der allgemeine Gang der Dinge, die Umwandelung des Sklavenverhältnisses in den Kolonat oder das Hörigenwesen, schon vọ sich aus humanisierte. Den christlichen Lehrern stammt dieses Besitzrecht, wie alles Recht, aus dem Sündenfall, und ist seit ihm die von Gott zugelassene Ordnung. Sie hat ihren Ursprung in dem Uebermaß menschlicher Habsucht, vor allem in dem Fluche Noahs über den unehrerbietigen Cham. -Auf den Urfreveln der Menschheit, auf welchen auch der Staat überhaupt ruht, ruht auch die einzelne Institution der Sklaverei, und so kennen zwar nur die menschlichen Gesetze den Unterschied von Sklaven und Freien, aber gleich allen übrigen Gegensätzen, welche den Staat begründen, ist jene Institution eine Zuchtrute in der Hand Gottes, und in diesem Sinne namentlich auch das Staatsgesetz, welches den Sklaven in Schranken hält, von Gott gesetzt, so daß es nicht überschritten werden darf, so lange es dem Sklaven nichts zumutet, was Gott mißfällt. * Der Prädestinatianer Augustin fügt dem die Begründung aus der natürlichen Ungleichheit der Menschen hinzu. So haben die Christen an dem Sklavenrecht schlechterdings nichts geändert. Sie haben die Sklavenehe geschützt, haben Nichtchristen zur Freilassung oder zum Abkaufenlassen ihrer Sklaven verpflichtet, weil die Sklaven hier religiös gefährdet schienen; sie haben die Freilassung selbst als gutes Werk der Entsagung und des Eigentumsverzichtes befördert, wobei übrigens die große Zahl der Frejlassungen später auch wirtschaftlich begründet ist; sie haben den Sklaven religiöse Gleichheit in vollem Umfang gewährt, was später bei der Verweltlichung und der Durchsetzung der profanen Maßstäbe sozialer Schätzung sich übrigens sehr einschränkte; da gefährdete es zu sehr die allgemeine soziale Ordnung, und Gregor der Grosse hebt die Fähigkeit von Sklaven zu geistlichen Aemtern geradezu wieder auf. Aber an dem Rechtsinstitut als solchem, auch an dem Recht der grausamen Bestrafungen, haben sie nichts geändert, es geht unbedenklich und nur durch die wirtschaftliche Entwickelung stark zurückgedrängt in das Mittelalter über bei voller Empfindung des Gegensatzes der Institution gegen die innere Freiheit und 
Gleichheit der Christen. Es ist das vielleicht das charakteristischeste Zeichen für die Stellung der Christen zur Welt, für die Weltverwerfung, die doch in die Welt sich fügt und die an Aenderungen des sozialen Systems nicht denkt und nicht denken kann. Wohl kannte die Kirche bei alledem die Schäden und Leiden dicses sozialen Systems und war sie keineswegs gewillt mit dem System auch seinen Leiden sich ohne weiteres zu fügen. Aber was sie hiergegen aufbot, ist keinerlei Art von Sozialreform, von organischer Veränderung, 'sondern einzig und allein die Liebestätigkeit ${ }^{67}$ ). Das ist i hre Form der Heilung der sozialen Gebrechen,

67) Harnack >Mission 127-171, Ratzinger , Geschichte der Armenpflege 1868 und besonders das Meisterwerk Uhlhorns. Von Uhlhorns Auffassung unterscheidet sich die meine, abgesehen von der stark apologetischen Tendenz Uhlhorns, auch gerade in der abweichenden Auffassung von der Bedeutung der , Welt * für Urchristentum und Kirche. U. deutet in das Evangelium die lutherische weltgestaltende, gerade im System der sozialen Arbeitsteilung Gott dienende Berufssittlichkeit hinein und läßt erst aus Askese, Verkennung des Wesens von Arbeit und Besitz und Verwandelung der Gesinnungssittlichkeit in Werkheiligkeit die katholischasketische Behandlung der Welt und damit auch der Liebestätigkeit entstehen. Aber er selbst sagt, daß jene Sittlichkeit im Evangelium nur keimhaft enthalten gewesen und dann a $11 \mathrm{mählich} \mathrm{entfaltet} \mathrm{worden} \mathrm{sei.} \mathrm{\gg Dieser} \mathrm{himmlische} \mathrm{Beruf}$ schließt den irdischen in sich, denn eben in seiner irdischen Berufsarbeit soll jeder seinen Beruf zum Gottesreiche betätigen, darin das Reich Gottes fördern, indẹm er an seinem Teile mithilft, die große dem Menschen bei der Schöpfung gestellte Aufgabe, die Erde zu beherrschen, zu lösen S. 77. , In dem Maße, als dann a $1 \mathrm{lmählich}$ die übrigen (nach der Familie) menschlichen Gemeinschaften von christlichem Geiste durchdrungen werden, entwickeln auch sie in diesem Kreise Liebestätigkeit. Der Staat, die bürgerliche Gemeinde, die Korporationen alle nehmen Teil an Lösung der gemeinsamen Aufgabe๔, S.65. So konstruiert Uhlhorn; allein seine eigene Darstellung zeigt dann, daß gerade diese christliche Durchidringung und Weltbeherrschung nicht erreicht und nicht erstrebt wurde, und zwar von Anfang an. Von der alten Zeit heißt es S. I If.: >Die Aufgabe, die Welt zu fliehen, steht in erster Linie; die Aufgabe, die Welt mit dem neuen Leben zu durchdringen, geht den Christen erst allmählich auf «. Aber das, was allmählich kommt, ist in Wahrheit ganz entgegengesetzt. Etwas später heißt es nämlich: »der Zug auf Weltentsagung ist noch stärker als der auf Weltaneignung “. 127. Noch später: $>$ Nun stand die Kirche auch vor der großen Aufgabe, das sie umgebende Volksleben, Staat, Wissenschaft, Kunst, die sozialen Verhältnisse mit christlichem Geiste zu durchdringen und von innen heraus umzugestalten. An dieser Aufgabe ist sie gescheitert und dadurch in falsche Bahnen gedrängt ๔. 20I. Von der konstantinischen Zeit: $₫$ Zu einer wirklichen Durchdringung des Volkslebens mit dem Sauerteig des Evangeliums .. kam es aber auch nicht einmal annähernd und deshalb mußte das Christentum nach der andern Seite 
und sie bildet in ihrer Geschichte in der Tat ein glänzendes Kapitel, in den ersten Jahrhunderten nach innen gewendet und eine Insel lebhaftester gegenseitiger Fürsorge schaffend innerhalb des heidnischen Lebens, später in den schweren Nöten des Massenelends dem Staate die Bekämpfung abnehmend und oft an Stelle des Staates ein eigenes Zentrum der Fürsorge schaffend. *Den Waisen will sie die Fürsorge der Eltern, den Witwen die des Mannes ersetzen, den zur Ehe Reifen zur Ehe verhelfen, den Arbeitslosen, soll sie Arbeit geben, den zur Arbeit Unfähigen Erbarmen erweisen, den Fremden ein Obdach, den Hungrigen Speise, den Durstigen Trank, den Kranken, daß sie besucht werden, den Gefangenen Hilfe verschaffen . Dazu kommt die Fürsorge bei öffentlichen Kalamitäten, die Bestattung der Leichen, die Aushilfe der Gemeinden untereinander. Alles geschieht dabei in der alten Zeit durch die Gemeinde selbst, wo Bischof und Hilfsarbeiter jeden persönlich kennend im Stande sind zugleich zu zentralisieren und $\mathrm{zu}$ individualisieren. Gegen Mißbrauch hilft die Kirchenzucht, und, was die Gemeinde nicht ordnet, das erledigt eine außerordentliche private Wohltätigkeit. In der nachkonstantinischen Zeit erweitert sich mit dem nun einsetzenden sozialen Elend und der rapid steigenden Mitgliederzahl die Liebestätigkeit zur Schaffung von Anstalten, Fremdenhäusern und Hospitälern, zur Ernährung und Kontrolle ganzer städtischer Massen durch die Kirche, zu einem Eingriff auch der kirchlichen Gerichtsbarkeit und des kirchlichen Asylrechtes zum Schutz der

hin zerstörend und zersprengend wirken «. 218. Schließlich: »Die alte Welt war nun einmal für das christliche Leben undurchdringlich. Erst die germanische Welt sollte und konnte eine wirklich christliche werden 4.342 . In alledem ist schon das Grundverhältnis des Evangeliums zur Welt d. h. zu den sozialen Verhältnissen falsch aufgefaßt und das Gottesreich als éine innerweltliche ethische Neuordnung des Lebens verstanden. Das ist ganz unrichtig. Aber auch wenn es dann erscheint, als sei die Kirche an dem undurchdringlichen Heidentum gescheitert und erst dadurch in ihre katholisch-asketische Richtung gedrängt worden sei, so ist das wiederum unrichtig. U. hat nirgends gezeigt, daß die Kirche überhaupt jemals einen solchen Willen gehabt hätte, der dánn an dem Widerstand des Heidentums hätte scheitern können. In Wahrheit ist sie niemals gescheitert, weil sie diesen Willen niemals gehabt hat. Gescheitert ist sie nur in dem Glauben an die Möglichkeit, durch Liebestätigkeit das Elend wenigstens für die Minimalansprüche aus der verchristlichten Welt beseitigen zu können und hat sich daher wieder in die kleinen Kreise des Mönchtums zurückgezogen, welchen letzteren Umstand U. sehr treffend anerkennt. Vgl. S. 347 . 
Leidenden, woneben die Tätigkeit der Klöster und eine unendlich zersplitterte Privatwohltätigkeit hergeht. Für unsere Darstellung kommt es aber nicht auf diese Einzelheiten, sondern auf den Sinn und Geist des Ganzen an, wie es gemeint war im Verhältnis zur Lage der Welt und der Dinge. Hier ist nun dreierlei hervorzuheben. Die Liebestätigkeit ist erstlich ihrer eigentlichen Absicht nach nicht Heilung sozialer Schäden und nicht Bestreben die Armut aufzuheben, sondern Offenbarung und Weckung der von Christus mitgeteilten und verkörperten Gottesgesinnung der Liebe. Sie will vor allem Liebe zeigen und Gegenliebe wecken. Daß sie die Not überwindet ist nur eine Folge, nicht die erste Absicht, aber durch. diese glückliche Wirkung eine Probe auf die Göttlichkeit des neuen Liebesprinzips. Die Armut bleibt dabei gerade als Förderungsmittel der Gotteserkenntnis geschätzt und wird durch Verschenken oft selbst herbeigeführt. Zugleich erstreckt sich die Heilung der Uebelstände auch als solche Folge nicht weiter als auf die Sicherung des Existenzminimums. Der Geist der Mäßigkeit und Bedürfnislosigkeit soll nicht beseitigt, sondern bei Schenkern und Beschenkten vielmehr gefördert werden. Darnach bemißt sich die Höhe der Gaben und die Art der Liebesarbeit. Nur aus dem religiösen Charakter der Liebe als Gesinnungsoffenbarung und der gleichzeitig damit verbundenen Schätzung der Armut ist es auch erklärlich, daß die Liebesarbeit bald wie ganz von selbst bei der Vergröberung der alten Gesinnungsethik zur Ethik der guten Werke in asketische Leistungen hinübergleiten kann, die ihren Zweck gar nicht mehr in dem Wohl des anderen, sondern in der Sicherung des eigenen Seelenheils haben. Zunächst freilich drängt die Liebe und zwingt die Not und wird die neue Religion der Liebe damit gepriesen, daß sie eben mit dieser Liebe ganz von selbst auch die sozialen Nöte und Leiden überwindet und mehr noch als die Leiden selbst die Gesinnung überwindet, in der die Leiden allzu drückend empfunden werden. Dann aber

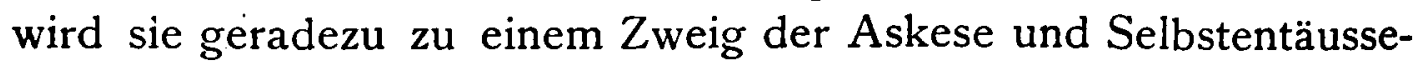
rung. $Z$ weitens ist die derartig als Wirkung auftretende Beseitigung der Not eben auch absichtlich beschränkt auf Liebestätigkeit, auf freie Beitragsleistung zur Gemeindepflege und auf den freien Willen der Privatwohltätigkeit. Nur eine neue Gesinnung, keine neue Gesellschaftsordnung sollte kommen. Auch in der nachkonstantinischen Zeit läßt die Kirche wohl ihre Anstalten, ihre Gerichtstätigkeit und ihre Bischöfe staatlich privilegieren, stellt ihre Liebes- 
und Zuchtmittel der staatlichen Rechtspflege, "ihre Autorität und ihre Listen der staatlichen Gerichtsübung und Kontrolle der Bevölkerung zur Verfügung, aber sie drängt den Geist sozialer Fürsorge der Gesetzgebung nicht auf, beansprucht ihn vielmehr für sich und vom Staat nur Unterstützung ihrer Liebestätigkeit. Sie verzichtet damit auf das einzige Mittel durchgreifender Besserung. Das aber ist nicht zufällige Beschränktheit und Einsichtslosigkeit des christlichen Denkens, sondern stammt aus seiner prinzipiellen Stellung zur Welt. Bleibt die Welt trotz aller relativ guten, von Gott zugelassenen Ordnungen das Reich der Sünde und des Satans, der Ort der Pilgrimsichaft und der Himmelsbereitung, so hat auch eine positive Weltverbesserung keinen Sinn, ja es bleibt die Betätigung der eigentlichen Grundgesinnung besser gesichert, wenn man auf Derartiges sich gar nicht einläßt. Die Dienstleistungen, zu denen der christliche Staat für die Kirche veranlaß̉ wird, ändern an diesem Prinzip gar nichts. Die Frage der Möglichkeit aber, ob es bei solchen Grundsätzen überhaupt möglich sei, auch nur bis zur Sicherung des Existenzminimums die Not zu überwinden, läßt das Gottvertrauen und die absolute Selbstgewißheit der Kirche nicht aufkommen. In den ersten Jahrhunderten der besseren wirtschaftlichen Verhältnisse gelang es ja auch, die Not zu überwinden; in dem Massenelend der späteren Zeit hat die Kirche dann freilich mit ungeheuren Mitteln oft vergeblich gekämpft, aber dann erblickte man in dem Elend Strafen der göttlichen Vorsehung und Boten des Weltendes. Das Dritte ist, daß eine derartige Sozialreform durch die Liebe, soweit sie überhaupt Sozialreform sein wollte, materiell und geistig nur möglich ist in kleinen Gemeinden mit durchgängiger persönlicher Bekanntheit und Beziehung ihrer Glieder, mit dem von außen her zusammenhaltenden Druck des Gegensatzes und mit einer wenigstens relativen Gleichartigkeit der sozialen Zusammensetzung. Als all dies aufhörte und die Kirche ohne äußern Gegensatz extensiv mit der ganzen Gesellschaft sich deckte und deren Differenzen alle im eigenen Schoß trug, da gewann die Liebestätigkeit auch ein anderes Gesicht. Die Beziehung auf die Brüder wird eine abstrakte und allgemeine, und die Schenkungen gehen daher an die Kirche, an Anstalten, ans Allgemeine. Die Liebesarbeit selbst wird entpersönlicht; die Bischöfe lassen sie durch ihre Beamten auf Grund der Matrikeln vollziehen; sie gewinnt in den Händen reicher Bischöfe 
und Besitzer oft den Charakter der alten römischen Liberalität. Andrerseits zersplittert sich das private Almosen in unüberlegten Schenkungen. Auf diesem Boden verwandelt sich dann die ganze Liebestätigkeit aus einer Hilfe für andere in asketische Selbstentäußerung, in gute, Lohn verdienende Werke für sich und andere, in Büßungen für Sünden und in Milderungsmittel für das Fegfeuer. In dieser Richtung wirkt nicht nur das ursprüngliche religiöse Interesse der Liebestätigkeit und dessen Verwandelung in Askese, sondern auch die Unmöglichkeit, das darin zugleich ursprünglich liegende, wenn auch beschränkte, soziale Interesse gegenüber Massengemeinden und unpersönlichen Massenverhältnissen durchzuführen. Der Zweck und Sinn verschiebt sich, und trotz immer erneuter Betonung der Liebesgesinnung und trotz großartiger Leistungen verliert die Liebestätigkeit die früher mit dem Motiv doch eng verbundene Wirkung einer Ueberwindung der sozialen Not, einer Ausgleichung der Besitzgegensätze und einer seelischen Verbindung der Gemeinde unter sich. So gehen Klöster, Hospitale, bischöfliche Fürsorgetätigkeit in das Mittelalter über als hochwichtige Kulturträger, aber doch zugleich auch als asketische Institutionen, in der Opferung für welche man sein Seelenheil bewirkt. Von einer Ausgleichung des sozialen Bestandes der Gemeinde in sich selbst als Folge der Liebe ist nicht mehr die Rede. Das aber ist zugleich ein Zeugnis wie eng begrenzt die soziale Bedeutung und Leistungsfähigkeit dieser Liebestätigkeit überhaupt war. Bei aller Unersetzlichkeit und Bedeutung. dieses Teiles sozialer Hilfe ist sie doch eben eine Lösung des sozialen Problems überhaupt nicht gewesen und hat sie ein solches nur sehr bedingt sein wollen, weil ihr das soziale Problem selbst nur die Heilung der äußersten Nöte und Leiden durch Gewährung eines Existenzminimums war, bei im übrigen geforderter Ergebung und Fügung in die Leiden der sündigen Welt und irdischen Pilgrimschaft. Dabei war jenes Minimum nicht einmal ein Recht und Anspruch, sondern eine von der Liebe gewährte und mit Liebe und Demut zu erwidernde Gabe. Es kam eben auf die Stiftung der Gesinnungs- und Liebesbeziehungen, nicht auf die materielle Hilfe als solche an. Die davon ausgehenden Wirkungen der $F$ weichung und Verinnerlichung der menschlichen Verhältnisse gegeneinander ist der Natur der Sache nach unmelibar und bedeutsam genug. Aber irgend eine organische Reform geht davon nicht aus. Daran hindert der Begriff von 
Staat und Welt. Wie weit die oft behauptete Erweichung des harten römischen Eigentumsbegriffes * als Folge von dem behauptet werden darf und wie weit sie wirklich stattgefunden hat, vermag ich nicht zu sagen. Beweise sind für diesen Satz, wo ich ihn gelesen habe, nicht angeführt. Mir scheint vielmehr rechtlich eine solche kaum stattgefunden zu haben. Ethisch ist es mehr das Mißtrauen gegen das Recht des Besitzes und die religiöse Pflicht der Liebestätigkeit als eine Empfindung der Gesamtverantwortung der Gesellschaft für ihre Glieder und der Bedingtheit des Einzeleigentums durch die Interessen des Ganzen. Das letztere setzt bereits ein Interesse an der Formung des Ganzen der Gesellschaft voraus, und gerade das hat dem alten Christentum gefehlt.

In der Liebestätigkeit übernimmt die Kirche in weitestem Umfang die Heilung der sozialen Schäden einer immer schwieriger werdenden Gesellschaftsverfassung. Aber sie bedeutet keinerlei Eingriff in diese selbst, keinen Gedanken an einen organischen Aufbau und Neubau. Die einzige Wirkung des Christentums in dieser Hinsicht ist seine eigene tatsächliche Wirklichkeit als Kirche. Als solche bedeutet es für die Gesellschaft die Heraufführung eines neuen Standes und damit die Einfügung eines wichtigen Bestandteils in das immer mehr ständisch werdende Gefüge des Staates. Die Bischöfe und der ihnen zugehörige Klerus werden von Konstantin ab, öffentlich-rechtlich als besonderer Stand anerkannt und von den folgenden Kaisern mit immer steigenden Standesprivilegien ausgestattet, sodaß die obersten Spitzen des Episkopats in den Rang von höchsten Staatswürdenträgern und politisch maßgebenden Kräften hineinwachsen. Dabei gab die Abwesenheit der Erblichkeit dieser Aemter dem Staat durch Einfluß auf die Besetzung ein Mittel beständiger Kontrolle und Nutzbarmachung in die Hand. Mit den Standesvorrechten zusammen wirkte zur Erhöhung und Sonderstellung dieses Standes die Privilegierung zum Gütererwerb, die Verleihung von Dotationen und Immunitäten, die Ueberweisung des heidnischen Tempel- und häretischen Kirchengutes, das Recht Legate anzunehmen, der Heimfall des priesterlichen Privatvermögens an die Kirche bei mangelnden Leibeserben, der ungeheure Schenkeifer der Sünder und der den Himmel verdienen Wollenden. Es entsteht eine ungeheure tote Hand, vor allem ein kolossaler kirchlicher Grundbesitz. Aber so wichtig die Herausbildung dieses neuen Standes für das ständisch werdende Gefüge des Staates sein mußte, so 
- sehr es ihm neue verwendbare Mächte und gefährliche Unberechenbarkeiten zuführte, so bedeutsam insbesondere diese Standesbildung für das heraufsteigende Mittelalter $d$. h. für die Rückverwandelung der antiken Demokratie und bureaukratischen Großstaatsidee in die ständische, naturalwirtschaftliche Monarchie war, für die Einführung christlich-ethischer Ideen in das soziale Leben hat er in der alten Kirche nicht allzuviel bedeutet. Außer der vom Bischof geleiteten, mit zahlreichen Beamten ausgestatteten, Hausarmen- und Anstaltspflege verbindenden, Liebestätigkeit hatte der Klerus nicht allzuviel Spielraum. Hier sollte der Bischof mit den Armen täglich speisen und tat es auch oft genug, sollten die Kleriker arm und ohne Prunk ein Vorbild der Aufopferung für andere sein und waren es auch in zahllosen Fällen. Das Kirchengut war Armengut und diente öffentlichen $Z$ wecken. Der Einfluß der christlichen Ideen dagegen auf die Reichsgesetzgebung war sehr geringfügig. In dieser Richtung hat der neue Stand nichts durchgesetzt, vielleicht auch nichts durchsetzen wollen, als die Ausrottung der Heiden und Häretiker sowie die Privilegierung der Kirche. Das übrige sah die Kirche als ihre eigene Sache an, und hier setzte sie die alte Fremdheit gegen den Staat und die bestehende Ordnung fort. Sie brachte aus dem alten genossenschaftlichen Zustand die Gewohnheit einer weitgehenden schiedsrichterlichen Tätigkeit der Bischöfe in Zivilstreitigkeiten und einer kirchlichen Behandlung der Kriminalfälle mit sich. Das erstere wurde bei Erklärung der Parität den Christen wie auch den jüdischen Patriarchaten offiziell eingeräumt; man konnte die Exsequierung bischöflicher Schiedssprüche vom Staat verlangen und eine große $Z$ ahl von Rechtssachen vor das bischöfliche Urteil ziehen, bis Arcadius und Honorius diese konkurrierende Gerichtsbarkeit aufhoben. Die Grundsätze, nach denen hier geurteilt wurde, würden einen Einblick in die damalige christlich-soziale Auffassung geben, ich habe darüber leider nichts in Erfahrung bringen können. Die Hauptsache aber ist, daß diese konkurrierende Gerichtsbarkeit nicht eine Reform der Gesellschaft, sondern den Rest der Fortdauer der Kirche als Staat im Staate, die fortgesetzte Fremdheit und Sprödigkeit gegen Staat und Gesellschaft bedeutet, weshalb die Kaiser sich auch zu ihrer Aufhebung genötigt sahen. Den gleichen Charakter trägt der Anteil an der Strafrechtspflege, nur daß hier der Staat sehr viel weniger zu Zugeständnissen geneigt war. Sogar die Kriminal- 
klagen' gegen Geistliche dem geistlichen Gericht vorzubehalten gelang nur ganz vorübergehend. Die Kirche erlangte nur gewisse Privilegien für die gerichtliche Behandlung der höheren Geistlichkeit und einen indirekten Einfluß durch Ausbildung des Fürbittenwesens und Beeinflußung des Strafvollzugs und des Begnadigungsverfahrens; auch übte sie starken Druck auf die Richter durch Bedrohung der Richter mit kirchlichen Strafen. Das hat vielfach die Rechtspflege im Sinne christlicher Ideen beeinflußt und gemildert, großenteils aber auch dem Schutz kirchlich verdienter, durch Rechtgläubigkeit oder Parteinahme ausgezeichneter Personen gegen das weltliche Gericht und die weltliche Macht gedient; es hat daher auch die schroffsten Verbote der Kaiser hervorgerufen. Einen mildernden und humanisierenden Einfluß auf die Gesetzgebung hat die Kirche damit aber nicht ausgeübt, diese wurde in der christlichen Aera im Gegenteil grausamer und härter; die Auflösung der sozialen Ordnung verlangte rauhere Mittel, und die sichtbaren Einflüsse auf das Gesetz bestehen nur in der Einführung der dogmatischen Intoleranz und Glaubensverfolgung in das Gesetz. Noch wichtiger als durch die bisher genannten Dinge wurde die -Standesbedeutung der Bischöfe durch die Zuweisung öffentlich-rechtlicher Befugnisse in Sachen der Armenpflege und sozialen Fürsorge, wozu sie sich durch die alte Geübtheit der Kirche in diesen Dingen und durch den kolossalen kirchlichen Besitz einem Staat empfahlen, der selbst der Bekämpfung der Not nicht mehr gewachsen war. Der Bischof wurde vom Staat anerkannt als der Patron der Armen und Elenden, und bei dem Mangel einer staatlich organisierten Armenpflege, bei der Härte und Grausamkeit der Gesetzgebung, insbesondere des Strafrechts, bei dem Massenelend der damaligen Zeit, bei den unaufhörlichen Kriegen und den seit dem fünften Jahrhundert immer häufiger und schrecklicher werdenden Barbareneinfällen konnten die Kirche und die Bischöfe von den schönen Vorrechten, die ihnen vom Staat verliehen wurden, in segensreichster Weise Gebrauch machen «. So lag in der Hand der Kirche das Asylrecht, das nun von den heidnischen Tempeln und Kaiserstatuen auf die christlichen Kirchen übertragen und von diesen mit dem bischöflichen Fürbitterecht verbunden wurde. Doch wurde dies Recht jetzt nur rechtgläubigen Christen zu teil und vielfach ein kirchliches Machtmittel gegen die Staatsbehörden, weshalb es von diesen auch mit erheblichen Einschränkungen umgeben 
wurde; insbesondere wurde verhindert, daß es allzusehr zum Schutz der wirtschaftlich Schwachen, der Verschuldeten und Sklaven, dienen konnte; so stand das kirchliche Asylrecht an Humanität schließlich hinter dem heidnischen zurück. Weiter lagen in der Hand der Kirche der Kampf gegen den Mädchenhandel und gegen Ausschreitungen des Bordellwesens; ebenso der Kampf gegen die Kinderaussetzung und die Versorgung der Findelkinder, ebenso die Kontrolle des Strafvollzugs in den Gefängnissen, insbesondere der Rückkauf der Kriegsgefangenen, wo die Kirche aber nicht zu hindern vermochte, daß diese Befreiten großenteils zur Abhilfe gegen den Arbeitermangel des Großgrundbesitzes vernutzt wurden. Milderungen des Sklavenloses gehörten zu ihren Befugnissen, insoferne sie das Recht erlangte, daß die Freilassung der Sklaven zu vollem römischen Bürgerrecht wie vor dem Prätor so auch vor dem Bischof rechtlich erfolgen konnte; sie ermahnte zu Freilassungen als gutem Werk der Askese und nahm den Schutz der Freigelassenen gegen Wiederversklavung in die Hand; ihre eigenen Sklaven dagegen konnte sie nicht freilassen, da diese zum Kirchengut gehörten und als solches unveräußerlich waren, ein für die ganze Lage charakteristischer Selbstwiderspruch. Das letztere deutet auch darauf hin, $\mathrm{daB}$ die kirchliche Grundherrschaft schwerlich im Sinne christlicher Musterwirtschaften gehandhabt wurde; alle Spuren deuten vielmehr darauf hin, daß dieser Besitz nach damaligen Rentabilitätsgrundsätzen verwaltet wurde ohne alle besonderen christlichsozialen Rücksichten. Christliche Musterwirtschaften waren nur die Klöster, die aber eben auch mit den Grundsätzen der Welt gebrochen hatten.

Die soziale Funktion des neuen Standes ist somit eine sehr erhebliche und sichert den christlichen Ideen unter Schutz und Privilegierung des Staates eine beträchtliche Einwirkung. Allein es ist doch nur eine Korrektur und Milderung der bestehenden Ordnungen, eine Ausgleichung der schlimmsten Härten, zu denen neue Härten der kirchlichen Herrschsucht und der exklusiven Christlichkeit hinzukommen. Die Kirche bleibt in alledem cise Institution neben der Welt und dem Staate. Gerade das soziale Hervortreten der Kirche in der Standesabsonderung des Klerus ist von diesem Gedanken der Weltfremdheit geleitet, bedeutet die Sicherstellung der Kirche und des Klerus neben der Welt, und keineswegs die Herrschaft und Leitung des Klerus über dem 
Kulturganzen. Deshalb wird trotz aller Leistungen für das Ganze andererseits gerade der Gegensatz des geistlichen Stańdes gegen die Welt betont, die Teilnahme an Staatsgeschäften und öffentlichen Aemtern immer neu ausdrücklich verboten, der Z̈ölibat aus rein asketischen Gründen und nicht etwa aus Gründen politischer und sozialer Herrschfähigkeit gefordert, das Mönchtum als die Pflanzschule des hohen Klerus empfohlen im Gegensatz zu dem aus der Aristokratie stammenden weltlichen Klerus. So bedeutsame Anknüpfungen diese politischssoziale Stellung des Klerus für die mittelalterlichen Gedanken darbietet, überall fehlt doch der eigentlich mittelalterliche Gedanke, daß hieraus eine geistliche Leitung der Gesamtkultur abzuleiten sei ${ }^{67 a}$ ).

67 a) Vgl. zu alledem Edgar Löning, Gesch. d. deutschen Kirchenrechtes I I878. Der erste Band schildert vortrefflich und äußerst lehrreich das nachkonstantinische Kirchentum. Hier schlägt besonders ein Kap. II-V. Ueber die Wirkung auf das staatliche Recht s. S. 316. Vgl. auch die Zusammenfassung der sozialen Bedeutung des Episkopats S. 362: „Die Machtstellung welche die Bischöfe im 4. und 5. Jahrh. einnahmen, beruhte auf kirchlichen und weltlichen Grundlagen. Der religiös-kirchliche Einfluß, welchen der Bischof als Träger der Kirchengewalt innerhalb seines Gebietes aúf die Gläubigen ausübte, wurde gestützt und gesteigert durch das große Vermögen der Kirche, das er fast unbeschränkt verwaltete und durch welches er den gesamten Klerus und einen großen Teil der wenig bemittelten Stadtbevölkerung in seiner Abhängigkeit hielt, sowie durch die wichtigen öffentlich-rechtlichen Befugnisse, mit welchen ihn der Staat nach und nach ausgestattet hatte. Stellt man das von Löning entworfene Bild in den Zusammenhang der hier entwickelten 'allgemeinen Lage und Grundgedanken, dann tritt freilich auch noch stärker als bei ihm die Tatsache hervor, daß alles das nur ein sehr bedingtes Eingehen auf die Welt und ganz und gar nicht eine christliche Einheitskultur darstellt. Von der smittelalterlichen Unterwerfung des Staates unter die Kirche S. 77 darf daher auch nicht als keimhaft verwirklichter geredet werden. Es handelt sich nur um Benützung der Kaiser für einige speziell kirchliche Machtzwecke, nicht um Christianisierung des Gesamtlebens. Darüber unten bei der Frage nach dem Verhältnis zum Staate. - Ueber die Art, wie Bischof und Kleriker die öffentliche Armenpflege und Liebestätigkeit ausüben, das arme Leben der Bischöfe und Kleriker, die Behandlung des Kirchenvermögens als Armengut, aber auch das allmähliche Eindringen vornehm ständischer Lebensgewohnheiten in den Episkopat und die Zerteilung des Kirchenvermögens in Anteile für Bischof, Klerus, Arme und Kirchenfabrik als Anfang vom Ende der altkirchlichen Armenpflege s. Ratzinger >Armenpflege $6 \mathrm{I}-\mathrm{I} 40$. R. betont mit Recht, daß diese Auffassung für die alte Kirche chạakteristisch ist und daß mit dem Uebergang des Kirchenvermögens in rein kirchliche $Z$ wecke seit dem neuen Vermögensrecht der pseudo- 
Gegenüber dieser von allen Seiten her sich zeigenden Fremdheit der Kirche gegen die Welt ist nun freilich an einem Punkte eine fast völlige Verschmelzung von Kirche und Welt anzuerkennen. Das ist dann freilich charakteristisch genug nicht ein Gebiet des sozialen Lebens, sondern ein Gebiet des rein geistigen Lebens, die $\mathrm{W}^{\prime}$ is s e n s chaft. Aber diese Verschmelzung mit der Wissenschaft brachte der Kirche die sozialen Theorien der antiken Spekulation und wirkte damit indirekt auf ihr eigenes soziales Denken aufs stärkste. Hier ist die Verschmelzung übrigens ja auch leicht $z u$ begreifen. Die W'issenschaft war das dasjenige Element, das mit dem Bestehenden am wenigsten eng zusammenhing und in dem System der Arbeitsteilung am wenigsten feste eigene Träger und Formen hervorgebracht hatte, ja das am meisten selbst über die Bedingungen des antiken Lebens hinausgewachsen war. Und genauer angesehen findet sich doch auch hier im Grunde die gleiche Stellung zur Welt, wie sonst; nur daß auf dem Gebiete der Wissenschaft viel bemerkbarer und bewußter als auf dem des sozialen Lebens die Spätantike Tendenzen zeigte, die über sie selbst und ihr bisheriges Wesen weit hinausführten. Das stark rhetorische Schul- und Bildungswesen hat die Kirche belassen, wie es war, und mit einigen Kautelen einfach benützt. In den Weltanschauungsfragen dagegen verfuhr sie mit schroffer Auslese. Denn das, was angeeignet und in die eigene Tätigkeit der christlichen Literaten, Gelehrten und Lehrer übernommen wurde, das ist nur die dem Christentum wahlverwandte und in seiner Stellung zur Welt ihm nahe kommende religiös-ethische Philosophie der Spätantike. Es vollzieht sich die weltgeschichtlich wichtige Verschmelzung des Christentums mit dem Platonismus und dem religiös gewendeten Stoizismus. Der erste gibt seinem besonderen Erlösungsevangelium die allgemeine theoretische Grundlegung in der Mystik: in dem großen Prozeß des Ausgangs der Welt aus Gott und ihrer Rückkehr zu Gott durch den Logos oder die Gotteserkenntnis nimmt die christliche Erlösung. die Bedeutung der Vollendung dieses Prozesses ein. Der zweite gibt der terminologisch und begrifflich ganz ungefügen, rein an der Anschaulichkeit der Vorgänge hängenden christlichen Moral eine theoretische Unterlage und eine Terminologie: das sittliche Naturgesetz als die Herrschaft der göttlichen Vernunft über Leidenschaft und Beisidorischen Dekretalen diese ganze soziale Funktion des Episkopats einging und aufhörte bis heute. 
şehren der Menschen und die Vereinheitlichung der Menschen m gemeinsamen. Besitz der göttlichen Vernunft, das ist der Kern and sachliche Inhalt der christlichen Ethik, der dem Menschen anerschaffen ist, dann im Dekalog des Moses zusammengefaßt and schließlich in der Lehre Christi von neuem verkündigt worJen ist, zu dem nur die besonderen evangelischen Ratschläge oder die höheren christlichen Tugenden sowie das christliche System Jer Gnadenhilfen, der Gnadenbefähigung des schwachen oder auch völlig verderbten Willens, hinzukommen. Das Weltprinzip des Logos, der in Christus Mensch wird und die Kirche stiftet, und andererseits das sittliche Naturgesetz, das mit dem Logos selbst gegeben, im Dekalog des Moses enthalten und in der allgemeinen Sittenlehre Jesu den Unterbau der auf das Jenseits abzielenden Vollkommenheitslehre bildet: das sind die beiden Grundbegriffe und Angelpunkte aller wissenschaftlichen Theologie und Ethik, wodurch sie sich von den mehr biblischen und volkstümlichen, vor allem am religiösen Mythos haftenden und antiken Volksglauben massenhaft rezipierenden Christentum des unteren Durchschnitts unterscheidet ${ }^{67 b}$ ). Aber darüber hinaus geht nun aber auch die Rezeption der antiken Wissenschaft nicht. Die Empiriker werden leidenschaftlich abgelehnt. Die Naturwissenschaften verfallen völlig; der Physiologus und die Weltbeschreibung des -Kosmas Indicopleustes sind die Proben eines aus biblischen Ideen und märchenhaften Kuriositäten gemischten Naturbildes. Gleichfalls verfallen Historie und Kritik; die Mönchsgeschichten mit ihren grotesken Wundern und die aus Profanhistorikern ausgeschmückte jiblische Urgeschichte mit den darauf seit Nimrod folgenden and bis zur Gegenwart dauernden vier danielischen Weltreichen sind die Proben des Geschichtsbildes. In dieser Opposition zegen die empirisch-exakte Wissenschaft mündet das Christen:um in die Eigenbewegung der ausgehenden Antike ein und beschleunigt den Untergang eines kritischen und rein sachlichen Wissens. In der wissenschaftlich gebildeten Oberschicht verschmilzt sich seine religiöse Idee mit Stoa und Platonismus d. h. nit den dualistischen, mystischen und ethisch-humanitären Mächten, ss entsteht eine christliche Philosophie und eine christliche Rheorik und Sophistik; in der Unterschicht wuchert der Mythos

67 b) Ueber den Unterschied dieser beiden Stufen s. meinen Aufsatz $>$ Der Be;riff des Glaubens \&. f. Religion und Geisteskultur 1907.

Troelt sch, Gesammelte Schriften. I. 
weiter, indem er sich mit Elementen der antiken Volksreligion und ihrer Kulte durchsetzt ${ }^{68}$ ).

Alles Nähere gehört hier der Dogmengeschichte an. Für unseren Zusammenhang von Bedeutung ist im besonderen zunächst nur die Rezeption des Stoizismus, des stoischen s sittlichen Naturgesetzes oder Gottesgesetzes oder Naturrechts*. Denn diese Rezeption ist nicht bloß das Mittel, die innerchristlichen ethischen Begriffe überhaupt zu fixieren und zu benennen, sondern es ist auch das Mittel, die Welt, das heißt den. Ştaat, das Recht und das System der sozialen Funktionen, in das richtige Verhältnis zum Dasein der Kirche und der Erlösungsgemeinschaf̣t zu setzen. War fast alles bisher Geschilderte die Ordnung nach innen, die Regelung der Gesellschaft als Bestandteils des eigenen Lebens und trat dabei der Begriff von Staat und Welt nur insofern hervor, als beide eben dadurch in das innere Leben der Kirche hineinragen,

o8) Vgl. Harnack >Lehrbuch der Dogmengeschichte ; für die Christianisierung der literarischen Berufe und Formen, Hatch, Griechentum und Christentum \&, deutsch von Preuschen 1892, v. Schubert $>$ Kirchengeschichtec I 806; für das Fortwuchern und die Verschmelzungen des Mythos Usener $>$ Religionsgeschichtliche Untersuchungen I 1889, Bernoulli sDie Heiligen der Merowinger 1900, Lucius >Heiligenlegendene 1905. Monographien über das Verhalten der Zeit zu realer Naturwissenschaft und kritischer Geschichte wären sehr erwünscht; sie würden die geistige Lage erst recht beleuchten. - Bei dieser Sachlage ist es $\mathrm{m}$. E. nicht ganz zutreffend, die Rezeption der $>$ Wissenschafte als $>$ Verweltlichung zu bezeichnen, so wenig wie das Eingehen auf den Staat einfach als Verweltlichung zu betrachten ist. Es ist doch eben nur diejenige Wissenschaft rezipiert worden, die schon spiritualistisch, dualistisch, religiös und ethisch gerichtet war. Der eigentlichen Verweltlichung gehört nur die Aufnahme der Rhetorenmanier und der sämtlichen Spitzfindigkeiten und Eitelkeiten der Disputiersucht und Silbenstecherei an. Es ist eben eine sinkende und formalistische Bildung mit einer erschreckenden Hypertrophie des formellen Scharfsinnes und der Rhetorik. Aus eben diesem Grunde ist es auch schwerlich zutreffend, die Gnosis als akute Verweltlichung im Gegensatz zu dieser chronischen zu bezeichnen, wie Overbeck und Harnack getan haben. Die dem Christentum nahe stehenden Teile der Gnosis sind doch auch dualistisch und asketisch. Es ist in alledem nur ein Streben vom besonderen Historischen und rom Mythischen zu allgetmeinen Grundlagen und zu Begriffen d. h. eben zur Wissenschaft. Das wissenschaftliche Denken als solches aber braucht keine Verweltlichung zu sein, wie Overbeck meint. - Eben deshalb ist es auch irreführend, mit Thamin und anderen von einer Ueberwältigung der christlichen Ethik und Gnosis durch die sAntiker zu reden. Die rezipierte Antiker ist eben die nicht mehr antike Antike sondern die spiritualistisch und dualistisch gewordene Antike. 
so handelt es sich nunmehr um das Verhältnis zum $S$ t a at im $\mathrm{G}$ a $\mathrm{n} z$ en und $\mathrm{n}$ ach $\mathrm{A} u ß \mathrm{~B} \mathrm{n}$. Hierfür aber werden wir gerade die stoische Ethik, den Begriff der.Natur und ihres Gesetzes, eine außerordentliche Bedeutung gewinnen sehen. Schon bei Paulus anklingend wird der Begriff von den Apologeten und Alexandrinern in engem Zusammenhang mit dem Logosbegriff der christlichen Ethik zu Grunde gelegt. Seit den Vätern des vierten Jahrhunderts tritt er zugleich mit der Lehre von einer durch den Sündenfall eintretenden Verderbung des Naturgesetzes immer stärker in den Vordergrund, wie sich das bei allen bisherigen Themata bereits gezeigt hat. Er vor allem ermöglicht schließlich auch die Abfindung mit dem Staate und damit die prinzipielle Beantwortung der Frage nach dem Verhältnis zur Welt. Was für das Dogma der Neuplatonismus ist, 'das ist für die Ethik und vor allem die Sozialphilosophie die Stoa. Erst im Hochmittelalter werden wir dann über die stoischen Kategorien die neuplatonischen-auch in der sozialen: Theorie emporwachsen sehen ${ }^{69}$ ).

09) Leider fehlt über dieses Thema eine Monographie, vgl. meine Anzeige von Seebergs Dogmengeschichte Gött. Gel. Anzeigen 190I S. 22-26. In der alten Kirche ist die Sache zuerst unter dem Logosbegriff versteckt, dann mehr beiläufig als Voraussetzung der Ethik behandelt, namentlich bei den Lateinern im Anschluß an Cicero. Aber diese Beziehungen sind von höchster Wichtigkeit für die Folge Gierke III 124. Zu einem Fundamentaldogma herausgearbeitet ist die Sache erst von der Scholastik. Daher hat sie sich den Dogmenhistorikern der alten Kirche entzogen. Vgl. Hergenröther, Katholische Kirche nnd christlicher Staat 1872 S. 13 f.

Die Gleichung ist grundlegend vollzogen von Philo, vgl. Hirzel A Appopos voHOб (Abhh. der philol.-hist. Klasse der Sächsischen Akademie I903 Bd. XX S. 16 -17.) Die Lehre vom $\alpha$. v. sei bei Philon teils unter dem Einfluß seines Glaubens teils der Philosophie geprägt: „Ungeschriebene Gesetze stellen in ihrem Leben die Weisen der alten Geschichte, die Patriarchen und Stammväter dar, von denen ebendeshalb zur Nacheifferung der Späteren Moses geschrieben hat. In ihnen ist das Gesetz erfüllt und persönlich geworden. Sie selber aber bedurften wiederum einer Norm, nach der sie richteten, und die ihnen die Natur darbot. Auch diese Norm wird von Philo einmal als ungeschriebenes Gesetz bezeichnet .. A. v. ist ihm ein Gesetz, das nicht auf Stein oder Papier sich darstellt, sondern lebendig hervortritt in dem Handeln und Treiben, sei es einzelnet hervorragender Vertreter desselben, der Patriarchen oder Heroen, sei es endlich des höchsten Wesens, des Universums oder der Gottheit.\& Den Inhalt der Bücher De Abrahamo, de Josepho, de vita Mosis, de decalogo faßt Heinrici dahin zusammen: „In den beiden ersten Schriften wird das Normative der Lebensführung dieser Patriarchen herausgearbeitet; ihr Leben sei die Verkörperung des ungeschriebenen Gesetzes, des beseelten 
Damit kommen wir zum letzten der großen sozialen Probleme des Christentums, dem Verhältnis des Christentums zum it a a t.

und vernünftigen Gesetzes, in dem die Menschennatur nach ihrer Vollendung erscheine und das die Voraussetzung sei für das später kodifizierte Gesetz. Abraham wird dargestellt als Typus des rechten Erkennens, Joseph als Typus des Staatsmannes, ... (eine verloren gegangene Schrift) schildert Isaak als

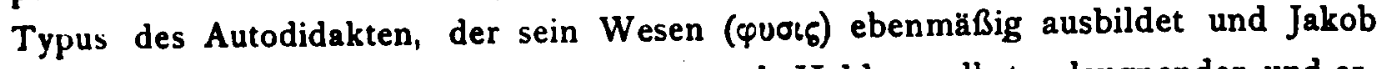
als Typus des Asketen, das will hier sagen als Helden selbstverleugnender und erfolgreicher Tatkraft. Das Hauptstück aber ... ist das Leben des Moses, in dem der Held als vollkommener Gesetzgeber erscheint, der zugleich als König, Priester und Prophet gefeiert wird. Die Schrift de decalogo schloß sich nach den Angaben ihrer Einleitung an die Reihe der vónor äjpaçor an. Sie verherrlicht die ewige sittliche Wahrheit, die unmittelbar von Got seinem Hermeneuten mitgeteilt ist als die Grundlage aller weiteren Gesetzgebung. (Theol. Litztg. I903 col. 77.) Jeder Leser der beiden einzigen Ethiken der alten Kirche, des Pädagogus des Clemens und der Offizien des Ambrosius, erkennt, wie beide ohne weiteres diesem Ideengang folgen. Die ausdrückliche Nachahmung Philons durch Ambrosius und die Alexandriner konstatiert auch Thamin, St. Ambroise et la morale chrétienne au 4ème siècle 1895. Die Gleichung zwischen Naturgesetz und mosaisch-christlichem Gesetz ist hergestellt teils durch die Identität des in ihnen wirkenden Logos teils durch die bekannte Lehre von der Entlehnung der griechischen Weisheit aus dem Orient. - Ueber Paulus s. Quimbach $\gg$ Die Lehre des h. Paulus von der natürlichen Gotteserkenntnis und dem natürlichen Sittengesetz « Freiburg 1906 (Straßburger Theol. Studien VII 4); Q. betont mit Recht schon hier die wesentliche Identität des Naturgesetzes mit dem Dekalog. - Waldstein >Der Einfluß des Stoizismus auf die älteste christliche Lehrbildung ‘ (Theol. Stud. u. Krit. 1880) meint, die Rezeption der e th i schen Lehren der Stoa sei auf Justin und Klemens beschränkt, da allerdings sehr gründlich, wobei der Logos das stoische Naturgesetz bedeute nach dem Worte des Chrysipp:

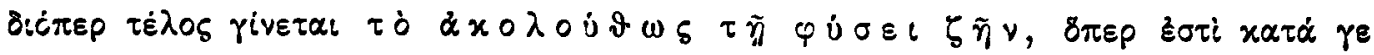

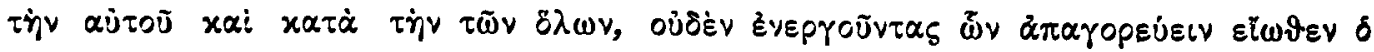

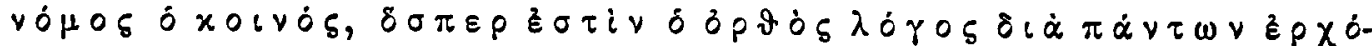

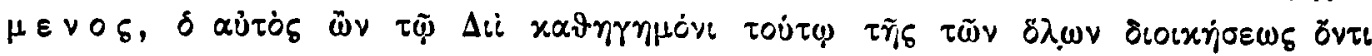
S. 636. Aber die Sache erstreckt sich in Wahrheit viel weiter, ist überall die wie selbstverständliche Begleitung des Logosbegriffes oder eine wie selbstverständlich aufgegriffene Voraussetzung. Ich notiere einige Stellen: Justin Apol. II 8

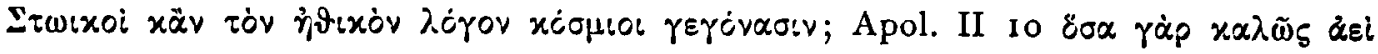

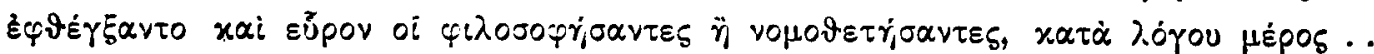

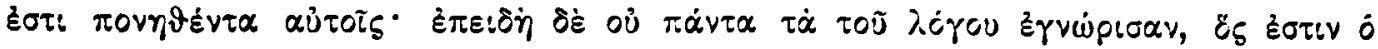

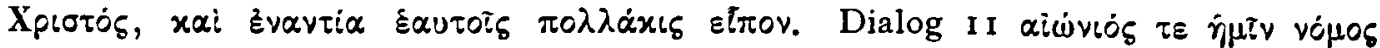

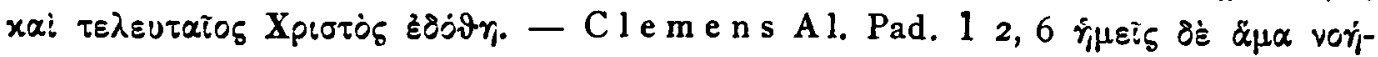

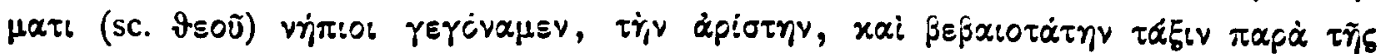


In dem Verhältnis von Staat und Kirche ist es möglich nach zweierlei zu suchen. Man kann fragen, wie weit das Grundschema soziologischen Verhaltens und Fühlens, wie es das Christentum in der Beziehung auf das religiöse Objekt hervorgebracht hat, be-

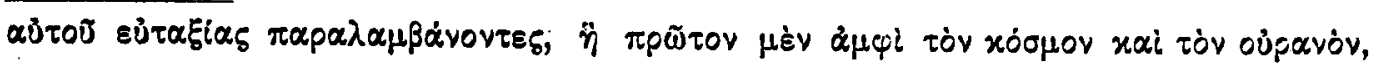

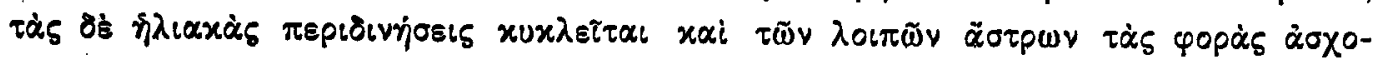

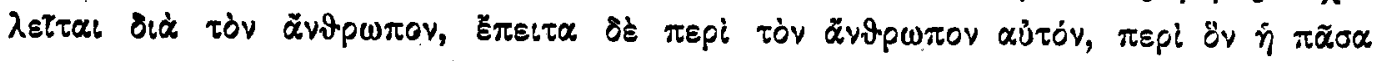

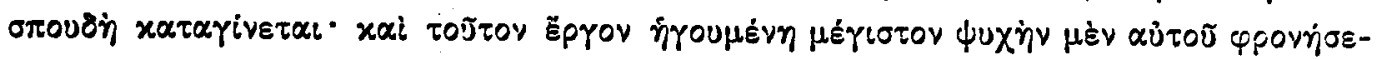

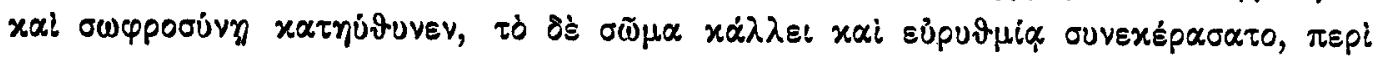

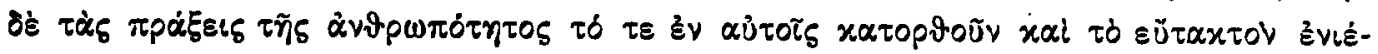

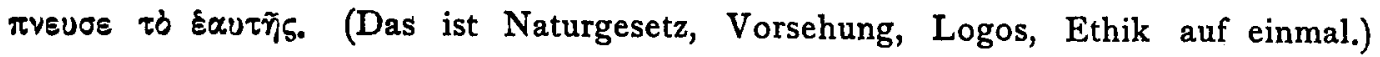

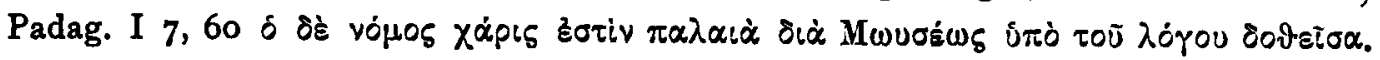
- Origenes s. später anzuführende Stellen. - Irenäus (Harvey) IV 27, 3 Quare igitur patribus non disposuit Dominus testamentum? Quia slex non est posita justise, justi autem patres virtutem decalogi habentes in cordibus et animabus suis .... propter quod non fuit necesse admoneri eos correptoriis litteris, quia habebant in semetipsis justitiam legis. Cum autem haec justitia et dilectio.. cessisset in oblivionem et extincta esset in Aegypto, necessario Deus .. semetipsum ostendebat per vocem. IV 9, 2 und IV 24, I die Unveränderlichkeit des göttlichen Gesetzes, derzufolge auch das Gesetz Christi mit dem des Moses und der Natur identisch sein muß, nur unter Abstreifung der gesetzlichen Form und unter

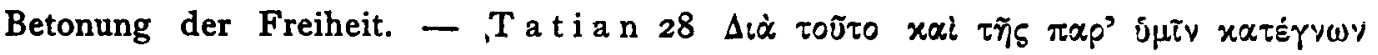

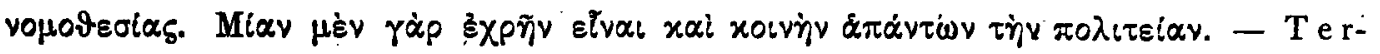
tullian: De virg. rel. I: Sic eț justitia (nam idem Deus justitiae et creaturae) prima fuit in rudimentis, natura Deum metuens. Dehinc per legem et prophetas promovit in infantiam, dehinc per evangelium efferbuit in juventutem, nunc per paracletum componitur in maturitatem. De test. anim. 5: Magistra natura, anima discipula. Quicquid aut illa edocuit aut ista perdidicit, a Deo traditum est, magistro scilicet ipsius magistrae. - L a c t a n z : Just. VI 8: Suscipienda igitur Dei lex est, quae nos ad hoc iter dirigat, illa sancta, illa caelestis, quam Marcus Tullius in libro de re publica tertio paene divina voce depinxit: sest quidem vera lex recta ratio, naturae congruens, diffusa in omnis, constans, sempiterna, quae vocet ad officium jubendo, vetando a fraude deteneat, quae tamen neque probos frustra jubet aut vetat nec improbos jubendo aut vetando movet. Huic legi nec abrogari fas est neque derogari aliquid ex hac licet neque tota abrogari potest, nec vero aut per senatum aut per populum solvi hac lege possumus .. sed et omnes gentes et omni tempore una lex et sempiterna et immutabilis continebit unusque erit quasi magister et imperator omnium Deus. ... Quis sacramentum Dei sciens tam significanter enarrare legem dei posset quam illam homo longe a veritatis notitia remotus expressit? Ego vero eos, qui vera imprudentes loquuntur, sic habendos puto, tamquam divinent spiritu aliquo instincti . . quod (d. h. die volle Darlegung) quia facere ille non poterat nobis faciendum est, quibus ipsa lex tradita est ab illo uno magistro et imperatore omnium Deo. Hujus legis caput primum est ipsum Deum 
wußt oder unbewußt etwa auch in die anderen soziolo. $\mathrm{g}$ is chen $\mathrm{T}$ y pen hine ing e $\mathrm{t} r$ age $n$ ist, wie weit der christliche Individualismus auch in Staat, Gesellschaft, Korporation, Familie die Empfindungen der Freiheit, Gleichheit und Selbstwertigkeit des Individuums geweckt und wie weit sein Liebesuniversalismus christlich-patriarchalische Empfindungen auch in die übrigen Verhältnisse hineingestiftet hat, wie weit etwa Demut und Liebe auf die Beziehungen der Menschen überhaupt abgefärbt haben. Für die vorkonstantinische Kirche ist nun etwas Derartiges selbstverständlich ausgeschlossen; hier kann man nur

nosse ... Dixi quid debeatur deo, dicam nunc quid homini tribuendum sit. Ambrosius: De officis: I 84 naturam imitemur I 124 ne quid contra naturam, ne quid turpe atque indecorum sentiamus I 223 decorum est secundum naturam vivere, secundum naturam degere, et turpe est quid sit contra naturam. I 229 appetitus rationi subjectus est lege naturae ipsius. III 3 I Justus legem habet mentis suae et aequitatis ac justitiae suae normam III 19 haec utique lex naturae est, quae nos ad omnem stringit humanitatem, ut alter alteri tamquam unius partes corporis invicem deferamus. III 25 Zusammenfallen von Sittlichkeit und Nutzen nach Gesetz der Natur, ebenso III 28 und III 24. II 80 unde igitur haec vel Tullius vel Panaetius aut ipse Aristoteles transtulerint, apertum est satis, folgt Hinweis auf das alte Testament, ebenso II 6. Epist. 53, 10: Non fuit necessaria lex per Moysen, denique subintravit .. in locum naturalis legis intraverit. Itaque si illa suum servasset locum, haec lex scripta nequaquam esset ingressa; ebenso 53, 2: Ea igitur lex non scribitur sed innascitur, nec aliqua percipitur lectione sed profluo quodam fonte in singulis exprimitur et humanis ingeniis hauritur. - A mbrosias t e r: Com. in Ep. ad Rom. 3, 20 haec ergo est lex naturalis, quae per Moysen partim reformata partim firmata. - Hi e r o n y m u s, Kommentar zu Jes. 24, 6: Audeant Judaei, qui se solos legem accepisse domini gloriantur, quod universae primum gentes totusque orbis naturalem acceperit legem et idcirco postea lex data sit per Moysen, quia prima lex dissipata est unter Berufung auf Paulus, Rom. 2, 14. Von Augu stin gibt Jodl I 596 eine Anzahl Stellen: Lex vero aeterna est ratio divina aut voluntas Dei, ordinem naturalem conservari jubens, perturbari vetans. Contra Faustum 22, 7. Ich füge schließlich nach Gierke III 128 hinzu: Isidorus Hisp. Orig. V 2 omnes quidem leges aut divinae sunt aut humanae; divina natura, humanae moribus constant, und aus der Glossa ordinaria: jus naturale dicitur, quod in lege Mosaica vel in Evangelio continetur. - Das stärkste Gewicht aber ist vielleicht darauf zu legen, daß Lactanz, Ambrosius und Augustin in ihren Werken geradezu ausgesprochenermaßen auf Cicero fußen. Der erste Teil von de civitate verläuft an der Hand ciceronianischer Darlegungen, des Ambrosius Offizien sind eine teilweise wörtliche Umbildung von Ciceros Offizien. Diese Tatsache hat ihren Grund in der Voraussetzung der Identität der christlichen Ethik und des Naturgesetzes und Naturrechtes. 
negativ sagen, daß die alten am Stadtstaat und am Militär erwachsenen soziologischen Grundschemata von ihm aufgelöst und die antike Staatsidee zersetzt worden ist. Für die nachkonstantinische Zeit aber bedürfte es einer sehr viel eingehenderen Kenntnis ihrer rechtlichen und sozialen Geschichte als mir zur Verfügung steht, um die Frage zu beantworten. An sich läge Derartiges bei der wachsenden Verbindung von Staat und Kirche ja nicht fern. Doch scheint mir als seien die Wirkungen hier noch außerordentlich gering. Die in den alten Ideen festgewurzelten Institutionen und die geistige Bildung sind zu alt, zu selbständig, zu wurzelfremd, um noch neue Antriebe in sich aufzunehmen, und die Kirche ist noch zu jenseitig, noch zu sehr Kind des Kampfes und Sieges, noch zu innerlich spröde, um sich derartig in das innere Gefüge des Staates einzusaugen. Man wird eher umgekehrt von einer starken soziologischen Beeinflussung der Kirche und ihrer Anstalten durch das römische Korporationsrecht und durch die Fortwirkung des alten jus sacrum reden dürfen. Andererseits wird man die steigende religiöse Verherrlichung der Krone und ihres Beamtentums, den ganzen Byzantinismus, weniger auf kirchliche als auf alte heidnisch-orientalische Einflüsse zurückführen müssen; und wenn in der Auflösung des Westens die Kirchen und Bischöfe oft die Funktionen des Staates übernehmen, so ist das nur der Zwang der Notlage und der Ausdruck des Machtverhältnisses, aber keine innere Annäherung der Lebensform des Staates an die der Kirche. Vollends von einer Neigung zu politischem Individualismus kann keine Rede sein, wenn auch in wissenschaftlicher und ästhetischer Hinsicht, vielleicht auch im Familienleben, das Individuell-Persönliche sich stärker entwickelt, übrigens im Einklang mit der ganzen späthellenischen Entwickelung, die von der Kirche in sich aufgenommen worJen ist ${ }^{70}$ ).

70) Vgl. Gierke, Genossenschaftsrecht III 122-186; über die Umfärbung der ioziologischen Grundgefühle feine Bemerkungen in dem Abschnitt vertus nouvelles sei Thamin S. 250-278. S. auch die berühmte Stelle bei Lactanz V I5 und 16 iber die Gleichheit, die das Wesen der von den heidnischen Morallehrern vercannten, ja auch bei Cicero nicht recht aufgefaßten Gerechtigkeit sei. Den Christen st dies enthüllt. Aber praktische Konsequenzen zièht auch Lactanz nicht aus der İleichheit: dicet aliquis nonne sunt apud vos alii pauperes, alii divites, alii servi lii domini? nonne aliquid inter singulos interest? nihil nec alia causa est cur nobis nvicem fratrum nomen impertiamus, nisi quia pares nos esse credimus. nam cum 
So darf man in der alten Kirche nur nach der prinzipiellen Zurechtlegung des Verhältnisses von Kirche und $\mathrm{Re}$ ich Gottes einerseits und $\mathrm{Sta}$ at und Welt a ndererseits als von zwei innerlich wesensgetrennten und durch diese Wesensgetrenntheit an einer gegenseitigen Durchdringung gehinderten Größen suchen ${ }^{21}$ ). Hier ist nun das Problem, wic sich bisher schon an verschiedenen Punkten gezeigt hat, ein eigentümliches Doppelproblem, nämlich einerseits die weitgehende Anerkennung der Welt und ihrer Ordnungen nach den stets zu Grunde gelegten Sätzen des Paulus, andererseits die grundsätzliche Verwerfung der Welt und des Staates als eines Erzeugnisses der Sünde und des Reiches der Dämonen. Dabei ist die Grundvoraussetzung die Gleichsetzung des Staates und der Gesellschaft mit der "Welt . Das oben geschilderte Kontrastbild, das die allein wahre Erlösungsgemeinschaft sich schuf in dem Begriffe der sündigen und verlorenen Welt, bestimmt sich bei der wachsenden Notwendigkeit praktischer Auseinandersetzung immer näher als Inbegriff des Staates und der Gesellschaftsordnung. Nachdem die

\footnotetext{
omnia humana non corpore sed. spiritu metiamur, tametsi corporum diversa sit condicio, nobis tamen servi non sunt, sed eos et habemus et dicimus spiritu fratres, religione conservos. divitiae quoque non faciunt insignes, nisi quod possunt bonis operibus facere clariores ... cum igitur et liberi servis et divites pauperibus $\mathrm{h} u \mathrm{mil}$ it at e a $\mathrm{nimi}$ pares simus, apud deum tamen virtute discernimur: tanto quisque sublimor est, quanto justior ... si non tantum quasi parem, sed etiam quasi minorem se gesserit, utique multo altiorem dignitatis gradum Deo judice consequetur. nam profecto in hac vita saeculari brevia et caduca sunt omnia. Hier ist der folgenschwere Schritt getan, die Gerechtigkeit als Gleichheit $z \mathbf{u}$ interpretieren, aber die Gleichheit ist noch rein auf das religiöse Gebiet eingeschränkt, wo ihr Rationalismus von selbst seine Grenzen findet.

71) Vỵl. K. J. Neumann, Der römische Staat und die allgemeine Kirche I r900; Gierke III 122-128; I Iarnack, Mission I 206-227; Bigelmair 76-124; Hergenröther, Katholische Kirche und christlicher Staat 1872 . Weinel, „Stellung des Urchristentums etce. Besonders wichtig ist der erste Band des großen Werkes der Brüder Carlyle. Hier fand ich alles bestätigt, was ich von meinen Kenntnissen aus selbst erschlowen hatte, nur mit einem reicheren Quellenmaterial belegt, als mir zugänc,lich war. J. Carlyle hat sich das letztere mit Hilfe eines Stabes theologischer Helfur beschaff. Die Orientierung seiner Arbeit ist insofern anders, als es ihm nur auf die Bloßlegung der Fundamente des Mittelalters ankommt, während es nir auf das Vurhälmis der sozialen Bildungen $z$ den christlichen Grundideen und Aurgang punkten ankommt.
} 
Wissenschaft teils abgeschlagen, teils christianisiert war und die privaten Lebensformen verchristlicht, die idololatrischen Gesetze beseitigt waren, blieb als In begriff der Welt der Stat a n sich. Die Welt im Sinne des Spätjudentums und des Urchristentums und dann weiter der ganzen alten Kirche ist eben kein kosmologischer Begriff, sondern ein politisch-sozial-historischer. Er bedeutet das Heidentum, die Völker, die außerjüdische Welt, die durch Abfall und Bosheit ein Reich der Dämonen geworden ist und die sich immer mehr zuspitzt in dem großen, den Kaiserkult fordernden Imperium der Cäsaren. Die Stätten des Kaiserkults sind auch für die christliche Apokalypse der Thron des Satans, des Herrschers dieser Welt. Indem dann das Heidenchristentum es wesentlich mit dem römischen Reich zu tun hat, werden die Cäsaren zu den Herren und Repräsentanten der »Welt«. Das Christentum bezeichnet sich selbt als $\beta \alpha \sigma t \lambda \varepsilon i \alpha$, so wird auch sein Widerpart, die Welt, zu einer $\beta \alpha \sigma \lambda \varepsilon^{i} \alpha$, die im Cäsar, im Reichsrecht und Reichskult anschaulich ist. Die Welt wird zum Reich und mit ihm zum Inbegriff der bestehenden Gesetze und Ordnungen. Denn ein Reich ist zugleich Träger von Gesetz und Recht; und mit Gesetz und Recht ist zugleich die ganze Gesellschaftsordnung umfaßt. Die Frage des Verhaltens $z$ u den Gesetzen ist die Frage des Verhaltens zur Welt. Die Welt ist aì̀v oũtos oder saeculum, d.h. der der Wiederkunft Christi vorangehende Geschichtsabschnitt. Mit dem metaphysisch-kosmologischen Begriff der Welt,

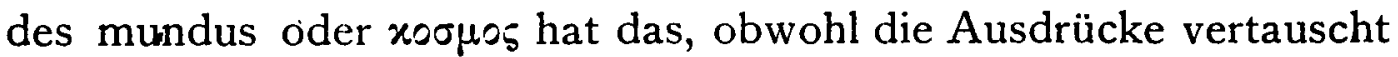
werden, nichts zu tun; die gnostischen Lehren, die die Welt und ihre Sünde aus der Materie und Sinnlichkeit ableiten wollten, wurden abgeschlagen; es bleibt bei der alttestamentlichen Lehre, daß die Schöpfung gut ist, aber die "Welt" vom Sündenfall herkonmt, vom verderbten Willen und der Verführung der Dämonen. Von daher stammt auch der Staat, und er gilt daher von diesem Anfang an zugleich mit den Ordnungen von Ehe, Arbeit, Eigentum, Sklaverei, Recht und Krieg als das einheitliche und wesentlich unveränderliche Prinzip der »Welt «; alle natürlich auch von den Christen beobachteten Veränderungen, der Uebergang des Weltreichs vom Orient nach Rom, dann der Zusammenbruch der altrömischen Tradition und die Orientalisierung des Reiches seit den Severern, die neue Verfassung und Verwaltung Diokletians, ändern nichts an seinem Prinzip; und auch die Verchristlichung hat daran nichts geändert, sofern der Staat als Staat, und 
nicht als der von der Kirche zu lenkende, geheiligte und entsühnte Diener, als der von ihr beseelte Leib, in Betracht kommt. Was von der Welt gilt, gilt daher auch vom Staate, er ist gut und böse zugleich, wie sie ${ }^{72}$ ).

72) Einfach und charakteristisch zum Ausdruck gebracht in den Akten der scilitanischen Märtyrer, wo der Christ Speratus auf die Aufforderung zum Schworren

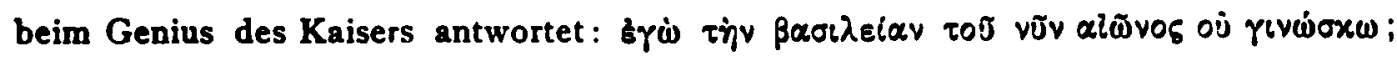
die Zusammengehørigkeit von saeculum und Kaisertum in einer viel zitierten Stelle Tertullians: set Caesares credidissent super Christo, si aut $\mathrm{Ca}$ es a res $\mathrm{n}$ on e ssent necessarii saeculo, aut si et Christiani potuissent esse- Caesares Neumann 149. Als das letztere eintrat, blieb doch der erstere Gedanke bestehen. Derselbe Tert. sagt im gleichen, freilich absichtlich freundlich gestimmten Apologeticum, >die Christen ordnen den Kaiser Gott, aber nur Gott unter, er ist nach ihm der erste und steht über allen Heidengöttern. Er ist von Gott auserwhhlt und eingesetzt und dankt ihm seine Größeর, Neumann 150.' Daß es seine Größe ist, dem Reich der Sünde vorzustehen, übrigens doch auch diesem weltliche Ordnung zu geben, ist dabei der Hintergedanke. Die Frage nach der Stellung zur Welt ist daher identisch mit der Frage nach der Stellung $z \mathfrak{u}$ den, $\mathrm{Ge}$ setzene des Imperiums, Neumann 115 und 168. Aber auch nach der Reinigung der Gesetze des Imperiums gilt von ihm der Gesamtcharakter der terrena civitas: Invenimus ergo in terrena civitate duas formas: unam suam praesentiam demonstrantem, alteram coelesti civitati significandae sua praesentia servientem. Parit autem cives terrenae civitatis peccato vitiata natura, coelestis vero civitatis cives a peccato naturam liberans gratia. . I Ibi humanus usus ostenditur, hic divinum beneficium commendature. Augustinus De civ. Dei XV 2. Das ist die Doppelseitigkeit aller Staaten, die des israelitischen dereinst und jetzt des römischen christlichen, der unter der ersten forma $z u$ dem allgemeinen, in sich gleichartigen Typus der civitas terrena gehört. Das letztere ist ausdrücklich ausgesprochen De civ. Dei XVIII, 2, I : Societas (d. h. die civitas terrena) igitur usquequaque mortalium diffusa per terras et in locorum quantislibet diversitatibus, un $\mathrm{u}$ s $\mathrm{ta}$ m $\mathrm{n}$ ejusdemque natutae qua edam communione devincta .. adversus se ipsam plerumque dividitur et pars partem, quae praevalet, opprimit.. sed inter plurima regna terrarum, in quae terrenae utilitatis velcupiditatis est divisa societas (quam civitatem mundi hujus universali vocabulo nuncupamus) dua regna cernimus longe caeteris provenisse clariora, Assyriorum primum deinde Romanorum. . Nam quo modo illud prius, hic posterius, eo modo illud in Oriente (d. h. Nimrod) hoc in occidente surrexit. denique in illius fine hujus initium confestim fuit. Regna caetera ceterosque reges velut appendices istorum dixerim. Das heißt die, Welte ist praktisch identisch mit dem römischen Staat. Das Gleiche gilt aber auch ron den römischen Juristen bis Justinian. TThe Roman lawyers indeed usually deal with the matter only from the point of view of the Roman common- 
Die Doppelstellung zu dieser $*$ Welt $*$ ist daher immerdar eine gleichzeitige und 'in denselben Personen stattfindende; sie verteilt sich nicht auf verschiedene Lehrer, sondern ist allen eigentümlich, nur in ihren Bestandteilen verschieden accentuiert. Man mißversteht alles, wenn man das nicht beachtet und für prinzipielle Unterschiede hält, was nur Nuancen sind; das gilt auch von den großen Theologen des christlichen Kaiserreiches und von ihnen mit ihren Versuchen prinzipieller Formulierungen erst recht. Das gilt schon von den grundlegenden Sätzen des Paulus, der den Gläubigen in der Welt als Fremden und Pilgrim wandeln läßt und zugleich die Obrigkeit als von Gott zum Guten verordnet betrachtet. Nach den ersten blutigen Zusammenstößen mit der Staatsgewalt lodert freilich in der Apokalypse ein die jüdische Apokalyptik und den heidenfeindlichen Messianismus in sich aufnehmender fanatischer Staatshaß auf und kehrt dann in mancherlei einzelnen Erscheinungen wieder; aber mit dem Montanismus wird das endgültig ausgeschieden. Die eigentliche Hauptentwicklung bewegt sich weiter auf der von Paulus vorgeschriebenen Linie. Aber da zeigt sich dann erst recht die hierin enthaltene Doppelrichtung, einerseits Anschluß an die bestehende Ordnung, andererseits schroffster Gegensatz gegen den im Kaiserkult, im Verbot der christlichen Vereine und in seiner grausamen Christenverurteilung sich dämonisch offenbarenden Staat. Je nach Friedensoder Verfolgungszeiten, auch je nach Temperament und Denkweise der Lehrer schwanken die Bestimmungen, stets aber ist beides beisammen. Auch in den schwersten Zeiten der grauenvollen und bewunderungswürdigen Martyrien, in denen sich trotz aller Gemeinsamkeit mit vielen Strömungen der Spätantike doch ein besonderer Geist des Christentums heroisch und glaubenschaffend zeigt, wird man an dieser Doppelnatur nicht irre; man betrachtet die Leiden als Prüfungen und Strafen oder als Anfeuerungsmittel, zu denen sich Gott der Hand des Staates bedient, ohne daß'dessen Ordnung im Ganzen aufhörte, gut und von Gott zu sein. Als dann der Staat sich überwunden erklärte und die Kirche in sein eigenes Gefüge aufnahm, da fielen die ungerechten und mit Götzen-

wealth . . and, after all, the Empire was to the Roman much the same as the world. The principles which belonged to it were at least the principles of the civilised world, and their application to the conditions of the world at large was natural and easy.e Carlyle 70. 
dienst befleckenden Gesetze weg, und konnte die Güte der Staatsordnung sehr viel nachdrücklicher anerkannt werden. Aber wie in der Leidenszeit die Güte; so verschwand in der jetzt anbrechenden Glanzzeit nie die Schlechtigkeit und Sündhaftigkeit des Staates aus den Augen der Kirchenlehrer.

Es ist ein Widerspruch, der irgendwie gelöst werden mußte. Praktisch ist er wohl verständlich. Es kommt darin die ursprüngliche Weltindifferenz des Evangeliums, die apologetische Erweiterung des Gegensatzes zu dem Gegensatz einer verlorenen sündigen und einer erlösten heiligen Menschheit und schließlich die asketisch-dualistische Umfärbung dieses Gegensatzes zu dem der Körper- und Sinnenwelt und der Welt geistlicher und jenseitiger Uebersinnlichkeit zum Ausdruck. Aber ebenso kommt darin zur Geltung der von der Praxis, von der Größe und Ausbreitung, von der Verflechtung der Kirche in das Gemeinleben aufgezwungene Kompromiß mit der Welt, der ein inneres Recht insofern gegenüber dem grundlegenden Prinzip behält, als dieses die Welt als Gottes Schöpfung betrachtet und ein Minimum der weltlichen Lebensbedingungen als Voraussetzung und Mittel der-eigentlichen ethischen und religiösen Werte immer festhält. Alles dreht sich um Gestaltung und Umfang dieses Minimums; an dieser Frage gehen die großen Gruppen auseinander: die Hauptentwickelung und die offizielle Lehre dehnen dieses Minimum beständig aus unter Aufrechterhaltung der prinzipiellen Ueberweltlichkeit, das Mönchtum schränkt es auf das denkbare Mindestmaß ein unter Verzicht auf Anteilnahme am großen Weltleben und unter Anerkennung einer niedrigeren Stufe der Weltsittlichkeit neben sich. Der Widerspruch ist verständlich, aber trotzdem unerträglich, und die Lehrer der Kirche hätten nicht die zwar einseitigen, aber schatfen und großen Denker sein müssen, die sie waren, wenn sie nicht den Widerspruch theoretisch zu lösen versucht hätten.

Indem der Staat mit seinen Gesetzen das ganze soziale System festlegt und darstellt, ist die Frage die nach dem Wesen der „G e s e t $z$ e . Hier hatte man in der älteren Literatur sich beruhigt bei den beiden biblischen Sätzen, daß die Obrigkeit ihre Gewalt von Gott habe zum Zweck der bürgerlichen Ordnung und daß man im Konfliktsfalle Gott mehr gehorchen müsse als den Menschen. Diese Sätze aber schafften nicht hinreichende Klarheit. Denn einmal waren sie rein dogmatische Behauptungen, ohne eine allgemeine prinzipielle und im Zusammenhang mit der 
religiösen Idee durchsichtige Begründung; und zweitens gaben sie für alle Fälle, die über den Zusammenstoß mit den den heidnischen Kult fordernden und die Christenvereine verbietenden Gesetzen hinausgingen, keine Entscheidung. Trotz der paulinischen Formeln konnte hier der christliche Prophet und Traktatschreiber Hermas die Gesetze der Gottesstadt und die der Weltstadt in schärfsten Gegensatz stellen: „Willst du wegen deiner Aecker und der übrigen Habe dein Gesetz gänzlich abschwören und nach dem Gesetz dieser (Welt-) Stadt leben? Siehe zu, daß es dir nicht zum Verderben wird dein Gesetz zu verleugnen ... $\mathrm{Da}$ du in der Fremde wohnst, so erwirb dir nicht mehr als das Nötigste und gerade Hinreichende und mache dich bereit, damit du, wenn der Herr dieser (Welt-) Stadt dich wegen Widersetzlichkeit gegen sein Gesetz verbannen will, du seine Stadt verlassen und nach der deinigen fortziehen und nach deinem eigenen leben kannst, ohne Mißhandlung zu erdulden, in großer Freude. * Auch der Hebräerbrief stellt die Gottesstadt und die Weltstadt einander scharf gegenüber ${ }^{72 a}$ ). Sobald diese schwersten Kämpfe überstanden waren und es auf die Anpassung an das gesetzliche soziale System überhaupt ankam, bedurfte man einer allgemeinen von den Christen anzueignenden Theorie über Begründetheit und Geltungsmaß der Gesetze «. Hier sind es erst die Apologeten, die, wie sie christliche und stoische Ethik überhaupt verschmelzen, so auch die Gesetze der Weltstadt mit denen der Gottesstadt wenigstens bedingungsweise in inneren Zusammenhang bringen ${ }^{72 b}$ ).

72 ^) Hermas, Sim 1. Hebr. 11, 16. Die Bezeichnung der Welt und der Kirche als $\pi \dot{\delta} \lambda_{i \zeta}$ oder civitas bedeutet auch zwei Gesetzgebungen oder auch zwei verschiedene Sitten. S. Weinel, Stellung S. 52 und 63.

${ }^{72}$ b) S. Weinel S. 6I: „Eigentlich erst die Apologeten üben solchen Sprachgebrauch (die beiderseitigen vónor aufeinander zu beziehen), und bei ihnen stehen als "Gesetzgeber « mindestens ebenso oft die Philosophen als die Staaten dem Christentum gegenüber. Immerhin gibt es bezeichnende Stellen genug. Nur daß eben die Apologeten schon die staatliche Gesetzgebung ähnlich wie auch die Philosophie als Elemente und Vorstufen christlicher Gesetze oder des Gesetzes Gottes anzuerkennen geneigt sind. Freilich sind ihnen diese Staatsgesetze elementar und ziemlich unwirksam (Justin I I2), vor allem auch $2 u$ verschieden unter einander, ja einander entgegengesetzt; denn auch =Schädliches \& ist gesetzlich geboten II 9. Die Dämonen sind es ja, die zum Teil diese Gesetze gaben, wie denn auch die Träger des Ideales schon vor dem Christentum, Männer wie Heraklit und die Stoiker, immer wieder von der Behörde verfolgt worden sind II 8«. Die 
Das. mit dem christlichen Sittengesetz identifizierte Naturgesetz und Naturrecht der Stoa gibt das Auskunftsmittel. Bei den Stoikern und den von ihnen beeinflußten Juristen war, wie bereits früher angedeutet, das positive Recht und Gesetz als Ausfluß des aus der göttlichen Natur und Vorsehung der Dinge fließenden Naturgesetzes und Naturrechtes betrachtet worden und die Geltung der Gesetze auf das Maß des in ihnen ausgeprägten naturrechtlichen Gehaltes begründet. Indem den gebildeten Christen dieses Naturgesetz als die Schöpfungsordnung, als der Inhalt des Dekalogs und als Bestandteil des christlichen Sittengesetzes und des in Christus inkarnierten Logos erschien, stellte sich ihnen auch jenes Naturrecht geradezu als eine christliche Lehre dar. Damit war aber dann die allgemeine Begründung und die kritische Regel für die Geltung der *Gesetze* gegeben. Hatte man früher beim Gesetz fast nur an das mosaische Gesetz und etwa auch an das neue Gesetz Christi gedacht, dagegen die Gesetze des Staates sich selbst überlassen, so wurde nun die Kritik der Gesetze des Staates, ihre bedingte Anerkennung und Verschmelzung mit dem christlichen Gesetz und ihre bedingte Verwerfung als von Dämonen und Sünde getrübt, eine Aufgabe der christlichen. Literatur und Praxis. Nach dem zögernden Vorgang der Apologeten spricht hier klar und deutlich der große Origenes. Er fand bei dem heidnischen Polemiker Celsus den Christen den Gedanken des stoischen Naturrechtes und seiner Verkörperung in dem Gesetzessystem des Staates vorgehalten, wobei Celsus von den Christen die Unterwerfung unter dieses Gesetz fordert und von ihrer Weltfeindschaft Verödung und Verarmung des Staates befürchtet. Origenes eignet sich den Gedanken des Celsus durchaus an, betont dann aber die Inkongruenz der bestehenden positiven Gesetze gegen die Regel des Naturgesetzes und Naturrechtes. Soweit die Staatsgesetze mit dem letzteren übereinstimmen, sind sie gut und göttlich, soweit sie es nicht tun, sind sie ungöttlich und verdienen keinen Gehorsam. >Den staatlichen Gesetzen darf man nur dann gehorchen, wenn sie mit dem göttlichen Gesetz übereinstimmen; wo aber das geschriebene Gesetz des Staates etwas anderes befiehlt als das natürlich-göttliche Gesetz, da muß man das erstere verabschieden und allein der Wei-

Apologeten bedeuten, daß die wissenschaftlich gebildete Oberschicht das Wort nimmt und $\mathrm{da}$ ist nun begreiflicherweise weder die alte Gegensätzlichkeit noch die Unbestimmtheit des paulinischen Prinzips mehr möglich. 
sung Gottés folgen.* Das Verbot der christlichen Vereine und die Forderung des Götzendienstes geht gegen das natürlichgöttliche Gesetz und ist mehr ein skythisches Barbarengesetz als ein Rechtsgesetz. In dem letzteren Satz drückt sich auch charakteristisch die Voraussetzung aus, daß das römische Recht von Rechts wegen dem natürlichen entsprechen müsse und daß die Christengesetze der Römer eigentlich barbarisch und der Römer unwürdig sind. Damit ist der Weg einer Begründung und einer Begrenzung der Gesetze betreten, auf dem wir nach und nach alle Kirchenväter finden. Lactanz hat die gleiche Lehre im Anschluß an Cicero begeistert vertreten, und ihr folgen unter.Anschluß an Cicero alle abendländischen Lehrer, auch das Gesetzbuch Justinians. In der Zeit nach Konstantin wird die Anerkennung des Satzes mit der Verchristlichung des Staates allgemein, und die endgültige Akzeptierung des Staates beruht auf der ethisch-juristischen Theorie, daß seine Gesetze aus dem göttlichen, mit dem Dekalog identischen, Naturrecht hervorgehen ${ }^{73}$ ).

73) Die Stellen des Orig e nes bilden Ausgangspunkt sowohl bei Neumann

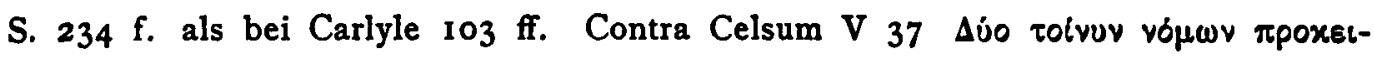

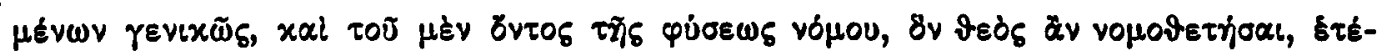

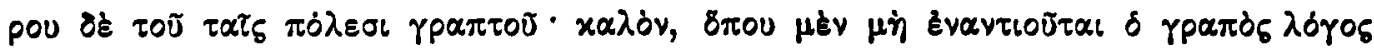

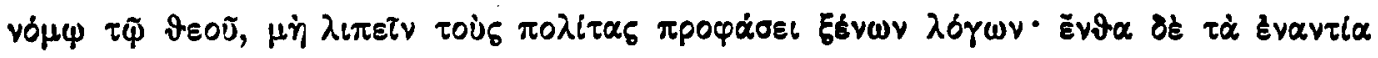

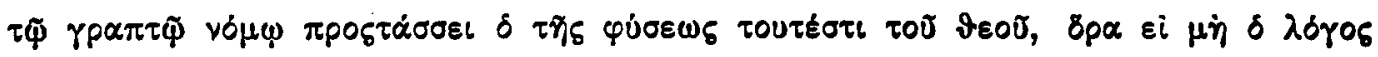

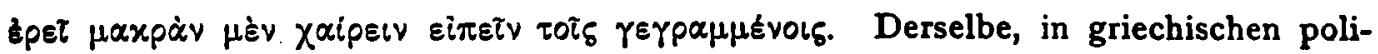

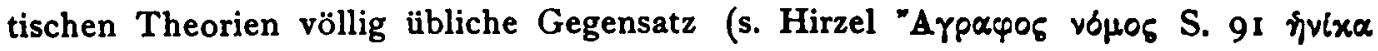

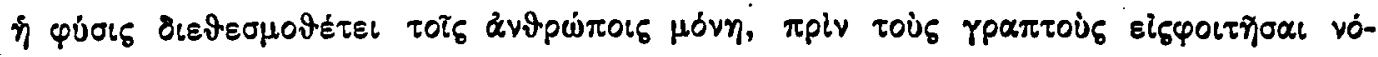
HO0६) kehrt als offenbar technische Lehre bei Origenes ofter wieder contra Celsum VIII 26 und VIII 75. Neumann führt noch eine sehr charakteristische Stelle aus dem Kommentar zum Römerbrief IX 26 und 27 an, auf die O. selbst c. C. ViII 65 hinweist. Er sagt zu Röm. 13, I-2: $>$ Non est enim, inquit (Paulus), potestas nisi a Deo«, dicet fortasse aliquis: quid ergo ? et illa potestas, quae servos dei

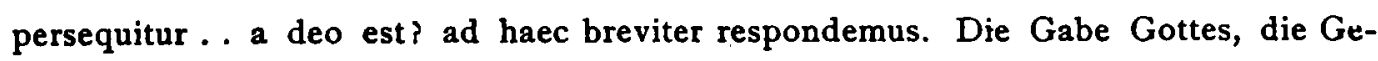
setze, sind zum Gebrauch, nicht zum Mißbrauch. Erit autem justum judicium Dei erga eos, qui acceptam potestatem secundum suas impietates et non secundum $d i$ $\mathbf{v}$ in a s temperant 1 e ges .. Non hic (Paulus) de illis potestatibus dicit, quae persecutiones inferunt fidei: ibi enim dicendum est, sdeo oportet obtemperare magis quam hominibus, sed de ist is communibus dicite. Bei Origenes hat der Gedanke eine stark polemische Spitze, man fühlt aber unmittelbar auch seine Möglichkeit konservativer Deutung. Diese tritt mit dem Frieden von Staat und Kirche immer deutlicher hervor; dabei zeigt sich dann bei den Abendländern der Einfluß Ci- 
Allein damit scheint nun aber doch fast $z u$ viel bewiesen, damit scheint der Staat vergöttlicht zu sein. Das war natürlich

ceros und der Juristen. Hier wird der Staat aus dem Sozialtrieb des Naturgesetzes und sein Gesetz aus dem göttlichen Naturgesetz abgeleitet, wobei natürlich immer die Schwierigkeit des Widerspruchs des positiven Gesetzes gegen das Naturrecht auftaucht. Darüber s. weiter unten. Die berühmte Stelle des Lactanz, wo Ciceros Naturrecht verherrlicht wird Inst. VI 8, ist bereits angeführt: nec vero aut per senatum aut per populum solvi hac lege possumus neque est quaerendus explanator aut interpres Sextus Aelius nec erit alia lex Romae alia Athenis, alia nunc, alia posthac. Dazu die Ausführung VI 10 Deus .. animal nos esse voluit sociale. . . causa coeundi ipsa potius humanitas . natura hominum societatis ac communionis appetens VI II conservanda igitur est humanitas (die Natur als Begründerin der Staatsgemeinschaft und ihrer Gesetze) .. discordia igitur ac dissensio non est secundum hominis rationem verumque illud est Ciceronis, quod ait hominem naturae oboedientem homini nocere non posse. Das ist das Wesen des wahren jus und der wahren justitia. Epitome Inst. 53 si enim nos idem Deus fecit et universos ad justitiam (die naturgemäße societas) vitamque aeternam pari condicione generavit, fraterna utique necessitudine cohaeremus. Es ist aber der Irrtum der Philosophen und Juristen, daß sie diese societas juris nur nach dem irdischen, statt nach dem himmlischen Nutzen bemessen. Die gleíche Kritik halber Zustimmung und halber Verbesserung übt Inst. 3,8 an dem Begriff des naturae convenienter vivere. Ebenso Augustin De civ. XIX 12 homo fertur quodam modo naturae suae legibus ad ineundam societatem pacemque cum hominibus quantum in ipso est, omnibus obtenendam. De bono conjugali I: Lnusquisque homo humani generis pars est et sociale quiddam est natura magnumque habet et naturale bonum. De civ. XIX 5:- quod autem socialem vitam volunt (philosophi) esse sapientis, nos multo amplius approbamus. De lib. arb. 6: nihil est in lege temporali justum, quod ex lege aeterna non derivetur. De vera religione $3 \mathbf{I}$ : Conditor legum temporalium, si vir bonus est et sapiens, illam ipsam consulit aeternam, de qua nulli animae judicare datum est, ut secundum ejus immutabiles regulas quid sit pro tempore jubendum vetandumve discernat. Contra Faustum 22, 7: Lex vero aeterna est ratio divina aut voluntas Dei ordinem naturalem conservari jubens perturbari vetans. Die Eigentumsrechte gelten durch kaiserliches Recht, stammen aber zuhöchst von Gott, von welchem diese menschlichen Rechte herrühren, durch die Fürsten vermittelt, Reuter >Augustinische Studien $\propto$ I 887 S. 382 . De civ, II 21,2 nimmt A. Ciceros Definition des Staates spopulum non omnem coetum multitudinis, sed coetum juris consensu et utilitatis communione sociatum esse \& referierend auf, 19, 2 I kommt er darauf zurück und leugnet, indem er den Begriff akzeptiert, daß nach ihm das heidnische Rom ein wirklicher Staat gewesen sei, da ihm bei seinem Heidentum und seinen Greueln die wirkliche justitia gefehlt habe, aber das ist nur die Verurteilung des naturwidrigen positiven Rechtes. An anderen Stellen schlägt er den naturrechtlichen Gehalt der römischer Gesetze, der trotzdem besteht, sehr 
nicht die Meinung der Kirchenlehrer. In dem Maße als praktisch die Kirche den Staat und die Gesellschaft akzeptierte, mußte sie erst recht auch ihren inneren Gegensatz gegen dieses Naturrecht empfinden und wahren, das in Sklaverei, Handel, Gewalt und Rechtshärte doch dem sozialen Ideal der Kirche gründlich widersprach, wie wir bereits bei den einzelnen Geboten gesehen haben.

viel höher an. Seine eigene Definition gibt er 19, 24 ^populus est coetus multitudinis rationalis, rerum quas diligit concordi communione sociatus «. Hier ist die justitia ausgelassen, weil ihm das zu absolut dünkte, dagegen die ratio belassen, weil diese als mehr oder weniger betrachtet werden kann; denn der populus ist tanto utique melior, quanto in melioribus, tantoque deterior quanto in deterioribus concors. So will er auch den heidnischen Römerstaat einen Staat nennen quamdiu manet qu a l is cunque rationalis multitudinis coetus. Ganz in die gewöhnliche naturrechtliche Lehre der Väter mündet dann die interessante Stelle De diversis quaestionibus 3 I ein: Justitia est habitus animi communi utilitate conservata suam cuique tribuens dignitatem. Ejus initium est ab natura profectum. deinde quaedam in consuetudinem ex utilitatis ratione venerunt: postea res et ab natura profectas et a cónsuetudine probatas legum metus et religio sanxit. Natura jus est, quod non opinio genuit, sed quaedam innata vis inseruit ut religionem pietatem, gratiam, vindicationem, observantiam, veritatem. So werden die Wahrheitsmomente der heidnischen Religion, Moral und des Gesetzes auf die Natur zurückgeführt. Aus dem ungeschriebenen Zustand geht das dann in den geschriebenen über: quod genus pactum est, par, lex, judicatum. - Die Quellen von alledem liegen in der griechischen Lehre vom vónos äpạ̧os s. Hirzel und vor allem in der Lehre Cicèros, Senecas und der römischen, stoisch beeinfußten Juristen; hierüber Carlyle I, I-78; K. Hildenbrand, Geschichte und System der Rechts- und Staatsphilosophie I I860, M. Voigt, Die Lehre vom jus naturale der Römer 1856, Zielinsky, Cicero im Wandel der Jahrhunderte 1897. Bei den Vätern ist nur gegenüber dem heidnischen Staate die Würdigung des positiven Rechtes aus dem Naturrecht sehr viel schwieriger, daher viele Schwankungen und widersprechende Aeußerungen, was namentlich von Augustin gilt. Gegenüber dem christlich gewordenen Staate aber ermöglicht die Lehre eine sehr konservative Stellung, vor allem unter den gleich weiter zu schildernden näheren Bestimmungen. Mit dem Gesetzbuch Justinians und den Definitionen des Isidorus Hispalensis geht die Lehre dann ins Mittelalter, über Justinian s. Carlyle I 7 $\mathbf{I}-79$, Stellen aus Ambrosius, dem Ambrosiaster, Hilarius und besonders Isidor ibid. I I04-110 SSt. Isidore has obviously reproduced with certain changes of detail the theory of the tripartit: character of law (jus naturale als reines, urständliches Naturrecht, jus gentium als das überall vorhandene, aber getrübte Naturrecht, jus civile als die besondere Formung des Naturrechts im positiven Recht) which we have alveady seen in the works of Ulpian and in the Institutes of Justinian. With this work the conception passes into the common stock of mediaeval tradition. I I 0 .

Troeltsch, Gesammelte Schriften. I. 
Das hat sie denn auch in der Tat gründlich getan. Aber es ist nicht mehr einfach der alte Protest, sondern auch hier ergeben sich neue Gedanken, indem sie auch hier dem Vorbild der Stoa folgt, die gleichfals ihrerseits bei ihrer Theorie von der Begründung der bestehenden Gesetze im Naturgesetz sich den Gegensatz des Bestehenden gegen ihr humanes Sozialideal nicht hatte verbergen können und daher für diesen Widerspruch einen Ausweg gesucht und gefunden hatte. Der Ausweg hatte für sie in der Unterscheidung der Urzeit oder des goldenen Zeitalters von der Folgezeit gelegen. In der Urzeit hatte das Naturgesetz voll gewaltet ohne Sklaverei, ohne Gewalt, ohne Besitzgegensätze, wobei die einen mehr eine wirkliche Vollkommenheit der Freiheit und Gleichheit, die anderen mehr eine kindlich unschuldige, aber noch entwickelungsbedürftige ethische Normalität annahmen. Erst Selbstsucht, Geiz, Gewalttat, schlechte Gesetze haben dann die gegenwärtige Lage herbeigeführt, in der das Naturrecht nur getrübt und entstellt zum Ausdruck kommt. Verzweifelnd an der Durchführung ihres Sozialideals in der Gegenwart haben sie es in die Urzeit geflüchtet und der Gegenwart nur aufgegeben, die positiven Gesetze möglichst dem Naturgesetz anzupassen. Diese Gedanken haben nun die christlichen Lehrer einmütig aufgegriffen und mit ihrem biblischen Gedanken vom vollkommenen Urstand vereinerleit, wobei die Naht deutlich genug sichtbar geblieben ist: der biblische Urstand kennt nur ein Menschenpaar, die kirchliche Lehre vom dort vorhandenen absoluten und vollen Naturrecht setzt aber mit den Stoikern eine Mehrheit von vielen Menschen voraus; und beides vereint sich nur dadurch, daß die Kirche lehren muß, daß ohne Sündenfall die Menschheit sich so entwickelt hätte. Nicht minder kommt die Naht darin zum Vorschein, daß in diesem Zusammenhang nach dem Vorbild der Stoiker der Urstand vor allem Freiheit, Gleichheit und Abwesenheit des $Z$ wanges zeigt, während die kirchliche Urstandslchre, wo sie nur ihren eigenen Impulsen folgt, die religiöse V'ollkommenheit, die Gottesliebe, die Demut und den Gnadenstand betonen muß. Aber der Gedanke war für die Väter so befrciend und erleuchtend, daß sie ihn gleichwohl nachdrücklichst übernahmen. Alle von ihrem Prinzip aus unerträglichen sozialen Institutionen sind, wie wir im einzelnen bereits gesehen haben, aus den Urfreveln der Menschheit entstanden: die patriarchalische Männerherrschaft, der Privatbesitz, die Sklaverei und 
letztlich das Prinzip des Ganzen, der Staat, sind aus der Sünde entstanden, wobei in die stoische Geschichtsphilosophie die $\mathrm{Pa}$ triarchengeschichte mit dem Fluch der Paradiesesaustreibung, mit Kain, Ham und Nimrod naiv hineingearbeitet wird. Der römische Staat ist der Nachfolger des nimrodschen babylonischen Staates und wird als Träger der bestehenden Gesetze dauern bis zur Wiederkunft Christi ${ }^{74}$ ).

74) Die Lehre vom reinen Naturrecht des Urstandes mit Freiheit und Gleichheit bis in die Familie hinein ist allgemeine Lehre der späteren Väter und in dem Maße hervorgetreten als die Zurückführung des bestehenden Staates auf das Naturrecht den Abstand vom reinen Naturrecht zu betonen nötigte. Stellen bei Overbeck, Sklaverei, I98-201, Uhlhorn, Liebestätigkeit I 292 f., Carlyle I 11 I-I46; Sommerlad 95-170; besonders ausführlich nach Theodoret S. $165 \mathrm{f}$. Es sind stets die Fragen nach dem Eigentum, der Sklaverei, der Familiengewalt, der Staatsgewalt, die darauf führen. Ueber die auch hier zu Grunde liegende stoische Lehre s. Hirzel 84-9I, Pöhlmann, Gesch. d. antiken Kommunismus II 607 bis 614 und besonders Carlyle $\mathrm{I} I-32$ über Cicero und Seneca. Cicero rechnet mit einem Urstand der vollen Gleichheit und der Vollkommenheit, aus dem heraus das gegenwärtige Recht mit Sklaverei, Eigentum, Gewalt und Staatsgesetz erst durch eine allmähliche Verschlechterung entsprungen ist. Seneca rechnet mit einem Urstand, der weniger vollkommen als der Entwickelung zur Vollkommenheit fähig, jedenfalls aber durch Unschuld und kindliche Glückseligkeit ausgezeichnet war und keinen Zwang kannte. In der Entwickelung ist dann die Sünde hervorgetreten, aber zugleich mit ihr die die Sünde bekämpfende, aus dem Naturrecht stammende Staatsordnung als Heilmittel gegen die Sünde und Mittel der Erreichung eines besseren Zustandes. Höchst interessant sind die hier einschlagenden und für die Väter überaus bedeutsamen Lehren der Juristen. Sie leiten das positive Recht zunächst einfach aus dem jus naturale $a b$, geraten aber bei der Frage nach der Vernünftigkeit der herrschenden Gesetze, namentlich der Sklaverei, vielleicht auch des Eigentums, auf die Einsicht, daß in ihnen die volle Vernunft nicht herrsche, daß diese und mit ihr das jus naturale nur in einem besseren Urstand geherrscht haben könne zusammen mit der natürlichen Gleichheit aller vernunftbegabten Menschen. Deshalb unterscheiden sie vom reinen und absoluten jus naturale das getrübte und unter den Bedingungen der Verschlechterung, der malae consuetudines, stehende relative Naturrecht oder das jus gentium. Das positive Recht oder jus civile ist dann die positive Gestaltung des getrübten Vernunftrechtes im empirischen Recht. Das ist dann in das Corpus Justinianeum und in die Literatur der Väter einfach übergegangen; vgl. die vorige Anmerkung. Carlyle I 33-79. Inst. II I, I I : Palam est autem vetustius esse naturale jus, quod cum ipso genere humano rerum natura prodidit: civilia enim jura tunc demum coeperunt, cum et civitates condi et magistratus creari et leges scribi coeperunt. Inst. I 2, 2: Jus gentium oinni humano generi commune est. Nam usu exigente et humanis necessitatibus gentes humanae quaedam sibi constituerunt: bella enim orta sunt et captivitates secutae et servi- 
Damit könnte freilich, wie vorhin zu viel, so jetzt wieder zu wcnig bewiesen zu sein scheinen. Die Nachwirkung der ursprünglichen Vernunft in der Gesetzesbildung scheint bei dem absoluten Gegensatz der bestehenden Verhältnisse gegen die ursprüngliche Gleichheit und Freiheit dann doch nicht allzu hoch einzuschätzt werden zu dürfen. In dieser Schwierigkeit tritt nun ein dritter entscheidender Gedanke ein, der erst das Ganze abrundet: der naturrechtliche Gehalt der gegenwärtigen Ordnung ist nicht bloß ein Fortwirken der getrübten Vernunft, sondern er ist die Umformung des Naturrechts, die nach göttlichem Willen unter den Bedingungen der Sünde eintrat. Wo einmal Zügellosigkeit, Ungleichheit, Geiz und Gewalttat eingedrungen ist, kann das Naturrecht nur mehr in Gestalt von Rechts- und Zwangsordnungen auftreten und so gegen die Verderbnis reagieren. Gerade der Rechtsund Zwangscharakter der Gesetze, die das Eigentum schützen, die Massen nach einer Idee des Rechtes organisieren und beherrschen, die Ungleichheiten im Sklavenstande ausprägen, im Kriege die Barbaren und Kulturfeinde züchtigen, ist das Wesen des Naturrechtes unter diesen Bedingungen. Es ist eine Folge, aberzugleich ein Heilmittel gegen die Sünde. Es sichert die Ordnung und die pax terrena mit den allein noch möglichen Vernunftmitteln, und diesem $Z_{\text {weck }}$ entsprechend kann dann das positive Recht doch wenigstens nach dieser zweiten Form des Naturrechtes reguliert werden. Alle Institutionen in Eigentum, Sklaverei, Patriarchalismus, Staat und Militär können und müssen bestehen als Ausdruck gerade der göttlichen Vernunft, sie müssen nur ihrem Sinn entsprechend dem Zwecke der Ordnung und der Heilung der Sünde angepaßt werden. Es ist der wichtige Gedanke, eines re lative $\mathrm{n}$, den Bedingungen der allgemeinen Sündhaftigkeit entsprechenden Naturgesetzes neben dem a b s o l u te n Naturgesetz des Urstandes. Es ist die gemeinsame Lehre der Väter mit selbstverständlichen Nuancen in Einzelheiten. Auch Augustin hat sie ausgesprochen und zu Grunde gclegt, wenn auch aus gleich zu erörternden Gründen, weniger betont als andere; er ist im Zusammenhang mit seiner Erbsündenlehre und seinem Prädestinatianismus auch hier ein einigermaßen

tutes, quae sunt juri naturali contrariae. Jure enim naturali ab initio omnes homimes liberi nascebantur. Ex hoc jure gentium et omnes paene contractus introducti sunt ut emptio, venditio, locatio, conductio, societas, depositum, mutuum et alii innumerabiles. 
vereinzelter Theologe. Aber mit den Kompendien des Isidorus, den Aeußerungen Gregors des Großen ist die Lehre als Grundlehre an das Mittelalter übergegangen. Dabei ist auch in diesem Punkte die kirchliche Lehre in so naher Verwandtschaft mit der stoischen, daß man auch hier geradezu an eine Abhängigkeit zu denken geneigt sein muß. Für die Stoa bestand ja bei ihren verwandten Voraussetzungen genau die gleiche Schwierigkeit, den gegebenen Staat als Ausdruck des Naturrechts zu betrachten und doch dieses gegenwärtige Naturrecht gegen das vollkommene der Urzeit abgrenzen zu müssen. Nachdem schon Cicero angedeutet hatte, daß die Unterwerfung unter geordnete Herrschaft ein Heilmittel gegen Zügellosigkeit und Bosheit sei, hat Seneca den Gedanken ausführlich entwickelt und seinerseits in dieser Reaktion des Naturrechts gegen die Sünde ein Mittel des Fortschritts gepriesen. Bei den Juristen finden sich bis in das Corpus juris hinein Spuren der gleichen Denkweise. Ob die Kirchenväter ihre Lehre auch in diesem Falle dieser Quelle entlehnt haben, ist bei der Spärlichkeit jener Aeußerungen und bei dum Mangel ausdrücklicher Beziehungen auf sie nicht sicher zu sagen. Nachdem sie die Voraussetzungen von der Stoa übernommen hatten, ist die Auffindung dieser letzten Lehre ja auch nahe genug gelegt, und daß die Folgerung selbständig gezogen werden konnte, scheint ihr Vorkommen bereits bei Irenäus zu zeigen. Jedenfalls haben die Väter ihr insofern noch ein besonderes Gepräge verliehen, als sie neben dem Charakter der Institutionen des relativen $\mathrm{Na}$ turrecht's als Heilmittel auch den der Sündenstrafe betonten. Sie hatten damit den Vorteil, die über den Heilungszweck überschießenden Härten dieses Naturrechts und überhaupt die Entartungen dieses Naturrechts im positiven Recht würdigen zu können, die dem Rationalismus der Stoa dauernd Schwierigkeiten bereiteten. Sie nähern sich damit unter Umständen einer stark realistischen Auffassung des positiven Rechtes und des geschichtlichen Staatslebens, das namentlich als Heidentum sich für sie nicht so einfach rationalisieren ließ. Aber wie weit darin z. B. auch Augustin geht, die naturrechtliche Grundlage selbst ist um deswillen nicht aufgegeben ${ }^{75}$ ).

75) Irenaus adv. haer. (Harvey) V. 24 bei Gelegenheit der Versuchungsgeschichte : der Teufel lügt, die Reiche der Welt gehören nicht ihm, sondern Gott, der sie hat entstehen lassen nach dem Sündenfall, um in der zügellosen und selbstsüchtigen Menschheit durch Recht und Gewalt wenigstens ein gewisses Heilmittel gegen die 
Eine Frage aber ist bei alledem noch nicht beantwortet, die freilich zunächst praktische Bedeutung nicht hatte, aber sie stei-

Sünde zu schaffen. Ebenso Lactanz Inst. Epit. 54: Der Sündenfall hat die societas inter se hominum, das vinculum necessitudinis zerbrochen. Dann bildeten die Menschen Gesetze pro utilitate communi, ut se interim tutos ab injuriis facerent. Es ist die gemeinsame Lehre von Ambrosius, Augustin, Gregor dem Großen, Isidor, Carlyle I 130. Besonders ist auch Augustin so zu verstehen, wie auch Reuter, Aug. Studien 138 hervorhebt. Reuter weist eingehend nach, daß der Staat für Augustin zwar nach absolutem Maßstab ein Erzeugnis der dem Urstand entgegengesetzten Sünde ist, $\mathrm{daß}$ er aber nach relativem auch einen gewissen ihm immanenten Vernunftwert behält und in diesem relativen Wert eine durch die Sunde in ihrer Form bedingte Reaktion der Vernunft ist. De civ. 19, 2 I im Anschluß an Cicero: Gewalt und Unfreiheit schließe die vernünftige Gerechtigkeit nicht aus, ideo justum esse, quod talibus hominibus sit utilis servitus et pro utilitate corum fieri, cum recte fit, id est cum improbis aufertur injuriarum licentia; die Sklaverei ist Folge der mit dem Sündenfall eingetretenen Veränderung und zugleich eine Strafe, verum et poenalis servitus e a lege ordinatur, qua e naturalemordinem conservari jubet perturbari vetat: quia si contra eam légem nonesset factum, nihil esset poenali servitute coe r c e $\mathrm{d}$ u m. Daher sollen die Sklaven gerne dienen, donec transeat iniquitas et evacuetur omnis principatus et potestas humana et sit Deus omnia in omnibus. Sehr richtig weist Reuter die Ueberschätzung der bekannten Bezeichnung des Staates als grande latrocinium IV 4 als einer Zurückführung des Staates überhaupt auf die Sünde zurück: »A. meint, der Staat w ü r de einem latrocinium gleichen, wenn die justitia nicht irgendwie darin waltete; er nennt an der einen Stelle (IV 4) das, was nicht Staat ist, Staat, während er an der andern (die schon erwähnte Definition nach Cicero 19, 2I) den positiven Beweis führt, daß der Staat nur da sei, wo die physische Gewalt wenigstens verhältnismäßig durch die selbṣt verhältnismäßige justitia (im Unterschied von der justitiae veritas) geleitet werde 139. All das würde nie fraglich erschienen sein, hätte man Augustin im Zusammenhang der christlichen und stoisch-juristischen Naturrechtslehren betrachtet. Auch hat man für A. im Auge zu behalten, daß seine Erfahrungen mit dem Staat des Honorius $z \mathfrak{u}$ einer allzugroßen naturrechtlichen Verherrlichung des Staates nicht einladen konnten, daß De civitate eine Polemik gegen die Heiden mit mög* lichster Herabsetzung ihres Staates ist und daß die antidonatistischen Schriften gegen die donatistische Verwerfung der Staatseinmischung die positive Seite von Augustins Staatslehre stärker betonen; da ist es aber dann allerdings der christliche Staat, der die natürlichen Gerechtigkeitselemente des Staates durch die wahre christliche Gerechtigkeit stärkt. - Ich fuge nach Carlyle noch einige Stellen bei: Gregor der Grobe Exp. moralis in Job. 21,15: Omnes homines natura aequales sumus, sed accessit dis pensatorio ord ine, ut quibusdam praelati videamur. . variante meritorum ordine (d. h. mit dem Sündenfall) alios aliis dispensatio occulta postponit. - Isidorus Sententiae 47: Propter peccatum primi hominis humano generi poena 
gend erlangen sollte. Es ist die Frage nach dem Wesen und dem Recht der Gewalt, aus der die Gesetze des Staates und damit des jetzt herrschenden relativen Naturrechtes floßen. Diese Gewalt ist faktisch natürlich der $\mathrm{K}$ a is er. Aber die ethische Deutung, Begründung und Eingrenzung dieser Gewalt des Kaisers ist ein offenes Problem. In der alten Zeit begnügte man sich damit, dem Kaiser den Kult und den Gehorsam gegen gottwidrige Gesetze zu versagen, im übrigen aber ihn mit geflissentlich apologetischer Betonung aufs höchste zu ehren als von Gott verordnete Gewalt, gegen die es nur den Ungehorsam des Leidens und Duldens gibt. Wurden nun aber die "Gesetze * auf das Naturrecht zurückgeführt, so mußte auch die die Gesetze erlassende Gewalt aus ihm begründet werden. Bei den Stoikern und Juristen geschah dies in der Tat, indem der demokratische Ursprung der kaiserlichen Gewalt durch Uebertragung der Volksrechte auf den Princeps behauptet und die kaiserliche Gewalt als in dem Maße gerechtfertigt bezeichnet wurde, als sie den Sinn dieser Uebertragung, die Fürsorge für die Ordnung, aufrecht erhält. Dieser naturrechtliche Ursprung aus dem freien und gleichen Volke durch stillschweigende Uebertragung ging noch bis in das Gesetzbuch Justinians über und fand bei den römisch empfindenden Kirchenvätern seinen Nachklang. Damit gehen in die kirchliche Literatur des Naturrechts auch sporadisch die demokratisch-vertragsrechtlichen Begründungen der Staatsgewalt über, freilich vorerst ohne jede praktische Bedeutung. Denn es sind lediglich Gemeinplätze römischen Denkens, gelehrte Reminiszenzen aus philosophischer und juristischer Literatur; irgend eine innere Verbindung dieses naturrecht-

divinitus illata est servitutis, ita ut quibus aspicit non congruere libertatem, his misericordius irroget servitutem . . aequus Deus idto discrevit hominibus vitam, alios servos constituens alios dominos, ut licentia male agendi servorum potestate dominantium restringatur ... Inde et in gentibus principes regesque electi sunt, ut terrore suo populos a malo coercerent atque ad recte vivendum legibus subderent. Da versteht man erst ganz, weshalb jeder Gedanke an Sozialreform fehlen muß. Die entsprechenden Aeußerungen bei Cicero und ganz besonders deutlich bei Seneca s. Carlyle I I 2 und 25. Auch die juristische Unterscheidung des jus gentium von einem jus naturale hat den gleichen Sinn ibid. 6o. - Von der Staatslehre Dantes aus zurückblickend, hat auch Voßler diesen Charakter von Augustins Staatslehre erkannt und als Ausgangspunkt gerade der positiven Würdigungen bezeichnet : - Derselbe Staat, der seinem Ursprung nach Organisation der Sünde ist, wird alsbald seinem $Z$ wecke nach, eine Organisation gegen die Sünde`. Göttliche Komödie I 378. 
lich-demokratischen Gedankens mit dem ganz innerlichen und rein religiös verbleibenden christlichen Persönlichkeitsgedanken findet vorerst nicht statt; eine wirkliche innere Verbindung vollzieht überhaupt erst der radikale Calvinismus. An diesem Punkte, in der Frage nach der Geltung der kaiserlichen Gewalt, ist also der naturrechtliche Gedanke, auch der des bloß relativen Naturrechtes, von den Vätern nicht durchgeführt. Der Grund hierfür liegt unzweifelhaft in der alten religiösen Empfindung, die das Weltleben als Gottes Schickung und Fügung hinnimmt und die kaiserliche Gewalt stets einfach und ohne weiteres als von Gott zugelassen und dadurch eingesetzt betrachtet hat. Hier regt sich in der Weigerung, auf die naturrechtliche Rationalisierung einzugehen, der alte Glaube an den Willensgott, der die Mächte einsetzt nach Belieben. Verstärkt ist dieser Gedanke durch den Hinblick auf die alttestamentlichen Einsetzungen der Könige und durch den Abscheu vor der Konsequenz des naturrechtlichen Gedankens, daß es dann erlaubt sein müsse, einen an das Naturrecht sich nicht bindenden Kaiser abzusetzen. Das würde Empörung gegen die von Gott gewollte und gesetzte Tatsächlichkeit sein. Auch gottlose Kaiser müssen ertragen werden, und zwar nicht um ihrer naturrechtlichen Begründetheit willen, sondern als Gottesstrafe für die Sünden. In diesem Punkte also behauptet sich dem naturrechtlichen Rationalismus gegenüber der alte religiöse Irrationalismus, und sein Ergebnis ist das Gottesgnadentum. Die Autorität der Kaiser stammt von Gott, schon bei den heidnischen, und noch mehr bei den christlichen Kaisern. Daher hat auch Augustin, der die Sünde und ihre Strafe am stärksten betonende und zugleich den prädestinatianischen Irrationalismus lehrende Kirchenvater, die naturrechtliche Betrachtung des Staates und seiner Gesefze zwar anerkannt, aber in engeren Grenzen gehalten als die anderen Väter; er wollte Raum behalten für gottlose Kaiser als Schickung Gottes und als Sündenstrafe, für die moralische Verwerfung der regierenden Gewalten, sofern sie nicht von der göttlichen justitia sich leiten lassen. So hat auch Justinian neben der demokratischen Uebertragungslehre in seinem Gesetz das Gottesgnadentum proklamiert. Nur kann für dieses alte christliche Gottesgnadentum ein Kaiser Kaiser sein sowohl in der Gnade als auch im Zorn Gottes, je nachdem die Menschen gerade einen guten oder schlechten Kaiser verdienen. So versagt für die Väter das naturrechtliche Schema, das sonst die antike Gesellschaft zu akzeptieren und zu begrenzen in Einem vermochte, 
gegenüber dem Kaisertum, der potestas temporalis. An diesem Punkt schwankten auch die Juristen, die zwar einerseits die Ableitung des Prinzipats aus dem Volkswillen geltend machen, aber andererseits doch sich auch wieder zum reinen Absolutismus bekennen. Man wird auch den Einfluß dieses Absolutismus nicht vergessen dürfen, wenn man das Gottesgnadentum der Kirchenväter verstehen will. Die Kaiser geben zwar die Gesetze oder sollten sie geben nach dem Maßstab des relativen Naturrechts, beruhen aber ihrerseits nicht selbst auf ihm, sondern auf Gottes Einsetzung. Daher ist die Frage nach der Würdigung des Staates nicht identisch mit der des Kaisertums selbst, und die naturrechtliche Theorie vom Staate ist etwas anderes als die über die Geltung des Kaisertums. Hier knüpfen sich vielmehr für das christliche Kaisertum Fäden ganz besonderer und außerordentlich dichter Art. Denn wie es von Gott unmittelbar stammt, so hat es auch seine besondere Aufgabe in dem Verhältnis von Welt oder Staat einerseits und Kirche oder Heilsanstalt andererseits. Seine Sonderstellung nämlich bedeutet keinen Verzicht auf Begrenzung des Kaisertums. Es sollte nur nicht von unten, vom Naturrecht her, begrenzt werden. Sehr wohl aber kann und muß es von oben her, von demselben Gott her, begrenzt werden, der es eingesetzt hat, das aber heißt, es muß begrenzt oder geleitet werden durch die Gott verkörpernde Institution, die Kirche. In allen weltlichen Dingen gilt Gehorsam der Laien und Kleriker gegen den Kaiser, aber in allen geistlichen, in Fragen des Dogmas, des Kirchenrechtes, des kirchlichen Besitzes und der kirchlichen Gerichtsbarkeit, gilt das Recht Gottes. Ja die weltlich-kaiserliche Gewalt gilt nur in dem Maße als göttlich berechtigt, als sie durch Dienst für die Kirche und Unterordnung unter sie sich entsühnt und heiligt. Das Kaisertum leistet der Kirche Schutz und Privilegierung, an eine christliche Staats- und Sozialreform in den eigenen Beziehungen des Staates ist nicht gedacht. Aber indem das Kaisertum die Kirche in die Fähigkeit voller und ungehemmter Tätigkeit versetzt, so weiht, heiligt, durchgeistigt die letztere selbst das ganze große Gefüge der weltlichen $Z$ wecke, mit der innerlich ihnen sich entziehenden und äußerlich sie duldenden Gottesliebe. Sie gibt damit dann den Naturrechtselementen des Staates erst die göttliche Kraft und Tiefe, macht die weltliche justitia der gesetzlichen Ordnung zur vollkommenen justitia einer die Welt zur Entsagung und Liebestätigkeit gebrauchenden Frömmigkeit. Zu dieser 
Wirksamkeit aber muß ihr die kaiserliche Gewalt verhelfen; sie hat sich der Gottesherrschaft zur Verfügung zu stellen. Es ist der in der Kirche zunächst ausgebildete the okratische Gedanke, der aus der soziologischen Gestaltung der religiösen Gemeinschaft sich ergab und der nun hinübergreift in das politische und soziale Gebiet. Das Letztere hat bekanntlich Augustin vor allem in seinem großen Werke ausgeführt. Aber er hat, was weniger beachtet wird, auch das erstere dort vorausgesetzt und behauptet. In dem unausgeglichenen Streit beider Gesichtspunkte liegt der doppelschlächtige Charakter auch dieses Werkes des großen Mannes, das eben daher auch der Zukunft doppelte Tendenzen übermittelte. Theokratie und Naturrecht heiligen gemeinsam den Staat; was das eine nicht vermag, vermag das andere, und der Kaiser jedenfalls ist in erster Linie bestimmt durch sein Gottesgnadentum und seine theokratische Abhängigkeit. Der Staat selbst aber bleibt in alledem der Inbegriff der $*$ Welt ${ }^{76}$ ).

70) Vgl. Carlyle I 63-78, 147-193, dem ich hier den entscheidenden Gesichtspunkt dafür verdanke, daß der Kaiser für die Väter von der naturrechtlichen Konstruktion ausgeschlossen bleibt, während das für die philosophisch-juristische Theorie nicht so der Fall ist. Daher behandelt auch Reuter das Problem des Verhăltnisses der Gewalt der christlichen Kaiser zu der Kirche als ein besonderes, vom allgemeinen Stastsproblem verschiedenes. Aug. Studien S. 14I-152. Reuter irrt nur, wenn er glaubt, daß damit die Theorie von einem >christlichen Staate begründet und von hier aus auch erst die naturrechtliche Würdigung des Staates eingegeben sei. Die letztere hat mit der Christlichkeit des Staates nichts zu tun, und die Christlichkeit des Staates besteht nur in der Herrscherstellung, die die Kaiser der Kirche gaben, die dann im übrigen die Verchristlichung d. h. die Gesiunungswandelung rein von sich aus bewirkt. Immerhin kann so gesagt werden, $\mathrm{daB}$, der Staat erst in dem Maße zum wahren Staat werde, als er christlich $\propto$ d. h. als der Kaiser der Kirche dienstbar ist. Das Ideal des wahren Staates ist dann eben nicht mehr an dem Naturrecht gemessen, sondern an der Glaubensgemeinschaft. In diesem Punkte ist Augustin innerlich bei seinem hochgespannten Ideal des Gnadenstandes und der Gottesliebe wie bei seiner extremen Ansicht von der sündigen Verderbung nie so tief auf den naturrechtlichen Gedanken eingegangen, als die anderen Väter. Aber auch bei ihnen bleibt irgendwie der Sprung zwischen den zwar verwandten, aber doch verschiedenen stoischen und christlichen Gedanken. Die ersteren kommen bei dem Pessimismus Augustins gegenüber dem wirklichen Staat nicht zur vollen Wirkung. Die letzteren können bei der Ueberlassung der $>$ Welt $\propto$ an den Staat sich dann nur Luft machen durch Forderung der Privilegierung und Alleinherrschaft der Kirche; aber ein christliches Staats- und gar Wirtschaftsprogramm, wie Sommerlad - übrigens Augustins Inkonsequenz gegenüber seinen naturrechtlichen Lehren mit Recht betonend - S. 213-216 will, ist das nicht. Das hat erst das Mittelalter 
So sind es überhaupt zwei ganz verschiedene Mittel, mit deren Hilfe die Kirche die Stellung zu den sozialen and politischen Problemen gewinnt, die relativ-naturrechtliche und die theokratisch-absolutistische Theorie. Mit Hilfe der ersten gewinnt sie das Mittel, diè an sich ihren Grundbegriffen widersprechende, aber in der Richtung auf das Jenseits und im Sündengefühl gering geschätzte, soziale Wirklichkeit teils zu ertragen, teils ihren naturrechtlichen Prinzipien gemäß zu regulieren. Mit Hilfe der zweiten gewinnt sie das Mittel, für irdische Dinge den Kaiser und Staat gewähren zu lassen, aber für alle die Religion und die Kirche betreffenden Dinge sie in ihren Dienst zu stellen. Die Gebrochenheit der Stellung des alten Christentums zu allen sozialen Problemen kommt hierin charakteristisch zum Ausdruck. Soziologisch mögen die Grundideen des in Gott begründeten Individualismus und der in Gott begründeten Menschheitsgemeinschaft von einer unermeßlichen und ihrer Natur nach unkontrollierbaren Wirkung gewesen sein. Die Stellung zu den sozialen Problemen aber fiel in steigendem Maße zusammen mit der zum Staat als dem Träger und Inbegriff des gesamten gesellschaftlichen Lebens. Demgegenüber gab es bei der Sprödigkeit gegen die Welt und bei der kirchlichen und asketischen Entgegensetzung gegen die unerlöste Menschheit einerseits nur das Mittel, Staat und Welt indirekt $z$ u christianisiere $n$, indem man sie auf das mit dem Gesetz Moses und Christi identische, aber im Sündenstande nur relative Naturrecht zurückführte. Diese Christianisierung lief dann aber darauf hinaus, daß man sie äußerlich beließ, daraus entwickelt. Wenn S. Augustins theokratische Lehre als Reaktion gegen die naturrechtlich-gleich heitlich-asketische Reaktion, die die Soziallehren des 4. Jahrhunderts gegen die Feudalisierung der Gesellschaft bedeutet haben sollen, konstruiert und darin ein Wieder-Einbefassen des Weltlichen unter das Geistliche durch die Macht der Kirche sehen will, so ist das stark übertrieben, enthält aber m. E. doch einen Kern des Richtigen. - Die Lehre der Juristen über den demokratischen Ursprung der Kaisergewalt Carlyle I 64, auch im Corpus Justinianeum S. 169; die absolutistische Lehre 69 f. - Damit mündet meine Darstellung in die bekannten Darstellungen der theokratischen Herrschaft der Kirche über den Staat aus, die aber dabei die Staatslehre der Väter leicht fälschen, indem sie einfach vom Staat als Produkt der Sünde reden, was er ihnen durchaus nicht ohne weiteres ist. Nicht $z u$ vergessen ist der Unterschied des Orients, wo die Theokratie zur Uebernahme der Kirche in das Ressort des Staates wurde, vom Occident, wo die Kirche umgekehrt den Staat oder vielmehr den Regenten sich unterzuordnen beansprucht. 
wie sie war. Der andere Ausweg war, daß man die The okratie des kirchlichen Sozialgebildes zum Herrn machte auch über die zeitliche Gewalt oder das Kaisertum. Diese Verchristlichung des Kaisertums lief dann darauf hinaus, daß die Kirche durch den Staat sich selbst Einheit und Festigkeit verschaffte, sich vor allem auf ihrem eigenen Gebiet mit Benutzung seiner Gewaltmittel zum Herrn machte, das soziale Leben selbst aber dem Kaiser überließ. Durch die Theokratie hat sie Einheit des Dogmas und Einheit des Kirchenrechts erst erlangt, die ohne Konstantin nie gekommen wäre und von der Gewalt des Staates, nicht von der immanenten Logik der dogmatischen Idee erzwungen worden ist. Durch seine Gewalt hat sie ihr Verfassungsnetz aufgebaut, ihr Vermögen erworben und ihre den Staat ergänzende und korrigierende Gerichtsbarkeit gewonnen. Sie sorgt damit unmittelbar nur für sich, das übrige soziale Leben hat sie dem Kaiser und dem Gesetz überlassen. Eine einheitliche christliche Kultur hat sie unter der Nachwirkung der alten Weltfremdheit und unter dem Druck des Parallelismus der beiden selbständigen Sozialgebilde, des universalen Imperiums und der universalen Kirche, im Altertum nie gewonnen, nie gewinnen wollen und nie gewinnen wollen können. Das unter der Theokratie der Kirche stehende und auf dem Grund des relativen Naturrechtes aufgebaute - heilige römische Reich * ist das Ergebnis, in das all diese Widersprüche auslaufen und das daher eine innere Einheit weder ist noch sein will.

Aber mit diesen von ihm herausgearbeiteten Gedanken überliefert das Altertum der Zukunft die Elemente, aus denen das Mittelalter eine einheitliche christliche Kultur aufzubauen imstande sein wird. Staatsgewalten, die nicht die Härte und die technische Rechtsfülle des Prinzipats besitzen, sondern jung sind und von der Kirche selbst mitgebildet wurden, werden der Theokratie sich leichter einfügen, und damit wird das Ganze son der Theokratie aus wenigstens in der Idee gedacht und empfunden werden können. Andererseits wird gegenüber neuen, weniger festen und un. entwickelteren sozialen Verhältnissen ihr Hervorgang aus dem relativen Naturrecht leichter anschaulich gemacht, das relative $\mathrm{Na}$ turrecht noch mehr dem christlichen Sittengesetz angenähert werden und damit das soziale Leben naiver und vollständiger als christlich empfunden und christlich geregelt werden können. Von der einen Seite wird die Theokratie tiefer nach unten greifen und 
von der andern Seite das christliche Naturrecht stärker nach oben sich annähern können. Ja die Fiktion des christlichen Naturrechtes, die Staat und Gesellschaft als von einem christlichen Gesetz aus geordnet zu betrachten ermöglicht, wird das Mittel sein, durch das überhaupt allein von einer christlichen Einheitskultur die Rede sein kann und man eine solche sich glaubhaft machen kann; und dieses christliche Naturrecht wird auch noch den Tochterkirchen des abendländischen Katholizismus, dem Luthertum und dem Calvinismus, ganz ebenso die Mittel liefern, sich als christliche Einheitskultur $\mathrm{zu}$ betrachten und $\mathrm{zu}$ gestalten. Die christliche Theorie des Naturrechts, in der sich das reine Naturrecht des Urstandes, das ganz entgegengesetzte relative Naturrecht des Sündenstandes, das oft die größten Greuel einschließende positive Recht und die trotz allem Naturrecht wahre Güte erst von sich aus mitteilende theokratische Obergewalt beständig stoßen, ist als wissenschaftliche Theorie kläglich und konfus, aber als praktische Lehre von der höchsten kultur- und sozialgeschichtlichen Bedeutung, das eigentliche Kulturdogma der Kirche und als solches mindestens so wichtig wie das Trinitätsdogma oder andere Hauptdogmen ${ }^{77}$ ). Das christliche relative Naturrecht ist die Er-

77) Die Bedeutung der Lehre von dem Verhältnis der Lex naturae zur Lex Christi als eines Fundamentaldogmas ist von Katholiken auch naturgemäß immer betont worden. Sie ist das völlige Korrelat zu der allgemeinen Unterscheidung von Vernunft und Offenbarung und wendet diese Unterscheidung nur nach der Seite des Aufbaues eines praktischen Kulturganzen s. den Artikel , Gesetze von Wirthmüller im katholischen $\gg$ Kirchenlexikon ${ }^{2}$ e von Wetzer und Welte; Lehmkuhl, Theologia moralis I 39-139; Ottiger, Theologia fundamentalis I 37-147; Cathrein >Moralphilosophie ${ }^{3}$, 1899 (I 313 Hinweis auf Augustin und Antike, I 483 auf Isidor von Sevilla) und die klare populäre Darstellung des Jesuiten Theodor Meyer $>$ Die christlich-ethischen Sozialprinzipien und die Arbeiterfrages I904 (die soziale Frage beleuchtet durch die >Stimmen aus Maria Laach Heft I); hier ist der Unterschied des absoluten und relativen Naturrechts klar entwickelt S. 40 und als Grundbedingung einer kirchlichen Kultur- und Soziallehre, sdes sittlichen Organismus der Gesellschaft «, die naturgesetzliche und religiöse Garantie bezeichnet (67), wobei unter religiös \& theokratisch zu verstehen ist. Auch Gierke hat in seinem großartigen Werke die Bedeutung dieser Begriffe klar erkannt und in seinem nicht minder großartigen $\gg$ Althusiuse den Prozeß der Loslösung und Verselbständigung der antik-stoisch-juristischen Elemente und damit den Uebergang in das moderne liberale Naturrecht gezeichnet. Die protestantischen Theologen sind dagegen in diesem Punkte fast sämtlich so gut wie blind. Ihnen ist die Christlichkeit von Staat und Gesellschaft so selbstverständlich, daß sie 
gänzung, die die Kirche sich geschaffen hat, indem sie die Verkürzung der Naturbasis des Lebens, die das Evangelium mit seinem großen der Ewigkeit zugewendeten Enthusiasmus und Heroismus gelehrt hatte, erst Schritt für Schritt ermäßigte, dann die Naturbasis, wie sie sie vorfand, als Erzeugnis des relativen Naturrechts unverändert erduldete und schließlich vom Mittelalter ab bei der Aenderung des allgemeinen Lebens als auf den christlich-kirchlichen Lebenszweck durch die Vorsehung hingeordnet betrachtete. Die soziologischen rein ethisch-religiösen Grundbeziehungen des Evangeliums sind dann inkrustiert in der Kirche, im kirchlichen Gehorsam und in dem kirchlichen Einheitsgefühl, die sozialen und politischen Elemente sind durch die christliche Theorie des Naturrechts der Kirche einverleibt und assimiliert. Aber freilich bleibt in diesem Naturrecht der Bodensatz des stoischen Rationalismus, bleibt der Naturbegriff als Kern des Gottesbegriffes und die rationelle Gleichheit aller vernunftbegabten Wesen; aus diesem Bodensatz werden sich rationalistische Reaktionen erheben, bis sie im 17. Jahrhundert, sich selber völlig wieder findend, die kirchliche Kultur zersprengen. Sie war als Einheitskultur nur möglich durch Theokratie und christliches Naturrecht.

keinerlei Sinn und Blick für die mühsamen Umwege haben, auf denen sich die alte Kirche, das Mittelalter und ihre eigenen protestantischen Vorfahren erst die Christlichkeit dieser Dinge zu sichern wußten. Sie wissen nur von der sHeiligung und christlichen Durchdringung der Welte zu reden, die angeblich der Sinn des Evangeliums und der paulinischen Glaubenslehre ist und lassen diese ssozial-kulturelle. Tendenz dann mit Uhlhorn teils an der Undurchdringlichkeit und Irreformabilität der fest und steif gewordenen heidnischen Welt, teils mit den meisten an der Brechung des evangelischen Ideals durch die katholische Werkheiligkeit, Askese und Kirchenverherrlichung oder gar an der Verderbung des reinen Glaubensbegriffes durch spiritualistische Mystik und durch eine den antiken Mysterienkulten angenäherte physisch-realistische Erlösungslehre scheitern. Auch ist ihnen bei ihrer Antithese von Glaube und Gesetz mit dem Begriff des Gesetzes der ganze Gedanke einer inhaltlichen Bestimmtheit und sachlichen Tendenz des christlichen Ethos so sehr abhanden gekommen, daß ihnen das ganze christliche Ethos in der Abwehr der guten Werke und in der richtigen Pestimmung der die sittlichen Kräfte mitteilenden Gnade aufgeht, nach der Seite des Inhalts aber in eine völlige Bestimmungslosigkeit verfällt. Daß auch die Dogmenhistoriker gegenüber der ganzen Lehre vom Naturgesetz großenteils sehr unsicher tasten, weil sie dessen Funktion für die Lösung des Problems der , Weltc und des ssozialen Lebense nicht verstehen, habe ich an Seebergs Dogmengeschichte gezeigt, Gött. Gelehrte Anzeigen 1903. 
Damit haben wir freilich der weiteren Untersuchung vorgegriffen. Aber es ist nötig, sich hieran die Bedeutung der in den geschilderten Kämpfen errungenen Begriffe klar zu machen. Die soziologische Kraft des Christentums ist eingeengt auf die Kirche, das soziale und politische Leben ist kirchlich akzeptiert und wird in der Zukunft auch gestaltungsfähig werden. Damit scheint dann freilich das a t te Ideal des Evangeliums, die Anarchie des nur Gott verantwortlichen und Gott dienenden Glaubens, der unendliche Wert der freien Seele und die Ausströmung der Gottesliebe in der Bruderliebe, verschwunden oder doch verdeckt und verstümmelt.

Allein es lebt fort in Gedanken und Institutionen, nur freilich stark dadurch verändert.

Es lebt fort in der $\mathrm{Kirche}$ selbst, in dem priesterlichsakramental gebundenen, aber doch immer zu lebendiger Befreiung fähigen Gedanken der Heiligung und der Bruderliebe, die auch in der kirchlichen Bindung wirken und aus ihr sich je und je zu befreien immer wieder Neigung haben. Die Kirche hat ja das Neue Testament zwar als lebendige Fortsetzung der Menschwerdung ersetzt oder doch erweitert, aber nicht beseitigt. Auch sorgt die trotz aller Theokratie und allem Naturrecht nie aufgegebene innere Fremdheit des Glaubens gegen die Welt dafür, $\mathrm{da}$ immer wieder, die soziologischen Ideale des reinen Gottesglaubens als etwas 'von der Welt verschiedenes empfunden werden.

Es lebt fort in dem Gedanken des Urstandes und des absoluten $\mathrm{Naturrechtes,}$ an dem immer wieder das Ideal der Freiheit, der Gotteinigkeit, der Gleichheit und der Liebe vor Gott und in Gott anschaulich gemacht wird. Freilich ist in dieses Urstandsideal der Begriff der Gleichheit aus der Stoa abstrakt und rationalistisch aufgenommen und mit dem der Gerechtigkeit verschmolzen worden. Daher werden von diesem Urstandsideal immer wieder naturrechtliche, kommunistische und sozialistische Ideen im religiösen Gewande ausgehen und wird bei der Emanzipation des modernen Naturrechts dieses an dem Adam der Kirche selbst eine Stütze zu haben meinen. Aber die Urstandslehre hat außer diesem stoisch-rationalistischen Gehalt noch soviel religiösen der Veranschaulichung des religiösen Ideals am Urmenschen, daß diese Wirkung der stoischen Beimischung lange Zeit nicht allzugefährlich wird. Außerdem haben gerade die prädestinatianischen Kirchenlehrer mit verständlichem Instinkt 
gegen den Rationalismus einer allgemeinen Gleichheit die Verschiedenheit der Menschen auch im Urstand und in der Wesensanlage schon betont, ein Vorspiel der Gegensätze, die später auseinandertreten sollten ${ }^{78}$ ).

Es lebt schließlich fort im Mönchtum. Das Mönchtum ist in seinem Ursprung eine höchst komplexe Erscheinung, aber in seiner Wirkung nichts anderes als das Asyl, in das sich das àlte, vereinseitigte christliche Ideal geflüchtet hat. Wie dieses die Naturbasis im Heroismus verkürzt und die Kulturwerte ignoriert hatte, so beschneidet das Mönchtum die erste und verneint es die zweiten durch die Askese. Wie die volle Idee des Evangeliums nur in einem Kreise persönlich wirklich verbundener Menschen möglich war und in der Kleinheit der ersten Jüngerschar ihren natürlichen Boden hatte, so führt das Mönchtum künstlich diese Verbundenheit und diese Kleinheit wieder herbei. Indem es aber das volle Ideal, wie man es noch empfinden und verwirklichen konnte, großartig und erschütternd darstellt, so wollte es doch dadurch nicht die Christlichkeit der Uebrigen aufheben. Noch ist das Verhältnis von Kirche, Laien und Mönchtum ungeklärt. Aber das Mönchtum tritt doch in Funktionen für das Ganze ein. Es nimmt die eigentlich christlich-sozialen Tätigkeiten, soweit es sie gibt und geben. kann, in seine Hand kind bereitet damit seine zukünftige Einfügung in ein Ganzes christlicher Kultur vor. Die

70) Doch ist diese Gleichheitslehre auch für den Urstand nicht ohne Widerspuch geblieben. Augustin nimmt (Stellen bei Overbeck 200, Quaest. in genesin 53) auch für den Urstand Verschiedenheiten der Anlage und Begabung an, aus denen sich freiwillige Unterordnungsverhältnisse in richtiger Proportion ergeben, mit den ethischen Wirkungen dieser Ueber- und Unterordnungsverhältnisse. Im Sündenstand wird diese Unterordnung nur zwangsmäßig und oft verkehrt, indem die rohe Gewalt die an sich zum Herrschen bestimmte stärkere und bessere Vernunft unterordnet. Carlyle I 127 führt ein Stelle von Gregor Ep. V 59 an, wo das Gleiche behauptet und als Beispiel auf die sündlosen Engel verwiesen wird: Quia vero creatura in una eademque aequalitate gubernari vel vivere non potest, caelestium militarium exemplar nos instruit, quia, dum sunt angeli et sunt archangeli, liquet, quia non aequa ${ }^{1} c=$ sunt, sed in potestate et ordine sicut nostris differt alter ab altero. Si ergo inter hos, qui sine peccato sunt, ista constat esse distinctio, quis hominum abnuat huic se libenter dispositioni submittere, cui novit etiam angelos obedire. Hier schlägt gegen die ganz unchristliche Idee der abstrakten Gleichheit der paulinische $\mathrm{Pa}$ triarchalismus durch. Die Sache verdiente bei der Wichtigkeit des Gleichheitsbegriffes eine weitere Untersuchung. 
Religiosen legen, in der Zucht und Pflege der Seelen erfahren und das Seelenheil auch der Weltleute bedenkend, den Grund zur individualisierenden Seelsorge, die den formalistisch und überflüssig gewordenen Katechumenat der Kirche ersetzt, und schaffen die Anfänge christlicher Schulen, woran die Kirche in ihrem Belassen der Welt in ihrem Stande nicht gedacht hat. Sie setzen an Stelle der rhetorisch-sophistischen Schule der Spätantike die religiöse Gesinnungsschule, die, später von Pfarr- und Domschulen nachgeahmt, auch die Weltleute erzieht. Die Mönche machen die wissenschaftliche Arbeit des Denkens über die göttlichen Dinge zu einem Mittel der Seelenzucht und Gottvereinigung neben den Tugenden der Askese und sind, die asketischtranszendenten Züge der Stoa, der Kyniker und des Platonismus vollendend, wie die wahren Christen so die wahren Philosophen. Die Weltleute empfangen aus der Mönchsliteratur das wahre Wissen, das sie in der Unruhe der Welt nicht finden können. Die Mönche leben in angestrengter Arbeit und doch in völliger Gütergemeinschaft als große kommunistische Produktivorganisationen. Die Weltleute empfangen von ihnen, wo es not tut, Arbeitsunterricht, Arbeitsermahnung und Liebestätigkeit. Die freie Arbeit und die Forderung, allen Lebensunterhalt auf Arbeit zu begründen, kommen zu ihrer vollen Ehre doch erst in den Klöstern und gehen erst von hier aus in die Welt. So sind die Klöster gerade in ihrer Askese und in ihrer Abschließung kleiner Kreise die wesentlichen Träger und Ausstrahlungszentren dessen, was man jetzt christliche Kultur nennen kann, einer mit innigster Gottesliebe verbundenen und aus ihr begründeten Erkenntnis, Arbeit und Liebestätigkeit. Trotz aller Exzentrizitäten und Roheiten sind sie in ihrer Gestaltung durch die großen Mönchsväter die Herde der wchristlichen Kultur * und werden in dieser Richtung immer bedeutender hervortreten ${ }^{79}$ ).

${ }^{79}$ ) Vgl. die treffliche Darstellung von v. Schubert Lehrbuch d. KG ${ }^{2}$ I $_{785}-813$, auch Uhlhorn I 332-354. Der Lutheraner gesteht hier zu: >Wenn auch zunächst in kleinem von der übrigen Welt abgeschlossenen Kreise sind hier die neutestamentlichen Gedanken von der Arbeit verwirklicht. Man arbeitet, weil es Gott geboten, jeder tut in seinem Beruf stetig das Seine, Arbeit lund Gebet sind verbunden, Arbeit wechselt mit Ruhe, und der Zweck der Arbeit ist nicht bloß der selbstsüchtige, für sich etwas zu gewinnen, sondern andern damit zu dienen S. 347. Es wăre nur hinzuzufügen, daß diese Berufe lediglich in geistlicher, wissenschaftlicher und einfachster Handarbeit bestehen, in ihrem Ertrag ergänzt werden durch Troelts c b, Gesammelte Schriften. I. 
Damit erst ist das Bild vollendet. In Bibel, absolutem Naturrecht und Mönchtum liegen die alten soziologischen Ideale zu einer neuen geistigen Wirkung auf das Ganze des Lebens bereit. In der Kirche sind diese Ideale durch die Festlegung der Gotteskraft in Priester und Sakrament kirchlich gebunden, und die Schöpfung der Kirche ist die eigentlich große soziologische Leistung, deren inneres Grundschema nicht allzu tief in das Gesamtleben eindringt, am meisten noch in die Familie. In der Theokratie und dem relativen Naturrecht sind dann auch die sozialen Probleme bewältigt, indem Staat und Gesellschaft äußerlich und rechtlich bleiben, was sie sind, die Seelen aber ihnen innerlich völlig anders gegenüberstehen, ohne Drang sie zu ändern, aber ihre Ordnungen für das jenseitige Heil und die allgemeine Lebenssicherheit benützend. Das sind die Soziallehren der alten Kirche, sic enthalten zugleich in sich den Keim zu den neuen ganz andersartigen Soziallehren des Mittelalters und zur Zersetzung eben dieser selben Soziallehren im Beginn der Neuzeit.

\section{Der Mittelalterliche Katholizismus.}

\section{Das Problem.}

Das Altertum hat in der priesterlich-sakramentalen Wunderund Gnadenorganisation der. Kirche den soziologischen Zusammenhang der christlichen Idee ausgewirkt, den absoluten Individualismus und Universalismus des Evangeliums in einen sozialen Qrganismus zusammengezogen, innerhalb dessen jedem Individuum durch Unterordnung unter die Gnadenanstalt ein ewiger Wert des Seelenheils zuteil werden konnte, in welchem aber doch die beilsverbürgen-

die Mildtätigkeit der Klosterverehrer und auf ein äußerstes Minimum des Bedürfnisses bercchnet sind. Die dem Weltleben unentbehrlichen weiteren Berufe fehlen und werden von anderen ausgeübt. Scharfe Gegensätze zwischen den die Weltgeschäfte besorgenden Christen und den Asketen schildert in der gallischen Kirche Hauck, K.G. Deutschlands ${ }^{3}$ I904 I 53-90; hier ist auch deutlich, wie die Asketen von außen herein kommen und die Gemeinden selbst von sich aus die ausschließliche Askese nicht erzeugen, wie aber, einmal vorhanden, die Asketen sich als die allein folgerichtigen darzustellen wissen. Ueber die Arbeitspflicht und die Arbeitsehre in den Klöstern und die davon ausgehende Wirkung für den Begriff der Arbeit überhaupt s. Ratzinger »Armenpfleges S. 99-102. - Ueber die Bedeutung des Mönchtums für die Schaffung einer christlichen Schule ebenda, außerdem mündliche Mitteilungen des Herrn v. Schubert. 
den Autoritäten und die hierarchischen inneren Gliederungen des Organismus sowie die patriarchalische Lehre von der Ergebung und Fügung in die Ordnungen der Welt den Individualismus bedeutend einschränkten. Wie weit von hier aus ein soziologisches Grundschema und Ideal der Beurteilung aller menschlichen Verhältnisse in die Gemüter eingezogen ist, kann im einzelnen nicht ermittelt werden. 'Jedenfalls hat die Kirche es unterlassen, die außerkirchlichen Verhältnisse und Ordnungen von einem solchen Ideal aus zu regeln. Sie hat im ganzen die Verhältnisse einer festgewordenen Welt hingenommen und sich mit ihnen durch die Theorie vom relativen - Naturrecht abgefunden. Denjenigen, welche sich auf diesen Kompromiß nicht einlassen wollten, öffnete sich ein Ventil im Mönchtum, das eben darum aber auch in kein klares und prinzipielles Verhältnis zur Kirche kam und der Kirche nur allzuoft ein schlechtes Gewissen machte. So war die Haltung gegenüber Staat und Gesellschaft eine eigentümlich gemischte. Es war ein Teil naturrechtlicher Anerkennung, ein Teil theokratischer Unterjochung und Benützung, ein Teil Stützung der nicht mehr ausreichenden Kräfte des Staates durch die Kirche, und ein Teil Verwerfung von Staat und Gesellschaft überhaupt, die sich in der Theorie von der Sündigkeit aller Stiftungen des relativen Naturrechts und in der Praxis der Weltentsagung auswirkte. Eine innerlich einheitliche christliche Kultur gab es weder tatsächlich noch in der Idee und im Prinzip. Der ganze Gedanke war dem Altertum fremd.

Es ist gegenüber der alten Kirche der entscheidende Unterschied des Mittelalters, dass es dieses Ideal in der Praxis und noch mehr in der Theorie kennt, und als ein solches Ideal wirkt mit einigen Anpassungen an das moderne Wesen seine Theorie noch in allen Soziallehren des heutigen offiziellen Katholizismus fort ${ }^{80}$ ). Aber auch auf die

80) Dieser Unterschied des Mittelalters gegen die alte Kirche ist allgemein erkannt und anerkannt s. Hauck KG. Deutschlands I, ir 6 ; Uhlhorn, Liebestätigkeit II, 5, - Der alten Welt als Ganzes und abgesehen von einzelnen christlichen Persönlichkeiten blieb das Christentum im Grunde immer etwas außerliches. Die heidnische Vergangenhheit, das ganze vom Heidentum durchzogene und gesättigte Kulturleben der alten Völker erwies sich doch zuletzt als für den christlichen Geist undurchdringlich. Erst die germanischen Völker sind in Wahrheit christliche Völker geworden. Noch in ihrer Jugend vom Christentum ergriffen, sind sie selbst mit ihm aufgewachsen, alle Kultur ist ihnen durch die Kirche vermittelt; und wie sie selbst das Christentum tiefer erfaßten, als es die im Heidentum alt gewordenen Griechen und Römer vermochten, so hat auch bei ihnen das Christentum ihrVolks- 
Anfänge des Protestantismus ist dieses Ideal einer christlichen Einheitskultur übergegangen, grossenteils mit denselben Mitteln von ihm behauptet, mit denen das Mittelalter es hatte begründen und ausführen lernen; und auch in dem gründlich verwandelten modernen Protestantismus wirkt dieses Ideal wie ein selbstverständlicher Grundgedanke fort, den es nur gilt, auf eine neue Basis zu stellen.

leben mit allen seinen Aeußerungen in einem Maße beherrscht, wie das in Rom und Byzanz niemals der Fall war.e S. 7: "Eigentlich erst die von Clugny im 10. Jahrhundert ausgehende Erweckung bezeichnet den Wendepunkt zum entschiedenen Sieg des Christentums. Harnack, ,Wesen des Christentums. S. 153: -Was hat die romisch-katholische Kirche geleistet? Sie hat die romanisch-germanischen Völker erzogen und zwar in einem anderen Sinne als die östliche Kirche die Griechen, Slaven und Orientalen. Mag auch die ursprüngliche Anlage, mögen elementare und geschichtliche Verhältnisse jene Völker begünstigt und ihren Aufschwung mit bewirkt haben, das Verdienst der Kirche wird dadurch nicht geringer. Sie hat den jo'jendlichen Nationen die christliche Kultur gebracht (wo-

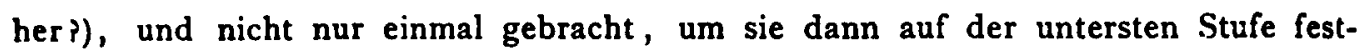
zuhalten, nein, sie hat ihnen etwas Fortbildungsfähiges geschenkt und sie hat selbst diesen Fortschritt in einem fast tausendjährigen Zeitraum geleitet. \& Sell, \$Katholizismus und Protestantismus in Geschichte, Religion, Politik und Kultur\&, I908 S. 36: -Der Fortschritt der mittelalterlichen Stufe des Katholizismus besteht darin, daß hier das Christentum nicht wie in der alten Kirche eine Allianz geschlossen hat mit einer bereits fertigen Kultur, wie es die antike war, sondern daß das katholische Christentum zur Grundlage der ganzen abendländischen $\mathrm{Ku} l \mathrm{t} u \mathrm{r}$ wurde, indem es in die geistige Substanz der germanisch-romanischen Völker überall umbildend eindrang.e Ehrhard, ,Der Katholizismus und das 20. Jahrhundert" 4902 S. 24 : Aus dieser-Verbindung der neuen germanisch-romanischen Reiche mit ihren spezifischen Natur- und Kulturanlagen mit dem Geiste der lateinischen Kirche wurde eine neue Zeit geboren, die sich in einer unübersehbaren Fülle von Tatsachen aus. wirkte. Diese Fülle von Tatsachen nun wird aber beherrscht durch eine Reihe von inneren Faktoren und Momenten, welche die charakteristische Merkmale des christlichen Mittelalters ausmachen: 1) Die Verbindung des Papsttums und Kaisertums als der beiden höchsten Vertreter der Christenheit und der dadurch bedingte Universalism us, des Mittelalters. 2) Die gegenseitige Durchdringung des politischen Staatswesens und des katholischen Kirchenlebens und der daraus hervorgehende Synergismus zw ischen Kirche und Staat.' 3) Die Alleinherrschaft des christlichen und kirchlichen Geistes auf allen Gebieten des höheren Kulturlebens.e S. 35 : >Es ist das unsterbliche Verdienst Gregor VII, den Kampf um die Freiheit der Kirche aufgenommen und dadurch die volle Auslösung dergebundenenkirchlichen $\mathrm{K}$ äfte angebahnt zu haben... Jetzt entfaltete sich die christliche Kulturblüte des Mittelalters, die zwei Jahrhunderte andauerte und auf 
Das P roblem ist also einfach genug zu formulieren: Wie konnte im Mittelalter aus der altkirchlichen Ueberlieferung, der neuen Lage und den neuen Gedankenbildungen dieses Ideal entstehen, und welche Gestalt hat es hier angenommen? Die Bedeutsamkeit der Frage wird von allen denen unterschätzt, welche schon der alten Kirche oder dem Christentum überhaupt das Streben nach einer christlichen Einheitskultur zuschreiben. Daß davon nicht die Rede sein kann, daß vielmehr, wie für Stoa und Platonismus, so noch mehr für das Christentum eine auf die Werte der freien gotteinigen Persönlichkeit und der universalen Menschengemeinschaft begründete Sozial- und Kulturlehre die größten Schwierigkeiten hatte, daß insbesondere das Christentum zwar eine mächtige, aber auch weltfeindliche, rein religiöse Organisation hervorbrachte, in ihr nach innen die Lebensverhältnisse leidlich seinem Prinzip entsprechend ordnete, aber nach außen die Verbindung und Verknüpfung nicht finden konnte: das hat die bisherige Darstellung gezeigt. Es ist eben nicht so einfach, auf den überweltlichen Werten der Gottesliebe und Bruderliebe eine Kultur und eine Gesellschaft aufzubauen. Die mit der ersten verbundene Selbst- und Weltverleugnung und der mit der zweiten verbundene Verzicht auf Recht und Gewalt sind keine Kulturprinzipien,

allen Gebieten des höheren Kulturlebens Früchte bleibenden Wertes zeitigte ๙. Die inneren Schwierigkeiten, die sich einem solchen Aufstieg von dem Wesen des altkirchlichen Christentums her entgegenstellten, sind in diesen Darstellungen meist unterschätzt. Sie hat mit scharfem Blick zum Hauptgegenstand seiner Untersuchung gemacht v. Eicken, Geschichte und System der mittelalterlichen Weltanschauung, 1887. Seine Meinung, daß die Ueberwindung dieser Schwierigkeiten in der Rezeption des römischen Weltreichgedankens durch die asketisch-hierarchische und die Welt nur durch ein politisches Reich zum Heil zwingen könnende Kirche gelegen habe, kann ich freilich als richtig nịcht anerkennen. Darüber später. Hier nur bereits die Bemerkung, daß alle universalen und die Welt vergewaltigenden Tendenzen der Kirche von dem dogmatischen Wahrbeitsbegriff und der allein selig machenden Wirkung der Sakramente ausgehen, wie auch Hauck zeigt I, 552 f., II, I10, 502, 535; v. Schubert KG. I, 726, 730. Es ist die Soziologie des religiösen Gedankens, die hier herrscht, die Dialektik der Idee und nicht der historische Zufall, den hier v. Eicken in auffallendem Gegensatz. gegen seine sonstige rein dialektische Konstruktion zu Hilfe nimmt. Aber gerade an diesem Punkte sitzt der Zufall nicht. Soweit Recht und Ideal des römischen Reiches rezipieri wird, geschieht es im Dienste der völlig selbständigen kirchlichen Entwicklungstendenz. - Ueber die katholische Einheitskultur als Werk des M.A. s. auch Mausbach, Christentum und und Weltmoral 1905, wo dieses Ideal des Katholizismus nach Thomas zutreffend 
sondern radikale und universale religiös-ethische Ideen, die nur sehr schwer in die Gebilde weltlicher Zweckmäßigkeit und in die Schutzvorrichtungen sich einfügen, die der Kampf ums Dasein gegen sich selbst hervorgebracht hat. Sind ja doch die Sozialideale des Platonismus und Stoizismus rein im Zustand der Utopie geblieben und haben sie, die bei aller Verwandtschaft mit den christlichen Ideen doch dem antiken Volks- und Staatsleben viel näher blieben, durch ihre Idealkonstruktionen nur den Abstand vom gewöhnlichen Weltlauf zur Empfindung gebracht. Wenn das Christentum seinen Idealstaat, die Kirche, auf rein religiöser Basis zu bauen imstande war, so hat es dann doch das auf dieser Basis Mögliche mit dem übrigen Gesellschaftsleben nur schwer vermitteln können. Das Mittelalter aber erlebte den Ausbau der Kirche zu einem alles umfassenden, verknüpfenden und vermittelnden sozialen Ganzen, das den soziologischen Kreis der Religion selbst und auch die politisch-sozialen Bildungen umfaßte, und verwirklichte so auf seine Weise zugleich das, was der auf einen Einzelstaat abzielenden platonischen Republik vorschwebte, die Herrschaft der Weisen und Gotteskundigen über eine in Ständen sich aufbauende organische Gesellschaftseinheit, und das, was der stoische Menschheitsstaat erstrebte, die Gemeinsamkeit aller in einem ethischen Universalreiche. Das Programm, das das sinkende Altertum in Platonismus, Stoa und Christentum hervortrieb als neues Menschheitsideal und das in der Vereinigung dieser drei Strömungen das Altertum nur sehr bedingt hatte verwirklichen können, überwindet nun die Widerstände und kommt zu einer wenisstens relativen Verwirklichung. Dann aber ist das vom Mittelalter gestellte Problem in der Tat von großer historischer Bedeutung und von Bedeutung auch für die Beurteilung aller modernen christlichen Soziallehren, die durchgängig mehr. an die mittelalterlichen als an die altchristlichen Ideen anknüpfen.

Freilich ist hier nicht möglich, das gesamte unendlich reiche und mannigfaltige Mittclalter selbst unter diesen Gesichtspunkten zur Darstellung zu bringen. Es kann sich nur darum handeln, das Ergebnis dieser Geschichte, wie es von der Zukunft in der Gestalt des Thomismus-übernommen und als klassisch herausgechildert, aber das darin für die clristliche Idee selbst liegende Problem mit charakteristischer Oberflächlichkeit behandelt ist. Meine Darstellung wird vor allem zeigen, daß diese katholische Einheitskultur weder historisch noch systematisch angecehen die selbstverständliche Blütea der christlichen Idee ist. 
gehoben wurde, in den Hauptpunkten zu charakterisieren. Aber die Notwendigkeit, den Thomismus verständlich zu machen, führt dann freilich auf die allgemeinen Verhältnisse des Mittelalters zurück, die unausgesprochen aber entscheidend die Lehre des heiligen Thomas ( $\dagger$ 1274) bestimmt und erst möglich gemacht haben. Denn es steht bei ihm mit dem Gesamtproblem aufs klarste so, wie es in der Einleitung bereits angedeutet wurde und wie es von der ganzen bisherigen Untersuchung bestätigt wurde. Die christlichen Soziallehren setzen zunächst einen bestimmten Begriff von der christlich-religiösen Gemeinschaft selbst voraus, in der der religiöse Gedanke sich unmittelbar soziologisch auswirkt. Für die Soziallehren im engeren Sinne ist dann die Frage, wie weit jene Gemeinschaft so allumfassend und alldurchdringend angesehen und durchgeführt wird, daß es ihr gelingt, auch die sozialen sonstigen Bildungen unter das von ihr erzeugte und von ihr verwirklichte soziologische Grundschema zu beugen, oder ob sie mit ihnen als mit fremdartigen und draußenliegenden Erscheinungen nur paktieren kann. Wenn die thomistische Sozialphilosophie das erstere unternimmt, so setzt sie erstens eine gewaltige Entwickelung des soziologischen Organismus der christlichen Idee voraus und zweitens die Möglichkeit, von dem in ihm entwickelten soziologischen Grundschema aús das Ganze zu beherrschen. Das setzt aber dann weiter den Gedanken einer mit der Kirche gegebenen univers̀alen christlichen Kultur voraus, aus der heraus dann erst die Eingliederung der einzelnen sozialen Bildungen in den Geist des Ganzen erfolgen kann. Die Frage ist daher die, wie es $z$ u e iner solchen Voraussetzung für den hl. Thomas hat kommen können, und erst dann ist die Frage, wie er a us diese $n$ Voraussetzungen heraus seine Soziallehrentatsächlich entwickelt hat. Es ist der Mangel der meisten Darstellungen, daß sie das Zustandekommen dieser Voraussetzungen nicht als das eigentliche Problem ansehen, sondern sofort auf die Wiedergabe der thomistischen Lehren selbst eingehen ${ }^{80 a}$ ). Jedoch das eigentlichste und schwierigste, aber auch lehrreichste Problem liegt in

80a) Der Grund dieses Mangels liegt darin, daß Thomas selbst seine Sozial, lehren rein literarisch-gelehrt aus dem Aristoteles und rein ideologisch-moralisch aus den Forderungen der Ethik entwickelt mit auffallender Beiseitesetzung der praktischen ihn umgebenden politisch-sozialen Verhältnisse, vor allem des Lehensstaates und des Agrarwesens. Aber das ist im Grunde doch nur Schein. Sein ganzes Unternehmen setzt die gewordene Einheitskultur voraus; sein Grundgedanke 
der Frage nach dem Zustandekommen jener Voraussetzung. In ihr münden alle besonderen Verhältnisse des sog. Mittelalters, alle politischen, sozialen und wirtschaftlichen, aber auch alle kirchenund religionsgeschichtlichen samt den geistig-wissenschaftlichen Bewegungen zusammen, und nur durch ein derartiges Zusammenmünden konnte sie zustande kommen. Ihre, wenn auch noch so annähernde, praktische Verwirklichung ist daher auch an die Fortdauer oder Wiederherstellung dieser Zustände gebunden, und alle Versuche, die Soziallehren des Katholizismus ohne diesen Untergrund durchzuführen, werden entweder zu Unmöglichkeiten oder zu bedeutsamen $W$ andlungen der Soziallehren selbst führen müssen ${ }^{81}$ ).

Die Aufgabe der Untersuchung wird daher sein zu zeigen, wie unter den neuen Verhältnissen der soziologische Ausbau des christlichen Systems selbst sich vollzog, wie hierbei die das Altertum charakterisierende Fremdheit von Kirche und Welt sich verlor und einer gegenseitigen inneren Durchdringung Platz machte und aus alledem das Ideal einer internationalen allumfassenden kirchlichen Kultur entsprang. Erst von da aus werden dann die eigentlichen Soziallehren des Thomismus in großen Zügen darzustellen sein. Die nachthomistischen Lehren des Spätmittelalters bringen dann den Zerfall der mittelalterlichen Gesellschaft und Gesellschaftslehre zur Anschauung und bereiten die modernen Verhältnisse vor, fallen aber damit aus dem Rahmen unseres Gegenstandes heraus. Sie gehören in die Geschichte der Entstehung der modernen Gesellschaft und ihrer Theorieen. Daher soll nur von derjenigen Opposition gegen die offizielle kirchliche Sozialphilosophie noch die Rede sein, welche wesentlich christliche Ideen engerer Art gegen die über den gesellschaftlichen Kosmos ausgebreiteten offiziellen Lehren aufstellen und die damit eine Unterlage für die Sekten des Spätmittelalters und der Reformationszeit bilden. Es wird sich zeigen, daß diese Sekten und ihre Sozialethik einen eigenen Typus der christlichen Soziallehren entfalten neben dem kirchlichen Typus und seinen Soziallehren. Der Gebrochenheit und Relativierung der christlichen Maßstäbe in einer bewegt sich, wie wir sehen werden, im Schema des ständischen Stufenbaus, und seine aristotelisch-naturrechtliche Theorie ist faktisch ziemlich weitgehend auf die bestehenden Verhältnisse eingerichtet, im Anschluß an welche das Naturrecht einen mit dem christlichen Ideal wohl verträgliche Gestalt annimmt. Das erscheint ihm nur alles als selbstverständlich. Diese Selbstverständlichkeiten aber gilt es historisch zu erklären. Das hier Gebotene ist ein Versuch dazu.

${ }^{81)} \mathrm{S}$. darüber im allgemeinen Sell, Katholizismus und Protestantismus I 59 bis 193, m. E. zu optimistisch. 
kirchlichen Einheitskultur tritt bei ihnen der Radikalismus der christlichen Sozialethik und die Tendenz auf -kleine Kreise gegenüber, in denen dieser Radikalismus möglich ist. Damit fällt dann aber überhaupt auf das Ganze der christlichen Soziallehren eine wichtige Beleuchtung zurück. Die thomistisch-kirchliche Einheitskultur ist nur die eine ihrer Entwickelungsmöglichkeiten; neben ihr steht die andere radikale Möglichkeit, die an Evangelium, absolutes Naturrecht und Mönchtum anknüpft. Die in der alten Kirche noch unklar gemischten Tendenzen gehen auseinander.

Dabei ist von vornherein eines im Auge zu behalten. Es. handelt sich zwar um die Geschichte der kirchlichen Sozialphilosophie, einer Lehre, eines Gedankens. Aber eine solche Geschichte braucht um deswillen durchaus nicht rein als ein dialektischer Prozeß verstanden $\mathrm{zu}$ werden. So sehr einmal angesponnene Gedanken ihre eigene dialektische Konsequenz und Entwicklung haben, zu deren Entfaltung sie teils durch den inneren Trieb auf Herausbildung ihres Gedankengehaltes, teils durch die Nötigung zur Beantwortung neuer aus der Praxis sich aufdrängender Probleme veranlaßt werden, so sind doch einmal die grundlegenden Gedanken in den großen fruchtbaren Lebenssystemen nicht einfach und einheitlich, sondern vielmehr meist selbst schon die $\mathrm{Zu}$ sammenfassung eines Komplexes; andererseits sind in dem unendlichen Spiel der sich verwickelnden Kräfte überall, wie Ed. Meyer treffend sagt ${ }^{82}$ ), die Zufälle mit in Rechnung zu setzen, d. h. das Zusammentreffen von selbständigen, unter einander nicht zusammenhängenden Kausalreihen. Beides ist in unserer Geschichte reichlich der Fall. Daß die christliche Idee in ihrer Zusammenfassung von Ueberweltlichem und Innerweltlichem, in ihrem reichen, Schöpfung und Weltgüte mit Erlösung und Weltpessimismus verbindenden Gottesbegriff selbst schon ein komplexes und spannungsvolles Gebilde ist, das ist früher gezeigt worden und wird seine Bedeutung in der Entwicklung der mittelalterlichen Idee von neuem kund tun. Ebenso wird die dem Mittelalter mögliche Durchdringung von Geistlichem und Weltlichem sich nicht aus gedanklich-dialektischen Entwicklungstrieben, sondern aus tatsächlichen Verhältnissen erklären; denn es gibt keine Dialektik, die aus der christlichen Idee heraus selber ein solches Verhältnis programmatisch festzulegen imstande wäre; hier wirken die Möglichkeiten und Nötigungen, welche der tatsächliche Verlauf der Dinge in der Entwickelung des außer-

'2) S. Eduard Meyer , Zur Theorie und Methodik der Geschichte \& 1902 S. $17 \mathrm{f}$. 
kirchlichen Soziallebens an die kirchliche Organisation heranbringt. Es muß in stillschweigend vollzogenen, als selbstverständlich angesehenen allgemeinen Veränderungen seinen Grund haben, weshalb jetzt möglich wurde, was der alten Kirche unmöglich war, weshalb jetzt gewünscht und erstrebt werden konnte, was ihr kein Ideal war. Schließlich ist dann noch bei der Gestaltung einer Einheitskultur unter den zu schildernden, besonders dafür günstigen allgemeinen Verhältnissen und Konstellationen immer noch die Frage, wie weit hier die christliche Idee nur etwa eine günstige Lage für ihre Durchsetzung zu benützen imstande war oder wie weit die Einheit nur eben dadurch zustande kommen konnte, daß auch die christliche Idee ihrerseits den herankommenden Einflüssen sich konformierte.

Vor allem muß man sich vor einer Neigung der Theologen hüten, auf deren im übrigen höchst verdienstlichen und teilweise glänzenden Forschungen sich neben den Forschungen von Juristen, Profanhistorikern und Nationalökonomen zum größten Teil die folgende Darstellung aufbaut, vor der Neigung, überall Abweichungen und Fehlbildungen gegenüber dem Evangelium oder auch überall Anbahnungen und Vorbereitungen der reformatorischen Lösungen des Problems zu sehen. Hier gilt das tiefsinnige Wort Rankes, daß jede Epoche unmittelbar ist zu Gott, und zwar darf man es dahin erweitern, daß sie unmittelbar ist zu Gott in ihrem Großen und Wahren, wie in ihrer Untreue gegen sich selbst und ihren besseren Geist. Die mittelalterliche Religion und ihre Soziallehren sind nicht eine Verbildung des Wesens des Christentums*, aber auch nicht eine anderen Zielen dienende Entwicklungsphase der christlichen Idee, sondern eine der allgemeinen Konstellation entsprechende Formung des religiösen Bewußtseins mit ihr eigenen Vorzügen und Wahrheiten und ihr eigenen Fehlern und Schrecknissen. Sie und die ihr entsprechende Gestaltung der Sozialphilosophie sind zunächst aus sich selbst zu verstehen und aus den Ueberlieferungen nur insoferne, als sie aus ihnen gemäß ihrem eigenen Bedürfnis ihre geschichtliche Nahrung und Anregung schöpfte. Das religiöse Leben auch des Christentums ist in jeder seiner großen Bildungen ein anderes und neues und muß in erster Linie jedesmal aus sich selbst verstanden werden. Wie damit die Beziehung auf ein einheitliches und allgemeines Ideal zu vereinigen sein mag, liegt außerhalb der Grenze und des Interesses der reinen Historie ${ }^{83}$ ).

85) Vgl. meine Auseinandersetzung mit Loisy und Harnack , Was heißt Wesen des Christentums ?s. Christl. Welt 1893 und die mit Rickert: Modeme Geschichtsphilosophies. Theol. Rundschan I901. 
2. Ansätze im Ergebnis der altkirchlichen Entwickelung.

In erster Linie handelt es sich um den Ausbau der religiös-kirchlichen Gemeinschaft selbst. Das ist immer noch die erste Angelegenheit des Christentums, nach deren völliger Sicherstellung die sozialen Fragen immer erst in zweiter Linie kommen. Hier sind nun die wesentlichen Grundlagen des Katholizismus bereits im Altertum festgestellt; aber in diesen Feststellungen liegen doch zugleich noch offene Fragen für die Zukunft. Die durch den gemeinsamen Gegensatz gegen Staat und Welt zusammengehaltenen und zugleich eine Minorität darstellenden Gemeinden waren bis dahin durch den Druck des Gegensatzes und der Majorität fest gefügt. Indem sie in die Periode der Parität und dann einer steigenden Privilegierung durch den Staat übertraten und zugleich numerisch außerordentlich zunahmen, zeigten sich die Unvollkommenheiten, Lockerheiten und Widersprüche des bis dahin bewunderungswürdig funktionierenden Gefüges; die vom Staat in seinem eigensten Interesse unternommenen Versuche zur Vereinheitlichung der Kirche in dogmatischen und rechtlichen Dingen, von der eigenen Gesetzgebungsarbeit der Kirche unterstützt, vermochten sie nicht zu beseitigen. Der Träger des Ganzen, der Episkopat, bedurfte einer stärkern Einheit und Geschlossenheit in sich, die Schismen und Absplitterungen in Lehr- und Kultfragen unmöglich machte, einer sicheren Gliederung gegenüber dem dem Bischof untergeordneten Klerus, einer Ausbildung größerer Verwaltungseinheiten über den Episkopaten selbst, einer sicher erkennbaren Einheit und Quelle seiner Befugnisse. Die Zusammenfassung des Episkopats in allgemeinen Synoden war ungenügend, da die Berufungsinstanz stets der Kaiser war und die Kompetenz einer Synode, ob sie allgemein oder partikular war, ob ihre Beschlüsse durchgeführt wurden oder nicht, ob sie untereinander zusammenstimmten oder nicht, von Erfolg; Machtverhältnissen, Willkür und Zufall abhängig war. Die in der Zeit der alten kämpfenden Freikirche und Genossenschaft sich trefflich ergänzenden episkopal-aristokratischen und gemeindlich-demokratischen Elemente gerieten in Reibung, jemehr die Bischofswürde ein begehrtes Herrscheramt $\left.{ }^{84}\right)^{-}$- und eine für den Staat wichtige,

84) Ueber den Zudrang zum Bischofsamt, namentlich der den alten und wohlhabenden Geschlechtern angehø̈renden Dekurionen, d. h. der für die Steuersumme 
seinem Einfluß unterstehende Macht wurde; die Unsicherheiten der Bischofswahl, mit den streitenden Einflüssen von Gemeinde, Nachbarbischöfen, Staat und großen Kirchenfürsten, gefährdeten die Sicherheit des Instituts und öffneten der Einmischung fremder Gewalten und Interessen die Eingangspforten. Auch der dem Bischof untergeordnete Parochialklerus war in Wahl und Amtsabgrenzung noch $\mathbf{z w i s c h e n ~ d i e s e n ~ v e r s c h i e d e n e n ~ E i n f l u ̈ s s e n ~ g e t e i l t ~}{ }^{85}$ ). Die aus der Kleinheit fast plötzlich in die Massenhaftigkeit übergehenden und dabei stark verweltlichten Gemeinden fielen aus der gegenseitigen Kontrolle wie aus der Herrschaft der Bischöfe heraus, und die bloß die groben offenkundigen Sünden treffende Kirchenzucht war kein ausreichendes Mittel der geistigen Kontrolle und Beherrschung ${ }^{86}$ ). Weiter waren die in dieser Lage sich bildenden Mönchsvereine und Klöster mit ihren starken Neigungen zur Absonderung und Selbständigkeit ein gefährlicher Sprengstoff und ein bedenklicher Konkurrent des Priestertums. Ebendaher ist auch der eigentliche $Z$ weck der kirchlichen Institution, die Aufrechterhal. tung der Lehreinheit und der Einheit der sakramentalen Kräfte, von der Kirche trotz nachdrücklichster staatlicher Hilfe nicht durchgesetzt worden. Es splitterten die arianischen, die nestorianischen

verantwortlichen, in zwangsmäßiger Erblichkeit des Amts gebundenen städtischen Beamten s. Löning, Gesch. des deutschen Kirchenrechtes I, I878, S. I48 ff. Sie suchten sich dadurch ihren peinlichen Verpflichtungen zu entziehen. Ueberhaupt die reichen Klassen streben ins Bischofsamt ibid. 152. Dagegen dann immer wiederholte Staatsgesetze, Versuche zur Einschränkung der Zahl der geistlichen Stellen, Anweisungen, den Klerus aus dem Mönchtum zu rekrutieren.

s5) Ueber diesen letzten Punkt Löning > Gesch. des deutschen Kirchenrechtes ^ I, S. 131 u. 158. Andere aus der Unklarheit des Verhältnisses der aristokratischen und demokratischen Elemente entspringende Unklarheiten lagen im Kirchengut. Es verwandelte sich aus Korporationsgut in Anstaltsgut, welche Entwicklung die kaiserliche Gesetzgebung stillschweigend sanktioniert.

86) Ueber den Uebergang der Disziplinargewalt aus der Hand der Gemeinde in die des Bischofs und ihre Verwandelung in ein an Stelle Gottes ausgesprochene Urteil, über ihre das Verhältnis zu Gott, nicht zur Gemeinde betreffende Wirkung s. Löning I, $254 \mathrm{ff}, 265 \mathrm{ff}$. Ohne Bußsakrament kann es zu keiner wirklichen, alles umfassenden Disziplin kommen, auch die Folge des sozialen Boykotts knüpft sich erst sehr langsam an den Kirchenbann. In Gallien hat man ein wöchentliches privates Beichten mit Bereitwilligkeit zur Uebernahme der Bußpflichten für das Mittel zu einer geistlichen Zucht der Bevölkerung gehalten und damit die Grundlage des Bußsakraments, des eigentlichen Herrschaftsmittels der Kirche erst gelegt, Hauck KG. Deutschlands I, 275 und Karl Müller, KG. I, I892, S. 313-I5. 
und monophysitischen Kirchen ab, die sich durch Anschluß oder Unterwerfung unter fremde Staatshoheit sicherten. Der donatistische Bauernaufstand glaubte nur an die Sakramentalkraft reiner Priester und nicht an den charakter indelebilis; er eröffnete damit die große Reihe der antikirchlichen Sektenbildungen, die späteren Zeiten außerordentliche Beschwerden machen sollten. Die großen Kirchenfürsten gerieten in heftige Rivalitäten untereinander, in denen die dogmatischen Kämpfe zu Mitteln kirchenpolitischer Auseinandersetzungen wurden. Politische Staatsraison und theologische Dilettantenneigungen führten die Kaiser zu beständigen Eingriffen in diese Kämpfe. So wurde gerade mit der Durchsetzung und Anerkennung der Kirche die im Episkopat verkörperte soziologische Einheitstendenz zersplittert und erschwert trotz der mächtigen Nachhilfe des Staates. Andererseits wurde auch die politische Absicht bei der Rezeption der Kirche, die Einfügung der Kirche unter die staatserhaltenden und den Staat tragenden Mächte, nur sehr eingeschränkt erreicht; die kirchlichen Kämpfe und die dem Staate gegenüber inkommensurablen kirchlichen Mächte haben besonders im Westen geradezu auflösend und zerstörend gewirkt. Es ist ein neues soziologisches Gebilde, dessen eigene Natur und Folgerichtigkeit noch nicht voll entwickelt ist und dessen Verhältnis $\mathrm{zu}$ den übrigen soziologischen Bildungen und Kreisen weder für es selbst noch für diese'geklärt ist.

Welches sind nun aber die Gründe, warum die Entwickelungstendenz so ins Stocken gerät und die Verhältnisse so ungeklärt sind? Es ist nicht bloß die natürliche Unfertigkeit eines jungen Gebildes und die Schwächung des Gemeingeistes, die bei jeder Verwandelung einer Minorität in eine Majorität eintritt, und die bei dem massenhaften Namen- und Zwangschristentum in der Tat besonders lähmend wirkte. Es sind Hemmungen, die in Idee und Wesen des bisherigen Christentums selbst liegen. Das neue Verhältnis zum Staat d. h. zur kaiserlichen Gewalt wirkt bei aller außerordentlichen Verstärkung doch zugleich hemmend und verwirrend. Aus der Hand des Staates hat die Kirche die Einheit ihres Dogmas und der Verfassung empfangen, aber diese selbe Staatsgewalt war doch zugleich eine fortwährende Einmischung fremder politischer Gesichtspunkte, Interessen und Mächte in das kirchliche Leben. Der von der Kirche zunächst wie selbstverständlich anerkannte kaiserliche Ab- 
solutismus, der den Ausbau von Kirche und Dogmen bewirkte, war zugleich eine Störung der Einheit und Geschlossenheit der Kirche wie ihrer religiösen Interessen. Die allgemeine Theorie der Kirchenlehrer über den Staat konnte hier zu keiner Klarheit helfen und steigerte nur die Verwirrung. Die Staatsordnung als Ordnung des relativen Naturrechts und das absolute Kaisertum im Dienst der theokratischen, von den Bischöfen getragenen Heilsidee, der die Kaiser das Gebilde des relativen Naturrechts im Falle geistlicher Interessen unterordnen sollten, das gestattete wohl eine positive Würdigung des Staates, aber kein klares Verhältnis. Klar wurde das Verhältnis erst, wenn die Kirche durch ihre Organe das Kaisertum wirklich einheitlich beherrschen und leiten konnte, und wenn sie eine konkrete Anschauung davon hatte, wie mit Hilfe des Kaisertums das weltliche Leben wirklich im einzelnen dem Interesse des ewigen Heils eingegliedert werden konnte. Allein da fehlte es an allen Punkten. Der Episkopat besaß nicht die Geschlossenheit, die das Kaisertum hätte unter sich beugen können; die Kaiser dachten nicht daran, die alte römische Staatsidee zu Gunsten eines geistlichen Priesterreichs aufzugeben; und bei der Festigkeit und Fremdheit des alten Staates gegenüber den kirchlichen asketisch-geistlich-innerlichen Mächten waren die Bischöfe selbst bereit, in weltlichen Dingen sich ohne weiteres wie bisher dem Kaiser als der von Gott eingesetzten Macht zu unterwerfen. Wo aber die Grenzlinien zwischen geistlichen und weltlichen Dingen liegen, ist schwer zu sagen, und dies festzusetzen gab es keine Instanz. Noch schienen die geistlichen Interessen in der Bekämpfung der Häretiker, der $\mathrm{Z}$ wangschristianisierung der Heiden und der Privilegierung der Kirche aufzugehen. Eine Beugung des gesellschaftlichen Lebens im ganzen und einzelnen unter kirchliche Maßstäbe zu fordern, darauf war die kirchliche Ethik nicht gerüstet, dazu galt die soziale Ordnung zu sehr als fest und unwandelbar, dazu war der asketische und religiöse Geist der Welt innerlich noch zu fremd, dazu war die Welt, so wie sie war, in keiner Weise geeignet. Zwar finden sich in der Beteiligung des Episkopats an der. politischen und sozialen Tätigkeit, am bürgerlichen und am Strafrecht, in den öffentlich-rechtlichen Befugnissen der Bischöfe und der Geistlichkeit, in der sozialen Fürsorge der Bischöfe während der politischen Wirren für alle Bedürfnisse ihres Sprengels die Ansätze zu einer solchen Einverleibung des sozialen 
Lebens in die Kirche. Allein sie sind einerseits Notprodukt und prinzipwidrig, mehr vom Interesse der Kommunen und Provinzen als dem der Kirche diktiert, heftig bekämpft von den Asketen, die derartige Dinge als Verweltlichung des Bischofsamtes ansahen, und oft in der Tat mehr von den weltlichen als von den geistlichen Instinkten der Bischöfe getragen. Andererseits bedeutet die rechtliche Sonderstellung des Klerus, die Fortdauer seiner richterlichen Tätigkeit, die Delegierung der Wohlfahrtstätigkeit an ihn in dem Sinne, wie der Staat diese Dinge betrachtete, eine Fortdauer der alten Sonderstellung der Kirche im Staat, die der Staat teils gewähren läßt teils für seine $Z$ wecke nützt, und damit gerade statt der Einigung von Kirche und Welt die allen offenkundige Trennung beider; die Trennung hielt sich dabei auf der Linie, auf der sie sich schon vorher gehalten hatte, und wurde von beiden Seiten her genau abgegrenzt, um die Kirche nicht zu sehr in die Weltförmigkeit zu verstricken. Bei dem Bündnis des Staates mit der Kirche erlebte jeder Teil seine Ueberraschungen. Der Staat hoffte die Kirche seinen Erhaltungsmitteln einzugliedern und stieß auf die Souveränität einer rein geistlichen Macht. Die Kirche hoffte mit Hilfe des Staates ihre Einheitstendenz abzuschließen und nahm in den Einmischungen des Staates ein Element beständiger Störung, einen unter Umständen nützlichen und unter andern Umständen auflösenden, jedenfalls immer von außen hereinwirkenden Fremdkörper auf. Wohl mochten in dieser Lage ein Chrysostomus, Leo I., Gelasius und Augustin die theokratische Unterstellung des Kaisers unter das Priestertum nach dem Vorbild des Alten Testamentes fordern und damit das »Programm des Mittelalters entwerfen. Allein das Programm ist im Orient nie, im Occident erst nach einem halben Jahrtausend verwirklicht worden. Zwischen Augustin und Gregor VII. muß etwas anderes liegen als bloß die Auflösung des Reiches und die Lähmung aller Verhältnisse durch die Barbarei. Sonst hätte es nicht so lange gedauert bis zu seiner Verwirklichung, und aus der bloßen Zersetzung der kirchlichen Einheit allein wäre der neue Charakter der Kirche gerade im Verhältnis $\mathrm{zu}$ den sozialen Dingen nicht hervorgegangen. Das, was dazwischen lag, muß die Gründe in sich enthalten, warum das Wirklichkeit werden konnte, was bei Augustin ein unbestimmtes Programm blieb. Dies Programm war eben in der alten Kirche nicht bloß ein noch unverwirklichtes Programm, sondern es waren auch gar keine Mittel 
und Wege sichtbar, auf denen es verwirklicht werden konnte; die Weltfremdheit der Kirche und die Selbständigkeit des in uralter Rechts- und Verwaltungstechnik gefestigten Staates machten jeden Gedanken einer solchen Verschmelzung unausdenkbar. Die prinzipielle Theorie von der Lex naturae machte den Staat wohl im allgemeinen annehmbar, aber sie bedeutete doch den von der Kirche verschiedenen Staat und enthielt bei aller behaupteten Identität mit der Lex Mosis oder dem Dekalog doch keinerlei konkreten Hinweis darauf, wie die Kirche ihrerseits praktisch die weltlichen Verhältnisse in Besitz, Handel, Recht, Gesellschaftsgliederung, politischem Aufbau und geistigem Leben normieren soll. Alles ist bestenfalls auf einen Parallelismus mit gelegentlichen Ausgleichungen zugeschnitten, und sobald die Parallelen sich schneiden, ist Weisheit und Theorie zu Ende ${ }^{87}$ ).

Der soziologische Ausbau der einheitlichen Priesterkirche hängt an der Herausbildung eines ne u e $\mathrm{V}$ erhältnisses $\mathrm{zum} \mathrm{Stat}$ a wo der Staat die geistlichen Lebenszwecke und -Normen sich aneignet, sein eigenes Gefüge mit dem der Kirche

87) $\mathrm{Zu}$ den beiden letzten Absätzen vgl. außer dem dritten Stück des ersten Kapitels die treffliche Darstellung bei Edgar Löhning sGesch. d. deutschen Kirchenrechtese I, 1878, dessen erster Band die nachkonstantinische Kirche sehr klar und treffend darstellt. Bes. Kap. I, S. 20-Ioz und die Abschnitte über den Anteil der Bischöfe am bürgerlichen und öffentlich-rechtlichen Leben S. 289-33I; ein besonders unsicherer Punkt im System ist die Bischofswahl, in deren Unsicherheiten der alte gemeindliche und der neue universalkirchlich-autoritative Charakter des Systems in Kampf geraten, ähnlich wie später die Unsicherheit der Papstwahl vor der Schaffung des Kardinalats eine der schwächsten und ungeklärtesten Stellen im soziologischen System bedeutete. Beispiele über die Kulturarbeit der Bischöfe und ihr Einrücken in soziale und öffentlich-rechtliche Funktionen aus der gallischen Kirche bei Hauck >KG. Deutschlands \& I, 13 I ff., über den Widerspruch der Asketen gegen diese Entwicklung S. 76-8o. Haucks Darstellung zeigt auch, wie zufällig und außerlich dieses Eintreten der Bischöfe in soziale und politische Arbeit begründet ist; die eigentliche Konsequenz der christlichen Idee, wie sie jetzt empfunden wurde, vertritt Salvian S. 70, der womöglich durch Vererbung alles Besitzes an die Kirche Gütergemeinschaft und im übrigen Abschließung von der Welt verlangt. Ueber die materielle Durchführbarkeit des Gedankens macht er sich gar kein Bedenken, und andererseits ist auch die Sozialpolitik der Bischöfe nicht prinzipiell damit begründet, daß die Durchführung der christlichen Idee im Leben etwa ein stärkeres Eingehen auf die Naturbasis fordere. Ueber die beiden Klassen gallorömischer Bischöfe, die weltförmig-politischen und die asketisch-eigentlich christlichen s. auch Löning I, I $20 \mathrm{f}$. 
innerlich verbindet und dadurch auch das allgemeine gesellschaftliche Leben unter die Normen der Kirche mittelbar oder unmittelbar beugt. Das ist in schweren Kämpfen im Osten und Westen geschehen, beidemale aber in sehr verschiedener Weise. Im konkreten tatsächlichen Verlauf dieser Kämpfe und Bildungen muß ein erheblicher Teil des Neuen begründet sein, das das sog. Mittelalter brachte. An sich wäre ja natürlich auch das Umgekehrte denkbar, daß nämlich die Kirche theokratisch die Leitung in die Hand nimmt und den Staat sich direkt unterwirft. Allein einmal -war der Staat noch weitaus der stärkere Teil, andererseits war die Kirche noch viel zu spröde und auf ihr bloß geistliches Wesen gestellt, als daß daran konnte gedacht werden: hier gibt es nur gelegentliche hierarchische Träume, die rasch mit der Versicherung der Unterwerfung des Priestertums in allen weltlichen Dingen unter die Staatsgewalt enden. So ist der nächste Ausweg aus den Spannungen und Schwierigkeiten das christliche Staatskirchentum. Es ergibt sich im Osten direkt aus der inneren Entwickelung; die besonderen Gründe, die im Westen hierzu mitwirken und ihm dort eine besondere Gestalt geben, werden an ihrem Ort hervorzuheben sein.

Im Osten wurde nach schweren Kämpfen ein Zustand der geschlossenen Einheit erreicht, indem das Kaisertum selbst zu einer geistlichen Würde sich wandelte und die religiös-kirchlichen $Z$ wecke in seine eigene Idee aufnahm, dafür aber die Kirche zu einem Departement der Staatsverwaltung machte. Der alte orientalisierte und feudalisierte Römerstaat mit seiner hellenistischen Bildung und Literatur blieb bestehen, nahm aber das geistliche Wesen in sich auf und stimmte beides durch die Staatsgewalt auf einander. Versteht man unter dem sog. Mittelalter die geistlich-weltliche, natürlich-übernatürliche, staatlich-kirchliche Einheitskultur, an welchem Merkmal sich ja auch die Kultur der islamitischen Staaten aus ähnlichen Gründen beteiligt, so ist das oströmische Reich echtes Mittelalter, und es gehört zu den wunderlichen Meinungen, wenn man sagt, der Osten habe kein Mittelalter gehabt ${ }^{87 a}$ ). Er hat

87a) Z. B. Seeberg Lehrbuch d. Dogmengeschichte II I898 S. 2 >Der Geist der griechischen Kirche hat kein Mittelalter gehabt. Denn er ist über die antiken Probleme des Origenes nicht herausgekommen (?), d. h. die griechische Kirche hat keinen Augustin gehabt. Man kann die ganze mittelalterliche D. G. als Geschichte dés Augustinismus behandelne. Ich glaube vielmehr, daß die besondere Art des abendländischen Mittelalters in der politisch-sozialen Entwickelung das Entscheidende 
es bis heute, und wir sehen vor unseren Augen die merkwürdigsten Kombinationen dieses Mittelalters mit modernsten politischen und wirtschaftlichen Einrichtungen und Strebungen. Nur freilich ist dieses östliche Mittelalter sehr verschieden von dem westlichen. Der Unterschied liegt darin, daß auch der theokratisch und geistlich stilisierte, römisch-hellenistische Staat der alte Staat mit dem alten Recht und der alten Kultur blieb, die mit der christlichen Ideenwelt sich nur ausglich, aber nicht innerlich verband. Die alte Fremdheit der uralten. Gegner blieb trotz aller Milderung bestehen, und das ganze System blieb ein Parallelismus, dessen Glieder nur' durch das geistlich interessierte und qualifizierte Kaisertum im richtigen Verhältnis gehalten werden. Auf die gemeinsame Regulierung beider durch das geistlich-weltliche Kaisertum beschränkt sich die Vereinheitlichung, cine innere gegenseitige Durchdringung findet nicht statt. Dic Real-Macht des Staates kann sich bei dem ungestörten Parallelismus begnügen; er braucht nicht, wie die Ideenmacht der Kirche im Falle ihrer Herrschaft müßte, eine innere gedankliche Durchclringung zu bewirken. Jaher fehlen dem byzantinischen Osten dic ticfen inneren Spannungen des abendländischen Mittelalters und dic Herausbildung analoger Erscheinungen wie die Renaissance und die Reformation. Die letzteren ziehen einen guten Teil ihrer Wirzeln aus den Versuchen innerer Verschmelzung, wie sie das abendländische Mittelaiter rastlos unternahm; die stets lebendig bleibende Antike hat im Orient keine Renaissance gewirkt, und aus den Versuchen einer Vertiefung und Erneuerung des religiösen I.ebens entspringt im Orient stets nur die Askese, sei es auch eine so moderne Askese wie die Dostojewskis und Tolstois ${ }^{88}$ ). litwas der Reformation Verwandtes hat dort keinen Boden.

Wie aber kommt es zu der andersartigen Entwickelung des A bendlandes? Hier ergibt sich im Endergebnis ein ganz auch für den ethisch-geistigen Grundcharakter ist. Gegenüber der rein dialektisch-. idcologischen Auffassung der Kirchen- und Dogmengeschichte ist hier ein Stück -Maraismuse wohlberechtigt. Der Augustinismus bildet nur ein besonders wichtiges Mittel zur Bewältigung der aus dieser Entwickelung sich ergebenden Probleme und auch das schlicł引lich nur in enger Verbindung mit dem dem Augustin ganz fremden Aristotelismus: Es wird die Aufgabe des Folgenden sein, das zu zeigen.

88) Hierzu vgl. Karl Neumann »Die Weltstellung des byzantinischen Reiches IS95 u. besonders , Byzantinische Kultur und Renaissancekultur * 1903. Leider ist die (ieschichte der russischen Kirche zu unbekannt, als daß die sicherlich höchst interessanten Parallelen und Gegensätze gegenüber der der abendländischen Entwickelung hier verfolgt werden künnten. 
anderes Verhältnis zum Staat und durch dessen Vermittelung zum sozialen Leben überhaupt, die hierarchisch-theokratische Einheitskultur. Aus dem Entwickelungstrieb der religiös-kirchlichen Idee als solcher hat das, wie gezeigt, nicht direkt hervorgehen können. Welches aber sind die Ereignisse gewesen, die sie trotzdem in diese Bahnen gelenkt haben?

Es sind die großen grundlegenden Ereignisse der abendländischen Kirchengeschichte. Erstlich die Zerschlagung der Reichskirche in germanisch-romanische Landeskirchen, in denen die Kontinuität der bisherigen Entwickelung fast ganz aufgehoben schien ein halbes Jahrtausend lang und von denen die fränkische Landeskirche die Trägerin der Hauptentwickelung wurde, in dem karolingischen Reiche sich aufgipfelnd, vom ottonischen fortgesetzt, und im salischen dann sich überschlagend in die Universalkirche. Auch das ist ein Staatskirchentum, aber ganz anders als das des Ostens, nicht auf der Stärke des Staates, sondern auf der inneren Durchdringung von Geistlichem und Weltlichem beruhend, die dem Staate erst seine Kraft und Kulturmission gab und daher auch ein völlig anderes Ergebnis für die Kirche hatte als der Byzantinismus. Zweitens die Ausbildung der $\mathrm{Pa}$ a a lide e und des von ihr getragenen kirchlichen Universalismus in engem Zusammenhang mit einer neuen Welle eines internationalen, weltindifferenten Asketismus und einer von den Orden getragenen kirchlichen Wissenschaft. Indem das deutsche Königtum aus seinen landeskirchlich-religiösen Ideen durch das universale Kaisertum herausgetrieben und zur Fürsorge für die Gesamtchristenheit geführt wird, hebt es die universalkirchliche Papalidee wieder in den Sattel, und diese behält das Erbe in ihrer Hand, das ihr ein halbes Jahrtausend landeskirchlicher Durchdringung von Kirchlichem und Staatlichem, Geistlichem und Sozialem zugeworfen hat. Die germanisch-romanische Landeskirche ist etwas anderes als die byzantinische Staatskirche, und hier muß der erste Grund des Unterschiedes liegen. Die Bedeutung dieser Vorgänge gilt es im einzelnen anschaulich zu machen.

3. Die landeskirchliche Periode und die Durchdringung von Geistlichem und Weltlichem.

Das Aufkommen der germanisch-romanischen Staaten, neben denen die keltischen und später die slavischen und der ungarische stehen, bedeutet zunächst ein völliges Erlöschen der Reichskirche und eine scheinbar für immer eintretenue $A$ ufhebung des 
kanonischen Rechtes der alten Einheitskirche. Nur in der angelsächsischen Kirche wurde das kanonische Recht, die römische Kultsitte, der Zusammenhang mit dem Zentrum, dem römischen Bischof, aufrecht erhalten. Alle anderen, und vor allem das Mitteleuropa einigende und ihm gemeinsame Kulturgrundlagen gebende fränkisché Reich, haben die Kirche rein als Landeskirche verwaltet, dem Organismus ihres neuen Staatswesens eingefügt, und die Einheitskirche nur in einem konventionellen Respekt vor dem Papst und in dem Gedanken der Gemeinsamkeit alles Christlichen festgehalten. Auf diesen Gebieten ergab sich ein von dem altkirchlichen völlig abweichendes Kirchenrecht, dessen Grundzug das Besitzrecht und Besetzungsrecht des Grundherren an den auf seinem Grund befindlichen Kirchen ist. Damit ist dann erst die Entwickelung der kirchlichen Vassalität und des kirchlichen Lehenswesens ermöglicht, das die Kirche völlig in die Hand der Grundherren und Lehensherren, zuoberst des Königs, gab. Die Gründe für dieses Aufkommen des ganz neuartigen landeskirchlichen Prinzips liegen noch im Dunkeln. Das System der Eigenkirche hängt unzweifelhaft mit dem alten vorchristlichen Kultuswesen zusammen. Das landeskirchliche Prinzip, das seinerseits durch die Eigenkirche im Laufe der Zeit enorm gefestigt wird, mag vielleicht von den arianiśchen Kirchen stammen, die durch ihren Ausschluß von der orthodoxen Kirche und bei den nationalen Gegensätzen auf eine landeskirchliche oder nationalkirchliche Formation gedrängt waren und hierin wohl auch an Traditionen des alten vorchristlichen Volkskultus anknüpfen mochten. Bestehen diese Vermutungen zurecht, so erleuchteten sie sehr charakteristisch die Lage: die aus dem Gegensatz gegen den hcidnischen Staat entsprungene, rein universalistisch-religiöse Ethik kann kein inneres Verhältnis zum Weltlichen finden, aber die Nachwirkungen des germanischen Volkskultus, in dem wie in allem Heidentum religiöse und natürlich-soziale Elemente innerlichst verbunden sind, bringen dann wieder die Einheit beider wie etwas selbstverständliches mit sich ${ }^{88 a}$ ). Wie das byzantinische Staatskirchentum an die Ueberlieferung der römischen Staats-

86 ) Vgl. das wichtige Werk von U. Stutz, Die Eigenkirche. Auf die arianischen Kirchen wies mich Herr Kollege von Schubert hin, der in Bälde einen dieses Thema lechandelnden höchst erleuchtenden Aufsatz veröffentlichen wird. Er glaubt darin auch die Abhängigkeit der fränkischen Kirche vom arianischen Vorbild erweisen zu künnen. 
religion anknüpft, so hinge dann auch das westliche Landeskirchentum mit heidnischen Grundlagen zusammen. Aber gleichzeitig erklärte sich dann auch der Unterschied zwischen jenem Staatskirchentum und diesem Landeskirchentum. Dort gliedert ein starker Staat mit alter Kulturtradition die Kirche sich ein, hier bildet ein neues Staatsleben sich mit Hilfe der Kirche, die völlig naiv und gläubig ihre Aufgaben mit den seinigen identifiziert und durch die rechtlich-wirtschaftlichen Verhältnisse mit seinem Gefüge zusammenfällt. Kulturstark genug, um dem jungen Staat seine intellektuellen, organisatorischen und moralischen Grundlagen zu geben, war der lediglich mit der Aneignung beschäftigte und den neuen Rechts- und Eigentumsverhältnissen unterworfene gallisch-germanische Klerus andrerseits doch auch geistig und materiell zu unfrei, um an eine selbständige kirchliche Kultur nur zu denken. So kam es zu der "Landeskirche . Jedenfalls kann an der Neuheit des Prinzips kein Zweifel sein. Die Reste der alten Reichskirche vermochten dieser Entwicklung sich nicht zu widersetzen, da sie auf ein immer kleineres Gebiet zurückgedrängt wurden, den größten Teil an Ostrom und an die islamischen Reiche verloren und in ihrem Kern, dem Papsttum, mit eigenen territorialen Sorgen überhäuft waren. Zwar hat von der angelsächsichen Kirche her die Reform und kirchliche Organisation des Bonifacius, den die fränkischen Herrscher in.ihre Dienste zogen, den Zusammenhang mit Rom wieder hergestellt, die italienisch-benedektinische Mönchsregel über die schottisch-kolumbanische zum Siege gebracht und eine möglichste Annäherung an das kanonische Recht erstrebt; aber, indem die fränkischen Herrscher diese Reform ihrer in der Tat sehr verwilderten Kirche benützten, brachen sie ihr doch die universalkirchlichen Konsequenzen $a b$ und benützten sie nur für geistige Belebung und organisatoris .le Festigung ihrer Landeskirche. Als es dann mit Karl d. Gr. zu der Zusammenfassung aller nördlichen Bestandteile des ehemaligen römischen Reiches und der neuen Missionsgebiete kam, da ward die Landeskirche zur Reichskirche, aber zu einer Reichskirche im Sinne der fränkischen Landeskirche. Es war eine Landeskirche, die nun auch den Papst umfasste. Der Kaiser regierte die Kirche und benützte sie als wesentlichen Träger der Organisation und Kultivierung seiner Völker, indem er ihre innere, rechtliche und grundherrliche Entwicklung in diesem Sinne leitete und sie zugleich für die öffentlichen $Z$ wecke in Dienst nahm. Davon verblieb auch 
nach der Zerteilung des karolingischen Reiches für ganz Mitteleuropa diese Grundrichtung des Kirchentums. Die Wiederaufnahme der karolingischen Staatsidee durch das sächsische Kaiserhaus vermochte freilich geistliche und weltliche Würdenträger nicht mehr in der Stellung von bloßen Beamten festzuhalten, es mußte beide zu Fürsten werden lassen; aber da stützte es sich nun erst recht auf das geistliche, durch seine Nichterblichkeit den Einflüssen der Krone unterstehende Fürstentum, das zugleich für Kulturarbeit und politischen Zusammenhang des Reiches aufzukommen hatte. Aehnlich wie Karl d. Gr. hat in England Alfred d. Gr. gewirkt. So ist es geblieben bis zu dem Ausbruch des großen gregorianischen Kampfes um die Trennung der Kirche vom Staat, um die Wiederaufrichtung der Universalkirche und des kanonischen Rechtes. Wo die Wirkungen des Kampfes nicht hinreichten, in den entfernten skandinavischen Ländern, ist es auch dann noch beim Alten geblieben.

Soweit der große Zusammenhang, dessen Einzelheiten der Kirchen-, Rechts- und Wirtschaftsgeschichte angehören ${ }^{80}$ ). Für unsere Frage ist hierbei der entscheidende Gesichtspunkt, daß dieses halbe Jahrtausend einer landeskirchlichen Entwicklung die

$\left.{ }^{80}\right)$ Vgl. hierzu von Schubert die Entstehung der Schleswig-holsteinischen Landeskirche 1895 mit einer sehr lesenswerten Einleitung über die Bedeutung der landeskirchlichen Periode des abendländischen Katholizismus. Des gleichen Verfassers zweiter Band von seinem "Lehrbuch der KG.* konnte ich leider noch nicht benützen. Löning,$G$. d. deutschen Kirchenrechtes II, 1878 enthält nur die merowingische Kirche, die aber doch die Grundlage des Ganzen bildet; hier ist das Kapitel über die öffentlichen Funktionen des Bischofs von Bedeutung S. 220 bis 275; außerordentlich viel Material im Einzelnen enthält Haucks großartige Kirchengeschichte Deutschlands in den ersten drei Bänden. Die die Grundzüge der Institutionen scharf hervorhebende KG. von Karl Müller I, 1892 betont die bleibende Bedeutung Karls d. Gr. S. 353 u. bes. 359: $\gg$ Gebl sben ist die Verbindung von Staat und Kirche, die der Institutionen und Kompetenzen, durch die das Christentum wirklich die volkstümliche Religion werden und die Kirche in Jahrhunderte langer Arbeit in ihren Grenzen zum Ziel kommen konnte. Karl hat dem Staat die neuen großen humanen Aufgaben vorgeschrieben, die die germanische Vergangenheit nicht gekannt hatte, und doch hat er den Kreis der Aufgaben, die un mittelbar durch den Staat und seine Beamten erfüllt werden sollten, nicht wesentlich erweitert. Denn wie er seine Aufgabe von der Kirche erlernt hatte, die darin teilweise die Erbin des alten Reiches gewesen war, so hatte er auch deren Erfullung in ihren Händen gelassen und sie dabei nur in seinen Dienst gestellt, zugleich aber sie zum selben $Z$ weck mit einer Menge staatlicher Gewalten ausgestattet. Unter seinen Nachfolgern ist die Erinnerung an beides in Staat und Kirche wieder 
religiöse Organisation und Idee in de $\mathrm{n} D$ i e $\mathrm{nst} d$ es $\mathrm{St}$ a a tes und seiner Kulturaufgaben stellte. Nicht eine innere.

verschwunden. Im Lauf der Zeiten hat die Kirche jene ihr geschichtlich zugekommenen Aufgaben und Mittel als göttliche Stiftung an sie ausgegeben, beansprucht und sich eben damit gegen den Staat gestellt. E's bezeichnet den Anfang der neuen (d. b. modernen) Zeit, daß der Staat jene Ziele wieder als die seinen erkennt und ihre Realisierung mit seinen Mitteln und seinem Beamtentum erstrebt.\& Daß die karolingischen Grundlagen und Ideen übrigens sich fortsetzen bis zur gregorianischen Revolution, darüber s. Hauck III, 435 und noch unter Heinrich III S. 572, auch die Kanonisation Karls d. Gr. durch Barbarossa IV S. 264. Ueber die völlig analoge -Durchdringung von Staat und Kirchea in England bis $1066 \mathrm{~s}$. Böhmer Kirche und Staat in England 1890 S. 48-56. - Aehnlich wie K. Müller urteilt K. Lamprecht Deutsche Geschichte II, I892 S. 48: :In der Tat war es, aus der Vogelschau des endenden Mittelalters gesehen, das verdienstliche Werk Karls d. G., daß er weltliche und kirchliche Interessen zu jener Einheit verbunden hatte, die erst die schwersten Kämpfe von den Zeiten Gregors bis auf Luther zu lösen vermochten.» S. 49: Eben darin liegt die Bedeutung Karls d. G., ja des Karolingischen Staates und der Karolingischen Kultur überhaupt, daß sie universell und neidlos die sehr verschiedenen Einflüsse, unter denen das Zeitalter stand, aufzunehmen und $z \mathfrak{u}$ dem $z \mathfrak{u}$ verknüpfen begann, was das eigentliche mittelalterliche Wesen bezeichnete ... die Vermittelung aber übernahm schliefslich die Kirche, und das Verdienst Karls d. G. ist es, eben die Kirche dauernd in diese Vermittlerrolle gedrängt zu haben. « Ueber die Fortdauer dieser Grundzüge, ,dieser Art von kirchlich - staatlicher Endosmose « bei den Ottonen s. S. 15 I f. Ueber die ganz analogen französischen Verhältnisse, die nur zunächst hinter der deutschen Ordnung zurückblieben, aber seit der Einigung Frankreichs Deutschland in allen Kulturbeziehungen und schließlich auch politisch überholten s. Rambatid -Histoire de la civilisation française $I$, I90I, wo eine vorzügliche systematische Uebersicht über alles kulturgeschichtliche Material gegeben ist. - Hervorzuheben ist auch hier Uhlhorns "Liebestätigkeit $\ltimes$, deren zweiter Band 1884 die soziale und wirtschaftliche Entwicklung des Mittelalters als Hintergrund der christlichen Ideen schildert. Er betont das Aufhören des städtischen Charakters des Christentums und damit das Aufhören einer besonders organisierten Liebestätigkeit der Gemeinde. Die Liebestätigkeit verwandelt sich, wozu Karl d. G. die Anweisung gab (S. 6I), in die soziale Fürsorge der Bischöfe und Aebte für ihre grundherrlichen Untergebenen und im allgemeinen Reichsdienst, und weiterhin in die besonderen Organisationen des Spitals mit weitreichenden allgemeinen Funktionen für das soziale Leben; die letzteren Organisationen gehen dann teils an das Mönchtum, teils an besondere ritterliche und bürgerliche Spitalorden über. Dabei hört dann doch auch die Liebestätigkeit der Gemeinde d. h. der Gemeindeleitung nicht auf, sie dauert nur eben im engen Zusammenhang mit der grundherrlichen und politischen Fürsorge fort, wie Hauck IV, 52-55 gegen Uhlhorn geltend macht. Auch Uhlhorn betont, wie erst auf diese Weise das Christentum zu einer Christianisierung der Gesellschaft 
Nötigung und Konsequenz des religiösen Gedankens, sondern die Macht der Verhältnisse und der Zwang eines kulturlosen Staates, der die kirchliche Organisation und die in ihr lebendige Tradition antiker Kultur für seine Zwecke verwenden mußte und mit ihrer

kommt im Gegensatz zu seiner Fremdheit gegen die Gesellschaft in der römischen Welt $S .5$, ohne aber die Gründe für diese Wandlung genauer zu analysieren; er meint nur, daß die Germanen das Christentum tiefer erfaßten als es die im Heidentum alt gewordenen Griechen und Römer vermochten S.6. Allein das wird man, wie dic sorgfältigen Analysen Haucks zeigen, gerade von dem sehr eudämonistisch und gesetzlich vergröberten, vorbernhardinischen Christentum durchaus nicht sagen künnen. Die Gründe liegen vor allem in der Kulturlosigkeit der Germanen und in der Einstellung der Kirche als Kulturvermittlerin durch die karolingische staatsidee. - Beispiele solcher bischöflicher Kulturfürsorge gibt Hauck bei Bernward von Hildesheim III, 396, ähnlich S. 410, 414, 438. Ein Denkmal solcher Fürsorge ist das Hofrecht des Bischofs Burchard von Worms, der im Namen der Trinität und auf Grund von Verhandlungen mit allen Gruppen seiner Herrschaft das Straf- und Zivilrecht ordnet, um ohne Rücksicht auf Stand und Vermögen auch den Armen gutes Recht zu sprechen vgl. Gengler „Das Hofrecht des B. Burchard 1859 . Unter den Ottonen sind neun Zehntel aller Marktherrschaft, damit Handelsrecht und Münzrecht, in den Händen der Bischöfe, Lamprecht IV, 99. Leber England s. Böhmer S. 55: $\gg$ Das Ziel, das man dabei im Auge hatte, war nicht allein das äußere Ansehen der. Kirche, sondern auch die Beherrschung und Leitung aller Stände des christlichen Volkes « nach dem $\gg$ Gesetz Gottes $\propto$. Zu diesem Behuf aber verlangte man nicht eine größere Trennung, sondern eine neue innigere Verschmelzung von Kirche und Stant, forderte man von dem Geistlichen einen ebenso großen Eifer für die Durchführung der Gesetze des Landes wie für die Durchrührung der $\triangleright$ Gesetze Gottes $\propto$. Auch nach Einführung der münchischen Reformbewegung strebte man nur in ausgedehnterem Naße als bisher, das öffentliche und private Leben mit dem Geiste der Religion zu beherrschen S. 6o. - Der Charakter dieser sozialen Wohlfahrtstätigkeit besteht dabei vor allem freilich in der Bekämpfung der Schäden durch Vereinigung kirchlicher und weltlicher Rechtsprechung, in dem Drängen auf Gerechtigkeit, in der Handhabung des Zivilrechtes, in der Aufrichtung von Schulen und in der Heilung der Leiden durch Liebesanstalten. Die eigentliche Hauptsache, die prophylaktische Gestaltung der politischen und sozialen Verhältnisse, die es gar nicht zum lebel erst kommen lassen und die Grundlagen einer moralisch gesunden Gesellschaft vorerst in einer rechtlich-sozial und wirtschaftlich gesunden Lebensverfassung suchen, fehit dabei. Hierfür war die Reflexion über politische und wirtschaftliche Dinge noch viel zu unentwickelt und fehlte, von dem Anfang her, der Blick für die Abhängigkeit alles Ethischen und Geistigen von der Beschaffenheit der Naturgrundlagen des Lebens. - Auch das geschichtsphilosophische Werk v. Eickens, S. 169-307 beachtet natürlich diese $\rightarrow$ E,ndosmose $r$. A ber gerade hier zeigt sich die Gewaltsamkeit und die falsche Voraussetzung seiner Konstruktion, die direkt aus dem Wesen des »asketisch-hie- 
Hilfe erst eine eigene Kultur aufbauen konnte, haben das Christentum zur Entfaltung einer derartigen Kulturtätigkeit und zur Einbeziehung der nicht unmittelbar kirchlichen Lebenssphären unter kirchliche und religiöse Ideen erst gezwungen. Insbesondere ist es die Genialität Karls d. Gr., die ihm diesen Weg gewiesen und damit die eigentümlichen Grundlagen der mittelalterlichen Christenheit auf die Dauer wesentlich bestimmt hat. Doch ist es schwerlich bloß die persönliche Genialität Karls d. Gr., die hierin wirkt. Das Werk Karls d. Gr. hat seinerseits zum Untergrunde überhaupt eine andere Staatsidee, als es die von den Kirchenvätern übernommene spätantike Staatsidee war. War diesen der Staat Folge und Zuchtmittel der Sünde zugleich, im übrigen absolutistisch geartet und nur gelegentlich auf Verwendung dieses Absolutismus zu gunsten kirchlicher Privilegien gerichtet, so liegt im karolingischen Staate bei aller äußerlichen literarischen Fortdauer der patristischen Staatslehre ein Einfluß der germanischen Ideen des Königtums vor. Die Göttlichkeit des Königtums erscheint in allen Kundgebungen und Theorien stark gesteigert, überdies aber das Königtum in Zustandekommen und Ausübung an die Mittätigkeit des Volkes und der Grossen gebunden, verpflichtet das Recht, $d$. h. die Wohlfahrt und den Rechtsschutz der Volksmassen zu bewahren, Treue und Fürsorge $\mathrm{zu}$ leisten. Ihm liegt die Idee der Verpflichtung der Könige für das Wohl des Ganzen zu Grunde, woraus sich dic Absetzbarkeit der Könige im Falle der Unwürdigkeit und Untreue, aber auch die

rarchischen acdanken= dialektisch die kirchliche Kultur crklären will. Daher sieht er in dem karolingischen Kulturideal nicht das, was es war, die Zusammenschweißung weltlicher und geistlicher Interessen, aus der erst die kirchliche Kultur hervorgehen konnte, den Zwang, den der Staat auf die Kirche zur Aufnahme weltlichsozialer Interessen ausübte, sondern umgekehrt das, was sie nach der Logik der Entwickelung sein mußte, nämlich die erste Stufe in der Verschlingung des weltichen Lebens durch die alles dem Heil und der Kirche unterwerfende Dialektik des priesterlich-asketischen Ideals. Abel gerade das umgekehrte ist der Fall! Nicht die Dialektik der Idee, sondern der Zwang der Tatsachen wirkt hier und pflanzt der Idee einen Tricb ein, den sie an sich selbst nicht hatte. - Hamack Dogmengesch. III, 299 cignet sich die These von Eickens im allgemcinen an, fügt aber sehr richtig hinzu: „Ihren aggressiven Charakter hat dje Kirche doch erst ausgebildet, nachdem Karl d. G. ihr gezeigt hatte, wie der Vicirius Christi auf Errlen zu regieren habc. Nicolaus I. hat ron Karl I., die gregorianischen Päpste haben von Otto J.. Heinrich II. u. III. gelernt, wie der rector ecclesine sein Antt zu verwalten habe. 
Pflicht der Fürsorge und der gemeinsamen Tätigkeit für die Gesamt2wecke ergibt. Damit ist der Staatsidee ein neuer Charakter eingepflanzt, der zunächst im karolingischen Typus eine Ausweitung der Macht des Königs über alle und damit auch die kirchlichen Wohlfahrtsmittel möglich macht, und der dann später umgekehrt die Unterwerfung der Könige unter ein rein kirchliches Recht verständlich werden läßt. Die Christianisierung des germanischen Königstums macht den König, wo er seine Aufgaben ideal empfindet, zum Vertreter der Gerechtigkeit und der Fürsorge für alle seine Volksgenossen, denen er Treue um Treue erweist. Und auf diesen neuen Grund stützt sich dann auch die von der antiken Staatslehre übernommene Lehre von der Göttlichkeit des Königstums und empfängt wieder neuen Sinn. Nicht die lediglich zu duldende göttliche Einsetzung in die Macht, sondern der zweckvolle Inhalt der Macht begründet die Göttlichkeit des Königstums. Stellvertreter Gottes ist es in seiner Verwirklichung der christlichen Lebensordnung ${ }^{90}$ ).

Es wäre freilich eine solche Christianisierung des germa: nischen Königtums nicht möglich gewesen, wenn wirklich das Christentum wesentlich asketisch von Grund aus gewesen wäre, wenn das Evangelium, die altchristliche und altkirchliche Literatur. wirklich nur asketische Tendenzen überliefert und veranschau-

90) Ueber diesen Einschlag einer neuen Idee vom Staat und vom Wesen des Königs s. die Nachweise bei R. W. and A. J. Carlyle, A History of medieval political theory S. $214 \mathrm{ff}$. Daher treten im karolingischen Zeitalter auch die patristischen Theorien vom Staate zurück und zeigt sich hier überall ein viel positiverer und aktiverer Charakter des Staates. Dabei bleiben die patristischen Formeln, wo sie gelegentlich auftauchen, formell unverändert, aber sie sind selten und haben einen neuen Koeffizienten, bis sie mit dem gregorianischen Streit wieder häufig werden S. I98. Im übrigen bleiben die stoisch-christlichen Lehren über den Urstand und die allgemeine Gleichheit der Menschen in ihm erhalten, auch die Stellung zur Sklaverei, die letztere mit bemerkbarer Milderung; die Versklavung nichtchristlicher Kriegsgefangener dauert unbedenklich fort, Hauck I 143, 532, 547 II 89, 359. Auch die Herabdrückung der Freien und Hörigen zu Leibeigenen macht keine christlichen Bedenken. All das folgt aus dem Naturrecht des Sündenstandes und den Gesetzen, die der Christ zu respektieren hat. Insoferne ist alles beim alten geblieben. Aber der mit dem Sündenstand eintretende Staat wird entsprechend der Wirklichkeit und dem germanischen Herkommen viel mehr positiv und jetzt geradezu als direkte Gottesstiftung gewürdigt, wozu die Wirkung der kirchlichen Krönungs- und Kaiserweihe noch als wichtige Verstärkung hinzukommt. Jetzt beginnt auch die Rolle des alten Testamentes und der Verweisungen auf Davids Salbung, während die alte Kirche vom Neuen Testament her nur den Weg des Paulus zur Duldung des Staats gehen konnte. Das politische soziale Bedürfnis hilft sich charakteristisch mit dem alten Testament, wo das Neue versagt. Ebd. S. $216 \mathrm{f}$. 
licht hätten, wenn die Unvereinbarkeit in der alten Kirche lediglich in der Weltfeindlichkeit des Christentums bestanden hätte. In-Wahrheit war ja aber die christliche Moral doppelstufig gestaltet worden und schloß die kirchliche Ueberlieferung ein großes Stück des antiken Kulturerbes, innerlich verbunden mit ihren Grundgedanken, in sich, so daß die sogenannten $\gg \mathrm{Re}-$ naissancen* der karolingischen und ottonischen Epoche und die spätere starke Entwicklung antiker Kulturelemente sich bei jeder Wiederbelebung der kirchlichen Literatur und Kunst von selbst verstanden. Davon wird später noch zu sprechen sein. Zunächst ist es für die Lage charakteristisch, daß vor der Aufnahme der burgundischen und kluniazensischen Reformbewegung das Klosterwesen insbesondere von Karl d. Gr. bewußt in den Dienst von Kulturaufgaben gestellt wird, namentlich dem Unterricht und der Wissenschaft $\mathrm{zu}$ dienen hat. Was die Benediktinerregel zunächst im Interesse der Mönche gefordert hat, die wissenschaftliche und landwirtschaftliche Arbeit, wird von Karl d. Gr. in den Dienst des Staates und der Gesellschaft gestellt. Weiterhin war die neue Wendung dadurch erleichtert, daß in der römischen Reichskirche der Episkopat doch schon eine Reihe öffentlicher Funktionen auf sich genommen hatte, und daß in der Zeit der Auflösung ihm überhaupt die Bewahrung der bürgerlichen Ordnung und der Kulturtätigkeit zugefallen war. So lag in der Kirche die Möglichkeit, für die Kulturzwecke des Staates und der Gesellschaft verwendet zu werden, wenn auch freilich kein eigener, innerer Trieb. Sie ist durch das Bedürfnis des kulturarmen Staates dazu veranlaßt worden, und ist darauf eingegangen, weil das ihre Machtstellung und ihren Einfluß erhöhte, weil sie ihre eigene grundherrliche Entwicklung ganz von selbst dazu zwang und weil den germạnischen Christen die Empfindung eines inneren Gegensatzes zwischen alter Staatskultur und innerkirchlichem Gesellschaftsideal gänzlich fehlte. Ueber die Möglichkeit einer inneren Vermittlung der weltlichen und geistlichen Aufgaben machte man sich, soweit meine Kenntnis reicht, keine Gedanken. Wurde man bedenklich, so diente das Mönchtum als Ableiter des asketischen Bedürfnisses neben seinen wissenschaftlichen und grundherrlichen Aufgaben. Der christliche Staat und die christliche Gesellschaft verstanden sich . nun ohne alle Theorie ebenso von selbst, wie sich vorher deren Getrenntheit von selbst verstanden hatte. Eine besondere Bedeutung hatte in diesem Zusammenhang die, 
wie bereits angedeutet, grundherrliche Entwickelung der Bistümer und Klöster selbst. Sie ist herbeigeführt teils durch die Askese selber, die für himmlischen Lohn und für die Tilgung irdischer Sünden und Gewalttaten sich Schenkungen an die Kirche in außerordentlichem Umfang auferlegte, wobei diese Schenkungen meistens Landschenkungen waren ${ }^{91}$ ). Sie ist weiterhin herbeigeführt durch die allgemeine wirtschaftliche und soziale Lage, die nach allmählicher Aufzehrung des Landes in freier Okkupation und Rodung das Emporsteigen des Großgrundbesitzes und das Unfreiwerden des durch Lehen und Prekarie sich in den Schutz des Großgrundbesitzes stellenden Kleinbesitzes bewirkte. An diesem Anschwellen des Großbesitzes ist nun aber die Kirche in hervorragendem Maße beteiligt, indem sie bei milderer Behandlung und im Besitz zahlreichster Immunitäten bei solchen Selbstvergebungen bevorzugt wurde. Der Stand der landwirtschaftlichen Technik, die keinen Großbetrieb kannte, nötigte solchen Gròßbesitz zu einer Verwaltung durch Pächter, Halbfreie und Unfreie in kleinen Einzelwirrtschaften und schuf so ein kompliziertes soziales und rechtliches System, das den Besitzer zur rechtlichen und so. zialen Fürsorge für diese abgestuften Verhältnisse nötigte ${ }^{92}$ ). Die kirchliche Liebestätigkeit mußte damit von selbst zur Sorge für Hintersaßen und Kommendierte werden, während die besonders organisierte altkirchliche Liebestätigkeit der Gemeinde verfiel und für die übrig bleibenden Liebeszwecke, die mit der allgemeinen Fürsorge nicht erledigt waren, das Spital und später die Ordenstätigkeit eintrat. Karl d. Gr. schrieb ausdrücklich, wie den Krongütern, so vor allem den kirchlichen Gütern diese freilich noch sehr elementare Sozialpolitik und Wohlfahrtspflege vor, und dabei ist es dann bei allen wohlgesinnten Bischöfen und Aebten auch geblieben. Diese ganze soziale Wandlung selbst aber hatte wiederum ihren Grund in der Durchsetzung der reinen Naturalwirtschaft ${ }^{93}$ ). Unter den Merowingern endet die Geldwirtschaft, und mit der Ausbreitung des Reiches von der alten städtischen Kultur Galliens wegr über die deutschen naturalwirtschaftlichen Gebiete verschwindet der städtische Charakter der alten Kirche, der sie bis in das innerste Wesen hinein bestimmt hatte. Neben den Bistümern steht deren ausgebreiteter Landbesitz und damit jetzt die mit vollen priesterlichen Rechten und Landbesitz ausgestattete I.andpfarrei; diese Landpfarrei wird außer durch ihren Beruf einer ethischen Kulti-
91) Vgl. Lhihorn II, 43-54.
92) Uhlhorn II, 57-60.
93) Lamprecht II, $90 \mathrm{ff}$. 
vierung des Volkes durch ihre wirtschaftlichen Beziehungen und Abhängigkeiten tief in die allgemeinen Interessen hineingezogen. Die Entwickelung des Kirchengutes machte derart die Kirche zu einer sozialen Macht und interessierte sie im Fall ihrer Abhängigkeit von anderen an dem Stand des Ganzen. Indem die Naturalwirtschaft bei zunehmendem Mangel freien Landes den Frohnhof mit der Technik der Bewirtschaftung durch Auslehnung und Vergebung, Frohnden und Tribute hervorbringt, wird auch der kirchliche Besitz in diese Formation hineingedrängt und nimmt bei seiner Größe hier geradezu eine führende Stellung ein. Und das hat noch eine weitere wichtige Folge. Bei dem Geldmangel mußten die Besoldungen der Beamten in Landvergebungen bestehen, und mit diesem ergab sich die Erblichkeit des Amtes, das ganze Lehens- und Feudalwesen. Nun war aber der kirchliche Besitz der Natur der Sache nach nicht erblich und bot sich den Königen als einziges Mittel dar, durch immer neue Verleihung von Kirchengut sich einen Stamm nicht erblicher Beamten zu ziehen und dadurch der Auflösung des Reiches in erbliche Territorialherrschaften vorzubeugen. Damit war dann von selbst gegeben, daß der Klerus zur eigentlichen Beamtenschaft des Reiches und zur wesentlichen Stütze der königlichen Macht wurde. So aber wurde er nun auch von dieser Seite her in allgemeine politische und soziale Wohlfahrtsinteressen hineingezogen, mit öffentlichen Befugnissen ausgestattet und zugleich in seiner eigenen grundherrlichen Entwickelung gefördert. Freilich war damit die bereits angedeutete völlige Aufhebung der kanonischen Idee vom Kirchengut verbunden, das Anstaltsgut der Kirche sein sollte, nun aber Eigentum dessen wurde, auf dessen Grund und Boden die Kirche stand und nur belehnungsweise vergeben wurde. Das machte Könige und Herzöge zu Obereigentümern des Kirchengutes und die Belehnten zu Territorialherren gleich anderen Feudalherren, zog aber mit dem Kirchengut selbst die Kirche in alle Interessen des Reiches und der Gesellschaft hinein.

Nicht zu vergessen ist schließlich die die ganze Zeit erfüllende Missionstätigkeit, die mit den Kreuzzügen nur auf ihren Gipfel kommt. Die altkirchliche Mission war freie Predigt innerhalb eines gleichartigen, vom römischen Reich getragenen Lebensganzen und pflückte die Früchte der inneren religiösen Entwickelung des Altertums. Die Mission des Mittelaiters ist, wie auch die moderne, überall zugleich politische und Kulturmission. Die Stiftung neuer Bis- 
tümer war stets eine Handlung des Staates und zugleich eine Germanisation, die die kirchliche Organisation für politische Verwaltungs- und kulturelle Erziehungszwecke verwertete. Die Kreuzzüge brachten geistliche und halbgeistliche Herrschaften hervor, die wenigstens in der Theorie christliche Staaten sein sollten und in den Ritterorden der Christenheit besondere Organe für christliche Wohlfahrtszwecke aller Art zur Verfügung stellten "4).

All das zusammen bewirkte eine innere Durchdringung von Kirche und Staat, von Weltlichem und Geistlichem, von Asketischem und Sozialpolitischem, die der Kirche des Mittelalters ein von der alten Kirche völlig verschiedenes Gepräge geben und die sich von einer modernen ethisch begründeten Sozialpolitik nur dadurch unterscheiden, daß jede tiefere und umfassendere Reflexion auf das Wesen der politischen, wirtschaftlichen und sozialen Vorgänge und Bildungen fehlt und daß ebenso der ganze Gedanke der Abhängigkeit geistiger und ethischer Werte von der Gesundheit ihrer wirtschaftlichen und sozialen Unterlagen und damit die prophylaktische Politik sehr unentwickelt ist. Allein das hat der christliche Idealismus mit den ihm eingeschmolzenen stoischen und platonischen Elementen gemeinsam. Daran ist in dieser von der Idee beherrschten Welt und vor allem bei der großen Einfachheit der Verhältnisse noch nicht zu denken. Noch ist sogar der Empirismus und Realismus der aristotelischen Staatslehre und Ethik nicht in Wirkung getreten, der der thomistischen Staats- und Gesellschaftslehre bei all ihrem ideologisch-moralistischen Charakter doch wenigstens, wie wir sehen werden, eine gewisse Rücksicht auf rationelle Wohlfahrtspolitik verleiht.

4. Die universalkirchliche Reaktion und die katholische Einheitskultur.

Aber freilich gegen dieses Landeskirchentum, das sein Zentrum in der stärksten, best organisierten und best ausgestatteten deutschen Kirche hatte, erhebt sich seit dem Io. Jahrhundert wieder der universalkirchliche Gedanke in enger Verbindung mit einer neuen Welle des asketischen Ideals und einer Wiedererhebung der romanischen Welt gegen das Uebergewicht der deutschen Kirche. Damit verbunden ist die Wiedererhebung des kanonischen Rechtes gegen das landeskirchliche und des kanonischen Begriffs vom Kirchen-

94) Ueber den neuen Charakter der Mission s. Haucks ganze Darstellung; über die Kreuzzüge als Mission s. Uhlhorn II $93 \mathrm{f}$. 
gut gegen die Eigenkirche. Wie sich diese Elemente fanden und vereinigten, gehött auch hier im einzelnen der Kirchengeschichte an. Hier ist nur hervorzuheben, was für unseren Zusammenhang von Wichtigkeit ist. - Das ist der Ausgangspunkt des Rückschlages von der romanischen Askese her. Hier war die Kirche bei der Auflösung der karolingischen Monarchie in große Seigneurien vielfachst zerrüttet und beraubt und damit eine kirchliche Reaktion gegen die weltlichen Gewalten nahe gelegt worden; hier war die altkirchliche Tradition lebendiger und war der uniformierende und organisierende Trieb stärker als in der deutschen Kirche. Die Neubelebung war naturgemäß asketisch, wobei der mit dem Jahre 1000 zu erwartende Ablauf des 1000 jährigen Reiches mitwirken mochte; die Forderungen selbst aber gingen um des willen nicht etwa auf Entweltlichung der Kirche, sondern umgekehrt auf volle Restituierung des Kirchengutes an Kirchen und Klöster, auf freie Verfügung der Kirche über das Kirchengut, auf strenge Durchführung des kanonischen Rechtes in der Bischofs- und Abtwahl sowie in der Behandlung des Kirchengutes, was die Unabhängigkeit der Kirche von den weltlichen Herren und zugleich die Fortführung ihrer grundherrlichen und fürstlichen Befugnisse bedeutete, auf strengeren, erst persönlichen und dann organisatorischen Zusammenhalt der reformierten Klöster unter einander, auf Uniformität in der Kirche und Gegensatz gegen die reichspolitische Verwertung des Episkopats. Der Drang nach Einigung im kanonischen Recht, der das erste in der ganzen Bewegung ist, führte dann allmählich zum Anschluß an das Papsttum, von dem allein eine Einigung und ein Schutz gegen die politischen Bischöfe ausgehen konnte, und das umsomehr, als zum kanonischen Recht nunmehr auch die pseudoisidorischen Dekretalen gehörten, in denen während der nachkarolingischen Wirren der Klerus bereits die Sicherung gegen die landeskirchlichen Metropoliten und die Landesherren durch die Erklärung des Universalepiskopats des Papstes beansprucht hatte. Diese den soziologischen Ausbau der Kirche erst abschließende Idee taucht nun, zunächst aus ähnlichen Gründen wie seiner Zeit im 9. Jahrhundert, neu auf, und die kluniazensische Partei sucht ihre Anhänger in das Pontifikat zu bringen. Dazu verhalfen ihr schließlich die deutschen Kaiser selbst, die ihrerseits ihrer Kirche nur dann völlig Herr zu sein meinten, wenn sie den Papst in ihrer Hand hatten, und die überdies durch ihre oberitalienische Politik stets auf ein Verhältnis zum Papst ange- 
wiesen waren ${ }^{95}$ ). Indem sie außerdem selbst die asketischen Reformtendenzen teilten und von einem streng geistlich gesinnten Papst Unterstützung für ihre eigene ethisch-reformierende Kirchenpolitik erwarteten, halfen sie der neuen universalkirchlichen Bewegung auf den Thron, ohne von ihr eine Erschütterung des kirchlichen Belehnungssystems zu erwarten, auf dem das deutsche Reich beruhte. Mit Gregor VII. aber traten die radikalen Konsequenzen des neuen Systems hervor: die $\mathrm{Zu}$ sammenfassung der Kirche in der Hand des Papstes, die strenge Durchführung des kanonischen Rechtes in Ehelosigkeit ${ }^{96}$ ), Wahl und Amtsführung der Bischöfe, und die prinzipielle Unterordnung auch der königlichen und kaiserlichen Gewalten in allen Fragen des Heils unter die Kirche, wobei die Kirche zu entscheiden hat, was solche Fragen des Heiles sind. Der ungeheure Kampf mit seinem verworrenen Wechselspiel der Kräfte und den zahlreichen hereinwirkenden Zufällen kann hier auf sich beruhen ${ }^{97}$ ). In der Hauptsache ist er eine rein ideologische Reaktion und hängt er, wie mit der internationalen Askese, so mit den universalen spezifisch christlichen Ideen zusammen, die nun eben einmal nicht national sind. Es kommt daher auf das dogmat is che Ergebnis wesentlich an, in welchem sich der soziologische Ausbau der Kirche für immer theoretisch vollzog und mit diesem Ausbau die für alles übrige entscheidende Grundstellung des Katholizismus zu allen sozialen Problemen festgelegt wurde. Daß die kirchlichen Ansprüche tatsächlich nur sehr bedingt durchgesetzt wurden, daß neben de ${ }_{i}$ schroff hierarchischen Tendenz in den italienischen Kommunen folgenreiche demokratische und häretische Bewegungen hervortraten, daß die asketische Welle in der Entwickelung des Feudalwesens zur ritterlichen Kultur stark zurückebbte,

95) So begründet Lamprecht den weltgeschichtlichen Vorgang; Hauck denkt mehr an persönliche Beziehungen einzelner Kaiser und Päpste, und an persönliche Eigenschaften Hildebrands III 516, an die mit dem Kaisertum verbundene ideelle Hochstellung des Papsttums III 537, an die zunehmende Popularität der Forderung der Geltung des kanonischen Rechtes, das gerade in Rom von den vorkluniazensischen Päpsten mit Füßen getreten wurde III 563; er nennt es eine tragisc'je Selbsttäuschung Heinrichs des III., der die Tat Karls d. Großen mit dem umgekehrten Effekt wiederholte III 542.

$\left.{ }^{96}\right)$ Die Ehelosigkeit des Klerus hatte neben dem asketischen auch einen wirtschaftlichen Grund; sie verhinderte die Belastung des Kirchengutes durch Priesterweiber und -Kinder. Hauck III 528.

${ }^{97}$ ) Leber die Motive und die Durchsetzung des Gregorianismus vgl. die eingehende Darstellung von Mirbt, die Publizistik im Zeitalter Gregors VII., 1894. 
daß nach dem Höhepunkt der hierarchischen Ideenwelt d. h. nach dem Innozentischen Zeitalter sehr bald die alten landeskirchlichen und universalkirchlichen Gegensätze, die papalen und episkopalen Ideen wieder in Reibung gerieten, all das ändert nichts daran, daß der Ertrag der gregorianischen Kämpfe die Konsequenz des soziologischen Gedankens der sakramentalen Priesterkirche und Erlösungsanstalt überhaupt ist und bleibt für alle Zukunft.

Das zeigt sich in den dog matis chen Entwickelungen des zwölften und dreizehnten Jahrhunderts. Sie fügen zu den beiden, bis zu diesem Zeitpunkt den ganzen dogmatischen Besitz bildenden Grunddogmen, dem Dogma von Kirche, Kanon und Tradition und dem christologisch-trinitarischen Dogma, die neuen spezifisch. mittelalterlichen Dogmen hinzu: I) das Dogma vom Universalepiskopat des Papstes, 2) das Dogma von der Ueberordnung der geistlichen Gewalt über die weltliche und 3) das Dogma von der Gnadeneinflößung in den sieben Sakramenten. Offiziell formuliert worden ist zwar im Mittelalter selbst nur das letztere, aber die beiden ersteren, die erst mit dem Vaticanum zum Abschluß kamen, sind doch als latente Dogmen zu bezeichnen und wirken praktisch so gut wie formulierte. Ihre Bildungsgeschichte im einzelnen gehört der Dogmengeschichte an, die auch in dieser. Hinsicht vor allem die Abschlüsse und Redaktionen beim $\mathrm{h}$. Thomas besonders hervorzuheben hat ${ }^{98}$ ); hier interessiert uns nur ihre soziologische Bedeutung.

98) Von diesen drei Dogmen pflegen die beiden ersten von den protestantischen Dogmenhistorikern dem Kirchenrecht und der Kirchengeschichte und die Sakramente der Kultusgeschichte in der Hauptsache überlassen zu werden. Zwar hat Harnacks glänzende Dogmengeschichte, die den Stand der Forschung bis heute beherrscht, den Schwerpunkt von der dialektischen Entwickelung auf die psychologische Erklärung verlegt. Aber man wird datin noch weiter gehen müssen, und gerade die modernen soziologischen Forschungen und Fragestellungen werden hier den Kreis der psychologischen Bedingungen für die Ideenbildung bedeutsam erweitern. In die Geschichte des Dogmas ist die des Rechtes und des Kultus wenigstens auf katholischem Boden immer mit hereinzunehmen, denn in beiden liegen die Hauptwurzeln des Dogmas. Der Christuskult und das Christusmahl gehen dem altkirchlichen Christusdogma voran und bedingen es zum großen Teil. Das Kirchenrecht geht dem Kirchendogma ebenso zum guten Teil voran. Die Bedeutung der Glaubensvorstellungen in ihrer Logik rein für sich ist überhaupt sehr viel geringer als man denkt in Kult und Recht liegen ihre Hauptwurzeln. Gerade eine soziologische Betrachtung der Kirchen zeigt im Kultus das eigentliche Bindemittel und im Rech ihre Bindeform; es ist nur natürlich, daß diese soziologischen Grundelemente vor allem im Dogma sich wiederspiegeln, und daß die rein logisch-theoretisch-spekulativen Elemente mehr daneben hergehen als Interessen der obersten Theologenschicht. Eine reine Gedankenreligion mit bloß accidenteller Bedeutung des Kultua

Troelts ch, Geammelte Schriften. I. 
Die erste Forderung der Reform war im Zusammenhang mit der Internationalität und dem geistlichen Rigorismus der Askese auf eine planmäßige Durchführung des kanonischen Rechtes, auf strenge Selbständigkeit und Unabhängigkeit der geistlichen Funktionen gerichtet. Das war nur möglich durch die Heraushebung des Zentrums der Kirche, durch Emporhebung des Papsttums, das allein die Gleichmäßigkeit verbürgen und durchführen konnte Diese Zentralisierung wiederum hatte eine innere und notwendige Begründung nur, wenn die Herrschaft des Papstes über die ganze Kirche und insbesondere über die Bischöfe dogmatisch festgestellt, als Ǵlaubenssatz und Jus divinum erkannt war. Das wiederum war schließlich nur möglich durch die Theorie vom "Primat des Papstes*, oder dem obersten -Priester-, Lehr- und Hirtenamt des Papstes*, wonach er allein und unmittelbar die Kirche regiert und die Bischöfe ihr Amt nur als Ausfluß des päpstlichen Amtes und auf Grund der jurisdiktionellen Oberaufsicht und Zuweisung des Papstes führen dürfen. In der vollendeten Konsequenz ist es das Dogma vom Universalepiskopat des Papstes, der in den Bischöfen nur seine Stellvertreter hat und alle drei Gewalten von sich aus den Bischöfen und ihrem Klerus erst in der Konsekration übergibt. Das ist das Dogma Gregors VII. Es ist zugleich die eigentlich konsequente Vollendung des Gedankens, dem es dann freilich an Einschränkungen nicht fehlte. Erst als seine Konsequenz ergibt sich dann auch das Dogma von der Unfehlbarkeit der kathedralen Entscheidungen über Glaube und

und des Rechtes ist erst der Protestantismus; aber der Katholizismus enthält Kult und Recht als wesentliche ja vielleicht entscheidende Elemente des Religiösen; dafür aber ist auch, wie sich zeigen wird, das soziologische Element, Kult und Recht, im Protestantismus viel schwächer entwickelt. Die katholische Dogmengeschichte nimmt daher auch jene beiden Dogmen mit in die Dogmengeschichte auf, vgl. Schwane, Dogmengeschichte der mittleren Zeit 1882 und vereinigt sie mit der Sakramentslehre zur Ekklesiastik. Diese Ekklesiastik und die Anthropologie d. h. die Lehre von Sünde und Gnade seien die entscheidenden mittelalterlichen Promulgationen des Dogmas; dabei hängen beide Gruppen aufs engste zusammen, denn die Sakramentslehre hat zur Folie die Sünden- und Gnadenlehre, ist nur die konkret gewendete Gnadenlehre. Dagegen sind die großen theologisch-philosophischen Systembildungen, mit denen die protestantische Dogmengeschichte sich mit Vorliebe beschäftigt, nur Vereinheitlichungen und Vermittelungen des dogmatisch-kirchlichen Besitzes mit dem Kulturbesitz, Reflexionen über das Dogma, aber selbst kein Dogma. Von den drei genannten Hauptdogmen ist übrigens das zweite, das dem modernen Katholizismus die größten Schwierigkeiten macht, bei Schwane nur flüchtig behandelt. 
- Sitte, in dem die Einheit des Organismus der Kirche sich völlig abschließt. Hand in Hand damit geht die politisch-juristische Sicherung des Papsttums durch die Neugestaltung der Papstwahl, die in die Hand des Kardinalats gelegt und damit den kaiserlichen und lokalen Einflüssen entzogen wird, und der. Wahlkörper des Kardinalats entwickelt sich dann zum Regierungsorgan für die ganze Kirche. Ebenso gehört dazu die Zuweisung des Rechtes zur Berufung allgemeiner Synoden an den Papst und die Notwendigkeit der Bestätigung ihrer Beschlüsse durch den Papst. Vor allem aber gehört. dazu die Entwickelung des kanonischen Rechtes als des vom Papst erteilten und geleiteten Universalrechtes der Christenheit; es greift überall ein, wo direkt oder indirekt religiöse Interessen in Frage kommen. Darin liegt vollkommen klar die Vollendung des soziologischen Gedankens der Kirche. Erst wurde die Einheit und Begründung des religiösen Sozialgebildes in den mystischen Christus gelegt, dann wurde der mystische Christus in dem christlichen Priestertum der Bischöfe sozusagen lokalisiert, dann mußte unter den Bischöfen die Einheit hergestellt werden, indem ihre geistlichen Gewalten aus einer gemeinsamen Quelle emanieren und von ihr aus dauernd geregelt werden. Die religiöse Wahrheits- und Lebensquelle, aus der der soziologische Zusammenhang hervorgeht, wird immer enger gefaßt, und schließlich wird der Papst als Nachfolger Christi und des Apostelfürsten Petrus die eigentliche Fassung und Sicherstellung der Quelle. Ein auf dem Wunder der absoluten Wahrheit und der sakramentalen Erlösungskräfte beruhender Organismus bedarf der klaren, dauernden und sicheren Konzentration und Abgrenzung des ihn hervorbringenden Wunders gegenüber allem Wandelbaren, Unsicheren -und Bloß-Menschlichen. So resorbiert der Papst das ganze Wunder in sich und wird zum Zentralwunder der Christenheit, das seine Wunderkraft in genau geregelter Weise dann erst wieder von sich ausstrahlt durch die verschiedenen Stufen der Hierarchie hindurch bis zum letzten Dorfpfarrer und Mönchspriester. Die im Papsttum konzentrierte Hierarchie ist das Dogma, das die soziologische Einheitstendenz vollendet, wie sie auf Grund der einmal mit dem Begriff des Christusleibes in der Kirche und des christlichen Priestertums eingeschlagenen Entwickelung sich vollenden mußte. Freilich ist diese volle Konsequenz immer nur von großen Gruppen der dogmatischen und kirchenrechtlichen Literatur gezogen worden und ist sie nur die eigentlich kurialistische Lehre; allein sie setzt mit 
den pseudoisidorischen Dekretalen, die ja zu dem von der Reform betonten kanonischen Recht gehörten, und mit der gregorianischen Kirchenidee und Politik ein und hat seitdem immer das Recht und die Macht der Konsequenz für sich gehabt. Im übrigen sind die Spuren der Ueberwindung früherer andersartiger Stufen in dem Dogma erhalten geblieben und hat auch eine schwankende Theorie oft genug die volle Konsequenz aufgehalten. Der Ausgangspunkt des Ganzen, die in der Succession begründete Priesterweihe des alten Gemeindebischofs, haftet noch immer bloß am einfachen Priester; der Bischof selbst ist über den Diözesanklerus emporgestiegen zu der Instanz, als der die geistliche Gewalt emaniert an den Priester, hat aber, selbst in seiner Konsekration keine wirklich sakramentale Krafteinflößung, sondern seine Kraft setzt sich zusammen aus der auch ihm nur als Priester erteilten Priesterweihe und aus der ihm mit der Konsekration erteilten Lehr- und Jurisdiktionsgewalt. Diese letztere wiederum wird von ihm ausgeübt als Zuweisung des Papstes und unter Kontrolle und Ingerenz des Papstes, aber eine wirkliche Emanation des Bischofsamtes aus der Papstgewalt lehrt nur die extreme kurialistische Theorie, während die gemäßigte Theorie die Selbständigkeit des Bischofsamtes mit der Abhängigkeit von dem absoluten Monarchen auszugleichen strebt. Der Papst wiederum empfängt seine alles bedingende Wunderkraft weder durch sakramentale Weihe wie die Priester, noch durch Konsekration wie die Bischöfe, sondern lediglich durch die ordnungsmäßig vollzogene I'ahl. Darin sind Unebenheiten und Möglichkeiten $\mathrm{zu}$ wichtigen faktischen Differenzen erhalten geblieben, aber die Praxis hat sich in steigendem Maße dem vollen Universalepiskopat des Papstes zubewegt, und schon jetzt in den gregorianischen Kämpfen ist das Ideal scharf formuliert. Es ist - auf das Ganze gesehen das wahre Ideal, denn es ist die Konsequenz des soziologischen Aufbaus des christlichen Organismus ${ }^{99}$ ).

ay) Vgl. Döllinger, *Das Papsttume 1892, der (S. 37) schon von den pseudoisidorischen Dekretalen ab die Tendenz auf den Universalepiskopat als das eigentlich entscheidende Noment bezeichnet, eben deshalb aber auch allen Nachdruck auf die Beweise legt, daßs das der alten Kirche widerspricht und nur durch eine durchgreifende Korrektur ihrer Ueberlieferungen historisch bewiesen werden konnte. Ám letzteren ist kein $Z$ weifel, aber auch daran nicht, daß die pseudoisidorische und gregorianische Konsequenz aus der Sache selbst entspringt. Einen möglichst vermittelnden Standpunkt nimmt Schwane (S. 494-579) ein, wo die Lehren bis 1215 dargestellt sind; die Lehre des h. Thomas S. 539-547, wo der Universalepiskopat durch die an sich bestehende vom Papst nur geleitete selbständige Gewalt der 
Aber über diese erste und eigentliche Forderung der Reform geht die Konsequenz des Gedankens und der Praxis bald hinaus auf ein weiteres Gebiet, auf das weltliche Gebiet, auf die Temporalia. Aus der Forderung der Herrschaft des Papstes in der Kirche mußte die Forderung der Freiheit der Kirche vom Staat und über dem Starat erwachsen, das, was Gregor VII. die »Gerechtigkeit * nannte. Jemehr die einheitliche Herrschaft des Papstes und des kanonischen Rechts gerade durch die Einmischung der weltlichen Gewalt in die Bischofs- und Abtsernennung und durch die ganze politisch-soziale Rolle des Episkopats als organischen Bestandteils der Staatsordnung gehemmt war, um so mehr forderte die ge-

Bischöfe wenigstens in der Theorie eingeschränkt ist; praktisch ist trotzdem die Regierungsgewalt des Papstes universal und unmittelbar S. 542. Voll entwickelt ist der Universalepiskopat dann in der Summa de ecclesia des Torquemad a S. 567 bis 574. Daß das jedoch schan der Sinn des gregorianischen Systems ist, darüber s. Hauck III 763-766; das Bistum ist vicariae dispensationis munus S. 764. Vgl. auch Hauck IV 164, Beschluß der 2. Lateransynode I139, daß der Papst die Bischöfe mit ihrer Gewalt belehnt; und die Meinung, daß während der Suspension die bischöfliche Gewalt an.den Papst zurückfalle. IV 725 die ausdrücklichen Erklärungen Innocenz III. und die Promulgation seines Gesetzbuches ohne Mitwirkung der Bischöfe und der charakteristische Satz: In tantum apostolicae sedis extenditur autoritas, ut nihil praeter ejus auctoritatem in cunctis ecclesiarum negotiis rationabiliter disponatur, IV 729 ff. entsprechende Umgestaltungen der Bischofswahl. Ueber die Durchsetzung des Universalepiskopats s. auch Karl Müller KG. I 56I und Mirbt, Publizistik 559-572. Ueber das kanonische Recht als Universalrecht der Christenheit s. v. Eicken S. $548-588$, der freilich auch hier übertreibt, indem er das geistliche Recht als das. logisch allein vom Standpunkt der Kirche aus berechtigte ansieht. Es handelt sich immer um ein Nebeneinander des weltlichen und geistlichen Rechtes, bei dem dann freilich oft Reibungen entstehen. Dabei betonen die Theologen ausdrücklich, daß erst in dieser Lehre die Einheit der Sozietäte erlangt werde Schwane 539, 547, 567. So auch Schwane selbst S. 535: „Die ... Geschichte des Papsttums während der ersten Jahrhunderte des Mittelalters ist nicht etwa wie die Geschichte anderer menschlicher Sozietäten, vorwaltend aus der physischen, materiellen und geistigen Kraft ihrer Träger zu erklären, sondern sie ist eine unter besonderer und übernatürlicher Leitung stehende und eine immer reicher sich-entfaltende Darstellung und Ausprägung einer Idee, die von Christo dem Herrn gegeben und in Petrus verkörpert wurde, aber auch im Glauben der ganzen Christenheit fortlebt und in diesem Glauben einen immer deutlicheren Ausdruck gewinnt «. Es ist die Idee des Priestertums und der Hierarchie. Darüber S. 518: ,Die Verfassung beruht auf dem von Christo angeordneten Unterschied $z$ wischen Klerus und $L$ a ien oder auf der von ihm eingesetzten Hierarchie als der Trägerin der lehramtlichen, 
schlossene Einheit der Kirche die Ausschaltung jeder Einmischung, die nur durch Herrschaft über den Staat klar sicher zu stellen war. Die * Gerechtigkeit * verlangt die Herrschaft des wahren Herrschers, der geistlichen Gewalt, damit jede Beeinträchtigung des wahren Herrschers im Prinzip ausgeschlossen sei. Und im Prinzip ausgeschlossen ist sie nur dann, wenn der Staat der Kirche prinzipiell untersteht als ein von ihr zu bestimmendes Organ für die Beherrschung der weltlichen Dinge, für Einordnung der weltlichen Verhältnisse und Werte unter den geistlichen, von der Hierarchie getragenen absoluten Lebenszweck. Das Dogma vom Universalepiskopat verlangt zu seiner Ergänzung das Dogma von der Theokratie. Die Einmischungen fremder Gewalten waren nicht sicher auszuschließen durch die Rückkehr zum bloßen Parallelismus, wie es viele Fromme der Reform und vor allem Peter Damiani erwarteten und wie es dann später wieder die Franziskaner und Dante forderten. Eine bloße Selbständigkeit der entweltlichten und armen, lediglich ihren geistlichen Funktionen lebenden Kirche neben einem freiwillig und aus christlicher Liebe ihr dienenden Staat, das war keine praktisch mögliche Idee. Denn da hatte die Erfahrung tausendfach gezeigt, daß dann die Reibungen doch immer wieder eintraten. JDie volle Freiheit und Selbständigkeit der Kirche wurde nur erreicht, wenn die temporalen Gewalten der Kirche untertan waren, von ihr in ihrem Wesen bedingt und in allen das Heil

priesterlichen (d. h. sakramentalen) und hirtenamtlichen Autorität, indem in der Kirche alle obrigkeitliche und Heilsgewalt nicht von unten aus dem Volke, sondern von oben von Christo dem Herrn kommt und entweder durch ein Sakrament unmittelbar von Christo oder durch die Willenserklärung des von Christo bestellten Vorgesetzten, namentlich des Oberhauptes der Kirche, verliehen wirda. Man sieht deutlich die Stufen des soziologischen Prozesses: der mystische Christus, der Priester-Bischof, der Diözesanbischof, der Papst-Bischof. Man sieht auch unmittelbar das erreichte Maß der Vercinheitlichung: das Priestertum beruht auf Sakrament und stammt von Christus, lir chof und Papst beruhen auf Willenserklärung und haben ihrè letzte Quelle im Aposiclfürsten Petrus; völlig unifiziert ist nur die Lehr- und Regierungsgewalt im Papst, die Sakramentalgewalt bleibt dem Priester vermöge der Weihe, aber sie steht unter der Kontrolle i's Rischofs und durch ihn unter der des Papstes. Das aber genügt für die Finheitlicbleit; die Aufsaugung auch der Sakramentalgewalt in den Apostelfürsten und den Papst ist nicht nölig gewesen, die völlige Aufsaugung der Lehrund Regierungsgewalt erst mit dem Vatikanum erreicht, wenn auch seit Gregor VII. immer schon theoretisch verlangt. 
betreffenden Angelegenheiten geleitet wurden. Da aber schließlich alles und jedes irgendwie unter Umständen das Heil berühren kann, und da die Kirche festsetzt, wo eine solche Beziehung auf das Heil vorliegt, so bedeutet der ganze Gedanke der Freiheit der Kirche die Herrschaft über den Staat und das zeitliche Leben. So werden in dem großen Kampfe die schroffen augustinischen Sätze über den Staat wieder hervorgeholt und ebenso die in den antidonatistischen Schriften entwickelte Lehre Augustins von der Indienststellung des Staates für die $Z_{\text {wecke der Kirche und der Weihung }}$ des sündigen. Staates durch diesen Dienst. Sie werden dabei radikal yerschärft; die von Augustin betonte und doch immer einen Kéim des Naturgesetzes anerkennende Sündhaftigkeit des Staates wird maßlos gesteigert, und sein doch nur die Hilfe zur Ausrottung der Ketzer in Anspruch nehmendes theokratisches Programm ungeheuer erweitert; es wird eine Herrschaft der Kirche über alles Zeitliche, eine Belehnung der Fürsten durch die Kirche mit ihrer Gewalt, eine Regierung und Kontrolle des ganzen staatlich-gesellschaftlichen Lebens. Und wo man nicht so weit ging, wo man eine selbständige Begründung des Staates in Gott und dem Naturgesetz festhielt, da forderte man doch die Unterwerfung des Staates wenigstens in allen das Heil betreffenden Dingen bei sonstiger Selbständigkeit. In dieser gemäßigten und - auf das Ganze gesehen - konsequenten Gestalt, hat der $h$. Thomas die Lehre fixiert. Aber da stets die Kirche feststellt, wann ein solcher Fall vorliegt und wie er $z u$ entscheiden ist, so kommt das praktisch auf dasselbe hinaus. Die letztere Theorie, die ja mit der altkirchlichen Staatstheorie zusammenhängt und den naturgesetzlichen Charakter des Staates festhält, ist die herrschende geworden. Aber auch sie bedeutet nur etwas gemäßigter die Theokratie. Man wird auch hierin lediglich die Konsequenz des soziologischen Gedankens einer auf absolute Wahrheiten und Lebenswerte aufgebauten religiösen Gemeinschaft sehen dürfen. Für die antiken Völker fiel der Staat mit der Religion zusammen und waren die natürlich bedingten soziologischen Verbände der Familie, des Geschlechtes, der Stadt, des Reiches zugleich religiöse Objekte und Kultverbände. Löste sich das religiöse Leben von diesen natürlichen Verbänden und gründete es sich statt auf deren Kultordnungen auf Gedanken, Gefühls- und Gesinnungswerte; dann mußte es eine eigene Organisation erzeugen, und diese mußte dann naturgemäß sich als die höhere übergeordnete empfin- 
den, die die natürlichen Verbände von ihren Ideen aus reguliert und durchdringt. Das ist bereits der Sinn der platonischen Politeia und des stoischen Humanitätsreiches, und es ist in noch viel höherem Grade der Sinn der christlichen Gemeinschaft. Sie wird den Staat und die sozialen Verbände ablehnen, so lange sie sich nicht sicher fühlt, ihn durchdringen zu können; sobald sie aber seine Anerkennung aus inneren oder äußeren Gründen nicht mehr umgehen kann, wird sie ihn und alle natürlichen Gemeinschaften mit ihrem obersten Ideal eines auf letzte absolute Werte begründeten Gemeinwesens durchdringen und beherrschen wollen. Das ist von der Sache unabtrennbar; eine mindestens geistige und seelische Beherrschung wird von solchen Idealen immerdar gefordert werden, wie es ja heute noch überall geschieht auch von den entschiedensten Spiritualisten., Wo aber die religiöse Gemeinschaft im Priestertum und im Organismus der Papstkirche inkarniert ist, da wird diese Herrschaft zur Herrschaft der Priesterkirche über den Staat, des Papstes über die Könige und die ihnen untergeordneten sozialen Verbände werden. Das ist die unausweichliche Konsequenz. Die Theokratie des Hochmittelalters hat denn auch diese Konsequenz gezogen mit dem vollen Bewußtsein um ihre innere Notwendigkeit und sie mit all den furchtbaren kirchlichen Machtmitteln aufrecht erhalten, die heute noch das Grauen des Lesers hervorrufen und die das moderne katholische, stark spiritualisierende Kirchenrecht gerne als überwundene mittelalterliche Roheit und Unkultur hinter sich liegen läßt. Allein, wie es mit den Mitteln der Durchführung auch stehen möge, der Gedanke selbst ist bis heute selbstverständlich in Kraft geblieben. Alle Versuche, von dieser Theokratie wieder auf den Parallelismus zurückzugehen, sind entweder mit einer Wiederbelebung der Eschatologie verbunden wie bei den Franziskaner-Spiritualen oder sie sind idealistische Grübeleien und Verkennungen der realen Gegensätze, wie die romantische Staatsiehre Dantes, und in beiden Fällen jedenfalls wirkungslos ${ }^{100}$ ).

100) Ueber den Hervorgang der Freiheitsforderung aus der Einheitsforderung s. Hauck KG. III, 766-769, 804, 835, 838. Hauck unterschätzt m. E. die logische Notwendigkeit des Gedankens. - Die letztere ist glänzend dargestellt bei Gierke -Genossenschaftsrechte III, 515-545, ahnlich unter Vorlegung der Dokumente und Erläuterung ihrer Konsequenz bis heute bei Hoensbroech, > Moderner Staat und römische Kircher 1906. - Ueber die Rezeption des Gregorianismus in England s. das lehrreiche Buch von H. Böhmer, -Kirche und Staat in England und in der Normandie im 11. und 12. Jahrh.\& 1899. ,Der Gregotianismus ist die Anschauung, daß der 
Die dritte Frage ist die nach den Mitteln der Aufrechterhaltung einer derartigen kirchlichen Herrschaft über die Gemüter. Die Mittel müssen, wenn sie organisch aus dem Wesen der Kirche hervorgehen sollen, in dem Sakramentalismus der Kirche liegen; denn auf diesem ist im Grunde das ganze Priestertum aufgebaut. Der Priester allein hat durch Stiftung von Christus her die Kraft sakramentaler Gnadeneinflößungen und damit das erlösende Wunderelement der Kirche in der Hand, ohne das es keine Rettung aus der Erbsünde und aus dem FegKirche von Rechts wegen volle Autonomie zukomme und das eng damit verbundene Dogma von dem göttlichen Berufe des Papsttums zur Weltherrschafte. Ueber die Kontinuität: Am frühesten begegnen uns beide auf dem Boden der ehemaligen fränkischen Reichskirche. Schon Pseudoisidor fordert volle Autonomie der Kirche und Ueberordnung des Geistlichen über alle Laien. Benedikt Levita stellt bereits das Eigentumsrecht der Gründer und der derzeitigen Besitzer der Kirchen am Kirchengut in Frage, und in Nikolaus I. erscheint zum ersten Male ein Papst, der nicht nur als Herr der Kirche, sondern auch als Oberherr aller Weltreiche gelten will und handelt. Wie die theokratische Staatsidee, so entsteht also zur selben Zeit im Gefolge der karolingischen Renaissance auch die hierarchische Anschauung uber das Verhaltnis von Kirche und Staat. Aber die politischen Umwälzungen, die nach dem 9. Jahrh. eintreten, die Angriffe der Normannen und Sarazenen, die Entwickelung des deutschen Königtums und der großen Lehnsherrschaften in Frankreich, die Unterwerfung der Kurie unter die Obermacht des römischen Adels, stellen sich dem Aufschwung der Hierarchie hemmend entgegen. Erst um die Mitte des II. Jahrh. sind diese szwischen eingetretenene Gewalten, teils wie die Sarazenen besiegt und überwunden, teils wie das deutsche Königtum, der römische Adel und das territoriale Fürstentum in der Mehrzahl der französischen Großlehen so geschwächt, und ist zugleich die moralische Kraft der Hierarchie so gewachsen, daß sie die nie vergessenen Ansprüche aus der Zeit Nikolaus I. wieder geltend zu machen vermag. Sie wird dabei in Deutschland unterstützt durch eine Erhebung des ganzen sächsischen Stammes und eine Revolution der Fürsten, und in Frankreich durch die streng kirchliche Gesinnung der führenden Kreisea S. I f. Daß schon in der alten Kirche die Forderung der Autonomie die der Theokratie zur Folge, hatte nur ohne jeden praktischen Effekt, darüber siehe Löning,.Gesch. des deutschen Kirchenrechts I und oben. Ueber die Lehre des Thomas von einer nur indirekten Beherrschung der weltlichen Gewalt durch die Kirche durch Kontrolle aller auf geistliche Interessen bezüglichen Dinge s. Jourdain, La philos. de S. Th. I I854 S. 423-428. Doch entscheidet auch bei Thomas darüber, ob ein solcher Fall vorliegt, die Kirche vgl. De regimine principum I, 15 und v. Eicken 377. - Zur prinzipiellen Einsicht, daß diese Forderung der Autonomie und damit der Herrschaft zum Wesen einer Religion gehört, die sich auf Gedanken und Wahrheiten universaler Art gründet im Gegensatz zu den Staats- und Geschlechterkulten der Antike, und daß eipe solche Religion, 
feuer gibt. Von hier aus müssen auch die Herrschaftsmittel der geistigen und ethischen Kontrollè entwickelt werden. War das Priestertum zunächst auf die Garantierung der das ganze Gefüge bestimmenden religiösen Idee und Tradition gerichtet, so ist wichtiger als diese Garantierung oder als die Lehrgewalt schon in der alten Kirche die Sakramentalgewalt geworden, die ja auch dogmatisch die Priestergewalt oder potestas ordinis im engsten und eigentlichsten Sinne des Wortes geworden ist. Sie hält den Organismus zusammen und bedeutet die wesentlichste in der Kirche zirkulierende Wunderkraft ; in sie hat sich die Gegenwart des erlösenden, heiligenden, Kräfte steigernden und rettenden mystischen Christus in den Seelen verwandelt; nur vermittelst ihrer wirkt die das ganze Sozialgefüge hervorbringende, den Einzelwert der Seele schaffende und die Liebesverbindung bewirkende Gottesliebe des Christentums sich aus. Je mehr mit der Zeit die Garantierung der Lehrwahrheit Sache der ober-

zur Kirche geworden, die Forderung der Herrschaft der Kirche und des Priestertums erheben muß, vgl. K. Rieker, $>$ Der Ursprung von Staat und Kirchee in $>$ Festschrift für Emil Friedberg $₫ 1908$ und Troeltsch, $\triangleright$ Religion und Kirchee Preuß. Jahrb. 1895. An diesem Punkte hat der moderne Katholizismus sein Kirchenrecht stark spiritualisiert und zur Entschädigung für den Entgang nach dieser Seite sein Dogma und das ganze religiös - geistige Leben aufs höchste sverrechtlichte s. U. Stutz, „Die kirchliche Rechtsgeschichte 1905. Durch Verzicht auf materielle Gewalt und lediglich den Gebrauch der geistlichen Gewalt soll der moderne Katholizismus sich vom mittelalterlichen oder gregorianischen unterscheiden und zu einem rein geistigen Kulturprinzip des Fortschritts werden, s. Ehrhard, $\triangleright$ Der Katholizismus und das 20. Jahrh.\& 1902. Aber es bleibt bei der geistigen Weltherrschaft, und diese wird auf materielle Mittel, vor allem auf die Beherrschung des Staates mindestens in Schul- und Kirchenfragen, schwerlich je verzichten können. Die mittelalterliche Papstherrschaft ist nicht bloß die Form der geistigen Weltherrschaft unter den Bedingungen einer allgemeinen Barbarei und der Unentwickeltheit der profanen Kulturwerte, sondern ist eine wirkliche Konsequenz des Gedankens, von der der moderne Katholizismus schwerlich je loszureißen sein wird, wie Hoensbroech $\mathrm{m}$. E. stets richtig hervorhebt. Die vielbeklagte und in ihrer Konsequenz für die Kirche selbst verhängnisvoll gewordene Politisierung der Kirche ist doch das unumgängliche Ergebnis des ganzen soziologischen Gedankens. Auch bei dem spiritualisierten heutigen Kirchenrecht ist doch die praktische Folge der kirchlichen Idee die Beeinflussung der staatlichen Gewalt durch die katholische Demokratie, um mindestens die Herrschaft in der Schule und die Autonomie der kirchlichen Verwaltung zu behaupten. Auch der scheinbar vom mittelalterlichen System völlig gelöste amerikanische Katholizismus sucht doch auf dem Gebiet der Kommunalverwaltungen die Herrschaft, um dadurch wenigstens sein Schulwesen staatlich $2 u$ begünstigen, s. Houtin, L'américanisme. 
sten Instanzen wird, um so entscheidender wird die Umfassung des ganzen Lebens der Gläubigen durch die Sakramente. Das große Hauptdogma ist daher die Ausbildung der Lehre von den sieben, von der Geburt bis zum Tod den Menschen umgebenden und tragenden Sakramenten und des Begriffs der durch diese Sakramente mitgeteilten Gnade und ihres Verhältnisses zu den natürlichen Beschaffenheiten und Kräften. Die Ausbildung dieser Lehren im einzelnen gehö der Dogmengeschichte an; auch hier ist der h. Thomas måßgebend geworden. Hier ist nur der soziologisch entscheidende Gesichtspunkt hervorzuheben, nämlich die enge Verbindung, in welche die dritte große kirchliche Gewalt, die Jurisdiktionsgewalt, mit den Sakramenten tritt. Das ist der bis heute entscheidende Punkt, der das soziologische Gebilde der mittelalterlichen Kirche als des Trägers der Einheitskultur auch zur Durchsetzung dieses Einheitsgedankens befähigt. Die große Waffe Gregors ist der Ausschluß von den Salramenten, die Exkómmunikation, die seiner Nachfolger Interdikt und Kreuzzugserklärung. Wenn mit jener jetzt im schroffsten Unterschied von den Zeiten der alten Kirche zugleich sich die bürgerlichen Folgen einer Ausschließung aus der Gesellschaft und völliger Rechtlosigkeit sich verbinden, so zeigt das nur, wie stark inzwischen kirchliche und soziale Verhältnisse sich durchdrungen und verfilzt hatten. Die Kirche hält in der Theorie die alte Geistigkeit fest, indem sie mit dem geistlichen Urteil sich begnügt; aber sie erwartet von den weltlichen Gewalten die bürgerliche Bestrafung eines derartig auch in die bürgerliche Gesellschaft nicht mehr passenden Menschen. Es ist das nicht, wie oft gesagt wird, Heuchelei, sondern die mit der Verbindung von Geistlichem und Weltlichem sich naiv einstellende Ueberzeugung, daß der grobe Sünder und Häretiker zwar eine geistliche Vergebung finden könne, aber für die bürgerliche Gesellschaft ein gemeingefährlicher und durch die weltliche Gewalt zu strafender Revolutionär sei; wir werden die gleiche Meinung bei den Reformatoren finden. Freilich wurden diese Waffen, im Uebermaß gebraucht, stumpf und erregten Bedenken gegen die Vermischung des Geistlichen und Weltlichen. Aber als sie stumpf wurden, hatten sie ihren Zweck bereits erfült, und nun konnte an ihre Stelle das viel feinere Mittel nicht einer Ausschließung von den Sakramenten, sondern eines Sakramentes selbst treten, dessen Vollzug mit der Ausübung der Jurisdiktion über das Gewissen und das Handeln verbunden 
war. Es ist das unendlich wichtige, mit einem Teil der übrigen Sakramente als Vorbedingung kunstreich verbundene Sakrament der Buße, die Stütze der geistlichen Weltherrschaft. Aus ihm erwächst die ganze christliche Ethik der Kirche als Erforschung und Beratung der Gewissen, als Tilgung der Sünden und Anleitung zu Genugtuungen und Verdiensten, als Vereinheitlichung aller ethischen Probleme und Gegensätze durch die Autorität der Kirche, die die Verantwortung für die Vereinheitlichung der Lebensleistung damit vom Individuum weg und auf sich nimmt. Durch es wiederum wird die Ethik der Kirche aus einer bloßen Theorie zur praktischen Macht, die große und kleine, vornehme und geringe Gewissen berät, bestraft, entsündigt und vor allem hinleitet auf die Verwirklichung des wahren Lebenswertes, die Rettung der Seele aus der sündigen Welt. Der enge innere Zusammenhang des Sakramentsdogmas mit den beiden vorgenannten Dogmen von der Einheit und von der Herrschaft der Kirche liegt dabei auf der Hand. Er ist auch von der Theorie deutlich erkannt und ausgesprochen. Der historische Gott-Mensch stiftet in seiner Vereinigung von göttlicher und menschlicher Natur die Kirche als das Abbild seiner selbst, als einen gott-menschlichen Organismus. Dieser Organismus muß um seiner Göttlichkeit willen absolut einheitlich sein und das Natürliche beherrschen, wie im Gott-Menschen die göttliche Natur die menschliche beherrscht. So tritt er denn auch im Kult als der sakramentale Christus hervor, der hier jedesmal von neuem die Einigung des Göttlichen und Natürlichen dartut und den opfernden Priester zum Bewirker dieser Einheit macht, und so kommt er auch an jeden einzelnen durch die sinnlich-übersinnlichen Vehikel der Sakramente, um das Natürliche unter die Leitung des Göttlichen zu stellen, das Göttliche im Natürlichen und. Materiellen sicher und wunderbar mitzuteilen. Die Sakramente sind die Verlängerung, die Fortsetzung und Wiederholung der Mitteilung der Gottheit an die Kreatur durch Menschwerdung oder Materialisierung des Göttlichen. Diese Leitung aber kann bei dem ganzen Charakter der christlichen Idee kein reiner Sakramentszauber sein, sondern muß zugleich ethisch kontrollierend und leitend sich auswirken, und so wächst aus dem Sakramentsgedanken das ganz ethisch und jurisdiktionell gedachte Bußsakrament hervor, das seinen bloß sekundär sakramentalen Charakter darin dogmatisch zeigt, daß es keine eigentliche materia sacramenti hat, das aber praktisch zusammen mit der Messe das Grundsakrament wird. Einheit 
und Autonomie der Kirche und sakramentale Gnadendurchdringung der Menschheit, verbunden mit der daran geknüpften Jurisdiktion über die Gewissen, das gehört aufs engste zusammen und vollendet den soziologischen Ausbau 100a).

In dieser Geschlossenheit bedeutet das neue universalkirchliche Prinzip die Revolution der bisherigen Staatsordnungen und die Trennung der Kirche vom Staat. Aber, obwohl gelegentlich einige Idealisten sie dabei auf ihre ursprüngliche Armut zurückführen und wirklich gesondert neben den sich selbst überlassenen und aus gutem Willen der Kirche dienenden Staat stellen wollten, ist diese Trennung der Kirche vom Staat nicht a uch umgekehrt eine Trennung des Staates von der Kirche. Es

100a) Vgl. Schwane 579-643, wo man die zentrale Wichtigkeit dieser kultischdogmatischen Lehren für das System des kirchlichen Organismus verstehen lernt zugleich mit der der Wichtigkeit des Objekts entsprechenden ungeheuerlichen Systematik, Apologetik und haarspaltenden Scholastik. Hugo von St. Viktor hat charakteristisch die ganze Theologie unter dem Titel der Sakramente abgehandelt S. 580. Ueber die Kontinuität dieses und der beiden ersten Dogmen mit dem Gedanken des Gottmenschen, also mit der kirchlichen Grundlehre s. S. 518: > Mit dem erwähnten Grunddogma (von der hierarchischen Einheit) hängt ein anderes unzertrennlich zusammen, es ist das von der Selbständigkeit der Kirche neben und über dem Staate, weil sie eine in sich vollendete und für sich existierende Sozietut ist, welche, auf dem Gottmenschen als auf ihrem Eckstein und Fundament aufgebaut, die ewigen Heilsangelegenheiten der Menschheit zu besorgen hat und alle Menschen und Nationen in ihrem Schoß zu vereinigen berufen ist.\& Das Mittel dieser Herrschaft sind die Sakramente und dabei ist es skongruente, d. h. zur Einheit des ganzen Gedankens passend, daß auch sie wie der Gottmensch aus Geistigem und Sinnlichem zusammengesetzt sind. S. 583: >Die Heilung des gefallenen Menschen durch die Sakramente entspricht sowohl dem Arzte, dem im sichtbaren Fleisch erschienenen Sohn Gottes, als auch der Natur des zu Heilenden, der aus Leib und Seele besteht $\star$. Aehnlich S. 589: $\gg$ Daß die Form (d. h. die das sakramentale Wunder bewirkende Kraft der priesterlichen Weiheworte) gerade im Weihewort besteht, ist für die christlichen Sakramente sehr bezeichnend, weil sie so ein Abbild ihres Urhebers, des Gottmenschen, sind, in welchem das persornliche Wort Gottes mit der menschlichen Natur, speziell auch mit einem sichtbaren Leibe, hypostatisch verbunden war . Es ist die Sakrament, Priestertum und Christologie aufs innigste verbindende sinnlich-übersinnliche Erlösungslehre der Kirche, die im Orient die Wendung auf die Mystik, im Abendland die Wendung auf die Willensbildung, Willensveredelung, Krafteinflößung, Sündenerkenntnis, Verdemütigung und kirchliche Willenskontrolle und Willensleitung genommen hat. Daher verbindet sich hier mit dem Sakrament der Buße, das in engem Zusammenhang mit der Wandelung und der Kommunion zum Zentralsakrament wird, eine ungeheuer kompliziert entwickelte und in den Vollmachtssphären abgegrenzte Jurisdiktion. Ueber das erst grobe Mittel der Jurisdiktion, die Exkommunikation in dem gregorianischen, bürgerlichen Boykott nach sich ziehenden Sinne, s. Döllinger, Papsttum S. 53 f.; auch ungerechter Bann ist sehr zu fürchten und ein so Gebannter nicht aufzu- 
bleibt vielmehr die ganze feudale Entwickelung des Kirchengutes, es bleibt die organische Anteilnahme der Kirche am Staats- und Rechtsleben, nur jetzt nicht mehr im Dienste eines theokratischen Royalismus, sondern im Dienste einer hierarchischen Theokratie und einer kirchlich geleiteten Kultur. An Stelle des karolingischen Typus tritt der gregorianische ${ }^{101}$ ). Das bedeutet die Durchsetzung einer kirchlich geleiteten Kultur, die nun ihre Ideen und Maßstäbe wesentlich empfing von der jetzt mächtig entwickelten und die übrigen Länder weit überholenden französischen Kultur. An sich freilich ist das gregorianische Ideal mehr ein juristisch-diplomatisches. Aber es ist zugleich doch auch ein ethisches, indem es auf der Voraussetzung beruht, daß die Herrschaft der Wahrheit auch die moralische Erneuerung der Welt bewirken werde. Zugleich wird die päpstliche Universalkirche ein Kultur- und Geistesprinzip, indem nun in sie die französische Theologie der Bernhardiner und Viktoriner, der Normandie und Abälards einströmt und später die Bettelorden und ihre seelsorgerliche wie wissenschaftliche Tätigkeit sich mit ihr zu einem einheitlichen Prinzip verbindet. Italienische Jurisprudenz und französische Theologie,

nehmen S. 54, Exkommunizierte umbringen aus Eifer für die Kirche ist nach Urban II. und Gratian kein Mord S. 58; jeder Gebannte nach Nikolaus I. und Gratian ein Ketzer S. 59; im Jahre 1337 die Hälfte der Christen exkommuniziert, die bischöflichen Offizialen exkommunizieren in jeder Sitzung roooo Seelen; in jeder Pfarrei 30, 40, auch 70 Personen exkommuniziert S. 8I; Gregor XI. exkommuniziert bis in die 7. Generation S. 82. Ueber den Uebergang dieser im Anschluß an das altkirchliche öffentliche Bußverfahren geübte Jurisdiktion in foro externo zu der sehr viel wirksameren, mit Beichte und Genugtuungssystem des Bußsakraments verbundenen jurisdictio in foro interno s. Loofs, Leitfaden zum Studium der Dogmengeschichte ${ }^{3}$ I 892 S. 258 . Ueber die Gestaltung der Absolution zu einem sakramental-priesterlichen Akt s. Karl Müller, „Der Umschwung in der Lehre von der Buße im 12. Jahrh.\&, Theol. Abh. Weizsäcker gewidmet 1892. Wie weit diese Lmgestaltung mit der hierarchischen Tendenz der Kirche zusammenhängt, ist hier nicht untersucht; ich kann hier nur die Vermutung aussprechen. S. auch K. Müller KG. I, 574 ff. mit dem Schlußsatz: $>$ Im übrigen ist im Mittelalter der Gebrauch des Bußsakraments in der Laienwelt, wenn nicht ganz besondere Verbältnisse vorlagen, allein noch nicht viel über die jährliche Pflichtbeichte hinausgegangene S. 576. Doch ist mit den Ablässen das vorausgehende Beichtsakrament verbunden, und dient so die ungeheure Entwickelung des Abiaßwesens auch der Ausbreitung der Beichtkontrolle. Die volle Ausbildung der Buß-und Beichtpraxis hat freilich erst das Zeitalter der Gegenreformation gebracht. - Ueber die Bedeutung und die Schwierigkeiten der Sakramentslehre für die Schließung des Kirchenbegriffs s. Mirbt, Publizität S. 424-446.

101) Vgl. Hauck IV, Kap. I, wo namentlich die Fortdauer und Auswirkung des karolingischen Typus unter neuen Exponenten betont ist. 
Philosophie und Poesie schaffen in ihrer Vereinigung den Geist der kirchlichen Universalkultur, wobei die Frage nach den Gründen dieser großartigen Entwickelung des französisch-normannischen Geistes und des Uebergewichtes dieser Kultur über das ganze Abendland auf sich beruhen kann. Die Universalkirche hielt überdies und vor allem die Ergebnisse der landeskirchlichen Durchdringung von Geistlichem und Weltlichem fest und stellte sie nun nur unter die Leitung der autonomen Kirche, ihrer mächtig entwickelten Gerichtsbarkeit und ihres philosophisch-theologischen wie rechtlich-politischen Denkens. Was das Altertum nicht besaß, die Einheit einer kirchlichen und christlichen Kultur, ist so erreicht, und die kirchlichen Maßstäbe greifen bis auf den untersten Grund der Gesellschaft und ihrer verschiedenen Einzelkreise. Diese Einheitskultur ruht freilich in letzter Linie auf der Macht des religiösen, priesterlich-sakramental-asketischen Gedankens überhaupt, aber in ihrer Behauptung ist sie doch prinzipiell und praktisch eine Autoritäts- und Zwangskultur, indem sie überall von der Kirche geleitet ist und indem alle Widersprüche auf dem Gebiete der Sitte, der Politik, des Denkens von der kirchlichen Disziplin und Strafgewalt niedergehalten werden. Jemehr der große Kirchenstreit zugleich auch hier und dort die Skepsis weckte, dem Individualismus hier und dort Raum gab, häretische und enthusiastische Bewegungen neben der Kirche entstehen sah, um so schärfer bildete die Kirche die furchtbare Waffe ihres Ketzerrechtes aus, durch das sie, entsprechend der jetzt eingetretenen Zusammenfassung des Weltlichen und Geistlichen, den kirchlich-dogmatischen Ausschluß zugleich zu einer Vernichtung der bürgerlichen oder auch gar der physischen Existenz überhaupt machte ${ }^{102}$ ).

Immerhin ist diese allen sozialen Ideen des Katholizismus $\mathrm{zu}$ Grunde liegende Einheitskultur doch noch nicht genügend ver-

102) Ueber diese internationale Kultur s. Hauck, KG. Deutschlands III u. IV, Karl Müller, KG. I, 463-585, H. Reuter, „Gesch. Alexanders III. und der Kirche seiner Zeite 1860-64, H. Böhmer, \Kirche und Staat in Englands S. 405-4II, nach Robert Pullen 417, nach Joh. von Salisbury 42I-426; Lamprecht, DG. Bd. III u. IV; v. Ejcken, > Geschichte und System der mittelalterlichen Weltanschauung s 1887; Rambaud, Hist. de la civilisation française I, 308-458. Als Papstherrschaft a ngesehen hat diese Kultur freilich einen stark juristisch-diplomatischen Zug, wobei es nur auf die Autonomie der Kirche, die Ausbreitung der kirchlichen Jurisdiktion über möglichst viele Gebiete, die Herrschaft des Papstes in der Kirche und die prinzipielle Unterordnung der weltlichen Gewalten ankommt, ohne daß eine Regierung der Welt nach den ethischen Maßstäben der Kirche dabei das unmittelbare Motiv und die eigentliche Wirkung gewesen wäre. Allein dieses Unternehmen 
standen und der Quellpunkt der aus ihr hervorgehenden sozialen Begriffsbildungen noch nicht genügend aufgeklärt durch diese Einsicht in Gründe und Art der vom Mittelalter erst bewirkten Durchdringung der weltlichen Lebensformen mit den geistlichen Ideen. Die Ausbildung einer staatlich-kirchlichen Kultur in dem halben Jahrtausend des germanischen Landeskirchentums, wobei der kulturschwache Staat von der kirchlichen Kultur durchdrungen und die letztere vom Bedürfnis des Staates zu unvorhergesehenen Entfaltungen genötigt wurde, und die Beibehaltung dieses Ergebnisses von der durch eine neue asketische Welle emporgehobenen universalkirchlichen-Einheits- und $Z$ wangskultur, das ist wohl die Hauptsache, aber nicht das Einzige. Es bleibt immer noch die Frage nach dem Wesen eben der Askese, die die Theokratie in die

der Papstherrschaft ist verbunden mit den internationalen, besonders von Frankreich ausgehenden Strömungen, den asketischen Bewegungen, den zentralisierten Ordensbildungen, dem kirchlichen Recht, den Universitäten und der Theologie und dadurch ist diese Papstherrschaft doch zugleich die geistig-ethische Normierung einer christlichen Kultur, und sie rechtfertigt doch auch damit allein ihre Gewaltsamkeit vor sich selber. Ueberdies ist die Voraussetzung, daß die so hergestellte Herrschaft des Glaubens und der Kirche ganz von selbst auch die ethische Besserung und Normgemäßheit des Lebens bedeutet. Ueber den Zwangscharakter dieser Kultur vgl. Döllinger, Papsttum I 14-127, K. Müller, KG. I, 556-559, 588-592 und vor allem H. Ch. Lea, A History of the inquisition of the middle ages, New York 1888; auch wo nicht direkter $\mathrm{Zwang}$ vorliegt, kommt doch überall der psychologisch zwingende, supranaturale Autoritätscharakter in Betracht, gegen den sich dann freilich auch fast von seinem ersten zwingenden Auftreten ab vereinzelte skeptische Bedenken entgegenstellen, s. H. Reuter, Gesch. der Aufklärung im MA 1875/77. - Die literarischen und ideellen Anlehnungen für diesen, in seiner Eigenart doch erst aus der ganz bestimmten Situation geborenen Kulturgedanken boten Augustin, Gregor d. G. : und Pseudoisidor. Doch wäre es falsch, darin mit v. Eicken die Ausführung des augustinischen $>$ Programmse der civitas Dei unvermittelt zu sehen. Für Aug. ist die civitas Dei keine geistlich-weltliche Einheitskultur gewesen, sondern im Gegenteil die dem Staat und staatlichen Interesse stark entgegengesetzte rein kirchliche Gemeinschaft, welche letztere er noch dazu in dem spiritualistischen Sinne der Gemeinschaft der Erwählten im Prinzip versteht und nur praktisch mit der sakramental-objektiven Kirche in eins setzt. Dieser Spiritualismus hat überhaupt keine Beziehung auf die Welt, aber neben ihm ist die Lex naturae als selbständiges Prinzip der weltlichen Nützlichkeitswerte anerkannt. Wenr er - vor allem in den antidonatistischen Schriften - dann doch die Weihung und Entsühnung des weltlichen Staates durch den Dienst für die Kirche verlangt, dann ist damit wesentlich die Unterstützung der Kirche gegen Heiden und Häretiker durch die Kaisergewalt verlangt. Der Name Civitas Dei aber, der so viele zu der Deutung als kirchlich organisiertes Weltleben verleitet (am tollsten Lamprecht, DG. I, $307 \rightarrow$ Das glänzende Lehrgebäudt eines Christenstaatese !), hat diese Bedeutung überhaupt nicht. Erst Gregor hat diese augustinische Civitas Dei entspiritualisiert, mit der sakramentalen 
Höhe getragen hat und die von der altkirchlichen Weltscheu und Weltindifferenz verschieden gewesen sein muß, wenn sie fähig sein sollte, eine solche theokratische Kultur zu tragen. Es bleibt weiter die Frage, warum und wie jetzt eine Durchführung der christlichsittlichen Maßstäbe in Staat, Gesellschaft, Handel, Wirtschaft und Familie, möglich wurde, die der alten Kirche mit ihrer Kapitulation vor den aus der Sünde stammenden Ordnungen unmög. lich gewesen war. $\mathrm{Daß}$ sie theoretisch möglich wurde, versteht sich doch nur daraus, daß sie zuvor faktisch in irgend einem Maße möglich geworden sein muß; und diese Gründe einer faktischen Ermöglichung müssen dann dem katholischen Kultur- und Sozialideal einen dauernden Charakter und eine dauernde Beziehung auf

Priesterkirche endgültig identifiziert, mit dem natürlichen Leben nach der Lex naturae durch semipelagianischen Kompromiß vereinigt, im übrigen aber eine Leitung der Kultur durch die Kirche $z$ war in seinem eigenen Bezirk praktisch betätigt bei der Abwesenheit einer ordnenden Staatsgewalt, aber nicht als Aufgabe eines vom Papst geleiteten Imperiums gefordert. S. Vossler, Dante I, 395-400; Loofs, Grundriß des DG. 242-248. Pseudoisidor schreitet in dem Bedürfnis der Emanzipation der Bischöfe von der Metropolitangewalt zur päpstlichen Universalmonarchie fort, abes bedeutet noch nicht den Gedanken einer kirchlichen Kultur, sondern nur die Konsequenz des Ausbaus der Priesterkirche. Erst aus dem Zusammenwirken der neuen Askese, der gregorianischen, Verfassungsidee und der romanisch-christlichen Kultur, der großen internationalen Orden und der Einigung des christlichen Europa im Kampfe gegen den Islam entspringt diese Kulturidee, die zu ihrer Voraussetzung die Ueberwindung der Sprödigkeit des alten Christentums gegen eine fertige, überlegene und in der Wurzel heidnische Kultur hatte. Diese Ueberwindung aber ist in der landeskirchlichen Epoche der gegenseitigen Durchdringung eines kulturschwachen Staates und einer ihm gegenüber relativ kulturstarken und ihren Kulturbesitz in dieser Lage entwickelnden Kirche geschehen. Das wird in der mittelalterlichen Literatur selbst allerdings $\mathrm{m}$. W. nicht besonders hervorgehoben, weil es zu den selbstverständlichen Voraussetzungen des praktischen Lebens gehört, von denen aus man auch die altkirchliche Literatur deutet. So kann der Schein entstehen, als hätte das Mittelalter keinerlei neue, ethische Doktrin, wie Th. Ziegler Gesch. d. Ethik II S. 242 und 280 meint, während es in Wahrheit ein neues Fundament und damit eine ganz andere Färbung aller seiner Doktrinen hat. Ueber den neuen Charakter und Inhalt bei scheinbarer bloßer Fortführung der altkirchlichen Ueberlieferung s. auch sehr treffend Carlyle, Medieval political theory S. $197 \mathrm{f}$. Die Meinung Zieglers, man könne die mittelalterliche Ethik darstellen ohne Rücksicht auf den konkreten Boden, auf dem sie sich bewegt, S.. 242 ist ein Irrtum, der sich an seiner ganzen Darstellung sehr gerächt hat. Sie hat dadurch den entscheidenden Punkt verfehlt und bringt es nur zu der stets wiederholten Klage, dass das Mittelalter so sehr katholisch gewesen sei. - Die Entstehung der glänzenden französischen Geisteswelt und ihre Vereinigung mit der internationalen Kirchenherrschaft ist übrigens ein noch nicht hinreichend aufgehelltes kultur- und kirchengeschichtliches Problem. Das letztere möchte ich in der Hauptsache für ein Werk des h. Bernhard und vor allem der Bettelorden halten.

Troeltsch, Gesammelte Schriften. I. 
bestimmte faktische soziale und wirtschaftliche Zustände geben. Es bleibt insbesondere schließlich die Frage, wie sich für den Niederschlag des hochmittelalterlichen Bewußtseins in der The or i e die Vermittelung der religiös - jenseitigen und der innerweltlichen Zwecke gestaltet habe, welche Vermittelung, zunächst von den Tatsachen herbeigeführt, doch nur um so dringender der theoretischen Klärung bedurfte und damit $z \mathrm{u}$ einer wichtigen Fortbildung und Relativierung der christlichen Ideenwelt führte. Diese letzte Frage führt uns dann unmittelbar zu dem Hauptpunkt unserer Untersuchung, zu der Darstellung der Sozialphilosophie des Thomismus und ihrer allgemeinen theologisch-ethischen Grundlagen. Zuvor aber gilt es, die beiden ersten Fragen zu beantworten.

5. Die Bedeutung der Askese im System des mittelalterlichen Lebens.

Die internationale kirchliche Kultur ist von einer neuen Flutwelle der Askese emporgetragen, und von der theokratischen Universalkirche ist diese Askese in ihre Leitung genommen worden.

Man hat um deswillen diese kirchliche Kultur als eine rein asketisch begründete angesehen und das Problem gestellt, wie diese Askese in Weltherrschaft und Weltkultur habe umschlagen können. Es sei geschehen, weil die Askese, auf das jenseitige Heil gerichtet, doch dieses Heil in der sakramentalen Kirche des Diesseits verkörpert sah und daher die Herrschaft der kirchlichen Erlösungsanstalt etablieren mußte; soweit sie dann auch weltliche Kulturelemente in sich aufgenommen und befördert habe, sei dies teils im Interesse der Herrschaft der Kirche, teils in inkonsequenter Anpassung an die nun einmal nicht zu ertötende Natur der Dinge geschehen ${ }^{103}$ ). Allein eine wirklich reine Askese hätte einen solchen Umschlag nicht vollziehen können, wenn sie wirklich allbe-

103) So v. Eicken, Geschichte usw.๔, mit Einschränkungen auch Harnack, DG. III, 298: -Das Christentum ist die Askese und der Gottesstaat. „Die Weltflucht im Dienste der weltbeherrschenden Kirche, die Weltherrschaft im Dienste der Weltentsagung, das war das Problem und das Ideal des Mittelalters.\& Bei v. Eicken liegt der Konstruktion die weitere Substruktion zu Grunde, daß er das entstehende Christentum selbst für ein Erzeugnis der antiken gnostisch-dualistischen Erlösungslehre hält, die sich im jüdisch-christlichen Messianismus, im leidenden und die Welt authebenden Gottmenschen, ihren persönlichen Erlöser schafft. Daß diese Charakteristik auf das alte Christentum nach der ethischen und sozialen Seite hin ebensowenig zutrifft, als sie nach der dogmengeschichtlichen zutrifft, glaube ich im Bisherigen gezeigt zu haben. Aber wäre auch der Ausgangspunkt richtig, so wäre doch von ihm aus das Mittelalter nicht zu konstruieren. Daß aus der Askese die Welt- 
herrschendes Ideal und alleiniger Selbstzweck gewesen wäre. Wo und sobald sie wirklich sich so empfand, da trat auch überall die Auflösung der kirchlichen Einheitskultur und der theokratischen Weltbeherrschung ein; die widerspruchsvolle Geteiltheit der Stimmung bei Peter Damiani und dem h. Bernhard, die Opposition Arnolds von Brescia, die Entwickelung der Waldenser und Franziskaner bezeugt das deutlich. Von ihr aus wäre aber auch die Entwickelung der Bodenkultur und Grundherrschaft, der Kunst, der Wissenschaft gerade aus den Orden und ihren Anregungen heraus unverständlich, und von ihr aus führte vor allem kein Weg zu den Soziallehren des Mittelalters, die Familie, Staat und Wirtschaft dem Corpus Christianum ganz unzweifelhaft positiv eingliedern. Die Askese kann nicht das eigentlich allein berechtigte Vollkommenheitsideal und damit Wesen und Prinzip des mittelalterlichen Katholizismus gewesen sein, dem gegenüber alles andere nur prinzipwidrige Kompromisse wären. Das ist auch schon von dem ganzen geschichtlichen Wesen der christlichen Askese her unmöglich. Sie ist ein ganz und gar komplexes Phänomen und steht in einem sehr verwickelten Verhältnis zu der Grundidee des Christentums, wie das bereits früher gezeigt wurde. Vom Evangelium her wiesen zwei Richtungen nicht in die eigentliche Askese, aber in eine

beherrschung nicht logisch entwickelt werden kann, hat Eicken selbst gefühlt, indem er mit der Askese die Hierarchie noch vereinigt S. 133, die gar nicht aus der Askese, sondern aus dem Sakramentalgedanken und Priestertum folgt, und indem er überdies die Hierarchie noch die römische Reichsidee rezipieren läßt S. II9 u. I56; allein der Ausbau der Theokratie folgt völlig aus der soziologischen Konsequenz des Xiphengedankens mit seinem Wahrheits- und Sakramentsbegriff; erst das vollendete Papsttum geht auf das Imperium zurück, wozu italienisch-nationale und humanistische Stimmungen kommen. Der Fehler des geistvollen v. Eickenschen Buches ist erstlich, daß es die Ideenbewegung rein logisch als Hervorbringung des Ganzen durch eine alles umfassende Dialektik betrachtet (vgl. S. 313), während die Dinge zunächst psychologisch als Zusammenströmen verschiedener Reihen zu nehmen sind, in denen sich die von einzelnen Elementen ausgehende Dialektik nur mehr oder weniger durchsetzt, zweitens daß er die christliche Grundidee als Askese formuliert ohne die Komplexität und Vieldeutigkeit des Begriffes zu beachten, ohne den verschiedenen Motiven und Bedeutungen der Askese nachzugehen und vor allem ohne zu beachten, daß die Ueberweltlichkeit der christlichen Idee stets mit dem hebräischen Schöpfungsglauben zusammengeht und in dieser Verbindung gegen die dualistische Gnosis und Askese sich prinzipiell behauptet hat, schliefilich daßs es die aus der Askese selbst unerklärbare Tendenz der Weltherrschaft durch den Zufall der Rezeption der römischen Herrschaftsidee erklärt, wo gerade hier nicht der Zufall sondern nur die Konsequenz des Gedankens herrscht; der 
starkc Ueberweltlichkeit und in eine starke Zurückhaltung der christlichen Gemeinde gegen die Formen eines entwickelten Weltlebens: einmal die Zentralstellung des ethisch-religiösen Lebenswertes der Gottes- und Menschenliebe, dem alles andere untergeordnet wird und neben dem die innerweltlichen Kulturgüter - etwa abgesehen von der Familie - nur in dürftigen Andeutungen in den Horizont des Evangeliums treten, und zweitens der Rigorismus der Gesinnungs- und Liebesethik, die auf Recht und Gewalt verzichtend alles, wenn irgend möglich, durch persönliche Einwirkung und durch innere Ueberwindung des Unrechts auswirkt. Aus beidem zusammen folgte eine begreifliche Schwierigkeit der Eingliederung in das große Wèltleben, die durch die apologetisch-supranaturale absolute Abgrenzung gegen die erbsündige, gnadenlose Welt und durch die Steigerung der Konflikte beim Aufstieg in die soziale Oberschicht und deren Kulturzusammenhänge nur größer wurde. Hierin sowie in dem Einbruch aller asketischen Motive der Zeit und in der Ausbildung von Mitteln der religiösen Konzentration und Belebung hatte das Aufkommen der Askese und dann des Mönchtums seinen Grund; aber es blieb trotz Erbsünde, Teufel und Dämonen die ursprüngliche Güte der Welt und Schöpfung, und von dieser Grundposition aus konnte auch die Lehre von der Begründung der sozialen Bildungen in einem göttlichen Naturgesetz, das identisch ist mit dem Gesetz des Moses, durchaus konsequent aufge-

Grundgedanke ist eben nicht die Askese. Der Satz S. 354: Diese energische Behauptung der irdischen Existenzinteressen nötigte die Kirche, denselben im W'irtschafts-, Familien- und Staatsleben eine beschränkte Duldung zu gewähren, welche mit der strengen Logik des Systems im Widerspruche stands, ist für die Kirche direkt unrichtig und gilt nur von einzelnen Aeußerungen der Asketen selbst. Die gleich unten zu schildernde Lehre von der Lex naturae und ihr Einsatzpunkt in der christlichen Idee selbst ist von ihm durchaus verkannt, insbesondere die thomistische Lehre trotz gelegentlicher Zitierungen nirgends in ihrer eigentlichen Struktur gewürdigt. Die bunten Zitationen aus einem Haufen heterogener Literatur sind kein Mittel, die mittelalterliche s Weltanschauung \& $z \mathfrak{u}$ verstehen, und vollends die Klagen über die moralische Verderbtheit der Herrscher sind kein Beweis für den >Gottesstaat \&; es gibt ebensoviel Klagen über Verderbtheit der Kirche. In der christlichen Idee selbst aber gibt nur die Erbsünde und der Teufel Raum für die Mortifikation, alles übrige ist dualistischer Import oder religiöse Erregtheit und Uebertreibung oder Mittel und Technik für die religiöse Konzentration, als welche die >Askesea ja von der kirchlichen Theorie allein anerkannt wird, vgl. Zöckler, Kritische Gesch. d. Askese ${ }_{1} 6_{63}$. 
nommen werden. Damit ging dann freilich das Christentum in eine Fülle schwer vereinbarer Motive auseinander, in kirchliche Organisation, in mönchische Rettung des strengen, weltüberlegenen Ideals und in ein Weltleben gemäß den erbsündig getrübten, aber doch zugleich zur Heilung der Sünde bestimmten Lebensformen der Lex naturae. Bei dieser Mannigfaltigkeit der Motive ist es geblieben auch bis zu der uns jetzt beschäftigenden Periode; daran haben auch die mächtigen asketischen Flutwellen nichts geändert, welche die päpstliche Theokratie und die ihr entsprechende, von den Orden erzeugte und überall hin verbreitete christliche Weltkultur emporgetragen haben. Die Askese ist immer nur ein Motiv neben anderen geblieben, ist nie zum systematisch begründeten Ausdruck der christlichen Moral ${ }^{104}$ ) und nie zum alleinigen Exponenten eines theologischmetaphysischen Systems geworden. In dem letzteren hat vielmehr immer der alttestamentliche Schöpfungsglaube mit Stoa und Aristoteles zusammen mitgeherrscht, und auch der seit Augustin immer stärker hervortretende Einschlag des Neuplatonismus bedeutete nur einen Stufenbau, aber keinen prinzipiellen Dualismus. Unter diesen Umständen ist es nicht Verweltlichung durch die Hierarchie oder Konzession an die Natur, sondern eine ganz folgerichtige Entwickelung, wenn asketische, weltliche und theokratische Elemente sich zu einem Kosmos gegenseitiger Anerkennung und Förderung verbinden, und wenn innerhalb dieses Kosmos die Askese in ihrer eigentümlich-abendländischen Entwickelung den Weltwerten und Weltformen Raum läßt. Zugleich bleibt der Askese ihre große Bedeutung als Mittel der Intensivierung aller religiösen Bewegungen, als Kraft der Erwekkungsperioden, wobei es dann naturgemäß im einzelnen an Uebertreibungen und an Souveränetätserklärungen der Askese nicht fehlt. Aber im ganzen ist sie doch nur das von bestimmten Zentren ausgehende und organisierte Belebungsmittel, wie es denn ja auch in keinem religiösen System und Kult jemals ganz an asketischen Belebungs- und Intensivierungsmitteln gefehit hat; nur die unter dem Einfluß des Immanenzgedankens und unter der Vorherrschaft der innerweltlichen Ethik stehende moderne Kultur ist momentan fast ohne alles Verständnis dafür. Zu welcher Strenge, Energie und Exzentrizität immer eine universale und transszendente Religiosität die Askese steigern mochte,

104) Daruber sofort Nuheres. 
für das Ganze und für die offizielle Theorie blieb sie immer nur eines der Mittel des Systems neben anderen. So ist sie denn auch in der Tat das in immer neuen Anläufen wachgerufene, immer wieder stumpf werdende und immer wieder erneut geschärfte Mittel der Intensivierung der Religion, aber nicht ihre alles gestaltende Grundidee ${ }^{103}$ ). Zur Gestaltung der kirchlichen Kultur vielmehr wirken mit ihr zusammen die sich entfaltende selbständige Konsequenz des soziologischen Gedankens der Kirche, die die Menschen nicht unter die Askese, sondern unter Sakrament und Priester beugt, und außerdem das mit aller christlichen Weltbeárbeitung eng verbundene Kulturerbe der Antike, das als Bildungsbesitz der Kirche und als Grundlage aller weltlichen Soziallehren in der Lex naturae fortdauert und seit den Kreuzzügen sich ganz außerordentlich mehrt; es bleibt doch eben auch für das Mittelalter dabei, daß die Heranziehung und Einschmelzung der antiken monotheistischen Religionslehre und Ethik neben der Kirchenbildung die große Grundtatsache ist, die dem Christentum eine weitere Entwicklung, eine prinzipielle Ausgestaltung seines Gedankengehaltes und eine Entfaltung seiner der Welt zugekehrten Seite, möglich gemacht hat. Aber allerdings bringt auch an diesem Punkte die mittelalterliche Kirche gegenüber dem Altertum eine tatsächliche und theoretische Neuerung. Sie unterwirft die im Altertum die Kirche gefährlich bedrohende und Ideenwelt wie Organisation sprengende Askese wieder der Kirche, gliedert sie dem Kosmos der kirchlichen Tätigkeiten praktisch ein und stellt theoretisch die Weltfrömmigkeit und die Mönchsfrömmigkeit in ein festes Verhältnis der Vereinbarkeit.

Das e rste in der Bildung dieses Kosmos ist die sichere Ein- und Unterordnung der Askese und des Mönchtums unter die Kirche. So sehr das letztere selbst immer wieder zu einem gewissen Independentismus streben mag und so locker das Verhältnis beider in der alten Kirche gewesen ist, das Mittelalter ordnete es zunächst den Bischöfen und dann, als es zu organisierten Ordensgruppen sich zusammentat, dem Papsttum unter; alle andere Askese war oder wurde häretisch. Die Reibungen zwischen Säkular- und Regular-

$\left.{ }^{105}\right)$ Die asketischen Bewegungen des Mittelalters stehen in voller Analogie zu den methodistischen Erweckungszügen, Heiligungs- und Gemeinschaftsbewegungen oder zu den Betreibungen neuer Kulte und Devotionen wie der Herz-Jesu-Kult, der Lourdeskult und ähnliches, was wir heute noch vor uns erleben.. 
klerus sind dann nicht mehr solche der Prinzipien, sondern solche der Berechtigungen innerhalb der kirchlichen Jurisdiktionsgebiete. Damit ist dann aber die Idee des Mönchtums selbst verändert. Es ist ausdrücklich nicht Selbstzweck, sondern Mittel der Kirche für gesamtkirchliche Zwecke. Der Zug der Kirche zum Mönchtum ist der Zug zu einem unvergleichlichen Belebungs- und Machtmittel. Auch die Monachisierung des Klerus ist vor allem die Ausrüstung des Klerus mit der stärksten Wirkungsfähigkeit und Weltunabhängigkeit. Das Mittel zum Heil ist aber nicht Mönchtum und Askese, sondern einzig und allein Kirche und Sakrament. Umgekehrt hat nun auch das Mönchtum den Zug zur Kirche. Denn die Durchsetzung der Erweckungen und Reformen kann nur im Bunde mit der internationalen Macht der Kirche bewirkt werden und die Herrschaft der Weltleute über die Klöster nur durch die Hilfe der Kirche gebrochen werden, und im übrigen bleibt ja auch die Tugendkraft des Mönches und der religiöse Gehalt der asketischen Leistung gebunden an die Einflößung der Gnade in den Sakramenten, welche letztere wiederum nur durch die Kirche möglich ist ${ }^{106}$ ).

108) Ueber die Verkirchlichung des Mönchtums s. Harnack, Gesch. des Mönchtums, S. 4I; zahlreiche Beispiele erst des Konflikts von Mönchtum und Kirche in der gallischen Kirche, dann der systematischen Unterordnung des Mönchtums unter die Bischöfe und schließlich unter die Kurie bei Hauck, KG. Deutschlands. Besonders lehrreich sind hier die verschiedenen Entwickelungen der sachlich sich so nahe stehenden Waldenser und Fránziskaner. Ueber das Verhältnis von Mönchen und Priestern nach Thomas A. s. Grabmann, Zur Lutherbiographie, Hist. Polit. Blätter 1906 S. II I : Unter dem Einfluß des Pseudodionysius beantwortet Th. die Frage, wer im Stande der Vollkommenheit sei, dahin, daß zum Stande der Vollkommenheit die Bischöfe und Ordensleute und zwar in vorzüglicherer Weise die Bischöfe gehören: die Ordensleute, weil sie durch das Gelübde sich dauernd zu den Werken der Vollkommenheit verpflichten, die Bischöfe, weil sie dauernd das Hirtenamt ubernehmen, die Bischöfe in vorzüglicherer Weise, weil sie sich zur Vollkommenheit aktiv (perfectores), die Mönche bloß rezeptiv (perfecti) verhalten (Ps.-Dionys) und weil dem aktiven Prinzip (agens) der Vorrang vor dem rezeptiven Faktor (patiens) gebührt (Augustin) .... s. Sobald Th. den Stand der Ordensleute mit dem ordo der Priesterwürde und dem priesterlichen Charakter vergleicht, gebührt dem Priester in Bezug auf die Vollkommenheit unbedingt der Vorrang vor den nicht-ordinierten. Mönchen . . manifestum est excellere praeeminentiam ordinis quantum ad dignitatem, quia per sacrum ordinem aliquis deputatur ad dignissima ministeria, quibus ipsi Christo servitur in sacramento altaris; ad quod requiritur major sanctitas interior quam requirat etiam religionis status. 


\section{2

Weiterhin kommt für die Zusammenordnung des mönchischen Lebens und Ideals mit dem weltlichen die katholische Idee des Organismus, der gegenseitigen Vertretungen und Ergänzungen, die ganze mittelalterlich-soziologische Atmosphäre des ständischen Stufenbaues mit verschieden wertvollen, aber sämtlich notwendigen Diensten für das Ganze in Betracht. Dieser Gedanke wird uns spätẹ noch eingehend beschäftigen; hier ist er bereits insoferne zu betonen, als er es ist, der stellvertretende Leistungen eines Standes für die übrigen und überhaupt eines Individuums für andere möglich und notwendig macht. Im Organismus strömen die Leistungen der einzelnen Teile zusammen und werden so vom Ganzen her wieder den Einzelnen in ihrem Effekt zugewendet. Die Idee der stellvertretenden Büßung und Leistung ist wirklich eine lebendige Kategorie des frommen Denkens; die Stellvertretung Christi in Strafe und Verdienst ist nur ein Spezialfall dieses allgemeinen Gedankens; der Schatz der Kirche, in den jene Ueberschüsse zur Verteilung im Ablaß zusammenfließen, ist seine lebendige Gegenwart und Anschaulichkeit. So kommt es $z u$ dem Gedanken der kirchlichen Stände, die in Laientum, Religiosentum und Priestertum aufsteigen und auch die Gliederungen des Laientums so indirekt in das System des Corpus Christianum aufnehmen. So haben die Weltleute für das Ganze die Aufgabe der Aufrechterhaltung und Fortpflanzung, an der die Asketen sich nicht mitbeteiligen können, und die Asketen die Aufgabe der Darstellung des Ideals in einer besonders gesteigerten Weise und der Leistungen für die andern in Fürbitte, Büßung und Verdienst. Daher die unermeßlichen Schenkungen und Stiftungen an die Klöster, mit denen man sich Anteil sichert an den Leistungen des Mönchtums. Und umgekehrt gestattet die Askese in den Einrichtungen des Halbmönchtums, der Tertiarier, der Vereine und Gilden eine den Weltverhältnissen angemessene Einschränkung der Askese, also allerhand Vermittelungen und Ausgleichungen, die nur Sinn haben unter der Voraussetzung einer prinzipiellen Anerkennung des Weltlebens als auch an seinem Teil notwendig für das Ganze ${ }^{107}$ ). Die ständische Atmosphäre und organische Denkweise kennt eben gar nicht die Einheit des "Vollkommenheitsideals«, wie es der protestantische und der moderne Individualismus fordern. Wie die verschiedenen Dienste der Stände sich unterscheiden und doch 107) Vgl. Lhlhorn, Liebestätigkeit II, 98 f., I 20 f. 
in der Einheit des Ganzen zusammengehen, so ist auch die Verschiedenheit der christlichen Vollkommenheit in Arten und Mitteln und die gegenseitige Ergänzung dieser Verschiedenheiten in dieser Atmosphäre ein ganz natürlicher und selbstverständlicher Gedanke. Daher tritt jetzt erst auch die vielbemerkte Aehnlichkeit der Kirche oder vielmehr des kirchlich geleiteten Corpus Christianum mit dem platonischen Staate hervor ${ }^{108}$ ); die naturgemäß verschiedenen Leistungen der Gruppen und Stände ergänzen sich in der Idee des Ganzen. Davon hatte freilich das Evangelium noch nichts gewußt, dem diese Atmosphäre fremd war und dessen radikaler Individualismus inzwischen durch die kirchliche Einheitsidee stark zurückgedrängt worden ist; dafür hatte es aber mit seiner religiösen Ueberweltlichkeit und seinem Rigorismus auch nur schwierige Probleme geschaffen, sobald die Gemeinde in die große Welt trat. Das Mittelalter hat das vom Evangelium gestellte Problem in seiner Weise gelöst, indem es die Ueberweltlichkeit durch die Askese sicherstellte, daneben den Weltleuten ein nur der Askese angenähertes Leben zuwies und beide Stände zur gegenseitigen Ergänzung vereinigte im Organismus der Kirche. So lehrt denn auch die thomistische Theorie, da $\ddot{B}$ die Vollkommenheit für alle Christen an sich gleich sei, für alle auf der in den Sakramenten eingeflößten Kraft beruhe und für alle in der Gottes- und Nächstenliebe bestehe, daß aber die verschiedenen Stände verschiedene Mittel zur Herbeiführung der Vollkommenheit hätten und

$\left.{ }^{108}\right)$ S. Zeller, Vorträge und Ab̆handlungen I, 1865, Der platonische Staat in seiner Bedeutung für die Folgezeit๔. Es zeigt sich hier wieder die Analogie von Christentum nnd Platonismus auch von der Seite der soziologischen Auswirkung des ethisch-religiösen Gedankens her. Die Herrschaft der religiös-sittlichen Idee führt zur Herrschaft der Philosophen und Priester, und sobald eine einheitliche Gesamtkultur erzeugt werden soll, läßt sich die Ueberweltlichkeit des Systems nur in der Form behaupten, daß die eigentlich religiösen Ideale einem bestimmten Stande zugewiesen werden, während die weltlichen Aufgaben anderen Ständen zufallen, diese aber unter scharfe Kontrolle der religiös-ethisch Leitenden gestellt werden. Weil das Christentum erst im Mittelalter zu einer Einheitskultur kommt, kommt auch die soziologische Gleichung mit dem Platonismus erst jetzt zu ibrer Auswirkung, wăhrend im Altertum gegenüber einer fremden Welt die stoischen Kategorien aushelfen mußten. Auch hier erkennt man die Wahlverwandtschaft und das Recht des Zusammenflusses von Christentum und Platonismus. Dagegen möchte ich die Aehṇlichkeit nicht, wie Zeller anzunehmen scheint, S. 75, auf eine Weiterentwickelung der von der Kirche aufgenommenen mit anderen Elementen verschmolzenen platonischen Ideen zuruckführen. Die Analogie ist spontan. 


\section{II. Mittelalterlicher Katholizismus. 5. Die Askese des Mittelalters.}

daß unter ihnen der Asketenstand, der status monasticus, besonders wirksame und vortreffliche Mittel besäße; trotzdem könne aber unter Umständen ein Laie höhere Stufen der Vollkommenheit erreichen als ein Mönch. Die modernen katholischen Theologen fügen hinzu, daß auch Weltleute kanonisiert werden können und kanonisiert worden seien; was über diese Lehre hinausgehe, sei Einseitigkeit, Uebertreibung, Selbstverherrlichung des Mönchtums, an der es ja allerdings nicht fehle ${ }^{100}$ ).

So ist die Askese von den anderen Momenten des Corpus Christianum her eingegrenzt und einem reicheren Ganzen einge-

109) Ueber die Idee des Organismus mit seinen gegenseitigen Stellvertretungen s. Uhlhorn, >Liebestätigkeit II, 96, 137, 255, 269 hier z. B. die Siechen : die armen Siechen sind in ihrer Weise ebenso berechtigt wie andere; sie bilden einen Stand, der für das Ganze ebenso nötig ist und dem Ganzen ebenso dient wie andere Stände«, nämlich durch stellvertretende Leiden und durch Gelegenheit zum Almosengeben und Verdienste erwerben. Böhmer, $>$ Kirche und Staat nach Robert Pullen S. 419: >Die Prälaten als Stellvertreter Gottes nehmen in dem universalen Menschheitsverband, der bei ihm Staat und Kirche umfaßt, in der Kirche, den vornehmsten Rang ein und sind dazu berufen, die beiden übrigen $\mathrm{Stände}$ der christlichen Menschheit, die continentes, die Mönche, und die conjugati, die Laien, zu regieren.* Ueber die gegenseitigen Stellvertretungen in Verdienst und Büßung innerhalb dieses Systems s. Schwane, Dogmengeschichte, S. 668-674, bes. 669: DDen Charakter von Genugtuungswerken tragen ganz besonders das Gebet, Fasten und Almosen an sich, weil ihre Uebung einen Kampf gegen die sinnliche Natur und insofern etwas Lästiges und den natürlichen Wünschen Entgegengesetztes verlangt... Sind die Menschen schon von Natur aus Glieder eines Geschlechts, so sind die geheiligten Christen noch viel inniger als Glieder vom Leibe Christi verbunden, sodaß das Gute und das Böse des einen Gliedes allen übrigen zu Gute kommt, bezw. zum Unheil gereicht.\& So sind auch die Leistungen des Mönchs $s t$ a $\mathrm{n}$ d e s zu verstehen, es ist stellvertretende Verwirklichung des Ideals, Fürbitte und stellvertretende Leistung; vgl. Grabmann a. a. O. 104. $\bowtie$ Daß in solch beschaulichen Orden die Gesinnung der Nächstenliebe gesteigert, und daß das in solchen Klöstern geübte Fürbittgebet und Opferleben Taten christlicher Nächstenliebe sind, soll hier nur angedeutet sein.\& - Ueber die aus solchen Umständen sich ergebende Geteiltheit und doch wieder behauptete Einheit des christlichen Vollkommenheitsideals s. die Aus-

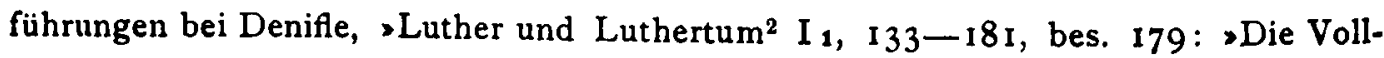
kommenheit des christlichen Lebens besteht eben in der möglichst vollkommenen Erfüllung jenes Gebotes (der Gottes- und Nächstenliebe) d. h. soweit es in der $\mathrm{Z}$ e it (d. h. auf Erden) und in den vers chiede nen $\mathrm{St}$ anden möglich ist.\& Dagegen Scheel in den Erläuterungen zu der Uebersetzung von Luthers Schrift $\rightarrow$ De votis monasticis « Luthers Werke, Ergänzungsband II, Berlin 1905 und gegen Scheel wieder Grabmann, Das christliche Lebensideal nach Thomase, Hist. 
gliedert. Aber das wäre nicht möglich, wenn sie nicht selbst in ihrem eigenen Wesen die Möglichkeit dazu in sich trüge, wenn sie wirklich nur Büßung, Mortifikation, transszendente Kontemplation und somit Verneinung des Weltlebens wäre. Das ist sie freilich oft genug, und wo sie das ist, bildet sie auch einen toten

Polit. Blätter 1906, S. I-27, 89-114 und N. Paulus, >Zu Luthers Schrift über die Mönchsgelübde`, Hist. Jahrb. d. Görres-Gesellschaft 1906, S. 487-516. Die beiderseitige konfessionelle Apologetik kann hier auf sich beruhen. Rein historisch genommen, haben jedenfalls die katholischen Gelehrten recht, wenn sie behaupten, daß die vom Protestantismus gemeinte Einheitlichkeit des Lebensideals von der offiziellen katholischen Theorie überhaupt nicht gefordert werde, daß diese aber doch auf ihre Weise dabei die Einheitlichkeit wahre und die Askese keineswegs zur eigentlich allein wahren Vollkommenheit mache. S. Grabmann S. Io I f.: „Der Grundirrtum der Protestanten ist eine gänzlich falsche Auffassung des Begriffes: Einheitlichkeit des Lebensideals. Wenn von einer Einheitlichkeit des christlichen Lebensideals die Rede ist, so ist damit eine spezifische, eine wesentliche Finheit und nicht eine mechanisch-numerische (das soll wohl heißen: für jedes Individium gleiche und es unmittelbar auf das Ziel beziehende) gemeint. Es ist innerhalb des spezifisch einheitlichen Lebensideals eine vielfache quantitative Abstufung möglich. Durch diese graduellen Unterschiede wird doch keine wesentliche Verschiedenheit bedingt. Diesen graduell, jedoch nicht spezifisch verschiedenen Formen der Verwirklichung des Lebensideals entspricht auch eine Mannigfaltigkeit der himmlischen Belohnung (auch Dantes Himmel ist ständisch gegliedert). Durch den Gehorsam und die Virginität oder besser durch die denselben zu Grunde liegende Gesinnung der liebenden Hingabe an Gott stehen den Ordenspersonen Mittel zur Verfügung, wodurch sie eine gewisse Stufe des spezifisch einheitlichen Lebensideals erreichen können. Es ist damit keineswegs ausgeschlossen, daß Weltleute auf ande rem Wege eben dieselbe Stufe erreichen können.\& S. 99: >Daraus, daß die Ordensleute sich durch Gelübde zum Streben nach Vollkommenheit verpflichten, folgt noch nicht, daß die anderen Christen keinerlei Verpflichtung num Vollkommenheitsstreben haben, da man bekanntlich durch ein Gelübde sich zu etwas verpflichten kann, wozu man an sich schon gebunden ist. Das Streben nach Vollkommenhe it ist für jeden Christen nicht Sache freien Beliebens, sondern Pflicht. Ordensleute, wie Weltleute haben nach Vollkommenheit zu streben, wobei freilich den ersteren ein mehr determinierter Weg sich öfnet. $\gg$ Das allgemeine Ideal ist die Gottes- und Nüchstenliebe, aber verschieden sind die Mittel. Die Askese ist ein besonders vorzügliches Mittel, nur accidentialiter besteht die Vollkommenheit aus den evangelischen Räten. «Daraus, daß das Ordensleben als der bessere Stand bezeichnet wird, folgt doch nach allen Regeln der Logik nicht, daß die Weltleute einem schlechten oder wenigstens minderwertigen (!) Stande angehören. Es folgt daraus nicht einmal, daß das Ordensleben für alle das Bessere ist c 100. Dazu ist zu bemerken, daß diese Autoren zugleich natürlich die Existenz zahlreicher sunerleuchtetere Asketen und asketischer Schriftsteller zugeben, daß ein mit besonderen Vollkommen- 
Punkt, von dem aus keine Verbindung zu den übrigen möglich ist. Auch ist nicht zu leugnen, daß einem System der Gnadensittlichkeit, die durch fortwährende Wunder im Gegensatz gegen die natürlichen Kräfte erzeugt wird, auch inhaltlich ein übernatürlicher und naturwidriger Bezirk des Handelns zu entsprechen scheint; und das ist die Stelle, an der sich in der Tat als Konsequenz des mittelalterlichen Systems die Askese darstellt und oft genug fühlt. Allein die Motive der Askese sind in der Mortifikation, der Kontemplation und Büßung nicht erschöpft. Daneben gibt es vielfache andere Motive, die sie aus einem Selbstzweck zu einem Mittel machen; sie ist Mittel der Erweckung, der Bändigung und Unterwerfung der Sinnlichkeit, der Stärkung für den kirchlichen Beruf, der Uebung in Tugend und religiöser Gesinnung, des Heroismus und besonderer Auszeichnung; sie ist immer überhaupt Begleiterscheinung religiöser Erregung oder besondere Berufsbefähigung des Volkserweckers und Missionars. Auch ist die Gnadensittlichkeit doch kein reines Wunder, wie gleich näher zu zeigen, sondern Fortführung, Entsündigung und Ueberhöhung der Natur, zu der sie durchaus in keinem reinen Gegensatz steht. Hier hat insbesondere die thomistische Theorie im Gegensatz zu allerhand Exzentrizitäten sehr nüchtern geurteilt. Unter diesen Umständen ist es begreiflich, daß ein derartig komplexes Phänomen bei allen wirklich oder scheinbar rein negativen Tendenzen doch auch Möglichkeiten der Weltanerkennung und positiven Weltarbeit in

heitsmitteln ausgerïsteter Stand nur Sinn bat als Bestandteil eines Systems sich ergänzender Stănde, und daß der Vorzug eines Vollkommenheitsmittels, das doch seiner Natur nach gleichzeitig gar nicht von allen angewendet werden kann und darf, die Schwierigkeit der christlichen Ueberweltlichkeit im Verhältnis zu den Weltwerten und besonders die geradezu widerspruchsvolle Stellung der eigentlichen Askese zu ihnen darstellt. Aber richtig ist, daß in diesem Widerspruch der Katholizismus nicht bloß a f die asketische Seite des Widerspruchs festgenagelt werden darf, als wärediesedie alle in k on s eque nte. Der Katholizismus ist überbaupt die Zusammenbiegung zahlreichster heterogener Kräfte (s. Harnack, Mission S. 225), wie das wohl derartige umfassende Machtgebilde immer sein werden. So kann auch das Urteil Harnacks -Mönchtums S. 46, der in den asketischen Erweckungsbewegungen seit Clugny das Bewußtsein zum Ausdruck kommen läßt, daß es innerhalb der Kirche nur e in Lebensideal und e in e Sittlichkeit geben könne, daß zu dieser darum alle mündigen Christen, d. h. die Geistlichen verpflichtet seien\&, nur mit starken Einschränkungen gelten. Beispiele der gleichzeitigen Hochschätzung der weltlichen Sittlichkeit bei Hauck IV, $98 \mathrm{f}$. 
sich trägt. Es ist nicht logisch durchgearbeitet und, wie bereits betont, nicht systematisch begründet, sondern aus den verschiedensten Motiven und Widersprüchen zusammengeflossen und enthält darum in sich selbst sehr verschiedene Möglichkeiten.

Jedenfalls ist das, wie Harnack sehr schön gezeigt hat, bei der abendländischen Askese der Eall. Augustin, der Freund der Askese und Herold der mystischen Kontemplation, hat doch in immer wieder zitierten Anweisungen das Irdische im Interesse des Himmlischen zu nützen befohlen; sein Platonismus sah im Irdischen, soweit es nicht der Erbsünde unterlag, das Himmlische durchscheinen, und dieser Gedanke ist bis zum Platonismus der Renaissance stets neu gewendet worden. Gregor d. Gr. hat mit derberer Art die mönchischen Verdienste geschätzt, aber damit auch das System der Ergänzungen und Stellvertretungen verbunden, das so ungemein praktisch verwertbar war. Die BenediktinerRegel hat Handarbeit und wissenschaftliche Tätigkeit vorgeschrieben. Karl d. Gr. hat, wie bereits erwähnt, das Mönchtum absichtlich beschränkt und namentlich für Schul- und Bildungszwecke nutzbar gemacht. Die Askese des Frühmittelalters ist dann zunächst wesentlich eschatologisch-eudämonistisch begründet als Büßung und Verdienst für eigene oder fremde Sünde und entlastet und ergänzt damit im Grunde doch nur das Gewissen des weltlichen Standes. Die großen internationalen Erweckungsbewegungen und Ordenskongregationen vom IO. Jahrhundert ab bringen freilich eine außerordentliche Gefühlsvertiefung und Verinnerlichung, deren Helden und Vorbilder Bernhard und die Viktoriner sind. Platonisierende Kontemplation und passionierte Christusliebe, aus augustinischen Anregungen wieder auferweckt und mit einer ergreifenden Glut und Zartheit erfüllt, bereichern das ganze religiöse Gefühlsleben und heben seine Temperatur. Aber es ist dies doch wesentlich Belebung des religiösen Gedankens überhaupt und fühlt sich im Dienst der Kirche wie der Brüder. Die Kontemplation muß durch Carität ergänzt werden, und die Gottesliebe liebt in Gott zugleich das eigene Selbst und alles Hohe und Große in der Welt. Die franziskanische Mystik vollends ist zwar einerseits die höchste Steigerung der Askese, aber sie will doch dadurch der inneren Mission, dem Volk und den Massei dienen und ist andrerseits verbunden mit einer eigentümlichen religiösen. Naturverherrlichung und einem gefühlsmäßigen Individualismus. So konnte daran die individualisierende Kunst der Vor-Renaissance anknüpfen. Dantes 
Weltgedicht schließlich, das den Dichter als Mystiker und als Bewunderer des Mönchtums zeigt, vereinigt damit trotz aller tiefen inneren Spannungen wie selbstverständlich die humanistisch-antikisierenden Motive der Weltbewunderung und die Schätzung der innerweitlich-politischen Leistungen. Soweit aber die asketischen Erweckungsbewegungen in die Bahn des wirklichen Dualismus und Asketismus gerieten, spalteten sie sich von der Kirche ab als Häresie, deren Wurzeln von der katharischen bis zur franziskanischen Häresie ja gleichfalls in der Reaktion gegen die Verweltlichung der Kirche lagen. Die Askese ist also, wie hier nur in aller Kürze gesagt werden kann, auch für sich selbst nicht bloß Mortifikation und dualistische Kontemplation, sondern positive Arbeit für das Ganze, Mittel im Dienste des Corpus Christianum, und in der Entfesselung des religiösen Gefühls zugleich eine gefühlsmäßige, künstlerische Weltverklärung. Solche Askese hat die Bildung einer Einheitskultur nicht verhindert und nicht verhindern wollen, und, wo sie sie durchbrochen hat, da hat sie sie nur für sich selbst und den Einzelfall, aber nicht für das Ganze durchbrochen. Ja die zahlreichen Schöpfungen eines Halbmönchtums bedeuten, daß die Askese selbst Vermittlungen und Ausgleichungen sucht und eben damit sich selber nur für relativ notwendig erklart. Ihre großen Bewegungen machen das Schiff flott, aber sie bemannen es nicht ${ }^{110}$ ).

6. Relative Annäherung der tatsächlichen sozialen Lebensformen an das kirchliche Ideal.

Freilich ist das Zusammengehen solcher Askese und des von ihr belebten Ideals der Gottes- und Nächstenliebe mit dem

110) Vgl. Harnack, sMönchtum\&, DG. III die Abschnitte zur Geschichte der Frömmigkeit 296-306 u. 364-49I, Vossler, Dante I, 80-99; Karl Müller, KG. I, 745-480, über die eschatologische und eudämonistische Motivierung der Askese als Verdienst und Büßung im ganzen Frühmittelalter s. Uhlhorn, Liebestätigkeit II, 122, 158, Böhmer, Staat und Kirche S. 38; Hauck, KG. II, 246; III, 346, Karl d. G. und das Mönchtum II, 566, III, 342; der schärfere Geist der romanischen Askese I V, $320 \mathrm{ff}$. Für die bernhardinische Epoche ist man heute noch an Neander -Der h. Bernhard und sein Zeitalter ${ }^{2}, 1848$ und Liebner, sHugo v. St. Vii-ic: 1832 angewiesen. Kommt man von der üblichen Meinung über die sAskese des Mittelalters her, so staunt man, wie wenig asketisch und eigentlich mönchisch sich diese Leute geben; es ist überall wesentlich Seelenpflege, Erbauung, Menschenund Selbsterkenntnis, Belebung der religiösen Stimmung und daneben stark betont die Verpflichtung zur Carität, hinter der der Selbstgenuß der religiösen Beschauung zurücktreten muß und die dem Dienst an der Welt als dem besonderen Berufsdienst 
Weltleben nur möglich, wenn das letztere sich auch seinerseits den evangelischen Idealen weitgehend unterwirft und unterwerfen kann. Das war in der alten Kirche nicht der Fall, und darum brachte es die alte Kirche auch gar nicht zu dem Gedanken einer christlichen Einheitskultur; das ihr gegenüberstehende Weltleben war zu selbständig und gefestigt, vor allem zu kompliziert, zu sehr von Recht und Staat und komplizierter Wirtschaft erfüllt, als daß ihr das möglich und denkbar gewesen wäre. Der Geist der antiken Polis und des bureaukratisierten hellenistischen Staates stand ihr überall im Wege. Wenn das. Mittelalter eine Finheitskultur wenigstens im Ideal geschaffen hat, so muß der Grund dafür nicht bloß in der Gestaltung der Kirche und Askese, sondern auch in dem Weltleben selber gelegen

des Mönchtums sich zuwendet; daneben bleiben die Weltdinge unangefochten, vorausgesetzt, daß sie im wahren religiösen Geiste getan werden; s. Neander 4I, -Die Liebe zu Christus, die sich auf das rein Menschliche in ihm bezieht, betrachtet Bernhard als eine Stufe, auf welcher die Seele sich zu der Liebe Gottes um seiner selbst willen, welche die Liebe zu allem Wahren und Guten in ich schließe, allmählich erhebe.* Das ist der Weg, auf dem eine asketisch gesteigerte Mystik schließlich zur religiösen Weltverklärung und Humanität kommen kann, wie das der hl. Franz am deutlichsten zeigt. Oder Neander 46 nach Bernhard:- Wie die Verherrlichung Gottes das Ziel der ganzen Schöpfung ist, so ist dies das Ziél der religiösen Entwickelung, alles nur zu wollen um Gottes willen. Eine solche Grundstimmung ist eigentliche Vergöttlichung. Doch hienieden kann der Mensch nur in einzelnen Momenten auf dieser Höhe sich erhalten «, d. h. die Vergöttlichung des Weltlichen scheitert auf Erden nur an der Unzulänglichkeit der religiösen Kraft und Durchdringung. S. 50: Die Askese ist ihm Mittel nie Ziels. S. 55: Er ging von dem christlichen Gesichtspunkt aus, daß we gen der verschiedenen $B$ edür fnisse und Standpunkte der Menschen verschiedene Formen und Lebens we is e $n$ in der Kirche sein müßten, ohne daß eine Trennung daraus entstehe, weil die verschiedenen Glieder mit einander verbunden wären durch den Geist der Liebe. Er betrachtet hier die asketischen Lebensweisen (der verschiedenen Kongregationen) nicht als etwas an und für sich Verdienstliches, sondern als Mittel, die verschiedenen Krankheiten der Menschen zu heilen, daher (auch) sie verschieden sein müßten.\& Ueber die Franziskanerbewegung s. Thode, »F. v. A. und die Anfänge der Kunst in Italien \& $^{2}$ r 904 und P. Sabatier, Vie de St. F. ${ }^{4} 894$. Daß die letztere Bewegung in ihrer religiösen Naturmystik und ihrem Individualismus eine das Mittelalter auflösende Seite hat, kann hier außer Betracht bleiben, jedenfalls darf der asketische und kirchliche Gedanke nicht so einfach ignoriert werden wie bei Thode. Sehr nüchtern, wie ich glaube, allzu nüchtern schildert Hauck die Reflexe dieser Bewegungen auf die deutsche Kirche. 
haben, das in seiner neuen Gestalt sich jetzt dem Ganzen leichter einfügte als ehedem. Denn auch jetzt denkt die Kirche nicht an Sozialreform und Sozialpolitik, an eine ihren Ideen entsprechende Gestaltung des Zusammenhangs zwischen dem wirtschaftlich-rechtlichen Unterbau und dem ethisch-geistigen Ueberbau, den sie selber erst im Gegensatz gegen die wirkliche Lage herzustellen hätte. Auch sie, und sie erst recht, ist in dieser Hinsicht von der verwegensten Ideologie erfülltt ${ }^{111}$ ). Wenn das geistliche Weltregiment in Ordnung ist und Glaube und Liebe stark und normgemäß sind, dann versteht sich alles übrige von selbst. $Z$ war hat der karolingische Staat und das frühmittelalterliche Landeskirchentum jenes beides mit einander verschmolzen. Aber sozial gestaltende Ideen hatte dabei doch nur Karl d. Gr., und auch er konnte sie nur haben, weil die tatsächliche Lage der Dinge seinen Staat und die Kirche zu gegenseitiger Ergänzung ineinanderschob, und weil dieselbe Lage eine solche Ineinanderschiebung möglich machte. Weiterhin haben sich beide doch ganz überwiegend bloß durch den $Z$ wang und die Ermöglichung der Umstände miteinander verbunden, und, als die päpstliche Theokratie den Kaisern und Königen die Leitung aus der Hand nahm, da trat sie nur einfach in deren Erbe ein. All das vollzieht sich ohne stärkere Reflexion und ohne tiefere Eingriffe in das Leben. Wenn Kirche und Weltleben nun zusammengehen, so ist es nicht ein Werk bewußter Sozialreform der Kirche, sondern ein rein faktisches Ergebnis der Umstände. Der eigentliche und letzte Grund für die Möglichkeit einer inneren Einigung muß daher in den rechtlichen, wirtschaftlichen und sozialen Zuständen der romanischgermanischen Völker selbst gelegen haben, die sich ganz von selbst dem kirchlichen Ethos fügten oder doch ihm entgegenkamen. So sehr der militärisch-feudale Geist des kriegerischen Ehrbegriffes und die Vorherrschaft der brutalen Gewalt, die damit verbundene Fülle von Roheit und Lebensunsicherheit dem christlichen Geiste fremd und feindlich zu sein scheinen, so muß doch in diesen Zuständen andererseits etwas gelegen haben, was die Durchsetzung erleichterte, jedenfalls leichter machte als in der antiken und in der modernen Welt. Sucht man die besondere Eigenart des Mittelalters im Gegensatz zu diesen beiden sich klar zu machen, so wird sich auch der Grund jener leichteren Durchsetzung und damit der Möglichkeit einer relativen christlichen

111) S. Hauck, KG. D. II, 222, doch die Ansätze bei Karl d. G. II, 277 f. 
Einheitskultur ergeben.

In dem sinkenden Römerreich waren trotz aller Erschütterungen die Fortdauer des antiken Staatsgedankens, die Herrschaft eines die Lebensbeziehungen formalisierenden Rechtes und einer die Verwaltung rationalisierenden Bureaukratie und schließlich die erschöpfte, aber in ihren verweltlichenden Wirkungen immer noch empfindliche Geldwirtschaft das Hindernis gewesen, ein Hindernis, das fortdauerte, auch nachdem das alte heidnische Religionswesen vernichtet war. Im vollen Gegensatze hierzu hatte das Mittelalter überhaupt keinen Staat im antiken und modernen Sinne des Wortes. Ihm fehlte bei seiner grundlegenden Naturalwirtschaft das Beamtentum, oder vielmehr seine Beamten wurden mit Grundbesitz entlohnt, was die Folge einer Umwandelung in erbliche Grundbesitzer und der Haftung der Gewalten am Grundbesitz wie eines privaten Rechtes mit sich brachte. Insbesondere die militärische Organisation war bei der Unmöglichkeit, die alten Gesamtaufgebote für längere und entferntere Kriegsführung zu verwenden, an dieses System der Belehnung und der Erteilung von Immunitäten gebunden, wo dann nur die großen Lehnsherren und diese wieder mit einem auf ähnliche Weise von ihnen geschaffenen militärischen Aufgebot in Betracht kamen. Dadurch hob sich die kriegerische und später ritterliche von der bäuerlichen und dann der bürgerlichen Bevölkerung ab, und es entstanden zwei Völker im Staate, zu denen als drittes die Kirche und der Klerus hinzukam, soweit dieser nicht mit seinen Spitzen in die feudale Verfassung einging. Und in der gleichen Richtung wirkten die zahlreichen aus wirtschaftlichen, sozialen und ähnlichen Gründen erfolgenden Vergebungen und Unterordnungen der gewöhnlichen Freien, so daß die alte Volksgemeinschaft der Adeligen und freien Bauern sich in das künstlich verschränkte, vielfach über- und ineinandergeschachtelte, halb anarchistische Lehenswesen verwandelte, dem dann die Königs- und Kaisergewalt, sowie die kirchliche Gewalt als oberste Spitzen und oberste Lehnsherren sich überordnen. Die Kirche beansprucht die Fürsten als ihre Lehnsträger und nimmt das ganze System in ihr hierarchisch abgestuftes Gefüge auf. Andererseits stehen unter diesen bunten Hoheiten dic domanialund hofrechtlich gebundenen Schichten, die aber doch ron der antiken Sklaverei sich weit entfernen und auch ihrerseits lediglich an die Scholle und an die mit ihr zusammenhäingenden, verschiedenartig abgestuften Leistungen gebunden sind, aber mit 
hestïndiy :uestejyerter, persönlicher Freiheit auch ihrerseits das Verhältnir der Unterordnung inmer mehr in ein solches gegenseitiger ldienste und Verpllichtungen, des Vertrags und der Treue sich wandeln schen. Unter solchen Umständen gibt es überhaupt kein Staatsgefühl, keine gemeinsame und glcichartige 13czogenheit auf dic Zentralgewalt, keine alles behcrrschende Souveränetät, kein slcichmäßjiges öffentliches Bürgerrecht, keine abstrakte und formell-rechtliche Bindung: Soweit etwas derartiges vorhanden war, kam es nur der Kirche zu, aber in keiner Weise dem Staate. Nicht Gehorsam, sondern Vertrag, Pietät, Treue, Glaubc, Jauter Gesinnungsclemente beherrschen neben der Gewalt dic Beziehungen, und der Geist der Feudalität dringt auch in das Hörigenverhältnis ein; nicht cinmal das Heer beruht auf abstraktem Recht und Gchorsam, sondern auf gutem Willen und Mannentreuc. Dazu kommt, daß dic so entstehenden Gruppen dann in sich selbst ständisch verbunden sind und sich gliedern in Genossenschaften, die von Genossenschaftsgruppen der Ritter und Adeligen heruntergehen bis zu solchen der freien bauern, der Ilörigen, Hofarbeiter und Handwerker, später der städtischen Gewerbe, die ein eigenes, vom Staate unalgeleitetes kecht besit\%en, ja auch dem entsprechend vielfach cisenes Standessericht ausüben. In diesen Genossenschaften wiederum lebt rin Geist der Solidarität und der persönlichen Verständisums und . Iushilfe. der auch seincrseits trotz aller traditiomalintischen Strenge drenno allem rechtlichen Formalismus ent-

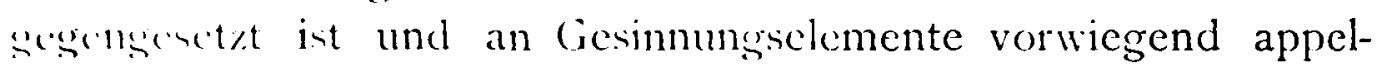
licrt. Hiesem allsemeinen (iciste entspricht dann schliefslich auch dar Recht im en imel stratrecht. In zahlreiche (jerichtshoheiten zersplittert, von ben birision nach brauch und billigkeit gefunden, vielfach ich cincr allem abstraliten Rechtsgrainte völlig entgegengesetzten simbolik hedicnenol, w allem den römischen Besitz- und Eigentum-:oris und das abstralite Handels- und Geldrecht nicht linnend, int es aluch seinerseits der Ausdruck ciner noch nicht rechetich fomalieierten und nivellicrten Gescllschaft. Nur die Kirche hat cin seschriebenes kecht und cinen formellen

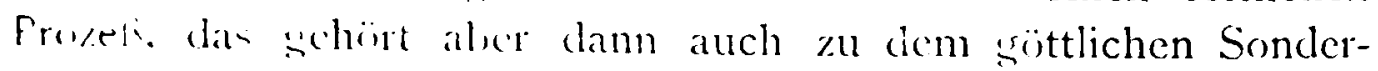
charatere der Kirche und int wen ihren Mafsitaben stark becinHute. Alles das hän:ot zusammen mit der von der Spätantike bereits

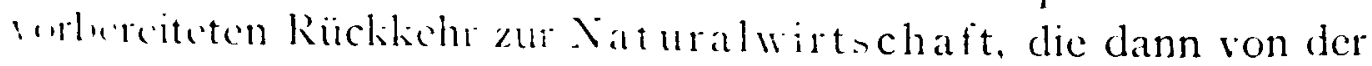


binnenländischen Kultur des Mittelalters vollendet wurde. Es ist eine Rückkehr zu den einfacheren Lebensverhältnissen, in denen sowohl die persönliche Lebensbeziehung als die Reste alter sozialistischer Gemeinsamkeiten vorherrschen. Der Geist der alten Polis ist gebrochen. Von ihm leben nur die stoischen und neuplatonischen Elemente fort in der Hand des priesterlichen Standes, und das sind diejenigen Elemente, in denen er selbst sich bereits zersetzt hatte. Dieser agrarische Charakter aber bedeutet die Kleinheit und Zerstreutheit der Siedelungen, den Ausschluß der Freizügigkeit, da jedes Land seinen Herrn und jeder Herr sein Land, schließlich auch jeder Arbeiter und Handwerker seine Scholle haben mußte; wer die verlor, war deklassiert. Das aber bedeutet wiederum eine starke Konzentration alles Lebens auf persünliche Bezichungen, Solidarität und Gemeinsamkeit der Lebensführung, einen weitgehenden Kommunismus gegenseitiger Aushilfe und Angewiesenheit, wo jede Ortsgruppe schließlich zu einer Art Gemeinwirtschaft mit gegenseitiger Beschützung und gegenscitigen Diensten zusammengeht. Es fehlt die Mobilisierung des Lebens und der Intelligenz, die Unabhängigkeit von der unmittelbaren Naturgabe, das Vertrauen zu einem soziale Vorhältnisse regelnden und schaffenden Rationalismus. Alles erscheint als Gabe der Natur, als selbstverständliche Lebensform und damit als gö̈ttliche ()rdnung, als gute Gabe oder als Strafe und Gericht. Wer l'ilger, der Reisende, der Vagabund ist auf Liebestätiglecit und Hospiz angewiesen, die s geradezu als die Ergänzung der normalen () reinungen durch dic besonderen Liebeserwcisungen erscheinen. L'nd auch noch lange, nachdem die Städte aufgekommen waren und die der agrarischen I lïrish it sich entziehenclen Massen an sich gezogen hatten, herrichte doch auch noch in ihnen nach Mörlichkeit patriarchalische $L^{\prime}$ eber- und Lnterordnung, Genossenschaft und Vertrag, d. h. die rom antilien und modernen Recht so verschiedene vertracs- und I'ictätosesinnung. In scharfem Enterschied ron der antiken, das Asiarwesen auflösenden und alles an sich zichenden stadt, war die mittelalterliche Gewerbestadt noch auf lange hinaus cine halb atrarische und die dort ausgebildeten lebensformen nur modlificicrende Schöpfung. Von der besonderen Bedeutungs, dic hicrbei aie Stadt für das ethisch-relinizi.. Icleal gewann, wird noch zu reden scin. Vor allem aber fehlten die seistiuen un ? e thi

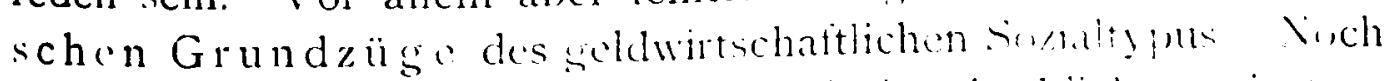
gab es keine nennensworte (ieldwirtschate sic hide wenistens 
im Norden bis in die städtische Periode hinein sehr begrenzt und war in der Zeit der Bildung der kathol. Sozialideale nur eine peripherische Ergänzung der Natural- und Eigenwirtschaft. Damit fehlt aber auch der der Geldwirtschaft entsprechende geistige und moralische Typus, der auch da, wo die Geldwirtschaft noch nicht mit dem unbegrrenzt kalkulierenden Kapitalismus, dem Erwerb um des Erwerbes willen, zusammenfällt, doch bereits seine charakteristischen Linien in das geistige Leben einträgt. Er macht in seiner Konsequenz alle Werte abstrakt, vertauschbar und meßbar, mobilisiert den Besitz und gruppiert in ungeahnter, den natürlichen Lebensabhängigkciten überlegener Weise die wirtschaftlichen Werte und die daraus entspringenden Möglichkeiten. Er entpersönlicht die Werte, macht das Eigentum abstrakt, individualistisch, schafft ein rationalistisches Handels- und Besitzrecht, erhebt den Menschen über die naturgegebenen Lebensbedingungen, knüpft sein Schicksal an Voraussicht, Intelligenz und Berechnung, ersetzt die Vorsehung und die solidarische Aushilfe gegenseitiger Verbundenheit und Treuc durch jederzeit dienstbereite, und verwertbare, auf Vorrat angchäufte Produkte, erzeugt große Besitz- und Bedürfnisunterschicde, führt vom einfachen Konsumtionsstandpunkte zu dem der künstliche Werte und Bedingungen schaffenden Produktion. Er setzt das formelle abstrakte Recht, das abstrakte, entpersönlichende Denken, den Rationalismus und Relativismus in Bewegung. Damit führt er eine unruhige und wechselnde soziale 1)ifferenzicrung herbei, die nicht auf der Festigkeit des Bodens, sondern auf den zufälligren Ansammlungen der alles in alles verwandeln könnenden Geldmittel beruht. Es lösen sich die persönlichen Abhängigkeiten von der Natur und den sozialen Gruppen, das Individuum gewinnt an abstrakter Freiheit und Besonderung und verfällt andererscits unbekannten Abhängigkeiten, die es als Mächte des überlegenen Menschenverstandes und als Inbegriff lockender Möglichkeiten empfindet. Der Einzelne kompensiert den Virlust des konkreten Indiviciualismus, d. h. der unendlich differenzierten und durch ständisch-genossenschaftliche Verbinclungen gesicherten Sonderart, durch den abstrakten Individualismus d. h. durch dic Geltendmachung der individuellen Kräfte an sich, aus denen er Verbindungen, Gemeinschaften, Ordnungen, lntemehmungen erst rationell aufbaut und denen er die Verhältnisic rationell dienstbar macht. Alles das ist infolge der nach den kicuzzügen sich hebenden und mit dem städtischen 
Gewerbe sich verbindenden Geldwirtschaft eingetreten, aber nur langsam, Stück für Stück. Dem Zeitalter der Bildung der idealen kirchlichen Soziallehren fehlt dieser Geist und Typus noch ganz. Mit dünner Bevölkerung und großer Sterblichkeit, mit den primitivsten Verkehrsmitteln und in größter Unsicherheit die neu gerodeten Gebiete bewohnend lebt diese Gesellschaft in sinnreich gegliederter Eigenwirtschaft, in unmittelbarer Naturabhängigkeit, in Verbindungen, in deren Stiftung sich die rohe, ganz naturalistisch empfundene Gewalt und die innerlich gesinnungsmäßige Pietät und Treue teilen. Wissenschaft und Literatur gehört den kleinsten Kreisen an. Das populäre Denken ist beherrscht von Phantasie und Symbolik. Das Einheitsbedürfnis im Leben und Denken ist äußerst gering und im Großen befriedigt durch den Gedanken der Einheit der Kirche und der Christenheit sowie durch das christliche Weltbild mit Schöpfung und Weltende und seinem Mittelpunkt in der Gnadenanstalt der Kirche. Und alles das ist zusammengehalten im Geistlichen wie im Weltlichen durch Gewohnheit und Selbstverständlichkeit, durch Pietät und Glaube, Vertrag und Treue, durch allerhand Reste des Gemeinbesitzes und durch eine gegenseitige Aushilfe, die bei mangelndem Verkehr und bei der Abwesenheit einer geldwirtschaftlich vertriebenen Gütermenge die naturgemäße Voraussetzung für die Existenz der einzelnen Gemeinschaftskreise ist ${ }^{112}$ ).

112) Auf eine derartige Kombination hingewiesen wurde ich durch Beobachtungen an der Schrift eines japanischen Christen (Utschimura, *Wie ich Christ wurde", Stuttgart, Gundert), die zeigt, wie die christliche Moral dem in japanischen feudal-naturalwirtschaftlichen Verhältnissen Aufgewachsenen gar keine besonderen Schwierigkeiten macht und mit der konfutsianischen als verwandt empfunden wird und nur die Motivation durch die Gottesliebe und die Christusidee eine Steigerung der ethischen Kräfte liefert. Derselbe Japaner wird am Christentum fast irre, als er es in Amerika und Europa kennen lernt, wo alle Lebensbedingungen das reine Gegenteil des Christentums bedeuten und er es nur in kleinen Kreisen ausnahmsweise betătigt findet. Aehnliche Beobachtungen läßt Lafcadio Hearn in $\star$ Kokoro einen bekehrten Japaner machen. - Uebrigens ist das Zusammentreffen der christlichen Moral mit dem ständischen Wesen des Mittelalters als Zusammentreffen zusammengehöriger, aber doch rein tatsächlich sich findender und erst hinterher in der Theorie als verbunden fostzuhaltender Größen von keinem Geringeren anerkannt als von F. J. Stahl, -Der christliche Staat \&; S. 5: $\gg$ Das ist endlich vielleicht eine göttliche Einwirkung welche in vorherbestimmter $\mathrm{Harmonie}$ bei den christlichen, namentlich den germanischen Völkern, die Grundgliederung, die kein Volk sich selbst gibt, in der Uranlage und in der Reife zu einer äußeren Darstellung und Abspiegelung innerer christlicher Verhăltnisse gestaltet. Aber das, wie es teils nïher, 


\section{$24^{\text {r. }}$ II. Mutclalteil. Kathulizismus. 6. Soziale Lebensformen des M.A.}

I)icer : : in\% wriale Aufbau init seinen überall überschbaren persinlirhen liexiehungen, seinen Zusammenschichtungen in Ständen und Korporationen, eciner Betonung der gegebenen Machtrerhältnisse und ihrer Nutzung für gegenseitigen Dienst, mit seiner Freigrebun:s des Individuums in seiner festgesetzten Sphäre und siner Nhwesenheit des abstrakten Rechtsformalismus, mit seinen seschlewenen Kreisen und unendlich abgestuften Solidaritätsgefühllen. mit scinen wenig differenzierten materiellen Bedürfnissen, wo dic worken Besitzdifferenzen im Grunde doch nur die verschicdene Grös: des in einer Wirtschaft zu versorgenden Kreises bedeuten und Nacht und Ansehen auf dem Besitz von Land und Ieuten beruht, mit seiner Rechnung auf Vertrag, Treue und Pietït, mit sciner Verpersönlichung auch des Hörigkeitsverhältnisses: alles das bedeutet einen verhältnismäßßig günstigen Boden

teils unferuter zul christlichen Religion, teils notwendig durch ihren Geist geboten und leil, frei, aber von ihm durchdrungen, teils mehr naturw üchsi:' und teils Werk sittlicher Tat ist, - alles das zusammen als untrennbare. linheit int es, wa, den Sitant bestimmend, ihn zu einem christlichen macht.

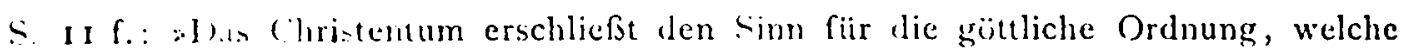
dic Verchindenheit des Berufes im sozialen I,eben eingerichtet und jedem seine eigenc Wejle verlielen, und len Nenschen anweint, in diescm abgegrenzten Kreise

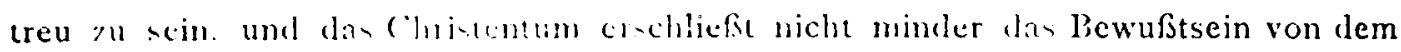

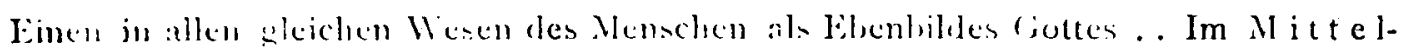

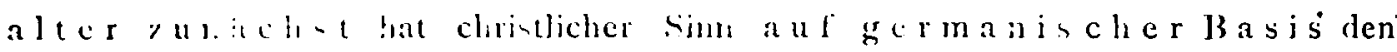

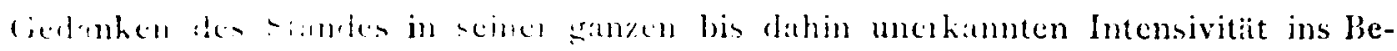

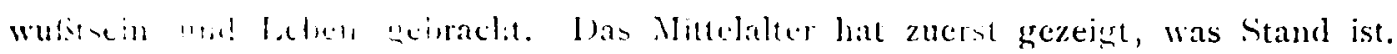

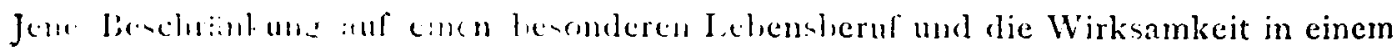

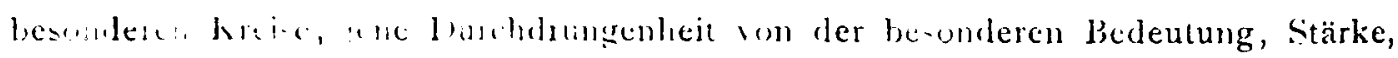

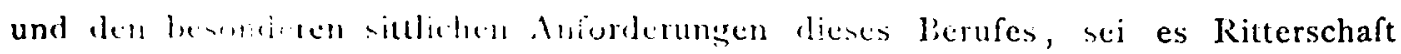

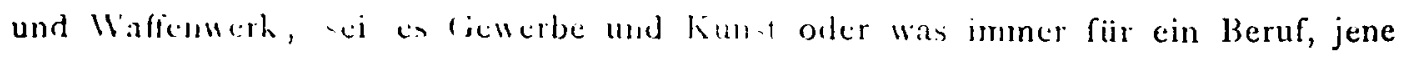

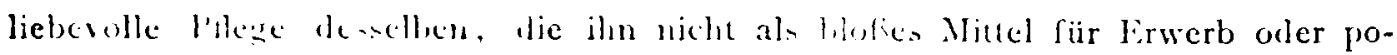

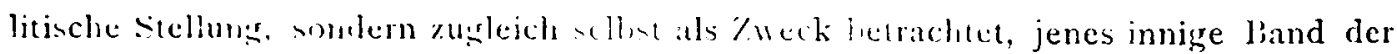

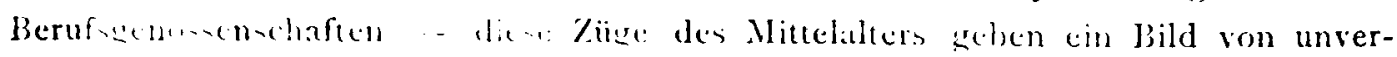

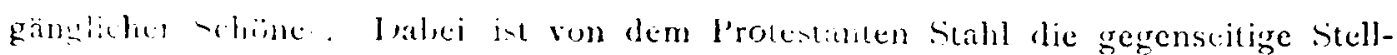

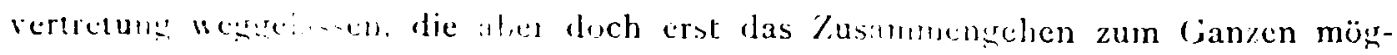
lich m.chl, und in we sache zu sehr im Sime der lutherischen Berufidec gefärll. - - Si, ln die inteusive ('hristianisierung, die nach Lhlhorn, Liebestätig-

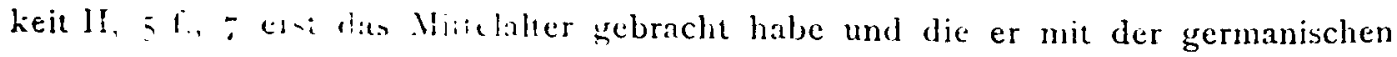
Gumbicicfe crkbirt, dult neben diesen unzweifelhaften (iemütsanlagen noch durch

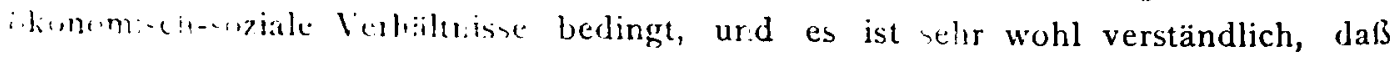

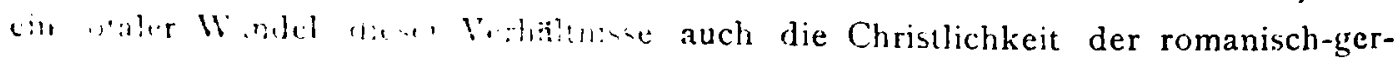

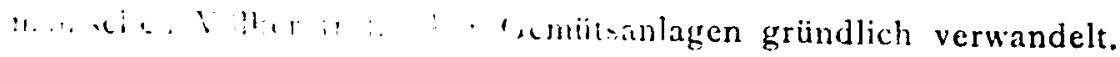


für die Verwirklichung der ethischen Ideale des Christentums, wic sie unter der Leitung der Kirche sich gestaltet hatten. lis gab, indem auch bis zur Entstehung der immer noch lans: kirchlich gebundenen Laienliteratur und -Kunst die Kunst und dic Wissenschaft der Kirche unmittelbar angehörten, keine innerweltlichen Kulturwerte, die ein eigenes göttliches Recht gegen dic Kirche und ihre Ideale hätten empfinden und beanspruchen können. Es gab nur die Souveränetät der Kirche, aber keine solche des Staates, der wirtschaftlichen Produktion, der Wissenschaft, der Kunst. Der überweltliche Lebenswert des Evangeliums mochte auf Weltsinn, Genußsucht, Roheit und Gewalttat stoßen; auf konkurrierende ideale Güter, auf eine von der Kirche unabhängige sclbständige, Eigenrecht und Eigenkraft in sich besitzende Ordnung der weltlichen Kultur stieß sie nicht. Nit einem so wenig reich entwickelten Kulturleben, das überdies stets von den kaum gebändigten Trieben der Leidenschaft und Wildheit überall durchbrochen wurde, war der Sünden- und Vergänglichkeitspessimismus des Mittclalters wohl vereinbar, der die Folie der Alleinherrschaft des relisiösen Lebenswertes bildete und mit allen Mitteln der Phantasic verstärkt wurde. Da war die Welt wirklich nicht viel mehr als - Material der Pflicht «. Und auch die Fassung der Pflichten selbst, die Innerlichkeit einer auf abstraktes Recht verzichtenden, auf (icsinnung, persönliche Lebensbeziehung und Beeinflussung gehenden Moral, der ganze ideale christliche Anarchismus der Gesinnungsmoral, sowie die christliche Licbesidee mit ihren segenseitigen persönlichen Diensten und ihrer Bekämpfung des Nammons, hatte einen verhältnismäßig günstigen Boden. Vor allem auch dic Eigentums- und Besitzverhältnisse waren dieser Moral günstig. Wie die Kirche selbst eine große kommunistische Anstalt cler Solidarität und Versorgung aller war, so war das jeder kileine Kreis in sich selber durch gegenseitige Liebe und Treue und gegenseitige Erweisung des Dienstes; und nur den Deklassierten, den Kranken und Abnormen brauchte die kirchliche Liebestätigkeit, vor allem die der Orden, vorwiegend zu dienen. I)eren Vorhandensein aber war wiederum normal und wünschenswert, da sie Gelegenheit und Stoff zur Liebestätigkeit gaben; weit entfernt davon, durch rationelle Sozialpolitik verhindert und beseitigt $\mathrm{zu}$ werden bildeten vielmehr auch sie einen normalen christlichen „Stand $\%$, der für das Ganze notwendig war. Jedenfalls läßt sich in Theorie und Ideal die Sache so ansehen, und so ist zu 
begreifen, daß auch das Weltleben neben dem asketischen Leben als den christlichen Maßstäben unterliegend und unterliegen könnend betrachtet wurde, wenn auch freilich im asketischen Leben dic Bedingungen immer noch sicherer und günstiger waren. Aber es ist doch eben nur ein Gradunterschied, der die Einheit der Kultur nicht hindert ${ }^{113}$ ).

Freilich hing nach einer andern Seite hin gerade dieser soziale Aufbau mit dem feudal-kriegerischen Geiste und mit dem feudalen Ehrenprinzip zusammen, widersprach hier also der christlichen Lehre vom Verzicht auf die Gewalt und der christlichen Demut, vor allem der christlichen Liebesidee. Und hier lag auch in der Tat cin tiefer innerer Gegensatz gegen die universale religiöse Menschheitsmoral. Nach dieser Seite hin erwies sie sich auch jetzt als nur in begrenztem Kreise durchführbar, und hier behielt das Kloster den Charakter der Lebensverhältnisse, in denen allein die christliche Nloral ohne Kompromiß durchführbar ist. Die Angriffe auf die Verweltlichung der Kirche, die Versuche, die

113) Hier muß ich mich begnügen, auf die von mir konsultierte, im übrigen ja sehr bekannte Literatur zu verweisen : Bücher, Entstehung der Volkswirtschaft ${ }^{4}$, 1904 ; Gierke, Genossenschaftsrecht I, Schmoller, Grundriß der allgemeinen Volkswirtschaftslehre; Waitz, Deutsche Verfassungsgeschichte; Jellinek, Recht des modernen Staates ${ }^{2}, 1905$, S. 309-316; v. Inama-Sternegg, Deutsche Wirtschaftsgeschichte; Lamprecht, Agrargeschichte (im Mittelalter) im HWB. der Staatsivissenschaften²; Brunner, Quellen und Geschichte des deutschen Rechtes in Encykl. der Rechtswissensch. ${ }^{6}$ hrg. v. Kohler; Lamprecht, „Deutsche Geschichte I-IV; Rambaud, „Civilisation française a; vor allem aber Simmel, Die Philosophie des (jeldes ${ }^{2}$ 1908, wo das marxistische Problem der Bedingtheit des geistigen Lebens durch das ükonomische in einer äußerst geistreichen und lehrreichen Form behandelt ist ohne alle materialistischen Voraussetzungen. Was Kautsky, Gesch. des Sozialismus I, I S. 35-39, ausführt, ist unglaublich dürftig und karrikiert; richtig ist nur sein Hinweis darauf, wie die Ethik der Kirche mit der Naturalwirtschaft allerdings zusammenhängt. Die zur politischen Anstalt gewordene Liebesanstalt der Kirche habe ihr Liebesprinzip immerhin in Gestalt eines gewissen naturalwirtschaftlichen Kommunismus und in der Mitteilung des L'eberschusses betätigt, den die Naturalwirtschaft ja gar nicht anders verwenden kann, so lange sie nicht für Markt und Kunden, sondern nur zum Selbstgebrauch produziert - Bezüglich der Geldwirtschaft im Mittelalter ist hinzuzufügen, daß Geldwirtschaft noch nicht ohne weiteres Kapitalismus bedeutet; für Strafen, Kriegszüge und Regierung war Geld unentbehrlich und vorhanden; als Berechnungsmittel wurde es fiktiv gebraucht. Aus dem Vorhardensein solcher Geldelemente, das nicht zu bestreiten ist, ergeben sich aber noch nicht die oben geschilderten Folgen kapitalistischen Geldgebrauches. 
Geistlichen der Kollegiatkirchen der Chorherrenregel zu unterwerfen und die immer neuen Anläufe der Askese wandten sich gerade gegen die Einbeziehung der kirchlichen Würdenträger selbst in das feudale System. Allein einerseits war diese Unterlage der Roheit und Gewalttat wie des weltlichen Ehrbegriffs der Gegensatz, von dem die kirchliche Moral stets sich abhob und ihre Antriebe zu energischer Geltendmachung empfing, der sie verhinderte, zur Sentimentalität oder Heuchelei zu werden. Andererseits aber unternahm die Kirche es, gerade diesen feudalen Geist in ihrem Sinne zu moralisieren, indem sie das Rittertum zu einer halb geistlichen Würde machte, seine Waffenfähigkeit für ideale Zwecke, den Schutz von Witwen, Waisen und Bedrängten weihte, den Ehrbegriff zu einer Verpflichtung gegen Gott und Menschen, zur Mannentreue gegen Christus und die Heiligen, den Frauenkult zum Dienst für die Gottesmutter machte, und damit das Kriegswesen und die Gewalt wenigstens durch die Lenkung auf christ-

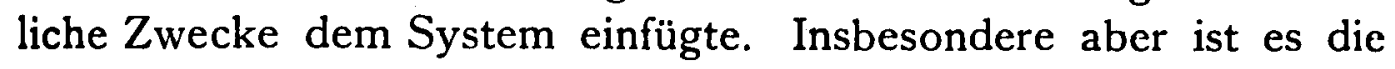
Bedeutung der von der Kirche organisierten Kreuzzüge, das militärische Element und mit ihm alle sozialen Schwierigkeiten und Spannungen der feudalen Welt auf christliche Aufgaben abzulenken, welchem $Z$ weck die Kreuzzüge nach außen ebenso dienten, wie die nach innen. Die Liebesmoral konnte die Ergänzung durch die kriegerische Moral nicht entbehren, hat sie aber möglichst in den Dienst der Liebe und des Glaubens gestellt. Wenn hierbei sich trotzdem eine stark weltliche ritterlich-höfische Laienkultur ergab, so wurde diese dann von der bürgerlich-städtischen wieder abgelöst oder stark eingeschränkt, und mit Hilfe der dem Volk zugewendeten Bettelorden dann diese bürgerliche Kultur ähnlich wie bisher das Rittertum, nur mit viel durchgreifenderem Erfolg und viel größerer historischer Wirkung, in religiöse Lebensformen und Abzweckungen gelenkt, sodaß jene ritterliche Kultur eine wirkliche Durchbrechung der kirchlichen nicht bedeutete ${ }^{114}$ ).

114) Ueber die Christianisierung des Rittertums, das in der Stauferzeit aus dem unmittelbar der Krone sich ergebenden Dienstadel oder den Ministerialen, den hauptsächlichen militärischen Kräften, und aus der Verschmelzung dieses niederen Dienstadels mit dem älteren Grundadel hervorgeht und seine Hauptcharakterzüge von Frankreich aus empfängt s. Rambaud, Civ. franc. I, I79f.; über die ritterliche Laienkultur und deren weltlichen Geist s. Lamprecht D. G. III; über die volle Weltlichkeit der provençalisch-ritterlichen Kultur und die Verwandelung seiner Poesie beim Uebergang in den Bürgerstand, wo die Minne wieder ethisch 
Hier ist nun der Ort, der ethisch-geistigen Bedeutung der mittelalterlichen Stadt zu gedenken. Die aus der Begebung der alten Volksfreiheit, der militärischen (Jrganisation und den politischen Bedürfnissen des Königtums erwachsende Grundherrschaft hat mit ihren starken sozialen Differenzen, ihrem Fehdewesen, ihrer Gewalttat den christlichen Ansprüchen nie voll entsprochen, so vielfach ihre I.ebensordnungen dem auch entgegenkommen mochten. Erst als die aus dem Zerfall und Ueberschuß der Grundherrschaft entstehende Stadt ihre bunte aus allen denkbaren Verhältnissen herausgezogene Bewohnerschaft vereinigte, war der Boden geschaffen, auf dem die großen Vorzüge der mittelalterlichen Gesellschaft von den Roheiten und Gewalttätigkeiten des Feudalismus gereinigt werden konnten. Die Lebensbedingung der Stadt als wesentlich gewerblicher Vereinigung ist der Friede, die Freiheit und die Beteiligung des Eigeninteresses aller Bürger am städtischen Leben, die ungestörte Arbeit und die Begründung des Besitzes auf persönliche Leistung und Arbeit. Nach all diesen Seiten hin' entsprach die Stadt in hohem Maße den Forderungen der christlichen Ethik. Als unmilitärische friedliche Arbeitsgemeinschaft, die das militärische Element nur zur Verteidigung bedarf, und noch frei von den kapitalistischen und großstädtischen Zügen ist sie das Musterbild der christlichen Gesellschaft, wie wir das bei dem $h$. Thomas finden und näher zu erläutern haben werden. Wenn unter politischem und wirtschaftsgeschichtlichem Gesichtspunkt die mit dem zwölften Jahrhundert einsetzende Periode städtischer Kultur auch als Vorbereitung und Grundlegung der modernen Welt erscheint, so ist sie doch zunächst für die Geschichte der Ethik und des religiösen Lebens mit ihren großen Domen und ihrem intensiven kirchlichen Leben, mit ihren

und religiös spiritualisiert und geradezu in den Dienst religiöser Allegorie gestellt wird und franziskanische Mystik eindringt (von hier aus auch Dantes Beatrice zu verstehen) s. Vossler, Dante I, 486--50I und Die Philosophischen Grundlagen zum süßen neuen Stil I904; das zugleich ein charakteristisches Zeichen für den Unterschied des Feudalismus und der Stadt. Immerhin ist die ritterliche Kultur derjenige Punkt der mittelalterlichen Christlichkeit, wo der prinzipwidrige Kompromiß mit einer fremden geistigen und ethischen Macht in der Tat deutlich vorliegt. An solchen Kompromissen hat es natürlich nie gefehlt, wie denn keine religiöse Ethik ohne solche auskommen wird. Aber es ist wichtig einzusehen, daß diese Kompromisse nicht in der Anerkennung von Staat, Familie und Wirtschaft als solcher liegen, wie von Eicken meint, sondern in der Anerkennung der feudal-militärischen Ehrenmoral und der Spirltualisierung der höfischen Liebesformen. 
religiös geweihten Gilden und Zünften, ihrer sozialpolitischen Fürsorge für geistliches und weltliches Wohl, ihren christlichen Pfarrschulen und Liebesanstalten, ihrem Frieden und ihrem Gemeingeist der Höhepunkt der lintwiekelung des mittelalterlichen Geistes. Es bleiben zunächst die Grundzüge des agrarisch-naturalwirtschaftlichen Gesellschaftscharakters mit alledem, was der kirchlichen Ethik entgegenkam, und es fehlen die dort verbleibenden Hemmnisse in den großen Besitzdifferenzen und der militaristischen Feudalität. Im Unterschied von der den Grundadel zusammensiedelnden antiken Polis, die militärische und Handelspolitik treibt und die Bürger sämtlich auf der Grundlage der Sklavenarbeit zu großen oder kleinen Rentnern und Staatspensionären erzicht, ist die mittelalterliche Binnen- und Gewerbestadt eine Gemeinschaft der Arbeit, des Iriedens, des gleichwertigen und bescheidenen Besitzes, der durchgehenden Solidarität, lauter Grundzüge, die dem christlichen lithos einen günstigen Boden gewähren, jedenfalls einen unendlich viel günstigeren als die antike . Polis. Zugleich erzeugte aber doch auch dic Stadt erst dic Intensität und Beweglichkeit des geistigen Lebens, ohne die eine starke Intfaltung der christlichen Ideenwelt nicht müglich ist, und um deren willen das Christentum von Anfang an städtischen Charakters grewesen ist. Aber die mittelalterliche Gewerbestadt hing doch mit den Bcdingungen des einfacheren agrarischen I.cbens noch so eng zusammen und war als Stadt der freien Arbeit und Genossenschaft vom Geiste der antiken Polis so weit entfernt, daß in ihr zunächst jedenfalls die stärkstc Verbindung der christlichen Idee und des Weltlebens stattfinden konnte. In ihrer weitcren Entwickelung hat freilich gerade sic diese Verbindung wieder gesprengt, vor allem in den italienischen Städten ${ }^{114 a}$ ).

Alles in allem ist es also zunächst ein rein tatsächliches Zusammentreffen, das in den mittelalterlichen sozialen, ökonomischen und politischen Zuständen eine verhältnismä̈ßiss durch-

14a, Auf dienc bedeutung der Stadt macht mich Max Weber aufmeiksam. Im übrigen vgl. hicran Iamprecht, DF; III, Bücher, lintstehung der Volkswirtschaft, Schmoller, Cirundriß $254-276$, vor allem den großen Artikel von Max Weber Agralucelichte (Altertum) llWb. ler Staatswissenschaften ${ }^{3}$, wo man eine hüchst crlcuchencle Larstellung des Lnterschiedes der antiken und mittelalterlichen stadt findet. - Arnold, Recht und Wirtschaft in geschichticher Ansicht sos, meint $\therefore 8_{3}$ : Ille stidle waren anfangs nichts weiter als die kïnstlichen Treilhänser der Kirche. Laß aler auch hier schwere Klassenk:impfe niche :ushlieben, daribe s. Kantsky, Surialismu, $\therefore$ 40-103. 
gehende unmittelbare Christianisierung der Kultur möglich machte. Aber es blieb natürlich nicht aus, daß sich auf dieses tatsächliche Zusammentreffen auch die Reflexion warf, die verbundenen Elemente auch theoretisch mit einander vermittelte und aus ihnen ideale Regeln des Sein-sollenden abstrahierte. Erst damit ergibt. sich eine innerliche Begründung und Einheit des Ganzen, und diese Gedankenwelt ist der dauernde Untergrund der katholischen Soziallehren. Sie erfordert daher eine besondere Betrachtung. Mit ihr gelangen wir zum Thomismus. Seine Lehren waren bereits bisher bei den einzelnen Fragen der mittelalterlichen Dogmen und der Askese wesentlich in Betracht gezogen worden. Nun handelt es sich um den prinzipiellen Aufriß der Einheitskultur in der Lehre des großen Heiligen, durch den er der Normaltheologe des Katholizismus geworden ist.

7. Die theoretische Durchleuchtung der kirchlichen Einheitskultur in der thomistischen Ethik.

Die theoretische Begründung und Konstruktion der kirchlichen Einheitskultur ist das Werk der theologischen E thik. Sie fällt mit der mächtig entfalteten, wesentlich romanischen Theologie und Kirchenphilosophie des Hochmittelalters zusammen, und, wie diese überhaupt die Aufgabe der Vermittelung, Vereinheitlichung und Systematisierung sich stellte, so strebte vor allem auch die Ethik ihrerseits darnach, natürliche und übernatürliche Moral, natürliches und göttliches Gesetz, natürliche Kräfte des freien Willens und übernatürliche Kräfte der Gnade mit einander zu vermitteln. Indem hierbei Politik, Oekonomik, Soziallehre unter der Herrschaft der Ethik bleiben, wie in der Antike, bekundet diese Ethik, daß ihr die selbständige Entwickelung aller dieser Lebensgebiete und Wissenschaften aus eigenen inneren Notwendigkeiten und psychologischen Grundanlagen theoretisch und praktisch noch unbekannt ist. Das ist nicht etwa eine theoretische Unvollkommenheit, vielmehr ist es die ganz außerordentlich viel geringere praktische Entwickelung, die diese Dinge im Unterschiede von der modernen Welt erst erreicht haben, und die sich nun darin spiegelt, daß sie lediglich von der Ethik nach rein ideellen Maßstäben beurteilt werden. Eine praktisch höher entwickelte Gesellschaft und Wirtschaft hätte von der Ethik sich auch so einfach nicht bewältigen lassen.

So liegt also alles an dem Vermittelungscharakter, und es 
ist nur selbstverständlich, daß sich diese Vermittelung zunächst mit Hilfe der schon von der alten Kirche ausgebildeten Gleichung des stoischen Naturgesetzes und des mosaischchristlichen Offenbarungsgesetzes sowie mit Hilfe der gleichfalls dort schon nach dem Vorbild der Stoa ausgebildeten Unterscheidung eines absoluten und eines relativen $\mathrm{Na}$ turrechts vollzog. Von der Doppelwirkung dieser Gleichung, einerseits den Staat als etwas Göttliches zu betrachten, andererseits ihn als Erzeugnis der Sünde aufzufassen, war im Frühmittelalter im Zusammenhang mit dem germanischen Landeskirchentum und der karolingischen christlichen Staatsidee mehr die erste Seite betont worden. Das christianisierte germanische Königtum hatte sich nicht als Erzeugnis der Sünde gefühlt, wenngleich das Ideal des absoluten Naturrechtes, die Gleichheit und der Kommunismus, für den Urstand immer festgehalten worden war. In den gregorianischen Kämpfen war dann die andere Seite des christlichen Naturrechts $z u$ ihrer Geltung gekommen, die Auffassung des Staates als Erzeugnis der Sünde und als eines Mittels gegen die Sünde, das eben um deswillen unter die Leitung der kirchlichen Gewalt und Idee gestellt, von ihr entsündigt, geweiht und regiert werden muß, wenn es den Makel seines sündigen Ursprungs verlieren soll; indem gleichzeitig die römisch-absolutistische Fassung der Staatsgewalt abhanden gekommen war und die germanische Idee der Bindung des Wahlkönigs an seine Gerechtigkeitspflichten herrschte, war es möglich gewesen, aus dieser Idee die Folgerung der Absetzung ungerechter Könige, der Einsetzung und Leitung der Könige durch den Papst zu ziehen ${ }^{115}$ ). War aber nun die Einheitlichkeit einer kirchlich geleiteten respublica christiana derartig hergestellt, so mußte sich jetzt die Aufgabe ergeben, nicht bloß äußerlich juristisch-diplomatisch die Eingliederung des Staates und der Gesellschaft in die Kirche zu erwirken, sondern diese Ein-

${ }^{115}$ ) Vgl. R. W. u. A. J. Carlyle, Hist. of medieval theory. I Part IV The political theory of the ninth centurye. Reuter in seiner , Gesch. d. Aufklärung im Mittelalter hebt mit feinstem Spürsinn überall die Elemente naturrechtlichen Denkens heraus, behandelt sie aber leider unter dem völlig schiefen Gesichtspunkt der >Aufklärung a. In Wahrheit aber ist hier von einer Aufklärung, d. h. von der Abschüttelung des Historischen und des Wunders nur bei radikalen averroistischen Sekten die Rede. Abälard ist bei Reuter völlig verzeichnet. Reuter begreift eben wie viele Theologen nicht, daß das Christentum ohne Rekurs auf allgemeine Notwendigkeiten sich geistig nicht hätte behaupten können und daß es ohne Aufnahme 
gliederung auch begrifflich und dialektisch zu begründen und damit cine einheitliche christliche lithik zu schaffen. Das führte zugleich mit der Entwicklung der Dogmatik und Metaphysik, die von dem arabisch-jüdischen Aristotelismus in neue Probleme hineingezogen wurden, die Häresie zu bekämpfen hatten und der kirchlichen Einheitskultur auch die kirchliche Wissenschaft zur Verfügung stellen mußten, zu einer neuen Belebung und Ausarbeitung der altchristlich-stoischen Sozialphilosophie und Ethik. W'ie bereits die alte Kirche das rein positive Wunder der Kirche durch den Platonismus und Stoizismus auf allgemeine, innerlich notwendige Gesetze des Geistes zurückgeführt hatte und damit das Christentum sowohl intensiv $z u$ einer allgemeingültigen Größe erweitert als es auch extensiv auf die dem Evangelium fernliegenden Gebiete des sozialen I cebens ausgeweitet hatte, so werden diese Mittel eincr Lniversalisierung des Christentums jetzt von neuem aufgeboten und neubelebt. Die Kirche ist das Prinzip des Universalismus und greift nach allem, was ihr die Darlegung des Christentums als univcrsaler Wahrheit und universaler, auf alle Verhältnisse anwendbarer Ethik möglich macht. Das Grundereignis der alten Kirche, die Verschmelzung des Positiv-Historisch-Christlichen mit den allgemeinen geistigen Notwendigkeiten und Gesetzen des Platonismus und Stoizismus, schlägt daher jetzt in neue Triebe aus; und auch die mit ihm eröffnete Grundtendenz, das Gesamtleben der religiösen Idee einzugliedern, kommt nun zu einem Erfolge, zu dem die alte Kirche bei ihrem bloßen Dulden des Naturrechts und seiner Bildungen nicht hatte kommen können. Sie erntet dabei in erster Linic die Ergebnisse der veränderten allgemcinen Verhältnisse, entwickelt aber doch in der Kombination von Augustin, Gregor d. G., Dionysius Areopagita, Aristoteles und den jüdischen und arabischen Philosophen zugleich völlig neue Gedanken, die über die alte Gleichung weit hinausgehen.

insbesondere der stoischen Sozialphilosophie dem sozialen Leben einfach hilflos gegenübergestanden hätte. Mit dem neuen Testament allein sind überhaupt keine Soziallehren zu erzeugen. Und was in Stoa und Christentum zusammenkommt, das sind doch nicht fremde, sondern wahlverwandte und aus gemeinsamer Situation erwachsene Elemente. Es ist nicht eine Anleihe bei einem röllig fremden >antiken « Denken, wie mit sehr unzulässiger Generalisierung der »Antike" auch viele Nichttheologen die Sache auffassen. Im übrigen aber ist Reuters Buch höchst lehrreich als Zeugnis der massenhaften Fortdauer antiken Stoffes im Mittelalter. 
Hier handelt es sich um Erläuterung des Sachverhalts an der thomistischen Ethik ${ }^{116}$ ). Dic Prinzipien dieser Ethik liegen wie die der Erkenntnis in der Metaphysik, was sich für eine solche rein religiöse Denkweise von selbst versteht und von Stoizismus und Platonismus ganz ebenso anerkannt ist; auch die jetzt rezipierte aristotelische Lchre nimmt an diesen Bestimmungen der idealistischreligiösen Spekulation trotz all ihres Empirismus Anteil und fügt der metaphysischen Ethik der Vernunft insbesondere die Beziehung bei, daß es sich in allen Vernunftgesetzen um die stufenweise Verwirklichung des die einzelnen Wirklichkeitssphären beherrschenden Vernunftzweckes handelt. So licgt nach Ausweis aller Instanzen das Prinzip der Ethik zunächst im ewigen göttlichen Welt- und $\mathrm{Na}$ turgesetz der Vernunft, das den ganzen Kosmos durchwaltet und in den verschiedenen Wirklichkeitsreichen deren besonderen Vernunftzweck auf die ihnen jeweils angemessene Weise verwirklicht, in jedem niederen Reiche das nächstfolgende höhere Reich vorbereitet; im Reiche des menschlichen Lebens wird es zu dem Vernunftgesetz der Freiheit, das die Sinnlichkeit, die Affekte und Passionen auf den Vernunftzweck hin zu regulieren hat. Der ethische Dualismus, den die Stoa in ihren späteren Systemen bereits aus dem Gegensatz des Naturgesetzes gegen die Affekte entwickelt hatte, ist hier scharf formuliert; zugleich ist er aber doch in der Weise des Aristoteles vermittelt, indem die Emporentwickelung der Vernunft

${ }^{116)}$ Ueber die beherrschende Rolle des Naturgesetzes bei Abälard und im Decretum Gratiani s. Luthardt, Gesch. d. chr. Ethik I 270 und 249. Wenn L. hier hinzufügt das war die Konsequenz jener altkirchlichen Beseitigung des Prinzipats des Glaubens für die Ethik und der Parallelisierung von Glauben und Werken*, so vergißt der Lutheraner hier, daß Luther und der Altprotestantismus die gleichen Begriffe aus denselben Gründen wie die alte Kirche und das Mittelalter aufs ausgiebigste verwertet hat. - Zu Thomas vgl. die sog. Summa contra gentiles und die große dreiteilige Summa theologica die in der pars secunda die Ethik enthält; außerdem die breit exzerpierende Darstellung bei Werner >Der h. Thomas von Aquino II 1859. Rieters Die Moral des h. Thomas ist mir leider nicht zugänglich gewesen. Unentbehrlich zum Verständnis des Thomismus ist Renans bekanntes Buch Averroès et l'Averroisme ${ }_{1} S_{52}$. Im übrigen vgl. die mehrfach genannten Geschichten des Dogmas und der christlichen Ethik, sowie Froschhammer, Th. v. A. und Jourdain, La philosophie de St. Thomas und Janet, Histoire de la philosophie morale. Aus der Summa kommen besonders in Betracht die Traktate de fine hominis, de virtutibus, de legibus, de justitia et jure; außerdem die durch das Ganze zerstreuten Materialien der Lehre vom Urstand, von der Sünde 
aus den natürlichen Trieben und Affekten oder die den Seelenstoff regulierende und auf den Vernunftzweck durch Maß und Ordnung beziehende Einsicht das Naturgegebene des Seelenlebens verarbeitet und zum Stoff der Sittlichkeit macht. Von Seite des Menschen aus gesehen stellt sich dieser Auftrieb zum Vernunftzweck dar als Tugend, von Gott aus gesehen stellt er sich dar als das der Natur erteilte Vernunftgesetz, das auch als Freiheit die Wirkung des Gottesgesetzes im Menschen ist; so sind die aristotelische Tugend- und $Z$ wecklehre und die stoische Lehre von Natur- und Vernunftgesetz verbunden und verschmolzen. Auch dem christlichen Gedanken der Gnade, die sich in der Form der Freiheit verwirklicht, ist damit präludiert; es ist doch stets nur das Gottesgesetz der Vernunft und damit Gott, der in der Freiheit wirkt. Im Urzustande herrschte dieses Naturgesetz in vollkommener Klarheit, und wenn auch bei seiner Fortdauer

und dem Gegensatz des Sünden- und Gnadenstandes. Des weiteren sind hier bereits zu nennen an Arbeiten, die der Sozialphilosophie des h. Thomas gewidmet sind: J. Baumann, >Die Staatslehre des h. Th.\& 1873, eine Sammlung von Uebersetzungen und Exzerpten aus den betreffenden Schriften des Th., aber ohne Rücksicht auf den eigentlich entscheidenden Zusammenhang mit den theologischen Grundlehren und daher sehr unvollständig, zugleich mit einer ungebührlichen Betonung des Kommentars zur Politik des Aristoteles, welcher Kommentar nach Thömes eben nicht die Ansichten des Thomas, sondern die des Aristoteles wiedergibt, den Thomas in Unterschied von sonstiger Gewohnheit mittelalterlichen Kommentierens von seiner eigenen Meinung unterscheidet, zugleich mit Verkennung des Umstandes, daß der zweite Teil dieses Kommentars nicht von Thomas selbst stammt, sodaß die Partien von S. 107-166 gestrichen werden müssen (s. Thömes 25-36); ferner Feugueray, Essai sur les doctrines politiques de St. Th., 1857, sehr lehrreich und verständig, nur gleichfalls die Aristoteleskommentare überschätzend, die theologischen Lehren, bes. die Urstandslehre, nicht in ihrer vollen Bedeutung erk ennend, und von der irrtümlichen Idee erfüllt, als gebe es eine den großen Prinzipien von 1789 entsprechende christliche Politik der égalité et fraternité deren Spuren es bei Thomas und den alten Kirchenvätern aufzudecken gelte; der ganze christliche Positivismus und Patriarchalismus in sozialen Dingen, wie er mit dem Gottesbegriff und der Lehre vom Sündenfall zusammenhängt, ist hi山r unterschätzt; schließlich N. Thömes, Commentatio literaria et critica de S. Thomae Operibus ad ecclesiasticum, politicum, socialem statum reirepublicae Christianae pertinentibus, deque ejus doctrinae fundamentis atque praeceptis, Berliner Dissertation von 1874, wo der Gesamizusammenhang der Gedanken und die Lage der Quellenkritik wie die wichtigsten Fundstellen kurz aber gut verzeichnet sind. Für die monographische Einzelarbeit ist hier noch sehr viel zu tun. 
die natürliche Ungleichheit der Menschen sich geltend gemacht und allerhand Ueber- und Unterordnungsverhältnisse mit sich gebracht hätte, so hätte es doch keine rechtliche Gewaltherrschaft, sondern nur Freiwilligkeit und keinen privaten Sonderbesitz, sondern den Gemeinbesitz der Liebe entwickelt; auch die Geschlechtlichkeit des Menschen hätte ohne libido rein im Dienst des Vernunftzweckes als Komplettierung der Menschheit zu der gottgewollten Zahl bestanden. Das Gebären wäre ohne Schmerzen gewesen und die patriarchalische Männerherrschaft hätte nicht die Familie beherrscht; die Arbeit wäre ohne Härte und Sorge und die Erde ohne Leiden und Tod gewesen ${ }^{117}$ ). Indem der

117) Siehe Summa I a 2 ae qu. 90 Principium exterius (neben dem inneren der Tugend) movens nos ad bonum est Deus qui et nos instruit per Legem (et juvat per gratiam). Das führt dann auf die Grundfragen: utrum lex sit aliquid rationis und de fine legis. Unter dem ersten Titel wird die ganze metaphysisch-rationale Gesetzeslehre entwickelt: qu. 91 a. I : Legem autem a Deo exire praesupponit (ut patet) legem ipsam in Deo esse. Das allgemeine Weltgesetz geht auf den Weltzweck qu. 90 a. 2 : oportet, quod lex maxime respiciat ordinem, qui est in beatitudine. Dies allgemeine Weltgesetz durchdringt alle Kreatur und gipfelt sich im Menschen zum bewußten Freiheitsgesetz empor qu. 9 I a. 3 : Etiam animalia irrationalia participant rationem aeternam suo modo, sicut et rationalis creatura; sed quia rationalis creatura participat eam intellectualiter et rationaliter, ideo participatio legis aeternae in creatura rationali proprie lex vocatur... in creatura autem irrationali non participatur rationaliter unde non potest dici lex nisi per similitudinem ... Inter cetera rationalis creatura excellentiori quodam modo divinae providentiae subjacet, in quantum et ipsa fit providentiae particeps sibi ipsi et aliis providens. Unde et in ipsa participatur ratio aeterna, per quam habet naturalem inclinationem iui debitum actum et finem. Et talis participatio legis aeternae in rationali creatura lex naturalis dicitur. Unde patet quod lex naturalis nihil aliud est, quam participatio legis aeternae in rationali creatura. Aus diesem Anteil an der göttlichen Gesetzesvernunft geht das menschliche Rechtsgesetz hervor wie das menschliche Denken aus den aus Gott ausstrahlenden logischen Grundbegriffen q:? 91 a. 3 : ita etiam ex praeceptis legis naturalis quasi ex quibusdam principiis communibus et indemonstrabilibus est quod ratio humana procedat ad aliqua magis particulariter disponenda. Et istae particulares dispositiones adinventae secundum rationem humanam dicuntur leges humanae. Siehe dann besonders die große Darstellung in qu. 93-97, wo das ganze Naturrecht aus der lex aeterna abgeleitet und narh seinem Gehalt bestimmt wird. Für diese Lehren gibt Thomas als Gew ̈̈hrsmunner neben Cicero und Aristoteles die uns schon von früher bekannten allkirchlichen Autoren, besonders natürlich Isidorus und Augustin, von dessen cicernnianischer Definition des Staates als aliquis rationalis cuetus auch er ausgeht: Im Ubrigen aber ist die Voraussetzung, daß die Bibel die gleiche Lehre ausführlic', I roe lt:ch, Gesammelte Schriften. I. 
Mensch durch die Sünde aus diesem Urstand fiel, blieb ihm ein wichtiger Rest dieser praktischen Vernunft oder die Kenntnis des Naturgesetzes in den Grundprinzipien. Aber einmal wurde diese Erkenntnis immer mehr verdunkelt, sodaß die Anwendung des Naturgesetzes, die Entwickelung der Folgerungen aus ihm, sein Ausbau zum positiven, Zeit und Umständen Rechnung tragenden und daher variierenden positiv-menschlichen Gesetz ihm immer schwieriger und eine göttliche Neuoffenbarung des Naturgesetzes um so wünschenswerter wurde, je mehr die Menschen diesen Mangel empfinden lernten und in dieser Empfindung auf eine solche Neuoffenbarung vorbereitet wurden. Andrerseits nahm unter den Bedingungen des Sündenstandes das Naturgesetz die neue Form als poena et remedium peccati an, indem die Einrichtung der rechtlichen Gewaltherrschaft, des Privateigentums, der Sklaverei, die Verbindung des Geschlechtslebens mit den Leidenschaften der Begierde und das strenge patriarchalische Familienrecht einesteils als demütigende, den Sündenfall in Erinnerung bringende Strafen sich darstellen, andererseits das bonum naturae, den Vernunftzweck der gemeinsamen Glückseligkeit, in den jetzt noch allein möglichen und förderlichen, die Sünde disziplinierenden Ordnungen aufrecht erhalten ${ }^{118}$ ). Immerhin aber ist in all diesen

und ausdrücklich enthält. Hier kehren besonders stets die berühmten Paulusstellen Röm. 2, 15 wieder; aber auch alle alttestamentlichen Stellen vom ewigen göttlichen Gesetz und die altestamentlichen politischen Beispiele spielen eine entscheidende Rolle. Der maturrechtliche Rationalismus erscheint durchaus als biblische Lehre, was natïrlich eine instinktive Konformierung des Naturrechts und des Aristuteles mit den alttestamentlichen sozialen und politischen Verhältnissen zur liolge hat.

11x, Indem die L'rstandslehre durch den Einfluß der Augustinischen Gnadenlehre neugestaltet wird und die antike Lehre rom vollkonmenen Menschheitsantin: oder goldenen Zeitalter nun in christlichen Dogma zur Lehre von ciner doppelten Vollkommenheit, einer Vollkommenheit der Vernunft und des bonum naturace in deren komnaturalen Grenzen (imago Dei) sowie einer Vollkonsmenlicit der ïbermatürlich erteilten, die Natur exzedierenden Gnadenmitteilung oder substantiellen Gottesvereinigung (similitudo Dei oder donum superadditum) sich culitert, wird das eigentliche Wesen des Sündenfalls nicht mehr der Vulust des sabsoluten Naturrechtsa, sondern der durch Schuld bewible Verlust der mystischen Gnadenvollkommenheit. Dieser die Erbsünde begriindende und enthaltende Ver!ust hat damn erst indirelit die Zerstörung auch der naturalis perlectio oder des bonum naturae zur Folge und mit ihm dann auch erst die ncllen Bedingungen des sündenstands für die verbleibenden principia practica 
Ordnungen ein außerordentlich starker Gehalt des Naturgesetzes, beruht ihre verpflichtende Kraft auf diesem Gehalt, lassen sie sich immerdar aus ihm wieder regulieren und auf ihr vernunftnotwendiges Maß zurückführen. Das ist umsomehr der Fall, seit die Neuoffenbarung des Naturgesetzes im Dekalog das Verständnis des Naturgesetzes neu belebt und die Vernunft über ihre Urprinzipien . wieder aufgehellt hat. So entsteht trotz aller Erbsündenlehre der Eindruck einer sehr starken Rationalität oder mindestens Rationalisierbarkeit aller weltlichen, sozialen Ordnungen, und vor allem der Findruck, daß in beidem die Göttlichkeit und Christlichkeit dieser Ordnungen klar zu Tage liegt. So werden sie tatsächlich

legis naturae. Sie treten unter die Bedingung erschwerter äußerlicher Lebensverhältnisse, einer durch die Erbsünde bewirkten Trübung auch der natürlichen Vernunft und Einsicht, einer Entzweiung von Vernunft und Passionen auch auf dem Gebiet des Naturrechts, die in dem durch Schuldbewußtsein von der Erbsünde her veränderten und durch das Donum supperadditum nicht mehr übernatürlich regulierten und garantierten, sondern den natürlichen Fährlichkeiten des Wechsels und der Leidenschaft überlassenen Menschenwesen unausbleiblich ist. Werner II $535 \mathrm{f}$. Daher tritt jetzt viel stärker der Verlust des Gnadenwunders und die daraus abgeleitete indirekte Folgerung für die Trübung der Vernunft hervor, während in der alten Kirche der direkte Gegensatz des absoluten mit der christlichen Ethik identischen Naturrechtes gegen die sündige Trübung des Gesetzes und die Unkraft der Erfüllung vorherrschte. Man findet daher bei Thomas auch die Lehre vom relativen Naturrecht als remedium et poena peccati nicht so prinzipiell durchgebildet wie in der alten Kirche. Auch trägt die Anlehnung as die entwicklungsgeschichtliche Konstruktion dis Aristoteles, die im Unterschied von der Stoa keine absolute Anfangsvollkommenheit kennt, sondern die Vernunft sich stufenweise gegen die Unklarheiten der Sinnlichkeit und der Passionen durchsetzen und dabei Staat, Familie und Gesellschaft erzeugen läßt, unverkennbar dazu bei, die lex naturalis humana als ein natürliches Entwicklungsprodukt, nicht als bloße Modifikation des vollkommenen absoluten Naturrechtes erscheinen za lassen. Immerhin aber finden sich doch die alten stoisch-christlichen Grundanschauungen als selbstverständliche Voraussetzung an allen Orten, wie das bei der Beibehaltung des Gedankens der libertas und communis possessio im Urstande und bei der ganzen Idee eines vollkommenen Urzustandes auch nach der Seite der Vernunft und der vernünftigen Sozialordnung selbstverständlich ist. Prinzipiell erörtert ist das Problem unter dem Titel: Utrum lex naturae mutari possit? I a 2 ae qu. 94 a. 5 : Isidorus dicit in lib. 5. Etymologiarum, quod communis omnium possessio et una libertas est de jure naturali. Sed haec videmus esse mutata per leges humanas. Ergo videtur, quod lex naturalis sit mutabilis. Sed contra est, quod dicitur in Decretis dest. 5 s naturale jus ab exordio rationalis creaturae coepit, nec variatur tempore sed immutabile permanets. Respondeo: dicendum, quod lex naturalis potest intelligi mutari duplicitur. Uno 
durch diese Rationalisierung auch überall möglichst auf die Grundideen eines christlichen Patriarchalismus gestimmt, wie später im einzelnen zu zeigen ist. Die Annahme der ersten und die $\mathrm{Zu}$ versicht zur zweiten ist viel stärker als in den äußerlich gleichlautenden Theorien des kirchlichen Altertums. Es handelte sich ja eben auch in Wirklichkeit überall um Sozialbildungen, die bei ihrer Unentwickeltheit und ihren besonderen Eigentümlichkeiten mit dem kirchlichen Ethos leichter vereinbar waren als die des späten Altertums. Dieses engere und zugleich nicht bloß theoretische, sondern unmittelbar praktische Zusammenrücken des Naturgesetzes mit dem christlichen Ideal äußert sich theoretisch vor allem darin,

modo per hoc, quod aliquid ei addatur. So erklären sich Zusätze sowohl im alttestamentlichen Sittengesetz als in der menschlichen Gesetzgebung. Alio modo potest intelligi mutatio legis naturalis per modum subtractionis, ut scilicet aliquid desinat esse de lege naturali, quod prius fuit secundum legem patura lem. Et sic quantum ad prima principia legis naturae, lex naturae est omnino immutabilis; quantum autem ad secunda praecepta, quae diximus esse quasi quasdam conclusiones propinquas primis principiis, sic lex naturalis non mutatur, quin ut in pluribus sit rectum, quod lex naturalis habet. potest tamen mutari in aliquo particulari et in paucioribus propter aliquas speciales causas impedientes observantiam talium praeceptorum. Zu diesen Hindernissen gehört in erster Linie der sündige Zustand der entfesselten Selbstsucht und Herrschsucht, der neue Formen des Gesetzes nötig machte und neue Offenbarungen des Naturgesetzes. So erklärt sich auch die Einführung der Todesstrafe aus den neuen Bedingungen der Sündhaftigkeit, nachdem Gott mit der Einführung der Todesstrafe für alle Kreatur vorangegangen war. Vor allem aber: Dicendum, quod aliquid dicitur esse de jure naturali dupliciter Un o modo, quia ad hoc natura inclinat, sicut non esse injuriam alteri faciendam. A lio modo quia natura non inducit contrarium, sicut possemus dicere, quod hominem esse nudum est de jure naturali (Paradiesesnacktheit), quia natura non dedit ei vestitum, sed ars adinvenit (nach dem Sündenfall). Et hoc modo communis omnium possessio et una libertas dicitur esse de jure naturali, quia scilicet distinctio possessionum et servitus non sunt inductae a natura sed per hominum rationem ad utilitatem humanae vitae, et sic etiam in hoc lex naturae non est mutata nisi per additionem. Die utilitas ist die dem Sündenstand angemessene, und jene doppelte Betrachtung der lex naturae und die doppelte Betrachtung des Naturrechts ist die als absolutes und relatives Naturrecht, s. Meyer, Die christlich-ethischen Moralprinzipien und die Arbeiterfrage 1904, S. 36. Immerhin ist deutlich, wie hier die stoisch-altchristliche Devolutionslehre mit der aristotelischen Evolutionslehre sich mischt, und wie gelegentlich die letztere unter dem Linjen Vorbehalt der Verwundung und Trübung der Vernunft das Feld behält. Im iibrigen zum Urzustand und zur Veränderung des absoluten Naturrechts durch dic neuen moralischen und physischen Bedingungen des Daseins s. Werner, D. h. 
daß die Gleichung von Naturgesetz und Dekalog viel prinzipieller und technischer durchgeführt wird. Der Dekalog ist geradczu das logisch durchgeführte Kompendium des Naturgesetzes, die Lehre von den naturgesetzlichen Pflichten gegen Gott und gegen den Nächsten; insbesonders die Pflichten gegen den Nächsten sind dort in logisch richtiger sozialphilosophischer Reihenfolge von der Familie zu den allgemeinen Beziehungen der Gesellschaft fortgeführt. Dabei besteht die verpflichtende Kraft des Dekalogs in seiner Begründung auf die logische Notwendigkeit des Naturgesetzes, während die anderen nicht naturgesetzlichen Gebote des alten Testamentes rein positives Gottesgesetz sind. Diese Heranziehung der naturrechtlichen Ordnungen an die christliche Sittlichkeit wird nun aber noch bedeutsamer, wenn man bedenkt, daß der Dekalog durch die katechetische Tradition vor allem der Beichtvorbereitung allmählich zur Formel des christlichen Sittengesetzes überhaupt wird und von der Theorie geradezu als Keim und Same des neutestamentlichen Sittengesetzes, als von Christus wiederholt und bestätigt und zur Grundlage seiner eigenen Sittengesetzgebung gemacht, angesehen wird ${ }^{110}$ ).

Th. II 503, 457, $536 \mathrm{f}$., $542 \mathrm{f} ., 460$, dazu 1 a 2 ae qu. 98 Dicendum, quod in statu isto (Sündenstand) multiplicatis dominis necesse est fieri divisionem possessionum, quia communitas possessionis est occasio discordiae, ut philosophus dicit in II Polit. Sed in statu innocentiae fuissent voluntates hominum sic ordinatae, quod absque omni periculo discordiae communiter usi fuissent, secundum quod uniciuque eorum competeret, rebus quae eorum dominio subdebantur; cum hic etiam nunc apud multos bonos viros observetur. Das Naturgesetz der libido als strafender Umwandelung des absoluten von der libido freien Naturgesetzes in ein relatives s. I a 2 ae qu. 91. a. 6: Sed inquantum per divinam justitiam homo destituitur originali justitia et vigore $r$ ationis, ipse impetus sensualitatis, qui eum ducit, habet rationem legis, inquantum est poenalis et ex lege divina consequ e $\mathrm{ns}$ hominem destitutum propria dignitate. - Hinzugefügt sei. daßß bei Dante der Saturnhimmel der der Mönche ist und so das saturninische Urzeitalter der Stoa mit der christlichen Ethik verbindet; die berühmte Allegorie vom Kirchenwagen spielt auf dem $>$ Boden des naturrechtlichen Paradieses «, Voßler I 417; in Dantes Monarchia die Lehre vom Staate als poena et remedium peccati, ebd. 388; ganz ebenso das Schema Gersons bei Thömes S. I06 I) Jus cujuslibet creaturae : leges insitae omnibus rebus. 2) Jus creaturae naturalis: lex proprie divina et lex proprie naturalis (als. Naturrecht). 3) Leges hominum viatorum: lex canonica et lex civilis (Kirchenrecht und relatives Naturrecht).

149) Daß der Dekalog die Formel des christlichen Sittengesetzes wurde, wie in unseren heutigen Katechismen, ist nichts weniger als selbstverstandlich. 
So könnten die natürlichen Sozialordnungen geradezu als Ausfluß des christlichen Sittengesetzes und die altkirchliche Spannung zwischen Welt und Ueberwelt, sozialem Leben und Kirche geradezu überwunden scheinen. Indem die tatsächlichen Verhältnisse nach dem Naturgesetz, dem Dekalog und den alttestamentlichen und antiken Vorbildern geleitet werden, fügen sie sich dem biblischen Ideal der Offenbarung ein, soweit nicht die Bedingungen des Sündenstandes schmerzliche aber unabänderliche Einbußen des Ideals veranlassen. Damit ist die Gesellschaft im allgemeinen und im Prinzip christlichen Maßstäben unterworfen, die Offenbarung aus der Vernunft ergänzt. Beide sind im Begriff des mit demDekalog identischen Naturgesetzes vermittelt. Die auf beide aufgebaute Sozialphilosophie ist ohne weiteres christlich. Allein das ist in Wahrheit doch nicht unbedingt der Fall. Daran hindert schon der Umstand, daß der Unterschied $z$ wischen dem absoluten und idealen Naturrecht des

Die alte Kirche kannte nur allerhand schwankende Formulierungen, Tugendund Lasterkataloge, formelhafte Aufzählungen von Gaben des Geistes, überdies die augustinische Formel vom Doppelgebot der Liebe, der Gottesliebe im engeren Sinne und der Bruderliebe in Gott, nach Doctrina christiana. Erst die Ethik der Scholastiker, der Volksprediger und der Beichtvorbereitungen macht den Dekalog populär. S. v. Zezschwitz' Art Katechetik in PRE 2 . Dann aber erhielt damit auch die Gleichung von Naturgesetz und Dekalog eine theoretisch und praktisch weit erhöhte Bedeutung; nun konnte auch die Materie des Dekalogs aus dem Naturgesetz erläutert und erweitert werden. Zum Bestandteil des Katechismus wird der Dekalog erst durch die Reformation, die überhaupt erst den Katechismus schafft. Vorher sind es Beichtbücher für Ungelehrte, speculum ecclesiae und ähnliches, wo Dekalog, Sakramentslehre, oratio dominica und symbolum zusammengestellt sind. - Die Lex divina des Dekalogs und des alten Testaments als auf innerweltliche Vernunftzwecke bezogen wird unterschieden von der nova lex als auf den übernatürlichen Gnadenzweck bezogen und rein an die Gesinnung appellierend Ia 2 ae qu. $9 \mathrm{I}$ art. 5. Doch sind beide nur als lex perfecta und imperfecta unterschieden, dem Entwickelungsalter der Menschheit entsprechend und die erste zur zweiten hinführend, sie im Keim andeutend und enthaltend. Ueber die Gleichung von Dekalog und Naturgesetz s. qu. 98, mit dem Nachweis, daß dieses Gesetz nur accidentiell Tod und Sündenerkenntnis bringen sollte, dagegen wesentlich auf die Gnadeneigießung und die Kirche hin erziehen und vorbereiten sollte. Hier ist der paulinisch-augustinische, nachher von den Reformatoren aufgenommene Dualismus von Gesetz und Evangelium am deutlichsten: zugunsten einer aufsteigenden und die innerweltliche Moral positiv einbefassenden Entwickelung durchbrochen. Qu. 98 a. 5 : Dicendum quod lex vetus manifestabat praecepta legis naturae et super-addebat quaedam propria praecepta (d. h. die jüdischen Zeremonial- und Judinalge- 
Zweite Vermiltelung durch Stufenfolge von d. natürl. Ethik 2. Gnadenethik. 263

Urstandes und dem relativen Naturrecht des Sündenstandes doch nie vergessen wird und alle Gegenwart als ihrem Wesen nach hinter dem Ideal zurückbleibend charakterisiert. Daran hindert aber vor allem die Grundtatsache, daß das eigentliche chiistliche Sittengesetz doch einen ganz anderen sittlichen $Z$ weck voraussetzt als das Naturgesetz, daß es in Wahrheit doch eben nicht in dem Dekalog aufgeht, sondern, den Dekalog als bloßen $>$ Keim und Samen * betrachtend, ihn erst in einer mystischen und spiritualisierenden Deutung durch das eigentliche neutestamentliche Sittengesetz als christlich bezeichnen kann. Die dem Mittelalter eigentümliche Fassung des Christlichen als des Uebernatürlichen oder vielmehr die volle Herausarbeitung der Konsequenzen des Uebernatürlichkeitsgedankens ist das Entscheidende. Dieses Uebernatürliche liegt nicht bloß im Wunder des Gottmenschen, im Wunder der Kirche und der Sakramente, im Wunder der Erlösung aus der erbsündigen Welt. Es hat nicht mehr wesentlich apologetische Bedeutung wie in der alten Kirche. Es entfaltet sich als ein eigenes logisches, religiöses und ethisches Prinzip. Die Kreatur nämlich, auch

setze). Qu. 98 a. 6: Lex vetus disponebat ad salutem quae erat futura per Christum ... statim post peccatum primi hominis non competebat legem veterem dari; tum quia nondum homo recognoscebat se ea indigere de sua ratione confisus, tum quia adhuc dictamen legis naturae nondum erat obtenebratum per consuetudinem peccati. Oportebat hujusmodi auxilium quodam ordine dari, ut per imperfecta ad perfectionem manducerentur. Et ideo inter legem naturae et legem gratiae oportuit legem veterem dari. Ueber den systematischen Charakter des Dekalogs als Inbegriff des Naturgesetzes qu. 100. Der Dekalog beschließt das ganze Naturgesetz virtuell a. 3 : Utraque horum praeceptorum continentur in praeceptis decalogi. Nam illa, quae sunt prima et communia continentur in eis, sicut principia in conclusionibus proximis. illa vero, quae per sapientes cognoscuntur, continentur in eis e converso sicut conclusiones in principiis. Andererseits aber ist der Dekalog aych identisch mit dem christlichen Gesetz und verteilen sich seine zwei Hälften auf die Gottesliebe und Bruderliebe, s. die Abhandlung: ,Expositio in duo praecepta caritatis et in decem legis praecepta. Nicht zu übersehen ist die materielle Wirkung dieser Gleichung, sie färbt durch beständige Einfügung alttestamentlicher Ethik (vgl. auch das Verfahren in de regimine principis) das Naturrecht materiell., und auch die Rezeption der aristotelischen Lehre ist doch dadurch bedingt, daß in ihr die konservativen, antikapitalistischen, auf Măßigkeit und Selbstbeschränkung gerichteten Züge hervorgehoben sind. Es ist doch nirgends reiner Aristotelismus, sondern immer ein biblisch untermischter. Freilich wăre im einzelnen die Ruckwirkung dieser biblisch-christlichen Elemente auf Fassung und Deutung der aristotelischen Ethik erst zu untersuchen, s. Feugueray S. 204, Thömes 10I f. 
die vollkommene, ist bloß natürlich, hat nur natürliche Gesetze und Zwecke. Uebernatürlich ist allein Gott, und das Wesen der christlichen Liebernatürlichkeit ist daher, daß sie die Kreatur über die konnaturalen Grenzen erhöht zu Gottes eigener Lebernatürlichkeit, zur Teilnahme am Wesen Gottes. Die natürliche Religion und Ethik ist Gotteserkenntnis und Befolgung von Gottes Gesetz. Aber die übernatürliche Religion, der übernatürliche $Z$ weck und das übernatürliche Gesetz, kurz die Uebernatur, das ist die von der Gnadenwillkür Gottes verliehene Ueberschreitung der Grenzen der Natur, das gnadenweise geschenkte Schauen Gottes, wie er sich selbst sieht. Die Aufgaben der Vermittelung sind daher nicht mehr wie in der alten Kirche die einer Vermittelung zwischen vollkommenem und relativem Naturrecht, sondern zwischen Naturrecht und Uebernatur überhaupt. Die erstere Aufgabe tritt zurück hinter der zweiten, und insbesondere alle Ethik und Sozialphilosophie beruht in letzter Linie nun auf der Vermittelung von Natur, vollkommener oder unvollkommener Natur, mit der Uebernatur ${ }^{119 a}$ ).

Der Dekalog ist in Wahrheit noch nicht das christliche Sittengesetz, und das mit jenem einige Naturgesetz steht dem eigentlich christlichen Sittengesetz, der nova lex, so nah und so fern, wie eben auch der Dekalog. Es ist Vorstufe und Vorbereitung, und, wenn das Naturgesetz damit biblisch begründet und getragen ist, so ist es um deswillen doch nur indirekt christianisiert. Biblisch ist offenbarungsmäßig, aber nicht ohne weiteres christlich; denn die Bibel stellt für Thomas cinen universalhistorischen Entwickelungsgang mit Stufen dar. Der Dekalog bleibt in der Gesetzgebung Christi erhalten als Vorstufe und Einleitung zur christlichen Sittlichkeit und als Anleitung zur äußeren tusführung ihrer neuen Gesinnungsmotive. Die Formel des eigentlich christlichen Sittengesetzes aber ist die Augustinische Formel von der Gottesliebe als dem absoluten und höchsten, schlechthin einfachen sittlichen $Z$ weck, in welchem $Z_{\text {weck die }}$ Forderung der

:29a) $S$ hierüber sehr charakteristisch Denifle, "Die katholische Kirche und das Ziel der Mlenschheits 1906, mit besonderer Beziehung auf die Gesellschaftslchre, wesentlich auf Thomas beruhend; auch Mausbach: Christentum und Weltnorale rgo5. Gegenüber dem Sündenfall der modernen weltlichen und indivilualistischen Kultur erscheint hier die kirchliche Kultur als eine ganz anderartige, aui . illag fremden Grundbegriffen beruhende Welt. Freilich ist dann auch das, " is für das Y.A. weit und groß war, in dieser Gegensätzlichkeit eng und völlig $\therefore \cdot 1$, remil 
Gottesliebe im engeren und eigentlichen Sinre durch Selbstheiligung, Selbstverleugnung, Kontemplation und die der Nächstenliebe durch gemeinsame Bezogenheit aller auf Gott, gemeinsame Verbundenheit aller in Gott und innigste gegenseitige Aufopferung in Gott enthalten ist. Es ist die Selbstliebe in Gott, die nicht das natürliche, sondern das gottgeeinigte Selbst liebt, und die Bruderliebe in Gott, die nicht den natürlichen Mitmenschen, sondern den Bruder in Gott liebt. Das sind die in der ganzen Scholastik immer wiederkehrenden Formeln. Diese eigentlich christliche Ethik wird nur durch die eingegossenen Kräfte der sakramentalen Gnade möglich, hat ihren eigentlichen Ausdruck in der Ecclesia militans und triumphans, betätigt sich in der höheren Moral der Askese uud Carität, und verleiht einen ihr eigentümlichen himmlischen Lohn, die visio beatifica Dei, womit Gottes Gnade sein eigenes im Menschen vollzogenes Erlösungsund Erhöhungswerk krönt. Diese mystisch gedeutete evangelische Ethik bildet einen unverkennbaren scharfen Gegensatz gegen die innerweltliche Ethik des Naturgesetzes, des Aristoteles, des Dekalogs und der geordneten allgemeinen Wohlfahrt, wie das ja bei der ganzen Grundanlage der christlichen Ethik nicht anders möglich ist und im Leben der mittelalterlichen Gesellschaft in dem Verhältnis von Staat und Kirche, von Laien, Religiosen und Priestern klar zutage lag und auç in der sittlichen Forderung an den einfachsten Laien sich noch geltend machte. Auch wenn die Gottesliebe in gewissem Sinn mit zum Naturgesetz gehört und aus der aristotelischen Betonung der theoretischen Tugenden entwickelt wird, so genügt das doch nicht zum Ausdruck des vollen christlichen Ethos; es leitet nur zu ihm hin, ist aber auch abgesehen von seiner erbsündigen Trübung noch nicht identisch mit der eigentlichen und vollen christlichen Gottesliebe; es ist nur die natürliche Gottesliebe aus eigener $\mathrm{Kraft}$, noch nicht die übernatürliche, durch die Sakramente allein einzugießende Gottesliebe.

Theoretisch kommt das wieder am besten und charakteristischesten zum Ausdruck in der jetzt erst klar durchgebildeten Urstandslehre; sie bildet einen Hauptfortschritt gegenüber der patristischen Theologie. Hier wird grundlegend die skonnaturale. Vollkommenheit des Menschen in den Grenzen seiner vernünftigen Natur unterschieden von einer, die Natur exzedierendenء, schon im Urstand durch reines Griadenwunder, wenn auch ohne priesterliches Sakrament, von Gott unmittelbar ver- 
liehenen, Vollkommenheit. Das absolute Naturgesetz und die vollendete praktische Vernunft hätte nur Vernunftzwecke, nur ein bonum naturae, nur eine natürliche Gottesliebe, nur eine natürliche Menschenliebe, und mit alledem nur einen natürlichen Lohn verwirklichen können. $\mathrm{Zu}$ diesem bloß konnaturalen Naturgesetz kommt nun aber - nach der Meinung mancher durch es vorbereitet -, die übernatürliche Gnadenvollkommenheit einer mystischen Gottesgemeinschaft und mystischen Bruderliebe mit einem übernatürlichen himmlischen Lohn hinzu. Es ist die similitudo Dei, die zur bloßen imago Dei hinzugefügt wird, die Gott der menschlichen Natur nach ihrem Wesen zu verleihen nicht genötigt gewesen wäre, die reine Gnadengabe und -Uebernatur * ist ${ }^{120}$ ). Diese similitudo bildet daher das Hauptinteresse der Urstandslehre; das absolute Naturgesetz, das in der alten Kirche wie in der Stoa die Urstandslehre beherrscht hatte, tritt jetzt dahinter an Wichtigkeit zurück. Der Jammer des Sündenfalles ist daher nicht sowohl der Verlust des absoluten Naturgesetzes und der ihm entsprechenden Lebensformen als der Verlust des mystischen Gnadenwunders, nach dessen Verlust durch eigene Schuld auch die verbleibende Erkenntnis des bloßen

120) Altes und neues Gesetz s. Werner II $57 \mathrm{I}$, die Formulierung des neuen mystischen Sittengesetzes Werner II 583, die ausführliche Darlegung Summa I a 2 ae qu. 106-108; die Analyse des neutestamentlichen Gesetzes im Anschluß an Augustin, und wie dieser statt auf den Dekalog auf das Naturrecht sich berufend qu. 108 art. 3. S. außerdem den Traktat de fine I a 2 ae qu. I-5, den Schlüssel der ganzen Ethik, die mit Augustin vom Zweckbegriffe aus arbeitet und dem neuplatonisch-mystisch-christlichen $Z$ weck der Seligkeit und Gottesschauung den aristotelischen Zweck der Wohlfahrt, Ordnung und Vollentfaltung der geistigen und leiblichen Kräfte und Tätigkeiten eingliedert und unterordnet als einen Mittelzweck, dessen Erreichung für den finis ultimus disponiert und vorbereitet. S. auch Heinrich. -Lehrbuch der kath. Dogmatik S. 269f. S. auch I a 2 ae qu. rog a. 3 : Natura diligit Deum super omnia, prout est principium et finis $n$ at $u$ ralis boni. Caritas autem (d.i. die sakramental gewirkte mystische Tugend der nova lex, die alle anderen mystisch-supranaturalen Tugenden in sich enthält), secundum quod est objectum beatitudinis et secundum quod homo habet quandum s o c i e ta tem spiritualem cum Deo. Addit etiam caritas super naturalem dilectionem Dei promptitudinem quandam et delectationem, sicut habitus quilibet virtutis (d. h. die sakramentale Wundersittlichkeit) addit super actum bonum, qui fit ex sola naturali ratione hominis. Daher hat auch die naturgesetzliche Vernunftsittlichkeit einen natürlichen, die mystische Gnadensittlichkeit einen übernatürlichen Lohn; es gibt eine natürliche Seligkeit des Naturgesetzes und eine tubernatürliche des 
Naturgesetzes zum übernatürlichen Heil gar nichts helfen kann und überdies zur Strafe verdunkelt, durch Schuldbewußtsein unsicher gemacht ist und daher die sinnlichen Naturtriebe und Passionen nicht mehr durch die Vernunft beherrschen kann; es wandelt sich in das relative Naturrecht; aber der Abstand des letzteren gegen das erstere ist bei aller Schmerzlichkeit doch jetzt nicht mehr die entscheidende Tatsache; das Entscheidende liegt jetzt im Verlust jenes Gnadenwunders. Der gleiche Sachverhalt zeigt sich nicht minder klar als bei der Urstandslehre in der Erlösungsl e h re selbst. Die Erlösung muß die Ur- und Erbsünde jenes Verlustes vergeben, muß die mit ihnen eingetretene Verwundung und Verderbung auch der naturgesetzlichen Kräfte des Menschen büßen und heilen. Aber die Hauptsache ist, daß sie durch die Sakramente überdies jenes mystische Gnadenwunder der *Uebernatur * erneuert und in den eingegossenen Tugenden und Habitus wieder jene die Grenzen des Naturgesetzes, der natürlichen Gottesliebe und der natürlichen Seligkeit exzedierende Wundersittlichkeit der Uebernatur verleiht. . In der Erlösung handelt es sich nicht mehr um tunlichste Wiederherstellung des absoluten Naturgesetzes vermittelst der Kirche, sondern um eine mystische Seligkeit und

Gnadengesetzes, Werner II 519. Qu. 114 a. 2 : Vita aeterna est quoddam bonum excedens proportionem naturae creatae, quia etiam excedit cognitionem et desiderium ejus .. Et inde est quod nulla creatura creata est sufficiens principium actus meritorii vitae aeternae (also auch ganz abgesehen von der Sünde, auch vom Standpunkt des absoluten Naturrechts aus), nisi superaddatur aliquod supernaturale donum quod gratia dicitur (und zwar im Urstand sogut wie im Sündenstand, in welch letzterem $z u$ dieser Gratia nur die Heilung und Vergebung der Erbsünde h inzukommt). Ueber den Aufst eg vom einen zum andern Thömes S. 58 : Thomas hujus vitae bona, nec solum illa, quae in eruditione animae sed illa quoque, quae in corporis bona condicione ceterisque rebus exterioribus ponuntur, multum ad beatitudinem simperfectam, quae in hac vita haberi possite valere declaravit, sive ut spraeambula vel praeparatoria\&, sive ut sperficientia s sive ut sadjuvantia extrinsecus sive ut sconcomitantia. Eam ob causam multam artem dialecticam magnumque studium in id/consumpsit, ut rectum et verum hujus vitae bonorum faceret ordinem gradusque recte disponerete. Ebenso Feugueray S. 31, 37, 38. - L'eber die augustinische Deutung der neutestamentlichen Ethik und ihr Verhältnis zu dieser selbst s. die Bemerkung des ersten Stückes S. 328; ich halte die Dentung für zutreffend, wenn man von der Einführung der intellektualistischen und substanziellen Mystik absieht und eben damit den ganzen Uebernatürlichkeitsgedąnken bei Seite laßt. Auch in der Ethik des Evangeliums ist der religiöse Zweck das alles bestimmende und organisserende Zentrum, nur daß die Einigung mit Gott eine 
Liebe, die im Jenseits ihre Vollendung in der Gotteinigkeit und in der Liebeseinigkeit der Geister in Gott findet und dann mit dem Naturgesetz überhaupt nichts mehr zu tun hat, das bei absoluter wie relativer Gestalt doch immer an die sinnlich-körperliche Wirklichkeit und an die natürliche Endlichkeit gebunden bleibt.

Der Gegensatz zwischen Welt und Gottesreich, zu dem das altchristliche Ethos sich folgerichtig verdichtet hatte, ist erhalten geblieben, aber er ist jetzt völlig anders geartet als in der alten Kirche; und wenn es wesentlich Augustins Gedanken sind, die damit zur Auswirkung kommen, so stellt der Gegensatz sich doch in dieser Ausarbeitung immer noch anders dar als bei Augustin. $\mathrm{Er}$ ist nicht mehr der einer mit dem absoluten stoischen $\mathrm{Na}-$ turgesetz einigen kirchlichen Ethik gegen das relative Naturrecht der römischen Gesellschaftsordnung, wobei man teils sich

Einigung des Willens mit dem Gotteswillen im ethischen Gehorsam ist und daß die Bruderliebe die Offenbarung und Wirkung der Gottesgesinnung ist, gerade in ihrer ethischen Leistung und umgekehrt von der ethischen Leistung auch zu 'Gott, zum wahren Gotteswillen und der wahren Gottesgesinnung hinführt. Insoferne halte ich meine Sätze gegen Harnacks Einwendungen, Preuß. Jahrbb. Märzheft 1907, aufrecht. Der Protestantismus bleibt in diesem Punkt an Klarheit hinter der augustinischen Ethik zurück, indem er teils das christliche Sittengesetz in den Dekalog verlegt, teils überhaupt auf jede Formel für dasselbe verzichtet und nur von Auswirkung des Glaubens redete. Eben deshalb stellt sich aber auch für den Katholizismus das Problem der christlichen Ethik, das direkt aus dem religiösen Zweck motivierte Ethos mit dem nicht direkt aus jenem motivierbaren Ethos zu vereinigen. Das Problem hat natürlich auch für den Protestantismus bestanden und wir werden sehen, welche Schwierigkeiten es ihm bereitet hat. Der scholastisch-augustinische Problemansatz selbst ist aber jedenfalls sachgemäß und der Grundtendenz des christlichen Glaubens entsprechend. Vgl. hierzu F. J. Schmidt : , Gottesliebe und Nächstenliebe (Preuß. Jahrbb. 1908 Aprilheft), der zu der Meinungsverschiedenheit zwischen Harnack und mir Stellung nimmt und meiner Auffassung beitritt. Freilich tut er es rein spekulativ-dogmatisch durch Deduktion aus der christlichen Idee. Ich habe meinerseits die Begriffsbestimmung rein empirisch aus dem Evangelium aufgenommen, und erst später bei diesen Studien gesehen, wie nahe verwandt diese Deutung der augustinisch-scholastischen ist, nur freilich immer mit Abzug des mystisch-intellektualistischen und sakramentalen Einschlages. Schmidt bemerkt gar nicht, wie seine Formeln sich fast wörtlich mit denen der Viktoriner, Augustins und des Thomas treffen. Diese. Analysen werden in der protestantischen Literatur leicht unterschätzt und von der nicht-theologischen leicht ignoriert; sie enthalten aber in Wahrheit viel richtiges Gefühl und scharfsinnige Konstruktion. 
n die unabänderliche Ordnung fügt, teils sie innerhalb der Kirche nach Möglichkeit überwindet. Der Gegensatz besteht vielmehr zwischen zwei Zweckstufen, zwischen der mystischen Uebernatur und ihrer jenseitigen Seligkeit einerseits und dem Naturgesetz überhaupt andererseits, wobei der Unterschied zwischen dem absoluten Naturgesetz des Urstands und dem relativen des Sündenstands verhältnismäßig gleichgültig geworden ist; beide stehen als Natur der Uebernatur gegenüber. Der Zweckstufe der innerweltlichen Ethik des Naturgesetzes mit dem Vernunftzwecke der Organisation, Einheit und Wohlfahrt der Menschheit in alien geistigen und materiellen Gütern steht die Zweckstufe der überweltlichen Ethik, des christlichen Sittengesetzes, gegenüber, innerhalb deren alles abzielt auf die sakramental bewirkte Einigung mit der göttlichen Lebenssubstanz und in der göttlichen Lebenssubstanz. Daher steht auch der Dekalog als Inbegriff des Naturgesetzes und als Offenbarung an ein partikulares Volk unter dem Sittengesetz Christi und bedarf für seine Christlichkeit erst der Deutung aus diesem. An Stelle des mehr ethisch-praktischen stoisch-christlichen Gedankens der in Gott freien Persönlichkeit und der ohne Recht und Gewalt human geeinten und sich gegenseitig dienenden Menschheitsgemeinschaft steht die Verbindung des sakramentalen Wundergedankens mit neuplatonischer und christlicher Mystik. Der zu überwindende Gegensatz ist nicht mehr in erster Linie der einer partikular zerteilten, auf Recht und Gewalt und Selbstsucht sich stützenden Gesellschaft gegen das universale Liebesreich der Gotteskindschaft, sondern der Gegensatz zwischen der 'ihr. vernünftiges Gesetz auswirkenden Natur und' dem eigentlich-christlichen Lebensziel des sakramental-mystischen Gnadenwunders, zwischen dem aus der ersten folgenden natürlich-christlichen Gesellschaftssystem des Weltlebens und der aus der letzteren folgenden Gemeinschaft der mystischen Liebe und Seligkeit. Die Vermittelungsaufgabe ist nunmehr eine doppelte: nicht nur absolutes und relatives Naturgesetz, sondern vor allem Natur und Uebernatur sind zu vermitteln.

Die neue Formulierung des Gegensatzes ist umfassender und prinzipieller. So ermöglicht sie auch eine neue und prinzipiellere, damit das Weltleben sicherer anerkennende und zugleich sicherer eingrenzende Lösung. Das ist ja auch durch den Gedanken einer Einheitskultur notwendig gefordert und dient seinerseits wieder diesem Gedanken als Grundlage. Hierin kommt dann auch das 
eigentlich Neue in der Theorie des Mittelalters zum Vorschein, und es ist nur natürlich, daß von diesem Neuen aus auch die Grundlagen der christlichen Ethik sich verschieben; nur ist im Auge zu behalten, daß, wenn diese Verschiebung zu Gunsten einer größeren Anerkennung des Weltlebens stattfindet, darin nicht bloß eine Fortentwickelung der Theorie liegt, sondern die Wirkung der tatsächlichen relativen Christianisierung des Weltlebens sich durchsetzt. Der Aristotelismus, mit Hilfe dessen diese Fortentwickelung stattfand, ist von der Pariser Universität und dann von den Päpsten ausdrücklich verworfen worden, genau wie heute der sog. Modernismus. Wenn er sich schließlich doch durchgesetzt hat, so ist die Ursache davon der Umstand, daß seine Rezeption Probleme des praktischen Lebens und prinzipiellen Denkens löste und doch dem obersten religiösen Grundgedanken sich unterstellen ließ. Die Ueberwindung liegt nämlich nicht mehr bloß in der Anerkennung der weltlichen Ordnungen als der Aeußerungen des relativen Naturrechts, wobei dann ja doch die mit dem absoluten Naturrecht identische Ethik der Kirche kein rechtes innerliches Verhältnis zu ihnen finden konnte. Die Ueberwindung liegt vielmehr in dem Gedanken einer $\mathrm{St} u$ fe $\mathrm{n}$ folg e. Wie der Hauptgegensatz der von Natur und Gnade ist, so ist die Ueberwindung des Gegensatzes die Annahme eines Stufenverhältnisses, das in der Entfaltung der Vernunft von der Natur oder dem Naturgesetz emporführt zur Gnade. Der das ganze System durchdringende aristotelische Entwickelungsgedanke, der überall die Potenzen durch die formende Vernunftkraft gestaltet werden läßt, wird auch auf dieses Verhältnis angewendet. Die Entfaltung des Vernunftriebes oder des Naturgesetzes schafft die Vorbereitungen, an die im Urstand schon das Gnadenwunder der mystischen Sittlichkeit anknüpfen konnte, und sie schafft ebenso im Sündenstand durch die Wirkungen des relativen Naturgesetzes und der relativen Vernunfteinsicht die Dispositionen und Vorbereitungen, auf denen der Ueberbau der Gnadensittlichkeit zugleich mit den Büßungen und Vergebungen für die sündhafte Verderbung der Natur sich aufbauen kann. Absolutes und relatives Naturrecht sind schließlich beide gleicher Weise als Vorstufe und Voraussetzung dem Gnadenwunder untergeordnet, und die zwischen ihnen bestehende Differenz ist verhältnismäßig geringfügig gegenüber der von Natur und Gnade überhaupt. Absolutes und relatives Naturrecht rücken nah zusammen als 
verschiedenen Lagen entsprechender Ausdruck der Vernunft und weihen damit die natürlich-sozialen Bildungen zum Ausdruck der Gottesvernunft. Aber diese Vernunft ihrerseits ist dann untergeordnet als Vorbedingung und Disposition unter die Gnade. Damit wird der aristotelische Entwicklungsgedanke eingetragen in den neuplatonischen Gedanken vom Aufstieg der Seele von den politischen Tugenden $\mathrm{zu}$ den kontemplativ-theoretischen und von diesen zur mystischen Gottesanschauung, welch letztere dann freilich erst durch das Wunder der Gnadensittlichkeit möglich wird. So ist dann der natürlich-soziale und ethische Vernunitunterbau dem Ganzen völlig eingegliedert, gerechtfertigt als Aushuck derselben Gottesvernunft, die. auch im Dekalog sich .ffenbart, und doch zugleich als bloße Vernunft untergeordnet unter die sakramentale kirchliche Wundersphäre mit ihrer höheren Sittlichkeit. Die Vernunftsittlichkeit und die natürlich-soziale Welt ist die Vorstufe der Gnade und mit dieser zusammengefaßt durch den gemeinsamen Ausgang beider aus Gott, durch die von Gott gestiftete kontinuierliche Emporleitung aus der Vernunft und Natur zu der Gnade, wobei die Korruption der Vernunft und des natürlich-sozialen Systems im Sündenstande doch den Vernunftcharakter nicht soweit austilgt, daß er nicht mehr ordnend, disponierend und vorbereitend für die Gnade wirken könnte." Auf diese Weise ist nun die Welt der sozialen Bildungen rationalisiert und christianisiert und zugleich doch dem höheren absoluten Zwecke der mystischen Sittlichkeit als Mittel und Voraussetzung eingegliedert. Die alte, mit Hilfe der Stoa gefundene Ausgleichung dauert fort in der Behandlung und Betrachtung der Sozialgebilde als Ausfluß der mit dem Dekalog identischen Gottesvernunft; aber darüber erhebt sich die neue weitergreifende Ausgleichung, die jene Sozialgebilde als Unterstufe der Gnadensittlichkeit betrachtet. $\mathrm{Zu}$ der mit Hilfe der Stoa gefundenen Ausgleichung kommt die mit Hilfe des Neuplatonismus konstruierte, und den Uebergang von der ersten zur zweiten hilft die aristotelische Lehre von einer aufsteigenden Reihenfolge der Zweckstufen finden, von einer beständigen Ueberbauung der bereits erreichten Stufe, die dann zur Potenz für einen neuen Aktus wird. Die dem Dekalog und dem Naturrecht entsprechende Vernunftethik und Vernunftordnung ist die Potenz, die durch den Aktus der Gnade und die von ihm geschaffenen Habitus der übernatürlichen Tugenden erst richtig geformt und geleitet wird. Die katholische Kultur ist das 
von der Gnadensittlichkeit ,formierte (relative) Naturrecht des Sündenstandes. So kann diese Ethik, solange sie von dem Vernunfttrieb und den naturgesetzlichen Sozialbildungen spricht, einen zwar den Gemeinsinn, die Liebe und die Freiheit nach Möglichkeit betonenden, aber doch völlig innerweltlich-rationellen Charakter tragen und völlig in der Weise des Aristoteles und der Araber die geistleibliche Eudämonie zum Zwecke und Organisationspunkt der Moral machen und dann doch dieses Ganze der naturgesetzlichen Ethik einem über sie übergreifenden Organismus der Verwirklichung des absoluten religiösen Zwecks einordnen als Mittelzweck und Voraussetzung, die nur berechtigt sind, wenn sie überall auf die Dienste für den absoluten $Z$ weck bezogen werden. Die alte Kirche hatte mit den ethisch-sozialphilosophischen Allgemein begriffen der Stoa gearbeitet und ihnen die Wundergemeinschaft der Kirche als durch die Sünde noch gebrochene Wiederherstellung der vollendeten Vernunftethik gegenübergestellt. Die thomistische Ethik arbeitet mit den ethisch-sozialphilosophischen Begriffen des Aristoteles und des Neuplatonismus und stellt den ersteren eine Verbindung der kirchlichen Uebernatürlichkeit mit dem letzteren gegenüber, in der die kirchliche universale Gnadenanstalt und Wundergemeinschaft als ein prinzipiell übervernünftiges Reich der durch göttlichen Gnadeneingriff verliehenen Mystik erscheint.

So geschlossen nun aber dieser Aufbau erscheint und soweit er über die altkirchlichen Lehren hinausgeht, so sehr sind in ihm doch auch die altkirchlichen Gegensätze erhalten geblieben. Sie halten sich nur auf einer tieferen Linie. Das ist stets im Auge zu behalten, um diese Einheitskultur nicht für christlicher zu halten, als sie wirklich ist. Ihre Christlichkeit ist unmittelbar nur durch die Herrschaft der Gnadensittlichkeit und des Gnadenorganismus bewirkt, aber der beherrschte Stoff der Welt ist nirgends direkt christianisiert. Der Glaube an die Göttlichkeit und Biblizität des seine eigene Logik besitzenden Naturrechtes ist in Wahrheit das eigentliche Mittel der Christianisierung, und diese ist insofern doch nur eine indirekte. Daher bleit. die Fundamentalvoraussetzung der katholischen Ethik bis heute neben der kirchlichen Theokratie formell das Prinzip des biblisch anerkannten rationalen Naturrechtes und inhaltlich eine Fassung des Naturrechtes, die den alttestamentlich-patriarchalischen und aristotelisch-konservativen Zügen entspricht und damit auch die 
soziale Wirklichkeit des Mittelalters in den Grundzügen als Ausdruck der Vernunft betrachtet. Die eigentlich christliche Ethik dagegen bewegt sich auf der Stufe der sakramentalen Gnadensittlichkeit und greift in die Naturstufe nur durch die alles umfassende Theokratie der Kirche ein. Die eigentlichen Regeln des innerweltlichen Lebens selbst fließen daher auch jetzt noch nicht direkt aus dem christlichen Ethos, sondern aus Naturrecht, Aristoteles, Dekalog und altem Testament. An eine christliche Sozialreform und Sozialgestaltung ist auch jetzt direkt nicht gedacht, sondern nur die den christlichen Ideen untergeordneten naturrechtlich-alttestamentlichen Gesetze regeln von selbst die weltlichen Sozialbildungen in einem indirekt christlichen, auf die christliche Ethik disponierenden Sinne. Der Gegensatz ist gemildert, aber nicht aufgehoben. Die christliche Einheitskultur verdankt ihre Einheit nicht direkt den christlichen Ideen, sondern den von den christlichen Ideen beherrschten und angeeigneten naturrechtlich-aristotelisch-alttestamentlichen, wobei das Naturrecht theoretisch stark der christlichen Idee konformiert und praktisch in einer der christlichen Idee entgegenkommenden Gesellschaftsordnung ausgeprägt ist. Damit bleibt dann doch innerhalb dieses letzteren eine große Unsicherheit und Gefährdung der christlichen Maßstäbe. Denn das, was die natürliche Ordnung von der christlichen unterscheidet und sie zu einer bloßen Vorstufe macht, ist außer der "natürlichen "Kraft des Handelns und der snatürlichen* Beziehung auf innerweltliche geistig-soziale $Z$ wecke das Beherrschtsein des Naturrechts des Sündenstandes durch die mit der Sünde eingedrungene Grundeigenschaft des Menschen, die sich in Lage und Umstände, in Gott und Gesetz nicht fügen wollende Superbia; sie ist die Quelle alles Kampfes und aller den Kampf dämpfenden Rechts- und Eigentumsordnung. Neben dem neuplatonischen Unterschied der weltlichen und mystischen Religions- und Sittlichkeitsstufe bleibt somit der alte Gegensatz des Kampfes ums Dasein und seiner Ordnungen gegen die christliche Liebes- und Freiheitsmoral. Der Gegensatz ist erhalten geblieben, aber hinter den wichtigeren von Natur und Uebernatur zurückgedrängt und, sofern er jener in ihrer gegenwärtigen Beschaffenheit immanent ist, zugleich mit ihr dem Stufengang vom Natürlichen zum Uebernatürlichen untergeordnet. Insoferne ist er aus der Gleichzeitigkeit in das Nacheinander eines Stufengangs verwandelt ${ }^{121}$ ).

221) Ueber den Stufengang s. Werner II 507, $519 \mathrm{ff}$. aus der Tugendlehre, Troeltich, Gesammelte Schriften. I. 
Dabei ist nicht $z u$ verkenn $n$, welche außerordentliche Bedeutung diese Einführung der Begriffe eines Stufenganges und fortschreitenden Aufstieges, und das heißt die Rezeption des Aristoteles und seine organische Verbindung mit dem Neuplatonismus, für das Ganze der christlichen Ethik hat. Er macht es möglich, einerseits die radikal-religiöse Ethik im Ziel festzuhalten, indem sie umgeformt wird zur Mystik, andererseits aber doch auch alle übrigen ethischen Werte, soweit sie in den Horizont

Baumann 82 aus de reg. princ., Feugueray S. 155 f., 193, Thömes 72 . S. auch die vorhergehenden Anmerkungen. - Ueber den Mangel jeder eigentlich direkt christlichen Politik und Sozialreform und die Abschiebung aller positiven Sozialgestaltung, soweit siel überhaupt gefordert wird, auf die Prinzipien des Naturrechts und damit der unterchristlichen Ethik s. sehr richtig Feugueray S. $212 \mathrm{f}$, sL'idéal de la société chrétienne comme but et la réalisation successive de cet idéal par une prâtique sociale appropriée, voilà une idée qui est aujourdhui dans toutes les têtes. Or, on chercherait vainement dans saint Thomas le moindre pressentiment de cette idée. Pour lui, au contraire, et c'est son erreur capitale, il n'y a point de politique chrétienne. Il ne voit point que le christianisme a inauguré une civilisation nouvelle; il ne sait même point que les principes chrétiens du droit et de la justice sont très différents des principes de l'antiquité, soit chez les Gentils, soit chez les Juifs. Il connaissait, il est vrai, la grande supériorité de la loi nouvelle sur la loi ancienne; il fait souvent la comparaison des deux lois, et il montre que la loi nouvelle l'emporte, en ce qu'elle a pour but non plus le bien sensible et terrestre, mais le bien intelligible et céleste, en ce qu'elle ne règle pas seulement les actes extérieurs, mais, de plus, le mouvement de l'esprit, cohibet manum et animam, en ce qu'elle commande par amour et non plus par la crainte. Voilà la raison de la supériorité de la loi nouvelle; mais quant aux préceptes moraux, quant à la règle des actes extérieurs et des rapports des hommes entre eux, la loi nouvelle n'a pas innové; elle n'a rien eu à ajouter à la loi ancienne. S. Th. le dit expressément: Lex nova super veterem addere non debuit circa exteriora agenda (2 a 2 ae q. 108 a.2); et cette loi ancienne, la loi juive, il fait bien le remarquer, n'était elle mêmé, quant a sa morale, que la loi de la nature, la loi primitive, de sorte, qu'en réalité la loi morale de l'humanité, selon $\mathrm{S}$. Th., n'a pas changé, et que la morale des Chrétiens ne diffère pas de celle des anciens; elle ne diffère du moins que dans l'ordre dé la grâce, pour ce qui se reporte au salut des âmes; mais dans l'ordre de la nature, pour les préceptes de la justice, pour la règle des rapports entre les hommes et, par conséquent, pour les principes de la politique, le christianisme et l'antiquité n'ont qu'une même conscience... il donne à l'homme les moyens du salut éternel, mais son action ne s'étend pas sur les choses d'ici-bas et ne modifie pas la condition temporelle des hommes. Das Urteil ist charakteristisch für viele; es ist dabei übersehen die innere Schwierigkeit einer christlichen Gesellschaftsgestaltung; und es ist weiter übersehen das Maß von innerer Christianisierung und Konformie- 
des Mittelalters getreten sind, und die ganze Naturbasis in die christliche Ethik als Unterstufe und Voraussetzung hineinzuziehen. Das ist eine weitgehende $\mathrm{Re}$ lativie $\mathrm{r}$ ung der radikalen Grundsätze der echten christlichen Ethik, bei der aber doch durch den Gedanken einer von den natürlich-vernünftigen Werten zu den spezifisch religiös-ethischen emporführenden Entwickelung der Standpunkt selbst gewahrt wird. Es ist eine Relativierung, ohne die eine christliche Einheitskultur nicht möglich ist; und soferne eine universale weltbeherrschende Kirche wiederum ihrerseits ohne Einheitskultur nicht möglich ist, gehört eine solche Relativierung zum Wesen der Kirche. Sie muß als Welt und Kultur beherrschende Raum schaffen für die Naturbasis und für die innerweltlichen ethischen Werte, und sie tut das, indem sie diesen einen relativen Wert zuerkennt und von diesen relativen Werten $z u$ den absoluten erst emporführt. Indem aber die absoluten Ideale vereinigt werden mit der Anerkennung relativer, $\mathrm{zu}$ ihnen hinführender Ideale, werden sie doch schließlich auch selbst relativiert und ihrer Ausschließlichkeit beraubt. Sie gehen in verschiedenartige Verbindungen mit den weltlichen Idealen ein und werden damit selbst prinzipiell verweltlicht, in den Fluß des Werdens hineingezogen und in bloße Annäherungswerte an das Absolute verwandelt. Seine reine Durchführung muß einem besonderen Stande überwiesen werden, dem Asketenstande, der es stellvertretend für die anderen verwirklicht und seine Wirkungskraft aufrecht erhält, so daß es von ihm aus immer wieder in die bloß relativen Verwirklichungen kräftigend. hineinstrahlt. Das Absolute bleibt gewahrt nur in dem Begriff des eigentlichen letzten Ideals und in dem Vorhandensein des kirchlichen Gnadeninstitutes selbst, das als objektive Inkarnation der übernatürlichen Wunderkräfte jederzeit deren Gegenwart und Wirkung sicher stellt, unabhängig von dem Maße subjektiver Verwirklichung des übernatürlichen Ideals in den einzelnen Gläubigen. Sie ist die dauernde Gegenwart des Absoluten und dispensiert

rung des Naturrechts an die christliche Idee, der ganze bisher geschilderte Boden der praktischen mittelalterlichen Sozialverhältnisse, der freilich in die thomistische, an Aristoteles angeschlossene Konstruktion auffallend wenig direkt hineinwirkt, umsomehr aber indirekt Auslese und Betonung und die Haltung des Ganzen bewirkt. Man braucht nur das Naturrecht der Aufklärung und die antike Staatslehre damit zu vergleichen, um den Unterschied zu bemerken. Das Naturrecht ist eben keine eindeutige Größe, sondern von der jeweiligen Gesamtidee abhängig. Das scholastische Naturrecht ist faktisch ein stark christianisiertes. 
daher dic Einzelnen von der subjektiven Verwirklichung des Absoluten, kann bei ihnen mit Annäherungen zufrieden sein, die die Läuterung im Purgatorium vollenden wird. Die Moral wird so kompliziert und relativ, eine teleologisch-evolutionistische Moral verschiedener, auf einander zusammengestimmter Zweckstufen. Aber wie die Kirche selbst das Absolute darstellt, so bewirkt sie auch die Einheitlichkeit der Moral, indem sie mit ihrer Autorität die Abstufungen und Bewertungen feststellt, und mit ihrer Kasuistik dem Einzelnen die Verantwortung für die Vereinheitlichung dioses komplizierten Ethos abnimmt. So wird indirekt die an sich freie teleologische Moral durch Auslegung der Kirche gesctzlich und autoritativ, und hier kann darum die ganze populäre Heteronomic des Verdienstglaubens eindringen, die in den eigentlichen Grundgedanken des Thomas keinen Ort hat. Die Kasuistik und Gcsetzlichkeit der katholischen Moral ist von dieser Seite her die liolge ihrer Kompliziertheit, bei der die Einheitlichkeit nur durch autoritative Festsetzungen $\mathrm{zu}$ behaupten ist. $\mathrm{Zu}$ diesen abcr ist die Kirche befähigt als die Inhaberin der absoluten Kräfte, Ziele und Wahrheiten. Sie und nur sie ist die Inkarnation des Absoluten und der Einheit ${ }^{121 a}$ ).

Die jetzt erreichte Vermittelung ist eine Relativierung. Diese Relativicrung aber ist ohne Verlust des absoluten Zieles erreicht durch den Gedanken einer geistig-ethischen Entwickelung. Aus der widerspruchsvollen doppelten Moral der alten Kirche ist eine cinheitliche Entwickelungsmoral geworden. So scheint das jetzt aufgebotene Ausgleichsmittel ein dem modernen Denken sehr verwandtes, der Entwicklungsgedanke, zu sein. Allein die hicrbei vorausgesctzte Entwicklung ist in Wahrheit doch keine eiscntliche und wirkliche Entwicklung, kein in innerer Notwendigkicit und Kontinuierlichkeit sich hervorarbeitendes Ganzes, das als Ganzes mit seinen Durchsetzungsstufen und seinem Ziel in dem ver-

1:1a) Visl. meinen Aufsatz »Katholizismus und Reformismus in der Internationalen Wuchenschrift 100\%. Teber das Verhältnis der Gesetzlichkeit und Heteronomic zur immeren Freiheit und Autonomie in diesem System s. Gottschick, Ethik 1907. $\therefore$. 6;. Aus dem teleologisch-mystischen Charakter folgt objektiv im Grunde die Freiheit, aber pädrgogische Rücksichten, die Kompliziertheit des Ethos und dic liordirung der Einheitlichkeit führeu für die handelnden Subjekte oft zu ciner starken Beugung unter Autorität und Heteronomie. Jedenfalls aber ist das lroblem viel komplizienter als lie protestantische Polemik im allgemeinen annimmt. E- gibt natiirlich auch noch andere Seiten, von denen her die Gesctzlichkeit und dav Verdienstuesen in das katholische System einsirömt. 
sorgenen göttlichen Lebensgrund begründet wäre. Sie ist ein bloß irchitektonisch geordnetes System ron $Z$ weckit $u$ f e $n$, wo die jedesmalig einsetzende neue Stufe durch einen beionderen göttlichen Schöpfungsakt eröffnet wird und die Kontinuierichkeit im Verhältnis zur vorangehenden nur eine äußere Vorsereitung und Vermittelung ist, die der göttliche Weltarchitekt zeordnet hat, um ohne allzugroßen Sprung die neue Stufe an tie vorangehende anschließen zu können. So beruht in dem uufsteigenden Zwecksystem der Wirklichkeit überhaupt jede neue Stufe auf einem sozusagen natürlichen Wundereingriff Gottes and beruht vor allem die höchste, das Menschentum abschließende und zusammenschließende Stufe der kirchlich-sakramentalen GnaJensittlichkeit auf einem übernatürlichen, völlig einzigartigen, rein aus der Gnadenwillkür fließenden und nicht mit Wesen und Begriff des Menschen und der Welt gesetzten Wunder. In diesem Sinne hat der hl. Thomas gegen den averroistischen Monismus feinsinnig und gedankenreich die Besonderheit der einzelnen Wirklichkeitsstufen, die Sonderart und die individuclle Eigenexistenz des menschlichen Geistes und die Möglichkeit einer den Tod überdauernden Fortentwicklung des Geistes behauptet. In Verfolgung dieses Gedankens hat er dann aber auch den ganzen mythisch-supranaturalistischen Wundereingriff der Kirchenstiftung und der sakramentalen Gnadensittlichkeit behauptet und zur Grundlage der Verwirklichung des absoluten Lebenszweckes gemacht. Das mystische Lebensziel liegt ihm nicht im Wesen und Begriff des Menschen wie dem Neuplatonismus, sondern zu dem natürlich sich entwickelnden Wesen und Begriff tritt er erst durch ein Willkürwunder der Gnade hinzu. Die Uebergänge zwischen diesen derartig innerlich inkohärenten Stufen sind sorgfältig, aber rein äußerlich vermittelt, indem der Gipfel der vorausgehenden Stufe stets an den Anfang der neuen möglichst herangeschoben und der Sprung von der einen zur andern nach Möglichkeit verkleinert wird ${ }^{1210}$ \%. Besonders schwierig wird das bei der natürlichen Disposition und Vorbereitung zurWunderstufe oder zur Gnade, wo es bald mehr gilt die Anknüpfung,

121 b) Damit soll nicht gesagt sein, daßs für den modernen Entwicklungsbegriff hier keine Probleme bestünden. Er ist gewiß auch heute noch und heute erst recht ein die großten Schwierigkeiten in sich bergender Begriff, s. Bergson, L'évolution créatrice. Aber das kann hier nicht weiter verfolgt werden. Es soll nur gesagt sein, daß jedenfalls in dieser thomistischen Gestalt die Vermittelungea und Uebergunge keine innere Notwendigkeit, sondern nur eine anthropomorphe Willkurlichkeit und Gesetztheit haben. 
bald mehr den Gegensatz herauszuheben, und wo der Ort all der verwickelten Diskussionen über Freiheit und Gnadenkraft, Sünde und Gnadensittlichkeit ist, auf die hier nicht weiter eingegangen $z u$ werden braucht. Mit der Verkleinerung des Sprungs ist das rationelle Bedürfnis nach Einheit und Kontinuierlichkeit des Denkens befriedigt, vor allem aber auch dasjenige Bedürfnis, das uns in diesem Zusammenhang beschäftigt, das Bedürfnis nach Eingliederung und Annäherung des innerweltlichen Gesellschaftslebens an den die letzten Werte und Prinzipien des Lebens enthaltenden soziologischen Organismus des religiösen Lebens. Indem dieser selbst zur päpstlichen Theokratie und allumfassenden, teils direkt teils indirekt das Gesamtleben bestimmenden soziologischen Grundform des menschlichen Daseins wird, ist das innerweltliche Leben ihm auf doppelte Weise eingegliedert: einmal indem es auf die stoisch-christlichen Gedanken eines Gesinnungsfreiheit und humane Liebesgemeinschaft möglichst betonenden, Konservatismus und Radikalismus sinnreich mischenden Naturrechts reduziert wird, und dann und vor allem indem dieses Naturgesetz in seiner Entfaltung über sich selbst hinausweist auf einen absoluten, die natürliche Gottesliebe und natürliche Humanität erst vollendenden übernatürlichen Lebenszweck, der mit dem mystischsakramentalen Gnadenwunder der Kirche eintritt ${ }^{122}$ ).

Das sind die Grundideen, auf denen die Ethik des Thomismus beruht, und von denen aus die für eine Einheitskultur unentbehrliche Schätzung des weltlichen Gesellschaftslebens auch dialektisch gerechtfertigt wird. Die dogmengeschichtliche Frage, wie sich im Einzelnen diese Lehre aus der französischen Kirchenphilosophie, der jüdischen und arabischen Philosophie, dem Aristoteles und patristischen Einwirkungen gebildet habe, kann hier außer Be-

12:) Ueber den Entwicklungsbegriff bei Thomas s. Werner II $469 \mathrm{f}$., $518 \mathrm{f}$., 533, 547, und den ganzen Abschnitt über die Zweckstufen II 295-317; Feugueray S. 131, 190 f., 193; Suma i a 2 ae qu. 97 a.1: >Humanae rationi naturale esse videtur ut gradatim ab imperfecto ad perfectum veniats. Das gilt aber auch vom Verhältnis der Natur zur Gnade selbst; wobei die Gnade bald wie eine Perfektion der Natur, bald wie ein rein supranaturaler Ueberbau erscheint. Qu. 106 art. 3: Non enim aliquid ad perfectum adducitur statim a principio, sed quodam temporalis successionis ordine, sicut aliquis primum fit puer et postmodum vir; daher der Stufengang der Offenbarung von der lex naturae zur Lex vetus und von da zur Lex nova. Der im Grande rein architektonische Charakter dieser Entwicklungsidee gut gezeichnet bei Gaf, Gesch. d. christl. Ethik I 432, 324 f. 
tracht bleiben. Entscheidend aber ist, daß der Heilige nicht bloß in der Verarbeitung all dieser Einflüsse einer der größten Denker des Katholizismus war, sondern daß er auch bei seiner streng päpstlichen Gesinnung die engste Verknüpfung dieser Ethik und Kulturidee mit der universalen Einheitskirche und der Papstherrschaft vollzogen hat. Es liegt auf der Hand, daß die Verbindung eine durchaus logische und aus dem Sachzusammenhang erwachsende ist. Das kunstreiche System einer auf lauter Wunderkräften und Offenbarungsstufen beruhenden Ethik kann nur durch ein Zentralwunder der Autorität und göttlichen Objektivität zusammengehalten werden. Auch ist klar, daß eine solche Autorität eine durchaus formell-gesetzliche, das Göttliche rein formulierende Autorität sein muß und damit sowohl Recht wie Notwendigkeit hat, diesem Wahrheitsbesitz und dieser Zielerkenntnis die Welt gewaltsam zu unterwerfen, soweit sie ihr nicht freiwillig entgegenkommt. Das letztere aber ist bei dem emporführenden Stufencharakter des Naturgesetzes ja auch als Regel zu erwarten.

Es ist wie die ganze Scholastik eine wesentlich architektonische Denkweise mit der Zurückschiebung der Einheit in die weise ordnende Kraft des göttlichen Weltarchitekten, die dem menschlichen Denken nur die Verehrung der großen Schöpfungsund Wundereingriffe und die nachsinnende Erkenntnis der von Gott dazwischen gelegten Vermittelungen übrig läßt. In dem Gedanken der Kontinuierlichkeit liegt seine rationalistische Tendenz, in dem Gedanken der beständigen weiter führenden Eingriffe, der Gnaden- und Kirchenstiftung und zuletzt der Prädestination liegt die irrationale Tendenz. Vermittelt sind beide lediglich durch ein architektonisch-rhythmisches Bild vom Stufenbau der Welt. Architektonisch gegliedert ist so der Aufstieg der Menschheit und der Aufstieg der Einzelseele zum absoluten Zweck; architektonisch gegliedert ist auch die Idee der Gesellschaft, die aus der Verwirklichung des höchsten $Z$ weckes resultiert, indem hier nicht bloß das Individuum die einzelnen Stufen durchläuft, sondern auch die Gesellschaft in den Stufen der Stände - vom Unfreien zum Freien und Adligen und Bürger und von da zum Mönch und Priester und den Spitzen des Staates wie der Hierarchie - aufsteigt. Das letztere hängt mit dem bloß architektonischen Charakter des Denkens eng zusammen und ist besonders noch zu betonen. Das ständische soziale System und das scholastische 
Denken entsprechen und bedingen einander. Die einzelnen Glieder sind in beiden Fällen nicht jedes für sich auf die letzten Werte und Prinzipien bezogen, sondern nur durch Vermittelung eines Ganzen, in dem sie äußerlich architektonisch verbunden sind und an dem sie nur in sehr äußerlich abgestufter, quantitativer Weise Teil haben. Die bloß architektonische Einheit der Gesellschaft und Kultur kommt insbesondere noch weiter darin zum Ausdruck, daß nicht nur im Längsschnitt die Stufen der Entwickelung des Individuums wie der Menschheit bloß äußerlich zusammenhängen, sondern daß auch im Querschnitt die einzelnen Gruppen eine ruhig ertragene bloß äußerlich abgestufte Beziehung auf den Sinn des Ganzen haben, daß nur das Ganze die Idee des göttlichen Lebensorganismus verwirklicht, daß aber die einzelnen Stände und Individuen sehr ungleich an dem eigentlichen Ideal und letzten Zweck beteiligt sind, wie ja auch die himmlische Seligkeit ihre Stufen und Stände hat. Durch Wundereingriffe vermittelte Uebergänge und lediglich quantitative Beziehungen auf das Ideal vertragen sich hier überall mit den Begriff der Weltharmonie, wie die ständische Verschiedenheit sich selbstverständlich mit der Einheit der Gesellschaft verträgt. Es gibt keine Einheitlichkeit des sittlichen Ideals, weder materiell, indem allen das gleiche Ziel gesetzt wäre, noch formell, indem die Verschiedenheit auf die vom Individuum nach seiner Sonderart zu erwirkende individuelle Sittlichkeit geschoben und jedem wenigstens das formell gleiche Ziel einer individuellen Selbstbildung zugeschrieben würde. Es ist vielmehr eine Verteilung der Rollen, Stände und Dienste in einem sich gegenseitig architektonisch ergänzenden und stützenden Ganzen, dessen innere Einheit in dem all das auf einanderbeziehenden göttlichen Willen und in der diesen Willen ausführenden, die Rollen verteilenden und die Verantwortung übernehmenden kirchlichen Autorität liegt. "Die geordnete Verschiedenheit der kirchlichen Stände soll die harmonische Mannigfaltigkeit der Naturordnung und der staatlichen Sozietät auf einer höheren Stufe im Reiche der Gnade wiederholen. Die Verschiedenheit der Aemter ist eine in der Idee des Gesellschaftsorganismus, der hierin dem menschlichen Einzelorganismus gleicht, bedingte Notwendigkeit und ermöglicht möglichst vielen eine wirksame Beteiligung am öffentlichen Leben der Kirche. Die Abstuiung der Aemter und Dienste gehört zur Wohlordnung des Ganzen und dient zum Schmuck und zur Schönheit der Kirche « ${ }^{123}$ ).

:i) Der Zusammenhang der scholastisch-architektonischen Logik mit der stän- 
Das System enthält auch sonst offenkundige Schwierigkeiten und Unklarheiten in dem künstlichen Abbrechen und Anknüpfen: die Unterscheidung der übernatürlichen Gottesliebe von der natürlichen, die Verwandelung der neuplatonischen Mystik, die in

disch gegliederten sozialen Wirklichkeit ist ein ähnlicher Gedanke, wie Simmels Gedanke von einem Zusammenhang des modernen Rationalismus und Relativismus mit der Geldwirtschaft und ihren sozialen Wirkungen. Es ist das eine Anwendung des marxistischen Gedankens der Abhängigkeit des geistigen Ueberbaues von dem sozial-ökonomischen Unterbau, die mir bei der nötigen Vorsicht berechtigt und erleuchtend scheint. Natürlich wird damit die Logik nicht zu einer einfachen Spiegelung und Uebersetzung ökonomisch-sozialer 7ustände in vermeintliche Denkgesetze, die sich dem Denker in scheinbare logische Notwendigkeiten verwandeln. Allein alles Denken hat jederzeit gewisse Selbstverständlichkeiten, bei denen es sich als Axiomen beruhigt. Fïr das wirkliche Denken selbst sind das dann freilich keine Axiome; sie werden von ihm bei kritischer Selbstbesinnung ja auch wieder aufgelöst und zurückgeschoben, ohne daß die sozialen Unterlagen sich bereits hxtten $z \mathfrak{u}$ wandeln brauchen. Allein es beruhigt sich eben doch gerne bei ungeprüften Selbstverständlichkeiten, vor allem wenn sie das praktische Leben anschaulich beherrschen. Die moderne Beruhigung bei der Möglichkeit, alles an einem festen rationellen Maßstab messen zu können, und die Selbstverständlichkeit, alles in alles überführen zu können, empfängt sicherlich vom scheinbar objektiven Werte des Geldes und der damit möglichen allgemeinen Vertauschbarkeit einen starken psychoflogischen Antrieb zur Verfestigung als Denkgewohnheit, während freilich die rein logische Arbeit selbst, wo sie nur sich selbst folgt, diesen psychologischen Einflüssen nicht unterliegt und jene Vorurteile in Frage stellt. Aehnlich scheint mir die scholastische Neigung, bei einer äußerlich architektonischen Einheit sich $2 \mathbf{u}$ beruhigen und die Wertbeziehung des Individuums erledigt zu haben, wenn es nur in irgend einer Gruppe einen quantitativ abgestuften Anteil am Sinne des Ganzen hat, unter dem psychologischen Einfluß des ständischen und korporativen sozialen Lebens in Staat, Gesellschaft und Kirche zu stehen. Eben daher ist ihr der moderne Individualismus, der jedem auf eigene Weise unmittelbaren Anteil am Sinne des Ganzen geben will, unbekannt. Das schließt natürlich aber im übrigen nicht aus, daß die scholastische Logik anderwärts rein dem logisch-dialektischen Triebe folgt. Auch gehen solche psychologische Einflüsse auf das Logische zu seiner Festlegung auf angebliche Selbstverständlichkeiten nicht nur vom Sozialen und Oekonomischen aus, wie gerade in der Scholastik etwa die Eschatologie zeigt, bei der aber auch in den Stellvertretungen, Büßungen und Wergeldern die soziale Unterlage durchscheint. Immerhin glaube ich auch hier gezeigt zu haben, daß diese psychologischen Einfüsse vom Sozialen her sehr erheblich sind und die christlichen Soziallehren des Katholizismus hier von einem faktisch-psychologischen Element bedingt sind, nicht von der Dialektik der christlichen Idee, deren Individualismus hierbei sich nicht befriedigen kann und auch tatsăchlich sich hiervon losgerissen hat, wie beim Protestantismus zu zeigen ist. 
innerer Konsequenz aus dem Prozeß des Geistes hervorgeht, in ein radikales Kirchenwunder ist die eine; die schwankende Betrachtung des Naturgesetzes bald im aristotelischen Lichte einer siegreichen Vernunftentwicklung, bald im kirchlichen Lichte einer völligen erbsündigen Verderbtheit ist die andere; damit verbinden sich die Unsicherheiten der -Vollkommenheitslehre «, die an sich jedem Individuum das Ziel der mystischen Gnadensittlichkeit vorschreiben müßte, aber bei der faktischen Unmöglichkeit dem Durchschnitt nur eine Annäherung in Aussicht stellt und die volle Gnadensittlichkeit einem besonderen Stande zur stellvertretenden Ausübung mit Hilfe besonders günstiger Mittel, dem Mönchtum, zuschreibt oder doch als ihm leichter erreichbar bezeichnet. Im ganzen aber ist es unzweifelhaft ein großartiger und geistvoller Versuch, die verschiedenen Motive menschlicher Gemeinschaftsbildung, die innerweltlich-sozialen und die religiös-universalmystischen, zu kombinieren. Es ist in seinem Unternehmen, die Selbständigkeit dieser verschiedenen Lebensgebiete zu wahren und auch in dem Aufstieg der Lebensbewegung die innern Differenzen der Stufen zu behaupten bei gleichzeitig festgehaltener Beziehung auf einen letzten religiösen $Z$ weck, der Wahrheit des I.ebens oft vermutlich viel näher, als die biologisch-naturalistischen Konstruktionen moderner Soziologie mit ihrem das Individuum im Kollektivismus erdrückenden und alles in alles monistisch übergehen lassenden Relativismus. Jedenfalls ist es die große Grundform der katholischen Sozialphilosophie bis heute. Die Gegensätze, die es verarbeitet, bietet das Leben und wird es stets von neuem hervorbringen, seit neben den weltlichen Sozialbildungen eine sicherlich durch nichts mehr zu vertilgende universale, ethisch-religiöse Idee, die Idee der gotteinigen Persönlichkeit und der gotteinigen Menschheitsgemeinschaft, um die Schaffung einer ihrer Idee entsprechenden Gemeinschaft kämpft und diese Ideen über den Kreis der eigenen Kultgemeinschaft in das allgemeine Leben hinauszutragen streben muß. Die mittelalterliche Theorie hat die Gegensätze unzweifelhaft scharf durchgedacht und ebenso unzweifelhaft sich genähert. Wenn überhaupt das christliche ethische Ideal als höchstes Ziel behauptet und zu einer universalen Geltung gebracht werden, also die natürlichen Lebensformen und innerweltlichen ethischen Ideale sich einverleiben soll, so wird das schwerlich jemals anders möglich sein als durch den Gedanken einer von den innerweltlichen zu den überwelttichen Lebenswerten empor- 
leitenden Entwickelung 128s).

Die besondere Art, in der Thomas das getan hat, hing freilich von der tatsächlichen Gestaltung des Lebens und von dem besonderen Denken der Epoche' ab, in welchem der Willens-Irrationalismus des Gottesbegriffes und die daraus folgenden verschiedenen Stiftungen und Eingriffe mit dem logischen und ethischen Einheitsbedürfnis nur durch einen anthropomorphen architektonischen Weltplan und durch lediglich architektonische Ueberleitungen von Stufe zu Stufe verbunden sind. Es ist kein Wunder, wenn die folgende Kritik der Scotisten und dann vor allem der Occamisten daraus den reinen Indeterminismus und die reine Willkür herausdestilliert hat, aber es ist ebenso selbstverständlich, daß von dieser Kritik der $\mathrm{Ka}$ tholizismus später wieder auf die thomistische Lehre, auf ihre Kontinuierlichkeiten und Uebergänge, zurückgegangen ist. Die sog. nominalistische Theologie des Spätmittelalters hat unzweifelhaft eine scharfsinnige Kritik an diesem Vermittelungssystem geleistet und durch dessen Aufösung sowohl eine freiere Bewegung des weltlichen Lebens gestattet als auch dem religiösen Gedanken eine freiere, von Vernunftrücksichten weniger gebundene Selbstdurchsetzung ermöglicht. Hier wuchs die Theologie der Reformatoren aus der Zersetzung des Thomismus und der Wiederaufrichtung der absoluten Gegensätze heraus. Aber sie mußten dafür dann auch für die Grundlegung der Sozial- und Kulturethik neue Wege beschreiten. Für den Katholizismus dagegen bedeutete dieser Nominalismus nur eine Auflösung der seiner Kulturidee unentbehrlichen Vermittelungen ohne die Schaffung einer neuen. Nicht bloß das Dogma, sondern vor allem auch die Sozialethik ist im Nominalismus aufgelöst, und mit dem Gegensatz von Vernunft und Offenbarung klaffen auch Staat und Kirche auseinander. Und auch die humanistische Fortentwickelung der bereits in der Scholastik eingeschlossenen antiken Elemente, wie sie etwa bei Nikolaus von Kues und Thomas Morus erfolgte, ging über die katholische Idee einer von der Gnade beherrschten und gelenkten Natur und Kultur immer weiter hinaus, sodaß auch gegen den Humanismus die Wiederbetonung des all das im Gleichgewicht haltenden Thomismus nötig wurde ${ }^{123 b}$ ). Deshalb mußte der sich reorganisierende

123 a) Vgl. meine Abhandlung: ,Grundprobleme der Ethike, Z. f. Theol. und Kirche 1902; auch die glänzende Charakterisierung von Dantes Ethos bei Vossler, Dante I S. 558-569.

199 ט) Ueber diese noch sehr wenig erforschte und vor allem nach der Seite 
Katholizismus der Gegenreformation auf das thomistische Vermittelungssystem und seine Ethik zurückgreifen. Damit aber mußte er auch auf dessen Voraussetzungen in der tatsächlichen Lage tunlichst, wenigstens in Gestalt von Forderungen, zurückgreifen. Deshalb verlangt er immer wieder, wenigstens in den Grundzügen, die allgemeinen politisch-sozialen Verhältnisse, auf denen er sich im Mittelalter aufgebaut hatte, und behauptet er bis heute die philosophischtheologische Methode seiner architektonischen Logik. Noch die moderne katholische Sozialphilosophie beruht auf beiden Forderungen, wenn sie auch die erstere einigermaßen ermäßigt und modernisiert. Bis heute entspricht der Metaphysik des natürlich-übernatürlichen Stufenbaus des Weltalls ein ständisch-abgestuftes Gesellschaftsbild und eine quantitativ abgestufte Moralität der einzelnen Stände in ihrem Verhältnis zum absoluten Ideal, entspricht der Aufgabe einer Zusammenstimmung und Vereinheitlichung dieser verschiedenen ethischen Motive die Forderung einer das Ganze leitenden Autorität, die dogmatisch und ethisch übersichtliche, absolut verbindliche Lehrsätze aufstellt, das Einzelindividuum von dieser Arbeit des Ausgleichs entlastet und das Gesamtleben autoritativ beherrscht. Wo sich der Katholizismus auf die Gesellschaftslehre des modernen Rationalismus und Individualismus einläßt und den Geist einer alle Bewegung und Lebenseinheit aus sich selbst hervorbringenden Innerlichkeit und Autonomie ohne autoritatives Gesetz und darum ohne $Z$ wangsgewalt sich aneignet, da verfehlt er sich gegen seinen eigenen traditionellen Geist und sind zersetzende Rückwirkungen auf seine Metaphysik und seine Ethik unausbleiblich. Das zeigte sich im Zeitalter der Aufklärung, als die katholische Theologie die Kantische Ethik und Sozialphilosophie im Gefolge der neuen

ihrer Ethik und Sozialphilosophie noch sehr dunkle Periode vgl. jetzt die Andeutungen eines Verständnisses bei Hermelinck : ${ }_{D}$ Die theologische Fakultät in Tübingen vor der Reformation 1477-1534* 1906, dazu meine Anzeige GGA. 1909. Ueber die humanistisch angehauchte Ethik und Sozialphilosophie des Kusaners s. außer Gierke III die Darstellung bei Eucken, Beiträge zur Einführung in die Geschichte der Philosophie 2 1906; über die ganz in den universalen Theismus der Renaissance einmündende Ethik des Thomas Morus s. die lehrreiche Studie von $\mathbf{H}$. Dietzel, Beiträge zur Gesch. des Sozial. u. Kommunismus, Vierteljahrsschrift für Staats- und Volkswirtschaft V. - Ueber den Thomismus der Gegenreformation, die durch ihn ermöglichte Rezeption der Renaissance-Kultur und die damit gegebene hohe Kultur des Katholizismus, die zunächst die der protestantischen Lănder weit überflügelte, s. Gothein, Staat und Gesellschaft des Zeitalters der Gegenreformation (Kultur der Gegenwart II, V, I). 
Persönlichkeitsmetaphysik aufgenommen hatte, dann aber von der Reaktion des katholischen Gesellschaftsideals aus auch die allgemein metaphysischen Theorien wieder ausstieß. Und es ist heute die Bedeutung des sog. Amerikanismus und Modernismus, diesen engen Wechselzusammenhang wiederum schlagend darzutun; ihm wird durch Rezeption des so bunten modernen naturphilosophischen, geschichtsphilosophischen, sozialphilosophischen und metaphysischen Denkens schwerlich gelingen, was dem Thomismus durch die des einfachen und geschlossenen Aristotelismus gelungen ist. Auch wird der Boden der unendlich komplizierten praktischen Verhältnisse des modernen Lebens sich einer solchen neuen Ausweitung des katholischen Ethos weniger leicht fügen, als es die von Thomas vorgefundene soziale Lage getan hat ${ }^{128}$ o). Der Thomismus wird voraussichtlich immer wieder siegen, bis er sich irgend wann einmal zu Tode gesiegt hat.

128 e) Für den Katholizismus der Auf klürung s. Ludwig, Weihbischof Zirkel von Würzburg in seiner Stellung zur theolog. Auf klărung und zur kirchl. Restauration 1904/6. Hier springt in die Augen, wie der unglaublich tief in das katholische System eingedrungene Kantianismus in erster Linie vor dem Sozialideal der Natur und Gnade vereinigenden Universalherrschaft der Kirche zurückweicht. Für die modernen Verhältnisse vergl. das äußerst interessante Buch des Abbe Houtin: "L'américanismer. Auch Loisys , Quelques Lettres 1908 weisen wiederholt auf die Unverträglichkeit des thomistisch-kurialistischen Gedankenganzen mit dem modernen sozialen Denken und seinen metaphysisch-ethischen Prămissen hin. Die Versuche, den modernen Katholizismus bloß die modernen sozialen Ideen rezipieren zu lassen ohne Beeinflussung der Dogmatik, Ethik und Kirchenphilosophie überhaupt, sind Illusionen, und aus guten Gründen stellt sich bei solchen bloß sozialen Modernisten doch schließlich immer auch die dogmatische und philosophische Kritik ein. Wieweit hierauf dann ein neues System des Katholizismus sich begründen läßt, ist bisher nicht gezeigt worden. Hierüber s. die beiden Schriften M. Legendre et J. Chevalier, Le catholicisme et la société, Paris 1907 (Collection des doctrines politiques publiée sous la direction de Mater, II) und G. Tyrrel, Medievalism, London 1908. Das erstere Buch ist unbedeutend, das letztere dagegen höchst interessant; es zeigt einen organisch-evolutionistischen Katholizismus, der nichts anderes ist als der in den Individuen frei und innerlich gewirktt Gemeingeist des Christentums, der als Religion von der Theologie verschieden und nur als Religion, nicht als Theologie göttlich ist, der daher in dogmatischen und ethischen kirchlichen Festsetzungen nur provisorische Deutungsdogmen sieht und somit für diese letztere keine Gewaltherrschaft in Anspruch nehmen kann; für das erstere fallen sie ganz von selbst weg; damit vereinige sich dann leicht das moderne soziale Leben, die freie Kirche in freien Staat. An der religiösen Reinheit und dem modernen Charakter der ganzen Konzeption ist kein Zweifel, aber sie hebt $\mathrm{m}$. K. 
8. Die mittelalterliche Sozialphilosophie nach den Grundsätzen des Thomismus.

Mit dieser theoretisch-ethischen Durchdringung der kirchlichen Einheitskultur ist ein das Ganze des Lebens umfassender und gliedernder Grundgedanke gefunden. Der Stufenbau eines von den sinnlich-animalischen $\mathrm{zu}$ den geistig-sozialen und von da $\mathrm{zu}$ den religiös-überweltlichen $Z$ wecken aufsteigenden Reiches der Zwecke, das das Reich der Natur und der Gnade, die außerreligiösen Sozialbildungen und die Gnadenanstalt der Kirche, den Urstand, den Sündenstand und das Jenseits umfaßt in dem Begriff des Corpus Christianum oder in dem über ihre natürlichen Vorstufen erweiterten Begriff der Kirche: das ist der Grundgedanke und die plastische phantasiemäßige, mit Metaphysik und Geschichtsphilosophie eng verbundene Anschauung, in der die Unterschiede und Gegensätze des Lebens zur Einheit zusammengehen. Mit dieser Einheitlichkeit des Kulturgedankens aber ergibt sich nun auch die Einheitlichkeit des soziologischen Grundgedankens, des soziologischen Grundschemas, das die gemeinsame Bezogenheit der Menschen auf einander in der Erreichung des absoluten Endzweckes und in der Betätigung der dazu hinführenden Mittelzwecke als ein allgemeines und prinzipielles Ideal ausdrückt. Erst jetzt wird es ein Bedürfnis und erst jetzt wird es möglich, den soziologischen Grundgedanken der christlich-kirchlichen Idee als Kern und Norm aller überhaupt möglichen und berechtigten soziologischen Bildungen zu formulieren und die letzteren aus ihm zu konstruieren. Was von ihm aus nicht konstruierbar ist, das kommt auf die Rechnung der sündhaften Verderbung und Normwidrigkeit. Aber die in dem Naturgesetz und dessen Beziehung auf das Gnadenreich sich auswirkende Vorsehung sorgt dafür, daß im ganzen alle soziologischen Bildungen in dieser Richtung verlaufen, daß auch die durch die Sünde herbeigeführten Trübungen und Institutionen der Gewalt, des Zwangsrechtes und der Unfreiheit zu Mitteln der Beförderung des Guten und der Hemmung der Sünde umgebogen werden ${ }^{124}$ ). Gegen die wirklich zerstörenden

den Katholizismus auf und ist praktisch überhaupt undurchführbar, ohne die Einheitlichkeit des Dogmas und damit das Rückgrat des Katholizismus zu zerbrechen. S. auch Karl Holl, Der Modernismus, 1908, dessen Urteil S. 4 I f. mir völlig zutreffend erscheint.

124) Quellen für das Folgende sind neben den Bibel- und Aristoteleskommentaren die große Summe, von der hier besonders die secunda secundae mit der 
Verderbungen aber, die 'der reine Egoismus und die leidenschaftliche Zügellosigkeit hervorbringt, genügen Predigt, Disziplin und Aufrechterhaltung des reinen Glaubens und der kirchlichen Herrschaft, wobei diese einzelnen Störungen. dann von selbst Spezialethik in Betracht kommt, die kleine Summe, deren drittes Buch die Ethik behandelt, und die Schrift De regimine principum, von der jedoch nur das erste Buch und Teile des zweiten als von Thomas herrührend betrachtet werden. Außerdem sind zu beachten die Darstellungen bei Jourdain I, Janet I, bei den schon genannten Baumann, Feugueray, Thömes, wozu noch hinzuzufügen ist Max Maurenbrecher, Thomas' Stellung zu dem Wirtschaftsleben seiner Zeit 1898 (leider nur ein erstes Heft erschienen). Neben den thomistischen Schriften selbst sind die modernen Neuthomisten stets mit heranzuziehen, weil sie das zerstreute Material systematisch gesammelt haben, seine innere Bedeutung gegenüber dem andersartigen modemen Geiste erst recht ins Licht stellen und durch ihren Kampf gegen die moderne Gesellschaftslehre auch die historische Bedeutung des Thomismus anschaulich machen. Hier sei besonders hervorgehoben die schon erwähnte sehr lehrreiche Schrift von Theod. Meyer, S. J., >Die christlich-ethischen Sozialprinzipien und die Arbeiterfrage a 1904, erstes Heft der Serie sDie soziale Frage beleuchtet durch die Stimmen aus Maria Laach «, wo man auch in den tubrigen, sich uber alle modernen, sozialen und politischen Fragen verbreitenden Heften vielfache Belebrung über den , Geist c des katholisch-christlichen soziologischen Denkens findet; außerdem Cathrein, -Moralphilosophie. Eine wissenschaftliche Darstellung der sittlichen, einschließlich der rechtlichen Ordnung \& ${ }^{3} 1899$, sowie Ratzinger, Die Volkswirtschaft in ihren ethischen Grundlagen 188I; auch v. Nostitz-Rieneck, Das Problem der Kultur, 1885. Es ist ein Mangel der meisten Darstellungen der thomistischen Gesellschaftslehre und Politik, daß sie gerade nicht auf den darin ausgepragten Idealtypus soziologischen Denkens oder auf das Grundschema achten, sondern die einzelnen Lebren unvermittelt nebeneinanderstellen. Aber diese sind teils das zeitgeschichtlich am meisten Gebundene und wenigst Wirksame, teils werden sie in ihrem historisch wirksamen Gehalt so nicht verständlich, sondern erscheinen ohne Rücksicht auf jenen Geist als eklektische Mischungen aus Bibel, Vatern, Aristoteles, Cicero, Seneca, kanonischem Recht und zeitgeschichtlichen Verhälnissen, über die sich Janet als über eine große Konfusion beklagt. In Wahrheit ist hier aber alles zusammengetragene Material sehr klug und sicher einem prinzipiellen Gedanken eingegliedert. - Zu erwăhnen ist auch hier von Eicken, der allerdings die ganze mittelalterliche Kultur- und Gesellschaftslehre als ein Prinzip darzustellen sucht. Aber seine Darstellung wird geradezu zur Karikatur, indem er alles mit gewaltsamstem Doktrinarismus aus dem Begriff der Weltherrschaft der Askese konstruiert, die Kirche im Prinzip Familie, Staat, Gesellschaft völlig auf heben und durch sich selbst ersetzen lußt. Der asketische Gottesstaat als alleinige Form der Gesellschaft unter Auf hebung von Geschlechtsleben, Staat und Herrschaft, Eigentum und Ungleichheit soll das allein richtige Ideal der Kirche sein. Wenn sie trotzdem das relative christliche Naturrecht zu ihrer Ergänzung hinzunimmt, so soll das von der wider- 
wenigstens zu Ausnahmen und überwindlichen Zufälligkeiten werden, im übrigen in Demut als Sündenstrafe ertragen werden müssen ${ }^{126}$ ).

Die alte Kirche hatte keine einheitliche Sozialphilosophie. Für sie klafften das Sozialgebilde der Kirche und die außerkirchstrebenden Natur der Welt aufgedrängt sein; und wenn die führenden Theologen dieses Naturrecht aus der christlichen Idee konstruieren und nachdrücklichst anerkennen, so soll das eine heillose Unklarheit sein, durch die die Kirche nie zum logischen Verständnis ihres eigenen Prinzips gekommen sei. Aber all das sind Konstruktionen von falschen Voraussetzungen aus. $\operatorname{Er}$ unterläßt es grundsätzlich, sich mit den eigenen Konstruktionen der Theologen, besonders des Thomas, auseinanderzusetzen, da er ja weiß, was diese Theologen nicht wissen und geradezu bestreiten, nämlich, daß die Weltherrschaft der Askese der einzige katholische Grundgedanke ist, und $d a ß$ hinter jeder Beziehung weltlicher Institutionen auf einen religiösen Lebenswert die Konsequenz der die Welt verneinenden asketischen Weltherrschaft lauert, auch wenn die betreffenden religiösen Aeußerungen selbst keine Ahnung von dieser Konsequenz haben. Statt an die großen Theologen hält er sich lieber an eine Masse musivisch angehäufter Einzelzüge, die mit Vorliebe der mönchischen oder der weltlich-oppositionellen Literatur entnommen sind. So aber entsteht ein falsches Bild, von dem aus überdies der heutige Katholizismus und seine Sozialphilosophie gar nicht zu begreifen wäre. - Ueber Thomas hinaus auf die gesamte mittelalterliche Gesellschaftslehre bezieht sich der Abschnitt >Die publizistischen Lehren des Mittelalters « bei Gierke, Genossenschaftsrecht III 501-644, dessen reiches Material zur Ergänzung des Thomismus stets im Auge zu behalten ist. Material auch bei Gierke, Althusius und die Entwickelung der naturrechtlichen Staatstheorien 1880. - Ueber die allgemeine Situation s. A. Ehrhard, Das Mittelalter und seine kirchliche Entwickelung, 1908.

125) S. Cathrein II 373. „Selbstverständlich werden wir nur die Gesellschaften in den Bereich unserer Untersuchung ziehen, die sich aus der $\mathbf{N}$ a $\mathrm{t} \mathbf{u}$ der Menschen notwendig ergeben und allein einer philosophischen Untersuchung fähig und bedürftig sind, weil sie allein eine von Natur bestimmte Aufgabe und Einrichtung besitzen. Bei den freien Gesellschaften kommen philosophisch nur die allgemeinen Rechtsgrundsätze in Betracht, die wir schon früher bei Besprechung der Verträge (s. oben $340 \mathrm{ff}$ ) dargelegt haben.e Sie werden geregelt nach den Vorschriften der Tugend der Gerechtigkeit. Dabei ist die Einhaltung der nicht gegen die Gerechtigkeit verstoßenden Verträge eine Pflicht de lege naturae. Das vereinfacht die katholische Gesellschaftslebre sehr und beseitigt von vorneherein eine große Menge des Materials, mit der die moderne Soziologie sich beschäftigt, um nicht naturrechtliche Normen, sondern empirisch begründete Allgemeinbegriffe der soziologischen Beziehungen zu finden. Die Zusammenziehung des Natürlichen und Normativen, wofür die stoische Lehre vom Naturgesetz und die christliche von der Vorsehung die Grundlage liefern, ist der entscheidende Grundgedanke. Darin berührt sich die katholische Soziallehre mit ihrem modernen Gegenpol, der biologischpsychologistischen Soziallehre (hierüber s. P. Barth, $\gg$ Die Philosophie der Geschichte 
lichen Sozialgebilde auseinander. Zwar lernte sie mit Hilfe der Stoa die letzteren aus einer Zentralidee, der Lex naturae, ableiten und insofern als gottgesetzt anerkennen; aber sie sah in ihnen doch wesentlich nur die durch die Sünde getrübte und entstellte Gestalt der Gesellschaftsordnung, die in Gewalt, Recht, Todesstrafe, Krieg, Privateigentum und Handel der eigentlichen Idee widersprach, und diese Züge zwar teils zur Bestrafung teils zur Disziplinierung der Sünde angenommen hatte, aber in ihnen doch zugleich durch Heidentum und menschliche Selbstsucht stark verdüstert war. Für das innerkirchliche soziologische Ideal kamen ganz andere Dinge in Betracht, die Autorität des Priestertums und die Erlösungsmacht der Sakramente, die Selbstheiligung, Selbstverleugnung und Hingabe an die Kirche, die kein Recht und keine Gewinnsucht kennende Liebe. So blieb beides geschieden, und die theoretische Identifikation der Lex naturae mit der Lex Mosis bezog sich doch mehr nur auf die Einheit des absoluten urständlichen Naturrechtes mit dem jüdisch-christlichen Gesetz, gab nur die allgemeine Gewissensberuhigung über das Recht der außerkirchlichen Sozialbildungen, aber kein Mittel. sie in ihrer konkreten gegenwärtigen Gestalt zu übernehmen und anzuerkennen, es sei denn durch Duldung und Ergebung in den sündigen Weltlauf und in dessen bis zum Weltende festgewordenen Formen. Daher ging beides praktisch doch niemals zu eincr Einheit zusammen. Daher war es auch theoretisch unmöglich aus rt: soziologischen Grundidee des Christenglaubens heraus dice Ge hill:.: zu begreifen und zu regulieren. Hier sind insbesondere die Srhu ankungen Augustins charakteristisch, der auf der cinen Seite den Gedanken der aufsteigenden Zweckreihen und der Benitzung des Irdischen für das Himmlische ausbildete, und der dann andercrseits in seiner Sünden- und Prädestinationslehre doch wieder das natürliche Gesellschaftsleben, wie es tatsächlich war, radikal verwarf und verurteilte, ohne aber darum etwa cinen neuen ideegemäßen Aufbau der Gesellschaft zu fordern. Eine einheitliche christliche Sozialphilosophie war so unmöglich; eine in dic I.chre

als Soziologies I 1897 ), der gleichfalls das Naturnotwendige das Normalw: ist, nur daß im einen Fall die Natur aus dem Normativen und im anderen das $N$ rnative aus der Natur interpretiert ist. Der moderne erkenntnis-theoretische Ilealismus dagegen schafft mit seinen Grunduntersuchungen über das Verhältms de: Vatürlichen und Normativen, des Psychologischen und des fitiligen iiberhaupt andere Grundlagen der Sozialethik, vgl. Tönnies, Ethik und Sozialismus, Archiv XXV

Troeltsch, Gesammelte Schriften. I. 
von der Kirche und die von der Lex naturae gespaltene Sozialphilosophic aber vertrug sich nicht mit dem Anspruch der christlichen Idee, alles aus ihrem absoluten Lebenswerte zu begreifen und das daraus nicht Begreifliche zu verwerfen. So blieb hier der volle Widerspruch.

Die hochmittelalterliche und insbesondere die thomistische I.ehre konnte und mußte dagegen eine einheitliche Sozialphilosophic konstruieren, weil sie von dem Gedanken der Tatsächlichkeit und Gefordertheit einer christlichen Einheitskultur ausging. Wie sie zu dicser Voraussetzung als cincr selbstverständlichen praktisch kommen konnte, wie sie diese Voraussetzung auch theoretisch aus dem Begriff der Zweckstufen konstruicrte, ist im Bisherigen gezeigt worden. lintscheidend ist für sie die neue Auffassung des Naturgesetzes, bei dem der Unterschied zwischen dem absoluten Urstand und dem relativen Sündenstand zurücktritt, über dem Charakter der Zerstörung und Strafe der der Heilung und positiven Fimporleitung betont wird. Auch ohne Sündenfall würden die menschlichen Sozialbildungen eingetreten sein, nur im Geiste der liebe und freiwilligen Ueber- und Unterordnung, ohne Widerstand der Sinnlichkeit gegen die Vernunft und darum ohne Schmerzen und Leciden. Aber sie würden abgesehen von dieser andern Gesinnungsbegründung faktisch doch den tatsächlich entstandenen recht :̈hnlich sresehen haben. Das Naturgesetz ist eben nicht mohr identisch mit dem christlichen Gnadengesetz und dem stoischen soldenen Zcitalter, sondern nur natürliche Vorstufe und Vorform Wr mystischen Gnadengemeinschaft, die im Sinne der aristotelischen linuwickelungslehre als Auswirkung des Vernunftriebes am natürlichen Stoff verstanden wird ${ }^{126}$ ). Es hat darum naturgemäß

1"B) Vis. Wemer Il $460 \mathrm{f}$. und i a 2 ae qu. 96 art. 3 . wonnch auch ohne Sündenfall sich eine natürliche Lingleichheit der Menschen in Beziehung auf geistige und kürperliclie Eigenschaften ausgebildet und zu natürlich notwendigen I Ierrschaftsverhältnision geführt hätte. Am auffallendsten ist die Veränderung gerade bei den heiden dicsen Zusammenhang ron Alters her beherrschenden Frundproblemen des Eigrntums und der Sklaverei. Hier hatte die alte Kirche mit der Stoa fast lurch fchend das Privateigentum und die Sklaverei für das reine Naturrecht absolut concint und beides lediglich auf Rechnung der Sünde als Strafe und Heilmittel gesetza. I begeren ist num aber Thomas seneigh, dem Aristoteles folgend, beides unter

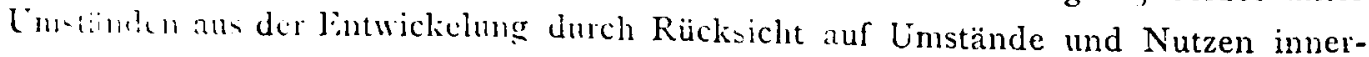
halh scuince Grenzei auch rom rcinen Naturrecht her ohne Rücksicht auf den siindentall an rechtfertigen. Fs diene der menschlichen Entwickelung, wenn aus 
Mängel und Schranken und Aeußerlichkeiten, an denen man sich nicht stoßen darf, und es wird darum auch in seiner getrübten und relativen Gestalt beziehbar auf die Gnadensittlichkeit ünd die Kirche. Es bezieht sich seinem Wesen nach auf irdische Wohlfahrt und auf Gott nur als auf das natürlich erkennbare Prinzip der Ordnung und Harmonie. Es braucht daher Pädagogik und Disziplin, Gesetz und Regel, menschliche Anwendung und Ausbildung der Prinzipien ${ }^{127}$ ). Das Reich der Natur wird zur Vorhalle des Reiches der Gnade ${ }^{128}$ ). Damit aber tritt ein beiden

dem ursprünglichen negativen Kommunismus der freien Okkupationsmöglichkeit das Privateigentum entstehe; nur seine besonderen Formen sind durch den Sündenstand bedingt, wie ja auch die Erlösung es wieder wenigstens zum allgemeinen Gebrauch durch die Liebespflicht frei mache, s. Janet I $374-377$ und 2 a 2 ae qu. 57 über natirliches und positives Recht und qu. 66 art. 2 über Privateigentum. Aehnlich, wenn auch zurückhaltender, urteilt er über die Sklaverei; in den Expositiones, dem Kommentare zur aristotelischen Politik folgt er ohne Widerspruch der aristotelischen Begründung der Sklaverei aus der natürlichen Ungleichheit, in der eigenen Ausfuthrung Summa I qu. 96 art. 3 und 2 a 2 ae qu. 57 a. 3 erklärt er als naturrechtlich und ohne Sünde notwendig die Herrschaftsverhältnisse überhaupt; das Sklavenverhaltnis dagegen als Strafe der Sünde, unter den Bedingungen der Sünde aber als durch den Nutzen des Sklaven wie des Herm berechtigt. Daneben aber wird dann doch wieder die Sklaverei auf das Völkerrecht (Kriegsgefangene) zurückgeführt, das ein die konkreten Umstănde berücksichtigendes Naturrecht ist ohne Nebengedanken an die Sünde. S. Janet 377-379; zu beidem auch Maurenbrecher, der mit Recht bei der Lehre von der Sklaverei die Widersprüche, bei der vom Eigentum die Abweichung von der alten patristischen Lehre stark hervorhebt. Bezüglich des dritten Hauptproblems des Dominiums, der politischen Herrschaft, ist aus dem obigen klar, daß es auch für das reine Naturrecht sich von selbst verstand und versteht; nur die besondere Form der königlichen Zwangsgewalt ist Folge der Sünde, aber als Heilmittel gegen die Sünde gerechtfertigt, Janet I 398 und De reg. princ. II 8 und $1 \mathrm{I}$.

127) Die Grenzen des Naturgesetzes im absoluten wie im relativen Stande als Gesetz des Gebotes und der innerirdischen Zwecke, worin es mit dem mosaischen ubereinstimmt, gegenüber dem evangelischen Gesetz der Freiheit, der Liebe, und des übernatürlich-mystischen Zweckes s. I a 2 ae qu. 107 und 108. Die beiden Gesetze können unterschieden werden secundum quod una propinquius ordinat ad finem, alia vero remotius: puta in una eademque civitate dicitur alia lex, quac imponitur viris perfectis, qui statim possunt exequi ea, quae pertinent ad bonum commune; et alia lex datur de disciplina puerorum, qui sunt instruendi, qualiter pustmodum opera virorum exequantur qu. 107 art. 1 ; auch hier die Entwickelungsidee.

120) Der ganze Gedankengang der Ethik ist, daß das absolute Ziel der beatitudo oder visio dei excedens facultatem creaturae nur erreicht werden kann durch 
gemcinsam übergeordneter Zweckzusammenhang hervor und mit diesem Zweckzusammenhang auch ein beiden gemeinsames, in den beiden Sphären nur modifiziertes soziologisches Grundschema. Von diesem Grundschema kann und muß eine einheitliche Sozialphilosophie ausgehen, die nicht mehr mit verschiedenen Voraussetzungen für die Kirche und für die Welt, sondern mit einem eine vorausgehende Selbstbearbeitung und Verdiensterwerbung aus natürlicher Vernunft oder aus dem Naturgesetz. Diese natürlichen, von der den Menschen erteilten Freiheit bewirkten und an der planmäßigen Weltbearbeitung Gottes die Menschen beteiligenden, im letzten Grund aber wieder auf göttliche Vernunftimpulse zurückgehenden Verdienste sind die Disposition und Vorbereitung, auf Grund deren lie Gnadentugenden erst eingegossen werden können. So kommt aber auch die gaize Vorbereitung unter die Leitung des religiösen Endzweckes und damit der Kirche, und, indem diese Vorbereitung von der Lex naturae bewirkt ist, auch all das in dieser Lex Enthaltene. Das aber ist der ganze Umfang weltlicher Tätigkeit; I a 2 ae qu. 94 a. 2: das erste ist die Selbsterhaltung mit allem, was dazu gehört. Das zweite sind die geschlechtlichen Verbindungen und Aufzucht der kommenden Generation. Sind diese beiden den Menschen mit allen Kreaturen gemein ex lege naturae, so ist das dritte der lex naturae der Menschen eigen, nämlich die Erkenntniszwecke und die sozialen Verbindungen der Menschen. Indem all das auf den absoluten Zweck bezogen wird, wird es auch auf die Kirche bezogen, und es ergibt sich so ein doppelter Begriff der Kirche, die Kirche im engeren Sinne als die sakramental-hierarchische Erlösungsanstalt und die Kirche im weiteren Sinne als die res publica Christiana oder Corpus Christianum oder regnum Christi, d. h. als der Inbegriff der vom absoluten Gnadenzweck formierten Lebensbeziehungen. Treffend Feugucray S. 31: Partout la grâce vient se joindre à la nature, non pas pour la détruire, mais pour s'ajouter à elle et pour l'élever en la dominant. Cette capitale distinction se retrouve également en politique. Outre la politique rationelle et philosophique et au dessus d'elle il y a politique théologique, qui vient, non pas la renverser, mais en modifier les conclusions et lui donner un nouveau charactère. L'ordre naturel des sociétés humaines se complète et s'achève ainsi dans l'ordre surnaturel.* Thümes S. 24 zitiert aus dem Boethius-Kommentar: $\gg$ Nec solum in spiritualibus, sed etiam in usu corporalium dirigit religio christiana et beatitudinem animae et corporis repromittit. Et ideo regulae ejus universales dicuntur, utpote cotam vitam hominis et omne, quod ad ipsum quolibet modo pertinet, et continentes et ordinantes. « Dabei ist ausdrücklich zu betonen, daw̉ der Ausdruck spolitisch « stets alles Soziale überhaupt und keineswegs nur das Staatliche meint, wie Thomas in Erklärung der neuplatonischen Stufenfolge von virtutes purgati animi, purgatoriae et politicae sagt: -Est enim considerandum, quod ad politicas virtutes, secundum quod hic dicuntur, pertinet non solum bene operari ad commune, sed etiam bene opcrari ad partes communis sc. ad domum et aliquam singularem personam . Thömes 72. Leber den doppelten Kirchenbegriff und das regnum Christi s. Meyer $65>$ Von diesem standpunkte aus wird nun auch der sittliche Naturorganismus der menschlichen 
axiomatischen Grundideal aller denkbaren und möglichen Sozialbildungen rechnet und das der Kirche zu Grunde liegende Schema auch auf die außerkirchlichen Gebilde in abgestufter Weise anwendet. Erst so kann von einer einheitlichen christlichen Soziallehre gesprochen werden, die auch die außerreligiösen Sozialbildungen aus dem der'Kirche selbst zu Grunde liegenden soziologischen Ideal ableitet, beurteilt und formt. Erst so kommt es zu dem Hochgefühl, daß erst die Kirche den Schlüssel aller sozialen Erkenntnisse und das Heilmittel aller sozialen Nöte in ihren Händen trage, wie es die modernen Thomisten angesichts der heutigen sozialen Krisen und der Wirren des heutigen Lebens stets von neuem triumphierend verkünden. Aber eben damit ist auch deutlich, daß diese rettende Soziallehre des Christentums ein seh.

Gesellschaft betrachtet und als ein herrliches Glied, zugleich mit dem übernatürlichen Gesellschaftsorganismus der christlichen Kirche und als unzertrennlich mit diesem verknüpft, in jene großartige Weltharmonie eingefügte. Dazu De reg. principum I 12. Aehnlich S. 34 ,Wer immer an soziale Reformen Hand anlegen will, muß sich wohl bewußt sein, daß er einen doppelt heiligen Tempel betritt. Er ist geheiligt durch die grundlegende Natur, wieder geheiligt durch die göttliche Hend des Welterlösers, der auf und uber diesem Naturgrund sich als den - auch in sozialer Beziehung - zweiten Adam, als das regenerierende Prinzip der gesamten sozialen Struktur aufgestellt hate. Ferner Thomas, Summa III qu. 8 art. 1 und 2 . -Genus humanum consideratur quasi unum corpus, quod vocatur mysticum, cujus caput est ipse Christus et quantum ad animas et quantum ad corporac. Weitere Stellen bei Gierke III 5 18: > Unzählige Male verwenden Theologen und Kanoniker das Wort ecclesia im Sinne des die weltliche Ordnung einschließenden Menschheitsreichese. Vinc. Bellovacensis spricht von duo latera corporis unius. Aus der Summe des Stephan Tornacensis: In eadem civitate sub uno rege duo populi sun et secundum duos populos duae vitae, duo principatus, duplex jurisdictioniv ...lo procedit; die civitas ist die ecclesia, der König Christus, die Vïlhrı kleill und Laien, die Lebensordnungen die geistliche und weltliche, die principatus stmi - tiet dotium und regnum, die Rechtsgebiete das divinum und humanum. Zugleich wird dabei allgemein an die geistige und leibliche Seite des Menschen angeknüpft und der jenseitige und diesseitige Lebenszweck als Ziel der beiden Ordnungen unterschiedene. "Der mittelalterliche Geist ist mit sich einig, daß der Dualismus kein endgültiger sein kann, daß vielmehr die Gegensätze ihre Aufhebung in einer hüheren Einheit finden müssen. Stellen über dieses ad unum reduci, die ordinatio ad unum, die unitas principii und über die Begründung dieser Forderung mit der Einheit und Absolutheit der alles umfassen müssenden christlichen Lebenswertung s. S. $519 \mathrm{f}$. Das ist ubrigens auch die Voraussetzung der staatlichen, antikurialistischen Gesellschaftalehre, die nur innerhalb des Systems eine freiwillige Konkordanz statt einer von der Kirche absolutistisch geleiteten fordert, Gierke III 537-539. 
kompliziertes geschichtliches Produkt ist und nichts weniger als leicht und einfach aus den christlichen Grundideen selbst hervorgeht. Erst umfassende wissenschaftliche Anleihen bei der Antike und tiefgreifende faktisch-geschichtliche Entwicklungen haben die universalc s christliche Sozialphilosophie * ermöglicht ${ }^{129}$ ).

Dic Komplikationen, Anleihen und tatsächlich-historischen Bedingtheiten sind aus dem Bisherigen klar geworden. Nun handelt es sich darum, den Sinn und Inhalt jenes jetzt herausgebildeten und den übrigen Bildungen zugleich mit $z u$ Grunde gelegten $c h r$ is tlichen soziologischen Grundschemas zu erkennen. Was ist das soziologische Grundideal der christlichen Soziallehren, das von der Kirche her auch den außerkirchlichen Sozialbildungen erst zu ihrem vollen Wesen und Geist verhilft und damit das gesamte menschliche Gemeinschaftsleben auf gewisse Grundgefühle und Normen stimmt? Was ist der "Geist " des christlich-katholischen soziologischen Denkens überhaupt, durch den es sich als General-Heilmittel für aile sozialen Schäden bis heute und heute erst recht empfiehlt? ${ }^{130}$ ) Hier werden wir in der Tat wesentlich christliche Ideen hervortreten sehen, aber auch hier geht es nicht ab ohne starke

1:9) Das zeigen sehr charakteristisch die historischen Partien von Ratzingers - Volkswirtschafı «, der an die evangelische Predigt Jesu eigentlich nur indirekt anknüpft, indem aus der Gottmenschheit Christi die Heiligung des Menschlichen und aus seinem Zimmermannsberuf die Heiligung der Arbeit und W irtschaft abgeleitet wird! Vor allem muß das Wort et cetera adjicientur vobis herhalten. Wirklicher Anschluß ist auch nach R. eigentlich erst an Paulus möglich. Auch die Patristik liefere bei ihrer Bedingtheit durch eine ganz in Luxus und Pauperismus verkommene Gesellschaft nur erst sehr unvollkommene und einseitige Regeln. Erst das Mittelalter sei die klassische Zeit, zu der nur ein ssehr langer Weg « hinfü hrte, und zu der die Gegenwart unter Aufrechterhaltung der großen kapitalistischen Produktionsfortschritte zurückkehren soll, indem diese durch staatliche Regelung nur der wirklich produktiven Arbeit zugute kominen sollen.

$\left.{ }^{130}\right)$ Das Bewußtsein um den Besitz eines solchen Grundschemas als Panucee aller sozialen Schäden charakterisiert die neuthomistische Literatur, s. Meyer S. 5: - Die politischen Fragen sind solidarisch mit den sozialen verwachsen. Diese Solidarität liegt aber viel tiefer, als man vielfach anzunehmen gewohnt ist. Sie ruht keineswegs auf der Oberfläche der äußeren Wechselwirkungen der beiden so eng verbundenen Gebiete. Ihr wahrer und einziger Grund ist kein anderer als die anteilbare Einheit der gesamten sittlichen Weltordnung. $\therefore$. 5: Die Lösung der sozialen Fragen vollzieht sich auf der Grundlage seiner unwandelbaren-und heiligen Prinzipien, welche die natürliche Basis bilden für den gesamten gesellschaftlichen Organismus . S. 6: Die unwandelbare Idee und die 
Anleihen bei der idealistischen antiken Spekulation und allerhand verschiedenartige weitere Einflüsse.

Das Evangelium hatte ein soziologisches Grundschema entwickelt, das man als radikalen religiösen Individualismus und religiösen Liebesuniversalismus bezeichnen kann. Daraus ging aber weder eine eigene religiöse Organisation noch eine Norwesentliche Grundlage der sozialen Struktur«. S. 7: Die Fâhne unverletzlicher und gesunder Prinzipien ... ist durch die Kirche und ihre priesterlichen Organe die berufenen Sittenlehrer und uneigennützigen Ratgeber des christlichen Volkes, hochzuhalten«. S. 9: sottes Wahrheit, die innere Harmonie und Ordnung, d. h. das ewige Gesetz von Sitte und Recht... ist ihre (der Gesellschaft) natürliche Lebensbedingung $\alpha$. S. 23 : Die $W$ ah $r$ heit und die unatänderliche Notwendigkeit eines sittlichen Prinzipse. S. 28 : DDie Gesetze de: sozjalen Daseins «. - Gierkes Genossenschaftsrecht III. hat seinen tigentlichen Höhepunkt in der Aufweisung eines solchen Grundschemas, S. 510: - Dic Entwickelung der romanistisch-kanonistischen Korporationstheoric berülirte sich in vielen Punkten mit den Bestrebungen des mittelalterlichen Geistes, $K i_{i} \mathrm{ch}$ e und Stat in ihrer Gesamterscheinung prinzipiell zu crfassen und so das Wesen der menschlichen licsellschaftsordnung übchaup wissenschaftlich zu begreifen. In ihren Anfängen bis zu den Zeiten des grr,lien Investiturstreites zurückreichend, brachten es diese Bestrebungen doch crst im 13. Jahrhundert zu einer geschlossenen publizistischen Theorie. Von da an ununterbrochen fortgebildet und entfaltet, waren die publizistischen L.chren zingleicli die Trägerinnen der ersten selbständigen Staats- und Rechtsphilosophie. Ind gerade hierdurch führten sie eine vollständig neue Macht in die Geschiclice dur Rechtsbegriffe ein. Dieses Resultat wurde einer gemeinschaftlichen Arbeit verschiedener Wissenschaften verdankt. Theologie und scholastische Philosophie, politische Historie und praktische Tendenzpublizistik trafen hier mit der zunft. mäßigen Jurisprudenz auf dem gleichen Felde zusammen. So ungleicharting aber Ausgangspunkte, Ziele und angewandte Hilfsmittel waren, die mittelalterliche $W_{1}$...... schaft bewahrte hier wie überall eine weitreichende Einheit und Cemeinsamkeit. Denn zunächst stand man .. auf dem Boden einer gemeinsamen Weltanschauunu, deren oberste sätze dem mittelalterlichen (jeiste nicht als Fund, sondern als geoffenbarte Voraussetzung menschlicher Wissenschaft galten. Sodann aber enilehinte man von allen Seiten einander bereitwillig dasjenige, was man brauchte.. Auf diese Weise wurden Elemente von verschiedenster Herkunft zu einem 5 y $\$ 1$ em verbunden: I. Die heilige schrift und ihre Auslegung. 2. Dic Patristik und vor allem der Gottesstaat des Augustinus lieferten die spezifisch christlichen Zïge der mittelalterlichen (jesellschaftslehre. 3. Aus der mittelalterlichen Ficschichtsage und den durch sie bedingten volksmäßjigen Anschauungen floßen ilır dic eigentümlich germanischen Vorstellungen zu. 4. Die Wiederbelebung der antiken Staatsphilosophie und vor allem die zum unumstößlichen Kanon gewordene Politik des Aristoteles war von vorneherein jedenfalls für die wissenschaftliche Form der gesamten 
mierung der außerreligiösen Sozialbildungen unmittelbar hervor. Von Fall zu Fall, von Person zu Person wendete Jesus dieses Ideal an, im übrigen befahl er den Weltlauf dem himmlischen Vater, der mit dem Kommen des Gottesreiches das Ideal allgemein verwirklichen wird. Ueber das Wie? machte das Evangelium sich überhaupt keine Gedanken. Erst aus dem Kult des Auferstandenen ging eine neue Religionsgemeinde hervor, die den Individualismus und Universalismus Jesu in dem Gedanken einer Kultgemeinde zusammenfaßte und in dieser Gemeinde jedem Individuum religiöse Gleichheit und innigste Verbundenheit mit dem anderen gewährte. Indem sie aber mit Dogma, Priestertum, Sakrament in sich selbst starke. Unterschiede ausbildete, konnte sie das Ganze nur zusammenfassen in dem Gedanken eines solidarischen Organismus, innerhalb dessen jedes Glied seine Ehre und seinen Zweck hat und doch auch jedes Glied sich in die ihm zukommende Funktion für das Ganze fügen muß. Hierfür hatte schon Paulus die berühmte und dauernd wirksame Formel geprägt. Nach innen in ihrem eigenen Wesen wird die Kultgemeinschaft zu einem verschiedene Stufen und Funktionen umfassenden, aber doch alle am Zweck und Sinn des Ganzen solidarisch beteiligenden $\mathrm{O}$ rga $\mathrm{n}$ is $\mathrm{mu}$ s. Die Geltung des Individuums, die Verbundenheit zu einem überindividuellen Ganzen und die Einverleibung verschiedener Stufen und Funktionen oder innerer Gliederungen in die Idee des Ganzen sind damit ausgedrückt. Andererseits ragen in die Gemeinde die verschiedenen Differenzierungen, Erschwerungen und Begünstigungen hinein, die durch die Zugehörigkeit zu den außerkirchlichen Sozialgebilden und durch natürliche L'nterschiede bewirkt werden. Diesen Differenzen begegnete die christliche Sozialidee von Anfang an mit dem Gedanken des Liebes-Patriarchalismus, der freiwilligen Fügung und Ergebung in diese Unterschiede, die von den einen zur Fürsorge und Hingebung für die tiefer Stehenden, von den andern zum Vertrauen, Geduld und Demut gegenüber den höher Stehenden genutzt werden sollen, um gerade in diesen willigen Leber- und Lnterordnungen eigentümliche ethische Werte der gegenseitigen persönlichen Bezogenheit hervorzubringen. Auch hier ist

Lehre mafgebend. 5. Und zu allen diesen Quellenkreisen fügte die Jurisprudenz das uigeheure positiv-rechtliche Material, welches im römischen und kanonischen Recht und z. T. in neuerer Kirchengesetzgebung aufgespeichert wars. Das Wesen der so konstruierten Gesellschaftsordnung ist für Gierke die sorganische Idees; dem Patrarchalismus nidmet er keine besondere Beachtung. 
Paulus mit seinen Formeln vorangegangen. B e ides $\mathrm{n} u \mathrm{n}, \mathrm{d}$ i e Ide e des Organismus und des Patriarchalismus, wird vonder mittelalterlichen Soziallehreals Sinn des Grundschemas hervorgeholt und als sein eigentlicher, Geist*entwickelt.

Der mächtige ständische Ausbau der Kirche des Mittelalters mit ihren Ständen der Kleriker, der Mönche und der Laien, wobei wiederum der Klerus außerordentlich reich in Stufen gegliedert ist, sowie der gleichzeitige ständische Aufbau des gesellschaftlichen Lebens vereinigen sich zu dem Gedanken eines in Ständen und Gruppen gegliederten Organismus überhaupt. Das Corpus mysticum mit seinen Diensten und Pflichten, aber auch Ehren und Notwendigkeiten der einzelnen Glieder für das Ganze wird zum Schema des Gesellschaftsbegriffes an sich, und jeder Gesellschaftskreis wird als corpus morale et politicum oder als corpus mysticum bezeichnet, womit die Bezeichnung der Einzelnen als Glieder in einem organischen Ganzen stets gegeben ist ${ }^{181}$ ). Zugleich

181) Vgl. hierzu Thomas, Contra Gent. III 16-25, der Weltorganismus mit der Verordnung alles Seienden überhaupt auf Gott als Ziel, III 112-12I, der Zusammenhang der den Menschen gegebenen Leges in einem organisch auf das oberste Ziel der Gottesliebe gerichteten Ganzen; über den Ausgangspunkt und Typus der organischen Denkweise im Corpus mysticum Christi Summa III qu. 8 und vor allem die Auslegung der das organische Gleichnis darbietenden Paulusstellen Röm. 12 und I. Cor. 12. In epist. ad Romanos c. XII lectio II und ad Corinth I c XII lectio I 73 . Die Anwendung der organischen Idee im platonischaristotelischen wie im biblischen Sinne auf die menschlichen Gesellschaften uberhaupt und den Staat insbesondere De reg. princ. I c. 1-3, 12. - Vortreffliche Darstellung bei Gierke, Genossenschaftsrecht III und Althusius: die allgemeine Idee des Organismus der Welt, der Menschheit, der einzelnen Teilgesellschaften, der Kirche, des Staates, der Familie und aller dazwischen gelagerten Gesellschaftsgliederungen nach dem Vorbild des beseelten Universums, des Verhältnisses von Leib und Seele, des tierischen Organismus, des platonischen Mikrokosmus, wonach der Makrokosmus des Staates der Mensch im Großen ist, und nach der spezifisch aristotelischen Lehre von einer besonderen Kategorie des aus der Vernunft fließenden, bestimmte Zwecke verwirklichenden, formenden Kollektivwillens s. Gierke III 514-517; der Gliederungen in diesem Organismus auf Grund der naturgesetzten Ungleichheit und der daraus entstehenden Arbeitsteilung mit Beziehung jedes Gliedes auf den Gesamtzweck III 553-556. Vortreff liche Zusammenfassung bei Althusius S. 60-62. Aehnlich, wenn auch weniger vollständig bei Maurenbrecher S. 29-38. M. betont, daß die Begründung der Notwendigkeit des Gesellschaftsorganismus trotz der uußeren Anlehnung bei Thomas eine andere ist als bei Aristoteles; bei dem letzteren ist es das Streben der Vernunft, die nur in der politischen Gemein- 
aber ist eine derart willige Aufeinanderbeziehung aller dieser Teilc und Glieder, die in einzelnen Fällen rein durch Gewalt ihre Stellung haben, die einen großen Bestandteil prinzipieller Unfreiheit enthalten und doch zugleich durch die Idee eines kastenartigen Traditionalismus in ihrer I age erhalten werden, nur möglich durch starke Betonung der patriarchalischen Ideen. Dieser Patriarchalismus wird zwar in den meisten Darstellungen des katholischen Sozialideals nicht besonders hervorgehoben. Iir scheint schaft zur Vollbetätigung kommt und in dieser Sclbstbetätigung der Gemeinschaftsvernunft die Eudämonie des Menschen erst vollendet; bei Thomas ist der Grund die Notwendigkeit der Arbeitsteilung und der Frgänzung der Berufe und Erwerbe, dic wiedcrum gerade für Aristoteles keine Rolle spielt. M. erkennt darin eine anderc Orientierung des organischen Gedankens als bei Aristoteles und leitet sie von den unwillkïrlich vorschwebenden Bild der ständischen ';liederung des Mittelalters als. Dic thomistische Dcutung wärc in den Augen des Aristoteles hellste Hanausie. Das ist gewif richtig, aber nicht das Wichtigste. Das eigentliche Vorbild ist das Corpus mysticum der Kirche, das nach den bekannten paulinischen Cleichnisse seine verschiedenen Stände und Berufe als sich ergänzende Arbeitstcilung darstellt. Auf diesem Wege vor allem, durch Konformierung mit dem Gedanken des Corpus mysticum, ist die organische Anschauung eines in seinen Gliedern sich ergänzenden arbeitstciligen (janzen auf die Gesellschaftslehre überhaupt iibertragen; heißen doch alle organischen Kollektivkürper nach diesem Vorbild geradezu teclmisch corpora mystica und wird die Gliederung auch dieser weltichen corpora mystica geradezu als Hierarchic bezeichnet; s. die Stellen und Ausführungen bei Gierke III 518, 546-553, Althusius 132-135, $227 \mathrm{f}$. Dabei ist für den organischen Charakter die Entstehungsweise, ob durch Gewalt, durch Vernunfttrieb oder durch Vertrag, verhältnismäßig gleichgiiltig, da in alledem doch Gott als die causa remota wirkt und auch insbesondere die vertragsmäßjige Entstehung nur durch die von Gott geleiteten Vernunftriebe der sich einigenden Gruppen bedingt ist und auch die Gewalttat unter der Leitung der Vorsehung steht. Siehe Gierke III 568-581, 556, Althusius 63, 66. Das Entscheidende ist, daß die von verschiedenen (Qucllen her verschieden inspirierten Anschauungen über die faktische Entstehung der Gesellschaften sie doch ihrem Wesen nach immer in die Idee des Orsanisinus und seiner göttlichen Vernunftnotwendigkeit einmünden lassen. Wo die Theorieen von der Entstehungsweise dagegen gegen die Idee des weltlich-geistlichen Organismus verselbständigt wurden und $z u$ davon abweichenden Folgerungen führten, da sing man auch von dem eigentlichen katholischen Ideal ab und geriet auf moderne Wege, sei es der Souveränitätslehre, sei es des demokratischen Naturrechtes, wogegen dann wieder das echte thomistische Ideal seit den großen Staats- and Gesellschaftstheoretikern des 16 . Jahrhunderts mit einigen Modernisierungen erneuert wurde. S. Gothein, Staat und Gesellschaft des Zeitalters der Gegenreformation in s Kultur der Gegenwarte II 5. - Außerdem s. die knappe, aber lehrreiche Darstellung bei Th. Meyer 28-70 und Cathrein II 373-379. 
mit der organischen Idee als solcher gegeben zu sein, die ja auch von sich aus die Verschiedenheit der Gruppen und Dienste betont und damit ein gegenseitiges Sichineinanderfügen der organischen Ungleichheiten fordert. Allein aus der organischen Idee folgt doch nur dic Arbeits- und Diensteverteilung überhaupt und $z$ war als eine rationelle, notwendige und harmonische. Aber neben den durch die Idee des Organismus geforderten Ungleichheiten gibt es solche, die über den Zweck der harmonischen Ergänzung der Glieder durch einander weit überschießen, die rein von der Uebermacht der Gewalt, rein von der Willkür des positiven Rechtes und der Privilegierung oder vom Zufall der Natur geschaffen sind; es gibt die Verschiedenheiten der Anlage und des Schicksals, die nur aus cinem verborgenen und rationell nicht zu erklärenden Willen Gottcs abzuleiten sind. All das vereinigt sich in dem Begriffe des Patriarchalismus und wird von ihm lediglich innerlich-ethisch überwunden. Weiterhin schießen auch die beständigen Mahnungen an die Herrschenden zur väterlichen Fürsorge und Liebe, sowie die Mahnungen an die Lntergebenen und Untergeordneten zur Demut und Dankbarkeit über die Forderungen hinaus, welche die bloße organische ldee im Interesse der gegenseitigen Harmonie erheben müßtc. Die Forderungen sind daher auch stets mit Bibclstellen, besonders mit Paulus und der alttestamentlichen Spruchwcisheit begründet. Klassisch dargestellt ist diese Idee in dem Typus der liamilie, und von hier aus ist sie auf das Ganze übertragen, wie die Idee des Organismus vom Corpus mysticum der Kirche her auf die übrigen Sozialbildungen ausgebreitet worden ist. Schon in der altkirchlichen Ethik war die Mannesherrschaft in der Familic über Frau und Kinder und die willige Unterordnung der I Familienglieder wie der Dienstboten unter die hausväterliche Gewalt das Urbild sozialer Bezichungen, waren die Tugenden des Gehorsams, der freien Selbstüberwindung, der Pietät und hingebenden Liebe für die letzteren, die Tugenden der Fürsorge, Aufopferung, Verantwortungsbereitschaft für die ersteren als Grundtugenden der engsten und innerlichsten menschlichen Beziehungen gepriesen. Das bleibt auch für die mittelalterliche Familie, in der aus dem germanischen Altertum gleichfalls die Mannesherrschaft als Nachwirkung der alten militärischen Organisationen im stärksten Grade hereinragt, ja geradezu hinter die bereits erreichten und der altkirchlichen Familienlehre zu Grunde liegenden römischen, hellenistischen und jüdischen 
Milderungen zurückgeht. Auch hier milderte das Christentum diese Herrschaft nur durch seine Lehre von der Freiwilligkeit und Liebe von innen heraus und verselbständigte es nur durch die Freiwilligkeit der Unterordnung einerseits, durch die Fürsorgepflicht andererseits die Individuen innerlich gegeneinander, indem es die Ueberund Unterordnungsverhältnisse äußerlich bestehen ließ, wenn auch mit erheblichen und immer steigenden Sicherungen für die individuelle Persönlichkeit der Frauen, Kinder und Dienstboten. Aus dem Patriarchalismus der naturhaften Gewalt wird der Liebespatriarchalismus der freiwilligen Unterordnung und der Fürsorgepflicht. Damit werden dann freilich auch die Beziehungen selbst gemildert und humanisiert. Von der Familie aus als dem Ur. schema menschlicher Beziehungen wird dieses soziologische Ideal auf alle Ueber- und Unterordnungsverhältnisse überhaupt übertragen. Die Christenheit ist, wie immer wiederholt wird, eine große Familie, in der die familienhaften Tugenden alle die unendlich verschiedenen Gegenseitigkeitsbeziehungen ethisch heiligen und verkłären ${ }^{132}$ ).

132) Die patriarchalische Idee steckt überall in denjenigen Ausführungen über den Organismus, die sich an Paulus und das Corpus mysticum halten, während die an Aristoteles (und indirekt an Plato) sich anschließenden Ausführungen nur die sozialen Zweckmäßigkeiten und die Erfordernisse für die Einheit des Ganzen im Auge haben. Hier schlagen dann die paulinischen rein ethischen Gedanken durch, die nur die Ungleichheiten des realen Lebens mit der religiösen Gleichheit der Gotteskinder versöhnen und die ersteren ethisch überwinden, aber keine organische Gesellschaftstheorie begründen wollten. Hier sind höchst charakteristisch die schon genannten Auslegungen von Röm. I2 und I Cor. 12. Den Ausgangspunkt solcher Betrachtungen bieten die Ungleichheiten der Menschen, die für Thomas zum Wesen des Menschen gehören. Sie sind einerseits mit der Idee des Organismus und der Arbeitsteilung gesetzt, aber sie haben noch weitere Gründe. I) greift auch bei Thomas der unerforschliche göttliche Wille ein, der die Menschen nicht, wie die untermenschliche Welt als einheitliche Gattungswesen, sondern als Individuen mit in jeder Person besonderer Bedeutung gesetzt hat und außerdem durch Prädestination und Vorsehung unter ihnen wesenhafte Unterschiede setzt: Contra Gent.III c. I03 Sola creatura rationalis dirigitur a Deo ad suos actus non solum secundum speciem, sed etiam secundum individuum. Aber die hierbei sich ergebenden Unterschiede sind trotz der Beteiligung des Menschen an der Weltregierung Gottes durch seine Vernunft doch selbst bedingt durch die göttliche Vorsehung: Participat rationalis creatura divinam providentiam non solum secundum gubernari, sed etiam secundum gubernare. . Omnis autem inferior providentia divinae providentiae subditur quasi supremae. Gubernatio igitur actuum rationalis creaturae, inquantum sunt actus personales, ad divinam providentiam pertinet. Das ergibt aber starke Unter- 
Organismus und Patriarchalismus sind derart die Begriffe, in denen sich das Grundschema darstellt. Dabei hängen beide Ideen unter einander eng zusammen. Sie sind beide aus dem schiede: Lectio III ad Cor. I 12 : Etsi membrorum distinctio sit opus naturae, hoc tamen agit natura ut instrumentum divinae providentiae. Daher sagt Paulus unum quodque eorum in corpore; aber Paulus fügt hinzu et, sicut voluit, posuit Deus membra diversa, wozu Th. bemerkt : Nam prima causa institutionis rerum est voluntas divina secundum illud Psalm I 33 >omna quaecunque voluit fecite. Sic autem et in Ecclesia disposuit diversa officia et diversos status (das begreift die weltlichen Glieder mit in sich) secundum suam voluntatem; unde et Ephes. I I I dicitur spraedestinati secundum propositum ejus, qui operatur omnia secundum consilium voluntatis suae. Dabei ist im Auge zu behalten, daß Thomas sich streng zur Prädestination bekennt; den freien Willen für eine Form der Ausführung des Gotteswillens und das Böse für einen defectus erklärt: Contra Gent. III 402 : necesse est praedictam distinctionem hominum ab aeterno a Deo esse ordinatam. Da ist ein reichlicher Spielraum des rein positiven göttlichen Willens auch in allen nicht bloß das Heil angehenden Dingen selbstverständlich, obwohl im Gottesbegriff die Vernunft dem Willen übergeordnet ist: hier liegt eine der dunkelsten Stellen im thomistischen System, das Irrationale ist weder im Gottesbegriff noch sonst wirklich beseitigt, obwohl das System sich möglichst rational gebärdet. 2) liegen die Unterschiede in der $\mathrm{N}$ a $\mathrm{t} \mathrm{u} \mathrm{r}$, was Th. überall da hervorhebt, wo er dem Aristoteles folgt: Illi qui intellectu praeeminent, naturaliter dominantur; illi vero qui sunt intellectu deficientes, corpore vero robusti, a n a tu ra videntur instituti ad serviendum unter Berufung auf Aristoteles und Proverbien. Diese natürliche Ungleichheit dient der Ordnung, welche erst verkehrt wird, wenn die natürliche Ungleichheit durch Sünde und Leidenschaft in eine unnatürliche verkehrt wird: inordinatio provenit ex eo, quod non propter intellectus praeeminentiam aliquis praeest, sed vel robore corporali dominium sibi usurpat, vel propter sensualem affectionem aliquis ad regendum praeficitur. . Hujusmodi autem inordinatio divinam providentiam non excludit, provenit enim ex permissione divina propter defectum inferiorum agentium, sicut et de aliis malis superius dictum est. Damit ist 3) die Begründung der eine gerechte Ordnung überschießenden Ungleichheiten durch den $S$ ü $\mathrm{n}$ de $\mathrm{n}$ f a ll berührt, die allenthalben wiederkehrt. Die letzte Ursache liegt 4) im positive n Recht, das in Regierungsform und ständischer Privilegierung je nach Umständen Unterschiede setzt, die in besonderen Lebensansprüchen, Ehrerweisungen und einer besonderen Quote der Anteilnahme am bonum commune ganz selbstverständlich zum Ausdruck kommt. Hierfür ist charakteristisch die Lehre von der justitia distributiva, die die Beteiligung der einzelnen differenzierten Gruppen und Personen an dem bonum commune der Gesellschaft regelt; s. Summa 2 a 2 ae qu. 61 a. 2 : in distributiva justitia datur alicui privatae personae, inquantum id, quod est totius, est debitum parti; quod quidem tanto majus est, quanto ipsa pars majorem principalitatem habet in toto. Et ideo in distributiva justitia tanto plus alicui de bonis communibus datur, quanto majorem illa persona habet principalitatem in communitate. Quae 
christlichen Grundgedanken, dem Gedanken der Gottes- und Menschenliebe, begründet und abgeleitet. Die solidarische Einheit des Organismus entspringt zunächst vom Gedanken der Ge-

quidem principalitas attenditur in aristocratica secundum virtutes, in oligarchica secundum divitias, in democratica secundum libertatem et in aliis aliter. Im Anschluß an Aristoteles wird diese Beteiligung am Gesamtgut als der Stellung proportional bezeichnet. Daher stammt aber auch die verschiedene Strafwürdigkeit von Vergehen gegen verschieden hochgestellte Personen; daher ist die verschiedene Behandlung des > Ansehens der Person $<$ vor Gericht nicht bloß nicht gegen die Gerechtigkeit, sondern sogar von der distributiven Gerechtigkeit gefordert, s. ebd. qu. 62 de acceptione personarum. Das Urbeispiel solcher durch Naturgewalt, sündige Verderbung, göttliche Ordnung und menschlich-positives Recht bedingten Herrschaftsstellung nebst der Ethisierung dieser Herrscherstellung durch Freiwilligkeit und Liebe der gegenseitigen Beziehungen ist die $\mathrm{Fa} \mathrm{milie} \mathrm{mit} \mathrm{der} \mathrm{patria} \mathrm{potestas}$ über Frau, Kinder und Gesinde s. ibid. qu. 57 a. 4 sutrum jus dominativum et jus paternum debeant distinguie: auf das Familienverhältnis ist der Begriff des Rechtes nicht anwendbar, da Kinder und Gesinde Teile des Herrn und nicht ihm gegenüberstehende Personen sind, eine Charakteristik, die etwas gemildert auch auf die Frau zutrifft; aber sofern die Frau, Kinder, Gesinde auch als Menschen in Betracht kommen, sind sie Träger von eigentlichen Rechten: ideo inquantum uterque (filius et servus) est homo, aliquo modo ad eos est justitia et propter hoc etiam aliquae leges dantur de his, quae sunt patris ad filium vel domini ad servum; sed inquantum uterque est aliquid alterius ( $d . h$. ein Stück des Herrn selbst), secundum hoc deficit ibi perfecta ratio. . . Uxor autem, quamvis sit aliquid viri, . . tamen magis distinguitur a viro quam filius a patre vel servus a domino... inter eos non est etiam simpliciter politicum justum, sed magis justum oeconomicum. Diese Formeln stammen von Aristoteles, über den realen sozialen Inhalt, den sie decken, s. die vortrefflichen Ausführungen von Marianne Weber, Ehefrau und Mutter $200-278$. Die christlich-ethische Versetzung dieser Rechtsverhältnisse in die Sphäre der Freiheit und Liebe in Christo zeigen dann die oben notierten biblischen Auslegungen und die Traktate über die theologische Tugend der Liebe und der Eintracht, auf die Thomas selbst verweist, ibid. qu. 80 über die virtutes justitiae annexae und qu. 8I: de aliis autem hic enumeratis supra dictum est partim in tractatu de caritate, sc. de concordia et aliis hujusmodi. Hierin aber ist die Familie das Vorbild aller Ethisierungen der Gewalt, Ueberordnungs- und Ungleichheitsverhältnisse: de reg. princ. I I: Qui domum regit non rex, sed paterfamilias dicitur, habet tamen aliquam similitudinem regis, propter quam aliquando reges populorim patres vocantur. Ueber die Familie, das Gesinde einschließend, als Quelle aller patriarchalisch-ethischen Bewältigung der Ungleichheiten s. auch Th. Meyer 70 bis 142, bes. S. 78: $>$ In dieser ursprünglichen Sozialanstalt, die so unmittelbar die Spuren der ordnenden Hand Gottes an sich trägt, erscheint die organische Ungleichheit der Glieder als ein Grundgesetz. Damit aber ist zugleich der göttliche 
meinde und der Kirche aus, wo alle Glieder Teile sind des Christus oder des Christusleibes und die verschiedenen kirchlichen Stände des Klerus, der Mönche, der Laien sich in gegenseitiger Liebe und in gemeinsamer Gottesliebe mit ihren verschiedenen Funktionen ergänzen zum einheitlichen Leibe der Kirche oder zum Corpus mysticum. Diese Lehre vom Corpus mysticum wird dann nur erweitert und theoretisch angeschlossen an die platonische und aristotelische Lehre von der harmonischen Zweckeinheit der Gesellschaft bei verschiedener Bestimmung und Leistung der einzelnen Glieder und Gruppen. So erscheint die ganze christliche Gesellschaft als ein in Gruppen und Stände außerkirchlicher und kirchlicher Art gegliederter, von der Verwirklichung des absoluten Heilszweckes beseelter und gestalteter Organismus, eine Analogie zu der Zusammenfassung verschiedener Elemente und Gruppen im untermenschlichen und einzelmenschlichen Organismus. Damit tritt er ein in die Stufenreihe der kosmischen Zweckreiche als das Reich der organisierten menschlichen Vernunft, als die Stufe der Emporhebung des Vernunftreiches in die mystische Lebenseinheit. Ueber ihm steht dann nur mehr das Zweckreich des immateriellen Geistes oder der Engel, das in seinen verschiedenen Chören und Ungleichheiten gleichfalls organisch gegliedert ist. Ganz ähnlich

Plan der ganzen Gesellschaftsbildung bis zur Volksgemeinschaft authentisch vorgezeichnet. Denn der weitere Aufbau muß sich naturgemäß seinem grundlegenden Anfang analog gestalten.: Aehnlich betont den vom Familienideal her über das Ganze ausgebreiteten Geist des Patriarchalismus der Freiwilligkeit und Liebe Ratzinger, "Die Volkswirtschaft in ihren sittlichen Grundlagen S. 474: In der Familie finden wir bereits die sittlichen Grundgesetze, nach denen die Gesellschaft sich entwickeln konnte und fortschreiten mußte. Sie heißen Liebe und Freiheit. Die Elternliebe sorgt für das vollständig hilflose Kind und weist ihm nach einer längeren Entwickelung einen Kreis freier Betätigung an. Aus der Elternliebe entspringt die Autorität, das Recht, die Betätigung der Familienglieder zu beeinflussen, auf einen bestimmten Kreis hinzuweisen und dadurch Schranken zu setzen. Da aber die Autorität nur der Ausfluß der Liebe ist, so ist klar, daß die Freiheit nicht mehr beschränkt wird, als es die wohlwollende Sorge des Familienhauptes für die Gesamtheit notwendig macht. Liebe, Autorität, Vereinigung einerseits, Freiheit. Gercchtigkcit, Gleichheit andererseits bilden die Grundlagen des sozialen Gebäudes, der Familie im Kleinen, der Gesellschaft im Großen.* S. 406: "Gleichen Anteil werden nicht alle haben können, die Gesellschaft gliedert sich vielmehr patriarchalisch und hierarchisch; es wird immer Stufen, Hoch und Niedrig, Reich und Arm geben. Aber eines ist nicht notwendig, daß es Enterbte gebe, wie heute. Jeder kann und soll nach seiner Stellung und Arbeitsleistung Teilhaber sein.* 
ist aus der christlichen Liebesidee der Patriarchalismus zu verstehen und abzuleiten, nur daß es sich hier nicht um die Eir schmelzung der objektiven innerkirchlichen und innergesellschaftlichen Gruppen in ein solidarisches Liebesganzes handelt, sondern um die Differenzen der Ungleichheit, wie sie subjektiv empfunden werden als Bevorzugung oder Zurückstellung in den Lebensansprüchen. In der Liebe wird der persönliche Einzelwunsch ausgelöscht und wird die Bevorzugung der einen zu einem Dienst für andere, die Benachteiligung der anderen $\mathrm{zu}$ einer Unterstützung durch jene, und im einen wie im anderen Falle erweitern und bereichern die Handelnden ihr Selbst aus den so gestifteten, durch die Liebeseinheit des Ganzen vermittelten Beziehungen. Dabei erwächst freilich die Notwendigkeit dieses Patriarchalismus erst aus den Bedingungen des Sündenstandes und ist er nur der kämpfenden Kirche eigentümlich. Im Jenseits gibt es wie bei den Engeln nur mehr wieder die organische Gliederung für sich allein.

So nahe verwandt beide Begriffe durch ihre gemeinsame Begründung im Liebesbegriffe sind, so haben sie doch sehr verschiedene, ja entgegengesetzte Funktionen im Zusammenhang des Ganzen. Der Begriff des Organismus setzt die Einheit der menschlichen Gesellschaft als auf ein absolutes Ziel d. h. als auf die Kirche und ihr Heil bezogen voraus. Er bedeutet also die Einheit in der Anerkennung der Kirche als der Seele des Ganzen, wobei sich die Freiheit und die ungehinderte Herrscherstellung der Kirche von selbst versteht. Er bedeutet zugleich die Notwendigkeit gegenseitiger Rücksicht aller Gruppen, Stände und Mächte aufeinander, die vollendete soziale Harmonie und damit die Forderung, diese Harmonie herzustellen, wo sie in Wirklichkeit gebrochen wird. $\mathrm{Er}$ bedeutet schließlich und vor allem einen eigenen Selbstzweck und eine eigene Würde jedes Gliedes im System und damit die Forderung, jedem Gliede zu dieser Stellung zu verhelfen, wo es sie noch nicht oder nicht mehr inne hat. Damit aber ist die organische Idee das aktive, gestaltende, kritische und gelegentlich nach Bedarf revollitic. näre Prinzip der christlichen Soziologie. Ungerechte, das Gesetz Gottes nicht einhaltende Institutionen dürfen und müssen verändert, gottlose Herrscher abgesetzt oder vermahnt und gebessert werden. Das Recht des Widerstandes und der Empörung ist ein Recht des christlichen Gewissens gerade um der 
Liebe und der organischen Harmonie willen, wenn anders es ausgeübt werden kann, ohne daß daraus noch größere allgemeine Zerrüttungen entstehen. Insbesondere die Kirche ist zu ihrem Kampf gegen gottlose und unbotmäßige Staatsgewalten und damit zur Revolution berechtigt. Sie hält damit nur die Einheitlichkeit des christlichen Körpers aufrecht. Auch die sonst so stark betonten ständischen Unterschiede werden in dieser Solidarität und in der Beziehung auf den religiösen Endzweck ausgelöscht. Die Sprache der Gesellschaftslehre kann dann fast demokratisch klingen und den naturrechtlich-christlichen Anspruch des Individuums auf Anteil am Ganzen und seinen Gütern stark betonen. Im kanonischen Recht, d. h. in dem höchsten, allen partikularen und ständischen Rechten übergeordneten Recht des Corpus Christianum, sind alle gleich rechtsfähig und werden alle dem gleichen Rechtsverfahren unterworfen, vorbehaltlich ihrer Rechtgläubigkeit d. h. ihrer Beziehung auf den Zentralzweck des Organismus. Es ist ein Anfang des Gedankens subjektiver öffentlicher Rechte ${ }^{183}$ ). An diesem Punkte hängt sich daher auch das individualistisch-naturalistische Naturrecht in die christliche Ideenwelt ein, und es dringt so tief in sie hinein, als es bei der Vorherrschaft des organischen Solidaritätsgedankens überhaupt möglich ist. Nur in den Begriff der Kirche selbst dringen diese individualistisch-naturrechtlichen Elemente nicht ein. Hier gibt es nur absolute Herrschaft des Papstes und keine Mitwirkung der Unterthanen, der Individualismus des organischen Systems beschränkt sich hier auf das von der Kirche zu verleihende Seelenheil. Die konziliare Bewegung hat dann freilich die organische Idee auch auf die Kirchenregierung selbst im Sinne einer Mitbeteiligung der Individuen, zunächst der Bischöfe, dann aber auch gewisser Laienstände, an der Kirchenregierung ausgedehnt und dies damit begründet, daß die Kirche als societas perfecta, als

183) Hierzu vgl. Feugueray und Baumann, vor allem Gierke, wo alle diese Züge mit Sorgfalt zusammengestellt sind und aus einer breiten, weit über Thomas hinausgreifenden Literatur belegt sind. Dort sind auch die thomistischen Stellen angegeben; über subjektive öffentliche Rechte als Folge aus der Gliedschaft im Organismus und der Beziehung auf den Zentralzweck s. bes. S. 553, 569-574 $595-599,619-621$, das Revolutionsrecht 624-626, Althusius 138 und 275; v. Eicken 550 und 557 . Weitere Sammlungen solcher demokratisch-individualistischen Anschauungen auf Grund des organischen katholischen Naturrechts bietet Figgis, From Gerson to Grotius, Cambridge 1907, wo die Entwickelung des moTroelisch, Gesammelte Schriften. I. 
Inbegriff der Gesellschaft, das Ideal des Organismus in diesem Sinne zu verwirklichen habe. Allein die Kirche hat eine solche Deutung und Ausdehnung der organischen Idee abgewiesen 133a); sie pflegt einen weitgehenden persönlichen Individualismus, aber sie läßt ihn nicht in die Kirchenregierung selbst hineinreichen, sondern wendet ihn nur gegen etwaige ihn bedrückende gottwidrige weltliche Institutionen. Wenn aber nach dieser Seite der organische Gedanke den Individualismus, 'd. h. die Beteiligung und Mittätigkeit des Individuums an den Gesamtwerten des Lebens, zur Geltung bringt und seinen Ansprüchen gemäß die Wirklichkeit zu rationalisieren auffordert, so ist andrerseits durch die gemeinsame Gebundenheit der Individuen in der Anerkennung dieser Werte und in ihrem Zusammenwirken zu deren Herbeiführung doch wieder auch eine außerordentlich weitgehende Solidarität proklamiert. Von da aus schlägt dann der Individualismus um in den Sozialismus.

dernen demokratischen Naturrechts aus den kirchlichen Ideen heraus sehr lehrreich beschrieben ist. Wie stark der moderne Katholizismus auf demokratisch-individualistisch-rationalistische Ideen einzugehen im Stande ist, das zeigen die bekannten Spectator-Briefe. Aus Hitze: \Kapital-Arbeit zitiert Uhlhorst \Kath. u. Prot. gegenüber der sozialen Frage* 1887: ^Revolutionen sind geistige Taten, das sittliche Element überragt bei weitem das Materielle... Es ist ein Kampf des historischen und des Vernunftrechts, ein Kampf der freien Persönlichkeit gegen die verknöcherte Sozietät, des ungehemmten, ungezügelten Geistes gegen die entgeistete Form, des Fortschrittes gegen den Stillstand, des erwerbenden Rechtes gegen das erworbene Recht, und da eine friedliche Versöhnung nicht möglich ist, so muß der blutige Kampf entscheiden, es ist fast eine Naturnotwendigkeits S. 25. Alles das aber ist im Rahmen der thomistischen organischen Idee gedacht. Dort heißt es das Revolutionsrecht gegen den Tyrannen oder gegen eine ihrem Vernunftzweck nicht entsprechende Herrschermacht. Es ist ein aus der aristotelischen Ethik übernommener technischer Terminus. Doch sind jene öffentlichen subjektiven Rechte nicht rom Staat erteilt oder erst durch staatliche Anerkennung zu Rechten gemacht, sundern aus dem Naturrecht der organischen Idee zu verstehen, für den Staat verbindlich und von der Kirche aufrecht erhalten; das ist ein fundamentaler Unterschied gegenüber der modernen staatsrechtlichen Betrachtung vgl. Jellinek, System der subjektiven öffen .ichen Rechte ${ }^{2}$ 1905. Daher bestreitet die moderne katholische Literatur nichts so heftig als die Lehre von dem rechtsschöpferischen Wesen des Staates.

199a) Ueber die Ausdehnung der individualistischen und konstitutionellen Elemente der organischen Idee auf die Kirchenregierung und über die Theorie von der Kirche als societas perfecta, d. h. als des Inbegriffs des soziologischen Grundschemas s. John Neville Figgis, From Gerson to Grotius Cambridge I907, S. 35-16. 
Dazu darf nämlich nur noch die christliche Selbstbescheidung und Bruderliebe sowie die Einschätzung des Privateigentums als einer zwar relativ nützlichen, aber sekundären und teilweise stets wieder aufzuhebenden Entwickelung hinzukommen, und die Theorie eines für alle Bedürfnisfälle eintretenden Kommunismus ist fertig. $\mathrm{Er}$ hat seine stets lebendigen Beispiele an den Mönchsorden, schließlich an der Kirche selbst, aber auch Zünfte und Hofverfassungen enthalten kommunistische Elemente. Stets ist solcher Kommunismus freilich zu verbinden mit den Rechten und dem Schutz des Individuums und immer soll er die nützliche Privatinitiative anerkennen und schützen; auch dient er nie lediglich dem materiellen Wohl, sondern immer nur als Voraussetzung einer die höheren Lebensziele sichernden perfecta societas. Er ist daher immer nur ein relativer und im Bedarfsfall eingreifender. Aber die organische Idee kann von hier aus - neben aller Uebernatürlichkeit und Festigkeit der religiösen Grundlagen des Ganzen - doch, wie gelegentlich stark demokratisch-individualistische, so auch sozialistisch-kommunistische Forderungen hervorbringen und damit sehr tief in die gegebenen Verhältnisse einschneiden; sie begründet beide gleicher Weise mit der rationalen Lex naturae wie mit dem Ethos der Offenbarung, die auch in dieser. Hinsicht schließlich zusammenmünden und deren Verbindung jene Begriffe von dem modernen rationalistisch-demokratischen Individualismus oder auch Sozialismus bei aller formellen Aehnlichkeit doch grundlegend unterscheidet ${ }^{\mathbf{1 3 3 b}}$ ).

13311) Ueber die kommunistischen Züge siehe weiter unten bei Besprechung der Begriffe vom Eigentum. Es ist $z u$ betonen, daß es immer nur ein relativer, für den Bedarfsfall eintretender Kommunismus ist. Außerdem hat das Mittelalter bei der Abwesenheit der individualistisch-liberal-kapitalistischen Wirtschaftsordnung und bei der relativen Herrschaft des Kommunismus in den sozialen Tatsachen ihn prinzipiell $z u$ betonen nicht notwendig gehabt. Bei der heutigen Reaktion gegen die inzwischen eingetretene liberale Wirtschaftsordnung holt aber der Katholizismus prinzipiell seine kommunistischen Züge hervor und berührt sich hier vielfach mit den Sozialisten, wie Uhlhorn, Prot. u. Kath., in einer Reihe von Beispielen mit echt lutherischer Abneigung verzeichnet, s. S. 21-26, auch G. Wermert, Neueie sozialpolitische Anschauungen im Katholizismus innerhalb Deutschlands, Jena I $\$ 85$, auch die sozialen Botschaften Leos XIII. Immer aber ist dieser katholische Kommunismus ein nur relativer, von der Kirche geleiteter und auf ständische Gruppeneinheiten mit Selbstbegrenzung und gegenseitiger Unterstützung abzielender, d. h. er bleibt im Rahmen der ständisch-organischen Idee, wofür wieder Uhlhorn S. 22, 27, $9 \mathrm{f}$, die Belege darbietet. 
Dahingegen liegt in der patriarchalischen Idee der konservative, alles stabilisierende und die tatsächlichen Lagen anerkennencle Charakter des Systems. Die Ungleichheiten jeder Art zuehörcn zum sozialen Körper in kirchlichen und weltlichen $\mathrm{Zu}$ sammenhängen; die Gleichheit ist eine ausschließlich religiöse, und auch hier ist die Stellung von Klerikern, Mönchen und Laien eine verschiedene. Diese Ungleichheiten aber äußern sich vor allem in den Herrschafts- und Dienstverhältnissen, in den Vermögensunterschieden, Aemtern und Berufen. Da soll jeder in scinem Stande blciben und jeder gerne dem andern dienen. Nicht Fortschritt und Veränderung, sondern die Erhaltung gesunder Glicderungen und die Genügsamkeit bei der jeweiligen Stellung im /usammenhange des Ganzen sind die christlichen Tugenden. llier ist Widerstand nur geboten, wo das christliche Gewissen verletzt und dic Ausübung des Glaubens behindert wird. Nach dieser Seite hin wirlit die christliche Soziologie konservativ und traditionalistisch, ja in vicler Hinsicht geradezu quietistisch ${ }^{133}$ ). Hier kommen dann dic ,Gedanken von den natürlichen Ungleichheiten cler Talente und Kräfte und vor allem die Theorien über die Wirkung der Sünde zur Geltung, die den Menschen zur Strafe und Zucht unter Gewaltherrschaften unterwirft; die letzteren sind dann durch Gott als causa remota ebenso gewirkt wie etwaige vernunftgemäisc I lerrschaftsbegründungen mittelst Vertrag und Volksbeschluts. Von dieser Seite her erscheinen dann die herrschenden Gewalten als durch Gottes Vorschung und Zulassung eingesetzt und kommen politisch die Gedanken des Gottesgnadentums, der patriarchalisch-christlichen Erzieher- und Vorbildpflichten für sie \%ur (ieltuns, wic sic im Traktat Je regimine principis entwickelt sind. Lind noch mehr als auf dem Gebiet der Politik gewinnt diecer Gedanke auf dem eigentlich sozialen Gebiet Bedeutung. lier bewirkt er die Stabilität der Stände, die alles beherrschende: Bedeutungs des ständischen Gedankens. Neben dem Schut\% des Individuums und der Solidarität der gegenseitigen IIilfi im Kahmen der Standesorganisation bedeutet er vor allem die Kuhe und loucr der gesellschaftlichen Ordnung, dic

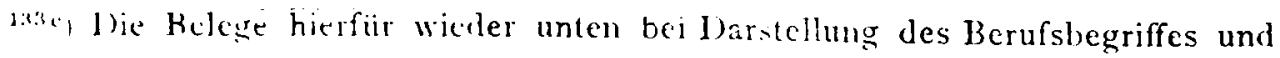
Acr Fiage des (ileichheitsbegriffes; s. auch die Ausführmgen über die Askese und iiher den auchitcktunischen Charakter der Entwickelung. Der ständische Gedanke ewei-t sich ibledl als eine der wesentichsten Ingredienzien des ganzen mittelalierlichen Inonkem in all scinen Verweigungen. 
Selbstbescheidung bei gegebenen Verhältnissen, die Stillstellung des bedrohlichen Kampfes ums Dasein dırch Anerkennung der gegebenen Gruppenordnungen. Und in engem Zusammenhang mit dieser Stabilität der Stände ergibt sich der wirtschaftliche. Traditionalismus, der jeden bei seiner Nahung schützt, aber auch jede Gruppe bei dem ihr zukommenden niedrigeren oder höhcren Lebensstandort festhält ${ }^{134}$ ).

$\mathrm{Ob}$ aber mehr die erste oder mehr die zwcitc, dic fortschreitende oder die stabilisierende Tendenz im einzelnen liallc zur Anwendung kommen soll, das ist jedesmal Gegenstand einer verwickelten Kasuistik, die ihre Entscheidung aus den Folgen und den Wirkungen auf das Ganze nimmt und dalsei im übrigen tunlichst sich auf die aristotelische Gesellschaftslehre und Ethik beruft; doch werden dabei jedesmal Gedanken herangezogen, die in der Tat in der Konsequenz des kirchlich-christlichen Grundgedankens liegen oder in sie eingebogen werden können. Es ist die eigentümliche Mischung aktiv-gestaltender und passiv-quietistischer Stimmungen, legitimistisch-absolutistischer und

194) Ueber den straditionalistischen Charakter des Systcms, dis Bleiluen in den Berufen und ständischen Gruppierungen, die Verpönung des licrufswcibi: ts außer etwa der Konversion zum Mönchtum, s. Maurenbrecher 48, 50, 5.3, sy; iile: den straditionalistischen Charakter insbesondere des wirtschaftlichen Denkcis. w. es auf Erhaltung der standesgemäßen Existenzgrundlage fiir jeden Einzelncn ur.d auf Garantierung eines solchen nicht zu überschreitenden Existenzmaljes lurch obrigkeitliche und genossenschaftliche Regulierungen, im übrigen auf Cenüg :.mokeir und Sparsamkeit ankommt, s. Ratzinger, „Die Volkswirtschaft in ihren sittlichen Grundlagen $\approx$ I88I ; R. erkennt in der Rückkehr zu diesen Grundsätzen und in dur Beugung des mit der Arbeitsteilung zusammenhängenden und daher nicht zu bcseitigenden Kapitalismus unter eine obrigkeitliche Regelung nach diesen (jrundsälzen die christliche Forderung an die Sozialwissenschaft der Gegenwart. Das Mittclaltet szeigte dieses glänzende Resultat christlicher Kultura S. 144. Durch Opfer, d. h. durch Verzicht auf die frei kalkulierende Produktion des Kapitalismus und Eneuerung des patriarchalischen Geistes soll die am Rand des Abgrundes stehende liegenwart diese Rückkehr vollziehen S. 403. Leber den traditionalistischen Charahter der thomistischen Berufs- und Wirtschaftslehre s. auch Max Weber, Die prot. Fithik etc. Archlv XX, S. 20-26, XXI S. 81-83. Ueber die patriarchalisch-konscrvative Aulfassung politischer Dinge s. den Traktat De reg. princ., der nur gegenüber moralisch schlechten und gottlosen Fürsten ein übrigens sehr verklausuliertes Revolutionsrecht einrüumt, den frommen und seine Liebespflicht erfüllenden Fürstcn dagegun als Stellvertreter Gottes feiert und ihm einen besonderen Rang himmlisclier Bclohnungen zusichert; s. auch den Fürstenhimmel in Dantes Paradies. 
demokratisch-individualistischer Anschauungen, der Revolution von oben und von unten, des optimistischen Rationalismus und der pessimistischen Sündenstimmung, die bis heute die Soziologie des katholischen Denkens beherrscht, und die man weniger aus dem Zusammenfließen heterogener Quellen, wie antiker, germanischer, kirchlicher und biblischer Ideen, als vor allem aus der Doppelrichtung des soziologischen Grundschemas, aus dem Nebeneinander der organischen und patriarchalischen Idee, zu begreifen hat. Diese Vielseitigkeit und mannigfache Anwendbarkeit liegt in der christlichen Idee selbst, sobald sie in weltlich-soziale Verhältnisse hineingetragen wird; sie ist nicht erst die Folge zufälliger geschichtlicher Zusammenflüsse. Von diesen letzteren ist nur die Form der theoretischen Durchführung und das Maß des sozialen Horizontes abhängig. Die Spannungen und Widersprüche fallen bei alledem für katholisches Denken nicht so sehr ins Gewicht, da in all diesen Schwierigkeiten die kirchliche Autorität durch Beziehung des jeweiligen Falles auf den höchsten Zweck des ganzen Systems, den religiösen, die Entscheidung gibt. Von hier aus erklärt sich der stark kasuistische und nach den Verhältnissen sehr verschiedenartige Charakter der Entscheidungen, die Möglichkeit temporum ratione habita unter verschiedenen Verhältnissen sachlich sehr abweichende Maßnahmen zu treffen, begründet. Die in diesem Schema gcbundenen verschiedenartigen Grundrichtungen haben dann freilich später in der geschichtlichen Entwickelung aus der katholischen Lehre heraus auf verschiedenste Weise zur Emanzipation und Säkularisierung, zu modernen Entwickelungen der einzelnen Elemente geführt. An die organisch-individualistisch-naturrechtlichen Bestandteile knüpfte der aufkommende Liberalismus, an die patriarchalischpositivistischen die rein realistische Souveranitätslehre des Absolutismus, sei es als machiavellistisches Grwaltrecht, sei es als rcligiös rerbrämtes Gottesgnadentum, an. Aber es ist der Stolz der katholischen Soziologie, diesen modernen Einseitigkciten gegenüber das harmonische, die verschiedenen Tendenzen ausgleichende und in dem religiösen Grundgedanken zusammenbindende Prinzip zu besitzen. Zugleich ist ihr die Unmöglichkcit, diese Harmonie ohne beständiges Eingreifen der Autorität aufrecht $z u$ erhalten, die ganze Unentbehrlichkeit einer göttlichen \%cntralautorität für ein nur aus dem religiösen Lebenszweck zu gliederndes System, der Beweis für die Vernunftnotwendigkeit der von ihr behaupteten göttlichen Autorität des Papsttums. Es ist 
von da aus völlig begreiflich, wenn die Kirche trotz aller Erschütterungen und Fortschritte des Spätmittelalters immer wieder auf die thomistische Lehre zurückgegriffen hat ${ }^{135}$ ). Sie ist auch unter diesen Gesichtspunkten das eigentliche Meisterstück der Vermittelung, und es wird nicht zu leugnen sein, daß in der Tat in dieser Soziallehre ein reiches Maß guter psychologischer Beobachtung und eine Fülle von Mitteln zur Lösung schwerer soziologischer Probleme liegt, denen die modernen Soziallehren ihrerseits nur mit großer Mühe zu begegnen wissen.

Besonders durchdringen sich nun aber beide Betrachtungsweisen in dem für das ganze System so wichtigen Begriff des Berufes, des officium oder ministerium, der dem einzelnen Gliede im Zusammenhang des Ganzen zufällt. Die paulinische und altkirchliche Lehre von dem Bleiben in dem Stande; in welchem man berufen ist, wird in der Anerkennung der ständischen Unterschiede und Gliederungen als de Lege naturae notwendiger, mit der lex naturae zusammen der Gnade eingeordneter Stellungen $\mathrm{zu}$ der Lehre vom gliedlichen officium und ministerium oder vom - Berufer innerhalb des Ganzen. Da nicht alle das Gleiche und Ganze bewirken können, sondern da aus der Ungleichheit der menschlichen Kräfte die Arbeitsteilung folgt, so ist die beruflichständische Gliederung nicht etwas erst aus der Sünde und der Weltverkehrung Folgendes, sondern etwas von Gott mit der Weltharmonie und der Gnade selbst Gewolltes. Es ist aufs stärkste $\mathrm{zu}$ betonen, daß damit ein der alten Kirche unbekannter Gedanke in die Sozialphilosophie und in das ganze soziologische Empfinden eingefürt ist. An ihm ist die in dem ganzen thomistischen und hochmittelalterlichen System erkennbare starke Wendung zu einer positiven Wertung der *Welt «, zur Eingliederung des Bestehenden in den Kosmos der Lebenswerte, mit Händen zu greifen. Die Schätzung der Arbeit und der Berufe im Evangelium stand unter den handwerkerlich-kleinbürgerlichen Gesichtspunkten, die aus der talmudischen Ethik bekannt sind und dem hellenistischen Orient weithin gemeinsam waren. Aber sie wurden bei der über der Urzeit lagernden Erwartung der großen Weltverwandlung nicht positiv für das religiöse Ziel gewertet; sie gehören dem provisorischen Lebenszustand an. Die auf die Welt sich einrichtende Kirche arbeitete dann vor allem das Ideal der urständlichen Gleichheit aus dem rein religiösen Gleichheitsgedanken

186) S. hiertiber die Andeutungen bei Th. Meyer, S. $48 \mathrm{f}$. 
heraus, verherrlichte damit die neue Lebens- und Liebesordnung der Kirche und betrachtete die bestehenden Ungleichheiten als Folgen des Sündenfalles; dazu kam der Zustand der alten Gesellschaft, in der bei allen ständischen und wirtschaftlichen Bindungen und Gliederungen doch immer das Ideal des Bürgers der nicht direkt am banausen Geschäft interessierte Rentner blieb. Hier hatte das Christentum den Geist der alten Polis niemals völlig überwunden. Wenn nun im Hochmittelalter die Berufsidee als Wertung der ungleichen Arbeits- und Leistungspositionen für das Liebesganze des Systems, als Amt und Dienst für das Ganze mit dem ethischen Werte einer hierin stattfindenden persönlichen Beziehung auf das Ganze, sich durchsetzt, dann liegt der Grund naturgemäß nicht bloß in der Verwertung der paulinisch-organischen Gedanken und in dem Vorbild der kirchlich-organischen Gliederung, sondern auch in der faktischen Gestalt, welche die mittelalterliche Gesellschaft angenommen hatte. Es ist das zunächst das Urbild des Feudalsystems mit seinen Korporationen, Abhängigkeiten und Diensten, dann aber wohl vor allem das Urbild der gewerblichen Stadt des Mittelalters mit ihrem Zusammenschluß zu einem System von Gliederungen, Rechten und Diensten der freien Arbeit, das hier zu Grunde liegt. Nicht umsonst betont Thomas in seinen wirtschaftlichen Ausführungen stets die Stadt, in welcher jenes System der Dienste, von dem Gewaltsinn und den Brutalitäten gereinigt, auf freier Arbeit und persönlicher Leistung für das Ganze beruhte. Diese Tatsächlichkeit wird durch Einfügung in das religiöse und organische Schema als "Beruf idealisiert und rationalisiert. Und zwar steht die Sache hier nicht etwa umgekehrt. Nicht die christliche Arbeitsschätzung und eine kirchliche Bewegung zur Emanzipation der Unfreien hat diese Welt bürgerlicher Berufe hervorgebracht. Sie ist in erster Linie das Werk ökonomischer und politischer Verhältnisse, wie später noch zu zeigen ist. Vielmehr umgekehrt hat die in der Stadt vollzogene Emanzipation, Arbeitsteilung und Freistellung der bisher Unfreien ganz wesentlich den neuen positiven Begriff des Berufes als eines rationellen Bestandteils des sozialen Systems geschaffen. Aber in dieses rationelle, unter Umständen ein soziales Programm ermöglichende System der Berufe schieben sich dann doch auch hier wieder die irrationell-patriarchalischen Elemente ein, und damit erhalten dann doch die pessimistischen und konservativ-duldenden Elemente des altkirchlich-sozialen Denkens wieder einen starken, wenn auch gedämpften Einfluß. Es bleibt 
nämlich doch die Pflicht und Stellung des einzelnen Gliedes eine vielfach durch rein positives Recht, durch Gewalt und Zufall bedingte, und es werden auch die so erwachsenden unwürdigen und unfreien Stellungen und Pflichten als Berufe und Dienste gewertet, in denen der Christ zu bleiben hat. Wie in der Familie die bis zu völliger Aufsaugung des Frauenvermögens durch das männliche gehende und ein weitgehendes Züchtigungsrecht einschließende Mannesherrschaft alles beherrscht und geduldig als Folge des Sündenfluches getragen werden muß, wie die Massen der Unfreien den Herren zu dienen verbunden sind seit dem Sündenfall, wie auch die eigentliche Sklaverei im ganzen Mittelalter fortdauert, wie die Arbeit durch den Sündenfall zur Strafe und zum Schmerz geworden ist und verschiedenen Ständen und Berufen sehr verschieden stark auferlegt ist, wie die Lebensansprüche nach Stand und Rang sich aufs stärkste unterscheiden und dem Höherstehenden auch in höherem Maße zugestanden werden müssen, wie die Berufe und Stände der Väter vom Einzelnen nicht verlassen, sondern geduldig fortgesetzt werden müssen und keiner über seinen Stand hinausstreben soll, so ergießt sich von hier aus über das Ganze eine Stimmung der Geduld, der Demut und des Leidens, die mit der Berufsfreudigkeit der organischen Gliederung nichts zu tun hat, um somehr aber Ergebung in die Folgen des Sündenfalls und in die gottgesetzten Ungleichheiten ist. So verbinden sich auch hier Rationalität und Irrationalität, zweckmäßige Entwickelung und positive göttliche Satzung, aufstrebende Zielbewegung und Trübung durch Sünde und Sündenstrafe, wie das im ganzen hochmittelalterlichen System der Fall ist. Es ist begreiflich, daß aus all diesen Verwickelungen nur eine kasuistische Berufs- und Standesmoral den Ausweg findet ${ }^{136}$ ).

196) Hierzu vgl. Maurenbrecher 29-38; Max Weber, >Protest. Ethik u. s. W.c, Archiv XX 36-42. Die Mural wird unter diesen Gesichtspunkten oft geradezu ztit Standes- und Berufsmoral, $\therefore$ die Analyse der auf Thomas fußenden lithik des Antonius von Florenz bei Gaßs I 375-383: Die universell angelegte lithik begibt sich sofort in die Schranken einer Klassenmoral, von denen sit auch weiterhin beherrscht wird\&, seine auf Uebung, Werktătigkeit, Verdienst, Gehorsam und Indulgenz gegründete und schlechthin kirchlich konservative Standesmorals. sLebermaßige Betonung des Gehorsams und seiner Verdienstlichkeit, spedantische Autzahlung der Artigkeiten, deren man sich den Vorgesetzten und Würdenträgern gegenubber $2 u$ bedienen hat.. - Zum Gegensatz gegen die spatantike Gesellichati 
Sind nun derart schon in der Zusammenfassung beider Ideen sehr stark auseinandergehende Tendenzen gebunden, so enthält auch jede einzelne von ihnen in sich selbst eine Mehrzahl sehr verschiedenartiger Motive, und in diesen Komplikationen liegen weitere Schwierigkeiten, die die kirchliche Sozialphilosophie zu überwinden hat.

Klar auf der Hand liegt das bei dem $\mathrm{P}$ a tri a r ch a lis $\mathrm{mus}$. Er enthält zunächst nichts anderes als die Lehre von einer wesenhaften Ungleichheit der Menschen, die in letzter Linie begründet ist auf die irrationale Setzung Gottes, dessen Wille Verschiedenes und Ungleiches setzt; weiterhin die innere ethische Ueberwindung dieser Ungleichheiten in dem Gedanken der Liebe, die dienend wie fürsorgend überall in Freiwilligkeit und Aufopferung das eigene Selbst an das Ganze und an die Brüder hingibt. Es ist ein rein ethisch-religiöser soziologischer Gedanke, der mit dem der religiösen Gleichheit und der tatsächlichen Verschiedenheit unmittelbar gegeben ist und an sich den bestehenden Ungleichheiten gegenüber sowohl quietistisch und passiv, wie reformierend und reinigend verwendet werden kann, je nachdem die bestehenden Ungleichheiten lediglich als solche hingenommen werden oder nachdem unter ihnen nur die wirklich unabänderlichen und wesenhaft in der menschlichen Natur und geschichtlichen Entwickelung

s. den grofen Artikel von Max Weber, Agrargeschichte (Altertum) im Handwörterbuch der Staatswissenschaften ${ }^{8}$; bes. S. 67 . - Vom heutigen Katholizismus wird zugleich mit seiner absichtlich betonten Schätzung der Kultur auch der Begriff des Berafes stark betont. Uhlhorn $>$ Katholizismus und Protestantismus gegenüber der sozialen Frage 1887, meint daher, daß der moderne Katholizismus in diesem Punkte slutheranisiert und daß sas Leben der Welt eine ganz andere Berücksichligung bei ihm finde als bei Thomas . Aber das ist ganz unrichtig. Die Kulturethik des hl. Thomas nach dem Satze: Gratia praesupponit et perficit naturame enthält alle Motive des modernen Katholizismus. \Die Wiedergabe der thomistischen Lehres S. II : >Das Beste wäre, alle Menschen würden Mönche und Nonnen und führten ein beschauliches Leben. Das ist ja nun freilich nicht möglich, die Notwendigkeit bringt es mit sich, daß der Mensch das aktive Leben statt des beschaulichen wählen muß, d. h. er muß arbeiten, weil er sonst verhungern würde. Höher weiß Thomas die Arbeit nicht zu würdigen«, ist zwar eine bei Protestanten weit verbreitete Meinung, aber positiv falsch. Sie bleibt an einzelnen Aeußerungen hängen und generalisiert diese ganz unzulässig, übersieht vor allem; daß das thomistische System im Ganzen gerade ein Kultursystem, ein stark modernistisches System ist für seine Tage. Jeder Katholikentag mit seiner auf den Thomismus begründeten Kulturverherrlichung könnte darüber belehren. 
begründeten anerkannt werden. Weiterhin aber ist darin enthalten der altkirchlich-dogmatische Gedanke von einer Ausgestaltung der Ungleichheit in Unterschieden der Macht und Herrschaft, des Besitzes und der natürlichen Eigenschaften, die nicht Folge der gottgesetzten Ungleichheit an sich ist, sondern Folge und Strafe des Sündenfalls, indem die mit dem Sündenfall einsetzende Begierde, Selbstsucht, Herrschbegier und Sinnlichkeit die menschlichen Verhältnisse im Gegensatz gegen die christliche und natürliche Idee der sozialen Harmonie beeinflußt. Hier schreibt nun die katholische Soziallehre auch noch in ihrer mittelalterlichen Fassung, wo sie allerdings die altkirchliche Passivität und Fremdheit weitgehend überwunden und ein positiv-organisches Verhältnis zu der natürlich-sozialen Entwicklung gefunden hat, doch in weitem Umfang die Tugenden der Duldung und Demut vor, die Stimmung der Sündenstrafe und des bereitwilligen Leidens um der Sünde willen. Es ist ein christlicher Miserabilismus, der hier sich geltend macht und, wo er mit asketischen Neigungen und Uebungen sich verbindet, oft bis zur Selbstverwerfung und Würdelosigkeit geht, dann aber auch mit allen pessimistischen und weltverwerfenden Stimmungen zusammenfließt. Im Thomismus ist das letztere für das Ganze der Sozialphilosophie sehr stark in den Hintergrund gedrängt und die positive Stellung $\mathrm{zu}$ den sozialen Gliederungen und Empnrentwickelungen lebhaft betont, aber im einzelnen und gelegentlich bleibt dieser Miserabilismus mit all seinen Voraussetzungen in der Sündenlehre und der Doktrin von der Welt- und Menschenverderbnis erhalten. Von diesen einzelnen Punkten kann er nach Bedarf immer wieder sehr weit in das Ganze eindringen. Dazu ist er gerade in der hochmittelalterlichen, den Aristoteles rezipierenden Lehre doppelt geneigt, weil mit dieser nun noch ein drittes Element in die Sozialphilosophie eindringt, ein wenn auch sehr begrenzter ethischer Naturalismus. Was von dem christlich-stoischen Standpunkt der alten Kirche aus rein als Sündenstrafe und Weltverderbnis erschien, das stellte sich von dem empirisch-realistischen und entwickelungsgeschichtlichen Standpunkt des Aristotelismus aus als eine in der Natur begründete Differenz dar, dic, auf Verschiedenheiten der Begabung und der psychophysischen Anlage beruhend, die Menschen teilt in Herrenvölker und Sklavenvölker, die Berufe teilt in voll vernunftgemäße und edle und in lediglich dienende, vernunftlose und unedle. Daraus ergibt sich für die Edlen der Herren- 
standpunkt und das Gottesgnadentum, für die Unedlen die berufsmäßige Bestimmung zum Dienen und zur Unselbständigkeit. So wenig das nun freilich an sich der christlichen Idee entspricht, es konnte teils von der organischen Lehre, die auch unedle Verrichtungen in dem Organismus nötig hat, teils von der Sündenlehre, die ganze Völker und Klassen durch die Sünde als der Strafe ausgeliefert betrachten kann, teils von der Vorsehungsidee her, die das Emporkommen der Gewalten zuläßt und die Herrscher einsetzt, begründet werden und hat erfahrungsgemäß oft genug in diesem Sinne gewirkt. Schon bei einem so stark ethisch empfindenden Manne, wie dem hl. Thomas, ist es erstaunlich, wie widerspruchslos er den aristotelischen Herren- und Junkerstandpunkt als Konsequenz der Natur sich gefallen läßt ${ }^{137}$ ).

Fast noch schärfer aber treten die in der organ ischen Idee gebundenen verschiedenartigen Motive auseinander. Die christlich-organische Idee ist von den modernen $>$ organischen * Ideen über die Gesellschaft in Wahrheit sehr gründlich und sehr cha-

197) S. oben Anmerkung 132; außerdem Maurenbrecher 63-75; trotz Anerkennung der allgemeinen Arbeitspflicht macht Th. starke Unterschiede; er konstruiert die Unterschiede der Arbeit in geistige und körperliche und macht wieder unter der letzteren Unterschiede, wobei er dann stark die vornehmen und edlen Berufe über die unedlen und gar unfreien Berufe stellt. Er stellt die abhängigen Lohnarbeiter, die nicht am Stadtregiment teilnehmen und wohl früher unfrei gewesen seien, unter die Banausen und schmutzigen Leute; ähnlich stellt er bei seinem städtischen Horizont die Bauern als eine untergeordnete Klasse hin; die Unfreien behandelt er oft mit der naturalistischen Geringschätzung des Aristoteles, wenn er ihnen auch Persönlichkeit und Menschenrechte zuschreibt. Aber all das sind doch starke Konzessionen an den Naturalismus, die in auffallendem Gegensatz zu den christlichen Grundideen stehen. Sie entstehen nur allzuleicht von dem Patriarchalismus aus, wie sie ja auch dem heutigen Konservatismus bei aller Betonung seiner Christlichkeit sehr nahe liegen. S. auch Feugueray $\therefore 60-8 \mathrm{I}$, der dicsen Naturalismus aus der Psychologie des Thomas, d. h. aus seiner Lehre von der Bewirkung der Individualisation durch die körperlichen Elemente des Organismus ableitet. Das würde letztlich auf Prädestination hinausführen. Das ist richtig, doch nur ein Moment im Gedankengang des Patriarchalismus. Daß übrigens Prädestinationslehre und Naturalismus denselben Sachverhalt nur mit verschiedenen Vorzeichen meinen, hebt mit Recht im Anschluß an Feuerbach auch Jodl I 167 hervor. Nur macht freilich das Vorzeichen sehr viel aus; immerhin kann es verloren gehen, und dann wird aus dem Patriarchalismus der Herrenstandpunkt, über dessen wahres Wesen das M.A. sich leichter täuschen konnte als die Gegenwart, die neben der konservativ-christlichen Begründung die darwinistische vor Augen hat. 
rakteristisch verschieden ${ }^{138}$ ). Vor allem betont sie trotz aller gelegentlichen biologisch-naturgesetzlichen Analogien, daß der Gesellschaftsorganismus ein Werk der bewußten vernunftgemäßen Schöpfung ist, in der der Mensch zwar den aristotelischen Vernunftrieb auswirkt, aber in bewußter Willensordnung. Darin beteiligen sich die Menschen an Gottes, aus Vernunft und Willen hervorgehender Vorsehung und Weltregierung, oder vielmehr Gott erhebt sie darin zu Teilnehmern und bewußten Ausführern seines Willens ${ }^{139}$ ). Es ist also weniger die gesetzlich-evolutionistische Bildung, als die den Gliedern vorgeordnete Einheit des Ganzen, die in der Idee des Organismus betont und als eine von Vernunft und Wille gesetzte bezeichnet wird. Das ist das Wesentliche, was vom aristotelischen Gedanken übernommen wird ${ }^{140}$ ). Dann aber entsteht die Frage, worin jene dem Einzelnen vorgeordnete Einheit besteht. Es ist die bekannte Schwierigkeit der organischen Gesellschaftsidee im idealistischen Sinne Platons, daß die Gesellschaft eine Idee der Harmonie und der Herrschaft höchster geistiger Werte über die Natur verwirklicht, das aber nur im ganzen tut, im einzelnen jedoch die Individuen für dic Herbeiführung dieses Idealwertes vernutzt, ganz gleichgültig gegen eine wirkliche Bcteiligung jedes einzelnen Individuums selbst an dem durch das Ganze dargestellten Werte. An dieser Schwierigkeit nimmt trotz des Gegensatzes gegen den platonischen * Menschen im großen* und trotz seiner Kategorie einer spezifischen kollektiven Willenseinheit auch Aristoteles Anteil, indem ihm der Staat

138) Beispiele hier(ür bei P. Barth, , Geschichtsphilosophic als Soziologie und Kistiakowski, „Gesellschaft und Einzelwesen «. Für den mittelalterlichen Denker bedeuten die biologischen Analogien sehr viel weniger; weil ihm der ganze moderne Begriff des Naturgesetzes fehlt.

${ }^{130}$ ) Ich halte mich hier und im folgenden an die die thomistischen Lehren sehr präzis wiedergebende Darstellung der organischen Idee bei Th. Meyer, >Die christlich-ethischen Sozialprinzipien \&. $45-47,7 \mathrm{~S}$. Der Mensch ist abbildlich an Gottes Vorsehung beteiligt in der Schöpfung des Staates, sie ist cin Werk nicht des Naturtricbes, sondern des Vernunftriebes, der Staat int ein Artefakt, das unter der Leitung der Vorsehung und unter dem Typus der organischen, von Gottes Weisheit beherrschten Welteinheit steht. $\therefore$, auch Gierke III 556,629 f. Thomas betont dic ratio constituens civitatem.

14') Die Betonung der Einheit vor der Vielheit und ihr Zusammenhang mit Aristoteles wie mit der kirchlichen Autoritätslehre s. Gierke III 515 f.; daher denn das Drăngen auf Einheit und Monarchie auch in den Einzelbildungen der Gesellschaft. 
dic Verwirklichung der in der Gemeinschaft sich auswirkenden Vernunft ist, die das Ideal der gesetzlichen Harmonie und Ordnung, aber nicht eine Beteiligung des Individuums als solchen an den Vernunftwerten verwirklicht; daher sein junkerhafter Standpunkt gegenüber den banausen Berufen und den Sklaven liefernden Völkern ${ }^{141}$ ). Eine derartige Fassung der Einheit des Organismus aber ist, obwohl Thomas ihr gelegentlich huldigt, für die

141) S. hierzu die außerordentlich lehrreichen Aufsätze von H. Dietzel, >Beiträge zur Geschichte des Sozialismus๔, Z. f. Lit. und Geschichte der Staatswissenschaften I. D. zitiert aus Plato, Wir haben jedem Teil gegeben, was ihm entspricht, und dadurch das Ganze schön gestaltet und bemerkt dazu: sdie Stelle enthält eine der plastischsten, konkretesten Formulierungen der »organischen Sozialtheories, nämlich insoferne sie nur an die objektive Idee des Ganzen nicht an den Wert des Individuums denke. S. 394. Sa finden sich auch bei Thomas Stellen, wo er von der pulchritudo oder dem decor des Ganzen als Sinn der organischen Idee spricht und die Verschiedenheiten der Stellungen der Glieder hiermit begründet: s. De reg. princ. 3 : sNon enim est pulchritudo in corpore, nisi omnia membra fuerint decenter disposita; turpitudo autem contingit, quodcunque membrum indecenter se habeat; Epist. I ad Cor. Lectio I: Pertinet autem ad decorem et perfectionem ecclesiae, ut in ea diversa ministeria sint, quae significantur per ordines ministrantium, quod mịabatur regina Saba in domo Salomonis. « Ibid. Lectio III Perfectio corporis non tota consistit in uno membro, quamvis nobiliori, sed ad ejus perfectionem requiruntur etiam ignobiliora und Ita etiam (wie im organischen Körper) in Ecclesia sine officio abjectarum personarum, puta agricultorum et aliorum hujusmodi, praesens vita transiri non possit, quae tamen posset duci sine aliquibus excellentioribus personis contemplationi et sapientiae deputatis, quae Ecclesiae deserviunt ad hoc, quod sit ornatior et melius se habens. Das ist der platonische, völlig das Individuum der Realisation der Idee opfernde Einschlag im thomistisch-sozialen Denken. Es ist gleichfalls der Grundcharakter der idealistischen Staatslehre Hegels, worüber Dietzel in seinem $\gg$ Rodbertus . S. auch desselben Verfassers Artikel „Individualismus \& im Handwörterbuch der Staatswissenschaften. Uebrigens hat dieser decor des Ganzen bei Thomas den Sinn, dem Genusse Gottes zu dienen und Gott zu verherrlichen, er verkündet die Ehre Gottes. Darin kommt dann wieder der Willenspositivismus zu seiner Wirkang. S. Summa I qu. 65 art. 2 : Aequalitas justitiae locum habet in retribuendo; justum est enim quod aequalibus aequalia retribuantur. Non autem habet locum in prima rerum institutione. Sicut enim artifex ejusdem generis lapides in diversis partibus aedificii ponit absque injusticia, non propter aliquam diversitatem in lapidibus praecedentem, sed attendens ad perfectionem totius aedificii quae non esset, nisi lapides diversimode in aedificio collocarentur, sic et Deus a principio, ut esset perfectio in universo, diversas et inaequales creaturas institut, secundum suam sapientiam absque injustitia, nulla tamen praesupposita meritorum distinctione. 
christlich-organische Idee völlig unmöglich, da ihr gerade alles auf die Beteiligung des Individuums an dem durch das Ganze zu verwirklichen den Werte geistig-persönlichen Lebens ankommt ${ }^{142}$ ). Indem nun aber einerseits die organische Idee die differenzierte Eingliederung der Einzelnen in das Ganze und die ungleiche Bezie-

142) Dieser Widerspruch ist faktisch von Thomas überall erhoben, indem sein Begriff des Gliedes, des officium und ministerium, doch gerade jedes Glied am Ganzen beteiligen und seine Ethik die religiös-ethische Gleichheit gerade in allen Unterschieden sicher stellen will. Darauf geht die ganze Idee des Liebespatriarchalismus hinaus und darin ergänzt sie die organische Idee. S. auch Meyer in dem Abschnitt >Es gibt nichț Unheilvolleres, zumal für die inneren sozialen Verhältnisse des Gemeinwesens, als die dem Heidentum entlehnte Mißdeutung des organischen Grundcharakters der Gesellschafte S. 57-70. Das wendet sich gegen die platonische, aristotelische und Hegelsche Fassung der organischen Idee und betont gegen sie den christlichen Individualismus, der nicht Verwirklichung einer abstrakten Idee, sondern Beteiligung des Individuums an den höchsten Lebenswerten verlange. S. 58 -Das freiheitsmörderische sozialistische Ideal Platos๔, $>$ Was Aristoteles in gleicher Weise wie Plato fehlte, war der christliche Schlüssel zum vollen Verstandnis jenes (des organischen) Prinzips, die rechte Wertschätzung der persönlichen Würde des Menschen 4 . S. 61 $\rightarrow$ Die auffallende Verwandtschaft der neuheidnischen mit der altheidnischen Auffassung und Verwertung eines an sich nicht unrichtigen (des orga-. nischen) Prinzips ist keineswegs zufälig. Sie ruht in dem beiderseits bestehenden Gegensatz zum christlichen, einzig wahren Verständnis des gesellschaftlichen Organismus S. 63: $>$ Das leitende Korrektiv lag eben im christlichen Bewußtsein und namentlich in der christlichen Wertschätzung der persönlichen Würde des Menschen. Hören wir nur zwei Hauptvertreter der spezifisch-christlichen Sozialphilosophie, den h. Augustin und den h. Thomass. Wie freilich die organische Idee mit einem solchen Individualismus überhaupt zusammenbestehen kann, hat weder Meyer noch einer seiner beiden Gewährsmänner gesagt. In Wahrheit wird, wie oben gezeigt, das organische Prinzip hierdurch geradezu aufgelöst und bleibt nur sein Name bestehen. Allerdings handelt es sich hier um den schwierigsten Knoten der Sozialethik; nicht das Individuum als solches, sondern das mit absoluten ethischen Werten erfüllte hat Selbstwert und ein jedes nur Ziel und Anspruch zu diesen Werten zu gelangen; andererseits aber lassen bei der naturgegebenen Beschaffenheit sich jene Werte nicht für und in allen Individuen oder jedenfalls nicht für alle und in allen gleich verwirklichen, sodaß nur der leitende Einfluß dieser Werte auf das Ganze sicher gestellt werden kann, wobei zahlreiche Individuen als Voraussetzung und Mittel vernutzt werden. So schwankt jede Sozialethik zwischen der Verwirklichung der objektiven Werte an sich und der subjektiven Beteiligung der Individuen an diesen Werten mit starken Konzessionen an den Naturalismus; vgl. meine Bemerkungen zu dem Referat von v. Schultze-Gävernitz in den sProtokollen des Ev.-soz. Kongressese 1907. 
hung der Glieder auf den Zweck des Ganzen lehrt, andererseits aber der christliche Individualismus cine Beteiligung jedes Individuums an dem Gesamtzweck verlangt, wird sowohl die dem Organismus vorgeordnete Einheit als auch die Stellung des Individuums zu dem Zentralzweck des Organismus etwas ganz anderes. Die vorgeordnete Finheit wird im letzten Grunde zu der das Ganze beseelenden und leitenden Autorität, die nach den Grundsätzen der distributiven Gerechtigkeit jedem nach seiner Stellung und seinem Maße die Beteiligung an dem Zentralwert des Ganzen zuweist. So wird jeder Einzelorganismus innerhalb des großen Systems als von einer Autorität geleitet und zusammengehalten betrachtet, indem sie den spezifischen Zweck des einzelnen Kreises, der Familie, der Stadtgemeinde, des Staates, der Zünfte und Gesellschaften gerecht d. h. mit Rücksicht auf den Einzelnen verwirklicht. Und so erhebt sich über dem Ganzen mit dem religiösen Zentralzweck die religiöse Autorität als die eigentliche Seele der ganzen menschlichen Gesellschaft in all ihren Stufen und Gruppen, dic teils die Einzelgruppen ihre Zwecke selbst verwirklichen läßt, teils berichtigend und Gerechtigkeit stiftend im Notfalle in sie eingreift und vor allem das Ganze selber in seinen Grundverhältnissen leitet und bedingt, um jeden auf seine IVeise und an seinem Ort an dem ewigen Zwecke seinen entsprechenden Anteil finden zu lassen. An Stelle eincr die Entwickelung treibenden und in ihr sich verwirklichenden Vernunftidee steht die alle Individuen direkt oder indirekt auf den höchsten Zweck hinleitende Autorität, oder vielmehr das Produkt der vernünftigen Entclechie und Gesellschaftsentwickelung wird von der übernatürlichen lutorität erst wahrhaft im Sinne der Gerechtigkeit organisiert, die bei der sich selbst überlassenen Vernunft immer gefährdet ist, auch noch ganz abgesehen von der Trübung durch den Sündenfall. Der »Organismus « ist in letzter Linie als autoritative Leitung der von Naturtrieb und $Z$ weckeinsicht geschaffenen Gliederungen auf den eigentlichen und letzten, den religiösen $Z$ weck hin gedacht, und die leitende Autorität ist das kirchliche Lehr- und Hirtenamt mit seiner Gipfelung im Papst. Ebendeshalb war es auch unlogisch, wenn die konziliare Theorie auch die die Autorität darstellende Hierarchie selbst im Sinne des Organismus konstruieren wollte. Sie leitet den Organismus, ist aber nicht selbst organisch zu verstehen, womit freilich am deutlichsten die Durchbrechung der eigentlich organischen Idee ausgesprochen ist. Die organische Einheitsidee verwandelt sich 
in die Autoritätsidee, die gemäß der infalliblen Autorität die Anteilnahme der Individuen am Wert des Ganzen regelt, ohne von ihnen darüber zur Rede gestellt werden zu können. Vertrauen und Pietät gegen die Autorität löst das Problem ${ }^{143}$ ). Damit bleibt nun aber doch eine sehr ungleichartige Beziehung der durch den

143) Ueber die Autorität als Seelé des ganzen Organismus Summa 2 a 2 ae qu. 60 art. 3: Potestas saecularis subditur spirituali sicut corpus animae; ibid. I qu. 96 art. 4: Quandoque multa ordinantur ad unum, semper invenitur unum at principale et dirigens; Contra Gent. IV 76: optimum autem regimen multitudinis est, ut regatur per unum . . unitatis congruentior causa est unus quam multi; Summa 2 a 2 ae qu. Io a. I I : Humanum regimen derivatur a divino regimine et ipsum debet imitari. Contra Gent. IV 76: Manifestum est, quod, quamvis populi distinguantur per diversas dioeceses et civitates, tamen sicut est una ecclesia, ita oportet esse unum populum Christianum. Sicut igitur in spirituali populo unius ecclesiae requiritur unus episcopus qui sit totius populi caput, ita in toto populo christiano requiritur quod unus sit totius ecclesiae caput. De reg. princ. I c. 2: manifestum est, quod unitatem magis efficere potest, quod est per se unum quam plures; das bedeutet die monarchische Verfassung jedes Organismus. Der Abgang von der aristotelischen organischen Idee ist hier so deutlich wie bei der Begründung der organischen Idee auf die Arbeits- und Diensteverteilung, und wie hier das Urbild des corpus mysticum leitend ist, so dort das Urbild der einheitlichen kirchlichen Idee. Ueber die Autorität als Zentrum des Organismus s. weiter Gierke III 517, 547, 560 f., bes. 555 : Endlich leitet man aus dem Wesen des Organismus die absolute Notwendigkeit einer einheitlichen Kraft her, welche als summum movens die übrigen Kräfte belebt, leitet und normiert; und man gelangt so zu dem Satze, daß jeder gesellschaftliche Körper eines herrschenden Teiles (pars principans) bedarf, mag man nun in diesem Teile das Haupt, das Herz oder die Seele des Ganzen erblicken. Aus dem Vergleiche des Herrschers mit dem Haupte wird sogar vielfach ohne weiteres die Naturgemäßheit der Monarchie abgeleitet, da es doch nur E in Haupt geben könne; ja es wird daraus nicht selten gefolgert, daß ohne die Verbindung mit dem rechtmäßigen Oberhaupte der ganze Körper und jedes Glied desselben alles Lebens entbehre.*. Das gilt natürlich vor allem vom Papste in seiner Stellung über der Kirche und über der res publica christiana. Ganz ebenso Th. Meyer, S. 50: Das wesentlich leitende Element jeder Gesellschaft, die Autorität, welche gleichsam als die Seele derselben ihre Lebenseinheit bedingte; S. 66: >Obwohl der $h$. Thomas einerseits mit Recht hervorhebt, daß der natürliche Bildungsprozeß der Gesellschaft vom Besonderen zum Allgemeinen, von der Familie zur Gemeinde und zur bürgerlichen Gesellschaft und insoferne von unten nach oben sich vollzieht, so kann nach $\mathrm{ihm}$ doch der ideale und zweckliche Zusammenhang dieses wundervollen geistigen Organismus nur dann richtig begriffen werden, wenn man sich im Geiste gleichsam in den zentralen Mittelpunkt der gesamten Weltordnung stellt. Von hier aus tritt dann zuntichst die Autoritut als wesentliches Troelts ch, Gesammelte Schrifton. I. 
Organismus an verschiedene Stellen gebannten und damit sehr verschieden zur Erreichung des Z Zweckes begünstigten Individuen. Diese, Schwierigkeit nun begegnet die kirchliche organische Lehre e einerseits durch die religiöse Doktrin der gegenseitigen Stellvertretungen, die aus ihrem Verdienst- und Liebesgedanken hervorgegangen war, und andererseits durch die Doktrin von einer quantitativ verschiedenen, darum aber doch das prinzipielle Ziel nicht aufhebenden Vollkommenheit. Beide Gedanken sind bei der Würdigung der mittelalterlichen Askese bereits hervorgehoben worden; auch bei der Charakterisierung des bloß architektonischen Charakters der Entwickelungsidee mußte bereits darauf hingewiesen werden. Hier zeigt sich nun ihr Wert und ihre Funktion im System des Ganzen, ihre grundlegende Bedeutung für die ganze katho-. lische Sozialphilosophie. Nur in dieser Form konnte der wesenhaftc christliche Individualismus einem System eingegliedert werden, das dic Individuen unter die Herstellung einer in sich gegliederten sozialen Einheit beugt, und das zugleich in dieser Gesellschaftseinhcit die Bedingungen des natürlichen Lebens mit seinen von Natur und Geschichte im Kampf ums Dasein bewirkten starken Differenzen, mit seinen Gegensätzen gegen das überweltliche Ideal der religiösen Liebesethik, anerkennt. So ist die ungeheure, dem christlichen Persönlichkeits- und Liebesidealismus wesenhaft einwohnende Schwierigkeit, überhaupt ein allgemeines Gesellschaftsideal zu erzeugen, überwunden: die kirchliche Autorität nimmt alle Gesellschaftsbildungen unter ihre Verwaltung und sichert dem Finzelnen die gerechte Beteiligung am Zentralzweck; die Gleichheit der Anteilnahme aller am objektiven Werte des Systems ist dahei gebunden an die sittliche Leistung des Individuums und kein Naturanspruch; überdies genügt die proportionale, der gliedlichen Stellung angemessene Anteilnahme am bonum commune in weltlichen und geistlichen Dingen; auch die Anteilnahme am über-

Element der Gesellschaft nach Wesen und Ursprung, nach Zweck und Aufgabe, nach ihrer Beziehung mach oben zu Gott und nach unten zu den Untergebenen ins rechte Licht. Im Widerschein des letzteren aber klärt sich in ebenso hellen Linien das vom Schöpfer beabsichtigte innere Verhältnis der organischen Teile zu einander und zur Ciesamtheit. Ja es erhalten daraus sogar die Prinzipien einer gesunden Nationalükonomie und guten Verwaltung eine vielseitige Beleuchtung. * Dazu Contra Gent. III $1-3$ IV 23. Daher unterscheidet Meyer in der organischen Idee den konstitutiven und den Verwaltungsorganismus S. 53, der erste ist die aristotelische Idee, der zweite die darauf aufgepfropfte katholische. 
natürlichen Heil ist eine proportional verschiedene. Wie die Entwickelungsethik eine Relativierung der radikalen christlichen Maß3stäbe ermöglicht und auch relative ethische Werte auf das christliche Ideal bezieht, so besiegt der Gedanke der "Proportionalität* die Schwierigkeiten des mit dem organischen Gedanken gesetzten sozialen Relativismus. Dafür, daß jedenfalls diese proportionale Gleichheit innerhalb des Organismus durch eine gerecht verteilende Autorität erreichbar ist, sorgt die Vorsehung, die Kirche und die den Gesetzen der Sozialbildung einwohnende Weltvernunft. Jedes wirkliche und volle Fernbleiben von dem objektiven Werte überhaupt hat seinen Grund in Schuld und bösem Willen des Individuums. Wenn nun freilich dieses Böse letztlich auf Prädestination zurückgeht, so ist damit ein dunkler irrationaler Hintergrund aufgetan, der im thomistischen System und im heutigen Katholizismus nicht gerne stärker beleuchtet wird. Der göttliche Wille wird vielmehr im System nur soweit stark betont, als die Institutionen und Differenzen überhaupt auf ihn zurückgeführt werden, doch so, daß dabei ihre

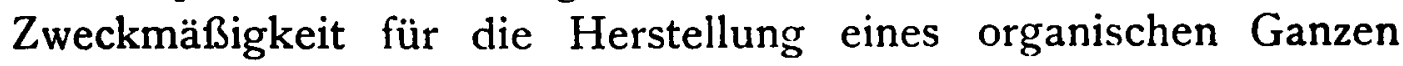
vor allem ins Auge fällt. Diesen Differenzen gegenüber ist dann aber eben doch eine wenigstens proportionale Anteilnahme am absoluten Lebens- und Gemeinschaftswerte möglich, und diese proportionale Beteiligung rechnet auf die Gesinnungen der Genügsamkeit und Ergebung wie der Fürsorge und Liebestätigkeit, durch welche diese Differenzen wieder in der den ganzen Organismus hervorbringenden Gottesliebe ausgelöscht werden. Liegt die eigentliche Schwierigkeit einer idealistisch-religiösen Sozialethik wie der christlichen darin, daß sie die Individuen erst durch Erhebung zu allgemeingültigen objektiven, die Gemeinschaft verbindenden Werten vollendet, aber dic Beteiligung des Einzelindividuums an diesen von der Gemeinschaft getragenen objektiven Werten gegenüber den von der Natur her wirkenden Differenzen nur ungleich und mangelhaft zu sichern vermag, so ist hier die Schwierigkeit überwunden durch den Glauben an das in der Sozialbildung waltende, alle befriedigende Vernunftgesetz, durch die die distributive Gerechtigkeit durchsetzende, das Ganze beseelencle und in der kirchlichen Zentralautorität gipfelnde Autorität, und durch die Begnügung mit einer bloß proportionalen, der gliedlichen Stellung entsprechenden und darum quantitativ verschiedenen Anteilnahme der einzelnen an den absoluten und relativen Gemeinschaftswerten. So ist auch der nicht minder wesenhafte Gegensatz der 
Liebesethik gegen die weltlichen Interessengliederungen aufgelöst, indem die Liebesethik im höchsten Sinne asketisch zugespitzt und einem besonderen Beruf und Stand zugewiesen, den Weltleuten aber eine mindere Vollkommenheit zugewiesen wird, die doch bei der Beziehung auch ihrer Leistungen auf den höchsten Zweck darum nicht aufhört auch ihrerseits Vollkommenheit zu sein. Von hier aus erstrecken sich Einheit und Unterschiede bis in die triumphierende himmlische Kirche hinein: die verschiedenen Stände und Berufe haben ihren besonderen Lohn und ihre verschiedene Seligkeit, und Beatrice belehrt ihren Dichter im Paradies, daß die verschiedenen Grade der Seligkeit die Seligkeit doch nicht aufhören lassen, Seligkeit zu sein ${ }^{144}$ ).

144) Vgl. oben den Abschnitt über die Askese; auch den über den architektonischen Charakter des thomistischen Denkens; ein klassischer Ausdruck hierfiir bei Marsilius von Padua bei Gierke III 552: componitur (der Organismus) ex quibusdam proprotionatis partibus invicem ordinatis suaque opera sibi mutuo communicantibus et ad totum. Von Thomas s. die Ausführung zu I Cor. XII lectio III, wo es heißt, daß die activi notwendig sind für die contemplativi sindigent enim contemplativi per opera activorum sustentari Prïlaten, die ohne sie nicht existieren könnten. Wie die Virginität ergänzend neben der regulären Ehe steht, zeigt Ratzinger S. 94: *Weit entfernt, daß die Virginität, wie man ihr zum Vorwurfe macht, die Gesellschaft mit Unfruchtbarkeit schlägt, wird sie Veranlassung, die Fruchtbarkeit zu erhalten. Die Erklärung dieses scheinbaren Widerspruches liegt in der sittlichen Ordnung, in der Macht des Beispiels, in der Kraft des Opfers. Die Jungfräulichkeit weckt durch das größte Opfer, durch die heldenmütigste Entsagung, durch die höchste Tugend die sittliche Kraft derjenigen, welche in der Ehe leben, und trägt damit bei die Gefahren zu beseitigen, welche der Ehre der Familie und der Ehe drohen, wenn die Kraft des Opfers mangelt.: Ueber die quantitative Ungleichheit der Vollkommenheit, d. h. der eigentlichen Beziehung auf den Zentralzweck des Organismus vgl. Summa i a 2 ae qu. 108 a. 4: quod homo totaliter ea, quae sunt mundi, abjiciat, non est necessarium ad proveniendum ad finem praedictum, quia potest homo utens rebus hujus mundi dummodo in eis finem non constituat, ad beatitudinem aeternam pervenire. Sed expeditius perveniet totaliter bona hujus mundi abdicando et ideo de hoc dantur consilia evangelii. Dabei entscheidet die Geeignetheit, also die Naturanlage: praedicta consilia, quantum est de se, sunt omnibus expedientia, sed ex indispositione aliquorum contingit, quod alicui expedientia non sunt, quia eorum affectus ad ea non inclinantur. Hier steht wieder Prädestination und göttliche Willenssetzung im Hintergrunde. Ueber die quantitative Unterschiede bis in die Seligkeit hinein Contra Gent. III 58 Quum finis proportionaliter respondeat his, quae sunt ad finem, oportet, quod sicut aliqua diversimodepraeparanturad finem, ita diversimode participent finem. Visio autem divinae substantiae est ultimus 
So hebt sich aus allen Verwickelungen die katholische Sozialphilosophie immer wieder zu imponierender Einheit empor. Man sollte nun meinen, ein derartiges System müsse tief einschneiden in das praktische soziale Leben. Das ist auch tatsächlich mannigfach geschehen, aber niemals planmäßig und bewußst als kirchliche Sozialreform. Hierin liegt ein weiterer charakteristischer Zug. Die Konzentration des Christentums auf das Innerliche, Persönliche und Religiöse setzt sich darin fort, daß auch bei der Herstellung einer christlichen Einheitskultur nur die stärksten Widerstände, der Gegensatz selbständiger weltlicher Mächte, gebrochen und gewisse Rechte der Kirche festgelegt werden, daß aber jeder Gedanke an eine planmäßige, die Naturbasis erst unterwerfende und gestaltende Ordnung noch fern liegt. Dazu fehlten freilich auch noch die Einsichten in die Schwierigkeiten und Komplikationen, die die Naturbasis für die Verwirklichung ideeller Werte in sich enthält. Diese Sozialphilosophie ist wohl ein alles umfassendes soziologisches System ist, aber auch jetzt noch auf der Höhe der gedanklichen Durchbildung ke in Programm einer eigentlichen Sozialreform. Die christliche Soziallehre des Nittelalters ist das so wenig, als die der alten Kirche es gewesen ist, wenn auch freilich aus anderen Gründen. Hatte die alte Kirche sich in die fest und irreformabel gewordenen Ordnungen der alten Gesellschaft gefügt und sie als sündige Verderbung der naturrechtlichen Ordnung ertragen lernen, im übrigen ihre Schäden durch karitative Tätigkeit geheilt, so hat die hochmittelalterliche Kirche fest an die gottgesetzte Harmonie von Natur und Gnade geglaubt und die relative Annäherung der wirklichen sozialen Ordnungen an die kirchlichen Ideale für die naturnotwendige, begriffsgemäße Welteinrichtung angesehen, die zu ihrer Sicherung nur der Herrschaft der Kirche bedarf und der immer neuen Stärkung der religiösen Grundsätze. Die Zusammenfassung der Kirche im Papsttum organisiert die Kirche religiös und hierarchisch, ordnet die politischen Gewalten dem Gefüge ein, aber für das soziale Leben im engeren Sinne und für das wirtschaftliche Leben läßt

finis cujuslibet intellectualis substantiae. Intellectuales autern substantiae non omnes aequaliter praeparantur ad finem; quaedam enim sunt majoris virtutis et quaedam minoris; virtus autem est via ad felicitatem. Oportet igitur quod in visione divina sit diversitas, quod quidam perfectius et quidam minus perfecte divinam substantiam videant. .. Idem ergo est, quod omnes beatos facit, non tamen ab eo omnes aequaliter beatitudinem capiunt. 
sie das Naturgesetz sorgen. Darauf beschränkt sich alle sozialc Gestaltung. Für die alte Kirche war eine Sozialreform zu schwierig, für die mittelalterliche war sie überflüssig. Sie hat den tatsächlichen Zustand idealisiert und für das wahre, von Vernunft und Offenbarung gleichmäßig geforderte, Ideal erklärt. Sie hat die relativen Annäherungen und Vorstufen, die sie in den tatsächlichen Verhältnissen vorfand, als Naturgesetz verabsolutiert und den kirchlichen Gedankengängen entwicklungsgeschichtlich-architeltonisch eingegliedert. Sie überläßt jetzt sogar die karitative Tätigkeit den Orden, Korporationen und Städten und beschränkt sich nur auf die Durchsetzung ihrer selbst, womit dann alles übrige von selbst in Ordnung kommt. Ihre Sozialreform ist lediglich der Kampf für die Kirche und das Naturrecht; das aber bedeutet nicht eine Neugestaltung der Gesellschaft nach den radikalen christlichen Ideen, sondern eine Verewigung des verhältnismäßig befriedigenden Zustandes und eine Emporleitung'von den relativen natürlichen Gesellschaftswerten zu den absoluten übernatürlichen der Kirche. Das Christentum braucht die Welt nicht umzugestalten; Gott regiert sie vielmehr so, daß sie der Kirche entgegenwächst. Daher ist auch die moderne katholische Sozialreform theoretisch in erster Linie die Rückkehr zu den Grundsätzen des christlichen Naturrechts und zur Herrschaft der Kirche, der Gegensatz gegen die Meinung, daß neue Verhältnisse einen prinzipiellen Neubau des sozialen Denkens verlangten, und der Kampf gegen die Irrlehren des Liberalismus. Erst ganz neuerdings tritt das Papsttum mit Belehrungen auch über die sozialen und wirtschaftlichen Fragen hervor, nachdem die moderne Welt deren Schwierigkeiten und Verwickeltheiten dargetan hat. Aber was es hier lchrt, ist nur die bewußte und planmäßige Geltendmachung der »natürlichen « Grundsätze gegen eine aus den Fugen gegangene Welt ${ }^{144}$ ). Die Idee an sich ist die der mittelalterlichen Kirchc. Sie kapituliert nicht wie dic alte Kirche vor der Macht der unter dem Einfluß der Sünde stehenden Naturbasis des Lebens; sie will aber auch nicht wie der moderne Idealismus durch menschliche Arbeit und Einsicht die Unterwerfung einer widerstrebenden und schwierigen Naturbasis unter die hüchsten ethischen Ideale eines unbedingten Per-

3*a) Das ist ror allem ein Verdienst Leos XIII., des "sozialen Papstes; seine Erlasse liegen allen modernen katholischen Arbeiten zugrunde; vgl. Mausbach. Christentum und Weltmoral, S. 44. 
sönlichkeitswertes und einer freien innerlichen Geistesgemcinschaft erst herstellen, sondern sie glaubt an die gottgesetzte Harmonie der Naturbasis und des christlich-kirchlichen Ueberbaus, wie sie die großen Zeiten des Mittelalters annähernd verwirklicht und darin das große Gesetz der göttlichen Weltregierung gezeigt haben. Durch die liberalen Theorien ist das wahre Verständnis des Naturrechts verloren gegangen, und durch die liberale Praxis ist der Gang der wahren Natur sündhaft zerstört worden. Es gilt die Wiederherstellung des wahren Naturrechts und der Herrschaft der Kirche, und die Natur wird wieder ihren harmonischen Gang gehen, ergänzt und unterstützt durch karitative Tätigkeit und durch zweckmäßige Heilung der spezifischmodernen, aus Kapitalismus und Maschinenarbeit entstandenen Schäden ${ }^{14 \dot{j}}$ ).

145) Vgl. hierzu Ratzinger, $>$ Gesch. d. kirchlichen Armenpflegea, der über das Mittelalter besser orientiert als die entsprechende Darstellung Uhlhorns; S. 247: »Mit dem Ende des 12. Jahrhs. hatte die kirchliche Armenpflege, wie sie durch die karolingische Gesetzgebung geregelt worden war (diese war eine Ueberführung der altkirchlichen freien Armenpflege in eine staatlich geforderte), fast iiberall aufgehört; die kirchliche Gemeinde kümmerte sich um ihre Armen nicht mehr, der Weltklerus war nicht mehr gesonnen, um die Armenpflege sich anzunehmen. Die kirchliche Gesetzgebung, welche jetzt ausschließlich von den Päpsten ausgeübt wurde (im Gegensatz zu der die Armenpflege offiziell regelnden Legislatur der altkirchlichen Konzilien), zog die Armenpflege nicht mehr in das Gebiet ihrer Tätigkeit, das Kirchenvermögen hatte den Charakter cines Armenfonds vollständig eingebüßt. Nur der Regularhlerus vergaß nie seine Pflichten gegen die Armen, und so lange es Klüster gab, übten sie Werke der Wohltätigkeit. Zu den Klöstern gesellt sich cin ganz neuer Faktor, die Vereine und die Orden, welche aus dem Laienstande sich rekrutierend an die Stelle einer geordneten kirchlichen Armenpflege traten, um den Untergang derselben nicht gar zu empfindlich werden zu lassen. Fast $z u$ gleicher Zeit bildete sich das Korporationsleben in den Städten aus, die Zünfte bildeten sich, zu deren Aufgaben es auch gehörte, für ihre verarmten Mitglieder zu sorgen. Dieses sind die Elemente, die seit den Kreuzzügen allmählich hervortraten, in die leer gelassene Stelle der kirchlichen Hausarmenpflege einrücken, ohne letztere ersetzen zu können. Den Klüstern war es unmöglich, jene strenge Kontrolle zu üben, welche bei der Armenpflege nötig ist, wenn sie nicht mehr schader als nützen soll, und die Vercine und Orden beschränkten ihre Tätigkeit fast ausschließlich auf das Hospital. Was die (alt)lirchliche Gemeinde, den Seelsorger an der Spitze, durch das Mittel der Hausarmenplfege geleistct hatte, das wurde von jetzt an ein unerreichbares Ideal. Yon da an allerdings hat der Vorwurf eine Berechtigung, die Armenpflege der Kirche sei nur ein $\Lambda$ lmosengeben, keine Armenpflege gewesen.e Für Thomas ist charakteristisch, daß neben seiner Darstellung der persönlichen 
Damit hängt nun schließlich auch die letzte Grundeigentümlichkeit der katholischen Soziallehre zusammen, ihre eigentümliche Auffassung des $\mathrm{R}$ e c h t e s, ihr scharfer Gegensatz gegen die moderne Lehre von der Schöpfung des Rechtes durch den Staatswillen.

Moralităt im Aufstieg von den natürlichen Tugenden 20 den übernatürlichen und neben seiner Sozialphilosophie mit ihrem Kosmos des natürlich-übernatürlichen Organismus die Frage einer Sozialreform und auch nur die nach einer die sozialen Schäden heilenden Mission der Kirche gar keine Rolle spielen; über die Abwesenheit der. Sozialreform in jedem Sinn bei ihm s. Maurenbrecher S. 49: >Für Thomas wird die Lebenshaltung des Einzelnen durchweg nach dem Stande bedingt, dem er angehört, in den er nach dem Ratschluß der Vorsehung hineingeboren ist; unter die übliche Lebenshaltung seines Standes soll niemand herabsinken; aber darüber hinauszustreben ist gleichfalls verboten. Eine soziale Hebung der unteren Stände, eine sEmporentwickelung der Massen c kennt demnach Thomas nicht; sein soziales Ideal trugt durchaus konservativen Charakter; auch darin entspricht er ganz der Auffassung, die man im allgemeinen im Mittelalter über diese Dinge hatte. Ebenso S. 88 f., auch Feugueray S. 213 f., Uhlhorn, siebestätigkeit « II 448. Wie sehr auch die modemen katholischen Sozialideale eine Rückkehr zur natürlich-übernatürlichen Gesellschaftsharmonie des Mittelalters sind, darüber s. Ratzinger, >Die Volkswirtschafte, S. $325 \mathrm{f}$. $>$ Würde und Ehre der Armut und der Arbeit, Liebe zur Armut und zum einfachen Leben selbst inmitten des Reichtums, Verbindung und Ausgleich zwischen Reich und Arm durch die Liebe und die Freiheit (d. h. Freiwilligkeit) «, das ist das Sozialprogramm. Damit kehrt man zum Naturgesetz zurück, das in diesen Gesellschaftsformen dann auch ganz von selbst den größtmöglichen Wohlstand wirkt, S. 323: Dieselben Ideen, welche den Menschen zur idealen Höhe der Vereinigung mit Gott emportragen, beantworten auch die Fragen der politischen Oekonomie: über das Verhältnis von Reich und Arm, über Erwerb und Verwendung des Reichtums, über Arbeit und Arbeitsertrag u. s. w. Das Christentum bringt denjenigen, die seine Lehre bekennen und befolgen, nicht bloß das Reich Gottes, es gibt ihnen auch alles übrige dazu: Wohlstand, Gleichgewicht zwischen Reichtum und Armut, Fortschritt in der Arbeit und in der Herrschaft über die Natur, Freiheit und Gleichheit aller nach Ursprung und Ziel, Schutz gegen Erniedrigung und Ausbeutung in der brüderlichen Gesinnung und in dem Bewußtsein, daß alle Söhne des himmlischen Vaters sind. \& Das aber kann es nur unter Zuhilfenahme des Naturgesetzes und seines organischen Kosmos der Stände und Berufe. Die modernen Strömungen katholischer Sozialphilosophie, die auf die selbständige Bewegung der modernen Gesellschaft eingehen und sie gegen diese kirchlich-naturrechtliche Doktrin unabhängig machen wollen, sind eben deshalb schwere Einbrüche in das Prinzip. Der politisch-soziale Modernismus ist nicht minder gegen das Prinzip als der dogmatischreligionsphilosophische und teilt dessen Schicksal s. Loisy, Quelques lettres sur des questions actuelles 1908, der mit Recht auch vor allem den politisch-sozialen Gegensatz der Kirche gegen die moderne Welt betont und wenig Hoffnung für den Sieg eines solchen politisch-sozialen Modernismus hegt. 
I.äßt diese alles Recht, auch wo es inhaltlich vorstaatliche soziale und ethische Ideen sanktioniert, formell als Recht nur durch den Staatswillen zustande kommen und erteilt sie damit dem modernen Staat die Unruhe eines immer neuen Versuches zur Umwandelung ethischer und rationeller Forderungen in Rechtsbestimmungen, so betrachtet die katholische Soziallehre das Naturrecht als vor clem Staate gegeben und diesen verbindend zu einer positivrechtlichen Ausarbeitung der organisch-patriarchalischen Prinzipien des christlichen Naturrechtes. Er ist frei, dabei den verschiedenen Umständen und wechselnden $Z$ weckmäßigkeiten Rechnung zu tragen, bleibt aber daran gebunden, seine Schöpfungen als Ausarbeitungen der Prinzipien des Naturrechtes zu betrachten und sie nach der Einsicht in dieses fortschreitend zu verbessern. Das bedeutet auch hier, daß alles Wesentliche gefunden und gegeben ist, daß der Gang der Natur und Vorsehung von selbst in die richtige Erkenntnis leitet, daß der Staat wie alle positive Rechtssetzung sich nach diesem zu richten habe, von dort her die Rechtsverbindlichkeit seiner Sätze erst erlange. Dann aber ist eben auch jeder Gedanke großer sozialer Neuschöpfungen ausgeschlossen, die mit einem neuen Recht vom Staate her die neuen Verhältnisse zu ordnen hätten. Dann gibt es nur das Zurückgreifen auf ewige und unwandelbare Prinzipien, die nur in der Einzelanwendung den neuen Verhältnissen angepaßt werden mögen. Es ist kein revolutionäres, erst aus neu entdeckter Vernunft die Welt umgestaltendes Naturrecht, wie das Naturrecht der Aufklärung oder wie die modernen Staats- und Gesellschaftstheorien; es ist ein konservatives, organisch-patriarchalisches Naturrecht, das unter dem Schutz der Kirche steht und nur der christlich-erleuchteten Vernunft voll verständlich ist, wenn es an sich auch aus reiner Vernunft hervorgeht. Es ist ein Rationalismus mehr der Beruhigung bei erkannten und beweisbaren Wahrheiten, als der kritischen Initiative und Reform. Die Weltordnung beruht auf der Vernunft, aber auf der Vernunft Gottes und nicht auf der des Menschen, auf der objektiven, nicht auf der subjektiven Vernunft. Darum allein auch paart sie sich so leicht mit dem Supranaturalismus und der kirchlichen Gnadenmystik ${ }^{146}$ ).

110) Ueber diese Eigentümlichkeit des mittelalterlichen Rechtsbegriffes s. Gierke III 609-627, der auch die großen Widersprüche und Verwickelungen aufweist, die hierin lagen und liegen. - Auch v. Nostitz-Rieneck, S. J., ’Das Problem der Kultur Erg.-H. zu Stimmen aus Maria Laach), 1885, S. 20: Die gegebene Grundlage der 
Von diesen beiden letztgenannten allgemeinen Charakterzügen aus ergibt sich num aber nicht nur ein abschließendes Bild der aus dem Thomismus entspringenden und dauernd die Führung behaltenden allgemeinen Spzialphilosophie des Katholizismus, sondern es fällt von hier aus ein Licht a uch auf das prinzipielle Wesen einer christlichen Sozialphilosophie überhaupt, auf die sozialphilosophischen Möglichkeiten, die im christlichen Gedanken liegen, und damit auf den Weg ihrer Entwickelung nach rückwärts und nach vorwärts. Das Mittelalter schafft eine christliche Einheitskultur und eine alles umfassende christliche soziologische Grundidee. Diese Einheitskultur ist aber doch auch ihrerseits nicht eine Sozialreform nach christlichen Grundsätzen, sondern nur die Akzeptierung der relativ entgegenkommenden tatsächlichen Verhältnisse und ihre Verschmelzung mit der religiös-kirchlichen Welt zu einem harmonischen Entwickelungsganzen. Das wird dadurch möglich, daß die von den allgemeinen Verhältnissen entgegengebrachte Lage nicht als glücklicher historischer Zufall, sondern als begrifflich notwendige Auswirkung der Natur betrachtet und der ererbte Begriff des sittlichen Naturgesetzes nun auf diese politisch-sozialen Verhältnisse übertragen und aller positiven staatlichen Gesetzgebung als Grund und Norm vorgeordnet wird. So wird nun das von der tatsächlich vorliegenden Lage ausgeprägte Naturgesetz mit dem Ethos und dem Gemeinschaftswesen der Offenbarung verbunden, genau wie die teleologisch-unsterblichkeitsgläubige Metafhysik mit dem Dogma. Der in beiden Fällen stattfindende Stufenbau des Aufstieges von der Natur zur Offenbarung

Kultur besteht erstens in der gesamten stofflichen Natur, zum zweiten besteht sie sim Naturrecht, dem natürlichen Gesellschaftsrecht und dem natürlichen Individualund Privatrecht. Und nur weil diese Basis gegeben ist und feststeht, hat die historische Entwickelung des positiven Rechtes einen klaren Ursprung und einen sicheren Grund.s Auch hier gilt, was für den ganzen Katholizismus gilt S. 8: \Wir folgen zwei Führern, welche stets denselben Weg weisen: gesunder Vernunft und christlicher Weltanschauung «. Das gilt dann freilich nur von einem Naturrecht und einer gesunden Vernunft ganz bestimmter historischer Prägung, nämlich thomistischer Prägung. Vgl. ibid. S. 49 f., wo versucht wird, dem Fortschritt und der Variabilität im positiven Recht Luft zu machen. S. 52: , Wenn nun die wirtschaftlichen und geistigen Fortschritte so groß sind, daß neue Zustände der Volkswirtschaft und der Volksbildung geschaffen werden, dann ist die überkommene Gesellschafts- und Rechtsordnung, richtiger ein Teil ihrer positiv-rechtlichen Satzungen in Staats- und Privatrecht, zu den neuen Zuständen nicht mehr passenda. 
hat aber seinen letzten Grund im Wesen Gottes selbst, dessen Wesen es ist, durch die Natur hindurch emporzuführen zur Uebernatur in einem auf Entwickelung angelegten und trotz allen Sündenfalls auch unter den Bedingungen der Sünde sich entwickelnden .Weltprozeß.

Betrachtet man dieses Ergebnis als Aufsammlung der bisherigen geschichtlichen Entwickelung, so erleuchtet sich aufs einfachste der Weg nach rückwärts. Die christliche Ethik war rein für sich, wie bereits ausgeführt, die spezifisch religiöse Ethik einer personalistisch-religiösen Empfindungsweise, war Heiligungs- und Liebesethik, Hingabe an Gott im sittlichen Gehorsam und Vereinigung in Gott durch religiöse Bruderliebe. Sie kannte die Natur und die naturhaften Motive nur als die allgemeinen, in den engsten Grenzen zu haltenden Voraussetzungen des Lebens, im übrigen, wo sie darüber hinausgehen, als Selbsterhöhung des irdischendlichen Selbst und als Verleugnung der Liebe, entwarf daher ein Ideal der rein für Gott geweihten und in ihm wurzelnden Persönlichkeit sowie der rein durch Liebe alle Differenzen und Härten überwindenden Gemeinschaft, wußte aber auch, daß dieses Ideal erst auf einer neuen Erde und unter einem neuen Himmel voll verwirklicht werden kann. So stand sie von Hause aus im Gegensatze gegen alle Moral, die am Kampfe der Menschen miteinander orientiert ist und in Tapferkeit und Ehre das Ideal der Persönlichkeit, in Gerechtigkeit, zweckmäßiger Solidarität und billiger Abgrenzung der Interessensphären das Ideal der Gemeinschaft sicht. Sie kannte eine Ehre des Menschen nur vor Gott und konnte vor Menschen auf ihr Recht und ihre Ehre darum verzichten. Sie kannte eine alle Gegensätze im Feuer der Gottesliebe schmelzende Einheit der Seelen und darum kein Recht und keinen Kampf ums Recht. So konnte sie wohl das Ideal der monogamischen Familie sich aneignen, aber nicht das des Staates mit Recht, Krieg und Gewalt und nicht das des wirtschaftlichen Kampfes mit Reichtum, Macht und Besitz. Sie war in allen Punkten einer Moral entgegengesetzt, die aus dem Kampf ums Dasein hervorgeht und ihn bloß durch Veredelung der Kämpfertugenden und durch Solidaritäts- und Rechtsgedanken moralisiert, ohne ihn aufzuheben. Sie bedeutete vielmehr ihrerseits die radikale Aufhebung des Kampfes ums Dasein in Gott und kannte ihrerseits den Kampf nur als Kampf für Wahrheit und Liebe gegen Irrtum und Selbstsucht. Jedenfalls schritt sie überall über jene bloß relativen Moralisierungen 
des L.ebenskampfes hinaus zu dem absoluten Heiligungs- und Liebesideal, zur Stillstellung seiner Motive und zur Aufhebung derjenigen Lebensordnungen, die jenem Kampfe und seinen nur eingrenzenden Moralisierungen förderlich sind. So konnte sie mit der antiken Gesellschaft nichts anfangen, deren politische und Volksmoral überall die Spuren des Hervorganges aus einer Ethik des Kampfes und der Eingrenzung des Kampfes trug, sondern konnte aus der Antike nur die stoische Naturrechtslehre sich aneignen, die schon von sich aus in den gleichen religiösen Gedankengang eingetreten war und Persönlichkeitsmoral wie Menschheitsgemeinschaft aus der Teilhabung an der göttlichen Vernunft abgeleitet, dagegen die konkrete Welt des Staates und Rechtes als Trübungen dieser Vernunft im Sinne selbstsüchtigen und verworrenen Kampfes bezeichnet hatte. Insoferne damit für die sündige Gegenwart eine relative Wertung der sozialen Dinge erreicht war, wie sie im Kampf ums Dasein und im Gegenstreben der ethischen Bändigungsmittel geworden waren, hat die Kirche diese stoische Soziallehre sich angeeignet und durch die von ihr eröffnete relative Wertung der sozialen Institutionen sich mit der antiken Gesellschaft abgefunden. Das bedeutete aber doch nur ein Dulden und Ertragen, so lange die derart begründeten Institutionen und Sitten in ihrem Wesen doch noch die Züge des politischen Machtkampfes, des formalisierenden und legalisierenden Rechts, des wirtschaftlichen Konkurrenzkampfes trugen. Daß das späte Römerreich bereits zu bureaukratischen Regelungen und zünftigen Bindungen griff, das war bereits eine Stillstellung des Kampfes ums Dasein, mit der die christliche Ethik sich zu vertragen begann; aber das war doch nur in bescheidenem Maße der Fall oder doch nur wenig wirkungsvoll für diesen $Z$ weck. Nun aber schuf das Mittelalter mit der völligen Unentwickeltheit des Staatsgedankens, mit der Schwäche der wirtschaftlichen Konkurrenz, der Abwesenheit einer strengen und rationellen Rechtsordnung, der Dünnheit der Bevölkerungsmassen und der Ausschaltung der populationistischen Kampfmotive durch große Kolonisationen, mit der Aufrichtung halb kommunistischer, auf persönliche Dienste und gegenseitige Aushilfe angewiesener Lebenskreise, vor allem mit der traditionalistischen Regelung von Nahrungsschutz, Erwerbsspielraum und Konsumtion in der friedlichen Gewerbestadt, eine Lebensverfassung, in welcher der Kampf ums Dasein weitgehend reguliert und der formalistische Rechtsstandpunkt noch sehr unent- 
wickelt war. Das ständische und zünftige Wesen ist eine Erhaltung und Freigebung individueller Initiative, verbunden mit den stärksten Eingrenzungen seiner unabsehbaren Folgen und den persönlichsten Solidaritäten. Es gibt keinen Staat im antiken und modernen Sinne des Wortes und damit nicht den spezifisch politischen Machtsinn. Soweit die Kampfnatur der Menschen naturwüchsig in Abenteuer und Fehdewesen auflodert, bekämpft es der kirchliche Gottesfriede oder lenkt es die Kirche auf die heiligen Kriege $a b$; die rohe Gewalttätigkeit und Grausamkeit des Mittelalters scheint nur Sünde und persönliche Angelegenheit, gehört nicht zum Wesen und Aufbau der Gesellschaft. Das sind Verhältnisse, mit denen die christliche Ethik ihren Frieden schließen kann. Es ist ein Kompromiß, denn der Kampf selber bleibt; er ist nur eingegrenzt und reguliert; aber das ist dafür dann auch die *Natur", die von der Gnade noch überhöht wird. An einen solchen bereits so stark den Kampf begrenzenden und stillstellenden Zustand kann die Gnade anknüpfen. Die ständischzünftige Lebensordnung bei dünner Bevölkerung ist diejenige Stillstellung des Kampfes ums Dasein, bei der die natürlichen Lebensforderungen noch befriedigt werden können und der Aufstieg zur Ethik der Selbstheiligung und Bruderliebe noch möglich ist. Mit der unpolitisch-ständischen Gesellschaft des Mittclalters ist die christliche Ethik zum sozialen Ideal endlich im Prinzip gelangt. Aber auch jetzt noch kann sie es nicht direkt aus ihren christlichen Grundgedanken ableiten; denn es ist die Ethik der Natur und nicht die der Gnade. Aber sie schmilat diese Verhältnisse indirekt in ihr Ideal ein, indem sie die bisher schon diesem Zwecke dienende stoische Naturrechtslehre revidiert und aristotelisch ergänzt, indem sie nun weniger den absoluten Gegensatz gegen den rationellen Urstand als die relative Vernunftgemäßheit der politisch-sozialen Entwickelungen betont, indem sie in den jetzt frei vom alten Heidentum und seiner Staatsvergötterung sich formenden tatsächlichen 'sozialen Verhältnissen das Natur- und Vernunftgesetz erst zu seiner Vollentfaltung kommen läßt und diese Vernunftethik mit der Offenbarungsethik als doppelten Ausfluß des einen göttlichen Lichtes vermählt.

So versteht sich der Charakter der mittelalterlichen Sözialphilosophie, die eine christliche Kultur und Gesellschaft darstellt und doch keine Begründung und Gestaltung der Gesellschaft nach direkt christlichen Ideen ist. So versteht sich aber auch die 
weitere Entwickelung dieser Sozialphilosophie. Sie hat den ständisch-zünftigen, zugleich unpolitischen und wirtschaftlich traditionalistischen Charakter beibehalten, so lange es irgend möglich war. Hier ist auch das Luthertum trotz all seiner Besonderheiten ganz in den Bahnen der katholischen Sozialphilosophie gegangen. Der Calvinismus dagegen fand in Genf und in den atlantischen Staaten Verhältnisse vor, die ihn auf die modernen sozialen, politischen und wirtschaftlichen Verhältnisse einzugehen zwangen, und er hat dementsprechend die ganze christliche Sozialphilosophie und Ethik umgebildet; es wird ein Hauptpunkt der folgenden Darstellung sein, diese Umbildung beider auf calvinistischem Boden zu erläutern. Aber auch Luthertum und Katholizismus bekommen es mit der modernen sozialen Entwickelung, der Bildung der modernen Riesenstaaten, der kolossalen Steigerung der Bevölkerungsmasse, der Entfesselung des politischen Machtkampfes und des wirtschaftlichen Konkurrenzkampfes, mit der ins Unbegrenzte strebenden Produktion des Kapitalismus und mit der Freigebung der nur mehr durch gleiches Recht gebundenen Individuen $\mathrm{zu}$ tun. In dieser Lage half die alte Jehre von der Harmonie und dem Stufenbau nicht mehr aus. Es mußte nun zu christlicher "Sozialreform" gegriffen werden. Aber diese christliche Sozialreform nahm nur der Katholizismus stark in die Hand, der in seinem Ideal von der kirchlich geleiteten Gesellschaft Antrieb und Kraft zu einer solchen Reform besaß, während das an den Staat gebundene Luthertum hilflos in den Strudel des modernen Gesellschaftsproblems hineingerissen wurde. In dieser Lage aber besteht nun die katholische Sozialreform theoretisch im. Grunde nur im Rückzug auf das Naturgesetz, und das heißt auf die unpolitisch-ständische von der Kirche geleitete Gesellschaft, in welcher der Staat nur utilitarische Aufgaben hat, während die Kirche die Gesellschaft durch die im ständischen Gedanken liegende Idee der Selbstbescheidung und Gruppensolidarität zugleich wieder zum Frieden zurückzuführen hofft. Dafür bedarf es nichts als der Herrschaft des katholischen Gedankens und seiner christlich-naturrechtlichen Wissenschaft. Alle Vorteile der kapitalistischen Produktion lassen sich in ein solches System aufnehmen, wenn sie nichts sein wollen als technische Verbesserungen der Produktion und Verteilung. So ist die moderne katholische Sozialpolitik ein kapitalistisch regeneriertes Programm mittelalterlich ständischen Denkens und wird sie bewußt reformerisch, weil die zerstörte Harmonie von Natur 
und Gnade nicht mehr von selbst den Ausgleich besorgt, sondern vielmehr selbst erst wieder hergestellt werden muß unter sehr viel komplizierteren und schwierigeren allgemeinen Bedingungen. $\mathrm{Ob}$ dies Programm damit dem Zuge der modernen Entwickelung so unbedingt entgegensteht, wie der liberale Fortschrittsglaube meint, kann hier auf sich beruhen; bedenkt man, daß an der gegenwärtigen Entwickelung mancherlei Züge zur Schaffung neuer Hörigkeiten, Monopole, bureaukratischer Regulierungen hervortreten und daß der liberale Individualismus oft nur wie eine $Z$ wischenperiode $z$ wischen zwei Gebundenheitsperioden sich darstellen kann, so mag man es begreifen, wenn katholische Sozialphilosophen meinen, ihr soziáles Naturgesetz gelte heute noch trotz allem Liberalismus und es sei höchstes Bedürfnis, für diese kommenden neuen Gebundenheiten den christlichen Geist des Wertes des Individuums vor Gott und der Versöhnung in der Liebe zu pflegen; dies sei um so nötiger als der moderne Radikalismus die Moral wieder rein aus dem Kampf ums Dasein und seinen Selbstbegrenzungen abzuleiten oder gar einen Kampf ums Dasein ohne alle Moral zu lehren und die christliche Liebesmoral als eine Attacke auf alle naturwüchsigen und besten Instinkte der Menschheit zu bezeichnen im Begriffe sei; die beiden Typen der Sozialethik, die der Katholizismus sinnreich verbunden habe, seien im Begriff, sich aufs unheilvollste zu entzweien; damit drohe der erste natürliche Typus dem reinen Naturalismus zu verfallen und die kommenden Gebundenheiten in rohe Ausbeutung zu verwandeln; ihre Wiedervereinigung sei nur auf der Grundlage der katholischen Sozialphilosophie des organisch-patriarchalischen, ständisch-arbeitsteiligen, religiös geeinigten Menschheitsverbandes möglich: Sätze, die gewiß ihre gute Logik haben ${ }^{146 a}$ ).

1402) Auch hier zeigt sich die außerordentliche Bedeutung des ständischen Gedankens. Ueber seine Rolle in der modernen katholischen Sozialphilosophie s. Uhlhorn, Prot. u. Kath. S. 23, wo Hitze, Kapital und Arbeit, folgendermaßen zusammengefaßt ist: Was man erstrebt, ist überall Stärkung der Kirche, Schwächung des Staates. So sehr tritt der Staatsgedanke zurück, daß Hitze z. B. gar nicht mehr darauf reflektiert, daß Bauern, Handwerker u. s. w. doch zuerst alle Staatsbürger sind. Der Staat wird nach seinen Gedanken ganz durch di e $z$ u Korporationen zu organisierenden $\mathrm{Stände} \mathrm{verdrängt,} \mathrm{und} \mathrm{in} \mathrm{dem}$ erhofften Zukunftsstaate, wenn man das, was Hitze erstrebt, überhaupt noch Staat nennen kann, sind es eben die $\mathrm{Stände}$, welche durch eine Interessenvertretung ihre Angelegenheiten selbständig ordnen. ... Wenn man die erstrebte ständische Gliederung einstweilen durch eine massenhafte Vereinsbildung vorzubereiten sucht, diese Vereine aber selbstverständlich unter der Leitung der Kirche stehen und 
In diesen Zügen stellt sich das allgemeine soziologische Ideal der kirchlichen Einheitskultur, der Geist der katholischen Soziallehre dar. Es ist leicht zu zeigen, wie von hier aus dann auch die großen Einzelgruppen sozialer Bildungen, Familie, Stat und Gesellschaft, unter die Grundsätze einer christlichen Sozialphilosophie gestellt werden können. Sie sind jedesmal besondere Formen der Verwirklichung des Grundschemas in der Richtung auf einen besonderen ihnen naturgesetzlich zukommenden $Z$ weck. Ihre Christlichkeit besteht darin, daß I) die in ihnen staatfindende Verbindung von Individuum und Gemeinschaft im organisch-patriarchalischen Sinne empfunden und gestaltet wird, und daß 2) der ihnen naturgesetzlich zu Grunde liegende nächste Eigenzweck zu

unter dem Schutze des hl. Joseph, so kann man sich darüber nicht tăuschen, wie es mit den ihre Angelegenheiten selbst und ohne Einmischung des Staates verwaltenden Interessenvertretungen bestellt sein würde. Das Ziel ist ein von der Kirche beherrschtes, ein hierarchischer oder noch deutlicher ein theokratischer Sozialismuse. Dabei ist aber hervorzuheben, daß dieser Sozialismus nicht auf der Idee der Gleichheit, sondern auf der der Ungleichheit beruht und gerade von der Zusammenscharung der Gleichen $z \mathbf{u}$ unter sich ungleichen und zu verschiedenen Lebensansprüchen berechtigten Gruppen seine Nötigung zum ständischen Gruppencharakter hat, wie das Ratzinger allenthalben zeigt. Weiterhin ist diese Regulierung neben sozialistischer Sicherstellung des Einzelwohls doch noch zugleich überall eine starke Selbstbescheidung eines jeden nach seinem Stand und seiner Gruppe; nur dadurch wird die Konkurrenz ausgeschieden oder vielmehr auf das nützliche und moralisch zulässige Maß beschränkt. Der ständische Gedanke ist ein die Existenz sichernder Gruppensozialismus und Selbstbescheidung und Entsagung zugleich; s. Uhlhorn S. 9: >Man sehe z. B. die Vorschläge an, die Hitze zur Hebung des Handwerkes macht: die fabrikmäßige Arbeit soll eingeschränkt, für gewisse Produkte die fabrikmäßige Herstellung ganz verboten, die Bannmeile wieder eingeführt werden. Oder man lese das Werk Parvins, dieses echt katholischen Nationalökonomen, Ueber den Reichtume, in dem alles darauf hinausläuft, den Erwerbsbetrieb, den er nur als Selbstsucht $z u$ würdigen weiß, einzuschränken und die Entsagung als die höchste, wenn nicht fast sogar einzige, Tugend zu feiern. Oder man prüfe die Mittel zur Heilung der sozialen Schäden, welche in den historisch-politischen Blättern angepriesen werden. Vor allem soll die Produktion eingeschränkt werden. Es sollen sich Mäßigkeitsvereine bilden, deren Mitglieder sich verpflichten, kein Fabrikat z: kaufen, das nicht zur Befriedigung eines wirklichen Bedürfnisses dient, kein Hausgerät, kein Kleidungsstück anzuschaffen, das bloß zur Zierde dient. Das dadurch etsparte Geld soll dann zur Vermehrung der klösterlichen Institute verwandt werc̉en, die dann weiter dazu dienen, die Vermehrung der Bevölkerung aufzuhalten . Das letztere ist besonders wichtig; dieses Sozialideal setzt eine nicht allzu dichte Bevölkerung als erste Bedingung der Beseitigung des Konkurrenzkampfes voraus. 
dem religiösen Zentralzweck und damit zu der alles überwölbenden und zusammenschließenden Einheit der Kirche und kirchlichen Autorität in feste Beziehung gestellt wird.

Die kirchliche Sozialphilosophie lehrt jetzt einen vollkommen geschlossenen, logisch zusammenhängenden, entwicklungsgeschichtlichen Aufstieg und Fortschritt der Sozialbildungen. Die Ur- und Grundform ist die Familie, die nach Aristoteles und nach der Bibel als monogamische Familie die erste Wirkung der gemeinschaftbildenden Vernunft und die durch ihre Fortpflanzungsfunktion besonders geheiligte, gerade die persönlichen Beziehungen vorbildlich bestimmende Mustergestalt menschlichen Gemeinschaftslebens ist. Aus dem Zusammenschluß der Familien entsteht die Gemeinde, die Thomas aus noch zu besprechenden Gründen wesentlich als städtische in Betracht zieht, ncben der aber die dörflichen und hofrechtlichen Vereinigungen natürlich. auch in Betracht kommen. Ueber den Gemeinden erheben sich Provinz und Reich. Die Staaten sind von unbegrenzter Zahl. An ihre Zusammenfassung im Kaisertum denkt Thomas und das spätere Mittelalter nur wenig, die heutige katholische Soziallehre begreiflicher Weise gar nicht. Innerhalb der Gemeinden und des Staates bewegen sich dann schließlich die ständisch-beruflichen Gruppen und Genossenschaften, die die Träger des sozialen Lebens im engeren Sinne sind und bei denen die charakteristischen korporativen und ständischen Gliederungen des Mittelalters vorausgesetzt werden. Das Ganze aber wird zusammengeschlossen in der Kirche mit ihren hierarchischen Gliederungen und Ordensgenossenschaften, in letzter Linie also regiert vom Papste und durch ihn von Christus, dem Herrn der Christenheit selbst, wobei der Stand der Kleriker und der Asketen das eigentliche Mittel der Regierung ist ${ }^{14}$ ).

147) Das Grundschema in seiner Wirkung auf die Einzelkreise s. Gierke III 513f., 544 f., 559, 640; Althusius 60, 133 f., 232. Der Auf bau in Familie, (icmeinde, Reich, Kirche, Feugueray I77, I42 f., Gierke, Althusius 227, 229, 241 , Cathrein II 515, 520. Die ständische und korporative Gliederung der Gesellschaft ist überall mehr vorausgesetzt als naturrechtlich entwickelt. Gierke hebt mit Recht hervor, daß sie mehr als dem positiven Recht denn dem Naturrecht angehörig angesehen wird, Althusius 24I; er findet den Grund in der technischen Anlehnung an Aristoteles, dessen Stadtstaat sie nicht kannte. Ueberdies beruhen sie ja auch tatsłchlich auf positivem Recht, Privilegierungen, autonomen Beschlüssen u. s. w.. aber das ist doch nur die menschliche Ausführung und Zusatzbestimmung zum Naturrecht nach Grundsätzen der Zweckmäßigkeit. Bei dem berühmten Vorschlage in 
lïnc monographische Darstellung dieser Sozialgebilde würde über den Rahmen dieser Untersuchung hinausgehen. Sie würde auch mit schr viel zeitgeschichtlichen Besonderheiten der thomistischen Lehre und mit deren Abhängigkeiten von ihren Autoritäten zu tun haben. Denn es handelt sich hier bei Thomas vielfach un rcine buchgelehrte Theorien. Es seien daher nur die für die Dauer bedcutsamen Gesichtspunkte hervorgehoben ${ }^{148}$ ).

Dic Familie ist zunächst bestimmt durch ihren naturgesetzlichen Eigenzweck, der von selbst die Monogamie, das Privateigentum der Familie und das Erbrecht mit sich bringt und in der Erzeugung und Erziehung der Nachkommenschaft besteht. Malthusianische Bedenken sind noch unbekannt. Der patriarchalisch-organische Charakter der Familiengruppe, sei es daß sie als Kleinfamilie oder als in gemeinsamem Geschäft oder Betricb vercinigtc Großfamilie lebt, versteht sich nach allem Bisherigen von selbst; ebenso auch die Eingliederung der Dienstboten in die patriarchalische Ordnung der Familie. Die Würde der menschlichen Einzclperson ist dabei in einer Reihe von Sitten oder gesetzlichen Bestimmungen relativ gewahrt und vor allem in der persönlich-ethischen gegenseitigen Liebesbeziehung behauptet. Die Eingliederung der Familie in den religiöskirchlichen Zentralzweck besteht darin, daß sie möglichst den Charaliter der Geschlechtsgemeinschaft und des Geschlechtsgenusses verliert, indem ihr Zweck lediglich auf rationelle Fortpflanzung der Menschheit und damit der Kirchenglieder beschränkt ist und sic selbst als Sakrament zu einem Abbild der Einheit Christi und der Kirche wird; in beiden Hinsichten wirkt die asketische Einschränkung der Geschlechtslust, indem die Ehe lediglich zu einem Institut der Fortpflanzung und zu einem Symbol der geistlichen I.icbescinhcit wird. Im übriggen steht sie eben mit diesem Sakramentalcharakter rechtlich unter dem kirchlichen Eherecht, das de res. princ. für Gründung cines Reiches oder ciner Stadt ist die korporative lierulliche Gliederung und sogar die besondere Ansiedelung der zusammengehörigen (imppen vorgesehen, Baumann 74 f. Vgl. hierzu die Stellen bei Maurenbrecher S. 39 und 47, wo die Korporationen und Stände teils auf Natur und Vorsehung, teils auf positives Recht zurückgeführt sind, zugleich Berufung auf das Beispiel der Engclchöre. - Ueber das Zurücktreten der Reichsidee Gierke III 54 I-544.

148) Leber das Verhälınis der nur buchgelehrten Doktrin zu der Bezugnahme auf dic zeitgeschichtliche Wirklichkeit s, die lehrreichen Bemerkungen von Maurenlirccher, der die letzteren aus den unwillkürlichen Undeatungen des Aristoteles simmeich herausholt. 
die Kirche möglichst gegen das staatliche auszudehnen sucht, und unter weitgehendem Einfluß des Beichtstuhls. Indem die Kirche dann mit den christlichen Liebestugenden vollends die persönlichen Beziehungen innerhalb der Familie durchdringt und sie über ihre schon natürliche Verbundenheit in die religiöse Liebesverbundenheit erhebt, wird sie zur Urform und Vorschule aller sozialen Beziehungen, wie das bereits bei der Analyse des Patriarchalismus gezeigt worden ist ${ }^{149}$ ).

Der Sta at oder, wie man im mittelalterlichen Sinne richtiger sagte, die Obrigkeit hat naturgesetzlich den Zweck der Aufrechterhaltung von Ordnung und Landfrieden und damit die Aufgabe, die Voraussetzungen für ein friedliches Berufsleben, für das Mindestmaß einer wenigstens legalen Moralität und für das Ideal einer sowohl distributiven als kommutativen Gerechtigkeit, zu bewirken, $d . h$. dafür zu sorgen, daß jeder seinem Rang und Stande gemäß an dem Bonum commune des Staates oder an der irdischen Wohlfahrt beteiligt werde und daß der etwaige Austausch, die Vertragsverhandlungen und das Verhalten der einzelnen untereinander nach dem Maßstab strenger Rechtlichkeit und genauer Entsprechung von Leistung und Gegenleistung, von Schädigung und Buße vor sich gehen. Die Organisation, die er zu diesem $Z$ wecke teils durch inneren Vernunfttrieb teils durch verständige Einrichtung sich gibt, ist die patriarchalisch-organische mit ausgesprochener Neigung zur Monarchie, in der allein die Autorität der Regierung und die Einheit des Organismus nach dem Vorbild des Universums zur vollen Geltung kommt. Immerhin soll doch auch auf Grund derselben organischen Idee die Selbstwertigkeit der Glicder zum Ausdruck kommen. Das geschieht am besten durch eine ge-

149) S. Feugueray 177-186; Th. Meyer 70-141, Cathrein II $380-417$, v. Eicken 440-467. Nach Gothein, Art. >Agargeschichte, II. Nittela!ter u. Neuzeits in $>$ Die Religion in (Geschichte und Gegenwarte I S. $247 \mathrm{f}$ : : Direkt ge:-.en den Zusammenhang der Sippe ist die Ehegesetzgebung, in der das Zusammenwirken von Staat und Kirche am deutlichsten ist, gerichtet. Man kann sic radezu als eine Emanzipation des Individuums, namentlich des weiblichen, bezeichnen, ein Verdienst, das die Frauen dann auch mit dauernder Anhïnclichkeit an die Kirche vergolten haben. Die Durchfülrung der kirchlichen Eheschlliefiung in der Höhezeit des Mittelalters, die auch cin Ilöhepunkt der Stelling der Frau i-t,

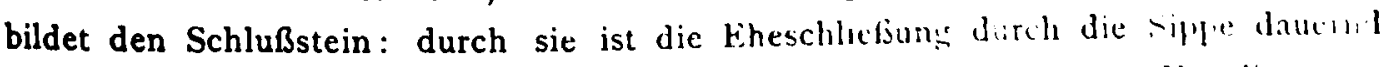

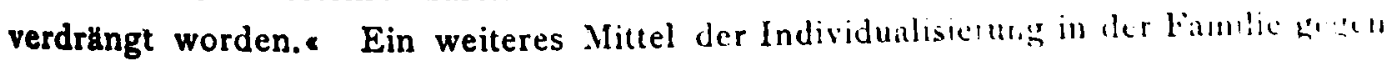

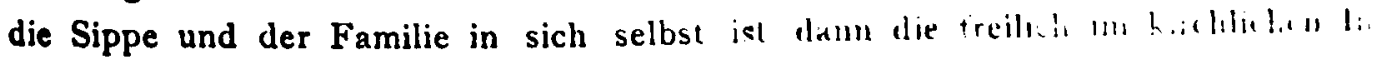
teresse durchgefuhrte Testirfreiheit. Ebd. $24 \mathrm{~S}$ 
mischtc Verfassung, wobei wohl an ständische Repräsentationen und dcren Mitwirkung gedacht ist; freilich fließen sie für Thomas beständig mit der Volksversammlung der aristotelischen Polis zusammen und sind in seiner Theorie die Beziehungen auf das konkrete Verfassungsleben der Zeit auffallend verblasst; das hat zur Folge eine verhältnismäßig große Unabhängigkeit der katholischen Theorie von dem Lehenswesen und der Feudalität, eine stark abstrakte Behandlung des Verhältnisses der öffentlichen Gewalt und der subjektiven öffentlichen Rechte. Gegenüber einer den Staatszweck verleugnenden selbstsüchtigen und tyrannischen Regierung besteht Revolutionsrecht und sogar Revolutionspflicht, freilich unter der Bedingung, daß durch eine solche Revolution nicht mehr geschadet als genützt wird. Die Einzelausführungen, die gerade hier bei Thomas sehr stark unter buchgelehrtem Einfluß stehen und weder auf den mittelalterlichen Staat noch auf die moderne Welt anwendbar sind, können hier auf sich beruhen; seine Lehre über die Entstehung des Staates, über das Verhältnis des natürlichen, positiven und Völkerrechtes, seine Anschauung von dem Verlauf der politischen Geschichte, sein Verhältnis $z u$ den Rechtstheorien und -Quellen seiner Zeit, haben nur monographisches Interesse. Die Hauptsache ist die Einschränkung des Staatszweckes auf die utilitarische Wohlfahrt und die legale Gerechtigkeit, die Verbindung von göttlicher Autorität der Staatsgewalt mit subjektiven Rechten und Ansprüchen der Individuen, die Bedeutung von Pietät, Vertrag und patriarchalischer Gesinnung für das politische Ganze. Das sind dauernde Grundzüge der katholischen Staatstheorie. Der Staat ist die Organisation der weltlichen und rechtlichen Interessen, soweit eine solche für die christliche Gesellschaft notwendig ist, und insoferne überhaupt nur eine Ingredienz der letzteren. $\mathrm{Er}$ ist die weltliche Seite dersclben Gescllschaft, deren geistliche die Kirche darstellt. Dabei ist dann auch die Beziehung des Staates auf den religiösen Zentralzweck leicht ersichtlich. Sie liegt außer in der Betonung der patriarchalischorganischicn I icbeselemente, die auch den Staat zur Vorschule christlicher Gesinuung machen, in der strengen Eingrenzung des Staatszweckes auf irdische Interessen und formale Gerechtigkeit. Dadurch wird dic Verselbständigung des politischen Ideals als eines ethischen Selbstzweckes ferngehalten, die für den antiken und modernen Staatsbegriff charakteristisch ist und die jeder Lehre von der letzten Geltung religiöser Lebenszwecke bedenklich sein muß. 
Ebenso ist diese rein utilitarische Auffassung eine Fernhaltung des Staates von alien geistigen, religiösen und höheren ethischen Interessen, die er vielmehr erst von der Kirche empfängt und die unter Leitung der Kirche bleiben müssen. In die ersteren Gebiete kann er beliebig eingreifen, ja gerade das wirtschaftliche Leben kann e durch Preistaxen und durch allerhand die Autarkie jeder Gemeinde schützende Vorschriften aufs tiefste beeinflussen; aber das geistige Leben muß er frei lassen für die Kirche. Das Verhältnis der Staaten untereinander soll das von Gliedern der christlichen Familie sein; Kriege sind nur als gerechte, durch die Schuld des andern hervorgerufene erlaubt und sollen das Gute fördern, Uebles vermeiden helfen. Auch sind sie nur als offizielle vom Fürsten angeordnete zulässig, während die Privatkriege und Fehden verboten sind. Der Egoismus der Nationalitäten vollends kommt für die internationale christliche Lebenseinheit noch gar nicht in Betracht; die Metaphysik der Kirche läßt die des Nationalgefühls überhaupt noch nicht aufkommen. Die Frage der Gerechtigkeit eines Krieges entscheidet in letzter Linie die Oberrichterin aller moralischen Dinge, die Kirche. Schließlich und vor allem kommt die Eingliederung in den geistlichen Lebenszweck zum : Ausdruck in der Theorie von der Oberherrschaft der Kirche, die zwar in den rein irdischen Angelegenheiten nur eingreift, wo sie mit d'n geistlichen Interessen zusammenhängen, aber über die Fälle solchen Zusammenhanges souverän von sich aus entscheidet. 1)ie geistliche Autorität ist die regierende und leitende Seele auch der weltlichen Autorität, ganz so wie Gott den Organismus der Welt regiert, auch da, wo er ihn zunächst seinen eigenen (jesetzen überläßt. Die Hauptaufgabe ist hier, daß überall der wahre Glaube und das ihm entsprechende kanonische Recht herrsche; doch sind Gewaltbekehrungen gegen Juden und Lnglaubige unerlaubt; allerdings werden die Häretiker im lalle hartnäckiger Leugnung aus Fürsorge für das Heil der Uebrigen exkommunziert und dann der Staatsgewalt zur Bestrafung übergeben als schädliche Störer der Gesellschaft. Unterordnungen von Gläubišn unter Ungläubige sind nur erlaubt, soweit es die äußeren Rechtsund Machtverhältnisse mit sich bringen. Der Verkehr mit Ungläubigen ist nur erlaubt, soweit er Hoffnung allf Bekehrung erwecken kann, im übrigen soweit die Not ihn gebietet. Nur durch die Taufe gehört man sowohl der staatlichen als der
kirchlichen Ordnung an, und für Ungläubige ist die Taute die 
Naturalisation in der christlichen Gesellschaft. Nimmt man hier noch die Leitung der fürstlichen Gewissen durch das kirchliche Ideal hinzu und bedenkt man die Forderung, daß es Aufgabe der Fürsten ist die Völker zur Tugend zu erziehen, so ist die Eingliederung des Staates unter den religiösen Zweck trotz seiner naturgesetzlichen Selbständigkeit eine alles beherrschende. Andererseits aber ist von einem so sich verstehenden Staat auch keinerlei ethisches Motiv des Widerstandes gegen diese Erfüllung mit dem absoluten religiösen Lebenswert zu befürchten. Differenzen sind nur möglich über das Maß und Verhältnis der Beteiligung der weltlichen und der geistlichen Gewalt an der gemeinsamen Aufgabe, wie ja der ganze ungeheure Kampf von Kaisertum und Papsttum nur eine Differenz solcher Art gewesen ist, soweit Theorien und Prinzipien dabei in Frage standen. Die thomistische Lehre vertritt hier klar und ehrlich die völlige Vorhcrrschaft der geistlichen Gewalt, in der'sich das Zweckreich der Vernunft und Erlösung erst einheitlich zusammenschließt ${ }^{130}$ ).

Sehr viel lückenhafter und unklarer liegen die Dinge bei der thomistischen Lehre von der eigentlichen Gesellschaft; sie ist auch nur sehr bedingt als typisch für die katholische Soziallehre anzusehen. Typisch allerdings ist der Grundzug, daß die ganze Gesellschaftsgliederung auf der Notwendigkeit der Arbeit und

150) Vgl. hierzu Feugueray, Baumann, Gierke; im übrigen v. Eicken 356-436, Cathrein II 449-678. So sind auch die bei Aristoteles politisch gemeinten Aeußerungen über die soziale Natur der menschlichen Vernunft von Thomas unwillkürlich lediglich sozial verstanden als Aussagen über die notwendige wirtschaftliche Ergänzung der Berufe innerhalb des Staates, was wiederum seinerseits Aristoteles von seinem antiken Ideal des Vollbürgers und Rentenbeziehers aus verwirft, s. Maurenbrecher 30 und 36, zugleich ein Beispiel für die Art des thomistischen $\gg$ Aristotelismus. - Gegen die modernen Staatstheorien charakteristisch Zirkel bei Ludwig II +19: Die Kirche hat im Himmel ihren Ursprung und hat sich auf der Erde niedergelassen, nicht als auf dem Gebiete des Staates, sondern als in dem davon ganz verschiełlenen Gebiete des Gewissens.. Die Kirche ist beschäftigt, für das 'wige Heil der Menschen zu wirken, während der Staat ihr zeitliches Wohl besorgts. -- Ueber den Kampf von Kaisertum und Papsttum s. jetzt Hampe, »Deutsche Kaiserguchichte 1909. Ueber die Gebundenheit der Kaiser in dem gleichen Ideal una dii liorderung bloß größerer Beteiligung an der Regierung der christlichen Gecullschaft, die dann die kaiserliche Politik der päpstlichen selbstverständlich witerlegen macht, s. S. 19: >Aber vertragen sich die Grundsätze einer christlichen Sittcnlehre in dem Maße, wie sie Heinrich III. übte, noch mit den Forderungen - ins off loreichen Staatskunst :e 
der sich ergänzenden Arbeitsteilung naturgesetzlich beruhe. Das ist gegenüber der alten Kirche, in der nur ganz gelegentlich sich solche Aeußerungen fanden, etwas Neues. Diese hatte im Grunde das alte Ideal des rentenbeziehenden antibanausen Bürgers festgehalten und für die arbeitenden Klassen nür Liebe und Mildtätigkeit verlangt, im übrigen die Arbeit nur im Kloster zur vollen Ehre gebracht. Jetzt spiegelt sich die mittelalterliche bürgerliche Ordnung in dem sozialen. Ideal von Arbeit und Eigentum und einer nur auf Arbeit begründeten Differenzierung. Daraus ergeben sich naturgesetzlich die Ständegliederungen und Korporationen gemeinsamer Arbeit, sowie die Aufgabe der die Gescllschaft leitenclen Autorität; sie besteht darin, einerseits für die Aufrechterhaltung dieser Gruppen und für Nahrungsschutz zu sorgen, andererseits die Einzelnen bei ihrem Stand und ihrer Arbeit festzuhalten, damit die gesellschaftliche Gliederung nicht gestört werde. Dabei denkt Thomas überall an kleine Wirtschaftseinheiten von autonomer Bedarfsdeckung, in welchem Sinne er die aristotclische Autarkie interpretiert; er setzt an Stelle der politisch-cthischen Selbstzwecklichkeit des Staates die Sicherheit einer nicht durch unübersehbare Zusammenhänge gestörten Bedarfsdeckung. "o nach Möglichkeit alle Bedürfnisse von der Wirtschaftseinheit sithut gedeckt werden und nach außen nur ein ergänzender Pin..ilhandel zu wünschen ist. Das ergäbe ein radikal auf persïnliche Arbeitsleistung und gerechten Lohn begründetes soziales Siystem, bei dem nur durch die Anerkennung des Erbrechtes, al naturgesetzlich in der Fortsetzung der Persönlichkeit durch dii: Familie begründet, die revolutionärsten Folgen vermieden wären ${ }^{151}$ !) Aber dieses System paßt sich ganz von selbst den gegebenen Verhältnissen an, indem die Arbeit differenziert wird in körperliche, geistigr und herrschende Tätigkeit, indem das Einkommen standesgemäls

151) So wird auch die Eigentumslehre ohne jeden Zusammenhang mit ler I.chre von der Arbeitsteilung und Berufsdifferenzierung ganz selbständig und uclegentl..h als Frage des Naturrechtes verhandelt, wo dann die Fragen des urtindlich." Kommunismus und des Rechtes des Eigentums im Sündenstande verhandelt werdell. Maurenbrecher S. $96 \mathrm{f}$. Instinktiv muß aber ein Zusammenhang bestanden haber, da Thomas die Eigentumsbildung aus dem anfänglichen Gebrauchskommunismusich naturgesetzlich notwendig entwickeln listit ur:! das gleiche vion der Arbeitsteilung lehrt. Auch hïgt die der alten Kirche gegenüber neue, an Aristoteles angeschlossene Theorie rom Naturiecht des Figcntums ilaurenbrecher \$. 104 f. I unzweifelhaft mit der venfalls neuen Schatzung der Berule und der Arbeit zusammen, die er ja gleichfalls aus dem Aristoteles herauszulesen meinte. $\mathrm{S}$. auch $\mathrm{M} . \$ .110$. 
sein muß und indem die Unfreiheit als Folge des Sündenfalls ohne wciteres acceptiert wird. Damit greifen nun ganz andere Motive in dic auf Arbeitsleistung und Sicherung eines ausgiebigen Existenzminimums begründete Idee der Gesellschaftsgliederung ein. Der Patriarchalismus durchbricht die einfache Grundtheorie, und der eigentliche Geist dieser Soziallehre wird nur mehr anwendbar auf die agrarisch-bäuerliche und die gewerblich-städtische Arbeit. Die domini saeculares oder die herrschende Aristokratie sowie die Männer des beschaulichen und gedanklichen Lebens, der W'issenschaft und der Kirche, rücken unter einen ganz anderen, sehr aristokratischen Gesichtspunkt. Die materielle Arbeit verbleibt den unteren Ständen, teils ein auch hier nicht zu umgehendes Zugeständnis an die Naturbedingungen der Gesellschaft ${ }^{161 *}$ ), teils eine Einwirkung des aristotelischen Aristokratismus.

Hier ist nun das Merkwürdige, daß in Gegensatz zu der Neigung des modernen Katholizismus für die ländliche Bevölkerung und ihr spezifisches Ethos bei Thomas wesentlich nur die Stadt in Betracht kommt. Der Mensch ist ihm von Natur städtisch, und das Landleben ist ihm nur eine Folge von Unglück oder Not; freilich ist seine Stadt selber zugleich stark agrarisch und deckt ihre Bedürfnisse im geordneten Austausch mit dem ihr untergebenen Lande. Diese völlig einseitige Beziehung auf die Stadt ist nun aber doch schwerlich nur durch den Zufall veranlaßt, daß der Italiener und Bettelmönch wesentlich bloß die Stadt kennt und daß der Kommentator des Aristoteles überall am. Stadtstaat hängen bleibt. Denn Aristoteles bevorzugt den Landbau vor den Gewerben, während Thomas den ersteren als schmutzig und elend bezeichnet; außerdem bezieht Thomas die aristotelische Geringschätzung des Gewerbes nur auf die abhängigen Lohnwerker, während er die am Stadtregiment teilnehmenden Gewerbetreibenden mit den aristotelischen Vollbürgern vereinerleit, ganz gegen den Sinn des Aristoteles: Vielmehr deutet all das hin auf den bereits früher hervorgehobenen Umstand, daß doch erst die mittelalterliche Stadt mit ihrem Friedensprinzip, ihrer Begründung auf freie Arbeit und korporative Arbeitsgruppen, mit ihrem stärkeren geistigen Interesse und ihrer fürsorglichen, jeden schützenden Verwaltung der eigentliche Bo-

\footnotetext{
1516, Leber diese Naturbedingungen sehr lehrreich Michels $>$ Die oligarchischen Tendenzen der Gesellschaft.e Archiv XXI.
} 
den für die christlichen Ideale wurde ${ }^{152}$ ). So ist zwar die Beschränkung auf die Stadt äußerst einseitig, aber sie veranschaulicht in dem Ideal der Stadt doch typische Züge der katholischchristlichen Gesellschaftslehre, die eine Uebertragung auch auf das Allgemeine und Ganze zulassen. Insbesondere ist nur von hier aus und nicht von der Anschauung der Feudalgesellschaft aus die Forderung der Sozialtheorie begründet, daß alles Einkommen und alle Differenzierung auf der persönlichen Arbeitsleistung beruhen müsse. Das ist bürgerliche, nicht mehr feudale Ethik. Thomas, selbst ein Sprößling des Feudaladels, ignoriert Lehenswesen und Feudalität, setzt aber überall die ständische Gliederung als selbstverständlich voraus. Er liebt es nur nicht, sie an der Feudalität $z u$ veranschaulichen. Und in diesem Sinne hat auch die übrigens so einseitige Orientierung des Thomas an der Stadt ihre allgemeine und typische Bedeutung für die katholische Sozialethik. Sie ist patriarchalisch in den Grenzen der notwendigen Konzessionen an die unvermeidlichen natürlichen Machtverhältnisse und Unterschiede, aber in keiner Weise feudal. Sie ist bürgerlich im Sinne der agrarisch-gewerblichen Stadt mit ihren festen Arbeitsgliederungen und ihren durchsichtigen Proportionen von Arbeit und Einkommen ${ }^{163}$ ).

Das Einzelne ist hier nur von monographischem Interesse. Allgemein bedeutsam sind wiederum nur diejenigen Züge an diesem bürgerlichen Ideal, die einer Verallgemeinerung für das Ganze fähig sind und den Geist dieser Arbeits- und Erwerbsordnung zeigen. Das Entscheidende ist einerseits die positive Schätzung der Arbeit, des Erwerbes, des Privateigentums, des Erbrechtes

152) Ueber diese christliche Bedeutung der Stadt, die erst eine wirkliche christliche Laienkultur von selbständiger Regsamkeit bringt s. Uhlhorn, Liebestätigkeit II 174, 201, 210; namentlich der Berufsbegriff gegenüber den bisherigen Geburtsständen ist in der Stadt $z u$ Hause S. 325 f, ebenso die Idee der gegenseitigen Ergänzung S. 404, Anfänge einer bewußten Sozialpolitik 450.

153) Die Belege zu alledem bei Maurenbrecher, der nur den Gründen nicht nachgeht, weshalb Thomas die Stadt so auffallend vor dem Lande bevorzugt. Daß die mittelalterliche Gesellschaftslehre der Theologen die Feudalităt ignoriert, ist auch sonst immer aufgefallen. Erst die romantisch-antirevolutionäre Staatsdoktrin der Restauration, L. v. Haller und de Bonald, kommen auf sie zurück. Sie ist aber von da auch heute nicht in die eigentliche katholische Soziallebre eingedrungen. Diese bevorzugt demokratische, buuerlich-agrarische und burgerlichmittelotundische Ideale. 
und die Einräumung einer naturgesetzlichen Pflicht für sich und die Seinigen, das dem Stande entsprechende und die Erhaltung der Familie sichernde $\mathrm{Maß}$ von Eigentum zu erwerben. Indem das naturgesetzlich, d. h. mit Rücksicht auf die Zweckmäßigkeit für die Produktion begründet wird, ist damit der die alte Kirche völlig beherrschende reine Konsumtionsstandpunkt aufgegeben und den realen Bedingungen des wirtschaftlichen Lebens Rechnung getragen. Andererseits ist es der, wie ihn Max Weber im Gegensatz zum kapitalistischen Geiste nennt, traditionalistische Geist der ganzen Wirtschaftsauffassung. Er kommt zum Ausdruck in der standesgemäßen Unterscheidung der Lebenshaltung und in der Anweisung an die politischen Gewalten, durch eine Politik des Nahrungsschutzes und der Preisregulierung jeden bei diesem standesgemäßen Einkommen zu erhalten. Es ist der Standpunkt der Konservierung der Nahrungen, der mit der Festhaltung stehender ständischer Gruppen und dem Ausschluß des Berufswcchsels, der Fortsetzung des väterlichen Berufs durch die Kinder, eng zusammenhängt. Er kommt weiter zum Ausdruck in der den Verkehr und Austausch regulierenden Preislehre vom pretium justum, das dem Warenwert objektiv genau entsprechen und nur den $\mathrm{Zu}$ schlag des für das Leben des Händlers Notwendigen enthalten soll; wie freilich ein solcher objektiver Wert festgestellt werden soll, darüber sagt die noch sehr kindliche ökonomische Reflexion nichts; sie passt sich den wirklichen Verhältnissen nur durch das Zugeständnis gewisser Schwankungen und durch gelegentliche Anerkennung subjektiver Faktoren in der Preisbildung an. Er kommt schließlich zum Ausdruck in der bekannten Zins- und Wucherlehre, die jetzt auf der aristotelischen Lehre von der Unfruchtbarkeit des Geldes beruht und eine ganze Gcldtheorie enthält; ihr Sinn ist im Grunde, sowohl der ungerechten Ausbeutung als einer gefährlichen Mobilisierung des Güterverkehres, der ganzen Unberechenbarkeit einer ins Unendliche hineinarbeitenden und rom begrenzten Kundenkreis sich emanzipierenden Produktion, vorzubeugen, auch ein Einkommen ohne Arbeit zu verhindern. Die außerordentlich verwickelten Einzelheiten und Abhängigkeiten dieser ökonomischen Lehren müssen hier auf sich beruhen. Begründung von Eigentum und Erwerb auf persönliche Arbeitsleistung, Güteraustausch nur soweit er nötig und dann nach Grundsätzen eines gerechten, niemand übervorteilenden Preises, den am kesten die Obrigkeit reguliert, Konsumtion nach dem Grundsatz 
einer nur den natürlichen $Z$ weck der Daseinsbehauptung erfüllenden Mäßigkeit und einer die Not anderer berücksichtigenden Mildtätigkeit, doch mit Zugeständnis starker standesgemäßer Differenzen und gelegentlicher Liberalitäten: das ist der Geist dieser ökonomischen Denkweise. Es genügt hervorzuheben, daß dieser Geist auch da bestehen bleibt, wo mit der unumgänglichen modernen Arbeitszerlegung und der Größe der modernen Versorgungskreise das Kapital anerkannt wird. Er ist auch dem Neuthomismus eigentümlich geblieben bis heute. Betonung des Eigentums für jeden, Konservierung in standesgemäßer Nahrung, Bescheidung und Eingrenzung der Produktion auf wirkliche Anregung der wirtschaft- lich notwendigen Gütererzeugung, Verzicht auf einen aus reiner Spekulation stammenden privaten Unternehmergewinn, möglichste Vereinigung von Kapitalbesitz und Arbeit, Bereitwilligkeit der Besitzenden eine solche Zusammenlegung nach Möglichkeit auch durch persönliche Opfer an Gewinnchancen in Assoziationen und Gewinnbeteiligung zu ermöglichen, schließlich neben diesen Gesinnungselementen starke staatliche Regulierungen zur Durchführung und Behauptung einer derartigen Gesellschaftsverfassung: das ist heute noch bei Ratzinger das christliche Sozialideal, an dem die Welt genesen soll ${ }^{154}$ ).

154) Hierzu vor allem Ratzingers $>$ Volkswirtschafte in ihren historischen und systematischen Partien. Ueber das pretium justum bei Thomas s. Brentano, Ethik und Volkswirtschaft in der Geschichte « 1901, S. 35 f.; darnach !at Th. den erlaubten Handelsgewinn gleichfalls von dem Maß der standesgemäßen Erhaltungsbedürfnisse abhängig gemacht und den subjektiven Bedingungen der Preisbildung (Liebhaberwerte u. a.) wenigstens einen beschränkten Einfluß auf das objektive pretium justum gewährt; also auch hier die Konzessionen an das praktisch Unvermeidliche. - Eingehender ist F. X. Funk, , Ueber die ökonomischen Anschauungen der mittelalterlichen Theologie a, Z. f. ges. Staatswissenschaft, 25. Jahrg. 1864. F. hebt die Lückenhaftigkeit, Zufälligkeit, zeitgeschichtliche Bedingtheit und spezifisch-theologische, den Beichtrat betreffende Art der Aeußerungen des Thomas hervor und hält sich mehr an Antonius von Florenz und Bernhardin v. Siena, teilt übrigens auch über Thomas das Wesentliche mit. Er h ebt hervor, daß die Erkenntnis von der produktiven Natur des Kapitals wohl vorhanden sei und in den berwhtigten $\$$ Zins titeln* auch zur Geltung komme, daß also auch hier schon bei Th. ne starke Annäherung an das praktisch Notwendige stattfinde, daß aber juristuche Autoititien (der römische Mutuatarvertrag) und aristotelische Theorien "Unfruchtbarkeit des Geldes) es nicht zu einer Lösung der Schwierigkeiten kommen liessen. Auch die altkirchlichen und angeblich biblischen Wucherverbote bestimmen ihn. Aber er ist im Begriff, den Unterschied von Wucher und Zins zu begreifen; nur, indem die aristotelische Theorie ihn zugleich mit dem positiven Rechte zwingt, bildet er seine, 


\section{II. Mittelalterl. Katholizismus. 8. Thomistische Sozialphilosophie.}

All das aber bezieht sich freilich erst auf das naturgesetzliche Ideal der Gesellschaft. Darüher steht der religiöse End-

diese Einsicht wieder bedenklich einschränkende, Lehre vom Wucher- und Zinsverbot aus, doch nicht ohne einschränkende Klauseln für das letztere im Lucrum cessans, wozu spăter das damnum emergens und das periculum sortis hinzukommen. - Aehnlich $\mathrm{Ch}$. Jourdain, sLes commencements de l'économie politique dans les écoles du moyen age, Mémoires de l'institut national de France, Académie des inscriptions et belles lettres, Bd. 28, Jahrg. 1854; J. sieht darin freilich nur die auf eine völlige Indifferenz in allen ökonomischen Dingen folgende Anregung eines ganz elementaren ökonomischen Denkens durch Aristoteles: quelques notions sur la monnaie, des maximes sevères en matière de prêt, d'injustes préventions contre le commerce tempérées par les sentiments pour ses avantages sociaux. S. 24 und verkennt den darin sich - freilich unbehilflich genug - aussprechenden eigentümlichen, von der christlichen Grundidee in der Tat inspirierten Geist. - Klar erkannt und cingehend dargelegt nach Thomas ist dieser Geist bei Ashley, sEnglische Wirtschaftsgeschichtes, übers. von Oppenheim I 1896, S. 129-167; er hebt auch treffend hervor, wie diese Auffassungen mit den tatsächlichen wirtschaftlichen Verhältnissen, d. h. mit ihrer meist bestehenden persönlichen Beziebung zwischen Konsumenten and Produzenten und der Unentwickeltheit des Handels- und Kreditgeschäftes zusammenhängt, welches letztere in einem Stadium hoher Entwickelung allerdings trotz aller günstigen Wirkungen auf Gütererzengung und Güterverteilung doch reich sei an ethischen Gefahren. Das ist in der Tat der sehr verständliche eigentliche Grundgedanke der christl. sokonomikc, wo sie, wie bei Thomas, dem bereits entwickelteren Verkehrsleben gegenübersteht. Die Notwendigkeit befriedigender Bedarfsdeckung anzuerkennen und doch die Gefahren eines zum Selbstzweck werdenden wirtschaftlichen Egoismus zu vermeiden, das ist der Sinn des Programms, und das. scheint ihm die mittelalterliche Stadt in dem ihm vor Augen liegenden Stadium der Entwickelung zu leisten. Dabei ist es dann freilich nicht geblieben, sondern aus der Stadt ist der moderne Kapitalismus und die moderne Staatsverwaltung hervorgewachsen; darum ist die moderne katholische Oekonomik jetzt umgekehrt mehr auf dio agrarischen Verhältnisse gerichtet und erstrebt in Bezug auf die Stadt ein Analogon der alten Gruppierungen und Bindungen, das der modernen städtischen Kultur nur durch ein Uebergewicht des Landes abgezwungen werden kann. Im übrigen ist ihr Sozialideal bis heute nicht entfernt in dem Maße agrarisch wie das lutherischkonservative. Darin äußert sich der größere Welthorizont des Katholizismus und wirkt auch die Tatsache sicherlich mit, daß die Grundlegung der Sozialethik bei Thomas sich bereits an der Stadt orientiert hat. - Der Artikel Th. v. A. von F. Walther im H. W. St. ${ }^{2}$ gibt eine stark an Maurenbrecher angelehnte, aber sehr vollständige Zusammenfassung. Sehr kurz handelt von Thomas, aber auf Grundlage seiner patristischen Voraussetzungen $O$. Schilling, Reichtum und Eigentum in der ethisch-rechtlichen Literatur, 1908. Das Buch bestätigt übrigens durchaus mit einem reichen Material von Zitationen die Darstellung, die ich vom Frühkatholizismus im ersten Teil gegeben habe. 
zweck. Seine christliche Beziehung auf diesen besteht zunächst darin, daß die für die Behauptung dieses naturgesetzlichen Systems nötige Selbstbescheidung, der Opfersinn und der ganze Traditionalismus wirklich aufgebracht werden können nur unter starker Mithilfe der christlichen Tugenden der Liebe, der Demut und der Hoffnung auf den eigentlichen Lebenswert im Jenseits. Es ist der Sinn der heroischen Entsagungen des Mönchtums, diesen Geist durch ihr Vorbild zu stärken und ihn der Gesellschaft als unentbehrliche Grundlage auch der natürlichen Lebensformen zu erhalten ${ }^{154}$ ). Weiterhin erscheint die Arbeit neben ihrem positiven Wert als Mittel der Existenz auch als ein wohltätiges Mittel der Askese, das fleischliche Gedanken bricht und die Zerstreuung der Weltlust hemmt. Ueberdies ist sie als Folge des Sündenfalls auch eine Mahnung zur Demut. Auch sie ist Strafe und Heilmittel zugleich. Unter diesen geistigen Einflüssen richtig verstanden und ausgeführt ist sie das Mittel zur Erhaltung der physischen Existenz der christlichen Gesellschaft, insoferne mit dem Besitz von Gott geordnet als Voraussetzung der höheren Lebenswerte. $\mathrm{Zu}$ allerhöchst aber dient sie nicht bloß der Selbsterhaltung der christlichen Gesellschaft, sondern der Liebe, indem der Erwerb zum Unterhalt der Kirchen und Klöster teils in festen Abgaben teils in freien Schenkungen befähigt und indem alles darüber hinaus zum Leben nicht Nötige in den Dienst der Bruderliebe und Mildtätigkeit gestellt wird. Im Falle der Not und des Bedürfnisses tritt die Gemeinsamkeit des Besitzes wieder ein, der ja überhaupt sich nur aus Zweckmäßigkeitsgründen zum Privateigentum entwickelt hat. So wird auch der Diebstahl des hl. Crispin gerechtfertigt. Hier kehren dann die bekannten altkirchlichen Gedanken wieder. Freilich

154 ^) Vgl. hierzu die Begründung für Wiedereinführung des Mönchtums bei Zirkel, Ludwig II. 164 f.: >Das Mönchtum ist die religiöse Idee, die in einzelnen Individuen in einem höheren Grad entwickelt eine Gewalt erhält, durch die sie sich alle Neigungen und Triebe der menschlichen Natur unterwirft. Daher das Gelübde der Armut, Keuschheit und des Gehorsams... Die Menschheit bedarf ein öffentliches Beispiel dieser Lebensweise, um sich daran zu erinnern, was sie in sittlicher Hinsicht vermag und $\mathrm{daB}$ die stärksten Leidenschaften nicht unüberwindlich sind, wenn sie dieselben mit ernstem Willen beherrschen will. Im Statsverband sieht sie die Anstalten dieser Art um so lieber, weil bei der Beschäftigung und Zerstreuung aller übrigen Stände sie einen $S t$ and gern in ihrer Mitte hat, der für alle übrigen der Gottheit den Tribut schuldiger Anbetung und des Dankes leistet.\& 
gießt die neue Soziallehre sehr viel Wasser in den Wein der radikalen Liebesethik. Die Pflicht des Verschenkens beginnt nicht bloß erst bei dem Ueberschreiten des Existenzminimums, das überdies standesgemäß sehr verschieden ist, sondern es ist geradezu eine l'flicht, zuerst die Selbsterhaltung sicher $\mathrm{zu}$ stellen, und es ist unerlaubt, die Grundlagen der wirtschaftlichen Existenz der Familie durch eine die eigene Existenz bedrohende Freigebigkeit zu gefährden. Das ist bei dem Mann, der selbst Bettelmönch war, gewiß nicht Weltsinn oder Gesetzlichkeit, sondern Rücksicht auf die Bedingungen des wirtschaftlichen Gedeihons. Für die aus. der Welt Ausscheidenden macht er dann um so schärfer die Notwendigkeit völligen Verzichts auf jedes Eigentum geltend und verteidigt diese Forderungen lebhaft gegen die alten Orden. Für das Weltleben aber erkennt er charakteristisch eine solche Relativierung des Liebesgebotes als unumgänglich an, auch dies, wie so vieles andere, ein Zeichen, daß wir auf ganz anderem Boden stehen als auf dem der alten Kirche, daß wir nun eine dauernde christliche Gesellschaftsordnung mit Eingliederung und Heiligung der Naturbasis des Lebens vor uns haben. Es ist nicht mehr die Liebestätigkeit als der einzige soziale Gedanke, der die Brücke schlägt von dem vollkommenen Urzustand der Gleichheit zu der kommenden Liebesgleichheit der himmlischen Seligkeit über eine der Sünde verfallene und der Vergänglichkeit bestimmte Welt. hinüber ${ }^{155}$ ).

Die Grundzüge der mittelalterlichen Sozialphilosophie sind damit auch nach den Einzelanwendungen hin deutlich. Sie hebt sich sowohl in ihrer Geschlossenheit und Allseitigkeit als in ihrer positiven Welteingliederung deutlich ab von der unbestimmten, lückenhaften und gegen die Welt nie recht ins klare kommenden Soziallehre der alten Kirche. Sie bekundet damit dann freilich vollends auch ihren Abstand von der soziologischen Idee des Evangeliums. Das Flügelroß des absoluten religiösen Individualismus und der radikalen Liebesethik ist vor den Pflug der Gesellschaftsordnung gespannt, zieht seine fruchtbaren Furchen in einem verhältnismäßig leicht bearbeitbaren Boden und strebt nur am letzten Ende in die Regionen der Uebersinnlichkeit und Ewigkeit hinein. Das neue Menschentum

155) Hierzu im einzelnen Maurenbrecher; auch v. Eicken $488-547$ f. und die erwähnte Abhandlung von Funk; außerdem Ratzinger, ,Volkswirtschaft a und viel Material bei Uhlhorn, sLiebestatigkeit II. 
der religiösen Persönlichkeit und der Liebesgemeinschaft in Gott hat seinen Kompromiß geschlossen mit dem alten Menschentum des Kampfes ums Dasein, des Rechts, des Zwanges, des Krieges und der (rewalt, mit der Naturbasis des Daseins ${ }^{156}$ ). Der Kompromiß war erst möglich auf dem Boden der mittelalterlichen Gesellschaftsordnung, die aus der Verjüngung der ganzen Gesellschaftsordnung in einer kulturschwachen Naturalwirtschaft zu den ersten, noch gemäßigten Anfängen der höheren politischen und wirtschaftlichen Differenzierung und Vereinheitlichung emporstieg und in einem starken Vorwiegen des. persönlichen Elementes über das abstrakte und rationalistische der religiösen Ethik leicht zugängliche Einsatzpunkte darbot ${ }^{157}$ ). Die kirchliche Theorie hat darum diese Zustände verabsolutiert in ihrem christlichen Naturrecht und dieses in ihrer wissenschaftlichen Metaphysik ebenso wie in ihrer Offenbarungslehre verankert. Es ist keine Ideologie, die die Naturbasis vernichtet und ignoriert, aber auch keine Sozialreform, die sie umwandelt und christianisiert, sondern eine Verbindung von Vorsehungsglaube und Rationalismus, die die von der Vernunft durchwaltete Naturbasis als von selbst auf den religiösen $Z$ weck hin geordnet betrachtet: die Zustände, welche tatsächlich und praktisch eine solche Annahme vorübergehend ermöglicht haben, werden verewigt zum Naturgesetz im architektonisch-entwickelungsgeschichtlichen Sinne dieses Begriffes und dabei selbstverständlich für diesen $Z$ weck gegenüber ihrer wirklichen Beschaffenheit noch erheblich idealisiert. Es mag fraglich sein, ob dies in der Tat die einzigen $\mathrm{Zu}-$ stände sind, die der christlichen Idee eine leidlich-mögliche Verwirklichung gewähren. Jedenfalls ist die katholische Kirche

${ }^{158}$ ) Vgl. hierzu die sehr charakteristische Aeußerung über den Kommunismus der Urgemeinde: Contra Gent. 135: Primus quidem modus, scil. quod de pretio possessionum venditarum omnes communiter vivant, sufficiens est, non tamen ad longum tempus. Et ideo Apostoli hunc modum vivendi fidelibus in Jerusalem instituebant, quia praevidebant per Spiritum S., quod non diu in Jerusalem simul commorari deberent. .. Unde non fuit necessarium nisi ad modicum tempus fidelibus providere et propter hoc transeuntes ad gentes, in quibus firmanda et perduratura erat Ecclesia, hunc modum vivendi non leguntur instituisse. Maurenbrecher notiert noch weitere ähnliche Stellen S. 109. Das ist eine grundlegende Einsicht, s. weiter unten den Gegensatz der Sektenlehren.

137) Das ist auch von Uhlhorn II $439 \mathrm{f}$. hervorgehoben; aber auch die Schattenseiten S. 441; sie bestehen darin, daß, sobald die snatürliche Ordnung versagte, man den sozialen Krisen hilf los gegenüberstand. 
nach den Zersetzungen dieser Soziallehren im 14. und 15. Jahrhundert im Zeitalter der Gegenreformation zu diesen Theorien wieder zurückgekehrt und hat sie diese nach einer abermaligen Erschütterung im 18. Jahrhundert mit einigen Neuanpassungen besonders an Demokratie, Kapitalismus und modernes Staatskirchenrecht von neuem aufgenommen. Wie sehr aber diese Theorien - wenigstens in ihren Grundzügen, in der Vereinigung von Naturgesetz und Gnadensittlichkeit zur einheitlichen christlichen Gesellschaft, -- das einzige bisher aufgestellte System einer christlichen Gesellschaftslehre sind, das zeigt sich schließlich vor allem auch darin, daß die aus der religiösen Krisis des 16 . Jahrhunderts hervorgehende Neuformung der' christlichen Idee, der Protestantismus, auch seinerseits eine Gesellschaftslehre nur aufstellen konnte durch die Weiterführung und Umbildung dieser katholischen Sozialphilosophie. Auch seine Sozialphilosophie beruht auf dem Begriff des Naturgesetzes.

Freilich liegt es nun hier nahe zum Schlusse auch die umgekehrte Frage zu stellen, wie weit ihrerseits die christliche Idee die soziale Entwickelung des Mittelalters bestimmt hat, nachdem sie selbst in ihrer sozialphilosophischen Ausgestaltung von den faktischen Verhältnissen sehr wirksam oder auch geradezu entscheidend beeinflußt worden ist. Ueber diese ganz außerordentlich schwierige und verwickelte Frage kann ich nur Vermutungen bescheidenstèr Art äußern. Doch seien sie trotzdem um der Vollständigkeit willen in derjenigen Kürze ausgesprochen, die Vermutungen geziemt. Dabei sehe ich von den bekannten allgemeinen Kulturwirkungen der Kirche ab, die freilich alle auch eine soziologisch bedeutsame Seite haben; sie ist die Lehrerin in Kunst und Wissenschaft, Technik und Organisation, Verwaltung und Recht, ist die Fortsetzung der antiken Kultur. Es handelt sich hier nur um eigentlich soziale Wirkungen und um solche, die aus ihren eigentlich religiösen Gedanken hervorgegangen sind. Ei n m a l scheint es mir hier fraglos, daß es der Kirche gelungen ist, der Gesellschaft den christlichen Begriff der Familie zu Grunde zu legen, jene Verbindung des autoritären Elementes $m^{: t}$ dem ganz persönlichen und individualistischen. Wie viel imme: zur Erweichung des alten germanischen und römisch-rechtlichen Patriarchalismus der Wegfall der Berechnung aller Verhältnisse auf militärische Organisationen, das Interesse der Geschlechter an dem Schicksal ihrer aus dem Verband her- 
aus heiratenden'Frauen und ihrer Kinder, die ökonomischen Bedürfnisse einer Sicherstellung und rechtlichen Konstruktion des Frauenvermögens getan haben mögen, das Persönlichkeits- und Liebesideal der Kirche hat doch w'ohl den stärksten Anteil an der Verinnigung und Individualisierung der Familienbeziehungen, wobei dann freilich nicht zu leugnen ist, daß sie auch das Ihrige zur Befestigung der hausväterlichen Autorität beigetragen hat. Dieser christliche Begriff der Familie bildet bis heute, verbunden mit stoischen und jüdischen Gedanken, den Grundpfeiler unserer Gesellschaftsordnung. Alle Reformen und Emanzipationen auf diesem Gebiete stehen vor der Grundfrage, wieweit sie innerhalb des Rahmens dieses Begriffes sich bewegen oder das Zukunftsland einer völlig neuen Gesellschaftsordnung eröffnen wollen. Das ungeheure Problem der Sexualmoral ist hier in einem ganz bestimmten Sinne gelöst, der den europäischen Völkern einen ihrer Hauptcharakterzüge gibt oder gab und der den modernen Individualismus bis $\mathrm{zu}$ einem gewissen Grade sich $\mathrm{zu}$ assimilieren weiß, der aber freilich gerade durch die modernen ökonomischen Verhältnisse wieder schwer bedroht ist ${ }^{158}$ ). $Z$ weit en s scheint mir für die Ueberführung der halbanarchistischen Feudalstaaten und Städteanhäufungen in den vereinheitlichten, bureaukratischen und souveränen modernen Staat das Vorbild der Kirche als der einzigen souveränen und mit einem reichen Beamtenapparat regierenden, auf unbedingten Gehorsam gestützten und mit einem formalisierten schriftlichen Recht arbeitenden Institution von höchster Bedeutung zu sein. Ja man wird sogar sagen können, daß der moderne Staatsbegriff mit seiner Bindung der. Einzelwillen an einen rechtlich darstellbaren Gesamtwillen und der gleichzeitigen Sicherstellung persönlicher unantastbarer Rechte des Individuums in dem Corpus mysticum der Kirche sein erstes Orientierungsmittel fand und dadurch von dem antiken Staatsbegriff mit seiner abstrakten Bindung des Staates an die Gesetze und seiner Unmöglichkeit, den Gesamtwillen gegen die Einzelwillen abzugrenzen, sich unterscheidet. Wenigstens sind alle diese modernen staatsrechtlichen Begriffe aus den von der Kirche gebundenen und auf den Gesamtwillen des Corpus mysticum bezogenen staatsphilosophischen Elementen erwachsen ${ }^{159}$ ). Darüber

158) Vgl. hierzu Marianne Weber, Ehefrau und Mutter S. 200-278; Schmoller, Grundriss I, 244-253; auch den schon erwähnten Aufsatz Gotheins.

159) Das ist der Grundgedanke von Gierke III ; auch von J. N. Figgis, From I roelts ch, Gesammelte Schriften. I. 
hinaus aber wird man drittens wohl überhaupt das ganze soziale Denken und Empfinden überhaupt als tiefgehend beeinflußt ansehen dürfen von dem Gedanken einer objektiven Gemeinschaft in absoluten Werten und Wahrheiten. Die geschichtsphilosophische Idee des sobjektiven Geistes * ist eine Umformung der kirchlichen Lebenseinheit ohne die kirchlichen Gemeinschaftsmittel. liür diesen Gedanken war der platonische Staat und der stoische Kosmopolitismus doch nur ein Vorspiel. Erst die Kirche hat praktisch eine Vereinigung vollzogen, die in absoluten geistigen Werten zunächst die Gemeinschaft bindet und gerade durch Anteilnahme des Individuums an diesen persönlichen Werten zugleich das Individuum auf sich selbst stellt als Eigenwert. In dieser Hinsicht setzt gerade der Liberalismus einen von der Kirche zuerst verwirklichten Gedanken in säkularisierter Form fort, und es ist sehr die Frage, wie weit dieses Ideal gegen naturalistische Rückschläge ohne jeden religiösen Halt zu behaupten ist. Es ist ein Hauptargument katholischer Apologetik, daß gerade die idealistischen und humanen Forderungen des Liberalismus an ihr ihren festesten Halt hätten. Und daß hier ein gewisser Zusammenhang vorliegt, ist sicher nicht zu bezweifeln, wenn auch freilich der Halt an der Kirche damals und noch mehr heute mit starken Einbußen gerade des idealistischen Individualismus und der Beweglichkeit der geistigen Inhalte bezahlt werden muß. $\mathrm{V}$ i ertens wird man sagen dürfen, daß die fortschreitende Milderung der Unfreiheit, die Lockerung des Hörigenwesens, die Hcrausbildung städtischer Freiheit aus den in der Stadt sich sammclnden Untertänigen und damit die Richtung auf das freie zünftige Gewerbe und damit dann auch die ganze Konzentration des neu entstehenden Kapitalismus auf die Organisation der freien Arbeit von dem religiösen Persönlichkeitsideal und seiner praktisch-rechtlichen Durchsetzung wenigstens mitbedingt ist. Wenn auch das neue Kapital von vorne herein in wesentlich anderer Lage ist als das antike und bei der intensiven Bodenwirtschaft nicht an Sklavenplantagen, an Investierung in Staatspacht und an ïlserwiegende, durch die Küstenkultur bedingte Beschäftiguns im Scchandel denken kann, vielmehr auf Binnenhandel und Gewerbe gewiesen ist, zu welchen $Z$ wecken es nur die zur Qua(ierson to Grotius, der das moderne politische Denken aus der in Katholizismus, Luthertum und Calvinismus sich spaltenden Idee der christlichen Gesellschaft erw:ichsch läßt unter gleichzeitiger Einwirkung der Renaissance. 
litätsarbeit erziehbare, durch Eigeninteresse belebte freie Arbeit verwenden kann, so wird doch die völlig neue Wendung des Kapitalismus auf die freie Arbeit und das daraus entstehende spezifisch moderne Sozialproblem des Verhältnisses der freien kapitallosen Arbeit zum rationell-kalkulierenden Kapital als mitbedingt durch die ethische Forderung der Freiheit des Individuums betrachtet werden dürfen. Ein Rückfall der neu aufstrebenden Kultur in dàs soziale System der Sklavenhaltung, der an sich ja nahe genug liegt und in Amerika praktisch geworden ist, wurde doch nicht bloß durch die politische und ökonomische Struktur ausgeschlossen, die dem neuen Kapital seine Wege vorzeichnete, sondern diese Struktur selbst ist - neben der gewiß den Hauptgrund bildenden Wirkung der hofrechtlichen Verfassung auf ökonomische und schließlich auch rechtliche Verselbständigung der Unfreien doch irgendwie auch bedingt durch die Arbeit der Kirche an der Eroberung von Persönlichkeitsrechten für die Unfreien. Sie hat es nie als Rechtsforderung aufgestellt, sondern hier stets das positive Recht und die Wirkungen des Sündenfalls respektiert, wie sie das auch gegenüber der das ganze Mittelalter durch dauernden Sklaverei getan hat. Aber indirekt und von innen heraus, namentlich in der Sicherung der Familie, hat sie aller Wahrscheinlichkeit nach doch in dieser Richtung wenigstens mitgewirkt. Vollends die städtische Freiheit und die Individualisierung des religiösen Lebens hängen unverkennbar als Wechselwirkung zusammen. Insofern geht der eigentliche Charakter der modernen ökonomischen Entwicklung doch mit zurück auf die Freiheit und die Menschenrechte, die die Kirche verkündigte ${ }^{160}$ ). Daß die Folgen

160) Vgl. Ed.. Meyer, „Die Sklaverei im Altertum\& S. 39 ; Max Weber, ,Agrargeschichte (Altertum) S. I 74 f. lehnt diese Auffassung freilich ab und denkt lediglich an die Sonderbedingungen der Entstehung der mittelalterlichen Stadt, die nicht zu militärischen, sondern zu ökonomischen Zwecken gegründet wurde und bei der Art des binnenländischen Verkehrs, der Art der Bedürfnisse und den Antezedentien der Entwickelung der Unfreiheit auf die freie Arbeit allein gerichtet sein konnte. Immerhin bringt er doch auch die Friedensidee der Kirche mit diesem ökonomischunmilitärischen Wesen der Gewerbestadt in Verbindung. Hier ist sicherlich zuzugeben, daß die Ausgleichung zwischen den verschiedenen Klassen der Unfreiheit und Abhängigkeit so gut wie die ökonomische und rechtliche Verselbständigung der Unfreien und Halbfreien ihren eigentlichen Grund in der Verwandelung der Grundherrschaft aus einer Eigenwirtschaft in ein System von Rentenbezügen gehabt hat und daß auch die Abgabe der Abhängigen an die Stadt, wo sie von ihrem Verdienste her zinsen konnten, ein Hauptmotiv für die Entstehung der Städte war. Aber trotzdem wird doch mit 
davon freilich sehr zweischneidig sind, das hat diese Erscheinung mit allen andern großen historischen Bildungen gemeinsam. Jedenfalls aber arbeitet die christliche Idee bis heute an der Beseitigung oder lïinschränkung der ungünstigen Folgen und erblickt sie gerade darin heute eine ihrer Hauptaufgaben. Die katholische Soziallchre arbeitet hier heute gerade in erster Linie mit; und es licgt nur in cler Konsequenz ihrer ganzen Entwickelung, wenn sie

Sicherheit angenummen werden dürfen, daß die christliche Idee und die Kirche auf diese Milderungen auch ihren Einfluß gehabt haben und daß namentlich in der Stadt dic Durchsetzung cler Freiheitsidee mit dem städtischen religiösen Leben zusammenhing. Maurer, Gesch. d. Fronhöfe II 80-93 führt die Milderung auf die sSittes zuriick und sagt S. 90: - Jemehr nun aber der Mensch in dem Leibeigenen Geltung erhielt, desto mehr hat sich die Lage der Unfreien gebessert«, gibt aber allerdings keine Belege an. Jedenfalls hat die Kirche die Ele der Unfreien geschützt und ihnen das Menschenrecht des Familienlebens gesichert, womit schon naturgemäß eine Lockerung der Abhängigkeit verbunden ist. Maurenbrecher 82. Langér, „Sklaverei in Europa während der letzten Jahrhunderte des Mittelalters«, Bautzener Cymmasialprogramm I $89 \mathrm{I}$, untersucht die Frage eingehend, führt von Anfang an die Nilderungen des alten Sklavenwesens bei den germanischen Staaten auf Einwirkungen des rümischen Rechtes und des Christentums zurück und räumt:auch. in den weiteren Entwickelungen der Kirche einen nicht unerheblichen Einfluß auf dic Milderung ein. Uebrigens ist die eigentliche Sklaverei von dem Hörigenwesen streng zu unterscheiden. Wenn das letztere zur freien Arbeit sich vielfach entwickelte, so hat die Sklaverei und der Sklavenhandel durch das ganze Mittelalter hindurch gednimert und ist von der Kirche niemals prinzipiell verworfen worden. Alle in theologischen Werken üblichen Verherrlichungen des Christentums, daß es im Mittelnlter wenigstens die Sklaverei abgeschafft habe, beruhen auf krasser I'mu issenheit oder verlogener Apologetik. Ungefähr das Gegenteil ist wahr. Dicse Sklaven sind in der Regel Nichtchristen und werden durch Kriegsrecht oder Handel gewonnen; oft freilich werden auch ganze christliche Ställe nach der Besiegumy versklast. In Spanien dauert die Sklaverei bis ins 18 . Jahrhundert und ist (w) da nach Amerika einfach übertragen worden. Die Milderung der dortigen Sklaverci durch die Kirche bestand nur in der Ersetzung der cinheimischen Sklaverei durch importierte Negersklaven, an die man in Spanien und Südeuropa gewohnt war. So kniipft sich die moderne amerikanische Negersklaverei unnittelbar an die de. Mittelalters an und hat, so lange sie bestand, dieselben theologischen Argumente für sich anzuführen gewußt. Wo sie in Europa auf hörte, sind politische und äkonomische Verhältuisse die Ursache; niemals aber ein Verbot der Kirche. Ja, lic Sklarerei nimmt in Südeuropa geradezu gegen Linde des Mittelalters einen Aufschwung, und die Kirche ist nicht bloß am Sklavenbesitz beteiligt, sondern verhängt anch geradezu Vershlarung als Strafe in den verschiedensten Fällen! Dic oben ausgesprochene Ansicht bezieht sich nur auf Hörige und Figene, die zu Freien oder 
bei der Lösung dieser aus ihrer eigenen Idee mit hervorgewachsenen Schwierigkeiten schwankt zwischen den älteren Mitteln des Patriarchalismus und den modernen einer individualistisch-demokratischen Arbeitsordnung; wie die ganze Lage selbst, so sind beide Mittel zum großen Teil aus ihrer eigenen Entwickelung und Geschichte hervorgewachsen. Schlie Blich dürfen auch zwei allgemeine Gesichtspunkte nicht übersehen werden. Die kirchliche Sozialphilosophie beruht auf der Idee der kirchlichen Einheitskultur und dem Sieg der Univerșalkirche über die Landeskirchen, von denen sie die Durchdringung des Geistlichen und Weltlichen übernommen hatte, über denen sie aber ihr neues, kirchliche Bil-. dung und Wissenschaft wie kirchliches Recht und kirchliche Politik zentralisierendes System aufrichtete. Es ist mit Recht betont worden, daß wir nur diesem Umstande die Einheit der europäischen Kulturund ihrer Bildungsgrundlagen in Antike und Christentum verdanken. Die Einheitlichkeit der abendländischen Kultur wurde präformiert von der Einheitiichkeit der Kirche und von dieser mit ihren eigentlichen Nahrungsmitteln versehen $\left.{ }^{161}\right)$. Andererseits aber bedeutet die Erziehung der europäischen Völker durch die Einheitsmacht der Kirche doch zugleich eine steigende Verinnerlichung und Subjektivierung des Gefühlslebens, eine Personalisierung aller Lebensbeziehungen, dic in den frühmittelalterlichen Ordensbewegungen ihren ersten großartigen Ausdruck findet und dann in der städtischen Kultur und den ihr entsprechenden neuen Orden auf einen Gipfel steigt, auf dem dann freilich schließlich die Einheit der Kirche zerbricht. Was auch immer Antike und Renaissance zur Vertiefung der Individua lität getan haben, die stärkste Wirkung hat das Christentum, das ja immer Stoizismus und Neuplatonismus zugleich in sich schloß, gehabt, und der eigentlich nachhaltige Durchbruch zum Individualismus ist doch die religiöse, nicht die weltliche Bewegung, die Reformation, nicht die Renaissance gewesen. Wenn aus dem naturhaften anarchistischen Individualismus der Unkultur der geistige Individualismus der autonomen, mit objektiven Werten er-

fast Freien wurden. Wie abhängig freilich derartige Dinge von ökonomischen Entwickelungen sind und wie vor dem modernen Individualismus die Kirche nur relativ hierauf wirken konnte und wollte, zeigt der Umstand, daß mit dem Zurücksinken in die Naturalwirtschaft seit dem 16. Jahrhundert in Deutschland die Leibeigenschaft wieder zugenommen hat.

181) S. Ranke, -Die Romanisch-germanischen. Völker«, Einleitung. 
füllten und darum einen eigenen Selbstwert darstellenden Persönlichkeit wird, so ist dieses Ideal modernen soziologischen Denkens - zugleich freilich mit allen ihm einwohnenden Schwierigkeiten eine Wirkung zwar nicht allein, aber doch großenteils des mittelalterlichen Christentums. Wie die Gemeinschaftsidee des >objektiven Geistes`, so hängt 'auch die Individualidee der *Persönlichkeit * mit der mittelalterlichen Periode eng zusammen. In den individualistischen Sektenbewegungen und vor allem in der Reformation werden wir ihn die kirchlich-katholische Hülle sprengen und auf die katholische Lösung der ihm einwohnenden Probleme mehr oder minder verzichten sehen ${ }^{162}$ ).

Es ist dann freilich unendlich reizvoll wahrzunehmen, wie mit diesem Durchbruch des religiösen Individualismus und mit dieser Zertrümmerung des alten soziologischen Organismus der sakramental-priesterlichen Kirche für den erneuerten christlichen Individualismus auch wieder das ganze Ringen um eine soziologische Organisation seiner selbst und um ein Verhältnis zu den sozialen Bedingungen von neuem entsteht, wie durch die Preisgabe der altkirchlichen und mittelalterlichen hierarchischen Inkrustation die erste Aufgabe außerordentlich erschwert und wie die zweite schließlich doch nur durch Fortführung und Umbildung der mittelalterlichen Lösung des Problems in den Grundzügen lösbar geworden ist.

9. Das absolute Gottes-und Naturrecht und die Sekten.

Ehe zur Darstellung der großen reformatorischen Neubildungen fortgeschritten werden kann, ist noch der radikalen Komplementär-Erscheinung zu gedenken, die auch die hochmittelalterliche, relativ konservative, die Welt anerkennende und sich eingliedernde Sozialtheorie des Christentums ebenso neben sich gehabt hat wie einst die alte Kirche. Die Wendung zum Konservatismus ist seiner Zcit durch den Paulinismus angebahnt und die in diesem vollzogene Verbindung des radikalen und konservativen Elementes ist dann in der thomistischen Soziallehre fortgebildet worden zu einem entwickelungsgeschichtlich-architektonischen Aufbau der christlichen Kultur. Dazu gab ihm die Neubildung aller sozialen

n. $\therefore$ Thode, F:an v. Assisi; Neumann Byzantinische Kultur und Renaissancekultur ; Brandi, ,Das Werden der Renaissance^, I908; Arnold Berger, >Die Kulturaufyaben der Reformation «, 1895. 
Verhältnisse im Mittelalter die Möglichkeit und die neuplatonische Lehre von dem stufenweise gegliederten Aufbau des Geistes die theoretischen Mittel. Für die Konstruktion der weltlichen Sozialordnungen wurde in diesem System die stoisch-patristische Theorie von der Lex naturae fortgeführt, aber mit der aristotelischen Politik und Oekonomik versetzt. Unter diesem Einfluß erwies sich die erstere als stark zurückgedrängt. Ungleichheit, Staatsbildung, Privateigentum und Herrschaftsverhältnisse gehören nicht erst dem relativen Naturrecht des Sündenstandes an, sondern wurzeln schon im Naturrecht und Urstand überhaupt; nur ihre besondere $Z_{\text {wangsform }}$ und ihre Schmerzen verdanken sie erst dem relativen Naturrecht des Sündenstandes. [Aber bereits neben dem Paulinismus hatte ein weltindifferenter oder gar weltfeindlicher Radikalismus bestanden in Gestalt des Liebeskommunismus der Urgemeinde und der chiliastisch-apokalyptischen Weltverwerfung, und ähnlich hat dann neben der den Paulinismus fortbildenden sozialen Entwickelung der alten Kirche der Radikalismus weiter bestanden in den montanistischen und donatistischen Sekten und vor allem im Mönchtum. Unter dessen Einfluß und in Anlehnung an die rationalistischindividualistische Naturrechtslehre der Stoa haben die großen Väter des vierten Jahrhunderts dann auch ein Naturrecht des Kommunismus, der Freiheit und Gleichheit gelehrt, während Augustin ein aristokratisches Naturrecht der Herrschaft der Guten lehrte. Es war das Ergebnis des ersten Hauptteils dieser Untersuchung, die doppelte Richtung hervorzuheben, in welche von Anfang an die Soziallehren des Christentums auseinandertraten. Das strenge Bibelgesetz, das radikale Naturrecht, das Mönchtum und die theologische Urstandstheorie zeigten sich dort als Motive und Aeußerungen einer neben den kirchlichen Kompromissen hergehenden zweiten radikalen Richtung ${ }^{162 \mathrm{a}}$ ).

Diese zweite Strömung bricht nun aber im Hochmittelalter gerade neben der im Thomismus sich gedanklich vollendenden kirchlichen Einheitskultur und Weltumfassung von neuem mit außerordentlicher Macht hervor. Gegen die Relativierungen und gegen dic Kompromisse des Sittengesetzes Jesu mit den Ordnungen der Welt erhebt sich der strenge Radikalismus der ganz auf Selbstheiligung und Bruderliebe gestellten Ethik des Evangeliums; er beruft sich, wie auf das Gottesgesetz des Evangeliums. so auf das Naturgesetz des Urstandes, das auch nur Heiligkeit und unbedingte I.iebe und $162 a)$ S. oben S. $175-178$. 


\section{II. Mittelalterl. Katholizismus. 9. Das absolute Gesetz und die Selkten.}

danit die Abwesenheit der weltlichen, politischen und wirtschaftlichen Ungleichheiten und Härten gekannt habe. Indem die Kirche bei ihrer Organisation einer allgemeinen christlichen Gesellschaft und Kultur diesen radikalen Gedanken keinen Raum bot oder vielmehr sie nur in Gestalt eines besonderen ihr dienenden Standes, des Mönchtums, ertragen konnte, waren sie auf eine Entfaltung neben der Kirche angewiesen. Der Gegensatz des radikalen Bibelgesetzes und der an ihm gemessenen Lebensführung der radikalen Christen gegen die relativierende und das Ganze umfassende kirchliche Ethik und Soziallehre führt zur Sektenbildung. Und so wird diese Sektenbildung neben dèr die kirchliche Ethik klassisch zusammenfassenden Soziallehre des Thomismus zur anderen klassischen Gestaltung der Soziallehre des Christentums. Das, was in der kirchlichen Einheitskultur und Gesellschaft nicht zu seiner vollen Geltung kam, schafft sich Raum in dén Sekten und wirkt von ihnen her auf die Kirche zurück.

Es ist hier nicht die Absicht, die zum Teil noch sehr dunkle und außerordentlich verwickelte Geschichte dieses Sektentums im Einzelnen darzustellen. Das muß auch hier der kirchen- und sozialgeschichtlichen Einzelforschung überlassen bleiben ${ }^{163}$ ). Aber es ist unum-

103) Die einzige Kirchengeschichte, die diesen Problemen im Zusammenhang uachgeht, ist die von Karl Müller I 1892, II, I, 1902, bes. vgl. I 207 u. II 85 f. kr sieht in diesen Sektenbewegungen das Eindringen des Mönchtums und seiner Ideale in die Laienwelt, das seit dem 13. Jahrhundert beginne und die Doppelform teils des gewaltsamen christlichen Sozialismus, teils der duldenden weltabgewandten Gemeinde annehme. ,In beiden Richtungen dringen die asketischen Gedanken und Kräfte der mittelalterlichen Kirche in die Laienwelt eine II 86 . Zugleich hebt er den Zusammenhang mit der Idee des absoluten Naturrechtes herrvor, wie sie von den Theologen des 4. Jahrh. gelehrt wrorden war. Doch trifft die Herleitung aus dem Mönchtum und der Askese nur einen Teil des vorliegenden Sachverhaltes und liegt der Zusammenhang mitunter geradezu umgekehrt; das Mönchtum stellt die Verkirchlichung von Tendenzen dar, die an sich einem ganz anderen soziologischen Typus angehören als dem kirchlichen und die in den Sekten ihren reinen Ausdruck finden. Die große Frage ist nach dem $\mathrm{Zu}$ sammenhang dieser Ideenwelt mit dem Evangelium selbst, auf das sie sich doch stets nachdrücklich beruft und aus dem sie auch unzweifelhaft direkt hervorgeht. Die Frage aber ist dann weiterhin die nach dem Verhältnis des Sektentypus und des Kirchentypus überhaupt sowie nach ihrem gemeinsamen Verhältnis zum Evangelium, aus dem sie beide hervorgehen. Müller hält von vornherein, wie die meisten Theologen den Kirchentypus fär das Normale und die Sekten für eine ebenso sekundäre Erscheinung wie Mönchtum und Askese, aus deren Populari- 
gänglich, die allgemeine Bedeutung dieses Sektenwesens für die christlichen Soziallehren überhaupt darzutun. Denn das fügt dem Bilde dieser einen neuen, beim Ursprung schon angelegten, aber jetzt erst breit hervortretenden Zug hinzu, der mit dem Uebergang in die moderne Welt immer bedeutender sich geltend macht und die Einsicht in den soziologischen Charakter des Christentums erst abschließt. Diese Bedeutung besteht nun aber darin, daß hiermit neben dem vom Christentum in seiner soziologischen Selbstge-

sierung sie angeblich erst hervorgehen. Ich glaube, daß hier eine spezifisch soziologische Untersuchung über die innere Struktur der beiderseitigen Gemeinschaftsverhältnisse ein anderes Bild ergibt. - Eine zusammenhängende Darstellung vom entgegengesetzten Standpunkt aus gibt L. Keller: Die Reformation und die zlteren Reformparteien 1875 . Hier ist die Sekte das Normale und wird überall, zum Teil sehr gewaltsam, auf die Waldenser zurückgeführt; zugleich werden diese letzteren wieder an eine unmittelbare uralte Tradition von der altchristlichen Kirche her angeknüpft. Weil der Sektentypus das Normale ist, so wird auch hier das Wesen der. Sekten nicht am Gegensatz des Kirchentypus und an der gemeinsamen Begründung beider im Evangelium erläutert. Vielmehr wird der Kirchentypus als Entstellung des reinen Christentums verworfen und an den Sekten die Toleranz und die praktische Ethik betont, dabei die Kulturlosigkeit teils bestritten, indem möglichst viel Literaten für sie reklamiert werden, teils entschuldigt aus den elenden Verhältnissen, in die die Verfolgung sie gestürzt habe. Die Betonung des Sektentypus überhaupt ist ein entschiedenes Verdienst der Arbeit, aber die materielle Schilderung der Sekten findet nicht die entscheidenden Charakterzüge; die ganze Schilderung visiert auf ein modernes, tolerantes und ethisch ernstes Humanitätschristentum, betont nur die Freiwilligkeits- und Subjektivitätsposition, ignoriert aber das wörtliche Bibelgesetz und dasradikale Naturrecht, den Enthusiasmus und Chiliasmus, womit dann freilich die Kulturlosigkeit der Sekten unter eine ganz falsche Beleuchtung tritt. Sie gehört zu ihrem Wesen. - Ohne jeden Wert sind die kurzen Andeutungen bei Luthardt, Gesch. der Ethik I 327-333; Ziegler, der in der mittelalterlichen Ethik überhaupt keine neuen Gedanken findet, ,ignoriert sie völlig. Sehr dürftig sind auch die Dogmengeschichten; hier gibt es nur die leicht hingeworfenen Bemerkungen von Seeberg, Dogmengesch. II 166-169. So gut wie gar nichts für den Gegenstand bietet Loserth, Geschichte d. späteren Mittelalters 1900, obwohl er die Auflösung der , geistlichen Kulturk schildern will I - Einen lehrreichen Abriß eines Teiles der Sektengeschichte gibt Lechler, Joh. v. Wiklif und die Vorgeschichte der Reformation, 1873. Nur ist hier alles auf die Reformation hin betrachtet und der Unterschied zwischen dem Biblizismus des Gottes- und Naturgesetzes bei den Sekten und dem lutherischen Biblizismus des Gnadentrostes und der ChristusMystik nicht beachtet; er ist aber in Wahrheit, wie später darzulegen, fundamental, und an ihm zeigt sich gerade der Punkt, wo die Reformation vom Sektentypus sich scheidet. 
staltung hervorgebrachten Typus der $\mathrm{Kir} \mathrm{che}$ der neue Typus der $\mathrm{S}$ e k t e erscheint.

Dabei liegen zunächst die rein tatsächlichen Unterschiede auf der Hand. Der Typus der Kirche ist die überwiegend konservative, relativ weltbejahende, massenbeherrschende und darum ihrem Prinzip nach universale d. h. alles umfassen wollende Organisation. Die Sekten sind dem gegenüber verhältnismäßig kleine Gruppen, erstreben eine persönlich-innerliche Durchbildung und eine persönlich-unmittelbare Verknüpfung der Glieder ihres Kreises, sind eben damit von Hause aus auf kleinere Gruppenbildung und auf den Verzicht der Weltgewinnung angewiesen; sie verhalten sich gegen Welt, Staat, Gesellschaft indifferent, duldend oder feindlich, da sie ja nicht diese bewältigen ünd sich eingliedern, sondern vermeiden und neben sich stehen lassen oder etwa durch ihre eigene Gesellschaft ersetzen wollen. Beide stehen ferner im engen Zusammenhang mit dem tatsächlichen Zustand und Lauf der Gesellschaft. Aber während die voll entwickelte Kirche den Staat und die herrschenden Schichten sich dienstbar macht und sich eingliedert, zu einem Bestandteil der allgemeinen Ordnung wird und diese von sich aus teils bestimmt teils sichert, damit aber auch von ihnen und ihrer Entwicklung abhängig wird, haben umgekehrt die Sekten die Beziehungen zu den Unterschichten oder doch $z \mathbf{u}$ den gegen Staat und Gesellschaft im Gegensatz befindlichen Elementen der Gesellschaft, arbeiten sie von unten herauf und nicht von oben herunter. Damit hängt schließlich auch ihre verschiedenartige Stellung zu der überweltlichen Lebensorientierung des Christentums und zu seiner Askese zusammen. Die Kirche bezieht alle weltliche Ordnung als Mittel und Vorstufe auf den überweltlichen Lebenszweck und gliedert die.eigentliche Askese als ein Moment ihrem Aufbau unter starker kirchlicher Leitung ein. Die Sekten beziehen ihre Gläubigen unmittelbar auf den überweltlichen Lebenszweck, und in ihnen kommt der individualistische, unmittelbar religiös mit Gott verbindende Charakter der Askese zu einer mindestens viel stärkeren und durchgängigeren Entfaltung, neigt der Gegensatz gegen die Welt und ihre Gewalten, unter die nun auch die weltförmige Kirche gehört, zu einer prinzipiellen und allgemeinen Askese. Auch ist nicht zu verkennen, daß die Askese in der Kirche und dem kirchlichen Mönchtum einen anderen Sinn hat als in der Weltenthaltung oder der Weltfeindschaft der Sekten. 
Die Askese der Kirche ist Tugendmittel und besonderer Höhe. punkt der religiösen Leistung, meist zusammenhängend mit der Unterdrückung der Sinnlichkeit oder sich äußernd in exorbitanten - Sondérleistungen, im übrigen aber gerade das Weltleben als die gewöhnliche Unterlage und eine relativ weltfreundliche Moral als durchschnittlichen Gegensatz voraussetzend. Die kirchliche Askese berührt sich darin mit der Askese der spätantiken Erlösungskulte und der kontemplativen Entsinnlichung, hängt jedenfalls zusammen mit der Doppelheit der Moral. Die Askese der Sekten dagegen ist nur das einfache Prinzip der Weltenthaltung, der $\mathrm{Zu}$ rückhaltung von Recht, Eid, Besitz, Krieg, Macht. Sie beruft sich auf die Bergpredigt und den schlichten, aber radikalen Gegensatz des Gottesreiches gegen die Interessen und Ordnungen der Welt. Sie betreibt die Entsagung nur als Mittel der Liebestätigkeit, als Voraussetzung eines durchgängigen Liebeskommunismus, und kennt bei der gleichen Verbindlichkeit ihrer Regeln für alle keine exorbitanten und heroischen Werke, auch keine Vertretung der Weltlichkeit und Durchschnittlichkeit der einen durch den Heroismus der anderen. Sie ist der einfache Gegensatz gegen die Welt und ihre sozialen Ordnungen, aber nicht der Gegensatz gegen die Sinnlichkeit und gegen den Durchschnitt. Sie berührt sich daher mit der Askese des Mönchtums nur insoferne, als dieses auch seinerseits sich besondere Lebensbedingungen für ein Leben nach der Bergpredigt und nach dem Ideal des Liebeskommunismus schafft. Aber sie ist meistenteils grundverschieden vom Mönchtum, soferne dieses Mortifikation der Sinnlichkeit und überverdienstliche Sonderleistung von Armut und Gehorsam um ihrer selbstwillen ist. Nicht Zerbrechung der Sinnlichkeit und des natürlichen Selbstgefühls, sondern eine Liebesverbindung, die von den Kämpfen und Abstufungen der Welt nicht berührt wird, ist in allem wesentlichen ihr Ideal ${ }^{163 *}$ ).

163 a) Ueber diesen wichtigen Unterschied in dem überhaupt sehr vieldeutigen und weitschichtigen Begriff der Askese s. oben S. 95-105. Die urchristliche Askese der Weltindifferenz und die kirchlich-spätantike Askese der Mortifikation sind stets zu unterscheiden. Wir werden einen neuen dritten Begriff der Askese beim Protestantismus kennen lernen. - In Zöcklers Buch über die Askese ist leider von derartigen Unterscheidungen wenig zu finden und das große Thema sehr urteilslos behandelt. Aber auch die übliche protestantische Polemik gegen die Aske :u geht an diesen Unterschieden vorbei, auch die Junghegelsche Geschichtskonstruktion z. B. bei v. Eicken, oder auch bei Viktor Hehn, hat dafür kein Auge. 
Alle diese tatsächlich 2 wischen der hochmittelalterlichen Kirche und den Sekten bestehenden Verschiedenheiten müssen irgendwie in der in nere $\mathbf{n}$ Struktur des beiderseitigen soziologischen Aufbaus begründet sein ${ }^{184}$ ). Und, wenn in der Tat beide

14) Für die folgenden Ausführungen verdanke ich einen Teil der entscheidenden Gesichtspunkte der inhaltreichen Abhandlung von Max Weber, Kirchen und Sekten in Nordamerika, Christl. Welt 1906 S. 558 ff. u. 577 ff.; außerdem s. Scheel, Individualismus und Gemeinschaftsleben in der Auseinandersetzung Luthers mit Karlstadt 1524/25, Zeitschrift für Theol. u. Kirche 1907, und meine Abhandlung, Religion und Kirche, Preuß. Jahrb. 1895. Wie überall, so steht auch hier im Hintergrunde meiner Untersuchungen Simmels Auffassung.von der Soziologie als der Wissenschaft von den formellen Strukturverhältnissen der verschiedenen Gemeinschaftsbildungen. - Die wesentlich gleiche Grundanschauung über das Wesen der Sekten vertritt Kawerau in dem Artikel sSektenwesen in Deutschlands, Protest. Real-Encyklop. ${ }^{8}$ ed. Hauck. Hier wird das am Freiwilligkeitscharakter und an der ethischen Bewährung erkennbare Christentum vom Anstaltschristentum der Kirche unterschieden und ist zugleich erkannt, daß nur die Kirche Volks- und Kulturreligion, die Sekte dagegen Konventikelreligion und ethischer. Radikalismus ist. Freilich weiter in die letzten Gründe ist der Unterschied dann nicht mehr verfolgt. Auch sind doch die modernen auf dem Boden des Protestantismus erwachsenen Sekten von denen des Mittelalters vielfach verschieden, indem die ersteren lehrhaften Differenzen bei der allgemeinen doktrinären Natur des Protestantismus größeren Raum geben und die ethische Bewährung weniger an dem naturrechtlich-göttlichen Christus-Gesetz der Bergpredigt als an der protestantischen Berufsethik messen. In der 'That sind beide-Merkmale, die Freiwilligkeit und Subjektivität der Gemeindeteilnahme einerseits and die radikale naturrechtlich-biblische Gesetzeslehre andrerseits an sich nicht notwendig verbunden. Verburiden ist der erstere nur mit dem strengen kompromißlosen ethischen Charakter der Bewährung, da immer auf ihr die wirkliche Anteilnahme am Heil und die Verbindung der Zusammengehörigen beruht. Daß die ethische Bewährung bei den mittelalterlichen Sekten den Charakter des Gottesgesetzes und absoluten Naturrechtes annimmt, ist aus dem Gedankenkapital des mittelalterlichen Christentums zu verstehen, in welchem der Begriff des Gesetzes nun einmal ein Grundbestandteil ist und bei jeder Neuformulierung auf das Gesetz Jesu und der Natur führt. - Wie nahe aber die Verbindung beider bei einer Orientierung gerade an der Predigt Jesu liegt, kann man auch aus ganz modernen radikalen Reformprogrammen sehen. Ich erinnere nur an Lamennais' Paroles d'un croyant und an des sozialistischen Pfarrers Kutter -Sie müssen. 1904. Hier ist christlicher Kommunismus, allgemeines Vernunftrecht und Ablehnung alles kirchlichen ethischen Kompromisses deutlich beidemale der entscheidende Charakterzug. Wenn die protestantischen Sekten dem Kommunismus und absolutem Naturrecht ferne stehen, so kommt das davon her, daß ihr Biblizismus an Paulus und nicht an der Predigt Jesu orientiert ist und daher mit dem Paulinismus die Anerkennung der Weltordnungen vertritt. Darum 
sich auf das Urchristentum beziehen und beziehen können, so muß schon in diesem selbst der letzte Grund jener Ausbildung einer doppelten Struktur enthalten sein; so muß von ihrem Verständnis ein Licht auf das soziologische Verständnis des Christentums über-

verzichten sie aber auch nicht etwa auf den ethischen, antikirchlichen Radikalismus, sie betätigen ihn nur an den Formen der Berufsethik. Aus dem gleichen Grunde ist ihnen die Idee des absoluten radikal-kommunistischen Naturrechts fremd; ihr Naturrecht, soweit sie diesen Gedanken fortführen, trägt die Freiheit des Individualismus, aber nicht die Gleichheit des Kommunismus an sich. - Unter etwas anderen Gesichtspunkten ist der hier beschriebene Gegensatz auch beobachtet in der trefflichen Schrift des Basler Pfarrers Ragaz > Das Evangelium und der soziale Kampf der Gegenwart 1906. S. bes. S, 20 f. : „Es scheint mir, daß die dabei zu Tage getretenen Gegensätze auf eine einzige große Antinomie zurückgeführt werden können, die sich durch die ganze Geschichte des Christentums zieht, ja sogar älteren Datums ist als dieses selbst. Ich ? möchte den Gegensatz als den zwischen der ruhenden und der vorwärtsdrängenden Form der Religion bezeichnen. Man könnte vielleicht auch von einer ästhetisch-kultischen und einer ethisch-prophetischen Frömmigkeit reden. Beide Ströme mögen in den Tiefen des gleichen Gebirges sich gesammelt haben, aber an verschiedenen Stellen treten sie zụ Tage, verschieden gefärbt ist ihr Wasser und verschieden ihr Geschmack. Sie cntspringen, soweit sie für uns in Betracht kommen, beide im Neue n Test a mente, aber nicht an der gleichen Stelle der eine hinten bei. Paulus und Johannes, der andere vorn bei den Synoptikern.s Im weiteren Verlauf jdentifiziert $R$. noch die erste Richtung geradezu mit der $>$ Kirchec, die zweite zwar nicht direkt mit dèr $>$ Sekte«, aber er verweist auf Franziskus, die Täufer, die kalvinistische Entwickelung, d. h. faktisch auf die Sekte. R. beruft sich zu meiner Genugtuung auf meine Darstellung des "Protestantismuse in der sKultur der Gegenwart $\mathrm{I}_{4}$ und zieht damit aus meinen dortigen Ausführungen Konsequenzen, die mir damals noch nicht so klar waren wie jetzt. Nur ist es weniger der Quietismus der Kirchen unmittelbar, als die Tendenz auf Volksbeherrschung und Finheitskultur, was die Kirchen zur Brechung und Relativierung der Maßstäbe des Evanyeliums veranlaßt, ebenso wie umgekehrt die Schwierigkeit der Durchführung jener Naßstäbe zur Beschränkung auf kleine Kreise und Freiwilligkeitsgruppen oder auf Sekten führt, von denen aus eine Universalgesellschaft bisher nur durch chiliastische Gewalttat möglich war. - Eine wichtige Analogie böte hier wie an anderen Stellen unserer ganzen Untersuchung die russische Kirchen- und Kulturgeschichte, wenn diese Dinge bekannter wären als sie sind. Hier kann ich nur verweisen auf die Artikel von Kattenbusch: "Die Kirche in Rußlands in Christl. Welt 1908, bes. S. 730 ff., ferner Graß, „Die russischen Sekten \& Bd. I 1907 u. desselben Autors Aufsatz > Die Bedeutung der russischen Sektenkunde für die Beurteilung von russischer Religiosität und Kultur* in $\gg Z$. f. Religion und Geisteskultur' ", herausg. von Steinmann, 1908, S. I6r ff. - Charakteristisch und lehrreich vom standpunkt lutherischen Kirchentums über die Sekten Gottschick, Ethik 
haupt zurückfallen. Indem erst an dieser Stelle der Unterschied zwischen beiden scharf und dauernd hervorbricht, ist erst jetzt der Ort, davon zu reden. Es ist auch das hier zu gewinnende Verständnis bedeutsamer für die kommende Entwickelung, in der

1907, S. 232 f.: >Das Wesen der Sekte besteht darin, daß sie die empirische Darstellung einer von der Welt geschiedenen Gemeinde von lauter lebendigen Christen sein will. Darüber wird sie zur begriffswidrigen Einengung der christlichen Gemeinschaft; denn sie verkennt nicht nur, daß die christliche Lebensentwickelung unendlich viele Stufen hat, sondern stellt auch partikulare oder gar fehlerhafte Kriterien des Charakterstandes auf; weiter verleugnet sie den universalen Beruf der Christenheit, das Reich Gottes in geschichtlicher Entwickelung zur Herrschaft über die Welt zu bringen. Denn sie sieht Staat, Wissenschaft und Recht, Kunst nur als Welt im schlechten Sinne an und verzichtet in chiliastischer Spannung auf die Arbeit für die geistige Ueberwindung der Welt. Im Gegensatz hierzu ist es das charakteristische Merkmal, wodurch eine christliche religiöse Gemeinschaft sich als $\mathrm{Kirche}$ bewährt, daß sie in universalem und geschichtlichem Geiste einerseits auch werdenden Christen und allen christlichen Individualitäten sich als Heimstätte öffnet, und so mit der Wahrheit Ernst macht, daß die Gemeinde als Ganzes dem Einzelnen vorangeht, und daß sie andrerseits ihre Rechtsordnung statt als Darstellung der Gemeinde der Gläubigen vielmehr als ein System von Mitteln zur Pflege und Verbreitung des Christentums organisiert und dabei auf die Aufgabe eingeht, die gottgeordneten Lebensphären mit christlichem. Geist zu erfüllen. In der Bewährung dieses Sinnes ist die Kirche allmählich in die Form der Volkskirche hineingewachsen, d. h. sie hat eine Form angenommen, vermöge derer sie sich die Aufgabe der Erziehung an den Völkern als Ganzen stellt und der Einzelne nicht erst durch freien Entschluß, sondern schon durch seine Geburt in das natürliche Volksleben unter ihren erziehenden Einfluß gelangt... Diese Vorzüge der Wirksamkeit kompensieren den unvermeidlichen Nachteil, daß in eine so geordnete Kirche Elemente der Welt im schlechten Sinne in relativ größerem Umfang eindringen als in eine Sekte. Nicht nur wegen dieses Umfanges, sondern vor allem wegen dieses ihres. universellen und geschichtlichen Ideals haben die großen Körper der katholischen und protestantischen Kirchen Anspruch auf das Prädikat Kirche «. Gegenüber dieser Beschreibung ist mit Händen zu greifen, daß der Sektentypus der synoptischen Predigt des auf die Zukunft gerichteten, entschlossene Anhänger sammelnden und die Welt a auf ein Mindestmaß herabsetzenden Jesus entspricht, während der Kirchentypus dem auf einen religiösen Besitz der Erlösung zurückblickenden und die Welt relativ akzeptierenden Missionsglauben der Apostel und vor allem des Paulus entspricht. Die von Wrede aufgedeckte Differenz zwischen Paulus und Jesus (Paulus I905, dem ich übrigens nicht in allem zustimme) erweist sich auch nach dieser Seite hin als der Ursprung geteilter Motive, die durch die ganze Geschichte des Christentums bewußt und unbewußt als getrennte hindurchgehen. Als biblische Begründung für den Vorzug des Kirchentypus weiß auch 
die Sekte immer stärker neben der Kirche hervortritt, als für die ganze bisherige Entwicklung der Kirche, die in den ersten Jahrhunderten selbst noch vielfach zwischen Sekte und Kirche geschwankt und erst mit der Ausbildung der Priester- und Sakramentslehre, den Typus der Kirche vollendet hat, die eben deshalb auf ihrem Entwickelungsgang bis zu diesen Jahrhunderten die Sekten nur in unbedeutendem Maße und in unklarer Unterscheidung neben sich gehabt hatte. Das erste deutliche Auftauchen des Problems bezeichnete der Gegensatz zwischen Augustins sakramental-hierarchischem Kirchenbegriff und den Donatisten. Aber mit dem afrikanischen Christentum erlosch auch dieser Gegensatz, und sein entscheidendes Hervortreten folgt erst auf die Vollendung des Kirchenbegriffes in der gregorianischen Kirchenreform.

Irreführend ist dabei der Ausdruck »Sekten «. Das Wort ist ursprünglich polemisch und apologetisch gemeint und bezeichnet solche von der offiziellen Kirche abweichende Gruppen, die gewisse Grundelemente der christlichen Idee festhaiten, die aber durch ihre Herausstellung aus der kirchlichen Kontinuität und Gemeinsamkeit - die übrigens meistens gar keine freiwillige ist sich als minderwertige Nebenbildungen, Einseitigkeiten, Uebertreibungen oder Verkürzungen des kirchlichen Christentums erweisen. Das ist natürlich lediglich eine Betrachtung vom Standpunkt der herrschenden Kirchen, von der Voraussetzung der Alleinberechtigung des kirchlichen Typus, aus; das moderne Staatskirchenrecht bezeichnet als Sekten geradezu diejenigen religiösen Gruppen, welche neben den offiziellen, öffentlich-rechtlich privilegierten Staatskirchen gar nicht oder nur mit minderem Rechte anerkannt und privilegiert sind. Eine solche Auffassung aber verwirrt den wirklichen Tatbestand. In den sogenannten Sekten kommen oft genug gerade erst wesentliche Triebe des Evangeliums zu ihrer Auswirkung, wie sie sich denn stets auch auf das

Gottschick nichts anzuführen als »die Tatsache, daß im N.T. der christliche Charakter der Familie über die bewußte Christlichkeit ihrer einzelnen Glieder übergreift, I Kor. 7 14, und daß auch Christus wie Paulus ihre Arbeit bezw. ihre Hoffnung auf die Bekehrung von Israel als Volk richten «. O. 233. Der erstere Punkt ist allerdings wichtig, aber er gehört dem Paulinismus an, und an der Frage der Kindertaufe hat sich dann auch charakteristisch Kirchen- und Sektentypus geschieden oder seine Kompromisse geschlossen. Das zweite ist gerade nicht als Kirche, sondern als eschatologische Tat Gottes gedacht. 
Evangelium und das Urchristentum berufen und die Kirche als abgefallen bezeichnen; es sind stets Triebe, die in den offiziellen Kirchen unterdrückt oder unentwickelt geblieben sind, natürlich aus guten und charakteristischen Gründen, die dann wieder von der leidenschaftlichen Parteipolemik der Sekten nicht gewürdigt werden. Aber an der Tatsache kann kein Zweifel sein, daß die Sekten bei ihrer größeren Unabhängigkeit von der Welt, ihrer beständigen Geltendmachung der Anfangsideale oft geradezu besonders charakteristisch sind für wesentliche Grundideen des Christentums; sie sind es in ganz besonderem Maße für die Entfaltung der soziologischen Folgerungen aus der christlichen Idee.

Das zeigt jedes tiefere Studium gerade der das Spätmittelalter erfüllenden und an ihrem Teil zu seiner Auflösung beitragenden Sektenbewegungen. Die großen Schutzschriften für die Sekten, die dann später Sebastian Frank und vor allem Gottfried Arnold geschrieben haben, verbreiten darüber die vollste Klarheit.

Der Hauptzug der christlichen Entwickelung folgt begreiflicher Weise bei seinem Trieb auf Geltendmachung eines universalen alles beherrschenden Ideales, bei dem Bedürfnis, große Massen zu beherrschen und darum die Welt und die Kultur zu bewältigen, dem Typus der Kirche. Hierin ist schon trotz seiner stark individualistischen und enthusiastischen Züge der Paulinismus vorangegangen, in dem er die Welt für den Herrn erobern wollte, mit der staatlichen Ordnung sich als einer göttlichen Ordnung und Zulassung abfand, die Berufe und Lebensformen bestehen ließ und nur die Einigung in dem Besitz der Gnadenkräfte des Leibes Christi verlangte, die durch den Geist dann das neue Leben von selbst und von innen heraus wirken und damit das baldige Kommen des Gottesreiches als des eigentlichen universalen Abschlusses vorbereiten sollten. Jemehr die Christenheit auf diese supranaturale und eschatologische Vollendung ihres Universalismus verzichtete und seine Herbeiführung selbst durch Mission und Organisation in die Hand nahm, um so mehr war sie genötigt, ihre Göttlichkeit und Christlichkeit von der subjektiven Beschaffenheit und Leistung der Giäubigen unabhängig zu machen und sie in ihrem objektiven Besitz an religiösen Wahrheiten und religiösen Kräften zu konzentrieren, welche letzteren in der Ueberlieferung von Christus und in der alles durchdringenden erfüllenden göttlichen Leitung der Gemeinde lagen. Von diesen objektiven Grundlagen aus konnten die sub- 
jektiven Kräfte immer neu wieder ausströmen und erneuernd wirken, aber jene fielen nicht zusammen mit diesen Wirkungen. Nur so war eine Massenkirche möglich, und nur so war die von einer solchen geforderten relative Anerkennung von Welt, Staat, Gesellschaft und gegebener Kultur keine Beeinträchtigung der Grundlagen. Die Göttlichkeit der Kirche blieb erhalten in ihren objektiven Grundlagen und brach aus ihnen immer neu hervor. Es galt nur diese in Tradition, Priestertum und Sakrament möglichst zu objektivieren, den soziologischen Beziehungspunkt objektiv in ihnen sicher zu stellen, und man stellte dann damit auch seine subjektive, nur im einzelnen nicht kontrollierbare Wirkung sicher. So war die religiöse Grundgesinnung, etwas göttlich Geschenktes und Erlösendes zu besitzen, gesichert und war zugleich die universalistische Tendenz zu ihrer Wirkung gebracht, indem sie vor allem das Gnadeninstitut der Kirche aufrichtete und zur Herrschaft emporhob. Sie mochte dann unter Nachhilfe des Bußinstitutes und der kirchlichen Seelenleitung, des Ketzerrechtes und der Glaubensüberwachung auch die innere Herrschaft gewinnen. Unter diesen Umständen war dann aber auch der Kompromiß mit den Staatsgewalten, der gesellschaftlichen Ordnung, den ökonomischen Lebensbedingungen unausweichlich, wie ihn die thomistische Lehre in einem feinsinnigen, umfassenden und die letzte überweltliche Lebensorientierung energisch festhaltenden Aufbau theoretisch konstruiert hat. Das Ganze liegt dabei in der Konsequenz des Evangeliums, sobald man das Evangelium als die Stiftung eines universalen, alle erlösenden Lebenszusammenhanges auffaßt, der zum Ausgangspunkt seiner Wirkungen die vom Evangelium geschenkte Erkenntnis und deren kirchliche Sicherstellung hat. Gerade die Herausarbeitung eines objektiven, soziologischen Beziehungspunktes, seinè Sicherstellung und das Streben, von ihm aus eine universale Weltgewinnung zu organisieren, führte zu dieser Entwickelung. Aber es ist ebenso offenkundig, daß damit der radikale, auf persönlichste Leistung dringende Individualismus des Evangeliums, seine radikale, alle im persönlichsten Lebenszentrum verknüpfende Liebesgemeinschaft, seine heroische Unbekümmertheit um Welt, Staat und Kultur, sein Mißtrauen gegen die zerstreuende und ablenkende Seelengefährlichkeit eines starken Besitzes und Besitzstrebens zurückgestellt oder auch gar verlassen sind, daß3 diese Züge nur als Momente im System, aber nicht als beherrschende Grundsätze mehr erscheinen. 


\section{3,0 \\ II. Mittelalterl. Katholizismus. 9. Das absolute Gesetz und die Sekten.}

1)ie Sikte n dagegen entwickeln nun gerade diese Seite des Evangeliums weiter oder machen sie vielmehr stets von neuem gelt'nd. Das I aienchristentum, die persönliche ethisch-religiöse Leistung, die radikale I iebesgemeinschaft, die religiöse Gleichheit und Brüderlichkeit, die Indifferenz gegen staatliche Gewalt und herrschende Schichten, die Abneigung gegen das technische Recht und den Eid, die Lösung des religiösen Lebens von den Sorgen des ökonomischen Kampfes im Armuts- und Genügsamkeitsideal oder in einer grelegentlich zum Kommunismus übergehenden Iiebestätigkcit, die Unmittelbarkeit des persönlichen religiösen Verhältnisse's, die Kritik an den offiziellen Seelenführern und Theologen, dic Berufung auf das Neue Testament und die Urkirche: das sind durchgängig ihre charaliteristischen Züge. Der soziologische Bezichungspunkt, von dem aus sich hier die Gemeinschaft bildet, ist ein anderer als der der Kirchenbildung zu Grunde liegende. Sctzt diese die objektive dingliche Heiligkeit vom Priesteramt, Succession, l)epositum fidei und Sakrament voraus, bezieht sie sich auf die dauernde im Priestertum stattfindende Inkarnation d's (iöttlichen, so bezieht sich die Sekte auf die immer neue gemucinsame Leistung der sittlichen Forderungen, denen als Objektives nur Gesetz und Vorbild Christi zu Grunde liegt. Und es ist unverkennbar, daß sie damit geradezu an die Predigt Jesu anknüpfen. Lamit verbunden ist daher bewußt oder instinktiv eine andere Stellung zur christlichen Lrgeschichte und eine andere Fassung des Chrintusdogmas. Bibel- und Urgeschichte sind die bleibenden, wörtlic h zu virstehenden Ideale, nicht ein geschichtlich bedingter und berrenzter Ausgangspunkt der Kirchenentwickelung. Christus ist nicht der in der Kirche fortwirkende, in die volle Wahrheit leitende Gottmensch, sondern der durch sein biblisches Gesetz die Gemeinde verpflichtende, unmittelbar herrschende Herr der Gemeinde. Entwickelung und Kompromiß auf der einen Seite, wörtliches Festhalten und Radikalismus auf der andern. Daher aher rührt dann auch die Lnmöglichkeit sroßer Massenorganisationen und die Beschränkung auf kleine persönlich verbundene Kreise, die Notwendigkeit immer neuer Einsetzung des Ideals und dic Schwäche der Kontinuität, der stark individualistische Charakter und die Wahlverwandtschaft mit allen gedrückten und aufstrebenden Unterschichten. Es sind zugleich die Kreise, in denen mit dem heißen Wunsch einer Besserung ihrer Lage die ganze Unkenntnis der verwickelten Lebensbedingungen zu Hause ist und daher eine 
gläubige Ideologie leicht auf eine Umgestaltung der Welt nach rein moralischen Liebesprinzipien hoffen kann. Die Sekten gewinnen so an Intensität des christlichen Lebens; aber sie verlieren an Universalismus, indem sie die Kirche als abgefallen bezeichnen müssen und menschlicher Kraft die Welteroberung nicht möglich glauben, weshalb sie auch immer zu eschatologischen Erwartungen getrieben werden. Sie gewinnen an individueller persönlicher Christlichkeit und bleiben näher an dem radikalen Individualismus des Evangeliums, aber sie verlieren an Unbefangenheit und dankbarer Hingebung an die göttliche Gnadenoffenbarung, betrachten das Neue Testament als das Gesetz Gottes, neigen mit der Aktivität des persönlichen Liebesverbandes zur Gesetzlichkeit und Betonung der Werke. Sie gewinnen an spezifischer Christlichkeit, aber sie verlieren an geistiger Weite und Aneignungsfähigkeit und revidieren so den ganzen ungeheuren Aneignungsprozeß, den die Kirche vollzogen hat und bei ihrer Sicherstellung der Christlichkeit in objektiven Grundlagen auch hatte vollziehen können. Die Kirche betont und objektiviert den Gedanken der Gnade, die Sekte betont und verwirklicht den der subjektiven Heiligkeit. Die Kirche hält sich in der Bibel an die erlösende Stiftung, die Sekte an das Gesetz Gottes und Christi.

Indem das die soziologischen Züge der Sekten fast durchgängig sind - von den rein dogmatisch begründeten Sondergruppen ist hier nicht die Rede, sie sind übrigens selten und auch die pantheistisch-philosophischen Sekten des Mittelalters laufen fast ununterscheidbar in die Sekte im praktisch-religiösen Sinne über hat ihre Sonderbezeichnung gegenüber den Kirchen doch ihren guten sachlichen Grund ${ }^{165}$ ). Sie sind in der Tat etwas anderes als die Kirche und die Kirchen. Nur bedeutet der Ausdruck »Sekte « nicht ein Werturteil über Verkümmerungen des Kirchlichen, sondern einen selbständigen soziologischen Typus der christlichen Idee. Das Wesen der Kirche ist der objektive a $n$ staltliche Charakter. In sie wird man hineingeboren, und durch die Kindertaufe tritt man in den Bereich ihres Wunderkreises. Das Priestertum und die Hierarchie als Inhaberin der Tradition, der Sakramentalgnade und der Jurisdiktion stellt auch

105) Ueber den prinzipiellen Sondercharakter der mittelalterlichen Sekten gegenüber den bloß dogmatisch bedingten Häresien des Altertums siehe Lechlcr I 42. Es ist der Charakter des $*$ Vereins $*$ S. 54 . Ueber den Donatismus als I'rtypus alles Sektentums s. Kawerau a. a. O. 
bei zufällisrer persönlicher Lnwürdigkeit des Priesters den objektiren Gnadenschatz dar, der nur stets auf den Leuchter gestellt werden und in den Sakramenten zur Wirkung gebracht werden muls, um scine Wirkungen vermöge der der Kirche eignenden Nunderkraft zu tun. Es ist die Permanenz des Gottmenschen, die V'erlängcrung der Menschwerdung, die objektive Organisation der IVunderkraft, von der vermöge göttlicher Weltregierung und Vorschung die subjektiven Wirkungen von selbst als Folge ausgehen. Von hier aus ist der Kompromiß mit der Welt und die Anknüpfung an die aus ihr entgegenkommenden Vorstufen und Jispositionen möglich; denn bei aller Unzulänglichkeit der Personen bleibt dic Heiligkeit und Göttlichkeit der Anstalt, und sie hat die Vuheißung, durch die ihr innewohnende Wunderkraft die Welt zu überwinden. Nit diesem Kompromiß wird aber auch erst der Lnirersalismus möglich; er ist eine tatsächliche Herrschaft des Instituts als solchen und eine gläubige Zuversicht zu sciner unwiderstehlichen inneren Wirkungskraft. Das persönliche Machon und Ieeisten ist, so sehr es gelegentlich betont wird und bis zu strenger liesetzlichkeit gehen mag, doch nur sekundär; die Ilauptsache ist der objektive Besitz und seine universal ancrkannte Herrschaft; vom übricren heißt es : et cetera adjicientur robis. lis kommt wesentlich darauf an, daß alle Individuen der Mäglichkeit der Kinwirkung dieser Heilskräfte unterstellt werden; daher ist die Kirche genötigt zur Herrschaft über die Gesellschaft und zur \%wangsunterwerfung aller Gesellschaftsglieder unter ihren Finflußbcreich; aber sie bleibt in ihrem Bestand doch wieder sanz unabhängig davon, ob diese Wirkung an allen Individuen auch wirklich erreicht wird oder nicht. Sie ist die große Erzieherin der Völker, dic wie alle Erzicher Stufen- und Reifeunterschiede zu machen versteht und ihr Zicl nur durch Anpassung und Konnivenz erreicht. Diesem anstaltlichen Prinzip des objektiven ()rganismus gegrnüber ist nun aber die Sekte die Gemeinschaft der Freiw illigkeit und des bewußten Anschlusses. Nlles hängt lither dann auch an wirklicher persönlicher Lcistun und Beteiligung; jeder hat inteil an der Gemeinschaft als selbständiges Glied; die Vérbundenhcit ist nicht cine durch den gemeinsamen Besitz vermittelte, sondern eine in persönlicher Lebensbeziehung unmittelbar verwirklichte. In die Sekte wird man nicht hincinscboren, sondern ihr tritt man auf Grund bewußter Bekehrungs bci; die in der Tat ja auch später aufgekommene 
Kindertaufe bildet für sie fast stets einen Anstoß. In der Sckte wird man gut und fromm nicht durch objektive Sakramentsversittlichung, sondern durch persönlichste Leistung; ihre Kritik wendet sich daher früher oder später stets gegen den Sakramentsbegriff. Das ist nicht eine Lockerung der Gemeinschaft durch den Individualismus, vielmehr eine Befestigung, indem jedes Individuum gerade durch Gemeinschaftsleistungen sich als berechtigt erweist. Aber es ist eine naturgemäß engere Begrenzung der Gemeinschaft, und bei der Aufzehrung aller Arbeit in der Behauptung und Betätigung gerade dieser Gemeinschaft eine Indifferenzierung gegen andere Gemeinschaftsformen, die aus weltlichem Interesse entspringen; und es ist umgekehrt wiederum ein Hereinziehen aller weltlichen Interessen in den engen Rahmen und die Maßstäbe des eigenen Bereiches, soweit er sie überhaupt in sich aufzunehmen vermag. Was aber nicht in diesen Interessenkreis der Sekte und in das biblische Ideal einzubeziehen ist, das wird verworfen und gemieden. Die Sekte erzieht daher nicht Völker und Massen, sondern sammclt dic Elite der Berufenen und stellt sie der Welt schroff gegenüber. Soferne sie don christlichên Universalismus behauptet, kennt sie ihn wie das Evangelium nur in eschatologischer Gestalt, weshalb sie überall schließlich die biblische Eschatologie neubelebt. Dabei versteht sich dann die größere Neigung der Sekte zu "asketischem " I.eben und Denken von selbst, auch wenn nicht das Urbild des Neuen Testaments darauf hinwiese. Die Abschließung der Gemeinschaft und die Betätigung des Individuums liegt gerade in der praktischen Strenge einer lediglich religiös und nicht vom Kulturinteresse her beeinflußten Lebenshaltung. Das ist dann aber auch eine andere Art von Askese, und von hier aus erklärt sich der oben schon konstatierte Unterschied gegen die kirchliche Idee der Askese. Sie ist nicht heroische, ihrem Wesen nach auf Einzelfälle sich beschränkende Sonderleistung eines besonderen Standes und Mortifikation der Sinnlichkeit im Interesse einer Unterstützung des höheren religiösen Aufschwungs, sondern einfach im alten biblischen Sinne Zurückhaltung von der Welt, Herabsetzung des weltlichen Genusses auf ein Mindestmaß und äußerste Anspannung der Liebesgemeinschaft. Wie der Sektentypus in der Predigt Jesu wurzelt, so ist seine Askese auch die des Urchristentums und der Bergpredigt, nicht die der Kirche und der Kontemplation, enger und ängstlicher als Jesu Anweisung, aber beim wörtlichen Verstand doch eben die Fortsetzung der Haltung Jesu gegen die Welt. Die Konzentration auf 


\section{11. Mittelalterl. Katholizismus. 4. Das absolute Gesetz und die Sekten.}

dic persönliche Leistung und dic soziologische Bezichung auf ein praktisches Ideal fordert die äußerste Strenge des Anspruchs an dic Leristungen und die Zurückhaltung ron andersartigen Verbänden. lis ist nicht die Popularisierung und Universalisierung eines ron der Kirche nur besonderen Ständen und Verhältnissen vorbehaltenen Ideals. Das kirchliche Ideal der Askese läßt sich gar nicht als universale Moral vorstellen, sondern hat scin Wesen am Absonderlichen und Heroischen. Das asketische Ideal der Sekte lagessen ist selbstverständlich cin allen mögliches und für alle bestimmtes Ideal, das seinem Begriff nach gerade die Gemeinschaft verbindet statt sie zu sprengen und seinem Inhalt nach auch einer allgemeinen Verwirklichung fähig ist, soweit der Kreis der Berufenen in Betracht kommt ${ }^{165 a}$ ). -...

165 a) C'm der Askese willen ist es bei einer großen (iruppe protestantischer Forscher üblich, die Seliten als etwas spezifisch Katholisches zu bezeichnen, obwohl sie doch gerade das Zentrum des Katholizismus, Hierarchie, Priestertum, Sakrament und Objektivität der Gnade, durchbrechen. Das geschieht bei denjenigen Forschern, die in der Schule Ritschls als das Wesen des Katholizismus die weltfeindliche Askese, - das münchische Vollkommenheitsideal , haben betrachten lernen und meinen, daß der Katholizismus nur aus Inkonsequenz und wegen äußerer Unmöglichkeit dieses Ideal nicht für alle durchgeführt habe, während die sitkten es für alle durchführen. Das steht bei diesen Theologen in engem Zusammenhang mit ihrer Auffassung des Neuen Testaments und des Protestantismus, wonach das erstere in seiner Idee des Gottesreiches einen ethisch-religiösen Verband gottvertrauender, in der Bruderliebe die Welt beherrschender Cläubiger, und der letztere die Wiederbeseitigung der Askese und die Rückkehr zu einem berufsfreudigen weltbejahenden Christentum bedeute, darin seinen Linklan! mil der modemen Wclt bezeugend. So sagt Brieger (-Die Reformation* in Clinkins Weltgeschichte $\therefore$. IgS) von den mittelalterlichen Sekten: Nur eine winzige Minderheit somlerte sich ab, etwa weil die Wärme ihres religiösen Gefühls anf kalte Satzungen stick, ihr sittlicher Ermet verletzt wurde, man setute sich zuriick uach der (jemcinde des aputolischen Zeitalters, von welcher die Papstirche mit ihren weltichen Zicien himmelweit abstand. Allein auch diese Abtrünnigen blieben in iluren seligiö̈sen Grundanschauungen in Uebcreinstimmung mit der Kirche. [Me sckten des ...1. tragen, su mannigfach diese Absplitterungen auch sein mögen. oline Ausnahme das liepräge den Katholizismus der Zeit. Sie gehüren ihm an, sind seine (iebilde. Nur auf diesem (irund und Boden konnten sie erwachen; mehr nuh, überanl läßs sich in den wilden Senkreisern das Cewebe

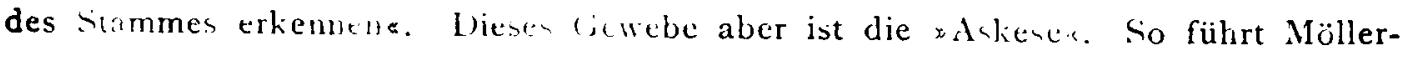
Kawerau, K.-li. III, die Täule und Sekten des Reformalionszeitalters auf den Katholizismus zurück wegen Astese und Gesetzlichkeit. So hat vor allem Ritschl die zweite grolie Sektenbewegung des Protestantismus, den Pietismus, als Einschleppung fremder katholischer Maßstäbe erklärt. Allein diese ganze Konstruk- 
So sind es in der Tat zwei verschiedene soziologische Typen, wobei es gleichgültig ist, daß sie in Wirklichkeit gelegentlich in einander übergehen. Will man dafür nicht die Ausdrücke "Kirche « und -Sekte \& gebrauchen, sondern bezeichnet man, was an sich eine zweckmäßige Terminologie ist ${ }^{165}$ ), alle aus monotheistisch-universalistisch-religiösen Motiven hervorgehenden soziologischen Bildungen als Kirchen, so müßte man Anstaltskirchen und Freiwilligkeitskirchen unterscheiden. Der Ausdruck ist Nebensache. Die Hauptsache ist, daß beide Typen in der Konsequenz des Evangeliums liegen und erstzusammenden Umkreis seiner soziologischen Wirkungen und damit a uch indirekt seinersozialen, stets an die religiöse Organisation anknüpfenden Konsequenzen erschöpfen. Die Kirche ist in der Tat nicht ein einfacher Abfall vom Evangelium, so sehr das zunächst bei dem Gegensatz von Hierarchie und Sakrament gegen die Predigt Jesu so scheincn mag. Wo nämlich das Evangelium in erster Linie als Gaje, Geschenk und Gnade empfunden wird und in dem Glaubensbilde des Christus als eine göttliche Stiftung sich darstellt, wo die innerliche

tion ist grundfalsch. Bezüglich des Katholizismus glaube ich im bisherigen gezeigt zu haben, daß gerade nicht die Askese, sondern die Vereinigung von Askese und Weltleben und die Möglichkeit, beide in dem Stufenbau der Gnadenanstalt zu kombinieren, für ihn charakteristisch ist. Daß die Wurzeln der »Askesex schon im N. T. liegen, ist heute allgemein anerkannt in engem 7,usammonhang mit der Erkenntnis des eschatologischen Charakters des N.T.S. Sic haben auch Luther genug zu schaffen gemacht, von dem Brieger an diesem Punkt urteilt, daß er das N. T. nicht in historischem Sinne, d. h. in seiner gesinnungsmäßigen Freiheit und Weltfreundlichkeit zu lesen verstanden habe, sondern zu Unrecht wörtlich genommen habe! Das alles zeigt aler, daß im m.a.lichen, reformatoriscitäuferischen und pietistischen Sektentum nicht katholische, sondern biblische Elemente wirken, die neben den andersartigen auf Kirche. Objektivität der Gnide und konservative Weltanpassung hinwirkenden Elementen des. ‥ T. eine eigene Tendenz und Geschichte haben. Es ist der Sektentypus, der überall als Komplementärbewegung neben dem Kirchentypus hergeht und überall in dem Maße durchbricht, als man sich an die synoptischen und enthusiastischen Partieen des $\mathrm{N}$. T. hält. Dabei ist auch die Vieldeutigkeit des Wortes "Askese "übersehen, von der bereits früher die Rede war.

165 b) $S$, meine Abhandlung, Religion und Kirche, I'reuß. Jahrb. 1895. Es wäre eine interessante Frage, wie weit die monotheistisch-universalen nichtchristlichen Organisationen oder Kirchen ähnliche Differenzen in ihrem Schoße tragen. Es ist zu vermuten, daß z. B. beim Islam ähnliche Differenzen sich finden. 


\section{3, 7 II. Mittelalterl. Katholizismus. 9. Das absolute Gesetz und die Sekten.}

Freih 'it des Geistes im ('nterschied von allem menschlichen Machen und (rsinisieren als der Sinn Jesu erlebt und die großartige Unbekümmerth it um weltliche Dinge auch im Sinne einer geistigen und innerlichen Unabhängigkeit bei äußerem Gebrauch derselben gefühlt wird, da wird man die Anstalt der Kirche als die naturgemäfie Fortsetzung und Umwandlung des Evangeliums betrachten. . Zugleich enthält sie mit ihrem unbedingten Universalismus doch den Grundtrieb der evangelischen Predigt, nur daß diese alle Einzelfragen der Möglichkeit und Durchführung dem wunderbaren Kommen des Reiches überlassen hatte, während eine in der IVeltdauer arbeitende Kirche hier selbst organisieren und ordnen und dabei ihre Kompromisse schließen mußte. Andrerseits ist aber auch die Sekte nicht eine bloße Vereinseitigung kirchlicher Lebenselemente, sondern eine unmittelbare Fortsetzung des evangelischen Gedankens. Der radikale Individualismus und Liebesgedanke kommt nur in ihr zu seiner vollen Geltung, nur sie konstruiert instinktiv die Gemeinschaft von ihm aus und erreicht gerade durch ihn eine ungeheure Festigkeit der subjektiv-innerlichen Verbindung an Stelle der bloßen äußeren Anstaltszugehörigkeit. Sie hält eben damit auch am ursprünglichen Radikalismus des Ideals und seinem Weltgegensatz fest und bleibt bei der Grundforderung persönlicher Leistung, die ja auch sie als Werk der Gnade empfinden kann: aber sie betont an der Gnade die subjektive Verwirklichung und Auswirkung und nicht die objektive Versichertheit und Gesenwart. Sie lebt nicht von dem Wunder der Vergangenheit und nicht ron dem Wundercharakter der Anstalt, sondern von dem immer neuen Gegenwartswunder und der subjektiven Wirklichkeit der persönlichen Lebensleistung. Die Kirche geht aus von der apostolischen Verkündigung des himmlischen Christus und dem Glauben an den Erlöser-Christus, in len das Evangelium sich umgesetzt hat, und sie hat darin den objektiven Schatz, den sie in ihrem sakramental-priesterlichen Aufbau immer weiter objektiviert. Insoferne geht die Kirche schon auf den Paulinismus zurück, der ja auch schon die Wurzeln des Sakramentsgedankens zeigt, aber freilich in dem pneumatischen Enthusiasmus und in dem Dringen auf persönliche Heiligkeit der neuen Kreatur sehr unkirchliche Elemente enthïlt. Die Sekte dagegen geht aus von der Predigt Jesu und desn Vorbild Jesu, von der subjektiven Leistung der Apostel und dem Nuster ihres armen Lebens, und schließt den vom Evangelium gepredigten religiösen Individualismus zusammen zur religiösen Ge- 
nossenschaft, in der das Amt nicht auf Weihe und Tradition, sondern auf religiöser Leistung und Kraft beruht und daher auch völlig den Laien anheimfallen kann. Die Kirche verwaltet die Sakramente unabhängig von der Würdigkeit der Priester, die Sekte mißtraut den kirchlichen Sakramenten, läßt sie durch Laien vollziehen oder macht sie abhängig von der religiösen Würdigkeit der Spendenden oder beseitigt sie ganz; ihr Individualismus drängt nach unmittelbarem Verkehr des Individuums mit Gott und ersetzt daher oft genug die kirchliche Sakramentslehre wieder durch die urchristliche Lehre vom Geist und Enthusiasmus. Die Kirche hat Priester und Sakrament, beherrscht die Welt und wird von der Welt darum mitbeherrscht; die Sekte ist Laienchristentum, unabhängig von der Welt und darum geneigt zur Askese und zur Mystik. Beides ist in den Grundtrieben des Evangeliums begründet. Es enthält den Gedanken eines objektiven Heilbesitzes in der Gotteserkenntnis und Gottesoffenbarung, und in der Ausgestaltung dieses Gedankens wird es zur Kirche. Es enthält aber auch den Gedanken der absolut persönlichen Religion und der absolut persönlichen Gemeinschaft, und in dessen Verfolgung wird es zur Sekte. Die Predigt Jesu, die vorwärts blickt auf das kommende Ende und das Reich, die entschlossene Bekenner sammelt und vereinigt, die der Welt und deren Kindern die schroffste Absage erteilt, geht in der letzteren Richtung. Der apostolische Glaube, der zurückblickt auf ein Wunder der Erlösung und der Person Jesu und in den Kräften seines himmlischen Herrn lebt, der etwas Fertiges und Objektives hinter sich hat, in dem er seine Gläubigen zusammenschließt und ausruhen läßt, geht dann in der ersten Richtung. Das Neue Testament wirkt sowohl kirchenbildend als sektenbildend. Es hat das von Anfang an getan. Aber die Kirche hatte den Vorsprung und die große Weltmission. Erst mit der strengsten Vollendung der Objektivierung in der Kirche reagierte gegen dieses Uebermaß der Objektivierung wieder die sektenbildende Tendenz. Und wie die erste sich vollzog im Zusammenhang mit der feudalen Gesellschaft des Frühmittelalters, so steht die letztere im Zusammenhang mit dem sozialen Umschwung und den Neubildungen der städtischen Kultur im Hoch- und Spätmittelalter, mit der Subjektivierung und Ansammlung der Massen in den Städten selbst und den Rückwirkungen dieser Städtebildung auf Landbevölkerung und Aristokratie.

Von alledem aus versteht sich weiterhin auch das verschie- 
dene Verhalten des Kirchen- und des Sektentypus zu dem $\mathrm{n}$ aturrechtlichen Gedankenkreise, der ja längst mit dem biblischen zu einer für das christliche Gefühl selbstverständlichen Finheit zusammengeschmolzen war. Die Kirche beweist die Rationalität und Allgemeingültigkeit ihres Sittengesetzes durch die Zurückführung auf das sittliche Naturgesetz, wie es in seiner Vollkommenheit am Schöpfungsmorgen der Menschheit bestanden hatte, und sie überhöht es in der Kirche nur durch die besondere Sittlichkeit, die aus der Begabung mit der sakramentalen Gnade der Uebernatur folgt. Aber das hat nur theoretisch-apologetische Bedeutung. Praktisch kann sie jenes Natur- und Gottesgesetz nicht durchführen, da es die allgemeine brüderliche Gleichheit, die Abwesenheit von Staat, Besitz, Recht und Zwang mit sich bringt. In der Welt der Sünde ist dieses Gesetz nicht möglich und würde eine Fassung des christlichen Gesetzes in diesem radikalen Sinne die Kirche zur Einflußlosigkeit verurteilen oder zur Revolution nötigen. So entschließt sich die Kirche zu einer Relativierung dieses absoluten Natur- und Gottesgesetzes, es ist im Sündenstande verwandelt in das relative Naturgesetz der staatlichen und gesellschaftlichen Ordnung, deren Macht-, Rechts- und Zwangscharakter zugleich eine Strafe, aber auch eine Heilung und Zügelung der Sünde ist. Auf dieses relative Naturgesetz aber kann dann die weltbeherrschende Erlösungsanstalt sich einrichten, indem sie seine Bildungen als Vor- und Unterstufe sich einordnet und mit der kirchlichen Zentralautorität einheitlich beherrscht. Die dabei unausbleiblichen Unvollkommenheiten sind Folge des Sündenstandes und werden durch die der Kirche verliehene Macht der Sündenvergebung getilgt, durch die von dem besonderen Stand der Asketen erworbenen Verdienste gedeckt. Ja, auf der Höhe der wissenschaftlichen Theologie und Ethik hat die Kirche die weltichen Sozialordnungen schon in das absolute Naturgesetz selbst als Konsequenz hineinverlegt und dem Sündenfall nur die Verwandlung in das schmerzenreiche Gewalt- und Zwangswesen zugeschrieben, so daß Staat, Gesellschaft und Besitz nun geradezu als von Gottes und Natur wegen vollberechtigt erscheinen. Demgegenüber nehmen nun die Sekten eine ganz andere Stellung zu dem Naturrecht ein. Sie halten sich nicht an die gelehrten patristischen und aristotelischen Untersuchungen über das Gottesgesetz, sondern an das klare Gesetz Christi oder der Bergpredigt. Lnd, wenn sie das Bedürfnis empfinden, diesem Gottesgesetz eine 
rationelle und allgemeingültige Begründung zu geben, da greifen sie lediglich auf das mit ihm identische Naturgesetz des Urstandes zurück, auf das reine Gesetz einer unverdorbenen Natur ohne Gewalt, Recht, Krieg, Macht, Eid und Privateigentum. Sie verwerfen den Kompromiß mit der Welt und darum das relative Naturgesetz. Sie wissen nichts von dem Stufenbau der Gesellschaft und des Universums mit seinen Uebergängen und Relativitäten; sie kennen nur absolute Gegensätze. Durch die Berufung auf das absolute und reine Naturgesetz geben sie aber ihrem Biblizismus dann doch eine verstärkte Betonung, eine einleuchtende Begründung und ein leidenschaftliches Pathos. Dabei sind noch mancherlei Unterschiede innerhalb der Fassung dieses absoluten Naturrechtes möglich. Es kann die Ungleichheit der Menschen einschließen an Stellung, Beruf, Einfluß, Besitz und die Ungleichheiten nur in der Liebe, in einem alles für das Ganze verwendenden Liebeskommunismus auslöschen. Es kann aber auch die Gleichheit und Gleichberechtigung aller Individuen bedeuten und dann zu demokratisch-kommunistischen Ideen führen. So oder so steht das neutestamentliche Gottesgesetz und absolute Naturrecht im Gegensatz gegen die bestehenden Verhältnisse. Je mehr dann aber nicht bloß die Gottwidrigkeit, sondern auch die Naturwidrigkeit dieser Verhältnisse betont wird, um so näher wird der Antrieb liegen zum Eingriff in sie, zur Reform, zur Besserung, zur Neubildung. Dafür gibt es dann freilich vcrschiedene Wege. Es gibt die reine Zurückziehung von der Welt und die Verwirklichung des Ideals in leidenden und duldenden, aber das Gottesgesetz haltenden Kreisen. Es gibt die friedliche und geordnete Reform, dic die staatlichen und kirchlichen Gewalten zur möglichsten Annäherung der wirklichen Verhältnisse an das Ideal veranlassen will, die Kirche im Sinne des Armutsideals und den Staat im Sinne des Friedensideals, oder die beim Versagen der Kirche den Laien und Obrigkeiten den Auftrag gibt, diese Reformen zu erzwingen. I)a es leichter ist, dic Kirche von dicsem Ideal aus zu reformieren als den Staat, und man zur Kirchenreform obendrein der staatlichen Hilfe bedarf, so richtet sich diese Reform nach dem absoluten Naturrecht und dem biblischen Gottesgesetz mit Vorliche gegen die Kirche und wird zur Kirchenrevolution. Wo aber der Gedanke sich auch gegen dic widernatürlichen und widergöttlichen Verhältnisse in Staat und Gesellschaft richtet, da wird er zur demokratisch-sozialistischen Revolution, 
380 II. Mittelalterl. Katholizismus. 9. Das absolute Gesetz und die Sekten.

die auch vor der (jewalt nicht zurückschreckt und dafür sich auf das Alte Testament und die Apokalypse beruft. Dabei stehen alle diese so oder so gearteten Gestaltungen des absoluten Naturrechtes in engem Zusammenhang mit allgemeinen sozialen oder auch politischen und nationalen Bewegungen. Bald ist es die gedrückte Lnterschicht, die sich sammeln will zu eigenem Dasein und zu persönlicher Anteilnahme an der Religion kommen will. Bald sind es nationalistische und staatsfreundliche Tendenzen, die wenigstens für die Kirche das Sektenideal durchsetzen und damit das Verhältnis zu einem nationalen Staat erleichtern wollen, damit in der Regel aber ihre naturrechtlichen Ideen auch auf den Staat abfärben lassen. Bald ist es die spätmittelalterliche soziale Revolution, die das Gottes- und Naturrecht für sich reklamiert und eine christliche Ordnung der Gesellschaft als Befriedigung ihrer Interessen mit Gewalt aufrichten will.

Diese Verdrängung des relativen Naturrechts durch das mit dem biblischen Gottesgesetz identische absolute Naturrecht enthält nun aber schließlich noch eine Reihe weiterer religiös und theologis ch bedeutsamerFolgen, die für den soziologischen Charakter des Sektentums und sein Verhältnis zum Kirchentum charakteristisch sind. Erstlich ist das Gottesgesetz nicht mehr in erster Linie reduziert auf den Dekalog. An seine Stelle tritt das neutestamentliche oder eigentlich christliche Gottesgesetz, das Gesetz Christi oder die Bergpredigt. Der Dekalog hatte sich mit dem relativen Naturgesetz leicht vereinigen lassen, und, indem das christliche Sittengesetz in der Hauptsache auf den Dekalog reduziert wurde, wurde es überhaupt auf das Niveau des Praktisch-NIöglichen und in der großen Masse Durchführbaren gesenkt. Das Besondere christliche Element kam dann nur zusatzweise in dem Ueberbau durch mystisch-kultische Forderungen und durch die evangelischen Räte zur Geltung. Demgegenüber ist das Gottesgesetz der Sekten auf das Spezifisch-Christliche gerichtet, freilich nicht sowohl auf die Gesinnungssethik der Bergpredigt als auf die dort gegebenen Beispiele und die vom Neuen Testament geforderten Bewährungen dieser Gesinnung. Das ergibt sicherlich eine Verengung des neutestamentlichen Gedankens, hält diesen aber doch in seiner charakteristischen Grundrichtung fest gegenüber den Ausweitungen durch die Kirche. Zweitens enthält die Einsetzung des absoluten Gottes- und Naturgesetzes in die alleinige Geltung die Beseitigung des ganzen Stufen- und 
Entwickelungsgedankens. Das wurde bereits berührt. Es bringt aber weitgreifende Folgen mit sich. Das ganze Bild der Welt und der Dinge wird dann ein anderes, worüber freilich die meist sehr schlichte Theologie der Sekten sich keine Rechenschaft gab. Gottes Verhältnis zur Welt wird viel einfacher und verständlicher. Sein Sinn und Gesetz ist völlig eindeutig in der Bibel und in der Stimme der reinen Natur ausgedrückt; es bedarf keiner verwickelten Gesetzeslehre. Die Forderung ergeht an alle gleich, und es bedarf keiner ständischen Abstufung der Vollkommenheit. Die Schöpfung geht nicht durch verschiedene Stufen herab bis zur Materialität, um dann wieder durch Stufen kunstvoll von der Natur zur Gnade und Uebernatur emporzusteigen. Sie stellt vielmehr die Welt einfach und unmittelbar vor die Aufgabe der Verwirklichung des Ideals, und dieses verliert den Charakter der mystischen Lebernatur mit ihrer Erhöhung der Essenz des Menschen über sich selbst. Von all diesen Dingen hört man in der Sektenliteratur nichts, und es muß unter diesem Einfluß geschehen sein, wenn im Spätmittelalter diese ganze. Idee des kosmischen Stufenganges zurücltritt, um einem unmittelbaren Verhältnis Gottes zur Kreatur Platz zu machen. Nicht wird dagegen hierdurch der Gedanke der berufsmäkigen Gliederung der Gesellschaft berührt. Diese versteht sich in diesen Kreisen, soferne sie nicht zum kommunistisch-demokratischen Sozialismus übergehen, von selbst. Ja, von Wiklif wird sie geradezu aufs stärkste betont. Seine Bibelübersetzung führt überhaupt das Wort Beruf in seiner heutigen

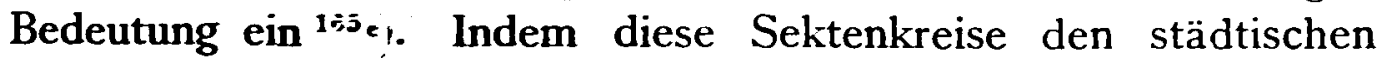
Unterschichten zumęst angehören, ist für sie Arbeits- und Berufsgliederung und die Arbeitsgesinnung selbstverständlich. Es ist nur die Eingliederung in den natürlich-übernatürlichen Stufenbau, die hier wegfällt. Damit hängt dann das dritte zusammen, die starke Betonung der Idee des Gesetzes. Der Katholizismus hatte für den Gottesbegriff die beiden großen Hauptbestimmungen der überendlichen, absoluten Wesenheit und des die Natur- und Geisteswelt reselnden Gesetzes. Beide Ideen waren in ihm nicht dialektisch ausgeglichen, aber sie lagen beide zusammen in beständiger Ergänzung und Abwechslung seinem Ideal der Menschheitsgesellschaft und der Gnadenwelt zugrunde, die Gottes natürliches und geoffenbartes Gesetz durch erlösende Gnadenkraft erfüllt und damit der mystischen Seligkeit der überendlichen Lebernatur teil-

165 c) S. Weber, Prot. Ethik, Archiv XX S. 40. 
haftig wird. Da nun die letztere Idee als Krönung des Stufenbaus für dic Sekten wegfällt und höchstens bei einigen Gruppen als Unmittelbarkcit des religiösen Verhältnisses übrig bleibt, rückt der Begriff des Gesetzes in die alles beherrschende Stellung. Gottes Wesen und Wille ist sein Natur- und Offenbarungsgesetz, die Bibel ist das Gesetzbuch der Offenbarung, das mit dem der Natur zusammenfällt. Einerseits äußert sich hierin die Gemeinsamkeit der bisherigen christlichen Ideenentwickelung, die für den Gottesbegriff eben nur die Verbindung jener beiden Begriffe erzeugt hatte und von der für die Sektentheologie instinktiv nur der zweite übrig blieb. Andrerseits aber ist es doch nur der Ausdruck für die Betonung der persönlichen Leistung und die Bedeutung des praktisch-sittlichen Gedankens. So wird an Stelle der Gnaden- und Erlösungsanstalt der Gesetzesbegriff zum Zentrum der Sektentheologie. Er gibt die wesentliche Wahrheit und den objektiven Rezichungspunkt dieser Gemeinschaften und färbt daher bei aller Beionung der Gnade, und etwa auch der Prädestination, doch den ganzen Zusammenhalt durch die Gesetzesstrenge.

Faßt man diese Hauptpunkte ins Auge, dann ergibt sich auch eine Schattierung der verschiedenen Erscheinungen, die bei einer ungenauen Handhabung des Ausdrucks "Sekte * vielfach unterschiedslos zusammengeworfen werden, weil sie sich überhaupt der kirchlichen Bindung entziehen. Die Sekte im eigentlichen Sinne ist ein wirkliches soziologisches Phänomen, ist eine Form strengster gemeinschaftlicher Bindung, nur eine Bindung anderer Art als die kirchliche Bindung. Unter ihren Begriff fallen daher an und für sich alle diejenigen Erscheinungen nicht, die überhaupt keine religiöse Gemeinschaftsbindung enthalten und höchstens durch Gleichartigkeit oder suggestive Ansteckung wechselnde Gruppierungen hervorbringen. So fallen unter ihren Begriff nicht die rein enthusiastischen und rein mystischen Phänomene, in denen die neuplatonischen Ingredienzen des mittelalterlichen Kirchentums oder auch völlig subjektive und spontane Erregungen hervortreten. Hier handelt es sich entweder um die rein individuelle unmittelbare Gottesgemeinschaft, die auf das innere Licht bcgründet ist und der Gemeinschaft an sich gar nicht bedarf, oder es handelt sich um epidemische Ansteckungen, die nur auf Uebertragung starker Affekte beruhen. Während die Sekten ihre Gemeinschaft in der biblischen Offenbarung, im Gottesgesetz und in dessen von der Gemeinde kontrollierten Erfüllung objektiv ver- 
ankern, hat die Mystik an sich überhaupt kein Gemeinschaftsprinzip, kennt sie die Gemeinschaft nur als Zusammentreffen der Gleichgesinnten. Aber indirekt wird dann doch der Sektentypus auch für diese Erscheinungen bedeutsam. Sobald sie nämlich sich als Gemeinschaft organisieren wollen, folgen sie dem Vorbild des Sektentypus. Da für sie die kirchliche Objektivität der sakramentalen Anstalt erst recht ausgeschlossen ist, müssen auch sie, soferne sie einen dauernden'Zusammenhalt erstreben, sich um die Freiwilligkeit der Teilnahme und die Strenge der ethischen Bewährung gruppieren. Damit rückt dann auch bei ihnen trotz aller Mystik und aller Lehren von der überendlichen göttlichen Substanz das biblische Sittengesetz in den Mittelpunkt, und sie konstruieren ihre Gemeinschaft von dem Gedanken Christi als des himmlischen Herrn, des Gesetzgebers und Vorbildes und von dem Prinzip der Erfüllung des Gesetzes aus. Damit laufen dann die verschied̈enen Erscheinungen ineinander über, kann die Selkte in mystischen Enthusiasmus und der mystische Enthusiasmus in die Sekte übergehen. Aber das Strukturprinzip selbst, soweit es vorhanden und durchgebildet ist, entstammt dabei immer dem Sektentypus, der Freiwilligkeitskirche, die sich den Gnadenstand ihrer Teilnehmer stets an der praktischen Bewährung und Heiligkeit klar macht. Wo das nicht geschieht, verlaufen sie in.Zufallsgruppierungen des Enthusiasmus, die sich zwar auf die neutestamentlichen Enthusiasmus berufen können, aber gerade vom Neuen Testament her immer wieder entweder auf den kirchlichen Anstaltstypus oder auf die Freiwilligkeitsgemeinschaft der das volle biblische Gesetz bewährenden Sekte zurückgeworfen werden.

Diese prinzipiellen und allgemeinen Erkenntnisse gilt es an der Geschichte des Sektentums zu erläutern, wobei ich freilich nur über fremde Forschungen berichten und sie aus den hier aufgestellten Gesichtspunkten deuten kann. Dabei wird sich zeigen, daß das kein konstruierter und von außen her aufgedrungener Schematismus, sondern eine aus dem Nachfühlen der Erscheinungen entsprungene und ihren inneren Zusammenhang erst erleuchtende Deutung ist.

Den Ausgangspunkt der mittelalterlichen Sektenbildung bildet die gregorianische Kirchenreform und -revolution ${ }^{166}$ ). Sie ist

186) Hierzu und zum Folgenden vgl. die überaus lehrreichen und umfassenden Aufsätze von Gioacchimo Volpe, Eretici e moti ereticali del. XI al XV secolo, nei loro motivi et riferimenti sociali, Rinnovamento 1907, Juni, August, Oktober. 
nach beiden Seiten hin entscheidend, nach der Seite der Kirchenbildung unmittelbar, nach der Seite der Sektenbildung mittelbar. In ihr erhob sich das kanonische und universale Papsttum gegen die seigneurale Landeskirche, in der alle Interessen des Lehensstaates mit denen der Geistlichkeit und alle Aufgaben und $Z$ wecke $\operatorname{der} G$ eistlichkeit mit denen des Lehensstaates eng verbunden waren, in der die Durchsetzung der Christlichkeit des Volkes ein Werk der großen, mit allerhand Regierungsaufgaben betrauten Bischöfe war. Eng verfilzt durch Verwandtschaft und Interessen mit dem Adel, umgeben von großen politischen und wirtschaftlichen Abhängigkeitskreisen, ergänzt durch ein nicht minder aus der Aristokratie gespeistes Klosterwesen und auch im Falle streng christlicher Interessen ken oben herunter reformierend, drückte diese Kirche namentlich in Frankreich und Italien auf die unteren Klassen und den niederen Klerus. In diesen Kreisen bestand daher ein lebhafter Gegensatz gegen die seigneurale Kirche und vor allem machten sich hier die städtischen Arbeiterschichten geltend, die in Italien und Frankreich mit den Städten selbst schon im I I. Jahrhundert eine Rolle zu spielen anfangen und die große soziale Bewegung der Bevölkerungssteigerung und Akkumulation in den Städten eröffnen. Sie hassen eine Kirche, die den niederen Klerus wie Unfreie behandelt, die die Grundherrschaft in ihren Zehnten ausnützt, die das Kirchenvermögen nicht für die Armen, sondern für die Kirche selbst oder für feudale Bedürfnisse der hohen Geistlichkeit verwendet, die in allem das Widerspiel des armen Lebens der Apostel ist und im Unterschied von der alten Kirche jede Nittätigkeit der Gemeinden ausschließt. Aus diesen Elcmenten schuf die Agitation Gregors die gregorianische Demagogie und verbündete sich mit ihr gegen die autonome seigneurale Kirche, selber freilich dabei ganz andere Ziele verfolgend und die populäre Erregung nur für ihre Zwecke benützend. In den lombardischen Städten und der sogenannten Patarie liegt das offenkundig zu Tage. Hier erhob sich in leidenschaftlichen Kämpfen das Laientrum gegen den simonistischen und verheirateten Klerus, und in den endlosen Wirren, wo dieser Klerus, vom Papst yebannt, in seinen Funktionen verhindert wurde und in jeder Stadt Bischof und Gegenbischof, Priester und Gegenpriester sich bekämpften und oft die geistlichen Funktionen ganz stillstanden, breitete sich dieses Laientum immer weiter aus. Die Ungültigkeit der Sakramente und Weihen simonistischer I'riester, 
die der Papst verhing und mit der er die Laien geradezu zur Kritik des Priestertums aufforderte, erneuerte die Lage des donatistischen Streites. Es konnte nicht ausbleiben, daß die Skepsis gegen die Personen zur Skepsis gegen das Amt, daß die Ueberordnung des Laien über den simonistischen Priester zur Unabhängigkeit vom Priester überhaupt wurde. Und in dieser kritischen Lage wurde dieses aufgeregte Laientum reif, die agitatorischen Einflüsse einer alten Sekte aufzunehmen, die zwar in ihrem. Dogma nur halbchristlich war, aber in ihrer Organisation den Sektentypus des Laienchristentums und der Kritik nach biblischen und urchristlichen Maßstäben in sich trug. Es ist die gnostischmanichäische Sekte der Katharer, die vom Orient her auf Handelswegen und von den byzantinischen Enklaven Italiens sich ausbreitete und von da in die nordalpinen Gebiete vordrang ${ }^{167}$ ). Je weniger ausreichend und intensiv die kirchliche und'seelsorgerliche Pflege der Gemeinden durch die feudale Kirche war, um so eher mußten sie geneigt sein, der feurigen Propaganda und der vorbildlichen praktischen Lebensstrenge dieser Sektenapostel $\mathrm{Ohr}$ und Aufmerksamkeit zu leihen. Dabei war ihr Dogma freilich nur bedingt christlich: ein manichäischer Dualismus in Verbindung mit schroffster metaphysisch begründeter Askese und der Seelenwanderungslehre, gestützt auf eine doketisch verstandene Christologie und auf das allegorisch gedeutete Neue Testament. Aber dieses Dogma ist auch im Einfluß nicht entscheidend, wohl auch vielfach verhüllt gewesen; es wirkte nur zur Anregung der Kritik gegenüber den kirchlichen, namentlich den hierarchischen und sakramentalen Dogmen, zum Rückzug auf die Bibel und zur Belebung des Geistes einer freien Laienargumentation. Das Entscheidende sind die soziologischen Züge der Sekte: das Laienchristentum und der Apostolat der vollkommenen, armen und enthaltsamen Asketen, die im Gegensatz gegen die unwirksamen kirchlichen Sakramente im »Consolamentum * eine wirksame Beichte und Absolution vollziehen. Ist hierin ein schwaches Element der Anstaltskirche enthalten - die Wirksamkeit des Consolamentum beruht nicht auf Weihe und Ordination an sich, sondern auf der Vollkommenheit der Spender - so traten doch diese Perfecti in der Propaganda zurück und blieben die Geheimlehren oft unbekannt. Das Wirksame war die freic Laien-

187) Vgl. hierzu Döllinger, Beiträge zur Sektengeschichte des M.A. I890 und Tocco, L'eresia nel ME. 1884 .

Troelts ch, Gesammelte Schriften. I. 
predigt und Kritik, die intime Gemeinschaft der Verstreuten, das praktische Vorbild der Armut, die Unbekümmertheit um Staat und herrschende Schichten, die Verwerfung der offiziellen Kirche und ihres Priestertums, die Verwerfung von Eid, Recht, Gewalt und Kirche, die Beseitigung der Abgaben und Zehnten, das selbständige Bibelstudium und die Kritik nach dem Maßstab der Urkirche. Ueber Ober- und Mittelitalien, Frankreich, Flandern, Holland und Rheinland erstrecken sich bereits gegen Ende des 11. Jahrhunderts derartige Gruppen, in denen katharische Einflüsse wahrscheinlich sind. Aus ihnen gehen charakteristische Führer hervor: Peter von Bruys, Heinrich von Toulouse, der Vlame Tamchelm, Eudo von Stella. An sie haben sich dann die Sektenbezeichnungen gehalten. Insbesondere ist Arnold von Brescia der deutliche Uebergang vom gregorianischen Parteigänger und mystischen Dualisten zu einer Fülle von davon ausgehenden häretischen Gruppen.

Der wcitere Fortgang der Häresie hängt mit dem Emporsteigen neuer Klassen und Schichten, der Entfesselung der Aktivität in den Unterschichten und den Städten zusammen. Daher ist auch zunächst ihr Boden in Südfrankreich, der Lombardei und Italien, wo die Städtebildung mächtig einsetzt. Italien erlebt so seine große Periode religiösen und philosophischen Aufschwungs, die cingekeilt ist $z$ wischen die Perioden religiöser Lauheit. In ihr spielen, dann vom allgemeinen Interesse belebt, kirchliche und sektenhafte Motive gegeneinander und erheben sich in diesen Gegensätzen Waldenser und Franziskaner, Bonaventura und Dante ${ }^{167 a}$ ). Erst jetzt geht die christliche Bewegung von den Höhen der Aristokratic, der Grundherrschaft, der Könige und Herren herunter auf den Grund des Volkes und wird der in den Städten zusammenströmende l'cberschuß der ländlichen Bevölkerung aktiviert zu

${ }_{167 n)}$ S. Voßler, Die güttliche Komödie II 28 ff. Aus Voßlers gerade in diesem Eande beronders origineller Darstellung bekommt man einen lebhaften Eindruck von der aufserordentlichen Verschiedenheit in der Stellung der Hauptvölker zu dem geislichen Lebenssystem des Mittelalters. Die seigneural-landeskirchliche Entwickelung ist hauptsiichlich getragen von dem deutschen König- und Kaisertum, danehen von lingland: hierzu s. Hauck u. Böhmer. Das große klassische System des Ilochmittclalters ist französischen Ursprungs und daher die enge Verbindung lirankicichs und des mittelalterlichen Gedankens. Provence und Italien sind ab:ce-chen ron den Kleriker-Kreisen seit dem Zeitalter Gregors d. G. einer zunehmenden Ieligiösin Indifferenz verfallen und pflegen in erstaunlichem Maße antik-humanistiscice Keminiszcnzen. Erst mit dem zwölften Jahrhundert setzt zugleich mit 
eigener Teilnahme an religiösen und kirchlichen Dingen. Wie die offizielle soziale Theorie der Kirche die berufsmäßig gegliederte Gesellschaft im eigentlichen Sinne erst dem Ideal der Stadt entnimmt, so wurzeln hier andrerseits auch die häretischen Bewegungen und verstärken sich hier die Bedürfnisse nach einer religiösen Betätigung der Laien, die in den Mönchsreformen und Ordensstiftungen des II. und I2. Jahrhunderts - vor den Bettelorden fast durchgängig dem Lande und der Aristokratie angehörig - nicht befriedigt worden waren. Die von verschiedenen Interessen her neu entfaltete Aktivität strömt bei der allbeherrschenden Macht religiöser Gedanken auch in die religiösen Interessen ein, es bildet sich eine lebendige religiöse Anteilnahme der Laien, und man sucht unter dem mehr oder minder losen Einfluß der bereits geschilderten Gruppen selbständig die Orientierung an dem alten Christentum und der Bibel. Auch die Kreuzzüge verstärken teils das Bedürfnis einer solchen Berührung mit dem Urchristentum, teils gehen sie neben anderen Motiven auch aus diesem hervor. Die Bibel und das Neue Testament erlangen eine im Verhältnis zu der bloß handschriftlichen Ueberlieferung erstaunliche Verbreitung und werden in die Volkssprache übersetzt. "Eine neue ideale Welt nimmt genauere Umrisse an und erleuchtet sich. Und alles, was man wußte oder ahnte und sich einbildete über das Leben der Urkirche, faßte sich in ein Bild von lebhaftesten Farben zusammen: evangelische Armut und apostolisches Leben, Gemeinschaft der Gläubigen und lebendige Anteilnahme an der Kirche; das Priestertum der Gemeinschaft als solcher eignend, gleichsam eine Emanation aus ihr; die Laien alle berechtigt, die Gnadenmittel mit zu verwalten und frei zu predigen; der Klerus zufrieden mit freiwilligen Gaben, nicht bewaffnet mit weltlichen Waffen und kein Pfleger der Zwietracht zwischen den Christen. Und wie es eine jugendliche Welt ist von absoluten Ideen und Gefühlen, so liebten viele plötzlichen und heftigen Ausdruck dafür. Sie fühlten sich ergriffen von einer unüberwindlichen Leidenschaft, sich in allen Stücken jener Lehre

der Entwickelung des Städtewesens die große religiöse Epoche Italiens ein bis zum 15. Jahrh. dauernd. In dieser Epoche aber bildet sich aus diesen Verbältnissen heraus der Unterschied des Kirchen- und Sektentypus aus und sind es gerade diese Gegensätze, die ihm die große Lebendigkeit und Bedeutung verleihen. Der Zusammenhang der nordischen Sektenbewegung mit der südlichen ist unzweifelhaft,. aber noch nicht genügend festgestellt. 
und jenem Leben der Urkirche anzupassen; sie hielten es für eine strenge Pflicht jedes Christen, zu leben wie die Apostel, d. h. zu predigen durch die Welt hindurch, die Massen zu erbauen durch das praktische Beispiel. Sie glaubten schließlich wie alle Träumer, Primitiven, des praktischen und des historischen Sinnes Entbehrenden an die Möglichkeit, die christliche Gesellschaft von innen heraus zu reformieren, sie zu bilden nach dem eigenen Ideal und nach der Spur der Schrift " ${ }^{168}$ ).

In die Bahn der eigentlichen Sektenbildung wurden diese Erregungen aber erst gedrängt durch die Kirche selbst, die sich, sobald ihr Ziel leidlich erreicht war und die Gefahren jener Allianz sich zeigten, nachdrücklich von den erst begünstigten demokratischen und kirchlich-oppositionellen Richtungen schied. Ihr Absolutismus war ja in Wahrheit das reine Gegenteil davon. So bildete sie nun ihr furchtbares Ketzerrecht aus und drängte alle Opposition in die Sekte. Vor allem wurde jedes selbständige Laienchristentum verhindert und das ihm offen gelassene Ventil der alten kanonischen Bischofswahl geschlossen; es wurde insbesondere das gegen die simonistischen Priester den Laien gegebene Recht der Prüfung zurückgezogen und lediglich dem Papst und den Legaten vorbehalten. Wie der Einfluß der Fürsten und der Seigneurie wurde nun auch der des Volkes aus der Kirche ausgeschieden. Die Sakramente wurden wieder völlig unabhängig von der sittlichen Beschaffenheit der Priester. Auch von der Verwaltung des Kirchengutes wurden die Laien ausgeschlossen. Das Priestertum wurde gegen das Laientum aufs schärfste abgegrenzt in Kleidung, Kultsprache und Lebenshaltung. Es war nunmehr allein berechtigt zur Predigt und jede Mitwirkung der Laien beim Kult ausgeschlossen. Die Theologie setzte sich technisch-scholastisch aller populären Literatur entgegen, und das Recht wurde eine hochgelehrte Sache der Juristen. Die dem neuen zentralisierten Kirchentum nötige Finanzwirtschaft betonte und verstärkte wieder die kirchlichen Abgaben und verzehrte das Armengut genau wie die frühere seigneurale Kirche. Der verhaßte Zehnte, den man simonistischen Priestern nicht liefern durfte, mußte der neuen gregorianischen Kirche erst recht gezollt werden. Die absolutistische Kirche mußte, wie sie das ja auch war, gegenüber der alten feudalen Kirche und gegenüber der patristischen Kirche der konziliaren Legislatur als etwas Neues erscheinen. Die Nötigung zur

${ }^{168}$ ) Volpe, Juni. S. $668 \mathrm{f}$. 
Erreichung ihrer Ziele, den ganzen iuristischen und politischen Apparat einer in alle Rechts- und Eigentumsverhältnisse eingreifenden Verwaltung und Politik zu entfalten, machte auf alle mystisch und innerlich gerichteten Gemüter den Eindruck der harten Aeußerlichkeit und Weltlichkeit. Dazu kam schließlich und vor allem, daß in dem Punkte der Herstellung der Moralität des Klerus die gregorianische Reform zweifellos gescheitert war. Ein strenges Urteil war durch ihre Ansprüche bei den Laien erweckt, aber diesem Urteil stand nun ein Klerus gegenüber, der in Wahrheit nicht viel anders war als der frühere oder den die immer erneuten Klagen wohl auch geradezu schlechter zeigten, als den früheren. Und gerade hiefür wurde nun das absolute Papsttum, das sich theoretisch als die Quelle und Organisation von allem darstellte, auch praktisch verantwortlich gemacht, und damit ergab sich eine endlose Kritik des neuen Systems.

In diesem Gegensatze der neubelebten biblischen und asketischen Frömmigkeit, die selbst zur Herbeiführung der hochmittelalterlichen Kirche mitgewirkt hatte, gegen das Ergebnis dieser Reform wurzelten die zunehmenden radikalen Bewegungen der Laienreligion, und die Ausschließlichkeit der Kirche gegen sie drängte sie zur Sektenbildung. So entstand vor allem die bedeudendste und einflußreichste Sekte, die Waldenser. Es war zunächst eine Bewegung der inneren Mission, der Volkspredigt, getragen von Missionaren in der Art der Apostel, die in der Volkssprache predigten, das arme Leben führten, auch zu den Kleinsten und Aermsten gingen und in allem die Missionsregeln der Aussendungsrede Jesu Matth. Io befolgten. Auf das kirchliche Verbot hin wurden sie zur Sekte, in der die religiöse Gleichheit aller Gläubigen, der Frauen und Männer zu Grunde lag und in der wie bei den Katharern das Bußsakrament von den frommen Asketen verwaltet wurde, die in Armút, Ehelosigkeit und heimlicher Seelsorgetätigkeit überall umherzogen. Sie verwarfen das Fegfeuer und die Einwirkung auf das Fegfeuer, die Ablässe und die Heiligenanrufung, das Schwören und Vergießen von Menschenblut, die Todesstrafe und den Krieg, stellten jeden auf seine eigenen persönlichen Leistungen und guten Werke, d. h. auf seine religiöse Subjektivität. Sie spalteten sich bald in die französische Stammgenossenschaft und die radikalere, Sakrament und Priestertum, den kultischen Pomp und das Kirchenrecht liberhaupt verwerfende lombardische Genossenschaft, die an ältere Reste lo- 
kaler Häresien anknüpfte. Die Ausbreitung beider Gruppen schritt rasch vorwärts; die französischen Armen beschränkten sich wesentlich auf Südfrankreich, die lombardischen drangen bis jenseits der Alpen vor ${ }^{169}$ ). In ihren Ausläufern mischten sie sich dann mit fremdartigen Elementen, vor allem dem ihnen ursprünglich ganz fremden mystischen Enthusiasmus, der ohne kirchliche und priesterliche Vermittelung im mystischen Aufschwung die Christlichkeit verwirkliche, oder mit den oppositionellen ekstatischen Bewegungen, die gleichfalls Ausbrüche einer kirchenfeindlichen Laienreligion waren. Die Ortlibarier, Joachimiten und Brüder vom freien Geiste floßen hier mit ihnen zusammen, und bis in die Vorstufen des Hussitismus lassen sich diese Wirkungen einer der Unterschicht angehörenden Bewegung verfolgen ${ }^{170}$ ).

Nahe verwandt ist der waldensischen Bewegung die ursprüngliche franziskanische; der heilige Franz selbst war vermutlich nicht frei von direkten waldensischen Einflüssen. Den Armen von Lyon und den lombardischen Armen entsprechen die Poverelli des Heiligen von Assisi. Auch die franziskanische Bewegung gehörte ursprünglich dem Sektentypus der Laienreligion an. Hier aber begriff die Kirche die Lage und gliederte die neue Bewegung ihrem System ein, machte aus ihr einen neuen, von ihr beaufsichtigten Orden und bediente sich seiner gerade zur Wiedergewinnung der gefährdeten städtischen Elemente. Aber auch so blieb der Orden mit seinen Laien-Affiliirten vielfach ein Anreger der Laienreligion und der kirchlich indifferenten Mystik, und in seinen späteren Kämpfen erhob sich in den Spiritualen der schroffe Gegensatz gegen die Verkirchlichung des Ordens. Sie predigten das Ideal der Urkirche vor Konstantin und Silvester, der armen Kirche und des apostelgleichen Lebens mit dem Dienst für die Armen, steigerten sich immer mehr im Hasse gegen die Hierarchie und mündeten in verschiedenartige Häresien und Sekten aus. Immer sind es ein neues Volk und Bewegungen von demokratischem Charakter in der Richtung auf Ziele, die zugleich religiös und sozial sind, jenes ausdrücklich und bewußt, dieses

169) Volpe hebt mehrfach hervor, daß sie besonders in den Kreisen der Weber und der Wollindustrie sich ausbreitete, d. h. in den Kreisen der umfassendsten und am meisten zur Hausindustrie gewordenen handwerklichen Produktion, in der soziale Reformideen am meisten oder allein zu Hause sind, vgl. auch Kautsky, Gesch. d. Sozialismus, S. 103.

170) Volpe S. 27, 24, 37, Oktober, S. $296 \mathrm{f}$. 
unsicher und verhüllt aus Mangel an sozialer Erfahrung und weil damals in gewissen Klassen auch jedes materielle Bedürfnis seine Befriedigung in einer religiösen Umformung suchte ${ }^{1 i 1}$ ).

Das von den heftigsten Kämpfen zwischen Kurie und Kaisertum, Städten und Adeligen, Klerus und Laien durchtobte Italien mit seiner früh einsetzenden städtischen Entwicklung ist der Ursprungsboden der meisten dieser Bewegungen. Seine Verhältnisse brachten es aber dann weiter mit sich, daß bald auch der Adel und die Landbevölkerung freiwillig und unfreiwillig in die häretischen Bewegungen hineingezogen wurden und diese dadurch wieder verstärkt wurden. Die Kirche nach dem göttlichen Gesetz des Evangeliums und dem Ideal der Urkirche reformiert, bald mehr nur als entweltlichte Priesterkirche, bald mehr als Laiengemeinschaft, wurde das Schlagwort, und mit ihm verbanden sich die häretisch-mystischen Einflüsse und die apokalyptischen Prophetien. In seiner Klostereinsamkeit verfaßtc der aus dem Orient zurückgekehrte Abt Joachim seine Weissagungen, in denen er das dritte Zeitalter verkündete, nicht mehr ein Zeitalter der Furcht und Knechtschaft, der Arbeit und Disziplin, sondern ein Zeitalter des Geistes und der Freiheit, des Friedens und der Gewaltlosigkeit, der Demütigen und Armen, ohne Klassen und soziale Unterschiede, ohne mein und dein; hier traten die Züge des göttlichen Gesetzes und Naturrechtes im Sinne der absoluten, durch keinen Kompromiß gedämpften stoisch-christlichen Soziallehre hervor. In der Unruhe der krisenreichen Zeit aufgegriffen, wurden diese Prophetien zu einem weiteren wichtigen Ferment der Sektenbewegung. Es kamen die Flagellanten, die Soccati, die apostolischen Brüder, die häretischen Spiritualen, Fra Dolcino und Gerhard Segalleli. "Es sind keine Orden mehr, man haßt die Orden und will keine Häupter; man will die Freiheit und Gleichheit der Urzeit ${ }^{172}$ ). *Vereinfachung des Lebens und der religiösen Organisation, Leidenschaft für die Urkirche und wörtliches Verständnis der h. Schrift, genaue Befolgung des Wortes und der Lehren Christi, vollständige und gleichsam mechanische Wiederholung des apostolischen Lebens: das ist der gemeinsame Untergrund, auf dem sich die verschiedenen Sekten erheben mit Unterschieden, die außerordentlich groß sein können ${ }^{173}$ ).

Das ist die große südeuropäische Sektenbewegung mit ihren
371) Volpe, Juli, S. 26.
179) Volpe S. 72.
173) Volpe S. $73 \mathrm{f}$. 
Ausstrahlungen. Ihr Grundelement ist der am Neuen Testament belebte und im Gegensatz gegen die materialisierte Anstaltskirche hervorbrechende urchristliche Individualismus und der Zusammenschluß der Individuen in der praktischen Lebensleistung der guten Werke mit starker Indifferenz und Feindschaft gegen die Welt und ihre Macht- und Besitzordnungen. Es ist die für die Sekte typische Verbindung des religiösen Individualismus und des sittlichen Rigorismus, welcher letztere sich an Bergpredigt und absolutes Naturrecht hält, wic das ja auch der ganzen radikalchristlichen Tradition seit der Urgemeinde und den Mönchsorden entspricht. Das Gemeinschaftsband ist dabei lediglich das wörtlich verstandene "Gesetz Jesu * und die gleichfalls auf diesem Gesetz beruhende Einrichtung der armen und nur für die Gemeinde lebenden Missionare und Apostel; die letzteren sind oft auch Priester und stehen dann in der Sukzession, aber ihre Berechtigung und Wirkung ist auch dann erst von der persönlichen sittlichen Reinheit und Strenge abhängig. Die paulinische Lehre verschwindet hinter dem Gesetz Jesu fast ganz. Dabei ist das Gesetz Jesu zugleich das Gesetz der Natur in seinem strengen vollen Verstand und als solch's meist im Sinne eines weitgehenden Liebeskommunismus und entsprechender Liebestätigkeit gedacht, nur gelegentlich in die demokratischen Gedanken der Freiheit und Gleichheit hinüberspielend. Als ein zweites ganz andersartiges Element macht sich dann neben diesen Hauptströmungen die mystische Religiosität geltend, die neuplatonisch und averroistisch beinflußt einen $\mathrm{Ge}$ meinschaftstrieb nur hat, sofern sie mit waldensischen und franziskanischen Ideen sich berührt. Und schließlich spielt in dem Ganzen die apokalyptische Prophetie mit, in der die zunächst auf kleine Kreise beschränkte Sektenbewegung den christlichen Universalismus festhält als ein in der neuen Weltzeit von Gott zu bewirkendes Wunder, womit dann oft Mystik, Freiheit und Gleichheit als die Ideale jener neuen Weltzeit sich verbinden. In den Wirren des Trecento zieht diese Sektenbewegung den Ghibellinismus in ihre Netze, wird in die politischen Verhältnisse verwickelt, verliert ihre ursprüngliche Orientierung uud stirbt schließlich in allerhand Wirren und Extravaganzen ab, nur einen leicht entzündbaren Rest apokalyptischer Ideen zurücklassend. Humanismus und Renaissance, weltliche Politik und der volle Sieg der Kurie machen ihr ein Ende, und in Italien und Südeuropa hat die kirchliche Anstalt von einem Sektenchristentum seitdem nichts 
mehr zu fürchten. Es ist einer der Gründe, weshalb es dort zu keiner der deutschen Reformation analogen Bewegung kommen konnte ${ }^{174}$ ).

Darauf folgt nun aber im I4. und I5. Jahrhundert im Norden eine nicht minder durchgreifende Sektenbewegung, die Wiklifie und der Hussitismus ${ }^{175}$ ). Sie haben im Unterschiede von dem italienischen Sektentum sich dauernd behauptet und haben mit verwandten allgemeinen Bewegungen dann den Boden des Protestantismus in mancher Hinsicht bereiten helfen. Grundlegend ist dabei die Wiklifie.

Auch für sie war der Ausgangspunkt der Gegensatz gegen den päpstlichen Absolutismus und seine Einwirkungen auf die politischen und ökonomischen Verhältnisse des Landes wie der Gemeinden. Wie überall seit dem I4. Jahrhundert die Staatsgewalten gegen diese kirchliche Einmischung sich wehrten, so trat auch das englische Königtum in eine Säkularisationspolitik großen Stiles ein. Hierin stellte sich Wiklif auf seine Seite. Es ist also in diesem Falle nicht die Reaktion der Unterschichten, sondern das nationale Gefühl und die politische Verselbständigung das erste Motiv. Aber was Wiklif hier geltend machte, war das alte Oppositions-Ideal der armen Kirche, der Kirche vor Sylvester und Konstantin, wie sie noch dem Gesetz Gottes und des Evangeliums entsprochen hatte. Nur eine solche Kirche stimmt zu dem religiösen Ideal und verträgt sich zugleich mit der Selbständigkeit der bürgerlichen Ordnung.

Beide Interessen, das Ideal der armen Kirche und der Selbständigkeit der weltlichen Gewalt, verband nun aber Wiklif in einer meines Wissens ihm eigentümlichen, sehr folgereichen Theorie vom göttlichen Recht. Es ist eine originelle Fassung des patristischen naturrechtlich-biblisch-gesetzlichen Gedankenkreises, in welchem von jeher mit dem Ideal der armen Kirche das absolute durch keine Kompromisse abgestumpfte Gottes- und Naturgesetz verbunden war. In der neuen kunstvollen Umbildung dieses alten Gedankens äußert sich. der gelehrte Theologe, während

174) Ueber diese Frage Volpe, Oktober, $296 \mathrm{f}$.

175) Hierzu vgl. Lechler sJ. v. Wiklife (der erste Band Wiklif, der zweite Huß und die anderen Vorreformatoren behandelnd); Buddensieg, J. Wiklif und seine Zeit 1885 ; über das Verhältnis von Wiklif und Huß s. Loserth, Huß und Wiklif. Zur Genesis der Hussitischen Lehre, 1884. Zum Kirchenbegriff bes. Gottschick, Huß', Luthers und Zwinglis Lehre von der Kirche, Z. f. Kirch.-Gesch., 1886. 
die waldensische und franziskanische Laienreligion nur einfach an die Bibel sich anschloß ${ }^{178}$ ). Das. göttliche Gesetz des Evangeliums nämlich, das auch ihm mit dem Naturrecht identisch ist, bestimmt nach seiner Theorie, daß aller Besitz und alle Gewalt von Gott stammt und nur demjenigen zu Recht zukommt, der Gottes Moralgesetz der Liebe, Demut und Selbstbeschränkung einhält; es

178) Hier teilt Wiklif die üblichen scholastischen Lehren vom Naturrecht und Gottesrecht, s. Lechler I 467 u. bes. die Stelle aus de civili dominio: sde quanto aliqua lex ducit propinquius ad conformitatem $\mathrm{l}$ e is $\mathrm{n}$ a $\mathrm{tu}$ a e, est ista perfectior. Sed lex Christi patiendi injurias propinquius ducit ad st a t u m a turae quam civilis. Ergo ista cum suis regulis est lege civili perfectiora; das ist der alte Unterschied von absolutem und relativem Naturrecht, wobei das erstere dem Urstand angehört. Wenn Lechler meint, die spätere Stelle aus De veritate scripturae sin tantum quod si lex aliqua dicit caritatem aut virtutem aliquam, ipsa adeo est lex Christi< besage ein Zurückstellen des Naturgesetzes hinter das christliche Gesetz, so ubersieht er die grundlegende Identität des absoluten Naturgesetzes und des christlichen Gottesgesetzes. Wiklif macht damit nur das absolute Naturgesetz gegen das relative oder zivile Gesetz geltend. Schon die ganze Bezeichnung der Bibel und des Christentums als ,Gottesgesetze, die bei Wiklif alles beherrscht, zeigt die Orientierung des ganzen Gedankenganges an den Begriffen des Gesetzes Gottes und der Natur, Lechler I 473. Auch die ganze Geltendmachung der Bibel als alleiniger Autorität und Quelle für das Gottesgesetz ist die Geltendmachung des absoluten und reinen Gesetzes gegen das relative Naturrecht der geltenden Gesellschaftsordnung und die Kompromisse der Kirche. Erst nach und nach folgt aus dieser Aufstellung der Bibel als alleiniger Autorität auch die dogmatische Kritik an rein theologischen Lehren; das ist ein wichtiger Unterschied von Luthers Lehre; s. de civ. dominio: Pure per observantiam le $\mathrm{g}$ is $\mathrm{Chr}$ isti sine commixtione traditionis humanae crevit ecclesia celerrime, et post commixtionem fuit continue diminuta. Lechler I 474. Aehnlich : Lex humana est mixta multa nequitia, ut patet de regulis civilibus $_{n}$ ex quibus pullulant multa mala; lex autem evangelica est immaculata. Lechler I 475. So ist die Bibel die scarta a Deo scripta et nobis donata, per quam vindicabismus regnum Dei๔, 476. Es ist das absolute christliche Naturrecht: die Geistlichen sollen suti pro suo regimine lege evangelica impermixtek oder sUtilius et undique expeditius foret sibi (ecclesiae) regulari pure lege scripturae, quam quod traditiones humanae sunt sic commixtae cum veritatibus evangelicis ut sunt modos 477. Daher >Lex Christi est medulla legum ecclesiae $\alpha$. Omnis lex utilis sanctae matri ecclesiae dicitur explicite et implicite in scripturac. Das aber ist dann auch das Naturgesetz des gesellschaftlichen Gesamtlebens: sTotum corpus juris humani debet inniti legi evangelicae tanquam regulae essentialiter divinaec. Die ganze Gesellschaft soll und kann nach dem Gesetz Christi reformiert werden und zwar ausschließlich von ihm aus. Doch kann das erst auf die Reform der Kirche folgen, s. c. 44 v. Buch I, De dominio civili. Der offizielle Theologe ist für Wi- 
ist ein Lehen, das nur solange dem Belehnten zusteht, als er das Gesetz seines Herrn hält. Da nun aber die Kirche dieses Gesetz nicht hält, kommt es dem Staate zu, ihr das unrechte Gut wieder abzunehmen und das Ideal der armen, nur ihren geistlichen Zwecken lebenden Kirche wiederherzustellen. Das Besitzrecht der weltlichen Stände tastet Wiklif hierbei nicht an, da bei ihnen eine solche Verleugnung von Gottes Gesetz wie im priesterlichen Stande nicht vorliegt. Ihr Besitz hängt mit ihren weltlichen Funktionen rechtmäßig zusammen, während die Funktionen der Kirche keinen irdischen Besitz fordern, ihn vielmehr ausschließen. Diese offenkundig am Lehensbegriff orientierte Fassung der Lex Dei oder Lex Christi oder Lex naturae hat eben zunächst nur die Absicht das Ideal der armen Kirche wieder herzustellen, und der hierin an sich enthaltene soziale Radikalismus bleibt gegenüber den weltlichen Ordnungen ohne Anwendung ${ }^{177}$ ). Immer-

klif Doctor traditionis humanae et mixtim theologus, Lechler I 477 , worin er unzweifelhaft Recht hat. Lex autem christiana debet esse s o l u m lex Domini et immaculate convertens animas (zu der biblischen Lebensstrenge und Liebe) et per consequens recusari debet a cunctis fidelibus propter commixtionem cujuscumque attomi Antichristi, Lechler I 478. Wenn Lechler hierin das reformatorische Schriftprinzip erkennt, so ist das nur bei der Ignorierung des mittelalterlichen naturrechtlich-soziologischen Ideenkreises möglich, noch weniger denkt Buddensieg an ihn. Und doch ist dies der eigentliche Schlüssel zum Verstăndnis! Für die von der paulinischen Gnadenreligion ausgehende Lehre der Reformatoren ist die Schrift Gnadenbotschaft und das Gegenteil einer Lex Christi. Ebendeshalb haben die Reformatoren auch gar keinen Sinn für eine gesetzliche Fassung des urchristlichen Radikalismus und die Reform der weltlichen Ordnungen nach ihm. Das ist ihr fundamentaler Unterschied von der Wiklifie, mit dem dann auch die Beibehaltung des Kirchentypus zusammenfällt.

177) Die Frage, weshalb Wiklif die radikalen Konsequenzen dieser Idee nicht zieht, ist sehr wichtig für seine Lehre. Seeberg bemerkt nur: „Es ist natürlich (l) nicht die Meinung, daß die Gerechten sofort den ungerecht von anderen ergriffenen Besitz an sich bringen sollten. Vielmehr sind die positiven Pflichten des Lebens (!) in dem evangelischen Gesetz enthalten «, S. 168. Stellen, die diesen dunklen Satz erklären, sind nicht angegeben. Die Grundschrift De civili dominio (jetzt publiziert in 4 Bänden von Poole, I885 ff.) gibt deutlichen AufschluB. Hier wird zunăchst das jus divinum oder evangelicum als das einzige absolute Recht statuiert, das dem Gerechten und Prädestinierten den Besitz an Gütern und Macht als Gottesgabe sichert, aber ihn zugleich zu einem Gebrauch dieses Besitzes im Liebesdienst des Ganzen, also zum Liebeskommunismus, verpflichtet. Nur in diesem Sinne ist Wiklifs Kernsatz omnia bona communia für Urstand und Erlösungsstand zu verstehen; in der Geistigkeit der Liebe und dem Besitz des höchsten mystischen 
hin ist es aber bedeutsam, daß hier mit der strengen Fassung der Lex Dei et Naturae die radikalen sozialen Konsequenzen gegen alle gegebene Ordnung hervortreten, auch wenn sie zunächst bloß gegen den kirchlichen Besitz praktisch gewendet werden; weiter-

Gutes ist aller Sonderbesitz allen gemeinsam trotz aller durch die prädestinierende Gnade bewirkten Differenz des tatsächlichen Besitzes: dominium enim naturale propter sui spiritualitatem aliud non excludit I 126. Es ist überhaupt nicht im stoisch - rationalistisch - individualistischen Sinne verstanden, sondern in dem Sinne eines alle Berufe und Aemter, allen Besitz und alle Macht im Dienst des radikalen Liebeskommunismus für die christliche Gesellschaft verwendenden Gemeingeistes; im übrigen aber bleibt die ständisch gegliederte Gesellschaft der vulgares, saeculares domini und sacerdotes. Mit der Prädestination ist grundlegend die Differenz der Berufe, ministeria et officia, behauptet (Lechler I 531), nur sind sie in den Dienst der Liebe bedingungslos gestellt und gilt diese Forderung nicht bloß einem besonderen Stande, dem Mönchtum (Lechler I $582 \mathrm{f}$.), sondern allen Christen insgemein; von ihnen allen gilt das Franziskanerideal: pure naturaliter vel evangelice dominantes perfectissime dicunt atque verissime cum Scriptura, quod omnia bona mundi sunt singulorum nostri ordinis et tamen nihil habemus civiliter in proprio et sic intelligit locutiones venerabilis ordinis fratrum minorum, qui sunt quasi nihil habentes secundum civilem solicitudinem et tamen omnia possidentes, I 129 . So werden die Unterschiede als Gnadengaben behauptet und doch in der Liebe ausgelöscht, sogar auch die Unterschiede von Herr und Sklave. Quilibet christianus debet reciproce alteri ministrare, ergo et esse reciproce servus et dominus; I 75 und es ist regula indispensabilis christianae religionis, qua scimus quemcunque christianum, inquantum est donis Dei fertilior, in tantum debet esse aliis membris Christi servitute subjectior et per consequens magis servus I 77. Das gilt - abgesehen von der erst durch Sünde entstandenen Sklaverei - bereits vom Urstand und auch vom Erlösungsstand: Jus divinum est jus a solo deo instit u t u m, per Christum verbo et opere explanatum ut lex evangelica I 125 , und dieses jus divinum creatum est jus divinitus inspiratum; jus humanum (in jus canonicum und jus civile bestehend) est occasione peccati adinventum. Die Sache liegt an sich wie bei Thomas. Dieses menschliche Gesetz wird nun aber hier sehr viel geringer gewertet als in der thomistischen Soziallehre, es ist in Wahrheit das aus der christlichen Gesellschaft $z u$ beseitigende Uebel, besonders auf dem Gebiete des künstlich erfundenen kanonischen Rechts, aber auch auf dem des bürgerlichen Rechts, wo ihm nur eine sehr beschränkte Geltung zugeschrieben wird: Ex istis incidenter patet divisio inter dominium naturale vel evangelicum et civile. Dominium quidem naturale est dominium divinitus institutum in primo titulo justitiae fundatum, quotlibet divites ex aequo compatiens, sed alienationem dominantis servata justitia non permittens. Dominium autem civile est dominium occasione peccati hominibus institutum, incommunicabile singulis et ex aequo multis dominis, sed abdicabile servata justitia S. 126 f., das heißt: das göttliche Recht bestimmt dem Gerechten und 
gehende Folgerungen sind unausbleiblich: Andrerseits aber wirkt dann aber auch die Messung der Kirche an der Lex Christi allmählich zu einer immer stärkeren Annäherung an den Sektentypus, worin Wiklif sich schließlich den Waldensern und den Grundideen der franziskanischen Bewegung nähert.

Seit dem Ausbruch des Schismas nämlich ging Wiklif immer mehr von seinem ursprünglichen, bloß patriotischen und kirchlichen Ideal zu einer Kritik des Kirchenbegriffes selbst und zu entsprechenden praktischen Versuchen über, die er gleichfalls aus dem Gesetz Gottes

Prädestinierten ein ohne Verletzung der Gerechtigkeit ihm nicht abzunehmendes und nicht veräußerliches Eigentum, das er im Dienst der Liebe schlechthin verwenden soll. Dagegen das menschliche Recht des Sündenștandes bestimmt ein zwangsmäßig gesichertes, nur wenigen eignendes und nicht für das Ganze bestimmtes Eigentum, das er eben wegen dieser Abwesenheit der Liebesfunktion für dás Ganze in geordneten Formen des Kaufes etc. veräußern kann und das ihm genommen werden kann. Dieses menschliche Recht ist aber die Aufhebung oder Verleugnung der Liebe und nur insoferne berechtigt, als es der sündigen Unordnung und Raubsucht steuert, also einen Rest von Naturrecht in sich bewahrt: unde supposito lapsu et cecitate proclivi bonis sensibilibus praecipue innitendi, necesse fuit leges et ordinationes humanas statuere, ne quilibet lapsus de bonis furtim caperet, quantumque voluntas indebite inclinaret I 128. Sequitur ergo, quod jus civile vel humanum, ut sapit justitiam, est jus ordinans idoneum ad custodiam temporalium pro utilitate rei publicae, ad refrenandum voluntates ipsam injuste dirrumpere et ad sagaciter ministrandum illa in necessitate temporum I 129. Es ist die alte Lehre vom relativen Naturrecht der gegebenen Ordnung als frenum et remedium peccati. Immerhin hält Wiklif sehr wenig von diesem Recht; der es bestimmende consensus populi ist ungerecht nisi praesupposita ratione, scil. quod persona dominans sit a Deo accepta. ad illud officium; et per idem nulla principia juris civilis de successione hereditaria vel commutatione mutua terrenorum est justa nisi de quanto est legis naturae particula $I$ 130. - All dies zeigt, daß der scholastische Begriffsapparat der Lex naturae stark zu Gunsten des absoluten Naturrechts verschoben ist; aber in diesem hat der Prădestinationsgedanke die Ungleichheiten so sehr befestigt, daß er konservativ wirken kann, solange ein Stand sein dominium als im wesentlichen gerecht und gottgemäß verwaltend betrachtet werden kann. Das nimmt Wiklif mit offenbarer englischer Selbstzufriedenheit von den weltlichen Ständen an, nur vom kirchlichen Stande leugnet er es, daher kehrt sich die revolutionäre Konsequenz vorerst nur gegen diesen. Im Hintergrunde aber lauert eine Prüfung auch des weltlichen Standes nach dem Gottesgesetz und ein christliches Gesellschaftsideal nach der Lex evangelii; es wird nicht individualistisch - kommunistisch sein, aber es wird ein Höchstmaß von freiwilligem Liebeskommunismus verlangen. Die revolutionären Konsequenzen und der radikale Gegensatz gegen die thomistische Sozialphilosophie liegen auf der Hand. 
ableitete. Die Kirche ist ihm nicht mehr die durch das Schisma gefährdete und von der Hierarchie ausgeplünderte Anstaltskirche, sondern die Zahl der Prädestinierten. Hier argumentiert der gelehrte Theologe, die Zierde Oxfords; aber damit tritt - soviel ich weiß zum ersten Male ${ }^{1770}$ ) - die später im Calvinismus so bedeutsame Wirkung des Prädestinationsbegriffs auf die soziologische Idee des Christentums mit voller Schärfe hervor ${ }^{178}$ ). Von Wirkungen des Prädestinationsgedankens war bisher nur insofern die Rede gewesen, als in ihm sich der Irrationalismus des christlichen Gottesgedankens verkörpert und von da aus der Individualismus sich in dem Sinne der wesenhaften Ungleichheit bestimmt. Nun aber tritt seine den Individualismus begünstigende Tendenz auch noch nach der anderen Seite hervor, wo er die Unmittelbarkeit des religiösen Verhältnisses bedeutet und den Begriff der kirchlichen Heilsanstalt zu zerstören beginnt. Die Prädestination macht die religiöse Gemeinschaft aus der Wirkung eines seine Wunderkräfte unbegrenzt ausstrahlenden hierarchisch-anstaltlichen Einheitskernes zu einer begrenzten Summe von Gläubigen, die nur an die Schriftgebunden sind, als an das Mittel der Auswirkung der Prädestination und sich äußerlich nur an der praktisch-ethischen Betätigung der Prädestination erkennen. Auch die erstere Wirkung des Prädestinationsgedankens ist bei Wiklif deutlich erkennbar und scheidet seine christliche Sozialreform von jedem egalitärdemokratischen Gedanken. Aber noch stärker tritt die, sweite Seite des Gedankens bei ihm hervor, da er mehr als an der Sozialreform an deren Voraussetzung, der Kirchenreform, interessiert ist. Sein Hauptinteresse ist daher vor allem die Entwertung aller

177 a) Doch verweist Bezold, Die Lehre von der Volkssouveränität im M.A. (hist. Zeitschrift 1876 ) auf Durandus v. Pourçain und Lull als Vorgänger $338 \mathrm{f}$; bei diesen fehlt aber die Einführung des Prädestinationsbegriffs und die Begründung.

${ }^{178)}$ Das ist ein alter augustinischer Satz, auch vom $h$. Thomas geteilt. Aber für Thomas ist die Kirche als sakramental-hierarchische Heilsanstalt das Mittel, durch welches die Prädestination sich verwirklicht. Außerdem werden bei. der Unerkennbarkeit des Heilsstandes und bei der äußeren Ununterscheidbarkeit, ob in einem die Potenz des Heils aktualisiert werden könne oder nicht, die Gesamtheit und mit ihr auch die Nichtprädestinierten unter den $Z$ wangseinfluß der Sakramente gestellt; hier wird die Scheidung erst nach dem Tode stattfinden. Auf diese Weise verträgt sich die Prädestinationslehre mit dem Anstaltsbegriff. Erst wenn diese Begrenzung wegfällt, äußert die Prädestination ihre den Kirchenbegriff auflösende Wirkung. S. die treffenden Bemerkungen bei Gottschick, „Huß', Luthers und Zwinglis Lehre von der Kirche๔, Z. f. Kirch.-Gesch., 1886, S. 352-356. 
anstaltlichen Elemente, die individuelle und persönliche Unmittelbarkeit des Gottesverhältnisses, das von Gott und nicht von der Kirche hervorgebracht wird und über dessen Bestand Gott und nicht die Kirche entscheidet; zu gleicher Zeit die Betonung der praktischen Bewährung, da nur an ihr die Prädestination sichtbar wird und nur in ihr die letztere ihren Zweck hat ${ }^{179}$ ). Dabei bewegt sich die praktische Bewährung selbst auf der Linie des biblischen Gottesgesetzes $d$. h. auf der Linie der Zurückhaltung von Welt und Besitz und der äußersten Lebensstrenge und einer in allen Aemtern und Berufen der christlichen Gesellschaft dienenden, alles durch die Liebe zum Gemeineigentum machenden Liebesgesinnung. Damit aber ist das Laientum in Wahrheit als der Träger der Gemeinschaft proklamiert, und ihm wird daher auch von Wiklif zu selbständigem Studium und zur selbständigen Kritik der Kirche das große Grundgesetz der Gemeinde, die Bibel, in der Landessprache in die Hand gegeben. Das Priestertum bleibt wohl bestehen, aber Wiklif verwandelt es in Missionare nach der Vorschrift von Matth. Io, die arm und mildtätig umherziehend das Gesetz Gottes verkünden sollten. Dieses Priestertum hat keinen Charakter indelebilis, und die Weihe kann schließlich auch fehlen; es hat keine Hierarchie und keine organisch-patriarchalische Abstufung, vor allem kein päpstliches Haupt. Der Herr der Kirche d. h. der Prädestinierten ist allein Christus. Damit aber ist der Grundpfeiler der Anstaltskirche zerbrochen und durch nichts anderes ersetzt. Freilich ist von keiner selbständigen Neuorganisation der Kirche, sondern nur von einer Reformation, von keiner Nebeneinanderstellung des Staates und der Kirche, sondern von einer Staat und Gesellschaft einschließenden Reform der Gesamtchristenheit die Rede. Aber die Christenheit selbst schwebt ihm dabei doch nicht als eine objektive Anstaltskirche vor, sondern als eine im praktischen

170) Vgl. Lechler I 534 : Gegen die Gefahr der Verzweiflung am eigenen Gnadenstande: , Vivat ergo homo, quam plene sufficit, conformiter legi Dei et habeat perseverantem voluntatem in lege illa standi in vita, defensione et publicatione; et tollitur occasio desperandi. 435: Quilibet debet examinare vitam propriam, quousque non fuerit sibi conscius de mortali peccato. Istam ergo examinationem tractare diligentissime est necessarium cuilibet viatori, cum quilibet, sicut debet habere spem suae salvationis, ita debet credere absque formidine, quod sit in gratia gratificante. S. 533 Non enim supponeret, quod sint tales (d. h. erwählte Mitglieder der wahren Kirche) nisi e videntia capta ex opere, quo sequerentur dominum Jesum Christum. 
Handeln sich betätigende, am Schriftgesetz sich selbständig orientierende und des objektiven Priestertums nicht notwendig bedürfende Gemeinschaft der Prädestinierten, die die Aufgabe der Reform vorläufig in einzelnen Vereinen und Persönlichkeiten in die Hand nimmt, bis die Zeit der Gesamtreform gekommen sein wird. Das aber ist die Aufösung der Anstaltskirche und die Anbahnung des Sektentypus ${ }^{180}$ ). Von hier aus ging dann Wiklif schließlich in der Kritik noch weiter, indem er auch den zweiten Grundpfeiler, den Sakramentsbegriff, untergrub, wenn auch freilich nicht völlig zerstörte. Er bekämpfte in der Transsubstantiationslehre bewußt das Zentrum der priesterlichen Herrscherstellung und machte die Eucharistie zu einem den leiblichen begleitenden geistlichen Genuß, wobei dem Priester nur die Ausspendung, nicht das Verwandlungswunder zufiel. Gleichzeitig kritisierte er nach dem Gesetz Christi auch die übrigen Sakramente, und beseitigte das Bußsakrament, die Firmelung, die letzte Oelung. Bestehen ließ er Taufe und Herrenmahl, das Ehesakrament, das eines Priesters an und für sich ja auch gar nicht bedurfte, und das sehr eingeschränkte Sakrament der Priesterweihe. Daß er bei dieser Kritik dann auch die zahllosen Weihen und Segnungen, Wallfahrten, Ablässe, Bruderschaften, Heiligendienst, Bilder und Reliquien, das Zölibat und die organische Gliederung der Kirche beseitigte, versteht sich von selbst. Eine positive Organisation der Prädestinierten und ihre A'usgestaltung zu einem geschlossenen Gemeinschaftskreise hat er nicht unternommen. Er begnügte sich wie der h. Franz mit der Organisation seiner Missionare, der Lollharden. In dieser Hinsicht fehlt seinen Begriffen der Abschluß. Aber es treten doch in ihnen die charakteristischen Wirkungen des Rückganges auf das radikale biblische Gesetz und Naturrecht und auf die evangelische Laienreligion hervor. Wie überall ist

180) Diese Konsequenzen mit Recht betont von Seeberg, Der Begriff der christlichen Kirche, I, 1885, S. 77 f. Dem hält Gottschick S. 77 f. aber ebenso richtig entgegen, daß diese Konsequenzen von Wiklif tatsächlich nicht gezogen werden, sondern eine Reform der Gesamtkirche erstrebt wird und Priester und Sakrament als Anstaltselemente bestehen bleiben. Die Konsequenz tritt erst dann ein, w wenn auch die Gewißheit der eigenen Prädestination als etwas betrachtet wird, was jedem zugănglich ist. Sobald diese Gewißheit erreicht ist, fällt ja allerdings die Autorität äußerer Institutionen dahins. S. 363. Nun hat aber doch in der Tat Wiklif die Notwendigkeit des Priestertums unsicher beurteilt und die praktische Bewährung als Merkmal der Prädestinierten bezeichnet. Von da aus ergibt sich der Sektentypus, aber er ist allerdings nicht konsequent durchgedacht. 
es auch hier der Individualismus des Sektentypus und die radikale Weltablehnung oder doch ein Mindestmaß weltlichen Besitzes und Genusses, dagegen ein Höchstmaß des Liebeskommunismus, die eng verbunden dem kirchlichen Anstaltsbegriffe und der kirchlichen organischen Soziallehre mit ihren Kompromissen entgegentreten.

Beide Konsequenzen, die die Wiklifie nicht gezogen hatte, die Gemeindeorganisation der Sekte und die sozialradikale Ordnung auch der weltlichen Verhältnisse nach dem Gesetze Gottes, zog der völlig auf Wiklifs Ideen beruhende $\mathrm{Hussitismus,} \mathrm{frei-}$ lich auch er in seinen verschiedenen $Z$ weigen auf sehr ungleiche Weise. Huß selbst blieb dabei hinter dem Radikalismus Wiklifs erheblich zurück, aber aus seinem Werke entwickelten sich die radikalsten Konsequenzen neben charakteristischen Kompromißformen.

In Böhmen hatte der nationale Gegensatz der Tschechen gegen die Deutschen und die mit den allgemeinen Oppositionsstimmungen zusammenhängende Kritik der Hierarchie bereits mehrfach zu religiösen Bewegungen geführt, auch waren hier Einflüsse von Sekten mannigfach bereits verbreitet. In diese Gärung schlugen die Gedanken Wiklifs ein, und zu ihrem Vertreter wurde Huß : „Die Kirche die Gemeinschaft der Prädestinierten, gültig in ihr nur das göttliche Gesetz, das Papsttum nur geschichtlich geworden und jetzt tatsächlich in Widerspruch gegen das göttliche Gesetz, also antichristlich, alle kirchliche Autorität davon abhängig, ob sie mit diesem Gesetz übereinstimmt, jedermann verpflichtet, den falschen Autoritäten zu widerstehen; dann die bittere Kritik der Zustände namentlich im höheren Klerus und Mönchtum, der Schäden im Gefolge weltlichen Besitzes und weltlicher Herrschaft der Kirche; die Pflicht der Obrigkeit, solche Schäden zu bessern, das Recht der Laien, Gottes Gesetz auch gegen die Hierarchie zu wenden und schlechte Priester zu meiden ${ }^{181}$ ). Für diese Gedanken Wiklifs starb Huß. Aber sein Mär.

181) Vgl. K. Müller, K.-G. II 79. Der Ausgangspunkt ist auch hier die augustinische Prädestinationslehre. „Denn eben die Prädestinationslehre des Wiklif ist es gewesen, die für sich allein und in ihren Folgerungen Huß vom Boden der katholischen Kirche entfernen mußte. Loserth 59. Im übrigen treten die Konsequenzen des Prädestinationsbegriffes bei Huß noch weniger hervor als bei Wiklif, indem $\mathrm{H}$. die Sakramentskritik sich nicht aneignet und auch den Priesterbegriff viel stärker festhält. Aehnlich wie bei Thomas ist ihm Priestertum und Sakrament das Mittel 
tyrertod entzündete eine sozial- und kirchengeschichtlich überaus folgenreiche Bewegung, die lange Zeit den ganzen Osten erschütterte, den vollkommenen Sektentypus und die revolutionäre Durchsetzung einer absoluten christlichen Sozialordnung aus sich hervortrieb und mit beidem lange - vermutlich noch bis in die Täuferkreise des Reformationszeitalters und in die radikalen Programme der Bauernaufstände hinein - nachwirkte. In dieser Revolution gliedern sich die Einflüsse der »evangelischen* Ideen in drei charakteristisch verschiedene Gruppen, deren Unterschiede für die soziologischen Wirkungen und die sozialen Folgen des Evangeliums überhaupt bedeutsam sind.

Die erste Gruppe, die sog. Kalixtiner oder Utraquisten halten die konservativen Grundlinien Hussens fest: sie werden zu einer schismatischen Anstaltskirche, die Priestertum und Sakrament be-

der Auswirkung der Prädestination, an das bei der Unerkennbarkeit der definitiven Prädestination der Einzelne sich zu halten hat. S. hierüber die treffliche Abhandlung von Gottschick S. 365 . Bes. S. 366 : >Wenn Wiklif allerdings auch erwählten Laien, wenn Christus sie unmittelbar beruft und begabt, die Befähigung zu - priesterlichem Tun im technischen Sinne vindiziert $z \mathrm{u}$ haben scheint, so ist für Huß ein spezifischer Unterschied von Klerus und Laien überall die Voraussetzung،, 366. Die von Christus beherrschte Gemeinschaft der Prädestinierten soll das Gottesgesetz verwirklichen, dessen Inhalt, um es mit einem Worte zu sagen, \das franziskanische Lebensideal ista. S. 368. \Die Faktoren, in welchen die Kirche in die Erscheinung tritt, die Sakramente und die priesterliche Verwaltung, bezw. die Predigt des Gesetzes Jesu, sind die jenem Zweck untergeordneten Mittel«, S. 370. -Weit entfernt von einem subjektivistischen, von dem Einzelnen ausgehenden Gemeinschaftsbegriff, hat $\mathrm{H}$. bezüglich des Leibes Christi durchaus die Vorstellung, daß der Einzelne vom Ganzen getragen wird*, S. 370. >Die Verbindung des Prädestinationsgedankens mit dem der Kirche hat für H. nicht die Entwertung der empirischen Kirche (d. h. der Anstalt), sondern das Bestreben zur Folge, dieselbe in Gemäßheit des Gesetzes Christi zu gestalten a. So haben sich nach dem Gesetz Christi die drei Stände der Kirche, die vulgares, die saeculares domini und die sacerdotes zu verhalten: >Die ersteren haben bei erlaubter Arbeit die Gebote Gottes zu halten; die zweiten haben die Zwangsgewalt oder das Schwert, das ihnen Gott verliehen, dem Zweck der Durchführung des Gesetzes Christi in den Dienst zu stellen und darum sowohl die Diener Christi zu schirmen als die Diener des Antichrists zu vertreiben; die dritten aber, die Stellvertreter Christi, sollen in gesteigerter Nachfolge Christi, die in einem der Welt abgewandten Leben sich kundgibt, der Kirche als Seele das Leben einflößen a $372 \mathrm{f}$. Man sieht, auch hier hat mehr noch als bei Wiklif, das franziskanische Ideal des Gottesgesetzes doch die Ständegliederung der Welt in sich aufgenommen. Iie ganze Kritik wendet sich nur gegen die im Besitz von Macht und Rechtsansprüchen verweltlichte Hierarchie, 
hält, nur den Laienkelch und die Volkssprache sowie ein geistliches Leben der Priesterschaft nach dem Gottesgesetz fordert; der Adel soll ihnen die kirchliche Reform erkämpfen und schützen. Sie haben sich folgerichtig schließlich gegen einige Zugeständnisse mit der Kirche wieder versöhnt; ohne Anschluß an deren Hierarchie und Succession war der Anstaltsbegriff im katholischen Sinne eben überhaupt nicht zu behaupten. Zur Bildung eines neuen, den katholischen ersetzenden Anstaltsbegriffs waren überhaupt keine Ansätze da ${ }^{182}$ ).

Die zweite Gruppe sind die radikalen Hussiten oder Ta b oriten, die durch den kirchlichen Bann zur bewaffneten Revolution und zur selbständigen Organisation nach dem Gottesgesetz getrieben wurden. Mit der religiösen Opposition verbindet sich bei ihnen der nationale $\mathrm{Ha13}$, das Bedürfnis nach einer neuen Nationalkirche, und neben dem für das reine Gottesgesetz eintretenden Adel erhoben sich demokratische Strebungen der bäuerlichen und

um sie in arme Diener Christi nach Matth. 10 zu verwandeln. Landeskirchen, nach dem Vorbild der Apostel seelsorgerlich und priesterlich versorgt, sind sein Ideal, > über deren Begrenzung hat $H$. allerdings nicht weiter reflektiert<, 393. Hiermit sind nun zweifellos im Priestertum, Sakrament und Abfolge von den Aposteln die Elemente des Anstaltsbegriffes bewahrt. Aber andererseits ist gegen Gottschick zu sagen, daß sie doch sehr unsicher gemacht sind und der Uebergang zum Sektentypus nahe gelegt ist. Sobald nämlich das amtierende Priestertum als gegen das Gesetz verstoßend außerhalb der prädestinierten Kirche steht und umgekehrt der prädestinierte Gerechte als Exkommunizierter außerhalb der Anstalt steht, sobald ferner zur Feststellung des einen wie des anderen Umstandes den Laien das Gottesgesetz der Bibel in die Hand gegeben wird, um den einen als bloßen praescitus und den anderen als praedestinatus $z u$ erkennen, ist die wahre Gemeinschaft eine durch die Laieneinsicht in das Gesetz Gottes und durch die Uebereinstimmung der Laien über das Gesetz Gottes zusammengebrachte und es wird die Aufgabe, den Zusammenschluß dieser richtig Urteilenden zu bewirken, die sich dann zur Besorgung der priesterlichen Geschäfte einen aus der Succession stammenden, aber frommen Priester gewinnen mögen. Damit aber ist der Anstaltsbegriff verfü̈chtigt bis auf einen letzten Rest, daß die Gemeinde aus der Succession einen Priester sich besorgen muß. Das das Urteil der Laien regulierende Gottesgesetz ist aber in keiner Weise, wie später das $>$ Wort im Luthertum, zum objektiven Produzenten der Gemeinschaft gemacht, sondern diese ergibt sich aus subjektiver Erkenntnis und Einsicht in das Gottesgesetz. Damit aber ist - wenn freilich auch hier infolge der Ausstoßung durch die Kirche - der Weg zur Sekte betreten, und so sind die Dinge ja auch wirklich gelaufen.

182) Das ist sehr richtig von Gottschick in seinem Verglēich des hussitischen mit dem lutherischen Kirchenbegriff erwiesen. 


\section{4 \\ II. Mittelalterl. Katholizismus. 9. Das absolute Gesetz und die Sekten.}

städtischen Unterschicht. Damit gewinnt die Bewegung ein neues Gesicht : > Nur das göttliche Gesetz, nichts anderes, soll gelten und jeder Laie hat das Recht zu urteilen und zu verkünden, was diescs Gesetz sei, was ihm widerspreche. Demgemäß wird nicht nur die Transsubstantiation und Verehrung der Hostie verworfen, sondern auch die Heiligenverehrung, der Bilderdienst, die ganze Masse der kirchlichen Feiertage, Segnungen und Weihen, der Eid, das Fegefeuer und die Suffragien für alle Toten, die priesterliche Beichte und die Ablässe, die Sakramente der letzten Oelung und Firmung, teilweise auch der spezifische Unterschied von Priestern und Laien, jedenfalls die Stufen des Klerus. Ihre Priester werden nicht durch Bischöfe geweiht, sondern durch die Gcmeinden eingesetzt; sie spenden Taufe und Abendmahl in den cinfachsten Formen und überall ohne Kirchen und Altäre, ohne priestcrlichc Gewänder und Liturgie, alles in tschechischer Sprache ${ }^{1 \S 3}$ ). Damit treten die Wirkungen des evangelischen Gottesgesctzes, d. h. des evangelischen Individualismus, durch kcinen Anstaltsbegriff mehr gebändigt und das ganze katholische Kirchendogma mit allen Konsequenzen vernichtend, schroff zu Tage. Aber damit zugleich wird auch das Gottesgesetz im Sinne des absoluten Naturrechts und des radikalen Christusgesetzes auf das ganze soziale Leben übertragen und nicht mehr durch lï̈rsten und Herrn, sondern durch die Gemeinde der christlichen Gotteskämpfer gewaltsam der Gesellschaft auferlegt. Dieser \%ug zur Gewalt ist ctwas Ncues. Es ließ sich auch aus dem Neuen Testament und dem Christusgesetz nicht begründen; nun griff man auf das alte Testament, seine Gotteskriege und die gewaltsamen Reinigungen Isracls durch fromme Könige, zurück. V'or allem aber : es ist nicht mehr das Wiklifitische Gesetz der lintsprechung von Recht ind Macht mit der christlich-sittlichen Gerechtigkeit und des Liebesdicnstes der Herrenstände für das Ganze, sondern das christliche Naturrecht der demokratischen Freilhcit und Gleichhcit. 1)er Prädestinationsgedanke hört auf zu wirlien und die rationalistisch-stoisch-christliche Gleichheitslehre wird als im Liangelium crncuert aus dem Urstand auf die Gescnwart iibertrasen: "die, die mit der Sünde und Welt ganz brechen. halen die Aufgabe, ihr cine neue Ordnung zur Seite zu stcllen, dic nicht auf lamilic und Staat. Eigentum und Herrschaft,

1sib Ich gube hice und weiter unen die rortreff lich knappen Formulierungen $\mathbf{K}$. Miillers, K.-L. II 4 . 
sondern auf die christlichen Gedanken der allgemeinen Gleichheit an Besitz und sozialem Verhältnis gebaut wäre... So versucht man jetzt, das Sondereigentum samt den Klassenunterschieden, Steuern und Abgaben abzuschaffen. An die Stelle des luxemburgischen tritt das Königtum Gottes d. h. in Wirklichkeit das des souveränen Volkes, das sich in allem als Gottes Werkzeug fühlt. Die Versuche sind freilich kläglich mißlungen und die Revolution hat schließlich nur die Herrschaft des Adels befestigt und die anderen Klassen zurückgedrängt. Aber die propagandistische Kraft jener Ideale blieb im Volk bestehen ${ }^{184}$ ). In beiden Richtungen, in der Herausarbeitung des Sektentypus wie in der des individualistisch-kommunistischen christlichen Sozialismus, vor allem in der Proklamation der Gewalt, und des heiligen Krieges, sind die Grundgedanken Wiklifs und Huß' weit überschritten; K. Müller verweist mit Recht auf den Gegensatz der Independenten gegen die Puritaner ${ }^{185}$ ); es ist in der Tat ein ganz ähnlicher Fall : über die kirchlich-anstaltlich gefaßte Idee einer christlichen Gesellschaft schreitet die sektenhaft und radikal-sozial entwickelte Konsequenz hinaus, nachdem sie in dem kirchlichen System durch dessen Objektivitäten und Relativierungen zurückgehalten gewesen war. Es. liegt daher nahe genug, nach den Einflüssen $z u$ fragen, die diese Abbiegungen und Fortentwickelungen konkret veranlaßt haben. Hier sind nun die einen der Meinung, daß alles sich als Konsequenz der radikalen Fortbildung der Ideen Wiklifs begreifen lasse. Andere greifen für die Erklärung der Fortbildung zum Sektentypus auf waldensische Gruppen zurück, die in Böhmen unzweifelhaft vorhanden waren, aber deren Einwirkung auf die Taboriten sich allerdings nicht belegen läßt. Noch schwieriger und wichtiger ist die Frage nach dem Ursprung des egalitären Sozialismus und des revolutionären Gewaltrechtes. Auch das könnte aus der freilich ganz andersartig prädestinatianischaristokratischen Idee Wiklifs sich erklären lassen, die bei der Entfaltung ihrer revolutionären Konsequenz aus der Herstellung der wahren Aristokratie und ihres Liebesdienstes für das Ganze leicht auch in radikale Demokratie umgeschlagen sein könnte. Immerhin ist der Unterschied grundlegend. So denken andre an Einflüsse der joachimitischen Eschatologie mit ihrem Zeitalter der Gleichheit und Freiheit, wieder andere an alt-

184) K. Müller, K.-G. II 85 .

185) Ebd. II 86. 
slavische kommunistische Ideen oder an die Umwandlung der Wiklifitischen Idee 'in bäuerlich und städtisch-handwerkerlichen Kreisen zur Demokratie oder an die Wirkungen, die der naturgemäße Kommunismus eines langen Heer- und Wanderlebens mit sich brachte ${ }^{188}$ ). Ich kann über die Frage der Herkunft nichts sagen und möchte nur den sachlichen Unterschied feststellen, der $z$ wischen der hier auftauchenden egalitären Idee des christlichen Naturrechts und evangelischen Gottesgesetzes gegenüber dem aristokratisch-prädestinatianisch gedachten Liebeskommunismus des Wiklifitischen Gesellschaftsideals ebenso wie gegenüber der die Naturdifferenzen aufnehmenden und organisch-patriarchalisch bewältigenden realistischen Sozialphilosophie des Thomas besteht. In Wahrheit kommt hier - durch welche Vermittelungen immer - die stoisch-rationalistische, egalitäre kommunistische Fassung des Urstandes und des evangelischen Gesetzes zum Durchbruch, wie sie die großen Kirchenväter des 4 ten Jahrhunderts gelehrt hatten, und an einer irgendwie bestehenden Kontinuität mit dem altchristlichen Radikalismus ist nicht zu zweifeln, wenn auch sicherlich die Gründe dieser christlichen Revolution nicht theoretische

180. Den Sektentypus führen Preger, „Ueber das Verhältnis der Taboriten zu den Waldesiern des 14. Jahrh.e (Abhh. der hist. Klasse des Münchener Akad. d. Wiss. 1887) und Haupt, Die Sekten in Franken vor der Reformation 1882, auf waldensische Einflüsse zurück, die unzweifelhaft möglich sind. Ihnen schließt sich Volpe, September, S. 297 f. an. Dagegen behauptet Loserth in lehrreichen, für aie Ideen Wiklifs bedeutsamen Rezensionen, Gött. Gel. Anzz. I889, S. 475 und Ebd. I89I S. I 40 ff. die Unmöglichkeit, diese Einflüsse bis jetzt nachzuweisen, und macht wahrscheinlich, daß es sich um reine Konsequenzen der Wiklifschen Lehre vom Prüfungsrecht der Prädestinierten handelt. Das ist möglich. Unmöglich scheint die Herleitung von Wiklif dagegen bei den individualistisch-kommunistischen Lehren. In ihrer Wiedergabe folge ich $K$. Müller, der seinerseits dem mir nicht zugänglichen F. v. Bezold, Zur Geschichte des Hussitentums, folgt. Sind diese Angaben richtig, so ist eine Herleitung von der Wiklifie schwer denkbar. Hier kann Wiklifs Lehre von der Bestimmung des Gottesgesetzes, auch für die weltliche Ordnung maßgebend zu sein (Loserth G. G. A. 1889, S. 483-492), nicht ausreichen; denn die Auffassung des Gottesgesetzes selbst ist eine andere. Woher diese kommt, vermag ich nicht $z u$ sagen. Ich halte bei der starken Einwirkung chiliastischer Ideen (s. Loserths übrigens sehr dürftige Skizze, G. d. spät. Mittelalters, S. 480 f.) joachimitische Einflüsse für möglich. Müller nennt altslavischen Kommunismus, was mir Max Weber als unmöglich bezeichnet, da dieser als Hauskommunion die Großfamilie bedeute und ganz anders konstruiert sei. Weber selbst denkt an Folgen des gemeinsamen Kriegs- und Wanderlebens. Die auf Palacky beruhende verhält- 
Ideen, sondern in letzter Linie praktische Verhältnisse und soziale Strömungen gewesen sind ${ }^{187}$ ).

Die dritte Gruppe zweigte sich allmählich von den Taboriten $a b$ und kam in den "mährischen Brüdern" zu ihrem Abschluß. Sie bekennen mit jenen das wiklifitisch-franziskanische Ideal, verwerfen aber die Mittel der Gewalt als unchristlich. So entsteht hier der religiöse Verein oder Konventikel mit dem Streben, nach innen im eigenen Kreise möglichst das Liebes- und Heiligkeitsideal $\mathrm{zu}$ verwirklichen, nach außen von Staat und Gewalt und weltlicher Macht sich zurückzuziehen und in freiwilliger $\mathrm{Zu}$ sammengehörigkeit das evangelische Gottesgesetz soweit zu verwirklichen, als es die Fortdauer der Welt und ihrer Ordnungen ermöglicht; damit ist auch der egalitäre Sozialismus wieder aufgegeben und durch den das Privateigentum und die weltliche Berufsarbeit voraussetzenden Liebeskommunismus der Gesinnung und praktischen Liebestätigkeit ersetzt. Es ist $\gg$ der erste große Versuch der Laienwelt, eine Religiosität zu verwirklichen; die nicht auf Kompromissen mit der Welt beruhte und mit sakralen Weihen und einer halben Sittlichkeit zufrieden wäre, sondern das ganze Leben in ihren Dienst nähme, der Rückzug der ernsten Christen aus der gefährlichen Welt zu enger brüderlicher Gemeinschaft, ausschließlichem Streben nach persönlicher Heiligung im Dulden und Entsagen, in unbedingter Friedfertigkeit und Selbstlosigkeit ${ }^{188}$ ). Ihr Stifter ist ein Laie, Peter von Chelzic, der von jeder durch Gewalt erfolgenden Propaganda der Wiklifie sich zurückzog, von allen

nismäßig ausführliche Skizze bei Kautsky, Gesch. d. Sozialismus, I I S. 195-239, rät auf Begharden\&, die auf Höfler, Geschichtsschreiber der hussitischen Bewegung 1856-66 wesentlich beruhende Darstellung von R. Zöllner, Zur Vorgeschichte des Bauernkrieges, 1872 , rät auf Begharden, Dolcinisten, italienische Chiliasten und altslavische kommunistische Gewohnheiten und Kriegskommunismus. Bezüglich der mit allen christlichen Ideen unverträglichen Gewaltsamkeit ist $z \mathfrak{u}$ beachten, daß hier das alte Testament zu Hilfe genommen wird neben dem neutestamentlichen Gottesgesetz, wie denn das alte Testament für die biblische Begründung einer weltlichen Ethik und sozialer Ideen oft aushelfen muß. Diese Ergänzungsrolle des A.T. neben dem. N.T. gerade in der Ethik und den Soziallehren verdiente eine Darstellung für sich. Sie wird uns besonders noch beim Kalvinismus beschäftigen.

187) Dás letztere mit Recht von K. Müller hervorgehoben, II 85 und I 207 ; nur hebt hier Müller den Unterschied vom späteren offiziellen kirchlichen Naturrecht nicht hervor, das gerade mit jenen patristischen Lehren gar nicht identisch ist.

188) K. Müller II 86. 


\section{11. Mittelalterl. Katholizismus. 9. Das absolute Gesetz und die Sekten.}

Christen, nicht bloß vom Klerus, die Zurückhaltung vom sündigen Treiben der Welt, insbesondere vom Handel und öffentlichen Leben mit seiner Herrschaft und $Z$ wangsgewalt, verlangte. Ackerbau und Handwerk sollten die Beschäftigungen der Christen sein, und gegen die Gewalt sollten sie nur Unrecht leiden, nicht tun. An diesem Punkte hatten Wiklif und Huß der gemeinkirchlichen Lehre von den Ständen der Kirche noch näher gestanden, den Eingriff der weltlichen Gewalt zur Reform der Kirche gefordert und die christliche Gesellschaft als eine Staat und Kirche gemeinsam umfassende und zur Wechselwirkung verbindende betrachtet; die Brüder lösten die religiöse Gemeinschaft vom Staate und schufen eine Gesellschaft in der Gesellschaft. Von der unmöglich erscheinenden Reform der Gesamtgesellschaft zog sich die christliche Idee auf sich selbst zurück, steigerte in ihrem Kreise den Individualismus der bloß religiösen Gleichheit und erfüllte ihn mit dem caritativen Gesellschaftsideal. Es ist die volle Rückkehr zum altchristlichen Sozialideal, nachdem die christliche Kultur der Kirche sich als eine Verweltlichung und Brechung der christlichen Mo. ral und die gewaltsame Durchsetzung des absoluten Natur- und Gottesgesetzes als eine blutige Utopie erwiesen hatte. "Die Kirche sollte arm, ohne Prunk und ohne Zeremonien, ohne Rechtsverfassung und frei von jeder Verbindung mit irdischer Gewalt, die Zugehörigkeit $\mathrm{zu}$ ihr durchaus freiwillig sein, ihr Priesterstand ohne Pfründen und ungelehrt, nur durch Wort, Gebet und Brotbrechen dem Volk dienen und seinen Unterhalt durch seiner Hände Arbeit gewinnen ${ }^{189}$ ). So lange man Priester hatte, die aus der katholischen Kirche zu der Gemeinde übergetreten waren, war das Priestertum kein Problem; als die guten Priester ausstarben, mußte man von den nahverwandten Waldensern sich einen Bischof weihen lassen. In dieser Wahrung der Sukzession liegt der letzte, allein noch beibehaltene Rest der Anstaltskirche. Die Zucht und Erziehung der Einzelnen übt aber nicht der Priester, sondern die Gemeinde selbst aus, ein deutliches Zeichen für das Ueberwiegen des Sektengedankens. Zugleich ist zu beachten, daß diese Sekte den bäuerlichen sowie handwerkerlichen Schich-

189) Ebd. II 15I. Wenn Müller hinzufügt: \Es sind die Heiligkeitsideale der mittelalterlichen Kirche, aber als Aufgabe der ganzen Gemeinde«, S. 152, so wäre noch beizusetzen: sund ohne die Vor- und Unterstufe der relativ naturrechtlichen Weltmoral «. An andérem Ort (Kultur d. Gegenwart I, Bd. IV S. 211 u. K.-G. II 30) hat der Verfasser das selbst betont. 
ten angehört und so auch ihrerseits den Zusammenhang und die Wahlverwandtschaft des sektenhaften und radikalen Christentums mit den Stimmungen und Bedürfnissen, mit den Lebensbedingungen und Weltfremdheiten der Unterschicht dartut; nur in dem Gesichtskreis der Unterschichten ist eine solche Fassung des Gesellschaftsideals möglich, und zugleich nur durch solche religiöse $\mathrm{Ge}-$ meinschaften läßt sich ihr Bedürfnis nach Persönlichkeit befriedigen, wenn es aus irgend welchen Gründen bereits geweckt ist. Um 1500 erhob sich gegen diese Verengung eine junge Partei, die; aus den höheren Schichten stammend, wieder ein positiveres Verhältnis zur Welt verlangte, den Eid und die Bekleidung öffentlicher Aemter freigeben wollte, ganz ähnlich wie die alte Christenheit in die weltlichen Berufe hineinwuchs. Der Entwickelungsprozeß von damals beginnt damit von neuem, führt aber bei der Enge und Kleinheit der Sekte nicht $z u$ den Ergebnissen einer die urchristliche Moral relativierenden kirchlichen Kultur, wie das das Ergebnis in der großen als Kirche sich gestaltenden Christenheit des Altertums war. Es bleibt bei einem nur etwas mehr der Welt angepaßten Konventikelwesen.

Der Hussitismus - dessen Kenntnis übrigens in der deutschen Forschung noch sehr zu wünschen übrig läßt, und die tschechische ist für uns unzugänglich - ist freilich zunächst eine lokale Angelegenheit, aber von stärkster historischer Fernwirkung und vor allem überaus bedeutsam und typisch für den ganzen hier besprochenen $Z$ weig der christlichen Soziallehren. Er zeigt die Herauslösung deș Sektentypus aus einer Entwickelung der kirchlichen Gedanken, die unter dem Einfluß der Bibel und der sozialen Verhältnisse bereits stark die individualistischen und die radikalethischen, die Welt auf ein Mindestmaß der Berechtigung herabdrückenden Forderungen betont hatte; von einer Askese im eigentlich mönchischen Sinne der Mortifikation ist nicht die Rede, sondern nur von einer Zurückhaltung gegen Staat, Macht, Recht, Eid, Krieg, Reichtum; das sollten sich diejenigen merken, welche in solchen Zügen nur die »katholische Verderbung des Christentums zur Askese ", und nicht die urchristliche Lebensstellung fortwirken sehen. Weiter ist es bedeutsam, wie in diesem christlichen Radikalismus die eigentlich-christlichen Liebesideen und der rein religiöse, die weltliche Ungleichheit einschließende Individualismus sich teils vermischen, teils entzweien mit dem egalitären Individualismus und dessen kommunistisch-demokratischer Konsequenz, 
das letztere ganz offenkundig nicht eine eigentlich-christliche, sondern eine stoisch-rationalistische Idee, die von demokratischen, aus der sozialen Entwickelung sich ergebenden Strömungen ergriffen und getragen wird und sich bei der allgemeinen Christlichkeit der Atmospkäre eine christlich-biblische Legitimation gibt. Schließlich ist charakteristisch die trotz alledem sich ergebende Schwierigkeit für den christlichen Universalismus. Er läßt sich behaupten nur in der chiliastischen Form, daß die in der Welt Gedrückten dann bei der großen Endentscheidung zu ihrem Rechte kommen werden. Soferne aber der universalistische Drang bereits in der Gegenwart sich betätigen will, entsteht neben jener leidenden, duldenden und hoffenden Christlichkeit die aggressive, die das Ende gekommen glaubt und damit sich zur Gewalt berechtigt meint, die den Gotteskrieg der Endzeit mit der in der Endzeit auch von der biblischen Apokalypse in Aussicht genommenen Gewalt kämpft, oder man rechtfertigt die Revolution durch die Anleihe bei den Gotteskriegen und den Sozialidealen des alten Testamentes. Alle diese Dinge haben sich dann in dem Täufertum der Reformationszeit und in dem englischen Independentismus wiederholt.

Aus điesem Knäuel verschiedenster Wirkungen. heben wir zunächst đie Fortwirkung der egalitären und darum revolutionären Fassung des christlichen Gottes- und $\mathrm{Naturgesetzes}$ heraus. Sie ist jene rationalistische Umdeutung der rein religiösen Gleichheit des Evangeliums, die unter dem Einflusse des stoischen Rationalismus bereits die großen Kirchenväter des vierten Jahrhunderts wenigstens für den Urstand vollzogen hatten, und die dann hinter der prädestinatianischen Lehre Augustins und hinter der an Aristoteles angelehnten Lehre von der naturgesetzlichen Ungleichheit zurückgetreten war. Durch welche Zusammenhänge dieses Wiederhervortreten bedingt ist, kann bei der jetzigen Kenntnis dieser Dinge schwer gesagt werden. Wir sahen diese Ideen bereits im Joachimitismus und bei Dolcino sich äußern, beim letzteren im Zusammenhang mit der Bauernerhebung des Val Sesia. Genährt sind diese Gedanken ja immer von der fortdauernden patristischen Tradition, von den demokratisch-republikanischen Elementen des Corpus juris und der religiösen Gleichheitsidee, die sich im Mönchtum auch ihre äußere soziale Form stets von neuem schuf. Im einzelnen freilich sind es jedesmal besondere Zusammenhänge 
und äußere Anlässe, vor allem demokratische Strömungen der bäuerlichen und unteren städtischen Bevölkerung, die diese Ideen hervorbrechen lassen und sich zu Nutze machen. Sie finden dann literarische Advokaten oder rhetorische Agitatoren, die ihnen juristische und theologische Lehren oder auch alte Sektentraditionen zur Verfügung stellen und ihre Rolle in den Bewegungen mitspielen. Daß solche Ideen weit verbreitet sind und auf allgemeines Verständnis rechnen, zeigt der Radikalismus, mit dem der allerdings sehr berüchtigte, aus dem Beginn des I4. Jahrhunderts stammende Roman de la Rose diese egalitär-demokratischen Ideale als solche des Urstandes verkündigt; daß ihm die besonderen christlichen Beziehungen hierbei fehlen macht nicht viel aus, denn das Urstandsgesetz ist eben zugleich das christliche Gottesgesetz $\left.{ }^{190}\right)$. Praktisch äußern sich diese Ideen in den großen Bauernaufständen des Spätmittelalters, die meistens zugleich mit der radikalen demokratisch-egalitären Naturrechtsidee arbeiten und sie mit der christlichen Freiheit und Gleichheit sowie mit dem Urstandsgesetz in Verbindung bringen. Der nächste Anlaß dieser Bauernaufstände liegt selbstverständlich auf ökonomischem und sozialem Gebiet, bald in der Besserung der Lage der abhängigen Bauern, die in England die Grundherren zu einem Versuche, zwangsweise die Hörigkeit wieder herbeizuführen und der Leutenot abzuhelfen, veranlaßte, bald in der Aussaugung der Bauern durch Kriegslasten wie in Frankreich, bald, wie besonders in Deutschland, in anderen komplizierten Verhältnissen, die hier nicht weiter zu erörtern sind. Aber sie bemächtigen sich dabei großenteils der egalitären und kommunistischen Fassung des christlichen Naturrechts, wobei die Wege, auf denen dies geschehen sein mag, gleichfalls hier nicht weiter erörtert werden können. Genug, daß die egalitär-sozialistisch-demokratischen Fassungen des natürlichen und göttlichen Rechtes sowie der darauf beruhenden christlichen Freiheit nirgends aus der Dialektik der reinen christlichen Idee hervorgehen, sondern überall erst durch politische und soziale Revolutionen herbeigeführt sind und auch in der Tradition ihren Anhalt nur an denjenigen Elementen der patristischen Ethik finden, die nicht der christlichen Ideeentwickelung selbst entstammen. Sofern diese Ideen mit Gewalt durchgesetzt und die Revolution christlich begründet werden soll, muß auch hier immer das Alte Testament aushelfen ${ }^{191}$ ).

$\left.{ }^{190}\right)$ S. v. Bezold, Lehre von der Volkssouveränität, S. $340 \mathrm{f}$.

101) Die Aeußerungen dieser demokratisch-kommunistischen Ideen sind ge- 
Weit entfernt von diesem revolutionären Geiste sind dagegen diejenigen Gruppen, die aus dem Individualismus des Sektentypus und aus dem Ideal der Unterwerfung der Gesellschaft unterden weltindifferenten Radikalismus der Jenseitsethik und des Armutsideals hervorgehen. Das ist eine zweite von dem Sektentypus ausgehende Strömung, die freilich mit der ersteren sich mannigfach vermischt. Doch sind beide stets $2 \mathfrak{u}$ unterscheiden; sie verhalten sich wie das Taboritentum zu den mährischen Brüdern, nur daß in beiden Fällen der den Böhmen eignende Gegensatz gegen die Kirche als solche fehlt. So sind lediglich in diesem zweiten Sinne diejenigen Experimente des Kommunismus $z u$ verstehen, die in den kleineren geschlossenen Kreisen der Begarden und Beginen, der Brüder vom gemeiṇsamen Leben und ähnlichen Or-

sammelt von Kautsky in seiner ,Geschichte des Sozialismus I I, leider mit sehr geringer Genauigkeit und ohne jedes Verstăndnis für die religiösen Motive und die Unterschiede der verschiedenen Gruppen. Der christliche Kommunismus des Mittelalters ist ihm eine kümmerliche, wesentlich durch literarische Ueberlieferungen der Ideen des alten christlichen Lumpenproletariats entstandene Frühgeburt des Kom-

- munismus, die, weil sie mit der noch herrschenden Produktionsstufe und mit der Tendenz der -Entwickelung ` noch nicht übereinstimmt, zugleich mystisch, asketisch, politisch unfähig und wissenschaftsfeindlich ist, während der reife, mit der Produktionsstufe der Gegenwart übereinstimmende Sozialismus von heute um deswillen in allen Stücken das Gegenteil ist I Reichliches Material, vor allem über die süddeutschen Bauernbewegungen und die Taboriten, gibt R. Zöllner, Die Vorstufen des Bauernkrieges. Ueber den englischen Bauernaufstand ${ }_{3} 38 \mathrm{I}$ und sein christlichkommunistisches Programm Kautsky I I S. 183-195. Die französische Jacquerie hat nach Luce, Histoire de la Jacquerie ${ }^{2}, 1894$, keine derartigen ideellen Elemente. Die Ideen der deutschen Bewegungen werden beleuchtet durch die Reformatio Sigismundi (ed. Böhm 1876), die neben einem relativ konservativen kirchlichen Programm doch im Interesse der Sklaven und Hörigen das Naturrecht und die christliche Freiheit, d. h. die Gedanken der Gleichheit und des natürlichen Gemeinbesitzes geltend macht. Böhm S. 48. Einen Abriß der deutschen bäuerlich-revolutionären Bewegungen gibt Brieger, Ref. (Ullsteinsche W. G.) S. 294-306. Hier zeigt sich überall die Gleichung der revolutionären Forderung mit dem Gottesgesetz und Naturgesetz des Urstandes, wo Adam grub und Eva spann, ebenso die Motivierung der Gewalt mit dem A. T. - Wie unsicher aber auch sonst kundige Theologen hier tasten, zeigt Seeberg, D. S. I $166 \mathrm{ff}$. In all den verschiedenen Aeußerungen Seebergs über das mittelalterliche Naturrecht sind nirgends dessen verschiedene Elemente und dessen Unterscheidung in absolutes und relatives Naturrecht erkannt, und ist insbesondere die tiefe innere Notwendigkeit der Rezeption dieses Begriffes überhaupt nicht verstanden. 
ganisationen gemacht worden sind. Es sind Versorgungsanstalten für Hilflose und Alleinstehende, für beschauliche Gemüter und Ausgestoßene. Sie werden im einzelnen technisch zu Produktiv-Assoziationen, bedeuten aber in ihrer Idee nicht ein die Gesellschaft reformierendes Naturrecht, sondern einen von ihr zurückgezogenen Kreis des asketischen Liebeskommunismus. Sie beleben an ihrem Teil die Laienreligion und damit den religiösen Individualismus, wie das ähnlich auch die Mystiker und die sog. vorreformatorischen Verfasser religiöser Traktate getan haben, aber ihnen fehlt jedes Programm der Gesellschaftsreform. Sie entsprechen dem sozialpolitisch harmlosen Typus des urchristlichen Liebeskommunismus.

Es ist nun aber schließlich nicht zu verwundern, wenn dieser religiöse Individualismus und der Radikalismus des evangelischen Gottesgesetzes noch weiter greift, wenn er auch' in das öffentliche Leben von Staat und Kirche und damit in die Ideenwelt der ihm gegenüberstehenden offiziellen Ordnungen selbst hineinwirkt. Vor allem so, wie er sich in der Forderung der armen und rein spiritualen Kirche kundgab und damit zugleich auch dem Verhältnis von Staat und Kirche neue Grundlagen schuf, mußte er auch der kirchlichen und juristischen Literatur Reformgedanken zuführen, seit die Reaktion gegen das überall eingreifende päpstliche Universalreich sich allenthalben zu regen begonnen hatte. Die Weltherrschaft und universale Gesellschaftsleitung der Kirche hatte, wie wir gesehen haben, auf der Abwesenheit eines eigentlichen Staates, auf dem Ersatz des Staatsgedankens durch den der kirchlichen Einheit und Leitung und schließlich auf der all das ermöglichenden Einfachheit der sozialen und wirtschaftlichen Verhältnisse beruht. Indem nun die nationalen Staaten und ein von der Ethik der Kirche nicht mehr so einfach zu bewältigendes Gesellschaftsleben sich geltend machten, entstanden die Krisen des mittelalterlichen Kirchentums und die Versuche einer Neuordnung. Die Staaten mußten nach Einfluß auf das Kirchentum ihres Gebietes streben und dazu Macht und Recht des Laientums in der Kirche proklamieren, wozu sich die Sektengedanken wenigstens teilweise als geeignet erwiesen, bis man lieber den Weg der Verhandlungen und Konkordate beschritt und die Fürsten mit dem Papste sich in die kirchliche Macht teilten. Andrerseits wurde damit auch der Bau der Kirche, die mit einer übergroßen Aufgabe sich übernommen hatte und 
an deren Konsequenzen zu leiden anfing, von außen und innen her erschüttert, und mußten die Vertreter des kirchlichen Interesses nach Reformen streben, die teils die Hilfe der Laien heranzogen, teils den Ausweg im Ideal der armen entweltlichten Kirche fanden und damit auch ihrerseits sich einzelnen Forderungen des Sektentums näherten, bis eine verstärkte Zentralisation der Kirche im Papsttum und die Konkordate mit den Landesfürsten solchen Reformen praktisch für immer ein Ende machten.

In ersterer Hinsicht sind es die Juristen und Theologen des französischen Königtums und auf ihnen fußend die literarischen Helfer Ludwigs des Bayern, und unter ihnen wiederum vor allem Marsilius von $\mathrm{Padu}$ a in seinem berühmten Defensor pacis, der den Frieden und die Reform der christlichen Gesellschaft durch die Sicherstellung der Staatsgewalt und die Zurückführung der Kirche auf ihren biblischen, vorkonstantinischen Zustand erreichen will. Die Analogie mit dem anfänglichen Gedankengange Wiklifs ist hier unverkennbar ${ }^{192}$ ). Doch bildet für die Sicherstellung des Staates hier nicht die prädestinatianische Gewaltbegabung, sondern die allgemeine offizielle Naturrechtslehre den Ausgangspunkt. In Bezug auf den Staat werden daher die mit der thomistischen Theorie gemeinsamen naturrechtlichen und aristotelischen Elemente nur stärker angespannt. Das positive Gesetz und die Institutionen der Regierung entspringen aus dem Willen des eigentlichen Gesetzgebers, des Volkes, oder seiner Stellvertreter, sind in ihrer Ausübung an die Kontrolle durch jenen Gesetzgeber gebunden, im übrigen vernunftgemäß monarchisch wie Gottes Weltregierung. Diese nur sehr relativ demokratischen Sätze gehen über die thomistische Lehre nur durch eine noch stärkere Betonung des Naturrechts und eine demokratischere Fassung desselben hinaus. Sie bekommen aber freilich ein völlig anderes Gesicht durch die ganz andersartige Stellung, die nun der Kirche dem Staate gegenüber gegeben wird. Diese ist nämlich hier nach dem mit dem Naturrecht an sich identischen Gottesgesetz, ganz wie der Staat zunächst aus dem Konsensus der Beteiligten hervorgeht, so auch ihrerseits in erster Linie identisch mit der Gemeinde der Gläubigen und nach der besonderen

$\left.{ }^{192}\right)$ Die Analogie ist auch später von Papst Gregor XI. ausdrücklich ausgesprochen worden; s. das Schreiben bei Riezler S. 297; als »waldensisch « bezeichnet seine Sätze Johann von Paris, s. Haller, Papsttum und Kirchenreform I, I903, S. 74. Keller S. IO2-II 3 reklamiert ihn für waldensische Einflüsse. 
Offenbarung des Gottesgesetzes in der Bibel auf ein rein spirituales Regiment durch das von der Gemeinde einzusetzende d. $h$. zur Weihe zu präsentierende Priestertum beschränkt. Die Gemeinde bestellt, kontrolliert, richtet dementsprechend ihre Priester. Die letzteren sind unter sich alle gleich, und die Bischöfe haben nur akzidentelle Vorrechte $d . h$. vor allem die Priesterweihe, in der die Sukzession von Christus her behauptet wird. Das Papsttum und die Hierarchie ist eine unheilvolle Stiftung Konstantins und lediglich menschlichen Rechtes, allenfalls für eine geistliche Leitung und Beratung unter Kontrolle der weltlichen Gewalt zu brauchen. Die Priester sollen Sakramente spenden und Buße verkünden, wobei aber das Bußsakrament nur deklaratorischen und nicht effektiven Charakter hat und die Gemeinde über den Fall entscheidet. Die Normen sind ausschließlich das Gottesgesetz der Bibel und im Zweifelsfalle das von der weltlichen Gewalt als dem Vertreter der Gemeinde zu berufende Generalkonzil aller Gläubigen oder ihrer Repräsentanten. In allen weltlichen Dingen, in Gerichtsbarkeit und Besitzrecht, sind die Priester von der weltlichen Gewalt abhängig, ihre Zahl ist von ihr zu bestimmen. Sie sind zum armen Leben in der Nachfolge Christi verpflichtet. Ihr Strafrecht, auch gegen Ketzer, beschränkt sich auf Ermahnung und Drohung; gemeinschädliche Ketzer beseitigt die weltliche Gewalt. Die äußere Durchführung des Gottesgesetzes unter Lohn und Strafe bringt erst das Jenseits; im Diesseits herrscht im Staat das politische Naturrecht und in der Kirche das Gottesgesetz in Gestalt der spiritualen Seelenleitung, die aber nie in Rechte des Staates eingreifen darf. Es ist deutlich, daß in alledem wesentlich die Interessen der weltlichen Gewalt bestimmend sind und daß das demokratische Gemeindeprinzip vom politischen Naturrecht auf das geistliche übertragen ist. Aber es ist doch bei aller Belassung des Priestertums und der Sakramente eine außerordentliehe Schmälerung des Anstaltscharakters, indem aus der objektiven priesterlichen Anstalt eine sich selbst nach dem Gottesgesetz regierende Gemeinde wird, die nun freilich dadurch, daß überall in ihrem Namen die sie vertretende politische Gewalt handelt, zu einer Dependenz der Staatsgewalt wird. Wenn auch an der religiösen Selbständigkeit der Gemeinde hier kein Interesse stattfindet, so ist doch unverkennbar, daß diese ganze Theorie aus der Atmosphäre des Individualismus und des reinen Christus-Gesetzes hervorgeht, den das franziskanische Programm der armen Kirche und der Laienreligion um sich ver- 
416 II. Mittelalterl. Katholizismus. 9. Das absolute Gesetz und die Sekten.

\section{breitete $\left.{ }^{1020}\right)$.}

Von stärkerem religiösen Akzent und kirchlich konservativer ist die Lehre des zweiten großen literarischen Anwalts in diesen Kämpfen, Wilhelm von Occams. Er betrachtet geistliche und weltliche Gewalt als die beiden koordinierten und auf $\mathrm{Zu}$ sammenwirken angewiesenen Häupter der christlichen Gesellschaft, wo nur in etwaigem Notstand ein Eingriff des Papsttums in das korrumpierte weltliche Regiment oder umgekehrt ein solcher der Laiengewalt in ein verweltlichtes Kirchenregiment als Notrecht zu behaupten ist. Die Bedrohung der franziskanischen Armutslehre durch Johann XXII. und die Veräußerlichung der politisierten Kirche scheint ihm nun einen Notstand der letzteren Art zu bedeuten, und er ruft Staatsgewalt und Laien in dieser Not zur Hilfe auf, da schließlich die Mitgliedschaft an der Kirche nur durch den Glauben und nicht durch das Priestertum bedingt ist. Auch hier ist es die sektenhafte Konsequenz der franziskanischen Laienreligion, die freilich nur als vorübergehendes Notrecht proklamiert wird, die aber dauernde Wirkungen zurückläßt : „Der Papst und sogar ein von ihm berufenes Konzil können irren; dann bleibt nur eine Kirchenversammlung, die auf dem Gemeindeprinzip und auf indirekten Wahlen beruhen und auch das weltliche Element nicht ausschließen soll*, *ja am Ende sind auch die Weiber nicht auszuschließen; denn in Glaubenssachen ist kein Unterschied zwischen geistlich und weltlich noch zwischen Mann und Weib. Das Notrecht selbst, das zu diesen radikalen Konsequenzen führt, wird mit dem im Naturrecht gelegenen Billigkeitsrecht begründet, das ja auch schon bei Thomas gegen das positive Recht die eigentlichen Intentionen des Naturrechtes und des Gottesrechtes im Notfalle sicherstellen durfte und mußte. So geht auch hier die Individualisierung der Religion in die Nähe des Sektentypus und erhebt sich auch hier mit diesem zusammen das radikale christliche Natur- und Gottesgesetz, bald mehr betont von der Seite der Armuts- und Liebesidee, bald mehr von der der Gleichheit der Individuen ${ }^{192} \mathrm{~b}$ ).

192 a) Ucber Marsilius und seine Vorgänger s. Riezler, Die literarischen Wi: sacher der Päpste zur Zeit Ludwigs d. Bayern 1874, der aber Marsilius m. E. viel zu sehr modernisiert und die entscheidenden Gesichtspunkte der mittelalterlichen Gesellschaftslehre nicht beherrscht. Ueber die ganze Lage sehr lehrreich Haller, Papsttum und Kirchenreform I; auch K. Köhler, Staatslehre der Vorreformatoren (Jahrbb. f. deutsche Theol. XIX u. XX).

192 b) Ueber Occam s. Riezler 249 ff., bes. 260-262. Ueber den Einfluß Mạr- 
Von kirchlicher Seite her ist es die Rechtslehre und Theologie der konziliaren Bewegung, die aus der kirchlichen Ueberlieferung selbst ein neues Prinzip des Kirchenbegriffes zu schaffen unternahm, seit die große soziale Utopie der päpstlichen Universalkultur und Universalherrschaft an den Folgen ihrer eigenen annähernden Verwirklichung $\mathrm{zu} \cdot$ Grunde $\mathrm{zu}$ gehen begann ${ }^{193}$ ). Sie hat $\mathrm{zu}-$ nächst bei dem Rückgang von dem Papsttum auf Bischöfe und Priester den Anstaltsbegriff nicht verlassen; aber in dem Maße, als sie das Laientum zu Trägern des Christentums und Richtern über die Kirche machte, hat sie sich auch ihrerseits teils dem Sektentypus, teils bei der Entwickelung demokratischer Grundlagen den individualistisch-rationalistischen Elementen des kirchlichen Naturrechts genähert. Indem man gegen das relative $\mathrm{Na-}$ turrecht des Sündenstandes und die Verfestigung der politischkirchlichen Gliederungen sich wandte, bedurfte man des absoluten Naturrechtes, und konnte es hier nun mehr mit Wiklif in der rein christlichen Gestalt des absoluten Liebeskommunismus und der Aufopferung der prädestinatianisch begabten Rechts- und Machtinhaber für das Ganze oder mehr in der rationalistisch-individualistisch-egalitären Gestalt aufsuchen, wie es von den stoischen und römisch-juristischen Elementen des kirchlichen Gedankenschatzes her sich darbot. Die Wiklifitische Lehre wurde von der ganzen Bewegung schroff verworfen; so blieb wesentlich das letztere übrig, verbunden mit dem Ideal der reinen und armen lediglich spiritualen Priesterschaft, das überall zugleich ein Recht der Prüfung und Ingerenz der Laien zum Zweck der Reinigung der Kirche in sich schließt, sobald die offizielle Kirche versagt Laienreligion, Gemeindekirche, arme und spirituale Kirche, Nasilius' und Occams ebd. 297 f. Der Occams ist begreiflicher Weise viel größer. Der Defensor pacis wurde erst $\mathbf{1 5 2 2}$ gedruckt. Die Parallele der occamistischen Theorie mit den Sektenlehren und ihr Zusammenhang mit dem radikalen Minoritentum ist auch betont von Haller, Papsttum und Kirchenreform I $8 \mathrm{I}$.

193) Daß gerade das avignonensische Papsttum die Zentralisation der Kirche vollendet und sie vor allem im kirchlichen Finanzwesen zum Ausdruck bringt, betonen mit Recht K. Müller, „Kultur der Gegenwart«, I 4, S. 2 I I und Haller, -Papsttum und Kirchenreform\&. Ler letżtere fügt hinzu, daß dieser Fiskalismus die notwendige Begleiterscheinung der Zentralisation war, indem eine solche Weltregierung wie jede Regierung vor allem Geld kostet. Und es ist bekannt, daß seit der Auf hebung oder Beschränkung jenes älteren Fiskalismus durch das Triden: tinum das Finanzwesen immer ein schwieriger Punkt im kurialen System geblieben ist.

Troelts ch, Gesammelte Schriften. I. 
turrecht gehören auch hier zusammen. Alles das ist dann freilich, weil es die eigentliche Wurzel des Anstaltsbegriffs in Priestertum, Sakrament und Hierarchie prinzipiell aufzuheben gar nicht denken konnte, schließlich nur zum Sieg der den Anstaltsbegriff konsequent verkörpernden und zentralisierenden Hierarchie ausgeschlagen; sie schlug durch Konzessionen kirchlicher Rechte an die Landesherren im Bunde mit ihnen die ganze Bewegung nieder. Aber die einmal entfesselten Gedanken blieben in Wirksamkeit und haben das ihrige zur Unterhöhlung des katholischen Kirchenbegriffes beigetragen ${ }^{194}$ ).

Zum Schlusse ist nicht zu vergessen, daß das ganze Spätmittelalter mit dem Wachstum einer seibständigen städtischen Laienkultur überhaupt eine mächtige Konkurrenz gegen die bisberige, kirchlich und priesterlich geleitete Ideenwelt schuf. Ihre

194) F. v. Bezold, LLehre von der Volkssuveränitäte, S. $35 \mathrm{I}-358$. S. 352 : Die Uebertragung der naturrechtlichen Konstruktion des Staates auch auf die Kirche. S. 353 : ,Von den Thesen Langensteins (1381) bis in die Zeit der Konzilien von Pisa und Kostnitz, welche sich uns in Gerson verkörpert, durchlief die Theorie von dem Verhältnis zwischen Papst und Kirche mehrere Stufen, bis sie den Boden der bestehenden Einrichtungen und der kirchlichen Tradition völlig verlassen und sich ganz dem (absoluten, das auch v. Bezold von dem relativen, mit der bestehenden Kirche und Gesellschaft wohl verträglichen Naturrecht der klassischen Theologie und Kirchen-Jurisprudenz nicht unterscheidet) Naturrecht in die Arme geworfen hatte «. Das Uebergewicht des göttlichen und natürlichen Rechts findet bei Gerson, wie schon bei Marsilius, seinen Ausdruck in der Erhebung der Epikie zur obersten und unanfechtbaren Rechtsinstanz. Die Epikie entscheidet, ohne sich auf juristische Spitzfindigkeiten einzulassen, nach ihrem eigenen Maßstab, nach dem einfachen Rechtsgefühl darüber, ob und wie dieses oder jenes Gesetz anzuwenden, umzudeuten oder abzuschaffen sei. Nach diesem höchsten Gesetz soll nun das allgemeine Konzil verfahren, welchem Gerson eine schrankenlose Macht beilegt. Diese Epikie ist in Wahrheit nur das Recht, gegen etwaige Mißbildungen des relativen Naturrechts und des darauf beruhenden positiven Rechtes das absolute geltend zu machen. Gerson argumentiert S. $354 \mathrm{f}$.: *Wenn die kirchlichen Gewalten ihre Pflicht versäumen, so rückt diese heilige Pflicht immer wciter herunter bis zu den Bauern, ja bis zum geringsten alten Weibe. » $\gg$ Für die Sammlung, Beruhigung und Erneuerung der Kirche๔, ruft er aus, smüssen nicht nur die weltlichen Fürsten, sondern auch die Bauern und Arbeiter und jeder Gläubige bis auf den allergeringsten eintreten, und wenn es Not tut, ihr Leben daran setzen für die Errettung der ganzen Herde nach dem Beispiel der Alten.« Und et führt $\mathrm{Cice}$ ro und Valerius Maximus als Zeugen für die antike Bürgertugend an, welche er in den Herzen seiner christlichen Zeitgenossen zu Gunsten einer geistlichen Republik entzünden möchte. S. 356: „Die Konzilsväter ... erwogen 
Wirkung war naturgemäß zunächst eine Einschränkung der kirchlichen Kultur, dann aber eine zunehmende Aufösung der Objektivierung der Religion im Kirchen- und Anstaltsbegriffe überhaupt. Sie wirkte so, auch wo sie es gar nicht wollte und wußte. Aehnselbst die Möglichkeit, von den Kräften der Massen zum Heil der Kirche Gebrauch zu machenc. Sodann verweist v. Bezold besonders auf Nikolaus von Kues. S. 357: Im Naturrecht, welches der menschlichen Vernunft innewohnt, muß jede bindende Bestimmung des positiven Rechtes ihren Ursprung haben. Dadurch steht das einzelne Gesetz mit dem innersten Wesen des Menschen im Zusammenhang. Da aber die $M$ enschen von $N$ a tur gleich mächtig und gleich frei sind, besitzt nur die Gesamtheit die konstituierende, Recht und Gewalt schaffende Befugnis.e "s Jede Regierung besteht allein durch Uebereinstimmung und freiwillige Unterwerfung aller«๙. Nicht nur das Königtum, auch das Priestertum sucht er auf diesem Wege zu erklären. „Im Volke sind ... alle Gewalten, die christliche so gut wie die weltliche in der Potenz enthalten.« Die a 11 erdings hinz u tretende göttliche Einwirkung, der radius formativus, wird dabei ziemlich in den Hintergrund gestellt. \& Vergleicht man solche Sätze mit den thomistischen, so springt der Unterschied in die Augen. Nicht das Naturrecht an sich macht den Unterschied, sondern Fassung und Verwendung des Naturrechts. Das radikale, absolute Naturrecht des Urstandes tritt gegen das relative, alle Institutionen rechtfertigende Naturrecht des Sündenstandes auf; und sein Gegensatz gegen das letztere ist um so schärfer, als es nicht aristotelisch-thomistisch im Sinne der natürlichen Ungleichheit, sondern stoisch-rationalistisch im Sinne der Gleichhelt verstanden ist. Und diesem Naturrecht vermag der Kirchenbegriff keinen rechten Gegenpart mehr zu halten, da er durch das Ideal der reinen spiritualen Kirche und das Recht der Laienkritik nach dem Maßstab der Bibel der festesten Stützen des Anstaltsbegriffes inzwischen beraubt ist. Auch ist durch die Entwickelung des Papsttums in den letzten Jahrhunderten diéses so sehr zum Ausdruck und Inbegriff der einheitlichen Heilsanstalt geworden, daß die Herabdrückung des Papsttums im Episkopalismus und im erneuerten Landeskirchentum die Grundbegriffe von der Kirche überhaupt erschüttert. Immerhin sind diese theoretisch den Kirchenbegriff aufösenden Bestrebungen nur sekundäre Elemente in dem großen Kampf der Kirchenreform, dessen politischen Kern das interessante Buch von Haller zeigt. Sind also diese Ereignisse zum Teil nur Kapitel aus der christlichen Dogmengeschichte, so sind sie zugleich nicht weniger, ja wohl noch mehr eine Phase in dem jahrhundertealten Kampfe zwischen Kirche und Staat, oder sagen wir genauer, zwischen katholischer Kirche und nationalem Staat ; Haller I 479. Doch erkennt neben dem kirchenpolitischen, vom englischen Staatskirchentum ausgehenden Impuls Haller die sekundären E!emente der Aufösung des Kircheabegriffes an, indem er auf den ,Pietismuse der Forderung der armen Kirche S. 89, auf den Einfluß des Defensor pacis $340 \mathrm{f}$. und vor allem Occams, S. $342 \mathrm{f}$. hinweist. Diese sekundären Elemente haben aber fortgearbeitet, nachdem die Konzilien im erneuerten Papsttum, den Konkordaten und dem Landeskirchentum 
lich wie die städtische Entwickelung Italiens dort die Sekten hervorgebracht hatte, so hat auch die später folgende des Nordens auf ihre Weise das Laienchristentum begünstigt. Die Denkmale davon liegen in der spätmittelalterlichen Literatur vor, deren berühmtestes Beispiel die auch für Luther und den Protestantismus so anziehende deutsche Theologie ist. Auch die religiösen Volksbewegungen des Spätmittelalters setzen die Lockerung des objektiven Kirchentums voraus ${ }^{195}$ ). In' alledem erwächst nun aber freilich ein soziologischer Typus der christlichen Idee, der auch mit dem Sektentum nicht mehr identisch ist, sondern einen neuen Typus bedeutet, der radikale religiöse Individualismus der Mystik. Er sucht überhaupt keine organisierte Gemeinschaft mehr, sondern nur den freien geistigen Gedankenaustausch, und die $\mathrm{r}$ e in $\mathrm{ge}$ dankliche Gemeinschaft, wozu nun auch die Druckerpresse erst die Möglichkeit gibt. Daher verschwindet hier auch dic I.ex Christi und das Naturrecht aus der beherrschenden Stellung. Das Einzelindividuum und die psychologische Versenkung und Analyse wird alles. Von der Lex Christi bleibt nur das Vorbild Christi. Dieser Typus gewinnt aber seine selbständige universalhistorische Bedeutung erst in den späteren protestantischen Dissentern und in ihren Verwachsungen mit dem Humanismus. Es wird daher von ihm näher erst zu reden sein bei der Darstellung des reinen Individualismus der protestantischen Dissenter.

Alle diese Theorien folgen nicht bloß der theoretischen Konsequenz des Gedankens, sondern sind Konsequenzen, die erst durch dic den Trieb zur Umbildung und Neubildung weckenden Verhältnisse hervorgeholt sind. Ihre Unterlage ist ein tatsächlicher Wandel der allgemeinen Verhältnisse, durch den erst die mittelalterliche Welt wirklich erschüttert worden ist. Diese oft dargestellten Dinge scien hier nur angedeutet. Es emanzipieren sich die politischen und wirtschaftlichen Interessen von dem internationalen Reich der Kirche und von der einschnürenden $W$ irtschafts-

zu einem Ergebnis gelangt waren, das die politischen Forderungen, aber nicht die religiöse Kritik und die Ideale des religiösen Individualismus befriedigte. - Ueber den Einschlag occamistischer und naturrechtlich-demokratischer Ideen in die konziliare Reformbewegung s. auch K. Müller, K.-G. II 65, 67 f. und K. Köhler a. a. O. leber die ganze Lage, in der die von $\mathrm{S}^{4} 4^{1} 3$ oben geschilderten Theorien sich bewegen, und die klare Darstellung bei v. Bezold in sKultur d. Gegenwarte II, Y, I.

195) Vgl. Karl Müller, K.-G. II I54-167. Gothein, Politische und religiöse Volksbewegungen vor der Reformation, 1878 . 
ethik der Kirche. Der Staat, den die christliche Einheitskultur überhaupt nicht in seinem eigentlichen Sinne gekannt hatte, erhebt sich aus den republikanischen Organisationen der Städte, dem Nationalgefühl der Völker, den militärisch-dynastischen Länderverbindungen. Der mit Monopolen, Kreditverkehr, Handelsgesellschaften und Hausindustrie einsetzende Kapitalismus sprengt die mäßigen Anerkennungen der natürlichen Bedürfnisse, die die einfache kirchliche Ethik allein gekannt hatte. Die mit dem Besitz und der politischen Verselbständigung verbundene Umformung der Lebensverhältnisse schafft eine Sinnlichkeitskultur, dic die kirchliche Einschränkung frommer Weltliebe auf die Seite schiebt. Der von der Kirche und den in ihr enthaltenen stoischneuplatonischen Ueberlieferungen erzogene Individualismus greift nach den künstlerischen Mitteln der Differenzierung und Ausbildung der Persönlichkeit neben den rein religiösen und zieht so Stück für Stück die Antike wieder an das Licht als das Mittel eincr Ergănzung und Fortbildung des Individualismus in andern als bloß rełigiösen Richtungen. Mit alledem tritt die kirchliche Leitung zurück. Literatur, Kunst und Wissenschaft gehen aus der Hand der Kirche in die der Laien über. Unter diesen Umständen erhebt sich neben den andauernden Neubelebungen des kirchlichen Gedankens, neben den subjektivistisch gestimmten Kreisen und Genossenschaften und neben der kirchlichen und religiösen Indifferenz vor allem jener dritte soziologische Typus der christlichen Idee, der nicht wie die Kirche an der Anstalt und nicht wie die Sekte an der wörtlichen Deutung des Bibelgesetzes hängt, sondern vielmehr ein die christlichen Gedanken frei mit allerhand anderen Elementen verknüpfender organisationsloser oder neben der Kirche stehender und sie für die Massen voraussetzender Individualismus ist. Er tritt nunmehr auch mehrfach mit den humanistischen Kreisen in Verbindung und entbehrt, wie er ohne alle eigene soziologische Organisation ist, jeder meßbaren und bestimmten sozialen Wirkung und Idee überhaupt oder schafft soziale Utopien, die aus christlichen und humanistischen Elementen frei gemischt sind, literarische Gedankenspiele, aber keine praktischen Reform- und Gestaltungsversuche. Hier eröffnet der Sozialroman des Thomas Morus die Reihe der freien Idealbildungen. Es ist der Typus, der von der neuen Welle kirchlichen Lebens im I6. und I7. Jahrhundert hinweggespült wird, der aber dann mit der modernen Welt wiederkehrt ${ }^{196}$ ).

196) Vgl. Dietzel, Beiträge zur Geschichte des Sozialismus (Z. f. Gesch. und 
All das zusammen macht erst die Auflösung der kirchlichen Kultur erklärlich. Aber was auch die letztgenannten vielfach geschilderten Erscheinungen dafür bedeutet haben mögen, die begriffliche und gedankliche Erschütterung - und ohne eine solche werden gedanklich begründete Systeme nie wirklich überwunden - geht doch von der Zersetzung des wesentlichen kirchlichen Grundgedankens, von den Wirkungen des Sektentypus, aus, in dem sich der radikale Individualismus und die radikale Liebesethik verbinden gegen den Kirchentypus mit seiner relativen Kulturfreundlichkeit und seiner Objektivierung und Verdinglichung der religiösen Kräfte.

Dabei ist für unsern Zusammenhang entscheidend die Bedeutung, die dieser Gegensatz nicht bloß für die Aufösung der mittelalterlichen christlichen Einheitskultur hatte, sondern die er überhaupt hat für das Verständnis der christlichen Soziallehren an und für sich. Dieser zu Beginn dieses Abschnitts ausgesprochene Grundgedanke hat nun seine Beleuchtung und Veranschaulichung erfahren, und 'damit ist seine außerordentliche Bedeutung für das Verständnis dieser Dinge klar geworden. Die Dinge sind im Grund überaus einfach, wenn man sie sehen will, wie sie sind.

Das Evangelium selbst bringt wesentlich ein ethisch-religiöses Menschheitsideal, freilich von den einschneidendsten sozialen Folgen. Aber diese Folgen zu ziehen überläßt es der Wunderkraft rottes, die beim Kommen des Gottesreiches alles ordnen wird. Die aus dem Evangelium entspringende Kult- und Religionsgemeinschaft ordnet das Leben der Gemeinde im Hinblick auf diese $\mathrm{Zu}$ kunft, aber doch in Auseinandersetzung mit der provisorisch zu ertragenden Gegenwart und nimmt hier gegenüber den bestehenden Verhältnissen und Ordnungen eine duldende, aber konservative Stellung ein, bloß im eigenen Kreise diejenigen Folgen der Verhältnisse nach Möglichkeit aufhebend, die mit dem neuen ethischen Ideal nicht verträglich sind. Die hieraus erwachsende prie-

\footnotetext{
Lit. der Staatswissenschaften II). Hier über Th. Morus. Ueber den neuen Typus einer individualistischen Bildungschristlichkeit s. vor allem die wichtigen Arbeiten von Dilthey im >Archiv f. Gesch. d. Philos. $V$ u. VI. Wie sehr das Ideal des Morus ein neuer soziologischer Typus der Religiösen ist, lehrt besonders die Untersuchung von Dietzel: Gemeinsamkeit in einem allgemeinen, dem Christentum und der Stoa entstammenden Theismus, und völlige Freigabe der religiösen Sondermeinungen im übrigen, zugleich starke Reduktion des Kultus.
} 
sterlich-sakramentale Kirche rettet die Absolutheit der Ideale und Kräfte in die hierarchische Kern-Organisation und relativiert ihre praktischen Maßstäbe bis zur Anerkennung der Ordnungen in Staat und Gesellschaft als der durch die Sünde notwendig gewordenen Trübungen und Modifikationen des urständlichen christlich-natürlichen Rechtes. Von dem Dulden und Anerkennen schreitet bei der Zerbrechung der antiken Welt die Kirche auf dem Boden der einfacheren mittelalterlichen Lebensverhältnisse zu einer eigenen selbständigen Gestaltung und Begrenzung der von ihr anzuerkennenden relativ-naturrechtlichen Ordnungen fort und richtet in der päpstlichen Theokratie die christliche Einheitskultur auf, in der das ethische Ideal des Evangeliums mit allen unumgänglichen Konzessionen an die Welt versöhnt ist und eine Stufenleiter ethischer Entwickelungen vom Weltleben zur mystischen Heiligung und armen Bruderliebe emporführt.

Gegen diese Verdinglichung und gegen diese Relativierung aber reagiert das Evangelium mit seinem radikalen religiösen Individualismus und mit seinen absoluten Forderungen, die schon ganz am Anfang sich nicht überall der kirchlich-konservativen Entwickelung gefügt hatten. In der Sekte kommt die Gemeinschaft in persönlicher Religiosität und ethischer Leistung zum Ausdruck, setzt sich der Radikalismus des ethischen Gesetzes des Evangeliums durch unter Verwerfung der Konzessionen an das relative Naturrecht des Sündenstandes. Daraus ergeben sich dann auch unmittelbar die einschneidenden sozialen Konsequenzen des Evangeliums als praktische Reform der Gesellschaft, in der alles dem Ideal der selbständigen religiösen Persönlichkeit und der vorbehaltlosen Bruderliebe dienen soll. Zunächst hofft man, dieses Ideal werde von selbst sich durchsetzen, wenn nur erst die verderbte, relativistische Kirche reformiert ist; dann hofft man auf den Wundereingriff Gottes und den chiliastischen Traum; dann greift man unter Berufung auf das alte Testament zur Gewalt und führt einen christlichen Kommunismus durch. Schließlich zieht man sich wieder zurück auf die von der Welt geschiedene Gemeinde, die in der eigenen Mitte das christliche Gesetz aufrichtet und die Ordnungen der Welt als Folgen der Sünde und fremde Umgebung duldet, bis deren Stunde einst geschlagen haben wird.

In diesen Gegensätzen verläuft die Entwickelung der christlichen Soziallehren. Die Kirche ist das Prinzip des Universalismus und der christlichen Kultur, der geistigen Freiheit, Beweglichkeit 
424 II. Mittelalterl. Katholizismus. 9. Das absolute Gesetz und die Sekten.

und Anpassungsfähigkeit, aber sie bindet sich an die Inkarnation ihres göttlichen Gehaltes in Dogma und Priestertum, schränkt ihre Relativierungen auf ein eng gebundenes $\mathrm{Maß}$ ein, und fordert die außere und ausschließliche Herrschaft über Staat und Gesellschaft, um für ihre innerlichen Gnadenwirkungen den Spielraum zu sichern. Damit ist sie gebunden an die allgemeinen Verhältnisse, die eine solche Theokratie und eine solche das Weltleben doch immerhin stark eingrenzende Ethik möglich machen. Indem sie das freiere Prinzip' ist, ist sie es nur, weil sie zugleich das dogmatisch-objektiv und kultisch-institutionell strenger gebundene ist. Die Sekte ist das Prinzip der subjektiv-persönlichen Wahrheit und Verbundenheit und der kompromißlosen evangelischen Maßstäbe. Damit verzichtet sie auf den Universalismus oder kann ihn nur durch die allen evangelischen Maßstäben widersprechende Gewalt herstellen oder muß zur Eschatologie füchten. Dafür abẹr betätigt hier der Einzelne das Evangelium auch in seinen sozialen Konsequenzen des radikalen Individualismus und der vor keinem Kulturgut Halt machenden Bruderliebe. Sie ist das beweglichere und subjektivere, wahrhaftigere und innerlichere Prinzip nur, indem sie zugleich das engere und gewaltsamere, an das wörtliche Verständnis des Evangeliums gebundene ist.

Ein dritter Typus, der organisationslose religiöse Individualismus mit der Freigebung sehr verschiedener Stellungnahme zu dem Wahrheitskerne des Christentums ragt nur erst als Weissagung kommender Entwickelungen in dieses Widerspiel von Kirchentum und Sektentum herein.

Es ist die unendlich schwierige Lage der christlichen Soziallehren in der modernen Welt, daß einerseits das Christentum nicht mehr ungebrochen kirchlich ist und doch die freie Geistigkeit und Anpassungsfähigkeit der Kirche sucht, ohne die bindenden Garantien des Kirchentums, daß es andrerseits bei seiner Stellung auf subjektive Ueberzeugung und Freiwilligkeit und ethisch-lebendige Bewährung doch die radikale Kulturlosigkeit, die konventikelhafte Enge, und die an das wörtliche Verständnis des Evangeliums angeschlossene Sozialreform der Sekte nicht ertragen kann. Nicht Kirche und nicht Sekte, hat es weder die dingliche Heiligkeit der Anstalt, noch den radikalen Anschluß an die Bibel. Die christlichen Ideen verbindend mit einem reichen Kreise moderner Anschauungen, die Gesellschaftsordnungen nicht aus dem Sündenfall, sondern aus natürlichen Entwickelungen ableitend, hat es nicht die feste 
Grenze aller Konzessionen und die soziale Macht, die das Kirchentum hat, aber auch nicht den Radikalismus und den geschlossenen Zusammenhang, mit dem die Sekte Staat und Wirtschaft, Kunst und Wissenschaft bei Seite setzen kann. In dem vollen Gefühl, die höchsten ethischen Ideale der Menschheit noch heute zu vertreten, kann es doch das in 'Evangelium enthaltene ungeschriebene soziale Programm weder so leicht rein für sich formulieren noch klar auf die widerstrebenden Verhältnisse anwenden. Es ist das Uebergewicht des dritten Typus, das sich allmählich für die gebildete Welt herausgestellt hat. Da gibt es dann nur mehr freie Vereinigungen der Gesinnung, die von Kirche und Sekte gleich weit entfernt sind ${ }^{197}$ ). Daneben arbeiten dann die Kirchen mit den Idealen vergangener Zeiten, wo sie als geistige oder

197) Das lehrt deutlich der an sich so gedankenreiche und ideal gesinnte ,Evangelisch-soziale Kongreß\&. Er sucht jedesmal eine theologisch-ethische Formulierung der christlich-sozialen Ideen, die nicht sektenmäßig an das wörtliche Verstăndnis der Bibel gebunden ist, sondern den >Geist des Evangeliumse wiedergibt, die aber zugleich doch auch nicht den eigentlich religiösen Besitz in die objektiven Anstaltsgüter der Kirche verlegt, sondern mit dem Radikalismus gerade der ethischen Forderungen des Evangeliums Ernst macht. Damit aber hat er dann weder die Sektengemeinschaft noch die Kirchen hinter sich, sondern nur die freie christlich bestimmte und mit den modernen Lebenselementen ausgeglichene, Gesinnung . Eine organisierte Gemeinschaft aber, die diese Gesinnung trüge, ist nicht vorhanden ; sie wird in Wahrheit von Kirchen oder Sekten zunächst erzogen und ist nur der von beiden losgelöste und zu einem freien Gesinnungsprinzip gewordene \Geist des Christentums, der ohne eigene soziologische Grundlage nur schwer sozial zu wirken im Stande ist. Dabei treten dann aber auch für diesen Geist des Christentums a die Schwierigkeiten einer Auseinandersetzung mit der Naturbasis der menschlichen Gesellschaft stets von neuem hervor. Man will das geistige, anpassungsfähige Verständnis des Evangeliums und den Universalismus des Volkschristentums, ohne die Relativierungen, wie sie die Kirche vornimmt, und ohne die Bergung des rein göttlichen Elementes in dem Anstaltscharakter der Kirche. Man will den ethischen Radikalismus einer auf die evangelischen Ideale gebauten Gesellschaft, ohne die Enge und Kleinheit der Sekte. Dabei kann man aber doch auch seinerseits den $\gg$ Geist des Evangeliums « nicht durchsetzen ohne opportunistische Beschränkung auf das erreichbar Mögliche und ohne die Entschlossenheit, das Bessere nicht den Feind des Guten sein zu lassen. Wie diese Sachlage nur aus der geschichtlichen Entwickelung verständlich ist, so beleuchtet sie umgekehrt rückwärts wieder die letztere, wo staatsbeherrschende $Z$ wangskirchen oder revolutionäre, auf dem Freiwilligkeitsprinzip beruhende Sekten die Aufgabe in die Hand genommen und auch ihrerseits beide mit der Naturbasis des sozialen Lebenss sich mühsam genug auseinanderzusetzen hatten. 
faktische Herrscher über Staat und Gesellschaft beide in ihrem Sinne einer christlichen Universalgesellschaft leiten und konstruieren konnten. Neben den Kirchen aber stehen die Sekten und bauen die christliche Gesellschaft als enge Lebenskreise pietistischstrenger Observanz in einer fremden Welt. Aus der Geschichte der christlichen Soziallehren erst versteht man diese schwierige, von jedem Aufrichtigen empfundene Lage.

Auch hier ist der folgenden Untérsuchung vorgegriffen worden. Aber dieser Vorblick erläutert erst den Zusammenhang des Ganzen. Und auch für die nächsten historischen Fragen macht er die Lage klar. Es wird die Aufösung des Spätmittelalters verständlich, da in ihm jener $Z$ wiespalt auseinander zu klaffen beginnt. Es wird aber auch klar, daß die aus dieser großen Gärung sich erhebende religiöse Neubildung, die Reformation, sofort vor der Schicksalsfrage stand: Kirche oder Sekte? Sie hat mit vollem Bewußtsein den Kirchentypus festgehalten und mit ihm den Gedanken einer christlichen Einheitskultur und -gesellschaft. Indem sie dies tat, setzte sie einen wesentlichen Grundzug des Katholizismus fort und tat sie das großenteils mit eben den Mitteln, die der Katholizismus hierfür ausgebildet hatte. Aber auch der Sektentypus ist nicht ohne Einwirkung auf den reformatorischen Gedanken geblieben, indem mit dem Biblizismus der R eformatoren auch die in der Bibel enthaltenen Keime des Sektengedankens sich regten und Geltung verschafften. Er bedingte sowohl die inneren Spannungen seines Kirchenbegriffes und seiner Ethik als die Absplitterung rein sektenhafter und mystischindividualistischer Gruppen. Nur als Herausbildung aus den im Laufe des Mittelalters entwickelten christlichen Soziallehren versteht man die neuen Soziallehren des Protestantismus. 


\section{Der Protestantismus.}

I. Das soziologische Problem des Protestan$\mathrm{t}$ is $\mathrm{mus}$.

Es sind zwei große klassische Typen von Soziallehren, die das mittelalterliche Christentum hervorgebracht hat: erstlich der Typus der ergänzten und relativierten christlichen Gesellschaftsidee, die im Thomismus sich darstellt, und zweitens der Typus der unergänzten, radikalen christlichen Gesellschaftsidee, wie die Sekten ihn ausgeprägt haben. Das Wesen des ersten ist; daß die Kirche als universale, mit absoluter autoritativer Wahrheit und sakramertaler Wunderkraft ausgestattete Gnaden- und Erlösungsanstalt die aus dem relativen Naturgesetz stammenden, den Bedingungen des Sündenstandes angepaßten weltlichen Ordnungen, Gruppen und Werte in sich aufnimmt als natürliche Unterstufe und Vorstufe der Gnaden- und Wundersittlichkeit, der geistlichhierarchischen Weltorganisation. Das Wesen des zweiten ist, daß die religiöse Gemeinschaft das Gesellschaftsideal rein aus dem Evangelium und dem Gesetz Christi erzeugt, seine Christlichkeit und Heiligkeit in der Verbundenheit und in der Praxis der Individuen, nicht in den objektiven Garantien der Institution erkennt, daher die außerchristlichen Ordnungen. Gruppen und Werte überhaupt nicht anerkennt, sondern sie entweder in stillem weltentsagenden Dulden meidet und von sich ausschließt oder in enthusiastisch-eschatologischem Anlauf bekämpft und durch eine rein christliche Ordnung ersetzt. In beiden Fällen ist das Wesen der christlichen Gemeinschaft selbst verschieden gedacht; im ersten Falle als Anstalt mit einem von den Individuen unabhängigen Depositum absoluter Wahrheiten und wunderbar versittlichender Sakramentalkräfte, im zweiten als eine aus persönlichem Entschluß und persönlicher Arbeit immer neu hervorgehende Genossenschaft. Daher im ersten Falle die Möglichkeit, auf die strenge christliche Vollkommenheit. zu verzichten oder sie doch auf einen besonderen Stand, den Mönchsstand einzuschränken und daher im zweiten Falle die prinzipielle Forderung solcher Vollkommenheit an alle. In beiden Fällen ferner haben die christlichen Grundideen von Sünde und Gnade eine verschiedene Bedeutung. Im ersten dient die Sündenlehre der Akzeptierung der gegebenen 
weltlich-sozialen Ordnungen, deren bloß relative Unchristlichkeit die Folge der Sünde und mit dieser und um dieser willen ertragen werden muß. Zugleich ist die Gnade die diese Ordnungen entsühnende, überbauende und unter eine universale Zentralinstanz beugende Wunderkraft die selber ihrem Wesen nach als wunderbare Oberinstanz über der Natur, auch der reinen und noch unverdorbenen Natur, empfunden wird und als Uebernatur der Natur im Stufenbau der Entelechien des Weltalls übergeordnet ist. Im zweiten Fall erklärt gleichfalls die Sünde die bestehenden Ordnungen, Gruppen und Werte des Weltlebens, macht sie aber dadurch nicht unumgänglich, sondern begründet umgekehrt damit. die Notwendigkeit ihrer radikalen Verwerfung durch den Christen und der Erzeugung einer sozialen Lebensordnung rein aus den evangelischen Anweisungen heraus. Die Gnade ist dementsprechend dann die Berufung und Erwählung aus der Welt heraus die Erfüllung mit Erkenntnis und Kraft der rein evangelischen Sittlichkeit, die an ihrer subjektiven Wirkung, nicht an ihren institutionellen Trägern erkannt wird, und die Hoffnung auf die Rechtfertigung der christlichen Gemeinde bei der großen Umwertung aller Weltwerte im Endgericht. Sie ist kein Ueberbau über der zu akzeptierenden sündigen und nichtsündigen Natur, sondern identisch mit der vollen, reinen, idealen Natur des Urstandes und gegenüber der gefallenen Natur nicht eine Entsühnung und Emporleitung, sondern ein reiner und radikaler, im wahrhaft christlichen Geiste und seinem Sittengesetz sich aussprechender Gegensatz. Daran knüpft sich eine Reihe weiterer Unterschiede, die der feineren religiösen Psychologie und dem theologischen Denken angehören. Insbesondere steht die Christologie in einem leicht erkennbaren Zusammenhang mit der ihr jeweils korrelaten Idee der Gemeinschaft, insofern die "Kirche $\approx$ in Christus den Kirchenstifter und den Begründer des objektiven Gnaden- und Heilsschatzes sieht, während die "Sekte in ihm den Gesetzgeber, das göttliche Vorbild, die anspornende Kraft, die in unmittelbare Tat sich umsetzende Gegenwart des übergeschichtlichen erhöhten Christus, das unmittelbarer Gegenwart und Wirkung fähige Aktivitätsprinzip erkennt. Doch gehört das mehr der Dogmengeschichte an. Das für unsern Zusammenhang Entscheidende liegt auf dem Gebiete des soziologischen Grundunterschiedes als Anstalt und Genossenschaft und des damit zusammenhängenden Unterschiedes der Ethik, wonach die einen die christliche Ethik durch die natürliche ergän- 
zen und dadurch zur Massenbeherrschung fähig werden, während die anderen die Ergänzung verwerfen und dadurch auf kleine duldende oder revolutionäre Kreise beschränkt sind. Die einen akzeptieren eine von den Maßstäben der christlichen verschiedene natürliche Ethik, die anderen verwerfen sie. Die einen betrachten die "Natur als etwas von der Gnade Verschiedenes, aber von ihr Organisierbares, die anderen betrachten die swahre Natur * als etwas mit der Gnade Identisches, während sie die gefallene Natur als mit ihr völlig unvereinbar verwerfen.

Die Gegensätze reichen bis in das Urchristentum und die alte Kirche zurück. Der erste Keim liegt schon in dem Gegensatz des Liebeskommunismus der jerusalemischen Urgemeinde und der konservativen Anpassung an die Gesellschaftsordnung, die Paulus proklamiert hat. Aber ihren vollen Charakter hat die Kirche erst durch die Verstaatlichung im Zeitalter Konstantins erhalten, die ihr die Durchführung ihrer universalen und absoluten Einheit, und Herrschaft erst ermöglichte und sie dann befähigte im germanisch-romanischen Mittelalter der mit Hilfe des Staats erworbenen Einheit auch den Staat selbst und mit ihm zugleich die ganze nichtreligiöse Kultur zu unterwerfen. Indem aber das Mittelalter erst eine christliche Einheitskultur auf diese Weise schuf, hat es auch erst die Komplementärbewegung, die Sekte, scharf und klar herausgesetzt. Damit ist die Auswirkung der Soziallehren des lateinischen Christentums erschöpft. Neue Aeste an dem Baume der christlichen Soziallehren konnte nur eine gründliche Wandelung der Säfte hervorbringen. Nur eine innere Wandelung und Fortentwickelung der christlichen Idee selbst konnte $\mathrm{zu}$ neuen Idealen einer christlichen Gesellschaftslehre führen.

Eine solche Neubildung erfolgte bekanntlich in der Krise des Spätmittelalters und brach mit der R e formation und dem Protestantismus erfolgreich an das Licht. Dabei ist die Refiormation durch die in dieser Krisis bereits entwickelten Kräfte positiv und negativ mannigfach bedingt. Zwischen ihr und dem den mittelalterlichen Geist klassisch ausdrückenden Thomismus liegen mehr als zwei Jahrhunderte, damit eine Fülle von Gegensätzen gegen diesen und Vermittelungen mit ihm. Teils ist es der Sektentypus mit seinen immer stärker hervortretenden Wirkungen, teils der radikale religiöse Individualismus einer von ihren scholastischen und kirchlichen Voraussetzungen sich befreienden Mystik, teils die 
kritische Selbstauflösung des thomistischen Systems in der spätmittelalterlichen theologischen Schule, dem Nominalismus oder genauer Occamismus. Für die Reformation war insbesondere der letztere wichtig. Er hatte die Vermittelungen zwischen Vernunft und Offenbarung, den Stufengang von der Natur zur Uebernatur, die Uebereinanderschichtung des konnaturalen und des supranaturalen Zieles der Menschen aufgelöst; er hatte die psychologische Selbstanalyse durch die empiristische Lehre von der inneren Erfahrung vertieft, den rein positiven Willenscharakter der göttlichen Setzungen betont und die Sakramente aus Eingießungen der Uebernatur in Eingießungen der an sich der menschlichen Natur zukommenden, aber durch die Sünde verlorenen Gerechtigkeit verwandelt. Im übrigen aber war er doch bei den eigentümlich katholischen Grundgedanken der universalen Kirchenherrschaft geblieben, hierin Occams und der konziliaren Theologen Besonderheiten abstreifend, und bei dem Gedanken der christlichen Einheitskultur; hierbei fuhr neben der jetzt viel stärker betonten positiven göttlichen Anordnung das sittliche Naturgesetz immer noch zu spielen seine Rolle fort. Durch Verträge der Staaten und der Kirche war das alte Kirchenwesen juristisch und dogmatisch wieder gesichert, aber Dogma und Ethos blieben. in Bewegung und eine kirchenfeindliche Stimmung blieb im Grund der Bevölkerungen. Es war im ganzen eine Wiederauflösung der vom Thomismus geschaffenen Einheit von Dogma und Philosophie, von natürlicher und übernatürlicher Moral, von Naturgesetz und positiver göttlicher Willenssetzung, in der sich die allgemeine Entzweiung des kirchlichen und des weltlichen Lebens spiegelte, die aber durch verstärkte Betonung der göttlichen Autorität den alten kirchlichen Einheitsgedanken festhielt und im übrigen der Vernunft und den natürlichen Kräften ein Ventil in den Selbstdispositionen für die Gnade, in der Mitwirkung des freien Willens, öffnete. Aus dieser Schule ging auch Luther hervor; der Thomismus lag hinter ihm bereits in weiter Ferne. Gegen sie richtete sich zunächst seine Polemik; aber ihre Fragestellungen, ihre dualistische und autoritative Denkweise, ihr Irrationalismus gegenüber der Philosophie und ihr Psychologismus in der Analyse der inneren Erfahrungen waren zugleich seine nächsten und eigentlichsten positiven Voraussetzungen. Doch gehören diẹse erst in der Aufhellung begriffenen Voraussetzungen nicht weiter in den Rahmen dieser Untersuchungen. Uns interessiert hier nur das 
Ergebnis und die neue religiöse Idee der Reformation ${ }^{1972}$ ). Unsere Frage ist daher: worin bestand jener Wandel der christlichen Idee, welches sind die neuen religiösen Ideen und welches sind deren soziologische Folgen?

So mannigfach die in der Reformation und dem Protestantismus zusammenströmenden Kräfte waren, so reich und vielseitig die aus ihr hervorgehenden Gruppen und Persönlichkeiten sich entwickelten, in den wesentlichen Grundgedanken lebten sie alle von den Ideen $\mathrm{L} u \mathrm{t}$ he $\mathrm{r} \mathrm{s}$, der für die dogmatișchen Hauptideen aller Gruppen schlechthin entscheidend war, so weit sie nachher auch auseinandergehen mochten. Nur die humanistischen Gruppen waren unabhängig von ihm, haben dafür aber auch rasch ihre Bedeutung neben ihm verloren, wenigstens für die nächsten Jahrhunderte; nur wissenschaftlich und schulmäßig haben sie dem Protestantismus ihre Kräfte zugeführt, ebenso wie dem erneuerten Katholizismus.

Es handelt sich also grundlegend um die religiösen Ideen Luthers und um die soziologischen Folgerungen aus ihnen.

197 a) Hiefür ist besonders Denifles bekannte Lutherbiographie hervorzuheben, die mit Recht betont, daß Luther nicht am Thomismus orientiert ist, ja ihn überhaupt nur sehr eingeschränkt kennt. Wenn er darauf den Vorwurf begründet, Luther habe die eigentliche große katholische Wissenschaft überhaupt nicht gekannt und in seiner Unwissenheit sich in eine minderwertige katholische Wissenschaft verbissen und damit überhaupt das Ziel seiner Polemik völlig verfehlt, so gehört das zur modernen katholischen Apologetik. In Wahrheit ist der Occamismus die Aufösung der unhaltbar gewordenen Einheit der katholischen Kultur und Theologie und insoferne der'naturgemäße Boden für eine neue Zusammenfassung und Ausgestaltung der christlichen Idee. Vgl. hierzu W. Köhler, Ein Wort zu Denifles Luther, 1904. Die Begründung von Luthers Ideenbildung auf den Occamismus ist stark und mit Recht hervorgehoben in dem höchst interessanten Buche Hermelinks, DDie theologische Fakultät in Tübingen 1477-1534c, 1906, in der zum erstenmal das Verhältnis von Thomismus und Occamismus in dieser wichtigen Wendezeit klargestellt ist (vgl. hierzu meine Anzeige in G.G.A. 1909). Die oben vollzogene Hervorhebung der für die lutherische Idee positiv bedeutsamen Punkte folgt Linsenmann, Gabriel Biel und der Nominalismus, Theol. Quartalschrift 1865. Immerhin setzt aber auch dieser Nominalismus die Grundzüge der mittelalterlichen Christlichkeit fort, insoferne auch ihm die universale Kirche und die Christlichkeit der ganzen Gesellschaft selbstverständliche Voraussetzungen bleiben; es wird nur die Mitwirkung der Laien, der weltlichen Gewalteń, der Konzilien an diesem Ideal stärker betont und der rationell-metaphysische Untergrund der Theologie beseitigt, ihr Autoritäts- und Offenbarungscharakter gesteigert. 
Hier ist nun hervorzuheben, daß bei aller Begründung in einem Jahrhunderte umfassenden inneren Wandel der Gesamtlage Luthers religiöse Idee doch eine hohe persönliche Originalität hat und vor allem, daß sie rein aus der inneren Bewegung des religiösen Gedankens selbst hervorgeht. Sie ist nicht als Reflex sozialer oder gar wirtschaftlicher Umwandelungen entstanden, sondern hat ihren wesentlich selbständigen Grund in der Initiative des religiösen Gedankens, aus dem die sozialen, wirtschaftlichen und politischen Konsequenzen erst hervorgehen. Für die Durchsetzung und den Sieg, die praktische Organisation und Gestaltung kommen dann freilich diese letztgenannten Kausalitäten ganz außerordentlich stark in Betracht. Aber bei der grundlegenden Entstehung selbst haben sie nichts zu suchen. Hier herrscht die Kausalität des rein religiösen Denkens. Höchstens indirekt sind allerdings auch hier gewisse Einflüsse von jenen Elementen her zu erkennen. Die von Luther verarbeiteten Gedankenmassen der nominalistischen Spätscholastik, der Mystik, der Oppositionsparteien sind nämlich ihrerseits zweifellos nicht ohne Zusammenhang mit den sozialen Wandelungen des Spätmittelalters. Die ganze darin ausgedrückte Individualisierung der Frömmigkeit und die Ablösung des religiösen Interesses von dem weltlich-politischen ist eine Folge der allgemeinen Verhältnisse, der städtischen Kultur, der Verselbständigung der Staaten und der wirtschaftlichen Interessen. Aber diese indirekte Wirkung ist eben nur eine indirekte. Sie machte nur den Boden frei für neue Konzeptionen, die aus den ganz persönlichen Kämpfen und Arbeiten des Erfurter und Wittenberger Mönches hervorgingen, und hält sie unter dem Einfluß einer Atmosphäre, in der eine starke religiöse Innerlichkeit mit Tätigkeits- und Ordnungstrieb verbunden ist. Das aber ist die Atmosphäre der damaligen deutschen städtischen Kultur. Wie überall an den großen Knotenpunkten der Geschichte ist es ein Zusammenwirken verschiedener, von einander unabhängiger Kausalitäten, die nur der doktrinäre Fanatismus auf eine einzige zurückführen wollen kann. Unter diesen verschiedenen Kausalitäten ist aber zunächst in diesem Falle die des religiösen Gedankens die schlechthin beherrschende und Anstoß gebende. Ebendeshalb kann man auch die reformatorische Ideenwelt mit keiner bestimmten sozialen Klasse in Verbindung bringen. Sie hat Bauern und demokratische Handwerker, städtisches Patriziat und Literatenwelt, den niederen im 
Kampf um seine Existenz begriffenen Adel, den hohen Adel der territorialfürstlichen Landherren, die städtischen Magistrate, die Zünfte und die städtischen Proletarier, ergriffen. Sie ist zunächst überhaupt von keiner sozialen Gruppe bedingt. Wenn man trotzdem ihr im ganzen einen bürgerlichen Charakter zuerkennen will und in gewissem Sinne auch kann, wenn man sie gegen die seigneurale frühmittelalterliche Kirche und gegen die demokratisch und proletarisch infizierten Sekten kontrastiert, so hat dies seinen Grund nur in jenem indirekten Zusammenhang. Dieser aber wieder beruht auf der psychologisch leicht verständlichen Tatsache, daß alle breite Massen ergreifende Individualisierung des geistigen Lebens überhaupt 'mit der Städtebildung zusammenhängt; innerhalb der städtischen Elemente aber ging die aus rein religiösen Gründen stark konservativ gesinnte Reformation mit den bürgerlichen Elementen zusammen, während das Proletariat dem radikaleren protestantischen Sektentypus größtenteils folgte. Erst der weitere praktische Gang der Dinge hat dann die Reformation zum Anschluß an die die Ordnung verbürgenden Gewalten, $d . h$. an die Landesherren genötigt, was somit ihrem grundlegend bürgerlichen Charakter keinen Eintrag tut. Das ist aber ein sehr verwickelter und nichts weniger als geradliniger und unmittelbar bestimmender Zusammenhang. Die Richtung selbst, die der individualisierte religiöse Gedanke hier genommen hat, geht vielmehr rein aus seinen eigenen inneren Kämpfen und Spannungen hervor ${ }^{198}$ ).

198) Die Ableitung der Reformation aus Klassenbewegungen ist selbstverständlich die Position Kautskys: „Sozialismus in Einzeldarstellungen I. I, S. 239-251. Ihm ist Luther der Agitator, der der kommunistisch-demokratischen Opposition, und der charakterlose Höfling, der dem aufsteigenden Absolutismus die religiöse Legitimation verschafft; auf dieser Doppelstellung beruhe seine große Wirkung. Der eigentliche Heros der Reformation ist Thomas Münzer, der das zweite häßliche Interesse Luthers nicht hatte. Begründungen sind in der ganz oberflächlichen und verständnislosen Skizze nicht gegeben. Aehnlich faßt von dem Dogma der »kollektivistischen a Geschichtserklärung aus Kalthoff ^Das Zeitalter der Reformations, hg. von Steudel 1907, die Sache auf. Der Herausgeber sagt: sIn den wirtschaftlich.en und Klassenkämpfen läßt uns K. die innersten treibenden Faktoren jener ganzen gewaltigen kulturellen Umwälzung erkennen und die darin hervortretenden Persönlichkeiten aus dem Kampf zwischen absterbenden und neu sich durchsetzenden Interessengruppen verstehen «, S. VIII. Allein dieses Programm wird überhaupt nicht einmal versucht durchzuführen. K. begnügt sich, ganz allgemein auf den bürgerlichen Charakter der Reformation hinzuweisen, und veranschaulicht 
Welches ist nun die religiöse Idee Luthers, wie sie der soziologischen Gestaltung des Protestantismus zugrunde liegt ?

Man pflegt den Protestantismus als die Wiedererhebung der

das vor allem an Dürer und Hans Sachs. Darin liegt unzweifelhaft etwas Berechtigtes, aber es ist keine Ableitung aus Klasseninteressen. - Die indirekte Bedeutung der stădtischen Entwickelung, der Laizisierung der Religion und der bürgerlichweltlichen Lebenstüchtigkeit ist stark betont von Dilthey: >Die Glaubenslehre der Reformatorene (Preuß. Jahrbb. 75, 1894), und von Amold Berger: >Die Kulturaufgaben der Reformatione 1895 und Lutherbiographie $I^{2},{ }^{\prime} 1908$. Hier ist mit rollem Recht die reformatorische Bewegung in den unentbehrlichen breiten kulturgeschichtlichen Rahmen gestellt. Aber, wie es bei solcher Zusammenschau leicht geschieht, verschwimmen hierbei die in Luther zusammenmündenden Linien in großer Unbestimmtheit und leidet auch die bestimmt-konkrete Auffassung von Luthers eigener Entwickelung. Luther ist doch eben ganz wesentlich Mönch, der zunăchst den großen mittelalterlichen Weg der Verwirklichung und Konzentration des religiösen Lebens, den Weg des Mönchtums, geht, und der Theologe, der aus eigenem inneren Erleben und theologischen Studium der Spätscholastik, der Mystik, Augustins, Bernhards und des Neuen Testaments seine Positionen gewinnt und erst von hier aus in die Beziehungen zu den Strömungen der Zeit eintritt. Auch ist hierbei übersehen, daß Luther aus dem Kirchenbegriff heraus arbeitet und diesen umgestaltet, aber nicht durch eine kirchenfreie Mystik und Laienreligion ihn ersetzt. Dadurch sind ihm von vorneherein die Ziele vorgezeichnet, die ihm die kirchliche Objektivität von Wort und Sakrament und die weiteren Folgen des Kirchenbegriffes vorschreiben, von denen sofort näher $\mathrm{zu}$ handeln ist. Deshalb ist er auch in erster Linie kirchlicher Theologe und sowohl von den Sektenhäuptern als von den ganz individualistisch denkenden Vertretern einer reinen Laienreligion scharf zu unterscheiden. Deshalb irren alle Darstellungen, die ihn nicht als Reformator der Kirche, sondern als Vertreter der rein individualistischen, von den heutigen Modernen bevorzugten Laieureligion auffassen und um deswillen in eine allzustarke historische Kontinuität mit der spätmittelalterlichen Laienreligion und dem bürgerlichen Denken statt mit der eigentlichen theologischen Ueberlieferung stellen. Die Einwirkungen des ersteren Elementes in seiner vormönchischen Zeit und durch das Medium der jedenfalls neue soziologische Positionen enthaltenden Spätscholastik, der Mystik und des Humanismus sind überhaupt noch erst genauer festzustellen, soweit etwas Derartiges bei solchen Unmeßbarkeiten möglich ist. Das Verhältnis seiner bereits in den Grundzügen ausgebildeten Lehre und der lutherischen Propaganda zu den sozialen Strömungen der Zeit ist jetzt beleuchtet in dem wichtigen Werke von Barge: AAndreas Bodenstein von Karlstadt<, 2 Bd., 1905. Hiernach steht Luthers eigene Lehre in ihrer fertig ausgebildeten Gestalt überall auf Seite der Regierungen und ihrer Ordnungsinteressen, die eine kirchliche Reform, die Brechung der Hierarchie, die Säkularisation und eine moralischautoritative Bemeisterung der aufgeregten Bevölkerungen verlangen; Luther selbst. 
paulinischen und augustinischen Gnadenreligion gegen die katholische Gesetzesreligion zu bezeichnen. Das trifft auch in der Tat das Wesentliche der Sache, aber es bedarf einer sehr bestimmten Erläuterung. Denn in dieser Wiedererhebung liegt der Schwer-

ist für soziale Reformen nur in diesem Rahmen interessiert, nachdem die ersten großen idealen Reformwünsche der Schrift an den Adel und der dann bei Versagung des Adels eintretenden Wendung auf kleine Gemeinden echter Christen mit einer christlichen Kastenordnung an" den realen Verhältnissen gescheitert waren. Ihm liegt an einer Sozialreform immer nur in zweiter Linie und auch hier nur um deswillep, weil damit bessere Voraussetzuugen für das religiöse Leben gewonnen werden. Er ist eben rein religiös interessiert und im übrigen eine durchaus konservative Natur. Daneben gab es die sozialrevolutionären Bestrebungen der Ba uern und des Proletariats der großen Städte, deren religiöse Beimischungen aber mehr hussitisch-taboritischer Art sind und die von der lutherischen Bewegung zwar mit erregt, aber nicht geistig und theologisch bestimmt sind. Schließlich gibt es eine dritte, von Barge besonders hervorgehobene Gruppe kleinhandwerkerlicher $R$ e f or $m$ b e w e g u $\mathrm{g}$ e $\mathrm{n}$, denen die Pfarrer und Schulmeister nahestehen; sie wollen in einem lang genährten Kirchenhaß ein freies Laien- und Gemeindechristentum, das kultisch den Katholizismus radikal beseitigt, theologisch die Amts- und Autoritätskirche aufhebt und sozialethisch allerhand Reformen unter Wahrung des Staates und der Rechtsordnung im Sinne strengerer Christlichkeit der Lebensführung und karitativer Fürsorge, auch elementare christlich-soziale Reformen der Gesellschaft überhaupt, durchführt; alles aber nicht durch die Landesfürsten, sondern durch die Ortsobrigkeiten und Gemeindevertretungen; die letzteren. Kreise nehmen die radikal - antisakramentale Theologie in sich auf und sind der Nährboden der Täufer, da überall die Landesherren oder stärkere Nachbargewalten derartige kommunale Selbständigkeit unterdrücken. Auch fehlt hier jeder klare Gedanke über eine umfassende und einheitliche Neugestaltung der Kirche, wie sie später der Calvinismus aus ähnlichen Ideen heraus entwickelte. Es sind lokale Provisorien mit der Erwartung, daß irgendwie die Ordnung der Gesamtkirche sich schon finden werde. Als diese, wie selbstverständlich, von hier aus sich nicht ergab, wurden diese Bestrebungen reif für die Bildung separierter Gemeinden oder der Täufer. So zeigt sich auch von dieser Seite her, daß von einer einheitlichen Klassenbedingtheit der reformatorischen Lehre und ihrer Entwickelung nicht die Rede sein kann. Eine sehr große Rolle spielt dagegen, wie Barge mehrfach hervorhebt, die im Spätmittelalter entstandene Abneigung gegen die katholische Kirche und die Laienselbständigkeit, welch letztere selbstverständlich weitverzweigte Wurzeln in nicht bloß ideellen Gegensätzen, sondern in realen sozialen Tatsachen hat. Immerhin aber darf man in einer so stark von religiösen Ideen durchsetzten Zeit die selbständige Bedeutung des Bibelstudiums durch die Masse nicht unterschätzen. Die ungeheure Streitliteratur mit ihrer für den modernen Menschen ganz unverständlichen Bemühung um Bibelaus- 
punkt nicht sowohl in dem Radikalismus der Geltendmachung der Gnade gegen das Gesetz als in dem neuen Begriff dessen, was dic Gnade ist. Die Betonung der reinen Gnade und der Ausschluß des freien Willens richtete sich doch unmittelbar nur gegen die herrschende spätscholastische Lehre, die Luther vorfand und aus der er herauswuchs. Nicht aber trifft er damit den Katholizismus überhaupt ${ }^{199}$ ). Ihm als Ganzem gegenüber liegt sein Gegensatz noch tiefer. Auch der Katholizismus war Gnadenreligion. Aber er hatte die Gnade als sakramentale Gnade der Uebernatur angesehen, als ein durch die Hierarchie einzuflößendes, höheres und mystisches, der Kirche anvertrautes Wunderwesen mit der Doppelwirkung der Sündenvergebung und der mystischen Wesensüberhöhung der Menschen. Mit diesem Gnadenbegriff hatte sich leicht der des Gesetzes verbunden. Denn diese Gnade mußte, sollte ihr ethischer Charakter gewahrt werden, vorbereitet sein durch ethische Prüfung und durch ernstes Heiligkeitsstreben, die beide sich am Gesetz maßen; sie mußte aus demselben Grunde bewährt werden in guten Werken, die wiederum am Gesetz zu messen waren und die ohne Schaden im Schema des Gesetzesbegriffes gedacht werden konnten, wenn es doch die IVundermacht der eingegossenen Gnade war, die so unter Befreiung der natürlichen Krälte des Menschen im Grunde allein dic guten Werke und Verdienste hervorbrachte. Die neue Idee I.uthcrs ist daher nicht bloß die radikale auf Kompromisse mit dem Gesetzesbegriff verzichtende Geltendmachung der Gnade über-

legungen ist nur aus einem selbständigen religiösen Interesse an der Bibelgemäßheit von Lehre und Leben zu verstehen. Außerdem ist, wie überall bei solchen allgemcinen Erregungen, mit cinem Bodensatz von Demagogie zu rechnen, die die buntesten und verworrensten, aber eben darum auch bedeutungslose und prinziplose Wildheiten emportreibt. - Indem ich den wichtigsten Inhalt des Bargeschen Buches so wicdergebc, drücke ich zugleich meine Abweichungen von ihm aus. Der slaienchristliche Puritanismuse, als dessen Apostel er Karlstadt mit starker Parteinahme (s. Karl Müller, Luther und Karlstadt, 1907) schildert, ist weder die eigentliche Konsequenz der lutherischen Idec - darüber gleich mehr - , noch ist er ein für deutsche Verhältnisse irgendwie aussichtsreiches Programm; warum, wird sich bei Aualyse des Calvinismus zeigen.

199) Das ist stark betont ron Krogh-Tonningh, „Der letzte Scholastiker «, 1904, womit Jer Thomist und holländische Karthäuser Dionysius gemeint ist. Der Gegensatz liegt aber eben auch nicht in der Polemik gegen den nominalistischen Semipelagianismus, sondern in dem Gnadenbegriff, der auch dem prädestinatianischen Thomas entyegengesetzt ist. 
haupt, sondern noch mehr die eines ne uen Sinnes der Gnade selbst. Andererseits hat ja auch Luther und der Protestantismus die Gesetzesidee keineswegs wirklich aus dem religiösen Zentrum beseitigt. Das Gesetz blieb als Erreger der Buße und als Voraussetzung des Glaubens und des Gnadenevangeliums. Das Gesetz blieb als nächster und erster Ausdruck des göttlichen Willens und Wesens, das nur einen freudigen und willigen Gehorsam aus Liebe und Vertrauen, aber eben doch eine Erfüllung des voll und spiritual verstandenen Gesetzes forderte. Das Gesetz blieb als Voraussetzung des Erlösungswerkes Christi, der in seinem Tode das Gesetz vernichtete und erst die Gnadenordnung frei machte. Das Gesetz blieb schließlich, wenn auch in sehr unklarer Stellung, als Regel für das Handeln im Gnadenstande, nur jetzt ohne Verdienst und Heilsbegründung, weil die das Heil begründende Gnade nicht Verdienste und gute Werke, sondern eine neue als ganze und im Prinzip Gott bereits verbundene Person hervorbringt. Es zeigt sich also auch von dieser Seite her, daß das Neue nicht in der Ueberwindung des Gesetzesbegriffes an sich, sondern in dem besonderen Inhalt des Gnadenbegriffes liegt, der dem Gesetz eine andere Bedeutung und Stellung zuweist als der katholische Gnadenbegriff getan hat. Das Wesentliche dieses neuen Gnadenbegriffes ist nun aber, daß die Gnade nicht mehr eine sakramental einzugießende, mystische Wundersubstanz, sondern eine von Gla ube, U eberze ugung, Gesinnung, Erkenntnis und Vertrauen anzueignende Gottesgesinnung, derim Evangelium und in Christi Liebe und Gesinnung \% u den Menschen erkennbare sündenvergebende Liebeswille Gottes ist ${ }^{200}$ ). Die Religion tritt in die Sphäre

200) Gut formuliert bei Preuß, Die Entwickelung des Schriftprinzips bei Luther bis zur Leipziger Disputation, 1901, S. 34: Scholastische Lehre war, daß odie Sakramente des neuen Bundes opere operato die rein sachlich als ethische und religiöse Kraft gedachte Gnade wirken. Verlangt wird nur, daß der betreffende keinen Riegel vorschiebe. Das entsprach durchaus der ganzen mittelalterlichen Grundanschauung, die das Verhältnis von Gott und Mensch als ein sozusagen dingliches, als einen Austausch von Handeln und Handeln, als ein Leistungs- und Lohnverhăltnis auffaßte. Diese Anschauung, die auch Luther in seinen Anfängen teilte, die ihn aber so wenig befriedigen konnte, daß sie ihn vielmehr in Verzweiflung trieb, war für ihn seit jenem grundlegenden Erlebnis im Prinzip überwunden. An die Stelle des alten trat jetzt ein durch Gottes Gnade, 
des Gedanklichen, des Psychologischen, des Geistes, aus der des Dinglichen und Substanziellen, das von Gedanke und Gesinnung nur begleitet war. Sie soll darum nicht aufhören ein Wunder zu sein. Denn das Wunder besteht nun darin, daß der Mensch in seiner Schwäche, Trotzigkeit, Verzweiflung und Uñreinheit einen solchen Gedanken aus dem Evangelium heraus fassen kann; er kann es so wenig aus eigenen natürlichen Kräften und der religiös erlösende Gedanke liegt so weit aus dem Gebiete der natürlichen Gedankenbewegung, daß er nur durch das Wunder der Prädestination zustande kommen kann. Es ist ein inneres Wunder des Glaubens an das Evangelium und Christus, nicht ein innerlich-äußerliches Wunder der hierarchisch-sakramentalen Gnadeneingießung mit der Folge der Kraft zu guten Werken und Verdiensten. Es ist auch nicht ein beliebig veränderlicher und beweglicher Gedanke, sondern eine mit absoluter Offenbarungsgewißheit dargebotene Er. kenntnis, die von dem Bilde des menschgewordenen, leidenden und auferstandenen Gottessohnes ausgeht und in der Bibel eine absolut wunderbare und authentische Darstellung dieses Christusbildes besitzt, wenn auch die Bibel im einzelnen nicht frei ist von allerhand Menschlichkeiten. In der so durch das $>$ Wort * gewirkten Glaubensgesinnung liegt daher für den Protestantismus der Kern der Religion, wie er für den Katholizismus in Priestertum und Sakrament, Gehorsam und Mystik, liegt. Es ișt die Glaubens-

die nur a ls persönliche Zuwendung Gottes zum Sünder vers ta n d e $n$ wurde, und des Menschen Glauben, d.i. sein persönliches Vertrauen zu Gott bestimmtes, rein persönliches Verhältnise. Daß Luther im katholischen Sakrament keinen Frieden und in der Selbstdisposition für das Sakrament nur Sündenangst, Gesetzesdruck und Eigengerechtigkeit empfinden konnte, das ist das Entscheidende. Hieran zeigt sich die andersartige religiöse Empfindung und von hier geht die Berufung auf die paalinische Gnadengewißheit in Christo aus. Auch Böhmer (Luther im Licht der neueren Forschung, 1906), der erst mein Mißverständnis tadelt, daß eine allerdings wichtige Konsequenz, die Sakramentslehre, zum Ansgangspunkt von mir gemacht würde, sagt das Gleiche : s Die Gnade wird von ihm nicht mehr aufgefaßt als eine übernatürliche $\mathrm{K}_{r a f t}$ oder Medizin, die dem Menschen durch die Sakramente eingegossen wird und dann doch geistige und sittliche Wirkangen hervorbringen soll, sondern als eine Gesinnung Gottes, die in dem , Worte Gottese verkündigt wird und durch das Mittel des Wortes wirkt, wie auch sonst die Kundgebung einer Gesinnung durch das Wort wirkt.e S. 17. Genau, das ist meine Meinung, und was Böhmer gegen mich sagt, ist Mißverständnis. Genau wie meine These ist Gottschicks Definition, Die Lehre der Ref. จ. d. Taufe, I906, S. 13. 
und Ueberzeugungsreligion an Stelle der hierarchisch-sakramentalen Religion; die zwei verbleibenden protestantischen Sakramente sind besondere Darstellungsarten des Evangeliums und enthalten inhaltlich nichts, was über die Wirkung des Bibelwortes hinausginge, sind daher keine Sakramente mehr im katholischen Sinne ${ }^{201}$ ).

In dieser Grundstellung liegen nun aber die weiteren Folgerungen teils unmittelbar teils mittelbar enthalten.

Erstlich ist es die Reduktion der ganzen Religion auf das-

201) Hierzu und zum Folgenden vgl. meine Darstellung in Kultur der Gegenwart I, IV, I: Protestantisches Christentum und Kirches. Dort ist auch die meiner Auffassung zugrunde liegende Literatur verzeichnet. In der zweiten Auflage I 909 bin ich auf die erhobenen Widersprüche eingegangen. Sie haben im wesentlichen an der sachlichen Auffassung nichts geändert, sondern wenden sich nur gegen meine Kontrastierung der reformatorischen Ideenwelt gegen die moderne Ideenwelt. Das aber ist ein Gesichtspunkt, der für die Gesamtdarstellung des Protestantismus unumgänglich ist, weil seine gegenwärtige Krisis daraus allein zu verstehen ist. Für die vorliegende Darstellung fällt dieser Gesichtspunkt weg. Hier handelt es sich lediglich um das Besondere der konfessionell-protestantischen Soziallehren gegenüber den lateinisch-katholischen und den altchristlichen. Doch wird sich auch hier zeigen, daß hier Grundvoraussetzungen fortgeführt sind, die erst der lateinische Katholizismus erworben hat; ja von der soziologischen und ethischen Seite her zeigt sich die Kontinuität noch viel deutlicher als von der rein dogmatischen her, die die Theologen meist allein im Auge haben. Indem nämlich die geschlossene Herrschaft einer religiösen Autorität und die dementsprechende stabile Verfassung der profanen Gesellschaft wie des profanen Denkens dem Mittelalter und dem Altprotestantismus gemeinsam sind und eben auf dieser Geschlossenheit, Autorität und Stabilität in beiden Fällen das ganze System beruht, indem ferner diese Geschlossenheit und Stabilität einer nach ihrer geistlichen und weltlichen Seite festgelegten christlichen Kultur und Gesellschaft theoretisch wie faktisch erst das Werk des Mittelalters ist, bildet dieses die Voraussetzung des Protestantismus und wirkt seine Idee im Protestantismus weiter. Die tiefgreifenden Unterschiede sind dabei selbstverständlich nicht zu übersehen, aber sie bewegen sich innerhalb eines gemeinsamen Rahmens. Und eben dieser gemeinsame Rahmen ist es, den die moderne Welt zerbrochen hat; ja, das ist dasjenige, was an ihr allein ganz deutlich als ihr Charakter zu fixieren ist; s. meine Abhandlung sDas Wesen des. modernen Geistes^, Preuß. Jahrbb. 1907. Mit der Zerbrechung dieses Rahmens werden aher dann die der modernen. Welt verwandten Motive des Protestantismus erst frei gesetzt und finden eine Entwickelung, die von dem Sinn und Geist der Reformatoren weit abführt, bei denen jener Rahmen mit dem Gegenstande selbst aufs engste zusammenhing. S. meinen Aufsatz: sLuther und die moderne Welte in $>$ Das Christentum<, Leipzig 1907. 
jenige, was allein Gegenstand von Glaube, Vertrauen und Gesinnung sein kann, d. h. auf den aus dem apostolischen Christusbilde zu schöpfenden Gedanken von Gott als dem heiligen, Sünden vergebenden und dadurch in ein höheres Leben emporhebenden Gnadenwillen. Weiter gehört zu diesem Gedanken nur, was ihn für den Sünder gewiß machen kann, nämlich die Erkenntnis von Gottes Offenbarung und Herablassung in dem menschgewordenen Gottessohne oder Logos. Und auch an diesem Christusbilde sind nicht seine dunklen und geheimnisvollen Wesensgründe, sondern die in seiner Herablassung zu Menschwerdung, Leiden und Güte liegende Vergewisserung über Gottes sündenvergebende Liebe das Wichtige. Das ist eine ungeheuere Reduktion des Dogmas und eine neue Begründung des Dogmas auf die gefühlte, Glaube und Vertrauen weckende Kraft. Die unbedingte Autorität des all das verbürgenden apostolische Christusbildes versteht sich zusammen mit dem Wundercharakter der. Bibel von selbst. Das Problem ist nicht, wie man dies beweisen, sondern wie man dessen persönlich sich getrösten könne, was nur durch die prädestinatianische Wunderwirkung des den Glauben wirkenden Gottes selber möglich ist. In jeder Regung des Vertrauens darf der Gläubige die errettende Wundermacht Gottes spüren.

$\mathrm{Z}$ we it e $\mathrm{n} \mathrm{s}$ liegt hierin der religiöse Individualismus, die durch Menschen und Priester nicht vermittelte Innerlichkeit der Gottesgemeinschaft. Damit entfällt jede Vermittelung durch Hierarchie und Sakramentseingießung, die sich ja gegenseitig bedingen. Die Konsequenz ist das allgemeine Priestertum und die Laienreligion, die Neubelebung der urchristlichen Selbständigkeit und Autonomie der vom "Geiste * gewirkten Gotteserkenntnis. Darin begegnet sich Luther mit den entsprechenden, gleichfalls aus der Bibel entspringenden Tendenzen des Sektentums. Allein, was entfällt, ist doch nur die priesterlich-sakramentale Vermittelung. Um so stärker bleibt die durch das Wort, d. h. durch die Bibel und, da sie wesentlich Zeugnis von Christo ist, durch das biblische Christusbild. Nur aus ihm will Gott erkannt werden. Nur in ihm zeigt er sich als Gott der Gnade, während ei überall sonst außer Christus als Gott der grausigen metaphysischen Rätsel und der Gesetzesangst erscheint. Nur das Vertrauen zu Christus ist wirkliches Gottvertrauen. Nur durch seine Vergegenwärtigung findet ein Verkehr der Seele mit Gott statt. Lnd sofern nun dieses Christusbild in der gottgewirkten Bibel in- 
karniert ist, ist diese oder das *Wort * die eigentliche und alleinige und alles andere, auch jede unmittelbare Mystik ausschließende Vermittelung des Verhältnisses zu Gott. Diese Bibel aber bildet mit ihrer Christusbotschaft den Kern der Kirche, die Gott durch Christus als die aus der Predigt hervorgehensollende Gemeinschaft der Gläubigen gestiftet hat. Für diese Gemeinschaft hat er auch das Amt des Wortes oder der Predigt von Christo eingesetzt als die dauernde objektive Grundlage und Vermittelung alles Heils. Gleichgültig und menschlichem Belieben anheimgestellt sind nur die Art der Berufung zu diesem Amt des Wortes und die technisch-juristischen Einzelheiten der Organisation. Hier bedarf es nur regelmäßiger Ordnung und berufsmäßiger Vorbildung überhaupt zum Ausschluß von Willkür und Unkenntnis ${ }^{202}$ ).

Das dritte, was hierin liegt, ist das Prinzip der reinen Gesinnungsethik. Macht Glaube, Gesinnung, Vertrauen zu Gott im Wort den Wert des Menschen überhaupt, so ist die Gesinnung auch Wurzel und Maßstab des daraus folgenden Ethischen. Es gibt kein kirchliches, autoritatives Sittengesetz und keine Abnahme der Verantwortung durch die Kirche, sondern nur den Trieb des eigenen Gewissens. Es gibt keine einzelnen guten Werke, sondern nur eine entscheidende Ganzheit der Gesinnung. Es gibt keine Verdienste und Mißverdienste, sondern nur Auswirkung oder Hemmung des prinzipiellen neuen Gesinnungslebens. Es gibt keine Rechnung mit Lohn und Strafe des Jenseits, sondern nur die Seligkeit der neuen Gesinnung, aus der alles Gute von selbst folgt. Dabei ist aber doch selbstverständlich, daß Norm und Maß dieses Gesinnungsguten das Gesetz des Dekalogs und des Neuen Testamentes bleibt, da ja beide, wie bisher, zusammenfallen mit dem natürlichen Sittengesetz und dadurch sich als Formel für den natürlichen sittlichen Trieb bekunden; der letztere hat in jenen biblischen Kundgebungen nur seine offenbarte Formulierung gefunden. Diese im Dekalog fixierten, an sich auch im natürlichen Bewußtsein liegenden Forderungen sind nur mit der aus dem Glauben quellenden religiösen Gesinnung zu erfüllen, um das Christlich-Gute zu bedeuten. Dabei ist offenkundig, daß die als selbstverständlich

${ }^{202}$ ) Hiezu vgl. Herrmann: Der Verkehr des Christen mit Gott ${ }^{5}$, 1908. Hier ist nur die lutherische Christuslehre stark modernisiert und die Bedeutung der Sakramente, vor allem der Realpräsenz des Leibes und Blutes Christi, sehr zurückgedrängt. Das richtige Bild entsteht erst, wenn man die Inkarnations-Christologie und die objektive Sakramentslehre wieder in diesen Zusammenhang einsetzt. 
fortgeführte Gleichung von Dekalog und Naturgesetz und christlichem Gesetz die Einbeziehung der innerweltlichen Ethik in die christliche bedeutet, wie sie das bisher für die ganze patristische und mittelalterliche Ethik bedeutet hatte ${ }^{208}$ ).

Aus dieser Gesinnungsethik folgt viertens die Weltbejahung dieser Ethik, die Beseitigung der mönchischen Askese, die Neugestaltung des Berufsbegriffes. Der religiöse Individualismus der Glaubensreligion, der keine quantitativ verschiedenen Aneignungen autoritativer Kirchendogmen, sondern nur die Ganzheit der Ueberzeugung kennt, überträgt sich auch auf die ethische Gesinnung. Sie ist überall ein Ganzes und darum überall prinzipiell gleich trotz aller Verschiedenheit der Betätigungen. Das bedeutet die individuelle Gleichheit des Vollkommenheitsideals für alle und beseitigt die harmlose Selbstverständlichkeit, mit der der Katholizismus die verschiedenen Grade, Stufen und Stände der Vollkommenheit ertrug. Es beseitigt zugleich die überverdienstlichen Werke, die gegenseitigen Stellvertretungen und Ergänzungen durch solche. Das bedeutet vor allem die radikale Beseitigung des Mönchstandes als eines Wahnes besonderer höherer Vollkommenheit. Aber die für alle gleiche Vollkommenheit ist dann doch nicht der Rigorismus des Christusgesetzes wie in der Sekte, sondern die prinzipielle Gesinnungsgleichheit der Vergebungsseligkeit, aus der das Tun der sneuen Person* frei hervorfließt. In der gleichen Richtung wirkt auch die mit der Glaubensreligion gegebene Beseitigung der sakramentalen Gnade der Uebernatur. Es gibt keine Uebernatur mehr und keinen Stufenbau von der Natur zur Uebernatur, von der säkularen Moral zur geistlich - überweltlichen. Das Halb- und Ganzmönchtum erscheint nur als besondere selbstgemachte Bedingung des sittlichen Handelns, die den natürlichen von Gott gegebenen-ßedingungen entflieht und durch künstliche Verhältnisse scheinbar sich schwerere Aufgaben stellt, in Wahrheit aber die christliche Weltüberwindung erleichtert. Es gilt die Welt zu überwinden, wo man sie findet, mitten in der Welt das Herz von der Welt befreien und sich von ihr unabhängig machen. Jeder besondere selbsterwählte Spielraum des Handelns, jede neben der weltlichen Ar-

109) Hiezu vgl. Gottschick, Ethik, 1907. Hier sind Motive und Sinn der lutherischen Ethik vortrefflich erörtert; man vermißt nur hier, wie freilich auch sonst, eine Auskunft über Luthers Begriff vom Inhalte des christlichen Sittengesetzes, worüber unten mehr. 
beit hergehende und über sie sich hinausstellende Liebesgemeinschaft hört auf; gerade in den gegenseitigen Diensten des Weltlebens erweist man sich die christliche Liebe. Damit tritt dann auch das System der Berufsgliederungen, die der Protestantismus im ganzen genau ebenso aus dem Naturgesetz hervorgehen läßt, in eine neue Beleuchtung. Es ist nicht die naturgesetzliche Ordnung der niederen Sphäre, uber der der Bau der Kirche und der mystischen Liebesgemeinschaft sich erhebt, sondern es ist die gottgewollte Sphäre alles und des ganzen christlichen Handelns, in der jeder den ihm aus dem geordneten System zufallenden Beruf als die ihm von Gott verordnete Lebensaufgabe und den von ihm verlangten Beitrag z̀u der christlichen Liebesverbindung zu erkennen hat. Die Berufe werden daher in ihren Hauptformen, wie der hausväterliche Beruf oder der Ehestand, der landesväterliche Beruf und das Regierungsamt, auf besondere göttliche Anordnungen und Stiftungen zurückgeführt. Das widerspricht nicht ihrer gleichzeitigen Ableitung aus dem Naturgesetz, sondern ist nur eine besondere göttliche Bestätigung und Einsetzung der wichtigsten von ihm geforderten Berufe ${ }^{204}$ ). So tritt an Stelle der bisherigen Bezeichnung als ministerium und officium

204) Diese Verschiedenheit direkt göttlicher Einsetzung und indirekter naturgesetzlicher Herbeiführung ist charakteristisch für die stark religiös-positivistische Haltung des Lutherschen Denkens. Doch vereinigt sich beides in dem Gedanken, daß so oder so Gott der Alleinwirkende ist und daß die besonderen Einsetzungen nur direkte Bekundungen des sonst indirekt und vermittelt den göttlichen Willen auswirkenden Naturgesetzes sind: siehe Luthardt, Luthers Ethik, 1867, S. 94 f.: Die natürlichen Ordnungen und Stände... gehören nur diesem zeitlichen und natürlichen Leben an. Aber obgleich sie nur weltliche Stände sind und der Vernunf unterstehen, sind sie damit doch nicht eigentlich profan, sondern Gottes Stiftung, Ordnung und Wille, und Gott ist in denselben gegenwärtig. Denn Gott gebraucht seine Kreaturen wie sLarven«, hinter denen er selbst verborgen ist und unter deren Vorhang und Deckele er alles tut.. Die Anschauung an der wirksamen Gegenwärtigkeit Gottes in allen seinen Kreaturen und Ordnungen hat er stets festgehalten. Sind nun aber diese weltlichen Stände Gottes Wille und Ordnung und ist er in ihnen gegenwärtig, so wird auch zwischen ihnen und dem Evangelium Gottes eine Beziehung stattfinden. Denn sie sind beide Gottes, wenn auch verschieden - dort die Ordnung Gottes des Schöpfers, hier des Erlöserse. Es ist schon hier darauf hinzuweisen, daß von hier aus die konservative Fassung des Naturgesetzes und Naturrechts im Luthertum entsteht, vgl. Eugen Ehrhardt, La notion du droit naturel chez Luther (Festschrift von Paris für Montauban, 1901, S. 287-320). 


\section{III. Der Protestantismus. 1. Das sosiologinche Problem.}

die als vocatio, worin angedeutet ist, daß die Berufsgliederung nicht aus der niederen, erst zu überbauenden Natursphäre stammt, sondern wie diese selbst eine direkte und unmittelbare Anordnung Gottes ist ${ }^{2040}$ ). Sie geht direkt aus seinem eigensten Wesen hervor, nicht erst mittelbar aus der gegen sein eigentlichstes Wesen differenzierten Natur. Das ist dann freilich ein neuer Naturbegriff, eine innerliche und wesenhafte Verbindung Gottes und der Natur, welche letztere die unmittelbare Setzung seines Willenswesens und nicht eine tiefere Stufe seiner Selbstentäußerungen ist. Freilich aber ist das Ganze dann doch so zu verstehen, daß dieses System der Berufsgliederungen ein feststehendes, durch göttliche Stiftung im alten Testament und durch Naturgesetz fixiertes System ständisch-patriarchalischer Ordnung ist, innerhalb dessen jeder in bleibende Kategorien gehört und für seine Zugehörigkeit meist durch die Geburt schon die sichere Anweisung erhält. Weiter ist nicht zu vergessen, daß diese unmittelbare Göttlichkeit der Natur eine einfache positive Willenssetzung ist, die der christliche Gehorsam hinnimmt und nicht mit eigenem Witz überbietet; ein wirklicher innerer Wesenszusammenhang dieser Natur mit Gott ist damit nicht behauptet und nicht empfunden. Ueberdies ist die Natur im Sündenfall derart verdorben worden, daß die gegenwärtige Natur der Menschen nicht bloß, sondern die Natur überhaupt nur ausnahmsweise Gott offenbart; im ganzen offenbart sie vielmehr die Bosheit und Verführungskunst des Teufels und das Elend der Sündenstrafe. So ist die innerweltliche Berufssittlichkeit allerdings eine Weltbejahung, aber eine Weltbejahung aus Gehorsam und Ergebung, nicht aus der Freude an Gottes Welt; das letztere Motiv wagt sich nur gelegentlich hervor. Die Weltbejahung hört im Grunde nicht auf, Askese, d. h. Weltverleugnung zu sein, nur ist es eine andere Askese als die heroische MortifikationsAskese der Kirche und als die gesetzliche Weltenthaltung der Sekten. Es ist die innerweltliche Askese der Ueberwindung der Welt in der Welt, der Selbstverleugnung im Beruf und im beruflichen Dienst für das Ganze, der Gehorsam, der in gegebenen

2040) Zum Verständnis des Unterschiedes beider Terminologien dient die Tatsache, daß sofficiume die offizielle lateinische Bezeichnung für >Zunft war, siehe Oncken, Gesch. d. Naturalökonomie, I I12. Officiums ist die natürliche Gliederung, vokatio die gleichzeitig darin liegende göttliche Veranstaltung, die letztere aber ist bei $S$. viel stärker betont. 
Bedingungen stehen bleibt und innerhalb ihrer den natürlichen Menschen und den Teufel überwindet ${ }^{205}$ ). Von den Spannungen und Schwierigkeiten, die in dieser den Katholizismus weit überbietenden Weltbejahung liegen und die für die Sozialphilosophie des Protestantismus von großer Bedeutung sind, wird noch vielfach die Rede sein müssen.

Alledem liegen natürlich in 1 e $\mathrm{t} z$ ter $\mathrm{L}$ in i e mehr oder minder bewußt neue Konzeptionen der religiösen Grundbegriffe, der Begriffe von Gott, Welt und Mensch, zugrunde. Das kann hier nicht weiter auseinandergesetzt werden ${ }^{206}$ ); es seien nur einige für unseren Zusammenhang bedeutsame Punkte herausgegriffen. Beim Begriff des Men s che n zeigt sich der neue Gedanke am deutlichsten in der Urstandslehre. Hier fällt die Staffelung von der natürlichen Vollkommenheit zu der übernatürlichen Vollkommenheit weg; die Vollkommenheit des Urstandes war das volle religiöse Gesinnungs- und Vertrauensverhältnis inmitten der natürlichen Wesensbeschaffenheit des Menschen als zu dieser gehörig. Daher ist die Sünde eine Aufhebung des menschlichen Wesens und die Erlösung die Wiederherstellung des Wesens zum vollen Gottvertrauen innerhalb der natürlichen Lebensarbeit. Hier ist das neue Verhältnis von Gott und Mensch mit Händen zu greifen. Für den Begriff von der W elt ist die natürliche Konsequenz der Fortfall des Stufengedankens. Er fällt nicht nur in der Ethik und in der Erlösungslehre, sondern in der ganzen Auffassung von der Welt selbst fort. Die Materialität und Natur ist nicht eine entferntere Stufe der göttlichen Weltschöpfung nach der reinen Geisterwelt, sondern der von der Schöpfung gesetzte Boden aller idealen Werte. Diese waren voll verwirklicht mit der Vollkommenheit der menschlichen Natur im Urstand und werden wieder hergestellt in der Erlösung. Sie bewegen sich innerhalb der gegebenen Welt und überhöhen diese nicht durch eine höhere Stufe mystisch-sakramentaler Wunderkräfte. Das Wunder dient bloß der Heilung des Sündenelends und der Wiederherstellung der Natur, aber nicht der Bewirkung der Uebernatur. Das ist ein

205) Hierzu vgl. Karl Eger, Die Anschaungen Luthers vom Beruf, 1900, und Max Weber, Der Geist des Kapitalismus und die protestantische Ethik, Archiv f. Sozialwiss. XX und XXI.

206) Hierzu vgl. Schlußkapitel von Harnacks Dogmengeschichte und F. Ch. Baur, Der Gegensatz des Kath. u. Prot. nach den Prinzipien und Hauptdogmen ${ }^{2}$ 1836 . 
anderer Wunderbegriff. $\mathrm{Er}$ geht aus dem die Sünde wieder aufhebenden Heilswillen Gottes, nicht aus der den innersten Kern der göttlichen Wesenssubstanz bildenden Uebernatur selbst hervor. Damit fällt dann freilich auch der Gedanke der Entwickelung weg, wie ihn der Katholizismus auf seine Weise in dem System des Aufstiegs von der Natur zur Gnade ausgebildet und mit der aristotelischen Lehre vom Stufengang der Entelechien verbunden hatte. Der Mensch staffelt sich nicht schon im Urstand auf zur übernatürlichen, von der Natur vorbereiteten Vollkommenheit; der Weltenbau und die Erde bilden sich nicht aus der Natur empor zum Reich der Gnade; die Gesellschaft knüpft nicht an Naturgrundlagen an, um an sie die Gnadengemeinschaft kontinuierlich anzuschließen. Vielmehr alles ist fertig mit einem Schlage und die aristotelische Entwickelungslehre verschwindet ebenso wie die neuplatonische Emanationslehre. Der Sündenfall ist nicht der Rückfall der Natur zu sich selbst und die Erlösung nicht die Emporbildung aus der Natur zur Gnade, sondern der erste ist die Aufhebung und das zweite die Wiederherstellung des Wesens. Uebergänge, Vermittelungen und Werdeprozesse gibt es hier nicht wie in der katholischen Dogmatik, sondern nur Fall und Wiederherstellung. Eben deshalb wird auch die christliche Ethik nicht angeknüpft und herausentwickelt aus Naturgrundlagen, sondern hergestellt durch das Wunder der Gnade und lediglich äußerlich versetzt in den Betätigungsspielraum der natürlichen Verhältnisse, die der Gehorsam zu akzeptieren hat. Hier geht das ganze katholische Vermittelungswerk in Metaphysik, Ethik und Gesellschaftslehre in Trümmer, entsteht aber freilich auch ein sehr hartes und gezwungenes Bild der Dinge, in dem die irdischen Relativitäten und Werdeprozesse keinen rechten Platz haben, wie sich in den Schwierigkeiten und Widersprüchen der lutherischen Ethik deutlich zeigen wird ${ }^{207}$ ). In letzter Linie kommt dieser ganze Sachverhalt zum Ausdruck im Gottesbegriff. Er ist nicht mehr gemischt aus dem naturhaften Begriffe der absoluten unendlichen, in verschiedenen Stufen sich entäußernden Substanz und dem personalistischen Begriffe des göttlichen Gesetzes, das in Natur und in Geisteswelt alles regelt und durch die Gnade das höchste mystische Offenbarungsgesetz erfüllbar macht mit Verdiensten und entsprechenden himmlischen Seligkeiten. Der Gottesbegriff stößt alle wissenschaftliche, das Endliche und Un-

${ }^{207)}$ Den Stufenbegriff hatten auch schon die Sekten beseitigt, wie oben ge- 
endliche vermittelnde Metaphysik ab und wird mit entschlossenem Anthropomorphismus als göttlicher Wille gefaßt, indem nicht mehr Natur und Uebernatur, sondern Gesetz und Evangelium, sittliche Forderung und sündenvergebender Liebeswille, Vergeltungsordnung und Gnadenordnung zusammenzudenken sind. Das Mittel, beide zusammenzudenken, ist der Genugtuungstod des Gottmenschen, der daher das protestantische Zentraldogma wird und den sonst überall ausgesstoßenen Stellvertretungsgedanken beim Gottmenschen zur höchsten Bedeutung bringt. In einem solchen Gottesbegriff sind andere Motive und Ziele der religiösen Gemeinschaft und andere Rechtfertigungen der natürlich sozialen Lebensformen gesetzt als in dem katholischen Gottesbegriff der absoluten Substanz und der Weltentwickelung von der Natur zum Wunder der Uebernatur. Das wird die folgende Untersuchung überall als letzten Grund erkennen lassen.

Das ist das Wesentliche der reformatorischen religiösen Idee. Es ist dabei unverkennbar, daß sie nicht eine einfache Wiederherstellung der biblischen, synoptischen oder paulinisch-johanneischen, Christlichkeit ist, sondern eine Reduktion des mittelalterlichen Dogmas, der mittelalterlichen Kirche und der mittelalterlichen Ethik auf die aus dem Paulus geschöpfte Glaubens- und

zeigt. Aber auch die occamistische Spätscholastik hatte mit ihrer Wiederherstellung eines absoluten Gegensatzes von Natur und Gnade den Stufen-, Vermittelungsund Entwickelungsbegriff beseitigt, s. Hermelink, Die theologische Fakultät in Tübingen, 1906, S. I I I und 122. Auch für den Urstand ist hier schon dieser Unterschied beseitigt, indem dort nicht eine Staffelung" von konnaturaler Vollkommenheit zu übernatürlicher stattfindet, sondern die Vollkommenheit an sich ein debitum naturae ist und bloß wegen der Schwäche des Menschen durch übernatürliche Gnade eingegossen werden muß, s. Linsenmann a. a. O. S. 648-65I. Doch ist Luthers Beseitigung jener Begriffe jedenfalls insoferne originell, als ihr Motiv nicht der Radikalismus des Gegensatzes, sondern der Gedanke der wesenhaften Zusammengehörigkeit von Natur und Gnade im Willen Gottes ist. Daher entsteht hier die eigentümliche Verschränkung gegenüber dem Katholizismus, daß das lutherische Verhältnis von Natur und Gnade einerseits eine innerlichere Verbindung, eine Immanenz der Gnade in der Natur ermöglicht, daß aber andrerseits bei der bloß willensmäßigen Setzung der Natur als des Betätigungsspielraums der Gnade wiederum jede innere Verbindung und Vermittelung wegfält und der genuine Protestantismus viel schwerer eine innere Anknüpfung an die $>$ Natur \& findet. Darauf beruht das relative Recht der katholischen Behauptung, daß der Protestantismus weniger inneren Zusammenhang mit Natur und Kultur habe, ein Umstand, der von den protestantischen Polemikern in der Regel nicht beachtet wird. 
Gesinnungsreligion, auf die paulinische Gnaden- und Christusreligion. Insbesondere ist dies deutlich an der Wertung des natürlichen Lebens, das erst das Mittelalter voll in das christliche einbezogen hat und dessen Einbeziehung jetzt nur anders motiviert und durchgeführt wird. Die mittelalterliche Ausweitung des Christentums zu einer christlichen Einheitskultur liegt als Voraussetzung zugrunde, wird aber von neuen religiösen Gedanken aus neu begründet und gestaltet.

Damit ist nun aber im wesentlichen auch schon die einfache Antwort gegeben auf die zweite Hauptfrage, die Frage nach den soziologischen Konsequenzen und Ausgestalt u n g e n dieser religiösen Umbildung des Christentums. In der Einzeluntersuchung werden dann freilich viele in der Komplikation dieser Gedanken begründete Schwierigkeiten hervortreten.

Das Entscheidende ist hier nicht die besondere rechtliche Gestaltung des lutherischen Kirchenbegriffes, von der erst im nächsten Abschnitt die Rede sein soll, sondern in erster Linie die Grundtatsache, daß diese ganze Denkwe ise von Hause a us wesentlich dem Kirchentypus angehört und damit allen protestantischen Gruppen die soziologische Grundbestimmtheit und die besonderen Schwierigkeiten des neuen Kirchenbegriffes mitteilt.

Trotz ihrer mannigfachen Berührungen mit dem Sektentypus, trotz ihres Individualismus, ihrer Laienreligion, ihrer Berufung auf die Bibel, ihrer Betonung der subjektiven Verwirklichung des Heils in persönlicher und innerlicher Christlichkeit und der Beschränkung der wahren Kirche auf das wirkliche, wiedergeborene Volk Christi, trotz alledem zeigt sie grundwesentlich keinerlei Neigung zum Sektentypus, sondern sieht den Kirchentypus als das selbstverständlich und allein Christliche an. Reform der kirchlichen Gnaden- und Rettungsanstalt auf ihre wahren Gnadengrundlagen im Wort, in der Erkenntnis Christi und in der darauf begründeten Gewißheit der Sündenvergebung; Reform des kirchlichen Priestertums zu dem von Christus eingesetzten Amt der Wortverkündigung oder der Christuspredigt; Reform der Sakramente zu den wahren von Christu. eingesetzten und keine Gnadensubstanz eingießenden, sondern das Evangelium der Sündenvergebung vergewissernden Riten und Gnadenzeichen: das ist von Anfang an Luthers Wille. Die Beibehaltung der groben äußerlichen Christen d. h. aller Getauften, die Taufe aller und die Unabhängigkeit der Gnadenmittel von 
der Subjektivität der Spendenden wie der Empfangenden verstehen sich für ihn von selbst. Auch nicht eine neue Kirche will er, sondern eine instauratio catholica $d . h$. die Zurückführung der einen allgemeinen apostolischen, von Christus gestifteten und mit Amt, Wort und Sakrament ausgerüsteten Kirche auf ihre lediglich Glauben schaffende geistige Wirksamkeit durch das Wort. Das Wort selbst aber, seine Grundlage in der Bibel, seine Veranschaulichung im Sakrament und seine Verkündigung in der Predigt, ist ihm ein allen Individuen vorgeordneter objektiver Stiftungsschatz, der der Anstalt eignet und auf geordnete Weise durch dazu bestimmte Beamte ausgespendet werden muß. Wo solche Beamte fehlen, kann es auch der Laie tun; aber er hat dann eben in dem Maße teil an der Objektivität des Gnadenschatzes. In dieser Hinsicht, in der Bedeutung eines der von Christus gestifteten Gnadenanstalt eignenden Depositums und in der völligen Unabhängigkeit der Gnadenanstalt von dem Maße ihrer subjektiven Verwirklichung, ist Luthers Gnadenbegriff mit dem katholischen völlig einig. Die Unterschiede liegen überall erst in der Fassung des Inhaltes der Gnade. Von da aus wird Wesen und Wirkungsart der Kirchenanstalt freilich eine erheblich andere. An Stelle der hierarchischen Sakramentskirche tritt die Schrift- und Predigerkirche, aber auch sie eine Anstalt, den Gliedern'vorgeordnet als ihr supranaturaler von Gott gestifteter und geleiteter Produzent, völlig unabhängig von dem Eintreten oder Nicht-Eintreten der subjektiven Bekehrungswirkungen bei den einzelnen Individuen, heilig und göttlich an sich durch die dem $*$ Wort* einwohnende Bekehrungskraft, herrschend als göttliche Institution, auch wenn nur ganz wenige sich bekehren lassen, und als einheitliche Institution sich erstreckend durch alle Sonderbildungen nationalkirchlicher oder sonstiger Art. Denn, wo Wort und Sakrament ist, da ist die Kirchenanstalt und der supranaturale Produzent aller Heilserfahrungen; und der Glaube ist gewiß, daß * das Wort Gottes nie leer zurückkommt $\kappa$, d. h. daß schließlich die ihm einwohnende Wunderkraft doch über alle Widerstände siegen und die Menschheit auch innerlich zu Christo bekehren muß. Eine allgemeine, die ganze Menschheit umfassende Bekehrung wird das freilich nie sein. Dazu ist der Teufel und die Sünde zu stark, und die Wirren der gegenwärtigen Kirche deuten auf das Weltende, wo der große Kampf zwischen Christ und Antichrist sich entscheidet. Das ist ein höchst spiritualistischer, ein sehr verinnerlichter, 
auf Wort, Sakrament und Predigtamt die Institution zusammenziehender und sie auf rein geistige Wirkung einschränkender Kirchenbegriff, aber immerhin und vor allem es ist ein Kirchenbegriff. Es ist eine Reform des katholischen Kirchenbegriffes aus dem Neuen Testament kann man gerade diese Gedanken am wenigsten belegen -, eine Zurückverwandlung des schlechthin universalen, alles umfassenden, eine absolute Wahrheitsinstanz und ein fortlaufendes Amt besitzenden Kirchenbegriffes in die reine Gnaden-, Glaubens- und Christusreligion, die keine andere objektive Stütze hat als das biblische Wort von Christus. Auf diese Stütze zieht sich der ganze Supranaturalismus, die ganze Objektivität und Heiligkeit, die ganze Unabhängigkeit der Anstalt vom Subjekt zusammen, aber sie ist dafür dann auch von der höchsten Wichtigkeit, von der alles entscheidenden Bedeutung. Sie ist der aller Subjektivität entrückte, schlechthin gesicherte und mit supranaturaler Wirkungskraft ausgestattete soziologische Beziehungspunkt, von dem aus es gilt, die Kirche zu rekonstruieren. Sie leistet dem Protestantismus das, was der Begriff des Episkopats und seinc schließliche Zusammenfassung im Papsttum dem Katholizismus geleistet hatte. Freilich fehlt es nun nicht an der Betonung, daß die Kirche nicht bloß im Wort, sondern zugleich in der innerlichpersönlichen Wirkung des Wortes und damit in der wiedergeborenen und heiligen Gemeinde besteht. Darin kommt Luthers Persönlichkeits- und Innerlichkeitsprinzip zum Durchbruch, und an diese Forderung haben dann die Wiedertäufer und Sektierer, wie später zu zeigren, in der Tat angeknüpft. Allein für Luther ist diese innerlich erncuerte Gemeinschaft wahrhafter Christen immer nur das Korrelat des sie crzeugenden Gnadenwortes und des Predigtamtes, gleichviel ob dies letztere von ordnungsmäßig Berufenen oder im Notfall von jedem beliebigen christlichen Bruder ausgeübt wird. $\mathrm{Da}$ man äußerlich und empirisch die wahrhaft Frommen von den Unfrommen nicht unterscheiden kann, so hat aber diese Beschränkung der Kirche keine praktische Bedeutung. Sie ist in Wahrlicit überall, wo das Wort ist. Und wäre auch nur ein Gläubiger da, so wäre die Kirche als Anstalt da, denn sie ist im Wort als dem immer wundertätigen; nie dauernd leer zurückkommenden Produzenten der Gemeinschaft immer virtuell enthalten. Die Kirche wäre da, auch wenn es nichts gäbe als das Wort. Aus ihm wüde sic jederzeit von neuem entstehen. Da aber ist es Pflicht aller Christen und besonders aller Obrigkeiten, in denen 
ja zunächst immer allein die Christenheit rechtmäßig repräsentiert ist, das Wort jedem zugänglich zu machen, für seine geordnete Verkündigung $\mathrm{zu}$ sorgen und damit in der Aufrichtung der Herrschaft des Wortes wenigstens äußerlich das Nötige zu tun, daß die Kirche aus ihm überall innerlich wahrhaft entstehen kann. Die Art und Weise, in der ein zukünftiges Konzil oder bei dessen Versagen die nächstverordneten Orts- und Landesobrigkeiten und ihre naturgemäßen Berater, die berufsmäßigen Theologen, das ordnen, ist dann eine Sache der ZweckmäBigkeit, der Anknüpfung an das bestehende positive Recht; nur soll dabei aller Aufruhr nach Möglichkeit vermieden werden und sind bis zur Schaffung allgemein geordneter Verhältnisse recht bunte Maßnahmen möglich, über die Luther je nach Gelegenheit sehr verschieden und widerspruchsvoll sich aussprechen kann. Besonders gegenüber unevangelisch gesinnten Obrigkeiten muß er zu Neuordnungen greifen, die vom Staat ganz unabhängig sind, und betont er die Unfähigkeit der weltlichen Gewalt, in geistliche Dinge hineinzuwirken. Als Konsequenz aber liegt auf der Hand, daß, wenn eine allgemeine Ordnung durch Reich und Konzil nicht eintritt und wenn die in diesem Wirrwarr sich nahelegende Erwartung des Weltendes gleichfalls sich nicht erfüllt, dann die Pflicht der Laien und vor allem der Obrigkeit eintritt, dem Wort Gottes zur reinen Wirksamkeit zu helfen, wie das schon Occam und die konziliaren Theologen gefordert hatten und wie es dem ganzen Geiste der bisherigen christlichen Gesellschaft entspricht. Die allgemeine Weltkirche ist damit nicht aufgehoben, der Katholizismus gewahit. Denn sofern das Wort in irgend einer Kirche nur überhaupt vorhanden ist, ist auch in ihr die eine allgemeine Kirche und ist die betreffende Partikularkirche nur eine Abteilung oder etwa eine Verderbung der einen allgemeinen Kirche. Nicht die "unsichtbare Kirche * ist das richtige Kennwort für Luthers Kirchenbegriff, obwohl er selbst gelegentlich diesen verwirrenden Ausdruck gebraucht hat, sondern die an Wort und Sakrament sichtbare, in ihren rein geistigen Wirkungen dagegen unsichtbare und unmeßbare Kirche, oder etwas anders ausgedrückt: die rein geistliche, in ihrer Wiedergeburtswirkung äußerlich nicht feststellbare, aber überall zugleich mit Wort und Sakrament vorhandene und mit der Möglichkeit universaler Wirkung von Staat und Gesellschaft auszustattende Wortkirche, die eben darum eine äußerliche christliche Ordnung des Staates und eine ihr Herankommen an alle ermöglichende, 
im übrigen sehr freie Organisation verlangt.

Luther und die Reformatoren fassen die christliche Idee wie der Katholizismus im Schema des Kirchenbegriffs. Das ist nun aber nicht etwa lediglich eine Nachwirkung des mittelalterlichen Denkens, eine ablösbare Schranke, sondern das liegt im Wesen ihres religiösen Gedankens selbst, der in dieser Hinsicht eben auch einig ist mit dem mittelalterlichen und altkirchlichen bis herab auf die paulinischen Ansätze des Kirchengedankens. Es liegt ganz einfach daran, da $\beta$ das Christentum wesentlich von Luther verstanden und gedacht wird als Gnade, als Grundlage der Heilsgewißheit. Eine Seele, die darauf gestimmt ist, ist prädestiniert für den Kirchentypus. Unabhängig vom eigenen Ich, von eigenen Anstrengungen und subjektiven Leistungen, rein als Gottesgabe, als Gewißheit und Sicherheit soll das Heil bereit liegen, und lediglich der aneignende Glaube soll es aufnehmen, damit er das große Prinzip einer objektiv göttlichen, lebenschaffenden Kraft in sich hineinnehme, die alles wirkt im Subjekt und durch das Subjekt, die aber selber unabhängig ist von ihm. Es ist der tiefe Gedanke einer alle Individuen erst hervorbringenden und in sich einigenden historischen Substanz des Lebens, verbunden mit dem religiösen Gedanken der Gnade, wonach der religiöse Besitz Geschenk und nicht Leistung ist und gerade in jener beseligenden Gabe die subjektiven Kräfte erst zur höchsten und reichsten Leistung entbindet; beides aber, historische Substanz und das in ihr liegende Gnadenmoment als supranaturale, von allem Weltlichen streng abgrenzbare Stiftung gedacht, deren supranaturale Grundelemente, Wort und Sakrament, frei und innerlich, ohne $Z$ wang und ohne Recht durch die ihnen einwohnende Gotteskraft den Glauben hervorbringen ${ }^{208}$ ).

204) Rudolf Sohm hat seine bekannte These, daß Kirche und Recht absolute Widersprüche seien, besonders an Luther veranschaulicht, dem er die völlige Beseitigung jedes Rechtselementes aus dem Kirchenbegriff zuschreibt: ,Luther hat j e d e m Kirchenrecht, jederlei göttlichem Kirchenrecht und im Grundsatz e be ns o dem als bloß menschliche, geschichtliche und darum veränderliche Satzung sich gebenden Kirchenrecht als solchem, welcher Art immer es sei, den Krieg erklärte, Kirchenrecht I, IS92, S. 46r. Ich kann den Satz in dieser Form nicht für richtig halten. Luther hat allerdings den Kirchen- und Religionsbegriff aufs höchste verinnerlicht und kennt weder einen quantitativen Dogmenglauben, sondern nur eine auf das Ganze des Evangeliums gerichtete Gesinnung, noch einen Rechtgläubigkeitszwang auf die Seelen, sondern nur religiüse Belehrung neben Unterdrüekung häretischer Aeußerungen als zerstörender Rebellion gegen die christliche Gesellschaftsordnung. Aber 
Solche Gòtteswirkung konnte für Luther nicht in individuellen Erleuchtungen und mystischen Erkenntnissen liegen, die ununterscheidbar sind von der eigenen Phantasie und dem subjektiven Leben. Es mußte ihm als etwas für alle Objektives, Gleiches und Gegebenes, als etwas schlechthin Autoritatives, Wunderbares und bestimmt Umgrenztes, von allem Menschlichen Verschiedenes sich kundgeben. Das aber war nur die göttliche Stiftung der Kirche und der überall auch äußerlich erkennbare und sichtbare produzierende Kern der Kirche, das göttliche Wort. Eben darum

indem sein verinnerlichter Kirchenbegriff doch im reinen und rein zu haltenden Wort sowie im richtig zu lehrenden und zu verwaltenden Sakrament seine $a \mathrm{u} u$ B $\mathrm{Ce}$ Fabbarkeit durch supranaturale konkrete Merkmale hat, entsteht von ihnen aus die Notwendigkeit, ihnen einen Apparat des rechtlichen Schutzes und der rechtlich geregelten Verwaltung zu verschaffen. Das unteriaßt Luther nur, so lange er auf die Wunderkraft des Wortes se̊lbst vertraut, das alles allein von selbst machen wird, und so lange die alte kirchliche Ordnung fortdauert. Aber nachher ist dieser Ueberidealismus ernüchtert worden. In der Zeit der GHrung und der bunten lokalen Reformversuche hat Luther die Gemeinden geradezu versuchen lassen, neue eigene Rechtsordnungen zu schaffen und dazu seinen Segen gegeben. Als daraus nichts wurde und der Bauernkrieg geführlichen Mißbrauch dieser Reformen mit sich brachte, verlangte er eine generelle Neuordnung ron Landes wegen, und da hat Luther in der neuen Landeskirche für das Wort die Nachbilfe eines menschlichen Rechtsapparates dulden und gelegentlich befördern mulssen, für den die Ansätze in der Reinheit der Lehre und der Sakramente und der Notwendigkeit einer geordneten Predigerbestellung. vorlagen. Aus diesen Resten der Sichtbarkeit und Konkretheit der Kirche entstekit wieder, wie einst aus der Sichtbarkeit im Bischofsamt, mit Notwendigkeit ein Recht. Auch hier ist es nicht ein Abfall Luthers von seinen Anfangspositionen, sondern das Wiederhervorbrechen der zuerst völlig zurückgeschnittenen Konsequenzen des Kirchenbegriffs, das heißt einer supranaturalen und darum universalen, an bestimmten Momenten auch äußerlich faßbaren und äußerlich aufrecht zu erhaltenden Anstalt. Versteht man unter Kirche wirklich eine in Offenbarung und Sakrament faßbare übernatürliche Anstalt, so erzeugt sie auch aus diesen supranaturalen Elementen ein supranatural begründetes Recht, sei es łun, daß man dessen Begründung und Schaffung den Gemeinden selbst oder daß man es der weltlichen Obrigkeit zuweist; immer werden Konsequenzen aus einem zur Rechtsbildung auffordernden Stamm supranaturaler Gemeinschaftsfundamente gezogen. Mag auch die Ausführung selbst den Umständen anheimgegeben und als rein menschlich betrachtet werden und beliebig veränderlich sein, dann wechselt das Recht, aber die Aufforderung zu seiner Bildung selbst bleibt. Nur ein der Faßbarkeit in reiner Lehre und Sakrament entkleideter, in reinen religiösen Gemeingeist und rein innerliche Gemeinschaft aufgelöster Kirchenbegriff kann des Rechts entbehren. Aber das 
wandte sich Luther mit solcher Schärfe gegen alle Sektierer, die in der Verwirklichung des göttlichen Gesetzes und damit in subjektiven Leistungen das Gemeinschaftsband und die Heilsgrundlage sahen. Alle soziologischen Objektivierungen der Gemeinschaft im Gesetzesbegriff waren ihm trotz der Offenbartheit des Gesetzes keine wahren Heils- und Gemeinschaftsgrundlagen, weil das Gesetz nichts ist ohne subjektive Leistung und so doch wieder die subjektive Leistung das Entscheidende wird. Ebenso verwarf er alle Mystiker, Enthusiasten und Schwärmer, da sie in ihren Erleuchtungen nichts Objektives, keinen vorgeordneten, klar göttlichen Produzenten ihrer Gemeinschaft haben, vielmehr ihre Erleuchtungen aus dem Subjekt hervorholen und ihre Göttlichkeit dann hinterher

ist dann auch kein Kirchenbegriff mehr, und ist auch nicht Luthers Kirchenbegriff gewesen. Das jst dann rein der Begriff des religiösen unfaßbaren Lebenszusammenhanges, und sein Gegensatz gegen das Recht ist dann nicht mehr der Gegensatz von Kirche und Recht, sondern von Religion und Recht, welcher allerdings ein fundamentaler und wirklicher ist. Das deutet dann aber auf eine Spannung zwischen Religion und Kirche selber hin, die eben in der Tat nicht identisch sind. Aus diesen Spannungen entsteht stets die Emanzipation der Religion von der Objektivität der Anstalt und von der supranaturalen Autorität und die Zuwendung zu einer unmeßbaren Innerlichkeie der Mystik und des Spiritualismus, wie das in der Tat die $\rightarrow$ Mystiker und Spiritualisten a der Reformationszeit getan haben und damit die Konsequenzen der Reformatoren zu ziehen meinten. S. meine Abhandlung: -Religion und Kirches, Preuß. Jahrbb., I895. Der Kirchenbegriff von Sohm schwebt zwischen dem einer universalen und supernaturalen Anstalt und dem eines rein innerlichen Geistes- und Gedankenzusammenhangs, der lediglich in der Fülle seiner subjektiv-persönlichen Wirkungen besteht. Das ist aber ein modernen Bedürfnissen angepaßter Kirchenbegriff. Hier muß ich der von Sohm abgelehnten (S. 467) Auffassung Höflings und Ritschls zustimmen. Die von Sohm dagegen angeführten Lutherstellen scheinen mir seine These nicht $z u$ beweisen, sondern nur, daß es Luther sehr schwer geworden ist, die Spiritualität, Freiwilligkeit und Innerlichkeit seiner religiösen Gemeinschaft mit dem aus der Forderung reiner Predigt und geordneter Bestellung des Predigtamtes folgenden Notwendigkeit eines Rechtes zu vereinigen, das als Recht für Luther immer etwas Menschliches und lediglich zu Duldendes bleibt, aber in seinem notwendigen Hervorgang aus Wort und Sakrament selber doch immer wenigstens im Ausgangspunkt ein jus divinum ist. Daher denn auch die Entwickelung des Amtsbegriffes im Luthertum und der Aeltestenverfassung im Calvinismus. Freilich liegen hier Widersprüche vor, aber diese liegen in einem Kirchenbegriff. der Sichtbarkeit und Unsichtbarkeit, Freiwilligkeit und Iniversalitat zugleich behauptet. Sie liegen schon im Kirchenbegriffe selbst, vicht erst in der Verbindung des Rechtes mit dem Kirchenbegriff. Darüber im nächsten Abschnitt mehr. 
in praktischen Leistungen, und dies heißt wieder in subjektiven Gesetzeserfüllungen, bewähren müssen. Deshalb kannte er in der Bibel auch nur den paulinisch-johanneischen Lehrtypus, in welchem die Gnade und deren objektive Vergewisserung im Christusleibe und im Christusbilde alles ist. Dagegen hatte er für den synoptischen, franziskanischen und waldensischen Christus und das Gesetz Christi, soweit es als allgemeine Lebensregel und als Grundlage der Gemeinschaft hätte in Betracht kommen können, überhaupt kein Auge. Er kommt gar nicht auf den Gedanken, daß es zwischen beiden einen Unterschied anders als in der Meinung gesetzgläubiger Sektierer geben könne. $\mathrm{Er}$ interpretiert alles völlig selbstverständlich aus dem Paulus und zwar aus einem Paulus, dessen enthusiastische und mystische Züge ihm völlig zurücktreten hinter den kirchlichen. Ihm ist daher schließlich die Kindertaufe das Schibboleth wie allen Männern des Kirchentypus. Sie dokumentiert die Objektivität und Universalität, die alle Individuen beanspruchende Weltweite der Kirche zugleich mit ihrem reinen Gnadencharakter, mit ihrer Unabhängigkeit vom Subjekt und von seiner Leistung, mit ihrer Einbefassung von Christen der verschiedensten Reifestufen. Die Spät- und Wiedertaufe dagegen ist das Symbol der Gesetzlichkeit und der Sekte, die Gemeinschaft und Heil auf die persönliche subjektive Leistung begründet. Die dogmatische Fassung des Taufbegriffes selbst ist dabei noch gleichgültig, aber sie nähert sich konsequent auch immer mehr dem Gedanken eines realen Heiligungswunders, das allen Getauften in der Möglichkeit der Berufung auf ihre Taufe einen character indelebilis gibt. Alle Buße und Bekehrung, alle Arbeit des religiösen und sittlichen Lebens ist ein Rekurs auf die Taufgnade, in welcher die Gnade jedem Kirchengliede grundlegend zugesichert worden ist, wie ein Fideikommiß allen in ihn Hineingeborenen gehört. Im Interesse dieser kirchlichen Anstalts-Objektivität hat er dann später die Sakramente, in denen sich das heilschaffende Wort von seiner objektivsten Seite zeigt und von denen insbesondere das Abendmahl in der Realpräsenz von Fleisch und Blut Christi die Objektivität auf den Gipfel bringt, immer stärker betont und damit den Sondercharakter der lutherischen Theologie begründet, während die Calvinisten bei der bloßen Vergewisserung der Gnade und dem geistigen Wortcharakter der Sakramente sich festlegten. So hat er auch die Beichte wieder hergestellt als Mittel der objektiven Zusiche- 
rung der Sündenvergebung durch das Amt des Wortes und als Sicherung einer gründlichen Vorbereitung in Glaubens- und Gewissensprüfung für den Empfang des im Absolutions-Wort sich verkörpernden Gotteswortes ${ }^{200}$ ). All das entsprang ganz wesentlich aus Luthers eigentlichster religiöser Position, aus seiner ganzen scholastisch-theologischen Herkunft und seiner ursprünglichen Auffassung der Bibel. Wie weit Eigentümlichkeiten seiner persönlichen Veranlagung und eine etwaige Beeinflussung durch die umgebende, von Autoritätsgedanken erfüllte Atmosphäre daran beteiligt waren, entzieht sich der genaueren Kenntnis. Luther war unzweifelhaft stark autoritativ veranlagt bei allem Sinn für die innere Freiheit und ebenso unzweifelhaft wesentlich konservativ gerichtet bei aller Furchtlosigkeit und Rücksichtslosigkeit in den Fällen, wo ihn sein Gewissen drängte. Allein alles das hat wohl mehr die besondere spätere Gestaltung seines Kirchenbegriffes und vor allem, wie wir sehen werden, seine Auffassung des Naturrechtes bedingt, aber nicht die Hauptsache, die Fortführung des Kirchenbegriffes selbst. Dieser war ihm wesentlich verbunden mit seiner Idee von der Gnade und dem Wort, seiner Beschränkung auf feste göttliche Kundgebungen im Gegensatz gegen angebliche Erleuchtungen und neue Offenbarungen, seiner Abneigung gegen jede andere Regelung des Lebens als durch die Gnadenoffenbarung, die an Wort und Kirche ihr festes objektives Maß hatte und auf Grund deren man sich übrigens in die Welt schicken konnte. Jede andere Normierung schien ihm Subjektivismus und Schwärmerei oder Festlegung auf gute Werke und damit Gesetzestreiberei ${ }^{210}$ ).

200) S. E. Fischer, Zur Gesch. der evangelischen Beichte, 1903.

$\left.{ }^{210}\right)$ Ueber die von Anfang in engster Verbindung mit dem neuen Gedanken rom Heil stehende Idee Luthers von der Kirche, ihre Uniabhängigkeit gegen Huß und ihren inneren Unterschied gegen die hussitische Lehre s. die vortreffliche Abbandlung Gottschicks, >Huß', Luthers und Zwinglis Lehre von der Kirche«, Z. f. Kirchengesch. VIII, 1886. Im Unterschied von Hussens Idee einer Gemeinschaft der Prädestinierten, die sich durch die Kirchenanstalt auswirkt, die Göttlichkeit der kirchlichen Institutionen und der Priester aber von der Uebereinstimmung mit dem ethischen Gesetz Christi abhängig macht und so trotz Behauptung des katholischen Charakters der Sakramente doch dem donatistischen Sektenbegriff sich nähert, ist es mit völligem Ausschluß aller sektenhaften Abhängigmachung der Kirche von der Verwirklichung des Christusgesetzes die Anstalt der Gnade oder des Wortes, die von der Taufe her alle umfaßt, aber alle nur regiert durch das Wort von der Gnade. Daher auch hier der andere Sinn des Biblizismus S. 377 : $>$ Huß' Schrift- 
Somit beherrscht der Kirchentypus das ganze reformatorische Denken und seine letzten Wurzeln liegen in der religiösen Eigenart der Reformation selbst. Nur als Reformator der Kirche war Luther zu seiner großen welthistorischen Wirkung befähigt. Nur

prinzip ist von dem reformatorischen darin unterschieden, daß für die Reformatoren der maßgebende Gedankenkreis, der den leitenden Inhalt der Schrift bildet und den sie durch die Autorität derselben gegen die Autoritätsansprüche der (katholisch)-kirchlichen Rechtsanstalt aufrechterhalten, das Evangelium von der freien, von Verdiensten unabhängigen vergebenden Gnade Gottes in Christo ist, für $\mathrm{Huß}$ aber das evangelische Gesetz«. - Die Voraussetzung von alledem ist die Kindertaufe und deren allgemeine Erteilung. Die letztere war für Luther wie für die an die Einheit der christlichen Gesellschaft glaubende Bevölkerung selbstverständlich: wo er bei Visitationen noch nicht Getaufte fand, mußte die Taufe nachgeholt werden, ohne daß darin irgend ein unerlaubter religiöser $Z$ wang gesehen worden wäre. Vgl. Barge, Karlstadt II, S. 142. An dem Recht der Kindertaufe und das heißt vor allem an der Notwendigkeit ihrer allgemeinen Erteilung ist Luther nie irre geworden, wie Karl Müller mit Recht gegen Barge ausführt; er mußte nur das Wesen des Taufvorgangs mit seiner allgemeinen Idee vom Heilsvorgang in Einklang setzen, was er durch die Theorie von einem in den Kindern gewirkten schlummernden Glauben tat. Vgl. K. Müller, Luther und Karlstadt, S. 217-221. So ist Luthers Kirchenbegriff nie bloß aus seinem Gegensatz gegen den katholischen, sondern immer auch aus seinem Gegensatz gegen die Sekten zu verstehen, und hier ist die Kindertaufe und die Universalität der Kindertaufe das Entscheidende. Dann treten neben dem Gegensatz gegen den katholischen Kirchenbegriff, der Beseitigung des jus divinum der Hierarchie, der Auflösung des dinglichen Sakraments- und Gnadenbegriffes, der Reduktion aller Kirchenund Erlösungswirkung auf rein geistige Wortwirkung, doch auch die bedeutsamen Züge hervor, die ihm mit dem katholischen Kirchenbegriff gemeinsam sind: der Anstaltscharakter, die Objektivităt, die Vorordnung vor dem Individuum und seiner Leistung, die Universalität, die jetzt freilich lediglich geistige Herrschaft über das Ganze der Gesellschaft. - Ueber den engen Zusammenhang von Luthers Kirchenbegriff mit dem Begriff der Kindertaufe, in welcher die Einkörperung in den Heilszusammenhang der glaubenstiftenden Wort-Anstalt vollzogen und so jedem ein von seiner eigenen Leistung unabhängiges Fundament gegeben ist, vgl. Gottschick, Die Lehre der Reformation von der Taufe, 1906. Die Kindertaufe ist geboten, und mir ist keine Stelle bekannt, die auch in den Zeiten der rückhaltlosesten Freigebung des Geisteskampfes auch das Taufen oder Nicht-Taufen der Kinder freigäbe. Damit aber ist die Hauptsache entschieden, ein in der allgemeinen Uebung der Kindertaufe primär sich kundgebender Anstaltszusammenhang. - Mit inm ist dann auch der von Rieker, Die rechtliche Stellung der ev. Kirchen Deatschlands, 1903, und J. N. Figgis >From Gerson to Grotiuse so energisch betonte Gedanke des Corpus Christianum gegeben, innerhalb dessen weltliche und geistliche 
der supranaturale Universalitätsgedanke führte ihn auch $\mathrm{zu}$ universalen und institutionellen Wirkungen; ohne das wäre Luther nur ein Sekten- oder Ordensstifter geworden oder ein einsamer Mann wie Sebastian Frank.

Mit dem Kirchentypus aber stellten sich auch alle ihm wesentlichensoziologischen Wirkungen. ein. Aus ihm ergab sich erstens die Uniformität, Ein-

Gewalt nur verschiedene Seiten des Einen ungeschiedenen Ganzen sind. Das aber ist der mittelalterliche Gedanké der christlichen Kultur- und Gesellschaftseinheit. Aus diesem Gedanken ergeben sich alle Grundzüge der protestantischen Soziallehren. Böhmer glaubt gegen diese These bemerken zu sollen: Indes in ì in prinzipiellen Punkte ist auch Luther, wie es scheint, im Bannkreis des mittelalterlichen Denkens geblieben, in seiner Anschauung von der Kirche. Die Kirche gilt ihm wie dem Katholizismus, nicht als ein freier von Menschen ins Leben gerufener Verein, sondern als eine von Gott gestiftete Anstalt, deren Bestimmung es ist, das Wort Gottes zu verkündigen, die Gewissen zu trösten, ' die Gewissen zu beraten. Also handelt es sich hier wohl wirklich nur um eine Umformung der mittelalterlichen Idee? Mit nichten. Es handelt sich nur um eine neue Formulierung der gemeinchristlichen Anschauung von der Kirche, bei der wiederum das Spezifisch-Kathol is che, nämlich die Meinung, daß eine bestimmte äußere Rechtsordnung für die Kirche wesentlich sei, völlig beseitigt wird. Denn der Glaube an die Kirche als eine Stiftung Gottes, durch die und in der der Geist Gottes in der Welt wirksam ist, ist so alt wie das Christentume, S. 120. Gewiß, aber das Entscheidende ist, daß neben dem Kirchentypus gleichalt der Sektentypus ist und wie jener Wurzeln im N.T. hat, weiter, daß der Kirchentypus erst im lateinischen Katholizismus zu einer inneren Durchdringung von Kirche und Welt im Corpus Christianum oder in der christlichen Gesellschaft geworden ist mit der Pflicht der Obrigkeit für diese Einheit durch Garantierung und Schützung der Anstalt zu sorgen und $\mathrm{da} B$ diese Idee vom Protestantismus fortgesetzt wird, daß also das Wesentlich - Katholische nicht bloß in der Bindung der Kirche an eine äußere Rechtsordnung liegt. In seinem sich beständig steigernden Gegensatz gegen den Sektentypus folgt der Protestantismus dem Kirchentypus und zwar dem mittelalterlichen Kirchentypus mit seinem Ideal einer einheitlichen christlichen Gesellschaft; und daher sind auch seine Soziallehren denen des Katholizismus in so vieler Hinsicht nahe verwandt. Ob man darin eine Schranke oder eine ewige Wahrheit sehen will, ist Sache der dogmatischen Anschauung. Tatsache ist nur, daß in der modernen Welt die religiösen Wurzeln des Kirchenbegriffes und damit dieser selbst sehr schwach geworden ist und daher auch ihre Soziallehren einen ganz anderen Typus tragen. - Ceber den lutherischen Kirchenbegriff in seiner begrifflichen Gestaltung s. Kolde, Luthers Stellung zu Konzil und Kirche bis zum Wormser Reichst̊g, 1876 ; J. Köstlin, Luthers Lehre von der Kirche, 1853; R. Seeberg, Der Begriff der christlichen Kirche, I, 1885. 
heit und allgemeine Herrschaft der Kirche, die bei der Unmöglichkeit einer europäischen oder deutschen Gesamtreform schließlich in die Aufrichtung einheitlicher Landeskirchen ausmündeten. Aus dieser Universalität wiederum ergab sich zweitens die Ausweitung der kirchlichen Ethik auf die Gebiete der weltlichen Kultur und Gesellschaftsordnung, die Akzeptierung der dem christlichsittlichen Ideal nicht unmittelbar entsprechenden, aber unumgänglichen Lebensordnungen, die Fortführung des die rein christliche Ethik ergänzenden Grundbegriffs der Lex naturae ${ }^{211}$ ). Wie sehr das

211) Dieses Wesen der Kirche, daß sie die Gesellschaft möglichst total beherrschen und zugleich die Kultur rezipieren müsse, ist sehr charakteristisch formuliert von dem verstorbenen Präsidenten des preußischen Oberkirchenrates, $H$. von-der Goltz, in >Grundlagen der christlichen Sozialpolitik \&, 1908, S. 203: „Die Kirche (die ihm mit der >religiösen Gemeinschaft $\propto$ selbstverständlich identisch ist) serscheint in allen drei Formen des sozialen Lebens (nämlich Familie, Staat, Gesellschaft), aber sie geht in keiner einzelnen auf und vermag auch von keiner einzelnen allein getragen $z u$ werden. Sie behauptet als Kirche (und zwar als universale Einheitskirche, die nur in der geschichtlichen Wirklichkeit durch die katholische Verderbung durchbrochen ist) ein Recht eigentümlicher Existenz und Wirksamkeit gegenüber allen sozialen Kreisen des natürlichen und irdischen Lebens. Diese herrschende Stellung der Kirche in der sozialen Welt beruht in dem Zusammenwirken von vier Faktoren: 1) dem christlichen Offenbarungsbegriff, welcher in der geschichtlichen Person Christi nicht nur das Werkzeug, sondern auch den Inhalt der Offenbarung des unsichtbaren Gottes anerkennt und die Kirche als das Organ des vollkommen abschließenden Wortes Gottes an die Menschen, als die $T r a ̈ g e r i n d e r$ absolute n religiös-sittlichen Wahrheit hinstellt (das ist der objektivistische und absolute Wahrheitsbegriff); 2) der Verlegung des eigentlichen Zieles des Menschen in das Jenseits, so daß alles Irdische nur als Schule für die Ewigkeit und die Kirche als Vermittlerin des himmlischen Gutes erscheint (das ist die allein selig machende Kraft der Kirche); 3) der Verbindung der ge- . trennten Kreisen und Schichten der Menschenwelt zu einem internationalen, alle sozialen Gegensätze ethisch überwindenden Gemeinwesen (das ist die aus den beiden ersten Faktoren folgende Universalität); 4) der sittlichen Belebung und harmonischen Gestaltung des gesamten Kulturlebens von den religiösen Motiven aus als Mittel der Verbindung allersittlichen Aufgabenzur. Einheit (das ist die aus der Universalität folgende Rezeption des Weltlebens, deren Spannung gegen das N. T. v. d. Golz wie alle Kirchenmänner gar nicht empfindet). Durch Kombination dieser vier Momente gelang es der Kirche, dem Seelenleben der Religion einen eigenen geschichtlichen Leib anzubilden, welcher sich als die höchste und vollkommenste Form sozialen Lebens geltend machte. Ihre eigentümlichste Grundlage hat die Kirche in der Offenbarung, ihren Hauptzweck in der Erziehung und Verbindung der Menschen für die Ewigkeit, ihr 
aus dem Kirchentypus folgt, zeigt sich vor allem daran, daß Luther persönlich diese Konsequenzen gar nicht ohne weiteres bequem lagen, sondern aus der I ogik des kirchlichen Gedankens heraus sich ihm allmählich immer stärker aufdrängten. Fr hat sie in der ersten

Mittel in der internationalen Organisation und in der Pflege der Humanităt im Kulturlebenء. Diese Charakteristik gilt ausdrücklich für die Kirche überhaupt, für Katholizismus und Protestantismus gleichermaßen, S. 24-30. Erst innerhalb dieses gemeinsamen Rahmens ergeben sich die Differenzen von Kath. und Prot., S. 284: - Diese Auffassung von der Stellung der Kirche im menschlichen Gemeinleben ist aber noch einer verschiedenen Deutung fähig. Die katholische Kirche macht ihren Organismus zum Selbstzweck und setzt überall die äußere Form mit dem geistigen Gehalt gleich (?); der Protestantismus weiß, daß alles Kirchliche nur Wert hat, sofern es auf ein innerlich freies, aber auch absolut festes und gewisses (hier liegt die Schwierigkeit des prot. Kirchenbegriffes) B a n d des persönlichen Lebensgrundes (!) mit Gott hinarbeitet<. Diese logisch und stilistisch gleich undurchsichtige Formulierung zeigt die Komplikation des protestantischen Kirchenbegriffes. Er wird nicht klarer durch folgende Näherbestimmung: „Sie darf nicht ihre wandelbare korporative Form und Lehre, Kultus und Verfassung als Zweck behandeln, sondern diese muß ihr das dem Wechsel der Zeiten angepaßte Mittel werden, um die Gemeinschaft mit Gott in den Herzen zu pflegen und reinigend und heiligend auf innerlichem Wege auf die Kulturwelt einzuwirken. Und wenn dabei ihr be rechtigter $\mathrm{E}$ influß bedroht ist, darf sie nicht in altjüngferlichem Tone sich an äußerliche Stützen hängen, sondern muß ihre Dienste begehrenswert machen und die Gerechtigkeit Gottes als überwindende Macht in die Gewissen hineinstrahlen. Nur bei einer so hohen, auf die Gesinnung gegründeten Fassung ihrer ethischen Aufgaben kann die Kirche auch ihre gesunde (d. h. nicht zwangsmäßig bewirkte und darum freudig ertragene) Stellung zu den Kulturaufgaben und $z u$ den verschiedenen Kreisen natürlich - sittlicher Gemeinschaft behauptens. In diesen Aeußerungen hat man alle Eigentümlichkeiten des Kirchenbegriffes und alle Schwierigkeiten des besonderen protestantischen Kirchenbegriffes beisammen; die letzteren bestehen in der Vereinigung von innerer Freiheit und absoluter Festigkeit, von universaler fHerrschaft und von geistig-innerlicher Selbstdurchsetzung unter Verzicht auf jede $Z$ wangsgewalt, von jenseitiger Abzweckung und harmonischer Kulturdurchdringung, von objektiver Anstalt und persönlicher Gesinnungsreligion. Auch die Beziehung dieser Kirche auf die snatürliches Gesellschaft, die v. d. Goltz konstruiert, ist nur eine Modernisierung der lutherischen Lex naturae und des aus ihr abgeleiteten Gesellschaftssystems. Ganz ähnlich bezeichnet einer der tătigsten kirchlichen Geschäftsführer der Konservativen, R. Seeberg, Die kirchlich-soziale Idee und die Aufgaben der Theologie der Gegenwartc (Zur syst. Theol. II, 1909) S. 327, die sg e su nde Frömmigkeit als zugleich kirchlich und kulturfreundlich, $d . h$. sin das Weltgetriebe vordringend und es beiligende. Das fordert sdie Natur der Menschen wie die Geschichte der Kultur und der Religion gleichermaßen , S. 328. Alle Gestaltungen des a atur- 
Richtung nur mühsam und widerspruchsvoll entwickelt, weil seine Verinnerlichung und Spiritualisierung des Kirchenbegriffes der Zwangsherrschaft eines universalen Kirchentums widersprach und weil sein Laienpriestertum ihn gelegentlich an die Grenze der vom Individuum her die Gemeinschaft konstruierenden Sekte führte. Aber auch in der zweiten Richtung ging es nicht ohne starke Schwankungen $a b$, weil sein Biblizismus ihn tief in die weltindifferente, dem weltlichen Wesen des Kampfes ums Dasein, der Macht, des Rechts, des Besitzstrebens entgegengesetzte Liebesethik des Evangeliums hineinführte und ihn auch hier zu Berührungen mit der Sektenethik führte.

Wenden wir uns zunächst zu der ersten Entwickelung.

Mit dem supranaturalen Kirchengedanken, der die Kirche als von Gott gestiftet und mit einer schlechthin autoritativen, gegen alle menschliche Meinung gesicherten Wahrheit ausgestattet betrachtet, war der entscheidende $\mathrm{W}$ ahrheits begriff gesetzt, der Einheit, Unveränderlichkeit, Universalität und Infallibilität der Kirche in dem sie begründenden Organisationskerne bedeutete. Für den Katholi-

lichen Lebens im Staat und in der Politik, im Handel und in der Industrie, in der Wissenschaft und in der Kunst, aber auch alle Großtaten der Gewaltigen und alle Werke der Alltagsmenschen stellen sich dem Christen dar als Wirkungen Gottes, in denen sich das Kommen seiner Herrschaft anbahnt und verwirklicht. Die Unterscheidung von Staat und Kirche, so wichtig sie sonst ist, darf nie den Sinn haben, als sei Gott nur in der Kirche wirksam oder als seien Gottes Diener frei von der Pflicht, ihm auch in den Formen der Familie, des Volkslebens, der Gesellschaft und des Staates zu dienen ๔, S. 334. Das heißt Herrschaft der Kirche über die Kultur ohne die hierarchischen Machtmittel und Herrschaftsweisen des Katholizismus. Auch für Seeberg ist das selbstverständlich der Sinn Jesu und des Neuen Testaments: \Die (durch die Kirche und das Amt) erlösende Herrschaft Gottes ist das schöpferlsche und leitende Prinzip der menschlichen Geschichte und si e orga nis ie rt diese Geschichte auf dem Wege der durch Wechselwirkung sich vollziehenden Entwickelung zu dem Ziele des Reiches Gottes. Diese beiden urchristlichen(!) Gedanken bedingen die eigentümliche Weltanschauung des Christentums๔, S. 333. Darum ist die Kirche für Seeberg genau so wie für die Katholiken Mausbach, v. Nostitz-Rieneck u. a. das >Prinzip des Fortschrittes \&. Bei ihrem Beruhen auf absoluten göttlichen Wahrheiten ist die Kirche natïrlich in der Hauptsache absolut konservativ, aber sauch der Hemmschuh ist ein Mittel des Fortschritts, wenn ohne ihn der Wagen in den ersten besten Abgrund hinabrollte und zerschelltes. Das alles sind in der Tat auch die Motive des lutherischen Kirchengedankens, nur in die Sprache moderner Mattigkeit und Geistreichigkeit übersetzt und ohne Gefüh] für die schweren Probleme, die Luther in diesen Gedanken empfand. 
zismus leisteten das Dogma und Tradition, Hierarchie und Sakrament, und von diesem Grundtriebe aus hat er sich zu dem weltbeherrschenden System entwickelt, das entgegen seinen ursprünglichen Prinzipien schließlich auch die $Z$ wangsdurchsetzung auf seine Fahne schreiben mußte. Für den Protestantismus war dieser Kern das Bibelwort und das das Evangelium versiegelnde Sakrament mit der selbstverständlichen Folge eines geordneten, aber in der Art der Ordnung von den Umständen abhängigen Predigtamtes. Damit handelte es sich für ihn um Fixierung des reinen Wortes und um Organisation eines den reinen Glauben einhaltenden Predigtamtes. In beiden Hinsichten hatte nun aber der neue Kirchenbegriff erhebliche Schwierigkeiten. Das ihm zu Grunde liegende -Wort sollte ja in Luthers großer und freier Denkweise nur das sein, was Christus treibt, das in der Bibel enthaltene paulinischjohanneische Christusbild in nizänisch-chalcedonensischer Deutung durch das Trinitätsdogma. Aber wie war dieses • Wort* innerhalb der Bibel abzugrenzen? Seine freie Herausgestaltung aus der Bibel und seine Begründung auf persönliche Erfahrung öffnete den buntesten Deutungen und der Mystik neuer, die Bibel übersteigender Erleuchtungen das Tor. Es blieb nichts übrig als das Tor zu schließen, als das freie Wort der Verkündigung und dessen geschriebene Grundlage in der Bibel scharf zu scheiden, jenes an diese streng zu binden und die Bibel als Ganzes zu kanonisieren, sie in ihrer Lebereinstimmung mit dem Dogma der alten konziliaren Legislatur zu kanonisieren, ihre Auslegung durch feste, aus ihr selbst d. h. aus dem Paulinismus gewonnene Maßstäbe' zu regulieren und so das protestantische Bibeldogma zu schaffen, nach welchem dic Bibel der Kern der Kirche, die schlechthin inspirierte Autorität und die durch die ihr einwohnende Bekehrungskraft wirksame Heilspotenz ist. Die Bibel beweist und bewirkt durch den ihr einwohnenden heiligen Geist ihre eigene Infallibilität; sie ist klar genug um alle Auslegungsdifferenzen selbst zu überwinden. Das war eine unumgängliche Konsequenz, wenn der Kirchenbeurriff wirklich auf sie begründet werden und ernsthafte Festigkeit scwinnen sollte. Die Ansätze zu einer freien historisch-mens h lichen Bibelbetrachtung verschwanden daher schon bei Luther, noch mehr bei der folgenden Orthodoxie. Der Kirchenbegriff als Begriff einer gottgestifteten Heilsanstalt forderte nun einmal eine fest begründete, genau umrissene, für alle gleiche und verbindliche Wahrheit, und dieser Wahrheitsbegriff forderte die unbedingte 
Autorität der Bibel, die wiederum ohne die Annahme einer Art literarischer Inkarnation Gottes nicht möglich ist. Der katholischen Fortdauer der Menschwerdung im Priestertum entspricht die protestantische Fortdauer in der Bibel. In der historisch-menschlichen Bibelkritik und in der Begründung der Bibelgeltung auf persönliche Heilserfahrung bleibt der wunde Punkt des ganzen Kirchenbegriffes ${ }^{212}$ ).

Der andere Punkt, das Problem der Organis ation e ines A m tes der Wortverkündigung, war nicht minder schwierig. Der Träger der Kirche ist das Wort und nicht eine in der Sukzession stehende Hierarchie. Das Wort aber hat wiederum sein Wesen in der Kraft zur persönlichen Ueberzeugung

212) Die Herausarbeitung der Autorität und alleinigen Infallibilität der Bibel zugleich mit der Begründung dieser Infallibilität auf die praktische, allein erlösende .Heilserfahrung von der Bibel s. bei Preuß, Entwickelung des Schriftprinzips bei Luther, 190I. Hier S. 6, 14, 60 sehr richtig die Unterscheidung von dem huma-. nistischen Schriftprinzip, das nach historischer Methode die Ursprünge herausarbeitet und daher wohl zu einer Messung an ursprünglichen Zuständen, aber zu keiner religiös begründeten Infallibilität gelangt. Treffend auch das Verhältnis zur Mystik, die im unmittelbaren Verkehr mit Gott die kirchliche und die Schriftvermittelung ignoriert: Luther modifiziert den Gedanken der Vereinigung der Seele mit Gott zur Vereinigung der Seele mit dem Wort und bezieht das allgemeine Offenbarungs- und Erlösungsprinzip des Logos stets auf Christus und das Wort von Christus, so sehr, daß auch alle, die Herrlichkeit der Logosschöpfung empfindende, christliche Naturbetrachtung durch die Betrachtung Christi und des Wortes vermittelt ist. Ueber das Verhältnis der kritisch-freien Schriftbehandlung Luthers und der gleichzèitig festgehaltenen Infallibilität der Schrift s. Scheel, Luthers Stellung zur h. Schrift, 1902. Luther und vor allem seine Kirche hat auf die Dauer beides nicht vereinigen können und das erstere zugunsten des letzteren aufgegeben. Das ist aber nur die Konsequenz des kirchlichen Autoritäts- und Organisationsbedürfnisses. Es ging nicht anders und konnte nicht anders gehen. Die Versuche heutiger Theologen, auf Luthers reicheres, Kritik und Autorität vereinigendes, nur im praktisch-religiösen Kern maßgebendes, anfängliches Schriftprinzip zurückzugehen, setzen einmal die Festigkeit gegebener Kirchen, die nur durch das orthodoxe Schriftprinzip erworben werden konnte, schon voraus, und vermögen zweitens doch nirgends Einheit zu schaffen, insofern dann überhaupt nirgends mehr eine autoritative Grenze zu ziehen ist. Mit dem Kirchen- und dem absoluten Wahrheitsbegriff einheitlich-normativer Erkenntnis verbunden muß das Schriftprinzip in die orthodoxe Lehre ausmünden wie die Institution des Papsttums in das unfehlbare monarchische Lehramt, und die die Bibelkritik akzeptierende moderne Rechtgläubigkeit befindet sich in derselben Lage wie der das Papsttum in eine pädagogische Aufsichtsbehörde zurückverwandelnde katholische Modernismus. 
und Wiedergeburt. So sind die eigentlichen Träger der Kirche, die rom Worte wiedergeborenen Christen, die wahrhaft frommen und lebendigen Christenleute, und ihnen kommt die Leitung wie die Organisation der Kirche zu. So scheint in der Tat die Kirche vom Zusammenschluß und der strengen persönlichen Christlichkeit der Gemeindeglieder her sich zu ergeben. Aber es scheint nur so. In den Wirren des Uebergangs, wo Altgläubige und Neugläubige noch durcheinander saßen, die alte Kirchenordnung noch nicht beseitigt und eine neue noch nicht aufgerichtet war, wo man noch auf ein Konzil oder eine Ordnung von Reichs wegen hoffen konnte, wo das Scheitern solcher Hoffnungen Luther den Gedanken an das Weltende nahe legte und alle Gemeindebildung ihm als Sammlung der Gläubigen für das Wiederkommen Christi erscheinen ließ, da hat Luther mehrfach Anweisungen gegeben, engere Kreise von wahrhaft Gläubigen mit eigener christlicher Lebensordnung, abgegrenztem Beicht- und Kommuniongebrauch selbständiger finanzieller Fundamentierung und eigenem Recht der Predigerberufung zu bilden. Es ist die Gärungsperiode der rein lokalen Reformversuche, wo Luther die Gemeinden auf Grundlage des allgemeinen Priestertums experimentieren ließ. Das ist oft als eine völlige Durchbrechung des katholischen Kirchenbegriffes gefeiert oder umgekehrt als vorübergehende Abirrung zum Sektentypus entschuldigt worden. Aber in Wahrheit ist weder das eine noch das andere der Fall. Der Kirchen- und Anstaltsbegriff an sich ist mit diesem > Gemeindeideal $\alpha$ in keiner Weise aufgegeben. Denn einmal sind auch diese engeren eigentlichen Christengemeinden vom lWort hervorgebracht und urteilen sie über die Lehre immer vermöge eines rom Wort und seiner wunderbaren Kraft selbst hervorgebrachten Konsens; die Gemeinde ist nur das Produkt des Anstaltskernes, des Wortes, und nie der Produzent der christlichen Gemeinschaft. Weiterhin aber sind diese Gemeinden nur als Kern der Christenheit, als vorläufige Erziehungsmittel gedacht, die die Menschen durch ihr Vorbild und ihren Einfluß erziehen sollen und von denen aus das Wort wieder in die Allgemeinheit wirken soll und wird. Aber nicht nur der kirchliche Anstaltsbegriff ist dabzi gewahrt; auch die Tendenz auf Universalität und auf schließlichen Zusammenfall der Gebietseinheit und der Religionseinheit ist dabei mit geringfügigen Schwankungen festgehalten. Ein irgendwann einmal eintretendes Definitivum ist dabei vorausgesetzt, und dieses Definitivum ist entweder das Weltende oder, wenn die Welt dauern 
soll, eine universalkirchliche Reform. Luther wendet sich zu diesen Gemeindebildungen überhaupt erst, nachdem der Aufruf an den Adel, d. h. an die Landesherren, sich vergeblich und die Hoffnung auf ein Konzil sich ins Unbegrenzte hinausgeschoben hatte. $\mathrm{Er}$ betrachtet sie als Sammlungen der Frommen in der Auflösung der Kirche vor dem Kommen des Antichrist; so selbstverständlich ist ihm die kirchliche Lebenseinheit, daß er deren Auflösung nur als Zeichen der beginnenden Endkämpfe sich erklären kann. Sie sind Provisorien und nichts Endgültiges und Wesentliches; und überdies ist es ihm selbstverständlich, daß neben dem die christliche Obrigkeit die äußere Christenheit, d. h. die christliche Ordnung des Lebens, gegen Aufruhr und offene Blasphemie aufrecht erhält. Ja, er empfiehlt die neuen Gemeindebildungen überhaupt nur da, wo bestehende Patronats- und positive Rechtsverhältnisse die Reform der gesamten Ortsgemeinde im evangelischen Sinne ausschließen. Hier sollen sich die wahren evangelischen Christen zusammentun und, wenn sie die Predigt einem Bruder übertragen, so ist es ein evangelisch gewordener Priester, womit ja auch die kirchliche Kontinuität gewahrt ist. Ueberdies sollen dabei die Gemeinden möglichst durch ihre natürlichen Vertreter, die Ortsobrigkeiten, handeln, damit alles in tunlichster Uebereinstimmung von gegebener Ordnung und kirchlichem Interesse geschehe und nicht aus der Willkür der Subjekte hervorgehe. Der Gottesdienst soll dabei allen geöffnet sein, nur der engere Kommunionsverband soll sich besonders konstituieren: die Kindertaufe versteht sich nach wie vor von selbst, und die Jugend muß zur religösen Unterweisung gebracht werden. Alle diese Versuche aber hören von dem Moment ab auf, wo die Unmöglichkeit einer Gesamtreform entschieden ist, wo man nicht mehr von den ganz verschieden gesinnten einzelnen Ortsgemeinden her zu operieren braucht, vielmehr die evangelischen Länder sich zu einer selbständigen Gesamtordnung ihrer kirchlichen Verhältnisse wenden. Da wird es dann selbstverständlich, daß die Landesherren und Obrigkeiten als zum Dienst am Gotteswort verpflichtete Gemeindeglieder und als die verordneten Repräsentanten der Gemeinde die kirchliche-Ordnung durch Visitationen in die Hand nehmen und die Herrschaft des reinen Wortes aufrichten, das wenigstens in seiner Reinheit überall auf den Leuchter gestellt werden und allen zugänglich gemacht werden muß. Das immer nur sehr relativ verstandene Gemeindeideal 
verschwindet, und das Landeskirchentum löst die universale Weltkirche ab, ohne sie dadurch aufzuheben, da ja überall, wo Wort und Sakrament ist, bei den verschiedensten Formen die allgemeine Kirche ist. Den Abfall der römischen Kirche aber kann Luther von seinem Ideal der allgemeinen Einheitskirche aus sich nur so erklären, daß der Papst der in der Apokalypse geweissagte Antichrist ist; so verschwindet der Anstoß, den der Abfall einer so großen und dauernden Grüppe von der ursprünglichen reinen Wortkirche bereiten muß, so lange man das Ideal einer allgemeinen, von Gott geleiteten und alleinseligmachenden Kirche festhält. Was Gott selbst geweissagt hat, das kann kein Argument gegen das von Gott aufgerichtete Institut der reinen Kirche sein.

So kommt in dem Landeskirchentum die Universalität und der Herrschaftsanspruch der Kirche mit der Sicherung der reinen Lehre und der geordneten rechtgläubigen Schriftverkündigung schließlich zur Geltung Luther wollte selbstverständlich nicht die Herrschaft der Landesherren in der Kirche; diese lag vielmehr in der Konsequenz der spätmittelalterlichen Entwicklung und war überhaupt nicht $z u$ umgehen, wenn einmal die ganze Ordnung den Landesherren anvertraut war. Luther wollte nur den Liebesdienst der Landesregierungen für die Kirche, bei völliger Selbständigkeit der inneren Wirkung des in diesen Kirchen aufgerichteten Gotteswortes. Es ist eine Trennung der Kompetenzen innerhalb eines gemeinsamen Lebenszusammenhanges, die von Hause aus praktisch sehr schwierig ist und die sich in ihrem reinen lutherischen Verstand nur durch den überidealistischen Glauben begründen läßt, , daß das Wort von selbst in der Kirche einhellige Erkenntnis und Predigt wirken werde und daß es gleichzeitig in den außerkirchlichen Beziehungen die frei sich ihm unterstellenden Obrigkeiten und Laien den richtigen Weg führen werde, soweit sie diesen nicht von selbst durch das Naturgesetz geführt werden. Indem auf eine Regelung durch die rechtliche Uebermacht der Hierarchie verzichtet wird, wird alles auf den Glauben an die nie versagende, einheitliche und vereinheitlichende Wirkung des Wortes abgestellt, das ohne gewaltsames Zutun der. Menschen die Einheit des Corpus Christianum hervorbringen soll und das, wo es das nicht zu Stande bringt, eben dem Teufel und der Sünde unterliegt, wie es in der bösen Welt zu geschehen pflegt. Von hier aus legen sich Luther dann immer wieder eschatologisch-apokalyptische 
Stimmungen nahe, wo es dann nur darauf ankommt, daß in dieser Verderbnis der Endzeit die Einzelnen ihre Seele retten durch Glauben und Dulden. Der enge Zusammenhang zwischen dem Vèrzicht auf einheitlich-christliche Lebensordnung und eschatologischer Stimmung wie umgekehrt zwischen der Einrichtung auf dauernde Weltverhältnisse und der Reform des gesamten christlichen Lebens zeigt deutlicher noch als alles andere, daß sein Kirchenbegriff den Gedanken der Universalität und das Ideal einer geistlichen Allbeherrschung des Lebens nicht aufgegeben hat, was beides denn ja auch in der Tat von der Voraussetzung einer absolut-offenbarten und alleinseligmachenden Wahrheit her gar nicht aufgegeben werden kann. Aber allerdings zeigt sich in diesen Schwankungen und in den anfänglichen Aeußerungen des »Gemeindeideals* die besondere Art des lutherischen Kirchenbegriffes, die die uniforme und allumfassende Herrschaft des Wortes rein auf die innere persönliche Ueberzeugurg und die Gemeinschaft rein auf den in der Liebe wirkenden Glauben an dieses Wort bei Gleichgültigkeit der äußeren technischen Ordnung begründen will. $\mathrm{Er}$ will die Objektivität der Anstalt und die Subjektivität der persönlichen Christlichkeit in seinem Begriff von »Wort « und »Glaube * als den bildenden Grundkräften der Kirche vereinigen. Bei der Schwierigkeit, diese Gegensätze zu vereinigen, ist es nicht verwunderlich, daß dieser Kirchenbegriff bald nach der einen, bald nach der anderen Seite über sein eigentliches Ideal hinausgeht ${ }^{213}$ ).

213) Rieker, der die Bedeutung des mittelalterlichen Gedankens: des Corpus christianum auch für Luther durchaus siegreich klar gemacht hat, hat allerdings in diesem Gemeindeideal Schwierigkeiten gefunden, die er zu leicht aufgelöst hat, wenn er im Anschluß an die dürftigen Bemerkungen von Achelis dieses sGemeindeideal als Abirrung zum täuferischen Sektentypus bezeichnet, die gegen die vor. herigen und nachherigen Aeußerungen Luthers gehalten als ein Tribut an ihm innerlich fremde Zeitneigungen erscheint, Rieker S. 74-86, Achelis, System der prakt. Theol. I, 35.f. Gegen diese Deutung hat Walther Köhler als gegen eine Verkennung und Unterschätzung des Gemeindeideals sich gewendet in einer höchst lehrreichen Untersuchung: DDie Entstehung der reformatio ecclesiarum Hassiae * von 1526, Deutsche Z. f. Kirchenrecht, 1906, S. 199-232 und in einem Aufsatz: „Zu Luthers Kirchenbegriff*, Christl. Welt 1907, S. 371-377. Dem folgte dann die eingehende Untersuchung von Drews, ¿Entsprach das Staatskirchentum dem Ideal Luthers?\&, I908, die diese Frage verneint und das Gemeindeideal als mit dem kirchlichen Grundgedanken wohl vereinbar, aber durch die besondere Uebergangslage bedingt zeigt; es kommt nur auf Aufrichtung des Wortes an, wie? ist gleichgültig; da es schließlich nur mit Hilfe der Landesherrn ging, so hat Luther 
Indem aber so die Universalität der Kirche nicht bloß durch die Kraft des Wortes, sondern durch die politisch-polizeiliche Aufrechterhaltung einer äußeren Christenheit und durch die Schaffung einer landeskirchlichen Organisation hergestellt deren Hilfe als Liebesdienst, aber nicht als Herrschaft akzeptiert. Noch weiter auf Begrindung des Gemeindeideals durch tatsächliche örtliche Verhältnisse ging Karl Müller, suther und Karlstadte S. 217-223, 123 ein, der die Notwendigkeit der Einrichtung neben den alten Patronatsverhältnissen betont, und Hermelink, $>$ Zu Luthers Gedanken über Idealgemeinden und von weltlicher Obrigkeit , Z. f. Kirchengesch., 1908, S. 267-322, uo der Zusammenhang dieses Gemeindegedankens mit apokalyptischen Stimmungen und zuglcich die antidemokratische Auffassung der Gemeinden als jedesmal durch dic Ortsobrigkeit möglichst vertreten gezeigt wird. Für unseren Zusammenhang kommt es darauf an, daß in alledem jedenfalls der kirchliche Gedanke selbst gewaht ist trotz scheinbarer Annäherung an den Sektentypus, s. auch Troeltsch, - Trennung von Staat und Kirche S. 9-23. Der Zusammenfall von Gebietseinheit und Religionseinheit ist bei alledem auch für Luther etwas Selbstverständliches, Dreu's $S$. 99, und aller anfängliche Verzicht auf Gewissenszwang bedeutete doch immer nur ein im Vertrauen auf das Wort begründetes provisorisches Gehenlassen, bei dem überdies die Obrigkeit jede offene Blasphemie und jeden Aufruhr, d. h. jede stürung der Einheit der christlichen Gesellschaft zu unterdrücken hatte. Darüber gleich mehr. Immerhin liegt in diesen Aeußerungen über das Gemeindeideal von 1522-1525 ein eigentümliches, nicht bloß örtliches und nicht bloß moinentanes Problem, das gerade für die soziologische Bedeutung des lutherischen Kirchenbegriffes höchst interessant ist. Es ist ein Versuch, innerhalb der allgemeinen christlichen Gesellschaft und der getauften Anstaltschristenheit engere Kreine zu stiften, in denen die radikale Christlichkeit verwirklicht wird, ohne durch diese engeren Kreise doch den allgemeinen Kirchencharakter aufheben zu wollen. Kühler nennt es ein Nebeneinander einer obrigkeitlich regierten und urganisierten christlichen Gesellschaft und der kleineren Kreise von Kult- und leicegrmem-chaftenx. Als Luther auf die Ausführung seiner Gedanken verzichtete, nahmen die Wiedertäufer sie auf, von dort übernimmt sie Butzer, von dort calvina, Christl. Welt $S .470$. Das Entscheidende ist aber, daß dabei die Wiedertiufer auf den weiteren Kreis der christlich regierten Gesellschaft verzichten, die Taufe nur als siätaufe der gereiften Christen gelten lassen und die Gemeinschaft der so getauften der weltförmigen Noral der angeblichen Christenheit und Kirche schroff gegenüberstellen. Umgekehrt verwandelt der Calvinismus sdie engeren Kreise. in die Gesamtkirche und gibt ihnen eine universalkirchliche Struktur, innerhalb deren er für die persünliche Christlichkeit aller Gebiets- und Kirchenglieder sorgt. Die Täufer streifen den Kirchengedanken ab, der Calvinismus verwandelt die engeren Kreise zurïck in die mit der Gebietseinheit zusammenfallende Anstaltshirclic. Luther sucht in jenen Aeußerungen der ersten Hälfte der zwanziger Jahre unverkennbar einen Mittelweg. Da dabei von Hause aus der Kirchengedanke absolut vorherrscht, so ist es njcht verwunderlich, daß er bei der defini- 
war, mußte Luthers Kirchenbegriff einen weiteren Zug in sich aufnehmen, der ihm innerlich fern lag und der doch aus der festgehaltenen Einheit und Universalität der Kirche notwendig folgte, die $Z$ wangsherrschaft dieses uniformierten Kirchentums. Das Prinzip der reinen Glaubens- und Ueberzeugungsreligion mußte die Freiwilligkeit, die innerliche Ueberzeugungszugehörigkeit zur Folge haben. In der Tat vertritt Luther anfänglich nichts schärfer als die Freiheit und Innerlichkeit der Wirkung des Wortes. Er will keine Zwangsunterwerfung und $Z$ wangsbekehrung der Altgläubigen und auch keine solche gegenüber den Neuerern. Das Wort soll frei zu Felde liegen und alle innerlich überwinden. Aber der Ton liegt auf dieser letzteren Erwartung. Dem reinen Wort allein wohnt die Wunderwirkung der Bekehrung inne, der menschliche und priesterliche Wahn wird in sich selbst vergehen. So ist Luther kein Vorkämpfer der Toleranz, aber wohl ein Vorkämpfer rein geistiger Wirkungen des Wortes ohne Nachhilfe äußeren $Z$ wanges. Nicht Duldung verschiedener Ueberzeugungen als subjektiv berechtigter, weil man ja über religiöse Dinge objektiv und zwingend doch nichts ausmachen kann, sondern absolute Selbstgewißheit von der alleinigen Wahrheit der eigenen Position oder vielmehr von der Göttlichkeit des Wortes und seiner Fähigkeit rein geistiger Selbstdurchsetzung, das ist die Toleranz, die von dem lutherischen Kirchenbegriff aus möglich war. Auch hier aber sollte die Freigebung des Kampfes nur ein Provisorium in der Zeit des gärungsreichen Uebergangs sein, an der endlichen Durchsetzung des Wortes hat Luther nicht gezweifelt, sobald er nicht in diesen Kämpfen die Vorboten des Endes, sondern den Durchgang zu neuen dauernden Verhältnissen erblickte. Aber er mußte erleben, was jeder solcher Glaube erlebt und was auch schon die alte Kirche erlebt hatte, daß nämlich die Idee und der Glaube allein nie zu einer unbedingt allgemeinen Herrschaft mit rein geistigen Mitteln kommen kann, daß die Beschränkung auf diese Mittel die

tiven Ordnung die vollen Konsequenzen des Kirchengedankens zieht und sowohl auf die Bildung engerer Kreise als auf die Uebertragung der Kirchenordnung nur an die Gemeinden verzichtet. Ihn im Sinne des Calvinismus auszubilden hinderte ihn außer den Verhältnissen sein jeder Gesetzlichkeit abgeneigter kirchlicher Gnadengedanke, wăhrend der Calvinismus in der Tat den Kirchengedanken mit einem sektenhaften $Z$ wangselement versetzt. Das wird uns noch näher beschäftigen bei der Darstellung des Calvinismus. 
Universalität und Einheit in Frage stellt. So mußte auch er zu

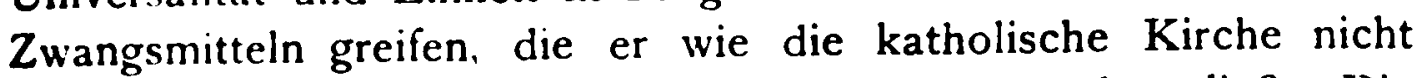
durch die Kirche, sondern durch den Staat ausüben ließ. Die Kirche selbst ist auf Freiheit, Liebe und Ermahnung gestellt. Aber dafür, daß alle getauft und ihr unterstellt werden, sorgt die Sitte, die gesellschaftliche Bindung aller Rechte an die Christlichkeit, und gegen dauernde Häresie schreitet der Staat ein, indem er in ihr die Störung auch der gesellschaftlichen Ordnung ahndet. Beide Ordnungen, die gesellschaftlich-staatliche und die kirchlichgeistliche Einheit fallen ihm eben, wie dem Mittelalter ganz selbstverständlich zusammen; und, wenn dieses Zusammenfallen sich nicht rein automatisch von selbst durchsetzt, dann wird es Pflicht des Staates, wenigstens äußerlich jede Bezeigung eines dauernden Gegensatzes unmöglich zu machen ${ }^{214}$ ). In Anbetracht der Erzie-

214) Der Gedanke einer von einer einheitlichen Weltanschauung beseelten Gesellschaft ist unzueifelhaft mittelalterlich, aber um deswillen nichts weniger als erledigt bis heute. Einen wirklichen gesellschaftlichen Zusammenhang gibt es ohne Einheit der Weltanschauung überhaupt nicht, und mán tut gut, sich daran zu erinnern, daß im Gegensatz gegen die moderne, gesellschaftsauflösende Anarchie der Weltanschauung und des religiösen Denkens zwei so grundverschiedęne Denker wie der Romantiker Novalis und der nüchterne Empirist Aug. Comte mit vollem Bewußtsein auf das Mittelalter als auf die klassische Epoche einer auf die Einheit der Ideen begründeten Gesellschaftseinheit zurückgegriffen haben. Heute hat man das gleiche Beispiel an der Sozialdemokratie vor sich. Auch die konservativen Parteien und die Kirchenmänner von heute arbeiten noch mit dem gleichen, wenn auch abgeschwächten Prinzip: s. Loofs, Luthers Stellung zu M.A. und Neuzeit, 1907, S. 19: Andrerseits ist zwischen Luther und der Neuzeit nicht die Kluft befestigt, mit der Troeltsch hier rechnet: Hatten nicht selbst wir bis 1874 im wesentlichen noch den Tuufzwang? Ist nicht die Gotteslästerung bei uns heute noch strafbar? Und haben wir nicht noch heute eine christlich gefärbte Autoritätskultur mit im großen und ganzen obligatorischen Religionsunterricht... Materiell wird der Begriff der Gotteslästerung jetzt freilich sehr viel anders gefaßt, als L. es tat. Aber in formaler Hinsicht ist der Unterschied gar nicht so groß.\& Das trifft, insbesondere für Preußen, zweifellos zu, ist aber auch nur ein Beweis dafür, daß hierin die gleichen Motive wie in der mittelalterlichen Gesellschaftsordnung fortwirken und $\mathrm{daB}$ die protestantische $Z$ wangskultur genau so $z u$ verstehen ist wie die mittelalterliche. Luthers Festhalten an der Einheit der religiösen Idee hat allerdings nicht bloß die Bedeutung einer mittelalterlichen Befangenheit, sondern einer aus dem Wesen einheitlicher Gesellschaftsverfassung und absoluter offenbarter Wahrbeitserkenntnis notwendig sich ergebenden Folgerung. Mit dem Ziel mußten aber schließlich auch die Mittel gewollt werden und werden sie immer von neuem wieder g.v .ult werden. 
hungsbedürftigkeit und Unreife der Massen mochte überdies ein Zwang zur Wahrheit und zum Heil völlig gerechtfertigt erscheinen, wie heute noch der Staat in der Zwangsschule und in tausend Mitteln zwangsmäßiger Gesinnungsbildung die Menschen zu ihrem Heile zwingt, wie jede Partei, jede Gruppe, ja sogar künstlerische und wissenschaftliche Richtungen ihre geistige Einheit nur durch $Z$ wangsmittel gröberer oder feinerer, direkterer oder indirekterer Art aufrecht erhalten. Kein soziologischer Zusammenhang kann dauernd ohne $Z$ wangsmittel existieren. Das ist eine Tatsache des Lebens, und aller Glaube an eine ausschließliche Macht der reinen Idee gehört nur unter die spiritualistischen Illusionen, nicht in das Reich der Wirklichkeit. Vor allem aber kann ein Zusammenhang, der auf absolute und alleinseligmachende Wahrheit begründet ist und mindestens die Zugänglichmachung dieser Wahrheit für alle samt ihrem Schutz gegen hartnäckige Untergrabung fordern muß,

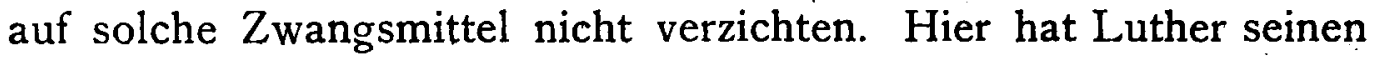
anfänglichen Idealismus gründlich korrigiert, indem er außer der Zugänglichmachung dieser $\mathrm{W}$ ahrheit für alle auch die Beseitigung aller überhaupt die Ordnung des christlichen Gemeinwesens störenden Häresien mit Gewalt durch die Obrigkeit forderte. Das traf. vor allem die Täufer mit ihrem andersartigen Ideal von Staat und Kirche. Schließlich aber fielen auch ganz konsequent rein dogmatische Häresien unter den Begriff einer Störung der christlichen Gesellschaft, die der Staat im Interesse des Corpus Christianum zu unterdrücken hat. Und auch in der. Art der Bestrafung verschärfte sich die Stellung der Wittenberger immer mehr. Von der bloßen Landesverweisung ging man zum ewigen Gefängnis und von hier sogar zur Todesstrafe weiter, alles eine Strafe im Namen des Staates nach vorausgegangener christlicher Ermahnung. Aber so dürstete ja auch die katholische Kirche nicht nach Blut, sondern ließ die Häretiker durch den Staat als hartnäckige Störer der christlichen Gesellschaftseinheit bestrafen. Und wie sehr es sich in alledem um die Behauptung der christlichen Gesellschaftseinheit handelt, zeigt die Hilfskonstruktion Melanchthons, der die Bestrafung der Häretiker aus dem Naturgesetz, dem das christliche Gesetz ergänzenden Grundgesetz der einheitlichen Gesellschaft, ableitet, indem schon das Naturgesețz den Schutz der Religion verlange. Der scharfe Gegensatz gegen die ursprüngliche Stellung Luthers liegt hier auf der Hand. Und doch ist es kein reiner Gegensatz. Denn aus dem Ideal der Einheitskirche 
mußte diese Konsequenz entspringen, sobald man nicht mehr an die rein spirituelle Durchsetzung des Wortes glaubte und doch dauernde Verhältnisse begründen wollte. Es bedurfte dazu gar nicht des gleichzeitigen Zwanges durch das Reichsrecht und durch die politische Lage. Is folgte aus dem. Gedanken der allein seligmachenden Kirche, die die schwachen und groben Sünder vor Versuchung bewahren muß. Und es läßt sich nicht leugnen, daß Luther und die Wittenberger Juristen nicht nur unter dem $Z$ wang der an der Kircheneinheit interessierten und die Täufer mit großer Nervosität fürchtenden Landesherren, sondern aus eigenem klaren Willen schließlich eine furchtbar grausame $Z$ wangsherrschaft gegen -Zwinglianer, Sakramentierer, Schwärmer und Wiedertäufer * aufgerichtet haben, ohne damit den Gedanken aufzugeben, daß die Kirche rein geistlich zu wirken habe. Es war eine Selbsttäuschung, die da möglich ist, wo man die Wahrheit absolut kennt und daher Toleranz für die Wahrheit, aber Intoleranz für die Unwahrheit von den politischen Gewalten fordern zu dürfen ehrlich überzeugt ist. Was den Rebellen bestraft und gewaltsam beseitigt, ist nicht die Kirche als solche, sondern das aus ihr folgende Ideal einer universalen Herrschaft der absoluten und alleinseligmachenden Wahrheit über die Gesellschaft, der absolutistischobjektive Wahrheitsbegriff und die von ihm getragene allgemeine christliche Gesellschaftsidee ${ }^{215}$ ).

215) Auch hier sind Luthers Aeußerungen nach Zeit und Umständen widerspruchsvoll, und die Sammlung und Erklärung dieser Aeußerungen ist je nach apologetischer oder polemischer, historischer oder dogmatischer Tendenz sehr verschieden. Aus den Zwickauer Akten hat Wappler eine Reihe von Religionsprozeßakten, Regienungsverfügungen und Gutachten der Wittenbergischen Theologen und Juristen veröffentlicht, die von der Visitation ab den furchtbarsten und kleinlichsten Gewissenszwang zeigen, s. Wappler, Inquisition und Ketzerprozesse in Zwickau zur Reformationszeit, 1908. Er hat damit eine Darstellung der Aeußerungen Luthers und Melanchthons verbunden, die den Gegensatz der anfänglichen Duldung und Nichteinmischung der Obrigkeit in den freien Geisterkampf gegen die spätere Anweisung alles Aufrührerische und Ordnungstörende mit Landesverweisung zu bestrafen aus Gründen äußerlich-weltlicher und zugleich christlicher Gesellschaftsordnung, bis zur schließlichen Betrachtung jeder dogmatischen Häresie als Frieden und Einheit störend und bis zur Todesstrafe scharf hervorgehoben. Wenn er aber dabei die Reformatoren an dem modernen Toleranzbegriff einer das Dogma hnter die Ethik zurückstellenden Religion mißt und ihre Abweichungen hiervon wegen ihrer Berufungen auf das Alte Testament für Früchte des finsteren alttestamentlichen Rachegeistes erklärt, so vergißt er in erster Hinsicht den den Reforma- 
Parallel mit der Entwickelung dieser ersten Konsequenz des Kirchentypus geht die der $\mathrm{z}$ weiten, die zunehmende Herausbildung der weltbejahenden $\mathrm{E} t \mathrm{hik}$.

Luthers Ethik hat zunächst einen Zug zur radikalen welttoren mit dem Mittelalter gemeinsamen absoluten Wahrheitsbegriff, von dem aus der moderne Toleranzbegriff mit seiner Möglichkeit verschiedener subjektiv berechtigter Wahrheiten nebeneinander als frevelhafte Skepsis und Blasphemie erschienen wäre, und übersieht er, daß die Heranziehung des A. T. hier wie sonst nur dazu dient, biblische Begründungen zu finden für Dinge, die aus dem N. T. nicht begründet werden konnten und doch eine Begründung bei ihrer praktischen Unumgänglichkeit verlangten. Weitere Beispiele in erschreckender Fülle zeigt Barges Karlștadt trotz der von Karl Müller gemachten Einschränkungen. Vom katholischen Standpunkt aus sammelt N. Paulus, Luther und die Gewissensfreiheit, 1905, die Stellen. Er deutet die anfängliche Toleranzforderung als Minoritätentoleranz, d. h. als Forderung an die papistischen Fürsten, sich in die geistlichen Dinge nicht einzumischen und das Evangelium nicht zu hindern, und zeigt, wie gleichzeitig mit diesen Forderungen Luther von der evangelisch gesinnten Obrigkeit die Abstellung der Messe als Pflicht christlicher Obrigkeit bezeichnet. Auch die den Täufern und Schwärmern bewilligte freie geistige Auseinandersetzung daure nur so lange, als er glaubte leicht damit fertig zu werden, habe aber bei der Entwickelung wirklìcher Opposition sofort aufgehört und dem härtesten Gewaltdruck Platz gemacht. Das ist sicher im allgemeinen nach beiden Seiten hin nicht unrichtig; aber es ist dabei der innere Trieb nicht beachtet, der doch Luther nicht bloß aus Opportunismus, sondern aus der Notwendigkeit seines Kirchenbegriffes heraus zunächst zu dem rein innerlich-geistlichen Aufbau der Gemeinden und rein geistlicher Ueberwindung der Gegner im Vertrauen auf die Unwiderstehlichkeit des reinen Wortes nötigte. Interessant ist die S. 27 angeführte Stelle, wo Luther auf den Einwurf, daß ja doch auch Kaiser Karl sich im Gewissen an seine Lehre gebunden fühlte und daher ihm die $Z$ wangsübung nicht zu verübeln sei, erwidert:,$W i r$ wissen, $d a ß$ erdeß nichtgewißist und nichtgewißseinkann, weil wir wissen, $d a \beta$ e $r$ irret und wider das Evangelium streitet, der Kaiser ist schuldig, daßer Gottes Wort erkenne und dasselbige gleichwie wir mit allen Kräfte n förderee. Hier liegt der eigentliche Nerv der Sache, wie unter Anziehung der gleichen Stelle auch von den meisten andern Darstellern erkannt ist, und es ist begreiflich, daß von .einer solchen Grundüberzeugung aus schließlich bei vielfachem und hartnäckigem Widerstand im Interesse der Unmündigen, Schwachen und leicht Verftihrbaren sowie im Interesse der christlichen Einheit der Kirche und der Gesellschaft auch Gewalt für die Wahrheit gebraucht werden darf und muß. Paulus verweist mit Recht auf die Aeußerung des modernen orthodoxen Lutherapologeten W. Walther: „Es muß jeder Unparteiische es für das einzig Richtige halten, wenn Luther dahin strebte, daß in e in e $m$ Land nur e in e Konfession herrschtea, S. 13. Es bedarf gar nicht des Hinweises auf das Reichsrecht gegen die Ketzer, auf 
indifferenten Christlichkeit und Innerlichkeit, den er nur allmählich mit der vom kirchlichen Gedanken aus geforderten und ihm immer selbstverständlichen Christlichkeit der Gesellschaft und der natürlich-staatlichen Lebensordnungen ausgleichen lernte. Auch hier

die von Tăufern drohende soziale und politische Gefahr, auf den Druck der katholischen Nachbarstaaten, wie das der gelehrte Pfarrer Bossert mit großem Ueberlegenheitsgefühl gegen Wappler zur Entschuldigung der Reformatoren hervorhebt, die hier s relativ beurteilt a werden müßten; Theol. Litztg. 1908, S. 153. Das neue Ketzerrecht, die Zensurforderung und die Konfessionseinheit geht letztlich aus dem Wahrheits- und Kirchenbegriff der Reformatoren selbst hervor, und die Widersprüche sind in den Widersprüchen eben dieses Kirchenbegriffes begründet, der eine allgemein christliche Kirche und Gesellschaft und doch eine rein innerlich-geistliche Wirkung will. Das ist undurchführbar: so hat man zum Zwang gegriffen, indem man diesen auf die Obrigkeit als Pflicht aus christlicher Liebe und auf Grund des Naturrechts abschob und den rein geistlichen Charakter der kirchlichen Selbstdurchsetzung auf eine der obrigkeitlichen Verurteilung vorausgehende theologische Ermahnung und auf die Duldung eines jeder Aeußerung sich enthaltenden verborgenen Mißglaubens beschränkte. Das ist in der Tat das alte katholische Ketzerrecht, wie Paulus sagt, nur mit dem wesentlichen Unterschiede, daß Melanchthon der weltlichen Obrigkeit, als dem vornehmsten Gliede der Kirche, die eigentliche Entscheidung in Glaubenssachen zugesteht, während man katholischerseits der unfehlbaren Kirche die Entscheidung über religiöse Lehren vorbehält. Wohl begehrte auch Melanchthon, daß in zweifelhaften Fällen die Fürsten sich nach dem Rat der Theologen richten sollen; allein in letzter Instanz entschied doch die weltliche Obrigkeite, S. 43. Darin kommt die Festhaltung an der geistlichen Wirkungsweise und die Charakterisierung der Häresie als Aufruhr und Störung der christlichen Gesellschaft zum Ausdruck, aber eben damit auch die Fortdauer der katholischen Idee von der einheitlichen christlichen Gesellschaft, die ihrerseits aus der Universalităt der Kirche folgt. Innerhalb des gemeinsamen Ganzen sind die Akzente verschoben, und in dieser Verschiebung ist die Spiritualität des neuen Kirchenbegriffes behauptet. Das wird auch sehr richtig als der entscheidende Punkt hervorgehoben von W. Köhler, Reformation und Ketzerprozeß, 1901, bes. S. 21-26, der auch zeigt, wie schwer den Reformatoren der Verzicht auf ibren ursprünglichen Glauben an die Allmacht der Idee oder des Wortes geworden ist, und wie schließslich die Abschiebung des Ketzerprozesses an die weltliche Gewalt als Hüterin der christlichen Gesellschaftseinheit doch auch die Vorbereitung eines rein kirch: lichen Ketzerprozesses fordert, auf Grund dessen die weltliche Obrigkeit dann das Ihre tun kann. Der Abschiebung an die weltliche Gewalt entspricht die Begründung des Ketzerrechts auf das Naturrecht bei Melanchthon S. 29, das im Dekalog zusammengefaßt den Schutz der. ersten Tafel, d. h. namentlich des hier sanktionierten Predigtamtes, durch die weltliche Obrigkeit vórschreibt. Es bleibt aber immer das Neue, daß die Unterdrückung nicht im Namen der Kirche und durch die Kirche, sondern im Namen der christlichen Gesellschaftsordnung und durch den 
ist es daher nicht ohne starke Widersprüche abgegangen, und, wie die Widersprüche auf dem Gebiete des Kirchenbegriffes die Kompliziertheit des protestantischen Verhältnisses von Staat und Kirche begründen, so bedingen die in der Ethik enthaltenen Widersprüche und Spannungen die Schwierigkeiten der protestantischen Sozialphilosophie ${ }^{216}$ ).

Staat erfolgt, während der rein kirchliche Ketzerprozeß nur die Reinhaltung der Lehre bezweckt. Es führt nicht das brachium saeculare eine Sentenz der kirchlichen Obergewalt aus, sondern der Staat schützt die christliche Gesellschaft und sich selbst im eigenen Namen. Der Effekt ist freilich derselbe. - Unbegreiflich ist es, wie Hermelink >Der Toleranzgedanke im Ref.-Zeitalter`, 1908, all dem.gegenüber Luther wieder zum Herold der modernen Gewissensfreiheit machen kann. Schon im m.a.lichen System sei nicht das Christentum, sondern der beigemischte Neuplatonismus der Vater der Intoleranz 1! Luther habe die Kirche auf eine rein geistige und innerliche Wirkung zurückgeführt, und, wenn die Reformatoren dem Staat das Recht der Ketzerbestrafung und der Durchführung einer gewaltsamen Glaubenseinheit zusprechen, so sei das ein von den neuen Erkenntnissen aus noch nicht gereinigter Staatsbegriff, der Staatsbegriff der Renaissance, Macchiavellis Allgewalt des Staates !! Die Täufer dagegen haben mit der Toleranz nichts zu tun. sSie waren gegen den Staat und das nichttäuferische Christentum in gefährlicher Weise intolerant^, wozu man bei Wappler die Aussagen der ganz passiven Täufer vergleichen möge !! Luthers Wahrheitsbegriff, dem das >Geistliche und Unsichtbare eine fertige Wahrheit ist, die Gott in die Herzen der Gläubigen senkt, und wo salles was dagegen streitet, ... sein Stück von Teufelswerk \& ist, sei ein in einzelnen Aeußerungen übrig gebliebenes Stück mittelalterlichen Neuplatonismus!! u. s. w. Toller und ungenierter kann man die Dinge nicht verdrehen, und solche Art von Apologetik ist es, die so viele theologische Schriften für Nicht-Theologen unerträglich macht.

216) Ueber Luthers Ethik ist immer noch das Beste Luthardt, $\gg$ Die Ethik Luthers in ihren Grundzügen \&, 1867. Freilich sind hier alle Spannungen und Schwierigkeiten geglättet und entsteht der Anschein einer völlig einheitlichen systematischen Deduktion. Das ist ihm dadurch erleichtert, daß er die ganze Sozialphilosophie so gut wie gar nicht beleuchtet. Eine historische und die Spannungen richtig hervorhebende Darstellung ist die treffliche Arbeit von Eger, Die Anschauungen L.s vom Beruf, I 900 ; nur irrt er, wenn er die Spannung auf die Nachwirkung des Mönchtums statt auf den urchristlichen Radikalismus oder auf die dialektische Unfähigkeit Luthers, eine systematische Ableitung der Kultur- und Humanitätsethik begrifflich zu gewinnen, auf die innere Schwierigkeit der Sache selbst zurückführt. Wertvoll für die Anfänge ist auch Braun, Concupiscenz\&. Vortrefflich und auch für Luther selbst wertvoll. ist Hupfeld, Die Ethik Joh. Gerhards. Ein Beitrag zum Verständnis der lutherischen Ethik ๔, 1908; aber auch hier ist gerade auf die Darstellung der Sozialphilosophie und die Analyse der Spannungen und Widersprüche verzichtet. Auf diese geht umgekehrt mit voller Energie, aber ohne Erkenntnis der den Zusammenhang erleuchtenden Grundbegriffe ein 
An sich ist Luthers Christlichkeit ein $\mathrm{R} \ddot{\mathrm{u}} \mathrm{ckg}$ a $\mathrm{ng}$ auf den rein religiösen Charakter der christlichen Ethik, wozu ihn gleicherweise, wenn auch mit verschiedener Färbung, die mystische Lehre von dem alleinigen Wert der Gottesliebe, die augustinische Grundformel der christlichen Ethik von der Liebe aller Dinge nur in Gott und um Gottes Willen und die evangelische Jesuspredigt von der Selbstheiligung für Gott und von der Bruderliebe um Gottes Willen anleiteten. Das Sittengesetz verschwindet in jeder Form als Gesetz, und es erhebt sich ihm wieder der freie $Z$ weckcharakter der Ethik, die nur einen absoluten Zweck, die Selbsthingabe an Gott im Glauben kennt; aus diesem einzigen wirklich gesollten $Z$ weck ergibt sich ihm dann mit sehr verschiedenen Motivierungen das ganze christliche Ethos von selbst. Die Schwankungen dieser Motivierungen zeigen nur, daß ihm die Erringung der religiösen Grundstellung der einzige wahrhaft sittliche Imperativ und $\mathrm{daB}$ ihm alles übrige verhältnismäßig gleichgültig und selbstverständlich war, sobald die Hauptsache feststand. Es ist die Rückkehr zur Ethik des Evangeliums, nur daß ihr imperativischer Charakter durch die apostolische Gnadenlehre umgebildet ist, die das, was Forderung ist, doch nur als Folge und Geschenk der Glaubenshingabe an die in Christus offenbare und verbürgte Gnade versteht. Der Glaube ist die höchste und eigentliche sittliche Forderung und zugleich ein Geschenk der Gnade: das ist die hohe Paradoxie und der Grundgedanke der Ethik Luthers. Das Handeln aber quillt von selbst aus ihm. Von hier aus stößt Luther allen gesetzlichen Moralismus aus bis zu der Gefahr antinomistischer Konsequenzen. Vor allem beseitigt er alle Vermittelungen und Uebergänge der katholischen Ethik, die die natürliche Moral mit der Oberstufe der mystisch-überweltlich-asketischen kasuistisch verzahnten. Er bezeichnet als Sinn und Kern der christlichen Moral lediglich die reine Gesinnungsinnerlichkeit des Gottvertrauens in Leid und Kreuz und die auf das eigene Selbst, alles weltliche Recht, auf den Gebrauch von Gewalt und Macht, ja auf den Eigenbesitz völlig verzichtende Bruderliebe. Die Färbung dieser eigentlich christlichen Moral ist bei Luther von allem Anfang an eine stark mystisch-spiritualistische

Lommatzsch, Luthers Lehre vom ethisch-religiösen Standpunkt aus, mit besonderer Berücksichtigung seiner Theorie vom Gesetz, 1879. Treff liche Einzeluntersuchungen bietet Gottschick, ,Ethik \& 1908. Für meine Gesamtauffassung muß ich auch hier verweisen auf meine Abhandlung: ,Grundprobleme der Ethike, Z. f. Theol. und
Kirche, XII, 1902. 
gewesen und vielfach auch später geblieben im Unterschied von der rein praktischen Moralität des Evangeliums, die das Sittliche als Mittel der Gottvereinigung behandelt und es nach der Kraft, diesem $Z$ weck zu dienen, abstuft ${ }^{217}$ ). Der weltindifferente, nur am

217) Hierüber vorzüglich Kapp, >Religion und Moral im Christentum Lutherse, 1902 ; Herrmańn, >Verkehr des Christen mit Gott \& 5, 1908; Thieme, >Die sittliche Triebkraft des Glaubense, 1895. Das Wesen der religiös bestimmten Ethik ist, daß hier als absolut verpflichtender und alleiniger Wert das religiöse Verhältnis selbst erscheint und daher alle sittlichen Werte - sei es der Selbstbearbeitung, sei es der Gestaltung der Beziehung zu den Mitmenschen - in den Dienst dieses höchsten Zweckes gestellt werden. So ist die Sache bei Jesus-verstanden, wie früher gezeigt. So ist sie jetzt auch bei Luther verstanden; die Wiederholung bei Luther ist eine Bestätigung der oben S. 37 entwickelten Auffassung (gegen diese und zustimmend zu Harnacks Einwänden inzwischen Thieme, Christl. Welt 1909, S. 77 I ff.: Bedeutung der Nächstenliebe bei Jesus). Von hier aus wird die erste Selbstpflicht die der Selbstheiligung und Selbsthingabe an Gott, und die Nächśtenpflicht wird die Liebe des Nächsten um Gottes willen und mit der Absicht, mit dem Nächsten zusammen in Gott sich zu vereinigen. Daß beides auch der Sinn der lutherischen Gottesliebe und Nächstenliebe ist, darüber siehe die treffenden Nachweise bei W. Walther, Die christliche Sittlichkeit nach Luther 1909 S. 35 und bei Thieme, Triebkraft, S. 17-53. Von Luther seien hier nur einige Stellen nach Thieme zitiert: "Ingressus in Christum est fides, egressus autem est caritas, quae nos justitia Dei indutos distribuit in obsequia proximi et exercitium proprii corporis ad succurendum alienae paupertati, ut et ipsi per nos attracti nobiscum ingrediantur in Christume S. 289; oder die berühmte Hauptstelle : sAus dem allen folgt der Beschluß, daß ein Christenmensch lebt nicht in sich selbst, sondern in Christo und seinem Nächsten : in Christo durch den Glauben, im Nächsten durch die Liebe. Durch den Glauben fährt er über sich in Gott, aus Gott fährt er wieder unter sich durch die Liebe und bleibt doch immer in Got t und göt licher Liebe, S. 284; oder : *Wenn ein Christ anfängt, Christum zu kennen als seinen Herrn und Heiland, durch welchen er ist erlbst aus dem Tod und in seine Herrschaft und Ehre gebracht, so wird sein Herz gar durchgottet, daß er jedermann wollt gerne auch dazu helfen. Denn er hat keine höhere Freude denn an diesem Schatz, daß er Christum erkennt. (Das ist die eigentliche ethische Selbstvollendung.) Darum fährt er heraus, lehrt und vermahnt die anderen; rühmt und bekennt dasselbige vor jedermann, bittet und seufzt, daß sie auch möchten zu solcher Gnade kommen. Das ist ein unruhiger Geist in der höchsten Ruhe, das ist in Gottes Gnade und Friede, daß er nicht kann still noch müßig sein, sondern immerdar darnach strebt und ringt mit allen Kräften, als der allein darum lebt, daß er Gottes Ehre und Lob wieder unter die Leute bringt, daß andere solchen Geist der Gnade auch empfangen S. 297. Das ist die Ethik des Evangeliums in etwas anderer Sprache, wie sie auch von Augustin und Bernhard in ihrer Sprache als Liebe zu Gott und Liebe zu den Kreaturen in Gott ausge- 


\section{8 \\ III. Der Protestantismus. I. Das soziologische Problem.}

eigenen Seelenheil und an der Vereinigung der Brüder in Gott interessierte Charakter der so begründeten Ethik ist von Luther an unzähligen Stellen aufs schärfste ausgesprochen worden; ebenso der Gegensatz dieser Heils- und Liebesethik gegen die aus dem Kampf ums Dasein entspringende Ethik des Rechtes, der Ehre, des Krieges, des Staates, der Vergeltung. An sich hängt der Christ mit den Weltaufgaben nur zusammen durch seinen Leib und durch die vorübergehende Verflochtenheit in das irdische Wiesen. Die Regeln der Bergpredigt vom Nichtwiderstehendem-Uebel, vom Nichtvergelten, von der Ueberwindung des Feindes und des Bösen rein durch Liebe sind auch ihm die eigentlichen Regeln des christlichen Handelns. Wahre Christen bedürfen des Staates nicht und auch nicht des Rechtsschutzes für das Privateigentum. Für die Betätigung dieses Glaubens; der, um der Seligkeit in Gott willen auf alles verzichtet und sich frei in der Liebe ausgießt, sind freilich die natürlichen Anlässe abzuwarten und zu benützen wie im Evangelium, und nicht besondere Verhältnisse zu schaffen und außerordentliche Opfer künstlich herbeizuführen wie im Mönchtum. Aber diese radikale religiöse Liebesethik steht doch, namentlich in den anfänglichen Aeußerungen Luthers, völlig fremd dem ganzen Bereich. der Vernunft, der Macht, des Rechtes, der Gewalt gegenüber, in den der Christ sich nur ergibt, weil das alles mit dieser sündigen Welt gegeben ist und weil der Liebesdienst am Nächsten bei der Lage der Dinge in der Welt nicht möglich ist ohne Benützung dieser Ordnungen der $W^{2}{ }^{218}$ ).

drückt worden war. Etwas scholastisch wirft Thieme die Frage auf, ob es hierbei keine Liebe zum Nächsten um seiner selbst willen gäbe, und beantwortet sie richtig dahin, daß ja gerade des Nächsten eigentlichstes Wohl bewirkt wird, wenn durch die Erweisung der Gottesliebe an ihn zugleich in ihm selbst die Gottesliebe und ihre Seligkeit entzündet wird. Dieses Motiv liege virtuell und unbewußt auch den Stellen zugrunde, wo nur von der Hilfe und Förderung gegenüber dem Nächsten überhaupt die Rede ist. Das ist gewiß richtig und erklärt es, warum in Luthers Ethik wie in der Jesu die weltlich-sozialen Verhältnisse keine ethischen Werte in sich selbst tragen, sondern nur Mittel und Anlässe sind, solche aus der religiösen Gesinnung zu entwickeln.

218) Die Konsequenzen gegen die Ethik der Ehre und des Rechtes: ,Nun siehe, diese Leute bedürfen keines weltlichen Schwerts noch Rechts. Und wenn alle Welt rechte Christen, das ist, rechte Gläubige wären, so wärë kein Fürst, kein König, Herr, Schwert noch Recht not oder nütz. Lommatzsch 207. Verzicht auf eigene Ehre Lommatzsch 240, zugleich mit dem Eingeständnis, daß >nur wenige 
Die Motivierung des ethischen Handelns aus dem religiösen Element heraus ist hierbei vielfach unsicher, aber doch unzweifelhaft beabsichtigt. Denn Luthers Glaube ist sein lebendig, tätig und geschäftig Ding *. Schwieriger ist die Frage, wie von dieser religiös bestimmten, allgemeinen Gesinnungsethik aus sich die wirkliche und ganz hochgeistliche Menschene zu solchem Lob fähig sind: Eine Darstellung von Luthers Verhältnis zur Bergpredigt wäre sehr wünschenswert. Der weltindifferente Charakter, der im Evangelium eschatologisch, bei Luther aber zunächst mystisch begründet ist, kommt klassisch zum Ausdruck in der berühmten Schrift von der $>$ Freiheit eines Christenmenschen $\ll$. Die Hauptstellen des deutschen Textes (Berliner Ausgabe I I): "Hier wollen wir antworten denen, die sich ärgern aus den vorigen Reden und zu sprechen pflegen: „Ei, so denn der Glaube alle Dinge ist und gilt allein genugsam fromm $z \mathbf{u}$ machen, warum sind denn die guten Werke geboten? So wollen wir guter Dinge sein und nichts tun." Nein, lieber Mensch, nicht also. Es wäre also, wenn du allein ein innerlicher Mensch wärest und ganz geistlich und innerlich geworden, welches nicht geschieht bis zum jüngsten Tage... Obwohl der Mensch inwendig nach der Seele durch den Glauben genugsam gerechtfertigt ist und alles hat, was er haben soll, außer daß derselbe Glaube und Genüge immer zunehmen muß bis in jenes Leben, so bleibter doch noch in diesem leiblichen Leben auf Erden und mu seinen eigenen Leib regieren und mit Leuten umgehen. Da heben nun die Werke an: Hier muß er nicht müßig gehen; da muß fürwahr der Leib mit Fasten, Beten, Mühen, Arbeiten und aller mäßigen Zucht getrieben und geübt sein, daß er dem innerlichen Menschen und dem Glauben gehorsam und gleichförmig werde, nicht hindern noch widerstreben, wie seine Art ist, wo er nicht gezwungen wird. S. 306... Daraus denn ein jeglicher selbst die Maaße und Bescheidenheit nehmen kann, den Leib zu kasteien; denn er fastet, wacht, arbeitet, soviel er sieht, daß dem Leib not sei seinen Mutwillen zu dämpfena S. 307... Wie Adam im Paradies, nur u m nicht mü $B$ ig zu sein, Arbeit erhielt, $\rtimes$ also auch bedarf eines gläubigen Menschen Werk, welcher durch den Glauben wiederum ins Paradies gesetzt und von neuem geschaffen ist, keiner Werke um fromm zu werden; sondern daß er nicht müßig gehe und seinen Leib bereite und bewahre, sind ihm solche fromme Werke zu tun allein Gott zu Gefallen befohlen.« S. 308... Das sei von den Werken insgemein gesagt und von denen, die ein Christenmensch gegen seinen eigenen Leib üben soll. Nur wollen wir von mehr Werken sagen, die er gegen andere Menschen tut. Denn der Mensch lebt nicht allein in seinem Leibe, sondern unter anderen Menschen auf Erden. Darum kann er nicht ohne Werke sein gegen dieselben; er muß ja mit ihnen zu reden und zu schaffen haben, wiewohl ihm derselbigen Werke keines not ist zur Seligkeit. Darum soll seine Meinung in allen Werken frei und dahin gerichtet sein, daß er anderen Leuten damit diene und nütze sei, nichts anderes sich vornehme denn was anderen nütze sei๔ S. 312 . . Wieviel nun das Werk Christo not war und gedient hat zur Frömmigkeit oder Seligkeit, so viel sind alle seine anderen und seiner Christen Werke ihnen not $z \mathbf{u} r$ 
inhaltliche Normierung des christlichen Lebens gestaltet, wie sie insbesondere zu den mit der radikalen Liebesethik in so schwerer Spannung befindlichen innerweltlichen Werten und Ordnungen sich verhält. Die Theologen pflegen jene allgemeine erste Frage nach der Begründung des Ethischen im Religiösen eingehend $z u$ verhandeln, vernachlässigen aber dieses zweite Problem, weil sie schon beim Evangelium nicht die Schwierigkeit $z u$ empfinden pflegen, wie es von einer Moral des absoluten religiösen Lebenswertes in Gottesliebe und religiöser Bruderliebe zu einer innerweltlichen Moralität überhaupt kommen Seligkeit, da sie alles freie Dienste sind zu Willen und Besserung der a nderen... Auf diese Weise gebeut auch St. Paulus Röm. 13 u. Tit. 3, daß sie sollen weltlicher Gewalt untertan und bereit sein, nicht daß sie dadurch fromm werden sollen, sondern daß sie den anderen und der Obrigkeit damit frei dienten und ihren Willen täten aus Liebe und Freiheit. So könne man sich aus Liebe auch an sich unchristlichen Ordnungen und Gesetzen unterwerfen S. 314. Daß das letztere von solcher Liebesmoral aus seine Schwierigkeiten hat und Handlungen fordert, die zu diesem Ideal an sich im Widerspruch stehen, das hat Luther sehr wohl empfunden, Lommatzsch S. 287 ; jedenfalls bedeutet aber diese Motivierung eine völlige Indifferenz gegen die innerweltlichen politischen, rechtlichen, wirtschaftlichen Werte selbst. - Die Herkunft dieser Gedanken aus Augustin (s. Hunzinger, Lutherstudien I I906) und aus der bernhardinischen und germanischen Mystik (Braun, Bedeutung der Concupiszenz) ist unverkennbar. Allein das Entscheidende ist hierbei, sich klar zu machen, daß das nur die seit A ugustin herrschend gewordene Undeutung des Radikalismus der Bergpredigt, die mystisch begründete und interpretierte Auslegung der Gebote von der absoluten Selbstheiligung für Gott und der absoluten Bruderliebe mit der völligen Auslöschung der weltlichen Kampf- und Rechtstugenclen, ist. Das Gebot des Verzichtes auf Recht und weltliche Ehre und der völligen Gesinnungshingebung allein an Gott ist zum Gebot der Demut und der Selbstliebe nur in Gott, und das Gebot der Bruderliebe als Bekundung der Gottesgesinnung ist zur mystischen Liebe der Brüder in Gott mit Mortifikation aller Selbstsucht geworden. Die Conversio ad Deum ist Hinwendung zum allein wahren Sein und zur Verbindung der Brüder in diesem allein Wirklichen geworden, die Leberwindung der bloß relativen im Kampf ums Dasein erworbenen Tugenden durch die radikale Liebesethik ist zur Abwendung von dem unwahren und unwirklichen, zerteilten und an die Selbstsucht appellierenden Nichtsein der Welt geworden. I: dieser Deutung aber folgt Luther durchaus dem urchristlichen Radikalismus, wie er um deswillen ja auch ins Kloster gegangen ist, in welchem die radikale Ethik sich allein - freilich verändert genug - erhalten hat. Von da ist er dann erst allmählich zur Neugestaltung dieses Radikalismus durchgedrungen, die ihn auch in das Alltagsleben jedes Individuums hineintragen ließ, ohne es äußerlich aufzuheben; im Zusammenhange damit ist dann auch die mystische Deutung immer mehr auf den eigentlichen Sinn der Bergpredigt zurückgegangen. 
könne. Aber in Wahrheit ist es dieses Grundproblem der christlichen Ethik, das hier bei Luther von neuem aufgeht. Der katholische Stufenkompromiß einer natürlichen und einer übernatürlichen Ethik ist aufgelöst, indem für Luther eine natürliche aus eigener menschlicher Kraft hervorgehende Ethik nichts als eine Verleugnung der Gnade überhaupt und die Einschränkung der Gnadenethik auf die daneben bestehende mystische Oberstufe nichts als eine Mißdeutung und Verengung der den ganzen Menschen verlangenden christlichen Moralität gewesen wäre. Es soll die rein aus der Gnade fließende, rein religiöse Ethik wieder hergestellt und zugleich restlos auf den ganzen Menschen angewendet werden. Indem er hierbei sei es mehr im mystisch-spiritualistischen Sinne, sei es mehr in dem der Bergpredigt - die eigentlich christliche Ethik der Gottes- und Bruderliebe in ihrem völlig radikalen Sinne heraushebt und zugleich alle Christlichkeit aus der bloßen $\mathrm{Zu}$ gehörigkeit $\mathrm{zu}$ einer sakramentalen Institution in die wirkliche volle Gesinnungsinnerlichkeit verlegt, scheint er auch von dieser Seite her nahe an die Grenze des Sektentypus und seiner radikalen weltindifferenten Christlichkeit zu kommen, wie er denn immer wieder die Seltenheit der wahren Christen und die Kleinheit der wirklichen Gemeinde betont und das aus der Nähe des letzten Gerichtes und letzten Abfalls erklärt. Was man in der herkömmlichen Darstellung gerne als mönchische Reste bei Luther ansieht, das ist zur Hauptsache - nicht durchaus - in Wahrheit evangelischer Radikalismus, zu dessen Verständnis allerdings das Mönchtum in gewisser Hinsicht günstig disponiert. Es ist eben deshalb zugleich Annäherung an den Sektentypus ${ }^{219}$ ).

$\left.{ }^{219}\right)$ Es ist unverkennbar, daß Luthers, Gemeindeideal' d. h. die von den Subjekten ausgehende Regelung der Berufung der Geistlichen und Kontrolle des Verhaltens der Gemeindeglieder zusammenhängt mit einer Anspannung der christlichen Ethik im Sinne des Liebeskommunismus und strenger Einhaltung der christlichen LebensregeIn, wie denn die das letztere aussprechende Leisniger Kastenordnung mit den das erstere aussprechenden Schriftchen $(\sim \mathrm{Da}$ eine christl. Gemeinde Recht habe alle Lehre $z u$ urteilen und Lehrer zu berufen* und Von der Ordnung des Gottesdienstes in der Gemeindes) an die gleiche Adresse gerichtet sind In der Vorrede zur ersteren billigt L., >daß ihr eine neue Ordnung des Gottesdienstes und ein gemeines Gut dem Exempel der. Apostel nach (d. h. der Urgemeinde) vorgenommen habt B. A. IV I S. III; in der Ordnung selbst heißt es: "Wir haben ein gründliches Wissen empfangen, daß alles innerliche und äußerliche Vermögen der Christgläubigen zur Ehre Gottes und Liebe Troelts ch, Gesammelte Schriften. I. 
Aber von irgend einem wirklichen Aufgehen in den Sektentypus ist gerade hier gar nicht die Rede. Luther hat derartige Konsequenzen stets mit leidenschaftlicher Schärfe abgewiesen. Die Gründe dieser Abweisung sind freilich von ihm nirgends prinzipiell und systematisch gefaßt. In ihnen wirkt eine der großen grundlegenden Selbstverständlichkeiten des Lutherischen Denkens, und diese Selbstverständlichkeit an das Licht ziehen, heißt erst den letzten Grund seiner Gestaltung der positiven Ethik herausfinden.

Der von ihm meist genannte Grund ist die $A b l e h n u n g$ aller Gesetzlichkeit. Jedes Dringen auf radikale eigentliche Christlichkeit ist ein Dringen auf die Werke statt auf die Gnade; mag an diesen Werken auch noch so sehr die Gesinnungsinnerlichkeit betont werden, das Kriterium des Christenstandes wären unter jenen Umständen menschliche Leistungen. Das aber geht des Nuchsten, Ebenchristenmenschen, nach Ordnung und Ansetzung göttlicher Wahrheit und nicht nach menschlichem Gutdünken dienen und gereichen solle (S. I17); gleichzeitig ist eine strenge Kirchenzucht durch die Gemeinde vorgesehen S. 118 f. Das ist unzweifelhaft eine Annäherung an den Sektentypus, wie denn auch W. Köhler mit Recht davon die täuferischen und calvinistischen Ideale ableitet, nur daß freilich bei beiden noch andere wichtige Dinge hinzukommen. Bei Calvin insbesondere kommt es weniger auf die Betätigung des allgemeinen Priestertums als auf die Stiftung einer von Gott geordneten heil. Gemeinde an, vgl. unten. Auch ist L. klar, daß eine derartige Gemeinde solcher, die mit, Ernst Christen sein wollen und das Evangelium mit Hand und Mund bekennen (S. 168), keine Masséngemeinde sein kann, mindestens vorerst. Daher in der berühmten Vorrede zur - Messe deutsche der Gedanke einer engeren Kommunionsgemeinde innerhalb der uußeren, den Predigtgottesdienst und die christliche Belehrung und Erziehung erfahrenden äußeren Christenheit, die Unterscheidung einer seordneten und gewissen Versammlung, darinnen man könnte nach dem Evangelio die Christen regieren. von der großen Pfarrgemeinde, wo snur öffentliche Reizung zum Glauben und zum Christentume ist. In dieser Ordnung könnte man die, so sich nicht christlich hielten, kennen, strafen, bessern, ausstoßen oder in den Bann tun nach der Regel Christi Mth. 18, 15. Hier könnte man auch ein gemeines Almosen den Christen auflegen, das man williglich gäbe und austeilte unter die Armen nach dem Exempel St. Pauli II Cor. 9, I e S. 167 f. Es ist eine der Hauptstellen, auf die sich später das pietistische Programm der ecclesiola in ecclesia stützte, nur daß L. nicht einen Rückzng aus der verweltlichten Kirche, sondern vordringende Kernorganisationen des bckehrenden Geistes innerhalb der Kirche meint. Doch hat L. hierfür einerseits dic ernsten Christen nicht und fürchtet andererseits, daß s nicht eine Rotterei daraus werde, so ichs aus meinem Kopf treibea $d$. h. nicht von selbst wachsen lasse S. 169. So verzichtet er auf solche ssonderlichen Gemeindene (S. 169). Hier das Richtige bei Eger S. $77-83$. 
gegen den Grundgedanken der Gndde, die nur in Glauben und Vertrauen angeeignet und deren Besitz nur hieran, nicht an den praktischen Folgen und Leistungen erkannt wird. Wie sehr auch ein solohes Dringen auf Freiheit und der Gegensatz gegen alles Reglementieren, Gleichmachen und Zwingen zu dem persönlichsten Charakter Luthers gehört, so ist alles das doch nur verständlich aus seinem Grundgedanken der alles objektiv bereits in sich enthaltenden gottgeschenkten Gnade, die durch menschliches Mühen nur verdunkelt würde. Daher wird bei ihm jenes Gehenlassen und jene Freiheit so leicht zum Quietismus, weil für das Wesentliche gesorgt ist und dieses nur durch menschliche Anstrengungen verdunkelt würde. Die Aktivität und $\mathrm{Ge}$ setzlichkeit des Calvinismus ist auf einen anderen Gnaden- und Kirchengedanken begründet und weist so auf die besondere Art der lutherischen Freiheit hin. Sie wurzelt in dem alles übrige überflüssig machenden Gnadenbesitz ' der Kirche. Von der Gnade wird zwar als Wirkung die eigentliche radikale Christlichkeit erwartet, aber sie ist unabhängig von dieser Wirkung und wirkt sich bei der menschlichen Sündhaftigkeit überhaupt nur unvollkommen aus ${ }^{220}$ ). Damit ist dann auch schon sein zweiter Hauptgrund genannt. Die Erbsünde wird immer nur im Glauben an Gnade und Sündenvergebung überwunden; sie empört sich stets von neuem gegen das Leben in der Gnade und hebt doch eben damit den Gnadenstand bei dem nicht auf, der im Glauben bleibt. Die radikale Christlichkeit zum Maßstab

220) Vgl. hierzu vor allem die Schrift: Wider die himmlischen Propheten, 1524. Hierin folgt Luther dem Paulinismus. Aber es ist wichtig zu beachten, daß er eben damit auch dem kirchlichen Element des Paulinismus folgt. Die sozialkonservative Haltung, die der Paulinismus seinerzeit annahm, ist zwar nicht, wie die katholische Ethik, eine Rezeption der Weltordnungen in die christliche Ethik, aber ein ausharrendes Dulden und Ertragen and vorsichtiges Benützen der Ordnungen einer von Gott einstweilen noch zugelassenen Welt. Aber auch diese noch sehr beschränkte Akzeptierung der Welt ist dem Paulus nur möglich geworden durch seinen Gnadenbegriff, indem dieser die christliche Gemeinde als Ganzes mit den Erlösungskräften des Christus erfüllt sein läßt und sie daher von der Aufgabe entlastet, die Abgrenzung erst durch radikale äußere Sonderung und Tätigkeit des Subjektes herbeizuführen; s. Wernle, Der Christ und die Sünde bei Paulus 1897 S. 60-72, wo nur der Zusammenhang des paulinischen $\bowtie$ Kirchengedankense mit dem Gnadengedanken nicht genug hervorgehoben ist. Diese Vorherrschaft des Gnadengedankens gibt dann überhaupt dem ganzen religiösen Denken den Zug zur Hinnahme der gegebenen Ordnungen als der nicht gewaltsam zu ändernden Verfügungen Gottes. 
des Christenstandes und der christlichen Gemeinschaft machen, hicße cine Vollkommenheit erträumen, die es auch bei den besten Christen selten oder niemals gibt und von der bei der großen Mchrzahl schon überhaupt nicht die Rede ist. Will man von cincr christlichen Vollkommenheit sprechen, so besteht sie in Glaube und Vertrauen, in der Angenommenheit der Person bei Gott, aber nicht in einer aktiven Vollendung des christlichen Ideals. Dic ist auf Erden unmöglich und wird uns erst im Jenscits beschert. So erlauben sowohl der Gnadengedanke als die lnübcrwindlichkeit der Sünde keine äußere Abgrenzung der vollkommenen Christen von den Unvollkommenen und liegt das zusammenhaltende Band der Christenheit überhaupt nicht in der praktischen Leistung, sondern in dem objektiven, durch die Kirche verbürgten und gepredigten Gnadenbesitz, der mit den verschiedensten Stufen christlicher Reife und den gründlichsten Rückfällen in Sünde und Fleisch verträglich ist. Nur in diesem objektiven Besitz und nicht in der subjektiven Leistung besteht die Christlichlicit, wenn auch aus dem ersten stets in irgend einem Malje dic zwcite flicßen muß. Aber dieses Maß selbst ist für die Christlichlicit und den Heilsbesitz gleichgültig ${ }^{221}$ ). Das führt sofort hinüber zu dem dritten Grunde. Jede Bemessung des Christenstandes an der radikalen Christlichkeit würde, meint er, zu Unterschcidungen und Trennungen der Christen untereinander führen, zu selbstgemachten Rotten und Sekten, was die Einheit des christlichen Kürpers aufhebt, den Hochmut der Sektierer und die Jicblosigrkeit der Trennungen zur Folge hat, statt daß Unvollkommenheit und Sünde durch gegenseitige Belehrung und Liebe und \%urechtweisung überwunden wird. Hier taucht die Voraussct/ung ciner Einheit des Corpus Christianum auf, dic man nicht absichtlich und künstlich sprengen, sondern die

$: 21$ I lese Lüuberwindlichkeit der Sünde ist eine bemerkenswerte Abweichung rom Paulinismus, der in der Gewißheit einer völligen Erneuerung und Veränderung der Christen die leberwindung der Sünde für clas Normale hielt und die asth won ihm anterkmute liffeckung einzelner Gemeindeglieder als Flecken und M.n:el im eiscntlichen Ideal der Gemeinde ansah, die durch Zucht zu beseiligen sind und run bald kommenden Gericht und Ende ausgebrannt werden. $S$. Wernle, Der Christ und die Sïnde, und Braun, L.s Lehre von der Konkupiszenz $\therefore$ 107-112. Darin liegen aber auch die sektenhaften Filemente des Paulus, wie sic auch in dem voll ihm neben der Vollendung der Offenbarung in Christus an"rkammin linthusiasmus licgen. Auf beides pflegen sich daher auch die Sekten li, lieute in berufen. 1 s sind clicn in Paulinismus beide Typen noch ineinander. 
man durch Liebe und Dienst zusammenhalten soll, innerhalb deren man sogar auch die groben und rohen Sünder und Unchristen wenigstens äußerlich dulden muß, da man ja über die wirkliche Christlichkeit des Einzelnen niemals sicher entscheiden kann und da die rohe Masse wenigstens äußerlich unter dem Zwang der christlichen Lebensordnung gehalten werden muß, teils zu Zwecken einer vorbereitenden Disziplin und Erziehung, teils zum Zweck einer Repression wenigstens des äußerlich bösen Handelns. Die Gnade darf nicht vorschnell auf die Menschen verzichten, sondern muß ein ganzes Volk durchdringen, und die Gesellschaft muß zum Besten der Frommen die groben Sünder niederhalten ${ }^{222}$ ). Damit ist dann aber eine Reihe weiterer Gründe eröffnet, die nicht unmittelbar aus dem Gnadengedanken hervorgehen. Die weltlichen Ordnungen und die natürlichen Güter sind auch für Luther selbstverständlich von Gott eingesetzt und geordnet. Natur und Sinnlichkeit, die Vielzahl einer auf gegenseitige Hilfe und Organisation angewiesenen Menschheit, die Obrigkeit und das Eigentum, das Recht und das Schwören, der Krieg und die Gewalt, all das ist von Gott gewollt und darum teils gut, teils zur Bekämpfung des Bösen unter den Bedingungen des Sündenstandes notwendig und unentbehrlich. So untersteht der Christ überhaupt nicht bloß der radikal christlichen Ethik der Bergpredigt oder der selbst- und weltverleugnenden Mystik. Sie gilt wohl an sich innerlich für die Person und die Gesinnung und die rein persönliche Wechselbeziehung. Aber außerdem ist der Christ in eine weltliche Natur- und Vernunftordnung

${ }^{222}$ ) Ueber die Selbstverständlichkeit der Idee des Corpus Christianum s. die Stellen bei Lommatzsch $258,275,282,527 \mathrm{f}$. Schon die Bezeichnung der drei Hierarchien, der Obrigkeit, des Hausstandes und des geistlichen Standes als Stände der Kirche zeigt das deutlich. Ebenso Rieker, Rechtliche Stellung S. 66-7I. Beide erkennen darin mit Recht die Fortsetzung des mittelalterlichen Gedankens, dessen Genesis aus den altkirchlichen Ideen nur nicht so leicht und einfach zu verstehen ist. Es war bei dem zweiten Hauptteil dieser Untersuchung meine Absicht, sie verständlich zu machen. Ist deren Ergebnis richtig, dann ist auch die Folgerung zu ziehen, daß trotz aller Rückgriffe auf Paulinismus und Augustinismus die reformatorische Ethik und die aus ihr hervorgehende Sozialphilosophie gerade den spezifischen Erwerb des Mittelalters, die Verschmelzung von Kirche und Welt zu einer ungeschiedenen Einheit fortsetzt und nur das Verhältnis der in dieser Einheit gebundenen Elemente neu ordnet; so auch Ehrhardt, La notion du droit naturel S. $308 \mathrm{f}$. 
gesetzt, die von Gott teils direkt gestiftet, teils indirekt zugelassen ist und die sowohl dem irdischen Wohl als der Repression des außerlichen Bösen dient und der daher der Christ sich zu unterwerfen hat, soweit sie nicht eine Verleugnung der reinen Lehre verlangt. Das aber heißt, daß die christliche Ethik im Sündenstande uberhaupt eine doppelte ist, eine rein und radikal christliche Ethik der Person und der Gesinnung einerseits und eine natürlich-vernünftige, nur relativ christliche, $d$. h. von Gott verordnete und zugelassene Ethik des A m tes andererseits. Gemäß der letzteren darf und muß der Christ Gewalt und Recht treiben, schwören und Ehescheidung vornehmen, Besitz und Eigentum erstreben, wo es Amt, Stand, staatliche und gesellschaftliche Ordnung und Notwendigkeit verlangen, während der innere Christ, die Person, von alledem nichts weiß und in der absoluten Liebe bis zur Auslöschung alles eigenen Interesses der Diener aller ist. So wird es für Luther trotz alles mystischen Spiritualismus und alles radikalen Liebescharakters seiner eigentlichen Ethik nicht schwer, schon im Sermon von den guten Werken und dann in der Schrift an den Adel geradezu ein Programm christlicher Gesellschaftsreform und christlicher Weltordnung zu entwerfen in einem Sinne, der das innerweltliche Leben im weitesten Umfange bejaht. Es bezieht sich das eben auf die äußere Christenheit, auf den Christen als Bürger und Glied der Rechtsordnung, auf das Corpus Christianum oder die christliche Gesellschaft, innerhalb deren das Gesinnungs- und Personchristentum erst das eigentliche und innere Christentum ist. Wie wenig aber beides zusammenfällt, zeigt der Umstand, daß er in den nächsten Jahren der tastenden Neuordnungen die wahren Christen gerne in engeren Kreisen innerhalb der Kirchen auch äußerlich darstellen möchte ${ }^{223}$ ).

223) Vgl. Luthard S. 76 f.: s Seine Stellung nahm Luther in der Unterscheidung 2wischen dem Gottesreich und dem Weltreich, wie er es nennt, oder mit anderen Worten in dem Satz von der Innerlichkeit des Christentums im Unterschied von dem äußeren Leben in der Welt, wie es auf der Schöpfung (sollte richtiger heißen: auf der Vernunft) beruht . . . Nach der Rechtfertigungslehre ist wohl kaum eine andere Lehre, welche $L$. so viel und eifrig treibt, als diese vom geistlichen und innerlichen Charakter und Wesen des Reiches Christi und dem darin begründeten Lnterschied vom Weltreich d. h. dem Gebiet des natürlichen geschaffenen Lebens. Das Evangelium hat es zunächst mit dem äußeren Leben gar nicht zu tun, sondern mit dem ewigen Leben, nicht mit äußeren Ordnungen und Veranstaltungen, welche mit den weltlichen Ordnungen in Konflikt geraten könnten, sondern mit den Herzen 
Diese Sätze Luthers sind uns zum Teil schon aus der bisherigen christlichen Ethik bekannt, und ihre Vereinigung in einem Zentralgedanken, der seine hier vorausgesetzte Selbstverständlichkeit enthält, ist nicht schwer angesichts der analogen patristiund ihrem Verhältnis zu Gott, mit der Gnade Gottes, der Vergebung der Sünde usw., kurz mit dem himmlischen Leben. Das Charakteristische für das Reich Christi ist die Gnadenordnung (und die Liebe), das Charakteristische für das Weitreich und das Weltleben ist die Rechtsordnung. Also sind sie ganz verschiedener Gattung und liegen nicht auf gleicher Linie, sondern gehören verschiedenen Welten an. Jenem gehöre ich als Christ, diesem gehöre ich als Mensch an (das ist moderne Formulierung, L. würde sagen der einen durch das Evangelium, der andern durch die Lex naturae). Denn wir stehen in $z$ wei $L$ ebenssphären, wir sind im Himmel und auf Erden zugleich. . "Christi Reich, sagt L., ist und soll kurzum sein ein göttlich Reich und doch dasselbe geistliche Reich gehet mitten in der Welt Reich, und Christus samt seinen Christen braucht der Welt. Aber sie tun das Alles als Pilgrime und Fremdlinge und Gästeder Herberge", gleichwie Christus auch getan hat. . . Daraus folgi, daß es nicht der Beruf Christi oder des Evangeliums ist, die Ordnungen des weltlichen Lebens zu ändern und neue aufzurichten. All das unterliegt seinen eigenen Gesetzen und der Vernunft, dazu man des heiligen Geistes nicht bedarf. . „Darum, sagt L., muß man die zweierlei Reiche weit von einander scheiden, darin man Sünde straft und Sünde vergibt, oder darin man Recht fordert und Recht nachlässet. In Gottes Reich, da er durchs Evangelium regiert, is t kein $R$ echtfordern, mangeht auchmitkeinem Recht $\mathrm{u} m$, sondern ist eitel Vergebung, Nachlassen und Schenken und kein Zorn noch Strafe, sondern eitel brüderlicher Dienst und Wohltat." „Die Kreaturen, sagt L., sind und stehen alle zuvor da, ehe er mit dem Evangelium kommt, das ist, alle weltlichen Sachen und Ordnungen, so von Menschen nach der Vernunftund vonGotteingepflanzternatürlicher Weisheit verfaß " sind (durch die Lex naturae)... Und so haben denn auch die Diener Christi sich dieser weltlichen Sachen nicht anzunehmen, sondern Gnade zu predigen. Was jene Sachen anlangt, da mögen ,Juristen hierzu raten und helfen, wie es gehen solle“... Das bleibt alles ruhig bestehen, bis zur großen Aenderung aller Dinge; denn bis dahin hat das Reich Gottes nur eine innerliche Gestalt und Jesus eine Herrschaft in den Herzen. . . Denn nicht das Aeußere sondern das Innere ist das Entscheidende; nicht um jenes sondern um dieses war es Christo zu tun. Das allein meinen auch die Worte Christi — besonders in der Bergpredigt - , in denen er seine Vorschriften eines Christenlebens gibt, daß man nicht schwören soll usw. Es kommt ihm nicht in den Sinn, Vorschriften für das äußere Leben $z \mathfrak{u}$ geben, sondern er meint nur das innerliche persönliche Verhalten. Nicht dem äußeren Beruf und dem dadurch bedingtenamtlichen Verhalten gelten seine Worte, sondern der Person undihrer Gesin$\mathrm{n}$ ung und inneren persönlicher Herzensstellung. Denn sonst würde Christus das 
schen und mittelalterlichen Ausführungen. Die hier obwaltende Selbstverständlichkeit ist nichts anderes als eben der $\mathrm{Ki}$ rchengedanke mit seiner Verlegung der Christlichkeit und Heiligkeit nicht in die subjektive Leistung und Aktivität der Personen, son-

ganze Weltwesen umstürzen, wenn man sein Wort vom äußerlichen Verhalten verstlinde. Denn es würde dannmit dem äußerlichenVerhaltenim irdischen Beruf und Amtinunlösbaren Widerspruch geraten (damit ist die Befolgung beider Ethiken zwar gefordert, aber auch ihr innerer Wesenswiderspruch anerkannt). . . Denn indem Jesus nur ein innerliches Verhalten fordert, einen äußeren Verzicht aber nur da, wo es der Glaube und das Bekenntnis verlangt, bestätigt er damit in dire $\mathrm{k}$ t alles dieses Aeußere, Besitz usw. und erklärt somit allen Verzicht darauf, wo er nicht durch jene Pflicht gefordert wird, für Pflichtverletzung (eine allerdings sehr indirekte und willkürliche Abfindung mit der Jesuspredigt). . . Die entscheidende Erkenntnis, welche L. in diesen Fragen immer geltend machte, war stets die, daß er unterscheiden lernte zwischen der inneren persönlichen Gesinnung des Christen und dem äußeren Pflichtverhalten seines weltlichen Amtes und Berufes «. - Dazu das Lutherwort: >Denn für dich selbst bleibst du in dem Evangelio und hältst dich nach Christi Wort, daß du gern den andern Backenstreich leidest, den Mantel zum Rocke fahren lässest, wenn es dich und deine Sache beträfe. So geht dann beides fein miteinander, daß $d u$ zugleich Gottes Reich und der Welt Reich genug tuest äußerlich und innerlich, zugleich Lebel und Unrecht leidest und doch Uebel und Unrecht strafest, zugleich den Uebel widerstehest und doch nicht widerstehest.. . oder das andere: > Meine Person, die e in $C h r i s t$ hei $B$ t, soll nicht für Geld sorgen und sammeln, sondern allein an Gott mit dem Herzen hangen. Aber äußerlich mag und soll ich des zeitlichen Gutes gebrauchen für meinen Leib und für andere Leute, sofern meine Weltperson geheta. - Das ist in aller Form eine doppelte Moral nach geradezu entregengesetzten P'rinzipien. Die Frage ist, wie Luther den schroffen Widerspruch lijste. Luthardt lüst ihn durch Verteilung auf Schöpfungs- und Erlösungsordnung, Mensch und Christ, wobei die Erlösung die Vollendung der Schöpfung, der Christ die Wahrheit der Menschen ist. Das ist aber eine erst der modernen Vermittelungstheologie entstammende Phrase. Die Lösung für Luther liegt in dem patristisch-mittelalterlichen Gedankenkreise des Naturrechts, vgl. Ehrhardt, La notion du droit natural, der aber auch Entstehung und ledeutung dieses Gedankenkreises nur mangelhaft ktusit. Indem Ehrhardt zunächst den schroffen Gegensatz der weltlichen Rechtsmoral und der evangelischen Liebes- und Leidensmoral (S. 290) richtig konstatiert und zeigt, wie L. anfangs bis zur Verwerfung des Dekalogs als eines Dokuments der Rechtsmoral geht, zeigt er gleichzeitig, wie L. doch die Rechtsmoral festhält einmal für die Unbekehrten, die einer Zucht, eines frenum et remedium peccati bedürfen, dann für die eigentlichen Christen, die nur durch eine Rechtsordnung vor Mißbrauch und Ausbeutung ihrer radikalen Liebesgesinnung und Leidensbereitschaft geschützt werden können, schließlich weil es de lege naturae nötig ist für die friedlichen Beziehungen in Staat, Familie und 
dern in die objektive Göttlichkeit des der Anstalt eignenden Gnadenschatzes; mit seiner die verschiedensten Stufen der faktischen Verwirklichung des Ideals umfassenden Universalität und seiner alle Getauften für die volle christliche Reife erst erziehenden

Wirtschaft S. 293 f.; zum letzteren die Stelle aus dem großen Galater-Kommentar: saepe a me audistis, quod ordinationes politicae et oeconomicae sint divinae, quia Deus ipse ordinavit et apportavit eas, ut solem lunam et alias creaturas. „Cet ordre d'idées conduit Luther à affirmer qu'ill existe un ordre social divin. naturel indépendant de la revélation spéciale de Dieu telle quelle est renfermée dans la Bible, ordre éternel et, dans ses principes tout au moins, immuable «. 295. Es ist die bekannte Idee von der Lex naturae, die in die Herzen geschrieben ist und die jetzt einen dem Sündenzustand angepaßten Charakter des frenum et remedium peccati hat, aber neben dem doch auch die naturrechtlich notwendige vernünftige Ordnung der natürlich-sozialen Dinge ist. Ueber das relative Naturrecht s. die Stelle aus dem Genesiskommentar bei Lommatzsch S. 286: Politia ante peccatum nulla fuit, neque enim ea opus fuit; est enim politia remedium necessarium naturae corruptae. Oportet enim cupiditatem restringi vinculis legum et poenis, ne libere vagetur. Ideo politiam recte dixeris regnum peccati. . . Hoc enim unum et praecipuum agit politia, ut peccatum arceat... Si enim homines non essent per peccatum mali facti, politia nihil fuisset opus." So akzeptiert er auch die betreffenden naturrechtlichen Stellen des römischen wie des sonst so streng verurteilten kanonischen Rechtes. Der letzte Grund für die Vereinbarkeit der natürlichen Rechtsmoral mit der christlichen Liebesmoral ist ihm aber schließlich die Identifikation des Dekalogs mit dem Naturgesetz einerseits und mit dem Sittengesetz Christi andererseits, indem er entgegen der ursprünglichen Verwerfung des Dekalogs diesen in scharfer Unterscheidung vom zeremonialen und politischen Gesetz des Moses für den Inbegriff der sittlichen Forderungen des Urstandes, des Naturgesetzes und des christlichen Gesetzes erklärt und die Bibel in weitestem Umfang als Zeugnis und Quelle des Naturgesetzes neben der Antike verwendet. Damit sind die alten katholischen Gedanken völlig wieder aufgenommen, wie deutlicher als Ehrhard S. 303 Lommatzsch S. 60-90 zeigt. So sagt L. in der Schrift gegen die himmlischen Fropheten „Mosis Gesetz und Naturgesetz sind ein Ding «ommatzsch 63 und im Großen Katechismus: $\gg$ Die zehen Gebote sind auch sonst in aller Menschen Herzen geschrieben, Symbolische Bücher « (Müller) S. 460 . Die doppelte Moral ist in den Dekalog und in das christliche Gesetz selbst hineinverlegt, wobei der dem Liebesgebot widersprechende Rechtscharakter die Folge der Anpassung des Naturrechts an die Bedingungen des Sündenstandes, also das uns bekannte relative Naturrecht, darstellt. Der Unterschied von der katholischen Ausgestaltung des Gedankens besteht dann aber darin, daß die doppelte Moral nicht stufenförmig als Aufstieg von der naturgesetzlichen Moral zu den besonderen Leistungen der christlichen Moral dargestellt wird und die letztere in ihrem vollen Radikalismus einem besonderen Stande zugewiesen wird, sondern daß jedes Individuum gleicherweise unter beide Gebote gestellt wird. Wir werden diesen Widersprüchen bei der Dar- 
Pädagogik; mit seiner aus dieser Universalität folgenden Rezeption der w'eltlichen, politischen und sozialen Ordnungen als der Stiftungen der natürlichen Gottesvernunft, wie sie unter dem Sündenstand sich gestalten mußten und wie sie um deswillen einen relativen Gegensatz gegen die radikale Ethik der Bergpredigt darstellen dürfen und müssen, mit ihr aber durch Vermittlung des Dekalogs doch wieder zur Einheit zusammengehen.

Freilich ist alles entsprechend den neuen Voraussetzungen anders verstanden als die analogen Sätze des katholischen Kirchentums. Die objektive Heiligkeit, die den Christenstand konstituiert und die das Einzelindividuum von der ihm ja doch unmöglichen Vollverwirklichung des christlichen Ideals entlastet, ist nicht die dingliche Heiligkeit der Anstalt, des Priestertums, der Sakramente, an der ein rein kultisches Tun beteiligen kann. Es ist vielmehr allein das Wort von der Sündenvergebung, das über aller Sünde und Unvollkommenheit als. tröstende und beseligende Kraft schwebt; an ihm gibt es Anteil nur durch den vollen persönlichen, aus der Buße geborenen Glauben, der allein die Gemeinde der Glaubenden heilig und bei Gott angenehm macht trotz ihrer Sünden und dauernden Unvollkommenheiten; es ist ein rein objektiver und als solcher entscheidender Schatz, auch

stellung der Soziallehren des Luthertums auf Schritt und Tritt begegnen. Etwas naiv meint Ehrhardt: >Mais cette distinction entre l'homme extérieur et l'homme intérieur n'est elle pas abstraite et artificielle et quel est le rapport entre la justice selon la loi naturelle, justice accesible même aux Non-Chrétiens, et la justice de Dieu ?a S. 318. Tiefer und prinzipieller erkannt ist der Widerspruch und das darin liegende Problem bei Lommatzsch S. 606. Im allgemeinen aber sind die Darsteller, weil sie den hierin - wirksamen alten patristisch-scholastischen Gedankenkreis vom Naturrecht und dessen organische Funktion für die Ermöglichung einer die Welt akzeptierenden kirchlichen Etkik nicht oder nur ganz dunkel kennen, geradezu hilflos gegenüber diesen Sätzen. Sie sind ihnen bald prinzipwidrige katholische Rückfäile, 'bald persönliche Besonderheiten und Unsicherheiten Luthers; ein Mann wie Ehrhardt kann die Identifikation des Naturgesetzes und des Dekalogs leugnen S. 319 und in all diesen Sätzen nur tinen Versuch sehen das vom Humanismus neubelebte historische Vorurteil des Naturrechts dem Evangelium unbewußt zu akkommodieren! Lommatzsch kann schreiben: >Kaum jemals aber zeigt sich aber deutlicher eine prinzipielle Unklarheit bei Luther als in diesen Bestimmungen. Sie betrifft nichts geringeres als seine Ansicht vom Uebernatürlichen zum Natürlichen oder der Offenbarung Gottes im weiteren Sinne zu einer solchen im engerene S. 7r! G. Müller, L. Stellung zum Recht, meint S. 26, die Sache klinge ähnlich wie bei Augustin, sei aber innerlich von ihm losgesagt! 
wenn er nur in voller Gesinnungshingabe angeeignet werden kann. Das Wort von der Sündenvergebung aber ist der supranaturale Produzent der Kirche, der ihr Wesen ausmachende und von ihr zu verwaltende Schatz göttlicher Stiftung, der Kern der Anstalt, der über alle ihr gläubig sich ergebenden trotz aller Ungleichheiten der Leistung ein völlig gleiches versöhnendes und Gott genehm machendes Licht ausstrahlt. Dementsprechend ist dann auch die Universalität dieser kirchlichen Ethik bei Luther anders gedacht. Sie bedeutet nicht die Uebereinanderschichtung verschiedener Vollkommenheitsgrade und die Zulassung einer auf verschiedene Gruppen verteilten doppelten Moral. Sie bedeutet vielmehr die gleiche Forderung an alle, verbunden mit dem Verzicht auf die aktive Vollkommenheit bei allen. Von allen fordert sie den Glauben und allen muß sie ihn wenigstens zugänglich machen durch Taufe und Predigt. Aber bei allen verbindet sie mit der Forderung des Glaubens auch die Toleranz der verschiedenen Auswirkungen des Glaubens, da bei der Unüberwindlichkeit der Sünde und der alleinigen Bedeutung des Sündenvergebungsglaubens schließlich die immer nur schwer erkennbaren Differenzen der Betätigung im wesentlichen nichts ausmachen. Nicht Relativierungen und Herabminderungen des christlichen Ideals bedeutet die lutherische Kirchenethik, sondern die Ersetzung der entscheidenden Bedeutung der praktischen Leistung überhaupt durch die alleinige Entscheidungskraft des persönlichen Herzensglaubens an .die Sündenvergebung. Es ist nicht mehr ängstlicher oder raffinierter Werkdienst, nicht Verteilung der Leistungen auf verschiedene Stände, nicht Kompensation der dinglichen Anstaltsheiligkeit durch Anstrengungen guter Werke und umgekehrt, nicht quantitative Abstufung der Vollkommenheit, nicht die Behauptung des Ideals zugleich mit dem Verzicht auf seine volle Durchführung. Es ist jetzt vielmehr die Toleranz der verschiedensten Grade und Stufen christlicher Reife um dessen willen, weil an ihnen überhaupt nichts liegt, sondern alles liegt an der Gnade der Sündenvergebung und der Seligkeit der Gerechtfertigten. Die kirchliche Universalität bedeutet jetzt eine alle umfassende Pädagogik der Predigt des Wortes und einen passiven Quietismus gegenüber den Resten der Sünde, verbunden mit dem Vertrauen, daß die von der Gnade ausgehende Kraft sie von selbst immer neu in irgend einem Maße überwinden werde und daß auf den irdischen Kampf der himmlische Sieg folge. So ist auch 
das dritte Merkmal der kirchlichen Ethik, die mit der Universalität und der Toleranz gegenüber der Nicht-Verwirklichung des christlichen Ideals verbundene Rezeption der weltlichen Vernunftordnungen in Recht, Macht, Gewalt und Besitz auf eine neue Weise verstanden, obwohl hier die Fortführung des katholisch-kirchlichen Gedankens von einer christlichen Einheitskultur am meisten als etwas Selbstverständliches von Luther einfach übernommen worden ist. Diese Rezeption ist nicht mehr verstanden als die Uebereinanderschichtung zweier Stufen, einer natürlich-weltlich-vernünftigen Stufe, die jene Werte unter die Leitung der Kirche und des höchsten Lebenszweckes der Uebernatur stellt. Die weltlichen Lebensordnungen werden $\mathrm{zu}$ reinen Formen und Voraussetzungen ohne jeden eigenen Inhalt und Zweck, zu Ordnungen, die Gott direkt eingesetzt oder indirekt durch die Vernunft angeordnet hat, die mit der Schöpfungsordnung der Vernunft und Gottes Gebot gegeben sind und in die der Christ sich zu fügen hat, wie in Sonne und Regen oder in Wetter und Wind. Es sind die nun einmal positiv geordnete Verhältnisse, innerhalb deren die christliche Liebe sich zu betätigen hat und die nicht zu Gunsten selbsterwählter Lebensbedingungen verlassen werden dürfen. Das Verhalten ihnen gegenüber ist nicht die Bejahung einer natürlichen Unterstufe und die Regulierung dieser von dem übergeordneten kirchlichen $Z_{\text {weck }}$ und Gemeinwesen aus, sondern der Gehorsam, der sich in gottgewollte Lebensbedingungen schickt und von ihnen sich die natürlichen Anlässe zur Betätigung der christlichen Liebesgesinnung darbieten läßt. Die innerweltliche politische und soziale Ethik wird aus einer Lehre von den relativen, dem höchsten Zweck der Uebernatur unterzuordnenden ethischen Werten zu einer Lehre von den gottgesetzten Formen und Voraussetzungen des christlichen Liebeshandelns, die in dem staatlich und rechtlich geordneten, zünftig und ständisch gegliedeiten Lebens fertig vorliegen. Man kann diese Formen aus dem natürlichen Sittengesetz begreifen und ihren scheinbaren Widerspruch gegen das christliche Ideal aus ihrer Angemessenheit zu den Bedingungen des Sündenstandes erklären, aber das Wesentliche ist ihnen gegenüber nicht die Erklärung und ethische Bejahung, sondern der religiöse Gehorsam und die demütige Füg Ing $^{224}$ ).

\footnotetext{
224) Die deutliche Erkenntnis, daß die radikale Ethik nur kleine Gruppen stiften würde, die christliche Ethik daher für eine Massengemeinschaft der Er-
} 
Die radikal christliche Ethik der Gottesliebe und der die Gottesliebe ausströmenden Bruderliebe sollte zugleich die Ethik einer Volkskirche und einer ausschließlich christlichen Gesellschaft sein. Dann aber konnte es nicht genügen, bloß bei der allgemeinen Notwendigkeit stehen zu bleiben, daß der Glaube sein Leben ausströme. Es mußte eine bestimmte inhaltliche Regel, ein christliches Sittengesetz aufgestellt werden, das den Massen vorgehalten werden konnte und das vor allem auch die Einbeziehung der weltlichen Moral sicher stellte. Hier griff Luther

gänzung durch die weltliche Moral bedarf, in der Schrift von weltlicher Obrigkeit B. A. IV, I S. 236: Eine streng und eigentlich christliche Gemeinschaft sei nicht möglich. \Gib die Welt zuvor voll ernster Christen, ehe du sie christlich und evangelisch regierst. Das wirst du aber nimmermehr tun; denn die Welt und die Menge ist und bleibt Unchristen, ob sie gleich alle getauft und Christen heißen. Aber die Christen wohnen, wie man spricht, fern von einander. Darum leidet sichs in der Welt nicht, daß ein christlich Regiment (im Sinne der Bergpredigt) gemein werde über alle Welt, ja, noch über ein Land oder große Menge. Denn der Bösen sind immer mehr als der Frommen. Darum ein ganzes Land oder die Welt mit dem Evangelio zu regieren sich unterwinden, das ist eben, als wenn ein Hirt in einen Stall zusammentäte Wölfe, Löwen, Adler, Schafe und ließe jegliches frei unter den anderen gehen. . . Hier würden die Schafe wohl Frieden halten und sich friedlich also lassen weiden und regieren, aber sie würden nicht lange leben, noch ein Tier vor dem andern bleiben. Darum muß man die beiden Regimente mit Fleiß scheiden und beides bleiben lassen, eines das fromm macht, das andere das äußerlich Frieden schaffe und bösen Werken wehrt; keines ist ohne das andere genug in der Welt. « Das alles hat nur Sinn unter der Voraussetzung der Notwendigkeit einer umfassenden Volkskirche. - Von einer andern Seite her sagt das Gleiche die Aeußerung in der berühmten Vorrede zum Psalter, daß das Psalter alle Höhen- und Tiefestufen der religiösen und sittlichen Zustände ausdrücke und daher besser sei für die christliche Gemeinde als die bloßen Erzählungen der heroischen Werke der Heiligen. „Zuletzt ist im Psalter (durch diese Darlegung verschiedener Reifestufen) die Sicherheit und ein wohlverwahrtes Geleit, daß man allen Heiligen (d. h. den in den Psalmen sich aussprechenden Frommen) ohne Gefahr darin nachfolgen kann. Denn andere Exempel und Legenden von den stummen Heiligen (d. h. lediglich die Berichte ihrer Taten ohne Aeußerung ihres schwankenden Innenlebens) bringen manche Werke hervor, die man nicht nachtun kann: vielmehr Werke aber bringen sie, die gef ährlich sind nachz utun und gemeiniglich Sekten und Rotten anrichten und vorr der Gemeinschaft der Fieiligen (d. h. der Kirche) führen und reifen. Aber der Psalter hält dich von den Rotten zu der heiligen Gemeinschaft; denn er lehrt dich in Freude, Furcht, Hoffnung, Traurigkeit gleichgesinnt sein und reden, wie alle Heiligen (d. h. dic Durchschnittsfrommen) gesinnt sind und geredet haben «. IV I S. 8. 
naturgemäß zur Bibel, von der es ja selbstverständlich war, daß s̀ie auch ihrerseits jenem christlíchen Grundtrieb einen Ausdruck gab. Dabei ist es nun aber charakteristisch, dab ihm als die den inneren Trieb objektiv darstellende Offenbarung des Sittengesetzes nicht die Bergpredigt erschien, sondern der Dekalog, der ihm wiederum identisch war mit dem natürlichen sittlichen Bewußtsein oder dem Naturgesetz, und der von Jesus und den Aposteln einfach bestätigt und gedeutet worden ist. So erwuchs der D e ka log zu seiner für den Protestantismus charakteristischen absoluten Bedeutung als Ausdruck und Inbegriff der vollen Lex naturae und der mit dieser identischen evangelischen Ethik ${ }^{226}$ ). Er empfahl

228) Der in der alten Kirche und im Frühmittelalter fast gar nicht für die kirchliche Lehre verwendete Dekalog war im Spätmittelalter zu starker Verwendung in den Beichtspiegeln gekommen (Kawerau im vorher angeführten Bande S. 43). Zur christlichen Zentrallehre, an der das Gesetz und sein Gegensatz, die Gnade, ferner das Genugtuungsdogma und die christliche Fthik gemessen wird, wurde er überhaupt erst im Protestantismus, und zwar im Calvinismus entsprechend seiner strengeren ethischen Gemeindeorganisation noch mehr als im Luthertum; doch ist die Grundlage bei beiden dieselbe. Ueber seine hier erlangte absolute Stellung s. Lommatzsch S. 60-90. Die genauere Ausführung des Lehrstückes mit seiner grundlegenden Theorie von den zwei Tafeln (bei der ich nicht zu sagen weiß, wie weit sie erst Luther eigentümlich ist; jedenfalls ist sie in dieser Ausführung und Wertung der Spiegel der reformatorischen Gedanken) und mit seiner Identifikation von Naturgesetz, christlichem Gesetz und Dekalog (wodurch es zugleich das einzige dieser ganz antiphilosophischen Theologie verbleibende Band zwischen Vernunft und Offenbarung, Natur und Gnade ist) ist dargestellt bei Eger 99-118, Hupfeld S. 75-104 und Troeltsch, Vernunft und Offenbarung bei Joh. Gerh. und Melanchthon 1891 S. 137 bis 173; bei der Abfassung dieser Schrift habe ich die Bedeutung des dekalogisch-naturgesetzlichen Gedankenkreises in der ganzen theologischen Tradition und mit ihr auch bei Luther noch nicht genügend gekannt und die Lehre allzusehr auf Melanchthon zurückgeführt. Luthers große Neuerung ist hierbei die Unterscheidung der justitia spiritualis und der justitia civilis, der motus spirituales und der allgemeinen natürlich-sittlichen Verpflichtungen; die letzteren werden christlich gut, wenn sie, wie die erste Tafel fordert, sim Glauben gehen 4 . Ueber dies sim Glauben gehene der an sich auch naturgesetzlich geforderten Werke s. die eingebende Darstellung bei Thieme S. 19-ro2. Hier das alles erleuchtende Wort: sIn diesem Werke (dem Glauben in Christum) müssen alle, Werke gehen, und ihrer Gutheit Einfluß gleichwie ein Lehen von ihm empfangen. S. 76. Freilich sind nun aber die Schwierigkeiten durch diese Zusammenfassung im Dekalog nicht rerschwunden. In seiner Urstandsfassung waren Dekalog und Naturgesetż, das , Gesetz der Natur und der Liebec allerdings ganz identisch. Im Sündenfall aber hat das Naturgesetz in der weltlichen Rechtsordnung eine Anpassung an die sündigen Zustände erhalten, 
sich als solche teils durch die ganze bisherige Ueberlieferung, die ja bereits diese Gleichung vollzogen hatte, teils durch seine katechetische Verwertbarkeit, ferner durch seine Geoffenbartheit und seine Zentralstellung im alten und neuen Testament; vor allem

und nun ist die Frage, wie weit beide jetzt im Sündenstande sich wieder einigen können. So ist das Problem sehr treffend auch bei Eger $92 \mathrm{f}$. formuliert. - An diesem Punkt liegen die wichtigsten Entwickelungen von Luthers Ethik. Die beiden Pole dieser Entwickelung bezeichnen die Schriften , Von weltlicher Obrigkeit, wieweit man ihr Gehorsam schuldig sei 1523 und die Auslegung der Bergpredigt 1532 . In der ersteren Schrift sagt Luther ausdrücklich, die Katholiken hätten die Bergpredigt und die Erfordernisse des praktischen Lebens so vereinigt, daß sie beides auf verschiedene Stände und auf den Unterschied von consilia und praecepta reduziert hätten, während er die Forderung der Bergpredigt und_Pauli von der absoluten, auf Recht und Gewalt verzichtenden Liebesmoral als für alle Christen insgemein geltend betrachte. Für dieselben Christen aber hält èr auch seinerseits die Forderung des praktischen Lebens, die Anerkennung von Recht und Gewalt, fest, aber in der Form, daß er darin die seit dem Sündenfall eingetretene, um der Sünde willen als frenum et remedium peccati gestaltete Rechtsordnung sieht, die aus der Vernunft stamme und außerdem von Gott (im A. T.) ausdrücklich eingesetzt und im N. T. von Christus durch Dulden und Ertragen ausdrücklich anerkannt worden sei. Der Christ gehört nun beiden getrennten und gegensätzlichen Ordnungen an; er unterwirft sich, da die ungeheure Majorität keine rechten Christen im Sinne der Bergpredigt sind und also des relativen Naturrechtes d. h. der Rechts- und Gewaltordnung bedürfen für Wohl und Ordnung des irdischen Lebens, und, da auch die Christen zum SchuŁz gegen Mißbrauch ihrer Leidensbereitschaft dieser Ordnung bedürfen, aus Liebe zur Masse der Unbekehrten und aus Gehorsam gegen Gottes Ordnung diesem Gesetz. Beide Ordnungen sind streng auseinanderzuhalten; insbesondere darf die weltliche Obrigkeit, als lediglich weltliche zur Repression der Sünde gestiftet und daher auf die äußere Sphäre des Weltlichen beschränkte Macht, sich in die geistlich-christlichen Dinge nicht einmischen. Am allerwenigsten dürfen das papistisch und ungläubig gebliebene Regierungen, deneñ aber im übrigen ihr Existenzrecht nicht $\mathrm{zu}$ bestreiten ist. Umgekehrt darf aber auch die geistliche Liebesethik nicht in die staatliche Rechtsordnung eingreifen und ihre radikale Liebeschristlichkeit zu einem Gesetz und einer Sozialreform für den Haufen machen. Denn die letztere bedarf des Rechtes; die Grundsätze der Bergpredigt, auf die unchristliche Masse angewendet, würden lauter Gräuel ergeben. Vielmehr stehen die Christen in doppeltem Stand und müssen wie Paulus die unchristliche Weltordnung ertragen und bestehen lassen. Man sieht, diese Schrift, in der man die Prinzipien der Gewissensfreiheit und des modernen Staates unbegreiflicherweise hat finden wollen, steht noch auf einem schroff dualistischen Standpunkt: die Bergpredigt »lehrt wohl, wie da die Christen untereinander kein weltliches Schwert noch Recht haben sollen; sie verbietet abẻr nicht, daß man -. denen dienen und untertan sein solle, die weltliches Schwert und Recht haben, 
aber doch wohl instinktiv durch die in ihm gegebene Möglichkeit einer Einbeziehung der innerweltlichen Moral und der innerweltlichen Ordnungen. Die Ethik einer universalen Kirche und einer aus der Sündenvergebung quellenden Ergebung in die Unüber-

sondern vielmehr, weil du seiner nicht bedarfst noch haben sollst, sollt du denen dienen, dienicht so hoch gekommen sind wie du und des selben noch bedürfen. B. A. IV I S. 239. Es ist das relative Naturrecht, in das jeder Christ um der noch bestehenden Massenhaftigkeit der Unchristen willen sich zu fügen hat, wenn er schon daneben für sich selbst als Person die Grundsätze der Bergpredigt anerkennt; und zwar darf sich dieser Verpflichtung niemand entziehen und damit etwa Sonderkreise Vollkommener stiften: der rechte Verstand der Bergpredigt ist, >daß ein Christ soll also geschickt sein, daß er alles Uebel und Unrecht leide, nicht sich selbst räche, auch nicht vor Gericht sich schütze, sondern daß er allerdings nicht bedürfe der weltlichen Gewalt und des Rechtes für sich selbst. Aber für andere mag er und soll er (als Richter, Henker oder Soldat) Rache, Recht, Schutz und Hilfe suchen und dazu tun, womit er mag. Also soll a $\mathrm{u} c \mathrm{~h}$ ih m die Gewalt, entweder von ihr selbst oder durch anderer Anregen, ohne se ine e ig e ne Klage, Suchen und Anregen, helfen und schützen. Wo sie das nicht tut, soller sich schinden und schänden lassen und ke inem Uebel widerstehen, wie Christi Worte lauten. Und sei du gewiß, daß diese Lehre Christi nicht ein Rat für die Vollkommenen sei, wie die Sophisten lästern und lügen, sondern ein geme ines strenges Gebot für alle $\mathrm{Ch}$ risten. . . Und kehre dich nicht an die Menge und gemeinen Brauch; denn es sind wenig Christen auf Erden... Dazu ist Gottes Wort etwas anderes denn gemeiner Brauche S. 245. Hier ist die Annäherung an den Sektentypus wieder mit Händen zu greifen, aber auch der Unterschied, nämlich die Anerkennung der relativen Lex naturae und der natürlich-gegebenen Verhältnisse um der Einheit der Volkskirche willen. Fast verschwunden ist nun aber dieser Dualismus in der Auslegung der Bergpredigt. Hier ist Amt und Stand, wie er von Gott geordnet ist, die Vornussetzung des Tuns, ein Mittel der Bruderliebe im ganzen und ein Befehl Gottes, dem man gehorchen soll. Die Rechtsordnung kommt in Betracht als System von Gott geordneter Stände, die um dieser Anordnung willen heilig sind. Das sind jetzt einfach >göttliche Ständes S. 292. Das Leben im Beruf und die Betrachtung des Berufes und des gesellschaftlichen Systems als eines von der Vorsehung herbeigeführten und aufrecht erhaltenen Systems zum Besten der Christenheit, das wird nun der Inbegriff der Ethik. Aus der Liebe, die das an sich christlich nicht Notwendige, die Lnterwerfung unter die Rechtsordnung zum Besten des Nächsten übt, wird der Gehorsam und der Vorsehungsglaube, der Staat, Gesellschaftsordnung und Recht als göttliche Ordnungen ehrt, in denen zu bleiben und dem Nächsten zu dienen einfach Gehorsamspflicht ist. Das ist von Eger sehr treffend im einzelnen.ausgeführt, der mit Recht zugleich zeigt, daß damit ein eigener ethischer Wert der Weltordnung immer noch nicht anerkannt ist. Man dient Gott in rocatione nicht per vocationem. Aber im übrigen ist das Bild ganz verändert. 
windlichkeit der Sünde konnte nicht an der Bergpredigt, sondern nur am Dekalog ihr Schibboleth haben. Die religiöse Volksethik Alt-Israels eignete sich hierzu besser als der rein auf die persönliche Innerlichkeit gerichtete Radikalismus der Jesuspredigt, und die spätere Ethik Luthers zog überhaupt in immer weiterem Umfang das alte Testament und die jüdische Moralweisheit heran ${ }^{220}$ ).

Wie der Staat nicht mehr von aller Einwirkung auf die Religion im Gefühl seiner niederen Natur sich zurückhalten muß, sondern als christliche Obrigkeit jetzt zum Dienst an der Kirche und für die Wahrheit verpflichtet ist, so sollen auch die Christen sich nicht mehr bloß duldend und zuwartend der Rechtsordnung geienüber verhalten. Von der Rechtsordnung selbst heißt es jetzt: \$Was ist der Welt Gerechtigkeit anderes, denn daß jedermann tue in seinem Stande, was er schuldig ist? Welches heißt desselbigen Standes $R e c h t$ als Mannesrecht und Frauenrecht, Kindesrecht, Knechts- und Magdsrecht im Hause, Bürgerrecht oder Stadtrecht im Lande; welches alles steht darin, daß die so anderen Leuten vorstehen und regieren sollen, solches Amt mit Fleiß, Sorgen und Treuen ausrichten, die anderen auch desgleichen schuldigen Dienst und Gehorsam treulich und willig leisten S. 300. „Solches alles hat Gote geboten, das muß icht unrem sein, ja es ist eben die Reinigkeit, damit man Gott sucht. Also, wenn ein Richter sein Amt treibt und einen Uebeltäter zum Tod verurteilt, das ist nichț sein, sondern Gottes Amt und Werk. Darum ist es ein gutes, reines und heiliges Werk (wo anders er auch ein Christ ist), welches er nicht könnte tun, wo nicht suvor ein reines Herz da wäres S. 306. Im ausdrücklichen Gegensatz gegen den oben geforderten Verzicht auf eigenes Rechtsuchen heißt es jetzt, man solle zunächst nach Frieden und Verträglichkeit trachten; w will aber solches nicht sein und kannst du es nicht leiden, so hast du Recht und Obrigkeit im Land, dabej du es in orden tlicher Weise magst suchen« S. 316 . Das sind ebenso scharfe Selbstkorrekturen wie die früher geschilderten in Bezug auf das Verhältnis von Staat und Kirche, Freiheit und $Z_{w a n g}$, und beide Korrckturen hängen untereinander selbst zusammen. Denn die anfängliche Forderung der Freiheit und Scheidung beruhte auf der Geringschätzung von Stłat und Rechtsordnung. In der späteren Gestalt aber ist Luthers Ethik dauernd geblieben, und die Dekalog-Erklärung der Katechismen hat ihr die dauernde klassische Gestalt gegeben bis heute.

${ }^{226}$ ) S. Eger, Anschauungen Luthers vom Beruf, S. 124: Es scheint nicht überflüssig, darauf hinzuweisen, wie stark auf diese sich stetig steigernde Weltoffenheit der lutherischen Anschauungen die Beschäftigung mit den alttestamentlichen Schriften eingewirkt hat. Die oben angeführten Stellen über den Wert der irdischen Gaben und Güter sind fast sämtlich Auslegungen verschiedener Schrifien des A. T. entnommen.\& DDem A. T. fehlt eben jede Spur von Weltflucht, ion Wieichg(i)tigkeit gegen irdische Dinge und Verhältnisse; es ist daher unter allen Limständen ein sichererus Mittel für Gewinnung eines gesunden Verständnisses dt.ssen, was die Erde bietet, als das mancherlei Mißverständnissen(!) ausgesetzten $N$. T. Der 
Aber, indem so der Dekalog zum Inbegriff des christlichen Sittengesetzes wurde, empfing er zugleich eine neue theologische Deutung. Es ist auch hier nicht mehr die Uebereinanderschichtung der Lex naturae und ihres von Christus beglaubigten Ausdruckes im Dekalog cinerseits und der höheren theologischen Tugenden sowie der evangelischen Räte andererseits. Der Dekalog und mit ihm die Lex naturae, wie sie in ihrem ursprünglichen Vollsinn war, wird ganz eingetaucht in die christlichen Gedanken und für völlig identisch erklärt mit dem evangelischen Grundgesetz der Gottes- und Bruderliebe, so daß es nichts mehr neben und über ihm gibt, sondern in ihm, sobald er voll verstanden wird, alles enthalten ist. $\mathrm{Zu}$ diesem Zweck wird der Unterschied der ersten und zweiten Tafel aufs stärkste betont. Die erste Tafel mit ihren das Verhältnis zu Gott betreffenden Geboten enthält die grundlegende Forderung von Ehrfurcht, Liebe und Vertrauen, die nur auf Grund der släubigen Gnadengewißheit erfüllbar sind. Sie fordert die richtige religiöse Grundverfassung, die motus spirituales, und ist die spirituale nder, wie wir sagen würden, die rein religiöse Forderung. Aus dieser Forderung oder ihrer Erfüllung ergibt sich dann aber auch die zweite Hälfte, die Forderung des Verhaltens gegen den Nächsten im Sinne einer die natürlichen gottgesetzten Lebensordnungen zum Anlaß und zur Voraussetzung nehmenden Liebesübun:r. Hierin ist die ganze Berufs- und Ständelehre, die ganze Fügung in die gegebenen Verhältnisse in Staat und Gesellschaft 'nthalten, die ganze Liebesbetätigung nicht oberhalb, sondern innerhalb der natürlichen Lebensformen. Aber wahrhaft ethischen Wert hat dic Erfüllung dieser zweiten Tafel nur, wenn sie aus der spiritualen Gesinnung des Glaubens. hervorgeht und auf das Ziel einer Betätigung und Bekundung des Herzensglaubens an den Xächsten, auf cinen Zusammenschluß aller in diesem eigentlichen und alleinigen Lebenswert hinarbeitet. Daher ist der Dekaloge und das Naturgesetz voll verstanden das rein christlich-spirituale lical. Wo Dekalog und Naturgesetz ohne diese Motivie-

Brilen, aui dem der Christ in Gottvertrauen lebt und wirkt, ist jelzt nach

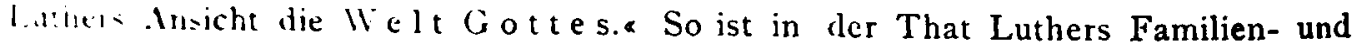
Wirt-cinacthik wrofenteils der jidischen Spruchweisheit entnommen. Nur ist das schucrlich 'me ungewollte Wirkung des $A$. ' $T$., sondern umgekehrt ein Deckungsuchen beim $A$. T. für die Dinge, die aus dem $\Upsilon$. T. nicht zu belegen waren. IV: werden sehen, wie der Calvinismus in dieser Richtung noch viel weiter gehen muste, um sich als biblisch zu behaupten. 
rung und Abzweckung verstanden werden. - und das haben die Heiden getan und tut bis heute die unerlöste Vernunft $-\mathrm{da}$ sind beide nicht voll begriffen. So haben die Heiden und die Lehrer der verbliebenen Reste der Lex naturae im Grunde nur die zweite Tafel gekannt und die erste vergessen. Sie haben dabei im positiven Recht, besonders im römischen Recht und in der philosophischen Moral, diese zweite Tafel sehr gut ausgelegt. Aber all das ist erst zu brauchen, wenn es mit der rechten christ" lichen oder spiritualen Gesinnung, mit dem Geist der ersten Tafel, der im Urstand zugleich der Geist der voll verstandenen Lex naturae war; beseelt und belebt wird. Ohne das ist alles kalte Selbstgerechtigkeit und heidnische Selbstliebe. So kann die wissenschaftliche Ethik des Protestantismus die Lex naturae nach dem Dekalog und nach Cicero und Aristoteles auslegen, aber die entscheidende Christlichkeit gibt erst die diese Formen beseelende und durchglühende, in Kreuz und Leid und Anfechtung bewährte Gesinnung der auf den Gnadentrost begründeten Dankbarkeit und Hingebung gegen Gott.

So wurde es für die Ethik des Protestantismus beider Konfessionen die Grundaufgabe, den richtigen Begriff des Dekalogs $z \mathrm{u}$ entwickeln, in welchem der innere Glaubenstrieb und die positive Offenbarung des Ideals zusammentreffen, in welchem die Unterscheidung und Aufeinanderbeziehung der ersten und der zweiten Tafel die eigentliche theologische Meisteraufgabe ist, und bei dem zwischen dem absoluten Dekalog und Naturrecht, wie beides im Urstand war und von Christus erneuert worden ist, und dem relativen Dekalogs- und Naturrechtsverständnis, wie es mit Verkennung der ersten Tafel die heidnisch-philosophische Ethik, die Jurisprudenz und das natürliche Gewissen hat, scharf $\mathrm{zu}$ distinguieren ist. In der absoluten Gestalt des Urstandes aber ist das Wesen dieses Sittengesetzes einfach eine religiöse Beseelung der nátürlich gegebenen Verhältnisse und Pflichten, eine Durchgeistigung der Natur mit den motus spirituales gewesen, wie die ganze Urstandslehre ja nicht mehr Natur- und Uebernatur übereinanderschichtet, sondern die Vollkommenheit des Menschen in seinem natürlichen Wesen bestehen läßt. Das ist bei aller Beibehaltung der Formeln und Theorien doch eine neue Deutung der patristischmittelalterlichen Gleichung von Dekalog und Naturgesetz, eine neue Fassung des Naturgesetzes selbst. Dieses ist nicht mehr der Radikalismus der Persönlichkeitsidee, der Gleichheit, des 
Gemeinbesitzes, des Lebens ohne Gewalt und Recht, sondern die Glaubensbescelung aller natürlichen Handlungen und Notwendigkeiten, da alles, was die gottgesetzte Natur fordert, vereinbar ist mit der Glaubensgesinnung der Gottesliebe und Bruderliebe. Aus einem solchen Naturgesetz können daher auch keine egalitären und keine kommunistischen Folgerungen mehr abgeleitet werden, nicht bloß weil es in seiner gegenwärtigen relativen Gestalt durch die Verhältnisse des Sündenstandes modifiziert ist, sondern weil es an sich keine solche Konsequenzen aus sich hervortreiben kann. Fs ist lediglich die Erfüllung der durch die natürlichen Verhältnisse und göttliche Ordnung geforderten Betätigungen mit dem religiösen Gesinnungsinhalt des Gottvertrauens und der Gotteshingebung sowie die Motivierung des sozialen Handelns aus der l.iebe, indem die soziale Nützlichkeit um der Liebe willen und nicht bloß um der Nützlichkeit willen betont wird. Freilich. ist dabei die Frage, welches die aus der Natur folgenden Verhältnisse sind. Darüber ist bei den unbestimmten aber schmerzenlosen und harmonischen Verhältnissen des Paradieses nicht viel zu sagen. Es versteht sich von selbst, daß damals beides sich vertragen hat und bedarf keiner genaueren Untersuchung. Jedenfalls herrschte unbegrenzte Liebe und Freiheit von $Z$ wang und Schmerz. Aber das dort und damals Vereinbare ist nun im Weltlauf auseinandergetreten: das mit Staat, Recht und Gewalt arbeitende relative Naturgesetz des Sündenstandes entzweit sich mit der auf Recht, Gewalt und Selbstdurchsetzung verzichtenden religiösen I.iebesmoral. Bei der Erneuerung und Auslegung des Dekalogs und Naturgesetzes durch Christus tritt daher der rein religiös bestinmte Lebenszweck und die rein religiös bestimmte Liebesgemeinschaft als das die innere Person betreffende eigentlich christliche Ideal ncben dic weltliche Berufs-. Staats- und Gesellschaftsmoral, der der Mensch durch Amt o oder durch Einordnung in die staatlich-gesellschaftliche Ordnung mit ihren Rechts- und Zwangsmerkmalen angehört.

Das ist der schwierige Punkt in der lutherischen Ethik. 'Die patristisch-thomistische Lehre hatte ihre doppelte Moral erklären können, indem sie das Naturrecht zu einer die Sünde zugleich strafenden und heilenden Ordnung modifizieren ließ und dann im Sündenstand über diesen Ordnungen die eigentlich-christlichen ()rdnungen als höhere Lebensgemeinschaft aufbaute. Wenn aber Luther jene katholische Theorie sich aneignete, so paßte sie 
nicht recht zu seiner Grundanschauung, da aus dieser sich wohl eine Entleerung der natürlichen Ordnung von ihrem ursprünglichen geistlichen Inhalt durch den Sündenfall, aber kein materieller Gegensatz beider ergeben kann. Entweder ist für eine Verwandelung des paradiesischen Naturrechts in ein vielfach entgegengesetztes Naturrecht des Sündenstandes, also für den wesentlichen Gegensatz des paradiesischen und des gegenwärtigen Naturrechts kein Raum, und dann muß das gegenwärtige Naturrecht und die ihm entsprechende politisch-soziale Ordnung in einer dem christlichen Gedanken wirklich konformen und mit ihm vereinbaren Gestaltung vorliegen oder in ihn übergeführt werden. Oder es hat sich in der Tat das paradiesische Naturrecht in ein ihm stark entgegengesetztes empirisches Naturrecht verwandelt, dann sind dessen Ordnungen nicht einfach Formen und Voraussetzungen, die mit christlicher Gesinnung und spiritualer Gottesliebe ausgefüllt werden können. Im letzteren Falle besteht ein materieller und direkter Gegensatz. Indem Luther den letzteren Fall annimmt, besteht zwischen seinem Ideal von Naturgesetz und Dekalog oder seinem Grundbegriff des christlichen Sittengesetzes und der wirklichen zwiespältigen Anweisung der Christen $z u$ einer inneren Moral der Person und einer äußeren Moral des Amtes ein überaus peinlicher Gegensatz. Hier bricht in Luthers Lehre die jeder christlichen Ethik wesentliche Spannung gegen die Welt und Natur wieder hervor, die er in seinem Ideal des Gesetzes aufgehoben hatte. Der Gegensatz, der im Katholizismus als Stufengegensatz der relativ-naturgesetzlichen Unterstufen und der eigentlich-christlichen Oberstufe sich ausgebildet hatte, wird hier in jede Persönlichkeit hineingetragen als Gegensatz zwischen $*$ Person * und *Amt . Indem Luther mit dem Katholizismus den kirchlichen Gnaden- und Universalitätsgedanken behauptete und ihm die Weltverwerfung der Sekte unmöglich war, mußte seine Ethik den Gegensatz von Weltmoral und Gnadenmoral auch ihrerseits in sich aufnehmen. Sie hat ihn nicht auf Stände und Gruppen zu gegenseitiger Ergänzung und Stellvertretung verteilt, sondern jedes Individuum einfach in die Duplizität der Moral hineingestellt und diese Duplizität teils aus Gottes Anordnung und Verfügung, teils aus der Sünde, teils aus den Bedingungen des körperlichen Lebens erklärt.

Immerhin hat Luther den Gegensatz im Laufe der Zeit zusehends gemildert. Wie im Kirchenbegriff über den anfäng. 
lichen Subjektivismus immer mehr die Objektivität der Anstalt herrschend wurde, so wurde in der Ethik gleichzeitig und in engem Zusammenhang damit immer mehr der Gegensatz von Amt und Person, von Bergpredigt und relativem Naturrecht gemildert. Dic weltlichen Ordnungen und Verhältnisse wurden immer mehr bloße Formen und Lebensbedingungen, die nicht sowohl auf die Relativierung der Vernunft durch die Sünde, als auf positive (Ordnung und Einsetzung Gottes und dem Naturgesetz entspringende allgemeine Voraussetzungen zurückgeführt werden ${ }^{22 i}$ ). So kann schließlich die aristotelische, ciceronianische

227) Diese Herabsetzung der staatlich-gesellschaftlichen Werte zu bloßen Formen und Voraussetzangen der Liebesbetatigung des Glaubens, indem die Nŭchstenliebe am besten durch Benutzung der dem Wohl der Gesellschaft dienenden Ordnungen betatigt wird, charakterisiert auch noch die Ethik des modernen Luthertums. Dabei wird dann die Wissenschaft als Mittel der für den Beruf und die Gesellschaft unentbehrliche Naturbeherrschung a und die Kunst als für die Frische der Berufsarbeit unentbelirliche sErholunge gewertet. S. Gottschick, Ethik S. 127: -Die weltlich-sittlichen Gemeinschaften in ihrer beruflichen Gliederung sind die unentbehrlichen Mittel zur Erhaltung des natürlichen Lebens der Menschheit, die die unerläßliche Voraussetzung für die Umgestaltung der Menschheit zum Reiche Gottes ist. An die Stelle von Luthers objektiver Begründung auf die lex divina naturalis ist also das Zeugnis der Geschichte zu setzen, welches beweist, daf nach Gottes Willen die verschiedenen Klassen der weltlichen Berufe auf das Reich Gottes abzwecken. Gilt dies alles schon von dem bürgerlichen, dem Erwerbsberuf, so erst recht, wenn in dem christlichen Beruf ebenso, wie es schon beim sittlichen geschehen muß, die über jenen weit hinausgehende Summe der Aufgaben eingerechnet werden muß, die als regelmäßsige, sich dem Einzelnen aus seinenkonstanten Verhältnissen in Familie, Gesellschaft, Staat und Kirche ergebene. Herrmann, Ethik ${ }^{3}$ 1904 S. 158 : , Wir erweisen uns nur dann als Christen in der Welt, wenn es uns selbstverständlich wird, in der unerschüplichen Gestaltungskraft der $\mathrm{Natur}$ (d. i. die Lex naturae Luther: ohne seine Festlegung auf bestimmte dauernde Ordnungen) das Wirken Gottes at sehen, also die natürlich begründeten menschlichenGemeinschaften, die wir in der Welt vorfinden, als von Gott uns gegebenen Grundlagen unserer Lebensordnung und Formen unserer Tätigk : it zu verwertena. Wie Luther die ständisch-zünftige, absolutistische und agrarische Lebensverfassung als dauernd vom Naturrecht geforderte und mit dem Christentum verträgliche Form des äußeren Lebens betrachtete, so wird hier eine unbegrenzt bewegliche Gestaltung dieser Dinge mit Einschluß der modernen militärisch-kapitalistischen und wissenschaftlich-künstlerischen Kultur als vom Glauben zu beseelende, Forme des natürlichen Ebens betrachtet. Ebenso bei v. d. Goltz, -Grundlagen der christlichen Sozialethiks, der in seinem ssoziologischene Teil die 
und stoische Ethik und die antike humanistische Politik, Oekonomik und Soziallehre wieder angeeignet werden. Sie bedeutet Materialien, Formen und Stoffe, die, der religiösen Motivierung entbehrend, an sich noch keine Moral sind, die aber als Ausfüsse des Naturgesetzes nur wieder mit dem ursprünglich im Naturgesetz enthaltenen religiösen Prinzip durchdrungen zu werden brauchen und dann christliche Moral werden. Der Gegensatz zwischen dem Gesinnungschristentum und der weltlichen Antsmoral verschwindet immer mehr als materieller und direkter Gegensatz und wird immer mehr aus einem Gegensatz zu einer gegenseitigen Ergänzung und Erfüllung des Zusammengehörigen. Die gegebenen und bei ihrer Vernunftgrundlage oder göttlichen Einsetzung immer dauernden Verhältnisse werden immer mehr zum Normalen, und die christliche Moral wird, wie die modernen Lutheraner sagen, immer mehr »zur Wahrheit der natürlichen «, das Werk der Erlösung besteht immer mehr in der »Verklärung des gottgeschaffenen Natürlichen, nicht in einer Art Ausrottung gottgeschaffener Natur « ${ }^{228}$ ), auch, darf man hinzusetzen, nicht bloß im geduldigen

lutherische Naturrechtslehre durch eine moderne Lehre von den sn a türlichen Grundformen in Familie, Stat und Gesellschafts entwickelt und diese ;Formen dann unter die Wirkung des christlichen Geistes stellt; S. 282: -Im Christentum übernimmt die Religion die Führung im menschlichen Gemeinschaftsleben. . Die Herrschaft des Geistes über die Natur wird hier zur allmählichen Vollendung geführt und sowohl alle individuellen und sozialen Gegensätze ausgeglichen als auch die eigentümlichen Kräfte der verschiedenen sozialen Kreise zur Harmonie gebracht «. Ebenso auch Luthardt ${ }_{2}$ Kompendium der Ethik, 1896: ¿Da der Geist erst. die Wahrheit des Menschen und das Christentum die Wahrheit des irdischen Lebens ist, so besteht die Wahrheit der Sittlichkeit des natürlichen Lebens darin, daß diese mit dem Sinn und Geist und dem sittlichen Vermögen geleistet wird, welches das Christentum darreicht. . . Gratia non tollit, sed sanat naturams. Hier ist überall jede Möglichkeit eines inneren Gegensatzes zwischen den natürlichen Formen der Kulturethik und dem sie erfüllen sollenden radikalen und jenseitigen Liebesgeist total vergessen und sind Luthers Kämpfe um dieses Problem ^katholische Reste $\alpha$. Das Wort Luthardts erinnert unmittelbar an das katholische Prinzip: >Gratia praesupponit ac perficit naturam a und zeigt zugleich schlagend den Unterschied. Im Katholizismus bildet Natur und Gnade einen Stufenunterschied, im Protestantismus fallen schließlich beide zusammen wie Form und Inhalt.

228) $\mathrm{Vgl}$ Luthardt, Compendium 10, Thieme IV; am unbedenklichsten bei Uhlhorn, Kath. u. Prot., S. 29: „Damit ist der Dualismus von Diesseits und Jenseits, von Natürlich und Uebernatürlich, von Christlich und Weltlich, von vollkommenen Christen und gewöhnlichen Christen äberwunden. Wissenschaft, Handel 
Erleiden der Natur, sondern in der demütigen und gehorsamen Bejahung. Dabei ist die sNaturs, d. h. die vom Naturgesetz bewirkte politisch-soziale Ordnung als eine stabile, eindeutig von der Vernunft im Sinne des Territorialstaates geforderte Gesellschaftsordnung, und das religiöse Gefühl sieht in ihr immer weniger den Gegensatz gegen dic radikale Liebesmoral, statt dessen vielmehr Stiftungen und Verfügungen Gottes, die Gehorsam verlangen. An Stelle des anfänglichen Spiritualismus, der freien Zwecksetzung aus dem absoluten religiösen Zweck und des damit gegebenen Weltgegensatzes tritt immer mehr der Gehorsam gegen dic positive Autorität. Wie an Stelle des Glaubens das Dogma, so tritt an Stelle der dem relativen Naturgesetz des Amts entgegenstehenden justitia spiritualis der Person der Gehorsam gegen Gottes Ordnungen und gegen die von ihm gesetzten Weltverhältnisse. Die relative, sündig verderbte Vernunftordnung wird zur autoritativen, rein positiven Tatsachenordnung, in die man sich ohne viel Gedanken fügt. So ist das Problem und der Widerspruch der lutherischen Ethik überwunden ${ }^{229}$ ). Die radikale ILiebes-

und Gewerbe erhalten ihre freie Bewegung wieder.* Daher meint L., der Protestentismus werde dic ssoziale Frage lüsen, wozu der Katholizismus innerlich unfuhig und nur außßerlich geschäftig sei.

290) Vgl. Fger S. $124 \mathrm{f}$ : : Was oben über die Umbiegung des Glaubensbegriffes und den des Gehorsams gegen das offenbarte Wort (joltes gesagt und über die Nebeneinanderstellung des Gehorsams gegen die Verheißungen und desjenigen gegen die Gebole Golles gesagt ist, findet seinen klarsten Ausdruck in der Stelle aus den Enarr in Genesin: Hacc sunt verae laudes ob e d i entia e, quae tantum est vel promissionum vel pracceptorum divinorum. In derselben Linie liegt, daß statt des in der "Frcileit eines Christenmenschen“ geprägten Schemas zur Kennzeichnung des christlichen Lebens: "Glaube und Liebe" jetzt das andere "Glaube und Gehorsam gegen (jolt" in den Vordergrund tritt. "Nachdem wir unsere Gerechtigkeil allein auf den verheißenen Samen gesetzt haben, daß wir auch Gott gehorsam sein und in diesem zeitlichen Leben das tun und halten, was er geboten hat.. Darum muB beiles zusammensein, Glaube und Gehorsam gegen Gott". Das macht die Werke des Christen im Unterschied von denen der Heiden heilig, daß sie im Glauben an Christus und im Gehorsam Gottes geschehen. Ebenso in der-Kirchenpostille: „Gott will, dafs wir nach der Vergebung deı Sünden in seinen Geboten leben`. Das, was uns Gehorsam abnötigt, ist je länger je mehr nicht die uns das Herz abgewinnende, in Christus offenbare Gnade ciottes, sondern die formale Aulorität des göttlichen Wortese S. I25. Der Parallelismus der Glaubenserkenntnis und des Sittengesetzes ist charakteristisch, beide haben aus gleichem Grund die identische Entwickelung genommen, bämlich um des Kirchenbegriffes willen. Merkwür- 
moral verschwindet hinter der Moral des Gehorsams gegen die Autorität. Auf die Gnade begründetes Gottvertrauen, in den Formen gesellschaftlicher Berufspflichten sich bewegende Nächstenliebe und gehorsame Ergebung in die vom Naturgesetz geschaffenen Ordnungen: das wird immer mehr der Inbegriff lutherischer Ethik.

So sind die ticfen innern Spannungen der christlichen Ethik, die bei jedem Unternehmen, das I.eben der dauernden Welt christlich $\mathrm{zu}$ gestalten, bisher hervorgetreten sind, auch in der reformatorischen Ethik crhalten geblieben. Auch sie ist cin Kompromiß und eine doppelte Moral vor allem in der grundlegenden Fassung bei Luther. Nur sind die Gegensätze nicht auf Stufen verteilt, sondern ineinandergeschoben zu einer Duplizität der Lebensstel lung jedes Individuums. Der Kompromiß ist tiefer in das Innere hineinverlegt und hierbei zunehmend gemildert, indem die Welt nicht sowohl als Stiftung der Sünde oder der unter Bedingung der Sünde stchenden getrübten Vernunft, sondern als direkte und positive Anordnung Gottes hingenommen wird. Die ergebungsselige Demut, die die Gnade der Sündenvergebung hinnimmt, gleicht sich immer mehr der Demut an, die die gottgeordneten Verhältnisse hinnimmt, und umgekehrt, sodaß der religiöse Stimmungsgehalt nach beiden Seiten ein gleichartiger wird. Allein die Naht bricht immer wieder auf. Sobald an dem Ideal der Bergpredigt der tiefe Gegensatz der gegebenen Verhältnisse gegen das wahrhaftige christliche Ideal zu Bewußtsein kommt und sobald die gegebene gesellschaftlich-politische Ordnung der Kirche und dem Worte Gottes sich nicht fügt, bricht der tiefe Groll gegen die Welt der Sünde und des Teufels los, richtet sich die Hoffnung auf den jüngsten Tag und erscheint das Christen-

digerweise haben die Theologen die erste Entwickelung viel beklagt, die zweite viel gepriesen, da sie ihnen das heute notwendige weltbejahende Humanitätschristentum darbietet. Daher überhaupt die Verschränkungen des modernen Urteils über Luther, das den anfänglichen, dem Sektentypus sich nähernden Individualismus preist und die gleichzeitige Befangenheit in katholischer Weltnegation beklagt, während es den Dogmatismus des alternden Luther wieder als Rückfall in den Katholizismus und seine gleichzeitige Weltbejahung als modernen Fortschritt rühmt. In Wahrheit gehören die beiden letzteren untrennbar zum Kirchentypus, wie die beiden ersteren ebenso untrennbar zu den Annäherungen an den Sektentypus gehören. Hierin zeigt sich, wie fruchtbar die Untersčheidung des Sektentypus und :des Kirchentypus, die in II gemacht worden ist, für die ganze Betrachtung ist. : Sie wird sich ebenso furchtbar für Calvinismus und Täufertum zeigen. 
leben wcsentlich als I.ceben unter dem Kreuz und als Hoffnung des seligen Jenseits. Die freudige Weltbejahung wird zur duldenden Weltergebung, und zwischen beiden geht insbesondere die Stimmung des Luthertums beständig hin und her.

Die Naht bricht aber auch von einer andern Seite her auf. Wird die Spiritualisierung des Dekalogs ernst genommen, wird wirklich alle irdisch-weltliche Leistung rein aus Gottesliebe und Selbstaufgabe abgeleitet und gerade in dieser Motivierung die Christlichkeit der Moral gesehen, dann sinken die weltlichen Ordnungen $z u$ rein faktischen Umständen, zu in sich völlig wertlosen Formen zusammen, innerhalb deren es gilt, die Welt zu haben, als hätte man sie nicht. Die Herabsetzung der Welt zu bloßen Formen und Voraussetzungen ist ebenso eine Akzeptierung der Welt als sie auf der anderen Seite eine Entwertung derselben ist. Dann aber ist ihre Auffassung eine asketische ${ }^{230}$ ) im Sinne jeder Leugnung eines Selbstzweckes und einer inneren Göttlichkeit weltlicher Ordnungen und Werte. Sie werden zu rein positiven Satzungen und Tatsachen, die nur aus dem Willen Gottes und aus keiner inneren Notwendigkeit stammen. Sie werden völlig formalisiert und ausgehöhlt, und das Ausharren in ihnen zum reinen Gehorsam und zum bloßen Dulden. Innerhalb ihrer wird die Welt nicht bejaht, sondern vergleichgültigt und überwunden, sodaß die Askese als Entwertung der Welt hier nicht mehr bloß

230) Vgl. hierüber meine Darstellung in der >Kultur der Gegenwart c. Charakteristische Stellen bei Herrmann, Verkehr S. 208: "Das heißt auch nicht die Welt verlassen und fliehen, wie sie (die Papisten) ihnen träumen; sondern du seiest in welchem stand, Leben und Wesen du wollest - denn du mußt ja etwas sein, weil du auf Erden lebst -, so hat dich Gott nicht von den Le uten, sondern unterdie $\mathrm{L}$ e u te gewiesen; denn es ist ein jeder Mensch um des andern willen geschaffen und geboren. Wodu nun, sage ich, und in welchen Stand duerfunden wirst, dasollt du die Welt fliehenc. ,Also bin ich von der Welt abgeschieden und bin doch in der Welts. So sagt auch Luthardt richtig: >Demzufolge ist im Bereich des äußeren Tuns nicht ein besonderes Gebiet des asketischen Tuns abzusondern, sondern es zieht sich nur das asketische Moment in alles Tun hinein Ethik L.s. S. 63; Braun, Concupiszenz: „So liegt Wahrheit in der Paradoxie: dadurch, daß Luther das Mönchisideal auf die Spitze trieb, hat er es in seiner Wurzel zerbrochen. S. 57. Das ist es, was Max Weber und ich meinen, wenn wir von einer sinnerweltlichen Askeses des Protestantismus im Unterschied von der überweltlichen oder, wenn man so sagen darf, nebenweltlichen Askese des Katholizismus sprechen. 
wie im Katholizismus an einzelnen Leistungen haftet, sondern die ganze Lebensleistung bis. ins Innerste durchdringt und nichts übrig läßt als die Hoffnung auf den lieben jüngsten Tag, der von diesen dem christlichen Ideal niemals ganz angemessenen und meist durch die Sünde noch völlig verkehrten Lebensbedingungen erlöst. Nur die eigenmächtige Selbstbefreiung von diesen Bedingungen, wie sie das Mönchtum vollzieht, ist verboten. 'Statt dessen ist die Gesinnung der Weltverleugnung hineingetragen in den täglichen natürlichen Weltgebrauch selbst. Daneben fehlt es dann nicht an Aeußerungen einer wirklichen Liebe zu Welt und Natur, die ja an sich gut und nur durch die Sünde verderbt sind, und die ganze Ethik kann gelegentlich wie eine religiöse Verherrlichung und Durchdringung der Natur erscheinen. Aber das ist eben der tiefe innere Widerspruch, die tiefe innere Spannung, die im Ganzen liegt und die uns zeigt, daß der vom Katholizismus unternommene Kompromiß hier nur an eine andere Stelle verlegt, mehr in die innere Tiefe hineingeführt ist; daß er aber ein Kompromiß bleibt. Es ist der vom praktischen Leben geforderte, mit der Universalität der christlichen Gemeinschaft unumgängliche, von der Verlegung der Heiligkeit aus der Aktivität der Subjekte in den objektiven kirchlichen Gnadenbesitz ermöglichte Kompromiß der rein religiösen Moral mit den Forderungen des Weltlebens.

Faßt man alles das zusammen und blicken wir auf die Darstellung des Mittelalters und der alten Kirche zurück, so kann man sagen : der Protestantismus führt die im späten Altertum schüchtern angebahnte, vom Mittelalter aber erst wirklich vollzogene Rezeption des Weltlebens in die Ethik einer christlichen Universalgesellschaft fort und steigert sie bis zum letzten möglichen Grade. Indem er eine Erneuerung des urchristlich religiösen Geistes ist, empfindet er zunächst gerade darin die höchsten Schwierigkeiten und nähert sich einerseits in der Bildung kleiner Gemeinden innerhalb der äußeren Christenheit und in der Scheidung der Gesinnungsmoral von der weltlichen Amtsmoral dem Sektentypus, der auch in der Tat aus ihm heraus an diesem Punkte entspringt. Indem er aber andrerseits zugleich das Ideal einer die ganze Gesellschaft umfassenden reinen Gnadenanstalt und die Einheit der christlichen Gesellschaft festhält, verwirft er den Sektentypus als Neigung zur Gesetzlichkeit und als lieblose Rottierung und Spaltung. Von dieser Verwerfung aus gelangt er zu einer immer steigenden Anerkennung des Weltlebens und der Weltmoral. Ganz analog wie im Thomismus der Gegensatz 
der relativen Lex naturae gegen die Gnadenethik immer mehr verschwand und zu einer Unterstufe der Gnadenethik wurde, so wird hier die Lex naturae immer mehr zu einer bloßen Form, die die christliche Gesinnung mit der religiösen Liebe und Kraft durchglüht und die sie zur Voraussetzung ihrer Betätigung macht. In engem Zusammenhang mit der Ausprägung der kirchlichen Gnadenanstalt zu einer Staat und Gesellschaft beherrschenden I.ebenseinheit wird auch die. Ethik ausgeprägt zu einer christlichen Beseelung des Lebens in den gottverordneten und darum heiligen -Ständen und Berufen c, die mit dem Naturgesetz gegeben sind und außerdem großenteils im Alten Testament von Gott unmittelbar eingesetzt oder bestätigt, vom Neuen Testament nicht widerrufen worden sind. Ist katholisch die Gnade die Perfektion und Ueberbauung der Natur, so ist sie protestantisch die Erfüllung der naturgegebenen Lebensformen mit der Glaubens- und Liebesgesinnung. Verteilt der Katholizismus beides auf verschiedene Stände, so fordert der Protestantismus von allen die gleiche Moral. Behauptet der Katholizismus die Möglichkeit der vollen Heiligkeit und behält er damit Sonderkreise höherer Christlichkeit, so verhaftet der Protestantismus alle unter die Unüberwindlichkeit der Sünde und gibt allen als gleiche Quelle der Moral die Glaubensgesinnung, deren Bewährung bei der Unmöglichkeit einer vollen Heiligkeit dann auch gegen die äußeren Lebensverhältnisse indifferent ist. Es ist die übliche Auffassung des Protestantismus, daß er gegenüber derjenigen Lösung des Problems `Christentum und Kultur «, die den Katholizismus und die Sekten gemeinsam beherrschte als Askese und Gesetzlichkeit, - dort als das Weltleben anerkennende und daher verweltlichte, hier als die Welt verwerfende und daher schroff einseitige Askese und beide Male als Gesetz seinerseits die gesetzesfreie Innerlichkeit des Christentums und damit dann auch die freie Durchdringbarkeit des Weltlebens mit der christlichen Gesinnung behauptet habe. Allein das ist beiden gegenüber nur bedingt eine wirklich neue Lösung. Das von ihm allerdings wieder hergestellte Prinzip der reinen Gesinnungsfreiheit ist doch ein inhaltlich streng an die Bibel gebundenes Prinzip und steht dadurch der Ethik des Sektentypus mit ihrer generellen Verwerfung von Recht, Macht, Staat, Gewalt, Eigennutz sehr nahe, und die Ausdehnung dieses Geistes vermöge einer kirchlichen Erlösungsanstalt über eine einheitliche christliche $\mathrm{Ge}$ sellschaft steht andererseits wiederum der Ethik des katholischen 
Kirchentypus sehr nahe. Die protestantische Lösung der Spannung in der doppelten Moral von Person und Amt ist nicht eine Ueberwindung, sondern eine neue Formulierung des Problems, und auch bei dem Protestantismus ist die Verflachung des Problems zu einer weltliche und christliche Moral einfach aus der Bibelautorität ableitenden Gesetzlichkeit nicht ausgeblieben. Sie ist nicht nur im Calvinismus, sondern auch im Luthertum eingetreten und in dem ersteren nur in dem Maße stärker betont als er überhaupt die sittliche Organisation der Gemeinde stärker durchführt ${ }^{230 a}$ ).

230 a) Dieser Satz von der richtigen Mittelstellung des Luthertums zwischen einem System gemäßigter Askese und kirchlicher Gesellschaftsleitung einerseits und einem sektenhaft enthusiastischem Radikalismus anderseits wird namentlich für das christlich-soziale Problem der Gegenwart gerne angeführt. Die echte chrịstlich-soziale Idec wäre es darnach, der freien ungesetzlichen Liebesmoral die Gesinnung vorzubehalten und die Sozialreform selbst lediglich den politischen und sozialen Technikern zuzuweisen, die aus dieser Gesinnung die geistigen Kräfte für ihre Aufgabe beziehen können. >Gewiß, äußert sich R. Sohm brieflich, ist das Evangelium als ein soziales Programm enthaltend verstanden worden. Dadurch wurde das Evan-

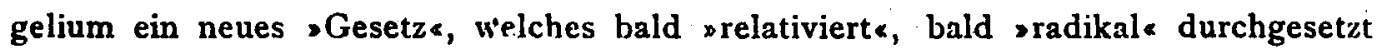
wurde. Die Entwickelung bestand aber, glaube ich, darin, daß dieser Standpunkt überwunden wird, und den ersten großen Fortschritt in dieser Richtung muß ich in Luthers Reformation erblicken. Den zweiten Schritt, der zur Gegenwart führte, vermittelte dann die Aufklärung... Die ethischen Konsequenzen der durch die Gottesliebe gegebenen Bruderliebe lassen sich in kein für alle Zeit gültiges $>$ Gesetze oder Programm: zusammenfassen und sind darum kein Bestandteil des Evangeliums, das für alle Zeit gültige Heilsbotschaft ist, das lediglich religiösen Inhalts ist, soziale Kräfte, aber kein soziales Programm hervorbringt<. Das ist nun aber jedenfalls nicht der Sinn des lutherischen Gedankens in seiner Anwendung auf soziale Dinge. Denn nach Luthers Idee sind die letzteren nicht frei beweglich, sondern durch Naturgesetz an eine völlig antikapitalistische Tendenz gebunden; die moderne Sozialgestaltung hat Luther im Namen der Natur wie in dem des Evangeliums verworfen, wie der nächste Abschnitt zeigen wird. Andrerseits ist aber auch das Evangelium für Luther nicht die persönliche Liebesgesinnung, die die Kräfte zu einer Verchristlichung der an sich aus dem Lauf der Dinge notwendig werdenden Sozialordnungen darbietet, sondern eine Personmoral der unbedingten Liebe und Leidensbereitschaft, die die Amtsmoral des Rechtes und Besitzes nicht durchdringt und formt, sondern duldet und leidet als einen unüberwindlichen mit der Sünde gesetzten Gegensatz. Eher fiele der Calvinismus unter diese Auffassung, der mit der christlichen Gesinnung in der Tat die gegebene Gesellschaft durchdringt und keinen unüberwindlichen Gegensatz der Amts- und Personenmoral kennt. Abẹr jede solche Gesinnung muß bei der Anwendung zum Programm und 
Aus diesen Aehnlichkeiten und Unterschieden gegenüber dem mittelalterlichen Katholizismus ergibt sich auch Aehnlichkeit und Unterschied der beiderseitigen Sozialphilosophie. Die protestantische Sozialphilosophie führt das naturrechtliche Gedankenkapital der Patristik und des Katholizismus in seiner engen Verschlingung mit dem christlichen Ideal fort, gibt aber der Beziehung und Zusammenfassung beider einen neuen Sinn. Da aber die Spannungen zwischen diesen beiden Elementen nur an einen anderen Ort verlegt sind, so kehren sie in veränderter Weise auch in der protestantischen Sozialphilosophie wieder. Andererseits ergibt

zum Gesetz werden und ist das daher im Calvinismus auch geworden, wobei sein Gesetz ja auch kein unwandelbares war, sondern den verschiedenen Lebensbedingungen der calvinistischen Völker mit großer Elastizităt folgte; das wird der dritte Abşchnitt zeigen. Die von Sohm klassisch formulierte Theorie ist vielmehr eine sehr moderne Theorie, wie er selbst anzudeuten scheint. Sie hat zur Voraussetzung die Einsicht in die Unmöglichkeit einer Festlegung der sozialen Ordnungen und die Beurteilung dieser Dinge nach ihrer immanenten rein weitlichen Notwendigkeit, eben damit der Rückzug der Religion auf das rein Gesinnungsmaßige und Religiöse. Sie enthält aber gleichzeitig die ebenfalls moderne Forderung, daß die christliche Gesinnung die soziale Welt durchdringen müsse, d. h. die Forderung einer einheitlichen Moral, die im Unterschied von Luthers Dualismus die immer bewegliche soziale Welt akzeptieren und zugleich doch auch mit ihrem eigenen (ieist durchdringen und gestalten soll. $\mathrm{Da}$ ist nur eben die Frage, ob und wie las gegenüber dem modernen sozialen Leben überhaupt möglich ist, und ob das nicht eine innerlichste Umbildung der christlichen Moral zur Einbeziehung der weltlichen Lebenswerte nötig macht, auch wenn bloß eine Gesinnungsdurchdringung der gegebenen Notwendigkeiten gefordert und auch wenn diese ernstlich unter das Ideal gebeugt werden sollen. Damit ist man aber bei den Problemen der modernen christlichen Ethik, die mehr Aehnlichkeit mit denen des Calvinismus als mit denen des Luthertums haben, freilich auch vom ersteren in einer heute nicht mehr möglichen biblizistischen, d. h. stark alttestamentlichen Weise gelöst worden sind. Nicht aus der Bibel, sondern aus der christlichen Gesinnung, d. h. aus dem entwickelungsfähigen christlichen Prinzip müssen heute diese Fragen beantwortet werden, wenn sie überhaupt beantwortet werden können. Das ist aber etwas anderes als die alte lutherische Position. Das ist ein modern entwickelungsgeschichtliches Denken, wie ja das die Worte Sohms selbst indirekt mir zu besagen scheinen. Die neue Position ist ein Ergebnis eines Fortschrittes, der vom Mittelalter zum Protestantismus und von diesem $z u$ einer aus dem letzteren entsprungenen, aber mit ihm nicht identischen modernen Christlichkeit führt. Dieser überall erkennbare Grundsachverhalt zeigt sich auch bei dem Problem der Soziallehren des Christentums, vgl. meine Darstellung des Protestantismus in sKultur der Gegenwarte I, IV, I S. $634-649$. 
sich von hier aus auch Aehnlichkeit und Unterschied gegenüber dem Sektentypus. Mit diesem teilt der Protestantismus die Gleichheit und Strenge der christlichen Forderung gegen alle und damit den religiösen Individualismus. Allein er leitet dieses Individuum überall erst $a b$ aus der Wirkung der erlösenden Gnadenanstalt und stellt es vermittelst dieser in den Zusammenhang der von ihr umspannten Kulturgemeinschaft. Darum stehen trotz alles Individualismus die protestantischen Soziallehren den katholischen sehr viel näher als denen des Sektentypus.

Damit haben wir nun endlich die Voraussetzungen für das Verständnis der protestantischen Sozialphilos ophie in der Hand. Von hier aus erhellt ihr wesentlicher Unterschied gegen die katholische Sozialphilosophie und auch ihr Verhalten zu dem christlichen Radikalismus, der aus dem Protestantismus ebenso als Komplementärbewegung hervorgegangen ist wie aus dem Katholizismus.

Es wird sich im folgenden darum handeln, die aus diesen Grundlagen emporwachsende Sozialphilosophie des Luthertums darzustellen, das ziemlich konsequent aus den angegebenen Grundlagen sich herausbildet, und sodann die des Calvinismus, die sehr erhebliche Modifikationen an dem gemeinsamen Gedankenkapital vorgenommen hat. Beiden Konfessionen gegenüber wird die Frage sein nach ihrem Kirchenbegriff und der Art der Sicherstellung der Universalität und Herrschaft der Kirche. Sodann wird es sich um die kirchliche Ethik handeln und die Art der Einverleibung der weltlichen Kultur und der profansozialen Werte in diese kirchliche Ethik. Da in dieser Zusammenfassung des Gesamtlebens unter die kirchliche Idee bewußt oder unbewußt das Ideal eines alle diese Bildungen umfassenden soziologischen Grundschemas enthalten ist, so wird es sich weiter um das hierbei jeweils vorschwebende soziologische Grundschema handeln. Erst auf diesen Grundlagen wird dann die letzte Frage nach der besonderen Gestaltung der sozialen Hauptphänomene in Familie, Staat und Gesellschaft beantwortet werden können.

Aber das konfessionelle Luthertum und der Calvinismus sind nicht die einzigen Erzeugnisse der lutherischen Bewegung. Neben diesen dem Kirchentypus folgenden Neubildungen sind aus ihr auch solche entsprungen, die den Kirchentypus gesprengt und mehr oder minder konsequent den Sektentypus entfaltet haben. Hier zieht sich von den Täufern und den Spiritualisten bis 
zu den Independenten, dem Pietismus und den modernen Sekten eine ununterbrochene Kette von Komplementärbewegungen, die, : wie bereits mehrfach gezeigt, aus Luthers Ideenwelt hervorgehen mußten, sobald dessen Voraussetzung, der Kirchengedanke, durchbrochen wurde und denen er selbst sich in seinem Gemeindeideal und in seiner radikalen mystischen Ethik bei aller inneren Fremdheit doch auf Haaresbreite genähert hatte. Sie bringen erst durch ihren Kontrast den konfessionellen kirchenbildenden Protestantismus zum vollen Verständnis. Ueberdies aber haben sie seit ihrer Loslösung von der Reformation diese aufs stärkste rückwirkend beeinflußt, das Luthertum, indem, sie es über die Gefahr des Subjektivismus aufklärten und in den strengsten Objektivismus hineintrieben, den Calvinismus, indem sie ihn zu weitgehender Aufnahme ihres Heiligungsgedankens veranlaßten und damit schließlich seine volks- und staatskirchliche Struktur brüchig machten. Und abgesehen von diesen Wirkungen auf die Konfessionen haben sie eine allgemeine weltgeschichtliche Bedeutung, indem sie mit ihren Konsequenzen und Ausläufern den religiösen Subjektivismus überhaupt, die Trennung von Staat und Kirche, die Independenz der Gemeinden und schließlich des Individuums bedeuteten und damit dem Subjektivismus der Aufklärung einen vollen Strom religiöser Motivierungen zuführten. So hat ein letztes Kapitel noch von dem Sektentypus auf protestantischem Boden zu handeln.

\section{Das I, uthertum.}

Auf dem Grunde der späteren, entschlossen landeskirchlichen Ideen Luthers erhob sich das gesamte Sozialwesen des Luthertums d. h. derjenigen kirchlichen und kulturellen Bildungen, die konsequent und ohne wesentliche Neuerung aus den lutherischen Ideen entwickelt worden sind. Iieses Luthertum ist über seine Stammlande hinaus freilich nur in die deutschen Territorialstaaten, die skandinavischen und baltischen I,änder vorgedrungen und hat auch an der deutschen Westgrenze starke Verluste an den Calvinismus erlitten. In Frankrcich, England, den Niederlanden und Schottland erlag es überall andersartigen, aktiver vordringenden kirchlichen Bildungen. Im Süden und Osten ist es durch die katholische Gegenreformation zurückgedrängt worden, die den Thomismus und die Renaissance zu einer neuen Verbindung sammenschmolz und dadurch dem Luthertum sozial und 
kulturell in vieler Hinsicht auf einige Zeit wieder überlegen wurde. Sein Fundament ist überall der Gedanke einer kirchlichen, von religiösen Ideen zwangsmäßig beherrschten Kultur, so sehr auch in ihm theoretisch weltliche und geistliche Gewalt von einander unabhängig gemacht sind und die katholische rechtliche und mit direkten .kirchlichen Mitteln zwingende Oberherrschaft einer internationalen, hierarchischen Kirche beseitigt ist. So bleibt das Zentrum seiner Soziallehren doch überall der Begriff der Staatskirche, und alle außerreligiösen Sozialbildungen erscheinen in dem Lichte, wie es sich aus ihrer Eingliederung unter den Gedanken einer von der Kirche mit religiösen Endzwecken durchwirkten einzelstaatlichen Gesellschaft ergibt. Das gehört beim Luthertum nicht bloß zum religiös-ethischen Ideal, es gehört zur Möglichkeit seiner Existenz, die ohne Halt ist, wenn nicht ein christlicher Staat oder eine christliche Gesellschaft dieser zarten organlosen Pflanze das Spalier darbietet, an dem sie emporwachsen und die Früchte ihrer reinen Innerlichkeit reifen lassen kann.

Der Kern des Ganzen ist daher der spezifisch lutherische $\mathrm{Begriff} \mathrm{der} \mathrm{Kirche}$, und für diesen ist wiederum die prinzipielle religiöse und dogmatische Anschaúung der Kirche von sich selbst grundlegend ${ }^{231}$ ).

Hier ist nun das Entscheidende erstlich die von Luther vorgenommene und von den lutherischen Theologen im wesentlichen während der klassischen Zeit des korrekten Luthertums

${ }^{231}$ ) S. hierzu Möller - Kawerau, Lehrbuch der Kirchengeschichte III $^{3}$, 1907, Riecker, Die rechtliche Stellung, und vor allem Sohm, Kirchenrecht I. Dic Darstellung von Solım ist nicht nur überaus geistvoll, sondern hat auch einen sehr unbefangenen, durch moderne kirchenrechtliche Konstruktionen nicht getrübten Blick für das Geschichtlich-Tatsächliche. Hier ist die lutherische Lehre in ihrem, innerlichsten und eigentlichsten Ziele verstanden. Die Paradoxie der Sohmschen Darstellung entsteht nur dadurch, daß sie den überidealistischen Wunder- und Glaubensbegriff des Luthertums von der Kirche, den dieses selbst durch ein sehr realistisches weltliches Kirchenrecht ergänzt hat, wie etwas auch ohne diese Ergänzung existieren Könnendes und Sollendes behandelt; und das historisch Anfechtbare ist die Gleichsetzung jenes idealistischen lutherischen Kirchenbegriffes mit dem urchristlichen, der noch überhaupt keine rechtliche Tradition hatte und nicht mit rechtslosen, aber rechtlich völlig unpräzisierten Vorstellungeı: arbeitet und vor allem das Amt unter den enthusiastischen Begriff des Charisma stellt. Darüber sogleich mehr; außerdem vgl. oben S. 452 f. Der Punkt, an dem ich von Sohms Darstellung des Faktischen abweichen zu müssen glaube, kommt später zur Besprechung, vgl. Anm. 236.

Troelt s ch, Gesammelte Schriften. I. 
immer festgehaltene ungeheure Spiritualisierung der Kirche. Der zwcitc entscheidende Grundzug ist dann aber, daß diese völlig spiritualisierte Kirche, die kein menschliches Zwangsorgan für dic licststellung der reinen Lehre mehr besitzen und die auch ihre Kirchenzucht durch kein äußerliches, rechtlich formulierbares Gewaltmittel durchsetzen kann und will, trotzdem ganz und gar auf den Gedanken einer einhelligen und unwandelbaren dogmatischen I.ehre erbaut ist, die nur in ihrer Reinheit und Geschlossenheit die Erlösung von Sünde und Verdammnis zu bewirken imstande ist; Jazu kommt, daß sie trotz ihrer Spiritualität und ihres Verzichtes auf cin ihr als solcher zustehendes Rechts- und Zwangsmittel doch zugleich das äußere Leben des von ihr beherrschten politischen Gcbictes unbedingt sich unterwerfen muß. Das sind Gegensätze, dic an und für sich zu jedem bisherigen christlichen Kirchenbegriff enthalten sind, deren Spannung aber nirgends so weit getrichen ist als im Luthertum und deren Feindseligkeit auch seine ganze lintwickelung gelähmt hat.

So versteht sich die idealistische Seite dieses Kirchenbegriffes, von der her er etwas völlig Neues in der Geschichte des christlichen Kirchenbegriffes ist. Die Schrift als Trägerin der reinen L.ehre von der sündenvergebenden und ernewernden Gnade bewirkt alles rein durch sich selbst, durch ihre dem Glauben gewisse innere Wunderkraft. Sie beweist durch das \%eugnis der inneren lirfahrung ihre eigene göttliche Inspiriertheit, dic sich in steigendem Maße auf den gesamten Schriftinhalt bis auf Interpunktion und Textform erstreckt. Sie ist dadurch die absolute und alleinige, die die Kirche selbst leitende Norm, dic Autorität, in der Christus selbst wirksam ist und neben der es kiner menschlichen Tradition, keines unfehlbaren Lehramtes. kines Priestertums und keiner Hierarchie bedarf. Sie legt sich selber aus, indem sie aus den klaren Stellen die dunklen normicrt unil durch dic Kraft des ihr einwohnenden heiligen (jcistes ein völlig cinhelliges, objektives Bekenntnis bewirkt; diese iun ier Schrift sclber hervorgebrachten Normen ihrer eigenen Auslesun: sind nicdergelegt in den Symbolen. Die Schrift oder der in und durch die Schrift wirksame Christus vollzieht das Work der l'rediyt und der Sakramente, wobei der ordnungsmäßig licrulere (iciutliche nur ihr ()rgan ist und rermöge der reinen l.cha (hrinius selbst in ihm redet, predigt und urteilt. Die Schnt. oder Christur durch sie, flößst den Glauben, die Liebe und 
den Gehorsam ein, vermöge dessen alle sich der Schriftwahrheit unterwerfen, den durch Charisma und Berufsbildung zur Verkündigung geeigneten Prediger willig anhören und die geistlichen Strafen gerne leiden. So regiert Christus durch die Schrift die Kirche, ist er selbst der Inbegriff der obersten Lösegewalt, der Bewirker der sakramentalen Vorgänge, der Träger der Jurisdiktionsgewalt, die formende, leitende, urteilende Macht in der Gemeinde, die alles durch rein spirituelle Wirkung leistet, was Papsttum, Priestertum, Hierarchie, römisches Recht und römische Zwangsgewalt durch äußerliche menschliche Mittel gclicistet haben. Das Regiment, die oberste Lehrinstanz und die richterliche Hoheit sind nicht bei der Gemeinde, die vielmehr nur das Produkt der Schrift und reinen Lehre ist; sie sind nicht bei den Geistlichen, die nur die geordneten Durchgangsstellen für die Selbstauswirkung der Schrift sind; sie sind nicht beim Landesherrn, der nur ein zum Dienst am Heiligtum verbundener Diener ist und der Selbstauswirkung des Wortes nur seine Dienste zur Verfügung stellt. Es ist vielmehr lediglich die auf das Wunder der Schrift erbaute Schriftkirche selbst, deren Wunderkräften man nur den Lauf lassen muß, um von ihr und Christus selbst schließlich alles hervorbringen zu lassen. Wenn katholisch der Papst die fortdauernde Inkarnation Christi, die lebendige Lehr- und Jurisdiktionsgewalt ist, su ist das für das Luthertum die Schrift, durch die wie in einem lebendigen, aktionsfähigen Wesen Christus alles unmittelbar selber wirkt ${ }^{232}$ ).

232) Hierüber vor allem Sohm: der Ausgangspunkt von der produltiven Wunderkraft des Wortes und nicht von der Gemeinde, S. 5II-5I3; der auf freier Liebe und Unterwerfung beruhende seelsorgerliche Charakter der Jurisdiktion S. 522, 529; der charismatische Charakter des auf die freie Liebe und "Gcstattung a der Gemeinde rechnenden, nur übrigens ordnungsmäßig einzusetzenden Amtes S. 500-505, 518; das Urteilen über die Lehre Sache der Pastoren, aber nur als der berufsmäßigen Organe für die Selbstinterpretation der Schrift oder als Yund Christi S. 52I, 492 f.; die Liebesordnung in der Gemeinde im Gegensatz zur Rechtsordnung S. 494-496. Das Entscheidende für das Luthertum ist der Glaube an die wunderbare, automatisch kirchenbildende Kraft des Wortes Gottes, s. die Stelle bei Sohm S. 492. Aehnliche Stellen S. 6I6; auch in der späteren Orthodoxic ist es der Grundgedanke, s. Schmidt, Die Dogmatik der er-luth. Kirche ${ }^{*}$ I $_{7} 6 \leq 432$. Dieser supranaturale und objektivistische Spiritualismus verbunden mit der Llee, daß der auf weltliche Wohlfahrtszwecke gerichtete rechtliche Statt an diese Sphäre nicht heranreicht, wohl aber ihr dienen darf, ist die Quelle der charakteristischen 
Dieser extreme Spiritualismus und alles auf die Kraft der Schrift stellende Wunderglaube war praktisch natürlich nicht durchzuführen. In Wahrheit bedurfte diese einhellige, alles überwindende und ordnende Wirkung der Schrift sehr stark der menschlichen Nachhilfe. Die einhellige Schriftdeutung ergab sich nicht von selbst, sondern mußte zwangsweise durchgeführt werden. Die geordnete Aufstellung der Prediger vollzog sich nicht von selbst, weder durch eine Selbstdurchsetzung der charismatischen Begabung, noch durch freiwillige Liebe und Unterwerfung unter das charismatische Amt; es mußte eine bestimmte Rechtsordnung für die Berufung von Geistlichen und für die Anerkennung ihrer Autorität geschaffen werden. Die Jurisdiktion des Bannes setzte sich nicht durch freiwillige Unterwerfung durch, sondern nur unter Mithilfe staatlicher Einwirkung und unter Anheftung auch bürgerlicher Strafen an geistliche Vergehen. Außerdem bedurfte 's der ganzen finanziellen und technischen Ordnung des kirchlichen Betricbes, wofür mit dem rein spiritualen Regiment der Schrift gleichfalls nicht gesorgt war, von der Verflechtung der Kirclk mit der Bekundung des Personenstandes und dem Eherecht yar nicht zu reden. Für die Erledigung all dieser Dinge besaß die rein spirituale Kirche der alles bewirkenden Schrift kein Oryan und vor allem keine innerlich notwendige, göttlich autorisierte Kic.slun: So mußte sie diese Dinge als rein äußerlich und ichnisch, als rein menschliche Zweckmäßigkeiten andern Instanzcn übergeben, dic vom göttlichen Geiste geleitet auf menschlich belicbigre Weise das Zweckmäßige hervorbringen würden. So blicb nur der Landesherr und die politische Gewalt, dic so wie so von amtsweren mit technisch-rechtlichen 1)ingen beschäftigt ist und die als wichtigstes Kirchenmitglied, als membrum praecipuum, der Kirche diesen Liebesdienst qu leisten verpflichtet ist. Dafür fanden sich dann auch noch naturrechtliche liegründungen. Die Obrigkeit schützt das mit dem Dekalog identische natürliche Recht und hat als christliche Obrigkeit dicses natürliche Recht in seinem Vollsinn zu behaupten, wie es auch dic erste, den wahren Kultus und reine Gottesfurcht fordernde Tafel einschließt. So ist sie als custos utriusque tabulae auch naturrechtlich zur Unterstiitzung des Kultus, der. reinen Lehre und

Aeuberungen Luthers über das Verhältnis von Geistlichem und Weltlichem, auch der am meisten modern klingenden. 
der kirchlichen Jurisdiktion verbunden ${ }^{233}$ ). Derart kommt es $-\mathbf{z u}-$ nächst noch möglichst in Luthers Sinn - zu einer Ergänzung der rein geistlichen Kirchenordnung durch eine rein weltliche Machtund Rechtsordnung, welche mit den weltlichen Zwangsmitteln des brachium saeculare das ausübt, was die Kirche als rein spirituale Liebes- und Freiheitsordnung nicht gewaltsam erzwingen kann und will. Ein rechtliches Zwangskirchentum ist aufgerichtet. Allein das Zwangselement wird nicht von der Kirche ausgeübt, sondern seinem niedrigeren Wesen entsprechend vom Staate. $\mathrm{Daß}$ das unter der Firma weltlicher $Z$ wangsordnung und unter dem Titel bürgerlicher Vergehen geschieht, rettet formell die geistliche Liebesnatur der Kirchenordnung, sichert ihr aber materiell die gleiche Wirkung, als ob sie das unmittelbar selbst bewirkte; denn es wird hierbei größtenteils von der weltlichen Gewalt auf Anzeige der geistlichen Seelsorgestellen hin vorgegangen ${ }^{234}$ ). Das Verfahren ist nur sehr umständlich. So war es dann zwar eine Preisgebung der ächt lutherischen Theorie, aber eine einfachere Sicherstellung der Wirkung, wenn schließlich in den Konsistorien kirchliche, vom Landesherrn bestellte Regierungsorgane geschaffen wurden, die im Zusammenwirken von Geistlichen und Juristen gleich direkt zwangsmäßig in die Kirche hineinregieren und unmittelbar Geld- und Gefängnis- und Leibesstrafen verhängen und exequieren konnten, die also in der Kirche und für die Kirche ein die reine Lehre und christliche Sitte aufrechterhaltendes Straf- und Zwangsregiment führten ${ }^{235}$ ).

283) Ueber die Theorie vom membrum praecipuum vorziiglich klar Sohm $55^{8}$ bis 573, über die custodia utriusque tabulae Sohm 549-558.

231) Vgl. Sohm 622 u. 627 ; sund wäre not, daß weltliche Obrigkeit nach Gelegenheit der Sachen die Verächter des (zunächst rein geistlichen, von Pfarrer und Gemeinde bewirkten) Bannes in ihre Straf auch nähme «, in dem von Luther unterschriebenen Wittenberger Gutachten von 1545 über die zukünftige Art der Kirchenregierung. Sie wird von Sohm mit Recht als spezifisch lutherische Ansicht bezeichnet entgegen der Melanchthons und der meisten übrigen, die der Kirchenregierung die unmittelbare $\mathrm{Mach}$ geben wollen, *nach der heiligen Schrift und $a \mathrm{u} \mathrm{ch}$ den gemeinen in unseren Landen gebräuchlichen und üblichen Rechten zu sprechen, .. arctiora mandata mit Bedrohung ernstlicher Poen als Geldstrafen, Gefängnis u. dgl. zu dezernieren «, und die weltlichen Behörden verpflichten wollen, die rechtskräftig gewordenen Urteile der Kirchenbehörde straks ohne Verlängerung und Verzug zu exequieren. S. 628.

235) Zum Ganzen die lichtvolle Darstellung bei Sohm, 542-633. Hier auch die richtige Erklärung für diese Entwickelung aus dem Verzicht auf den supra- 
Das, was so für Thcoric und Glaube nur ein nebensächliches menschliches Beiwerk an dem auf supranaturale Kräfte wesentlich erbauten kirchlichen Gebilde war, das wurde praktisch besrciflicherweise die Hauptsache. . Die Landesherrn schufen dic Einigung der Theologie zu einem einhelligen Dogma und gaben den symbolischen Büchern die Zwangsgeltung. Sie schufen kirchlich-staatliche Bchörden, welche Verwaltung und kirchliches Gericht in ihre Hand nahmen unter Beteiligung der Theologien. Sie übernahmen die christliche Glaubens- und Sittenordnung auf das weltliche Recht und gaben den geistlichen Strafen und Maßnahmen bürgerliche Rechtstolgen. In der Theorie regierte Christus und die Schrift in der Gemeinde, praktisch regierten die I andesherrn und die Theologen. Diese ganze Rechtsordnung war zunächst freilich etwas Menschliches, Veränderliches und Zufälliges. Aber bei ihrer entscheidenden Bedeutung für die Kirche sewann doch auch sie indirekt wenigstens einen dogmatischen und göttlichen Charakter. Indem nämlich die Wortverkündung ein geordnctes Amt forderte und dieses Amt von Gott in Christus selbst cingesetzt war, war dogmatisch die Notwendigkeit eines geordneten Amtes gegeben. Wenn auch der charismatisch Begabte zu diesem Amte jedesmal an sich bestimmt ist, so hängt doch scine Jinsetzung in das Amt an der Gottesordnung, daß ein Amt überhaupt sci und daß es auf geordnete Weise übertragen

naturalen Idenlismus, in Sohms persönlichet Anschauung eine Wirkung des Kleinglaubens. Wofiir er inshesondere Melanchthon verantwortlich macht, vgl. S. 6r2. J.uther lı, " ron solum angefïhrten stellen zeircen doch mehr einen Protest theologisch-biblisch legriimleler l.ulsheidemgen gegen juristisch-kanonistisch begründete als den Kamy, iles Frciwilighits- und Licbesorduung gegen die Rechts- und Zwangsordmun!: demn I.. ist ledeit, die Sïnder in Lehre und Leben dem weltlichen Gericht anziciegu zu weiterer weltlicher lestrafung. Damit ist doch nur mehr formell die licideritige Ordnung unterschicden, materiell kommt es auf ein Zwangs- und Rechinveri:inren auch in christlichen Lehr- und Zuchtsachen hinaus. Man bedurfte cuen des letzteren, und dic formellen Scheidungen Luthers waren praktisch bedeutun:slos. $l$ is wing eben nicht anders, $S .619$ : $\gg$ )as Begehren nach Rechtsordnung war auch hier stïker als der (jlaube an Christi Regiment und die Macht des Warte. Man w.lle das Kirchenrecht als Hilfe für das Wort. Gut, es kam, aber whim, um den Landesherrn zlim Herrn auch der Kirche einzusetzen «. - Ueber lic All wie es kam, s. K. Müller, Anfänge der Konsistorialverfassung, Hist. Z. 302, $\therefore 1-30$. 
werden müsse. So bleibt also ein jus divinum auch im Protestantismus, freilich nur ein kümmerlicher Stumpf: die Notwendigkeit, daß überhaupt ein Amt sei und daß der Träger auf geordnete Weise berufen werde. Daraus folgt notwendig ein Kirchenrecht jure divino, soweit es sich urn das Dasein des Amtcs überhaupt und um seine geordnete Besetzung handelt. Wie das gemacht wird, ist freie Sache rein menschlicher Zweckmäßigkeit. Es ist de jure divino, daß ein wenigstens diesen Punkt regelndes Kirchenrecht überhaupt sei. Das daraus entspringende materielle Recht selbst ist rein menschlich. Nur das `Daß *, nicht das *Wie? « ist göttlich. Ueberdies erstreckt sich auch so die Göttlichkeit des Kirchenrechts nur auf die Einsetzung des Schriftamtes, nicht aber auf die weiteren technischen Aufgaben des Kirchenrechtes. Immerhin aber genügt diese indirekte Göttlichkeit des Grundelementes des Kirchenrechtes, des geistlichen Amtes, um dem übrigens.ganz weltlichen Träger des Rechts der Amtsbestellung, der Obrigkeit, eine göttliche Mission und Autorität zu erteilen, die nicht verfehlen konnte, dann. auch in den übrigen Beziehungen dem vom Staat ausgeübten Kirchenrecht den Schimmer einer gewissen Göttlichkeit mitzuteilen und ihm damit die unentbehrliche innere Festigkeit zu geben. Aus dem übriggelassenen Stumpf eines supranaturalen Kirchenrechtes schlugen so wieder die Zweige eines wenigstens mittelbar göttlichen Rechtes aus, das die Leitung der Kirche oder vielmehr die amtliche Vertretung der reinen Schriftwahrheit den Geistlichen und den Landesherrn gibt. Was der Katholizismus durch ein unmittelbar göttliches Recht vollbringt, das vollzicht das jedes hierarchisch-priesterlichen Organs beraubte und rein spiritualisierte Luthertum durch die Obrigkeit und das weltliche Recht, dem aber eben darum auch eine gewisse Halbgöttlichlicit zuwächst. Die Scheidung des weltlichen und geistlichen Elementes ist nicht eine Trennung, sondern nur eine neue Nuancicrung ihres Verhältnisses: jetzt dient der Staat der rein geintlichen Kirche in freier Liebesgesinnung und beherrscht durch diesen Dienst die jedes selbständigen rechtlichen Organs entbehrende Kirche. Die Rivalität beider Gewalten ist theoretisch ausgeschlossen durch die Voraussetzung der in beiden sich durchsetzenden und beide im Glauben einigenden Schriftwahrheit wind praktisch durch die Schwäche der ganz vom Staat abhängigon Kirche sowie durch die Aufnahme der religiösen Aufgaben in 
den eigenen Lebenszweck des Staates ${ }^{236}$ ). Daß diese neue Regelung des Verhältnisses von Staat und Kirche nach der zweiten Seite hin ihre Vorbilder an dem spätmittelalterlichen Landeskirchentum hat, sei als bekannte Tatsache nur nebenbei erwähnt.

200) Damit habe ich in der hier allein möglichen Kürze Stellung genommen zu der berühmten These Sohms. Sie enthălt die wichtige soziologische Einsicht, daß jedes Kirchenrecht, das Recht der Kirche ist, als zum Schutz supranaturaler Größen bestimmt selber in diese Supranaturalităt hineingezogen wird und dadurch Eigenschaften erhält, die es für den präzisen und eigentlichen Juristen ganz inkommensurabel machen. Es liegt überdies der Widerspruch in diesem Recht, daß es das schlieBlich ganz individuell persönliche religiöse Leben durch formalistische und reln objektive Maßstäbe bindet und hindert. Allein das ist ein Widerspruch, der nicht in dem Dasein eines Rechtes in der Kirche, sondern im Begriff der Kirche als einer objektive Offenbarungsschütze durch fest erzwingbare Regeln schützenden Anstalt liegt. Der Idealbegriff der Kirche als einer lediglich durch das Wort sich selbst frei bildenden und regierenden Anstalt ist eine Utopie des Glaubens. Historisch ist nun die Frage, ob wirklich Luther rein und aussschließlich dieser Utopie des Glaubens gehuldigt habe, wie Sohm will, und die Einlührung eines göttlichen Rechtes in der Tat erst auf Rechnung Melanchthons, der Politiker und der Konsistorien komme oder mit anderen Worten, ob Luther, der so viele mittelalterlich-katholische Momente des Kirchenbegriffes, besonders den der alleinseligmachenden objektiven Lehre und der einheitlichen christlichen Gesellschaft, beibehalten hat, an diesem Punkte wirklich zur vollen Ausscheidung jedes göttlichen Rechtes aus der Kirche, jeder göttlich begründeten Sicherungsmaßregel für reine Lehre und Sittenordnung vorgeschritten sei. Die Antwort hängt an der Interpretation von L.s Lehre über das geistliche Amt. Sohm interpretiert den lutherischen Amtsbegriff ganz (S. 473) einfach all = dem urchristlichen charismatischen Gedanken und überschätzt die eigenen Ausführungen Luthers über den charismatischen Charakter des Amtes, S. 474: >Der Kern der Lehre Luthers ..., daß der Träger des Lehramtes ,nur von wegen der Gemeinde", nur im Auftrage der „Kirche" seines Amtes walte. Sein A m t kann er, geistlich angesehen, nur von $G$ ot t haben kraft der $G$ abe, welche ihm Gott gegeben hat, aber die A usübung des Amtes ist ihm nicht kraft Rechtsbefugnis, sondern lediglich kraft Gestat tung seitens der Versammlung (!) möglich. Tun hat aber Luther neben dieser supranatural-charismatischen Auffassung des Amtes auch unzweifelhaft die supranatural-rechtliche, daß das Amt der reinen Predigt ali die Schriftwahrheit repräsentierend und den amtlichen Mund der Gemeinde bildend von Gott gestiftet und-an die Voraussetzung einer ordnungsmäßigen, jede Rotlicrerei ausschliefienden Berufung gebunden sei. Das letztere wird von der herrschenden Auffassung mit Recht als Kern eines geistlichen Rechts betrachtet, indem Dasein und ordentliche Berufung de jure dafür gefordert und die Ausübung des Schriftrerständnisses der Gemeinde an diesen offiziellen Interpreten des Wortes Lebunden ist; nur die Art der Berufung ist menschlicher Sitte frei gelassen. Auf dieser letzteren Auffassung beruht die obige Darstellung. 
Aber auch dann ist hervorzuheben, daß das lutherische Kirchentum damit nicht lediglich einer ihm wesensfremden Ueberlieferung erliegt, sondern daß ihm auch von sich aus bei der Spiritualität seines Kirchenbegriffes und bei seiner Ablehnung eines göttlichen Gemeindekirchenrechtes, wie es später der Calvinismus durchbildete, gar nichts anderes übrig gcblieben wäre.

Dieser komplizierte staatskirchliche Lebenskreis ist nun aber trotz aller künstlichen Konstruktion ein soziales Ganzes. Für unseren Zusammenhang ist das Entscheidende die mit diesem Sachverhalt gegebene Deckung von Kirchengebict und Staatsgebiet, die Verfilzung von Kirchengewalt und Staatsgewalt, $\operatorname{der} Z$ us a m m e nfalldes Kirchlichen und Polit is chen in dem Begriff einer christlichen Gesellschaft. Gewiß gehört innerhalb dieser Gesellschaft zur eigentlichen Kirche, d. h. zur Gemeinschaft der durch das Wort wahrhaft Wiedergeborenen, nur der religiös lebendige Teil der Bevölkerung. Das ist die Ecclesia stricte dicta, von der die Dogmatiker reden. Aber davon ist nur unterschieden, jedoch nicht getrennt, die Ecclesia late dicta, d. h. die Summe der der Gebietskirche angehörenden und durch das Zwangschristentum des Staates in der Taufe der Kirche Zugeeigneten, die wenigstens äußerlich zum Hören des reinen Wortes, zur Einhaltung der christlichen Lebensordnung und zur Respektierung des christlichen Dogmas angehalten werden müssen ${ }^{237}$ ). Noch klarer kommt dieser

${ }^{237}$ ) Ueber diese externa disciplina, die die Obrigkeit als custos utriusque ta bulae staatlich und als membrum praecipuum ecclesiae kirchlich verpflichtet ausubt, s. die Worte Melanchthons bei Sohm: \$Magistratus est custos primae et secundae tubulae legis, quod ad externam disciplinam attinet, hoc est prohibere externa scelera et punire sontes debet et proponere bona exempla... Etsi enim magistratus non mutat corda nec habet ministerium spiritus, tamen habet suum officium externae disciplinae conservandae etiam in is, quae ad primam tabulam pertinent (d. h. in Fragen des Kultus und der Rechtgläubigkeit) ... Cum quaeras, quae sint officia magistratuum, tibi pingito magistratum cui de collo pendeant tabulae duae leyis Moysi. Horum custos esse debet politicus gubernator, quoad externam disciplinam attinet. Nam haec sunt summae leges, ex quibus ceterae honestae leges omnes tamquam ex fontibus derivantur«. Ueber die Art, wie diese externa disciplina zur Bewahrung christlicher äußerer Ordnung von den weltlichen Beamten gehandhabt werden solle, s. die Visitationsinstruktion von 1527, Sohm 607: \Die Amtleute, Schöffen, städtischen Räthe, adligen Gerichtspatrone sollen auch die Sachen strafen, „die unter Christen nit zu gedulden... als da sind: leichtfertig schwören und den Namen Gottes unnützlich annehmen, item Völlerei, Sauferei, Spiel, Mußiggang, item so in Wein- oder Bier- oder Trinkhäusern von den 
Zusammenfall der Kirche und der christlichen Gesellschaft zum Ausdruck in der lutherischen Ständelehre, die die mittelalterliche Gliederung der Bevölkerung in sacerdotes, domini saeculares und vulgares fortsetzt als Teilung in einen Status ecclesiasticus, politicus und oeconomicus und diese drei Stände ausdrücklich als Stände der Kirche oder als Hierarchien bezeichnet ${ }^{288}$ ). Diese auch Sachen, den Glauben beruhrend, schimpflich oder sonst leichtfertig gehandelt oder gezankt wird (also ein System der Denunziation, das nach Wapplers Aktenberichten in der Tat auch vielen Täufern sehr gefährlich geworden ist), Ehebrecherei, Hurerei, Ungehorsam der Kinder gegen die Eltern und sonderlich, so sich dieselbigen unterstünden, ihre Eltern mit Worten oder Handanlegung zu beschweren, item da sich die Kinder hinter der Eltern Wissen oder Willen verlobene. Ebenso ist zu strafen Unterlassen des Kirchgangs, Störung des Gottesdienstes und selbstverständlich die Irrlehre. Als Strafen sind Gefängnisstrafen den seigennützigen a Geldstrafen vorzuziehen. Später üben die gleiche disciplina die Konsistorien direkt im eigenen Namen S. 615 mit Geldstrafen, Gefangnis- und Leibesstrafen, auch mit dem großen Bann, d. h. der Folge des bürgerlichen Boykotts, suspensio ab officio, Absonderung vom Ratstuhl, Verbieten seines Handwerks, seiner Nahrung*. Sogar an ein eigenes konsistoriales Gefängnis ist gedacht. Diese Dinge zeigen erst, wie alles beherrscht ist von dem Gedanken der einheitlichen christlichen Gesellschaft. Auch Luther will all diese Dinge, nur nicht als Verfügung der geistlichen, sondern als solche der weltlichen Gewalt unter der Fiktion, daß alle diese Vergehen auch eine bürgerliche Seite haben, die der Staat als Stürung seiner Ordnung bestrafen soll! Demgegenüber nimmt der Calvinismus alle diese Dinge in die Hand des kirchlichen Zuchtgerichtes selbst, das über sehr wirksame srein geistliche. Strafen verfügt, und führt so von der Gemeinde her mit geistlichen Mitteln eine Sozialordnung durch, die das Luthertum der Obrigkeit anvertraute und die in den gemischten Konsistorien ganz unter die Gesichtspunkte staatlicher Interessen geriet, eben deshalb eine religiös-ethische Wirkung überhaupt nicht entfaltete.

2so) Gerhard bei Schmidt, Dogmatik S. 452: status sive ordines in e c clesia a $D$ e ins $t$ it u $t$ i numerantur tres, videlicet ecclesiasticus, politicus et oeconomicus, quos etiam hierarchias appellare consueverunt. Oeconomicus ordo inservit generis humani multiplicationi, politicus ejusdem defensioni, ecclesiasticus ad salutem aeternam promotioni. Oec. ordo oppositus est a Deo vagis libidinibus, polit. tyrannidi et latrociniis; eccles. haeresibus ac doctrinae corruptelise. Die Teilung ist uralt, siehe XXVIII 624; auch Böhmer, Luther S. 220; bei einem Bischof Gerhard von Cambrai 1036 (Luthardt Comp. S. 267) und dann wieder bei Stephan von Prag und Nikolaus von Clemanges, Köhler, Staatslehre der Vorreformatoren (Jahrbb. f. deutsche Theologie XX 95). Auch bei Wimpfeling I50I s. Roscher, Xationalökonomik, S. 37. Im letzten Grunde ist das übrigens wohl die platonische Einteilung der Stände seiner Politeia. Das Schema geht durch die ganze Ethik und Dogmatik des Luthertums hindurch und ist von der Ethik des modernen kon- 
für die einfachen deutschen Verhältnisse viel $\mathrm{zu}$ grobe Gliederung ist doch von großer praktischer Bedeutung. Denn sie bedeutet wie in der mittelalterlichen Kultur die Unterscheidung einer Kirche im eigentlichen und einer solchen im uneigentlichen Sinne ${ }^{238}$ ): im ersten bedeutet sie die nur in den Geistlichen und den kirchlichstaatlichen Behörden greifbare Predigtanstalt des reinen Wortes, im zweiten die christliche Gesellschaft im Gesamtumfang des staatlich-kirchlichen Gebietes und in der Gesamtheit ihrer Betätigungen und sozialen Bildungen. Das ist nichts anderes, als die mittelalterliche Idee des Corpus Christianum, innerhalb dessen es überhaupt eine Scheidung von Staat und Kirche, von Geistlichem und Weltlichem im modernen Sinne noch nicht gibt. Obrigkeit und Kirchengewalt sind zwei verschiedene Seiten der einen ungeschiedenen christlichen Gesellschaft, weshalb die Obrigkeit und der Staat direkt christliche Lebenszwecke haben und die Kirche die ganze Gesellschaft umfaßt. Aufgehoben ist nur die römische Uebereinanderschichtung eines in bescheidenem Umfang selbständigen Staates und eines zum gewaltsamen Eingriff in allen Interessen berechtigten Weltreiches der Kirche. An Stelle dessen ist eine freiwillige Konkordanz der christlichen Obrigkeit und der den weltlichen Beruf heiligenden Kirche im selbständigen Einzelstaat getreten, in der die Staatsgewalt der Kirche mit ihren Rechtsmitteln dient und die Kirche das Berufsleben in Staat, Recht, Gesellschaft und Wirtschaft als Gottes- und Nächstendienst heiligt. Der Zweck des Ganzen bleibt in der Theorie der religiöse Lebenszweck, nur das Verhältnis im Zusammenwirken der beiden diesen $Z$ weck vornehmlich verwirklichenden Gewalten ist ein anderes geworden ${ }^{239}$ ).

fessionellen Luthertums wieder aufgenommen, wobei man doch dem Pietismus eine Erweiterung über das enge Berufswesen hinaus in die sallgemeine christliche Humanität, z. B. innerer und äußerer Mission zu verdanken bekennt; s. Luthardt, Compendium der Ethik S. 267-269.

238 a) S. oben S. 292.

239) Ueber diese Idee des Corpus Christianum s. vor allem die trefflichen Ausführungen Rickers; ähnlich Sohm S. 540: „Den richtigen Standort für das völlige Verständnis der uns beschäftigenden Frage gewinnen wir, wenn wir die heutigen Vorstellungen von Staat und Kirche fahren lassen und uns in den noch mittelalterlich gestimmten kirchenpolitischen Gedanken des 16. Jahrhunderts versetzen. Die Begriffe Staat und Kirche im heutigen Sinne sind noch unbekannt. Der grundlegende Begriff ist der der Christenheit. In der Christenheit sind zwei Schwerter (zwei Regimente) von Gott gesetzt: das geistliche und das weltliche. Beide haben die Aufgabe, die Christenheit zu regieren, aber mit 
Mit dem bisher geschilderten Kirchenbegriff und dem Zusammenfall von Kirche, Staat und Gesellschaft im Corpus Christianum ist nun aber die entscheidende Voraussetzung für die lutherische Sozialphilosophic gegeben: Alle Sozialgebilde befinden sich im Rahmen der Kirche und beziehen sich auf den religiösen Lebens2weck der Gesellschaft. Die Frage ist nur, wie und in welchem Sinne hier die Bezichung stattfindet. Das erklärt sich, wenn wir die Grundzüge der $E$ thik des Luthertums uns vergegenwärtigen 239.)

Die lutherische Ethik ist eine doppelstämmige. Wie in der Gesellschaft Kirche und Staat, so stehen hier nebeneinander die Liebes- und Gnadenmoral einerseits und die Rechts- und Vernunftmoral andererseits. Die grundlegende Idce dieses Dualismus stammt von Luther und modifizicrt hier nur die mittelalterliche Doppelheit der Ethik. Melanchthon hat sie in dem Dualismus einer philosophischen und

verschiedenen Zielen und darum mit verschiedener Gewalt, das eine mit der geistlichen, das andere mit der weltlichen Gewalt. Das Wesen dieser beiden Schwerter und damit ihr gegenseitiges Gewaltverhältnis gilt es zu bestimmen. Das hat Luther getan. Seine Lehre von der Trennung der zwei Regimente stellt lediglich die reformierte Lehre des Mittelalters von den zwei Schwertern dar. Sie stellt klar die Frage nicht nach dem Verhältnis zweier Organisationen, sondern lediglich die Frage nach dem Verhältnis zweier Gewalten..., welche demselben einen großen Organismus der Christenheit angehören.a Weil die ganze Kultur des Luthertums hierauf beruht, habe ich diese in der ,Kultur der Gegenwart 4 als eine allerdings sehr tiefgreifende Umformung der mittelalterlichen bezeichnet. Davon urteilt dann freilich Böhmer S. 121, das sei snichts anderes als eine Behauptung, und 2war eine Behauptung, die eine klare Einsicht sowohl in das Wesen des Protestantismus wie des Katholizismus geradezu ausschließt a!

250.) Zur Ethik des Luthertums vgl. Troeltsch, Joh. Gerhard und Melanchthon; Hönnicke, Studien zur altprot. Ethik, I902 (dazu meine Rezension G.G.A. 1902 S. 577-583); Hupfeld, Ethik Joh. Gerhards, 1908 (dazu meine Rezension Th. L. 1909); auch die Geschichten der christlichen Ethik von Gaß und Luthardt; Th. Ziegler bleibt auch hier an der Peripherie. Lehrreiche Darstellungen der modernen lutherischen Ethik, aber ganz von lutherischem Geiste getränkt: Gottschick, Ethik 1907; Luthardt, Compendium der Ethik I896, reich an Zitaten aus der orthodoxen Ethik; v. Hofmann, Theolog. Ethik $187 \delta$, eine vortreffliche, wenn auch modernisierende Darstellung des Geistes der lutherischen Ethik. Die beiden letzteren lassen auch das Hochgefühl des Sieges dieser Ethik in Staat und Kirche nach der Interimsepisode der Aufklärung erkennen und geben eine Anschauung $v \backsim$ dem instinktiven Zusammenhang der modernen konservativen Partei mit dem Geist der lutherischen Ethik. Eine großartige Analyse der lutherischen Ethik im Verhältnis zur reformierten gibt Schneckenburger, vgl. >Darstellung des 
einer theoltgischen Moral fortgeführt, und die Orthodoxie hat jeden der beiden Stämme nur verbreitert und weiter verzweigt. Dabei ist wissenschaftlich ausgeführt nur der philosophische Teil der Moral; der theologische bleibt in den Dogmatiken stecken. Die Verbindung und Wechselwirkung beider zeigt nur das praktische Leben, das sie als etwas Selbstverständliches voraussetzt und betätigt. Das gilt freilich im Grunde von der ganzen bisherigen christlichen Ethik. Sogar die erstegrößere wissenschaftliche Ausführung der Ethik im Thomismus war in Wahrheit systematisch nur, soweit sie dem Aristoteles folgte und mit den aristotelischen Tugenden die christlichen auseinandersetzte; an eine Darstellung der ethischen Probleme im Gesamtumfang und in ihren letzten begn flichen Wurzeln dachte auch sie nicht. Wie so die christliche Ethik überhaupt mehr ein praktisch geltendes Ethos mit einzelnen theoretisch ausgeführten Punkten ist, so ist auch die Ethik des Protestantismus und vor allem des Luthertums keine mit ihrer Dogmatik irgend vergleichbare Theorie. Erst wo, wie einst in der Spätantilse und dann später im Aufklärungszeitalter, die ethischen Selbstverständlichkeiten des Lebens erschüttert sind, entsteht die ethische Theorie ${ }^{239}$ b). Das Christentum des Mittelalters und des konfessionellen

lutherischen und reformierten Lehrbegriffes«, I855. - Inımer im Auge zu behalten ist bei jeder Darstellung der protestantischen Ethik das lutherische Spezialdogma von der Auslegung der Bergpredigt, wonach diese nur die Gesinnung der Christen gegen den Christen ohne gesetzliche Bindung an ihre konkreten Beispiele regelt und vor allem neben dieser Gesinnungsanweisung gleichzeitig die bürgerliche und rechtliche Amts- und Berufsethik als gottgesetzte Rechtsordnung voraussetzt. Das ist ein biblisches Grunddogma, so wichtig wie die Rechtfertigungslehre, und steht gegenüber dem katholischen Dogma, daß die Bergpredigt die sevangelischen Ratschläge a einer einseitigen Vollkommenheitsmoral neben der Weltmoral für den besonderen mönchischen »Stand gebe, sowie dem Sektendogma, daß hach diesen Regeln die ganze "christliche Gesellschaft sich zu halten und daher sich von Staat und Welt als religiöser Sonderkreis zurückzuziehen habe. Das ist ein exegetisches Grunddogma des Luthertums gegenüber Katholiken und Täufern. Daher auch die charakteristische geschichtliche Konstruktion der Lutheraner, nach der die nachapostolische und altkirchliche Ethik unter heidnischen Einflüssen wieder > unsicher « geworden sei über das richtige Verständnis der Bergpredigt (v. Hofmann S. 294). In Wahrheit war das protestantische Dogma von der Bergpredigt noch nicht vorhanden und konnte nicht vorhanden sein. Es ist erst durch die mittelalterliche Entwickelung möglich geworden, worüber der relative Gegensatz nicht täuschen darf.

239 b) Darum ist es so verkehrt, zur Ehrenrettung des Altprotestantismus auch bei ihm schon stheologische Ethiker entdecken zu wollen. Die Leute von da- 
Zeitalters hatte eine wissenschaftliche Theorie seines Dogmas und in der damit metaphysisch begründeten Lebenswertung die Grundimpulse seiner Ethik. Herrschte jenes, so ergaben sich die ethischen Konsequenzen von selbst, und es bedurften nur einzelne Punkte einer besonderen Ausführung, wie das Verhältnis des Moralischen oder der »guten Werke zu der Gnade überhaupt, das Verhältnis der christlichen Moral zu den weltlichen Ordnungen und der nicht auf Gnadenversittlichung beruhenden Moral oder zu den beides regelnden Ueberlieferungen der antiken "philosophischen * Moral, das Verhältnis des Gesetzes und der Freiheit, des christlich-sittlichen Lebens und der Unüberwindlichkeit der Sünde. Alles übrige erledigte das Leben von selbst.

So muß denn die wirkliche lutherische Ethik des I6. und I7. Jahrhunderts erst von dem modernen Forscher gesucht und konstruiert, aus den Selbstverständlichkeiten des Lebens und den partiellen theoretischen Darlegungen herausgeholt werden, zu welchen Lehren nicht bloß die theologisch-dogmatischen sondern auch die juristischen und kameralistischen Darlegungen gehören ${ }^{240}$ ).

mals wollten und brauchten neben der Dogmatik keine Ethik, die erst seit den Erschütterungen der Aufklärung nötig geworden ist.

240) Belege für diesen Charakter in des Buddeus, Isagoge historico-theologica ad theologiam universam, Lpz. I720 II, 4: De theologia morali simulque de theologia mystica itemque jurisprudentia divina et prudentia tum christiana tum pastorali. Schon dieser Titel zeigt die Buntheit des Stoffes; der Rückblick auf die Geschichte der lutherischen Ethik S. $652-672$ hebt sie ausdrücklich hervor und bedauert, daß es keine systematische Darstellung gebe, obwohl Luther und Melanchthon alle Materien der Ethik erneuert hätten. Dazu kommt dann noch die theologia conscientiaria oder die Kasuistik S. 616, über deren Zusammenhang mit der lutherischen Praxis des Beichtstuhls, der die den Gnadenverlust bewirkenden Sünden von den ihn nicht bewirkenden unterscheiden mußte, Hupfeld sehr lehrreiche Mitteilungen macht. Auch nach dieser Seite hin stellt sich die Analogie mit der katholischen Ethik her: die kirchliche Ethik kann die von ihr verknüpften heterogenen Elemente nur durch Kasuistik und Beichtstuhl zusammenhalten trotz aller protestantischen Autonomie und Gesinnungsinnerlichkeit. Etwas Aehnliches zeigt sich uns beim reformierten kirchlichen Zuchtgericht. Der Unterschied liegt bloß in der Abwesenheit der Rechtsverbindlichkeit des Urteils, s. das Referat von Gaß II, I S. 157 über Balduin, Tractatus toti rei publica e utilis sive de casibus conscientiae 1628. - Ich gebe hier den Abriß der Materien nach $B$. wieder. I) Die eigentlich philosophische Ethik im aristotelischen Sinne beschäftigt sich mit Tugenden, Temperamenten u.s.w., was alles in die christliche Zentraltugend der Liebe hineingezogen wird, s. Luthardt, Compendium 
Es ist das für das Luthertum im ganzen einfach genug. Die lutherische Ethik ist in erster Linie die Begründung eines reli-

122-165. 2) Der andere Teil der Ethik ist die Lehre vom Naturrecht: Altera philosophiae practicae pars seujurisprudentiana$\mathrm{t} u \mathrm{ral}$ is de officiis hominum legibusque divinis, quibus illa diriguntur, praecipit. Für diesen zweiten Teil ist die Hauptautorität Cicero, während Aristoteles zwar ad vitae civilis usum unice accommodatus est, aber prudentiae potius quam obligationis legumque divinorum habuit rationem S. 308. Die Kirchenväter haben dieses Naturrecht mit der Offenbarung verbunden, die Scholastiker haben den Aristoteles, das jus civile und das jus canonicum unklar vermischt. Melanchthon, Benedikt Winkler u. a. haben dann das richtige Verhältnis hergestellt. Schließlich hat Val. Alberti in seinem Compendium juris naturae orthodoxae theologiae conformatum, dem die Juristen Dav. Menius und Veit Lud. v. Seckendorf gefolgt sind, das Naturrecht zutreffend aus dem Urstand abgeleitet, nur dabei die Sonderbedingungen und Modifikationen durch den Sündenfall nicht scharf genug hervorgehoben. Jedenfalls ist es praestantissima philosophiae practicae pars, quae vel maxime vitae civilis negotiis inservire debet S. 344. 3) Der dritte Teil der Ethik ist die eigentliche Politica, die Lehre von der Bewirkung der bürgerlichen Wohlfahrt in allen Ständen und Berufen: eo magis illa tractatio est necessaria, quo amplius ejus est usus, siquidem non tantum prudentiae civilis et aulicae, sed et christianae et theologicae et ecclesiasticae principia et fundamenta ex ea petenda sunt S. 317. Auch hier gibt es eine große Literatur, die erst in neuerer Zeit als politica sive prudentia civilis sich von der Lehre des allgemeinen Naturrechts deutlich abgrenze, früher jedoch vielfach mit diesem vermischt worden sei. Das Urbild dieser Prudentia civilis ist das mosaische Gesetz >omnes enim istae leges aequitati naturali sunt consentaneae S. 419; dann die salomonischen Weisheitsschriften, die ad prudentiam non minus quam ad doctrinam moralem seu vitam recte instituendam spectant \& S. 320. Die Ergebnisse seien zusammengefaßt von dem bekannten Theologen Dannhauer in einer P'olitica biblica. Außerdem kommt Aristoteles in Betracht, der aber den Anforderungen der Gegenwart nicht mehr ganz genüge; danach folgen Angaben über neuere Literatur zur Politik und Staatsverwaltung, bei denen Bodin und der die Rechte des Fürsten übertreibende Macchiavelli nicht $z u$ übersehen seien. Hieher gehört auch die Kameralistik, deren Zusammenhang mit dem christlich-ständischen Staat und dem Naturrecht Roscher, Gesch. der Nationalökonomik, zeigt. Buddeus nennt vor allem Seckendorffs Christenstaat: de omnium ordinum emendatione secundum indolem disciplinae Christianae praecipit S. 72I. 4) Ueber diesen drei bezw. vier Teilen der praktischen Theologie erhebt sich dann die eigentliche theologia moralis, die Lehre von den motus spirituales oder die theologia moralis mystica, wobei diese nur als reine, d. h. überall durch die Bcrufung auf den I Ieilstod Christi begründete und durch den Glauben an die Bibel vermittelte Mystik zulässiy ist: P'er thcologiam mysticam, puram scilicet, nihil aliud intelligi quam ipsam theologiam moralem stricte sic dictam quemlibet potest doccre collatic. Mysticam namque theologiam 
giösen Verhaltens gegen Gott, die in Gebet und Selbstdisziplin sich Gott demütig, freudig und dankbar hingebende Gottesliebe und dic Ausströmung dieser Gottesliebe, die Gott nichts geben kann, auf den Nächsten. Es ist ein den Ueberschwang der Rechtfertigungsseligkcit auslebender und den Nächsten dadurch zu Gott führender, mit ihm in Gott sich verbindender innerer Drang. Indeın cr aber für das letztere die naturgegrebenen Gelegenheiten, Anlässe und liormen des natürlichen Lebens in der Regel benützen und mystische Ueberschwänglichkeiten und Sonderkreise vermeiden soll, so handelt es sich in zweiter Linie um die Erfüllung der naturgegebenen Anlässe und Lcbensvoraussetzungen, vor allem der Familie, des Staates, der Berufs- und Arbeitsgliederung mit dieser Licbesgesinnung, die diese Formen zu Mitteln und Aeußerungsweisen der christlichen Nächstenliebe macht. Die Mystik der Gottes- und Bruderlicbe ergießt sich in die Formen des ständischzünftigen, familienhaften und hauswirtschaftlichen, des staatlichen und rechtlichen Lebens. Die Sublimität des höchsten religiösen Gefühls investiert sich in den nüchternsten und alltäglichsten Formen des Dienstes an der häuslich-bürgerlichen Gesellschaft, und die Ethiker des Luthertums unterscheiden sich bis heute nur dadurch, daß die einen mehr der spezifisch religiös-mystischen Ethik einen selbständigen Spielraum geben, die anderen sie ganz in dem Iiebesdienst an der geordneten Gesellschaft als dem "großen Werkhaus der Nächstenliebe " aufsaugen. Bei den ersteren bleibt eine Erinnerung an die ursprüngliche Spannung, die Luther zwischen Geistlichen und Weltlichen, Liebe und Recht gesetzt hatte, bei den letzteren überwiegt seine Forderung des Gehorsams gegen die naturgegebenen Ordnungen, die der in der Geschichte sich vermummende Gott selber geschaffen hat und in deren Formen er daher Liebe und Seligkeit des Gerechtfertigten mit cinfachem Gehorsam sich bewegen sehen will.

Das Ideal dieses Handelns spiegelt sich in dem Begriff des christlichen Sittengesetzes, das hier nicht sowohl als Bekehrung wirkendes Gesetz denn als Deutung und Beschreibung des mit der Rechtfertigungsseligkeit gesetzten Tätigkeitstriebes erscheint, ita nonnulli definire solent, quod sit divfna et arcana de Deo rebusque divinis sapientia, qua mens hominis regeniti illuminetur, voluntas virtutibus divinis instructa $\mathrm{ab}$ inquinamentis peccatorum purgetur, ut illa cum Deo arctissime uniatur. Id vero est, quorsum et theologia moralis tendit.s S. 672. - Die Bücher von Alberti, Dannhauer u.s. w. sind mir leider nicht zugänglich gewesen. 
für das daher die Gesetzesform nur uneigentliche Bedeutung hat Hier werden die lutherischen Gedanken von der Gesetzesfrei heit des Christen fortgeführt, aber sachlich doch immer mehr in eine rein evangelische Gesetzlichkeit des Katechismus hinübergeführt. Dieses Gesetz ist enthalten im Dekalog, der mit dem natürlichen Sittengesetz in der bekannten Weise identisch ist, also die naturgesetzlichen Anlässe, Gelegenheiten, Voraussetzungen und sozialen Formen in seiner zweiten Tafel und zugleich in seiner ersten Tafel die Beseelung mit der christlichen Glaubens- und Liebesgesinnung umschließt. Diese Unterscheidung der zwei Tafeln setzt die Doppelheit der Moral auch jetzt noch fort. Aber da die Bruderliebe überall angewiesen ist, sich nicht ins Blaue und Unbestimmte, in Sonderkreise und schwärmerische Gefühlsregungen zu verlieren, so bleibt für die rein innerliche, rein geistliche, auf Recht und Gewalt verzichtende Moral in der Praxis kein sehr erheblicher Spielraum; sie wird möglichst rasch übergeführt in das geordnete Liebeshandeln des Berufs, der bürgerlichen Ordnung, der gesunden Arbeitsteilung und des loyalen Gehorsams. Die rein persönlich-menschlichen Beziehungen werden nach Möglichkeit im Sinne der Ordnung und Ruhe auf die letzteren reduziert. Die häusliche und bürgerliche Tätigkeit bekommt überdies durch ihre Zurückführung auf göttliche Einsetzung eine religiöse Weihe, die schließlich ihren Makel, Rechts- und Kampfesordnung zu sein, fast vergessen läßt. So steht schließlich neben der ethischen Arbeit an dem persönlichen inneren Verhältnis zu Gott, das seine Krone findet in dem auf ernste Buße und Selbstprüfung folgenden leiblichen Genuß des Abendmahlschristus, nur mehr die durch göttlichen Befehl und Einsetzung geweihte Moral des Amtes und des Berufes, die durch Betonung der festen, ständigen und Frieden verbürgenden Ordnung ihren Zusammenhang mit der Härte des Rechtes wie mit der Unruhe des Kampfes ums Dasein theoretisch völlig und praktisch einigermaßen austilgt ${ }^{241}$ ).

Einer weiteren Ausführung der Gesinnungsmoral, mit der die weltlichen Formen beseelt werden sollen, bedurfte es nicht. Die alten Theologen geben sie an den geeigneten Orten der Dogmatik oder in praktisch-aszetischen Traktaten. Sie nennen diese christliche Moral überhaupt nicht Ethik, , sondern Pietas und handeln dem-

st1) Vgl. den Traktat De lege in Gerhards Loci comunes (ed. Cotta) Bd. V und VI. Hier auch eine ausführliche Erklärung des Dekalogs, in der viel ethischer Stoff enthalten ist.

Troelssch, Gesammelte Schriften. I. 
gemäß von ihr in scholae pietatis* oder ähnlichen praktischerbaulichen, übrigens den ganzen spinosen Apparat der dogmatischen Rechtfertigungslehre mit sich führenden Abhandlungen.: Erst die modernen Lutheraner haben diese Darlegung in eine selbständige $\gg$ theologische « Ethik verwandelt und in diese dann die unentbehrlichen Bestandteile der »natürlichen * Moral mithineingenommen. Wohl aber bedurfte es einer besonderen und ausführlichen Darlegung der Anlässe, Gelegenheiten und sozialen Formen, der natürlichen Tugenden und Gebote, die mit jenem Geiste erfüllt, geheiligt und verchristlicht werden sollten. Das erst war dann die eigentliche Moral, die »Ethik «, welche das alte Luthertum als solche kannte und anerkannte. Diese "Ethik * aber war nichts anderes als die stoisch und ciceronianisch belebte, humanistisch aufgefrischte aristotelische Schulethik, deren schulmäßige Gestalt Melanchthon mit einer Wirkung für zwei Jahrhunderte redigiert hatte und für die man zugleich die denselben Stoff ausführlicher behandelnde jesuitische. Neuscholastik heranzog. Das Gedankenkapital, von dem die $»$ Ethik beider Konfessionen lebte, war, wenn man unter Ethik im Sinne der Zeit nur die philosophische Ethik versteht, das gleiche, weil es nichts anderes als der gereinigte mittelalterliche Aristotelismus, der uns bekannte, auf Aristoteles reduzierte naturgesetzliche Gedankenkreis, ist. Da das Naturgesetz im Dekalog nur seine göttliche Proklamation und Zusammenfassung findet, so konnte diese "philosophische Ethik " auch auf Grund des Dekalogs entwickelt werden, ohne dadurch im mindesten ihren rein philosophischen und natürlichen Charakter zu verlieren ${ }^{211}$ a). Sie bchandelte in hergebrachter Weise den Begriff des natürlichen Sittengesetzes, des natürlichen Rechtes, den aristotelischen Tugendbegriff, die vier Kardinaltugenden, um zu zeigen, wie diese Erkenntnisse vorbercitend für die Buße wirken, als justitia civilis d.h. als der eigrentlich spiritualen Gesinnung entblößte und nur äußerlich loyale Disziplin der Ordnung dienen, die Vernunftbasis für den Gedanken der Existenz Gottes und der sittlichen Weltregierung bicten und schließlich bei der Beseelung mit der spiritualen Gesimnung in die Einheit des christlichen Liebesbegriffes zusammensch.n. Dic weitcren eigentlich naturrechtlichen Materien, die Familie, der Stat, die Arbeitsteilung und Oekonomie wurden in der Ethik

¿11n, Wic modernen Darsteller und Kritiker, die Entstehung und Bedeutung dicur (jedankenkreise nicht kennen, pflegen dann über »noch unklare Vermischung von philonphicher und theologischer Ethik zu klagen. 
selbst nur flüchtig berührt und fanden ihre eigentliche Ausführung in den auf das Naturrecht und positive Recht aufgebauten Sonderdisziplinen der Jurisprudenz, der Staatslehre, der Kameralistik und in den bei ihnen ihre Anleihe machenden Abschnitten der Dogmatik. Das römische Recht insbesondere schien eine Ausführung des Dekalogs und des Naturrechts zugleich; doch kam für die Sonderstellung dieser Materien auch noch ihr Zusammenhang mit dem geltenden positiven Recht überall in Betracht.

Die Analogie mit der katholischen Ethik liegt auf der Hand. In beiden Fällen kommt das Ethos des realen Lebens nur durch ergänzende Heranziehung des naturgesetzlichen Gedankenkreises und des antik-philosophischen Materials der Ethik zustande. Die eine weltliche Kultur zugleich mitumfassende kirchliche Ethik fährt fort, das Ergänzungsmittel zu benutzen, das zum gleichen $Z$ weck schon die alte Kirche herangezogen und das die mittelalterliche Kirche reich und scholastisch entwickelt hatte. Wie im Kirchenbegriff selbst, so setzt auch in der Begründung der von der Kirche zu rezipierenden weltlichen Kultur der Protestantismus Grundtendenzen der katholischen Tradition fort. Ebenso aber ist auch der Unterschied leicht erkennbar: es gibt keine die Harmonie der Stufen gewaltsam und rechtskräftig regelnde Hierarchie, und es handelt sich nicht mehr um ein Uebereinander, sondern um ein Ineinander beider ethischer Gedankenkreise. Es ist die Immanenz des Uebernatürlichen im Natürlichen, die aber nicht im Sinne moderner Immanenzlehren zu verstehen ist, nicht als Immanenz Gottes in der Welt, sondern als Immanenz der weltüberwindenden Gottesliebe im Gehorsam gegen die an sich gleichgültigen und sündig verdorbenen, aber von Gottes Willen positiv gesetzten Weltordnungen und als Immanenz der religiösen Liebe in den der irdischen Wohlfahrt und Ordnung dienenden $Z$ weckmäßigkeiten, die der natürlich gewiesene Weg zur Erweisung einer geordneten Nächstenliebe sind. Der Sinn und Zweck ist nicht die Förderung in den natürlichen Gütern, sondern die Betätigung des auf alle Willkür verzichtenden Glaubensgehorsams und der demütigen und dankbaren Liebe. Aber der Unterschied und Aehnlichkeit wären nicht erschöpfend erkannt, wenn nicht noch ein besonderer Punkt hervorgehoben würde, in welchem das Luthertum sich von der katholischen und auch von der mit der katholischen hier schließlich wesentlich einstimmigen reformierten Ethik entfernt. Es ist innerhalb des gemeinsamen rationalen naturgesetzlichen Gedankens 
die besondere Fassung des $\mathrm{Nat}$ a r r e chtes.

Hier hatte Luther ${ }^{242}$ ) eigentümliche Wege eingeschlagen. $\mathrm{Zu}$ nächst und an sich teilte er freilich die ganze uns bekannte Tradition, die ja nicht der Theologie, sondern der Vernunft und praktischen Philosophie angehörte, daher mit der römischen Theologie und dem kanonischen Recht nicht zugleich von ihm verworfen $z u$ werden brauchte. Er löste nur die Vermittelung und Vermischung auf, trennte jene sorgfältig von der biblischen Liebesethik, beschränkte sie auf die Sphäre des Amtes, Berufes, Rechtes und Staates und verlangte die Fügung aller in die dadurch bedingten, der Liebesethik so schroff entgegengesetzten Lebensformen. Aber dabei hat Luther nicht bloß das Verhältnis des Naturgesetzes zu Kirche und Evangelium neu geordnet, sondern auch jenes selbst neu interpretiert. Er gibt nämlich dem Naturrecht von Hause aus eine völlig konservative, lediglich die utilitarische $Z$ weckmäßigkeit der positiven Ordnung an sich betonende Deutung, bei der die Gestaltung der Gesellschaft selbst als von der Vorsehung in der natürlichen Geschichtsentwickelung hervorgebracht erscheint und jede Ordnung und Wohlfahrt an dem unbedingten Gehorsam gegen die vom geschichtlichen Prozeß emporgetragenen Gewalten hängt. Es ist die Verherrlichung der Gewalt um der Gewalt willen, die auf dem Boden der Sünde das Wesen des Rechtes geworden ist und daher die jeweils herrschende Macht als solche glorifiziert. Auch wenn sie ihre Gewalt schändlichst mißbraucht, ist doch die Gewalt ihr Wesen und ist jede Bestreitung der Gewalt eine Aufhebung des Begriffes der naturgesetzlichen

$\left.{ }^{242}\right)$ Vgl. hierzu K. Köhler, >Luther und die Juristen 1873; E. Brandenburg, M. L.s Anschauung vom Staate und der Gesellschaft 190I (Schriften d. Vereins f. Ref.-Gesch. 70); G. Müller, Luthers Stellung zum Rechte (Schriften des evang. Bundes 43/44) 1906; E. Ehrhardt, La nature du droit naturel chez Luther, Festschrift der Pariser Fakultät für Montauban; Cardauns, Lehre vom Widerstandsrecht im Luthertum und Calvinismus, Bonner Diss. 1903. - Bluntschli, Gesch. d. allgemeinen Staatsrechtes und der Politik 1864 S. 46-60 dringt nicht tief genug und gewinnt dem lutherischen Positivismus und Legitimismus mit Vorliebe die Seiten einer christlichen und moralischen Kritik an den Fürsten ab, die sich mit modern liberaler Kritik allenfalls berühren. Bergbohm, Jurisprudenz und Rechtsphilosophie 1892, eine radikale Kritik alles Naturrechts vom rein rechtspositivistischem Standpunkt, hat weder Kenntnis noch Verständnis vom kirchlichen Naturrecht und spricht insbesondere vom Naturrecht der Reformatoren S. 159 mit vollendeter Unkenntnis. Hinrichs, Gesch. der Rechts- und Staatsprinzipien seit der Ref. I I 848 gibt wenig für Luther, mehr für Melanchthon und Orthodoxie. 
Ordnung selbst und damit die Zerstörung der Fundamente aller Gesellschaft ${ }^{243}$ ). In seiner angeborenen konservativen Grundgesinnung, in seiner spiritualistischen Gleichgültigkeit aller äußeren Dinge für den Christen, in seinem Glauben an die allgegenwärtige Vorsehung, die hinter den menschlichen Gedanken rumort und ihr Wesen treibt, in der Angleichung der gesellschaftlichen Unterordnung an die religiöse Demut der absoluten Gnadenabhängigkeit, vor allem in seinem tiefen Gefühl für den Gegensatz der Liebesordnung gegen die Rechtsordnung und gegen den weltbeherrschenden Kampf ums Dasein : in alledem versteht er das Naturrecht instinktiv als die von Gott mittelst der Vernunft bewirkte Emporhebung unbedingt herrschender positiver Gewalten, an deren Vernünftigkeit und Göttlichkeit ihn keine noch so widervernünftige Wirklichkeit irre macht. So bestreitet er jede rationelle Konstruktion und Gestaltung der Gesellsch aft vom Standpunkt der Interessen und der Vernunft des einzelnen Individuums her, jede Mitwirkung der Einzelwillen zu einem sie alle umfassenden und befriedigenden »organischen « System. Damit verschwindet bei

249) Hier der radikale Unterschied von Occams Naturrecht, Ehrhardt 304. Vgl. z. B. die sErmahnung zum Frieden auf die 12 Artikel der Bauerne: sSo giebts auch das natürliche und aller Welt Recht, daß niemand solle noch möge sein eigener Richter sein noch sich selbst rächen (B. A. IV, I S. 3 I9). Könnt ihr nicht rechnen und denken, daß, wenn euer Vornehmen sollte recht sein, so würde ein Jeglicher wider den anderen Richter werden und keine Gewalt noch Obrigkeit, Ordnung noch Recht bleiben in der Welt, sondern eitel Mord und Blutvergießen... Nun ist alles gesagt von gemeinem, göttlichem und natürlichem Recht, das auch Heiden, Türken und Juden halten müssen, soll anders Ordnung und Friede in der Welt bleiben, $321 \ldots$ Ihr fahret über Gott, nehmt dazu der Obrigkeit ihre Gewalt und Recht auch, ja alles, was sie hat. Denn was behält sie, wenn sie die Gewalt verloren hat ?... In der Gewalt steht all ihr Gut, Leib und Leben, 320. Noch schärfer in der Schrift $\gg$ Ob Kriegsleute auch in seligem Stand sein können. 1526. So auch noch in der modernen lutherischen Ethik, vgl. v. Hofmann : , Als Angehöriger des Staates ist der Christ darauf angewiesen, sich mittels dessen, was die rechtliche Ordnung desselben bietet, gegen Gewaltsmißbrauch der Amtsinhaber bei seinem Rechte zu behaupten. Wo dies nicht möglich ist, da ist nur eines von beiden sittlich tunlich, entweder Gewalt zu leiden oder diesen Staat mit einem anderen $z u$ vertauschen, das Rechtsleben in einem anderen fortzusetzene 278. -Es ist dies Alles nicht bloß eine Sache der Klugheit, sondern so bringt es die Demut der Liebe zum nationalen Besitz mit sich, welche das Vorhandene als das von Gott gegebene ehrt und also nicht willkürlich etwas daraus machen will, wozu er vermöge der von Gott gegebenen Vorbedingungen nicht făhig iste, 273. 
ihm von selbst auch die Idee des Staatsvertrages, die Uebertragung der Gewalt durch offene oder stillschweigende Zustimmung der Beherrschten, jedes über den freimütigen Tadel hinausgehende Widerstands- und jedes Revolutionsrecht, jede egalitäre Fassung der menschlichen Gemeinschaftsbeziehungen und jedes kommunistische Ideal ${ }^{244}$ ). Das ist schon für den Urstand ausgeschlossen; jene Gewaltverherrlichung liegt im Wesen auch schon der reinen ungetrübten Vernunft, die bereits im Paradies Autorität und Pietät des Familienzusammenhangs und Fügung in die gottgegebenen Verhältnisse und Aufgaben bedeutete. Die Sünde hat jene Bedeutung der Gewalt nur ins Ungeheure gesteigert, indem die Aufrechterhaltung der Ordnung nur mehr durch positive Gewalt möglich ist, und hat sie freilich überdies mit der Bosheit und Selbstsucht verknüpft. Es bleibt aber auch unter ihrer Voraussetzung dabei, daß der Gewalt nicht widerstrebt werden darf. Die Nichtresistenz ist daher nicht erst eine Forderung des Evangeliums, sondern schon eine solche des Naturrechts, da auch nach diesem niemand Richter in eigener Sache sein kann und jede die Resistenz gestattende Gewalt ihren eigenen Begriff auf höbe, wie Luther den bäuerlichen Reformforderungen unermüdlich entgegenhält. Als später wenigstens für die Reichstände ein Resistenzrecht behauptet wurde, da hat er mit Recht gemeint, das vertrüge sich nicht mit dem den Bauern gegenüber geltend gemachten Begriff der Gewalt ${ }^{244 *}$ ).

An diesem Punkte hatte die mittelalterliche Ideenentwicklung starke Unsicherheiten gezeigt. Folgte man den stoischrationalistischen Elementen, die im kaiserlichen wie im kanonischen Recht auch ihren juristischen Niederschlag gefunden hatten, dann gelangte man zum Staatsvertrag, zur Unterwerfungs- und Uebertragungslehre, zum Revolutionsrecht, zum Tyrannenmord, zur rationellen, das Recht des Individuums berücksichtigenden Gestaltung des Staates. Folgte man dem Aristoteles, so kam man zur Lehre von der organisch-notwendigen Entstehung der Gesellschaft aus der Vernunft, zur Zurückführung der naturnotwendigen Entwickelung auf die Vorsehung und zur Unterwerfung unter den natürlichen Gang der von Gott geleiteten Dinge, bei dem nur die sündhaften Extreme zu meiden waren. Reflektierte man weiterhin zur Siche-

244) Ehrhardt S. 309 u. 310. Die Arbeit von E. erschöpft ihren Stoff leider sehr wenig.

244 a) Vgl. v. Schubert, Beitr. zur ev. Bekenntnis- u. Bündnisbildung 1529/39,

(Z. f. Kirch.-Gesch. XXX S, 295). 
rung der Gewalten besonders auf dieses göttliche Moment, so hob man die göttlichen Einsetzungen und mythologischen Verklärungen der Gewalten hervor, die Stiftung der Staaten durch die babylonische Sprachentrennung, die Einsetzung von Ninus und Bel, die göttliche Gesetzgebung im Alten Testament. Reflektierte man dann freilich wieder auf die nur relative Göttlichkeit aller Ordnungen im Sündenstand, so erhob sich das Ideal des Urstandes mit der Gleichheit, Brüderlichkeit und Besitzgemeinschaft. In der verschiedenen Mischung und Anordnung dieser Elemente bewegte sich die mittelalterliche Naturrechtslehre ${ }^{245}$ ). Luther hat nun darin insofern eine feste, wenn auch freilich sehr einseitige und nicht immer konsequent festgehaltene Ordnung geschaffen, indem er die stoisch - rationalistischen Elemente völlig bescitiste, dic natürliche Entwickelung der positiven Gewalten als unbedingt zu verehrende Stiftung der Vorsehung betrachtete, diese natürliche Entwickelung durch göttliche Einsetzungen und Bestätigungen im Alten Testamente beglaubigt sein ließ̧ und damit ein konservativ - autoritäres Naturrecht lehrte, das aus dem Begriff der Gewalt und ihrer Bestimmung für die menschliche Wohlfahrt die Forderung einer unbedingten Respektierung der Gewalt als Gewalt ableitete. Daß sie mit Härte und $Z_{\text {wang, Recht und }}$ Macht arbeiten muß, das kommt vom Sündenstande und dient der Repression der Sünde. Damit verbindet sich die Geringschätzung der Masse und des Pöbels, die nicht bloß die wahren Christen, sondern auch die vernünftigen und weisen Menschen seltene Vögel sein läßt. Die Leitungsbedürftigkeit ist im Sündenstande der Charakter der Masse, ist für Luther wohl aber auch an sich das Wesen des Menschen. Denn diese Gewaltenbildung fließt doch eben aus der Vernunft. Ordnung und Ruhe, langsame und organische Fortbildungen des Gegebenen sind ihm daher überall mehr Mittel des Gedeihens und des Fortschritts als Bruch und Neuerung. Wie auf christlichem Gebiet der Geist von innen heraus allmählich wirken soll, so auch auf natürlichem die Vernunft. Ueberall ist er gegen die Revolution vom Individuum her und für dic lcitende, langsam bildende, im Notfall zwingende Kraft der Autorität. In

245) Diese verschiedenen Elemente gut gegliedert bei k. Köhler, staatslehre der Vorreformatoren « (Jahrbb. f. deutsche Theol. XIX), „Der Widerspruch der letzteren (organisch-aristotelischen) Anschauung mit der schließlich auf die menschliche Willkür hinauskommenden Vertragstheorie scheint nicht zu Bewußtsein gekommen $2 u$ sein 359 . 
dieser Verherrlichung der Gewalt liegen gewisse Achnlichkeiten mit Machiavellis Lehre, die schon von den alten Lutheranern beobachtet worden $\operatorname{sind}^{246}$ ), nur daß Luther die Gewalten an

246) Mit Machiavelli stellt Luther zusammen Figgis, From Gerson to Grotius 62-107. Buddeus, Isagoge 323, sieht im Luthertum die rechte Mitte zwischen Machiavellisten und Monarchomachen quorum illi imperantibus plus quam decet concedunt, hi plus quam decet adimunte. Er findet begreiflicher Weise auch bei Bodin relative Wahrheiten; das verwandte Element in der Anschauung des Hobbes dagegen scheint nirgends erkannt worden $z u$ sein; erst Pufendorf, der in vieler Hinsicht auch lutherisch dachte (s. Bluntschli S. I 30 f., Lezius, Toleranzbegriff Lockes und Pufendorfs I 900 S. 58,68) ist darauf aufmerksam geworden, s. Bluntschli 12I. - Diese Gedanken des lutherischen Naturrechts sind es, die dann durchaus der Rechtsphilosophie von F. J. Stahl zugrunde liegen und bei Stahl ihre erste umfassende, übrigens sehr geistvolle philosophische Begründung erfahren, vgl. die lehrreiche Analyse Stahls bei E. Kaufmann, Studien zur Staatslehre des monarchischen Prịzips, Hallenser Diss. 1906. Bis in die Einzelheiten geht die Anknüpfung an Luther: die Obrigkeit und Gewalt eine schlechthin gegebene, den Individuen vorgeordnete Macht S. 79; die sozialen Institutionen, Familie, Vermögen; Staat, im güttlichen Willen, nicht in immanenter Notwendigkeit begründet, aber mit der Schöpfung gesetzt und mit der Natur sich auswirkend nach eigenen natürlich vernünftigen Gesetzen S. 82; das Recht ist das Ethische in seiner durch den Sündenfall bewirkten Umwandelung zu einer äußerlichen Zwangsmacht S. 83; Staat und Gesellschaft beschränkt auf Auswirkung der innerweltlichen Wohlfahrts- und Ordnungszwecke, zu denen Gewalt und Ordnung nötig ist, darin aber ganz selbständig und von der Offenbarung unbeeinflußt, S. 94; die Zurückführung auf die natürliche Vernunft zugleich eine $\mathrm{Zu}$ rückführung auf göttliche Vollmacht und Einsetzung S. 94. All das sind lediglich lutherische Sätze; es ist das Naturrecht »des Irrationalismus \&, wie es Kaufmann mit Recht dem Naturrecht des Rationalismus gegenüberstellt; nur hat Kaufmann bei einer ganz irrtümlichen Auffassung Luthers als Vertreter des modernen autonomen Individualismus S. 99 diesen Zusammenhang nicht erkannt. Das besondere zeitgeschichtliche Moment bei Stahl ist lediglich die Zuspitzung des sirrationalen Naturrechts gerade auf die legitimistische Monarchie, wozu Luther keine Nötigung empfand. Fürsten oder Magistrate gilt ihm glejch. - Von hier aus ist überhaupt bis heute die Politik der Konservativen zu verstehen, die eine alle Konsequenzen des Machtgedankens ziehende Gewaltpolitik mit einer auf das Innere der Gesinnung beschränkten Christlichkeit verbinden und einen ethischen Zusammenhang zwischen beiden getrennten Sphären nur durch die Theorie des patriarchalischen Autoritäts- und Pietätsverhältnisses zwischen Gewalt und Untergebenen behaupten. Vgl. die Forderung Stahls bei Kaufmann S. 96: , Du sollst diesen $\mathrm{Zu}$ sammenhang (mit der geschichtlich gewordenen Gewalt) nicht grundlos unterbrechen, du sollst Pietät haben vor dem, was durch Gottes Fügung oder Zulassung geworden ist; du sollst nicht bloß der Obrigkeit gehorchen, wo solche besteht, sondern du 
die Einhaltung des Vernunftrechts und in der christlichen Gesellschaft an den freien Gehorsam gegen das Evangelium bindet. Bis zum heutigen Tage vertragen sich die Darwinisten, Gewaltpolitiker und Herrenmenschen mit den lutherischen Konservativen leichter als mit den Vertretern des liberalen ethischen Individualismus. Die Grundzüge der konservativen Staatsund Gesellschaftslehre sind darin bis zum heutigen Tage vorgegebildet, und die "christliche Weltanschauung « unserer Konservativen beruht in den politisch und sozial wichtigsten Teilen auf diesem positivistischen und realistischen Naturrecht Luthers ${ }^{24}$ ).

sollst der in der Geschichte wurzelnden Dynastie Treue und Anhänglichkeit zollenء. Im übrigen ist das Nebeneinander eines alle Härten der Gewaltpolitik in sich schließenden, rechtlich $z \mathfrak{u}$ befestigenden Machtwesens und einer vorsehungsgläubigen Liebesmoral Folge der Sünde, wobei dann immer nur ein das positive Recht und die, Gewalt möglichst schonender und den abstrakten Doctrinarismus der Liebesmoral zurückstellender Kompromiß übrig bleibt. - Auch bei Bismarck ist das so auffallende Nebeneinander seiner Gewaltpolitik und seiner Christlichkeit nur aus dem Gedankenkreis jenes Stahlschen und lutherischen Prinzips des > Naturrechts des Irrationalismus a neben einer durch es gar nicht innerlich berührten Gesinnungschristlichkeit $\mathrm{zu}$ verstehen; bei dem calvinistisch und sektenhaft bestimmten Cromwell, auch bei Gladstone und Lincoln, ist ein derartiges Außer- und Nebeneinander ganz unmöglich gewesen. Bismarck hat sich für diese Trennung der außeren Gewaltpolitik und der inneren Gesinnungschristlichkeit auch gerne auf Luther berufen, s. Lenz, Bismarckș Religion (Ausgew. Vorträge u. Aufsätze, deutsche Bücherei Nr. 18) Art. Bismarck in $>$ Religion, in Geschichte und Gegenwart a; Meinecke, B.s Eintritt in den christlich-germanischen Kreis H. Z. 1902; O. Baumgarten, B.s Stellung zu Religion und Kirche 1900; jetzt vor allem E. Marcks, Bismarck I 1910. Der Eindruck des Bismarckschen politischen Denkens ist auch auf die heutige deutsche Christlichkeit ein außerordentlicher gewesen; aber die Verherrlichung der durch die Sünde notwendig gewordenen Gewalt unter der Zurückziehung der christlichen Ethik mehr auf die privaten Verhältnisse ist nicht erst eine Eigentümlichkeit der heutigen preußischen Religion, wenn freilich auch der Gedanke erst hier eine begeisterte Selbstverständlichkeit gewonnen hat, die Luther ganz ferne lag und - aus anderen Gründen - auch Bismarck.

247) Vgl. die Aeußerung der >Kreuzzeitung zu den aristokratischen Auslesetheorien des bekannten darwinistischen Soziologen Otto Ammon: SSchlagender als in diesem Buche kann die Hinfälligkeit der Lehre der blauen und roten Demokratie nicht dargetan werdens; es sind Ergebnisse, sgegen die auch vom streng konservativen Standpunkt nichts einzuwenden iste; s. Stillich, Die politischen Parteien in Deutschland I, Die Konservativen S. 32; Berufung der Kreuzzeitung auf Machiavellis Machttheorie S. 58. Oder auch den Satz aus dem Wahlprogramm der Konservativen 1849: Der konservative Kandidat soll ein politischer Mann sein. 
Allerdings hat Luther unter dem Einfluß der zum schmalkaldischen Bund führenden Verhandlungen diese Lehre durchbrochen und das Widerstandsrecht nicht bloß auf Grund positiven Reichsrechtes, sondern auch auf Grund des Naturrechtes behauptet. Allein das ist deutlich fremder Einfluß, vor allem hessischer und Straßburger Einfluß, und von einem großen Teil seiner Anhänger mit seinen eigenen Worten zurückgewiesen worden. In der Publizistik aus Anlaß der Magdeburger Kämpfe lebten die Resistenztheorien wieder auf, um dann aber zu verschwinden. Sie sind gegen Luthers eigentliche Meinung und Konsequenz. Seine eigentliche Ansicht über das Naturrecht tritt zutage, wenn er erklärt, daß Griechen und Römer das wahre Naturrecht nicht gekannt hätten, dagegen bei Persern, Tataren und derselbigen Völker mehr das Recht besser gehalten werde ${ }^{247 a}$ ).

Liegt an diesem Punkte eine starke Abweichung vom katholischen Naturrecht, so folgt ihm freilich Luther doch in anderen wichtigen Zügen, in der Vermischung der Moral und des Rechtes, in der Angleichung des Naturrechts an die christliche Moralität und an die daraus entspringende Betonung der Epikie oder Aequität, die das formelle Recht zu Gunsten des ethischen Urteils modifiziert. Natürlich gilt das nicht auf dem Gebiete des Staatsrechtes wie sich nach dem Bisherigen von selbst versteht. Auch nicht auf dem des Strafrechts. Hier ist vielmehr sein strenger Erbsündenbegriff und seine Forderung strenger Zucht, seine-Verachtung der Masse, seine Auffassung der Obrigkeit als Stellvertreterin der göttlichen Strafe und Vergeltung geneigt zur äußersten Strenge und hat er das Rädern, Köpfen und Quälen mit äußerster Härte empfohlen ${ }^{248}$ ).

Er soll wissen, daß die Gewalt ein im Staatsleben ewig wirkender Faktor ist und daß sie, die an sich unvernünftige, stets alsdann berechtigt angewandt wird, wenn sie dasjenige Vernünftige bewirkt, das sich als eine Grundbedingung des Staatslebens erweist a, Stillich S. 218.

247 2) Vgl. Cardauns, S. 8-19. Die Stelle über die Perser in „Ob Kriegsleute etc. BA. IV. I S. 398-402. Leider ist auch die Darstellung bei Cardauns nicht erschöpfend. Wie schwankend die Meinungen waren, zeigt v. Schubert, Beitr. Z. f. K.-G. XXX, S. 271-316. Das Naturrecht der rationellen Notwehr, das Naturrecht der reinen Gewalt, wie es gegen die Bauern ausgeprägt worden war, das positive Reichsrecht einer nur bedingten Oberhoheit des Kaisers und das göttliche Recht des bloßen Leidens und Duldens gehen hier durcheinander; siehe Melanchthons Gutachten S. 3 I3.

248) Vgl. die Begründung der ersten großen und selbständigen Ausarbeitung des Strafrechtes auf diese lutherischen Gedanken durch Ben. Carpzov bei Stintzing, 
Aber auf dem Gebiete des Zivilrechtes kommt ihm der Sinn des Naturrechtes überall auf Milde, auf Berücksichtigung der Motive, der Lage und der Bedürfnisse hinaus. Der Grundsatz des Naturrechts sei, daß man alles den Leuten tue, was wir von ihnen verlangen, daß sie uns tun. In dieser Hinsicht ist die Liebe der Sinn auch des Naturrechts und ist dieses der christlichen Moral konformiert. So kommt es zu seiner Forderung an das positive Recht, daß es überall dem Naturrecht und dem im Grunde damit identischen christlichen Ideal sich zu nähern habe ${ }^{249}$ ). Ist in allen Fragen der Gewalt und I.eitung, der Ueber- und Unterordnung sein Naturrecht eine naturalistische Anerkennung herrschender Mächte und Differenzen, sowie eine aristokratische Betonung der Distanzen, so ist in allen Fragen des persönlichen Verhaltens und der bloß zivilen Streitigkeiten sein Naturrecht ein solches der Billigkeit, des Gegensatzes gegen den strengen rechtlichen Formalismus, eine möglichste Reduktion des Rechtes auf die Grundsätze menschlicher Nachsicht mit dem Leidenden und Gedrückten und zweckmäßiger Beseitigung der Konflikte. Auch hier folgt ihm bis heute die konservative Gesellschaftstheorie, die in allen das Problem der Gewalt und Herrschaft nicht berührenden menschlichen Beziehungen für Wohlwollen und Billigkeit, für Ungeburdenheit durch den starren Rechtsformalismus eintritt. Sie scheut die Umgebung des Individuums mit abstrakten Rechtsgarantien, weil darin das individualistisch-rationelle Prinzip überhaupt liegt, aber sie ersetzt das Recht gerne durch christlich-patriarchalische Rücksicht und persönliche Billigkeit. Auf dem Gebiet der Gewalt ist. das Naturrecht dem christlichen Autoritätsgedanken angeglichen, auf dem Gebiet des Privatrechts dem christlichen Liebesgedanken. Die schroffe Härte der Gewaltlehre wird kompensiert durch eine christliche Milderung des Rechtsstandpunktes in den privaten Beziehungen. Das ist alte lutherische Lehre und heute noch kon-

Gesch. d. deutschen Rechtswissenschaft II, 1884 S. 70-80. Die große Rolle, die ir diesem Strafrecht der Hexenprozeß spielt, geht gleichfalls auf Luthers Dämonenglaube zurück, der die Bosheit der Welt und ihren Widerstand gegen das Evangelium sich nur aus teuflischen Wirkungen erklären konnte. Immerhin hat Luther die phantastischen Ausartungen des Hexenglaubens bekämpft, s. Kawerau in W. W., Berliner Ausgabe IV I, S. $44 \mathrm{f}$.

249) Hiezu Köhler in dem Abschnitt Das Verhältnis zum kanonischen Recht ๔ S. III-132. Hier ist mit Recht die Identität mit der mittelalterlichen Anschauung betont. Die ,Epikiec oder sAequität S. 46 u. 98 . 
servative Rechtsauffassung ${ }^{250}$ ), und in der Tat kommt hierin die Christlichkeit der Moral mehr zum Ausdruck als in dem öffentlichen Gewaltrecht; doch ist es auch hier eine stark patriarchalisch gefärbte Christlichkeit, die von dem mannhaften Individualismus und dem entsprechenden Rechtsbewußtsein der Calvinisten sich stark unterscheidet.

Indem nun aber das Naturgesetz für Luther überall Gottes Wirken in der Vernunft ist, liebt er es, Gott als Begründer dieser Ordnungen zu betonen und sucht er, wo es irgend möglich ist, unmittelbare göttliche Einsetzungen und Bestätigungen. Damit verschwindet dann aber der naturrechtliche Charakter seiner Aufstellungen ganz hinter dem mythischen. Die Familie ist eine Ordnung des Naturgesetzes, jedoch ausdrücklich zugleich von Gott eingesetzt. Der Staat ist indirekt mit der Familie eingesetzt, im übrigen jedoch im Alten Testament vielfach bestätigt. Die ökonomische Gliederung und die Arbeit geht auf Gottes Befehl bei der Paradiesesaustreibung zurück. Aber auch in Einzelheiten greift er gerne auf alttestamentliche Beispiele, sodaß es oft den Anschein gewinnt, als hätte er seine radikale Ablehnung jeder Bedeutung des jüdischen Gesetzes für den Christen vergessen und als behandle er das Alte Testament geradezu als Gesetzbuch. Für Ehefragen und für das Problem der Leibeigenschaft greift er gerne auf das mosaische Gesetz zurück, und bekannt ist seine verhängnisvolle Berufung auf die Bigamie des Alten Testamentes in dem Falle des hessischen Landgrafen. Aber hierbei kommt das mosaische Gesetz doch nur in seiner Identität mit der Vernunft, als göttliche Bestätigung oder Proklamation vernünftiger Regeln in Betracht, nicht als geoffenbartes Gottesgesetz. Freilich wird auf diese Weise eine bunte Mischung biblischer und naturgesetz-

250) Vgl. den Abschnitt bei Stillich >Die Rechtsauffassung der Konservativene S. 161-178. Die standesgemäß differenzierte Rechtsungleichheit und die die jeweiligen Umstände berücksichtigende Billigkeit im Gegensatz gegen die abstrakte Rechtsgleichheit S. I66. Ein tolles Beispiel solcher Kadi-Justiz ist das Urteil des Herzogs Karl von Burgund in $\gg$ Von weltl. Obrigkeit IV. I S. 272, auf das Luther sich beruft: ein Ritter, der die Frau seines Feindes zum Beischlaf bewegt und ihr dafür das Leben ihres Mannes verspricht, dann aber doch den Feind tötet, wird verurteilt, die Frau zum Weibe zu nehmen, dann nach der Brautnacht unversehens geköpft und seine Güter werden der Frau geschenkt. „Siehe ein solches Urteil ist aus freier Vernunft über aller Bücher Recht gesprungen, so fein, daß es jeder billigen muß und bei sich selbst findet im Herzen geschrieben, daß es also recht seic. 
licher Argumentationen erzeugt; aber diese Mischung beweist nur das, was für unsern Zusammenhang von grundlegender Bedeutung ist, die überall obwaltende Voraussetzung einer inneren Einheit und Konformität des Naturgesetzes mit dem christlichen Geiste, worauf allein die relative Einheitlichkeit der Kultur des alten Luthertums und heute noch die Christlichkeit des sehr unchristliche Elemente einschließenden konservativen Programms beruht ${ }^{251}$ ).

Hat so Luther seine naturrechtliche Idee oft in positiv-biblische Satzungen verhüllt und überdies im Falle der Opposition der Juristen, die naturgemäß mehr bei der Kontinuität des technischen Rechtes bleiben mußten, unter heftigem Wettern sich wieder auf den Gegensatz von Recht und christlicher Freiheit zurückgezogen, so haben diese Ideen eine rationelle Glättung und Reduktion erfahren durch Melanchton ${ }^{252}$ ). Er war der Naturrechts-

251) Ueber die Begründung der Institutionen auf Gott und den Sinn dieser Begründung s. Ehrhardt S. 303. Es ist immer mediate gemeint. Wie das verstanden ist, zeigt Luthers Zurückführung des deutsch-römischen Reiches auf Einsetzung durch Gott, obwohl L. die translatio imperii durch den Papst für einen bösen Streich hält; W. Köhler, L.s Schrift an den Adel, 1895, S. 242. >Ausgehend von der Absolutheit und unumschränkten Willkür Gottes ... erkennt L. in dem bösen Spiel des Papstes göttliche Absicht, stellt er die Handlung des Papstes unter göttliche Direktive, läßt er den Papst das mechanische Werkzeug des göttlichen Allmachtswillens sein.\& So erklärt Prof. Suchsland die konservativen Theorien über die Autorität in Staat, Moral, Recht, Ehe als gerade vom Standpunkt.strengster Wissenschaft, d. h. von der Voraussetzung der Auslese aus diktiert; die göttliche Einsetzung dabei sei dann das transzendente, dogmatische Glaubenselement, das nur hinzukomme, Stillich S. 33.

252) Vgl. hiezu Corpus Reff. XXI u. XVI; außerdem Köhler, Luther und die Juristen, 100-105; Troeltsch, Gerhard und Melanchthon; Ellinger, Melanchthon 1902, S. 585-589; hier seine Neigung zu den städtischen Aristokratien wie bei Erasmus; sehr gute Wiedergabe bei Hänel, Mel., der Jurist (Z. f. Rechtsgeschichte, hg. v. Rudorff VIII, I869). Hier das treffende Urteil: , Sein Standpunkt ist trotz aller Abneigung gegen dieselbe der der Scholastik, und, was ihn in allen seinen Schriften von ihr unterscheidet, ist weder eine größere Präzision der Begriffsbestimmungen, noch eine selbständigere freie Methode, weder neue befruchtende Gedanken noch auch nur eine vertieftere Benützung des Aristoteles, sondern lediglich die Popularisierung der Darstellung, der Versuch, die philosophische Betrachtung dem Leben näher zu bringen, und selbstverständlich vor allem die veränderte Anschauung über das Verhältnis von Staat und Kirche 269. Nur ist die Lehre von der Nichtresistenz noch zu betonen, wie $H$. an anderem Ort selbst sagt: -Es liegen der Politik selbständige und eigentümliche Begriffe und Prinzipien, wie 
lehrer des Protestantismus, dessen Entwurf von der gesamten Jurisprudenz weiterhin befolgt wurde, bei dem der philosophische Charakter des Naturrechts stärker hervortrat und bei dem die lutherischen Spannungen zwischen Recht und Christentum, zwischen Vernunft und Offenbarung in einer freundlichen gottgeordneten Harmonie beider schließlich verschwanden. Der Glaube an diese Harmonie und das Ideal einer Konkordanz von natürlichen Voraussetzungen und spiritualer Beselung ist von da ab dem Luthertum eigentümlich geblieben. Melanchthon entwickelte in seinen ethischen Schriften und juristischen Reden den uns bekannten naturgesetzlichen Gedankenkreis in den klassischen Formeln Ciceros und in der Anlehnung an Aristoteles, dessen Politik er auch kommentierte. Das ciceronianische Naturgesetz wird aus dem mit ihm identischen Dekalog erklärt, vermöge dieser Identität werden ihm auch die religiösen Elemente eingefügt, die es bei den Heiden verloren hatte. Damit ergibt sich eine Fassung des Staates und seines rechtlichen Strafamtes, das auf der Idee von der Vernunft als der

insbesondere, daß der Mensch zur Gesellschaft bestimmt sei und daß in ihr Ueberund Unterordnung herrsche, zugrunde, welche sie zu erkennen und in ihren Konsequenzen zu entwickeln hat. Aber es sind Begriffe und Prinzipien, die Gott dem Menschen einpflanzte. Dies ist es, was den Staat zur göttlichen Ordnung macht... Der bestehende Staat und das bestehende Gesetz sind göttlich, auch wenn sie drückend sind und die Freiheit begraben; auch ein göttlicher und ungläubiger Herrscher ist áls Zuchtrute Gottes in seinem Rechte zu achten. Jede eigenwillige und leichtsinnige Veränderung in Verfassung und Gesetz ist verwerflich; selbst Abweichungen von der Vernunft sind zu dulden, wenn sie nur nicht gänzlich der Natur widerstreben und dann dieselbe verderbene 260. Wie dann unter dem Einfluß der Problemstellungen des Schmalkaldischen Bundes Melanchthon und Luther das Resistenzrecht anerkennen und gelegentlich sich wieder zum rationalistisch-individualistischen Naturrecht verirren, zeigt Cardauns S. I4-19; hier gelegentlich Vorstufen von Calvins Lehren. Leider zeigt Cardauns nicht das Verschwinden dieser Lehren aus dem Luthertum; es hängt vermutlich mit der allgemeinen gnesiolutherischen Reaktion und der kursächsischen Sättigungspolitik zusammen, wodurch dann die Reformen und Fortschritte erstrebenden Mächte zum Calvinismus gedrängt wurden. Im späteren Luthertum dreht sich das Problem df* Resistenz nur mehr um das reichsrechtliche Problem des Verhältnisses von Territorialherren und kaiserlicher Gewalt, wo eine streng kaiserlich-konservative und eine calvinistisch beeinflußte, in Jena konzentrierte freiere Richtung einander gegenüberstanden, s. Stintzing, Gesch. d. deutschen Rechtswissenschaft II, I884, S. 40-54. - Das allmähliche Versickern der liberaleren Fassung des Naturrechts in der Schule Melanchthons s. bei v. Kaltenborn, Vorläufer des Hugo Grotius 1848. 
Trägerin der Disziplin und der Erziehung gegen die Sünde sowie des Schutzes für Ordnung und Wohlfahrt beruht; ebenso eine Auffassung des Zivilrechtes, die im römischen Recht die mit $\mathrm{Na}$ turgesetz und Dekalog identische positiv-rechtliche Ausformung des Naturgesetzes erkennt und für die kommenden Juristen das römische Recht genau so zur Norm und zum gegebenen Stoff macht, wie die Bibel es ist für die Theologen. Nicht als Judengesetz, sondern als Auszug des Naturgesetzes gilt der Dekalog, und darum ist auch für die Christen das vernünftige römische Recht ihr Gesetz und nicht, wie die Sektierer wollen, das mosaische Gesetz. Auf dieses geschriebene Recht bezieht er auch die aristotelische Lehre von der Herrschaft des Gesetzes im Staate. Auch hier ist das Evangelium im Bunde mit der Vernunft. Zugleich ergibt sich aus dem Naturgesetz die Gliederung in Stände und Berufe samt dem Privateigentum, das freilich erst dem relativen Naturrecht des Sündenstandes angehört, nun aber auch umso stärker als göttliche Stiftung zu behaupten ist. In alledem ist bei Melanchthon ein stärkerer rationalistischer Zug als bei Luther. Von dieser seiner Rationalisierung her ergeben sich dann auch wieder die alten rationalistischen Gedanken von der Zustimmung der Beherrschten zu der herrschenden Gewalt. Aber gleichzeitig führt er den Staat doch auf ein Mandatum Dei zurück, das schon in der paradiesischen Stiftung der Familien-Autorität enthalten gewesen ist, und damit mündet er dann ganz ein in das lutherische autoritative Naturrecht der Gewalt und Ordnung. $\mathrm{Ja}$, er steigert nun seinerseits diesen Gedanken, indem er die formelle Stringenz der gegebenen Rechtsordnung viel stärker geltend und von der Aequität einen viel geringeren Gebrauch macht als Luther. Das Widerstandsrecht hat er umgekehrt in weiterem Umfange behauptet als Luther, aber doch auch das nur unter Berufung auf das positive römische Recht, wo der Imperator erklärt, unter Zustimmung seiner Untertanen die Gewalt ausüben $\mathrm{zu}$ wollen, und unter Berufung auf das deutsche Reichsrecht, wo die ständische Libertät gegen einen vertragsbrüchigen Kaiser zum Widerstand berechtigt ist. Schließlich hat er gegen die schlimmsten Ungerechtigkeiten die Resistenz auch als de jure naturae berechtigt anerkannt, und Luther hat sich dem unwillig genug gefügt, die Frage den Juristen und der Vernunft befehlend. Aber die Wirkung davon im lutherischen Naturrecht ist gering. Im Ganzen hat hier Luthers Geist die Oberhand be- 
halten. Die Melanchthonschen Besonderheiten verschwanden, wie im Dogma, so auch im Naturrecht. Wenn der humanistische Verehrer des Aristoteles die aristokratischen Stadtrepubliken bevorzugte vor dem zur Tyrannis * neigenden Absolutismus, so verschwand auch das mit dem Rückgang der Städte von selbst aus der politischen Theorie des Luthertums. Zu Luthers Auffassung von der Gewalt paßte in der Tat der Absolutismus besser, und die Abneigung gegen die Sakramentierer war zugleich eine Abneigung gegen die oberdeutschen Republiken ${ }^{252 a}$ ).

In dem von Melanchthon geschaffenen Rahmen bewegte sich die ganze weitere Jurisprudenz; in staatsrechtlichen Dingen nur immer stärker den konservativ-autoritären Charakter betonend, wenn auch die Formeln von einer stillschweigenden Zustimmung der Bürger zur herrschenden Gewalt fortgeschleppt wurden ${ }^{253}$ ). Ein eigentliches Staatsrecht und eine ausgeführte

252a) Vgl. Cardauns S. 13: Mel. folgt anfangs den lutherischen Meinungen, zeigt dann aber sim Gegensatz zu Luther von vorneherein nicht erst unter dem Einfluß äußerer Begebenheiten a seine Vorliebe für ständische Kontrollen der herrschenden Gewalt. Cardauns hebt seine Vorliebe für $\mathrm{Ph}$. de Commynes hervor (über diesen ibid. S. 30 u. Baudrillart, Bodin 1853, S. 10-13), auch Anklänge an die erasmische Staatslehre Cardauns S. 3I f. - Ueber den Zusammenhang des Hasses gegen die Sakramentier mit der Abneigung gegen die Republik siehe v. Schubert, Bündnis und Bekenntnis 1529/30, 1908, S. 9. - M.s Schule s. Hinrichs I.

253) Vgl. Stintzing, Gesch. d. deutschen Rechtswissenschaft I, 188o. Sehr charakteristisch hier die Deduktion bei dem Juristen Konrad Lagus S. 302 f.: Unterscheidung von jus naturale primaevum und jus naturale secundarium, das letztere > durch Gottes Gnade dem Menschen verliehen gegen seine verdorbene Natura. -Das daraus fließende Recht nennen die Römer jus gentium, weil es bei allen Völkern beobachtet wird. Es wird auch jus divinum genannt. Mit Unrecht beschränken die Calvinisten diesen Namen auf die im Evangelium vorgeschriebenen Normen. Denn es gibt viele leges vere divinae, welche weder im Evangelium noch im mosaischen Gesetz ausgesprochen sind. Jus divinum ist alles, was Christi Willen entspricht und die reine menschliche Vernunft zum Schutze des Daseins der menschlichen Gesellschaft fordert. Dieses jus naturale hat mehrere gradus, welche im Dekalog (durch Unterscheidung der ersten und zweiten Tafel) angegeben sind. Seine Gebote, und zwar sowohl die der ersten als die der zweiten Tafel, lassen sich aus der menschlichen Natur und Vernunft herleiten. Allein da die Triebe der (sündigen) Natur des Menschen so mächtig sind, daß er oft gegen das judicium naturale handelt, so genügt es nicht, den Gehorsam seinem guten Willen zu überlassen. Daher ist es notwendig gewesen, andere legum carceres zu erfinden, um die Menschen durch öffentliche Autorität zum Gehorsam zu zwingen. Diese Betrachtung führt auf das positive Recht, jus civile, quod publica necessitate exi- 
politische Theorie bildeten sich überhaupt erst im 17. Jahrhundert, bis dahin blieb der Stoff auf Dogmatik, philosophische Ethik, Erklärung der aristotelischen Politik und Auslegung der hierzu geeigneten Stellen des römischen Rechtes verteilt und reproduzierte nur die bekannten Gedanken mit steigender Betonung der göttlichen Einsetzung der Obrigkeit, wie das dem zunehmenden Absolutismus entsprach und auch in den Staatstheorien des katholischen und anglikanischen Absolutismus geschah. Das geschlossenere Staatsrecht des I 7. Jahrhunderts wandte sich dann dem empirischen Rechtsstoff zu. Die prinzipielle Auffassung blieb jedoch dabei die lutherisch-melanchthonische von der Zurückführung des Staates auf die Vernunft und auf göttliche Einsetzung zugleich, und innerhalb des Territorialstaates selbst verband sich die neue Souveränetätstheorie Bodins mit der alten Lehre von der demütigen und vertrauensvollen Ergebung in die von Gott gesetzte Obrigkeit. Die naturrechtlichen Elemente der Theorie traten dabei immer mehr zurück und reduzierten sich schließlich auf den kahlen Satz von der göttlichen Leitung der Vernunft in der Hervorbringung der politischen Gewalten. Je mehr dann von der Grotianischen Schule ein rein rationales Naturrecht ausgebildet und von der Theologie emanzipiert wurde, um so mehr hielten sich die Lutheraner an diese göttlichen Einsetzungen, die zwar mediate geschehen aber doch göttliche Einsetzungen sind. Nun heißt es einfach: die Obrigkeiten stammen so, wie sie sind, von Gott. Für die philosophische Begründung eines irrationalen Naturreohts im Unterschiede vom rationalen Naturrecht, wie das später Stahl getan und damit die moderne konservative Theorie wissenschaftlich unterbaut hat, fehlten in dem herrschenden System aristotelisch-scholastischer Metaphysik alle Mittel und war innerhalb der gläubigen Atmosphäre auch kein Bedürfnis. Pufendorf, der in seiner Gesamtstellung ein guter Lutheraner war und nur den positiven Wert des Staates kulturfreudiger und optimistischer

gente civium suffragio (1) in aliqua re publica constituiturs. Dieselbe Deduktion und die Behandlung der Begriffe jus naturale primaevum und jus naturale secundarium als technische Begriffe bei Kling I 307. Es ist dasselbe, wie wenn ich in der bisherigen Darstellung stets sabsolutes und srelatives Naturrecht untersehieden habe. Ebenso bei dem maßgebendsten Juristen Joh. Oldendorp I 371 : Das jus naturale secundarium sei in dem Dekalog zusammengefaßt als Mittel gegen die Sünde, von da in die römischen 12 Tafeln übergegangen, die die Römer von den Griechen, diese aber van den Hebräern gelernt hätten. Erst mit diesen Angaben sieht man in den ganzen Aufriß des altlutherischen Denkens hinein. 


\section{6 \\ 1II. Der Protestantismus, 2. Das Luthertum.}

einschätzte als Luther, suchte von dem Grotianischen individualistisch-rationalistischen Naturrecht den Uebergang zu dem lutherischen Realismus und Positivismus des Rechts- und Machtgedankens, aber teils drängte die erstere Tendenz über ihn hinaus, teils fühlte sich der orthodoxe Sündenpessimismus und die spätlutherische Lehre von der göttlichen Einsetzung der Obrigkeit von ihm abgestoßen. So blieb er ohne Wirkung auf das kirchliche Naturrecht, und man begnügte sich in diesen Kreisen mit einer höchst aphoristischen Theorie und einer theologisch-absolutistischen Praxis. Als Christian Thomasius auf Pufendorfs Seite trat, schrieb der dänische Hofprediger Masius gegen ihn eine Schriit über ^das Interesse der Fürsten an der wahren Religion*, worin er die lutherische Konfession als sicherste Stütze des gemeinen Wesens prics und die Fürsten darauf aufmerksam machte, wic vortcilhaft für sie das Dogma sei, daß alle fürstliche Gewalt unınittclbar von Gott komme. Zugleich verdächtigte er die reformicrte und katholische Konfession, daß sie die Rebellion und den Aufruhr begünstigen, indem sie jenem Dogma widersprechen. Das ist nicht mehr ächt lutherisch, sondern die Aufpfropfung des Absolutismus auf die lutherische Lehre. Aber die letztere bot dafür in cler Tat hinreichende Möglichkeiten ${ }^{254}$ ).

254) Die Finzelheiten s: bei Stintzing II; die Lehren der Theologen des I7. !nhrh. bei Sclımidt, Ev.-luth. Dogmatik, 459 f.: Hollaz: Causa efficiens principàlis magistratus est Deus triunus, qui certis personis officium magistratus committit vel immedinte ( $E x$ 3, 10. Num 27, 18. I Sam 9, 15) vel mediate (Joh. 19, 11).. Ilodic ad officium magistratus personae habiles moder ante Deo legitime perveniunt vel per clectionem vel per successionem vel per justam occupationem \&. J. Gerhard: Magi.ntratum potestate aliqua instructum esse patet ex Rom 13, I . Potestas illa magistratus non est absoluta, illimitata et incleterminata, sed ad leges et normam superioris alicujus potestatis restricta. Cum enim potestatem suam a Deo magistratus acceperit, ilco Deum superiorem recognoscere et illius voluntati ac legibus in usu hujus polcstatis sese conformare tenetur ... Quando ergo politici absolutam potestatem (Jas ist die Lehre bodins) sumıno magistratui tribuunt, id non est accipiendum simpliciter nec respectu superioris sc. Dei, sed dumtaxat respectu inferiorum ma is istratum (das ist der runde Gegensatz gegen die calvinistische HauptIchre). . Propter peccatum protoplastorum non solum spiritualibus et aeternis futurae vitae bonis, sed etiam corporalibus et externis hujus vitae commodis genus humanum excidit. Scd Deus ex miranda et nunquam satis praedicanda benignitate propter filii intercessionem non illa solum sed etiam haec restituit ac reparavit ac media illis conservandis ordinavit.. Per magistratum politicum Deus conscrvat pacem et tranquillitatem externam, administrat justitiam civilem, defendit 
Aehnlich ging es mit der Entwickelung der snatürlichen * Wirtschafts- und Gesellschaftslehre. Zunächst bedurfte es hierfür überhaupt keiner eigentlichen Wissenschaft von diesen Dingen, da die gegebenen Verhältnisse als Ausdruck des Naturgesetzes und der Vorsehungsleitung selbstverständlich waren. Es bedurfte nur der prinzipiellen theologisch-ethischen Gesamtanschauung und daneben einer praktischen Regierungstechnik, die im Zusammenhang mit der gegebenen Lage und den positiv-rechtlichen Verhältnissen die Ueberführung der noch stark patrimonalen Staatsfacultates, famam et corpora «. Alles das geschieht vermittelst der naturgesetzlichen Vernunft, allein die spätere Lehre betont vor allem die göttliche Einsetzung des Gegebenen, worauf dann eine den empirischen Rechtsstoff bearbeitende Jurisprudenz sich begründet ohne viel Sorge um die - theoretisch behauptete - Ableitung aus dem Naturgesetz undder Vernunft. - Die Lehre der Juristen zusam mengefaßt bei Reinking : - Das Fundament seiner politischen Ueberzeugung ist die (vermittelte) göttliche Einsetzung aller Obrigkeit. Wer sich an ihr vergreift, Treubruch und Ungehorsam übt, hat Gottes Strafe zu erwarten, wenn auch im äußersten Notfall der Widerstand entschuldigt werden kann, wenn er einem Fürsten entgegengesetzt wird, der durch die Verachtung der Grundgesetze und rechtliche Gewalttat zum .Tyrannen s geworden ist (das ist auch hier ein Rest des naturrechtlich-rationalistischen Individualismus!). Als die beste aller Regierungsformen erscheint ihm die Monarchie, weil sie die älteste und nat ürlichste Ordnung, die den Frieden am ehesten wahrt, und der göttlichen Weltregierung am ähnlichsten ist «, Stintzing II 197. In reichsrechtlichen Dingen hat R. den kaiserlichen Standpunkt; das Reich ist die vierte Danielische Weltmonarchie mit ewiger Dauer. Autoritäten sind das römische und das Lehensrecht und die mittelalterlichen Juristen, $>$ R.s Werk ist mit jeder Faser in die Ueberlieferungen des M.A. verwoben, soweit nicht sein entschiedener Protestantismus ihn befreit hate 199. Die entgegengesetzte, moderne, niederländisch und calvinistisch beeinflußte Schule des Arumäus und Limäus scheint nach Stintzings Angaben auch nur in Bezug auf das Reichsrecht moderne Ideen gehabt zu haben. Die analoge Entwickelung im katholischen Absolutismus (nicht aber bei den juristischen Staatsphilosophen) s. bei Kaufmann S. I6f. und in Bossuets Politique tirée de l'Ecriture 1709; im englischen Absolutismus analoge Ausführungen bei Filmers Patriarcha 1680. Das Naturrecht wird den orthodoxen Lutheranern erst verdächtig, seit das Grotianische Naturrecht dasselbe von der Theologie emanzipiert hatte, s. Stintzing II 129; dem gegenüber schreibt Reinking eine sBiblische Polizei, d. i. gewisse aus heiliger göttlicher Schrift zusammengebrachte, auf die drei Hauptstände, als. geistlichen, weltlichen, häuslichen, gerichtete Axiomata, Frankfurt I653; sdie wiederholten Auflagen beweisen, daß das Buch den verdienten Beifall gefunden hate. Stintzing II $207 \mathrm{f}$. Gleichen Geistes ist Seckendorffs Deutscher Fürstenstaat 1655 und Christenstaat 1685. - Ueber das Verhältnis von Grotius u. Pufendorf zu diesen kirchlichen Gedankenkreisen s. Bluntschli u. Hinrichs, über Masius s. Bluntuchli S. 184 . 
verwaltung in eine bureaukratisch rationalisierte und finanziell gesichcrte Staatshoheit ermöglichte. Diese patriarchalische Wirtschaftslehre bediente sich dabei der konservativ-naturrechtlichen und theologisch-ethischen Theorien, genau so wie die Staatslehre. So bewegte sich die Theorie im engsten Zusammenhang mit der gleichfalls sehr aphoristischen Staatsphilosophie und der Erklärung des Aristoteles, in alter scholastischer Weise Staat, Gesellschaft und Wirtschaft lediglich unter ethisch-theologischen Gesichtspunkten und Interessen behandelnd; und auch die praktischen Anweisungen blieben erfüllt mit biblischen und humanistisch-antiken Belegen, in denen sie die prinzipielle theologisch-juristische Grundanschauung. zum Ausdruck brachten. Es ist unter der Voraussetzung der sündigen und verderbten Natur und der vorsehungsmäßigen Realtion der Natur gegen diese Verderbung eine religiös bestimmte, relative Physiokratie, eine auf die Bedingungen des Sündenstandes eingerichtete "natürliche* Wirtschaftslehre, in allem Wesentlichen lediglich die Fortführung der scholastischen Theorie, die nur den Aristoteles neubelebt und durch eine gewisse Wirklichkeitsbeobachtung der modernen Humanisten praktischer gemacht ist. Vor allem aber ist auch von dieser lutherischen Gesellschafts- und Wirtschaftslehre her dem lutherischen Naturrecht die Wendung zum Konservativen und Autoritativen gegeben in engem Zusammenhang mit der ganzen Auffassung des Wesens der Gewalt und der Ueberordnung ${ }^{255}$ ).

255) Hiezu vgl. Roscher, Gesch. d. Nationalökonomik in Deutschland, 1874. 'Trotz der Meinung, daß die Reformation eigentlich eine Erneuerung auch des wirtschaftlichen Denkens sei, erkennt $R$. doch den rein scholastischen Charakter bci der Charakteristik der beiden Hauptvertreter lutherischer Gesellschaftslehre; Melchior v. Ossa ( $\dagger$ 1557) und L. v. Seckendorff ( $\dagger$ 1692): zUnser Ossa steht gleichsam mit einem Fuß in der theologischen Periode der Nationalökonomik, mit dem anderen in der juristischen. Außer der Bibel, den »lieben « Kirchenvätern, dem Aristoteles zitiert er hauptsächlich nur die Corpora juris \&. I I5. Daß das letztere kein Gegensatz gegen das christliche Naturrecht ist, ist bereits gezeigt und beweist auch der Titel des Hauptabschnittes des Ossaschen Gutachtens \Von gottseliger, weiljlichen, vcrnünfigen und rechtmäßjigen Regierung und Institutione. Hier ist dic Identifikation von Bibel, Vermunft und Recht deutlich ausgesprochen. Eine ähnliche Charakteristik aus Anlaßs v. Seckendorff : \Jene theologische oder doch wenigstens religiöse Färbung der Staatswissenschaft und Nationalökonomik, welche die Reformation aus der scholastischen Periode $n i c h t$ ur beibehalten, sondern noch wesent licherwärmt und vertieft hatte, war unter S.s Zeitgenossen in raschem Verbleichen«, S. 240. Ueber die Entwickelung vom 
So haben wir also im klassischen Luthertum die freiwillige Liebeskonkordanz des weltlichen und geistlichen Regiments zur Verwirklichung des religiösen Lebenszweckes der christlichen Gesellschaft. Wir haben die Verschmelzung der natürlich-philosophisch-weltlichen und der biblisch-übernatürlich-spiritualen Ethik zum Ganzen einer die natürlichen Lebensformen mit religiöser Liebesgesinnung durchdringenden Lebensführung. Es ist ein einheitliches Lebenssystem christlicher Kultur wie im Katholizismus des Mittelalters. So hat dieses Gesellschaftssystem auch, wie dieser, das Ideal eines einheitlichen soziologischen Grundschemas; nur, wie Grundlagen und Sinn des einheitlichen

ersten zum zweiten s. S. 252: Der Fürst wird aus dem Patrimonialherren zum neueren Staatsoberhaupt; bei aller Frömmigkeit werden Staatswissenschaft und Volkswirtschaftslehre , von der gänzlichen Vermengung mit Theologie und Jurisprudenz sehr emanzipiert ; das staatswissenschaftliche und kameralistische Gebiet kommt über Aphorismen hinaus jetzt erst zur Systematik. Ueber die kirchliche Gebundenheit und die Benützung biblischer Beispiele für Vernunftlehren auch bei moderner gesinnten Autoren s, die Bemerkungen über Obrecht S. 152. Das Hauptinteresse galt der Erhaltung des Systems der Ständeteilung, dem auch die Kleiderordnungen und teilweise die Luxusgesetze dienten, S. II9, I2I, 127f., 247; es ist von Gott gesetzt, wie der Staat selbst, mit dessen Begriff es gegeben ist. Das zweite Hauptinteresse ist die Steigerung der Macht des Landesfürsten, der aber patriarchalisch an natürliches und göttliches Recht gebunden bleibt und nicht machiavellistisch regieren darf, S. 106, 129 f., 204. - Für die Theologen ist das Ganze eine Angelegenheit der Obrigkeiten, die dabei nach Naturgesetz und göttlichem Gesetz als das berufene Organ zur Auswirkung des Zweckmäßigen zu handeln haben; so Hutter: -Praecipua officia magistratus politici sunt: I) curam gerere utriusque tabulae decalogi, quod ad externam disciplinam attinet, 2) ferre leges de negoti is civilibus et oeconomicis consentaneas juri divino et naturali; 3) sedulo providere, ut leges promulgatae veniant in executionem; 4) delinquentibus pro qualitate delicti poenas irrogare, obedientes fovere et praemiis afficere oder Hollaz: Magistratus civilis est ordinatus ad bonum publicum idque quadruplex 1) ecclesiasticum, cum reges nutritii ecclesiae et episcopi extra templum; 2) civile, dum civium commoda tuetur et hostes externos finibus patriae propulsat; 3) morale, quatenus honestas praescribit leges, quibus subditi in officio continentur, ut vitam tranquillam agant in pietate et honestate I Tim 2, 2; 4) naturale, quo imperantes prospiciant subditis de commeatu et aliis necessariis instar Pharaonis Gen 4I, 34. Schmidt, Dogmatik 460. - Ueber das besondere inhaltliche Wesen dès wirtschaftlichen Naturgesetzes s. weiter unten. Ueber das Verhältnis der werdenden modernen Wirtschaftslehre und ihres individualistisch-rationalistischhedonistischen Charakters zu der des kirchlichen Naturrechts s. Onken, Gesch. d. Nationalbkonomie I 1902. 
Lebenssystems hier verändert sind, so hat auch das soziologische Grundschema des Luthertums einen veränderten Charakter. Der Unterschied liegt auf der Hand: das Grundschema des Luthertums ist nicht auf den Begriff des Organismus aufgebaut. Hatte das Mittelalter den christlichen Individualismus in seiner Gesellschaftsidee dadurch zum Ausdruck gebracht, daß es in allen Abstufungen der Gesellschaft doch dem Individuum einen rechtlichen Anspruch auf Befriedigung seiner Interessen innerhalb des Kosmos der Stände je nach dem Maße seiner Standeszugehörigkeit zusprach und der kirchlichen Oberleitung in letzter Linie die Regulierung des Organismus nach diesen Forderungen in die Hand legte, so ist der christliche Individualismus des Luthertums rein in die Tiefen der Gesinnung versenkt, ohne rechtlichen Anspruch an die Gesellschaft und an die Kirche, ohne Fähigkeit der äußeren Geltendmachung und im Grunde wesentlich und begrifflich ohne Gemeinschaftsbedürfnis überhaupt, indem er nur aus Liebe sich unter die Bedingungen des Gemeinschaftslebens beugt. Er ist hinter die Schlachtlinien alles äußeren Geschehens und Handelns zurückgegangen, rein bei sich selbst in der Burgfreiheit einer durch äußere Umstände und Rechte, durch Leid und Freud, durch Welt und Gesellschaft nicht zu brechenden und nicht zu beeinflussenden Innerlichkeit, die nichts als das kirchlich garantierte Wort voraussetzt und daher auch in der Kirche nur die Predigtanstalt des Wortes mit rein innerlich-wunderbarer Bekehrungswirkung, aber nicht eine ethische Gesamtorganisation der Christenheit kennt. Hier in dieser Innerlichkeit ist der lutherische Individualismus unbegrenzt und lediglich an Glaube und Sakrament gebunden, erhebt er den Christen zum König und Herrn über alle Dinge, gibt ihm einen unüberwindlichen Vorsehungsglauben und felsenfestes Gottvertrauen, eine völlige Freiheit der Charakterbildung aus dem aufgenommenen christlichen Geiste. Sobald er aber aus dieser Innerlichkeit heraustritt in die Formen und Verbindungen des realen Lebens, äußert er sich nur in der Unterwerfung unter die geltenden Ordnungen als Mittel, die christliche Liebe zum Bruder und zum Ganzen der Gesellschaft zu bekunden, oder im Leiden und Dulden der Bosheiten der Welt, ausgenommen den Zwang der Glaubensverleugnung selbst. Unbegrenzt in sich selbst, ist er ohne Organ und ohne Sicherung und darum auch ohne Wirkung nach außen. Sofern die christliche Gesinnung dennoch eingeht in die natürlich-weltlichen Ordnungen, 
äußert sie sich nicht als Stiftung einer Gemeinschaft von religiös begründeten Individualwerten, sondern als Aufsaugung aller weltlichsozialen Verhältnisse in die Gesinnung einer Liebe, die sich zum Wohl des Ganzen bedingungslos den von Gott und der Vernunft gestifteten Ordnungen unterwirft und Familie, Staat, Arbeit und Gesellschaft bloß zu Verwirklichungsmitteln und Betätigungsformen christlicher Liebes- und Gehorsamsgesinnung macht. Von den zwei Elementen des katholischen Grundschemas fällt das organische völlig weg und wird dessen Gehalt an Individualismus zurückverlegt hinter das reale Gemeinschaftsleben, wobei er zugleich unermeßlich gesteigert wird. Für das reale Leben dagegen bleibt nur das andere Prinzip, der Patriarchalismus, übrig, der nun auch seinerseits, ohne jeden Kompromiß mit dem organischen Prinzip zum äußersten Extrem gesteigert und zugleich viel prinzipieller in die religiöse Liebesund Gehorsamsgesinnung aufgelöst wird. Der thomistische Patriarchalismus war doch immer mehr eine Ergebung in die zur Strafe und Heilung der Sünde geschaffenen Gewalt-, Macht-, Standes- und Besitzunterschiede, während das organische Prinzip in seiner Betonung des Individualismus die Rechte der urständlichen Freiheit, Gleichheit und Liebeskommunion festhielt und überdies das Ordenswesen diese eigentlich christliche Ordnung wenigstens partiell verwirklichtc. Der lutherische Patriarchalismus dagegen sieht in dem jus naturale secundarium immer mehr lediglich die Ordnung und Stiftung Gottes, in die Demut und Ergebungsseligkeit des Gerechtfertigten ohne eigenmächtiges Deuteln sich fügt, und die weise Vernunftordnung, in deren Befolgung auch das natürliche Wohl am besten gesichert wird und die daher zu befolgen auch der christlichen Liebe eine fröhliche Pflicht ist. Dem entspricht im Luthertum, daß die Messung der gegebenen Verhältnisse an eincm andersartigen idealen Urstande immer mehr zurücktritt und daß die Entfaltung der dem patriarchalischen Verhältnis eignenden Tugenden der Fürsorge und Verantwortung wie des Vertrauens und der Pietät immer mehr zum Inbegriff aller Ethik wird, soweit sie auf das äußere Handeln in der Gemeinschaft sich bezieht. Wie das Verhältnis Gottes zu den Menschen selbst ein patriarchalisches ist, so wird auch das der Menschen zu einander ein solches. Und wie dicses Grundschema am reinsten betätigt werden kann innerhalb der Familie mit ihrer Angewiesenheit auf Autorität und Pietät, so wird die Terminologie wie die Gesinnung des Grundschemas von der Familie aus auf den Gesamtumfang des übrigen Lebens ausgebreitet. 
Der Fürst wird zum Landesvater und die Untertanen zu Landeskindern, der Gutsherr zum fürsorgenden, Gehorsam heischenden und Gott im Patrimonialgericht vertretenden Gutsvater und die abhängige Bauernschaft zu pietätvoll gehorchenden und gerne dienenden Gutskindern, der Arbeitgeber zum fürsorgenden, Dienstboten und Gesellen in der häuslichen Gemeinschaft und Zucht haltenden Hausvater und die Dienstboten und Lohnarbeiter zu willigen und dankbaren Hausgenossen, die in dem Hausherrn Gott dienen. In unübertrefflicher, klarer, herzlicher und kräftiger Weise hat Luther dieses Grundschema in seinen Katechismen beschrieben, und mit diesem Grundbuche lutherischer Ethik wurde es in unendlicher Wiederholung in die Seelen der lutherischen Gläubigen hineingehämmert. In der Katechismus-Praxis wurde die Erklärung des vierten Gebotes, das Zentrum aller Sozialethik und, was hier gelehrt worden war, verdeutlichte noch einmal die dem Katechismus beigegebene Haustafel etlicher Sprüche für allerlei heilige Orden, dadurch dieselbigen als durch eigene Lektion ihres Amtes und Dienstes zu vermannens. Bis zum heutigen Tage lernen so die lutherischen Kinder mit dem Katechismus, die Grundzüge einer patriarchalischen, agrarisch-kleinbürgerlichen Ethik, wo sie ^Gott fürchten und lieben, daß wir unsere Eltern und Herren nicht verachten noch erzürnen, sondern sie in Ehren halten, ihnen dienen, sie lieb und wert haben «, und wo sie Gott danken, daß er $\rightarrow$ mich geschaffen hat samt allen Kreaturen, mir Leib und Seele, Augen, Ohren und alle Glieder, Vernunft und alle Sinne gegeben hat und noch erhält; dazu Kleider und Schuhe, Haus und Hof, Weib und Kinder, Aecker, Vieh und alle Güter; mit aller Nahrung und Notdurft des Leibes und Lebens reichlich und täglich versorget, wider alle Fährlichkeit beschirmt und vor allem Uebel behütet und bewahret; und das alles aus lauter väterlicher, göttlicher Güte und Barmherzigkeit; ohne all meine Verdienste und Würdigkeit; das alles ich ihm zu danken und $\mathrm{zu}$ loben und dafür $\mathrm{zu}$ dienen und gehorsam zu sein schuldig bin ${ }^{256}$ ). Das lernen

$\left.{ }^{256}\right)$ Klassisch ist dieses Grundschema entwickelt im „Großen Katechismus : Man hat sich in die gegebenen Ordnungen zu fügen als in die smedia per creaturas bona percipiendia. Denn screaturae tantum manus sunt, canales, media et organa, quorum opera et adminiculo Deus omnia largitur hominibus... Quam ob rem et haec media (nämlich Eltern, Obrigkeiten und die allgemeinen Beziehungen des Nächsten zum Nächsten) . . non sunt respuenda neque temeraria praesumtione aliae rationes et viae investigandae, quam Deus praecepit.. So haben Eltern, 
alle Kinder aus allen Ständen, in der Großstadt und in der Kleinstadt, im Fürstenschloß und in der Fabrikantenvilla, im Gutshof

Obrigkeiten und christliche Mitmenschen von Gott den Auftrag in ihrer durch die Natur bewirkten Stellung empfangen, sut omnis generis officia nobis ostendant et exhibeant adeo, ut haec non ab illis, sed per illos a Deo peculiariter accipiamus (Symb. Bd. ed. Müller S. 390). Das wichtigste unter den so das Verhältnis zum Năchsten ordnenden Geboten der zweiten Tafel ist das vierte: du sollst deinen Vater und deine Mutter ehren, S. 405. Zunächst wird dieser Stand der Familie in seiner unmittelbaren Bedeutung geschildert, aber als höchstes Ideal soziologischer Beziehungen: $>$ Hunc parentum statum et ordinem Deus praecipue hoc ornavit elogio ante omnes, qui sub ipso sunt, status et ordines, ut non simpliciter praecipiat parentes esse amandos, sed honorandos... Est enim ho nor res a more multis modis sublimior, utpote qua non tantumamorem in se complectatur, verum etiam singularem quandam mode. stiam, humilitatem et reverentiam, quae cuiquam quasi majestati hic occultae habendasite S. 406. Aber dieses Grundschema erstreckt sich über alle Autoritătsverhältnisse und, da Autoritätsunterschiede bei der Ungleichheit der Menschen überall vorhanden sind, schließlich über alle Beziehungen überhaupt : >In hujus praecepti explanatione neque illud praetereundum est, quod ad multiplicem obedientiam superiorum attinet, nempe eorum, qui versantur in imperio et rei publicae procurationem sustinent. Si quidem e parentum potestate omnes aliae propagantur et mananta. So folgen die Verhălnisse zu den Obrigkeiten, wozu natürlich auch die Ortsobrigkeiten und die Gutsherrschaften gehören; dann die Lehrer aller Art und die Geistlichen, dann die Nachbarn, schließlich die Arbeitgeber und Dienstherrschaften sita, ut omnes, quotquot domini appellatione censentur, vice parentum sint ab iisdemque potestatem ac vim regnandi accipiant. Unde quoque secundum Scripturam omnes dicuntur patres, utpote qui in sua gubernatione officium patris obire ergaque subditos patris animum inducere debeant. Quemadmodum et olim apud Romanos et alios plerosque populos heros herasque patres et matresfamiliạs nominabant. Ita quoque suos magistratus et principes dixerunt patres patriae, nobis Christianis in dedecus et ignominiame S. $412 \mathrm{f}$. Das enthălt dann umgekehrt für die Eltern und Herren die Pflicht der Fürsorge: „Neque enim Dei voluntas est, ut aut perditi nebulones aut enormes tyranni hujus officii procurationem obeant..., sed cogitent potius, quod et ipsi Deo obedientiam debeant, ut officium suae fidei delegatum ipsis curae sit ac sollicitudini utque liberos, familiam et subditos suos non tantum nutriant et corporalibus alimentis provideant, sed omnium maxime ad laudem et gloriam Dei propagardam educante 417. Allerdings gilt im allgemeinen: serga fratres, sorores et proximum in genere nihil amplius (Deus) praecipit quam amore prosequendos essea S. 106; aber darauf folgt dann der Satz, daß es ein viel höher $D$ ing ist, ehren denn lieben, und bei der allgemeinen Abgestuftheit aller Verhältnisse (coram Deo omnes quidem pares sumus, sed nós inter nos hoc dispari et ordinato discrimine 
und im Bauernhof, im Taglöhnerkaten und in der Arbeiterkaserne. Es ist die Summe lutherischer Sozialethik.

Von hicr aus ergibt sich nun auch das Verständnis der e inzelnen Soziallehren über Familie, Staat, Wirt$\mathrm{sch}$ aft und Gesells chaft. Die in den letzteren enthaltenen, aus dem Naturgesetz stammenden Lebens- und Gemeinschaftsformen sind lediglich Formen und Durchgangsstellen für die Erweisung der relgiösen Liebesgesinnung, sind die Betätigung des in der Gnadengewißheit gewonnenen Gottesverhältnisses. Sie werden zu Teilstrecken einer von der Gottesliebe durchströmten Lebenskurve. Darin ist begründet, daß sie keinen eigenen $Z$ weck in sich selber tragen, daß ihre Alizeptierung nur Folge der Gottesergebung und des Gehorsams, auf keine Weise Zweck in sich selber ist. Auch als Mittel der Betätigung der Liebe dienen sie doch nicht dem Liebeszweck, das menschliche Leben in seinen innerweltlichen $Z$ wecken $\mathrm{zu}$ steigern, sondern nur als Mittel, die Liebesgesinnung in der von Gott nun einmal so geordneten Weise auszuströmen. Aber diese Grundidee geht nicht glatt auf. Die naturgesetzlichen Lebensformen tragen doch immer natürliche Lebenszwecke in sich, deren Selbständigkeit bei non possumus non discrepare 406 ) ist die Liebe überall mit Elementen der Ueber- und Unterordnung gemischt und überall mit dankbarer Demut oder fürsorgender Ueberordnung versetzt. - Ebenso klassisch formuliert ist dieses Grundschema samt seiner religiösen Begründung innerhalb der modernen luther. Ethik bei v. Hofmann : >Unsere Förderung der Welt ist eine konservative. Die Demutunserer Liebe $z$ u ihr schließt alle Wiliküraus S. I56f. S. auch Stillich S. 89: vorbildung für die von den Konservativen erstrebte soziale Gliederung der Gesellschaft aber ist die Familie. „Letztere“, sagt der langjährige Führer der sächsischen Konservativen Freiherr v. Friesen, „,bezweckt das harmonische $\mathrm{Zu}$ sammenwirken aller einzelnen Glieder in dem geschlossenen Ganzen, während der bureaukratische (d. h. der moderne) Staat in dem Prinzip der Gleichmacherei selbst das ursprünglich Gleiche für seine speziellen Zwecke auseinanderreißt und die hierdurch gewonnenen einzelnen Alome gewaltsam in sein Schablonenwesen hineinpreßt"«. Das sind bis heute die soziologischen Grundzüge der Weltanschauung bei den Konservativen, soweit ihre Politik eine Politik der Weltanschaung ist. Es ist aber auch klar, daß diese Anschauung eng mit einer antiindividualistischen, immobilisierten Gesamtlage von Politik und Wirtschaft zusammenhängt, und daß einer städtischmobilisierten individualistischen und kapitalistischen Kultur andere ethische und religiöse Ueberzeugungen entsprechen müssen. Daß die Schwierigkeiten des lutherischen Katechismus mehr noch als im Dogma in der Ethik liegen, weiß jeder Pfarrer in Großstädten und Arbeiterdörfern. Er vertritt ein soziologisches Grundschema, das in der modernen städtischen Kultur nicht durchführbar ist. Vgl. hiezu Traub, Ethik und Kapitalismus ${ }^{2}$ I907. 
jedem näheren Eingehen auf sie in der Praxis sich zeigen muß. Da stellt sich dann die Unmöglichkeit heraus, die innerweltlichen Zwecke rein in den religiösen Lebenszweck aufzulösen. Weiterhin haben die natürlichen Lebenszwecke und ihre Gemeinschaftsformen im Sündenstande einen Charakter des Rechtes, des Zwanges, des wirtschaftlichen Eigeninteresses und des Kampfes erhalten, der der eigentlichen Liebesmoral überall im Wesen widerspricht. Daraus ergeben sich dann eigentümliche Schwankungen und Widersprüche in den Soziallehren, welche der Katholizismus in seinem Stufensystem weniger drückend empfunden hatte und welche das Luthertum bei seiner Auflösung des Weltlichen und Religiösen ineinander stärker empfinden mußte. Luther selbst gab ihnen noch starken Ausdruck. Aber im Zeitalter der Orthodoxie verschwinden sie hinter der Lehre von dengöttlichen Einsetzungen und hinter der Ergebung in das Bestehende als göttliche Ordnung. Das Ergebnis ist so schließlich eine furchtbare Armut an Geist und Gedanken, die gegen die katholischen und calvinistischen Soziallehren sehr stark absticht ${ }^{257}$ ), und es ist nicht $\mathrm{zu}$ verwundern, wenn sie im 18. Jahrhundert gegenüber der ganz neuen westlichen Gedankenwelt theoretisch zusammenbrachen, wobei freilich praktisch an den Verhältnissen selbst so gut wie nichts geändert wurde. Das Luthertum der Aufklärung hat die Volksschule, die Freiheit der Forschung und des Gewissens, die Innerlichkeit der ethischen Autonomie, die Gemütstiefe der philosophischen Spekulation hervorgebracht, aber an den Soziallehren hat es nichts geändert. Praktisch hat auch Kant mit seinem Respekt vor der Obrigkcit in diescn lutherischen Kategorien gedacht ${ }^{257 a}$ ). Sie sind jetzt nur bureaukratisch und höfisch verweltlicht. Bei ihrer Wiederbelebung durch die preußisch-deutsche Restauration im 19. Jahrhundert haben sie clann als Kampfinstrument in der Hand einer Herrenschicht jene Beimischung männlicher Härte und klassenkämpferischer Rücksichtslosigkeit erhalten, die das moderne Luthertum von dem alten unterscheidet.

Der Ausgangspunkt aller Sozialbildungen ist für das Luthertum mit der katholischen Tradition die Familie. Sie ist es genetisch, insofern sie, bereits im Paradies oder Urstand gestiftet und

2b7) Hiezu siehe Figgis, From Gerson to Grotius, S. 62-107, wo Luther und Macchiavelli zusammengestellt sind.

2574) Vgl. Troeltsch, Das Historische in Kants Religionsphilosophie 1904, S. 37-42; Kalweit, Kant und die Kirche rgo4. 
nach dem Sündenfall bestätigt und neugeordnet, den Anfang aller Sozialbildungen darstellt, aus dem die übrigen mittelbar oder unmittelbar hervorgegangen sind. Der Staat wird teils als mit ihr gestiftet betrachtet, teils als mit der Sprachen- und Völkertrennung von Gott besonders veranlaßt, wobei er aber auch nur die $\mathrm{Zu}$ sammenfassung der ausgebreiteten Geschlechter unter ein Haupt ist. Sie ist zugleich der Ausgangspunkt aller Wirtschaft und aller Dienstverhältnisse, insofern die möglichst geschlosseneHauswirtschaft als das Ideal erscheint und die ökonomische Theorie im Grunde immer nur an den Familienhaushalt und an den analog vorgestellten fürstlichen Staatshaushalt denkt. Sie ist der Keim und das Vorspiel der Kirche, insofern die religiöse Hausgemeinschaft der eigentliche Zusammenhalt der Familie ist und in der Hausandacht und in der Katechismusunterweisung durch denHausvater das kirchliche Leben zunächst gepflanzt wird. Sie ist schließlich der Urtypus aller sozialen Gliederungen, indem sie urbildlich die Autoritätsund Pietätsverhältnisse darstellt, die aus der natürlichen Gliederung fließen. So ist es selbstverständlich, daß die ganze Sozialphilosophie mit dem Geiste der patriarchalisch verstandenen, monogamischen Familie vollständig durchtränkt ist.

Die Familie selbst ist ein Ausdruck der Regelung, mit der das Naturgesetz die aus der sexuellen Natur des Menschen folgenden soziologischen Probleme löst. Naturgesetzlich ist ihr $Z_{\text {weck die geord- }}$ nete Geschlechtsverbindung, die geordnete Kinderproduktion, und die in gegenseitiger Ergänzung der Arbeitskräfte sich vollziehende Hauswirtschaft als Kern aller wirtschaftlichen Betätigung. Aber die derart naturgesetzlich gestifteten Beziehungen werden beim Christen unmittelbar auch zur Form der ersten und elementarsten religiösen Liebesbetätigung, indem das Gatten- und Elternverhältnis die nächstliegende Gelegenheit zur Betätigung der Liebe darbietet und in diesem Verhältnis die gemeinsame Selbsthingabe an Gott und das göttliche Liebesgesetz betätigt werden soll.

Damit ist allerdings die protestantische Sexualmoral von der katholischen sehr wesentlich verschieden, und, daß Luthers eigene Eheschließung die priesterliche Virginität weithin sichtbar aufhob, ist nicht nur eine Auflösung des katholischen Priesterbegriffes; es liegt darin überdies die prinzipielle Bekundung einer Sexualmoral, die das Geschlechtsleben als etwas Normales ansieht und es $z \mathfrak{u}$ einem Mittel der wesentlichsten ethischen und religiösen Funktionen ethisiert für a ll e Gläubigen. Auch wird der Zweck der 
Ehe bei ihm nicht lediglich von der Aufgabe der Kinderzeugung und Aufzucht her konstruiert, wie das die häufige Erweichung und Anpassung einer asketischen Grundgesinnung ist und wie wir es beim Puritanismus kennen lernen werden. Der Zweck liegt ihm außerdem auch in einem eigenen selbständigen Gut der von den Ehegatten zu genießenden. Liebe, wobei aber freilich das spezifisch erotische Element und das allgemein menschliche, durch die gemeinsame Hauswirtschaft gesteigerte Element der lediglich ethisch-religiösen Verbundenheit in eine innere und feste Verbindung nicht gebracht sind.

So löst die monogamische Familie zunächst nach außen über haupt das Sexualproblem. Vor- und außereheliche Geschlechtsverbindung sind zu vermeiden und alle Geschlechtsgemeinschaft ist aut die Bahn der geordneten Ehe zu führen. Die selbstverständliche Folgerung hieraus ist die Mahnung zu früher Eheschließung. Populationistische und ökonomische Bedenken schlägt der entschlossene Vorsehungsglaube nieder, der das Kinderzeugen ohne jede künstliche Einschränkung zu einer Pflicht und die Rechnung auf die Möglichkeit des Lebensunterhaltes zur Gewißheit macht. Die Ehelosigkeit wird im Gegensatz zum katholischen Keuschheitsideal für nur ausnahmsweise durch besondere Anlagen und Verhältnisse geboten angesehen, im ganzen aber energisch bekämpft. Die eigentliche Ethisierung der Ehe nach innen, in der gegenseitigen Beziehung der Gatten und der Eltern und Kinder, leistet dagegen erst die christliche Beseelung mit der religiösen Liebesgesinnung, die bei Vorhandensein persönlicher, religiös vertiefter Neigung die sexuellen Beziehungen durch gegenseitige Rücksicht regeln wird, die das Elternverhältnis zur Schule fürsorgender und erziehender Opferwilligkeit und das Kindesverhältnis zu einer solchen der vertrauenden Pietät und demütiger Gehorsamsgesinnung gegenüber allem Uebergeordneten macht. 'Daraus folgt dann auch natürlich die Unauflöslichkeit der Ehe, aber nur als ethische und rechtliche Folgerung; der sakramentale Charakter der Ehe fällt weg. Daher ist in den - über den Ehebruch nur sehr.vorsichtig hinausgehenden - Fällen der Scheidung dem schuldlosen Teil die Wiederverehelichung gestattet. Daß innerhalb der Ehe moralisch und rechtlich eine weitgehende patriarchalische Mannesherrschaft als selbstverständlich erscheint, ist nicht bloß mit den ökonomischen Verhältnissen, der katholischen Ueberlieferung, sondern mit dem eigentlichsten Grundgedanken des Luthertums gegeben, welches die von Natur gesetzte 
körperliche Ueberlegenheit als Ausdruck eines von Gott gewollten Uebeṛordnungsverhältnisses und feste Ordnung als den Hauptzweck aller sozialen Organisationen ansieht. Der Hausvater ist der Rechtsvertreter, der nicht kontrollierte Gewaltinhaber, der Brotherr, der Seelsorger und Priester seines Hauses. Die Frau büßt die Sünde Evas in der Beugung unter den Mann, soll aber von ihm doch in Christo als religiös gleichberechtigt und gleichwertig betrachtet werden, von wo aus jene Unterordnung gemildert wird. Für den modernen Individualismus der Ehcauffassung fehlen noch die ökonomischen und rechtlichen, aber auch die ethischen Voraussetzungen.

Freilich ist nun aber die Ehe im Sündenstand doch nicht so ohne weiteres eine vollberechtigte Institution. Es bleibt für Luther die sexuelle Lust und die damit verbundene verwirrende Leidenschaft ein Zeichen der Erbsünde; im Urstand gab es keine Wollust, und die Unvermeidlichkeit der Wollust ist ihm der deutlichste Beweis der Allgemeinheit der Sünde. So ist die Ehe als die von Gott und der Vernunft gestiftete Organisation der Wollust im Grunde doch nur frenum et medicina peccati, eine Konzession an die Sünde, bei der Gott durch die Finger schaut und die unvermeidliche Sünde durch die Eheordnung einschränkt und heilt: Entstehen so von daher wieder Bedenken gegen dieEhe, dann beruft sich Luther auf ihre positive göttliche Stiftung und Einsetzung und bezeichnet sie einfach als Pflicht gegen Gottes Gebot. Damit ist sie gewe ht und gegen alle Bedenken geschützt, ja in ihrem christlichen Verstand die wichtigste und edelste soziale Leistung des Christen. Das spätere Luthertum hat zwar die Ableitung der \Lust \& aus der Erbsünde nicht aufgegeben, aber doch jene Bedenken immer weniger empfunden. Es hat, wie in allen Dingen, so auch hier einfach die göttliche Einsetzung betont und damit alle Schwierigkeiten niedergeschlagen, sodaß die naturgesetzlichchristliche Ehe lediglich als Gehorsam gegen Gottes positives Gebot erscheint und nun ähnlich wie im Katholizismus als Vorbild der Gemeinschaft Christi mit der Kirche allegorisch verherrlicht wird. Seine Probleme bezüglich der Ehe liegen daher ledislich auf dem Gebiete des Eherechts und der Teilung staatlichen und kirchlicher Kompetenzen im Eherecht. Während Luther es lediglich dem Staat hatte zuweisen wollen, kam es nun in die Hände der geistlich-weltlichen Behörden der Konsistorien, ein deutliches Zeichen für die hier obwaltende Verschmelzung geistlicher 
und weltlicher Funktionen der christlichen Gesellschaft.

In diesem Familienbegriff sind also die verschiedenen ihn bestimmenden Elemente keineswegs vollständig zu einer Einheit verbunden. Auch ist sich Luther durchaus bewuft, damit ein äußerst hochgespanntes Ideal zu verfreten, dem die Wirklichkeit mit ihrer » wüsten Rotterei und Buberei * durchaus, nicht entspricht. Aber daß die Wirklichkeit dieser Lösung des sexuell-soziologischen Problems so wenig nahekommt, erklärt er sich lediglich aus der sündigen Verderbtheit und den besonders bösen letzten Zeiten. An ihrer Möglichkeit an sich zweifelt er nicht im mindesten. Es ist nur der Widerstand des Teufels und der Fleischeslust, an dem das Ideal scheitert, auch die Ungenügsamkeit und der Luxus, dessen gesetzliche Einschränkung auch nach dieser Seite hin zur Behauptung der Standesgrenzen und Festlegung der Lebensansprüche $z \mathrm{u}$ wünschen ist ${ }^{258}$ ).

258) Vgl. hierzu J. Köstlin, Luthers Theologie 2, 1883, S. 48z: >L. definiert die Ehe als „conjunctio unius maris et unius feminae inseparabilis, non tantum juris naturae, wie die Kanonisten aussprechen: sed etiam voluntatis et voluptatis, ut ita dicam, divinae". Ihren $Z$ weck oder ihre causa finalis sieht er im Kinderzeugen, in der procreatio sobolis. Sie ist vor dem Sündenfall schon eingesetzt als Mittel, Staat und Kirche mit brauchbaren Gliedern zu versehen. „So ist die Ehe und der Hausstand nicht bloß fons et origo generis humani, sondern sie soll eben damit zugleich zur paratio ecclesiae dienen und fons rei publicae werden". Seit dem Sündenfall hat sie auch noch den Zweck, als Heilmittel gegen die Lust und als Damm gegen ihre sündhaften Ausbrüche zu dienen. Ja er bezeichnet dies jetzt als primus finis, während ihm übrigens der ursprüngliche Zweck finis magis principalis bleibt. Sündhafter Charakter behält ihm auch so jene Lust, aber approbatio et beneplacitum Dei tegit miseram turpitudinem libidinis et removet iram Dei imminentem illi concupiscentiae $\aleph_{.}$- Das innere Wesen der Ehe selbst erläutert L. am schönsten im großen Katechismus in der Auslegung des sechsten Gebotes, besonders am Schluß über die innereheliche sKeuschheit * Ubi enim volumus conjugali castitati locum esse, ibi necessum est ante omnia, ut vir et mulier in amore concordes conversentur, ut alter alterum ex animo mutua quadam benevolentia et fide complectatur. Quod si praesto fuerit, ipsa quoque castitas sua sponte sine mandato consequetur (Müller 426). Außerdem vgl. Wald. Kawerau, Die Ref. und die Ehe, 1892 (V. f. Ref.-Gesch. Nr. 39); Marianne Weber, Ehefrau und Mutter S. 282-285; hier ist mit Recht darauf hingewiesen, daß das sneue Frauenideal, das auf die sittlichen Eigenschaften der Hausfrau und Hausmutter, auf Liebe und Treue, auf Gottesfurcht und Gottvertrauen, auf Tüchtigkeit und Ehrbarkeit das Hauptgewicht legt \& (Kawerau 71), stark an Jesus Sirach angelehnt ist; weiter vgl. Rade, Stellung des Christentums zum Geschlechtsleben (Rel. Volksbb. V 7/8) 1910; Sammlung der wichtigsten Stelle bei W. Walter, Für Luther wider Rom, 1906 
Ganz ähnlich geht es mit den inneren Spannungen im St a a t sb e $g r$ iff des Luthertums ${ }^{25}$ ). Durch die Kreaturen als die Hand-

Ueber die populationistische und ükonomische Anschauung von der Sache s. Roscher, Gesch. d. Nationalökonomik S. 57-59. Ueber die Konkupiszenz s. Braun, L.s Lehre von der Konkupiszenz. Es ist das doch nicht ein so leicht fehlen könnender Rest des katholisch-mönchischen Wesens; der Gedanke liegt vielmehr im System, wie wir das Analoge bei Staat und Arbeit wieder sehen werden. In den trockenen Definitionen der späteren lutherischen Scholastiker (Schmidt, Dogmatik 46I-465) verschwindet dieser Zug, aber nur hinter der Positivität des Gebotes. L.s skatholische Reste ă̈ngen überall mit dem altchristlichen Gegensatz von Welt und Heil zusammen und betreffen wesenhafte Probleme des christlichen Denkens, wie denn das Problem der sexuellen Sinnlichkeit unzweifelhaft ein solches ist. Luthers Pessimismus gegenüber den wirklichen Verhältnissen im G. Kat. : Quoniam vero apud nos adeo foeda et nefanda omnium vitiorum et scortationum lerna cernitur, hoc praeceptum quoque adversus omnia impudicitiae genera et species constitutum est... Tantum ergo hoc praeceptuma nobis exigit, ut quisque tum pro se vitam castam agat, tum proximo quoque in hoc obinenda et tuenda sit auxilio (Müller 423). - Rade S. 51 sagt: $\gg$ Die Verlegung dessen, worauf es ankommt, in das Innerste der Person und die daraus entspringende Proklamation der christlichen Freiheit $m u ß t e$ eine völlige Umwälzung des Urteils über die äußeren Vorgänge des Geschlechtslebens zur Folge haben. Und es ist nur als ein Mitschleppen augustinisch-katholischer Traditionen einzuschätzen, wenn nun doch, nicht ohne Luthers Vorgang, in der evangelischen Kirche die Allgemeinheit menschlicher Sünde an die geschlechtliche Herkup̆ft eines jeden geknüpft wurdec. Diese logisch allerdings mögliche Folgerung aus em Prinzip der christlichen Freiheit ist. nun aber eben doch von Luther nicht gezogen worden. Das Geschlechtsleben und die erotische Liebe sind eben nicht frei verwertbare und zu gestaltende Gaben Gottes von eigener Schönheit, sondern hier wird immer nur ein Tribut an die Natur entrichtet, den der Christ zu einem Mittel der Ausübung der Nächstenliebe machen kann und soll. Bei L. fehlen die Voraussetzungen unserer Beurteilung, die biologische Auffassung der Lust und die poetische Verklärung der Erotik, vielmehr herrscht bei ihm das Dogma von der Lust als Folge des Sündenfalls.

259) Hierzu vgl. Köstlin, Theologie Luthers II $485-490,553-564$; J. Köstlin, Staat, Recht und Kirche und die ev. Ethik, Stud. u. Kritt. 1877; Brandenburg, L.s Anschauungen von Staat und Gesellschaft; Lenz, Luthers Lehre von der Obrigkeit (Preuß. Jahrbb. 75, I894); Jäger, Politische Ideen L.s und ihr Einfluß auf die innere Entwickelung Deutschlands (Preuß. Jahrbb. 1903); K. Köhler, Luther und die Juristen. Lenz beachtet den Zusammenhang mit der mittelalterlichen Ideenwelt zu wenig und knüpft den modernen Staat zu direkt an L.s Ideen an, Brandenburg betont mit Recht das erstere, unterschätzt aber doch den positiven Vernunftwert und die güttlich.e Gebotenheit des Staates, die allerdings erst später bei $L$. hervortreten. Eine Darstellung von Luthers Politik unter Betonung der weltabgewandten Züge gibt Gottfried Arnold, Unparteyische Kirchen- und Ketzerhistorie 1700 
röhren und Mittel der göttlichen Vernunft * ist der Staat in jedem einzelnen Falle auf sehr verschiedene Weise zustande gekommen und vom Evangelium, vor allem im 13. Kapitel des Römerbriefes, bestätigt und anerkannt. $\mathrm{Er}$ ist ein Werk der Vernunft und darum an sich auf die $Z$ wecke der bloßen Vernunft eingeschränkt, auf Bewahrung der äußeren Disziplin und Ordnung und auf die Bewirkung der menschlichen Wohlfahrt. Es ist derselbe polizeiliche und utilitaristische Staatsbegriff wie im Katholizismus, nur jetzt den Verhältnissen entsprechend mit stärkerer Betonung der Einheit der Gewalt. Das Mittel, das der Staat zu diesem Zwecke zur Verfügung hat, ist die Gewalt, die daher sein eigentlichstes Attribut ausmacht, von ihm stets gewahrt und von keinem Untertanen aufgelöst werden darf. Doch soll er diese Gewalt dem göttlichen Naturgesetz gemäß und zu Vernunftzwecken brauchen und wird die Obrigkeit, wie in der Scholastik, zum verwerflichen -Tyrannen \&, wenn sie sich nicht selber daran bindet. Freilich ist nach der eigentlichen und allein konsequenten Lehre Luthets ein Widerstand gegen diesen Tyrannen nicht erlaubt, außer dem passiven Widerstand des Duldens und der Auswanderung im Falle der Glaubensbedrückung. Naturgesetzlich und damit göttlich berechtigt ist der Staat in diesem Sinne überall, auch bei Türken und Heiden; ja er kann in seinem Natursinn dort sogar besonders verzüglich sein, und antike Staatslehre und Beispiele sind auch noch heute für den Staat von Nutzen.

Insofern ist der Staat etwas wirklich Göttliches. Nun aber ist doch seine Aufgabe, durch Macht und Gewalt sowie durch Recht und Gericht die Ordnung zu bewirken, etwas der eigentlich christlichen Liebesgesinnung völlig Entgegengesetztes. Der Christ soll Feindesliebe üben und Recht und Gericht möglichst wenig gebrauchen, nach Luthers anfänglicher Meinung gar nicht, dann zum Schutz gegen böse Buben, mit denen man sich christlich nicht verständigen kann. Von einer ethischen Anerkennung des Rechtes, des Rechtsgesetzes und Rechtssinns ist nicht die Rede. Vielmehr soll die Obrigkeit durch strenge Initiative in Recht und Polizei den Christen davor behüten, von sich aus das Recht allzusehr in Anspruch nehmen zu müssen. Ebensowenig gibt es einen ethischen Wert patriotischer und vaterländischer Gefühle. Im Falle der Unchristlichkeit der Obrigkeit verzichtet der II II und 12, 18-28; das neueste ist Karl Müller, Kirche, Gemeinde und weltliche Obrigkeit nach Luther, Christl. Welt 1910, doch ist hier der Staat nur gestreift. 
Christ auf Widerstand, oder wechselt die Obrigkeit. Das eigentliche Ideal des Christen ist der rechts- und staatslose Zustand der reinen Liebesgemeinschaft. Das weist darauf hin, daß der Staat bei aller Göttlichkeit und Vernünftigkeit doch nur eine Institution infolge der Sünde und gegen die Sünde, ein Erzeugnis des bloß relativen, gegen die Sünde unter den Bedingungen des Sündenstandes reagierenden Naturgesetzes ist. Da kommen dann auch hier all die augustinischen Anschauungen über den Staat als Erzeugnis der Sünde, die freilich erst dann richtig verstanden werden, wenn man ihn als ein gegen die Sünde selbst gerichtetes Erzeugnis der nur mehr unter Konzessionen an die sündige Roheit und Bosheit arbeitenden Vernunft ansieht.

So betrachtet erscheint doch nun wieder der Staat als etwas Unchristliches, der wahrhaft christlichen Moral geradezu Widersprechendes, und es ist nur zu begründet, wenn die Gewissen sich scheuen, nicht bloß staatliche Rechtshilfe in Anspruch zu . nehmen and Kriegsdienste zu leisten, zu schwören $u$. s. w., sondern auch an obrigkeitlichen Aemtern und der Gerichtsexekution sich zu beteiligen. Solchen Bedenken gegenüber greift nun aber Luther, genau wie bei der Familie, mit allem Nachdruck auf die göttliche Einsetzung und Bestätigung der Obrigkeit zurück. Ihre Funktionen ausüben, ihr gehorchen, sie für Rechtszwecke benutzen ist eine Pflicht des Gehorsams gegen Gott, der für seine Institutionen selbst die Verantwortung trägt und kein menschliches Klügeln über sie haben will. Die Ausübung der Herrschaft und des Rechtes ist Amt und Befehl, und Luther schildert mit Nachdruck den Kontrast der vom Landesherrn bis zum Büttel und Henker herunter sich vollziehenden Rechtsordnung, in der Regieren, Verordnen, Strafen, Hängen, Rädern und Köpfen ein Gottesdienst ist, gegen die außeramtliche rein persönliche Moralität, in der umgekehrt Feindesliebe, Opfern, Verzicht und Dulden, Fürsorge und Hingabe des einen an den anderen der wahre Gottesdienst ist. Die Paradoxie des Gegensatzes beider Gottesdienste macht ihm sichtlich Freude, und er rühmt sich mit Genugtuung, daß noch niemand so klärlich das göttliche Recht der unabhängigen, von keiner Kirche beherrschten und von keinem Gewissensbedenken verwirrten Obrigkeit aus der Schrift bewiesen habe. Hier greift der charakteristischeste und merkwürdigste Satz seiner Ethik, die Unterscheidung der Amtsethik und der Personethik, ein, in welchem er das große Problem der bisherigen Christenheit auf seine Weise gelöst hatte. In dieser Forde- 
rung des Gehorsams gegen das positive Gebot verschwinden dann alle die augustinischen Auffassungen des Staates und erscheint der Staat lediglich als die gottgeordnete Vernunftmacht, die alle Ordnungs- und Wohlfahrtsaufgaben zu vollziehen hat und gerade dadurch von der Kirche sich unterscheidet, die lediglich auf spirituale Wirkung und auf persönliche Lebensgemeinschaft gestellt ist.

Von hier aus ist dann auch der Krieg berechtigt. Er dart nur von der weltlichen Obrigkeit im weltlichen Interesse als Ausfluß ihres Amtes geführt werden, wenn sie Frieden und Wohlfahrt ihrer Bürger gegen Angriffe zu schützen hat. Nur als Notwehr hat der Krieg die Verheißung des Sieges; überdies muß er auch dann noch in der demütigen Gesinnung geführt werden, nichts der eigenen Kraft, sondern alles Gottes Gnade verdanken zu wollen. So ist jeder Glaubenskrieg und Kreuzzugsgedanke ausgeschlossen; für religiöse Interessen darf nur mit geistlichen Waffen gekämpft werden, und auch der Krieg gegen die Türken ist nur vom Kaiser als dem dazu Berufenen und nur im weltlichen Interesse des Schutzes seiner Völker zu führen. Aber freilich ist damit überhaupt jedes spezifisch-politische Denken und Wirken ausgeschlossen. Auch der weltliche Krieg muß gerechte Ursache haben, und die Untertanen sollen im Falle eines ungerechten Angriffskrieges ihres Fürsten die Teilnahme verweigern, indem sie dafür die Strafe in christlicher Geduld leiden. Auch der gerechte Krieg fordert zunächst die richtige moralische und christliche Gesinnung der Kriegführenden und Vorbereitung durch Predigt, da Gott dem Hoffärtigen keinen Sieg gewährt. Von Bündnissystemen und politischen Kombinationen ist hierbei erst recht nicht die Rede. Jedes Land steht für sich und wehrt sich im Vertrauen auf Gottes Vorsehung im Falle der Bedrohung. Es ist eine im einzelnen überall von der prophetischen moralisierenden Politik abhängige, im übrigen äußerst kindliche Politik. Luther ist überzeugt, daß die Vorsehung alle nicht in diesem Sinn unternommene Kriege mißlingen läßt und die Niederlagen als Zuchtrute und religiöses Erziehungsmittel gebraucht. So haben ihm auch die Römer, das mächtige Kaisertum, am meisten damit gewonnen, daß sie haben kriegen müssen; ein jeder wollte sich an sie hängen und Ritter an ihnen werden, sodaß sie sich wehren mußten; auch Hannibal, der Fürst aus Afrika unterlag, weil er angefangen hatte, »denn es ist Gott, der es tut, er will Frieden haben, und ist fremd denen so Krieg anfangen und Frieden brechen*. Es ist verständlich, daß eine derartige Ge- 
sinnung der Politik der Lutheraner so ungünstig wie möglich war; und wenn auch die lutherischen Fürsten, Diplomaten und Juristen, später auch Luther selbst, an sie sich nicht gebunden haben, so war sie doch überall der gefährliche Hemmschuh der lutherischen Politik und hat sie Ausbreitung und Schicksal des Luthertums bestimmt, das seine Stammlande nicht mehr zu überschreiten vermochte. Wie ganz anders steht dem die calvinistische Politik mit ihren Bündnissystemen und Glaubenskriegen dem gegenüber! ${ }^{260}$ ).

Fragen wir nun aber nach dem Verhältnis des Staates zu der Kirche und dem christlichen Gemeinschaftsleben, so entsteht wicder ein neues Bild der Sache. Ist nämlich der Staat von einer christlichen Obrigkeit beherrscht, dann ist er nicht mehr bloß eine göttliche und naturgesetzliche Institution der Schöpfungsordnung, dann ist er vielmehr eine der Formen, deren die Verwirklichung der christlichen Liebes- und Erlösungsgemeinschaft sich bedient. Dann ist die Unterwerfung unter seine Ordnungen und Gemeinsamkeiten ein christlicher Liebesdienst am Ganzen der Gesellschaft und zwar einer der notwendigsten und nächstliegenden, indem gerade die Benützung der staatlichen Lebensformen die Mitmenschen mehr fördert als die selbstgemachte Heiligkeit mönchischer Absonderungen. Dann wird insbesondere die Aufgabe der Obrigkeit der Liebesdienst der Erziehungund Bewahrung der Gesellschaft in christlicher Glaubenseinigkeit, Zucht und Ordnung und die Fürsorge für das Wort Gottes, die Reinheit und das Gedeihen der Kirche. Aus freier Liebe dient sie der Kirche, schafft sie ihr ein Kirchenrecht und eine finanzielle Fundierung, übt sie die Zensur und die Glaubenspolizei und schließt sie von ihrem Gebiet öffentliche Aeußerungen des Irrglaubens aus, wozu die nichtchristliche Obrigkeit nicht verpflichtet ist. Die Türken können mehrere Religionen nebeneinander

260) Vgl. die Traktate ১Ob Kriegsleute auch in seligem Stand sein können. 1526 und, Vom Krieg wider die Türken 1529 . Wieder muß hier das Alte Testament für den Nachweis der Berechtigung eines nicht eigentlich christlichen Gedankens herhalten. Freilich hat Luther über diese Dinge später weniger schroff aber auch weniger konsequent gedacht; s. Cardauns $1-17$. Aber im ganzen ist der Partikularismus und die Ablehnung der Interventionspolitik doch ein Grundzug des echten Lutherthums, wie die erwähnten Arbeiten von Schuberts zeigen. Ueber Kriegs- und Bündnisprobleme vgl. vor allem Hortleder, Handlungen und Ausschreiben von Rechtmäßigkeit des deutschen Krieges, Gotha 1617 u. I618, wo das Material gesammelt ist, bes. Bd. II.; s. hier die Abhandlung Ratzenbergers, daß Melanchthon, Jonas, Bugenhagen, Menius etc. von Luthers reiner Widerstandslehre abgefallen seien, S. 39, auch Theolog. Jahresbericht XXVIII 460 über Schweizer, Der Donaufeldzug von 1546. 
dulden, aber die christliche Obrigkeit muß sich in den Liebesdienst der Wahrheit stellen. So wird sie zwar alle weltlichen Dinge, auch Schulwesen und Armenwesen auf sich übernehmen, aber sie im christlichen Sinne und mit Rücksicht auf Förderung des christlichen Glaubenslebens behandeln. Ueber dem naturgesetzlichen erhebt sich der religiöse Lebenszweck der Gesellschaft, aber nicht wie im Katholizismus im Sinne einer Stufenordnung, die von der Oberleitung der Kirche im Bedarfsfall reguliert wird, sondern im Sinne eines Zusammenfallens der staatlichen Betätigung und der christlichen Liebesübung ${ }^{261}$ ). So sind wir wieder

201) Lenz meint: In diesem doppelten Verhältnis der christlichen Obrigkeit, in ihrer negative $n$ Funktion, den Frieden zu sichern, das Recht zu erhalten, das irdische Leben $2 u$ fördern, und in ihrer positive $n$ Pflicht, den Frieden zu sichern, glaube ich die Lösung des vielumstrittenen Problems zu sehen und den so oft vermißten Gleichklang in Leben und Lehre des Reformators. . . Zwei Reiche, beide von Gott gestiftet, sind durch die Welt hin ausgebreitet, Kreatur und Evangelium, ununterscheidbar in jedem Christen beisammen und doch prinzipiell ganz auseinanderzuhalten, wie Se ele und Körper, Idee und Erscheinung; aber der Glaube bleibt an ein von aller Erdenschwere dereinst befreites Ideal, an das Reich Gottes «, S. 435 f. Das ist eine sehr modernisierte Auflösung des Problems; in Wahrheit hält L. die alte Lösung der scholastischen Lehre fest, die Lösung mit Hilfe der Begriffe von Naturgesetz und Evangelium, nur auf den neuen Boden des Ineinander, statt auf den des Stufenverhältnisses, versetzt. Aber das Ineinander ist schwer herzustellen, daher stammen die Widersprüche. - Uebrigens beruft sich Luther selbst auf Augustin: sIch habe von der weltlichen Obrigkeit also herrlich und nützlich geschrieben, als nie kein Lehrer getan seit der Apostel Zeit, es wăre denn S. A u gu stine (Krieg wider die Türken B. A. IV, I S. 44I). In den Schriften iber den Bauernaufstand und den Krieg ist die doppelte Moral des Rechts-, Gewalt- und Machtgebrauches einerseits, der leidenden und alles opfernden, die Bergpredigt befolgenden Liebesmoral andrerseits in einer oft geradezu erstaunlich schroffen Unterscheidung gelehrt, 2. B. S. $322 \mathrm{f}$ : Was meint ihr, daß Christus dazu sagen wirde, daß ihr seinen Namen führt und nennt euch eine christliche Sammlung, so ihr doch so fern davon seid, ja so greulich wider sein Recht tut und lehrt, daß ihr auch nicht Heiden oder Türken zu heißen würdig seid, sondern viel ärger, als die da wider $g$ öt li iches und $n$ atürliches $R$ e cht, bei allen Heiden gemein gehalten, (durch Rebellion und Forderung eines christlichen Kommunismus) tobt und strebt ... Weiter wollen w- nun auch von dem $\mathrm{ch}$ ristlich en und e $v a n g e l i$ s $c h \in n R$ e $h t$ sagen, welches die Heiden nicht bindet wie das vorige. Denn so ihr euch ruhmet und gern höret, daß man euch Christen nenne und dafur wollt gehalten sein, so werdet ihr ja auch leiden, daß ich euch euer Recht vorhalte. Hört nun zu, liebe Christen, ever christliches Recht. So spricht Christus Mt. 5, 39: Ihr sollt dem Uebel nicht widerstehen, sondern wer dich zwingt eine 
bei einem augustinischen Gedanken, bei dem Gedanken der Theokratie. Nur ist diese Theokratie keine Hierokratie, keine Oberherrschaft der internationalen Hierarchie und kein rechtlich formulierbares Verhältnis, sondern es ist die freie Liebeskonkordanz der rein spiritualen, auf das Wort erbauten Kirche und der aus eigener Gläubigkeit freiwillig dienenden, von den Theologen nur frei belehrten weltlichen Obrigkeit, die beide gemeinsam beherrscht und getrieben sind vom Worte Gottes und seiner klar sich selbst auslegenden und durchsetzenden Wunderkraft.

Auch hier war sich Luther völlig bewußt, daß er trotz aller Konzessionen an den Rechts- und Wohlfahrtsstaat des Sündenstandes eine höchst idealistische, wirklichkeitsferne Lehre vertrat. Man braucht nur die Schilderungen des Ideals im großen Katechismus zu lesen, wie hier die christliche Obrigkeit nichts will als in Macht und Recht mit aller Strenge als Stellvertreter Gottes dem Glauben und der Liebe dienen durch das Amt und wie andererseits die

Meile Weges, mit dem gehe zwei Meilen. Und wer dir den Mantel nimmt, dem laß auch den Rock. Und wer dich auf die eine Backe schlägt, dem halte auch die andere dar ... Ja, Christus spricht Mt. 5, 44, wir sollen Gutes wïnschen denen, die uns beleidigen, und bitten für unsere Verfolger und lieben unsere Feinde und wohltun unseren Uebeltätern. Dies sind unsere christlichen Rechte liebe Freunde... An diesen Sprüchen greifet wohl ein Kind, daß christliches Recht sei, nicht sich sträuben wider Unrecht, nicht zum Schwert greifen, nicht sich wehren, nicht sich rächen, sondern dahingeben Leib und Gut, daß es raube, wer da raubt. Wir haben doch genug an unserem Herrn, der uns nicht lassen wird, wie er verheißen hat. Leiden, Leiden, Kreuz, Kreuz ist der Christen Recht und kein anderese. Oder S. 365: Es sind zweierlei Reiche: eines ist Gottes Reich, das andere ist der Welt (d. h. in diesem Falle nicht des Bösen, sondern der natürlichen Schöpfungsvernunft) Reich ... Gottes Reich ist ein Reich der Gnade und Barmherzigkeit und nicht ein Reich des Zornes oder der Strafe. Denn daselbst ist eitel Vergeben, Schonen, Lieben, Dienen, Wohltun, Friede und Freude haben etc. Aber das weltliche Reich ist ein Reich des Zornes und Ernstes. Denn daselbst ist eitel Strafen, Wehren, Richten und Urteilen, zu zwingen die Bösen und zu schützen die Frommen. Darum hat es auch und führt das Schwert. . Die Sprüche, die von der Barmherzigkeit sagen, gehören in Gottes Reich und unter die Christen, nicht unter das weltliche Recht. Denn ein Christ soll nicht allein barmherzig sein, sondern auch allerlei leiden etc. Aber das weltliche Reich, welches nichts ist denn göttlichen Zorns Diener über die Bösen und rechter Vorlauf der Hölle und des ewigen Todes, soll nicht barmherzig, sondern streng sein etc. . . ., auf die Bösen sieht es, daß es sie strafe und in Zaum und Frieden halte zum Schutz und Errettung der Frommenc. Das ist doch etwas anderes als das Verhältnis von Idee und Erscheinung! 
Christen in schrankenloser Liebe und Hilfsbereitschaft, ohne Rechtshändel und Uebervorteilungen, ohne Verfolgung ihres formellen Rechtes und in möglichstem Dulden des Unrechts ein friedliches und demütiges Leben führen sollen. Man erkennt hier ohne weiteres den überidealistischen, um nicht zu sagen christlich-utopischen Sinn dieses Staatsideals. Andererseits braucht man nur seine grollenden und heftigen Klagen über Fürsten und Juristen, über Feudalherren und Magistrate, sowie vor allem über den unverbesserlichen rohen und groben Pöbel zu lesen, um zu erkennen, daß Luther weit von der Meinung entfernt war, als entspreche die bestehende staatliche Wirklichkeit seinem Ideal. Was er auch immer sich für Mühe gegeben hatte, es im Unterschiede von den Täufern den Bedingungen der Wirklichkeit anzupassen, es war in dieser rohen und rauhen Welt so wenig $z u$ Hause wie sein spiritualistisches, aller Organe zur Selbstdurchsetzung entbehrendes Kirchenideal. Das liegt nicht, wie oft gesagt wird, am Mangel politischer Begabung, der dann etwa irgendwie ergänzt werden könnte. Es liegt an dem religiösen Grundgedanken selbst, der mit politischem Sinne unvereinbar ist. Wo ein solcher vorhanden ist, wird auch die Religiosität selbst eine andere, wie der Calvinismus zeigt. Bei den modernen Konservativen, die des politischen Sinnes gewiß nicht entbehren, geht eben darum das Religiöse und das Politische, die auf das Wesen der Macht begründete Gewaltpolitik und die in ihrer Innerlichkeit verharrende Gottseligkeit, bis zum vollen Widerspruch auseinander ${ }^{262}$ ).

262) Der Pessimismus scharf betont bei Brandenburg: >So schwebte auch ihm Anfangs wenigstens als Ideal eine christliche Gesellschaft vor, deren Haupt eine vom christlichen Geiste beseelte Obrigkeit sein sollte. Diese durfte freilich nicht mehr der geistlichen Gewalt untergeordnet sein und von ihr geleitet werden; sonst wäre ihr Tun erzwungen und wertlos gewesen; aber sie sollte bei äußserer Gleichberechtigung verbunden sein mit jener in gleicher christlicher Gesinnung ... Dieser Gedanke durchzieht L.s Schrift an den Adel. Aber der Traum entfioh schnell, und beim Erwachen fand sich $L$. allein mit wenig Gleichgesinnten unter den Heiden, und gewann die Ueberzeugung, $\mathrm{da}$ es so bleiben werde. Von nun an hat es keinen Sinn mehr für ihn, sich auszumalen, wie eine christliche Gesellschaft beschaffen sein könne und müsse. Denn sie wird ja niemals kommen; die wenigen in der Welt zerstreuten Christen werden nie eine geschlossene Körperschaft bilden kőnnen. Die Welt, wie sie ist, aber läßt sich nicht mit christlicher Liebe nach dem Evangelium regieren S. 9 ... Darum sagt Luther : „So dir Gewalt und Unrecht geschieht, sprich: das ist der Welt Regiment. Willst du in.der Welt leben, so mußt du das gewarten. Daß du es dahin bringen willst, daß es anders gebe, denn 
Bei dem späteren Luthertum verschwand die Spannung zwischen der amtlichen und der persönlichen Moral immer mehr und entstand jener -Typus, den man gemeinhin als den lutherischen bezeichnet: Unbedingter Gehorsam gegen die Gott vertretende es Christo gegangen ist, das wirst du nicht erlangen. Willst du bei den Wolfen sein, so mußt du mit ihnen heulen. Wir dienen hier in einem Wirtshause, de der Teufel Herr ist und die Welt Hausfrau und allerlei böse Lüste sind das Haasgesinde; und diese allesamt sind des Evangelii Feinde und Widersacher. So man dir dein Geld stiehlt, dich schändet an deinen Ehren, in diesem Hause gehts also su'. Nirgends finde ich das Wesentliche von Luthers Weltanschauung so klar ausgesprochen, wie in diesem Bilde. Der Mönch will dem Dienst des teuflischen Wirtes sich entziehen durch die Flucht; die streitende Kirche will mit außeren Machtmitteln dem Wirt das Regiment entreißen und das Gesinde sich unterwerfen; Luther hat zuerst gehofft, die Bewohner bekehren und mit christlichem Geiste erfullen zu können; jetzt hat er diese Hoffnung aufgegeben, will aber trotzdem in dem schrecklichen Hause bleiben. Denn er ist nicht aus eigenem Willen darin, sondern von seinem Gott hineingesetzt. Darum will er hier seine Pflicht tun, sich schlagen und peinigen lassen, wenn es dem bösen Herrn und seinem Gesinde gerullt, aber nicht vom Platze weichen, bis sein Herr ihn abruft, und jede gute Stunde, die er hat, als besondere Gnade preisen , $S$. 5 f. Brandenburg überschätzt nun aber meines Erachtens diese Stellen; wenigstens stehen neben ihnen solche; wo die christliche Lebensordnung in Amts- und Liebesmoral als etwas Mögliches und Wüschenswertes erscheint, wie ja darauf sein ethisches Grundbuch, der Große Katechismus, aufgebaut ist. Das eigentlich Charakteristische ist m. E. vielmehr das Alternieren zwischen jenem verzichtenden Pessimismus und dem Triumph, daß die wahrhaft evangelische Ordnung mit dem klärlich erwiesenen Recht des weltlichen Amtes und der ebenso klärlichen Innerlichkeit der Liebesgesinnung und der kirchlichen Gemeinschaft in evangelischen Larden endlich Wirklichkeit geworden sei. Die Grundsätze dagegen, in denen Lènz S. 440 das Fortwirken der lutherischen Gedanken als sLebensmark unseres Volkes s schildert ( In ihnen wurzelt das Recht unserts Schwertes, seine Macht und unser Gehorsam. Mit 2wingender Gewalt fésseln sie jedermann an den öffentlichen Willen, und in freiem Eifer dienen ihnen ohne Unterschied des Bekenntnisses die Millionen. Sie sind verwachsen mit jedem öffentlichen Amt, mit unserer Ehe und Familie, mit der Idee unseres Krieges (I) und aller (!) Arbeit des Friedens. Auf ihrem Grund erwuchs unsere ganze klassische Literatur (!) und noch immer beherrschen sie weite Gebiete unserer Kunst (!). Nur von ihnen aus ist echte Toleranz und die freie Forschung (1) möglich geworden ), sind nur sehr bedingt und teilweise lutherischen Ursprungs. Ein Fortleben der lutherischen Staats- und Gesellschaftsidee findet in Wahrheit nur statt in der -Weltanschauung der konservativen Partei und vor allem in deren Bannerträger Stahl, der aber doch den calvinistischen und independentistischen Individualismus in die neugeformte lutherische Staatsidee aufzunehmen für unumgänglich fand, vgl. Stahl, Der christliche Staat. 
und nur durch Gottes Zulassung in ihr Amt gelangte Obrigkeit und feudale -Unterobrigkeit ; Bindung dieser Obrigkeiten an natürliches und göttliches Recht, die immer mehr als die ohne Schwierigkeit zusammenwirkenden Grundgesetze der wahren christlichen Gesellschaft erscheinen; Fürsorge der Obrigkeit für alle weltlich-natürlichen und, soviel es ihr mit ihren weltlichen Mitteln und in ihrem Zusammenfall mit der Kirchenregierung möglich ist, auch für die christlichen Tugenden; Erhaltung des Friedens nach außen um jeden erträglichen Preis und des Friedens nach innen durch gründliche Bevormundung des beschränkten Untertanenverstandes. Der sündige Ursprung und Charakter des Rechtes und der Gewalt verschwand in der Harmonie des natürlichen und göttlichen Rechts, und diese Harmonie ermöglichte ein von der Sünde immer getrübtes, aber an sich sehr wohl durchsetzbares Ideal der christlichen Gesellschaft, in dem alle natürlich-vernünftigen Wissenschaften und die Offenbarung sich vereinigen $z \mathfrak{u}$ dem großen Ideal der menschlichen Gesellschaft. Den klassischen Ausdruck hat diesem Ideal L. v. Seckendorff in der Dedikation seines Teutschen Fürstenstaates gegeben: "Die Weißheit, durch welche Königreiche, Fürstentümer und Lande glückselig regiert werden, ist ihrem Ursprunge nach göttlich, an sich selbst herrlich und unvergleichlich und begreifet in ihrer Weite und Allgemeinheit alles dasjenige, was in anderen Wissenschaften stückweise sich befindet. Sie ist in dem Bezirk eines jeden Landes die unentbehrliche Sonne, durch welche alles erleuchtet, erwärmet und ernähret wird. Sie vergleichet sich einem unerschöpflichen Meer, darein alle anderen Weisheiten und Künste einfließen und durch hohe und verborgene' Art zu der gemeinen Wohlfahrt durch das ganze Land wiederum ausgetrieben und verteilet werden. Sie ist ein immergrünendes Paradies von allen schönsten und nützlichsten Pflanzen der Tugenden und guten Ordnungen, deren jede zu seiner Zeit und an ihrem Orte erfreuliche Früchte bringet. Diese Weisheit hat von dem Alleinweisen der König Salomo zu seinem Regierungsstande erbeten, bei welcher er die allergrößesten Schätze und Reichtümer der Welt zu einer Zugabe erlanget ${ }^{263}$ ). Der Pessimismis

203) V. L. v. Seckendorff, Teutscher Fürstenstaat ${ }^{5} 1687$ (zuerst 1656), bes. S. c. I, 5 und 8 des dritten Teils. Doch gesteht der Verfasser in der Vorrede : > Oft habe ich die Regula anstatt dessen, was ich in der Tat finden sollte aber nirgends oder wenig angetroffen, setzen müssen a. - Besonders charakteristisch für den Geist des Ganzen S. 194 f.: ,Der Hauptzweck dessen allen ist die heilsame Erhal- 
und Idealismus des ursprünglichen Luthertums ist verschwunden, und die Gesellschaftslehre trägt die Züge einer herzlichen und

tung der Polizei oder des ganzen Regiments in seiner hehren Kraft und Hoheit und das letzte Ziel ist die Ehre Gottese. In christlichen Staaten sei aber nicht bloß die Behauptung der Gewalt, Verhinderung der Verbrechen und Erhaltung des Friedens, sondern auch die sittliche Förderung der Untertanen die Aufgabe, seine stete Annaherung und Uebung, welche bei den heidnischen alten Volkern der Griechen und Lateiner durch mancherlei Unterrichtung der gelehrten Philosophen und Poeten gesucht worden. Aber in einer christlichen Polizei kann und muß die Obrigkeit hierinnen noch weiter gehen «. Sie muß Gesinnungen pflegen, und, weil diese rechtlich nicht erzwungen werden können, so ist hierfür die Kirchendisziplin, das Haus und die Schule mit zu verwenden. ,Gleichwohl sind aber auch etliche Stlicke, die fürnehmlich eines jeden Gemuit und Person betreffen, nachfolgig aber auch seinen Mituntertanen zu Schaden und Aergernis gereichen können, in den Landesordnungen bedacht, als da ist eine gebührliche außerliche Feier der Sonn- und Festtage, Vermeidung des schändlichen Vollsaufens und wo zu dem Ende von gewisser Zeit des Tages, da man mit Zechen und Schenken aufhören muß, geordnet. Ferner ein re $\mathrm{cht}$ mä $\mathrm{B}$ ige $\mathrm{r}$ Beruf und Handlung und Vermeidung des Müßiggangs .., zu welchem Zweck auch die Anordnung eines Zuchthauses für dergleichen unartige Personen zur Besserung ihres Lebens und zur Beruhigung anderer Leute ein vortreffliches Mittel ist. Die Erhaltung einer gebührlichen Ordnung und Vorzugs zwischen den Stžnden und Untertanen nach ihren Ehren, Stand und Amt bei allen Begebenheiten und Zusammenkünften, sowohl auch in Kleidung und anderen äußerlichen Dingen ...., damit Zerrüttung, Mißverstand und Aergernis verhütet werdec. Doch soll dieser Konservatismus nur dem Frieden dienen, nicht jeden Fortschritt ausschließen S. 215: Die Obrigkeit ist dahin bedacht, daß sie in dem Lande je mehr und mehr, was nützlich und austrăglich sein kann..., durch allerhand gütliche Mittel und Befreiungen anleite und also nicht in Gedanken stehe, daß es eben im alten Wesen bleiben müsse und nichts verbessert werden könnex. - In breitester Ausführung entwickelt die naturręchtlichen und christlichen Gedanken über den Staat Joh. Gerhard in seinem Loci (ed. Cotta 1775) Bd. XIII und XIV, jedoch in der Abstumpfung, die das Ideal einer christlichen Gesellschaft bei christlicher Gesinnung der Obrigkeit, reiner Kirchenlehre und demütigem Gehorsam der Untertanen sehr wohl für realisierbar hălt: -Utraque potestas ad ecclesiae collectionem conservationem ac propagationem itemque ad Dei gloriam ordinata est. Mutuas enim sibi tradunt operas ... Sine ecclesiastico ministerio commode quidem, at non pie; sine politica potestate pie quidem, sed non commode vivi potest. XIII 225! Die Magistratus sunt Dii terrestres. XIV 305! Diese Abstumpfung spiegelt sich in dem Ideal des Urstandes, der bei Entwicklung ohne Sündenfall trotzdem eine subjectio, nur eine subjectio filialis statt einer subjectio servilis gewesen wäre S. 240. Ueber Bündnisse: Foedere ipsa urgente rei publicae necessitate cum infidelibus et diversae religionis hominibus instituta non possunt absolute et simpliciter improbari; cavendum interim, ne adhaereat fiducia 
innig kräftigen, aber hausbackenen und spießbürgerlichen Landesväterlichkeit.

Ging die Staatslehre des Luthertums - vom modernen Standpunkt aus angesehen - hinter die thomistische Staatslehre vielfach noch zurück, so blieb seine $W$ ir $\mathrm{t} \mathrm{s} \mathrm{ch}$ a f $\mathrm{ts}$ e $\mathrm{th} \mathrm{k}^{268}$ ) bedeutend

in humanum auxilium ac diffidentia erga Deum neve defensio ecclesiae, quae est solius dei opus; foederibus illis transscribatur XIV 14. Unterstǘtzung beidrängter Religionsgenossen in fremden Ländern nur als diplomatische erlaubt XIV 72. Von der Bergpredigt heißt es nur, es seien nicht ganz buchstäblich zu nehmende $\mathrm{Pa}$ rabeln, und vom Rechte heißt es einfach: OObserva etiam quod magistratus dicatur constitutus subditis in b o $\mathrm{n} \mathrm{m}$, nimirum ut bonum publicum promoveat justitiam administrando, justos defendendo, sontes puniendo. Quare cum hoc bono et dono divinitus concesso utimur, hoc est cum officium magistratus imploramus, r e c te o mn in o facimuse XIV 135 . Wie in der Kirche das Kirchenrecht als göttliches Recht eingezogen ist und überhaupt kein Problem mehr ist, so hat auch für Staat und Gesellschaft Macht und Recht aufgehört ein Problem zu sein, es ist ein bonum divinitus concessum S. 137. Die alles durchdringende Polemik gegen die Taufer ist eine immer neu einsetzende, gründlichste Umdeutung der Bergpredigt aus anderen Stellen der Schrift, der Geist des Ganzen höchst philisterhafte Theologenpolitik.

204) Vgl. hierzu außer Roscher, Gesch. d. Nationalokonomik, und Aug. Oncken, Gesch. d. Nationalökonomie I 1902, die bekannten Abhandlungen von Schmoller, Zur Gesch. der nationalökonomischen Ansichten in Deutschland während der Reformationsperiode, Z. f. d. gesamte Staatswissenschaft 1860 S. 461-716; Wiskemann, Darstellung der in Deutschland z. Z. der Reform. herrschenden nationalök. Ansichten (Jablonowskische Preisschrift 1861); ferner Uhlhorn, Gesch. d. christl. Liebestătigkeit III I890; Uhlhorn, Katholizismus und Prot. gegenüber der sozialen Frage 1887 ; S. Eck in der ausführlichen Einleitung zu Luthers , Von Kaufhandlung und Wucher BA. IV I S. 494-513; K. Köhler, Luther und die Juristen S. III-124; H. Böhmer, L. im Licht der neueren Forschung S. 130-139; Brandenburg, L.s Stellung zu Staat und Gesellschaft; Frank G. Ward, Darstellung und Würdigung von L.s Ansichten vom Staat und seinen wirtschaftlichen Aufgaben, Conrads Abhh. XXI, 1898; schließlich meine Darstellung in Kultur der Gegenwart S. 544-552. - Ueber den allgemeinen wirtschaftlichen Rahmen, in dem sich die Stellungnahme der Reff. bewegt s. Lamprecht, Deutsche Gesch. V und VI, Schmoller, Das Merkantilsystem in seiner historischen Bedeutung (Umrisse und Untersuchungen 1890 S. 1-60), die zahlreichen Untersuchungen von G. v. Below, bes. der , Untergang der mittelalterlichen Stadtwirtschafte (Jahrb. f. Nationalök. und Statistik, 1901) und ; Territorium und Stadte 1900; Beispiele städtischer Wirtschaftslage bei Bothe, Frankfurter Patriziervermögen im 16. Jahrh., Archiv f. Kulturgesch., Beiheft 2, 1908; für ländliche u. territoriale Verhältnisse s. Schauenburg, 100 Jahre Oldenburgischer Kirchengesch. V 1908. Für das 17. Jahrhundert 
mehr im Geleise der durchschnittlichen katholischen Theorie. Freilich blieb auch sie nicht ohne große Veränderungen. Sie lagen in dem Wegfall des Mönchtums und der Beseitigung des mit diesem eng zusammenhängenden, , auf die klösterliche Caritas angewiesenen Bettels. Damit wurde weiter die Ehelosigkeit bedeutend eingeschränkt, der Arbeitsfleiß allen eingeschärft, der Besitz der toten Hand säkularisiert, wurden die Meßpfründen aufgehoben und vor allem die wirtschaftliche Oberleitung der Kirche beseitigt, die die Fragen der Preisbildung und des Wuchers vor das Forum des Beichtstuhls gezogen hatte; alles das wurde nun rein der weltlichen Gewalt und dem natürlichen Recht übergeben. Allein die Auffassung des natürlichen Rechtes selbst, dessen Grundzüge schon vom Mittelalter und dem kanonischen Recht als mit dem christlichen Gesetz übereinstimmend betrachtet worden waren, blieb ihrem sachlichen Inhalte nach bestehen. Es wurde nur das; was bisher bloß dem Weltmenschen kraft natürlichen Rechts anbefohlen war, auf alle ohne Ausnahme, ohne Duldung von Bettlern und Klöstern, ausgedehnt; und es wurde das, was die Kirche unter ihre Obhut genommen hatte, ganz der weltlichen Vernunft und Gesetzgebung anheimgestellt, aber als einer an das natürliche, mit dem christlichen Recht übereinstimmende Recht gebundenen.

So kann es uns nicht wundern, wenn alle charakteristischen Züge der mittelalterlichen Wirtschaftsethik hier wieder erscheinen, bloß mit den durch die neuen Grundlagen der Gesellschaft notwendig werdenden Modifikationen ${ }^{265}$ ).

Die Arbeit mit ihren Mühen und Sorgen ist an sich naturwidrig. Gott hat seinen Segen in der Fruchtbarkeit der Natur und in den Metallen der Berge Hingelegt zum dankbaren und

s. Kompilationén bei Händtke, Deutsche Kultur im Zeitalter des $30 \mathrm{j}$. Krieges 1906, v. Below, Die Frage des Rückgangs der wirtsch. Verhältnisse vor dem 30j. Krieg (Vierteljahrsschrift f. Soz.- u. Wirtschaftsgeschichte 1909 S. 160-167). Es darf heute als selbstverständlich gelten, daß die großen wirtschaftlichen und sozialen Umwälzungen des 16. Jahrhunderts unabhängig eintraten von der religiösen Bewegung und daß in ihnen das Luthertum zunächst eine wesentlich reaktionäre Stellung einnahm, während die kasuistische Ethik des Katholizismus mit ihr Kompromisse abzuschließen im Stande war.

265) Auch hier ist Aristoteles der Meister s. Schmoller 470, auch Melanchthon CR XVI 427. Es ist snatürliche Wirtschaftslehrea, ,Sie streifen, obwohl von ganz anderen Voraussetzungen ausgehend, oft sehr nahe an die physiokratischen Lehren. Schmoller 471 . 
demütigen Empfang; an die Bedingungen der Arbeit und Technik für das Zustandekommen der Güter ist wenig gedacht: Wenn - Gott mit der Gewinnung diéser Güter trotzdem jetzt die Arbeit verbunden hat; so geschah es aus pädagogischen Gründen gegenüber dem sündig gewordenen Menschen. Die Arbeit ist remedium peccati wie der Staat und die Ehe, gehört erst dem relativen Naturrecht des Sündenstandes an und dient hier als Strafe und Zucht, hat also wesentlich asketische Bedeutung. ${ }^{266}$ ). Nur ist sie eben um deswillen auch allen zuzumuten, die arbeiten können. Arbeitsfähige Bettler, untätige Mönche und müßige Rentenverzehrer sind schlechterdings schon gegen dieses Recht der Natur. Mit der Arbeit ist dann auch das Privateigentum, das aus ihr hervorgeht, von Gott geordnet, aber auch dieses erst infolge des Sündenfalls als Mittel der Zucht und Ordnung ${ }^{267}$ ). Unter besonderen Umständen, z.B. bei Hungersnöten oder gegenüber arbeitsunfähigen Witwen ist es ein Gebot der Aequität, auf die ursprüngliche Ordnung des Liebeskommunismus zurückzugreifen und den Raub beim Bäcker oder ein ${ }^{2}$ Notwücherlein « zu gestatten ${ }^{268}$ ). Das Maß des Eigentums soll das des standesgemäßen Bedürfnisses nicht überschreiten, doch ist die Freude am Besitz, auch an Gold und Silber, in den Grenzen dankbarer Genügsamkeit erlaubt ohne pedantische Abmessung des Bedürfnisses. Da es nun das Wesen der Arbeit und des Eigentums ist, dem Menschen das standesgemäße Einkommen zu verschaffen, aber darüber auch nicht hinauszugehen, so versteht sich die traditionalistische Haltung der Wireschaftsethik von selbst. In seinem Stande sich nach dem Herkommen nähren und darin als in einem gerechten Anspruch von der Obrigkeit geschützt werden, das ist das Wesen der Wirtschaftsordnung. Emporsteigen wollen, durch freie Initiative die gegebenen Ordnungen durchbrechen, die Gesellschaft durch das Bestreben des Individuums, seine Lebenshaltung' und seine gesellschaftliche Stellung zu steigern, beunruhigen und zersetzen: das ist gegen natürliches und göttliches Gesetz ${ }^{269}$ ). Unter der

206) S. besonders Brandenburg 6; Schmoller, 474 und 478 ; Eck 499.

267) Stellen aus Luther und Melanchthon bei Schmoller 705-708; 597; Uhlhorn 22.

288) Eck, BA. IV I. S. 504; das ist ganz die scholastische Lehre, s. oben XXVIII 63. Freilich stirnmt es nicht ganz mit der sonstigen Urstandslehre des Luthertums.

a09) Ueber den straditionalistischen a Charakter der lutherischen Eigentums- 
so zu behauptenden Nahrungs- und Gesellschaftsgliederung sind es wieder die naturgemäßen Stände, die vor allem Anspruch auf Schutz und moralische Anerkennung haben: der im unmittelbaren . Verkehr mit der Natur die Güter ohne Zwischenglieder zwischen Produktion und Konsumtion erzeugende Hauptstand feudaler und bäuerlicher Agrarier; der durch die natürliche Wohlfahrtsaufgabe geforderte Stand der Beamten und Soldaten, wozu die gestellungspflichtigen Feudalen gehören; der die von der bäuerlichen Wirtschaft nicht herstellbaren Güter erzeugende städtische Handwerkerstand; die zu Genügsamkeit und Gehorsam zu enmahnenden Taglöhner, Dienstboten und sonstigen Angestellten; schließlich auch der dem unentbehrlichen Tausch dienende Kaufmann, der zu den Selbstkosten einen seine Existenz sichernden Aufschlag hinzuerheben darf. Mit dem letzteren ist dann auch die scholastische Lehre vom pretium justum, die Empfehlung von Preistaxen, die scholastische Lehre von der Unfruchtbarkeit des Geldes und der Unmöglichkeit des Zeitverkaufs verbunden. Die Fortführung des patristischen und mittelalterlichen Zinsverbotes versteht sich dabei von selbst, ja wird gegen die in der Spätscholastik eingeführten Umgehungen mit verstärkter Heftigkeit gefordert; nur solle es auch hier ohne Revolution abgehen, indem bereits eingegangene Zinsverpflichtungen bestehen bieiben solten bis zur Ablösung oder Rückzahlung des Kapitals. Das Bürgschaftswesen und damit das Kreditwesen wird nicht minder heftig bekämpft als ein Eingriff in Gottes Vorsehung und freventliche Vermessenheit. Es ist überall möglichst der reine Konsamtionsstandpunkt, der eine möglichst direkte Beziehung zwischen den Naturgaben, der Arbeit und der Konsumtion herstellen will und alle unübersehbaren Komplikationen verabscheut. Es ist zugleich

lehre s. Max Weber, Geist des Kapitalismus, Archiv XX S. 44-50; über die moralische Abneigung gegen die Konkurrenz, die vor allem in Luthers Preislehre $z u-$ tage tritt, Schmoller 49 I f. Luther selbst sagt (Kaufhandlung BA S. 527): >man soll sich an mäßiger Nahrung genügen lassen . ., nicht Tag und Nacht in die Höhe trachtenc. Oncken nennt es die sasketische Auffassung vom Erwerb im Gegen satz zu der mit Adam Smith einsetzenden thedonistischen $\mathrm{S}$. 152, 149. In der Wucherfrage ist übrigens Melanchthon zu Kompromissen geneigter als Luther und ist auch von den späteren konfessionellen Lutheranern Luthers schroffe Haltung nicht fortgesetzt worden, Neumann, Gesch. d. Wuchers; doch bedeutet das kein neues Prinzip, sondern nur die überall $\mathrm{zu}$ beobachtende Abstumpfung von L.s ethischem Radikalismus. 
der Friedens- und Ordnungsstandpunkt, der alle Arbeitsgliederungen und alle Besitztitel als Mittel der Erhaltung konkurrenzloser Zustände betrachtet. Das fordert die Natur der Dinge, es ist aber zugleich die Forderung der Moral ${ }^{270}$ ), in der natürliches und göttliches Gesetz übereinstimmen, indem so jeder zu seiner Nahrung kommt, Ordnung und Friede gewahrt, die Liebe betätigt, die natürlichen Unterschiede eingehalten, die Abhängigkeit von Gott und der Natur gläubig anerkannt und die Wohlfahrt des Ganzen gefördert wird.

Die christliche Beseelung dieser natürlichen Wirtschaftsethik besteht dann darin, daß der gehorsame Dienst in den so vorgezeichneten Berufen zu dem eigentlichsten und nächsten Spielraum der Nächstenliebe wird. Indem jeder arbeiten und mit seinen Haushaltgenossen von dem Arbeitsertrag leben soll, fördert er Ruhe und Harmonie des Ganzen und leistet er den wichtigsten Beitrag zur Beförderung des Einzel- wie des Gesamtwohles. Pflichtmäßige Arbeit ist der beste Gottesdienst, und die in der Ausübung des Berufs betätigte Nächstenliebe ist besser als die Carität, die den Bettel großzieht, das Almosen zum Vèrdienst bei Gott macht, gleichgültig ist gegen den praktischen Effekt des Almosens, dem einen $\mathrm{zu}$ viel, dem andern $\mathrm{zu}$ wenig gibt und alle durch Werkheiligkeit korrumpiert ${ }^{271}$ ). Das ist eine außerordentliche Steigerung der Arbeitspflicht und der Arbeitsintensität. Es ist weiterhin trotz aller Bevorzugung der agrarischen Arbeit ein bürgerlicher und kein feudaler Gedanke, indem dem aus mancherlei Gründen von der Reformation sehr gefestigten Feudaladel doch die Arbeitspflicht, die Selbstbewirtschaftung oder der fürstliche Amtsdienst, damit zur Aufgabe gemacht wird; beides hat der Gang der Dinge von sich aus erzwungen, es ist aber doch auch eine Forderung der reformatorischen Wirtschaftsethik ${ }^{272}$ ). In all diesen Hinsichten ist das

270) Ueber die smoralischer Tendenz dieses agrarisch gefärbten Konservatismus s. Schmoller 476 , über die $>$ Natürlichkeit * möglichsten Festhaltens an der Urproduktion und der geschlossenen Hauswirtschaft s. S. 479, 564, Oncken 13 I.

371) Ueber diese christliche Beseelung: Schmoller 488, 707; Uhlhorn igf.

272) Auch dieser unfeudale Charakter charakterisiert schon die mittelalterliche Wirtschaftsethik; über das Verhältnis beider Elemente in der mittelalterlichen Stadt und im kanonischen Recht s. vortrefflich Oncken I 125; Oncken bezeichnet es als das System der sgebundenen Geldwirtschaftc, dem die spätere ungebundene städtischkapitalistische Wirtschaft gegenübertritt. Nur die letztere bekämpfen die Reformatoren. Nur so waren sie auch imstande, das rümische Recht zu bevorzugen, das 
neue System trotz der beibehaltenen mittelalterlichen Grundanschauung über das Wesen und Ideal des wirtschaftlichen Lebens selbst immerhin eine gründliche Veränderung. Die allgemeine Arbeitspflicht, die Beseitigung der toten Hand, die Ersetzung der alle sozialen Schäden aufnehmenden Carität durch staatliche Wohlfahrtspolitik und kirchlich-staatliche, nur die wirklich Arbeitsunfahigen versorgende Liebestätigkeit: das gibt ein neues Bild der Dinge, und auf diese neuen Züge konnten sich dann allerdings später die Tendenzen der modernen Wirtschaftsethik berufen. An sich selbst aber ist die Wirtschaftsethik des Luthertums durchaus reaktionär gemeint als eine Verbindung des natürlichen und göttlichen Gesetzes der strengen Eingrenzung auf gegebene und einfachste Verhältnisse und der Begnügung mit dem standesgemäßen Existenzminimum, immer zugleich begleitet von der Bereitschaft, auf das nur durch die Sünde herbeigeführte Eigentumsrecht nötigenfalls radikal $\mathrm{zu}$ verzichten.

Aber so sehr in diesem Bilde natürliche und christliche Ethik zusammenzustimmen scheinen, so fehlt es doch auch hier nicht an Konflikten. Die beständige Bekämpfung des Eigeñnutzes und des Vertrauens auf eigene' Kraft und Leistung, die Forderung der Ergebung in Verluste Teuerungen und Nöte als in göttliche Strafen und Zuchtruten, die Betonung der von selbst ohne Mühsal und Klügeln alles schenkenden Vorsehung, die auf jeden Besitz verzichtende Bruderliebe, alles das geht weit über die Grundsätze jener natürlichen Wirtschaftsethik hinaus und nähert sich dem evangelischen Radikalismus der leidenden und duldenden Sekte. Dem Einwand, daß die Befolgung solcher Grundsätze alles Wirtschaftsleben zerstöre, begegnete Luther nur mit der Antwort, daß das die Obrigkeit verhindern müsse und; wo das nicht geschieht, als der Welt Wesen und des Christen Recht erduldet werden müsse. Luther führt nicht nur den Kampf

der feudalen Verfassung ganz entgegengesetzt ist, und sowohl die Geldwirtschaft als den Prinzipat des Landesherrn begünstigt. Die moderne Wendung der Reformatoren besteht überhaupt wesentlich in der Anheimstellung der Wirtschaft an die Landesherrn, die zum Besten des Ganzen Besitz und Erwerb zu steigern berechtigt und verpflichtet sind; vgl. Schauenburg s. Theol. Jahresbericht 496. So beschritten sie unter dem Segen des Luthertums und ohne kirchliche Kontrolle die Wege des Merkantilismus wie der absolutistischen Wohlfahrtspolitik. Uebrigens hatte die Landesherrn zur Sammlung von Schätzen und damit zur Exemption von der blirgerlichen Moral bereits die Scholastik ermächtigt, Oncken I 128. 
gegen die ihm v̀orliegenden Erscheinungen des Frühkapitalismus und seine sozialen Konsequenzen, etwa gegen besondere Ausartungen der neuen Wirtschaftsordnungen, sondern er führt im Grunde den Kampf der christlichen Genügsamkeits- und Liebesethik, des Vorsehungs- und Ergebungsglaubens gegen den nie völlig zu zügelnden Egoismus und das weltliche Selbstvertrauen alles Besitzstrebens überhaupt ${ }^{273}$ ). Er kämpft gegen das neue Prinzip selbst. Erst wenn er dabei bis hart an die Grenze der Sektenethik kommt, dann betont er wieder Recht und Funktion des Besitzes, die Güte der göttlichen Gaben und die göttliche Einsetzung der Obrigkeit und damit der organisierten Gesellschaft. Es ist dasselbe Alternieren der Gesichtspunkte wie bei der Ehe und bei dem Staate. Die Doppelheit der Ethik Luthers bricht überall durch ${ }^{274}$ ).

373) Vgl. die höchst charakteristischen Stellen in $>$ Kaufhandlung a BA. IV I S. 523-527 über die vier Weisen, christlich mit anderen im Erwerbsgeschäft zu handeln: erstlich, daß man sich willig berauben lasse, wenn die Obrigkeit es zu hindern versäutht; zweitens, daß man den Bedürftigen umsonst gebe; drittens, daß man leihe ohne Wiedererstattung. Dann erst kommt die vierte Weise, daß man kaufe und verkaufe Ware gegen Ware oder Ware gegen Geld als Wertmesser und Wertaufbewahrungsmittel; zu dem letzteren $Z$ weck, ist dann aber die Fixierung des pretium justum durch die Obrigkeit nötig. Noch deutlicher ist der viel zitierte Brief an die Danziger yom Jahre 1525, wo er dais Zinsnehmen als vom Evangelium verboten bezeichnet, aber fortfährt: , Aber das Evangelium ist ein geistlich Gesetz, darnach man nicht regieren kann, sondern dasselbige jeglichen für sich selbst stelle, ob er es tun oder lassen werde. Und man kann und soll auch niemand dazu zwingen, gleich als zum Glauben; denn hie nicht das Schwert, sondern der Geist Gottes lehren und regieren muß. Darum soll man das geistliche Regiment des Evangelii ferner scheiden vom äußerlich weltlichen Regiment und ja nicht durcheinandermischen ... Das Evangelium lehret wohl frei alle Güter fah.ren lassen aber wer mich dazu zwinget und dringet, der nimmt mir das meine. So will er nach menschlichem Gesetz wenigstens einen beschränkten und amtlich festgesetzten Zins von $5 \%$ gelten lassen; Oncken I 144. Es ist auch hier wieder die bekannte doppelte Moral Luthers, um derenwillen man Luthers Haltung in der Zinsfrage oft schwankend genannt hat, was sie aber innerlich und an sich in der christlichen Forderung selbst nicht ist; sie wird es erst bei dem Verzicht auf die ernstliche Durchführung und bei der ergänzenden Anerkennung eines weltlichen Brauches.

270) So will Luther die auch dem erlaubten Kaufmannswesen wegen des unvermeidlichen Gewinnstrebens immer anhaftenden Sünden dulden: Darum sollst du dein Gewissen damit nicht beschweren, sondern als e in e andere un überwindliche Sünde, die uns allen anhängt, mit dem Vaterunser vor Gott bringen und ihm befehlen. Denn zu solchem Fehl drängt dich die Not

Troeltsch, Gesammelte Schriften. I. 
Damit wird aber auch erst der eigentliche Grund des Festhaltens an der mittelalterlichen Wirtschaftsethik klar. Es ist nicht etwa Befangenheit in einer herrschenden allgemeinen Selbstverständlichkeit wirtschaftlicher Anschauungen. Auch Sachsen war bereits über das naturalwirtschaftliche Wesen hinausgegangen, und gerade Luthers leidenschaftliche Polemik mit ihrer eingehenden Aufzählung der herrschenden Praktiken zeigt, daß er sich nicht in Uebereinstimmung mit seiner Zeit, sondern im Gegensatz gegen sie wußte ${ }^{275}$ ). Es ist auch nicht Befangenheit in der katholisch-scholastischen Tradition, gegen die er da, wo sie seinen l'rinzipien widersprach, wahrlich scharfsichtig und feindselig genug war; er hielt damit ja auch gar nicht ihre Theologie, sondern nur ihr wirtschaftsethisches Naturrecht fest. Vielmehr, wie sein eigentümliches politisches Naturrecht der Gewalt vollbewußt aus einer ganz persönlichen, zugleich realistischen und religiös-überidealistischen Anschauung entsprang, so ging auch sein wirtschaftsethisches Naturrecht und dessen Verbindung mit der christlichen Moral aus bewußter Prinzipiengesinnung hervor. Durchbrach er dort mit Bewußtsein die patristisch-naturrechtliche Tradition des politischen Rationalismus, so hielt er sie hier mit ebenso prinzipiellem Bewußtsein fest. Der Grund ist: er war genau wie die katholische Ethik überzeugt, daß nur diese mittelalterliche Fassung der Wirtschaftsethik der christlichen Moral entspreche, daß nur sie mit der christlichen Liebesmoral, dem Gottvertrauen und dem Weltverzicht sich vertrage. Hierin hatte er auch die Mehrzahl seiner Zeitgenossen, abgesehen von den an der städtischen Wirtschaftspolitik geschulten Humanisten wie Pirckheimer, Peutinger, Machiavelli und Vives, ohne Unterschied der Konfessionen auf seiner Seite. Auch die Territorial- und Reichsgesetzgebung bewegte sich in ähnlichen Ideen und kämpfte hier mit dem Widerstand der Städte. Wie oben gezeigt wurde, daß eine das Weltleben rezipierende christliche Ethik erst auf dem Boden der mittelalterlichen Gesellschafts- und Wirtschaftsverfassung, der Naturalwirtschaft und der handwerkerlichen Städtebildung möglich war, so ist das auch jetzt noch der Fall. Luther hält den Boden fest, auf dem allein die Verwirklichung der christlichen Moral bisher möglich erschienen war. Die vermehrte Leidenschaftlichkeit der Theorie und ethischen Ermahnung führt sich darauf zurück, daß nun dieser christlich-naturrechtlichen Idee der neue soziale Typus der kapitalistischen größeren Städte und der davon ausstrahlen-

275) Schmoller 479 . 
den sozialen Wirkungen gegenüberstand. Dieser neue Typus mit seinen Konsequenzen des frei beweglichen Individualismus, der Konkurrenz, der kalkulierenden Besitzsteigerung, der verwickelten und unübersichtlichen Beziehungen zwischen Konsumtion und Produktion war in der Tat für die christliche Ethik, jedenfalls für wesentliche Grundgedanken derselben, ein schroffer Gegner. Das hat Luther klar empfunden und von hier aus seinen wirtschaftsethischen Gegensatz gebildet, der in dieser Hinsicht mit dem katholischen völlig zusammentraf ${ }^{276}$ ). Darin setzt sich bis heute das Sozialideal und die Wirtschaftsethik der lutherischen Konservativen fort ${ }^{277}$ ), und darin berühren sie sich bis heute mit der katholischen Ethik, welche das von ihr allerdings viel stärker anerkannte demokratische Element doch in die Bahn einer neuen Ständebildung und in die Grenzen eines kirchlich bestimmten ständischen Rahmens zu drängen sucht. Die Motive bei Luther waren dieselben, wie es die der heutigen Konservativen, Katholiken und Mittelständler heute noch sind. Luther kämpfte gegen die Monopole und Handelsgesellschaften, gegen die aus der allgemeinen Preissteigerung folgenden Lohnforderungen der Taglöhner und Dienstboten ${ }^{278}$ ), gegen die Verabredungen der letzteren ${ }^{279}$ ), gegen den die Standesgrenzen und Kleiderordnungen sprengenden Individualismus, wie die heutigen Konservativen gegen die Börse, gegen die Begehrlichkeit der Massen, gegen das Koalitionsrecht, gegen die freie Konkurrenz kämpfen. Er hatte und Art des Werkes, nicht der Mutwille und Geiz; denn ich rede hier von den gutherzigen und gottesfürchtigen Menschen, die nicht gern Unrecht täten. Gleichwie die eheliche Pflicht nicht ohne Sünde geschieht und doch Gott um der Not willen solchem Werk durch die Finger sieht, weil es nicht ariders sein kannc. BA. IV I S. 519 f. Genau so steht es mit dem Ertragen der Gewaltordnung des Staates als eines Reiches des Zornes.

270) Ueber diesen Gegensatz Schmoller 569, 591, 692 und 719; über ein auch bei den Reformatoren vorhandenes und nur zu Gunsten der von der Erbsünde bedingten Lage eingeschränktes Motiv des Sozialismus richtig Schmoller $708 \mathrm{f}$; über die ethisch-religiös motivierte Parteinahme für die Armen und für die Schuldner (wie im kanonischen Recht) s. Schmoller 529 und 591. Das sozialistische Element, das - auf religiöser Basis und unter Voraussetzung der Sünde und der Ungleichheit - die kanonistisch-lutherische Lehre enthält, ist auch von Oncken betont S. 135 ; ebenda über die Zusammenhänge der physiokratischen Lehre mit dieser >natürlichen Witschaftsethike.

277) S. Oncken I 147, der auf K. L. von Haller und Adam Müller verweist.

278) S. Schmoller 513 .

or9) S. Schmoller 515 . 
freilich dabei im Unterschiede von den heutigen Konservativen wesentlich nur die ethisch-religiösen Maßstäbe im Auge und keinerlei Klasseninteresse und setzte dafür einen leidenschaftlichen Willen ein, der sich um die etwa möglichen wissenschaftlichen Erklärungen des feindlichen Typus und um die allgemeinen Gründe und Notwendigkeiten derihm vorliegenden Veränderungen gar nicht bekümmerte. Diese waren seiner kindlichen Auffassung vielmehr lediglich ein Werk des Teufels und der Bosheit, eine Zuchtrute Gottes über die tollen und ungebärdigen Deutschen oder ein Vorbote des End̦es der Dinge ${ }^{280}$ ). Er kann den Gedanken gar nicht fassen; daß es mit den wechselnden allgemeinen Lagen auch verschiedene wirtschaftsethische Folgerungen geben könnte, und ruft daher die Welt zurück zum natürlichen und göttlichen Recht. Die neue Wirtschaft ist gegen die Demut, gegen das Gottvertrauen, gegen die Bruderliebe, gegen die Natur und gegen Gott. Gegen sie muß daher die Obrigkeit im Bündnis mit der Gesinnungsbildung durch Kirche und Schule einschreiten.

Aus den politischen und wirtschaftsethischen Ideen erklärt sich dann schließlich das ganze Sozialideal, die Gesellschaftsgliederung und -verfassung überhaupt. Es ist das Ideal ständisch gegliederter Berufe, der Kosmos der Berufe, wie im mittelalterlichen Katholizismus, nur mit der Ausdehnung der Berufspflicht auf alle und mit unmittelbarer Einverleibung des Berufsgedankens in den Kern der christlichen Ethik. 1)ie Berufe sind teils die aus der wirtschaftlichen Arbeitsgliederung hervorgehenden, bei denen eine strenge zünftige Teilung wünschenswert ist. Teils sind es die kirchlichen und Schulberufe, denen die begabten Kinder zuzuführen als eine christliche Pflicht stetig cingeschärft wird. Weiter kommen dazu die fürstlichen, adeligen, amtlichen und militärischen Berufe, schließlich der Ueberschuß, der in den festen Gliederungen nicht verbraucht werden kann, aber den wechselnden Dienstbedürfnissen genügt ${ }^{281}$ ). Die Leib-

2s(i) Fin Beispiel von der Naivetät seiner Argumentationen bei Schmoller 566: daß 7. $\$, 9$ und 10\% unchristlich seien, das sehe man schon daraus, $>$ daß die Räuber und Wucherer, die das nehmen, häufig eines jähen Todes sterben, oder sonst schrecklich umicommen .

281) Ueber die soziale Gliederung in der Anschauung Luthers, die ganz der mittclalterlichen entspricht, s. Brandenburg S. II, Schmoller S. 475, 485-487, 688. Vie selbstverständlich für Luther die zünftige Gliederung ist, zeigt die Anekdote aus den Tischreden, wonach L. unter den Schneidern noch besondere Gruppierungen fiir die Anfertigung bloß von Hosen, Wämsern oder Röcken fordert, damit 
eigenschaft, die nicht aufgehört hat und mit dem endenden I6. Jahrhundert wieder stark zunimmt, wird von diesen Voraussetzungen aus genau beurtèilt wie das Sklavenwesen in der alten Kirche, als ein Stand, in dem man die innerliche religiöse Freiheit der Erlösung genießen darf, aber nicht die äußerliche rechtliche Befreiung suchen. soll ${ }^{282}$ ). An Antisklavereibewegungen denkt das Lutherdie Arbeit besser würde, Schmoller 487. Reiches Material zur Sozialgeschichte des Luthertums bei Drews: -Einfluß der gesellschaftlichen Zustände auf das kirchliche Leben (Z. F. Theol. und Kirche 1906) und $>$ Der ev. Geistliche in der dentschen Vergangenheit c 1905. Die Theorie führt vielfach die kahle scholastische Dreiteilung fort; der dritte Stand wird nie in seinen Bestandteilen, den städtischen und agrarischen, und dann weiter in deren beiderseitiger Gliederung konstruiert; vor allem der vierte Stand der Dienstboten, Tagelöhner, Hörigen und Leibeigenen erscheint nie als besondere Kategorie. Die Theologen handeln beim status oeconomicus in der Regel nur von der Hauswirtschaft, zu der sie das Gesinde rechnen und die sie möglichst als geschlossene Hauswirtschaft denken; vgl. die dürftigen Sätze bei Schmidt, Ev.-Luth. Dogmatik 462; hier wird nur die societas paterna, d. h. die engere Familie und die societas herilis, d. h. legitima dominorum et servorum conjunctio divinitus instituta ob mutuam utilitatem, unterschieden und für deren nähere Ausführung auf die Auslegung des Dekalogs verwiesen. Die eigentliche Sozialund Wohlfahrtstheorie und -Politik bleibt den Obrigkeiten, der fürstlichen Polizei und der Kameralistik überlassen; die theologische Ethik betont nur das allgemeinc Prinzip des Patriarchalismus. - Eine von Gottfried Arnold zitierte und ausgenutzte Schrift, Joh. Cuno, Spiegel aller Stände, war mir nicht zugänglich.

282) Hiezu Luther gegen die Forderung der Bauern, die Leibeigenschart aufzuheben BA. IV I, S. $334 \mathrm{f}$ : ॠs soll kein Leibeigener sein, weil uns Christus alle befreit hat. Was ist das? Das heißt christliche Freiheit ganz fleischlich machen. Hat nicht Abraham und andere Patriarchen und Propheten auch Leibeigene gehabt? Lest S. Paulus, was er von den Knechten, welche zu der Zeit alle leibeigen waren, lehrt! Darum ist dieser Artikel stracks wider das Evangelium und $r$ ä uberisch, damit ein jeglicher seinen Leib, so eigen geworden ist, seinem Herm nimmt. Denn ein Leibeigener kann wohl Christ sein und christliche Freiheit haben, gleichwie ein Gefangener oder Kranker Christ ist und doch nicht frei ist. Es will dieser Artikel alle Menschen gleich machen und aus dem geistlichen Reich Christi ein weltliches, äuferliches Reich machen, welches unmüglich ist. Denn weltliches Reich kann nicht bestehen, wo-nicht Ungleichheit ist in Personen, daßetlichefreisind, etlichegefangen, etliche Herren, etliche Untertanena. An anderer Stelle ermahnt er gar die von den Türken versklavten christlichen Kriegsgefangenen zum Ausharren in ihrem Sklavenstande: $>$ Du mußt denken, daß du deine Freiheit verloren hast und eigen geworden bist, daraus du dich selbst ohne Wille und Wissen deines Herm nicht ohne Sünde und Ungehorsam wirken kannst. Denn du raubst und stiehlst damit deinem Herrn deinen Leib, welchen er gekauft oder sonst zu sich 
thum nicht von ferne, und bis heute macht ihm weder die agrarische noch die industrielle Hörigkeit irgendwelche ethische Bedenken. Der Grund von alledem ist völlig klar. Die ständische Gliederung beseitigt die Konkurrenz, soweit es in Sündenstande möglich ist, und entspricht damit dem Liebesideal wie dem auf Friede und Ordnung gestellten naturrechtlichen Ideal. In diesem Sinne hat Stahl das ständische Prinzip von neuem als dás christliche naturrechtliche Prinzip vertreten ${ }^{283}$ ). Daß die gesamte Bevölkerung von einem solchen Prinzip aus immer versorgt werden könne, das sichert der unbedenkliche Vorsehungsglaube. Nur sonderliche Un. fälle und Strafen Gottes stören es, und dann sind die dadurch Deklassierten und Atomisierten der Fürsorge der christlichen Liebestätigkeit und der staatlichen Polizei befohlen, von der man nicht zweifelt, es werde ihr gelingen, alle etwaigen sozialen Schäden zu heilen. Soweit aber das Gefüge der Ständegliederung überhauptder mehr oder minder gewaltsamen Erhaltung, des polizeilichen Schutzes, der wirtschaftspolitischen Regelung und Unterstützung bedarf, ist das Sache der Obrigkeit ${ }^{284}$ ). An der Fähigkeit der Obrigkeit, gebracht, $d a B$ er forthin nichtdein, sondern sein $G$ ut ist wie ein Vieh oder andere seine $\mathrm{Habea!!} \mathrm{BA.} \mathrm{IV} \mathrm{I} \mathrm{S.} \mathrm{479.} \mathrm{So} \mathrm{hat} \mathrm{die}$ Wiederausbreitung der Hörigkeit in den ostelbischen Gutsbezirken seit dem 16. Jahrhundert (s. Gothein, >Agrargeschichte an >Religion in Geschichte und Gegenwarte I 2807) im Luthertum durchaus kein Hindernis gefunden. Eine auch rechtliche Fixierung der Menschenrechte ist wenigstens in Deutschland erst das Werk der Aufklärung und ist es bis heute geblieben.

283) F. J. Stahl, der christliche Staat, S. 8: das patriarchalische Grundschema; S. 17: der Gegensatz des modernen Prinzips. Die Fortdauer oder vielmehr die von der Restauration bewirkte Wiederbelebung dieser Tendenzen im modernen Konservatismus ist höchst interessant mit vielfachen Exzerpten aus der konservativen Presse geschildert von Stillich, Die politischen Parteien in Deutschland I. Freilich sieht Stillich hierin nur einen Ausdruck des konservativen Klassenkampfes und übersieht den Zusammenhang dieses Klassenkampfes mit der Wiederbelebung der rein ideologischen Motive des Luthertums, durch die allein er im Namen und mit den Kräften einer populären Weltanschauung geführt werden kann; s. S. 55 über die ständische oder, wie man jetzt zur Unterscheidung vom smechanisch-individualistischen « Prinzip sagt, >organische « Gesellschaftsauffassung der Konservativen; ebenso S. 87 und 219; S. 143 über den damit verbundenen wirtschaftlichen Traditionalismus.

284) Vgl. v. Seckendorff, Fürstenstaat S. 193: Allhier ist nun besonderlich anzufübren, wohin doch solche Ordnungen in weltlichen Sachen gerichtet zu werden pflegen... Insgemein ist gedacht, daß dadurch Gerechtigkeit, Friede und Aufnehmen oder Wohlfahrt des Landes oder der Leute 
all das bei gewissenhafter Befolgung des natürlichen und göttlichen Gesetzes zu leisten, zweifelt - und das ist der charakteristische Unterschied gegenüber der Gegenwart - im Grunde niemand. Teils sind die Verhältnisse in der Tat ganz außerordentlich viel einfacher als heute; teils fehlt mit der Statistik noch jede wissenschaftliche Erkenntnis der verwickelten sozialen Bedingtheiten und Abhängigkeiten; die Freizügigkeit existiert noch nicht, und das Bevölkerungsproblem steht in den ersten Anfängen der Diskussion. $\mathrm{Da}$ ist eine derartig kindliche Auffassung möglich. Die spätere theologische Ethik bekümmert sich daher in ihren sozialen Theorien um das Berufsystem nur

gesucht werde... Der Friede oder die innerliche Ruhe des Landes und die Sicherheit vor den Feinden fleußet her aus der Gerechtigkeit und die wird hinwiederum durch Friede und Ruhe befördert ... So sorgt der Landesherr (S. 205), >daß keinem Untertanen die Notdurft zu seinen Lebensmitteln außer sonderbarer Strafe und Verhängnis Gottes und sein selbst Verschulden ermangele, sondern er seine Nahrung in guter Ordnung und ohne ungebührliche Hinderung durch fleißige Arbeit und rechten Brauch des Seinigen haben möge๔. S. 206 : >2u diesem Ende ist in etlichen Landesordnungen die gemeine Satzung, daß ein jeder Stand bei seiner hergebrachten Nahrung bleibe, der Adel z. E. seiner Güter sich nähren, der Bürger, der Kaufmannschaft und Handwerks auch Brauens und Schenkens sich gebrauchen und der Bauersmann dem Ackerbau obliegen soll; doch alles nach Maße des Herkommens und jedes Ortes Gelegenheit. Hiernächst haben auch die meisten Handwerker ihre sonderbare Zunft- und Handwerksreguln oder Gilden- und Innungsbriefe, welche ihnen die Obrigkeit aufrichtet oder bestätigt; und wird darin nächst dem, was zur Erlernung und rechtmäßigen Uebung eines jedweden Handwerks absonderlich fürfällt, insgemein dieses in Acht genommen, daß eine jede Handtierungszunft bei dem, was zu derselben eigentlich gehöret, gelassen und von anderen ihnen kein Eintrag geschehe, eine gute Absicht unter ihnen gestiftet, auch Rottung, Selbsttätigkeit und Anmaßung sonderbarerer Gerichtsbarkeit verhütet werden, sie aber hingegen ehrlich und fleißig lernen, billigen Preis halten und niemand durch vorteilhafte Griffe übersetzen usw.\&. Niedrighaltung des Lohnes im vierten Stande S. 210. „Insonderheit muß zumal zu den Zeiten, da wegen vorgehender Kriege und Sterbensläufte die Leute nicht viel zu bekommen sind, auf die Taglöhner und Dienstboten genaues Aufsehen geführt werden, daß sie bei billigem Lohn und fleißiger Arbeit bleiben; denn ohne dieselben werden alle anderen Hantierungen und Haushaltungen gestopft und gehindert «. Selbstverständlich ist die Leibeigenschaft etc. S. 199: „Denn eben um deswillen, daß man für den bösen und 'schădlichen Leuten seinen Leib, Ehre und Gur sicher hätte, haben sich anfunglich durch göttliche Schickung so viele tausend Leute unter den Schutz einer oder wenig Personen begeben und denenselben so viel Macht, Vorzug und Gewalt eingerăumete. 
im ganzen, im einzelnen nur um die Hauswirtschaft, in der vor allem die christlich-ethischen Tugenden zu entwickeln sind. Die Regelung des Ganzen überläßt sie der Obrigkeit, die, vom Luthertum selbst stark gefördert, die Zentralleitung in die Hand nimmt und nach christlichem und natürlichem Recht für Konservierung der Stände in ihrer Nahrung, für Heilung der Schäden und für den etwa notwendigen Fortschritt zu sorgen hat. Diese Dinge fallen der Kameralistik und Polizeiwissenschaft anheim, und damit geht die lutherische Theorie in die Bahnen des Merkantilismus über, indem der Obrigkeit zum Besten des Ganzen erlaubt ist, was dem Einzelnen für sich nicht erlaubt sein kann, die Besitz- und Gewinnsteigerung, die Initiative neuer industrieller Unternehmungen, Monopole und Regale, Befreiungen und Veränderungen des ständischen Gefüges und seines $\mathrm{Z}$ wanges. Hier hat Seckendorff das Ideal der christlichen Polizei \& klassisch geschildert ${ }^{285}$ ).

285) Vgl. die Darstellungen dieser Kameralistik bei Roscher und bes. Oncken I 226-236: Die Kameralwissenschaft als spezifische Form der merkantilistischen Literatur Deutschlands trägt einen populationistischen Charakter einerseits und einen

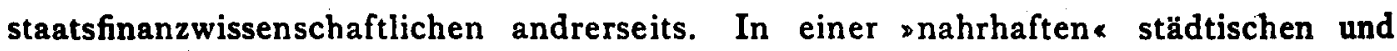
ländlichen Bevölkerung und in einem blühenden $\gg$ Aerarium « besteht der Reichtum des Landes. Man muß es den Kameralisten zum Ruhme nachsagen, daß sie mit redlichem Eifer bemüht gewesen sind, den ihnen gestellten Aufgaben gerecht zu werden, wobei freilich nicht geleugnet werden soll, daß, wenn damals der Reichtum eines Landesfürsten nach der Zahl seiner Untertanen gemessen wurde, dies meist in dem Sinne geschah, wie man in unseren Tagen einen Grundbesitzer nach der Zahl seiner Viehstücke einschätzte. Bemerkenswert ist die Aehnlichkeit des katholischen und des protestantischen Zweiges dieser Kameralistik in theologischethischen Voraussetzungen und praktisch-politischen Konsequenzen. Die protestantische Richtung ist nur reicher und mannigfaltiger vertreten S. 232. Oncken hebt mit Recht den shalbsozialistischen Charakter und die Neigung zum >Mittelstand hervor S. 229, betont aber nicht genügend den Zusammenhang mit der religiösen Moral. Es ist überall mit Händen zu greifen, daß die Betonung von Friede, Ruhe, Ordnung, die Ausscheidung der Konkurrenz, die Befestigung oder Neuregelung der ständischen Gliederung vom Standpunkt der dem freien Kampf ums Dasein entgegengesetzten Liebesmoral ausgehen. Der sfreie Lauf der Kommerziene ist -Bosheit und Albernheit« S. 231. Die ganze Gebundenheit und der Mangel an individueller Initiative ist ebenso religiös motiviert, wie in den Umständen begründet, ohne daß man die religiöse Theorie einfach als Spiegelbild der tatsächlichen Verhälınisse bezeichnen dürfte. Es ist ein Rückschritt hinter die städtische Laienkultur des Spätmittelalters, der einerseits in der realen politischen und sozialen Entwickelung der Machtverhältnisse und der Wirtschaft, andrerseits aber auch in der davon ganz unabhängigen reaktionären religiösen Theorie Luthers über wirtschaft- 
In der Zusammenfassung aller dieser Einzelheiten läßt sich nun auch die Frage beantworten, inwieweit das Luthertum eine christliche Sozialgestaltung und Sozialreform erstrebt hat. Die Antwort ist einfacher, als man bei der Verflechtung des Luthertums in eine außerordentlich wechselnde Sozialgeschichte, in den noch andauernden. Hochstand deutscher Kultur des I6. Jahrhunderts, in die Verwüstungen des großen Krieges, in den Neubau der deutschen Staaten, schließlich in die Aufklärungs- und Restaurationspolitik und heute in die großen modernen sozialen Probleme annehmen sollte. Die Einfachheit kommt davon her, daß seine Stellungnahme wesentlich auf der religiösen Theorie der reinen Spiritualität und Innerlichkeit der Kirche und der Zuweisung aller äußerlichen weltlichen Dinge an die Vernunft, die Fürsten, die Obrigkeit beruht bis zum heutigen Tage. Dabei war allerdings zu Anfang die Voraussetzung, daß natürliches und göttliches Recht, aus gleicher Quelle stammend, sich immerdar von selbst ergänzen werden, und daß eine christliche Obrigkeit die weltlichen Dinge nach natürlichem und göttlichem. Gesetz im Sinne des religiös-ethischen Ideals zu regieren und formen gewillt und imstande sein werde. Die christliche Sozialgestaltung fehlte nicht, aber sie war lediglich Sache der Obrigkeit und verfuhr nach der mit dem Evangelium übereinstimmenden, dem Sündenstand angepaßten natürlichen Vernunft. Als dann das moderne Naturrecht entstand in seinem Unterschied von dem christlichen Naturrecht des Sündenstandes und der relativen Vernünftigkeit, da war allerdings eine neue Lage geschaffen. Man half sich, indem man sich in das neue Naturrecht ergab wie einst in das alte und die Reformtätigkeit des Staates mit einem etwas verweltlichten religiösen Enthusiasmus begleitete. Als dann aber vollends die politische und soziale Entwickelung, auch hiervon emanzipiert, in die modernen Verhältnisse des reinen Macht- und Konkurrenzkampfes überging, da war die Sozialtheorie des Luthertums in größter Verlegenheit und konnte ihre ursprüngliche Lehre nur mehr predigen, aber kaum mehr realisiert hoffen, da ihr nicht wie dem Katholizismus und Calvinismus die Organe zu einer

liche und soziale Dinge begründet ist. Daß die hiemit erfolgende Bildung größerer und einheitlich verwalteter Staatseinheiten unter anderem Gesichtspunkt ein Fortschritt oder die Voraussetzung des Fortschrittes ist, versteht sich von selbst; nur lag derartiges nicht in der bewußten Absicht des Luthertums, weder des theologischen noch des juristisch-politischen. 
staatsunabhängigen Durchführung gegeben sind und der moderne Staat seinerseits sich nicht mehr wie im alten Luthertum als weltliche Seite des Organismus der christlichen Gesellschaft empfindet. Von da ab beginnt nun die soziale Hilflosigkeit des Luthertums, soweit es nicht calvinistische und moderne Ideen aufgenommen hat. In seinem eigentlichen, alten Sinne findet es Rückhalt nur mehr an der konservativen Partei, und es verbindet daher seine dogmatische Restauration mit der politisch-sozialen der Konservativen. Es ist nicht mehr der christliche Staat, auf den es seine Erwartung einer dem natürlichen und göttlichen Recht entsprechenden Sozialgestaltung abstellt, sondern die christliche Partei. Begreiflicher Weise berührt es sich dabei mit der anderen einst so heiß bekämpften, christlichen Partei, dem Katholizismus, in der Gemeinsamkeit der schristlichen Weltanschauung * und des Gegensatzes gegen den konfessionell und religiös indifferenten modernen militärisch-bureaukratischen Macht- und Riesenstaat.

Luther hatte freilich nicht von Anfang diese Wege der sozialen Passivität für die Kirche gewiesen. In der Zeit, wo die chaotische Gärung des deutschen Lebens mit der religiösen Reform zusammentraf und noch eine durch die andere zu dem Ziel eines politisch, sozial und kirchlich erneuerten christlichen Gemeinwesens kommen zu sollen schien, da hat Luther in der Schrift an den Adel ein Programm kirchlicher und sozialpolitischer Wiedergeburt für das ganze Reich entworfen, in der er alle Anregungen der Oppositions- und Reformparteien mit seinem neuen kirchlichen Ideal einer auf das allgemeine Priestertum begründeten Kirche verwoben hatte. Allein einmal ist hier Luther von der allgemeinen Bewegung über sich selbst hinausgehoben und, dann ist sein Prinzip doch auch hier insoferne schon vorgebildet, als nicht die geistliche Gewalt die Reformen herbeiführen und damit ein neues christliches Gesetz auferlegen, sondern die fürstlichen Obrigkeiten kraft der Vernunft und kraft der Liebe zum reinen Evangelium die außerkirchlichen Reformen rein aus sich bewirken sollten. *Vernünftige Regenten neben der Heiligen Schrift* sind die getrennten, aber jede auf ihrem Gebiet zur Reform »des christlichen Körpers * zusammenwirkenden Kräfte. Aber ein enthusiastischer Optimismus faßte noch beide Aufgaben als wesentlich zusammengehörig und zum gemeinsamen Sieg bestimmt auf ${ }^{286}$ ). Derart vorbereitet sollte dann ein Konzil die Gesamt-

286) Vgl. Brandenburg, S. 9 f.; über die Herkunft der Reformgedanken bei 
reform der Christenheit endgiltig in die Hand nehmen. Aus der Gesamtreform wurde nichts, und so wandte sich in den Zeiten der Gärung die Reform zu den einzelnen lokalen und kommunalen Obrigkeiten, die jede auf ihre Weise die Besserung unternahmen und dabei in dieser Zeit des Experimentierens durch Luthers "Gemeindeideal « unterstützt waren. Die Bürgerschaften und Magistrate, die bereits erhebliche kirchliche Rechte und die Tradition moralisch-polizeilicher Ordnungen besaßen, erließen nun neue Ordnungen, die das Kultuswesen und zugleich mit ihm das Armen- und Polizeiwesen in dem neuen evangelischen Sinne ordneten. Die Wittenberger Kastenordnung vom Januar 1522 und die Leisniger Kastenordnung von I523 sind die viel nachgeahmten Versuche einer christlich-sozialen Ordnung, die die frei werdenden Stiftungs- und Pfründenvermögen für Kirche, Schule, Armenwesen, Unterstützungswesen, Teuerungspolitik verwenden und die Handhabung dieses Vermögens durch gewählte Kastenvorsteher besorgen lassen wollten. Der Charakter dieser Ordnungen ist eine Evangelisierung und Verkirchlichung der bereits bisher in ähnlichem Sinne geübten städtischen Polizeiordnungen, und das ist infolge dieser Verkirchlichung allerdings als lokaler und kommunaler christlicher Sozialismus zu bezeichnen. Allein die Ordnungen waren utopisch und enthusiastisch und kamen nirgends zur Durchführung ${ }^{287}$ ). Vielmehr wandte sich Luther unter den Enttäuschungen des Bauernkrieges und bei der nun endlich entstehenden Möglichkeit einer nicht mehr lokalen, sondern territorialen Neuordnung von dem bedenklichen Gemeindeprinzip in jeder Weise $a b$ und ubergab, seinem wesentlichen Grundgedanken entsprechend, von nun ab alle politischen und sozialen Dinge als äußerliche weltliche Dinge ganz der Obrigkeit, der Vernunft und dem bisher ganz einseitig theologisch beschäftigten Manne s. W. Köhler, L.s Schrift an den Adel im Spiegel der Kultur- und Zeitgeschichte, 1895.

287) Vgl. Uhlhorn III 33-5I; Barge, Karlstadt I 352, 382-386; vor allem L. Feuchtwanger, Gesch. d. sozialen Politik und des Armenwesens im Zeitalter der Reformation, Berliner Diss. 1908 und die Fortsetzung davon im ? Jahrbuch für Gesetzgebung, Verwaltung und Volkswirtschafte 1909 XXXIII. Ich folge im wesentlichen der Auffassung Feuchtwangers, der Barge sehr bedeutsam ergänzt und korrigiert; vgl. die Analysen der Wittenberger >Beutelordnunge, der >Ordnung der Stadt Wittenberg « und der Leipziger $\gg$ Kastenordnung «, Diss. S. $9-16$. Ueber das zeitliche Verhältnis der Beutelordnung zur Stadtordnung s. K. Müller, Luther und Karlstadt 1907, Anhang, u. Barge, Die älteste evangelische Armenordnung, Hist. Vierteljahrsschrift XI 1908 S. 193-225 u. Theolog. Jahresbericht XXVIII 530. 
den Juristen, jener Trias, die er ebenso oft lobte als schalt. Er behielt der Kirche mit voller Klarheit lediglich die rein geistliche Erbauungs- und Unterrichtssphäre vor. Eine christliche Obrigkeit sollte dann unter der Wirkung des Evangeliums alle sozialen Aufgaben, soweit- sie überhaupt in den damaligen Horizont fielen - und das war wesentlich die Unterstützung der Deklassierten und Atomisierten, aus irgend einem Grunde in dem System der Berufe ihre Nahrung nicht mehr Findenden - von sich aus erledigen.

Das wäre das Ende aller direkt kirchlichen sozialen Tätigkeit und der Beginn einer rein weltlichen Wohlfahrtspflege und Armenpolitik gewesen. Allein die noch sehr wenig zentralisierten Landesherrschaften und die mit schweren Aufgaben belasteten Kommunen nahmen sich dieses Berufes nur sehr unvollkommen an. Da griffen nun Luthers Helfer, vor allem der organisationskundige Bugenhagen, ein und übernahmen die der Kirche doch so naheliegende Aufgabe wenigstens der Armen- und Krankenpflege. Es geschah nun freilich nicht mehr in dem utopischen christlichsozialen Sinne der Wittenberger und Leisniger Kastenordnung, sondern - es handelte sich dabei wesentlich um die Städte in einer sehr nüchternen Zusammenfassung kommunal-polizeilicher und kirchlich-seelsorgerlich-karitativer Tätigkeit. Nach dem Vorbild der ältẹren städtischen Armenpolizei und unter Anregung der _von den belgischen Verhältnissen ausgehenden Reform des Armenwesens durch Ludwig Vives wurden die Mittel aus Stiftungen, städtischen Zuschüssen und Klingelbeutelerträgen geschaffen, im Zusammenwirken geistlicher und weltlicher Behörden die Armen kontrolliert, die Vagabundage eingeschränkt, Hospitäler geschaffen und eine sichere Technik des Rechnungswesens eingeführt, insbesondere die alles verwirrende Vermischung mit den Kirchen- und Schulfonds vermieden. Allein auch diese neuen Kastenordnungen setzten sich nicht auf die Dauer durch. Teils waren die Probleme des Armenwesens unterschätzt, teils gelang es nicht, die verfügbaren Stiftungsfonds zu zentralisieren, teils fehlte es an der Ausbildung der ehrenamtlichen und wechselnden Beamten; vor allem aber war die neue. Frömmigkeit selbst zu sehr auf das persönliche Irnenleben gerichtet, auf die allgemeine Arbeitspflicht eingestellt und dem alten Karitätsgedanken abgewandt, als daß es hätte gelingen können, die nötigen Mittel zu beschaffen. So wurden die lutherischen "Kasten * meistenteils zu dürftigen 
Armenstiftungen neben anderen ${ }^{288}$ ).

Aus dem kirchlichen Sozialismus wurde auch in dieser Form nichts, und die Aufgabe der Wohlfahrtspolitik wurde den sich immer mehr zentralisierenden und alles bevormundenden Regierungen anheimgestellt, die nun freilich gerade in Hinsicht auf das Unterstützungswesen sich durch die kirchlichen Einrichtungen wiederum entlastet fühlten und so auch ihrerseits nichts taten. Aber das dauernde Prinzip war damit jedenfalls endgültig ausgesprochen, daß alle weltlich-politischen Dinge und damit auch die soziale Fürsorge Sache der Obrigkeit ist, während die Kirche lediglich das Seelenheil und das innere persönliche Leben betrifft. So ging das lutherische Sozialprogramm in die Sozialpolitik des patriarchalischen Merkantilismus über. Als dann der Staat in die moderne Ideenbewegung eingetreten und vom patriarchalischen zum aufgeklärten Absolutismus fortgeschritten war, da glitt die ganze christliche Sozialgestaltung hinüber in die moderne Wohlfahrtspolitik, und das Luthertum verlor jede innere Beziehung wie jeden Einfluß auf die nur mehr sehr uneigentlich christliche * Obrigkeit.

Je mehr nun aber hierbei die Wohlfahrtspolitik rein weltlich wurde und je deutlicher sich zeigte, daß das System der bloßen Berufe und Stände nicht alle zu ihrer Nahrung kommen ließ, sondern stets von einer Menge der Deklassierten und Hilfsbedürftigen umlagert war, je mehr insbesondere die unruhigere soziale Bewegung des modernen Lebens die Existenzen durcheinanderwarf, umsomehr mußte das Luthertum aus seinem bloßen Vertrauen auf die Vorsehung und das System der Berufe heraustreten und das auch bei ihm vorhandene christliche Liebesstreben nun wieder in der Form der freien Karität betätigen, in Anstalten, Genossenschaften, Vereinen und Stiftungen. Es kehrte mit dem Pietismus zur religiösen Sozialpolitik der Karität zurück, ohne Verherrlichung des Bettels und zunächst ohne kirchliche Gebundenheit der Karität, im übrigen aber eine Wiederaufnahme der katholischen und altchristlichen Karität ${ }^{289}$ ). Das ist so geblieben bis heute und hat unter

288) Vgl. Uhlhorn III 102-140 und Feuchtwanger, der sowohl die humanistisch-stadtpolizeilichen Quellen dieser zweiten Generation von sKastenordnungene als die Ursache ihres Scheiterns eingehend untersucht.

289) Vgl. Uhlhorn III. 315-414. Es ist aber ein Hauptmangel dieser an sich vortrefflichen Darstellung, daß sie die Rückkehr zum Karitätsprinzip nicht als solche erkennt und hervorhebt und daher auch die richtigen Gründe dieser $R$ ückkehr nicht einsieht. Sie liegen in dem Versagen des altlutherischen Patriarchalismus, der im System 
englischen Anregungen im 19. Jahrhundert als innere Mission eine ganz außerordentliche Blüte erreicht. Das strenge Kirchentum ist darauf nur zögernd eingegangen, aber schließlich hat es sich heute in eine mehr oder minder enge Verbindung zu dieser protestantischen Karität gesetzt. Weitere sozialreformerische Ideen hat das strenge, in der Restaurationszeit erneuerte und seitdem herrschend gewordene Luthertum abgelehnt. Es blieb hier bei den Gedanken Stahls, der die Sozialordnung in die Hand einer christlichen Obrigkeit legte und ihr die ständische Ordnung, der Berufe mit Einschränkung der modernen Lebensbewegung zur Aufgabe machte. Der Versuch Wicherns über die bloße Karität hinaus eine christliche Sozialreform von seite der Kirche einzuleiten und eine kirchlich-religiöse Fürsorge mit der staatlichen Sozialpolitik in großem. Stile organisch $\mathrm{zu}$ verbinden, ist gescheitert an der inneren Ungeeignetheit des Luthertums zu einer derartigen Aktion und an der Beschlagnahme seiner Ideen durch die konservative Reaktion ${ }^{290}$ ). Die Umbildung des Wichernschen Programms durch der Berufe alle versorgt glaubte und nur für Ausnahmefälle den $>$ Kastene bereit hielt. Es ist das Wesen der neuen Periode protestantischer Liebestätigkeit seit dem Pietismus, daß sie sich nicht mehr auf die Staats- und Ständeordnung und auf die vom kirchlichen Amt ausstrahlenden Wirkungen verläßt, sondern von den Laien und Gemeinden her die freie Karität organisiort. Statt dessen greift Uhlhorn zur Erklärung dieser neuen Periode auf den Einfluß der Philanthropie der Aufklärung zurück, was sicherlich den geringsten Anteil hat. Außerdem ist der reformierte. und der katholische Einfluß hierbei von Uhlhorn mehrfach mit Recht betont, auch der Gegensatz des lutherischen Amtskirchentums kennzeichnet diese Rückfälle in reformierte und katholische Laienbetriebsamkeit als etwas Neues und Fremdes. $\mathrm{Daß}$ 'man damit in der Tat dem katholischen Karitätsprinzip sich wieder näherte, zeigen die Berufungen Fliedners und Wicherns u. a. auf altkirchliche Einrichtungen, auch einzelne unwillkürliche Aeußerungen Uhlhorns: >Es ist Gefahr, wieder in ein massenhaftes Almosen zu geraten, umsomehr als die Vereine untereinander wenig oder gar keinen Zusammenhang haben und der Bittende dem Verein sehr äußerlich gegenübersteht . . Doch am bedenklichsten würde es sein, wenn diejenigen Recht hätten, welche in der Menge der Vereine ein Symptom darin sehen, $\mathrm{da} B$ die historischen Gemeinschaften, Staat und Kirche, in der Auflösung begriffen sind, wie in der römischen Kaiserzeit und gegen Ende des Mittelalters ‘ S. 412. Die Aehnlichkeit dieser Vereine mit den katholischen Orden ist oft beobachtet und umständlich geleugnet worden.

${ }^{200}$ ) Vgl. außer Uhlhorn III 347 f. -364 bes. Wernle, J. H. Wichern, 1908. W. faßt den Inhalt von Wicherns im Auftrag des Zentralausschusses für innere Mission 1849 verfaßter Denkschrift dahin zusammen: > Auf dem staatlichen Gebiet soll die innere Mission den Revolutionsgeist bekämpfen and sich der Gefangenen 
Stöcker führte nur zur Forderung einer größeren Selbständigkeit und Herrschaft der Kirche, damit zu einer Nachahmung der modernen katholischen Sozialreform und mußte im übrigen sich betreffs des allgemeinen Sozialideals an konservative und mittelständische Prinzipien in echt lutherischem Sinne anschließen; es wurde durch die Ablehnung von Seite der Konservativen schließlich auf sehr enge Gruppen eingeengt ${ }^{291}$ ). So ist es bis zum

und entlassenen Străflinge annehmen. Auf kirchlichem Gebiet ist ihre Hauptaufgabe, daß jedem einmal getauften Christen reichliche Gelegenheit gegeben wird, das lautere Wort Gottes zu hören, also Bibelgesellschaften, Bibelstunden, Mission usw. Auf allgemein sittlichem Gebiet soll sie der Prostitution, der Entartung der Leselust und der Trunksucht energisch entgegentreten, endlich auf sozialem Gebiet in jeder Weise zur Erhaltung und Rettung der Familie alles aufbieten, sich der Armen- und Krankenflege annehmen, den komm unistischen Organisationen der Arbeiter christliche gegenüberstellen, spez. für die besonders gefährdeten Handwerksgesellen und Lehrburschen, auch es mit innerer Kolonisation versuchen S. 38. Ueber die Gründe des Scheiterns richtig : >Die Rettungsmittel gehen fast alle von einem starken Unverständnis der wahren intellektuellen, politischen und sozialen Nöte der Neuzeit aus; sie nehmen das alte Autoritätschristentum und die alte mit dem Schein göttlicherAutoritat bekleidete politische und soziale Ordnung als schlechthin gegeben und selbstverständlich hin ... Sie vermögen vor allem der modernen Emanzipationsbewegung kein großes, positives Ziel gegenüberzustellen, in dem das tiefere Sehnen der neueren Zeit sich selbst zu finden vermöchte S. 39. Ueberdies geht aber auch das kirchliche Luthertum gar nicht auf diese ihm schon revolutionär dünkenden Vorschläge ein. Es ist die Tragik von Wicherns Leben, daß seine ganze Begeisterung und Liebeskraft sich an dieser festen lutherischen Tradition gebrochen haben. Neben der lutherischen Kirchlichkeit war das größte Hindernis . . die politische Reaktion und gerade dadurch, daß sie die innere Mission begünstigtec. S. 48. Wichern hat sich dieser politischen Ausschlachtung vergebens zu erwehren versucht S. 49.

201) Vgl. Göhre, Evangelisch-soziale Bewegung 1896. Hier ist besonders interessant der Nachweis, wie in Rud. Todt und seinem Zentralverein das Luthertum, von der Ërkenntnis der neuen Lage völlig überwältigt, ganz irre an sich selber wird, der neuen Zeit eine prinzipiell neue Sozialtheorie gegenüberstellen zu müssen glaubt und diese vom Sozialismus und der Bergpredigt sich diktieren läßt. Doch behielt auch Todts Staatssozialismus stark patriarchalische und konservative Züge. Stöckers Arbeit hat diese letztere Doppeltendenz noch stärker herausgearbeitet und schließlich die sozialreformerischen Tendenzen den mittelständisch-patriarchalisch-hochkirchlichen geopfert; Göhre 107. In dieser Richtung bewegt sich Stöckers Erbin die -Kirchlich-Soziale Konferenz weiter. Das gleiche Doppelgesicht tragen die evangelischen Arbeitervereine, Göhre S. 116 und 125. Die Ursache davon sind aber 
heutigen Tage über die erneuerte Karität hinaus zu keiner Sozialgestaltung von seiten der lutherischen Kirche gekommen. Die meisten wiederholen die alte Lehre von der Innerlichkeit der Kirche und der dem Staat $2 \mathrm{u}$ befehlenden Aeußerlichkeit aller Rechts- und Wohlfahrtsfrágen ${ }^{202}$ ); andere, wie die Christlich-Sozialen Naumannscher Art, verlassen überhaupt die Grundsätze des Luthertums und sehen sich genötigt, auf die allgemeinen politischen, wirtschaftlichen und sozialen Grundlagen der heutigen Gesellschaft zurückzugehen ${ }^{299}$ ); wieder andere, wie die Männer des nicht bloß politische Machtverhältnisse, sondern auch die nachwirkende Macht der alten Tradition lutherischer Ethik.

202) So z. B. der frühere hannöversche Kirchenleiter Uhlhorn, Kath. und Prot. Er will in Berufung auf die Tradition des Luthertums und in scharfem Gegensatz gegen die Stöckerschen Veränderungen des lutherischen Geistes die Kirche lediglich mit der Predigt des Wortes beschäftigt wissen und bezeichnet als soziale Leistungen der Kirche: 1. die Wiederbetonung der Ehre der Arbeit, wo die moderne Fabrikarbeit ebenso wie in der alten Kirche die Sklaverei christlich geadelt werden könne; 2. die Predigt eines den unendlichen Wert jeder Christenseele würdigenden Patriarchalismus an die Herren; 3. Sonntagsheiligung, Kirchenbauten, neue Pfarrstellen; 4. Schaffung kleinerer und lebendigerer Gemeinden; 5. Verkirchlichung der wild wuchernden, pietistisch und katholisch gefärbten Karität zu einer Aufgabe der Gemeindearmenpflege. Im übrigen soll aber die Kirche Gottes Wort lediglich auf den Leuchter stellen, sodaß s christliche` Staatsmänner, Juristen, Nationalökonomen, Parlamentarier, Fabrikanten, Bankiers und Arbeiter dann frei nach ihrer sachkundigen Einsicht die Sozialreform bewirken können. Der Kirche ist derartiges nicht befohlen: sIhr ist nur befohlen, was die inneren Güter, Gerechtigkeit, Friede und heiligen Geist angeht, und diese Güter sind zu gewinnen, wie auch immer die ăußere Lage der Menschen ist S. 44. Dabei ist dann vorausgesetzt, daß jene christlichen Staatsmänner etc. auch eine dem christlichen Ideal des Luthertums entsprechende Sozialgestaltung finden werden und daß die von ihnen gefundene keinerlei auflösende oder verändernde Rückwirkung auf das lutherische Dogma und seine Ethik haben könne I - Weniger unbesorgt in dieser Hinsicht ist Nathusius, Die Mitarbeit der Kirche an der Lösung der sozialen Frage ${ }^{3}$, 1904; er verlangt daher eine hochkirchliche Steigerung der Selbständigkeit und Macht der Kirche und gibt den schristlichens Staatsmännern usw. einige Winke, auf welche Voraussetzungen șie ihr Denken und Handeln zu begründen haben.

203) Vgl. Wenck, Gesch. d. Nationalsozialen 1905. Naumann vollzog den Weg von der Karität zur christlichen Sozialreform und von dieser zur allgemein politisch und wirtschaftlich begründeten Sozialgestaltung, die von religiösen Ideen aus nicht direkt bewirkt werden kann, und gab damit das religiöse Element seiner beschränkteren Sphäre wieder zurück. Damit kommt er wieder zur Tradition des Luthertums, aber mit der wichtigen Veränderung, daß er eine der ethischen Grundidee des Luthertums stark widersprechende allgemeine Sozialgestaltung fordert, von der aus dann 
evangelisch-sozialen Kongresses debattieren in der Erkenntnis der gründlich veränderten Lage von verschiedenen Standpunkten aus über die Möglichkeit neuer Wege ${ }^{294}$ ). Da, wo das alte Luthertum noch wirklich eine Macht ist, bei den Konservativen, besteht alle Sozialreform in der Brechung des rationalistisch-individualistischen Wesens der modernen Gesellschaft und in der Wiederbelebung einer ständisch gebundenen, aristokratisch gegliederten Gesellschaft, d. h. im Kampf gegen die liberale Weltanschauung und gegen die liberalen Schöpfungen auf dem politischen, wirtschaftlichen und sozialen Gebiete, woneben dann an Armen und Kranken die sinnere Mission. das Werk der Karität verrichten kann, jedoch vor jeder Erschütterung des Auturitätsgedankens sich hüten muß ${ }^{295}$ ). In diesen

auch naturgemäß eine kritische und auflösende Rückwirkung auf das lutherische Dogma und seine Ethik ausgehen mußte, wie seine s Briefe über Religion, bezeugen. Im übrigen betont er nun wieder zunehrnend die indirekte Bedeutung des religiösen Elementes für Freiheit und Wert der Persönlichkeit gegenüber dem zu erwartenden Druck eines bureaukratisierten Kapitalismus.

204) Vgl. die Protokolle des Ev.-soz. Kongresses seit 1890, bes. den Vortrag von P. Drews auf dem letzten Kongresse 1909; im übrigen Göhre 135-162. Der Kongreß ist mit dem Ausscheiden Stöckers und mit dem Abrücken von den Konservativen immer mehr zu einer Aufrollung aller theoretisch und praktisch bedeutsamen Grundfragen der Ethik des Luthertums geworden, was sich auch darin kundgibt, da13 seine Leitung in die Hand des Führers der fortschrittlichen protestantischen Thicolouie, Adolf Harnacks, übergegangen ist. Die aus den Protokollen zu verfglyende Gedankenentwickelung des freien, allmählich der Ethik mehr als der Jogmatik zugewandten l'rotestantismus ist überaus lehrreich und anziehend. Nur handelt es sich hier erst um die ersten Anfänge einer Neustellung der Probleme, hinter der die wissenschaftliche Ethik des modernen Protestantismus sehr zögernd einhergcht und die mit ihrem Ernst nur sehr kleine Kreise wirklich bewegt. Allein wo hat man heute überhaupt eine wirklich tiefgreifende Sozialethik ?

295) Vgl. hierzu Elisabeth $\checkmark$. Richthofen, Ueber die historischen Wandlungen in der Stellung der autoritären Parteien zur Arbeiterschutzgesetzgebung und die Motive dieser Wandlungen, Heidelberger Diss. I90I; hier S. 72: Der Gegensatz zwischen Industrie und Landwirtschaft, der zuerst (d. h. bei den Anhängern der christlich-sozialen Partei) zu einer Begünstigung des Arbeiterstandes gegenüber seinen skapitalistischen Ausbeutern zu führen schien, lut schließlich unter der Wirkung der ,Leutenot geradezu eine Abneigung gegen .V: 1 nahmen zur Verbesserung der Lage der Industriearbeiter gezeitigt ... Die Konservativen haben in der Sozialpolitik auf jegliche Initiative verzichtet und sich auf den Standpumlit einer rein agrarischen Interessenvertretung zurückgezogen. Traditionclle Anschautugen und gesellschaftliche Beziehungen verbanden sie mit denjenigen Industrellen. die 
Grenzen hat die innere Mission dann allerdings sehr großartiges geleistet, doch überwiegt in ihr das Propaganda- und Bekehrungsinteresse entschieden über das christlich-soziale ${ }^{2950}$ ).

Damit ist das Bild des Luthertums vollendet. Es läßt sich nun auch die Schlußfrage beantworten, wi e weit diese Soziallehren das Spiegelbild gegebener politischer und s.ozialer $Z$ ustände sind. Man wird dies für das eigentliche ihnen vorschwebende Ideal rundweg verneinen müssen. Die Soziallehren des Luthertums sind, wie die ganze lutherische Religiosität, ein echter Schößling der ganzen, Welt, Recht, Besitz, Macht und Gewalt ablehnenden oder indifferenten christlichen Liebesreligion und Liebesmoral, des Monotheismus, der die religiösen Lebenszwecke der gottgeeinigten Persönlichkeit für die einzigen wahren und bleibenden Lebenswerte erklärt und daraus die Liebesverbindung der Menschen in gemeinsamer Betätigung dieser Werte ableitet. Der Protestantismus hat allerdings noch weit mehr als der Katholizismus das innerweltliche Leben rezipiert und ist insoferne ähnlich wie dieser bestimmt durch die allgemeine soziale Entwickelung, die eine solche Berücksichtigung gebieterisch erzwang und noch in einer Verfassung sich befand, bei der sie ohne besondere Schwierigkeiten möglich war. Allein er hat dabei sorgfältig die Doppelseitigkeit des christlichen Ideals auseinandergehalten, die durch diese Konzeption entsteht und bei ihm gegenüber dem

eine patriarchalisch-herrschaftliche Arbeitsverfassung soweit wie irgend möglich aufrecht erhalten wollen, eine solche allein entspricht dem von ihnen vertretenen gutoritären Prinzip.« Vgl. auch Stillich, das Kapitel >Die Gesellschaftsauffassung der Konservativen «. Immerhin steckt dahinter eine Würdigung der ethischen Prinzipien des Gehorsams und der Autorität auf Grund des prinzipiellen Satzes von der wesenhaften Ungleichheit der Menschen, die nicht bloß durch Klasseninteressen diktiert ist, sondern die mit allen christlichen und lutherischen Fundamentalsätzen zusammenhängt; s. die Stellen bei Stillich S. 164-167. Es ist hier überall die Eigentümlichkeit des lutherischen Naturrechts, an der Natur die Ungleichheiten und die einer idealen Ordnung entgegenstehenden Hemmuingen $z u$ betonen, daraus ethische Werte des Gehorsams und der Fürsorge abzuleiten, statt sie direkt und reformierend durch ethischen Idealismus überwinden und aufheben zu wollen, sicher eine ernste ethische Frage, an deren Würdigung man sich nicht durch klassenkämpferische Ausnützungen des Prinzips verhindern lassen darf. Das Gleichheitsproblem bildet in der Tat einen der dunkelsten und schwierigsten Punkte in den modernen Soziallehren liberaler und sozialistischer Art.

295a) Vgl. Schäfer, Leitfaden der inneren Mission ${ }^{3}$ I893 und Uhlhorn, Liebestätigkeit. 
Katholizismus sowohl verinnerlicht als verschärft worden ist. Indem er entgegen der Zeitstimmung gerade die korporativ-ständischen, antikapitalistisch-agrarischen und mittelständischen Lebensformen samt einem auf Autorität und Pietät begründeten Patriarchalismus als die richtige Vermittelung beider Seiten festhielt, zog er seine Folgerungen aus dem ethisch-religiösen Ideal, nicht aus den herrschenden Zuständen. Ueberlegt man Luthers ideale Entwürfe und seine bitteren Klagen über die Unchristlichkeit auch der neuen evangelischen Welt, so hat man sehr viel mehr den Eindruck einer christlichen Utopie als den einer Rechtfertigung und Verklärung gegebener Zustände, und nicht ohne Grund hat einer der feinsten und originellsten Köpfe des Luthertums, J. V. Andreä, dessen Sozialideal in Nachahmung des Thomas Morus und Campanella in einer Utopie, genannt Christianopolis, beschrieben ${ }^{296}$ ). Wo die Soziallehren des Luthertums lediglich als religiöse Bestätigung der gegebenen Verhältnisse behandelt werden, wie dies bei der Orthodoxie oft der Fall ist, da ist es eine Abstumpfung und Verflachung des lutherischen Gedankens, gegen welchen der Grundtrieb der eigentlich lutherischen Ethik in den Mystikern und Spiritualisten, in den ethischen Reformatoren und schließlich in den Pietisten lebhaft reagiert; dabei verlor freilich diese Opposition ihrerseits dann oft die Orientierung an den echten lutherischen Grundgedanken und geriet in das andere asketische Extrem. Das gleiche gilt von den in modernen Darlegungen beliebten Verherrlichungen von Luthers Berufslehre, in der man eine religiöse Weihe und Anerkennung der modernen Kultur zu sehen pflegt. Das ist nur dann keine Gedankenlosigkeit, wenn man die moderne Kultur wesentlich als antikatholische Freiheit von Hierarchie und Mönchtum und im übrigen als konservativ-mittelständische Fesselung oder Milderung der modernen Lebensbewegung ansieht ${ }^{297}$ ).

290) Vgl. Joh. Val. Andreae, Reipublicae Christianopolitanae descriptio, Straßburg 16ı. Der Geist des Ganzen ist entschieden lutherisch. Der Kommunismus bei sorgfaltig aufrechterhaitener Privatwirtschaft und die aristokratische Verfassung sind aus den humanistischen Utopien übernommen, aber mit den Prinzipien des Luthertums ausgeglichen; vgl. dazu E. Ehrhardt, Un roman social protestant au 17 ème siècle, Paris, Fischbacher 1908.

207) Eine solche Verherrlichung der protestantischen Berufsidee in den einflußreichen Werken von A. Ritschl, Gesch. d. Pietismus, und Uhlhorn, Gesch. d. christlichen Liebestätigkeit, und Ders., Psot. und Kath. Hier erscheinen die kritischen, das Luthertum zum Weltgegensatz zurückrufenden Stimmen des 16. und 17. Jahrhunderto als katholisch-asketische und - was bei beiden identisch ist - als sek- 
Die religiös-ethischen Ideen des Luthertums sind keine Vergöttlichung und Verfestigung bestimmter Klassen- und Machtinteressen durch eine ihnen substruierte Weltanschauung. Vielleicht aber könnte das gelten von dem eigentümlichen irrationalistischen Naturrecht, mit dem das Luthertum die gegebenen Machtverhältnisse anerkannte und als von Gott mit der Sünde und Ungleichheit zusammen geordnete unabänderliche Lebensbedingungen konstruierte, in welche der innerlich dadurch ungebundene Geist äußerlich sich arbeitend und duldend ergibt. Aber auch hier liegen die Gründe, wenigstens im Ursprung und bei Luther selbst, nicht in irgend einem Klasseninteresse, sondern in der autoritativkonservativen Beanlagung Luthers selbst und in seiner eigentümlich scharfsichtigen Auffassung des Wesens der Gewalt und der Macht, sowie der wesenhaften Ungleichheit als der alle menschlichen Sozialbildungen bestiramenden Grundelemente. Er führt darin nur die patriarchalische Seite des scholastischen Naturrechts ${ }^{298}$ ) unter Abstoßung der individualistisch-rationalistischen Elemente fort. Er hat sie um dessenwillen aber auch als direkt unchristlich und aus der Sünde entspringend bezeichnet und sie nur unter dem Eindruck ihrer Unabänderlichkeit und Unentbehrlichkeit als göttliche Stiftung innerhalb der sündigen Vernunft anerkannt. Mit seiner eigentlich christlichen Idee hat er dieses Naturrecht nur durch die Stimmung der Demut, des Gottver-

\footnotetext{
tenhafte Rückfälle, die dann im Pietismus vollendet worden seien. Das ist aber eine Verkennung der dualistischen Elemente in Luthers eigenster Lehre. - Daß beide die Kulturdurchdringung wesentlich in konservativ-antimodernem Sinne denken, zeigt Uhlhorn, Prot. und Kath., wo er die Arbeiterfrage zu behandeln rät, wie Paulus das Sklavereiproblem S. 46, und Ritschl, der in seiner Göttinger Jubiläumsrede (Drei akademische Reden 1887) Liberalismus, Sozialdemokratie und katholische Gesellschaftslehre auf die gemeinsame Wurzel des individualistischen Rationalismus zurückführte, während er für das Luthertum eine historistiscla-antirationalistische Begründung der Gesellschaft auf Macht und Gewalt reklamierte etwa im Simue Heinrich von Treitschkes und die Ausfüllung der so geschaffenen Lebensverhïltnisse mit Gottvertrauen und Berufstreue für die anti-mittelalterliche moderne Kultur erklärtc; das führt dann zur Einsicht in die skonservative Aufgabe des geschichtlich verstandenen Staates « S. 6r. Aehnlich ist es gemeint, wenn bei Loofs, L.s Stellung, Luther als Ueberwinder des Mittelalters und Begründer der mokknen Welt erschcint; die smoderne Welt \& von Loofs ist etwa preußischfreikonservativ oder rechts-nationalliberal.
}

2ע8) Vgl. oben S. 297-300. 
trauens, der Leidensbereitschaft und der Strafwürdigkeit des erbsündigen Menschen verbunden. Wenn dann später dieses Naturrecht einfach zur Rechtfertigung des Gegebenen benutzt wurde und wenn die heutigen Haupterben lutherischen Geistes, die Konservativen, dieses Naturrecht zu einem mit Darwins, Selektionslehre und Nietzsches Herrenmoral sich berührenden aristokratischen Naturalismus ausgebaut haben, so sind das freilich Anwendungen des Gedankens im politischen und sozialen Machtinteresse, bei denen ihr Gegensatz gegen die eigentlich christlichen Ideen und ihr Klassenzusammenhang flagrant sind. Immerhin kommt auch hier dieser Gegensatz den meisten nicht zum Bewußtsein, indem sie die Unchristlichkeit jener Prinzipien mit der durch die Sünde geschaffenen Lage begründen und sie daher nicht bloß trotz ihrer Unchristlichkeit festhalten, sondern als gottgewollte Folgen der Ungleichheit und Repressionsmittel gegen das individualistisch-atomistische Böse gebrauchen zu müssen überzeugt sind ${ }^{299}$ ). Ueberdies liegen in dieser Theorie unzweifelhaft richtige Betrachtungen der Natur des Menschen und enthält sie nicht minder unbestreitbare ethische Werte in dem Gehorsams- und Autoritätsgedanken wie in dem Patriarchalismus selbst ${ }^{298}$ ). Die letzte Ursache ist also auch hier die alte ideologische Grundlage, die erst heute den Interessen so kenntlich dienstbar gemacht und mit ihnen nun freilich zu rẹcht unreinen Mischungen verbunden wird.

Schwieriger zu beantworten ist die umgekehrte Frage nach dem EinfluB, den seinerseits das Luthertum auf die Sozialgeschichte gehabthat. Hier ist von vorneherein zu unterscheiden zwischen den Wirkungen seines verinnerlichten Individualismus, der sich in der geistigen und ethischen

200) Vgl. die zahlreichen Belege aus der modernen konservativen Literatur bei Stillich S. 30-50.

999a) Für diese Sonderart des lutherischen Naturrechtes gegenüber dem katholischen (und calvinistischen) hat Ritschls Jubiltumsrede ein richtiges Gefühl. Richtig wird auch dort die katholische, liberale, sozialistische (und calvinistische) Idee mit dem griechischen Rationalismus in Verbindung gebracht, wenn auch sonst die Vorstellungen von der Geschichte der christlichen Soziallehren sehr unklare sind. 2u bemerken ist aber, daß schon die griechische Spekulation jenen Unterschied rorgebildet hatte und neben dem rationalistisch-individualistischen das antirationalistisch-positivistische Naturrecht lehrte, vgl. Hirzel, Nopos ärpaços Abhh. d. Suchs. Ak. 1900; auch Kürst, Entstehung der Vertragstheorie, Z. f. wiss. Politik 1909, S. 524-528. 
Entwickelung der deutschen Kultur bis auf Kant und Goethe unzweifelhaft kundgibt, und der sich vor allem in der Auffassung und Gestaltung der Familie auch organisatorisch niedergeschlagen hat, und zwischen den Wirkungen auf dem Gebiet der politischen, wirtschaftlichen und sozialen Institutionen ${ }^{300}$ ). Hier kommen wesentlich die letzteren in Betracht.

200) Ueber die allgemeinen Kulturwirkungen s. Arnold Berger, Die Kulturaufgaben der Reformation, und desselben Luther. Ueber die Doppelrichtung der Wirkung s. die Aeußerung des gut protestantischen Historikers $H$. Baumgarten in seiner berühmten Selbstkritik des Liberalismus (Preuß. Jahrbb. 1866): -Die ganz auf den inneren Menschen gerichtete Art Luthers gab dieser Einseitigkeit unseres Wesens auf Jahrhunderte die unbedingte Herrschaft ... Auch unsere lutherischen Fürsten hatten eine Politik und zwar eine ganz neue bis dahin nie gesehene Politik... die Politik der moralischen Bedenken, der hausväterlichen Gewissenhaftigkeit, der Tlichtigkeit im Kleinen und der Ohnmacht im Großen, des emsigen Fleißes im engeren Kreise und der bornierten Trägheit, wo Großes auf dem Spiele stand. Diese Politik hat das solide Bürgertum unserer Städte, das behäbige Gedeihen unserer Dörfer, die Blïte unserer Schulen und Universitäten, den gewissenhäften Fleiß unserer Amtsstuben, den Ernst unserer Wissenschaft, die Reinheit unseres Familienlebens begründet und gefördert, sie hat geschaffen oder doch ausgebildet Alles, worauf wir stolz sein können, was unser häusliches; privates, ökonomisches, Glück ausmacht. Sie hat aber auch geschaffen jene erbärmliche.Kleinstaaterei, welche nur Raum gewährt für den Familienvater, aber den Mann, den Bürger tötet, jenes armselige Philistertum, das die Kraft unseres Volkes in Banden schlägt jene traurige Gewöhnung unseres Geistes, in den kühnsten Phantasien den Himmel zu stürmen und vor den kleinsten Hindernissen der Erde die Arme mutlos sinken zu lassen. Sie hat dem Staat das männerbildende Mark ausgesogen und ihn sozusagen in einen Kleinkindergarten verwandelt, der uns vor allen Fährlichkeiten, aber auch aller Größe der bösen Welt bewahrt hat S. 456. Mit diesem Uebermaß lutherischer Innerlichkeit bringt Baumgarten dann auch die Staatslosigkeit und den Kosmopolitismus unserer klassischen Literatur und Philosophie in Verbindung. Und in der Tat hängt das mit der einen, der spezifisch christlichen, Seite Luthers zusammen. Die Sache hat aber doch auch ihre andere Seite. Auch der von Baumgarten in seiner realistischen Größe bewunderte und dem entgegengesetzte Bismarck berief sich auf das Luthertum. Das ist dann aber allerdings nicht das eigentlich Christliche in Luther, sondern sein irrationalistisches Naturrecht der Macht und Gewalt, das in den ersten beiden Jahrhunderten freilich nur der Legitimierung der Gewalt diente, aber bei der Emporraffung Preußens gegen den Liberalismus und die Revolution von Stahl hervorgeholt und glänzend entwickelt wurde; es dient seitdem in seiner Verbindung mit dem christlichen Gedanken der Sünde und der Ungleichheit (auf nichtreligiösem Gebiet) einer höchst realistischen Machtund Gewaltpolitik, die dem Christen als amtlichem Glied der durch die Sünde be- 
Man wird hier folgendes sagen können. An sich ist die spätmittelalterliche Tendenz der Entwickelung des Staates und die allgemeine soziale Schichtung durch es niçht verändert worden. Hier hat nur der Wegfall des Priesterstandes und seine Ersetzung durch den evangelischen Pfarrstand sowie die Beseitigung der kirchlichen Oberleitung und die an deren Stelle tretende rein staatliche Leitung das Bild verändert; auch die Säkularisationen und die Beseitigung des Mönchtums sind tief einschneidende Aenderungen, aber keine Eröffnungen neuer sozialer Entwickelungen. Einen weiteren Eingriff in die soziale Schichtung bedeutet das Aufkommen einer lateinisch-humanistischen Bildungsschicht, die durch den lehrhaften Charakter der neuen Religion und ihre enge Verbindung mit dem Schulwesen begünstigt ist; doch ist dies mehr eine Wirkung des mit der Reform verbundenen Humanismus als des religiösen Geistes selbst ${ }^{301}$ ).

Mehr aus dem Zentrum gehen die politischen Wirkungen hervor. Nicht als ob das Luthertum eine neue Staatsidee entfaltet oder gar einen neuen Staat geschaffen hätte ; aber es stellte dem in der Entwickelung begriffenen zentralisierten Territorialstaat in seiner Beseitigung jeder kirchlichen Selbständigkeit, in seiner Vergöttlichung der Obrigkeit und in seiner loyalen Leidsamkeit die allergünstigsten Bedingungen. Es hat dem territorialen Absolutismus den Weg geebnet; den feudalen Gutsherrschaften die Entwickelung des Rittergutes mit seinen Privilegien und seiner zunehmenden neuen Hörigkeit erleichtert ${ }^{302}$ ), die patriarchalische Bevormundung und die

dingten Ordnungen die Entfaltung aller Konsequenzen des naturalistischen Machtgedankens verstattet. So hat namentlich $H$. v. Treitschke das Luthertum dargestellt. Dabei ist dann ăhnlich wie bei Bismarck und anderen modernen Konservativen freilich der Machtgedanke oft Selbstzweck geworden, die Verpflichtung der staatlichen Macht, für die Christlichkeit der Gesellschaft zu sorgen in den Hintergrund gestellt und die Zusammenwirkung der realistischen Machtpolitik mit dem religiösen Lebensziel mehr ganz im allgemeinen der Vorsehung überlassen worden, die nun einmal die Menschen so eingerichtet hat; vgl. Lenz, Bismarcks Religion. Die deutsche Sozialgesetzgebung ist daher auch nicht mehr der Ausfluß einer prinzipiell christlichen Auffassung vom Staate, sondern eine gelegentliche Benützung christlicher Ideen für an sich politische $Z$ wecke, wo einmal das an sich Getrennte glitcklicherweise zusammenstimmt.

s01) Vgl. Wittich, Deutsche und französische Kultur im Elsaß 1900, eine weit uber ihr engeres Thema hinausreichende Arbeit.

109) Hieruber s. die eingehenden Nachweise bei Drews, Der Einfluß der gesellschaftlichen Zustunde. Durch die Forderung kirchlicher Sonderbedienung des Adels 
ständisch-korporative Gesinnung befördert. Nach außen freilich hat es durch denselben Geist die Aktionsfähigkeit der Territorien gehemmt und den Stillstand in der Ausbreitung, schließlich die fürchterlichen Niederlagen herbeigeführt. Mit dem eigentlich modernen Staate hat es nur durch Vermittelung des Absolutismus zu tun, der, einmal in den Sattel gehoben, schließlich stark genug war, sich seine eigenen modernen Wege zu bahnen und dabei die naturrechtliche Friedens-, Schutz- und Strafgewalt, sowie die christliche Liebespflicht der Obrigkeit weit hinter sich gelassen hat.

Nicht minder indirekt sind die Wirkungen auf dem wirtschaftlichen Gebiet. Hier ist sein cigentlichster Sinn der Traditionalismus und die agrarisch-mittelständische Produktion, die durch korporative Gebundenheit die Konkurrenz ausschließt, die Einfachheit der Bedürfnisse mit der Einfachheit des Verhältnisses von Produktion und Konsumtion möglichst verbindet. Indem es gleichzeitig den Bettel beseitigte, die Massen zur Arbcit nötigte, mit seinem Individualismus die Einzelnen doch auch nach der nicht-religiösen Seite anregte und mit seiner - zunäichst freilich nur den Mittelstand erfassenden - Schulbildung eine gewisse Beweglichkeit des Geistes schuf, hat es trotzdem auch ciner lebhafteren Entfaltung des wirtschaftlichen Lebens gedient. Die Hauptsache aber hat auch hier die Verselbständigungr der ()brigkeit getan, die, mit der Wohlfahrtspflege betraut und zur herrschenden Macht emporgehoben, die westlichen Produktionsmethoden einführte und dabei höchstens von einer günstigeren Disposition der lutherischen Bevölkerungen für die Arbeit profitierte. Im übrigen haben nicht umsonst merkantilistische Herrscher überall reformierte oder pietistische Emigranten eingeführt, wo sie Manufaktur und Handel heben wollten. Die moderne Wirtschaft - auch in dem bescheidenen Umfang, den sie in Jeutschland bis zum 19. Jahrhundert hatte - ist das Werk des Staates und keine Folge des Luthertums ${ }^{303}$ ). Dieses hat nur geringere Hemmnisse entgegengesetzt als der Katholizismus.

\footnotetext{
wurde geradezu auch die kirchliche Sitte zersetzt unter ohnmächtigem Widerspruch der Kirche.

$\left.{ }^{303}\right)$ Hierüber Haendtke, Deutsche Kultur im Zeitalter des 30j. Krieges S. 70: -Zweifelsohne war damals Deutschland in dieser (wirtschaftlichen) Hinsicht noch stark in mittelalterliche Anschauungen verstrickt; denn in welchem anderen Lande wäre es damals (1684-85) möglich gewesen, daß z. B. die so wichtige Bandmühle
} 
In Bezug auf die sozialen Grundempfindungen und die prinzipielle Auffassung der Gesellschaft schließlich ist das Luthertum immerdar ein Prinzip des Patriarchalismus und des Konservatismus gewesen, teils weil die religiöse Grundstimmung des Gottvertrauens und des Mißtrauens gegen menschliches Machen und Treiben, die Sündenempfindung des Leidens und Duldens gegebener Verhältnisse schon an sich zu konservativer Gesinnung geneigt machen, teils weil die Grundlagen der älteren Sozialverfassung mit ihrer ständischen Gliederung und ihrer grösseren Einfachheit des Verhältnisses zu den Gottesgaben der Natur von ihm als Voraussetzung seiner ethischen Ideale festgehalten werden. So ist es geneigt, das Gegebene demütig zu dulden, auch wenn es schlecht ist, und das Gegebene zu verherrlichen, wenn es mit jenen älteren Idealen übereinstimmt. Wenn heute im allgemeinen die protestantischen Iänder die führenden sind, so ist nicht zu vergessen, daß gerade im konfessionellen Zeitalter die Mütterländer der modernen Zivilisation Italien, Frankreich, auch Spanien, katholisch sind, und daß deren Erschöpfung keineswegs nur auf Rechnung ihres Katholizismus kommt, daß also umgekehrt auch dic protestantischen Länder und insbesondere die lutherischen ihre heutige Stellung jedenfalls nicht in erster Linie ihren religiösen Grundlagen verdanken können, so wichtig diese im einzelnen auch sind ${ }^{304}$ ).

Die Leidsamkeit des Luthertums bringt es mit sich, daß es der jeweils herrschenden Macht anheimfällt. Luther antwortete verboten wurde, wie es zu Nürnberg auf Bitten der Posamentierer geschah, oder daß (I666) zu Frankfurt a. M. die Erlaubnis verweigert wurde, einen Webstuhl aufzustellen, wie er 1665 auf der Messe zu Frankfurt zu sehen gewesen war ... Auch war es wohl sonst unerhürt, daß aus der Maschinenfrage ein premier confesseur et prédicateur de L'Electeur de Saxe fit une affaire de conscience.e Daneben halte man den vielzitierten Satz Uhlhorns, die Maschine habe etwas Protestantisches an sich 1 - Laveleye, Prot. u. Kath. u. deren Beziehungen zur Freiheit und Wohlfahrt der Völker, deutsch 1875, handelt zwar vom Protestantismus im allgemeinen, bezieht sich aber in Wahrheit immer nur auf den Calvinismus. Für das Luthertum stimmt unter den von ihm angeführten Gründen nur die gesteigerte Intellektualität der Lehr- und Buchreligion. Auf diesem Gebiet bedarf es noch sehr der genaueren Untersuchungen.

804) Vgl. zum Ganzen Troeltsch, Die Bedeutung des Protestantismus für die Entstehung der modernen Welt 1906 (s. auch Hist. Zeitschrift 1905). Die Ablösung der allgemeinen Kultur von den spezifisch lutherischen Voraussetzungen bei Beibehallung ihrer Formeln zeigt Haendtke. 
auf die Frage, ob diese Gesinnung den Christen nicht zur Beute jedes Schurken und Gewaltmenschen machen müsse, lediglich, daß es Aufgabe der Obrigkeit sei, dies zu verhindern, und daß man im Falle ihres Versagens allerdings leiden müsse. So hat das Luthertum den Einfluß der herrschenden Mächte überall erlitten. Die Weichheit seiner ganz innerlichen Spiritualität schmiegte sich den jeweils herrschenden Gewalțen an. Das heißt aber, daß es nach deren Verschiedenheit auch seinerseits sich sehr verschieden gestaltete. Von einer prinzipiell monarchischen oder absolutistischen Tendenz ist bei ihm nicht die Rede ${ }^{305}$ ). Das ist erst die Erfindung der modernen Konservativen. Nur weil in Mittelund Norddeutschland der Absolutismus und das Rittergut aufstand, hat es dort den loyalen Charakter entwickelt, der das - Ostelbiertum « charakterisiert. In den Reichsstädten hat es aristokratisch-republikanische Herrschaft vergöttlicht. In Württemberg, wo es keinen entsprechenden Adel gab, hat es bei aller Hochstellung des Landesherrn bürgerlich und bäuerlich demokratische. Ideen nicht verhindert, sondern sogar mit sich verschmolzen. In dem milltärischen Nationalstaat Schweden hat es die großzügige Angriffspolitik Gustav Adolfs und in den ständischen Gegensätzen der österreichischen Lande hat es die Erhebung des lutherischen Adels zu rechtfertigen gewußt ${ }^{306}$ ), in Dänemark und Norwegen ist eine wurzelfeste bäuerliche Demokratie heute aufs engste mit strammem, allerdings pietistisch gefärbtem Luthertum verbunden, und in Amerika blüht das denkbar orthodoxeste Luthertum unter dem Schutz der Demokratié.

Das aber wird man allerdings nicht verkennen dürfen, daß es seinem ganzen Wesen nach sich am leichtesten verbindet mit politischen Verhältnissen von monarchisch-aristokratischer Art und

${ }^{805)}$ Vgl. Brandenburg S. 18. Auf die Frage, warum Gott so verschiedenartige Obrigkeiten geschaffen habe, antwortete Luther: sIst Gott schuldig, daß er solchen unnützen Mäulern Ursach und Rechenschaft gebe, warum ers so haben will?s Ein so radikales monarchisches Gottesgnadentum, wie es die von Gierke (Atthusius' S. 70 ff.) analysierte Sohrift des Schlesiers Horn, >Politicorum pars architectonica de civitate, Traj. a. Rh. 1664 lehrt, ist nicht genuin lutherisch, sondern aus dem Gegensatz gegen die reformierte Vertragslehre erwachsen und von der Gedankenwelt des fürstlichen Absolutismus erfüllt.

${ }^{306}$ ) So hat z. B. Bernhard v. Weimar seine Condottierenwesen als sfürstlichen Beruf ‘ religiös zu rechtfertigen gewußt, Händtke S. 19. Gustav Adolf war politisch ein Verehrer des ganz unlutherischen Hugo Grotius, dessen Hauptwerk er beständig bei sich führte; H. G., Recht des Krieges und Friedens, Phil. Bibl. 15, S. 8. 
Soziale und politische Bedeutung des Luthertums für die Gegenwart. 603

mit einer wirtschaftlich-sozialen Gesamtlage von agrarisch-mittelständischer Beschaffenheit. Daher hat es sich den stärksten Ausdruck geschaffen in Politik und Weltanschauung der preußischen und deutschen Konservativen, in denen es heute noch die $\mathrm{Ge}$ schicke des deutschen Volkes mitbestimmt. In der großen Angriffsstellung, welche nach der Auswirkung des I8. Jahrhunderts in der französischen Revolution die älteren Geistesmächte gegen die moderne Welt wieder einnahmen und in der sie unter Vereinigung ideologischer und praktischer politisch-sozialer Mächte siegreich gegen die neue Welt vorrückten, ist die Restauration des preußischdeutschen Luthertums eines der sozialgeschichtlich wichtigsten Ereignisse ${ }^{307}$ ). Es verband sich mit der Reaktion des monar-

307) In Bezug auf die ideen- und sozialgeschichtlichen Zusammenhänge der großen europäischen Restauration fehlt es noch an jeder in die eigentliche Tiefe eindringenden und den Gegensatz gegen die moderne Welt herausarbeitenden Darstellung. Die Kirchengeschichten insbesondere, die hier viel $2 \mathrm{u}$ sagen hätten, lassen völlig im Stich. Sie verherrlichen entweder die Wiedererstehung des neuen Glaubens, die ihnen etwas Selbstverständliches ist gegenüber der sündigen Bosheit der modernen Welt, oder sie beklagen die Zerstörung aller Reformansätze, die ihnen das Werk reaktionärer Politik und Selbstsucht ist. Tiefere Auffassung findet man in dem an sich einem anderen Thema gewidmeten glanzenden Buch von Meinecke, Weltbürgertum und Nationalstaat 1908, das neben dem meist allein gewürdigten liberalen Zweige vor allem die Linien zeichnet, sdie von Stein zu Friedrich Wilhelm IV. gehen, also den romantisch-konservativen Zweig der nationalstaatlichen Gedanken. S. 19. Hier auch das Wiederemporsteigen des irrationalistischen positivistischen Naturrechts bei Burke $126 \mathrm{ff}$, bei Adam Müller 128, bei K. L. v. Haller $212 \mathrm{f}$. und die religiöse Deutung des Naturrechts als von Gott im Entwicklungsprozeß geleiteter natürlicher Vernunft 211 , das Festhalten dieser Entwicklung bei den mit den christlich-patriarchalisch-aristokratischen Lebensformen gegebenen und moralisch zu fordernden anti-revolutionären Zuständen 217 , die Berührung mit dem darwinistischen Naturalismus ohne Irrewerden an der religiösen Deutung 212, die Zusammenfassung dieser christlich-realistischen Politik gegen die revolutionär-doktrinäre in einer christlichen Universalpolitik, einem neuen Katholizismus 221, der Uebergang dieser Ideen in die pietistischlutherischen Kreise und die Wiedererweckung der alten lutherischen Soziologie unter Kompromiß mit der modernen Nationalitätsidee und unter Zuspitzung auf den monarchistischen Legitimismus 226-232, die komplizierte Mischung dieser Gedanken 245-291, die Herausentwicklung Bismarcks aus diesen Theorien 300-315. Nur ist das alles zu sehr unter die Firma $>$ Romantike gestellt, während in Wahrheit die Romantik bloß die Zuleitung zu den alten kirchlich-soziologischen Ideen bedeutet und von da ab neben der nationalistischen und der philosophisch-weltbürgerlichen auch die christlich-kirchliche Soziologie ihre Rolle spielt und nach dem 
chischen Gedankens, des agrarischen Patriarchalismus, der militärischen Machtinstinkte, gab der Restauration den ideellen und ethischen Rückhalt, wurde darum wieder von den sozial und politisch reaktionären Mächten mit allen Gewaltmitteln gestützt, heiligte den realistischen Machtsinn und die dem preußischen Militarismus unentbehrlichen ethischen Tugenden des Gehorsams, der Pietät und des Autoritätsgefühls. So wurde Christentum und konservative Staatsgesinnung identisch, verschwisterten sich Gläubigkeit und realistischer Machtsinn, reine Lehre und Verherrlichung des Krieges und des Herrenstandpunktes. So wurden die kirchlichen Reformbestrebungen gleichzeitig mit der liberalen Ideenwelt unterdrückt, die Anhänger der modernen sozialen und geistigen Tendenzen in eine schroffe Kirchenfeindschaft hineingetrieben und dem gegenüber dann alle christlich und religiös Fühlenden für den Konservatismus in Beschlag genommen. Als wesentliches Element in den Kräften der Restauration hat es seinen wichtigen Anteil an der aus den restaurativen Kräften hervorgegangenen politisch-militärischen Entwicklung Preußen-. Deutschlands und findet es sich in schroffstem Gegensatz zu den andern Elementen, die an der Entstehung des neuen Deutschland gearbeitet haben, den demokratisch-unitarischen und modernsozialen und wirtschaftlichen Bewegungen. In dieser letzteren Hinsicht steht es - mit der verwandten und doch wieder sehr andersartigen internationalen katholischen Restaurationspolitik sich bald freundlich bald feindlich berührend - in dem Schlüsselpunkt der schwierigsten und verhängnisvollsten Lebensfragen Deutschlands und trägt das Seinige bei zu der Aufreißung der Kluft zwischen restaurativ-patriarchalischen und fortschrittlichdemokratischen Kräften, in welcher alle gemäßigten Vermittelungsversuche versinken und die mit einem christlich-sozialem Programm überbrücken zu wollen in Deutschland ein idealistischer und ehrenwerter, aber flüchtiger und rasch widerlegter Traum war.

Siege des Bismarckschen Nationalismus heute wieder in völlig unromantischer Weise und in Verbindung mit bestimmten Interessen die Lage zu beherrschen sucht. Wenn diese Romantik sich zunächst dem Katholizismus zuwandte, so geschah es übrigens deshalb, weil er zunächst allein die Autorităt und Internationalität darbot, die zur Gegenwirkung gegen die Aufklärung nötig schien, während die lutherischen Kirchen in ihrer aufgeklärten Theologie und ihrer Staatsabhängigkeit dazu zunăchst untauglich waren. Seitdem sie in dieser Hinsicht sich verselbstandigt und organisiert haben, sind sie und nicht der starke liberale Elemente einschließende Katholizismus der eigentliche Hort des Konservatismus. 
Die Traditionen und die geistige Verfassung des Luthertums boten bei den Hauptmassen der gläubigen Welt in Deutschland hierfür keinen Boden, und umgekehrt machte der in jener Konstellation erzeugte grenzenlose $\mathrm{Haß}$ aller fortschrittlich-demokratischen Elemente gegen die Kirche auch bei diesen jede Anknüpfung unmöglich. So sind die Leistungen des Luthertums für einen ethisch-sozialen Neubau der Gesellschaft naturgemäß sehr beschränkt. Sie erschöpfen sich in der Hauptsache in der Karität der inneren Mission und wirken im übrigen restaurativ, nicht neubildend. Wo die christliche Sozialethik und Sozialpolitik andere Wege geht, da ist es auch ein anderer Geist als der des echten Luthertums. Es ist in der Regel ein calvinistisch beeinflußter Geist, und damit öffnet sich der Blick auf die zweite große konfessionelle Formation des Protestantismus, den Calvinismus.

\section{Der Calvinismus.}

Das Luthertum blieb nach seinen Anfangserfolgen stehen. Sein spiritualistisches Sich-Fügen und Dulden, die Begnügung mit der Objektivität der Gnadenmittel, sein Mangel an Kraft zu kirchlicher Organisation und sein unpolitischer Sinn werden die Hauptursache davon sein. Die Ausbreitung der Kirchenreform über den Westen und von ihm aus über die neue Welt fiel dem Calvinismus $\mathrm{zu}$, der heute als die eigentliche Hauptmacht des Protestantismus betrachtet werden muß.

Der Grund für diese Ausbreitung des Calvinismus liegt zunüchst darin, daß er bei den in der großen politischen Entwickelung befindlichen westlichen Völkern Fuß faßte. Aber er liegt doch tiefer noch in dem Wesen des Calvinismus selbst, der die auch auf liesen Gebieten vorhandenen Ansätze des Luthertums und Täufertums ganz oder beinahe verdrängte. Er liegt in dem aktiven Charakter, in der kirchenbildenden Kraft, in dem internationalen Zusammenhang und bewußten Ausbreitungstrieb des Calvinismus und nicht zuletzt in seiner Fähigkeit, auf die politischen und wirtschaftlichen Entwickelungen der westlichen Völker mit seiner religiösen Idee eingehen zu können, einer Fähigkeit, welche dem Luthertum von Hause aus fehlte ${ }^{308}$ ). So sind denn

${ }^{308)} \mathrm{Daß}$ der Unterschied des Calvinismus wesentlich auf diesem Gebiet zu suchen ist, hat zum ersten Male Hundeshagen gezeigt in seinen . Beiträgen zur Kirchenverfassungsgeschichte und Kirchenpolitik 1864, wo er den Mitarbeitern im 
auch Kirchenbegriff und Soziallehren des Calvinismus von denen des Luthertums sehr erheblich verschieden. Auch hat diese Verschiedenheit im Laufe der Zeit sich immer stärker herausgebildet, sodaß der Calvinismus heute sich als die mit der modernen de-

Fach der Kirchengeschichte den Rat gibt, statt dogmatisch-spekulativer Untersuchungen des Kirchenbegriffes ihrer Forschung sdie sichtbare empirische Kirchensozietat und deren freilich noch wenig genug erforschte Existenz- und Lebensgesetzee zugrunde zu legen (S. IX), also die Forderung einer soziologischen Behandlung der Kirchengeschichte. Nicht bloß in Genf, sondern auf allen Gebieten, nach welchen er vordringt, sind es große soziale Krisen, welche der Calvinismus vorfindet und in welche er als erregendes, aber zugleich als reinigendes und ordnungsstiftendes Ferment eingreift. Das Kampfgebiet ist für. ihn nirgends ein bloß religiöses oder ein kirchliches im rein religiösen Sinn; nirgends tritt ihm der römisch-katholische Glaube lediglich als ein solcher entgegen, sondern überall in einer bestimmten Solidarität mit dynastischen Interessen und Regierungsprinzipien. So liegt es in der Natur der Umstănde, daß Calvin und seine Mitarbeiter, wie $\mathrm{Zwingli,} \mathrm{nicht} \mathrm{bloß} \mathrm{Indivi-}$ duen, sondern kleinere und größere Nationalitäten ins Auge zu fassen haben. So ist auch für Calvin das Evangelium nicht bloß eine $\mathrm{Kraft}$, selig zu machen alle Einzelnen, welche daran glauben, nicht bloß ein Trost für bekümmerte Einzelgewissen, nicht bloß die Ueberwindung seelengefährlicher Irrtümer, sondern zugleich das Heilmittel für öffentliche und allgemeine Schäden, das Element der Reinigung and Erneuerung für größere gesellschaftliche Verbände und der Grundstein, solche auf demselben aufzurichten $>S$. 294 f. Damit ist in der Tat treffend der Unterschied gegenüber dem Luthertum ausgesprochen. - Die Erkenntnis, daß in dieser Sondergestaltung zugleich erhebliche Annäherungen an die moderne Welt enthalten sind - wiederum im Gegensaitz zum Luthertum -, kntipft sich an modernere Untersuchungen an: an Gierkes s Althusius s, an die durch Jellinek, Die Erklärung der Menschenund Bürgerrechte ${ }^{2} 1904$ angeregte Kontroverse und an die Abhandlungen Max Webers ,Ueber den >Geist des Kapitalismuse und die prot. Ethik Archiv XX u. XXI. die übrigens ausdrücklich nur eine der geistig-ethischen Voraussetzungen für den bürgerlichen Kapitalismus, nicht alle und am wenigsten den Kapitalismus selbst auf den Calvinismus zurückführt. Aehnlich bewegen sich in dieser Richțung Rieker, Grundsätze ref. Kirchenverfassung, und Figgis, From Gerson to Grotius 1907, v. Schulze-Gävernitz, Britischer Imperialismus und englischer Freihandel, 1906 und meine Darstellung in Kultur der Gegenwart IV ${ }^{2}$, Protestantisches Christentum und Kirche. Doch ist auch hierin schon Hundeshagen vorausgegangen: sUeber den Einfluß des Calvinismus auf die Ideen von Staat und staatsbürgerlicher Freiheite, 1840, auch Baudrillart, Bodin et son temps, 1853. - Als erster Grund der Durchsetzung des Calvinismus in Frankreich und den Niederlarden erscheint außer der territorialen Nacbbarschaft die Ueberlegenheit des Calvinismus in der selbständigen kirchlichen Gemeindebildung und die schärfere Gegenstellung gegen den Katholizismus s. K. Müller, Preuß. Jahrb. 1903 und Rachfahl, Wilh. v. Oranien und der niederländische Aufstand I, I906 S. 415. 
mokratischen und kapitalistischen Entwickelung allein übereinstimmende und ihr allein gewachsene Gestaltung des christlichen Kirchenwesens empfindet ${ }^{309}$ ). Ohne seine Orthodoxie aufzugeben, ist er im Laufe der Zeit - trotz ursprünglich engster Berührung mit dem Luthertum - zum Gegenteil des lutherischen Konservatismus, Staatskirchentums und Anstaltswesens geworden. Die moderne kulturgeschichtliche Bedeutung des Luthertums liegt politisch und sozial in seinem Zusammengehen mit den reaktionären Parteien, religiös und wissenschaftlich in der Entfaltung einer mit frommer Mystik und Innerlichkeit verschmolzenen philosophischen Theologie, die als Ethik freilich gleichfalls den Problemen des modernen politisch-sozialen Lebens' sehr ferne steht. Der Calvinismus dagegen hat im ganzen -- in neuerer Zeit unter Einwirkung des mit seinem Wesen eng zusammenhängenden Pietismus und Methodismus - seine unphilosophische Theologie behauptet oder nach den Störungen der Aufklärung wieder gefunden, jedoch in seiner engen Verbindung mit englischen und amerikanischen Volkseigentürnlichkeiten und Institutionen politisch und sozial den modernen Lebensstil, den man als Amerikanismus bezeichnen kann, mit sich verschmolzen und teilweise aus sich erzeugt; dabei versteht sich von selbst, daß dieser heute vielfach eine von jeder religiösen Grundlage gelöste Existenz besitz $\mathrm{t}^{310}$ ). Aber auch auf den Kontinent hat er zurück gewirkt. Nicht bloß in der Kirchenverfassung und dem Kirchenbegriff, dem kirchlichen Vereinswesen, der inneren Mission, der pietistischen Heiligkeit beeinflußt er das Luthertum, sondern als eine allgemeine geistige Macht erstreckt sich der von ihm gezüchtete Typus des Menschentums über die europäische Kultur, die dabei von dem ursprünglich vorhandenen Zusammenhang dieses Typus mit der Religiosität des Calvinismus meistens nichts

${ }^{809}$ ) Vgl. A. Kuyper, Reformation wider Revolution, deutsch von Jäger, 1904, Das Buch ist nicht nur Kuypers Regierungsprogramm, sondern, aus Vorlesungen an der streng calvinistischen Princeton-University bestehend, eine Art Gesamtbekenntnis des modernen orthodoxen Calvinismus. Uebrigens ist hier der Neucalvinismus in einer geradezu unerhörten Weise in den primitiven Genfer Calvinismus hineingedeutet. Es ist das Buch eines Dogmatikers und Politikers und als solches höchst lehrreich, als historische Leistung dagegen sehr irreführend.

310) Vgl. hiezu Rauschenbusch, Christianity and the social crisis, New-York 1908. Hundeshagen erzählt von dem Erstaunen eines amerikanischen Studenten, der meinte, in Deutschland sei das Christentum eine Wissenschaft, in Amerika sei es eine Praxis. 
mehr ahnt. In dieser Entwickelung hat er mit den Sekten sich zusammengefunden, die ihrerseits wieder, wie später zu zeigen, sich ihm vermöge ihrer eigenen Bewegungsrichtung annäherten. Mit ihnen zusammen hat er unter Mitwirkung politischer und sozialer Lebensbedingungen jenen Typus hervorgebracht. I)as wird in vollem Umfang erst übersichtlich werden, wenn wir auch den Sektentypus auf protestantischem Boden kennen gelernt haben werden. Doch ist das schon jetzt hervorzuheben, damit bei dem Calvinismus auf denjenigen Punkt geachtet werden könne, wo er schon in seinen Grundideen mit dem Sektentypus sich dauernder und innerlicher berührt, als das bei Luther - und hier kommt überdies nur seine Frühzeit in Betracht - der Fall gewesen ist.

Der Calvinismus hat eine überaus weit ausgebreitete und zugleich eine beträchtlich über die Genfer Anfänge hinausstrebende Entwickelung erlebt. Für sein Verständnis ist daher vor allem der primitive Genfer Calvinismus von den späteren Entwickelungen $\mathrm{zu}$ sondern. Dabei ist dann aber doch von vornherein $\mathrm{zu}$ fragen, wie weit diese schon in jenem wurzeln, wie weit sie über ihn hinalisgehen und durch welche Gründe sie über ihn hinausgeführt wurden. Es ist in solchen großen kulturhistorischen Zusammenhängen von vornherein selbstverständlich, daß derartige Entwickelungen nicht bloß durch die logisch-dialeltische Triebkraft des religiösen Gedankens bedingt sind, sondern zugleich durch die Zufälligkeit der besonderen historischen Laģen und Verhältnisse. Andererseits aber ist der Calvinismus ein so großartig strenger Gedankenkomplex, daß doch überall nach dem inneren gedanklichen Zusammenhang, der sich durch all diese Wandelungen hindurchzieht oder in ihnen herstellt, zu suchen ist ${ }^{311}$ ).

So ist die erste Aufgabe die Analyse des religiösen Sondergehaltes des primitiven Calvinismus, aus

311) Vgl. v. Bezold, Staat und Gesellschaft des Ref.-Zeitalters, (Kultur der Gegenwart II, V, I) S. 8 I : $\gg$ In vielen Beziehungen trägt Calvins Werk einen rückschrittlichen Charakter; steht er doch namentlich im denkbar schärfsten Gegensatz zu den humanistischen, künstlerischen und naturwissenschaftlichen Tendenzen des Jahrhunderts. Wenn trotzdem der Calvinismus immer wieder hier als wesentliches Ferment für die Entstehung des modernen Europa in Anspruch genommen wird, so gilt dies überwiegend von seiner Propaganda und Entwickelung außerhalb Genfs. Wie richtig das letztere ist, wird die folgende Untersuchung zeigen, nur daß hierfür doch auch die Grundlagen schon im primitiven Calvinismus vorhanden sind. Das erstere ist übrigens nur sehr bedingt richtig, vgl. Arnold, Calvin 1909. 
dem sich seine Kirchenidee, seine Ethik, seine Sozialideale grundlegend ergeben. Erst darauf kann dann nach der $W$ e iterentwickelung des Calvinismus und den politischen, ökonomischen, sozialen und kirchenpolitischen Umwandlungen des neueren Calvinismus gefragt werden.

Der primitive Calvinismus ist eine Tochterreligion des Luthertums. Er wollte ursprünglich dogmatisch und religiös nichts anderes sein als reines, den ganzen Protestantismus vereinigendes Luthertum mit der Fähigkeit, alle einseitigen Richtungen in sich aufzusaugen. Er nahm in zweiter Linie durch Butzers Vermittelung das Wahrheitsmoment des Täufertums, die praktisch-soziale Gestaltung der Gemeinde, in sich auf und berührte sich darin zugleich mit der Schweizer Reform. Er sicherte die lutherische Sakramentslehre gegen $Z$ wingli durch gewisse Zugeständnisse an diesen und hielt doch deren ursprünglichen Sinn aufrecht. Er vollzog schließlich mit den Oberdeutschen die strenge Reinigung des Kultus von allen katholischen Zeremonien, worin er sich auch mit $Z$ wingli begegnete, aber wollte damit doch nur Luthers Grundsatz der Schriftgemäßheit folgerichtiger durchführen. In Genf selbst auf strengste Lehreinheit und Lehrzucht dringend, meinte. Calvin doch die verschiedenen Länder und Kirchen durch Verständigung über peripherische Besonderheiten in den großen Bund des Gesamtprotestantismus verfassen zu können. Erst der Widerstand des deutschen Luthertums und die Verselbständigung des Anglikanismus machten den Calvinismus zu einer protestantischen Sonderkonfession ${ }^{312}$ ).

312) Vgl. im allgemeinen Kampschulte, J. C., seine Kirche und sein Staat 1869/99 Cornelius, Historische Arbeiten I 899 ; Doumergue, J. C., unvollendet, bisher 3 Bände, bunteste antiquarische Gelehrsamkeit und Apologetik; Marcks, Coligny I I 81 )2 mit sehr feiner Charakteristik; Rieker, Grundsätze reformierter Kirchenverfassung 1899 und Sohm, Kirchenrecht I; von den Kirchengeschichten vor allem Karl Müller. Besonders wichtig sind die beiden Arbeiten von Choisy, La Theocratie à Genève o. J. und L'état chrétien à Genève aux temps de Bèze o. J.; die dogmengeschichtliche und ethische Analyse in den Meisterwerken von Schneckenburger und A. Ritschl, wozu Lobstein, Ethik Calvins, I 877 hinzukommt ; ferner Rachfall, Oranien I I 1906, I, 2 I 997 II, 1908. Die Forschungsergebnisse des Jubiläumsjahres 1909 sind verzeichnet bei W. Köhler in Th. J. B. für Ig10. Hervorzuheben sind die -Calvinreden des Siebeckschen Verlages, die Calvin-Studien der Elberfelder (jemeinde hg. von Bohatek und $>$ Calvin and the reformation \&, vier Studien von Doumergue, Lang, Bavinck und Warfield, schließlich C. F. Arnold, Calvinrede. - Die in der heutigen Forschung stark hervortretenden Beziehungen zu Butzer und Straßburg finden sich bei Lang, Der Evangelienkommentar Butzers 1900 und vor allem dazu Troelis ch, Gesammelte Schriften. I. 
So ist denn auch das Stammkapital in Calvins Theologie und Religiosität lutherischer Herkunft. Calvin hat stets den größten Wert auf Uebereinstimmung und auf persönliche Beziehungen mit Luther gelegt. $\mathrm{Er}$ sah in ihm den grundlegenden und führenden Reformator, während er gegen $Z$ wingli mehr Abneigung empfand und Zurückhaltung zeigte. Er hat seine Bekehrung wesentlich lutherischen Einflüssen verdankt und weiterhin lutherische Schriften

W. Köhler Gött. Gel. Anzeigen Ig02; Anrich, Die Straßburger Reformation, Ch. W: 1905, v. Schubert, Calvinreden S. 141 . Von Calvin selbst kommt vor allem in Betracht die Institutio und die wundervolle, jetzt deutsch (in Auswahl) erschienene Briefsammlung hg. von R. Schwarz 1909. - Von Dogmengeschichten seien Loofs und Seeberg genannt. - Sehr viel bietet vor allem Göbel, Gesch. des christlichen Lebens in der rheinisch-westfälischen Kirche I 1 849, II 1852 III 1860 , der insbesondere den Analogien des Calvinismus mit Pietismus und Sektentypus nachgegangen ist, wie sie sich ihm in der niederländischen und niederrhèinischen Entwickelung des Calvinismus in Fülle ergaben. Erst durch dieses wertvolle, wenn auch etwas salbungsreiche Buch emprängt man das richtige Licht für die Sache, während Ritschls Gesch. d. Pietismus den Calvinismus Calvins als in Katholizismus rückfälliges Epigonentum Luthers behandelt. Das ist nur verständlich bei der wunderlichen Ritschlschen Schuldoktrin, daß der Sektentypus katholisch und daher jede Annäherung an ihn Katholizismus und, Rückfall ins Mittelaltere sei. Mit dieser Schuldoktrin ist das Verständnis der Sache unmöglich gemacht. Vielmehr ist mit den Täufern. zusammen der Calvinismus eher als radikaler Protestantismus und Biblizismus zu bezeichnen, während im Verhältnis dazu des Luthertum näher an katholischem Konservatismus und Anstaltsgeist bleibt. Das ist im vorigen Abschnitt gezeigt worden und von hoher Wichtigkeit für das Verständnis der Eigenart der calvinistischen Soziallehren, denen gegenüber Katholizismus und Luthertum unter sich relativ mehr verwandt sind und trotz aller Unterschiede innerhalb eines gemeinsamen Typus sich bewegen. Sehr richtig Schneckenburger I 6:»Zunächst dem Katholizismus als der geraden Fortbildung des lateinischen Christentums steht das Luthertum, eine vergeistigte Umbildung desselben, eine an seine historische Entwickelung anschließende eigentliche Reform desselben. In der reformierten Kirchengestaltung ist nicht sowohl eine bloße Reform des historisch gewordenen, eine geistige Fortbildung des lateinischen Christentums, als eine dem Prinzip nach neue und ummiltelbar aus der Schrift geschöpfte Gestaltung des Christentums nach seiner urspünglichen, Norm gebenden Erscheinung bezweckt. « Das wird bestätigt durch die unverkennbar größere Abneigung katholischer und altkatholischer Forscher - unter den letzteren Kampschulte und Moritz Ritter - gegen den Calvinismus als gegen das Luthertum. Ganz ähnlich spricht sich übrigens auch Ranke an einer berühmten Stelle über die Augsburgische Konfession aus. - Eine Uebersicht ïber die neuere Literatur zum Calvinismus gibt auch Knodt, Bedeutung Calvins und des Calvinisinus für die prot. Welt im Lichte der neueren uñd neuesten Forschung 1910. 
benützt. Was auch sonst auf ihn gewirkt hat, die humanistische Reformtheologie, die Schweizer Kirchenreinigung und die Straßburger kirchlich-soziale Reform- und Unionspolitik, er selbst hat alles Wesentliche auf Luther zurückgeführt. Allerdings ist es ein Luthertum in oberdeutscher, vor allem in Straßburger Beleuchtung, das durch die Unionstendenzen Butzers, die städtischen Verhältnisse, • die Konkurrenz der Täufer, die Einflüsse der benachbarten Züricher gefärbt ist, aber es ist nichtsdestoweniger ein entschiedenes Luthertum.

Die Grundlehren Luthers sind daher auch die Grundlehren Calvins. Calvin steht fest auf der lutherischen Rechtfertigungs- und Heiligungslehre, ja gibt ihr geradezu den systematisch reinsten Ausdruck unter allen Reformatoren. Gegenüber der absoluten Sündenverderbnis und Unfähigkeit des natürlichen Menschen ist die von Gott in Christo geschenkte Gnaden- und Sündenvergebungsgewißheit die Umwandlung der Seele zu freudiger Gottesgemeinschaft, zu sittlicher Kraft und tätiger Arbeit im Dienste Gottes. Weiterhin ist diese Rechtfertigungs- und Heiligungslehre genau wie bei Luther fest eingespannt in den Rahmen des Kirchenbegriffes. Sie vollzieht sich nur vermittelst der von Christus gestifteten, mit den objektiven Gnadenmitteln des Wortes und der Sakramente ausgestatteten kirchlichen Heilsanstalt, die alles subjektive und persönliche religiöse Leben überall erst durch Vermittelung der Schrift und des in der Schrift offenbaren Christus hervorbringt. Strengste Bindung an die kirchliche Heilsvermittelung; schärfste Betonung auch der Sakramente als objektiver göttlicher Vermittelungen; Hervorhebung der Kontinuität mit der christlichen Urkirche gegenüber dem Abfall des Papsttums; Begründung der Kirche auf die Bibel als den Glauben schaffenden und damit sich selbst beglaubigenden supranaturalen Produzenten der Gemeinschaft; Katholizität der Kirche, soweit Wort und Sakrament irgendwo noch unter der Hülle von Wahn und falschen Zeremonien erhalten sind; universale und uniforme Herrschaft der kirchlichen Wahrheit auf dem erreichbaren und beherrschbaren Gebiet; theokratische Verbindung von Staat und Kirche, Zwangsherrschaft der reinen Lehre wenigstens in der äußeren Anerkennung; engste Verbindung von Staat und Kirche bei fundamentaler innerer Verschiedenheit; Rezeption der weltlichen Kultur und christliche Beseelung des naturgesetzlichen Berufssystems; Identifikation von Dekalog und Naturrecht und Annäherung des posi- 
tiven Rechtes an beide: das alles sind mit dem Kirchenbegriff selbst auch die Grundzüge des calvinistischen Religionswesens. Er übernimmt sie als bereits fertige, ist daher frei von den Schwankungen, unter denen Luther diese Begriffe erst herausgebildet hat, und gestaltet sie aus mit der doktrinären Folgerichtigkeit, die die Eigentümlichkeit der Männer der zweiten, bereits ein festes Erbe voraussetzenden Generation ist ${ }^{318}$ ).

s1s) Vgl. den Beginn des IV. Buches der Institutio; hier die Kirche als Depot des vom Individuum unabhängigen Gnadenschatzes: Quia riditas nostra et segnities externis subsidiis indigent, quibus fides in nobis et gignatur et augescat et suos faciat progressus usque ad metam, ea quoque (Deus) addidit, quo infirmitati nostra consuleret; atque ut augescat Evangelii praedicatio, thesaurum hunc ad ecclesiam deposuit. Pastores instituit ac doctores, quorum ore suos doceret Eph. 4, II. Eos a utoritate instruxit. Imprimis sacramenta instituit, quae nos experimento sentimus plus quam utilia esse adjumenta ad fovendam et confirmandam fidem. Nam quia ergastulo carnis nostrae inclusiad gradum evangelicum nondum pervenimus, Deus se ad captum nostrum acomodans pro admirabili sua providentia modum praescripsit, quo procul dis juncti ad eum accederemus. Iust. IV I, I. - $\rightarrow$ Quia nunc de ecclesia visibili disserere propositum est, discamus vel uno matris elogio, quam utilis sit nobis ejus cognitio, immo necessaria: quando non alius est in vitam ingressus, nisi nos ipsa concipiat in utero, nisi pariat, nisi nos alat suis uberibus, deniquesubcustodiaet gubernatione nos tueatur, donec excuti carne mortali similes erimus angelis. Neque enim patitur nostra infirmitas a schola nos dimitti, donec toto vitae cursu discipuli fuerimus. Adde, quod extra ejus gremium nulla est speranda peccatorum remissio nec ulla salus. IV I, 4. In diese Kirche wird man hineingeboren wie in einen Fideikommis; vgl. Contre les Anabaptistes, Corpus Reformatorum 35, S. 522: Ainsi l'homme qui n'a esté receu en l'alliance de Dieu des son enfance, est comme estranger à l'Eglise, iusques à ce que par la doctrine de salut il soit amenć ì foy et repentance. Mais alors sa semence est aussi quant et quant faict domestique de l'Eglise. Et pour ceste cause les fetitz enfants des fidèles sont baptisés en vertu de cette alliance, qui est faicte avec leurs pères, en leur noms et à leurs profits. Die Ceistigkeit der Sakramente, die der Calvinismus lehrt, ändert also nichts an Kirchenbegriff. Die Kindertaufe soll vor der Gemeinde stattfinden, aber sie ist immer die Bezeugung der schon durch die Geburt vollzogenen Inkorporation in die Kirche vgl. Briefe II 34, 38, 245, 423. Beim Abendmahl vollends hat $\mathrm{C}$. gerade die objektive. Wunderspeisung, wenn auch als geistige, im Interesse des Kirchenbegriffes festgehalten und um deswillen sich als Lutheraner angesehen. Von der Zuchtübung und der Forderung würdigen Abendmahlsgenusses, dem Zentrum seiner Idee einer heiligen Gemeinde, hält er, alle separatistischen und sektcnhaften Konsequenzen ausdrücklich fern. Wo Wort und Sakrament ist, da ist 
So sind alle Besonderheiten des Calvinismus erst aus diesem mit dem Luthertum gemeinsamen Grundstock herausgearbeitet.

für ihn die Kirche, wie für Luther; und bei der Unerkennbarkeit des inneren Standes ist jede Trennung von Gläubigen und Ungläubigen unzulässig CR. 35, S. 68: Car la majeste de la parolle de Dieu et de ses sacrements nous doit estre en telle réputation, que partout ou nous la voyons nous soyons certains que là il y a Eglise, nonobstant les macules et les vices qui pourront estre en la vie commune des hommes. Der von der Kirche zu handhabende Abendmahlsausschluß ist gut, aber er ist stets nur ein Straf- und Erziehungsmittel der Kirche, niemals eine Separation der Reinen und Heiligen von der Kirche der reinen Lehre und des reinen Wortes, so viel Sünde sie enthalten mag: Je laisse à dire qu' encore posé le cas que nous nedeussions avoir a cune considération que des hommeset de leurmeurs (was eine falsche täufersche Voraussetzung sei), nous pourrions estre souvent abusez en reiettant une compagnie et ne la daignant estimer Eglise à cause des imperfections qui y, seraient. Car il se pourrait faire tout les coups, que nous ferons iniure à beaucoups de sainczt personnages, dont le nombre est caché entre les meschants comme le bon grain dessoubs la pouille. Das sind beinahe wörtlich alle Merkmale des Kirchenbegriffes im Unterschiede vom Sektenbegriff, die ich früher (II, 9) aufgezähit habe. Vgl. auch die völlig lutherischen Formeln für den Kirchenbegriff Briefe I 6, 57, 76, 27 I, II 158, 409: -Ich weiß Gott sei Dank recht wohl, daß die wahre Wirkung des Sakraments nicht von der Würdigkeit dessen abhängt, der es austeilte. Ferner die stărkste Betonung des ordnungsmäßig berufenen Amtes, ohne welches es keine Gemeinde und keine Kirçhe gibt und dessen Träger das Gefäß für die von seiner Würdigkeit unabhängige Wunderkraft der Kirche ist ; Briefe I 266 II I8, 47, 52, vgl. 272, 357 : Laien können niemand für ein Amt als tauglich erklären; auch die > Aeltesten * sind keine reinen Laien, sondern klerikal geweiht, Choisy 356. - Daraus ergibt sich auch hier die Folge von selbst, daß, soweit der Einfuß der Staatsgewalt reicht, nur die wahre Religion herrschen darf: Briefe I 9, 3II, 344, 445 f. II I17, 200. Die Umwege Luthers bis zu dieser Einsicht hatte Calvin nicht mehr nötig, nachdem die Tatsachen deutlich gesprochen hatten. Toleranz gibt es nur für die Wahrheit, und diese Toleranz muß Herrschaft werden. Für diese Selbstgewißheit der Alleinwahrheit ist am charakteristischesten die Aeußerung über die »falschen Märtyrer « der Täufer, wo doch Calvin selbst das Martyrium als Hauptzeugnis der Wahrheit bezeichnet; s. C. R. 35 : >Et mesme c'est ce qui discerne les martyrs de Dieu de ceux du Diable que de mourir pour iuste cause. Pourtant tout ainsi que c'est une constance louable que de souffrir la mort, si mestier est, pour le tesmoignage de la vérité: aussi c'est obstination enragée que de souffrir pour mauvaise querelle. Tellement que celuy qui en souffre le plus, est d'autant plus á vituperer «. Das ist eine Selbstgewißheit, vor der dem modernen Menschen schwindelt, aber sie ist der Kern des Kirchenbegriffes und der Kirchenherrschaft, der Kern der Größe jener Männer. Siehe auch Calvins Selbstbeurteilung Briefe I $45 \mathrm{I}$ : Was mich angeht, hohe Herrn, so bin ich in meinem Gewissen sicher, daß, was ich gelehrt und geschrieben habe, nicht in meinem Kopf ent- 
Sie sind aber um deswillen nicht etwa geringfügig, sondern trotzdem von der allerhöchsten und von originaler Bedeutung. Sie formen die religiöse Idee des Protestantismus zu einer neuen Grundrichtung, deren schließliche Ablehnung durch das ganz anders geartete Luthertum sehr woh! begreiflich ist. Die Unterschiede liegen im wesentlichen auf dem Gebiete des Gottesgedankens, der damit gegebenen religiös-ethischen Grundhaltung und der da-

standen ist, sondern von Gott habe ich es, und ich muß es festhalten, wenn ich nicht zum Verräter an der Wahrheit werden wille. Ebenso an den Rat I 444 und II 67. Dabei ist die Geistigkeit und Innerlichkeit der Kirche wie bei Luther gewahrt durch den Satz, daß die Kirche nicht den Glauben erzwinge, sondern nur im Interesse der Gesellschaft der Staat ein äußerlich christliches Leben und die Benuitzung der Gnadenmittel erzwinge; der Glaube ist eine Wundergabe Gottes und siegt nur durch die innere Kraft des Wortes. - Daß diese Kirche mit dem Staat auch die Kultur beherrschen und akzeptieren muß und will, das wird die folgende Darstellung zeigen; es ist überdits gegen die Anabaptisten überall aufs schärfste als Konsequenz des Kirchenbegriffes ausgesprochen C. R. 35 S. 92 : Touchant de la fin ou ilz pretendent, ie n'en diray que deux motz: qu' ilz (die Tăufer) se monstrent en cela ennemis de Dieu et $d u$ gen re humain. Car c'est faire la guerre à Dieu de vouloir mettre en vitupere ce qu' il honoré (d. h. im A. T. und durch den tatsächlichen Verlauf der Geschichte); de vouloir fouler aux piedz ce qu' il a exalté. Et on ne saurait mieux machiner la ruine du monde et introduire partout qu'en taschant d'abolir le gouvernement “civil.a - Die Betonung dieses objektiven Anstaltscharakters der Kirche steigert sich mit den Ausgaben der Institutio, Köstlin, Ueber Cs. Inst. (Stud. u. Krit. 1868) S. 48i ; Rieker neigt dazu das sgenossenschaftliche Element im Kirchenbegriff stärker zu betonen als das sanstaltliche S. 7I; er meint yjenes drohe dieses im Laufe der Zeit aufzusaugen . Das ist aber erst im Independentismus der Fall, der ebendeshalb nicht rein auf die reformierte Idee zurückgehen kann; solange Rieker sich rein an diese hält, muß doch auch er selbst das anstaltliche Element und die Uebereinstimmung mit Luther stark betonen S. 75, 8I f., 87.. Die $>$ Kombination zwischen der Prädestination und einem sektenhaften Individualismuse ist nirgends von Calvin vollzogen, da die Prädestination immer an die »Vehikel ihrer Auswirkung Wort und Sakrament gebunden ist. Ja es findet sich bei Calvin ganz wie bei Luther die Lehre von der Gegenwart der Kirche überall, wo Wort und Sakrament vorhanden sind, auch innerhalb des Katholizismus, Briefe I 352, 371, 437. Der Individualismus der Prädestinationslehre ist bedeutsam genug, aber mit einer >genossenschaftlichen. Fassung der Kirche hat er nichts $z$ tun. - Vollends von einem naturrechtlichen Zug des calvinistischen Kirchenbegriffes zu sprechen, wie Sohm, Kirchenrecht S. 697 tut, scheint mir eine völlige Verkennung des. Sachverhaltes; das ist stets eine Zurückdeutung des modernen Calvinismus in den primitiven. Das historische Problem liegt gerade in dieser Umwandelung und wird uns sehr $z u$ beschäftigen haben. 
von ausfließenden eigentümlichen Gestaltung der sozialen Aufgaben.

Das e rste und wichtigste ist die Herausarbeitung des Prädestinationsgedankens, des berühmten Zentraldogmas des Calvinismus. Es ist der allmählich formulierte und schließlich stark betonte Ausdruck des eigentümlichen Gottesgedankens Calvins überhaupt. Calvin ist auch hierin Luthers Schüler, und die Prädestinationslehre ist zunächst nur die logisch-systematische Heraushebung des Grundelements der lutherischen Lehre, zugleich eines Hauptpunktes der paulinischen Lehre, den sein strenger Bibelgehorsam als ein schlechthin verbindliches Glaubensgesetz betrachtete. Es ist dasjenige Element der lutherischen Lehre, durch das der reine Glaubenscharakter der reformatorischen Religion vor der Vermischung mit menschlichem Meinen und Denken geschützt wurde. Der Glaube ist keine menschliche, sondern eine durch absolutes Wunder von Gott gewirkte Erkenntnis. Zugleich war damit das Menschliche auch in der Gestalt aller menschlichen Verdienste und alles menschlichen Eigenwirkens ausgeschlossen und der Gnadencharakter der Glaubensreligion voll gewahrt. So scheint Calvins Prädestinationslehre zunächst nur dem epigonenhaften Scharfsinn des Schülers ihre Bedeutung zu verdanken, der die Lehre des Meisters systematisiert und dabei den treibenden yystematischen Nerv des Ganzen herausarbeitet. Aber Calvin war mehr als Schüler und Epigone. Hinter seiner Prädestinationslehre verbarg sich zugleich und überdies der seiner persönlichen Religiosität eignende Gottesbegriff. Es ist nicht nur das absolute Wunder, die Uebermenschlichkeit und Gnadenmäßigkeit des Heils, was Calvin im Prädestinationsgedanken sucht und formuliert. Es ist zugleich der absolute souveräne Willenscharakter Gottes. Die Idee der Gnade ist reine verdienstlose Gnade und hat schlechthin nichts zu tun mit einer Gerechtigkeit, welche die elende Kreatur vom Herrn der Welt fordern könnte. Es ist Gottes Wesen, den Einen das Heil ohne alles Verdienst frei willkürlich zu schenken und den Andern ihrer Sündhaftigkeit gemäß das Verderben zu bereiten. Niemand darf sich rühmen und niemand beklagen. Wie niemand einen Anspruch hat, ein Mensch zu sein statt eines Tieres, so hat niemand Anspruch darauf, ein Erwählter zu sein statt eines Verdammten. Gottes majestätischer Herrscherwille ist der Grund aller Gründe, die Norm aller Normen. Es gibt nur Gründe und Normen, die durch Gott gelten, aber keine, die über ihm und für ihn gälten. Er gibt sich selbst in völlig freier Willkür sein 
Gesetz; und dieses Gesetz ist das Gesetz seiner Selbstverherrlichung im Danke der verdienstlos Beseligten und im Jammer der verdienstmäßig Verdammten. Das heißt: es ist überhaupt nicht mehr wie beim Luthertum der Begriff der Liebe das Zentrum des Gottesgedankens, sondern der der Majestät, der die Mitteilung und W'irkung der Liebe durch Gott nur als ein Mittel zur Offenbarung der Majestät Gottes betrachten läßt. Gott hat hier nicht aus dem Bedürfnis nach Gegenliebe der Kreatur die Welt geschaffen, sein Weltplan ist nicht durch den freien Willen der Kreatur zerstört worden, und das Heil ist nicht die durch das Erlösungswunder wiederhergestellte universale Beseligung aller Kreatur. Vielmehr ist Gottes grundloser Wille der Grund der Welt und die Ursache ihres gesamten Laufes. Gott hat die Sünde Adams geordnet und verwendet Sünder und Gerechtfertigte in seinem Welthaushalt, die einen zum Symbol der alles Gute allein durch seinen Willen schenkenden Gnade, die andern als Symbol des Zornes über die Unheiligkeit und Bosheit. Nicht auf das egoistische Seelenheil der Kreatur und die Universalität des göttlichen Liebeswillens kommt es an, sondern auf die Ehre Gottes, die gleich gepriesen wird in der heiligen Aktivität der Erwählten und in dem ohnmächtigen Grimm der Verworfenen. Gott bietet in seinem Evangelium allen die Gnade an, aber in demselben Evangelium verkündigt er die Doppelheit seines Erwählungs- und Verwerfungsratschlusses, worunter die Vernunft sich zu beugen hat und was sie nicht klügelnd zusammenstimmen soll. So hatte auch Luther den verborgenen und den geoffenbarten Gott unterschieden, aber Luther hat sich schließlich an den geoffenbarten neutestamentlichen Gott gehalten und die Spekulation verabschiedet. Calvin hat sie festgehalten und damit den ganzen Gottesbegriff umgestaltet ${ }^{314}$ ).

\footnotetext{
314) $\mathrm{Daß}$ auch in diesem Stück Calvin zunächst einfach Luther folgt, zeigt schon ranz allein die Schrift Luthers gegen Erasmus De servo arbitrio (über deren Simn und Bedeutung s, die sorgfältige Arbeit von Zickendraht, Der Streit zwischen Erasmus und Luther 1909). Ueber die Verselbständigung und eigentümliche Herausbildung der Prädestinationslehre s. Alex. Schweizer, Die Zentraldogmen der reform. Kirche, 1854/56. Ueber die Bedeutung und Wirkung dieser Lehre auf Calvins Doktrin und vor allem auch auf seine Ethik ist viel gestritten worden; s. die verschiedenen Hauptauffassungen bei Hundeshagen S. 30I-306. Doch kann an der zentralen Bedeutung für Calvin kein Zweifel sein; s. Scheibe, Calvins Prädestinationslehre 1897. Ritschls Meinung, daß die Präd.-Lehre nur ein aus dem strikten Bibelgehorsam entstandenes Anhängsel sei, ist eine Wunderlichkeit, erklärbar aus seinem Bestreben, Calvin zu einem bloßen Epigonen Luthers zu machen;
} 
Hierin liegt eine Fülle von Konsequenzen. Der Calvinismus ist von vorneherein entlastet von allen Problemen der Theodizee; die so schwer auf dem Luthertum lasten und bei der Festhaltung der Universalität des Gnadenwillens immer wieder zu der Frage nach der Gerechtigkeit Gottes und zur Abhängigmachung des Heils von dem aufnehmenden Willen der Kreatur führen. Es wird Raum für verschiedene Zwecke Gottes nebeneinander: er offenbart sich in der Gratia universalis, in allen Gaben der Vernunft und in der Schönheit der Welt, in Erwählten und NichtErwählten, und er braucht bei diesen Gaben nicht bloß auf die Erlösung hinzuzielen; er offenbart sich in den Schmerzen und Strafen, die nicht bloß Erziehungs-, Läuterungs- und Sühnmittel sind, sondern die von seinem Herrscherwillen verhängt sind zur Darstellung seines Zornes, zur Stählung seiner Heiligen und zum Beweis der Nichtigkeit der irdischen Welt; er offenbart sich zu innerst, aber nicht ausschließlich in der Seligkeit der Gerechtfertigten, die Gott unbedingt vertrauen dürfen, aber auch ebenso unbedingt dienen müssen.

So eifrig auch Calvin in seinen Briefen die Wege der göttlichen Vorsehung ausdeutet, so handelt es sich dabei nie um den Beweis für die Güte Gottes, sondern nur um die Leitung, Prüfung und Rettung der Kirche, während das Leiden an sich für diesen Heroismus kein Problem ist ${ }^{315}$ ). Dem Alten Testament entspringt dieser Gottesgedanke nicht, außer etwa durch die Vermittelung des Paulus. Er entspringt vielmehr dem eigentlichen Wesen Calvins, bringt dann aber allerdings eine gewisse Wahlverwandtschaft mit dem Alten Testament mit sich. Damit ist dann ferner die Konsequenz einer durchaus praktisch-ethischen Abzweckung des Rechtfertigungsgedankens gegeben. Denn die Rechtfertigung ist nicht ein quietistisches Ausruhen in der dankbaren Seligkcit, son-

s. seine ,Geschichtl. Studien zur christlichen Lehre von Gott* Jbb. f. deutsche Theol. 1865 und 1868; die hier behauptete Uebereinstimmung mit dem Scotismus ist m. E. nur analogisch, nicht genetisch zu verstehen.

316) Lobstein 82-86. Bei Luther ist das Leiden wesentlich erst Folge der Sünde und durch sie gerechtfertigt. Die Wichtigkeit der Unterscheidung der Gratia universalis von der Elektionsgnade, die die Erbsündenlehre mildert, die Vernunft und Bildung rezipiert, der Lex naturae Raum gibt und überhaupt die st:urr pessimistischen und asketischen Züge abschwächt s. bei Bavinck in $>$ Calvin and the reformation und bei Kuyper S. IIO-118. Diese meist übersehene Seite der Sache ist sehr wichtig für das Problem der Askese und des Verhälınisses zur Kultur. 
dern ein Mittel und ein Sporn des Handelns. Es ist ein handelnder Wille, mit dem sie es zu tun hat, nicht eine lediglich Sünden vergebende Gnade. Er schafft und schenkt in der Frwählung die Gewißheit der Sündenvergebung, damit das in ihr befreite Gemüt Gott dienen und sich von Gott zum Organ seines Wesens machen lasse. Er macht sie durch die Rechtfertigung zu Gliedern des Christusleibes und durchdringt sie mit dem handelnden Christusgeiste, macht sie zu Kämpfern und Streitern Christi, zu Untertanen des Königreiches Christi. Nicht die Innigkeit und Tiefe des Gefühls ist die Probe der Rechtfertigung, sondern die Einergie und zusammenhängende Konsequenz des Handelns. Im Luthertum ist die eigentliche Probe und Bewährung der Rechtfertigung die weltüberlegene Seligkeit, die in engem Zusammenhang mit dem substantiell im Abendmahl sich dem Gläubigen vereinigenden Christus ihren Höhepunkt in der Unio mystica, in einer mystischen Gottesverbindung, hat. Für den Calvinismus ist bei der Transzendenz Gottes eine derartige Bewährung nicht denkbar, die Einigung mit Gott ist nur als Hingabe an den erwählenden und erneuernden Willen Gottes und als ein Handeln des immer sactuosen . Gottes im Gläubigen zu verstehen, wie ja auch im Abendmahl zwar eine wirkliche Vereinigung mit dem himmlischen Christus, aber nur eine solche im Geiste erfolgt, wie die Christusgemeinschaft überhaupt keine substanzielle, sondern eine Aufnahme in den handelnden und wirkenden Geist des Christus ist. - Finitum non est capax infiniti « heißt der reformierte Grundsatz, und der gibt dem Rechtfertigungs- wie dem Glaubensgedanken einen psychologisch anderen Sinn: statt des Charakters der Seligkeit in Gottes sündenüberwindender Gnade den Charakter der Erwählungsgewißheit und der handelnden $\mathrm{Kraft}^{316}$ ).

Die von da ausgehende Umfärbung des ganzen mit dem Luthertum gemeinsamen dogmatischen Besitzes ist hier nicht näher zu schildern ${ }^{317}$ ). Wohl aber ist es bedeutsam, daß von hier aus das dogmatische Kapital als Ganzes, die »reine Lehre selbst, eine bei aller Orthodoxie doch andersartige Stellung im Ganzen des Gedankens gewinnt. Für den Lutheraner objektiviert sich Seligkeit und Heil in dem einzigen sie beide hervorbringenden

316) Diese Charakteristik ist vor allem von Schneckenburger sehr fein entwickelt worden und von M. Weber fortgeführt Archiv XXI S. 21-25.

317) Das ist meisterhaft, aber vielleicht etwas überfein beí Schneckenburger geschehen. 
Mittel, in der reinen Lehre, die zugleich der Kern der Kirchenanstalt und das einzig Objektive am Christentum ist. Für den Calvinismus steht neben der reinen I ehre als Ausdruck der Gnade das Sittengesetz und als Ausdruck des handelnden göttlichen Willenswesens die Disziplin. Der produzierende Kern der Heilsanstalt ist für ihn die reine Lehre nur mit der göttlich geoffenbarten Disziplin zusammen. Der Gott Calvins kann sich nicht bloß in reiner Lehre offenbaren, sondern muß auch seine handelnde und schaffende Willensnatur kundgeben. Die reine Lehre ist daher nicht wie im Luthertum das ausschließliche Anliegen der Kirche, weil die Reinheit der Lehre die Reinheit des Glaubens garantiere und mit diesem alles Weitere von selbst gegeben sei. Sie ist nicht Selbstzweck, sondern, wie der Glaube Voraussetzung des richtigen Handelns ist, so ist auch die reine Lehre nur Voraussetzung und Mittel. Das bedeutet bei der systematischen Zielsetzung des Calvinismus allerdings auch einen theoretischen Ausbau der Iehre, der über die Bedürfnisse des Luthertums hinausgeht; aber die noch so allseitig und systematisch entwickelte Lehre bleibt Mittel zum Zweck, Voraussetzung des eigentlich Wertvollen, des christlichen Handelns. So ist es zu verstehen, daß der Calvinismus bei seiner starken L.ogik und seiner Rezeption der Bildung des westlichen Europa eine dem Luthertum gegenüber sehr gesteigerte Intellektualität behauptet und doch Lehre und System viel weniger zum Zentrum macht. Gott ist ihm irrational auch in dem Sinne, daß er an Maßstäben menschlicher Vernunft und Logik nicht gemessen werden darf; aber er hat die Vernunft zum Zweck irdischer Arbeit und zur Verherrlichung Gottes gegeben. So bildet auch die kultivierteste und scharfsinnigste Vernunft und Doktrin nur ein Mittel für übervernünftige Zwecke und eine Voraussetzung des Handelns ${ }^{318}$ ).

318) Vgl. Hundeshagen S. 396, 401, 447, 448: $D$ Die Dogmatik ist bei den Reformirten nur ein Locus in der Kirche, bei den Lutheranern umgekehrt die Kirche nur ein Locus in der Dogmatik «. Ueber die Intellektualität des Calvinismus s. Choisy L'état chrétien S. 523 und Kuyper 103-331; der letztere nit Beimischung von höchst gewaltsamer, aber für die Ziele des modernen Calvinismus höchst charakteristischer Apologetik. Ueber die Intellektualität, Bewußtheit und Reflektiertheit des Calvinismus von hier aus vortrefflich Schneckenburger; über die dadurch vermittelte Rezeption der westlichen Bildung und des. Humanismus, die trotz des herrschenden Pessimismus und der Askese viel stärker ist als im Luthertum, s. Arnold, Calvinrede. Der höhere Stand der geistigen Kultur im Calvinismus kommt auch sehr fein zum Ausdruck in C. F. Meyers Novelle über die Bartholomäusnacht. 
Schließlich findet noch eine letzte praktisch-ethisch bedeutsame Wirkung dieses Gottesbegriffes statt, die anders gefärbte Auffassung von der Quelle und Autorität der reinen Lehre oder von der Bibel. Der souveräne Gotteswille der Erwählung und der Bereitung einer erwählten Gemeinde gibt sich nicht bloß kund in der Liebesgesinnung und dem versölnnenden Liebesopfer Christi, das als Kern der Bibel aus ihr von dem erlebenden Glauben herausgeholt werden muß und neben dem die übrige Bibel verhältnismäßig gleichgültig wäre oder nur als Weissagung auf Christus aufgcfaßt würde. Die Offenbarung des souveränen Prädestinations-Gottes ist vielmehr als Ganzes eine Willenskundgebung positiver Art, ein Gesetz des Glaubens und der Sitte. Wie nicht der Gedanke der Liebe, sondern der der Majestät, Heiligkeit, Souveränität und Gnade in dem Gottesgedanken vorherrscht, so ist auch die Bibel weniger ein Mittel der Vergewisserung von Gottes sündenvergebender I iebe als eine Manife station zur Schaffung der Gottes Whre verwirklichenden Gemeinde und zur Niederschlagung der Bösen und Verworfenen. Lag es der zweiten Generation schon an sich nahe, die von Luther zur Grundlage aller Beweisführung gemachte Bibel abstrakt zu verselbständigen, so wurde die Bibel als Stiftung des antirationalen positiven Gotteswillens vollends ein Gesetz von durchgängig gleichartiger Beschaffenheit und Absicht, in welchem Altes und Neues Testament den gemeinsamen formellen Charakter der Offenbarung tragen und sich nur insoferne unterscheiden, als das Neue ausdrücklich gewisse Elemente des Alten abgeschafft hat. So kommt im Calvinismus das Alte Testament $z u$ einer höheren selbständigeren Geltung. Und wie nun schon der Gottesgedanke des Calvinismus dem Willenswesen Jahwes vielfach nahe kommt, so führen dann weiter die praktischen Bedürfnisse zu steigender Ausnützung des Alten Testamentes, wie sich sofort zeigen wird. Dadurch aber wird die calvinistische Theokratie zu einem Bunde Gottes mit der Gemeinde auf der Grundlage der Offenbarung, zu einem Dienst des Staates für die Kirche nach dem Vorbild der israelitischen Könige, zur Kontrolle des öffentlichen Lebens durch die Geistlichen nach dem Muster der Propheten. Ein neues Israel, eine neue heilige Stadt, begründet auf das neutestamentlich vertiefte göttliche Gesetz, geleitet von dem lohnenden und strafenden Gnadenwillen, erwählt zum Organ der Verherrlichung Christi, des Gottmenschen, in dem der verborgene erwählende Wille Fleisch und gemeindebildende 
Kraft geworden ist: das ist das Evangelium Calvins.

Hier wie an anderen Punkten tritt eine gewisse Verwandtschaft mit dem Täufertum zutage, die uns noch vielfach beschäftigen wird. Freilich ist die Prädestinations- und Heilslehre von der täuferischen Freiheitslehre tief geschieden, aber die Auffassung der die Prädestination auswirkenden Bibel berührt sich mit jenem. Die Bibel als Sittengesetz und die Verfassung der Urkirche als Verfassungsideal wurde bei den Täufern ähnlich betrachtet. Freilich ist die Begründung bei Calvin eine andere. Er will nicht, wie jene, überhaupt statt der Kirche eine neue und andersartige Gemeinschaft. Er will nur die Kirche radikal nach der Schrift reformieren und gibt der biblischen Autorität ihren Grund in einem Gottesbegriff, der zugleich auf die Hervorbringung der reinen, heiligen, schriftgebundenen Kirche gerichtet ist. Aber damit geht er doch über den Gedanken einer rein auf sich selbst beruhenden Heilsanstalt hinaus und berührt sich mit dem Motiv des Täufertums. Er nähert sich ihrem biblischen Purismus. Das ist der tiefste Punkt, an dem sich die äußerlich oft so ähnliche Lehre der Lutheraner und der Calvinisten über die Bibel unterscheidet. Die Lutheraner haben an der Bibel ein Interesse nur, soweit sie die Gnadenanstalt, die Sündenvergebung und das alles dies begründende Werk Christi betrifft, und handhaben hier die Bibel lehrgesetzlich genug. Darüber hinaus haben sie kein Bedürfnis, sie zum Gesetz zu machen. Wohl aber hat der Calvinismus ein solches. Er erstreckt die lehrgesetzliche Bibelautorität über ein weiteres Feld und verändert damit die Gesamtauffassung der Bibel im Sinne einer infallibeln Autorität für alle Fragen und Bedürfnisse der Kirche. Das Luthertum kontrolliert die ihm aus innerem Erleben erwachsene Lehre an der Bibel, der Calvinismus erneuert das ganze Christentum in Lehre und Kirche, Ethik und Dogma rein aus der Bibel. Hierauf und auf dem aktiven Charakter seiner in der Erwählung wurzelnden Religion beruht sein größerer reformatorischer Radikalismus ${ }^{319}$ ).

819) Ueber calvinistischen und lutherischen Biblizismus s. Schneckenburger I I6, 20, 27, Otto Ritschl, Dogmengeschichte des Prot. 1908 I 53-192. Göbel II 114, 154, 347 Folgen für Lyrik und Kult, 118 Analogie des puristischen, aus der Bibel abgeleiteten Kult erinnert an Waldenser und Brüdergemeinden, I 326 Laskis Biblizismus eine $>$ Vermittlung $z$ wischen den verfassungslosen Lutheranern und den separatistischen Wiedertäufern^, 3 II die gleiche Tendenz bei Calvin, der damit sauch wirklich den Wied ereintritt der abgesonderten Wiedertäufer erreichte, welche 
Ist derart die lutherische Prädestinationslehre und mit ihr der Gottesgedanke zu einem neuen Sinne fortgebildet, so ist das gleiche auch bei dem $\mathrm{z}$ weiten Hauptpunkte der Fall, bei dem religiösen Individualismns. Bei Luther handelte es sich im Grunde stets nur um die Heilsgewißheit und Seligkeit des Individuums, die aus der Gewißheit der Sündenvergebung sich ergibt, im Verhältnis zu der aber alles übrige nur der Ueberschwang der ausströmenden Gottverbundenheit, nur selbstverständliche Folge, nicht wesentlicher Zweck ist. Das ist anders im Calvinismus. Auch er betont die Innerlichkeit und Gesinnungsmäßigkeit, den rein persönlich individuellen Charakter aller Religiosität; auch er verwirft den bloßen Dogmen- und Autoritätsglauben sowie die Sakramentsmagie; auch er leitet das neue Leben aus dem Glauben ab. Aber wie ihm nicht die Seligkeit der Kreatur, sondern die Ehre Gottes im Zentrum steht, so ist auch die Verherrlichung Gottes im Handeln die eigentliche Probe der individuell-persönlichen Echtheit der Religion. Das Individuum ruht nicht aus in seiner Seligkeit, ergießt sich nicht nur etwa im persönlichen Liebesdienst und fügt sich nicht dann im übrigen bloß leidend und duldend den Weltordnungen ein, unter denen es steht, ohne sich völlig in sie auszugeben. Vielmehr es hat hier seinen ganzen Sinn darin, in diese Ordnungen einzugehen und, ihnen innerlich überlegen, sie zum Ausdruck des göttlichen Willens zu gestalten. In Kampf und Arbeit tritt es in die Aufgabe der Heiligung der Welt ein, stets gewiß, sich nicht an sie zu verlieren; denn es wirkt ja in allem nur die Erwählung aus, die gerade in der Kräftigung zu einem solchen Handeln besteht. Das ist freilich dem Luthertum nicht möglich, weil es an die Verlierbarkeit der Gnade glaubt. An diesem Punkte liegt der innerste Unterschied der beiderseitigen Fassung des religiösen Individualismus, der protestantischen Glaubens- und Gesinnungsreligion. Das Luthertum denkt die Prädestination nicht bis zur Konsequenz der Unverlierbarkeit des Gnadenstandes fort, weil es von Hause aus nur die Monergie der ${ }^{-}$Gnade in allem Guten sichern will, das Böse aber dem menschlichen Willen zuschreibt. So wird die Aufgabe des Luth_raners, nur den Glauben und den Gnadenstand zu bewahren, die immer neue Sorge um Rcinheit und Festigkeit des seitdem in Genf und in der ganzen calvinistischen Kirche kaum mehr vorkommen (?) und dann auch bald Duldung erlangten, die sie in den Zwinglischen (und Lutherischen) Kirchen niemals fandene. Sehr klar erkannt ist diese Analogie mit dem täuferischen Schriftprinzip bei A. Ritschl, Gesch. d. Pietismus I 72. 
werk- und verdienstlosen Glaubens ; alle Sorgfalt wird auf die Pflege des eigenen Gefühlslebens, die Erhaltung der Stimmung einer verdienstlosen Seligkeit gerichtet und die Ethik geradezu bloß als Bewahrung des Gnadenstands konstruiert, der durch grobe Sünden wie durch Vertrauen auf eigene Kraft verloren geht. Von dieser Verlierbarkeit des Gnadenstandes und darum auch von dieser Furcht weiß der Calvinismus nichts. Er braucht sich daher auch nicht auf die Selbstbewahrung im Gnadenstande abzustimmen, bedarf überhaupt nicht der stetigen Richtung auf das persönliche Gefühls- und Stimmungsleben. Er weiß, daß die Erwählung unverlierbar ist und wird darum die Arbeit nicht wesentlich auf seine Glaubenssicherheit, sondern auf die nach Gottes Willen zu bearbeitende Welt und Gemeinschaft richten. Er wird nicht Gott festhalten müssen, sondern umgekehrt selbst durch Gott gehalten sein. Er wird das neue, gottinnige Selbst nicht bewahren, sondern offenbaren müssen. So erhält der reformierte Individualismus nach allen Seiten Antriebe zur Aktivität, zu einem vollen Einsatz der Person in die Welt- und Gemeinschaftsaufgaben, zu einer rastlosen, eindringenden und gestaltenden Arbeit. Sein Individualismus ist nicht bloß härter und spröder in der religiösen Metaphysik begründet; er leidet auch nicht unter den beständigen Abbrechungen und Rückfällen, wie der des Luthertums, das sich dann immer bloß an die Sündenvergebung hält. Er organisiert zusammenhängend und systematisch, geradlinig und zielbewußt die Arbeit der Bewährung. Vor allem aber hat dieser spezifisch calvinistische Individualismus in der Ablehnung gefühlsmäßiger Expansion und in der Zurückstellung aller menschlichen Beziehungen hinter dem Gottvertrauen die Eigentümlichkeit, beim Herausgehen aus sich selbst sich stets auf sachliche Zusammenhänge und Zwecke zu richten. Calvins Briefwechsel ist von einer erstaunlichen Objektivität und Zurückhaltung des eigenen Selbst, verbunden mit einer rastlosen Sammlung aller für die $Z_{\text {wecke }}$ der christlichen Gemeinde. Die Kreatur hat keinen Selbstwert für das erwählte Ich, aber einen ungeheuren Mittelwert für die Aufgaben des Gottesreiches.

Es ist ein Individualismus, der verschieden ist von dem katholischen und von dem lutherischen, aber auch von dem optimistisch-rationalistischen der Aufklärung. Auf der Grundlage vernichtender Sündenerkenntnis und pessimistischer Weltbeurteilung, ohne jede Schönfärberei und Gefühlsseligkeit, ist es der Individualismus der Erwählungsgewißheit, des Verantwortungsgefühls und 
der Verpflichtung zum persönlichen Dienst unter die Herrschaft Christi. Er äußert sich in der reflektierenden und bewußten Art calvinistischer Frömmigkeit, in dem systematischen Geiste der Selbstkontrolle und der Unabhängigkeit von allem Kreatürlichen. Nur durch die erbarmende Gnade der Erwählung. hat das Individuum Wert, und nur Gott allein darf es die Ehre geben. Das ergibt einen auf der Folie der strengsten Selbstverurteilung sich erhebenden Aristokratismus und eine kühle, nur die weltliche Zweckmäßigkeit in Betracht ziehende Behandlung alles Weltlichen und Kreatürlichen bis in die bloß weltlichen und natürlichen Persönlichkeitsbeziehungen hinein. Indem dann bei den Nachfolgern Calvins die Dogmatik und die praktische Seelsorge immer dringender die Frage nach der Art der Gewißwerdung von der Erwählung zu erheben und zu beantworten hatte, ergab sich seit Beza die Lehre von der Vergewisserung der Erwählung an den Werken als den Kennzeichen des Gnadenstandes. Dieser immer lauter entfaltete Gedanke zwingt nun vollends das Individuum, das im Luthertum sich an die objektiven Gnadenmittel halten kann, zur Beobachtung seiner selbst und zur systematischen Steigerung und Zusammenschließung seiner Leistung. Das erhöht die Konzentration auf das eigene Selbst, die methodische Selbstbeurteilung und die straffe Spannung auf das Ziel der möglichsten Vollkommenheit. Er nähert sich unter Umständen der Gesetzlichkeit und dem Perfektionismus; er macht, obwohl die Auswirkung der Erwählung aufs strengste an Kirche, Schrift und Sakrament gebunden ist, doch das Individuum im Grunde unabhängig von der Kirche und stellt die Vergewisserung wie die Erwählung selbst völlig auf das individuelle Gewißwerden und Gewißmachen. Hierin liegt aber eine ungewollte Verselbständigung des Individuums gegen die Kirche, die sich mit dem Individualismus des Sektentypus leise berührt, wie auch die Strenge der Selbstkontrolle durch die Bibel an ihn erinnert trotz der Eintauchung des ganzen Gedankens in die Atmosphäre des strengsten Kirchen- und Gnadenprinzips, die dann immer wieder durch die Zurückführung aller individuellen Persönlichkeit und ihrer Leistung auf die Auswirkung der Prädestination erreicht wird ${ }^{320}$ ).

${ }^{320}$ ) Ueber diese Sonderart des reformierten Individualismus Schneckenburger und bes. Max Weber, Archiv XXI S. 5-14, wobei Weber sehr mit Recht hinweist auf den sehr verschiedenen Sinn, den das Wort Individualismus decken könne. Es kann die mittelalterliche Bewegungsfreiheit und Buntheit abgestufter Beziehun- 
Damit steht scheinbar im Gegensatz der d r it t e Hauptpunkt, die zentrale Bedeutung des Gemeindegedankens und die Aufgabe der Herstellung einer heiligen Gemeinde, einer Gott im geistlichen und weltlichen Handeln verherrlichenden Christokratie. Aber dieser Gemeindegedanke ist auch nicht von dem Kirchen- und Gradengedanken hergeleitet wie der lutherische, sondern von demselben Prinzip, das das Individuum zu verselbständigen scheint, nämlich von der ethischen Aufgabe der Bewährung und Auswirkung der Erwählung und von dem abstraliten Biblizismus. Die Kirche ist nämlich für ihn nicht bloß Heilsanstalt der Darbietung der objektiven Heilsmittel, von denen alles übrige als Folge zu erwarten wäre und von der aus die Ungöttlichkeit der Welt in Demut und Geduld crtragen werden müßte. Die Heilsanstalt soll vielmehr zu-

gen bei relativer Gleichheit der geistigen Lebensinhalte, die moderne Bewußtheit und Differenziertheit bei möglichster Gleichheit der rechtlich-sozialen Lage, die katholische Mystik und den katholischen Liberalismus, die lutherische Glaubensseligkeit und die reformierte Selbstkonzentration und Selbstkontrolle bedeuten. Nicht ein gesteigerter Individualismus, sondern eine besondere Art des Individualismus charakterisiert den Calvinismus, s. Weber S. 12. Vgl. auch Rieker S. 72 und Seeberg, Begriff der Kirche I ${ } 88_{5}$ S. 123 , die jedoch die Bindung der Auswirkung der Prädestination an die kirchlichen Mittel unterschätzen, weil sie glauben die späteren Indepedenten und Sekten direkt aus dem reformierten Individualismus ableiten zu müssen. Das ist aber gegenüber dem direkt an Luther angelehnten Kirchenbegriff unmöglich. Für Calvin sind Kirche und Prädestination keine Konkurrenten und ist der Kirchenbegriff in die Prädestination eingerahmt. Immerhin hat dieser Individualismus aus ethischen Gründen mehr Berührung mit dem der Sekten. Aber er ist, wie alle Annäherung an Gesetzlichkeit, Selbstbejahung des Willens, Herleitung der Gemeinschaft aus dem Zusammentritt der Individuen, was alles den Sekten zukommt, durch den in die Prädestinationslehre investierten Gnadenbegriff wieder aufgehoben. Dieses Wiederspiel der beiden Tendenzen hat Schneckenburger glänzend aufgedeckt. Er bemerkte auch erst die Analogie zur Sekte I 26: >Die äußere Kirche hat fast nur necessitas praecepti und es liegt nahe, sie sektiererisch ganz zu verwerfen ; 50: odie weit größere Bedeutung der kirchlichen Anstalt für den Lutheraner«; 157: DDie Kirche macht nicht die Gläubigen zu dem, was sie sind, sondern die Gläubigen machen die Kirche $z u$ dem, was sie ist: das ist der von Vinet sehr bezeichnend ausgesprochene Grundsatz, direkt entgegengesetzt der lutherischen Auffassung von dem Mutterschoß der Kirches; 167: ss war und ist noch immer der praktische Weg der Sektenbildung, wodurch sich etwaige Lehrunstimmigkeiten, häufiger noch aber bloß aszetische oder disziplinäre Dissonanzen, entladen. S. aber auch die Kehrseite der Sache in dem Abschnitt über die Unio cum Christo I 133-143, wo die Aufhebung dieser Konsequenzen durch die Prädestinations- und Gnadenlehre geschildert ist. 
gleich eine Heiligungsanstalt sein, sich in der Verchristlichung des Lebens der Gemeinde wirksam zeigen, indem sie den ganzen Umfang des Lebens unter die christlichen Gebote und Abzweckungen stellt. Sie soll zugleich die notwendigen Organe ausbilden, mit deren Hilfe die Gemeinde nach allen Seiten des Lebens in Kirche, Familie, Staat, Gesellschaft und Wirtschaft, in allen privaten und öffentlichen Beziehungen dem göttlichen Geist und Wort gemäß gestaltet werden kann. Es ist die Vollentfaltung der Gedanken, die Luther in den Jahren der Gärung und der lokalen Reformen gestreift, aber aus Mangel an wirklichen Christen hatte fallen lassen. Immerhin ist doch aber auch hier die Absicht eine etwas andere und der praktischen Verwirklichung fähigere, als es die Gedanken Luthers gewesen waren. Diesem kam es hierbei infolge seiner Betonung der Freiheit und Persönlichkeit vor allem auf die Folgerungen aus dem Prinzip des allgemeinen Priestertums an, auf die Selbstverwaltung und Selbstregierung der Gemeinde, wobei dann die Gemeinde auch noch die Mittel der Selbstkontrolle und Zucht ausbilden mochte, aber all das in voller Freiheit. Aber eben weil es ihm wesentlich auf das allgemeine Priestertum ankam, zog er sich dann vor der Verwertung dieses Prinzips durch die revolutionär demokratische Bewegung auf die bloße Sicherstellung der reinen Predigt durch die Landesherren zurück. Calvin kam es aber nicht auf das allgemeine Priestertum, sondern auf die Bewirkung der Kontrolle und Reinheit der Gemeinde an ${ }^{321}$ ). Er war von deren Notwendigkeit -so sehr überzeugt, daß er nicht zweifelte, hierfür ebenso wie für das Dogma die Grundlagen und Weisungen in der Schrift zu finden. So entwickelte er, genau wie Luther das Dogma, seinerseits auch die Verfassung und christliche Gestaltung der Gemeinde aus der Schrift. Sie enthielt ihm außer der Rechtfertigung und der Prädestination auch die Verfassung der Kirche in den berühmten vier Aemtern der Geistlichen, der Doktoren oder theoretischen Theologen, der Diakonen oder Armenpfleger und des Zuchtgerichtes, das aus Geistlichen und gewählten Gemeindevertretern gebildet werden sollte. Durch den Ausgangspunkt von dem ethischen Heiligungsinteresse und von den biblischen Weisungen statt von den Forderungen des allgemeinen Priestertums war die Sicherheit gegen jeden demokratischen und revolutionären Mißbrauch, gegen jeden religiösen Subjektivismus gegeben. Die in diesen Grenzen mög-

$\left.{ }^{321}\right)$ S. sehr treffend Rieker S. 139f; auch Köstlin Stud. und Krit. 1868 S. 483. 
liche Beteiligung der Gemeinde an der Bestätigung der ihnen vom geistlichen Kollegium vorgeschlagenen Pfarrer, an der Wahl der Diakonen und an der der Aeltesten und Zuchtrichter räumte dem allgemeinen Priestertum und religiösen Subjektivismus dann diejenige Rolle ein, welche olne jeden Schaden und ohne jede Gefahr eines Umschlages in weltlich-demokratische Bestrebungen gewährt werden konnte. Luthers Prinzip, für Ethik und Verfassung keine biblischen Dogmen zu haben und hier alles der freien Entwickelung zu überlassen, verbunden mit seiner Abneigung gegen jede Ueberordnung des ethischen $Z_{\text {weckes }}$ über die Rechtfertigungsseligkeit, hatten ihm diesen Ausweg unmöglich gemächt. Er mußte seine lediglich vom allgemeinen Priestertum aus entworfene und diesem die besondere Gestaltung überlassende Gemeindeidee aufgeben und sich auf die Objektivität der Predigtanstalt zurückziehen, die durch die Freigebung der Ordnungen und der Zucht an die Gemeinden lediglich bedroht, nicht gefördert war. Für Calvin aber bestand hier kein Gegensatz. Bei seiner Auffassung der Gemeindeaufgabe und der Gemeindeverfassung ergänzte sich beides trefflich, indem dieselbe Schrift, die sich dem Glauben als Dogma bezeugte, die Zustimmung zu den sittlichenund verfassungsmäßigen Ordnungen wirkte und damit das allgemeine Priestertum von Hause aus unter die wirksamsten Schranken stellte, ohne es aufzuheben ${ }^{322}$ ).

An diesem Punkt ist nun aber die Annäherung an den Sektentypus mit Händen zu greifen. Es ist hier nicht mehr bloß die instinktive Annäherung, die überall mehr oder minder durch die Bibel selbst bewirkt zu werden pflegt und die auch in Luthers Andeutungen seines engeren Gemeindeideals ernster Christen zu Tage getreten war. Hier liegt vielmehr ein besonderer, durch die Straßburger Reformatoren und durch Butzer vermittelter, Zusammenhang mit den Täufern vor. Wie man dort durch die Einrichtung des Bannes und der Sittenkontrolle den Täufern ihr berechtigt erscheinendes Wahrheitsmoment zugestand und ihnen durch eine strenge Heiligungsordnung der Gemeinde den Wind aus den Segeln zu nehmen suchte, so hat auch Calvin sich von der Christlichkeit und Biblizität dieser Forderungen überzeugt. Sie fügten sich überdies gut genug in seine ganze auf Alitivität gestellte Auffassung des Christusglaubens und der Prädestination ein ${ }^{323}$ ).

s22) Das ist ausführlich dargeleg! bei Hundeshagen und Choisy.

222) Sehr wichtig ist hier seine Schrift Contre les Anabaptistes C. R. 35. Hier 
Derart treten im Calvinismus eine Reihe von wichtigen Zügen hervor, die seinem Gemeindeideal mit dem täuferischen gemeinsam sind. Es ist vor allem die Einrichtung des Bannes und die Aufbehandelt Calvin den biblizistisch-konservativen $Z$ weig des Täufertums im ganzen sehr mild mit herablassendem Tadel gegen ihre Torheit und Ungebildetheit. Er bekennt namentlich bezüglich der Forderung der heiligen Gemeinde und der Exkommunikation die Gemeinsamkeit des Standpunktes, den auch die Täufer aus der Bibel gewonnen hätten, und bekämpft nur ihren atomistischen Separatismus, ihren lediglich auf die sittliche Würde der Person sehenden und die Objektivităt der Gnade verkennenden Subjektivismus und ihre Kulturfeindschaft. Insofern reiht sich in der Tat Calvin an das frühe lutherische Gemeindeideal an (W. Köhler, Christl. Welt 1907 S. $371-377$ ) und entspricht er den Tendenzen des von Barge aufgezeigten slaienchristlichen Puritanismuse. Nur ist aufs schärfste zu betonen daß Calvin jenes Ideal der heiligen Gemeinde gerade nicht vom Boden des Laienchristentums und des allgemeinen Priestertums zu erreichen strebte, sondern durch die Aufrichtung eines supranaturalen Kirchenrechts aus der Schrift, das von göttlicher Autorität war. Auch entzog er die Besetzung und Kontrolle des Predigtamtes der Gemeinde, indem er sie dem Pastorenkollegium und dem Rat anheim stellte, der Gemeinde nur ein Einspruchsrecht überließ. Auch die Laienältesten sind yon Geistlichen und Rat, nicht von der Gemeinde gewählt und haben halbklerikalen Charakter, Choisy L'état chrétien 536 . Versuche $z u$ einer weitergehenden Gemeindedemokratie wurden von den Geistlichen abgeschlagen Choisy 79, 149, 153. Die Reinheit der Abendmahlsgemeinde ist mit Begründung auf Paulus allerdings der Grundgedanke des Calvinismus, allein diese Reinheit wurde auf kirchlich-autoritärem. oder klerikal-staatlichem, nicht. auf sektenhaftem und laienchristlichem Wege aufrechterhalten. Deshalb, weil jeder Ausschluß durch das staatlich-klerikale Institut der Disziplin bewirkt wurde und bürgerliche Folgen hatte, war die Abendmahlsfeier stets ein bürgerlicher und kirchlicher Akt zugleich, Choisy 358. Nur so wurde Genf die sheilige Stadt , das s neue Jerusalem «, wie es mit Vorliebe genannt wurde, Choisy 430, 436. Das und die andere Stellung zur Kultur ist der Unterschied gegen das täuferische neue Jerusalem zu Münster; Luther gegenüber ist es die Supranaturalität des calvinistischen Kirchenrechtes, die den Aufbau einer festen Gemeinde ermüglichte und sie beim Kirchentypus erhielt, während Luther bei der Ablehnung jedes "neuen Gesetzes a in der Tat der Gemeindedemokratie und dem Sektentypus ausgeliefcrt worden wäre, wenn er seine Anfangspläne weiter verfolgt hätte oder hätte verfolgen können. Erst in Frankreich bei der Bildung staatsfreier Gemeinden kommt es zur Gemeindewahl der Aeltesten, Briefe $\mathrm{II}_{4}$ 69, der Pfalz hatte Calvin ein gemischtes Wahlsystem vorgeschrieben 413. Die Pfarrwahl lag aber stets in den Händen der Geistlichen II 330. Weitere demokratische Wendungen zur Laienchristlichkeit, Wahl der Geistlichen und Aeltesten durch die Gemeinde, Predigtbesprechungen unter Zuziehung der Gemeinde, was freilich sich bedeutend den täuferischen Gemeinden nähert, bei dem für Niederlande und Niederrhein so bedeutungsvoll gewordenen Joh. a Laski s. bei Göbel I 318-35I, 4 I2. 
fassung des Abendmahls als der Vereinigung würdiger und gläubiger Christen, von der die Ungläubigen fernzuhalten sind. Stets geht Kontrolle und Zuchtübung der Zulassung zum Abendmahl voran. So wird dieses außer der objektiven Vergewisserung des Sündenvergebungsheils auch die offizielle Revue und Reinigung der Gemeinde. Das letztere ist ein völliges Abweichen vom lutherischen Standpunkt. Die Abendmahlsfeier wird zum Mittelpunkt der Gemeinde. Die Reinheit der Abendmahlsgemeinde bleibt ein Gegenstand der ernstesten Sorge und führt zu Skrupeln und Enthaltungen; sie wird schließlich oft sogar ein Motiv der Separation. Während das Luthertum den Bann und die Sittenkontrolle der Obrigkeit übergab, übte ihn die calvinistische Gemeinde selbst aus, erst in späteren Zeiten auf rein geistliche Strafen sich zurückziehend. Die lutherische Vorbereitung auf das Abendmahl war die persönliche Ohrenbeichte und Absolution, das Abendmahl selbst eine Erfüllung der Vergebungssseligkeit mit der Realpräsenz des Leibes und Blutes Christi, die völlig isoliert ohne Gemeindefeier genossen werden können. Die calvinistische Vorbereitung dagegen sind prüfende Hausbesuche und Gemeinderevisionen, und das Herrnmahl hat Sinn nur als Gemeindeakt. Ganz ähnlich steht es mit der Taufe. Auch sie ist Gemeincleakt und bedeutet die Weihung des Kindes an die Gemeinde, worauf dann in den niederländischen und rheinischen Gemeinden erst die Vollaufnahme in die Gemeinde auf Grund eines ausführlichen Katechumenats folgte. Die Taufe ist die Anerkennung der zu mutmaßenden Erwählung und die Verpflichtung des Täuflings für die Gemeinde, aber keine Zuteilung der Gnade. Von da aus sind gelegentlich Bedenken gegen die Taufe aufgetaucht, vor allem gegen die Taufformel, sofern sie die Christlichisit des Kindes ausspricht statt nur die Verpflichtung zu ihr. Es ist klar, daß diese Behandlung der Taufe der Lehre der Täufer innerlich näher steht als derjenigen der Lutheraner und Katholiken ${ }^{32}$ ). Dazu kommt weiter die Hand-

824) Die Beispiele für all das bei Schneckenburger, Choisy und Göbel. Die Reinheit der Abendmahlsgemeinde als Hauptpunkt Schneckenburger I 64 f., Göbel II 73, die Taufe als Verpflichtung und der Anstoß an der Taufformel Göbel I 122, 175 f.; Schneckenburger I 254. Die Berührung dieser Ideen von Bann, Reinheit der Abendmahlsgemeinde und Taufe mit dem Täufertum und die von da aus auch in Calvinismus vorhandene Neigung, die Kirchlichkeit zu sprengen, vielfach hervorgehoben von Göbel I 88-99: $\gg \mathrm{Da}$ dies (die Separation) aus wichtigeren tiefer liegenden Gründen, weil man eben als $\mathrm{Kirch}$ e sich erhalten und nicht zur 
habung des göttlichen Gesetzes als des Mittels der Kontrolle und als der Regel für die fortschreitende Selbstheiligung der Einzelnen und der Gemeinde. Das biblische Sittengesetz ist nicht wie im I uthertum lediglich für die Erzcugung der Sündenangst und für den Gerechtfertigten nur, sofern in ihm der alte Mensch noch nicht überwunden ist, bestimmt, wobei dann die sittliche Leistung selbst ohne Gesetz aus dem Glauben fließst und nur für die populäre Unterweisung der christlich gedcutete Dekalog eine Anweisung des christlichen Handelns ist. Jas Gesetz ist hier vicl- mehr als positives christliches Sittengresetz, als Norm der Selbst' und Gemeindekontrolle, als Regel der aus der Erwählungsgnade folgenden Heiligung und der sie verwirklichenden Betätigung des heiligen Geisites gedacht. Wie in der Täufergemeinde herrscht auch hier eine strenge biblische Gesetzlichkeit der Moral in cler Selbstanschauung, in der Kontrolle und in der Selbstgestaltung des Heiligungslebens, wobei die vom Täufertum freilich schr abweichende inhaltliche Fassung des Gesetzes sofort näher zu erläutern sein wird ${ }^{325}$ ). Mit dieser Gesetzlichkeit verbunden ist dann weiter der Gedanke eines, kontinuierlichen Fortschrittes in der Heiligung, der zwar im echten Calvinismus nicht zur wirklichen Vollkommenheit, aber zu einer relativen, gradweise abzustufenden

Sek te werden wollte, nicht geschah, so blieb in allen Gemeinden immer noch sehr viel, in. manchen alles zu tun, um das hohe Ziel einer wahren, aus lauter Gläubigen bestehenden Gemeinde auch nur einigermaßen zu erreichen a. I 111 Bedenken gegen Kindertaufe und Fid; I13 Labadismus und Pietismus nur bekämpft, wo sie sektiererisch wirken; 211 zentrale Bedeutung der Hausgemeinde, uicht der Kirchengemeinde, weil erstere mehr zu wirklicher Christianisierung fähig ist.

325) Ueber diese Gesetzlichkeit s. Schneckenburger I 109-1.3I, Lobstein S. 51 bis 57; Inst. II 7,6-9; hier der Satz II 7, 1 2: Tertius usus legis, qui est praecipuus et in proprium legis finem propius spectat, erga $f$ deles locum habet, in quorum cordibus $j$ a $m$ viget et regnat dei Spiritus. Das Gesetz dient nicht der Sündenerkenntnis vor allem, wie im Luthertum, sondern dem Handeln des Wiedergeborenen; daher auch das Gesetz in den ref. Katechismen nicht vor, sondern nach dem Clauben. Mit katholischen Anklängen hat das nichts zu tun. Denn der Gehorsam kommt aus dem Glauben, wohl aber mit der Strenge der Heiligkeitsgemeinde; es ist mit der Prädestination durch den Bewährungsgedanken und die - bel Calvin selbst verworfene Lehre - von den Kennzeichen des Gnadenstandes verknüpft. Hierzu außer Schneckenburger Göbel II 137, 145, 206, 215. Die einzige Analogie ist die täuferische Gesetzlichkeit, deren Moralismus aber im Calvinismus durch die Zurückführung auf die Prädestination beseitigt ist. 
Vollkommenheit führt. Das Luthertum kennt die Vollkommenheit nur als die qualitative Vollkommenheit des Gerechtfertigten, nicht als stufenweise aufsteigende Entwickelung der Heiligung. Das ist ein relativer Perfektionismus, dem nur bei den Täufern etwas Aehnliches entspricht; denn mit der katholischen Lehre von der beständig durch sakramentale Gnadeneinflüsse und Todsünden unterbrochenen Heiligung hat das nichts zu tun. Es ist ein aus der Grundidee reformierter Aktivität und aus der biblischen Lehre von der Ueberwindung der Sünde folgender Gedanke aktiver Heiligung, wie er zum Ideal der heiligen Gemeinde notwendig gehört ${ }^{326}$ ). Schließlich und vor allem aber zeigt sich die Analogie in der reformierten Christuslehre. Sie hält zwar die altkirchliche $Z$ weinaturenlehre und die paulinisch-scholastische Stellvertretungs- und Genugtuungslehre so streng fest wie die der Lutheraner und Katholiken. Aber die Bedeutung Christi ist hier doch nicht in erster Linie die, im Sühntod den Zorn Gottes auszulöschen und die Rechtfertigungsseligkeit zu begründen, die, glaubend ergriffen, eigentlich allein den ganzen Christenstand ausmacht und lediglich durch Wort und Kirche vermittelt werden soll, um alles weitere von selbst hervorzubringen bei verbleibendem Widerstand des Fleisches und der Sünde. Hier ist vielmehr Christus wie bei den Täufern Gesetzgeber, Vorbild und vor allem Haupt und Herr der Gemeinde, die sich ihm verpflichtet zur Nachfolge und von ihm in seine handelnde Kraft durch den heiligen Geist hineingezogen wird. Wie für die calvinistische Dogmatik innerhalb der Zweinaturenlehre dem Menschen Christus die relative Selbständigkeit zukommt, sich selbst die Seligkeit durch Gehorsam zu erwirken und wie dieses Handeln Christi durch den heiligen Geist auf die Christusgläubigen übergeht, so ist er Vorbild der lückenlosen Treue und Heiligung, Gesetzgeber der christlichen Heiligungsregeln, Bürge vor Gott für die ihm Folgenden und seine Willensbewegung in sich Aufnehmenden. Während Christus lutherisch in der Einheit der göttlichen und menschlichen

326) Ueber diesen Fortschritt der Heiligung und den relativen Perfektionismus 8. Schneckenburger I 45, $78 \mathrm{f}$. und $166 \mathrm{f}$. Es ist die Vorstufe des Methodismus, wie Schneckenburger gerne hervorhebt; auch Heppe, Geschichte des Pietismus und der Mystik in der reformierten Kirche 1879 S. 49, 126, 415, der von da aus den Uebergang zu Puritanismus und Pietismus zeigt. Auch an Wernle, Der Christ und die Sünde bei Paulus, ist zu erinnern; hier sind die biblischen Grundlagen des Perfektionismus gezeigt. 
Natur die in Wort und Sakrament anschaubare Sündenvergebung ist und mit ihr sich selber und alles dem Glauben schenkt, so ist er reformiert das Haupt und der Herr der Gemeinde, der durch seine Erlösungstat sie sich verpflichtet und erst mit der Vollendung der Gemeinde zur Heiligkeit und der aus ihr folgenden jenseitigen Seligkeit auch seinerseits selbst vollendet ist. Dic Unio mystica cum Christo ist lutherisch ein die Glaubensseligkeit noch real ausfüllender Segen substanzieller Einwohnung; die Unio cum Christo ist reformiert eine Relation der Glieder zum Haupte, das sie regiert, anweist und vollendet durch die glaubenweckende und stufenweise heiligende Kraft des heiligen Geistes. Das ist in den Formen der Zweinaturen- und der Versöhnungslehre eine weitgehende Annäherung an den täuferischen Gedanken von Christus als dem Gesetzgeber, Vorbild und Gemeindehaupt, der erst mit dem künftigen Gottesreich vollendet sein wird. Die täuferische Neigung zur Verwerfung des Versöhnungsclogmas fchlt freilich völlig, aber die Versöhnung ist doch auch so mehr ein Mittel der Erzeugung der Gemeinde als der in sich selbst ruhencle, entscheidende Akt der Umstimmung des göttlichen Zorns und der Beschaffung des kirchlichen Gnadenschatzes ${ }^{327}$ ). Von hier aus wurde auch erst die reformierte Bundesvorstellung für die christliche Gemcinde möglich. Die Gemeinde gründet sich auf einen von Gott durch Christus mit den Gläubigen geschlossenen Bund, in dem Gott sich zur Erfüllung seiner Gnadenverheißung und die Gemeinde zum Gehorsam verpflichtet, ein Gedanke, der völlig unlutherisch ist und ohne weiteres an die Aussonderungr der frommen und strengen Christen zum Sektenverbande erinnert. So ist in jeder Gemeinde eigentlich ein doppelter Bestand, ein Bestand der wahren und echten, treuen und handelnden Christen und ein solcher der bloßen Schein- und Weltchristen. Deshalb reizt auch der Calvinismus zur Sammlung der letzteren innerhalb der Gemeinde, zur

327) Hierzu s. die glänzenden Abschnitte bei Schneckenburger über die mystische Inwohnung I 182-255. Christus Herr und Gesetzgeber I 126; der Herr, in den die Gemeinde eingepflanzt wird I 136 . Ich meine natürlich nicht, daß hier eine historische Einwirkung der Täufer vorliegt, sondern die Konsequenz eines mit den Täufern gemeinsamen Gedankens. Gleiche Ursachen, gleiche Wirkungen. Dabei ist ja auch der Unterschied, der aus den beiderseitigen übrigen Voraussetzungen folgt, völlig klar. Immerhin ist es merkwürdig, daß $\mathrm{m}$. W. auf diese Analogie noch niemand hingewiesen hat. Auf den Begriff der vom Luthertum unterscheidenden Christokratie weist allerdings Choisy mehrfach hin. 
Aussonderung der reinen Abendmahlsgemeinde aus den Unreinen, zur Unterscheidung einer engeren und wciteren Gemeinde, was alles an die Scheidung von Welt und Heiligen erinnert, welche die Sekte aufrichtet. Die eigentlichen Bundesglieder unterscheiden sich von der dic Verworfenen mitumschließenden Kirche ${ }^{328}$ ).

In alledem hat der Calvinismus Folgerungen aus dem von ihm aufgenommenen und als biblisch anerkannten täuferischen Ideal der heiligen Gemeinde instinktiv gezogen und damit die Analogien zu ihm nach verschicdenen Seiten entwickelt. Allein diese Analogien haben doch wider ihre feste Grenze in dem kirchlichen Geiste einer die Abstufungen anerkennenden christlichen Volksgemeinde und Staatskirche, in dem Gedanken der reinen, jede menschliche Initiative ausschlicßsenden Gnade. Erstlich nämlich ist das christliche Sittengesetz und die Heiligkeit der Gemeinde so verstanden, daß gerade die äußerlich auffallendsten Forderungen der Täufer, die Zurückhaltung von Amt, Macht, Recht, Eid und Krieg sowie der Kommunismus, rundweg verworfen werden und im Stande des der Sünde angemessenen relativen Naturrechts alle diese Dinge als christlich erlaubt und geboten gelten. Obwohl auch an diesen Punkten der spätere, pietistisch gefärbte Calvinismus gelegrentlich bedenklich geworden ist, so hat doch Calvin selbst und der ganze orthodoxe Calvinismus hier mit größter Freudigkeit die Welt bejaht und gerade umgckehrt alle cliese Dinge in den Dienst der heiligen Gemeinde gestellt, sodaß er, wenn man ihn einmal überhaupt mit der Sekte zusammenstellt, mehr der aggressiven reformerischen Sektc mit ihrer christlichen Sozialreform und den Gotteskriegen als der duldenden und leidenden Sekte ähnelt. In Wahrheit liegt ihm aber doch in viel höherem Grade die allgemeine kirchliche Denk-

328) Ueber den Bundesbegriff Schneckenburger I 159, Göbel I 385, schon Olevian bei Heppe 205-240. Daß hierin das calvinistische Freikirchentum wurzelt hebt Gübel hervor 401, 418 niederrheinische Kirche, 423 Freiwilligkeits-, Bekenntnisund Verpflichtungskirche, 443 die Analogie dieser Kirchenidee mit der Sekte voll erkannt. Infolgedessen ein eigentlicher Kirchenkern in der Kirche; Göbel II 7 I engere und weitere Gemeinden, II 4 I 5 zwei Gemeinden in jeder Gemeinde. Göbel betont die darin liegenden Uebergänge zum Pietismus, wie denn der die Bundestheologie vertretende Coccejus durch diesen Bundesgedanken mehr für den Pietismus getan hat als Voet mit seiner Einrichtung von Konventikeln, die Coccejus nicht mitmachtc. Coccejus hat durch die Bundesidee die Kirchenidee innerlich und geistig mehr aufgelüst als der orthodoxe Voct, der nur der Gemeindezucht durch seine Konventikel aufhelfen wollte. 
weise zugrunde, von der wir noch sehen werden, wie sie mit der Forderung einer spezifisch christlichen Heiligkeit ausgeglichen wird. Zweitens ist die ganze Gesetzlichkeit, der Appell an persönlichen Entschluß, der Gedanke des Vorbilds und des Christusgesetzes, des Bundes und der Christusgemeinschaft nicht indeterministisch als Unterordnung, Bekenntnis und Zusammentreten der Individuen empfunden wie im Täufertum, das auch die Prädestination stets hart bekämpft hat, sondern als von Gott durch den Geist erzeugte Auswirkung der Erwählung. Der Eindruck eines atomistischen Individualismus und einer bloßen Summierung der Individuen ist nur eine oberflächliche und an der Vollzugsweise haftende Auffassung. In Wahrheit geht vielmehr alles aus von der wirkenden Erwählungsgnade und ist die Unio cum Christo, der Bund der Gemeinde mit Gott, der Vorsatz der guten Werke, das Gesetz und die Gesetzestreue, die Selbstanschauung und die ethische Vervollkommnung eine Wirkung Christi, des Gottmenschen, der durch seine menschliche Natur und den heiligen Geist als Mittel all das von seiner Gottheit aus bewirkt. Der Gehorsam und die Nachfolge Christi, das Bundesverhältnis und die Christokratie: all das ist in Wahrheit insitio in Corpus Christi; die Aktivität ist eine von der Erwählung erst geweckte. Der individuellen Initiative bleibt nichts als die Erkenntnis dieser Leistungen als Kundyebungen und Kennzeichen des Geistes, welche Initiative selbst aber wieder vom Geist gewirkt ist und sich an ihrem Vorhandensein als Christuswirkung erkennt ${ }^{329}$ ). Auch die Scheidung von Weltkindern und Heiligen hat unter diesen Umständen einen anderen Sinn als bei den Täufern. Da man äußerlich - mindestens am Mitmenschen -- die Erwählung oder Verwerfung nicht unterscheiden kann, so ist jeder als Erwählter zu präsumieren und zu ermahnen, sind andererseits die Verworfenen wenigstens äußerlich in die Zucht der Gemeinde zu nehmen, damit sie nicht Aergernis geben und wenigstens äußerlich Gott die Ehre erweisen. Beide Gruppen sind in

329) Hierüber vor allem Schneckenburger in dem Kapitel über die unio mystica: >Nur insofern kann man sagen, der Glaube füh r t zur Gemeinschaft mit Christus, die er wesentlich selber ist, als der Glaube in der ersten anfänglichen Gestalt noch nicht alles dessen bewußt ist, sondern es erst auf seinem Entwickelungsprozesse bewußt wird, was er als Produkt der gottmenschlichen Tätigkeit bereits in sich schließt< I 2 I9. Indem zu den Auswirkungsmitteln der Prädestination die Kirche, Wort und Gnadenmittel gehören, ist auf diesem Wege auch die Kirchlichkeit selber eingeschlossen. 
Die hl. Gemeinde als alle Stufen, auch die Verworfenen, umfassende Kirche. 635

einem kirchlich-bürgerlichen Gemeinwesen zusammenzuschließen und durch Staat und Kirche in der Zucht Gottes zu halten. Erst das Endgericht wird die Scheidung bringen. Die Menschen sollen in der sichtbaren Kirche keine Scheidung zwischen der in ihr enthaltenen unsichtbaren Gemeinde der Erwählung und den Verworfenen vornehmen. Der Calvinismus hat das daher auch vor seiner Umbiegung zum Pietismus nicht getan ${ }^{330}$ ).

330) Vgl. Choisy, La Theocratie. Hier und bei Schneckenburger ist der echte kirchliche Calvinismus geschildert, bei Choisy der Genfer und der Calvins, bei Schneckenburger der der Orthodoxic. Der reformiert-pictistisch empfindende Gübel hebt dagegen überall die ihm besonders sympathischen Verbindungslinien mit dem Pietismus hervor, weshalb er auch ein scharfes Auge fïr die Analogien des Ur-Calvinismus mit dem Sektentypus hat. Dadurch wird sein Buch so sehr lehrreich, während sonst - sogar bei Schneckenburger - die Herleitung der gesetzlich-asketischen Zïge vom Katholizismus her üblich ist. Immerhin liebt es doch auch Schneckenburger, Methodisten, Quäker, Pietisten, Puritaner zur Verständlichmachung heranzuzichen. Ueber die bei alledem verbleibende Kirchlichkeit s. Choisy S. 262: Calvin n'admet pas la libertí de l'homme; elle est exclue de son système théologique et de son système social. Le rìgne de Dieu ne se propose pas a la libre acceptation de l'homme; il s'etablit par la persuasion, sans doute, mais aussi par la repression de toute rébcllion, par la contrainte. Calvin n'admet pas que l'honneur de Dieu consiste à proposer sa volonté souveraine à la volonté de l'homme, qui l'accepte librement ou qui la nie, qui lui obéit ou qui lui résiste, qui se donne ou qui se refuse. Pour lui l'honneur de Dieu est maintenu, quand l'homme est courbi devant sa loi dans une attitude de soumission, libre ou forcéc. Les péchds contre Dieu et sa parole sont jelentifiés aux lélits'. Das betrifft Erwählte und Verworfene gleich. Ilicr liçt der Hauptunterschied gegen jede freikirchliche und pietistische Erweichung und Akzentuierung des Calvinismus, auch gegen jedes Sektentum. - Den trotzdem bestehenden Zusammenhang beider erkennt auch Luthardt, Gesch. der christl. Ethik II : »So energisch sich dieser (d. Calv.) der Wiedertäufer zu erwehren sucht, so ist doch der Zusammenhang mit jencr doppelten Denkweise (der spiritualistischen Mystik und der gesetzlichen Heiligungsgemeinde) nicht zu verkennen. Und wenn am Anfang vielleicht nicht bewußt, ist es später doch auch mit Bewußtsein ausgesprochen und geltend gemacht worden«. Noch klarer erkannt ist die Sache bei Ritschl, Gesch. d. Pietismus I 6I-98, wo auch die andere Stellung des Luthertums 2u Bann und Kirchenzucht trefflich erleuchtet ist. S. 7 : so wie nun Calvin die Notwendigkcit des Bannes und so, wie er die Ausdehnung der Auktorität des NT. verstand, tritt er in demselben Maße auf die Seite der Wiedertäufer, als er sich vom Luthertum entfernt«. „Der Calvinismus will in Verfassung und in weltfiüchtiger Sitte dic primitive Kirche soweit kopieren, als es seine Existenz im Staate zuläßt. . . Diese Aufgabe nun entspricht, wie es die Wiedertäuferei kundgibt, dem Reformtrieb, der beim Ausgang des Mittelalters in den Massen lebte. I 96. Ritschls Herleitung dieser Annäherung an den Sektentypus von Calvins angeb- 
Vor allem aber liegt ein grundlegender Unterschied gegenüber dem Täufertum in dem inhaltlichen Ideal des die heilige Gemeinde beherrschenden Christusgesetzes. Hier nimmt der Calvinismus nicht bloß keinen Anstoß an dem Eingehen auf die Ordnungen des relativen Naturgesetzes des Sündenstandes, wie bercits hervorgehoben, sondern er empfindet überhaupt kein Bedürfnis sich mit dem Christusgesetz des Neuen Testamentes, der Bergpredigt, auseinanderzusetzen. An diesem Punkt weicht Calvin von der Sekte noch viel weiter ab, als Luther, im Sinn eines praktischen Lebensverstandes. Während er einerseits, über Luther hinausgehend, das Ideal der heiligen Gemeinde und der sie sichernden Kontroll-Einrichtungen übernahm und festhielt, hat er andrerseits geradc an dem Punkt, wo Luther dem Sektenideal durch seine Anerkennung der Bergpredigtmoral als der cigentlich innerlich-persönlichen Moral des Christentums folgte, keinerlci Sympathie und biblische Gemeinsamkeit gespürt. Wie bei seinem Gottesbegriff der Gedanke der freien Allmacht und souveränen Ehre den der Liebe überragte, so herrschte auch in seiner Auffassung des christlichen Sittengesetzes von Hause aus die Rücksicht auf Gottes Iihre vor dem Gedanken an die Forderungen einer allen Kampf und alles Recht in der Gottesgemeinschaft auslöschenden Bruderliebe. Nichts tritt gegenüber dem Luthertum in seiner Ethik so charakteristisch hervor als dic Abwesenheit des Bedürfnisses, die radikale Liebesethik der Bergpredigt gegenüber den Forderungen der Sozialethik des praktischen politischen und gesellschaftlichen Lebens zu rechtfertigen und auszugleichen. Ueber seinem ganzen Briefwechsel, der unzählige ethische Fälle beurteilt, liegt auch nicht ein Hauch jener weltfeindlichen Personmoral und ihres Gegensatzes gegen eine doch zu akzeptierende Amtsmoral. Calvin hebt aus der christlichen Liebesmoral das religiöse Element der Betätigung von Gottes Ehre und der Heiligung. für Gott unà Gottes Zwecke, das sie immer von bloßer Sentimentalität und bloßer Humanität unterschieden hat, aufs schärfste und völlig instinktiv heraus. Er hält ohne weiteres alles für geboten und erlaubt, was der Ehre Gottes - und das iichem französischem revolutionär-egalitärem Volkscharakter ist freilich charakteristischer für den preußisch-konservativen Ritschl als für Calvin. Der Lutheraner Ritschl, der an Objektivität des Kirchentums die sLutheraner übertrumpft, kann sich gar nicht denken, daß solche Dinge einfach christlich sind d. h. eine unzerstörliche Seite des altchristl. Gedankens darstellen. Außerdeın ist von segalitär sei C. keine Rede. 
ist die Aufrichtung, Behauptung und Reinhaltung der Kirche als einer mit Staat und Gesellschaft eng verbundenen Gemeinde der Heiligen - dienen kann. Alle Forderung des Verzichtes auf Gewalt und Recht, auf Besitz und Reichtum, auf Vergeltung und weltliche Ehre sind von ihm immer nur innerhalb der Grenze verstanden, daß jener Verzicht lediglich der Heiligung und Bruderliebe dient, aber nicht irgendwie Gottes eigene Ehre selbst gefährden darf. Wo diese im Spiele ist, da sind alle jene Mittel in den Grenzen der Wahrhaftigkeit, der persönlichen Milde und des reinen Interesses an der Sache ohne $\mathrm{Haß}$ und Schädigung gegenüber den Perșonen nicht bloß erlaubt, sondern geboten. In diesem Sinne deutet er ohne weiteres die Bergpredigt und beruft er sich vor allem immer wieder auf das Alte Testament, dem die Bergpredigt bei der Einheit der Bibel nicht widersprechen könne, auf die Reformen und die Politik der frommen Könige, auf den Dekalog und die spätjüdische Moral, auf David und die Psalmen. Der Erfolg alles Handelns ist stets in Gottes Hand zu legen, aber der Gläubige hat jedes erlaubte Mittel zu benützen und kann es unmittelbar auf den religiösen Zweck beziehen ohne den Umweg überr eine fremde Amtsmoral. Nur insofern ist diese erhalten geblieben, als auch Calvin überall diejenigen in den Vordergrund stellt, die durch Amt und Beruf zum Gebrauch von Gewalt und Recht, zur Ausübung von Politik und Krieg, berufen sind. Aber bei ihnen geht dies dann ohne jede Vermittelung und innere Spannung ein in die religiöse Aufgabe. Calvin selbst handelt und schreibt als ein in allen Künsten erfahrener Politiker und als ein alle Chancen erwägender militärischer Stratege. Der Masse fällt hierbei freilich nur der Gehorsam gegenüber den Führern zu, aber ohne alle Bedenken über deren christliche Befugnis, Macht und Gewalt zur Ehre Gottes zu brauchen. Auch gegen das Privateigentum und das Besitzstreben hat er, vorausgesetzt, daß alles ehrlich, mit Maßen und mit reichlicher Liebestätigkeit verbunden vor sich gehe, nichts einzuwenden. Alles das dient dem Wohl der Gemeinde, des Staates und damit der Ehre Gottes; es ist nur nach seinen Schranken, aber nicht an sich selbst ein Problem. Unter diesen Voraussetzungen begreift man erst ganz die starke Heranziehung des Alten Testaments. Nur wenn man die neutestamentliche Ethik so, wie Calvin, mit der alttestamentlichen verschmilzt, wenn man Gottes Liebe als Erwählungswillen und die Liebe zu Gott wesentlich als Heiligung des Einzel- und Gesamtlebens für Gott 
versteht, ist eine derartige Deutung des Neuen Testamentes möglich. Calvin hat es völlig instinktiv getan ohne Polemik gegen die lutherische Ethik, in der Ueberzeugung, durch seinen echt reformatorischen Biblizismus dazu genötigt zu sein, und in dem Gefühl, daß dem echt reformatorischen prädestinatianischen Gottesbegriff auch eine solche Ethik entspreche. Wie schon Luther zur Rechtfertigung seiner innerweltlichen Berufsethik in steigendem Maße auf das Alte Testament zurückgegriffen hatte, so tut das daher nun vollends Calvin; er konnte auch hier glauben, gemeinsame reformatorische Sätze nur strenger und praktischer durchzuführen; auch war Calvin niemals durch die Schule des Mönchtums durchgegangen. So war es ihm möglich, seiner Gemeindezucht und Staatsgestaltung eine Heiligungsethik zugrunde zu legen, die an Strenge mit der der Täufer sich vergleichen konnte, ohne doch die für die Gesellschaft unmögliche radikale Liebesmoral der Bergpredigt zum allgemeinen Gesetz zu machen. Hier liegt die eigentliche Quelle des angeblich alttestamentlichen Charakters des Calvinismus. Es ist dasselbe Motiv, das auch schon früher den Typus der gewaltsam reformierenden Sekte zum Alten Testament, seinen Gotteskriegen und Bundschließungen getrieben hatte. Nicht jüdische Gesetzlichkeit lebt hier wieder auf, sondern die alttestamentliche Rücksicht auf das praktische Volksleben. Und auch mit Rückfällen in den Katholizismus hat dies Ideal der heiligen Gemeinde nichts zu tun. Es ist das Sektenideal, aber verbunden mit der Anstaltskirche und durch die starke Verwendung des Alten Testamentes auf das Niveau des Möglichen erhoben, im übrigen aktivster und lebendigster Protestantismus. An Luthers duldender Leidensund Liebesmoral gemessen ist es freilich ein mehr praktischer und opportunistischer Standpunkt. Aber da der Zweck überall nur die unter völliger Aufopferung eigenen Interesses zu bewirkende Ehre Gottes und der Gemeinde ist, so ist es darum keine Herabstimmung der christlichen Moral auf die Durchschnittlichkeit, sondern nur die Heraushebung des andern immer mit jenem verbundenen Elementes der christlichen Moral, des rücksichts'us alles für Gottes Ehre leistenden Heroismus ${ }^{331}$ ). Wird diese Ehre

s31) Ueber Calvins Ideal des Heroismus und dessen bewussten Zusammenhang mit dem Platonismus (wohl auch und noch mehr dem Stoizismus), s. den Abschnitt in dem gleich zu erwähnenden Buch von Beyerhaus S. 153-I 55. Eine Färbung stoischer Moral liegt doch auf Calvins Humanismus, viel tiefer empfunden als bei Me- 
in der Aufrichtung einer heiligen Gemeinde gesehen und nicht bloß in der Bewährung der weltüberlegenen Innerlichkeit des Individuums, dann wird der Heroismus nicht bloß leidend, sondern handelnd und organisierend sein und die dazu nötigen Mittel ergreifen müssen. Gerade das ist aber der Charakter der calvinistischen Ethik, die an Verleugnung des persönlich-utilitarischen Wohles wahrlich das Ungeheuerste geleistet hat, auch wenn sie die Mittel der weltlichen Ordnungen benutzte für das Reich Gottes. Die Ehre Gottes liegt für Calvin eben nicht in der restlosen Selbsthingabe des Sünders an die vergebende Liebe als solche, sondern in der Hervorbringung der heiligen Gemeinde durch die Selbsthingabe an Gott und seine Gebote ${ }^{332}$ ).

lanchtons bloßem Schulmeister-Humanismus. Er ist der humanistischeste der Reformatoren s. Arnold S. IIf. S. auch die Analyse des Kommentars zu Senecas De Clementia bei Beyerhaus I-25. Man glaubt in seiner Fthik die Nachwirkung des Humanismus und des juristischen Denkens ebenso zu spüren wie in der Luthers die des Mönchtums.

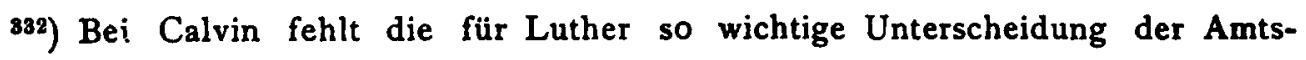
und Personmoral. Zwar hat Calvin auch hier die Formeln Luthers, vgl. Contre les Anabaptistes CB. 35 S. 77: Or il est vray qu'e n particulier l'usage du glaive ne doit estre permis a nul pour faire resistence au mal. Car les armes des Chrestiens sont prieres et mansuetude, pour posseder leurs vies en patience et vaincre le mal en bien faisant selon la doctrine de l'Evangile Luc. 2 I, 19. Rom. 12, 2 I. L'office de chacun de nous est de souffrir patiemment si on nous fait quelque outrage plus tot qui d'user de focre et violence. Mais de contamne $r$ le glaive publique, lequel Dieu a ordonne pour nostre protection, c'est un blasphème contre Dieu mesme. Aehnlich die Stelle bei Lobstein S. 12I. Aber hierbe i ist der Gegensatz der Rechtsordnung und ihres Straf- und Gewaltgeistes, ihres Zusammenhangs mit dem Kampf ums Dasein gegen die reine Liebes- und Freiwilligkeitsordnung ganz verloren gegangen. Die Rechtsordnung ist lediglich ein nützliches, gottgeordnetes Glied in dem Aufbau der rationellen Gesellschaft, wie bereits im AT. Das tritt am deutlichsten hervor in der calvinistischen Auslegung der Berg predigt, deren Resultate in der Schrift Contre les Anabaptistes CR 35, in der Institutio IV 20, 17-22 und in der Auslegung des Dekalogs II 8 fast identisch vorgetragen werden. Die Bergpredigt ist nach dem AT zu verstehen wegen der Unveränderlichkeit Gottes; Christus hat nichts hinzugesetzt und nichts geändert, sondern durch seinen Nicht-Widerspruch die ATliche Sozial- und Rechtsordnung bestătigt; lediglich pharisäische Mißdeutungen hat er bekämpft. So gehören zu Christi Gesetz auch die harten Strafgesetze bezüglich des Ehebruchs. Inst. II 8, 26: -Christo non est institutum legem aut laxare ant restringere, sed ad veram ac germanicam intelligentiam reducere, quae falsis Scribarum et Pharisaeorum commentis valde depravata fuerante. So werden Eid, Recht, Gewalt, Krieg, Besitz als von der 
So versteht sich also nclsen dem eigentümlich akzentuierten und auf sich sclbst gestellten Individualismus sehr wohl die Be-

Bergpredigt aherkannt bezeichnet. Auch fordert solche Auslegung das praktische Interesse der Gescllschaft vgl. Bezas Urteil über die Todesstrafe für doppelten Ehebruch, Choisy S. 185: \& Et ce d'autant que pour punir ce crime capitalement, il faut avoir esgard non sculement à l'impudicitć, mais a us si et principalement a l'interest de lasocict la umaine, laquelle ne peut subsister si la distinction des familles, hćritages et successions n'est conservée, ce qui rend ce crime naturellement capital, comme expose tres bien Mr. Calvin sur l'histoire de Juda, Genes. 28, 24\%. Die Geschichte von der lihebrecherin wird umgedeutet. So ergibt sich für Calvin aus der Bergpredigt lediglich ein Gebrauch der bürgerlichen Ordnungen und des Rechtes ohne persönlichen Haßs und Leidenschaft zum objektiven Zweck der Herausstellung des Rechtes und des Schutzes der Gesellschaft Inst. IV 20, I $\delta$ und R. 35 S. 44. Calvin weiß, daß schon das schwer und selten genug ist. - Das ist alles unzweifelhaft praktisch und verständig, aber ganz anders empfunden als Luthers Ethik. Der Grund der andersartigen Auffassung liegt darin, daß die Moral Calvins nicht ihren Schwerpunkt in der freiwillig überströmenden Liebe, sondern in der Lauterkeit des Gewissens und dem Heroismns der Selbstverleugnung für die Aufrichtung der christlichen Gemeinde hat. Die Liebe in Luthers Sinn ist ïberhaupt nicht ihr Grundbegriff, daher fehlt auch der Gegensatz des Rechtes und Zwanges s. Choisy, La Theocratie S. 258. Darüber gibt Calvin selbst deutlich Aufschluß. Die Summe der Ethik ist ihm (Briefe II I0o), $>d a ß$ wir stark sind im Hoffen und Dulden, daß wir nüchtern und mäfig uns der weltlichen Lüste enthalten, daß wir uns eifrig mühen, die Leidenschaften des Fleischẹs zu bändigen, daß das Streben nach Gerechtigkeit und Frömmigkeit kräftig in uns lebt, daß wir eifrig sind zum Gebet, daß uns der Gedanke an das ewige Leben aufüärts zicht«. Von Moses sagt er charakteristisch II 221, >woher er solche Festigkeit nahm, nämlich weil er hart geworden war im Aufschauen zu Gott<. Luthers so hochgeschätzte "Deutsche Theologie s verwirft Calvin *als ein Geschwätz vom Teufel geschmicdet in seiner Schlauheit, um die Einfalt des Ev. ganz durcheinanderzubringen. II 258. - Ganz besonders äußert er sich über die Li e be an Renata von Ferrara II $470 \mathrm{ff}$. zur Verteidigung des Hasses gegen die Bösen; insbesondere gegen ihren Schwager, den ermordeten Herzog von Guise. Renata wollte dicsen nicht verunglimpft sehen, darauf schreibt Calvin: Auf meine Bemerkung, David lehre uns durch sein Beispiel die Feinde hassen Ps. 31, 7 und 16I, 3: sagen Sie, das sei zu der Zeit gewesen, da es unter dem Gesetz der Strenge noch erlaubt gewesen sei, den Feind zu hassen. Nun, Madame, eine solche Auslegung könnte die ganze Schrift umstürzen, und deshalb müssen wir sie meiden wie tödliches Gift. Denn man kann wohl sehen, wie David den besten Menschen übertraf, den man heute finden könnte. . . Wenn er aber dann doch sagt, gegen die Verworfenen hege er einen tödlichen $\mathrm{Haß}$, so rühmt er sich zweifellos seines rechten reinen Eifers, der ganz in Ordnung ist, wenn folgende drei Bedingungen erfüllt sind: I) Daß wir nicht uns und unser persönliches Interesse 
tonung der Gemeinschaft in dem umfassenden Sinne eines staatlichkirchlichen Verbandes christlicher Heiligung unter Vorbild, Gesetz

in Betracht ziehen, 2) daß wir Klugheit und Vorsicht walten lassen und nicht leichtsinnig urteilen, 3) daß wir Maß halten und nicht über das hinausgehen, wozu wir berufen sind. Das können Sie an mehreren Stellen meiner Psalmen noch weiter ausgeführt lesen. Eben darum hat uns sogar der h. Geist den David gegeben, als Schutzpatron sozusagen, daß wir darin seinem Beispiel folgen. Es ist uns ja tatsächlich gesagt, daß er in diesem Eifer ein Vorbild unseres Herrn Jesus Christus war Ps. 69, 10 und Joh. 2, 17. Wollten wir nun den, der der Quell alles Mitleids und Barmherzigkeit war, an Milde und Freundlichkeit übertreffen, dann wehe uns! Um alle Auseinandersetzung abzuschneiden: wir wollen uns doch damit zufrieden geben, daß St. Paulus gerade diesen Spruch auf alle Gläubigen anwendet, daß der Eifer um Gottes Haus sie verzehren soll Ps 69, 10 und Rom. 15, 3. . . Das Mittel (gegen falsche Auffassung der Liebe) ist: Das Böse hassen, aber uns nicht an die Personen halten, sondern jeden seinem Richter überlassenc. - Das ist zugleich ein Beispiel der gleich herrorzuhebenden Sachlichkeit und Unpersönlichkeit calvinistischer Moral. Hierher gehört auch die bei Weber XXI S. I3 zitierte Auslegung des Racheverzichtes bei Hoornbeck: Denique hoc magis ulciscimur, quo proximum, inultum nobis, tradimus ultori Deo. Quo quis plus se ulciscitur, eo minus id pro ipso agit Deus! Ein ähnliches Beispiel S. 32. Hier sind wir durch eine Welt vom Luthertum getrennt. Charakteristisch ist auch die bei Beyerhaus mitgeteilte Stelle aus CR 57, 143: Car en cela (in der ^gegen die angeborene Liebes gehenden Tötung von Freunden, Brüdern und Nächsten Ex. 32, 27) monstrerez. . vous que vous estes vrais zelateurs du service de Dieu, quand vous tuerez vos propres frères, et que rien ne sera espargné: que l'ordre de nature sera mis sous le pied, pour monstrer que Dieu domine par dessus tout, et qu'il a son degré souverain . Für Luther ist die natürliche Liebesordnung (in ihrer urständlichen Vollkommenheit) identisch mit dem göttlichen Sittengesetz, bei Calvin tritt das natürliche Liebesgesetz und das positive göttliche Gesetz der bedingungslosen Verherrlichung an Gottes Souveränetät unter Umständen auseinander. Das führt auch diese Fthik auf die fundamentale Differenz im Gottesbegriff zurück. - Das ist nun jedenfalls cin ganz anderer Geist als der der lutherischen Ethik und auch als der les NT. Die biblische Berechtigung hierfür bietet für Calvin das $\Lambda \mathrm{T}$., das er zu diesem Zweck überall in das Neue hineindeutet. Sein Grundgedanke ist die Erfüllung des ewigen unveränderlichen Gesetzes durch die Erwählungsgnade in dem neuen Israel der von Christus gebildeten Gemeinde. Das ist von Choisy mit vollem Recht überall betont worden. Es ist nur hinzuzufïgen, daß ohne das die praktische Arbeit Calvins unmöglich geworden wäre, genau \$o unmöglich, wie die Luthers tatä̈chlich geworden ist. Von neutestamentlicher Geist aus ist eben unmittelbar überhaur" keine Weltgestaltung möglich. Das hat die ganze bisherige Untcruchung gclehrt, und Calvins Heranziehung des AT. für alles praktisch Wichtige ist nur circe weitere Probe darauf. So deutet auch heute noch z. B. Rauschenbusch, Christianits and the social crisis 1904, Jesu Predigt aus den Propheten und scin Gottesreich

Troeltsch, Gesammelte Schriften. I. 
und Herrschaft Christi. Die aus dem Neuen Testament und aus der täuferischen Kritik der Reformation aufgenommenen sektenhaften Motive sind mit den gleichzeitig anerkannten Motiven der kirchlichen Gnadenanstalt verschmolzen im Prädestinationsgedanken, der die ersteren durch seine Aktivität noch verstärkt und sie doch durch die letzteren eingrenzt. Daraus aber erklärt sich im ganzen Calvinismus die gleichzeitige Richtung auf aktive Gemeinschaftsgestaltung und auf persönliche Leistung, verbunden mit der methodisch rationalisierten, auf das Ziel der jenseitigen Seligkeit orientierten Planmäßigkeit und Vollständigkeit des Handelns. Das führt ihn überall zu organisierter und aggressiver Gemeindebildung, zu einer planmäßigen Bearbeitung des gesamten Gesellschaftslebens, zu einem >christlichen Sozialismus«, der freilich nicht wie der moderne wesentlich auf die materiell-wirtschaftlichen Vorbedingungen der höheren geistigen Kultur achtet, der auch selbstverständlich mit den durch Kapitalismus und Industrialismus geschaffenen modernen Klassenproblemen noch nichts zu tun hat, der aber jedenfalls die Fürsorge der Gemeinde für die Gesamtheit der Lebensinteressen vorschreibt und das religiöse Element gegen die übrigen weder isoliert, wie das Luthertum, noch in blossen einzelnen Stiftungen und Eingriffen hervorbrechen läßt, wie der Katholizismus ${ }^{333}$ ).

a us dem prophetischen Gesellschaftsideal und bezeichnet die Kirche als abtrünnig, weil sie dem mystischen Individualismus des Griechentums verfallen sei! Für alle politischen und sozialen Dinge beruft sich Calvin tatsächlich auf das AT. s. Briefe I 234, 345, 393, 405. Vgl. Choisy, L'etat chrétien S. $516 \mathrm{f}$.

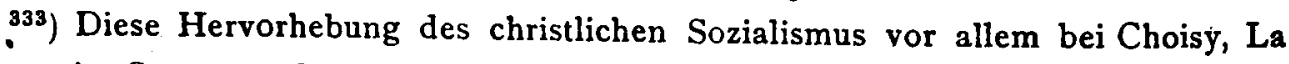
Théocratie, S. 244 und 278. Erst hier wird das Christentum bewußt und planmäßig sozial, nachdem es bei den Täufern und Sekten dazu einen sehr zersplitterten oder sehr schwärmerischen Anlauf genommen hat. S. oben S. 82 und 423. Auch an diesem Punkte erhellt die Analogie von Calvinismus und Sektentum, sowie ihre Grenze. Der Calvinismus versteht den christlichen Sozialismus als staatlich-kirchliche Lebenseinheit (Choisy 250-254) und stimmt die überidealistischen Maßsstäbe der Sekte herab zur praktischen Verständigkeit. Deshalb hat auch er und er allein Erfolg gehabt in einer tiefgreifenden Völkererziehung, Choisy 205: - Les peuples protestants sont là pour montrer que l'oeuvre ecclésiastique et sociale de Calvin, son effort colossal pour réaliser sur la terre l'idéal social du royaume de Dieu, n'ont pas été vainse. Vom modernen christlichen Sozialismus ist dieser altcalvinistische durch seinen noch überwiegend ethischen und ideologischen Charakter verschieden, während jener auf der ökonomisch-geschichtlichen und technologischen Grundlage der modernen Sozialtheorien ruht. Daran dachte jene Zeit überhaupt 
Damit ist der vierte Punkt schon berührt, die eigentümliche calvinistische Ethik. Hier wurde die mit Luther gemeinsame Motivierung der Ethik aus dem Glauben zunächst lediglich noch systematischer und klarer durchgeführt. Aber dabei ward doch die Ethik aus einer bloßen Folge zum Zweck der Rechtfertigung gemacht, was unter der Voraussetzung der Prädestinationslehre ohne jeden Rückfall in Werkheiligkeit und Lohngedanken sehr wohl möglich war. Es ist ferner die Normierung des christlichen ethischen Handelns handgreiflicher entworfen, indem der heilige Geist als Mittel dieser Normierung von vornherein klar und deutlich das biblische Sittengesetz darbietet, den Dekalog mit seiner Deutung aus dem Gesamtumfang der Bibel und in seiner Identität mit dem natürlichen Sittengesetz. Hier hatte ja auch das Luthertum nicht bei dem bloßen freien Trieb des Handelns stehen bleiben können, sondern hatte im Dekalog die göttliche Verdeutlichung des sittlichen Triebes anerkannt. Seine Theorie vom Dekalog, den zwei Tafeln des Dekalogs, der Identität des göttlichen und natürlichen Gesetzes, die christliche Deutung des Dekalogs als Gesinnungs- und Freiheitsgesetz, das auf die Kraft des heiligen Geistes zu seiner Verwirklichung rechnet: alle diese Theorien übernahm auch der Calvinismus. Aber er gab dem Dekalog eine festere Stellung im System, indem der usus legis bei ihm nicht ein distinktionenreiches Problem, sondern eine festgefügte Haupttheorie wurde. Warum sollte der heilige Geist in der Ethik der Klarheit entbehren, die er in cler Dogmatik wirkte, wo doch die Eibel ethische Weisungen ebenso gibt wie dogmatische? Das ist in Calvins Sinn weder ein Rückfall in Heteronomie noch in Gesetzlichkeit, da in diesem Gesetz ja nur der Glaubensinhalt nach seiner ethischen Seite verdeutlicht wird und der Wert der sittlichen Leistung ja nicht in einzelnen Werken, sondern in der aus dem Glauben entspringenden Gesinnung, im Ganzen der Persönlichkeit, im Gesamt-

noch kaum, weil ihre Verhältnisse sie nicht dazu nötigten. Immerhin aber kümmert sich der Calvinismus doch auch schon um die materiell ökonomische Unterlage des ethischen Lebens und weiß die Statistik zu schätzen. Davon später mehr. Ueber diesen christlich-sozialen Zug bis zur Gegenwart sind sehr feine Bemerkungen bei Karl Hartmann ,Englische Frömmigkeit, eine Studie a 1910 (Beilage zum Jahresbericht des prot. Gymnasiums zu Straßburg). Die Arbeit enthält über Calvinismus und Sekten eine Menge erleuchtender Angaben und bestätigt überall die Auffassung, die hier vorgetragen wird. 
umschwung der Bekehrung, liegt ${ }^{384}$ ). Durch den Dekalog klärt der heilige Geist lediglich die Erwählten über die zur Verwirklichung des Christusreiches führenden Regeln des Handelns auf, die dem bloßen dunklen Trieb und natürlichen Gefühl nicht überlassen bleiben können. Auch hier ist Calvin nur der systematische Denker und der praktische Organisator, der freilich damit aus dem freien Idealismus Luthers einen Schritt in die gebundene Durchschnittlichkeit des menschlichen Autoritätsbedürfnisses tut. Dazu kommen als weitere Eigentümlichkeiten. der calvinistischen Ethik die Perseveranz oder Unverlierbarkeit der Gnade, die im Unterschiede von der lutherischen Verlierbarkeit der Gnade und Wiederbolbarkeit der Rechtfertigung ein einheitliches, kontinuierliches, seiner selbst gewisses Subjekt der sittlichen Leistung schafft; ferner die Lehre von einer progressiven Vervollkommnung, die den Keim' der Erwählungsgnade immer bewußter macht und immer • vollständiger entfaltet im Gegensatz zu der Bedenklichkeit des I.uthertums gegen jeden Fortschrittsgedanken und gegen seine Verknüpfung mit der Anbahnung der himmlischen Seligkeit. Das gibt der reformierten Individual- und Sozialethik das Planmäßige, Rationelle, Umfassende und Fortschreitende, das überall ein Ideal nicht bloß der privaten christlichen Lebensleistung, sondern der einheitlichen Einbefassung alles Weltlichen in die religiöse Zielsetzung bedeutet. Eine größere Geschlossenheit, umfassendere Totalität und eindringendere Energie der Soziallehren ist hievon die naturgemäße Folge. Durch die Behandlung der sittlichen Fortschritte und Leistungen als der praktischen Kennzeichen des Gnadenstandes ist das dann noch ganz außerordentlich intensiviert und freilich auch veräußerlicht, damit jedoch dem Durchschnitt auch zugänglicher gemacht worden ${ }^{333}$ ).

Doch sind das alles mehr formale, wenn auch sehr folgenreiche, Charakter prägende Eigentümlichkeiten der reformierten Ethik. Wichtiger noch ist ihre inhaltliche Eigentümlichkeit: die aus der jenseitigen Zielbestimmung und der spröden Trennung von Gott und Kreatur folgende asketische Haltung, welche doch

334) S. Lobstein S. 58-60; Dekalog sowenig heteronom wie das natürliche Sittengesetz, beides Mittel der Versittlichung und Christianisierung der Gesellschaft.

${ }^{335}$ ) S. Lobstein S. 75-78: kein Bußkampf wie im Luthertum, sondern Entfaltung innerhalb der Gemeinde und durch die Gemeinde für die Gemeinde. Im übrigen s. vor allem Schneckenburger, dessen Meisterschaft sich besonders in der Analyse dieser Elhik zeigt, während die dogmatischen Analysen etwas zu sehr modernisieren. 
zugleich die positivste Weltarbeit einschließt. Hier liegt einer der folgenreichsten Punkte in der reformierten Ethik, der den ganzen eigentümlichen Lebensstil der calvinistisch erzogenen Völker bestimmt ${ }^{336}$ ). Die Askese an sich gehört, wie früher ge-

33n) Beispiele in Menge bei Kampschulte und Choisy. Schneckenburger gibt Leider hiervon keine Analyse. Er sieht wie sehr viele Darsteller nur die Rigorisităt einer an Werkheiligkeit streifenden Gesetzlichkeit und sucht die Aufgabe nur in der Erklärung eben dieser Gesetzlichkeit selbst. Er hebt die Angst vor Kreatụrvergötterung, die rationelle und methodische Planmäßigkeit des calvinistischen Handelns und die Beziehung auf die jenseitige Seligkeit mit der beständigen Spannung auf ein jenseitiges $Z$ iel hervor, die sich von der Lebenssicherheit des in der Gegenwart und im Glauben seligen Luthertums sehr unterscheide. Allein er macht keinen Versuch diese Gedanken in Zusammenhang mit der christlichen Askese und ihrer Geschichte zu begreifen. Auch bei Luthardt, Gesch. der christl. Ethik, ist dies nicht geschehe1. Die Theologen haften eben bei der Darstellung der Ethik fast immer an den Problemen der Form d. h. der Begründung oder Sanktion und der Kraftquelle oder religiösen Ermöglichung, aber nicht am Inhalt oder Zweck der Sittlichkeit. Dieser $Z$ weck aber ist bei einer Ethik, die sich im Gegensatz gegen die erbsündig verdorbene und unselige Welt die Seligkeit des Himmels sichern will, asketisch. Und hier ist die reformierte Ethik gegenüber der lutherischen viel dualistischer, planmäßiger auf das Jenseits und die Entwertung des Diesseits gerichtet, freilich ohne cs aufzuheben, sondern in der $A$ bsicht es zu benützen. Ritschl hat mit seinem Scharfsinn die reformierte Askese, die unverkennbare Annäherung an die mönische Weltfluchl erkannt, Gesch. d. Piet. I 76 ; es ist die Haltung der sfranziskanischen Tertiarier «. -Soweit das christliche Lebensideal des Calvinismus antikatholisch ist, ist es aus Luthers Anregung entsprungen; sofern es von Luthers Auffassung abweicht, ist es auf die Linie des franziskanischen Lebensideals zurückgebogens. S. 78: asketische Heiligkeit, nämlich strenge Ablehnung aller weltlichen Erholung und alles Spiels،. Herleitung und Begriffsbestimung dieser calvinistischen >Askese ist nun aber bei ihm ganz ungenügend, beinahe komisch S. 76. Eine eindringende, begriffliche Analyse hat erst Max Weber gegeben, bes. Archiv XXI 73. Beispiele in Fülle und Analysen von geringerer Klarheit bei Göbel: I 444-448 Synodalbeschlüsse; hier S. 447 die Berufsaskese; Ein Christ soll die Zeit, welche er noch zu leben hat, wohl anlegen (d. h. im Gegensatz gegen Vergnügungen), seinem Beruf getreulich nachzukommen und sonst, da er übrige Zeit hat, die Zeit zubringen mit gottseligen Gesprächen und sich wohl hütend vor Fabelbüchern und mit Vorlesung der heiligen Schrift und anderen gottseligen Traktaten; II 72 Selbstbezeichnung der reformierten Gemeindeglieder als $>$ Christen 4 , gegenüber den übrigen als ,Weltkindern ; II 47 weitere Synodalbeschlüsse gegen Vergnügungen, auch solche, die die Obrigkeit veranstaltet und erzwingt; II IO5, die Reformierten unterscheiden sich durch ernste Frömmigkeit und strenge Sittlichkeit, durch sorgfältiges Halten der ersten Gesetzestafel, durch große Ehrbarkeit und Eingezogenheit, n:mentlich in bezus auf üffentliche Lustbarkeiten (Tanz, Kirchweihen, Schützenfeste, Gelage, Theater) und durch die 
zeigt, dem Christentum erst an im Zusammenhang mit dem Erbsündenpessimismus, der die irdische Welt entwertet gegen die Welt der Erlösung und des Heils und der zugleich die Bändigung des

damit immer zusammenhungende Sparsamkeit und Ordnung, Fleiß und Rechtschaffenheit r. Das Charakteristische ist überall die unbedingte Arbeitsamkeit und die 'ediglich geistliche Erholung, die Herabsetzung der Sinnenkultur auf das unentbehrliche Maß, aber ohne körperliche Verwahrlosung oder Mortifikation, die rein utilitarische Behandlung aller weltlichen Dinge als bloßer Mittel und der Ausschluß jeder unbefangenen Selbstzwecklichkeit von irgend etwas Irdischem, die methodisch und planmäßige Disziplin und die Einstellung auf ein jenseitiges Endziel. In all diese Dingen ist das Luthertum viel läßlicher, unbefangener,. triebhafter und vor allem inkonsequenter. Die Stellung des Luthertums in diesen Dingen ist vor allem die der Prinziplosigkeit und Inkonsequenz, wie seine ganze Ethik mit ihrer Wiederholbarkeit der Rechtfertigung nicht auf Konsequenz, sondern auf jedesmaligen Genuß der in Christo ergriffenen Seligkeit gerichtet ist. Das letztere hat Schneckenburger treffend entwickelt, s. auch meine Anzeige von Hoennicke in GGA r902. Die Weltverneinung an sich kannte das Luthertum wahrlich genügend; vgl. die bei Schneckenburger zitierte Stelle Luthers: *Weinen gehet vor Wirken und Leiden übertrifft alles Thun. Es handelt sich darum, sese passibilem Deo praestare, der Mensch müsse Gott gegenüber zur reinen Materie werden, die ihre Form erhalte, von dem sie gestaltenden Gott. Auch wo in den älteren Lehrbüchern die guten Werke spezifiziert werden, kennt es nur abnegatio sui, toleratio crucis und precatio. I 140; die Stelle zeigt zugleich den Unterschied der handelnden reformierten Askese. - Der hier verwendete Begriff der sinnerweltlichen Askese schon bei Göbel III 334 : -Die römisch-katholische ä u ß r liche Weltentsagung und äußerliche Heiligung gegen die evangelische innerliche Weltüberwindung und Glaubensfreudigkeita. Das ist nichts anderes als der von Weber und mir gemeinte Gegensatz einer außerweltlichen und innerweltlichen Askese, die freilich ein Pietist leichter versteht und würdigt als ein steifer Kirchenmann wie Ritschl oder gar ein Rationalist wie Rachfahl. - Uebrigens s. den Artikel , Askese geschichtlich, von Heussi in Schieles Lexikon, der meiner Auffassung folgt. Der Artikel Askese ethisch von Scheel unterscheidet wenigstens instinktiv die beiden von mir geschiedenen Hauptrichtungen der metaphysischen und der disziplinären Askese; im übrigen hat er nicht genügend die Besonderheit der christlichen Askese erkannt; buddhistische und neuplatonische, orgiastische und kultische Askese sind alle etwas anderes. Das Christcntum hat bei der dauernden Einrichtung auf die Welt und dem Verzicht auf das kommende Gottesreich die jenseitige Spannung notwendig an eine andere Stelle seiner Gefühlswelt versetzen müssen. So entstand sein Asketismus $E_{s}$ ist das aber eine $\mathrm{ch}_{\mathrm{r}}$ ist liche Askese, deren Beeinflussungen durch fremde Elemente (neuplatonische, heidnische etc.) von ihrem Wesen wohl geschieden werden künnen und müssen. Scheel bestreitet von seinem modern immanenten Standpunkt aus die Berechtigung des Begriffs Askese im Prot., meint aler doch: "Ein sicheres, seiner religiös-ethischen Grundüberzeugung entsprechen- 
Fleisches und der Sinnlichkeit durch rationelle Disziplinierung verlangt. Das Evangelium hatte nur die Ueberweltlichkeit und das kommende Gottesreich auf Erden gekannt, weder die Welt verneint noch eine planmäßige Disziplin der Sinnlichkeit entwickelt. Erst mit der Einrichtung auf eine dauernde erbsündig verlorene Welt und der Verlegung des Gottesreiches in das Jenseits drang die Askese ein, von vorneherein in einer doppelten Bedeutung, einerseits als metaphysische Weltverurteilung, andrerseits als rationelle Sinnlichkeitsdisziplin. Beides konnte sich verbinden, konnte sich aber auch trennen. Die asketische Weltverneinung konnte in Antinomismus umschlagen, die asketische Disziplin konnte zu harter lohnsüchtiger und eudämonistischer Gesetzlichkeit werden. Der Katholizismus hat beide Arten der Askese gepflegt und vor allem das Problem empfunden, die asketische Sittlichkeit neben den doch unumgänglichen Notwendigkeiten des Weltlebens unterzubringen. Er hat das Problem in seiner Lehre von der Doppelstufigkeit der Moral

des Urteil über die Askese überhaupt hat er nicht gefunden.e Allerdings, und das hat gute Gründe. Die sinnerweltliche Askese c ist eben nach beiden Seiten, lutherisch und calvinistisch, nicht so leicht zu begründen und ihre Motive sind doch bei beiden vorhanden. Hier ist die entschlossene Doppelstufigkeit des Katholizismus leichter $z u$ begründen. Die innere Komplikation des Protestantismus, seine Stellung zwischen Immanenz und Transzendenz, zwischen Sündenpessimismus und Weltbejahung, kommt gerade in seinem Begriff der Askese zum Vorschein. Darum ist dieser auch so schwer zu fassen. Wo aber die Askese im Protestantismus klar betont und gefordert wird, da zeigt sich auch das Gefährliche, das in der Unbestimmtheit dieses wichtigen Momentes liegt. Sie hat dann immer etwas KirchenAuflösendes an sich, sei es im sektenhaften oder mystisch spiritualistischen Sinne, da die Askese im Protestantismus nicht unter kirchlicher oder Ordensleitung steht, sondern freie Gesinnungsangelegenheit oder persönliche Pflicht des Einzelnen ist .- Dieses letztere, die antiautoritative Wirkung der Askese (Max Weber Archiv XXI 65 f. 93) hat vor allem Ritschl richtig empfunden. So leitet sie auch tatsächlich im Calvinismus zum Pietismus hinüber, wie Ritschl richtig erkennt. Ritschls eigene Auffassung des Luthertums als einer durch Gottvertrauen und Rechtfertigungsseligkeit möglichen Weltverklärung und Weltgestaltung im Beruf ist freilich ein stark modernisiertes Luthertum, das die dualistischen, asketischen und pessimistischen Elemente im Gottvertrauen, d. h. in Wahrheit: unter dem Einflus moderner Immanenzideen, untergehen läßt. Das von ihm als Kern des lutherischen und damit des echten Christentums konstruierte Gottvertrauen, das auf die kirchlichen objektiven Gnadenmittel begründet ist und wie die Differenzen der aktiven Heiligkeit so die Anpassungen an die Welt im Volks- und Massenchristentum ermöglicht, dominiert in den alten Quellenschriften durchaus nicht und ist auch von Ritschl erst als deren unbewußte, unter Doktrinarismus versteckte Voraussetzung herausgeholt worden. 
gelöst und die Askese in ihrem vollen Sinne neben und über das Weltleben gestellt, das sich nur nach Möglichkeit und bei Gelegenheit asketischen Maßstäben unterwirft. Es war und ist eine Askese neben und über den Formen des durchschnittlichen Weltlebens, wesentlich in Klöstern und Bruderschaften und im Klerus gepflegt. Der Protestantismus hat jene Doppelstufigkeit aufgehoben und für alle in gleicher Weise die Durchdringung des Weltlebens mit dem Geiste der Weltverneinung und Weltüberwindung gefordert. Seelisch ungebunden durch die Güter der Welt, in der Welt die Welt. überwinden: das war sein Ideal. Er steigerte die sittlichen Anforderungen, indem er sie über alle gleichmäßig ausbreitete und steigerte den Erbsündenpessimismus, indem er den Bekehrungsund Erlösungsgedanken zur alleinigen Herrschaft über das ganze Dasein bringen wollte. Insoferne behauptete auch der Protestantismus die Askese, aber als eine innerweltliche.Askese. Innerhalb dieser Gemeinsamkeit gingen nun aber Luthertum und Calvinismus sehr bald ganz bedeutend auseinander. Es verteilten sich die beiden genannten Grundverschiedenheiten der Askese, die metaphysischgefühlsmäßige Entwertung der Sündenwelt und die methodische Disziplinierung der Sinnlichkeit. Das erste war clie asketische Stimmung des Luthertums, die das Jammertal der Sündenwelt bedauerte, aber im übrigen, in der Rechtfertigung Gottes gewiß und in den Sakramenten mit Christi Gegenwart gespeist, sie fröhlich und getrost liegen ließ, in sie sich fügend und schickend, die christliche Liebe in der Berufstreue erweisend, die Ergebnisse Gott überlassend und die durch die Sündenwelt hindurchbrechende göttliche Schöpfungsherrlichkeit gelegentlich mit Dank genießend. Es sind hier Annäherungen an die mystisch neuplatonische Entwertung der Sinnlichkeit und Endlichkeit, die bereits im Katholizismus einc schr große Rolle spielten, nicht ausgeblieben und ist im Zusammenhang mit der Weltfreiheit des Geistes auch die antinomistische Konsequenz - in schroffem Gegensatz gegen die reformicrte Gesetzlichkcit - gelegentlich aufgetaucht. Das Luthertum, las in allem Elend selig ist, hat auch hier keine Systematik und nimmt die Empfindungen wie sie kommen, die Weltangst und den Weltüberdruß, aber auch den dankbaren Genuß der Gottesgaben; rom cinen wie vom andern hängt nichts $a b$, da in der Rechtfertigung lie Wi.lt überwunden ist. Ganz anders steht der Reformierte zur Welt. Fir lainn nicht die Welt im Prinzip verneinen und im einzelnon acnießen. Diese Systemlosigkeit widerspricht seinem reflektie- 
renden und systematischen Geiste. Er kann nicht die Welt mit ihren Greueln liegen lassen und sich der fertigen Seligkeit getrösten. Jener Quietismus geht gegen seinen I)rang zu handeln und diese liertigkeit gegen seine Orientierung an dem Ziel der erst zu erreichenden Seligkeit. Seiner Unterscheidung von Gottes Allmacht und kreatürlicher Nichtigkeit ist jedes Ausruhen und Genügen an der Kreatur, und wäre es auch nur grelegentlich, eine Vergötterung der Kreatur. Sie ist überall schon an sich nur Mittel und nirgends gotterfüllter Zweck. Vollends die sündige Kreaturwelt ist ihm ein mit allen Kräften zu bekämpfender und zu überwindender Greuel. So muß er planmäßig, reflekticrend und fortschreitend dic Neigung zur Kreaturvergötterung und die an Sinnlichkeit und Selbstliebe hängende Sünde überwinden. Aber vollziehen kann er das bei sciner protestantischen Beurteilung der Weltberufe und bei seinem Idcal einer heiligen staatlich-kirchlichen Gesamtgemeinde nur unter gleichzeitiger Anerkennung des Weltlcbens.

Daraus ergibt sich nun eine innerweltliche Askese, die planmäßig und im weitesten Umfange alle weltlichen Mittel ancrkennt, aber sic nur zu Mitteln ohne jeden cigenen Selbstwert herabsetzt, um in dieser Benützung aller Mittel dic hcilige Gemeinde zu erzeugen. Der Weg aber, alles Weltliche zum bloßen Mittel herabzusetzen, ist eine rigorose Disziplin des Trieblebens, eine Jiechung alles bloß instinktmäßigen Gefühls und die Einschränkung. alles Sinnenlebens auf das Notwendige und Nützliche, die Sclbsterzichung und Sclbstkontrolle zu einem heiligen Leben nach dem Gesetze Gottes. Hierin ist jene Verbindung praktischen Sinnes und kühlen Utilitarismus mit jenseitiger Lebensorientierung, planmäßiger Bewußtheit und systematischen Strebens mit gänzlicher Uninteressiertheit am Genuß des Ergebnisses begründet, die den Calvinismus auszeichnet und in die alle bisher greschilderten Eigenschaften einmünden. Das ergibt ein lebhaftes politisches Interesse, aber nicht um des Staates willen; eine emsige wirtschaftliche Arbeit, aber nicht um des Reichtums willen; eine: eifrige soziale Organisation, aber nicht um des irdischen Glückes willen; eine unausgesetzte, die Sinnlichkeit disziplinicrende Arbeit, aber nicht um des Arbeitsobjektes willen. Die Verherrlichung Gottes, die Sammlung zur heiligen Gemeinde, dic Gewinnung der mit der Erwählung als Ziel gesetzten Seligkeit: clas ist der alleinige Zweckgedanke dieser Ethik, dem sich dann auch alle ihre formalen Eigentümlichkeiten unterordnen. Erst von hier aus 
ergibt sich der volle Sinn der calvinistischen Gesetzlichkeit und die - oft beobachtete - Annäherung an die katholische disziplinäre Askese; auch eine solche an die Werkgerechtigkeit und Lohnsucht ist nicht ausgeblieben; alles freilich im reinen Calvinismus aufgehoben durch den Gnaden- und Prädestinationsgedanken, der aber auf der andern Seite durch die Lehre von den Kennzeichen der Erwählung diese Entwickelung auch wieder beförderte. Es ist bekannt, daß Calvin selbst in diesen Fragen verhältnismäßig unbefangen urteilte und daß er in der auch den Verworfenen eignenden und sie zu höheren Leistungen befähigenden, also auch die Schönheit der Welt zeigenden Gratia universalis die Kulturwerte zu würdigen wußte. Allein diese "Gratia universalis ist doch nur ein die Askese wieder mildernder Fremdkörper im System, eingeführt durch den Eindruck des praktischen' Lebens und der antiken Bildung. Wo das Problem unter die christliche - und das ist die entscheidende - Beleuchtung tritt, da hört doch auch für Calvin jede Selbstwertigkeit kreatürlicher Leistung und irdischer Herrlichkeit auf und wird alles' zu Mitteln für die Aufrichtung der Herrschaft Christi. Die Gratia universalis, ohne Beugung der Kultur unter die Zwecke des Gottesreichs verstanden, gilt nur für die Verworfenen und Unwiedergeborenen. Der Erwählte und Wiedergeborene dagegen benützt ihre Güter schlechthin für den religiösen Zweck. Auch Calvins relative Anerkennung der Freude ist doch mehr als Erlaubnis der Erholung gedacht und nach ihrer Zweckmäßigkeit gewürdigt ${ }^{337}$ ). Der nach-

337) Rachfahl hat in seinem Angriff auf Weber und mich (Calvinismus und Kapitalismus, Internationale Wochenschrift 1909) den Begriff der sinnerweltlichen Askese unter Berufung auf einige Enzyklopädie-Artikel sehr von oben herunter behandeln zu dürfen gemeint. Allein von theologischen Dingen versteht er gar nichts; ich denke, das Angeführte genügt, um den Gebrauch des Begriffs, für den man nun einmal einen Namen haben muß und den die modernen Rationalisten - theologische und untheologische - gar nicht verstehen, von neuem zu rechtfertigen: - Wenn sich Rachfahl auf Loofs, Luthers Stellung S. 2 I f. beruft, so bekämpft Loofs doch nur die Meinung, als sei um solcher Askese willen der Protcstantismus ins Mittelalter $z u$ verweisen und für den modernen Menschen erledigt. Das ist aber meine Meinung gar nicht, wie Loofs selbst weiß, indem er meint, ich hätte bei anderer Gelegenheit mehr Verständnis für Askese gezeigt. Loofs nimmt meine Aussagen über Luthers Zusammenhang mit dem Mittelalter als Werturteile, was sie durchaus nicht sind. Daß Luther im M.-A. sstecken gebliebene sei, ist weder mein Ausdruck noch mein Gedanke. Ich betonte nur den Unterschied gegen die moderne Welt, wie er tatsächlich vorliegt; und da ist kein 
calvinische Calvinismus vollends hat Calvins Rigorismus begreiflicherweise verschärft und systematisiert zu einer puritanischen Gesetzlichkeit und rein utilitarischen Nüchternheit, die gegen das an diesem Punkt sehr inkonsequente Luthertum aufs schärfste abstechen. Es wäre ganz falsch, hierin eine Spur von Nachwirkung oder Einwirkung des Katholizismus zu suchen, der ja gerade die innerweltliche Askese nicht oder nur sehr wenig kennt. Es ist reinste Entwickelung echt calvinistischen Geistes und hat jenes nüchterne, utilitarische, energische und planmäßige, in der Erdenarbeit dem Himmels-

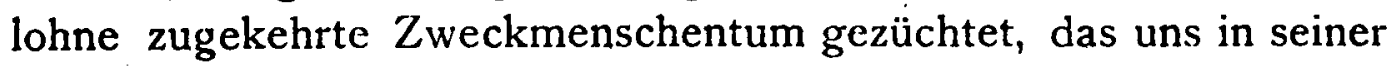
säkularisierten Gestalt heute nur allzu bekannt ist. Calvins eigenes Verhalten und seine Seelsorge in seinen Briefen ist das großartigste Denkmal solcher asketisch-utilitarischen Ethik. Dabei aber war dieses Handeln bei ihm noch erfüllt von echt religiöser Würde und Majestät, vom Gefühl der Verantwortung und der Tragweite, von dem Bewußtsein um die Größe des letzten Zweckes. So wurde auch seine ethische Systematik, seine Planmäßigkeit nicht kleinlich, sondern trug den Zug höchsten I'flichtgefühls gegenüber einer objektiven Lebensaufgabe, die nach den Gefühlen und Neigungen des Zweifel, daß sie in ihrer Praxis und in ihrer Theorie sehr wenig Platz für die Askese hat. Ueber die Askese selbst liegt darin kein Werturteil. Die mittelalterliche Welt hatte vieles vor der Gegenwart voraus und auch in den den Reformatoren mit dem Mittelalter gemeinsamen asketischen Elementen stecken dauernde Lebensinteressen und -Probleme, die sicherlich wiederkehren werden, freilich in völlig anderer Gestalt und Begründung. Man sehe hier Jakob Burkhardts Weltgeschichtliche Betrachtungen, eines des tiefsinnigsten und gedankenreichsten Bücher der letzten Zeit. Meine Differenz gegenüber Loofs bezieht sich in Wahrheit auf die Frage der Geschlossenheit und Ausbreitung des modernen Gedankens. Diese halte ich für sehr viel größer als Loofs es tut und die Lage der Kirche für sehr viel bedrohter, siehe meinen Aufsatz >Die Entstehung des modernen Geistese in Preuß. Jahrb. 1906. In der rcinen Tatsachenfrage über das Wesen der protestantischen Askese glaube ich dagegen mit Loofs ziemlich übereinzustimmen. Für Rachfahl ist also hier nichts zu holen. - In seiner zweiten Erklärung (JW 1910) >Nochmals Calvinismus und Kapitalismus * versichert Rachfahl, daß er es für geraten halte, mit dem Zutrauen zu meinen Sätzen über die Askese zu warten, bis sie von Loofs, Kawerau, Kattenbusch, Scheel und Lang anerkannt seien. Das sind freilich zum Teil sehr hervorragende Gelehrte, aber gerade an diesem Punkte, der Abgrenzung von Katholizismus, Luthertum, Calvinismus, Täufertum mit Hilfe des Begriffs der Askese, stehen sie unter dem Einflufs der bekannten Ritschlschen Thesen, die, mit theologisch-konfessionellen Werturteilen eng zusammenhängend, m. E. ganz falsch orientiert sind. Mit den banalen Bemerkungen Rachfahls über die Askese $\$ .728 \mathrm{f}$. werden übrigens jene Gelehrten selbst nichts $z u$ tun haben wollen. 
Subjekts nicht fragt, sondern alles in der Arbeit für Gott zusammenfaßt. Im echten und großen Calvinismus klingt immer etwas von diesem Unterton mit. Aber in der Entspannung friedlicher Zeiten, unter dem Einfluß menschlicher Durchschnittlichkeit und. im Zusammenhang mit der bürgerlich geschäftlichen Lebensarbeit ist dieser Ton cher auf Selbstgerechtigkeit und Pharisäismus, auf das Bewußtsein . des erwählten Volkes und des göttlichen Lohnes gestimmt. Das Alte Testament hat auch diese Stimmungen gerechtfertigt, und man hat in den Puritanern nicht ohne Grund oft christliche Juden schen wollen. Wenn die Leidsamkeit und Ergebungsseligkcit des Luthertums verbunden mit seiner Gefühlswärme und Naivetät, seiner gelegentlichen Freigabe des natürlichtriebhaften Empfindens großen Teilen der deutschen Kultur bis heute ihren Charakter der Abhängigkeit und der Gemütlichkeit zugleich aufgeprägt hat, so hat die Schule Calvins den calvinistischen Völkern die persönliche Reserve, die sachliche Nüchternheit, die aggressive Initiative und die rationalistische Plan-

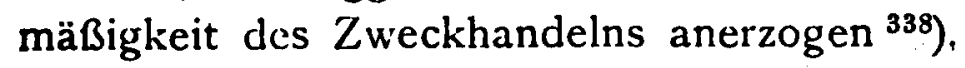

339) Vgl. Inst. III 7, I-2 ; Lobstein S. 79 f., 86, bes. 108-112: ,Soll man leben, so muf man auch die notwendigen Mittel des Lebens gebrauchen. Auch können wir das nicht meiden, was mehr zur Annehmlichkeit als zur Notwendigkeit dienen mag. Ein richtiges Maß ist hier zu beobachten, welches durch den Gedanken bestimmt werden muß, daß das Leben eine Pilgerschaft nach dem Himmel ist. -Grundsatz sei, die Güter zu gebrauchen für den Zweck, zu welchem Gott sie geschaffen hat. Geschaffen aber hat er sie nicht bloß zur Notdurft, sondern auch zur Annchmlichkeit. Auch die Lust der Sinne hat er bedacht, indem er die Blumen geschaffen und dem Gold und Silber, dem Elfenbein und Marmor eine Schönheit und einen Glanz verliehen hat, welche dieselben vor anderen Metallen und Steinen kostbar und wertvoll machen . ,Sodann ist das beste und sicherste Mittel die Unterordung des gegenwärtigen Lebens unter das ewige: man genieße das Leben, als genüsse man es nicht; man lerne die Armut ebenso geduldig als den Reichtum mäßig ertragen; man hüte sich aus den Mitteln dieses Lebens Hindernisse zum ewigen Leben zu machen. Zweitens ist vor Ueberschätzung der irdischen Güter zu warnen; diese Verkehrtheit zeigt sich sowohl in der Flucht. vor Armut und Niedrigkeit als in der Ehre und Gewinnsucht. Drittens bleibe man immer der Rechenschaft eingedenk, welche man für den Gebrauch der irdischen Güter schuldig ist. Endlich heißst uns Gott in allen Taten unseres Lebens auf unseren Beruf Rücksicht nehmen, um nach diesem Maßstab unsere Handlungen zu beurteilen und hieran zu orientieren.\& Iier auch eine Predigt angeführt, in der Wissenschaft und Kunst nach diesen Prinzipien angeeignet werden: >Quand un honme sera le plus exquis en science que on sauroit imaginer, si faut-il que nous apprenions de nous humilier, et que toute hautesse soit mise bas, que le savoir 
Indem nun aber die Berufsarbeit sowohl Spielraum als Disziplinierungsmittel für diese innerweltliche Askese war, erhielt auch der Berufsbegriff hier eine neue, besonders akzentuierte. Bedeutung, die ihn nicht bloß von der katholischen, sondern auch von der lutherischen Auffassung unterscheidet. Sie bildet die Brücke zu dem modernen Berufsmenschentum. Die alte Kirche hatte bei ihrer Spannung gegen die Welt sich die natürliche Arbeitsgliederung und soziale Abstufung gefallen lassen, als für das Heil gleichgültig und hatte lediglich die mit dem christlichen Glauben unverträglichen Berufe ausgeschieden ${ }^{339}$ ). Das Mittelaiter hatte die natürliche Unterstufe der weltlichen Arbeit und der natürlich-sozialen Gliederung in einen inneren Zusammenhang mit dem geistlichen Reich der Kirche gebracht, aber all das doch nur als vorsehungsmäßige Gliederung auf Grund des Naturgesetzes angesehen, die mit den eigentlich-religiösen Leistungen erst überbaut werden mußte und die für die Heroen des religiösen Lebens, die stellvertretenden Darsteller und Anreger eigentlichster christlicher Gesinnung, unverbindlich war $\left.{ }^{340}\right)$. Erst der Protestantismus zog auch hier Natur und Gnade zusammen, indem für ihn der erlöhumain que Dieu nous aura donné pour lui servir, soit assujetté à sa parole. Ebenso steht es mit der Eloquenz. Vray est que tous les deux procedent de la pure bonté de Dieu. Mais si faut-il venir là, que celui qui sera parvenu à la vraye clarté celeste, die, Je suis tien, Seigneur; et tout ce que tu m'as donné, aussi vient de toy: que tu le reçoives dono sur tout: puisque tu m'as fait la grace de estre instruit par ta parole, fay que tout le resterende l'honne uret l'hommage tel que il appartient à ceste science admirable, que j'ai apprinse en ton cscole .. Dieu a ressuscite les sciences humaines qui sont propres et utiles la conduite de nostre vie, et, en servant à nostre utilité, peuvent aussi servir à sa gloire .. Nulle bonne science n'est repugnante à la crainte de Dieu ni à la doctrine qu'il nous donne pour nous mener en la vie eternelle, moyennant que nous ne mettions point la charrue devant les beufs; c'est à dire que no us a y ons cesteprudence de nousservirdes artzs tout liberaux qu mechaniques en passant par ce monde pour tendre tousiours au Royaume celestex. Vgl. auch G. Lasch, Calvin und die Kunst, Christliches Kunstblatt 1909, wo die Unterschiede Calvins und Luthers auch auf diesem Gebiete deulich hervortreten. Das enthält zugleich die Stellung zur Renaissance. Nur unter Beachtung dieser Einbeziehung der irdischen Mittel unter das himmlische Ziel ist es richtig, die meditatio futurae vitae als Kernpukt von Calvins Ethik zu bezeichnen s. M. Schulze, Med. fut. vitae im System Calvins, 1901. Uebrigens hebt Lobstein hervor, daß Calvins Praxis in seinen Genfer Kämpfen strenger war als seine Theorie.

880) S. oben S. 117-129.

840) S. oben S. 3II-3I4. 
sende Gnadenwille zugleich die weltliche Arbeitsleistung zuwies und sie zum normalen, für jeden erforderlichen, Spielraum seiner Gnadengesinnung machte. Die Folgen dieses Berufsbegriffes in ökonomischer und sozialer Hinsicht waren außerordentlich, indem dadurch die Berufsarbeit und die Intensität des weltlichen Arbeitsinhaltes selbst zu einer religiösen Pflicht an sich, aus einem Mittel bloßer Bedarfsdeckung zu einem Selbstzweck der Betätigung des Glaubens in der Berufsarbeit wurde. Damit entstand jenes Ideal der Arbeit um der Arbeit willen, das die geistigmoralische Voraussetzung für die Durchsetzung des modernen bürgerlichen Lebensstiles ist ${ }^{341}$ ). Allein beim Luthertum sind diese Wirkungen nur sehr bedingt eingetreten. Sie finden sich in ihrer vollen Strenge erst beim Calvinismus. Für Luther blieb mit Paulus, der alten Kirche und dem Mittelalter der Beruf doch nur die Betätigungssphäre, in der man bleiben und die man nicht verlàssen soll. Die Ueberbietung der gläubigen Berufssittlichkeit durch eine berufslose Heiligkeit hatte für ihn keinen Sinn und keinen göttlichen Auftrag. Wenn dabei zugleich von ihm darauf hingewiesen wurde, daß gerade durch die geordnete Berufsarbeit und das ineinandergreifende System der Leistungen die Aufrechterhaltung des Ganzen und damit Gedeihen, Friede und Ordnung bewirkt wird, so fiel das mehr auf die weise Einrichtung und gütige Leitung der Vorsehung, nicht auf die planvolle menschliche Initiative zurück. Das Berufssystem wurde nicht bewußt entworfen und ausgebaut für die Zwecke der heiligen Gemeinde und der christlichen Gesellschaft, sondern hingenommen als göttliche Ordnung. Der einzelne vollends betrachtete seine Arbeit nicht als zweckmäßiges Mittel für die Erhöhung des Ganzen, sondern als eine ihm zufallendés Einreihung und Bestimmung. Daher konnte diese Berufsarbeit zugleich völlig traditionalistisch und reaktionär betrachtet werden als Bleiben bei der standesgemäßen Nahrung, wie das auch die katholische Ethik getan hatte. Die christliche Moral wurde betätigt in vocatione; nicht per vocationem ${ }^{342}$ ). Aber gerade an diesem Punkte liegt nun der Unterschied des Calvinismus. Er arbeitete bewußt und planvoll auf eine heilige Gemeinde hin ${ }^{343}$ ). Er vis

34) Hierüber s. vor allem Max Weber, der auch die sprachliche Entstehung des protestantischen, Berufse aus I Cor 7,20 im Verein mit Jesus Sirach II, 20 bis 21 eingehend analysiert.

34:) Hiezu vgl. Weber Arch. XXI 16-1 7 ; Lobstein S. $143 \mathrm{f}$.

343) Hier sei noch einmal auf Egers treffliche Schrift $\$$ Luthers Lehre vom Beruf verwiesen 4 a aßerdem oben S. $580-584$. 
band nicht bloß das Handeln des Einzelnen, sondern auch das der Gemeinschaft zu einer bewußten und planmäßigen Gestaltung. Und da das kirchliche Ganze nicht ohne Mitbeteiligung der weltlichen Ordnungen, ohne Einbeziehung der politischen und ökonomischen Leistungen der weltlichen Gemeinde, zustande kommen konnte, so galt es alle Berufe als Mittel für die Erzielung der heiligen Gemeinde $\mathrm{zu}$ ordnen, $\mathrm{zu}$ reinigen und anzufeuern. So ist hier das Ideal nicht die Ergebung in ein fertiges, von der Vorsehung geleitetes System der Berufe, sondern die freie Verwendung der Berufe als Mittel für die heilige Gemeinde. Die Berufe sind nicht bloße gegebene Formen, innerhalb deren die Nächstenliebe verwirklicht und der Glaube bewährt wird, sondern frei zu behandelnde Mittel, durch deren besonnenen und zweckmäßigen Gebrauch die Liebe erst möglich und der Glaube erst wirklich wird. Daraus ergibt sich eine beweglichere Auffassung des Berufssystems, eine weitgehende Rücksichtnahme auf das praktisch Mögliche und Zweckmäßige, eine zweckvolle Steigerung der Arbeitsintensität. Wie weit diese Rationalität und Beweglichkeit des Berufsbegriffes sich im Einzelnen gegen die auch hier fortdauernde ständisch-zünftig-polizeiliche Lebensverfassung durchgesetzt hat, ist dann freilich eine Frage für sich. Aber die später anzuführenden Beispiele geistlicher Sozialpolitik in Genf zeigen bereits eine erhebliche Freiheit der Bewegung. Dazu kommt noch etwas Weiteres, dessen Bedeutung gleichfalls erst später sich voll entfaltet. Indem nämlich unter die Aufgaben der heiligen Gemeinde gerade auch die asketische Selbsterziehung in der Arbeit, die Askese in der Abziehung von aller weltlichen Zerstreuung durch die Berufsarbeit, der Verzicht auf eine Verwertung des Arbeitsertrages zum persönlichen Genuß, gehörte, trat jener wichtige Nebeneffekt einer Anerziehung der Arbeitsgesinnung, eines Betriebes der Arbeit um ihrer selbst willen und als Selbstpflicht, ein, der nichts weniger als eine natürlich naheliegende Seelenverfassung ist, sondern nur aus einer das natürliche Triebleben gründlich verwandelnden religiösen Energie begriffen werden kann. Einmal so geschaffen kann diese Seelenverfassung in der Metamorphose

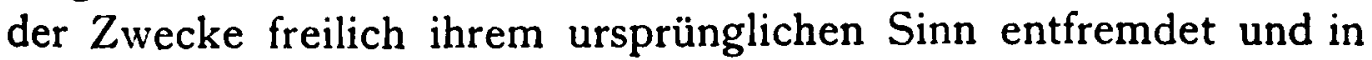
den Dienst anderer Gedanken gestellt werden, wie das heute vielfach geschieht. Aber man wird gerade an diesem Punkte den Unterschied katholisch, lutherisch und reformiert erzogener Völker immer beobachten können. Für die letzteren ist das faule Rentner- 
tum eine Sünde, die Betreibung eines zweck- und ertraglosen Berufes eine Torheit und Versäumnis, die Nichtbenützung einer Arbeits- und Gewinnchance Gleichgültigkeit gegen Gott. Trägheit ist das gefährlichste Laster, seelenschädlich vom Standpunkt der asketischen Disziplin und gemeinschädlich vom Standpunkt des sozialen Utilitarismus aus. Auch hier liegt freilich die volle Konsequenz des Gedankens bei Calvin selbst noch nicht vor. Seine stark aristokratische Lebensstimmung und seine Verbindung mit französischen Edelleuten gaben ihm eine weitherzigere und feinere Auffassung der Berufsleistungen. Der hugenottische Calvinismus war mit seiner starken Beteiligung des Adels zunächst überhaupt anderer Art; er ist erst seit seiner Entwaffnung und Fesselung, die jedenfalls dem Adel die Zugehörigkeit erschwerte, verbürgerlicht. Der verbleibende Rest des Hugenottentums und die hugenottischen Emigranten zeigen dann allerdings die bürgerlich geschäftlichen Züge deutlich genug. Es liegt aber im Grunde doch eine solche Verbürgerlichung im Verfolg von Calvins sozialer wie seiner rigoros-asketischen Ethik. Sie ist in der bürgerlichen Atmosphäre des niederrheinischen und niederländischen, des englischen und amerikanischen Calvinismus voll entwickelt worden. Das war der Boden, mit dem diese religiöse Ethik innerliche Wahlverwandtschaft hatte, ähnlich wie die doppelstufige Ethik des Katholizismus mit dem Stufenbau der mittelalterlichen Gesellschaft. Wie die agrarisch-feudale und mittelalterlich-städtische Lebensverfassung die Unterlage und Ermöglichung der mittelalterlichen christlichen Kultur war und von dieser wieder befestigt und durchdrungen wurde, so ist die beginnende bürgerliche Welt mit der Ethik des Calvinismus innerlich verwandt und wiederum von ihr religiös gefestigt und geformt zu einer vom Belieben und der zufälligen Meinung unabhängigen geistig-ethischen Macht ${ }^{344}$ ).

st4) Webers Abhandlung arbeitet in Wahrheit gar nicht bloß auf die Erläuterung des kapitalistischen Geistes aus der calvinistischen Berufsidee, sondern auf die Erklärung des bürgerlichen, modernen Lebensstiles hin, innerhalb dessen der >kapitalistische Geist s nur ein Moment ist. Es kommt ihm ja auch bei diesem selbst auf die modernen bürgerlichen $Z$ üge an und nicht auf die von Antike und Spätmittelalter her fortdauernden Elemente des moderner Kapitalismus. Das hat Rachfahl und der ihm nachredende Kurdt gar nicht begriffen. Ich schlage meinerseits bei dieser Ausbildung des bürgerlichen Lebensstils die auch von Weber betonte Differenz zwischen Calvin und dem Calvinismus noch höher an und möchte zur Erklärung des >bürgerlichen. Geistes in diesem späteren Calvinismus noch mehr, als es auch Weber tut, die Umwelt, die Abdrängung von Amt und offizieller 
Alles bisherige gilt von der übernatürlichen, spiritualen, durch die Erwählungsgnade ausgewirkten Sittlichkeit. Allein diese bedurfte eines Unterbaues in der natürlichen oder allgemeinen Kulturethik, wie ja auch die kirchliche Ethik seit langem einen solchen besaß; auch das Luthertum hatte nur das Verhältnis beider neu geregelt. Es sind die bisher bereits viel verhandelten Begriffe des sittlichen Naturgesetzes und des Naturrechts, die diese Funktion ausüben. Gerade an diesem Punkte zeigt sich nun aber weiterhin eine wichtige Besonderheit des Calvinismus. Dem Wortlaut nach gibt freilich Calvin auch hier nichts anderes als die lutherisch-melanchthonischen Formeln vom absoluten Naturgesetz des sündlosen Urstandes und dem relativen, den Bedingungen des Sündenstandes angepaßten Naturgesetz der Gegenwart ${ }^{345}$ );

Welt, von Feudalität und seigneuralem Grundbesitz hervorheben. Aber an dem engen Zusammenhang des »bürgerlichen Geistes « und des späteren und heutigen Calvinismus kann kein $Z$ weifel sein. Es befähigt ihn dazu gerade seine Herabstimmung der christlichen Moral von dem Spiritualismus und Utopismus der Liebe zur strengen Gottesfurcht, Arbeitsamkeit, Berufstreue und Redlichkeit. Der Unterschied dieses bürgerlichen Ideals gegen die feudal-seigneurale Welt, die mit den Autoritätsreligionen des Katholizismus, Luthertums und Anglikanismus sich viel besser abzufinden weiß und deren Moral sich von dem demokratischen Humanitätsgeist (aber auch von der eigentlich spiritualen Liebessittlichkeit) innerlich völlig frei hält, liegt auf der Hand; er wird auch gelegentlich sehr unverhohlen ausgesprochen. Ebenso aber auch der Unterschied gegenüber der antiken Moral und ihrem der Welt zugewandten freien Vollmenschen; vor mir liegt ein •Jahrbuch für die geistige Bewegung a IgI I herausgegeben von Jüngern Stefan Georges mit einem Aufsatz von Friedrich Gundòlf über $>$ Wesen und Beziehung «, wo die protestantisch-bürgerliche Moral und ihre säkularisierte Erbin als der Fluch erschèinen, dem nur eine beruflose, freie Selbstauswirkung aus der Einheit von Leib und Geist heraus abhelfen kann. Hier ist der Gegensatz richtig empfunden, wenn mir auch die Polemik praktisch hoffnungslos zu sein scheint. - Ueber das Hugenottentum siehe Marcks; über seine Verbürgerlichung Andeutungen bei Elster und Laveleye. Sein Sondercharakter bedürfte noch einer besonderen Untersuchung. Nax Weber berührt es kaum, auch Schneckenburger nicht. Es ist aber dem echten Geiste Calvins sicher näher verwandt als die niederländisch-niederrheinisch-englisch-amerikanische bürgerliche Welt. Wie es in Schottland steht, wo auch gerade der Adel stark beteiligt war, ist mir nicht bekannt; jedenfalls ist aber dort der Adel charakteristischer Weise größtenteils schließlich zum Anglikanismus zurückgetreten.

845) Vgl. Briefe II 267: ,Vor mehr als zwei Jahren fragte mich John Knox in einem Privatgespräch, was meine Ansicht über eine Frauenregierung sei. Ich antwortete offen, es sei eine Abweichung von der ursprünglichen wahren Naturordnung und deshalb unter die Strafen des menschlichen Sündenfalls zu 
von der Identität des Naturgesetzes mit dem Dekalog, wobei nicht nur der Dekalog, sondern das ganze alttestamentliche Gesetz

rechnen, wie z. B. auch die Sklavereic. Ebenso II 13. - Ferner bezüglich der Ehe; in reinem Naturzustande war die Ehe ohne libido; aber accensa post lapsum libidine ... illam ipsam conjugalem societatem in necessitatis $r$ e $m$ e $d i u m$ esse ordinatam, ne in effrenem libidinem proruamus Inst II 8,41. - Der Eid ist eine göttliche Einsetzung zum Wohl der Gesellschaft unter der Bedingung der mit der Sünde eingebrochenen Bosheit, Contre les Anabaptistes CR 35, S. 98 ; ebenso die Schwertgewalt der Fürsten und Regierungen ibid 78. - Weitere Ausführungen über das relative Naturrecht oder, wie es hier S. 84 heißt, über sdie durch die allgemeine Gnade eingeschränkten Folgen der Sündec, s. bei Kuyper S. 73-76, wo Calvin sich völlig als Träger der gemeinkirchlichen Lehre zeigt: >Durch seine tiefe Auffassung von der Sünde hat der Calvinismus die wesentliche Wurzel des. Staatslebens bloß gelegt und uns zugleich zweierlei eingeprägt: I. daß wir das Staatsleben und die Obrigkeit als jetzt unentbehrliche Rettungsmittel hinnehmen sollen, 2. aber auch, daß wir kraft unseres natürlichen Triebes stets gegen die Gefahr, die in der Staatsallmacht für unsere persönliche Freiheit liegt, auf der Hut sein miissena S. 74. An dem zweiten Punkt liegt das Neue, dessen Bedeutung sofort auseinanderzusetzen ist. - Sehr viel Material (über das relative Naturrecht freilich nur Andeutungen S. 131-133) in der äußerst sorgfältigen und überzeugenden Arbeit von G. Beyerhaus, Studien zur Staatsanschauung Calvins (Neue Beiträge herausgegeben von Bonwetsch und Seeberg VII) 1910. Einige Stellen auch in der höchst oberflächlichen Arbeit von A. Lang, Die Reformation und das Naturrecht (Beiträge zur Förderung christlicher Theologie) 1909 S. 20-22. Wie schon gegenüber seinen eigenen Citaten Lang schreiben kann, Calvin sei kein Freund des Naturrechts gewesen, ist mir unverständlich. Es ist für Calvin einfach selbstverständliche Voraussetzung und durchzieht seine Argumentationen überall, wo es zu berühren ihm nahe lag. Das ist in der Institutio natürlich am wenigsten der Fall. Sehr richtig Reyerhaus S. 66: >Hätte Lang auch Calvins Kommentare, insbesondere z. B. die Virläuterungen zum Dekalog CR 52, 261 ff. sowie CR 57, $554 \mathrm{ff}$. (dazu Beyerhaus $\therefore .96 \mathrm{f}$. und S. $157 \mathrm{nr} .4 \mathrm{~b}$ ) systematisch herangezogen, so würde er die Behauptung, das Naturrecht spiele bei Calvins Beurteilung rechtlicher und sozialer Verliältnisse keine Rolle', schwerlich aufgestellt und sein Gesamturteil über die Bedeutung der Lex naturae für Calvin wesentlich geändert haben«. Lang hat eben keine Einsicht in die innere Struktur des christlichen Naturrechts und seine Funktion für den Gedanken einer christlichen Kultur. Daher schon die ganz schiefen Behauptungen über Luther, bei dem angeblich das Naturrecht auch keine Bedeutung gehabt haben soll, und die Beschränkung des Naturrechts auf Melanchthon. So kommt er zu der Behauptung, das Naturrecht sei gegen Luthers und Calvins wahre Absicht nur in der Eile bei dem Mangel einer nach evangelischen Grundgedanken geklärten Slaatsauffassunge S. 50 aus den katholisch-mittelalterlichen Theorien übernommen worden, die, im >Katholizismus, also im Irrglauben, entsprungena, dann vom Liberalisnus adoptiert worden seien! Damit kehre sich also meine sverunglückte Thesec 
Fortführung d. Lehre v. Dekalog u. der mit ihm identischen Lex naturae. 659

und die israelitische Geschichte als Beispiel des Naturgesetzes erscheinen ${ }^{346}$ ); von der Anwendung der christlichen spiritualen Gesinnung auf die sozialen Stiftungen des Naturgesetzes und von der dementsprechenden Teilung des Dekalogs in die spiritualreligiöse und in die weltlich-moralisehe Tafel ${ }^{34}$ ); von der Ableium; der Liberalismus sei mittelalterlich und die evangelisch geklärte Staatsauffassung der Reformation modern I Meine These sei so erwiesen als Schlagwort und Schema, wie ssie meist der Partei zur Festlegung eines einseitig beschränkten Urteils dienen a S. 46. Wahrlich, bei solchen Apologeten ist kein Ding unmöglich, und auf eine Ungehörigkeit kommt es ihrem Leichtsinn auch nicht an! Dafür tragen sie aber bei zur >Förderung der christlichen Theologie «. - Unerheblich ist G. v. SchultheßRechberg, Luther, Zwingli und Calvin in ihren Ansichten über das Verhältnis von Staat und Kirche 1909.

840) Die Aeußerungen hierüber sind zahllos. Die Lebre von Gesetz und Dekalog in der Institution wird eingeleitet mit dem Satz: sPorro haec ipsa, quae ex duabus tabulis discenda sunt, quodam modo nobis dictat lex illa interior, quam omnium cordibus inscriptam et quasi impressam superius dictum est. Proinde (quod tum hebetudini, tum contumaciae nostrae necessarium erat) Dominus Legem scriptam nobis posuit: quae et certius testificaretur, quod in lege naturali nimis obscurum erat, et mentem memoriamque nostram excusso torpore vividius ferirete Inst II 8, 1. "Nihil est vulgatius, quam lege naturali hominem sufficienter ad rectam vitae normam institui. Nos autem expendamus, quorsum indita haec legis notitia hominibus fuerit; tum protinus apparebit, quousque illos ad rationis veriratisque scopum deducat \& II 2, 22. Dazu aus den Briefen II 140, sdem mag statt meiner der Satz des natürlichen Rechts antworten, den unsen Herr Jesus Christus als einen Teil des Gesetzes und der Propheten aufstellte, nämlich daß wir selbst nicht tun sollen, was wir nicht wollen, daß es uns angetan wirda. So las man schon bei Gratian. Das Gesetz ist unabänderlich und ewig für die Zukunft, war es aber auch schon vor Moses bei Hiob (s. die Predigt bei Lobstein S. 59-62), daher schließt es bei der Unveränderlichkeit Gottes auch jeden Unterschied zwischen dem Gesetz Moses und dem der Bergpredigt aus, die also ebenso vollendetes Naturgesetz ist. (Contre les Anabaptistes CR 35 S. 95). Bei Beza ist der Ausdruck sLoy divine, naturelle et universelle oder règle perpetuelle et infallible de toute justice oder Loy de Dieu et de nature geradezu der Terminus technicus für den Dekalog, Choisy, L'état chrétien, S. 180 f., 294, 296; die ATliche Geschichte als Illustration des Naturrechts in dem interessanten Gutachten der Venerable Compagnie bei Choisy S. $179 \mathrm{ff}$. Das ist ein weiterer Grund zur Rechtfertigung für die Benutzung des AT. - S. auch den Abschnitt über ordre de nature und jus naturae bei Beyerhaus S. $66-76$, die stoische Verfolgung des Naturgesetzes bis in die Tierwelt S. $148-152$ und die Analyse des Kommentars zu Seneca S. $3 \mathrm{f}$.

s47) Hauptstelle Inst II 8, I1. Die beseelende Spiritualität als Wesen der ersten Tafel Inst II 8, 16: Praecedat oportet vera religio, qua in Deum viventem animi referantur, cujus cognitione imbuti ... in omnibus vitae actionibus tamquam in 
tung des positiven Rechts als durch Zeit und Umstände bedingter und verschiedener Anwendung des Naturrechts, wonach das Positive im mosaischen und im römischen Recht wie im gegenwärtigen Staats-, Zivil- und Kriminalrecht als örtlich und zeitlich bedingte Ausformung des Naturrechts $z u$ verstehen ist ${ }^{348}$ ). Insofern scheint der Gedanke ganz derselbe zu sein wie im Luthertum. Ueberdies begegnet sich Calvin mit Luther in der strengsten Forderung des Respektes vor der Autorität, auch wenn ihre Träger moralisch minderwertig sind, sowie in der Ermahnung zur Genüg-

unicum scopum aspirent. Uebrigens gehört die Zweiteilung auch schon dem natürlichen Gesetz an Inst II 2,24 und Inst IV 20, 9: >Officium magistratus extendi ad utramque legis tabulam, si non doceret scriptura, ex profanis scriptoribus discendum csset: nullus enim de magistratuum officio disseruit, qui non exordium faceret a religione et divino cultue.

s48) Inst IV 20, 8: , Magna hujus dispensationis ratio posita est in circumstantiise. Hier ist der Ort der naturalis aequitas et officii ratio Inst IV 20, if. Libertas singulis gentibus relicta est condendi quas sibi conducere providerint leges: quae tamen ad perpetuam illam caritatis regulam (d. h. Gesetz Gottes und der Natur) exigantur, ut forma quidem varient, rationem habeant eandem. Nam barbaras et feras leges . pro legibus habendas minime censeo Inst IV 20, 15 . Weiteres in $\S 16$. Von hier aus erklären sich die positiven, für uns unverbindlichen Besonderheiten des jüdischen und römischen Rechtes Choisy S. 184 und 514. So ist die geschichtliche Entwickelung der Staaten und des Rechts trotz aller Unterschiede eine durch den natürlichen Kausalnexus bewirkte, indirekte Stiftung Gottes, eine Hervorbringung der Vorsehung; es ist die alte Lehre von Gott als der causa remota der Staaten, des Rechts und der Verfassungen: Perinde istud valet, non humana perversitate fieri, ut penes Reges et Praefectos alios sit in terris rerum omnium arbitrium, sed divina providentia et sancta ordinati one, cui sic visum est, res hominum moderari, quandoquidem illis. adest ac etiam praeest in ferendis legibus et judiciorum aequitate exercenda Inst IV 20, 4. Quodsi non in unam dumtaxat civitatem oculum defigas, sed universum simul orbem circumspicias ac contempleris vel aspectum in longiora saltem regionum spatia diffundas, comperies profecto divina providentia illud non abs re comparatum, ut diversis politiis regiones variae administrentur Inst IV 20,8. Die „Einsetzung der Obrigkeit durch Gott $₫$ ist also - abgesehen von der übernatürlichen Geschichte Israels - wie bei Luther stets durch die Vorsehung und das heißt den natürlichen Kausalnexus vermittelt gedacht. Es ist die stoische Lehre von der Vorsehung und dem Kosmos der politischen und sozialen Welt s. Beyerhaus S. 3, 7I, 109, 62, 127. So geht auch der scheinbare Rechtspositivismus auf Vorsehung und und Naturrecht zurück; Solent plerique nimis scrupulose inquirere quo quisque jure adeptus sit imperium : atqui hoc solo contentos esse decet, quod videmus eos praesidere $C R$ 83, 244. Historische und naturrechtliche Anschauung sind hierin vereinigt. 
samkeit, Bescheidenheit und Fügung in die gegebenen Umstände und Lebenslagen. Calvin scheint geradezu der positivistisch-autoritativen Fassung des Naturgesetzes bei Luther näher zu stehen als der rationalistischen Melanchthons; seinen persönlichen Instinkten hat sicherlich die erstere näher gelegen ais die letztere ${ }^{349}$ ). Trotzdem liegt aber auch hier, und gerade hier, ein starker Unterschied seiner Gesamthaltung von der Luthers und des Luthertums.

Das zeigt sich zunächst in zwei scheinbaren Aeußerlichkeiten. Einmal nämlich ist bei Calvin der Unterschied des absoluten und relativen Naturrechts weit weniger betont als bei Luther. Der Dekalog und das Naturgesetz werden immer wieder als ewige, unwandelbare Regel des göttlichen Sittengesetzes bezeichnet; auf die Abwandelung durch die Bedingungen des Sündenstandes wird dabei nur gelegentlich, aber nie im Prinzip Rücksicht genommen. Insbesondere der Staat erscheint an den Hauptstellen nie als bloßes Gegengift des Sündenstandes und Strafe für die

${ }^{349}$ ) Der leidende Gehorsam: Briefe II 14,64, außerdem Inst IV 20, I und 20, 25. besonders 20, 27: sNunquam in animum nobis seditiosae illae cogitationes venient, tractandum esse pro meritis regeme oder snihil refert, qua sit apud homines conditione, cujus gentis legibus vivas: quando in rebus istis minime situm est Christi regnum. \& Gößter Respekt vor der Obrigkeit Briefe I 213 II 80, 198, 220, 267, Vorzug der Reformation, daß sie die Obrigkeit inehr befestigt als der Papismus II 124. Der Traditionalismus der Genügsamkeit, des Nicht-Weiter-Kommenwollens, aber Frömmigkeit und Gottvertrauen als Ideal der Kindererziehung s. Lobstein 104. Behandlung der Menge im Stile Luthers Choisy $35^{\circ}$ sle peuple, qui est une beste farouche et dangereuse <, S. 352 sune beste à plusieurs testes. Genügsamkeit als Lebensideal Inst II 8, 46. Das cogere in ordinem Hauptinteresse und Lieblingsausdruck Calvins s. Beyerhaus S. 63; der leidende Gehorsam und der Ausschluß der mittelalterlichen Lehre von der Volkssouveränität S. 97 ; aber auch allmähliche Milderung dieser Lehre vom leidenden Gehorsam und zunehmender Rationalismus S. 123-1 29. Es spiegelt sich hierin nur der innere Gegensatz seiner ganzen Theologie, die einerseits den Rationalismus der Lex naturae weitgehend anerkennt und andererseits die Irrationalität des eigentlichen göttlichen Willens behauptet. Calvin kann auf der einen Seite sagen sut voluntas ejus sit pro lege et pro ratione et pro summa justitiae regula Beyerhaus $65, C R 68,685$; auf der anderen Seite kann er Offenbarungsgesetz und Vernunftgesetz identifizieren. Unter dem ersten Einfluß erscheint alle Obrigkeit als einfach von Gott eingesetzt und alle Untertanenpflicht als Betätigung der Selbstdemütigung, unter dem zweiten sind die Obrigkeiten an das Naturgesetz gebunden und von den Berufenen zu kontrollieren bis zur völligen Authebung des Souveränetätsbegriffes für die Obrigkeit. Der Zwiespalt zieht sich durch Calvins ganze Lehre hindurch, doch steigt mit der Zeit der Rationalismus der Staatsbetrachtung; Beyerhaus S. 88. 
Bosheit, sondern wird immer zugleich und vor allem als heilige und · gute Ordnung unmittelbar auf Gott zurückgeführt. Auch von einer Abwandelung des ursprünglichen Liebeskommunismus zu der Ordnung des Privateigentums ist nie die Rede; vielmehr erscheint das letztere gleichfalls als unmittelbare Stiftung Gottes ${ }^{350}$ ). Es tritt also der Kontrast von Urstand und Sündenstand - vermutlich unter der Einwirkung des Prädestinationsdogmas - viel weniger stark hervor; die politischen und wirtschaftlichen Ord-

350) Eine schroffe Aeußerung über den Staat im augustinischen und lutherischend. Sinne (vgl. oben S. 566--568) sucht man vergeblich. Er wird überall und direkt als göttliche Ordnung bezeichnet. Er ist sancta Dei ordinatio et donum ex eorum genere, quae mundis munda esse possunt Inst IV 20, 19. Er gehört zu den unentbehrlichen Mitteln des menschlichen Daseins : Sin ita est voluntas Dei, nos, dum ad veram pietatem adspiramus, peregrinari super terram, ejus vero peregrinationis usus $t a l i b u s$ subsidiis indiget; qui ipsa ab homine tollunt, suam illi eripiunt hu manit a te m IV 20, 2. Der Staat kommt nur von seiner positiven, rationellen, Gesellschaft und Kirche fördernden Seite in Betracht. Hier ist Calvin ganz der Jurist und Praktiker gegenüber dem Mönch und Idealisten Luther. - Bezüglich des Eigentums Spuren des scholastischen Begriffs vom Obereigentum Gottes und von einem ursprünglich staatlichen und kommunistischen Zustand bei Beyerhaus 76. Aber praktische Bedeutung hat das wenig. Die Institutio sagt einfach: Sic enim cogitandum est, unicuique evenisse, quod possidet, non fortuita sorte, sed ex distributione summi rerum omnium Domini; also das Eigentum ist ohne weiteres göttliche Ordnung, ebenso die das Eigentum garantierende Rechtsordnung CR 35 S. 87. In der Auseinandersetzung mit den Täufern, wo man die Auseinandersetzung mit dem Urkommunismus erwarten sollte, heißt es nur: De ce qu' aucuns d'entre eux ont tenu touchant la communauté des biens, item qu'un homme peut avoir plusieurs femmes et mille autres absurdites: je me deporte d'en toucher. Car eux mesmes, estant confuz en leur follies, s'en sont retiré tout bellement pour la plupart CR 35 S. 103. Die Täufer sind ihm weltunkundige und gutmeinende Toren, anmaßende Bibelausleger, die ihren Klein-Leute-Träumen folgen. Je demande à ces bons docteurs, que deviendra le monde! CR 35 S. 87 und 92 ; und wenn sie glauben, daß unter wahren Christen Recht und Gewalt nicht nötig sei, sagt Calvin einfach: c'est une resverie! Das praktische Leben könne schon wegen der unvermeidlichen Irrungen und Unklarkeiten, auch wenn gar nichts Böses dabei ist, ohne Staats- und Rechtsordnung nicht auskommen. Ueber die Art, wie der Staat ohne Sünde sich als patriarchalisches Weltreich entwickelt hätte, s. Kuyper S. 73. Die Tatsache, daß der Kommunismus des Urstandes für Calvin gar keine praktische Redeutung hat, hängt mit seiner ganzen Umfärbung der Liebesmoral zu einer Moral der Gottesverherrlichung zusammen und ist für seinen Rationalismus der Staats- und Gesellschaftsgestaltung von großer Bedeutung, wenn auch wenig beachtet. 
nungen erhalten von Hause aus viel mehr den Charakter göttlicher Ordnungen für den Zweck der Ruhe und Harmonie der Gesellschaft. Die augustinischen Stimmungen der lutherischen Staatsund Wirtschaftsethik, die ja auch bei Luther mehr den Anfängen angehörten, sind so gut wie verschwunden; das Problem ist nur die zweckmäßige Handhabung und Gestaltung dieser Gottesordnungen für die christliche Gesellschaft. Aehnlich steht es mit der zweiten Eigentümlichkeit, der Auffassung des Verhältnisses der ersten und zweiten Tafel durch Calvin. Calvin zählt bekanntlich nicht drei, sondern vier Gebote der ersten Tafel, indem cr das Bilderverbot als Gebot mitzählt und dafür dann das neunte und zehnte Gebot zusammenzieht. Das charakterisiert jeden calvinistischen Katechismus. Aber das hat seine tiefere Bedeutung darin, daß der Sinn der ersten Tafel überhaupt nicht die Forderung der spiritualen, weltbefreiten und weltüberlegenen, das Gute nur aus ihrer Innerlichkeit ausströmenden Gotteinigkeit ist, sondern das Gebot des reinen Kultus ohne' Bilder, ohne Magie und Ritualien und mit strenger Sonntagsfeier. Das ist ein völlig anderer Sinn der ersten Tafel; sie stellt den Purismus der Gesinnung und des Kultus auf die eine und gleiche Stufe des bedingunislosen Gehorsams. Daher fällt auch die lutherische Spannung zwischcr: der absoluten religiösen Liebesmoral der ersten Tafel und den Recht, Zwang und Gewalt einschließenden sozialen Forderungen der zweiten Tafel weg. Sofern auch Calvin wie Luther dic Spiritualität als die den Gehorsam gegen die zweite Tafel hervorbringende und erst christlich beseelende Gesinnung schildert. ist ihm diese Spiritualität die radikale Strenge und Gesinnungsmäßigkeit der Motive, die »von dem Angesicht des wahrhaftis verehrten und erkannten Gottes ausgeht *, nicht die der ganzen Rechtsordnung entgegengesetzte reine Liebesgesinnung ${ }^{351}$ ). Es geht also mit den beiden Tafeln wie mit dem Lnterschied der

961) Sinn der ersten Tafel Inst II 8, I6: Pura sit ergo conscientia vel ab occulissimis apostasiae cogitationibus, si religionem nostram Deo approbare libet. Sicuidem integram et incorruptam divinitatis suae gloriam non externa modo confessiunc requirit, sed in oculis suis, qui abditissimas cordium latebras intuentura. Simn der Spiritualität II 8, 6: , Paulus affirmans legem esse spiritualem significat non modo animae, mentis, voluntatis obsequium exigere, sed requirere angelicam puritatem, qu:te omnibus carnis sordibus abstersa nihil quam spiritum sapiate. Das ist ein ganz anderer Sinn der spiritualität als bei den Lutheranern, bei denen der Gegensatz Geist und Gesetz, Liebe und Recht ist (s. oben S. 494-497, 516). 
Person- und Amtsmoral; waren die Unterschiede schon bei Luther allmählich hinter den formellen Forderungscharakter zurückgetreten, so sind sie bei Calvin vollends verschwunden.

Aber das ist dann doch mehr als bloß die Uebernahme der späteren, den Unterschied verwischenden Lehre Luthers. Es steckt überhaupt ein anderer Geist darin. Die Hervorbringungen des relativen Naturgesetzes in Familie, Staat, Gesellschaft und Wirtschaft erscheinen bei Calvin fast nie von der Seite, wo sie Konzessionen an die Sünde sind und lediglich ertragen werden müssen, sondern fast immer von der Seite, wo sie zweckmäßige Veranstaltungen zur Bekämpfung des Bösen, zur Förderung des Guten und zur Verwirklichung der Ehre Gottes sind. Die Einreden der Täufer, die Luther in seiner Scheidung von Amts- und Personmoral relativ gewürdigt und denen er nur die Unzulässigkeit der Verwandelung des Evangeliums in ein Gesetz entgegengehalten hat, sind für Calvin einfach unpraktischer und phantastischer Unsinn. Er hält ihnen lediglich die Unveränderlichkeit des göttlichen Gesetzes entgegen, das im alten und neuen Testament nicht sich spalten kann, und den praktischen Widersinn ihrer Forderungen, die auch das Naturgesetz aufheben würden. So wenig denkt er an das absolute Naturgesetz als die eigentliche Regel, so selbstverständlich ist ihm das relative Naturgesetz als Gottes Ordnung, so sehr drängt er auf das Praktische, Mögliche und Zweckmäßige. Das aber hat zur Folge, daß die Staats- und Rechtsordnung zweckmäßig gestaltet werden kann und muß für die beiden $Z$ wecke, den religiösen der Aufrechterhaltung der wahren Religion und den sozial-utilitarischen der Bewirkung von Ruhe, Ordnung und Gedeihen; auf diese beiden Dinge allein kommt es ja an. Beides ist nun freilich zunächst lediglich Sache der herrschenden Gewalten selbst. Jede rationelle Erzeugung der Gesellschaft von den Individuen oder dem »Privatmann « her ist für Calvin völlig ausgeschlossen ${ }^{352}$ ). Aber auch so ist doch über Staat, Recht und Wirtschaft eine Atmosphäre der systematischen Zweckmäßigkeit und Rationalität ausgebreitet, die an den lutherischen duldenden Pessimismus in all diesen Dingen

\footnotetext{
352) Inst IV 20, 3 I $\times$ Quibus nullum aliud quam parendi et patiendi datum cst mandatum; de privatis hominibus semper loquor $\propto$. IV 20, 8: Et sane valde otiosum esset, quis potissimus sit politiae in eo quo vivunt loco futurus status, a I,rivatis homimbus disputari!
} 
garnicht denken läßt ${ }^{853}$ ). Aber noch mehr. Calvin denkt über die positiven Staatsformen sehr besonnen und relativistisch, indem er in ihnen die naturgesetzliche Idee des Staates nach Zeit und Umständen, nach Volksart und politischen Bedürfnissen durch das positive Recht ausgeformt sieht. Allein am meisten entsprechen dem Naturgesetz doch die Staatsformen, in denen Kontrolle und Zurechtstellung der regierenden Gewalt möglich ist, also Monarchien mit Ständen und gesetzlich befugten Beratern, Aristokratien mit gegenseitiger Beeinflussung der Gewalthaber, vor allem Republiken mit abgestuften Gewalten. Es ist die berühmte Theorie von dem Widerstands- und Reformrecht der magistrats inférieurs, die von Gott den Beruf haben beim Versagen der obersten Instanz für das Wohl der Gesellschaft und die Wahrheit der Religion einzutreten. Nur dem Privatmann ist das Eingreifen untersagt und der leịdende Gehorsam vorgeschrieben. Die amtlichen Instanzen aber sind berechtigt zu Kritik und Reform und können damit auf das $Z$ iel einer vernunft- und naturgemäßen Gestaltung der Gesellschaft hinarbeiten. Das verbreitet nun aber über das Ganze den Geist der zweckmäßigen Sozialgestaltung und der Kritik von Recht und Gewalt nach den ewigen Maßstäben des göttlichen und natürlichen Gesetzes. Was Luther erst nachträglich auf Grund des positiven deutschen Reichsrechtes sich abringen ließ und stets auf die Verteidigung der Religion gegen fremde Eingriffe beschränkte, das gehört bei Calvin von vornhercin zu den Forderungen des Naturgesetzes und erstreckt sich auf die rationelle ethische Gestaltung des Staates überhaupt, weil dieser am besten in einem positiven Recht sich ausformt, das die nötigen Untergewalten vorsieht zur Kontrolle und Zurechtweisung der obersten Gewalt ${ }^{354}$ ). Wenn auch der Privatmann bei ihm

353) Beispiele dieses Staatsrationalismus, der nicht von der Volkssouveränität, sondern von dem Gedanken des Staatszweckes ausgeht und dadurch schließlich die ethisch-philosophisch-christliche und auch die rechtliche Bindung der Obrigkeit an salus publica und weiterhin die Advokatie für die Kirche mit sich bringt, s. bei Beyerhaus S. $69,95-97,123$ bis 129. Wesen der Gewalt ist ad Dei cultum tuendum et promovendum et populi totius commodum et utilitatem procurandam 125 alles zu bemessen; all das ist am besten durch schriftiche Verfassung zu garantieren 123. Das ist etwas ganz anderes als Luthers Gewaltbegriff (s. olen S. $535-537$ ).

354) Die Belege hierfür in dem sehr gedrängten 20. Cap. des IV. Buches; vor allem die berühmte Stelle $\S 3 \mathbf{I}$, wo Calvin eine aristokratisch tempcrierte Republik für 
noch strenge von diesen Rechten ausgeschieden ist, so trennt ihn doch von der Mitarbeit an der Einführung einer ideégemäßen Staatsordnung nur eine dünne Scheidewand, die in dem Moment fallen wird, wo alle amtlichen Instanzen versagen. Calvins Naturrecht steht in Wahrheit dem katholischen Naturrecht näher als dem lutherischen, von dem er ausging. Insbesondere fehlt jener spezifisch lutherische Antirationalismus, jene Verherrlichung der Gewalt um der Gewalt willen als der Form, die die Gesellschaftsstruktur. unter dem Einfluß der Sünde angenommen hat, deren gottselige Fürsten für die Kirche sich segensreich bedienen können, die aber in der Regel nur mit Leiden und Dulden als das Gegenstück der Liebe ertragen werden soll. Dieser Unterschied ist, wie wir sehen werden, durch die Umstände noch bedeutend vertieft und für die ganze Entwickelungsgeschichte des Calvinismus grundlegend geworden.

\footnotetext{
das dem naturgesetzlichen Ideal nächstkommende Staatswesen erklärt. Daher hat auch die Vorsehung die meisten Staaten mit solchen Organen im geschichtlichen Prozeß ausgestattet: quales olim erant, qui Lacedaemoniis erant oppositi regibus Ephori aut Romanis consulibus Tribuni plebis aut Atheniensium senatui demarchi, et qua etiam forte potestate, ut nunc res habent, funguntur in singulis regnis tres ordines, cum primarios conventus peragunt (d. h. z. B. die deutschen Rechtsstände und die Etats génćraux in Frankreich). Von diesen magistrats inférieurs gilt: illis ferocienti regium licentiae $\mathrm{p}$ r o of $\mathrm{f}$ c i $\mathrm{u}$ intercedere adeo non veto, ut, si regibus impotenter grassantibus et humili plebeculae insultantibus conniveant, eorum dissimulationem nefaria perfidia non carere affirmem, quia populi libertatem, cujus se Dei ordinatione tutores positos norunt, fraudulenter produnt \&. Hierin hat man den Kompromiß von Luthers autoritärem Denken, das Calvin vollkommen teilt, mit seinem rationcllen und die Ansprüche des Individuums sicher stellenden Gesellschaftsideal. Leber die von hier aus immer von neuem ausgehende Kritik an der zweckmäßigen Gestaltung von Staat und Gesellschaft Choisy S. 493 f., Beyerhaus S. 108-130. - Charakteristische Worte Calvins auch bei Kuyper S. 76: Haec maxime optabilis est libertas, non cogi ad parendum quibuslibet, qui per vim impositi fuerunt capitibus nostris, sed electiionem permitti, ut nemo dominetur, nisi qui probatus fuerit and S. 77: sIhr Vülker, denen Gott die Freiheit gegeben hat, Eure eigenen Obrigkeiten zu wählen, seht zu, daß ihr diese Gunst nicht damit verscherzt, daß ihr Taugenichtse und Feinde Gottes zu den höchsten Ehrenposten erwählt«. Das ist ein rationelles Naturrecht, das schließlich zur Bindung der Obrigkeiten an vereinbarte, dem Ideal möglichst nahe kommende Gesetze führen muß, wie denn auch Calvin in diesem Sinne an den politischen Gesetzen Genfs mitarbeitete. Es ist ein Keim des Konstitutionalismus, wie Kuyper S. 89 mit Recht ausführt und Beyerhaus bestätigt.
} 
Ein derartiges Ethos bedeutet nun aber schließlich - und damit kommen wir zu dem fünften Punkt - die einheitliche Gesellschaft, das Corpus Christianum, das in unterschiedlichem, aber nicht getrenntem Wirken des geistlichen und weltlichen Regiments aufgebaut wird. Wie im Katholizismus und Luthertum herrscht auch hier der Gedanke der christlichen Kultur, der christlichen Gesellschaft, der Zwangseinheit des Glaubens ${ }^{355}$ ). Beim Luthertum ist es der freiwillige Liebesdienst der naturrechtlichen, an sich nur auf Recht, Landfrieden und Ordnung gerichteten Gewalt für die rein spirituale Heilsanstalt, die vom Staat mit ihren rechtlichen Organen ausgerüstet und in der Wirksamkeit ihres Geistes unterstützt werden muß. Beim Calvinismus ist es die pflichtgemäße Zusammenordnung der ihre christlichen und naturrechtlichen Pfichten aus Vernunft und Bibel erkennenden Obrigkeit mit der selbständigen und aktionsfähigen Kirche, die über eigene, göttlich-rcchtliche Organe für die Christianisierung der Gesellschaft verfügt, aber mit dem Staat in gemeinsamer Bindung an das Wort Gottes zusammenwirkt. Es ist ein cinheitliches Lebens- und Gesellschaftsganzes, das in weltlichen und geistlichen Dingen von einem gemeinsamen Ideal beseclt ist und das daher ein alles überspannendes soziologisches Grundschema besitzt, genau wie Katholizismus und Luthertum ein solches entwickelt haben ${ }^{356}$ ).

355) Die Belege hierfür geben die beiden Schriften von Choisy bis ins einzelnste. Das geht auch durch die ganze Tradition der reich und selbständig entwickelten reformierten Ethik hindurch. Noch im 18. Jahrhundert lehrt Lampe in seiner Ethik: Finis, in quem ipse Deus mundum conservat, est ecclesiac conservatio et electorum salus. Si salus singulorum est rei publicae finis, tum liquet, quod quo perfectior est salus, ad quam leges societatis civilis tendunt, co perfectior sit ipsa rei publicae forma. Salus temporalis et a eterna ita sibi invicem sunt innexae, ut illa absque hac inanis umbra sit. Luthhardt, Geschichte der Ethik II 219. Man beachte zugleich hier den utilitarischen Individualismus.

${ }^{356}$ ) Der Begriff eines solchen Grundschemas ist von Calvin selbst ausdrücklich formuliert, indem er bei Besprechung des 5. Gebotes das soziologische Verhältnis der Familie mit ihren Autoritäten und der Verinnerlichung der Autorität als die für alle übrigen Gemeinschaftsverhältnisse grundlegende und für alle gemeinsame sratio bezeichnet: Quoniam hoc de subjectione praeceptum cum humani ingenii pravitate valde pugnat (quod, ut est celsitudinis appetentia turgidum, aegre se subjici sustinet) ea, quae naturamaxime amabilis atque minime invidiosa superioritas, in exemplar proposita est, quia facilius animos nostros emollire et inflectere ad submissio$n$ is consuetudinem poterat. Ad omnen enim legitimam subjectio- 
Unter der Einwirkung des ganzen religiösen Gedankengefüges tritt zunächst im Calvinismus, wie bereits oben bemerkt, die Persönlichkeit ganz anders hervor als im Luthertum. Nicht demütige. Selbstaufgebung gegenüber Gott and liebevolle Selbstaufgebung gegenüber den Nächsten, sondern stärkste Empfindung persön-

nem ab ea, quae facillima est toleratu, nos paullatim, assuefacit Dominus : qu a ndo est om nium e a em ratio. Siquidem quibus attribuit eminentiam, quatenus ad eam tuendam necesse est, suum cum illis nomen communicat. In unum ipsum ita conveniunt Patris, Dei ac Domini tituli, ut, quoties unum aliquem ex is audimus, majestatis illius sensu animum nostrum feriri oporteat .... Quapropter ambiguum esse non debet, quia hic universal e m regula m statuat Dominus : nempe prout quemque novimus esse nobis ejus ordinatione praefectum, ut ipsum reverentia, oboedientia, gratitudine et quibus passumus officiis prosequamur. Nec interest, disquirere an indigni sint, quibus honor iste deferatur; nam qualescunque sint tandem, non sine Dei Providentia hunc locum assequuti sunte Inst II, VIII 35. Das scheint dasselbe wie der lutherische vom Familienideal her entwickelte Patriarchalismus. Allein, daß das doch etwas anders gemeint ist, zeigt die Fortsetzung: $\gg$ Sed istud etiam obiter annotandum, quod illis obedire nonnisi in Dominojubemur: neque id obscurum est ex jacto prius fundamento: praesident enim eo loco, in quem erexit eos Dominus .... Quae ergo submissio illis exbibetur, ad suscipiendum summum illum Patrem gradus esse debet. Quare si in legis transgressionem nos instigant, merito tum non parentis loco nobis habendi sunt, sed extranei, qui nos a veri patris obedientia subducere conantur. Sic de principibus, dominis et universo superiorum genere habendum. Indignum enim et absonum est, ut ad deprimendam Dei celsitudinem eorum eminentia polleat, quae, ut ab illa pendet, ita in illam diducere nos debet « Inst II, VIII, 38. Eine allseitige Schilderung des Wesens der Gesellschaft und des Verhältnisses der einzelnen Glieder zueinander s. Inst II, VIII, 46: Rechtmäßiger und ehrenhafter Gewinn ohne Sucht nach Reichtum; Untcrstützung aller im Genuß ihres rechtmäßigen Besitzes und möglichste Vermeidung des Streites mit betrügerischen und treulosen Menschen, auch bei Gefahr eigener Verluste; äußerste Hilfsbereitschaft in Fällen der Not; Korrektheit und Strenge in der Einhaltung aller rechtlichen Verpflichtungen; Gehorsam gegen rechtmäßige Obrigkeiten; Verpflichtung aller Autoritäten für das Wohl ihrer Schutzbefohlenen, beständiges Bewußtsein ihrer Verantwortung vor Gott; Pflichten der Geistlichen zu dogmatischer und ethischer Belchrung und gutem Beispiel; Vertrauen und Gehorsam des Volkes gégen die Geistlichen; milde aber autoritative Erzichung der Kinder, Achtung der Jugend vor dem Alter; freundliche und verständnisvolle Beratung der Jugend durch das Alter; freiwilliger und freudiger Gehorsam der Dienstboten um Gottes willen; brüderliches und fürsorgendes Verhalten der Herren gegen die Dienstboten; Sorge eincs jeden zunächst für seine eigenen nächsten Pflichten; schließlich beständiger Aufblick und Verantwortungsbewußtsein aller vor dem göttlichen Gesetzgebcr. 
lichen Wertes, dás Hochgefühl einer göttlichen Mission in der Welt, einer gnadenvollen Bevorzugung von Tausenden und eine unermeßliche Verantwortung erfüllen die Seele des Menschen, der völlig einsam und in sich selbst die ihn erwählende Gnadenwirkung empfindet und betätigt. Jedoch ist diese im Prädestinationsgedanken wurzelnde Persönlichkeitsidee nicht zu verwechseln mit modernen individualistischen und demokratischen Gedanken. Die Prädestination bedeutet die Berufung der Besten und Heiligen, der Minorität; zur Herrschaft über die Sünder, die Majorität;-sie schließt ein die Betrachtung der gegebenen Lebens- und Machtverhältnisse, sofern sie nicht Gottes Wort widersprechen, als göttlicher Fügungen, in die sich der Mensch demütig und willig ergibt. Aber innerhalb dieser Grenzen hat der Calvinismus eine Schätzung der erwählten Persönlichkeit, die durchaus an Kant erinnert, während Luther hier mehr im Gedankenkreis der Mystik bleibt. Mit dieser starken Betonung der Persönlichkeit ist dann aber auch die Gemeinschaftsidee eigentümlich bestimmt, deren starkes Hervortreten im Calvinismus gleichfalls schon berührt wurde. Die Gemeinschaft ergibt sich nicht wie bei den Lutheranern bloß mittelbar aus den Bedingungen der Leiblichkeit, aus den gegebenen Ordnungen der Lex naturae, aus den unsichtbaren Wirkungen der sichtbaren Lehre und Sakramentsübung. Sie ergibt sich vielmehr unmittelbar aus dem prädestinierenden Willen Gottes selbst. Sie ist nicht ein Mittel der Auswirkung der Rechtfertigungsseligkeit, in welchem doch die befreite und ihres Gottes gewisse Seele sich nie ganz verausgabt, sondern sie ist der Zweck der Rechtfertigung und Heiligung, in welchen alle Energie der religiösen Erneuerung einströmen soll. Bei aller individuellen Isolierung des einzelnen Erwählten im Vorgang der Auswirkung der Erwählung stellt ihn doch diese selbe Prädestination wiederum prinzipiell in die sich gegenseitig hebende und tragende, beurteilende und bessernde Gemeinschaft hinein ${ }^{357}$ ). Und diese Gemeinschaft ist jedesmal,

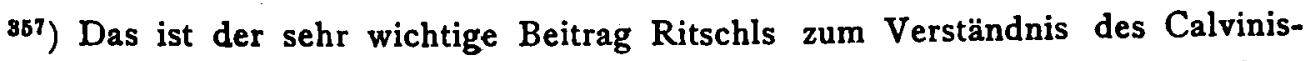
mus. Er hat von hier aus geradezu den mystischen Individualismus des Luthertums korrigiert und dem Luthertum den calvinistischen Gemeindegedanken aufzupfropfen versucht, auch das ein Beispiel der steigenden Bedeutung des Calvinismus in der Gegenwart; s. Rechtfertigung und Versöhnung sI S. 203-216: Calvin hat hierin einen Grundsatz gerettet, den Luther in seiner ursprünglichen richtigen Fühlung der Reziprozität des Rechtfertigungsgedankens mit dem Leben in der Gemeinde der Gläubigen dem unrichtigen Gefüge des römischen Bußsakra- 
wie die Israels, abgegrenzt als eine Volksgemeinschaft. Gott schließt seinen Bund mit jedem Volke und verlangt Treue um Treue, erzieht durch Strafgericht und Heimsuchungen, gibt sein Wort zur Erkenntnis seines Willens. Die einzelnen Völker und Kirchen aber stehen wieder unter einander in engster Verbindung und Wechselwirkung, wo alle für einen und einer für alle steht. Eine internationale religiöse Verbundenheit gehört zu den Grundideen des Calvinismus. Ein Bund christlicher Völker, in dem jedes Volk in seinem Bezirke die Idee des Gottesstaates verwirklicht: das ist der Wille Gottes, wenn er recht aus der Bibel verstanden wird ${ }^{358}$ ).

So ist es ein Grundschema, das weder den immer etwas vegetativen Charakter des Organismus hat; es wendet sich an den bewußten und klaren Zielwillen des einzelnen. Noch hat es den quietistischen Zug des reinen Patriarchalismus, vielmehr verbindet es mit einem starken Sinn für Autorität doch vor allem den Gedanken der gleichen Herrschaft des Gesetzes über alle. Es ist auch nicht die Auffassung der Gesellschaft vom Standpunkt der freien und beliebigen Assoziation oder des Vereins; denn sie wird hervorgebracht durch die leitende Kraft der Vorsehung im Natürlichen und durch die Macht der Prädestination im Uebernatürlichen. Alle bindet und vereinigt der hervorbringende göttliche Wille in einem dem freien Belieben des Individuums entrückten, alle verpflichtenden sachlichen Ziele. Andererseits aber ist es auch nicht die Leitung und Bindung der Gesellschaft durch eine greifbare übernatürliche Priesterautorität, sondern lediglich durch die Gemeinsamkeit des Geistes und durch die von ihm bewirkte $\mathrm{Zu}$ stimmung zum göttlichen und natürlichen Gesetz. Schwierigkeiten und Verwickelungen löst die Bibel und die besonnene Entscheidung des Gewissens vor dem Angesicht Gottes. Es ist eine gemeinsame Bindung in einem objektiven göttlichen Sach- und Zweckzusammenhang, an dem zu arbeiten das Einzelindividuum die höchsten und freiesten persönlichen Kräfte einsetzen muß und in dem doch alle durch etwas Ueberindividuelles aufs strengste ments und Kirchentums (?) entgegengesetzt hat S. 2 I6. Richtiger freilich wäre der Gegensatz bezogen auf eine gewisse mystische Neigung Luthers zur Isolierung des Individuums, die gerade umgekehrt bei Luther im Anfang vorwiegt und dann durch die kirchliche Idee zurückgedrängt wird, deren Wirkungen aber im ganzen Luthertum bleiben.

358) Vgl. Choisy und Kuyper allenthalben. Die Internationalität des Cal- 
vereinigt sind. Es ist das eine völlig neue Struktur des christlich-soziologischen Gedankens trotz der zahllosen Berührungen mit lutherischer, katholischer und altkirchlicher Ausdrucksweise. Die Eigentümlichkeit dieser Struktur gibt den calvinistischen Völkern bis heute ein ganz besonderes Gepräge starker Herausbildung und Verselbständigung der Individualität zur Initiative und zum Verantwortungsgefühl des Handelns, aber auch strengster Gebundenheit in gemeinsamen, sachlichen, durch ihren religiösen Charakter unantastbar gemachten Zielen und Werten. Daher hier überall der individualistisch-demokratische $\mathrm{Zug}$ und doch die starke Herausarbeitung der Autorität und Unwandelbarkeit des Gesetzes. Hier ist eine konservative Demokratie möglich, während die Demokratie auf lutherischem und katholischem Gebiet von vornherein in eine aggressive und revolutionäre Stellung gedrängt ist ${ }^{359}$ ).

Mit dieser Neubildung des soziologischen Grundschemas eng verbunden ist die dem Calvinismus eigentümliche Regelung des Gleichheits- und Ungleichheitsgedankens und der daraus sich ergebenden demokratisch-radikalen und aristokratisch-konservativen Strebungen. An diesem Punkt hat immer eines der Hauptprobleme der christlichen Gesellschaftsidee gelegen; es wurde überdies stets dadurch kompliziert, daß die mit den christlichen Soziallehren von alters her verschmolzene stoische Lehre für den Urstand die Gleichheit aller auf Grund des gleichen Vernunftbesitzes und Vernunftvermögens behauptet und daraus oft genug auch egalitäre Folgerungen für die Gegenwart gezogen hatte. Aehnliche Folgerungen waren auch in der christlichen Gesellschaftslehre, besonders bei den Sekten, nicht ausgeblieben, und verwirren die christliche Idee bis heute. In diesen Verwickelungen nahm der Calvinismus entschiedene Stellung bei dem Satze, daß Gleichheit und Ungleichheit nichts sind an sich, sondern nur in verschiedenen Beziehungen des Menschen gelten. Die Menschen sind gleich vor Gott, vor dem sie alle Sünder sind und vor dem

vinismus zeigte sich erst kürzlich bei dem Genfer Jubiläum und ist durch die rege Uebersetzertätigkeit, die alles wichtig Erscheinende sofort ins Englisch-Amerikanische übersetzt bekundet. Kuypers Buch selbst ist ein Denkmal dieser Internationalität.

s69) Von diesen Schilderungen des Grundschemas im Gegensatze gegen das der französisch-europäischen Demokratie ist das ganze Buch Kuypers durchdrungen. Er leitet davon den Unterschied der amerikanischen und französischen Demokratie als der beiden großen Weltmächte der Zukunft her, während ihm Deutschland als vom Pantheismus zur Schwäche verurteilt erscheint. 
sie alle gleich zum Gehorsam verpflichtet sind. Sie sind dagegen ungleich im Verhältnis zueinander, wo die göttliche Weltordnung die Ueber- und Unterordnung nicht erst als Folge des Sündenfalls, sondern mit dem Wesen des Menschen selbst geordnet hat. Gottes Wesen ist nicht die Vernunft und die alle Vernunftforderungen befriedigende Gerechtigkeit, woraus man die Gleichheit aller postulieren kann. Es ist vielmehr der souveräne Herrscherwille, der die einen erwählt und die anderen verwirft im ewigen Ratschluß, der an keiner für alle gleichen Vernunftordnung gemessen werden darf. So überwiegt in dem ganzen sozialen Fühlen die gottgeordnete Ungleichheit und sind die in so ungleiche Stellungen verteilten Individuen gleich nur in ihrer Unfähigkeit, aus eigener Kraft das Gute zu tun und in ihrer Verpflichtung zum unbedingten Gehorsam gegen den göttlichen Willen. Von hier aus ergibt sich im ganzen ein wesentlich konservativ-autoritativer Grundzug des Gesellschaftsideals. Die Irrationalität Gottes, der Weltordnung und der'Erwählung werden aufs stärkste betont, die gegebenen Ordnungen und Gewalten aufs nachdrücklichste anerkannt ${ }^{360}$ ).

$\left.{ }^{360}\right)$ Die Ungleichheit dauert fort im Jenseits, wie Calvin aus I Cor 15, 4I-42 folgert, Briefe II 66. Je höher einer steht, desto mehr ist er verpflichtet zum Martyrium II 277. Vgl. auch Troeltsch sPrädestination ChW 1907. - Charakteristische Stellen bei Beyerhaus 95: >Wir' sollen wissen, que d'autant plus qu'un homme sera eslevé il est obligé aussi et à Dieu et à ceux sur lesquels il preside comme il n'y a nulle preeminence sans charge, voir sans servitude. Der Kreis dieser sittlichen Pflichten, in dem diese servitude honorable sich betätigen soll, ist entsprechend den eudämonistischen Staatstheorien der Antike in dem umfassenden Begriff des Gemeinwohls gegeben.\& S. 133: „Diese Herrschaft einzelner viri maximi, die ihm als die ursprünglichste erscheint, wird . . folgendermaßen geschildert: >mediocris status hominum, ut si qui aliis praessent, non tamen dominarentur, nec sibi regium imperium sumerent, sed dignitate aliqua contenti civilem in modum regerent alios et plus autoritatis haberent quam potentiae CR $5^{I}$ I 59 a Beispiel Noah. Dieser Zustand, den Calvin mit Justinus als vetustissimus mundi status bezeichnet, genießt deshalb Gottes besonderes Wohlgefallen, weil er den Forderungen einer moderata administratio entspricht, d. h. seitens der Obrigkeit die aequalitas cum minoribus wahrt, seitens der Untertanen die Freiwilligkeit (sponte magis eos reverabantur quam imperio coacti). Dieses aristokratische Regiment. wurde zum ersten Mal durch den Ehrgeiz Nimrods durchbrochen: er ist das Urbild des Tyrannen, sein Name fortan mit einem Schandmal gezeichnet.\& - Diese Mischung von Aristokratie und Herrentum mit der freien Initiative jedes verantwortlichen Einzelnen charakterisiert dauernd die calvinistisch erzogenen oder beeinflußten Völker, sie stehen der egalitären, lateinischen Demokratie im Stile Rousseaus fern, der in dieser Hinsicht durchaus kein Schüler Calvins ist, so oft er dazu 
Aber auf der anderen Seite ist doch die Gleichheit vor Gott nicht bloß ein Trost, bloß eine über das irdische Elend erhebende höhere

gemacht wird. Hierin ist es begründet, daß in England der Stialismus der Selbsthilfe, der Kooperativ-Verbände und Gewerkschaften den erstei "Ausweg bildete und die eigentliche Sozialdemokratie nur schwer aufkommen konnt. Auch in Amerika wird man die langsamen Fortschritte des Sozialismus auf diese Erziehung zur Selbsthilfe mit zurückzuführen haben. Freilich wird dieser Unterschied durch die überall gleichen Wirkungen des industriellen Kapitalismus heute auch dort zunehmend verwischt. - Nach allen Seiten gewendet ist dieser Gedanke bei Kuyper, der im Calvinismus das große moderne Kulturprinzip sieht. Hier über den Gegensatz, in welchem die Amerikaner ihre Revolution gegenüber der französischen empfinden, s. das Wort Hamiltons bei Kuyper S. 80: Die Prinzipien der amerikanischen und französischen Revolution gleichen einander so sehr, wie die stille puritanische Hausmutter der ehebrecherischen Frau in einem französischen Skandalromana. Ebendort S. 78 der Gegensatz der französischen und englischen Revolution nach Burke: -Our revolution and that of France are just the reverse of each other in almost every particular and in the whole spirit of the transactions. - Auch Gladstone erklärt Ruskin: I am a firm beliver of the aristocratic principle, the rule of the best. I am out and out inegalitarian.. How are you to get the rule of the best ? Freedom is the answer Morley, Gladstones Life II 582. Die höchsten Tugenden sind für Gladstone: Self-command, self-control, respekt for order, patience under suffering, confidence in the law, regard for superiors II 124. - Auch Carlyle beruft sich für sein Ideal auf das Puritanertum und den Calvinismus, s. Baumgarten, Carlyle und Goethe 1906; >Das ewige Recht der Menschenwürde, die Aristokratie der Helden und der Gehorsam d. h. die Unterordung unter Besseres, das ist sein soziologisches Ideal. Der Gedanke der Gleichheit ist im radikalen Täufertum, imstoischen Naturrecht und im modernen Naturrecht zu Hause, aber nicht im Calvinismus. Er ist aus jenen Quellen allerdings auch in calvinistische Bevölkerungen eingedrungen, aber nie radikal durchgesetzt. In dem noch $z u$ erwähnenden Buch von IIägermann, Erklärungen der Menschen- und Bürgerrechte, heißt es S. 77 von Milton: - Wir lesen bei M., daß alle Menschen von Natur frei geboren sind. Freilich ist diese Freiheit bei ihm noch eine evangelische Freiheit; er nennt sie a due liberty and proportioned equality, both human and christian. Wie wir gesehen haben, ist man in den amerikanischen Verfassungen teilweise über diese Forderung der Gleichheit nicht hinausgekommen, wenn man es nicht vorgezogen hat, sie gar nicht zu erheben. Ueber die Herkunft der Gleichheit in Amerika aus der Aufklärungsliteratur s. ebenda S. 45. Besonders lehrreich in dieser Hinsicht ist Held, Zwei Bücher zur sozialen Geschichte Englands, 1881. Hier ist die Fortdauer der puritanischkonservativen Züge in allem Liberalismus ausdrücklich geschildert, bes. bei Burke. Ebenso ist hier überall der Zusammenhang der radikal-demokratischen Theorien mit den französisch-egalitären Sätzen gezeigt, bes. S. 340-342, 2S3-293: •Der Geist von Cromwells gottseligen Regimentern war noch lebendig bei der in langen Dezennien vollbrachten Formierung der Arbeiterbataillone, welche die sozialen Troelts ch, Gesammelte Schriften. I. 
Betrachtungsweise, die im übrigen alles läßt wie es ist. Vielmehr wirkt sie in Verbindung mit dem lebendigen Gemeindegeist und mit dem reformierten Individualismus doch recht kräftig auf die praktischen Verhältnisse ein. Das Sittengericht kennt keinen Unterschied der Person und macht auch vor dem Höchstgestellten nicht halt, es erinnert alle beständig an ihre Gleichheit vor Gott und an ihre Verpflichtung gegen die heilige Gemeinde. Die Prediger vermeiden ängstlich die Hervorkehrung ihrer Machtstellung und lassen den Vorsitz in ihren Versammlungen wöchentlich wechseln; Diskussionen mit den Laien über die Bibelwahrheiten sind bestimmt, den Unterschied von Clerus und Laien auszulöschen. Die Gleichgültigkeit von Rang und Stand für die eigentlich christliche Würde wird aufs stärkste eingeschärft und umgekehrt jede Vorzugsstellung als Verpflichtung für das Ganze aufgefaßt. Es besteht unzweifelhaft, rein logisch genommen, zwischen dieser Betonung bald des einen bald des anderen Elementes ein ungelöster Widerspruch. Allein das soziologische Grundproblem des Verhältnisses von Individuum und Gemeinschaft bleibt, sobald es auf den Stufen einer höheren geistigen Entwickelung zum bewußten Problem gemacht wird, immer ein antinomisches. Der Calvinismus hat beide Seiten dieser Antinomie in einer sehr bedeutenden und kraftvollen Weise miteinander ausgeglichen. Dadurch ist er neben dem organisch-patriarchalischen Grundschema der mittelalterlichen Gesellschaftsidee zu dem zweiten großen christlich bestimmten Sozialideal der europäischen Gesellschaft geworden, das dann auch eine ähnlich tiefe und breite Ausdehnung wefunden hat. Alle anderen waren und sind $z u$ spiritualistisch und utopisch, um die harten Gebilde des Kampfes ums Dasein und die Interessenverknotungen zu bemeistern. Ja, es kommt ihm diese große Bedeutung nicht bloß unter den christlichen Soziallehren zu. Er gehört vielmehr zu den großen Typen soziologischen Denkens überhaupt. Neben ihm stehen die Typen der franzö-

Schlachten dieses (19.) Jahrh. ausfochten und trotz aller Leidenschaften und Unklarheiten dem Staat und seinen Gesetzen treu blieben«. „Puritanische Anschauungen, die den Geist der Demokraie durch ein schroffes christliches Pflichtgefühl bändigten, lebten unter den Dissentern noch wirksam fort, Hampden blieb ein populärerer Held als Robespierre«. - Die Geschichte des Gleichheitsproblems wäre einer der wichtigsten Beiträge zum Verständnis der europäischen Gesellschaftsentwickelung. Sie ist freilich noch völlig ungeschrieben; Andeutungen bei Lorenz v. stein, Soz. und Komm. S. 3-128. 
sischen optimistisch-egalitären Demokratie, des Staatssozialismus, des proletarischen-kommunistischen Sozialismus und der bloßen Machttheorie an innerer Bedeutung und historischer Kraft zurück ${ }^{361}$ ).

861) S. die Darstellungen des Grundschemas bei Choisy, L'état chrétien S. $489 \mathrm{ff}$. : Le calvinisme est animé d'un grand esprit d'égalité, de justice et de solidarité sociales. La personne et l'activité de l'homme étant ... . sous la dépendance immédiate de Dieu et de sa parole, il s'en suit que tous les hommes sont également obligés envers Dieu et sont egaux devant sa loi. Aucun n'est capable de faire le bien que par un don de Dieu, par une communication de son Esprit. Puisqu'il est ainsi, aucun homme n'aura par lui-même le droit de dominer'sur les autres. L'autorité appartient à Dieu seul, et il n'y a pas d'acception de personnes devan't Dieu. Cette égalité fondamentale devant Dieu et devant sa loi a pour conséquence que l'autorité des parents sur les enfants, des magistrats sur les sujets, et même des hommes de science et de talent sur ceux qui en sont dépourvus n'appartient pas en propre à ceux qui la détiennent : elle appartient à Dieu qui' l'exerce par eux. En conséquence elle sera suspendue aussitôt qu'ils en abuseront ou qu'ils en useront contrairement à la volonté et au conseil de Dieu. Aussi a Genève les Ordonnances prennent-elles en main les droits des enfants vis-à-vis des parents injustes ou négligeants, aussi les ministres défendent-ils la cause du peuple et ses droits vis-à-vis dụ Magistratat, aussi la Compagnie et le Consistoire se font-ils les champions de la justice, de l'egalité de tous devant la loi, exigent-ils la punition des coupables hauts-placés, des gens de qualité, comme celle des coupables obscurs et sans influence. Et cependant, si l'esprit calviniste est un esprit de justice et d'égalité, ce n'est pas qu'il soit un esprit nivelleur; il reconnaît les différences naturelles, les inégalités providentielles, les charismes spéciaux, les rocations exceptionelles, les talents extraordinaires. Seulement ces inégalités ne constituent pas, à son sens, des droits pour celui qui en bénéficie, elles lui imposent des services. Le calvinisme a donné aux hommes de toute conditions le sentiment de leur solidarité dans leurs obligations morales et dans leur responsabilité vis-à-vis de Dien.e Dazu über die Selbstempfindung des Individuums in diesem Ganzen Choisy, La theocratie S. 279: Aussi les réformés calvinistes authentiques avaient ils à un haut degré le sentiment de responsabilité, l'esprit d'initiative, le besoin de véracité et l'énergie morale de la volonté maîtresse d'elle mêmex. Schilderungen des Grundscliemas, des , Verhältnisses von Mensch zu Mensch a auch bei Kuyper S. 19 bis 24 ; doch herrscht hier eine übertreibende Hervorhebung der demokratischen Konsequenzen: Erst auf Gott und darnach auf den Nächsten zu sehen, war das Bestreben, die Stimmung, die Geistesgewohnheit, der der Calvinismus Fingarig schaffte, und erst aus dieser frommen Ehrfurcht vor Gott, in der man sich gemeinsam vor Gott stellt, entwickelt sich ein heiliger demokratischer Sinn. Daraus folgt daß alle, ob Mann oder Frau, ob arm oder reich, ob schwach oder stark, ob talentvoll oder talentlos, als Gottes Geschöpf und verlorener Sünder nichts, schlechterdings nichts gegeneinander zu beanspruchen haben, daß wir vor Gott und so auch untereinander als Mensch und Volk gleich stehen und daß kein anderer 
Durch diesen Ausgleich von Gemeinschaft und Individuum, Autorität und Freiheit, Zwang und Initiative, Sachlichkeit und Begeisterung, Aristokratie und Demokratie kam der Calvinismus bei aller patriarchalischen Autoritätsgesinnung doch $z u$ einer bewußten Sozialgestaltung, nicht nur auf dem Gebiete der Kirche, sondern auf dem ganzen Gebiet der christlichen Gesellschaft überhaupt. Er räumte dem Individuum eine weitgehende Mitarbeit und einen Anspruch an das Ganze ein, so groß wie das innerhalb der angegebenen Grenzen nur möglich war. Er legte andererseits den sozial Bevorzugten so starke Verpflichtungen für das Ganze auf und verstand jede Vorzugsstellung so sehr als Aufopferung für das Ganze, der die Untergeordneten mit Pietät und Vertrauen begegnen sollen, daß3 alle Ungleichheiten doch in ein System von sich wechselseitig zum Besten des Ganzen fördernden Kräften praktisch aufgelöst wurden. Es war und ist heute noch eine Solidarität, ein Gemeinsinn und eine gegenseitige Verantwortlichkeit der Gemeindeglieder für einander, die stets von neuem durch gemeinsame Arbeit und Kritik das Gemeinleben den ethischen Maßstäben unterwerfen und ihnen entsprechend gestalten. So kam es hier zum ersten Mal in der Geschichte der christlichen Ethik zu einer bewußten und nach Möglichkeit erschöpfenden christlich-kirchlichen Sozialgestaltung. Der Calvinismus war, wie bereits oben bemerkt, christlicher Sozialismus in dem Sinne, daß er das ganze Leben in Staat und Gesellschaft, Familie und Wirtschaft, im öffentlichen und privaten Dasein nach den christlichen Maßstäben solidarisch ausgestaltet. Er sorgte für jedes einzelne Glied, daß es an natürlichen und geistlichen Gütern der Gemeinschaft den ihm den angemessenen Antcil erhalte, und suchte zugleich das Ganze der christlichen Gesellschaft wirklich bis ins einzelne zum Ausdruck der Königsherrschaft Christi zu machen. Der Grund, warum es erst

\footnotetext{
Unterschied zwischen Menschen bestehen darf, als insofern Gott dem einen Ansehen über den anderen verliehen hat oder auch dem einen mehr Gaben schenkte, damit er den anderen und in den anderen seinem Gott mehr diene. Aus diesem Grunde vcrurteilt der Calvinismus nicht nur alle Sklaverei und Kasteneinteilung, sondern ebenso entschieden alle serdeckte Sklaverei der Frau und der Armen, richtet sich gegen alle Hierarchie unter Menschen und duldet keine andere Aristokratie als solche, die persönlich dider als Geschlecht ein Uebergewicht in Charakter oder Talent durch Gottes Gnade beweisen kann, und zeigt damit, daß er dieses Mehr nicht für sich und seine eigene Größe rauben, sondern es für Gott in seiner Welt verwerten willz.
} 
hier $\mathrm{zu}$ einer prinzipiellen und durchgreifenden christlich-kirchlichen Sozialgestaltung kommen konnte, liegt nach allem bisherigen auf der Hand. Die Selte allein hatte im Verfolg der urchristlichen Ideale bisher den Versuch einer grundsätzlich christlichen Organisation der Gesellschaft gemacht. Aber sie hatte als Sekte sich eben damit aus der allgemeinen bürgerlich-rechtlichen Gesellschaft herausgestellt. Der Calvinismus hat nun aber in seinen Kirchenbegriff soviel von den Idealen der Sekte aufgenommen, $\mathrm{da} ß$ er es unternehmen mußte, seine Volkskirche zugleich als Bekenntniskirche, seine Einheit von Staat und Kirche zugleich als christliche Gesellschaft im strengen Sinne der persönlichen Christlichkeit eines jeden einzelnen rücksichtslos zu gestalten. Auf der anderen Seite ist er aber zugleich doch soweit "Kirche* geblieben, daß ihm das Ideal einer Gesellschaft und Staat, natürliches Leben und Kultus umfassenden Einheit nie fraglich wurde und die Abtrennung einer heiligen Sondergemeinde vom natürlich-allgemeinen Leben immer ein Verbrechen blieb. Um aber beides zu können bedurfte es in letzter Linie jener Ermäßigung und Wandelung der eigentlich evangelischen Ideale, die in seinem Anschluß an die alttestamentliche Volksmoral zum Ausdruck kamen. Er hat jene durch die Angleichung an das Alte Testament und an die natürliche Ethik derart den praktischen Lebensbedingungen angepaßt, daß sie möglich und durchführbar wurden. Es waren auch so immer noch außerordentlich hochgespannte Forderungen. In dem strengen Ernst der religiösen Erregung und in dem Zwang der großen Kämpfe ist es ihm für ein Jahrhundert gelungen, sein Ideal auch wirklich durchzusetzen. Dabei ist der Unterschied dieses »christlichen Sozialismus « von jedem modernen bereits angedeutet. Er setzte die Wohlfahrtspolizei der mittelalterlichen Stadt, die vom zünftlerischen Geiste geschaffenen Regulierungen und Ueberwachungen fort, freilich ohne deren monopolistische Starrheit. War in diesen Entwickelungen bisher bereits ein christlicher Sozialismus ausgebildet worden, aber in den Händen der weltlichen und bürgerlichen Institutionen verblieben, so nalım jetzt die Kirche diese Dinge gemeinsam mit der Obrigkeit planmäßig in die Hand. Freilich wich dann dieser kirchliche Sozialismus vor den modernen politischen und sozialen Entwickelungen zurück; aher als deren ethische und sozial bedenkliche Wirkungen hervortraten, da war es dann wieder der Calrinismus, der mit einem neuen, jetzt den modernen Verhältnissen angepassten, aber immer noch 
den puritanischen Geist verratenden christlichen Sozialismus hervortrat ${ }^{362}$ ).

s82) Den Charakter eines christlichen Sozialismuse, die gemelnsame Fürsorge der staatlichen und geistlichen Gewalt für äußeres Wohl und sittliche Korrektheit jedes Einzelnen, die Gesamtverantwortung der Gemeinde für jedes Glied, die bis ins kleinste Detail gehende soziale Reform und Fürsorge, hebt insbesondere Choisy hervor und belegt das mit zahlreichen Beispielen aus den Akten. Dieser Sozialismus ist durchaus antikommunistisch, macht aber überall die Gesamtheit verantwortlich für die einzelnen Glieder und verlangt gegebenenfalls die höchsten Opfer öffentlicher und privater Mittel. Dabei sind die Geistlichen die treibende Kraft; teils Strafen des Zunftgerichtes, teils Vorstellungen beim Magistrat sind ihr Mittel. Sie verlangen Regulierung der Getreidepreise, eventuell durch Staatsankäufe und durch sorgfältige Politik gegenüber Aufkäufern und Monopolisten Choisy, L'état chrétien S. 117, 121, 244; Luxusgesetze und Kleiderordnungen im Interesse der Sparsamkeit wie der Aufrechterhaltung der Standesgrenzen und der Dezenz S. 118, 148, 231 ; einen der Geschäftslage entsprechenden Zinsfuß S. I19, 190; Rückzahlung der Schulden in der gleichen Valuta, in der sie kontrahiert waren S. 120; Verbot des blauen Montags S. 153; statistische Erhebungen nach Distrikten über Vermögen, Unterstützungsbedürfnis, Familienverhältnisse usw. S. 166, 257; Regulierung des Wirtshauswesens und billige Weinpreise S. 167; Unparteilichkeit und Korrektheit des Gerichtsverfahrens aus Anlaß inkorrekter Rechtssprechungen S. 196; Anlage von Manufakturen zur Beschäftigung der Bevölkerung und sorgfältige Auswahl der aus der überfüllten Stadt Auszuweisenden unter sozialen Gesichtspunkten S. 246; strenge Moralität und Rechtlichkeit der Truppen auf den Okkupationsgebieten S. 290; Fernhaltung den internationalen Soldatensitten bei Durchzügen usw. S. 302 ; Hochhaltung der Volksrechte und genauere Justiz S. 342. Das alles sind Anträge und Lischwerden beim Rat. In anderen Dingen geht das Zuchtgericht selbständig vor: es bestraft kaufmännischen Betrug, betrügerische Kohlenhändler, einen Samtfabrikanten wegen zu geringer Breite seiner Stücke um einen Zoll, einen Fremde übervorteilenden Schneider, einen die Taxe überschreitenden Schlächter, einen überfordernden Chirurgen; es dient als Friedensrichter und Schiedsgericht, mahnt den Staatsanwalt an übersehene Vergehen, schülzt die Schwachen, verfolgt Kindermißhandlung usw. $\therefore 443 \mathrm{f}$. "Le consistoire intervient pour rélablir la paix et l'union dans les familles, pour rappeler les individus à leur devoir; il prend en main... les réformes favorables aux petits et aux faibles; il mande et censure les paresseux et les oisifs, les pères et les créanciers trop durs; il se montre sans miséricorde pour les usuriers, les monopoliseurs, les accapareurs, pour les commergants qui fraudent leurs clients. Il combat la rudesse des moeurs du temps, la brutalité des hommes, la négligeance dans les soins données aux malades; Theocratie S. 244. Es ist übrigens klar, wie in dieser geistlichen Sozialpolitik die Mittel und Gedanken der alten Stadt- und Zunftpolitik auf das Ganze des Gemeinwesens übertragen sind. Einzelnes hat Doumergue nachgewiesen. Die Uebernahme dieser Prinzipien auf die mit dem Staat gemeinsam handelnde Kirche und die systematisch- 
In letzter Linie ist es also auch hier die Vereinigung kirchlicher und sektenhafter Motive in einer trotz alledem neuen und ursprünglichen Empfindung von dem Wesen einer religiös begründeten Gemeinschaft, die das eigentümliche Wesen des Calvinismus ausmacht. Das entscheidet auch über die Gestaltung seines soziologischen Grundschemas. Von hier aus versteht sich seine Verbindung des wachsten und regsamsten Individualismus mit einer alle sozialen Unterschiede anerkennenden und aufeinander beziehenden Solidarität, seine Steigerung der Persönlichkeit und seine gleichzeitige Umfassung des politisch-wirtschaftlichen Gesamtlebens, seine Betonung der Gleichheit aller vor Gott und der zu gegenseitigem Dienst berufenen Ungleichheit der irdischen Berufsstellung, seine revolutionäre Messung aller Gesellschaft am idealen Maßstab und der konservative Sinn für Recht und Ordnung, für Autorität und geschichtliche Gegebenheit.

Soviel über die religiös-ethische Besonderheit des primitiven Calvinismus. Es ist in der Tat ein neuer Geist. Diesen Geist hat er in dem Jahrhundert ungeheurer Kämpfe, durch die er vor allem den Protestantismus gegen die Politik der Gegenreformation gerettet hat, im ganzen überall bewahrt. Doch steckt in alledem nichts, was über die gemeinsame Ideenwelt des 16 . Jahrhunderts, über katholisch-altchristliche, lutherische, täuferische und humanistische Gedanken bewußt und prinzipiell hinausginge. Die Zeitgenossen haben nur den antikatholischen Radikalismus als Sonderzug wahrgenommen. Den Lutheranern insbesondere gegenüber traten nur dogmatische und kultische Unterschiede ins Bewußtsein. Calvin suchte sie als bloß äußerliche und terminologische Verschie-

\footnotetext{
einheitliche Ausbreitung über das Ganze der Gesellschaft macht den Unterschied gegen die dem Staat und Zünften die Hauptsache überlassende und übrigens wesentlich karitative Sozialpolitik der Mittelalterlichen Kirche und des Luthertums aus. - Dazu kommen die starken Besteuerungen und Anleihen zugunsten der Armen, der Ortsarmen wie der Refugiés, die immer von neuem bis an die Grenze der Kraft aufgelegt wurden; ohne starke und beständige Geldhilfe von auswärts wäre das ganze System in dem stets bedrohten Genf nicht aufrecht zu erhalten gewesen. L'état chrétien S. $428 \mathrm{f}$. In dieser finanziellen Solidarität lebt der alte christliche Liebeskommunismus wieder auf. - Ueber den christlich-sozialen Charakter als Hauptmoment des Calvinismus auch Rieker S. 68 Göbel II 123. - Ueber die Entwickelung von diesem zünftlerisch-christlichen Sozialismus, der in der Elisabethanischen Gewerbe- und Armenordnung noch sich auspricht, zu dem modernen christlichen Sozialismus s. Held und v. Schulze-Gävernitz, Zum sozialen Frieden.
} 
denheiten zu behandeln und die Einheit des Gesamtprotestantismus aufrecht $z \mathrm{u}$ erhalten. Erst die Lutheraner brachen die Gemeinschaft und schieden sich vom Calvinismus als einer Ketzerei, die schlimmer als die des Mohamed und des Nestorius sei. Den eisentlichen Kern des Unterschiedes, der gerade in der Ethik und denSoziallehren lag, sah das lediglich auf Dogmatik eingestellte Auge des Zeitalters noch kaum. Er äußerte sich greifbar in der Tat auch nur in der besonderen Energie, die der Calvinismus als international werbende und gemeindebildende Kraft entfaltete. Ueberall war er geschäftig am Wege und benützte jede offen scheinende Türe, um in fremde Völker oder in fremde Höfe einzudringen. Calvins Briefwechsel enthüllt eine den Kontinent umfassende theologische Diplomatie und Strategie. Wo nennenswerter Erfolg erreicht war, da verlangte er radikalen Bruch mit dem Kult und den Zeremonien, ein offenes Bekenntnis, was ebenso viel sagte wie einen radikalen Neubau und die Organisation einer von den Trübungen des Teufels frcien Gemeinde. In diesem Verfahren uriterschied er sich grundlegend vom Luthertum, das überall zu Zugeständnissen an die alte Kirche bereit war, wo man nur die reine Predigt von der Rechtfertigung duldete und alles übrige der wundertätigen Macht des heiligen Geistes überließ. Diese Energie war daher auch zunächst das Geheimnis seines Erfolges, mit dem er Luthertum und Täufertum überflügelte. Radikaler Bruch, geordnete Neubildung der Kirche nach den Grundsätzen des calvinistischen Kirchenrechtcs und internationaler Zusammenhang der sich geistig und materiell unterstützenden neuen Kirchen: das ist das Programm der neuen Kirche, die sich von Genf aus verbreitete und den von ihr ergriffenen Völkern einen neuen Charakter aufprässte.

Von einer erkennbaren Annäherung an die moderne Kultur ist bei alledem noch nicht die Rede. Wenn eine solche trotzdem immer wieder sich als Tatsache aufdrängt und von der Entwickelung des Calvinismus, ohne daß diese irgendwo einen grundsätzlichen Bruch erlitte, schließlich - in einer freilich sehr einseitig bestimmten Richtung - herbeigeführt wurde, so kann diese Annähcrung nicht in den religiös-ethischen Grundgedanken selbst licuen, sondern muß in einer ursprünglichen Anpassung derselben an die tat,ächlichen Verhältnisse begründet sein, die, zunächst kaum merbbar, doch die Möglichkeit der kommenden Umbildungen in sich enthielt. Diese Anpassung muß dabei von Hause 
aus eine innerlich, aus dem Geiste des Calvinismus begründbare gewesen sein. Es muß die religiös-ethische Sonderart mit den gegebenen politisch-sozialen Kulturverhältnissen schon im Keim eine unlösliche innere Verbindung eingegangen sein, deren Ergebnisse dann in der Entwickelung des Calvinismus zutage traten und ihm cine Anpassungsfähigkeit an die moderne bürgerlich-kapitalistische Kultur ermöglichten, die dem Katholizismus und dem Luthertum fehlten oder jedenfalls in diesem Maße nicht zukamen. Nur so versteht sich die verhältnismäßig gradlinige Entwickelung des Calvinismus, die doch zu einem von dem Ur-Calvinismus so verschiedenen Ergebnis führte.

All dies ist in der Tat der lall gewesen. Indem die Genfer Verhältnisse von Anfang an Calvins politisches, soziales und wirtschaftliches Denken mitbestimmten, haben sie zu jener Anpassung geführt, deren volle Tragweite sich freilich erst viel später zeigtc. Es handelt sich nunmehr also um die Aufspürung dieses EinflussesderGenfer allgemeinen kulturellen Lage auf den $\mathrm{Calvin}$ is $\mathrm{mus}^{363}$ ).

Die erste Wirkung des Genfer Bodens ist nun freilich schr einfach lediglich die, daß sich hier allein die Verhältnissc fanden, unter denen Calvins Ideal einer heiligen Gemeinde verwirklicht werden konnte ${ }^{364}$ ). Das Calvin vorschwebende Ideal erfüllte auch weite Kreise der deutschen Reformationsbewegung ${ }^{36: 5}$ ). Allein in den fürstlichen Territorien war es ohne jede Aussicht auf Verwirklichung, da es die fürstliche Macht bedrohte. In den großen und selbständigen Stadtrepubliken widersprach es nicht minder der hergebrachten und in diesen Zciten nach den reformatorischen Erschütterungen sich wieder festigenden Macht der Geschlechter. Auch in Zürich mußte Zwingli sein Ideal in die Hand der Staatsgewalt legen. In Straßburg zerbrach das Lu-

${ }^{363}$ ) Die gleiche Fragestellung bei Marcks Coligny I I S. 286. Ich versuche hier nur noch etwas über die Analyse von Marcks hinauszugehen.

364) So sehr treffend auch v. Bezold, K. d. G. II, V, I S. 81; auch Marcks Coligny a. a. O.

${ }^{365}$ ) Hierüber s. Barges Karlstadt. Das muß vorsichtig machen gegen die Meinung, der Calvinismus sei die spezifisch französische und romanische Gestalt der Reformation, s. auch Hundeshagen I 293, Rieker S. 59 und Marcks Coligny I I S. 287; die richtigen Einschränkungen dieses Satzes bei Marcks S. 289 und 296. Ueber Zwinglis Reform in dieser Hinsicht s. Kreuzer, Zwinglis Lehre von der Obrigkeit 1909 (Kirchenrechtl. Abhh. hg. v. Stutz Nr. 57). 
thertum im Bunde mit der Oligarchie die bescheidenen Butzerschen Anfänge. Der mächtige Nachbarstaat Genfs, Bern, war nicht bloß das klarste Beispiel solcher Ausnützung der Reformation für die Oligarchie, sondern auch der eigentlichste Feind Calvins; er hat ihm das Leben andauernd schwer gemacht und wollte die selbständige calvinistische Kirche nicht aufkommen lassen, um sein eigenes Kirchenregiment nicht durch böses Beispiel zu gefährden. Das aber, womit Bern seinen Nachbarn bedrohte, war das Schicksal all der kleinen abhängigen Kommunen in Deutschland, die das -puritanische Laienchristentum * in einer selbständigen Gemeindekirche orsanisieren wollten und dabei von den die Ansteckungsgefahr resolut beseitigenden Landesherren oder Nachbarfürsten gehindert wurden, so daß den Anhängern dieses Ideals nichts übrig blicb, als an das Täufertum abzufließsen ${ }^{366}$ ). In Genf dagegen, das seine politische Freiheit und seine Verfassung im Kampf gegen seinen Bischof und gegen Savoyen errungen hatte, dessen lireiheit mit der Behauptung der Reformation unlösbar verbunden war ${ }^{367}$ ) und dessen junge Regierung ohne Herrschaftstradition einer sehr verwickelten politischen Lage gegenüberstand, da allein war der Ort zur Aufrichtung einer solchen Gemeinde, die mit ihrer eigenen Festigkeit zugleich den Staat zusammenhielt, trug und festigte, die init der Genialität ihres Leiters zugleich der politischen Leitung einen festen Halt gab. Hier hat Calvin dic auch in Genf vorhandene Neigung der alten Geschlechter zu einem Staatskirchentum nach Berner Muster in heißen Kämpfen niedergerungen und eine in allen äußeren Dingen dem Magistrat unterworfene, aber durch das Zuchtgericht selbständige und durch den dauernden Vorsitz Calvins gefestigte Kirche aufgerichtet, die das Rückgrat des jungen und unfertigen Staates bildete. Nur so konnte Calvin die frei nach dem Wort Gottes sich bestimmende, von ihren Geistlichen als ihren Tribunen geschützte und durch das Zuchtgericht im Einverständnis mit der Obrigkeit rein gehaltene heilige Gemeinde schaffen. Es ist eben - und das ist die allgemeine Bedeutung dieses Sachverhaltes - die Vereinigung von Volkskirche und Bekenntniskirche, von Heilsanstalt und Sek-

366) Vgl. die Reformationsgeschichte Rothenburgs bei Barge II 295-363; Abfließen an die Täufer II $452 \mathrm{f}$.

367) Vgl. die von Beza verfaßte Jubiläumsinschrift von 1584 , in der sla restauration de la religion et de l'antique liberté de Genève zusammengefaßt sind, Choisy l'état S. 233. 
tenideal, die christlich-soziale Ausgestaltung des Gesamtlebens nicht möglich ohne organisierte Herrschaft der christlichen Idee über die Gesellschaft; das aber heißt, da diese Ideale schließlich nur durch den Geistlichen sachkundig und rein vertreten werden können, nicht möglich ohne Herrschaft der Kirche über die Gesellschaft. Man mag alle hierarchischen Züge noch so sehr austilgen, die Selbständigkeit der weltlichen Macht auf ihren Gebieten noch so sehr betonen, die freie Mitarbeit jedes einzelnen noch so sehr heranziehen, wie das alles in Genf geschehen ist: es geht trotzdem nicht ohne Herrschaft der Kirche über Staat und Gesellschaft. Darum war diese erste durchgreifende soziale Ausgestaltung des Christentums auch die am meisten theokratische. Calvin hat mit denselben Worten wie Luther die Selbständigkeit und Weltlichkeit des Staates gelehrt, aber indem er - wie alle drei Konfessionen unter der Voraussetzung des einheitlichen Corpus Christianum - zugleich eine starke selbständige Kirche schuf und eine christlich-ethische Gestaltung der gesamten Gesellschaft und Kultur durch sie bewirken wollte, hat er tatsächlich doch den Staat der Kirche untergeordnet.

Wenn nun aber so der Genfer Boden erst die Aufrichtung des calvinischen Christentums möglich machte, so hat auf der andern Seite bei der starken Anerkennung der Selbständigkeit und des Rechtes aller weltlich-vernünftigen Ordnungen diese enge $\mathrm{Zu}$ sammenfassung von Gesellschaft und Kirche doch auch wieder stark auf die Ethik und die Sozialideale der Kirche Calvins zurückgewirkt.

Das zeigt sich in erster Linie an einem von da ausgehenden demokratisch-konstitutionellen Zuge. Zwarkann man dem entgegenhalten, daß Calvins persönliche Anschauung so undemokratisch und autoritär war wie möglich, daß Calvins Kirchenverfassung trotz der Beteiligung der gesamten Gemeinde an der Kirche doch auf Grund ihres göttlichen Kirchenrechtes und bei der besonderen Verflechtung mit der aristokratischen Stadtverfassung durchaus keine Gemeindedemokratie bedeutete ${ }^{368}$ ), schließlich daß

s08) Der Gemeindecharakter der calvinischen Kirche ist unzweifelhaft. Denn an allem ist die Gemeinde beteiligt, wenn auch nur durch sorgsam ausgesiebte Laienvertreter, wie im Zuchtgericht, oder durch das Recht der Zustimmung, wie bei der Pfarrwahl; vgl. den Satz aus CR. XL 9 bei Holl 54 : les pseudod-evesques ont ravy a l'assemble des fideles et tire a eux la cognaissance et puissance d'excommunier. Aber die Aemter selbst sind nicht Ausdruck eines freien Organisations- 
die Genfer Verfassung selbst unter Calvins Einwirkung und ent. sprechend dem Zuge der Zeit sich eher oligarchisch als demokratisch entwickelte ${ }^{369}$ ). Das alles ist richtig. Aber trotzdem wirkte die Verflechtung einer Gemeindekirche mit einer städtischen Republik in letzter Linie stark auf demokratische Gedanken, auf das Prinzip der Volkssouveränität, hin. Das ist einmal der Fall dadurch, daß die ganze Regierung auf das vernünftige, vom Naturgesetz verlangte Wohl des einzelnen hinarbeiten und der Staat in diesem Sinne vernunftgemäß sein soll. Das wird aber noch weit mehr dadurch bewirkt, daß das letzte und entscheidende Mittel zur Beeinflussung der politischen Gewalt in diesem Sinne der Appell an die Volksstimmungen und an die Wähler durch die Predigt ist. Der Cri au peuple ist in allen schwierigen Fällen dic ultima ratio Calvins und seiner Nachfolger. Durch Aufreizung der Massen in der Predigt, auch Denunziation und Rüge ungöttlicher oder unvernünftiger Regierungsmaßregeln arbeitet Calvin gegen die herrschenden Geschlechter und beeinflußt cr die Wahlen. Der berühmte Lobpreis der republikanischen Verfassung, des Fifers der Unterthanen für deren Aufrechterhaltung und der l'flicht der Obrigkeit für ihre Respektierung findet sich erst in den Ausgaben seiner Institutio seit 1543 als Einschub in

willens der Gemeinde, sondern göttliche Einsetzung, daher auch nicht an ein $\mathrm{Zu}$ standeliommen durch die Gemeindetätigkeit gebunden, s. Rieker, Grundsätze reformierter Kirchenverfassung S. 92, 126 f. u. $129 \mathrm{ff}$. So war denn auch in Genf die Kirchenverfassung sehr aristokratisch, die Pfarrwahl fand durch die Pfarrer statt, die Gemeinde hatte nur das Recht der Zustimmung. Die Aeltesten des Zuchtgerichts waren teils vom Rat delegiert, teils von den Geistlichen ernannt. Weitergehende, die Wahlen in die Hand der Gemeinde legende oder gar die Gemeinde zum Inhaber des Zuchtrechts machende Vorschläge wurden abgeschlagen, und zwar von den Theologen selbst, s. Choisy, L'ćtat chrétien S. 79, ebenso auf dem Gebiet der Staatsverfassung S. 149. Siehe die Schilderung, die Calvin selbst in dem Brief an Olevian nach Fieidelberg als Muster für die pfälzischen Einrichtungen gab, Briefe II 329-33I. Der gleiche Charakter der französischen Kirchenverfassung bei Marcks Coligny I I S. $33 \mathrm{I}$, über Genf S. 297 f. Auch die Synoden waren nicht Vertretungskörper, sondern nach göttlichem Recht gebildete Regierungskörper, Rieker 158. Immerhin aber ist der überall vorausgesetzte tacitus consensus der Gemeinde und das weitgehende Einspruchsrecht wenigstens ein demokratisches Element.

369) Die zunehmende Oligarchie in Genf bei Marcks Coligny I ${ }^{1}$ S. 299, der Calvins Anteil an dieser Entwickelung betont; überdies Choisy, L'état chrétien S. 148 . 
den übrigens seit 1536 unveränderten Text ${ }^{370}$ ). Dieses Recht auf den Cri au peuple ist denn auch während des ersten Jahrhunderts ein beständiger Streitgegenstand zwischen Magistrat und Predigern in den Akten beider Körperschaften gewesen. Die Geistlichen haben hierbei stets von neuem ihren Gewissensstandpunkt mit aller Schärfe betont, daß sie keine stummen Hunde sein dürfen, daß sie die Tribunen des Volkes seien. Sie haben damit den Rat wiederholt aufs stärkste eingeschüchtert und stets von neuem dessen Bitten hervorgerufen, es möchten doch solche Beschwerden erst im Stillen verhandelt werden, ehe sie auf die Kanzel gezogen würden. Erst gegen Ende des Jahrhunderts gelang es, diese Freiheit der Geistlichen einzuschränken ${ }^{371}$ ). Das aber kam tatsäch-

${ }^{370}$ ) Es ist die wichtige $P$ artie in Institutio IV, 20, 8 Equidem-cogitatio; vgl. den synoptischen Druck der Ausgabe C. R. XXIX S. I 105. Sie steht im Gegensatz zu der älteren Stelle VIII, 20, 7, wo die alle zur Knechtschaft verurteilende Monarchie als von der Schrift zur Bändigung der menschlichen Bosheit beglaubigt erscheint. S. dazu die bei Doumergue, Les origines historiques de la déclaration des droits de l'homme 1905 S. rof. mitgeteilten Stellen aus den Vorlesungen, die deutlich die Genfer Erfahrungen widerspiegeln: Zu Micha 5, 5 , Le prophète magnifie ici le bénéfice singulier de Dieu à savoir, que le peuple sera remis encore en sa liberté. Et de fait c'est l'état le plus désirable qui soit, quand les pasteurs (d. h. hier die Magistrate überhaupt) sont élus et créés par les voix communes des peuples. Car là où quelqu'un usurpe empire et domination par violence, c'est une tyrannie trop barbare. Là aussi où les rois dominent par succession et droit d'héritage, cela ne semble très convenable à la liberté. CR. XLIII 374. - Zu Deut I6, II : $\gg$ Quand nous voyons de ces exemples (d. h. schlechte Könige), conaissons que c'est un don inestimable, si Dieu permet, qu'un peuple ait liberté d'élire chefs et magistrats .. d'autant que c'est un don excellent, qu'il soit conservé, et qu'on en use en bonne consciences CR. XXVII 4II. Das wurde dann der offizielle Stil, in dem die Genfer von ihrer Republik als einer besonderen, die Christlichkeit des Staates ermöglichenden Gottesgabe sprachen, wie Choisy mehrfach zeigt. Auch bei Beyerhaus ähnliche Stellen S. I16-129.

371) Von Calvin zeigt das jede Calvinbiographie, z. B. Kampschulte II 355 bis 357 . Die Verhandlungen mit dem Magistrat über den cri au peuple und dessen Wirksamkeit bei Choisy L'état chretien. S. 55 : Colladin predigt gegen den Wucher und der Rat behandelt das als Meuterei. S. 154: Beza predigt im Auftrag der Minister gégen die Getreidepreise usw.; S. 190: Predigt gegen den Wucher und Verantwortung der Minister: $I l$ faut qu'il die librement que le magistrat ne fait ce qu'il pourroit et devroit faire. Les fautes se commettent. Eux qui en oyent parler, s'en enquierent et reprennent quelques fois en général, quelques fois en particulier. Les choses sont quelques fois évidentes et qui crèvent les yeux et on ne les veut voir. L'ilz (die Prediger) se taisoient là-dessus, que diroit le peuple? 
lịch auf eine Zuflucht zum eigentlich souveränen Herrscher, zum Volke, hinaus, und das umsomehr, als es sich hierbei gerade stets Qu'ils sont chiens muetz. Estimet-on qu'ilz veullent croistre de la ruine du magistrat ou qu'ilz tachent d'exciter sédition, conme s'ils ne scavoient pas qu'ilz seraient les premiers perdus? Mais c'est la crainte qu' ils ont qu'à faute de re veill e r les personnes, on se perde... Voyans donc cela, ilz sont contrains de faire office de tout, non toutefois pour entreprendre sur le magistrat, mais pour ce qu'on ne voit ce qu'on devroit voir. \& S. 25 I f.: Sechs Ratsherren setzen (unter Einfluß Bezas) dem Magistrat unter Berufung auf die religiöse Pflicht die Notwendigkeit auseinander, an Savoyen den Krieg zu erklären und fordern d'y mettre la main dès à présent et sans delay, sinon que voulions faire naufrage de la précieuse liberté, qu'il a pleu à Dieu nous donner et conserver jusqu' ici .. et, qui est le plus à deplorer, exposer à blasphème et opprobre le saint nom de Dieu, nostre souverain père et bienfaiteur, pour en estre grièvement responsables à son jugement. Das Volk murre bereits gegen den Rat. IIl faut que les bons magistrats respectent la voix commune et les lamentations des gens de bien principalement a ux états libres, oùsans le peuple ils ne sontrien.\& Das Recht dieses Krieges ist spiece ratifiée par le désir et le consentement de tout ce peuple fidèle et instruit en la crainte de Dieus. Der Rat antwortet, daß er das Gewicht dieser Vorstellung empfinde, und übergibt sie Beza zur Begutachtung. S. 298: Die Minister beschließen gegen einen Beschluß des Rats der Zweihundert in Appellationssachen. Daran schließt sich ein langer Streit zwischen den Ministern und dem Rat, der darin Auflehnung sieht. S. 347 : Die Minister erheben Vorstellungen gegen Unregelmäßigkeiten bei einer Wahl und unterstützen die Vorstellung durch Predigten. Auf Gegenvorstellungen des Rats bezeugt die Compagnie ihr sdéplaisir de ce que Messieurs ne s' unissent avec le peuple ni avec eux ainsy que naguèrea. Sie erklären squ' etant informé par le peuple des particularités, des défauts qui sont en la seigneurie, ils sont contraints de reprendre le magistrat en chaire, laquel'e est la chaire de veritéc. Weitere Beispiele S. 356, 375, 395, 396, 399, 610. S. 413: Die dauernde Bedeutung dieses cri au peuple in Genf. S. 467 treffender Vergleich der Minister mit der heutigen Wirkung der Presse. S. 469 das Gesamtbild: IIls étaient admirablement informés des circonstances matérielles, commerciales et morales de la population, grâce à leurs fonctions d'officiers de moralité publique. Leurs rôle de surveillants des doctrines et des moeurs les mettaient tout au courant des détails de la vie quotidienne des citoyens. Ce rôle de défenseurs et de tribuns populaires ou plutôt de prophètes de la loi dé Dieu a grandement contribué à les faire aimer des classes pauvres, il faisait d'eux des hommes admirablement placès pour servir de médiateurs impartiaux entre les différentes couches socialesa. Mit Recht hebt auch Choisy den konstitutionellen Charakter des ganzen Gemeinwesens hervor; S. 498: „Les édits politiques et les ordonnances ecclésiastiques, rédigés sous l'influence et avec la participation de Calvin, sont une autoritè supérieure au magistrat et mettent une barrière à ses visées absolutistes; c'est le droit constitutionel dont il ne lui est permis de s'écarter et auquel il ne peut toucher, sans 
um Interessen des Volkes, um gerechtes Gericht, Durchführung des Unterstützungswesens, um wirtschaftliche und politische Notstände und Unsitten und ähnliches handelte. Trotz aller Hochschätzung der Autorität und aller Verpflichtung des Privatmanns zum Gehorsam ist das doch die Parole: Durch das Volk und für das Volk.

Es ist daher gar nicht verwunderlich, wenn schließlich Calvins treuester Jünger und Nachfolger, Beza, angesichts der Bartholomäusnacht und der unverbesserlichen Gottlosigkeit der französischen Staatsgewalten die Theorie vom Untertanengehorsam überhaupt aufhob und für solche Notfälle unumwunden die Souveränität des Volkes als letzte Instanz verkündigte. Das ist die Bedeutung seiner kleinen Schrift »de jure magistratuum $\star$, die erst neuerdings sicher auf ihn als Urheber zurückgeführt ist. Seine Meinung war dabei noch kein künstliches rationalistisches Staatsrecht mit Staatsvertrag und ähnlichem, sondern nur der einfache Grundgedanke, daß göttliches und natürliches Recht das Volk zur letzten Quelle des Rechtes machen, wenn alle anderen Instanzen versagen; daß auch die bewaffnete Revolution erlaubt sei, wenn keine andern Mittel übrig bleiben; daß die Obrigkeiten an die in irgend einer Weise das Naturgesetz enthaltenden positiven Gesetze und mangels derer an das stillschweigend vorausgesetzte Naturgesetz gebunden bleiben und im Falle tyrannischer Verletzung von den dazu berufenen Instanzen gemahnt und gezwungen werden dürfen, wenn ihr eigenes Gewissen versagt. Es ist die Volkssouveränität, das Revolutionsrecht und die konstitutionelle Bindung. Aber all das ist freilich eingebettet in eine Menge von Vorbele consentement du peuple réuni en Conseil général . . . Le pouvoir du Magistrat se borne à un droit de contrôle et de conservation. In Konfliktsfällen kann er nur durch Berufung der Gutachten fremder Kirchen sich helfen. Comme le Magistrat, les fidèles doivent veiller à ce que tout ce qui ce fait dans l'église, soit conforme aux Ordonnances de la parole de Dieu; ils peuvent s'opposer à l'élection d'un ministre qu'ils ne jugeaient pas digne de sa charge et demander à l'autorité compétente la déposition de celui qui ne la remplirait fidèlement - das allein ist ein entschieden demokratischer $G$ rundgedanke, aber charakteristisch bleibt, daß dabei immer das Volk als durch seine von Gott bestellten Vertreter handelnd gedacht wird. Diese Vertreter sind im höchsten Sinne die Minister, die sich daher mit Vorliebe mit den Propheten des AT. und deren Volksmission vergleichen S. 72 und 123. Ein direktes Handeln des Volks gibt es nur bei den Wahlen, aus denen aber die Machthaber erst durch ein sorgfältiges Filtriersystem hervorgehen; außerdem durch Beschwerden und Denunziationen bei den Geistlichen und Aeltesten. 
halten und Einschränkungen, die mit diesem demokratisch-individualistischen Gciste die alte christliche Autoritäts- und Ergebungslehre sowie die Lehre von dem göttlichen Recht und der göttlichen Einsetzung der historischen Gewalten verbinden. Alle diese Rechte und Pflichten nämlich gelten zunächst nicht vom Privatmann, sondern nur von den irgendwie gesetzlich Berufenen, von Ständen, niederen Magistraten, Wahlkörpern, die im Interesse des Volkes zu handeln beauftragt und verpflichtet sind; auch handelt es sich nicht abstrakt um vernunftgemäße Gestaltung der Gesellschaft, sondern um Besserung oder Ersetzung der schlechten Obrigkeit, wornach dann die alten historischen und darum göttlichen Rechte wieder in Kraft treten; schließlich ist all das erlaubt nur gegen die wirklich zum Tyrannen entartete Obrigkeit d. h. gegen eine Staatsgewalt, die natürliches und göttliches Recht dauernd auföst und gegen die erste und zweite Tafel des Dekalogs sich grundsätzlich vergeht. Es ist immer noch ein Kompromiß der Lehren von der Göttlichkeit der Obrigkeit, welche der geschichtliche Prozeß unter der Leitung Gottes emporträgt, und von der leidenden Gehorsamspflicht des Christen, die die Bibel vorschreibt, mit dem reformierten Individualismus und seinem rationellen Gesellschaftsideal, dessen praktische Betätigung die eigentliche Pflicht gegenüber der Ehre Gottes ist und unter den Satz fällt, daß man Gott mehr gehorchen müsse als den Menschen. Es ist schon bei Calvin ein Kompromiß gewesen. Bei Beza ist in diesem Kompromiß nur der Ton noch viel stärker auf das individualistischrationelle und demokratische Element gefallen. Was diese Entwickelung der Theorie möglich machte, deutet er selbst an, indem er sich auf das Volkswohl als auf den $Z_{\text {weck }}$ des Staates und auf das Recht des Appells an das Volk gegen die Obrigkeit beruft, dem dann auch das Recht eines praktischen und bewaffneten Widerstandes folgen müsse. Das rationelle, in der Ethik des Calvinismus eingeschlossene und mit dem christlichen Individualismus verbundene Naturrecht des Calvinismus zeigt hier seine Bedeutung und seine Konsequenzen ${ }^{372}$ ).

${ }^{372}$ ) Es ist die berühmte Schrift De jure magistratuum in subditos, die bisher unter den sogenannten monarchomachischen Schriften anonym figurierte (auch noch bei Gierke, Althusius ${ }^{2}$ S. 4), die aber von Cartier (Bulletin de la Soc. d'histoire et d'archéologie de Genève Bd. Il I898-I904 S. I87-206) als von Beza stammend aus den Ratsprotokollen erwiesen ist. Mir liegt ein Druck von Basel 1580 vor als Beigabe zu Machiavellis Principe, zusammen mit den Vindiciae contra tyran- 
Die Schrift Bezas, der diese Theorien in seinen Vorlesungen einer internationalen Studentenschaft vorzutragen pflegte, mußte auf

nos. Der Rat verweigerte unter Billigung des Inhalts doch das Imprimatur aus Vorsicht gegenüber dem französischen Gesandten, und so erschien die Schrift mehrfach anonym. Ihr Inhalt wird von Cartier treffend mit folgenden Sätzen angegeben. S. I88: Il n'y a d'autre volonté que celle d'un seul Dieu, qui soit perpétuelle et immuable règle de toute justice (es ist sjus illud naturae, a quo uno pendet totius humanae societatis conservatio 266, gedacht in seiner Erstreckung auf beide Tafeln 207). - Les peuples auxquelles il a plu de se laisser gouverner ou par un prince ou par quelques seigneurs choisis, sont plus anciens que les magistrats, et, par conséquent, le peuple n'est pas créé pour les magistrats, mais au contraire les magistrats pour les peuples. - Toute résistence du sujet contre son supérieur n'est pas illicite ni séditieux. - Juste résistence par les armes n'est point contraire à la patience ni aux prières des chrétiens. - Tous se doivent opposer à ceux qui voulent usurper domination sur leurs concitoyens ou autres non sujets a eux. - Les états (Stände) sont pardessus les rois. - Les États ou autres ordonnés pour servir de frein aux souverains peuvent et doivent les réprimer par toutes voies, quand ils sont devenus tyrans. - Le bien public et les droits de la nation sont supérieurs a ceux de l'individu, même à ceux du souverain. - L'injuste usurpateur d' une domination peut devenir mágistrat légitime et inviolable, y entrevenant le volontaire et droit consentement par lesquels les légitimes magistrats sont créés. - Étant persécuté pour la religion, on se peut défendre par armes en bonne conscience. Das klingt freilich alles sehr modern demokratisch, aber darüber sind nicht, wie meist geschieht, die echt calvinistischen Restriktionen zugunsten des historischen Rechtes und seiner Auffassung als durch Gottes Vorsehung mittelbar bewirkt und darum doch von Gott gesetzt zu übersehen. Ich habe sie oben im Text angegeben, sie durchziehen immer wiederholt mit Betonung der christlichen Gehorsamsgesinnung das ganze Buch. Vor allem ist das wichtig für die Auffassung der Entstehung des Staates und des Staatsvertrages. Die Entstehung wird stets aristotelisch als organische gedacht; der Staatsvertrag einer gegenseitigen Verpflichtung von Untertanen und Herrschern, einer Bindung des Herrschers an natürliches und göttliches Recht, liegt darin nur stillschweigend und selbstverständlich. Das historische Recht ist überall anzuerkennen, ist aber ein göttliches nur, wenn es im Inhalt mit dem natürlichen und göttlichen Recht sich deckt, sonst wäre jeder Räuber göttlicheu Rechts S. 287. Die gegenseitige Obligation ist beim Bestehen bestimmter positiver Gesetze selbstverständlich, bei deren Mangel auf das stillschweigend vorausgesetzte Naturgesetz zu begründen S. 270 und 273. Von einer rationellen Staatsgestaltung durch einen Staatsvertrag ist keine Rede, es ist nur im historischen Recht der göttlich-natürliche Kern im Falle seiner totalen Verneinung zu behaupten. Und zwar nur auf legitimem Wege durch die Untergewalten; Privatleute können nur als von ihnen Beauftragte handeln, was freilich auf eine indirekte Heranziehung auch der Privatleute hinauskommt S. 279. Auf die Korrektur des Tyrannen folgt die Wiederherstellung des historischen Rechtes, sei es durch ihn selbst oder durch einen andern an seine Troelts ch, Gesammelte Schriften. I. 
Befehl des Rates anonym bleiben. Aber sie stand in sachlichem und persönlichem Zusammenhang mit einer Reihe verwandter berühmter Publikationen von Theologen, Juristen und Politikern. Hotmann hat das Manuskript gelesen, und seine Franco-Gallia ist aller Wahrscheinlichkeit nach gleichzeitig mit Bezas Schrift von beiden geplant worden. Die beiden, dazu Henri Estienne und Gentillet, bespra-

Stelle Tretenden. S. 293 : Si quidem cum non-nisi certis conditionibus administratio illi (d. h. dem Tyrannen) sit commissa: minime censendum est, novas pactiones cum ipso iniri, quoties interpellatur ut vel priores conditiones ratas habeat easque deinceps observet, vel alteri locum cedat, qui de illorum observatione magis sit futurus sollicitur . . . Ordines vero vel status regionis (d. h. die zur Revolution berechtigten Untergewalten), quibus haec autoritas a legibus est collata, eatenus sese tyranno opponere atque adeo ipsi justas et promeritas poenas irrogare et possunt et debent, donec $r$ es in $\mathrm{pr}$ is $\mathrm{t}$ in u m statum restitutae sint. Quodsi praestiterint, tantum abest, ut seditiosi aut perduelles habendi sint, ut contra officio suo et juramento probe defuncti tum demum censeri debeant S. 266. - Der Verzicht Christi und der Apostel auf Widerstand gegen die Staatsgewalt, ihr ganzes Leidensprogramm, erklärt sich daraus, daß sie noch Privatleute waren und keine Unterobrigkeiten zum Schutz des Rechtes zur Verfügung hatten, und so sind sie bis heute die Norm der bloßen Privatleute: Dominus noster Jesus Christus, prophetae item ac apostoli, cum privati erant homines, sese intra metas suae vocationis continuerunt S. 3091 Das ist doch überall die strengste Festhaltung des historischen Rechtes, und es ist begreiflich, daß der Genfer Rat die Schrift inhaltlich approbiert hat. Hat doch auch Luther, freilich erst unter dem Einfluß des Gutachtens der Juristen von 1530, sich solchen Anschauungen genähert bis auf den Satz vom Tyrannenmord und der mutua obligatio zwischen Volk und Herrschern, hat doch auch schon Melanchthon die Unterscheidung zwischen Privatleuten und Magistratus inferiores; ebenso Osiander (?); auch die erasmische und die scholastische Staatslehre steht hier im Hintergrunde, s. Cardauns, Widerstandsrecht S. 8- I5, 3I f. - Die positiven Gründe für die Berechtigung seiner Theorie hat Beza klar ausgesprochen. Es ist 1 . der christliche und der Vernunftzweck des Staates S. 2I6. Es ist 2. die Konsequenz des Rügerechtes S. 217. - Daß derartige Theorien unmittelbar aus Calvins Unterricht hervorgehen kơnnten, zeigt noch schlagender die Theorie von Knox, die in Genf konzipiert ist, und die das Widerstandsrecht fast ohne Kautelen lehrende Schrift des zweiten Pastors der englischen Gemeinde Goodman, How superior powers ought to te obeyed of their subjects and wherein they may lawfully by Gods word be desobeyed and resisted, Genf 1558. Die Schrift hat Calvin vorgelegen, und der Verfasser berichtet, Calvin habe sie als hart. und der Vorsicht bedürftig, aber als richtig anerkannt, Doumergue S. $28 \mathrm{f}$. Direkt aus der Institutio Calvins fließt der Traktat des englischen Bischofs Poynet: $A$ short treatise of politic power and of the true obedience which subjects owe to the Kings and other civile governors 1556, geschrieben in Straßburg, Cardauns 37-40. 
chen die Theorie und den literarischen Feldzugsplan ${ }^{373}$ ). Es ist die Literatur der sog. calvinistischen Monarchomachen, zu der übrigens auch der Begründer der selbständigen calvinistischen Ethik, Lambert Danäus, und ein so energisch im Zentrum calvinistischer Theologie, Diplomatie und Kirchenorganisation stehender Mann, wie Duplessis-Mornay, der Verfasser der Vindiciae contra tyrannos, gehören. Auf Bezas Anregung ging auch der erste Bericht über die Bartholomäusnacht, die Schrift De furoribus Gallicis zurück, wenn wirklich der Prediger Ricant ihr Verfasser ist, und noch der orthodoxe Theologe Jurieu vertrat diese theologisch-ethisch-politischen Theorien.

In dieser ganzen Literatur kehren die von Beza entwickelten Gedanken, die die Genfer Schuldoktrin darstellen, mit verschiedenen Anpassungen und Ausweitungen wieder, unverkennbar praktisch bestimmt durch den unheilbaren Gegensatz gegen die französische Krone und durch die Tatsache der hugenottischen und niederländischen Erhebung, aber doch nur eine begrifflich-theoretische Deduktion aus calvinistischen Grundprinzipien und darum charakteristisch für deren Tragweite und Möglichkeiten. Volkssouveränetät, Vertragslehre, Revolutionsrecht, gesetzliche Bindung der Herrschenden treten darin scharf hervor, aber ebenso scharf auch die echt calvinistischen Einschränkungen aller radikal-naturrechtlichen Sätze durch den Gedanken des historischen und darum göttlichen Rechtes und die Voraussetzung der prinzipiellen Ungleichheit der Menschen. Insbesondere ist die hierbei eingeführte Vertragslehre weit entfernt von ihrer späteren rein rationalistischen Verwertung, die sie in dem von der Theologie emanzipierten klassischen modernen Naturrecht der Aufklärung erfuhr. Nirgends handelt es sich um das Zustandekommen der Gesellschaft selbst durch den grundlegenden Gesellschaftsvertrag. Die wird vielmehr immer im Lichte der aristotelisch-organischen Theorie gesehen; es ist die Bildung der Gesellschaft durch Natur und Vernunft mit der gemeinsamen Unterwerfung der verschieden gestellten Glieder durch das die Vernunft ausdrückende Gesetz. Immer handelt es sich erst um den *Herrschaftsvertrag *, der als in jeder Herrschaft naturrechtlich enthalten vorausgesetzt wird und der positiv rechtlichen Formulierung gar nicht erst bedarf, obwohl eine solche meist in der Tat vorhanden ist und nur wieder aus den alten Volks- und ständischen Rechten hervorgeholt zu werden braucht.

378) Cartier, S. 204 f. 
Zugleich wird dieser naturrechtliche Vertrag wesentlich erläutert aus der Bibel des Alten Testaments, wo es ein Vertrag zwischen Gott einerseits und Herrscher und Volk andererseits ist, also etwas ganz anderes als der Urvertrag des klassischen Naturrechts. Naturrecht und Vertragsidee sind durchaus theologisch gewendet, indem sie ein in der Bibel urbildlich dargestelltes und in jedem Herrschaftsverhältnis enthaltenes Ingredienz darstellen, das nicht sowohl eine rationelle Konstruktion des Staates als eine moralisch-religiöse Kontrolle der herrschenden historischen Gewalten ermöglichen soll. Von einem radikalrationalen Neubau des Staates, der gleichgültig wäre gegen das göttliche Recht des geschichtlich Gewordenen, ist nirgends die Rede. Daher wird auch keinerlei bestimmte Staatsform von hier aus abgeleitet, sondern das, wie bei Calvin, den Umständen anheimgegeben. Es wird nur der calvinistische Gedanke der mutua obligatio von Volk und Herrschergewalt und von der Bedeutung der Kontrolinstanzen der unteren Behörden und Wahlkörper weiter entwickelt, freilich in einem Sinne, der mehr dem thomistischen und humanistischen Naturrecht entspricht als dem stark lutherisch gefärbten Autoritarismus Calvins ${ }^{374}$ ).

314) Vgl. hierzu Cartier, S. 204-206; Figgis from Gerson to Grotius; Baudrillart, Bodin et son temps 1853 ; Cardauns, Widerstandsrecht, I903; Treumann, Monarchomachen, 1895 (Staats- und völkerrechtliche Abhandlungen hsg. v. Jellinek Nr. I); Ėlkan, Publizistik der Bartholomäusnacht und Mornays Vindiciae, 1905 (Heidelberger Abbh. zur mittleren und neueren Gesch. Nr. 9); Méaly, Les publicistes de la réforme, I903 (Thèse der Pariser Faculté de théol. prot.); über Jurieu s. Doumergue S. 22 und Luran, Les doctrine politiques de J., 1904. Die theologische Ethik des Calvinismus ist leider in dieser Hinsicht noch nicht durchsucht worden, jedenfalls geht sie seit Beza hier in wichtigen Vertretern einig mit den Publizisten und Juristen. So darf auch die Annäherung der "Monarchomachen« an Rousseausche Prinzipien nicht überschätzt werden. Es handelt sich bei ihnen um biblisch-naturrechtlich-theologische Deduktionen, nicht um den entschlossenen Rationalisnus einer verselbständigten Staatsphilosophie. Das hat Treumann durch Aufweis der mangelnden Unterscheidung des Gesellschafts- und des Herrschaftsvertrages (Seite 50, auch Elkan 159), sowie in der Nachweisung der stheokratischen Einschränkungen (53 bis 57) erkannt, aber doch nicht genügend in seiner Bedeutung geschätzt. Es handelt sich nicht um $»$ Beibehaltung der Vertragsideen, ohne daß man deshalb an der theokratischen Begründung des Herrscherrechtes sich vergriff \& S. 56, sondern um Einführung dieser Idee als Ingredienz auch in alles historische Recht; nicht um Beseitigung eines bisherigen absoluten theokratisch-monarchischen Staatsideals (S. 77) - das hat es im Calvinismus nie gegeben - sondern um Einführung 
Weiter noch als Beza und die Hugenotten entfernten sich John Knox und die schottische Schule von dem ursprünglich-calvon Kontrollen in die wie immer geartete Verfassung. Die Vertragsidee ist daher weit entfernt von jeder Aehnlichkeit mit den Fassungen bei Hobbes, Grotius und Rousseau, bleibt auf dem Standpunkt des historischen und darum göttlichen. Rechtes. - So fehlt bei ihnen auch die notwendige Voraussetzung der späteren Staatsphilosophie des Gesellschafts- und Herrschaftsvertrages, die ursprüngliche Freiheit und Gleichheit. Zwar meint Elkan S. 30: sIm letzten Grunde basierte doch das ganze Gebäude auf der als ganz selbstverständlich angenommenen Freiheit des Menschen. Diese Lehre zu begründen, nimmt sich niemand die Mühe, es ist schwerlich jemand in den Sinn gehommen, sie zu bezweifeln. Damit erweist er aber nur die Abwesenheit dieser Lehre. In Wahrheit beruht gerade auf dieser Abwesenheit der calvinistische und unmoderne Charakter dieser ganzen Literatur. Der Gesellschaftsvertrag der Gleichen und Freien ist überflüssig, weil für die Entstehung der Gesellschaft die aristotelisch-organische Lehre gilt; mit dieser aber ist die Ungleichheit der Stände, die Unterscheidung des Privatmannes und des Amtsinhabers, die Herrschaft des objektiven Gesetzes, nicht der subjektiv gleichen Vernunftbeteiligung, gegeben. Ueberdies kommt dazu der Ausschluß des Gleichheitsgedankens durch die von der Prädestinationslehre ausgehende Stimmung. Die Jugendschrift des übrigens nicht calvinistischen La Boétie - Discours de la servitude volontairea, die von der ursprünglichen Freiheit und Gleichheit im stoisch-humanistischen Sinne ausging und die Knechtschaft aus freiwilliger Unterwerfung erklärte, ist von den Calvinisten abgelehnt worden (Baudrillart 68-73), Méaly 63, und wenn der Reveille-matin aus ihm Materialien entnimmt, so geschieht es mit charakteristischen Veränderungen : zu den Worten : „C'est le peuple qui prend le jouge macht er den Zusatz set pouvant vivre sous de bonnes loix et sous la protection des Estats veut vivre sous l'iniquité, sous l'oppression et injustice au seul plaisir de ce tyran.e Das Normale ist nicht Freiheit und Gleichheit, sondern gute Gesetze und Schutz des Privatmannes durch Kontrollgewalten, die die Macht auf ihren vernünftigen $Z$ weck und ihre göttliche Bestimmung einschränken. - $\mathrm{Zu}$ beachten ist, daß Cardauns die reformierte Theorie von dem

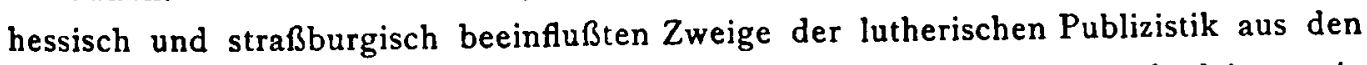
Zeiten des Schmalkaldischen Bundes und der Magdeburger Kämpfe herleitet, wie denn Bezas Traktat sich in seiner ersten Ausgabe 1574 als spublié de ceux de Magdebourg l'an 1550\& einführt (Cartier 187). Auch Ritter, Anfänge des niederländ. Aufstandes (Hist. Zeitschr. 58, 1887, S. 425), führt ein Schreiben von 1566 an, in welchem ein die Frage des Widerstands und die Berechtigung der magistratus inferiores betreffender Traktat erwähnt wird, und führt diesen Traktat auf das Gutachten der Wittenberger Theologen und Juristen oder auf die > Vermahnung der Pfarrherrn von Magdeburg 1549 zurück. S. auch Cardauns S. 7 I Bezas Berufung auf die Magdeburger. In der Tat finden sich in der deutschen Publizistik, freilich verworren und auf vielerlei Autoren verteilt, alle Gedanken und die wichtigsten Schulbeispiele der reformierten Theorie. Allein die calvinist. Lehren haben einen prinzipiell- 
vinischen politischen Programm, aber auch sie ohne in das moderne, rein rationalistische Naturrecht überzugehen. John Knox war in seiner vorcalvinischen Zeit bestimmt durch John Major, der katholisch verbleibend - die uns bereits bekannte katholische Lehre von der Volkssouveränetät mit starkem demokratischen Accent vertrat. Von hier aus scheint Knox einen starken und dauernden Eindruck behalten zu haben. Schroffe Aeußerungen über den Tyrannenmord in dieser Zeit erklären sich wohl von da aus. In Genf unter dem Einfluß Calvins eignete er sich völlig die Genfer Grundsätze an und belehrte er den schottischen und englischen Adel als die zur religiösen Reform und zur Kontrolle der Staatsgewalt Berechtigten und Verpflichteten magistrats inférieurs über ihre Reformations- und Widerstandspflicht, die nur um des Evangeliums willen und in der Richtung auf die evangelischen Reformen bestehe, aber Gewalt ausschließe und in allen welt lichen Dingen strengen Gehorsam einschließe. Aber gegenüber der Unmöglichkeit, hiermit sich die unentbehrlichen Machtmittel zu erhalten, und gegenüber der Gefahr, daß in England und Schottland die Königinnen durch Verheiratung mit auswärtigen katholischen Herrschern das Evangelium wieder völlig und planmäßig unterdrückten, wurde er zum entschlossenen Gegner der Erbmonarchie, deren Erbfolgerecht zu solchen Tollheiten führe und keinerlei Schutz gegen gottlose und ungerechte Tyrannen gewähre. So verlangte er die Wahl und Kontrolle der Monarchen wie die der Richter, erklärte er den bewaffneten Widerstand der magistrats inférieurs bis zum Todesurteil gegen den Tyrannen. für Recht und Pflicht; ja er rief schließlich auch die Privatleute auf, durch freie Bünde und eigene Initiative in die religiöse Reform und Gemeindebildung, damit dann aber auch in das politische Nachtgetriebe, nötigenfalls gewaltsam einzugreifen. Es ist die Lehre von der Volkssouveränetät als der Fordèrung der Vernunft und der Bibel, von Recht und Pflicht des bewaffneten Widerstandes bis zu der Hinrichtungsstrafe für gottlose Machthaber, von den Covenants und bewaffneten Erhebungen des Volkes für das Evangelium. Diese Lehre ist dann vielfach vertreten

theoretischen Grundzug und cine Herleitung aus dem religiösen Grundgedanken des Calvinismus, a er Ehre jottes und der (Bleichheit aller vor Gott, der sie von jenen lutherischen Theorien deutlich scheidet, wie denn diese Theorien im Luthertum sclbst ein inkomequentir und ver inglichor Seitenzweig gewesen sind, was

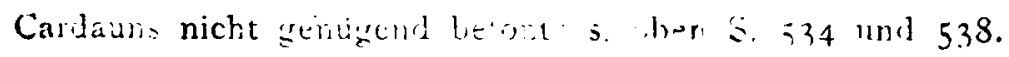


worden in der calvinistischen Ethik, in Schottland besonders von Buchanan, der zugleich einen sehr starken humanistischen Einschlag zeigt. Es ist die Lehre der presbyterianischen Schotten und Engländer unter den Stuarts, die Lehre der Generale des Cromwellschen Heeres, die sich als die in der Verwirrung allein übrig bleibenden legitimen Gewalten ansahen. Es ist die Lehre, die Karl I den Kopf gekostet hat. Aber republikanisch und rationellnaturrechtlich ist sie darum doch nicht. Auch sie ist noch christlich-naturrechtlich und biblisch-konservativ. Sie will nur eine Kontrolle der regierenden Gewalten nach den Grundsätzen des Volksrechts und des Wohles der christlichen Kirche; sie ist legitimistisch, soweit es geht, hält sich stets an die möglichst legitlmen Gewalten, die übrig bleiben, wenn die eigentlich legitime versagt. An einem rationellen Staatsaufbau vom Individuum her liegt ihr nichts. Sie will nur die Gewalt nach den Grundsätzen der selbstverständlichen Konstitution jedes Staates kontrol-' lieren, d. h. nach der Bibel und dem natürlichen Sittengesetz. Auch die englischen und schottischen Presbyterianier waren in diesem Sinne legitimistisch. Selbst Cromwell war, kein Republikaner der Theorie, sondern ein Mann der legitimen Gewalten, der sich von den Ereignissen treiben ließ, bis sie ihm die Situation aufzwangen, in der sein politisches Herrschergenie sich entfalten und dann seinen eigenen Gesetzen gehorchen mußte. Der Sinn der ganzen Theorie ist immer der geblieben, den Knox in seiner berühmten Unterredung mit Maria Stuart formulierte, als sie ihn einen Streber nach der Gewalt, einen Feind der Monarchen und Aufwiegler des Volkes nannte: Gott bewahre mich davor, irgend eine Herrschergewalt auf mich zu nehmen oder Untertanen frei zu stellen, daß sie tun, was sie wollen. Mein Ziel ist allein, daß Fürsten und Untertanen beide Gott gehorchen ${ }^{375}$ ).*

- 87h) Vgl. Martin, De la genèse des doctrines religieuses de John Knox, und De la genèse des doctrines politiques de J. K. in Bulletin de la société de l'histoire du prot. français I906 S. 193-2II und 1907 S. 193-22I. Außerdem Cardauns und Elkam. S. auch in dem gleich zu erwähnenden Buche von Bastide über Locke den Abschnitt théories politiques en Angleterre au 16 et 17 e siècles S. 137-176. Hier ist mit Recht - nach Gardiner - der konservativ-legitimistischcalvinistische Charakter auch der presbyterianischen und der independentistischen Bewegung betont im Unterschied von den Levellern und vefwandten Gruppen. Wir werden später sehen, daß die letzteren täuferischen und nicht calvinistischen Geistes sind. Die am sog. -Independentismus « beteiligten Kräfte sind eben grundverschie- 
Den Schritt zu einer rationellen Konstruktion des Staates und aller Gesellschaft von dem Gedanken der Volkssouveränität aus tat erst Althusius, dabei sich auf das Beispiel der Niederlande berufend, wie die Monarchomachen von dem Zusammenbruch ihrer Hoffnungen auf das französische Königtum ausgegangen waren. Er war strenger Calvinist, erst Lehrer an der calvinistischen Hochschule in Herborn, dann Syndikus der städtischen Republik Emden, durch Berufungen nach Franeker und Leyden als eines der Häupter calvinistischer Staatslehre anerkannt. Er wollte mit vollem Bewußtsein die Politik gegen Ethik, Theologie, Philosophie, Publizistik und Jurisprudenz verselbständigen, die zerstreuten Materialien für den Neubau einer eigenen Disziplin sammeln, Naturrecht und Dekalog nur als Voraussetzungen benützen, auf denen sich die eigentliche politische Theorie erst erheben sollte. Dabei hielt er den Gedanken der christlichen Gesellschaft und der Coinzidenz von Staats- und Kirchengebiet durchaus fest und befand sich insofern in der Tat noch im Geleise calvinistischen Denkens. Aber indem er die Voraussetzung der ursprünglichen Freiheit und Gleichheit aufstellte; indem er aus ihr die Gesellschaft in allen ihren Stufen, in der Familie, der freien Geselligkeit, der Korporation, der Gemeinde, der Provinz und dem Staat, mittelst eines ausdrücklichen oder stillschweigenden Gesellschaftsvertrages * hervorgehen ließ, den er vom bisher allein beachteten Herrschaftsvertrag unterschied; indem er schließlich die vom historischen Prozeß emporgetragenen Unter- und Obergewalten als vom Volkswillen eingesetzte und kontrollierte Mandatare auffaßte: in alledem löste er den bisherigen Kompromiß zwischen dem historisch-göttlichen Recht und den Rechten der Individuen auf. Er schlug sich auf die Seite des humanistisch-stoischen, rein naturrechtlichen Gedankens. Das ist nicht mehr die Kontrolle der herrschenden Obergewalt nach den Grundsätzen des göttlichen und natürlichen Rechtes durch die zur Wahrnehmung des Volksrechts und der religiösen Interessen verpflichteten Mittelinstanzen, sondern das ist die Konstruktion der Gesellschaft von der Freiheit und Gleichheit der Individuen her, mit denjenigen Einschränkungen, die die Bedingungen einer geordneten und dem christlichen Lebenszweck dienenden Gesellschaft verlangten ${ }^{3 i 6}$ ).

dene. - Auch Pareus in Heidelberg lehrte die Absetzbarkeit der Könige s. Bastide 144 ; das ist der englischen Revolution nicht eigentümlich.

${ }^{3 i 6}$ ) Ygl. Gicrkes Althusius ${ }^{2}$, wo mit der bewunderungswürdigen Gelehrsamkeit Gıerkes die Herkunft aller Gedankenelemente geprüft ist. Gierke hebt auch 
So hat denn auch derjenige Denker, durch den das Naturrecht und die Vertragslehre erst zu ihrer welthistorischen Wirkung kamen, Hugo Grotius, den Zusammenhang mit dem Calvinismus ausdrücklich gelöst, das calvinistische Staatskirchentum zugunsten einer rationalistisch und politisch motivierten Toleranz bekämpft, die monarchomachische Lehre ausdrücklich abgelehnt als Ausgangspunkt seiner politischen Theorie und sich theologisch dem humanistischen Rationalismus angeschlossen, der in den Niederlanden von Erasmus her seine Herrschaft nie ganz verloren hatte und in der arminianischen Theologie sich neu erhob. Von der urspriinglichen Gleichheit und Freiheit her leitete er den Staat aus einem Vertrage $a b$, dessen Sinn der rein rationelle Wohlfahrtszweck ist und der sich einem Völkerrecht des Krieges und Friedens eingliedert, das mit den konfessionellen Kriegren nichts mehr zu tun hat. Das ist trotz aller persönlichen Christlichkeit reirı weltlich gedacht. Die weitere Geschichte dieser Lehre gehört daher nicht der Geschichte des Calvinismus an, sondern der des rationellen naturrechtlichen Gedankens, dessen demokratische oder antidemokratische Ausgestaltung von nun ab nur mehr in losem Verhältnis $z u$ den christlichen Gedanken steht. Grotius selbst dachte ständisch und nicht demokratisch. Aber das hat bei ihm mit religiösen Motiven nichts mehr zu tun, sondern entstammt rein rationell-politischen Erwägungen; er war bekanntlich mit Olden Barneveld der Vertreter der städtischen Aristokratie. Der Gegensatz zwischen Calvins Wort $»$ stat (in Gottes Wesen) pro ratione voluntas * und Grotius' Lehre, daß das Vernunftgeset\% auch gelte, wenn es - per impossibile - keinen Gott gäbe, beleuchtet die ganze Kluft, die beide Welten trennt. Grotius stand damit, wie übrigens mit Recht das der bisherigen religiösen Theorie gegenüber Neue scharf hervor, bes. die Voraussetzung der allgemeinen Freiheit und Gleichheit vor dem Staatsvertrag S. 29, 79, I07; den Rückgang auf die souveräne Urversammlung S. 28, 30 ; den rationalistisch-apriorischen Charakter S. 59, 69; die Konstruktion des Gesellschaftsvertrages neben und vor dem Herrschaftsvertrag S. 76; die Durchführung des Repräsentationsgedankens S. 217 ; die Aufsaugung der Majestät des Herrschers in die des Volkes S. 145. Die Reste der calvinistischen Schätzung des göttlichgeschichtlichen Rechtes sind gering: Unterscheidung der Privatleute von den resistenzberechtigten Mittelgewalten S. 34 und die Anerkennung der Mittelgewalten in ihren historisch bedingten Formen S. 35. So konnte der Lutheraner Peter Gartz die Lehre des Althusius als Produkt des spresbyterianischen Irrgeistes S. 7, sie ist aber in Wahrheit ein Schritt über den echten Calvinismus hinaus und ein Mittelglied zwischen ihm und dem klassisch-rationalistischen Naturrecht. 
auch Leibniz, der katholischen Naturrechtslehre immer noch näher als der calvinistischen oder gar der lutherischen. In Wahrheit ist es eine neue Welt. Wo die Gesellschaft rationell konstruiert und der Individualismus auf die Gleichheit und Freiheit der Vernunft der Individuen begründet wird, da ist nicht mehr calvinistischer Geist, sondern da liegt die Emanzipation der stoisch-rationalistischen Ideen von ihrer Verschmelzung mit den christlichen und eine darauf begründete spezifisch-moderne individualistische Gedankenbildung vor. Sie wahrt in der Ausnahme des religiösen Gewissens von den Pflichten des Staatsvertrages, soweit diese, wie in der angelsächsischen Welt, vorbehalten wurden, calvinistische Reste, obwohl eine ähnliche Ausnahme auch von Spinoza aus rein philosophischion Gründen gemacht wurde. Aber sie entfernt sich in dem Naturrecht der französischen Demokratie und vor allem Rousseaus weit von jèder Spur calvinistischen Geistes ${ }^{377}$ ).

377) Das berühmte Hauptwerk des Grotius (von mir benützt in der Uebersetzung der Kirchmannschen Philos. Bibliothek i 869) zeigt überall den rein humanistisch-philosophisch-juristischen Charakter und die grundlegende Berufung auf die Stoa, von deren kosmopolitischem Menschheitsgedanken die ganze Problemstellung des Kriegs- und Völkerrechts ausgeht; von hier aus soll geradezu die Zeit der konfessionellen Kämpfe überwunden werden. Daher ist ihm das Naturrecht, die apriorisch-rationale Grundlage, völlig unabhängig von jeder Theologie und jedem Gottesglauben I 3I. Für das Verhältnis zur bisherigen protestantischen Staatslehre ist charakteristisch die Erklärung bezüglich des AT.: »Manche wollen das AT, zu einem Naturrecht erheben, allein mit Unrecht. Denn vieles darin stammt von dem freien Ratschluß Gottes ab, der allerdings mit der wahren Natur nicht im Widerstreit steht. I 60. Das ist die Beseitigung der Identifikation des Naturrechts mit der alttestamentlichen politischen Ethik. Bezügltch des NT. heißt es: „Des NT. bediene ich mich, weil man das, was den Christen gestattet ist, nur aus ihm entnehmen kann. Ich habe aber diesen Inhalt gegen den Vorgang der Meisten von dem Naturrecht selbst unterschieden; indem ich überzeugt bin, daß in diesem heiligsten aller Gesetze uns eine höhere Heiligkeit gelehrt wird als das Naturrecht für sichallein verlangt. Doch habe ich immer angemerkt, ob .einzelnes mehr angeraten als befohlen wird, da es unrecht und strafbar ist, von den Geboten (d. h. dem auch naturrechtlich Gebotenen) abzuweichen, während es das Zeichen eines edlen Sinnes ist, dem sein Lohn nicht entgehen wird, wenn man nach dem Höchsten (also den die Naturforderungen überbietenden evangelischen Forderungen) strebt \& S. 61. Das ist die Preisgabe der protestantischen Identifikation von Naturgesetz und Bergpredigt und die endgültige Emanzipation des Naturrechts von den Geboten der Bergpredigt, wie die spätere lange Beweisführung zeigt. Dazu kommt die energische Begründung des Vertrags auf die Voraussetzung eines ursprünglichen Kommunismus und einer ur- 
Auch den zweiten großen Begründer des modernen Naturrechts, John Locke, darf man nur mit Vorsicht in Verbindung. mit dem Calvinismus und seinem christlichen Naturrecht bringen. Zwar ist Locke von seinem puritanisch gesinnten Vater in calvinistischem Sinne erzogen worden; sein ganzes Wesen bat eine Richtung auf calvinistische Nüchternheit, Arbeitsamkeit und utilitarische Sachlichkeit behalten, seine Gesinnung war stets auf eine ebenso feine und klare als ernste und warme Frömmigkeit gerichtet. Aber den Puritanismus hat er doch schon früh in wesentlich independentem Sinne aufgefaßt, und seine spätere Kirchen- und Toleranztheorie entspricht dem Sektentypus, nicht dem Calvinismus. Andrerseits hat er nicht minder frühzeitig die Theologie in latitudinarischem Sinne aufgefaßt und später unter dem Einfluß von Arminianern und Socinianern ihr sein eigentümliches, sehr originelles und geistvolles, aber ganz uncalvinistisches Gepräge gegeben. Das zweite vereinigte sich dann mit dem ersten, sodaß seine Freigebung der Kulte zugleich die Freigebung des philosophischen und theologischen Interesses und die Sicherstellung der Gedankenfreiheit neben den Kirchen bedeutete. Vollends seine Staatstheorie des liberalen Konstitutionalismus

sprünglichen Freiheit und Gleichheit I 70, 74, 76, 80, 90, ferner die Ablehnung der monarchomachischen Theorien im Interesse einer einheitlichen und dem Glaubenszank entrückten Staatsgewalt I 195. Dementsprechend bestreitet Grotius auch die Prädestination und schließt sich dogmatisch den Arminianern und Sozinianern an. - Das Naturrecht der Zeit nach Grotius entfernt sich noch weiter von den calvinistischen Grundlagen. Rousseau vor allem, von dem Gierke treffend sagt, daß er den Herrschaftsvertrag in den Gesellschaftsvertrag zurückgeschlungen hat (Alth. 9 I f.), hat eben damit jedes. historische Recht vernichtet und das Ideal kleiner föderativer Republiken mit Wahrung der ursprünglichen Freiheit und Gleichheit durch die Begründung aller Gesetzgebung auf die Urversammlung aufgestellt, was den Schweizer Republiken entsprechen mag, aber mit dem Geiste des Calvinismus gar nichts zu tun hat, sondern sein reines Gegenteil ist. - Die Apologetik der französischen Protestanten, die auch bei den Freidenkern auf den Haß gegen den Protestantismus als den Störer der französischen Nationaleinheit stößt, liebt begreiflicherweise die Ableitung Rousseaus vom Calyinismus s. die erwähnte Arbeit von Méaly und sehr viel zurückhaltender Doumergue S. 53 und 55-63. Aber das ist nichtsdestoweniger cin Irrtum. Grotius und Pufendorf als >réprésentants de la politique calvinistes S. 25 2u bezcichnen, ist einfach falsch; der von D. mit besonderem Nachdruck angeführte Genfer Jurist Burlamaqui, $\nmid \mathbf{1 7 4 8}$, ist Vertreter des reinen individualistischen Rationalismus der Freiheit und Cleichheit, aber dem calvinistischen Denken ganz fernc. Auch Jurieu, +1713 , zeigt bereits diesen fremden Einfuß S. 22 f. 
hängt $\mathbf{z w a r}$ offensichtlich mit dem christlichen Naturrecht calvinistischer und scholastischer Fassung zusammen. So hat er sich denn auch gerne auf Hooker berufen, dessen Ecclesiastical Polity in ihrem ersten Teil ein Abriß des rationalen christlichen Naturrechts ist, im zweiten aber zu Ehren des Elisabethanischen Anglikanismus abbiegt zu einer Delegation des Volkswillens und der kirchlichen Advokatie und Konformität an die Krone, sehr im Gegensatz gegen die Majorität der anglikanischen Staatslehrer, die vielmehr in Filmers patriarchalischem Absolutismus ihren schärfsten, mit der lutherischen Gewaltlehre verwandten Ausdruck fand. Aber so sehr Lockes Naturrecht durch die Theorie von der mutua obligatio, von dem stillschweigenden Enthaltensein des Herrschaftsvertrages in allen Staatseinrichtungen, von dem rein irdisch-utilitarischen Charakter des Staates und dem Recht des Volkes zur Kontrolle und Absetzung der herrschenden Gewalten an das calvinistische Naturrecht erinnert, sein Naturrecht selbst ist in seinen Grundlagen doch anders gedacht. Er mischt die Elemente des bisherigen Naturrechts überhaupt neu, indem er weder an den stoischen Rationalismus, noch an die biblische Offenbarung, sondern an einen utilitarischen Empirismus anknüpft, von diesem aus dann freilich oft zu den älteren Gedanken wieder hinüberstrebt. Sein Naturrecht ist ein psychologisch zu erklärendes Ergebnis aus dem Urzustand der Gleichheit und Freiheit aller; die Menschen vereinigen sich zur Erhaltung und Eingrenzung eben dieser Freiheit und Gleichheit zunächst in naturgewachsenen Gesellschaften und gestalten die hierbei nötig werdende Herrschaftsgewalt nach ihrer Angemessenheit zu den Wohlfahrtszwecken der Individuen. Dies Naturgesetz des wohlverstandenen Interesses steht nun zwar unter der göttlichen Leitung und ist im Dekalog göttlich wiederholt und dargestellt, befindet sich also in Uebereinstimmung mit der Offenbarung. Aber seine Schöpfungen dienen lediglich dem Wohl der Individuen und nicht der Ehre Gottes. Die kirchlichen Gemeinschaften stehen völlig daneben und sind freie Vereine, die in allen politischen und moralischen Dingen der staatlichen Ordnung sich fügen müssen und nur in Kult und Theologie frei sind. Nichts fürchtet Locke so sehr als die Priesterherrschaft, sie sei katholisch, anglikanisch oder presbyterianisch. In den nie ganz zu vermeidenden Konfliktsfällen $z$ wischen kirchlichen und staatlichen Auffassungen des Moralischen empfiehlt er dann freilich wieder in der Weise Calvins den leidenden Gehorsam; gegenüber einer dauernd 
ungerechten Staatsgewalt erlaubt er die Erhebung und den Widerstand der Nächstberechtigten bis schließlich zum Recht der Revolution, da man Gott - und das ist bei ihm die sittliche Ordnung - mehr gehorchen müsse als den Menschen. Weiterhin betrachtet auch er die im historischen Prozeß emporgetragenen Gewalten als - indirekt - von Gott eingesetzt und hält er sich an das jeweilige positive Recht, das ihm in England eine besonders glückliche Verkörperung des konstitutionellen Naturrechts zu sein scheint, das aber auch sonst dieses Naturrecht stillschweigend als seine eigene Voraussetzung und seinen Maßstab in sich trägt. Aber diese starken Anklänge an das calvinistisch-christliche Naturrecht übertönen doch nicht den ganz andersartigen Grundton einer völligen Beseitigung des religiösen $Z$ weckes des Staates für Gottes Ehre, des Gedankens der alleinigen Souveränität Gottes, der prinzipiellen Ungleichheit und gehorsamen Fügung der Individuen in das Gegebene. Hier herrscht vielmehr der beweglichste individualistische Rationalismus einer rein utilitarischen Weltlichkeit, die aus dem religiösen Zusammenhange der Lockeschen Theorie völlig herausgenommen werden kann und in der Folge auch oft genug herausgenommen worden ist. Jener Rationalismus ist so selbständig philosophisch und staatsrechtlich begründet und entspricht so sehr der weltlichen Fortschrittsstimmung und den politischen Notwendigkeiten des Tages, daß die Einfügung in den religiösen Rahmen wenig innere Bedeutung mehr hat. Er steht neben diesem Rahmen, nicht in diesem Rahmen, wie ja auch die religiösen Vereine neben dem Staat stehen. Das aber ist auf klärerischer und nicht mehr calvinistischer Geist. So war denn auch die Aufrichtung des konstitutionellen Königtums Wilhelms III. in viel geringerem Grade ein Ausdruck der calvinistischen Idee von der mutua obligatio, als die Enthauptung Karls I ein solcher der calvinistischen Lehre von der Strafpflicht der magistrats inférieurs gegenüber den Tyrannen gewesen war: Immerhin hat es an derartigen religiösen Rechtfertigungen der zweiten Revolution nicht gefehlt. Aber der Vorgang selbst war in seinem Wesen viel weltlicher als jener ${ }^{378}$ ).

378) S. die Letters on toleration, der erste von 1685, und die Two treatises of government von 1690; außerdem Lezius, Der Toleranzbegriff etc., und die sebr lehrreiche, die ganze Zeit schildernde Arbeit von Bastide, J. L., Ses théories politiques et leur influence en Angleterre, I906; die Anschauungen von den kirchlichen Dingen und Theorien sind hier freilich oft sehr schief. Die Belege zum obigen finden sich in Kap. V und VI. - Eine Analyse Hookers bei Lang, Ref. u. Naturrecht S. 28-33, doch ist seine Originalität hier überschätzt. 
Viel ferner als Hugo Grotius und Locke stand dem Calvinismus der dritte Hauptbegründer des modernen Naturrechts, Thomas Hobbes. Auch er arbeitete freilich mit dem Begriffsmaterial des christlichen Naturrechts und behauptete sogar für den Idealfall das Zusammentreffen von göttlichem und natürlichem Recht und Gesetz, sicherlich nicht bloßß zum Schein. Allein nicht bloß konstruierte auch er das Naturgesetz der Gesellschaft antiidealistisch rein aus dem Egoismus, sondern vor allem sah er das. Wesen der aus diesem Egoismus hervorgehenden Vergesellschaftung in der Aufrichtung einer Gewalt, die ihrem Begriff, nach schlechthin souverän sein und daher auch die Gewalt über die Religion und Kirche einschließen muß. Es ist die Ableitung eines reinen Positivismus der Gewalt aus rationalistischen Grundlagen, die in mancher Hinsicht an lutherische Sätze erinnert. So hat auch der Lutheraner Pufendorf die Lehre des Grotius mit.der des Hobbes eigentümlich kombiniert und auch die Kirchengewalt als an die Obrigkeit delegiert angesehen. In solcher Lehre ist kein Hauch calvinistischen Geistes. Nur Lutheraner und Anglikaner, haben von den Dornen des Hobbismus Trauben zu pflücken verstanden, die Haupternte aber hatte die Aufklärung ${ }^{379}$ ).

Es wäre also ein Irrtum, die moderne Demokratie französischer oder auch nur amerikanischer Art ohne weiteres auf den Calvinismus zurückzuführen. Nicht einmal die Theorien ihres Naturrechts sind von ihm wesentlich ausgegangen. Sie stammte vielmehr im wesentlichen aus rein politischen und rein wirtschaftlichen Bewegungen, und ihre Theorien wuchsen aus dem gemeinsamen Grundstock hervor, aus dem das christliche und das humanistische Naturrecht sich nährten, aus der Antike. Allein das ist richtig, daß der Calvinismus in hervorragendem Maße, mehr als der Katholizismus und viel mehr als das Luthertum, die allmähliche Emanzipation jener Theorien von der Verkoppelung mit den christlichen Ideen angebahnt hat, wenn auch noch radikaler in dieser Richtung das Täufertum wirkte, wie sich bei Gelegenheit der englischen Revolution zeigen wird. Beide zusammen haben die moderne Demokratie mehr vorbereitet und ihr ein geistiges Rückgrat dargeboten als sic

${ }^{379}$ ) S. Lezius und oben 545; zum Ganzen meinen Artikel >Moralisten Englische. in $\mathrm{PRE}^{3}$ und .meinen Aufsatz ,Das stoisch-christliche Naturrecht und das moderne profane Naturrecht in $\mathrm{HZ}$ I911, auch in . Verhandlungen des ersten deutschen Soziologentagese 1911 , wo noch die lehrreichen Diskussionsreden zu finden sind. 
geschaffen. Und auch das erste ist gegen den eigentlichen Willen des Calvinismus geschehen. Aber wenn auch das scharf zu betonen ist, so ist andrerseits doch klar, daß sich der Calvinismus vermöge des in seiner Genfer Lage aufgenommenen konstitutionellen und kritisch-naturrechtlichen Prinzips sehr leicht der Demokratie anbequemen konnte und in seinen religiösen Ideen schließlich nicht nur kein Hindernis hatte, auf sie einzugehen, sondern sich als mit ihr wahlverwandt empfinden konnte. So wenig im Sinne Calvins die amerikanische Autoritäts- und Respektlosigkeit ist und so fern ihm vollends Rousseaus sozialer und politischer Rationalismus liegt, der Calvinismus kann sich mit beiden innerlich einigen, wenn die Majestät der religiösen Lebenssphäre vorbehalten wird. So ist der Calvinismus diejenige Form des Christentums geworden, die heute mit der modernen Demokratisierung innerlich verwachsen ist und ohne jeden Schaden an seiner religiösen Idee auf sie eingehen kann. Zugleich sind gerade durch seine religiös-metaphysische Begründung des Individuums, durch seine Festhaltung der wesentlichen Ungleichheit der Menschen und durch seinen konservativen Sinn für Ordnung und Gesetz die gefährlichsten Folgen der Demokratie, die Herrschaft der bloßen Zahl und die abstrakte Egalität, vermieden. Wieviel er selbst zu dieser Demokratisierung beigetragen haben mag, wird im Einzelnen sehr schwer zu sagen sein; besondere Entwickelungen, die ihn in dieser Richtung bestärkten, werden später noch zu besprechen sein. Daß er aber heute mit ihr innerlich verbunden ist und darauf seine charakteristische Weltstellung beruht, ist unverkennbar. Er hat sich dabei zugleich überall mit den Seliten ausgeglichen, die, von vornherein ungleich mehr auf demokratisch-individualistischer Basis stehend, heute mit ihm zusammen die Idee eines inneren Wesenszusammenhangs von Demokratie und Christentum vertreten. Auf das letztere wird im letzten Abschnitt noch näher einzugehen sein. Die eigentliche geistige Großmacht aber bleibt in alledem doch der Calvinismus ${ }^{380}$ ).

880) Das alles ist glänzend ausgeführt in dem oft angeführten Manifest Kuypers. Die aus der religiösen Tradition stammenden retardierenden Elemente im engliscten Liberalismus treten deutlich hervor bei Held, Zwei Bücher etc. - Ueber seinen Einfluß auf den Anglikanismus und seine Analogie mit den Sekten, die heute sin seinem Lager Zuflucht suchene S. Kuyper 8-10; auch Karl Hartmann ist hier Jehrreich, das Zusammenfließen mit den Sekten und Freikirchen S. 27-30, der calvinisch-demokratische Charakter der Initiative und Verantwortung S. 32 u. 13. 
Der zweite wichtige Punkt betrịftdie Wirtschaftsethik des Calvinismus, die sich aus geringfügigen Anfängen gleichfalls zu größter historischer Bedeutung sowohl für die Entwickelung des modernen Wirtschaftgeistes als auch für die des Calvinismus selbst entfaltet hat ${ }^{381}$ ).

381) Vgl. Kampschulte I S. $385-480$, bes. 429 f., II S. $342-387$; Wiskemann, Nationalökonomische Ansichten zur Zeit der Reformation S. So-87; Elster, Calvin als Staatsmann, Gesetzgeber und Nationalökonom, Jahrbb. f. Nationalökonomie und Statistik XXXI (auf Kampschulte und Wiskemann beruhend); Rachfahl, Calvinismus und Kapitalismus, Internationale Wochenschrift 1909 (in den Calvin betreffenden Notizen auf Kampschulte, Elster und Lang beruhend); Max Weber, Protestantische Ethik und der >Geiste des Kapitalismus, Archiv XX und XXI ; Laveleye, Protestantismus und Katholizismus in ihren Beziehungen zur Wohlfahrt der Völker, deutsch S. 127; Choisy, L'etat chrétien; E. Knodt, Bedeutung Calvins und des Calvinismus für die protestantische Welt (Vorträge der Gießener Konferenz) 1910. - Grundlegend ist heute Webers Abhandlung. Er hat zuerst das Problem in seinem großen kulturgeschichtlichen Zusammenhang und in der inneren Zusammenfassung des religiös-ethischen Elementes mit dem sozialen und wirtschaftlichen angefaßt. Ich habe meinerseits diese seine Erkenntnisse, die mir vor allem durch die Anschauung vom amerikanischen und niederrheinischen Leben bestäligt wurden, in meine allgemeiner gerichteten Arbeiten über Wesen und Kulturbedeutung des Protestantismus übernommen, natürlich nicht ganz ohne eigenes Urteil, das aber besonders herauszuheben gänzlich überflüssig ist. - Gegen Weber und mich hat nun Rachfahl in dem eben erwähnten Aufsatz seinen Angriff eröffnet, wo er das Gericht des Fachhistorikers, der zugleich allgemeine Kenntnisse von ökonomischen und theologischen Begriffen und Tatsachen zu besitzen meint, über die „Konstruktionen « in einem recht überlegen und höhnisch sich gebärdenden Stile hält. Nun bringt es meine Arbeitsrichtung ja freilich mit sich, indem sie aus dem Verständnis großer Kulturkomplexe die Unterlage für Werturteile gewinnen will, daß sie vielfach generalisiert. Und das ist unzweifelhaft: in generalibus latet error. Andererseits ist aber doch wieder, wie ich $>$ Bedeutung des Protestantismus \&. 2 f. ausdrücklich hervorhob, neben der historischen Facharbeit eine solche Generalisation trotz aller Gefahren des Irrtums unentbehrlich, wenn man die Historie als Mittel zum Verständnis unserer Kultur betrachtet. Möglichst wertfrei gehaltene, die vorhandene historische Erkenntnis so gewissenhaft als möglich benützende Generalisation ist nötig, um eine Unterlage für die hierbei einsetzenden kulturphilosophischen Wertungen zu erhalten. Das ist auch der Sinn dieses ganzen Buches. Auch hier werden übertreibende oder vereinseitigende Generalisationen nicht völlig vermieden sein, obwohl ich sie überall zu vermeiden strebte. Aber ich bin doch gewiß, daß gerade durch diese Generalisationen das historische Verständnis erheblich vorwärts gebracht ist. Ich messe das an den Generalisationen, die ich anderwärts finde (s. z. B. oben S. 565 die Auffassung ron Lenz) und die ich großenteils als irrtümlich bezeichnen zu müssen glaube. Dagegen hat sich nun Raehfahl als s Historikers und Fachmann 
Auch sie war von Hause aus in den. Grundzügen mit der des Luthertums verwandt. Sie teilte mit ihm die Schätzung der Arbeit als der gottverordneten Berufsbetätigung und damit als eines Gottesdienstes, aber auch als eines Mittels der Selbstzucht und Ablenkung von bösen Lüsten, die Forderung der allgemeinen Arbeitspflicht und die Beseitigung des Mönchtums wie des Bettels. Sie teilte auch den antimammonistischen Geist, das Dringen auf Selbstbescheidung und Mäßigung, auf Einhaltung der Standesgrenzen, den Kampf gegen den Luxus, der hier geradezu mit unerhörter Schärfe durch die Luxusgesetzgebung geführt und vom Sittengericht kirchlich unterstützt wurde. Auch Calvin war der Meinung, daß die Armut den christlichen Tugenden zuträglicher sei als der Reichtum, und erging sich in habe geantwortet in der Internat. Wochenschrift igro >Die Kulturbedeutung des Calvinismus , Weber im Archiv XXX 1910 >Antikritisches zum Geist des Kapitalismus«. Darauf hat Rachfahl in JW. 1910 s Nochmals Calvinismus und Kapitalismus repliziert noch sehr viel höhnischer und selbstbewußter als das erste Mal. In eine solche Polemik einzutreten habe ich keine Lust. Er spricht von Zurechtweisungene, die mir Weber erteilt hätte, sdie ich mit gebührendem Dank hingenommen hätte und sdurch die meine Anhänglichkeit und Begeisterung nicht erschüttert * worden sei ; von $>$ Gewissensriechereik, weil ich angedeutet hatte, daß seine Auffassung von der Bedeutung religiöser Elemente für die Kulturgeschichte etwas seicht sei; von einem -Widerruf «, den ich betreffs der Weberschen These geleistet hätte, der mich aber nicht hindere meine dauernde Zustimmung zu sbeteuern $<$ usw. Mit solchen Manieren hat die Diskussion keinen $Z$ weck. Zudem, der Analyse größerer begrifflicher Zusammenhänge ist Rachfahl nicht gewachsen. Von theologischen Dingen versteht er, wie bereits bemerkt, wirklich nichts, und, wenn er sich auf Autoritäten beruft, so beruft er sich gerade auf deren trivialste und herkömmlichste, durch theologische Werturteile stark beeinfiußté Sätze; namentlich auf Lang täte er besser sich nicht zu berufen nach dessen Leistungen über das Naturrecht Calvins. Wie es mit seinem Verständnis ökonomischer und sozialgeschichtlicher Begriffe steht, hat Weber gezeigt. So kommt es, daß nicht bloß mit dem persönlichen Stil seiner Polemik, sondern auch mit seinen sachlichen Ausführungen nicht viel anzufangen ist. Weder die Bedeutung der Askese für das Christentum noch den Begriff des kapitalistischen Geistes und des bürgerlichen Lebensstils hat Rachfahl richtig aufgefaßt. Er hat nicht die Ruhe, die Zusammenhänge zunächst einmal auf sich wirken zu lassen und zu analysieren, sondern schlägt gleich bei der ersten Umrißerfassung los, weil ihm etliche damit wirklich oder scheinbar nicht übereinstimmenden Tatsachen einfallen. So hat er es vorgezogen seine Kritik nicht als Mitarbeit an der Erleuchtung eines doch auch von ihm selbst anerkannten Problems zu geben, sondern als literarisches Skandälchen, wie es den Redaktionen mancher Zeitschriften erwünscht ist, und manchen Autoren als geistreich erscheint.

Troeltsch, Getammelte Schriften. I. 
zürnender Scheltrede auf die großen Handelsstädte wie Venedig und Antwerpen ${ }^{382}$ ). Aber gleichwohl gab er der reformierten Wirtschaftsethik schon in den Grundlagen eine Wendung, die dem Calvinismus auf dem Gebiet der Wirtschaftsethik genau so wie auf dem der Politik ohne ausdrückliche und bewußte Absicht doch einen völlig anderen Geist einflößte, als der des Lutherturns war und in der Hauptsache heute noch ist. Und zwar geht auch hier seine Sonderrichtung von den Bedingungen aus, die ihm das Genfer praktische Leben stellte.

Der entscheidende Wendepunkt nämlich war, daß Calvin überzeugt war, jener antimammonistische christliche Geist lasse sich auch auf dem Boden einer wesentlich geldwirtschaftlichen, kaufmännischen und industriellen Gesellschaft behaupten und durchführen. Er lenkte nicht; wie das Luthertum unter seinen Verhältnissen es konnte, auf die agrarisch-patriarchalischen Lebensformen der möglichst geschlossenen und möglichst von der Urproduktion lebenden Hauswirtschaft zurück, sondern er erkannte die geldwirtschaftlich-industrielle Produktion als selbstverständliche Grundlage und l:orm der Berufsarbeit neben der agrarischen an und hatte überall wesentlich mit den ersteren praktisch zu tun. Er fand auch den größeren Nutzen des kaufmännischen Geschäftes im Verhältnis zum landwirtschaftlichen Bodeneinkommen ganz in der

38:) Stellen bei Kampschulte I 430; dazu Briefe I 443 die Anerkennung der Armut, die Jesus gebot, im Unterschied von der mönchischen Armut. Zahlreiche Beispiele .gleicher antimammoniśtischer Gesinnung seiner Nachfolger bei Choisy: S. Is; f. auf einen Vorschlag der Kaufleute zur Errichtung einer Wechselbank mit lem Zinsfuß von $10 \%$ erkennen sie die belle apparénce des Projekts an, fürchten aber abus, désordres et dissolutions, verweisen auf die. Gefahren des Wechselgeschäftes in Paris, Venedig, Lyon, auf die Zerstörung Jerusalems und Roms durch den Reichtum "Si ce change est introduit, on dira, qu'à Genève chacun est banquier et qu'il n'a que des prêteurs. Si d'aventure Messieurs jugent néanmoins yue ce charse sera commode, ils prient de bien considérer s'il sera tolérable de Irčter à deux et demi par foire.. Ils pensaient que la cité serait plus forte en demeurant pauvrec. $S$. 346: Die V. Compagnie erklärt, dem Volk l'ordre, l'obéissance ct la modestie zu predigen. S. 229: sie fordern qu'on demeure en toute molestie et midiocriti. Ganz in diesem Sinn schon Calvin, Elster 191 »Et en général, que chacun ait à se vestir honestement et simplement selon son e stat ct y ualité et que tous, tant petits que grands, monstrent bon exemple de modesti e chrétie n ne les uns aux autres". - Noch die niederländische Kirche hat allau hohen Zinsfus, Leihhäuser und Lombardirinstitute als Ausbeutung der Armen hiftig bekämpft, s. Kinappert, Geschiedenis der nederlandsche hervormde Kerk. I9I I, $\therefore 17-152$. 
Ordnung, da er nur der Lohn des Fleißes und der Sorgfalt sei. Auch drang er wohl auf Ausmerzung christlich-bedenklicher Geschäftszweige, wie etwa der Kartenfabrikation, begünstigte aber im übrigen Bewegung und Fortschritt, wie denn auf seinen Antrag zur Beschäftigung der Armen und Arbeitslosen mit Hilfe eines Staatskredits die Tuch- und Samtfabrikation als Heimindustrie eingeführt wurde. In dem gleichen Sinne hat man später, als diese Industrie gegenüber der Lyoner Konkurrenz nicht zu halten war, die Uhren-Fabrikation eingeführt. So zeigt sich bei ihm auch nicht das Drängen auf Einhaltung der Standes- und Erwerbsarten, auf die Immobilisierung der Gesellschaft. Die für eine derartige Wirtschaft selbstverständliche Beweglichkeit wird von ihm nirgends bekämpft. Das aber sind Wirkungen des Genfer Bodens und der Genfer Atmosphäre, die bis in seine Briefe hinein erfüllt ist von geldwirtschaftlichen, kaufmännischen und handwerkerlichindustriellen Interessen ${ }^{383}$ ). Er mag als Jurist und Städter von Hause aus in diesen Dingen anders empfunden haben als der Mönch Luther, aber klar ersichtlich ist aus den Quellen jedenfalls, daß er in Genf gar nicht anders denken und empfinden konnte, wenn er praktisch wirken wollte, und daß er dieser Notwendigkeit sich ohne Bedenken und Schwierigkeiten hingegeben hat ${ }^{384}$ ). Freilich daß ihm ein inneres Eingehen derart möglich war, das ist wohl in der Sonderart seiner praktisch

383) Vgl. aus dem Brief de Usuris CR XXXVIII S. 247: >Quid si igitur ex negociatione plus lucri percipi possit quam ex fundi cujusvis proventu? - Unde vero mercatoris lucrum? Ex ipsius, inquies, diligentia et industrias.

384) Diese Rückwirkung Genfs hervorgehoben bei Kampschulte 429. Genf hatte bereits vor Calvin eine staatliche Zinsgesetzgebung, die er einfach übernahm. Sein als selbstverständlich sich gebendes Eingehen auf die kaufmännische Atmosphäre ist in den Briefen massenhaft bezeugt. Briefe I 33 kaufmännische Spekulationen in Hinsicht auf die Vertreibung Calvins; 81 und 306 Empfehlung von Gläubigen für Lehrlingsstellen; 209 Calvins eigene Schwierigkeit Darlehen zu finden für sich selbst; 283 Schwierigkeiten, einen Neffen Virets beim Ladengeschäft oder als Reisenden oder Schuldeneintreiber anzustellen; 294 solche, für einen geistlichen Kollegen Hypotheken zu beschaffen; 332 Anratung von Geldgeschäften an zwei Lausanner; II 109, Eintreten für Schuldhaft zur. Sicherung des Genfer Kredits; 360 Aufnahme einer Anleihe zu Gunsten der vertriebenen Waldenser; 140 Beratung eines Hugenotten über Recht der Zinsforderung nach natürlichem und göttlichem Recht; 393 Rat an einen Pfarrer, Geld auszuleihen, da es besser ist, als Handel oder andere vom Beruf abtreibende Geschäfte für den eigenen Unterhalt zu betreiben; 442 Schuldenmahnung an Jeanne d' Albret, für deren Gatten Calvin ein Darlehen von 10000 Franken 
handelnden und das öffentliche Leben mitbeherrschenden Ethik, in der Zurückstellung des radikalen Liebes- und Leidensgebotes hinter das Praktisch-Mögliche begründet; Luther würde auch in den Genfer Verhältnissen schwerlich anders gedacht und empfunden haben als in Wittenberg. Nicht als ob Genf eine besonders große und tätige Handelsstadt gewesen wäre ${ }^{386}$ ). In einer solchen würde vermutlich auch Calvin die Schwierigkeit, sich unter die Forderungen des Kapitalismus zu beugen, viel schwerer empfunden haben. Die Genfer Verhältnisse waren im Gegenteil bei der Umgebung mit feindlichen und konkurrierenden Nachbarn und bei der Kleinheit des Gebietes eng und kleinbürgerlich. Aber gerade in dieser Form war der Kapitalismus für Calvin annehmbar als ein mit der Stadt gegebener und der Treue, des Ernstes, der Redlichkeit, Genügsamkeit und Nächstenrücksicht sehr wohl fähiger Beruf. Gerade durch die Kleinheit und Bürgerlichkeit der Genfer wirtschaftlichen Zustände konnte der Kapitalismus sich in die calvinistische Ethik hineinstehlen im Gegensatz zur Verwerfung desselben durch die katholische und lutherische Ethik.

Das kommt in dem wichtigen Umstande zum sozusagen offziellen Ausdruck, daß Calvin und die calvinistische Ethik das kanonische Zinsverbot und die scholastische Geldtheorie verwarfen und umgekehrt eine der modern-wirtschaftlichen Auffassung näher kommende Lehre vom Wesen des Geldes, des Kredits und des Zinses aus eigenen und Freundesmitteln besorgt hatte und über deren Rückzahlungsweise Calvin als ,Nicht-Finanzmann Rat erbittet. Die gleiche Atmosphäre geht mit gleicher Selbstverständlichkeit durch die von Choisy mitgeteilten Protokollauszüge. S. 31 die Kompagnie ist gegen die Aufhebung der Schuldhaft, weil sie die auswärtigen Gläubiger und den Kredit schädigt, das gleiche 392 ; S. 34 Ablehnung einer Erhöhung des Zinsfußes wegen Erschwerung des Kredits und Teuerungsgefahr; S. 36 Zustimmung der Compagnie zur Verwertung der in Basel und Bern aufgenommenen Summen durch Anlage einer Staatsbank, ebenso S. 58 ; S. 47 Erledigung einer Beichte über kommerzielle Unkorrektheiten durch die Compagnie; S. 57 Anerkennung des Wechselgeschäftes nach göttlichem, natürlichem und bürgerlichem Recht, verbunden mit Bedenken über die Genfer Praxis; S. I40 Streben nach Frieden mit den Lutheranern im Interesse des Genfer Handels nach Deutschland; S. 194 Verwahrung des Rates gegen zu strenge Wuchergesetze »dans une ville ou la plupart sont débiteurs et où beaucoup ne savent pas distinguer entre usure et usure, entre ce qui est abus et ce qui ne l'est pas «; S. 388 Anerbieten eines Darlehens von 1000 Ecus ans der Tasche der zehn Stadtgeistlichen für die Aufrechterhaltung der Akademie.

385) Vgl. hiezu Holl, Calvinreden S. 6I f. 
vertraten, allerdings mit gleich noch zu besprechenden Einschränkungen. Calvin verließ damit den reinen Konsumtionsstandpunkt der bisherigen christlichen Ethik und erkannte die Produktivkraft des Geldes und Kredites an. Er empfand einen inneren Zusammenhang zwischen ökonomischem Fortschritt und moralischer Hebung, wie seine Mitarbeit an der staatlichen wirtschaftlichen Gesetzgebung und seine Auffassung von der Bedeutung eines wirtschaftlich wohlgeordnețen Gemeinwesens für die heilige Gemeinde. bekunden. Auf dieser Bahn sind dann Calvins Genfer Nachfolger geblieben. Beza und die Vénérable Compagnie bekümmerten sich beständig eingehend um die Fragen der wirtschaftlichen Prosperi-

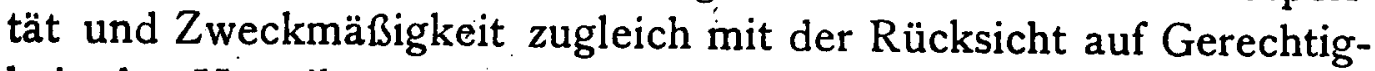
keit der Verteilung und auf Versorgung der Armen und Arbeitslosen. Auch wurden sie von der Staatsregierung beständig um Rat und Urteil in diesen Dingen angegangen. Sie interessierten sich für Besteuerung und Staatsanleihen, für die Höhe des Z Zinsfußes, die stets mit ihrer Bewilligung festgesetzt wurde. Sie begutachteten die Errichtung einer Staatsbank, sowohl um dem Stàat die Gewinne des Wechselgeschäftes zuzuführen als um den bedürftigen Gewerben billigen Kredit zu verschaffen ${ }^{386}$ ). Aus dieser Genfer Praxis ist dann eine vorsichtig eingegrenzte Rezeption des Kapitalismus in die calvinistische Ethik aller Länder überhaupt übergegangen. Die hugenottisch-französischen, niederländischen und englischen Verhältnisse haben das Ihrige weiter dazu beigetragen um überall mit besonderer Nuance das moderne Geschäftsleben religiös zu rezipieren. Sehr wichtig war in dieer Hinsicht der Umstand, daß die Calvinisten in Frankreich und England, anfänglich auch in den Niederlanden und vor allem in der Zeit ihres Exils am Niederrhein, als Minoritäten von dem öffentlichen Leben und den staatlichen Aemtern abgedrängt und damit $z u$ einer überwiegend geschäftlichen Existenz geradezu genötigt wurden. Aber auch abgesehen davon haben die Calvinisten bei ihrer Arbeitsamkeit und Eingezogenheit, ihrem rationellutilitarischen Geiste auch bei an sich dem Geschäftsleben wenig günstigen Verhältnissen eine starke Neigung zu ihm gezeigt ${ }^{387}$ ).

880) Beispiele allenthalben bei Choisy, L'etat chrétien; die Errichtung von Banken S, $36 \mathrm{f}$. und $187 \mathrm{ff}$.

287) Die Einzelheiten gehören in wirtschaftsgeschichtliche Darstellungen, sind aber uberhaupt nicht so einfach statistisch darzustellen. Dazu kommt, daß in de Nachbarschaft des Calvinismus auch andere Gruppen, anglikanische, sektenhafte 
Das trug dann aber Konsequenzen in sich, die weit über das von Calvin und den Genfern gewollte Maß hinausgingen. Einlutherische, eine gewisse Färbung von dem Calvinismus annahmen. Die Tatsache selbst ist bekannt und allgemein anerkannt. Außer der berəits oben erwähnten Literatur verweise ich auf die hübsche Zusammenstellung bei Arnold, Calvinrede S. 28-33, hier S. 31: >Auf calvinistischem Boden ist das Sprichwort entstanden: Der Glaube versetzt Berge, und arbeitet dabei mit Hacke und Spaten. Auch das Luthertum brachte die Arbeit zu Ehren; aber indem es diese auf den $>$ Beruf 20g, wurde die freie Initiative des einzelnen weniger bestimmt entfesselt.... Calvin hat wie kein anderer unter den Reformatoren betont, was die Arbeit produktiv mache, seien nicht allein die physischen und die geistigen, sondern vor allem die moralischen Kräfte . . . Der objektive Wert des in der Arbeit Geleisteten, der ökonomische Erfolg, besteht darnach nicht in dem augenblicklichen Gewinn, sondern einzig und allein darin, daß reell gearbeitet wird. Ein Gedanke von geradezu ungeheurer Tragweite! Man verkennt diese Tragweite deshalb so leicht, weil man es für ebenso selbstverständlich hält, wie es einfach ist.. Darauf folgt eine Skizze der Ausbreitung und Wirkung des reformierten Industrialismus und Kapitalismus. - Ein charakteristisches Zeugnis für die Niederlande führt Weber aus der Schrift Political Arithmetic des berühmten Nationalökonomen W. Petty an: Antikritisches S. 184 : -Dissenters of this kind - gemeint sind die Träger des holländischen Freiheitskampfes, in erster Linie Calvinisten - are for the most part thinking, sober and patient men, and such as believe, that labour and industrie is there duty towards Godヶ. Was nicht im Widerspruch steht, sondern sich ergänzt mit der anderen Stelle des gleichen Autors ebd. S. 188: These people - nämlich die puritanischen Dissenter - believing the justice of God and seeing the most licentious persons to enjoy most of the world and its best things, will never venture to be of the same religion and profession with voluptuaries and man of extreme wealth and power, who they think have their portion in this worlda. - Die Ausbreitung des bürgerlichen Kapitalismus über die einzelnen Gebiete und die dabei obwaltenden Modifikationen siehe bei Weber, Antikritisches, S. 186-188, 192; Schlußwort S. 571 und $594 \mathrm{f}$. Hier ist auch gezeigt, wie auch auf an und für sich dem Kapitalismus ungünstigem Boden, wie in Ostfriesland, Neuengland, Ungarn, solche oder doch verwandte Wirkungen eingetreten sind. Die Sache hängt also nicht etwa bloß vom Milieu ab. - Zahlreiche Beispiele für die Niederländer und den niederrhein. Calvinismus gibt Göbel II 39: „Ihre Mitglieder (der Aachener reformierte Gemeinde) bestanden fast nur aus reichen und vornehmen Kaufleuten, indem alle Evangelischen nur als Beisassen geduldet und daher weder zu Aemtern noch zu Zünften, noch zum Kleinhandel zugelassen, sondern nur zum Großhandel berechtigt waren. II 47 : Die Kredenzbriefe der Abgeordneten und Aeltesten zu den Synoden mußten, um jeden Verrat und Verdacht fern $z u$ halten, in der Form kaufmännischer Kreditbriefe ausgestellt werden . II I06: sUnd (nach einer Schilderung der asketischen Lebensstrenge) da sie ohnehin in Jülich und Berg von allen öffentlichen Aemtern ausgeschlossen waren, so war es "desto natürlicher, daß der ganze niederrheinische 
mal überhaupt, wenn auch mit allen Kautelen, aufgenommen, wirkte der Kapitalismus überall, wo er mit dem Milieu ge-

Handel und die hier so bedeutende Industrie vorzugsweise in ihre Hände kam und noch heute vorzugsweise sich in ihren Händen befindet. Dadurch wurden die von den Evangelischen bewohnten Landstriche, namentlich der Bergische, Märkische und Jülichsche, durch ihre außerordentliche Fabriktätigkeit und ihren Handel eine der reichsten und merkwürdigsten Gegenden in Deutschland, welche zugleich den Ruf großer Kirchlichkeit und Frömmigkeit erhalten hate. II 205 aus einer Erklärung Labadies: Die Aeltesten und Diakonen erfüllen gegen die Glieder und Armen ihrer Abteilungen ihre Pflichten, die Richter lieben die Gerechtigkeit und die Kaufleute handeln für den Himmel und die Meister arbeiten für die Ewigkeitc. Ueber die ökonomische Bedeutung des Labadismus s. II 238 und 259, er ist nur gesteigerter Calvinismus in dieser Hinsicht. - Bezüglich der englisch-puritanischen Wirtschaftsethik sagt Cunningham, der berühmte englische Wirtschaftshistoriker, in einer kleinen Schrift : The moral witness of the church on the investment of money and the use of wealth Cambridge 1909, S. 23 ff. folgendes: Wie der Fehler der heutigen kirchlichen Ethik (in England) eine einseitige Neigung zum Sozialismus sei, so sei die umgekehrte Einseitigkeit und Vernachlässigung anderer mitspielender Faktoren die Eigentümlichkeit der puritanischen gewesen. Ihr Kampf gegen Faulheit und Genußsucht und ihre Empfehlung disziplinierter Arbeit habe sie geradezu kapitalistisch gemacht. Unemployment and idleness were the charcateristic evils of $17^{\text {th }}$ cent. in England and Scotland; the great need for introducing a godly, sober and righteous life into the community appeared to be that of getting the population to submit to the discipline of work. There were no half measures in the Scotch treatment of vagrants according to the act of 1663. Capitalists who set up manufactories were empowered to impress any vagrants and ,employ them for their service as they see fit' for eleven' years, without wages except meat and clothing. Good subjects were recommended to take into their service poor and indigent children, who were to do any task assigned to them till they had attained the age of thirty, and to be, subject to their master's correction and chatisement in all manner of punishment (life and torture excepted). The 17 th cent. Puritans took a stern view of the discipline which was good for children, to that they might be kept from forming habits of idleness and drifting into evil of every kind. While there was a strong sense of the religious duty of insisting on hard and regular work for the welfare, temporal ond eternal, of the people themselves, there was a complete indifference to the need of laying down or enforcing any restrictions as to the employment of money. Capital was much needed in England, and still more in Scotland, for developing the ressources of the country and for starting new enterprises; freedomforthe formation and investment of capital seemed to the thoughtful city men of the 17 th cent., who were mostly in sympathy with puritanism, the best remedy for the existing social evils. They were eager to get rid of the restrictions imposed by the popes laws, which it was pos- 
geben war, seine sich selbst steigernden Folgen aus, zog aus der spezifisch reformierten Frömmigkeit und Arbeitsamkeit Recht-

sible to bring up in ecclesiastical courts, as well as to be free from the efforts of the Kings Council to bring home to the employing and mercantile classes their duty to the community. The agitation against the interfereme of the Bishops in civil affairs, and the triumph of Puritanism swept away all traces of any restrictions or guidance in the employment of money. In so far as a stricter ecclesiastical discipline was aimed at or introduced, it had regard to recreation and to immorality of other kinds, but was at no pains to interfere to check the action of the capital ist or to protect the labourer From the time when the rise of puritanisme paralysed the action of the church (d. h. die Staatskirche), and prevented her from maintaining the influence, she had habitually exerted, it has been plausible to say that Christian teaching appeared to be brought to bear on the side of the rich and against the poor. The puritans were probably right as to the most serious evils of the day; and the economic means of overcoming them; they may well have felt that religious duty impelled them to the line they tooks. Die Schrift ist auch sonst charakteristisch, sie uußert sich zu einer Denkschrift der Geistlichkeit über christliche Wirtschaftsethik und entwickelt ihrerseits eine moderne Anpassung altchristlicher Ideen an das, als selbstverstündlich zu akzeptierende modern-kapitalistisches Leben; das Maß des durch Kapitalismus und Zins zu stiftenden Nutzens soll zum Maß der christlichen Wirtschaftsethik gemacht werden. - Bezüglich des ganz überwiegend reformierten Bremen ist lehrreich das Tischgespräch eines Bremer Großkaufmanns mit einem Wiener Kaufmann über den verschiedenen Lebensstil der üppigen Wiener und der strengen und sparsamen Bremer Großkaufleute, das ich in dem Sonntagsblatte der > Bremer Nachrichten Nr. 30 u. 31 von 1910 ( Von alter Bremer Art ") gefunden habe: ,Weiß er wohl, Musje R. (der Wiener), warum wir das nicht so machen?.. Weil wir freie Reichsbürger sind. - Aber doch, sagt der andere, ebenso große Kaufleutel Und eben deswegen, fährt der Bremer fort, viel Geld brauchen und also sparen müssen. Damit er mich aber recht verstehe, muß ich ihm erklären, was es mit einem großen Kaufmann in einer freien Reichsstadt eigentlich sagen will. Das ist ein Mann, der immer mehr arbeitet, um immermehrzuverdienen, und immermehrverdient, um immer mehr zu arbeite $n$, weil er auf diese Weise sein Geld nicht verzehrt, sondern es hingibt, um immer mehr Hände zu beschäftigen und immer mehr Hungrige satt zu machen. Der Wiener Kaufmann kann Landgüter kaufen und viel aufgehen lassen. Ich verdenk es ihm nicht. Entsteht Not im Lande, so greift sein Kaiser in die Tasche. Aber hier wendet sich der freie Staat an seine freien Bürger. Der reiche Bürger bewilligt gern und gibt gern. Auch nimmt der Bürger in bedrängten Lagen, wie billig, seine Zuflucht zu dem Bürger in einer besseren Verfassung. Hat einer viel erworben, so hat er auch viele Ansprüche zu befriedigen und befriedigt sie gern als Mitbürger und als Christ. Jetzt wollte ich ihm noch das Rezept mitteilen von der Medizin, mit welcher ich sterben will! (Das bisherige war das Rezept für das Leben.) Es steht Matth. 24, 12 und 13: Wer in der Gerechtigkeit beharret und in der Liebe bis ans Ende, der wird selig.e 
fertigungen und Verstärkungsmittel an sich, die ihm in den reforniierten Gemeinden einen besonderen Charakter und eine besondere Intensität verliehen ${ }^{388}$ ). Die Ermahnung zur beständigen fleißi-

Dar Bremer motiviert zwar seinen Lebensstil mit dem repuplikanischen Charakter Bremens, aber schon 'die religiösen Wendungen des Gesprächs zeigen, daß es sich um calvinistische Ethik handelt, wie der Aufsatz den Verfasser auch sonst als streng religiös zeigt. - In den hier mitgeteilten Stellen tritt vielfach der Zusammenhang dieser Entwickelung mit der Minoritätsstellung der Reformierten und der Abdrängung vom offiziellen Leben zutage, wic das auch Weber, Antikritisches S. 188, betont. Doch ist das nach dem Ausweis anderer Stellẹn nicht entscheidend. - Ein wichtiger Punkt bleibt in der kapitalistischen Entwickelung des Calvinismus die Verschiebung in die Mittelklasscn und das Bürgertum. Hierher gehört in England der Gegensatz zwischen der ,Squirearchie und den bürgerlichen, immer wieder noch in der Cobdenschen Bewegung in charakteristischer Art an den Dissent angelehnten Mittelklassen Schlußwort 558; der bürgerliche Charakter s. Schlußwort 573 : -Es ist nun aber eine der Leistungen des asketischen Protestantismus, daß er dieser Tendenz entgegenwirkt, daß er insbesondere den von ihm als ,Kreaturvergötterung' abgelehnten Tendenzen, den splendor familiac durch Immobilisierung des Besitzes als $\mathrm{r}$ e $\mathrm{n}$ t e $\mathrm{n}$ bringenden Vermögens zu sichern, wie der ,seigneurialen' Freude am ,high life', dem schünheitstrunkenen Rausch im ästhetischen Genießen and Sichausleben' wie dem protzenhaften Bedürfnis nach ostensiblem Prunk gleichmäßig widerstrebt. $<$. Diese Verbürgerlichung ist $m$. E. eines der Hauptprobleme in unserem Zusammenhang und noch keineswegs in ihren Ursachen geklärt, s. die Bemerkung von Weber, Antikritisches, S. 188: >Die interessante Erscheinung, welche in der Beziehung zwischen den $\mathrm{K} \mathrm{l}$ a s s e $\mathrm{n}$ und dem religiösen Leben zu beobachten wäre - fast in allèn Ländern - ist die allmähliche Wandelung der anfänglich - oft sogar mit Einschluß des Täufertums - vertikal durch die soziale Schichtung gehenden Risse (d. h. religiös bedingter Gruppenbildung) in horiz ontale (d. h. die religiöse Stellung mit Klassenschichten zusammenfallen lassende): hier setzt dann das Recht der geschichtsmaterialistischen ,Deutung' ein «. Diese Deutung ist aber noch nicht geliefert. Auf dieses Problem bin ich auch im Verlauf meines ganzen Buches gestoßen, vermag es aber - insbesondere an diesem Punkt - nur sehr dürftig aufzuklären; es scheint mir bald die Minoritätenstellung und AusschlieBung, bald eine innere Konsequenz der calvinistischen Ethik und oft beides zusammen wirksam zu sein. Jedenfalls spielt am Anfang die soziale Schichtung eine viel geringere Rolle und herrscht humanistische Weltbildung wie adlige Sitte stark vor. Es ist ein starker Gegensatz zwischen dem Calvinismus, den der , Colignye von Marcks zeichnet, und dem bei Dowden und Göbel gezeichneten. Auch wäre noch zu zeigen, wie weit diese Verschiebung etwas Generelles ist.

388) Daß der Kapitalismus aus dem Calvinismus stammt, hat niemand behauptet. Wohl aber, daß beide eine gewisse Wahlverwandtschaft für einander hatten, daß die calvinistische Berufs- und Arbeitsethik, die den Geldverdienst bei gewissen Kautelen für erlaubt erklärt, ihm ein geistiges und ethisches Rückgrat geben konnte 
gen Arbeit, verbunden mit der Einschränkung der Konsumtion und des Luxus, bewirkte eine Tendenz zu steigender Kapitalbildung, die ihrerseits - bei der Notwendigkeit ihrer weiteren Verwertung in Arbeit und nicht in Genuß - wieder zu immer gesteigertem Umschlag nötigte. Arbeitsgebot und Luxusverbot wirkten in ihrer Vereinigung "ökonomisch als Sparzwang*, und der Sparzwang wirkte Kapital bildend. Das erreichte Kapital aber wirkte zur Steigerung der Intensität und Extensität der Arbeitsleistung. Wie weit diese Wirkungen überall eingetreten sind, ist eine Frage für sich. $\mathrm{lm}$ ganzen aber liegt diese Wirkung in der Natur der Sache und ist sie nach allgemeinem Urteil bei den wich.

und $\mathrm{da} B$ er wiederum so organisiert und innerlich gestützt sich hier stark, wenn auch in den Grenzen des Anti-Mammonismus, entwickelt hat. S. Weber, Antikritisches S. 200: sKein Zweifel, daß wo ein (Wirtschafts-)System und ein ,Geist" von unter einander besonders hohem Adäquanzgrade auf einander stoßen, eine Entwickelung von auch innerlich ungebrochener Einheitlichkeit (d. h. wo Geist und Wirtschaftssystem zusammenstimmen, was nicht immer der Fall ist) einsetzt, von der Art, wie diejenige, die ich zu analysieren begonnen hatte (d. h. wie die calvinistische Entwickelung). Das Zusammentreffen selbst ist, wie ich das oben bei der ebenfalls relativ hohen Adäquanz zwischen dem mittelalterlichen System und der katholischen Ethik bereits sagte, ein historischer Zufall. Aber aus solchen Zufällen, d. h. aus der Verbindung voneinander unabhängiger, aber einander adäquater Tendenzen, (Weber, Schlußwort XXXI 580 , Das Menschentum, welches durch das Zusammentreffen religiös und ökonomisch bedingter Komponenten geschaffen wurde ; 583 : -Die protestantische Askese schuf ihm (dem bürgerlichen Kapitalismus) die positive Ethik, die Seele, deren jenes Getriebe bedurfte, damit >Geist und >Forme einig seienc. S. 588: Es vermählte sich ein Strom von psychischen Inhalten, der aus sehr spezifischen sittlich-religiösen Wurzeln entsprang, mit kapitalistischen Entwickelungs $\mathrm{m} \ddot{\mathrm{g}} \mathrm{l}$ i chke ite $\mathrm{n}$ ), gehen die großen historischen Entwickelungen hervor. Die christliche Ethik hat große faktisch bedeutsame Weltwirkung nur erlangt, wo sik von einem solchen Zufall unterstützt war. Für sich allein, wo sie nicht von einem solchen Zufall unterstützt war, bleibt sie sIdee oder manchmal auch sPhrase Freilich wirkt dann die Verbindung auf den religiös-ethischen Geist zurück, wie ich beidemale zeige. In der Geschichte des christlichen Ethos hat es nur zwei solcher -Zufälle gegeben, das mittelalterliche System und das calvinistische, dessen Erweiterung durch die verbürgerlichte Sekte der nächste Abschnitt zeigen wird. Es gibt andere, oft gewiß feinere und tiefere Fassungen des christlichen Ethos, denen eine solche historische Wirkung versagt blieb und bleibt, weil sie die Gunst jenes Zufalls nicht fanden oder ihrem Wesen nach nie finden konnten. Wenn ich hier von Zufall rede, so ist das natürlich logisch gemeint, daß sich hier keine immanente Entwickelung konstruieren lasse, nicht daß diese Dinge sine Deo geschehen seien. 
tigsten reformierten Völkern auch tatsächlich eingetreten ${ }^{389}$ ).

Aber das ist gar nicht das Entscheidende, worauf es hier ankommt. Nicht der Beitrag des Calvinismus zur Ausbildung des kapitalistischen Systems selber ist die Hauptsache. Diese wird vielmehr erst deutlich, wenn man mit Weber und Sombart nach dem ethischen und weltanschauungsmäßigen *Geiste oder nach der > Wirtschaftsgesinnung* sucht, die dem System seinen festen Grund und Halt in den Gemütern gegeben hat und es trotz seines Gegensatzes gegen die natürlichen menschlichen Instinkte in den Seelen als ein Gesinnungsprinzip hat Wurzel schlagen lassen. Jenen Instinkten entspricht sehr viel mehr der ökonomische Traditionalismus mit Durchbrechungen durch einzelne rücksichtslose Erwerbsjäger, aber nicht die sachliche und abstrakte Herrschaft der Arbeit und des Erwerbs an sich, die immer neue Steigerung der Arbeit durch jeden Arbeitsertrag ${ }^{389 a}$ ). Hier liegt nun - neben verwandten, aber andersartigen. Wirkungen des Judentums - die Bedeutung, die der eigentümlich calvinistische Typus des inneren ethischen Verhaltens zu der geschäftlichen

880) S. Weber, Antikritisches XXX 19I f., Schlußwort XXXI $594 \mathrm{f}$.

889a) Die Entstehung und das Wesen des skapitalistischen Systemse ist bekanntlich das Hauptproblem der gegenwärtigen wirtschaftsgeschichtlichen und theoretischen Forschung. Analysen des Systems geben Weber, Prot. Ethik XX S. II -35 , Sombart, Die Juden und das Wirtschaftsleben, 1911, S. $186-198$ und in seinen bekannten früheren Werken Deutsches Wirtschaftsleben des 19. Jahrh. und vor allem Der Kapitalismus; s. auch den Artikel K. von Traub in RGG. Eine Darstellung des Werdens des ,Systems a in England gibt Held, Zur sozialen Geschichte Englands, wo sich überhaupt vortreffliche Bemerkungen zur Sozialgeschichte finden. Bei Held fällt der Nachdruck mehr auf die äußeren technischen usw. Gründe der Ausbildung des Systems. Den geistig-ethischen Grundlagen ist er nur in der Analyse der politischen und nationalökonomischen Theoretiker nachgegangen; aber er verfolgt sie nicht bis in das eigentlich populäre Ethos hinein. Diese Frage aber hat Weber als die Frage nach Entstehung und Wesen des skapitalistischen Geistese, Sombart als Frage nach der, Wirtschaftsgesinnung * erhoben, und beide haben dabei in die Tiefen des populären religiösen Ethos gebohrt. Ueber den Unterschied von skapitalistischem Geist c und skapitalistischem Systeme, die nicht zusammenfallen brauchen und auch oft nicht zusammenfallen, s. Weber, Antikritisches S. 201-202. Erst aus dem sZufall des Zusammentreffens beider erwächst die geistige Herrschaft des Kapitalismus. Diese Unterscheidung ist Rachfahl unverständlich, er macht darüber nur Witze. Im übrigen betone ich, daß Weber und Sombart das Wesen des Kapitalismus aufdecken wollen und dazu die religiös-ethischen Elemente nur heranziehen. Ich will umgekehrt die Bedeutung des Kapitalismus für die calvinistische Entwickelung klar machen. Es sind also sehr verschiedene Gesichtspunkte, unter denen unsere Untersuchungen stehen. 
Arbeitsleistung und seine religiöse Würdigung des Gelderwerbs gewonnen hat. Die protestantische Berufsethik mit ihrer reformierten Rezeption des kapitalistischen Erwerbes und ihrer reformierten Strenge und Kontrolle der die Erwählungsgewißheit bestätigenden Arbeitsleistung machte den Dienst im Beruf, die systematische Ausnutzung der Arbeitskraft, zu einer um ihrer selbst willen notwendigen und gottverordneten Leistung, im Verhältnis zu der der Gewinn die göttliche Bestätigung und Anerkennung ist ${ }^{390}$ ). Diese Berufs- und Arbeitsauffassung mit ihrer Verpönung jeder Untätigkeit, der Benützung jeder Erwerbschance und dem Vertrauen zum göttlichen Segen kam nun aber den geschäftlichen Berufen und dem Gelderwerb in hohem Maße entgegen. Sie unterbaute einer Welt der spezialisierten Arbeit, die die Arbeit um der Arbeit willen betreiben lehrte und damit unseren heutigen bürgerlichen Lebensstil hervorbrachte, die seelische Grundhaltung, aus der sie hervorgehen konnte, an deren Fortdauer aber freilich sie nicht gebunden ist, nachdem sie einmal die Lebensverfassung der modernen Völker geworden ist. So entstand ein bestimmter, besonders mächtiger und einflußreicher Strom des bürgerlichen kapitalistischen Geistes, vor allem der Typus der bürgerlichen Lebensführung überhaupt. Es ist die Herrschaft der Arbeit und des Berufs, des Erwerbs an sich, über den Menschen, eine Objektivierung der Arbeit und des Arbeitsertrages, die nur ${ }^{380}$ ) Sehr scharf präzisiert bei Weber Schlußwort XXXI 582 f.: :Lob und Empfehlung gewissenhafter Arbeit für den in der Welt stehenden Laien findet sich selbstredend zu allen Zeiten (doch nur bedingt im Urchristentum, mehr bei den Kynikern)

Die Aussprüche Luthers nach gleicher Richtung sind bekannt. An der Lehre vom Segen auch weltlicher Arbeit hat es außerhalb des Protestantismus gewiß nicht gefehlt Aber was hilft sie, wenn, wie im Luthertum keine - in diesem Fall: psychischen - Prämien darauf gesetzt sind, daß diesen theoretischen Lehren nachgelebt wird? Oder wenn, wie im Katholizismus, die weitaus größeren Prämien auf ganz andere Arten des Verhaltens gesetzt sind? und überdies in Gestalt der Beichte ein Mittel gegeben ist, welches dem einzelnen immer aufs neue ermöglicht, sich von schlechthin allen Arten von Verfehlungen gegen die Postulate der Kirche an das Leben seelisch zu entlasten? Während umgekehrt der Calvinismus in seiner Entwicklung seit der letzten Zeit des I6. Jahrhunderts, und ähnlich das Täufertum, in dem Gedanken von der Notwendigkeit asketischer B e wä h r ung, im Leben überhaupt und speziell auch im Berufsleben, als subjektiver Verbürgung der certitudo salutis - also nicht als Real-, sondern als einer der wichtigsten Erkenntnisgründe der eigenen Bestimmung zur Seligkeit - eine sehr spezifische und in ihrer Wirksamkeit auf die sem Gebiete nicht leicht zu überbietende psychische Prämie für die asketische Lebensmethodik, die er forderte, schufe. 
möglich war, wo die Arbëit durch eine derartige asketische Berufsethik in die Sphäre des an sich Notwendigen durch die grundlegende religiöse Auffassung erhoben worden war. Der anfänglich sozial indifferente, starke Adelsgruppen in sich befassende Calvinismus ist durch die politische Entwicklung der verschiedenen Ländern verbürgerlicht, aber diese Verbürgerlichung entsprach auch durchaus gewissen Elementen seines Geistes ${ }^{391}$ ). Selbstverständlich glitt eine derartige Auffassung des Kapitalismus bei der Ermattung der religiösen Triebfedern und der Verdünnung der religiösen Atmosphäre leicht in die rein weltliche Auffassung hinüber. Die klassische ökonomische Theorie seit Adam Smith hat ja die Grundlagen der Wirtschaft in geradezu entgegengesetztem, rein hedonistischem Sinne konstruiert. Dabei lag der Gegensatz gegen die religiöse Ethik nicht in ihrem Utilitarismus an sich. Dieser war für die weltlichen Dinge, insbesondere auch für die Wirtschaft, schon das ausschließliche Prinzip auch ihrer Auffassung. In dieser Hinsicht setzte die englische ökonomische Wissenschaft nur die religiösen Grundüberzeugungen fort. Das Moderne und Anticalvinistische liegt erst in dem radikalen Individualismus, liegt auch hier in der Einführung der Gleichheitsidee und in dem Wegfall der Rücksichten auf Autoritäten, ständische Vorzugsstellungen, Wohlbefinden des Ganzen. Ganz ähnlich wie in der Ausbildung der politischen Theorien scheiden sich daher die Gruppen der Theoretiker in mehr konservative und in radikal-individualistische. Adam Smith selbst war, ähnlich wie Locke, noch zwischen beiden Richtungen geteilt. Erst bei Bentham und seiner Schule ist jeder Faden zerrissen, der die neue Wirtschaftsethik mit der alten verbindet ${ }^{391 \bullet}$ ). Das Manchestertum mit seinem doktrinären Optimismus, die brutale Verherrlichung der Konkurrenz als Emporzüchtung im Kampf ums Dasein, schließlich die Gedankenlosigkeit, mit der heute die kapitalistische Kultur ihre Arbeitshast, ihre Krisen, ihr Fach- und Be-

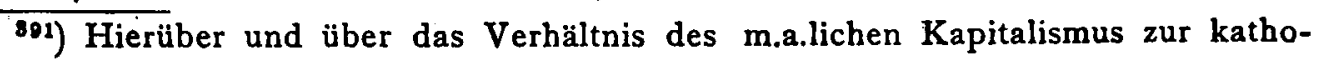
lischen Ethik sowie über die anderen nicht asketisch und bürgerlich motivierten Arten des Kapitalismus s. Weber XXX. 193-197.

801 a) Vgl. Held S. 144-342; S. 249 über Bentham: "So wenig die Lehre an sich neu war, ihre einseitige Anwendung durch Bentham in England, war etwas Neues: sie bedeutete den nackten Rationalismus und den völligen Bruch mit den puritanischen Traditionen der englischen Demokraties. Sie ist auch hier franzossischen Ursprungs, wie Held hervorhebt. Ueber die konservativ-ethischen Elemente bei Smith s. Held 154-175. 
rufsmenschentum wie ein Schicksal hingenommen wird: all dieses bedeutet dann eine völlig veränderte Welt. Aber das und alles Nähere gehört in die Wirtschaftsgeschichte, nicht in die des Calvinismus. Von der ganzen Sache wird später bei Gelegenheit der Sekten noch weit $\mathrm{zu}$ sprechen sein.

Für unser Thema ist das Bedeutende und bis heute Wichtige, daß bei diesen christlichen Gruppen und bei ihnen allein, der moderne wirtschaftliche Betrieb mit dem christlichen Denken vereinbar wurde, daß er hier bis heute mit einem guten Gewissen möglich ist. Man braucht sich hier nur der Umschweife zu erinnern, mit denen der Katholizismus diese moderne Wirtschaftsform erträglich macht und im Grunde immer wieder zu hemmen versucht, oder der Abneigung, mit der das alte Luthertum und der heutige deutsche Konservativismus den Kapitalismus offiziell betrachtet. Dann wird die Bedeutung dieser neuen calvinistischen Form des Christentums für die gesamte moderne Entwicklung und insbesondere für die Stellung des Protestantismus in ihr verständlich. Es ist die einzige Form christlicher Soziallehren, die die Grundlagen der modernen Wirtschaft allgemein akzeptiert und zwar nicht weil hier *größere Einsicht in das Wesen der wirtschaftlichen Vorgänge erreicht worden wäre, sondern weil hier die hyperidealistischen und spiritualistischen Hemmungen im ethischen Grundgedanken weggefallen sind, die sonst diese Entwicklung verhindert oder zurückgehalten haben, weil vielmehr statt dessen geradezu fördernde Kräfte in der reformierten Ethik enthalten sind ${ }^{392}$ ). $\mathrm{Ob}$ eine solche christliche Ethik gegenüber der katho-

392) Das ist eines der wichtigsten Ergebnisse der Studie von Max Weber. Ihre volle Bedeutung wird erst später gewürdigt werden können, wenn wir nach der Analyse der protestantischen Sekten zu dem Gesamtbegriff des »asketischen Protestantismus a kommen werden. Dieses Ergebnis halte ich durchaus fest gegen Rachfahls Kritik, der die Tatsache selbst ja anerkennt, nur ihre Bedeutung für die wirtschaftsgeschichtliche Entwickelung viel geringer anschlägt und ihre Wurzeln im spezifisch-calvinistischen Geiste nicht sehen will. In der ersten Hinsicht hat er Webers Einschränkungen, die daneben selbstverständlich eine Fülle anderer Motive für die Entstehung des modernen Kapitalismus anerkennen und auch ganz andere Gruppen von Trägern dieser Entwickelung nennt, zwar angeführt aber nicht beachtet. In der zweiten Hinsicht hat er eine nur durch Kampschulte, Elster und Lang vermittelte Kenntnis der Lehre Calvins und des alten Genf und verkennt er daher sowohl im Politischen wie im Wirtschaftlichen die Konsequenzen der eigentlichsten Genfer religiösen Idee. Er hält Calvin für einen Traditionalisten im lutherischen Sinn, der nur umsichtiger über die Zinsfrage denkt und im übrigen Redlich- 
lischen und lutherischen ein reiner Vorzug ist, ob sie nicht vielmehr einen Hauch der nüchternen Geschäftigkeit und der trok-

keit und Ernst der Arbeit, also allerhand ethische Elemente des wirtschaftlichen Lebens, betont. Im übrigen ist ihm, wie Kampschulte, der Calvinismus eine naturwidrige Exaltation des religiösen Gefühls, die nur kurze Zeit dauern und auf weltlichem Gebiet nicht viel Großes stiften kann. Die wahre Beförderung der modernen Fortschritte liegt für Rachfahl bei den Rationalisten und Toleranzchristen erasmischer Schule und bei der verhältnismäßigen Emanzipation des protestantischen Staates von geistlichen Rücksichten. Das Ganze ist eine am unrechten Ort für die Toleranz eingelegte Lanze. Aber die Toleranz an sich bedeutet nichts für die wirtschaftliche Entwickelung, es kommt auf die wirtschaftliche Art der zur Toleranz Zugelassenen an. Das ergibt sich sehr hübsch aus den bei Bastide S. 214 zusammengestellten Empfehlungen der Toleranz für England : >L'exemple de la Hollande avait frappé les Anglais; Sir William Temple... attribuait la prospérité de ce pays à la liberté religieuse e t à la présence de nombreux réfugiés. Enfin l'arrivée des huguenots (nach der Aufhebung des Edikts von Nantes), fuyant la persécution, et qui se faisaient remarquer par leurs qualités de travail, confirmait l'idee que le dissident est un auxiliaire de la richesse publique. Sir W. Petty disait, que ,le commerce est le plus vigoureusement pratiqué dans tous les états et sous tous les gouvernements par la partie hétérodoxe de la nation et par ceux qui professent des opinions différentes de celles qui sont officiellement reçues'. On se rapelle quelle importance Shaftesbury accordait dans son mémoire sur la tolérance à l'argument économique. Cet argument se retrouve un peu partout. Charles Wolseley .... dans un petit traité sur la liberté de conscience, signale le départ pour la Hollande des tisserands dissidents de Norwich. Un auteur anonyme .. sans insister ... sur le côté thẻologique de la question . . repliquait au Dr. Dove que la liberté religieuse etait l'école des ames nobles et généreuses'. Les artisans de Norwich qui émigrent, sont les meilleurs citoyens: ,Les hommes à principes religieuses ne sont ils pas des hommes sensés et sérieux, qui sont $d u$ bien à une nation! Ne sont ils pas généralement en tous commerces et métiers les plus travailleurs et les plus prospères ?‘ Es ist klar, daß es nicht die Toleranz an sich ist, die hier gemeint ist, sondern die Rezeption oder Beibehaltung einer bestimmten Klasse von Bürgern: das sind eben die Calvinisten mit ihren bekannten kommerziellen Eigenschaften. Auch ist klar, wie diese Autoren beobachten, daß die Schule der konfessionellen Bedrückung und Ausschließung jene geschäftlichen Eigenschaften befördert, schließlich daß diese Eigenschaften mit moralisch-religiösen Grundsätzen zusammenhängen. Aehnlich konnte zugunsten der täuferischen und pietistischen Selten argumentiert werden, die in der gleichen Schule ähnliche Eigenschaften auf ähnlich religiös-ethischer Grundlage entwikkelten. Es ist nicht der Calvinismus an sich, der hier in Betracht kommt, sondern der in der Schule der Unterdrückung und der Minorität entwickelte Calvinismus. Aber dessen Entwickelung hängt doch wieder mit der grundlegenden calvinistischen Ethik im allgemeinen und seiner Wirtschaftsethik insbesondere zusammen. Katholische Minoritäten hat es gleichfalis in England gegeben, aber von ihnen hört man nichts 
kenen Banausie trägt, ist eine andere Frage. Dic Hauptsache ist, daß sie den führenden modernen Staaten, oder doch Hauptgruppen ihrer Bevölkerungen, eigentümlich ist und daß sie hier einen Einklang mit der modernen Wirtschaftswelt bewirkt, der der Christlichkeit anderer Völker fehlt.

Aber freilich würde nun die Christlichkeit in dieser calvinistischen Rechtfertigung des Kapitalismus sehr verkannt, wollte man nicht zugleich die Grenzen im Auge behalten, mit denen der eigentlich christliche Liebesgedanke auch hier die Erwerbsethik umgibt und die bis heute überall da wirksam geblieben sind, wo in aller kapitalistischen Arbeit doch die reformierten Grundgedanken lebendig geblieben sind. Die Arbeit ist eine unentbehrliche Askese und der Gewinn eine Segnung Gottes für treue Berufserfüllung. Aber niemals gilt Arbeit und Erwerb rein dem persönlichen Interesse. Immer ist der Kapitalbesitzer ein Verwalter der Gaben Gottes, der sie zum Besten des Ganzen der Gesellschaft steigern und verwenden, für sich nur die dem eigenen Existenzbedürfnis dienende Quote verwenden soll. Aller Ueberschuß soll gemeinnützigen und vor allem den Zwecken der.kirchlichen Liebestätigkeit dienen. So haben sich die Genfer für besondere Notfälle und regelmäßig sowohl für die Ortsarmen als für die zahlreichen Refugianten bis an die Grenze des Möglichen besteuert. Die kirchliche Liebestätigkeit, die, vom Diakonenamt verwaltet, mit zu den Forderungen des göttlichen Kirchenrechtes gehörte und äußerst energisch organisiert war, hat mit freiwilligen Beiträgen von oft erstaunlicher Höhe stets ihre Aufgaben zu leisten vermocht. Daher stammt noch heute, auch bei ganz indifferent Gewordenen, die Sitte, für öffentliche und christliche Zwecke große Anteile des Gewinnes zu opfern, die uns von den amerikanischen Millionären bekannt ist. Von diesem Liebesgeiste aus ist aber auch die eigentliche Geld- und Zinstheorie so gut wie die derartiges. Siehe auch Weber im $>$ Antikritischen Schlußworte XXXI S. 565-569 und >Antikritischese XXX 182-188. - Solche, denen diese Toleranz zugute gekommen ist, sind auch die Juden. Ihre Bedeutung hat Sombart ähnlich analysiert wie Weber die des Calvinismus und der Sekten. Doch hat Sombart m. E. c.. Rolle der Juden stark überschätzt und verkannt, daß der jüdische Kapitalismus ein anderer ist, als der gewerblich-bürgerliche. Sicherlich falsch ist seine Gleichsetzung von Puritanismus und Judaismus wegen der Betonung des A.T.s bei den Calvinisten. Denn die calvinistische Wirtschaftsgesinnung ist eine andere als die jüdische und der Anschluß an das A.T. ist ein sehr verwickelter, s. oben S. 638-640. Immerbin sind daraus mancherlei Analogien hervorgegangen. 
Praxis bestimmt worden. Erlaubt ist nur der Produktivkredit zu Geschäftszwecken, nicht der Wucherkredit, um lediglich von Zinsen zu leben. Armen oder sonst durch Unglück Bedrängten dürfen keine Zinsen abgenommen und auch nicht Darlehen wegen mangelnder Sicherheit verweigert werden. Alle derartigen Geschäfte sind nur mit Rücksicht auf das öffentliche Wohl des Gemeinwesens abzuschließen. Der Schuldner soll mindestens ebensoviel mit dem Geld gewinnen als der Gläubiger. Ueberall soll das Gesetz der Billigkeit obwalten nach dem Satz des Evangeliums und des Naturrechts, daß wir den Leuten tun sollen, was wir wollen, daß sie uns tun. Schließlich sollen die Zinsen ein je nach der Lage gesetzlich festzustellendes Maximum nicht überschreiten. So die Theorie. Nach diesen Grundsätzen ist in Genf auch gehandelt worden. Der Kampf gegen den Wucher und gegen die Ausbeutung der Armen füllt die Rats- und Konsistorialprotokolle, und diese christlich-sozialen Elemente der calvinistischen Lehre haben dann auch ihren Niederschlag in der Ethik gefunden. So ist es zu verstehen, daß gegenüber der modernen Ausbildung des Kapitalismus der Umschlag in einen christlichen Sozialismus immer nahe gelegen hat und noch nahe liegt. Es ist oben gezeigt worden, wie ein solcher Sozialismus von Hause aus in der Genfer Idee der heiligen Gemeinde lag. Er hat sich in den Gemeinden unter dem Kreuz fortgesetzt, wo die religiöse Idee sich frei entfaltete. Wie weit er die staatliche Gesetzgebung calvinistischer Länder mitbestimmte, ist erst noch zu erforschen. Die große englische Armen-, Arbeiter- und Lohngesetzgebung trug - freilich in dem zünftlerisch-ständischen Sinne und vor allem mit Rücksicht auf Erziehung zur Arbeit Spuren seines Geistes. Gegen die manchesterliche Staats- und Wirtschaftsauffassung hat dann Carlyle bewußt wieder altpuritanische Gedanken geltend gemacht. Der heutige christliche Sozialismus der Engländer ist wesentlich calvinistischen Ursprungs, und die Wirksamkeit der amerikanischen Kirchen ist oft geradezu eine christlich soziale, gegen die Ausartungen des Kapitalismus gerichtete. In der Schweiz, den Niederlanden, in England und Amerika gibt es heute sozialistische Geistliche, während das auf dem Boden des Luthertums als ein Angriff auf alle heiligen Grundlagen der gottgesetzten Ordnung, als Einmischung in rein weltliche Dinge, als verwerflicher Revolutionsgeist und menschlicher Eingriff in den Gang der Vorsehung, betrachtet 
wird; die sozialen Häresieen sind bei uns gefährlicher und verwerflicher als die dogmatischen. Das aber bedeutet wicderum, $\mathrm{da} ß$ der Calvinismus in größerem Einverständnis mit der modernen sozialen Lebensbewegung sich befindet als das Luthertum, auch als der Katholizismus, der wenigstens in seinen romanischen Stammländern gleichfalls diese Häresieen von sich fernhält. Darauf aber beruht dann auch das ungeheure Selbstgefühl des Calvinismus, die einzige, dem modernen Leben gewachsene Form des Christentums zu sein, indem er einerseits die modernen Produktionsformen vor dem Gewissen i zu rechtfertigen und andererseits deren Ausartungen durch den christlichen Sozialismus zu bekämpfen weiß. Er fühlt sich als das moderne Christentum, quicht weil er in der Theologie dem modernen Denken entgegenkäme - vielmehr das Gegenteil ist der Fall und nur der überwiegend praktische Charakter führt zur Zurückstellung des Dogmatismus sondern weil er mit der politischen und wirtschaftlichen Lebensgestaltung im Einklang ist und deren Probleme fördernd und einschränkend versteht, während das philosophisch verseuchte Luthertum unpraktisch und weltfremd $\mathrm{sei}^{393}$ ).

30s) Calvin ist ein Gegner des täuferischen Kommunismus, den er wiederholt bekämpft; aber gerade aus sozialen Gründen; denn wenn alle ihre Güter verkauft hätten, so müßten auch die Reichen betteln und hätte niemand ein Haus zur Wohnung und Aufnahme von Armen $\mathrm{R} \mathrm{XXXV} \mathrm{488.} \mathrm{Im} \mathrm{übrigen} \mathrm{ist} \mathrm{seine} \mathrm{Denk-}$ weise eine bewußt soziale auf religiöser Grundlage, siehe den Abriß christlicher Ethik Inst. III 7-10, der die Erklärung des Dekalogs II 8 ergänzt und aus der christlichen Beseelung vertieft: Nostri non sumus: Inde consequitur, ut ne quaeramus, quae nostra sunt, sed quae ex Domini sunt voluntate et faciunt ad gloriam ejus promovendam . Quum enim nos privat am nostri rationem omitter e jubet scriptura, non modo habendi cupiditatem, potentiae affectionem, hominum gratiam ex animis nostris eradit, sed ambitionem quoque et omnem gloriae humanac appetitum aliasque secretiores pestes eradicat III, 7, 2. Perspicimus abnegationem nostri partim quidem in homines respicere partim in Deum III, 7, 3 . Damn folgt die Ausführung des ersten Gedankens, Jam in quaerenda proximi utilitate officium praestare, quantum habet difficultatis! . At Scriptura, ut eo nos manuducat, praemonet quidquid a Domino gratiarum obtinemus, esse nobis $\mathrm{hac}$ leg c concreditum, ut in commune ecclesiae (d. h. die ganze christliche Gescllschaft) bonum conferatur ideoque legitimam gratiarum omnium usum esse liberalem ac benignam cum aliis communicationem. Alle Güter sind deposita Dei ea lege fidei nostrae commissa, ut in proximorum bonum dispensentur. Folgt das bekannte paulinische Gleichnis vom Organismus. Nullum membrum suam facultatem sibi habet nec in privatum usumapplicat, sedad socia membra 
Weniger bedeutsam für die Folgezeit, dafür um so wichtiger für das erste Jahrhundert seines Bestandes war eine $\mathrm{d} r$ it t e Richtung, in der der Calvinismus durch die Genfer Lage und dann durch

transfundit ... Sic pius vir, quidquid potest, fratribus debet posse: sibi non aliter privatim consulendo, quam ut ad communem ecclesiae aedificationem intentus sit animus. Haec itaque . nobis sit methodus: quidquid in nos Deus contulit, quo proximum queamus adjuvare, ejus nos esse o.economos, qui ad reddendam dispensationis rationem adstringimur. Eam demum porro rectam esse dispensationem, quae ad dilectionis exigatur regulam. Ita fiet, ut non modo alieni commodi studium cum popriae utilitatis cura semper conjungamus, sed hanc illi subjiciamus III 7,5. Dabei gilt es zu bedenken, snon hominum malitiam reputandam eșse, sed inspiciendam in illis Dei imaginem: 'quae inductis et obliteratis eorum delictis ad eos amandos, amplexandosque sua pulcritudine ac dignitate nos alliciat III, 7,6 , Ita secum quisque cogitabit, se, quantus quantus est, proximis debitorem rei esse; nec alium exercendae ergo ipsos beneficentiae statuendum esse finem, nisi quum facultates deficiunt: quae. quam late extenduntur, ad caritatis regulam limitari debet III 7, 7. Das ist geradezu ein Programm des christlichen Sozialismus. - Von da aus ist denn auch Calvins Einschränkung des Zinses, der Kampf gegen den Wucher, die bürgerliche Gesetzgebung über Verkehr und Verzehr, vor allem die Einrichtung der kirchlichen Armen- und Wohlfahrtspflege bestimmt. In derselben Richtung arbeitete die Compagnie unter Beza mit beständiger Kontrolle des öffentlichen Lebens, worüber Choisy zahlreiche Mitteilungen macht. Ueber die rationelle Armenpflege und die kolossalen hiefür verwendeten Summen, Uhlhorn, Liebestätigkeit III $141-169$ und Choisy allenthalben. - Wo die Verbindung mit dem Staat fehlte, war der christlichsoziale Ausbau nur noch intensiver Sache der Gemeinde selbst, wie bei der Laskischen Fremdlingsgemeinde in London und den nach ihrem Vorbild organisierten niederländischen und niederrheinischen Gemeinden; hierzu Simons, Eine altkölnische Seelsorgegemeinde 1894, Aelteste evangelische Gemeindearmenpflege vom Niederrhein 1895, Niederrheirisches Synodal- und Gemeindeleben unter dem Kreuz 1897; hier S. 20: >Die Synode ist also, modern geredet, vom christlichen Sozialismus nicht weit entfernte. Ueber die Elisabethanische Sozialgeset/gebu'ng und ihren Zusammenhang mit puritanischen Gedanken s: die oben angeführte Schrift Cunninghams und Held 16-38. - Ueber diese Einschränkungen und das auch in der reformierten Ethik festgehaltene pretium justum siehe Weber, Antikritisches XXX 188, 194, 201 f.; auch Laspeyres, Geschichte der volkswirtschaftlichen Anschauungen der Niederländer 1863, hier S. 256-270: die theologischen Anschauungen über den Kapitalismus, die das Zinswesen zwar anerkennen, aber es mit Rücksicht auf die Armen eingeschränkt wissen möchten; andererseits aber auch hier der Hinweis auf die starken theologischen Elemente in den ökonomischen Theorien auch der Nicht-Theologen S. 3I. Charakteristisch calvinistisch ist die Formel für die brasilianischen Unternehmungen S. 82 :. De hooghste Wet, rakende Brasil, behoovt te wesen de Eere Gods ende de Welstand der Participanten 
die weiteren politisch-kirchlichen Entwickelungen beeinflußt worden ist. Es ist die Richtung auf die Ausbildung der religiös e.n Politik und internationalen gegenseitigen Unterstützung, schließlich derbewaffneten Interventi ons politik. Wie die Genfer Selbständigkeit überhaupt mit der Reformation eng zusammenhing, so war sie dauernd nur durch Verbündung mit den protestantischen Mächten, den reformierten Kantonen, den deutschen Konfessionsverwandten, zu behaupten, da sie von Frankreich, Savoyen und Bern stets bedroht war ${ }^{394}$ ). Ueberdies war Calvins ganze Stellung zu Genf oft nur durch Unterstützung der auswärtigen Kirchen möglich, deren Gutachten und Zustimmungen von ihm oft erbeten wurden und ihn in schwierigen Verwickelungen gestützt haben. Dazu kam der oben geschilderte Missionsdrang und Universalismus, der freilich zunächst nur auf das Wort und die Macht der Wahrheit vertraute. Allein in der Praxis waren für all das die diplomatischen und weltlichen Mittel unentbehrlich; sie hatten in der Schule der Genfer Politik sich überdies schon von selbst für die allernächsten $Z$ wecke der Selbsterhaltung aufgedrängt. Sie wurden auch nach außen notwendig und mußten auch anderen Kirchen anempfohlen werden. Die diplømatische Korrespondenz Calvins, die Tätigkeit Bezas als politischer Agent, die hugrenottischen, niederländischen und pfälzischen Verhandlungen sind allbekannte Aeußerungen dieser Notwendigkeiten. In der Theorie spiegelte sich das durch die Lehre von der gegenseitigen Verbundenheit und Unterstützungspflicht aller Kirchen, was natürlich die gleiche Pflicht für die mit ihnen verbundenen Staaten und Gemeinwesen bedeutete ${ }^{395}$ ). Daraus ergab sich allerdings zu-

34t) Charakteristisch an Bullinger Briefe I 342 : $\gg$ Wir müssen auch dieser Stadt Rechnung tragen und zwar nicht in letzter Linie. Wollte ich nur für mein Leben oder für meine eigenen Verhältnisse Sorge tragen, so könnte ich gleich anderswohin gehen. Aber wenn ich erwäge, wie wichtig dieser Weltwinkel zur Ausbreitung des Reiches Christi ist, so bin ich wohl mit Recht darauf bedacht, ihn zu schützen «. Damit rät Calvin ein Bündnis mit Frankreich an, das erlaubt sei, wie Abraham mit dem Heiden Abimelech und Isaak und David gleichfalls mit Heider Bündnisse geschlossen hätten für Zwecke des Gottesreiches.

395) Siehe Briefe I 31: Was sollte uns hindern, eine Art öffentlicher Synode zu berufen, in der jeder, was seiner Kirche frommt, vorschlüge, ein Plan zum weiteren Handeln in gemeinsamer Beratung aller gelegt würde und, wenn nötig; Staaten und Obrigkeiten sich durch gegenseitige Einrichtungen unterstützten und mit ihrer Macht einander stärkten.. Aehnlich I 137 . Ueber Calvins Internationalität s. Rieker S. 184. 
nächst nur die Notwendigkeit finanzieller, persönlicher, theologischer Unterstützung und diplomatischer Hilfe ${ }^{396}$ ). Die weitere Frage aber war dann sofort, wie weit diese Hilfe eine bewaffnete sein dürfe und müsse, und das heißt, wie weit der Glaubenskrieg als letztes Entscheidungsmittel erlaubt und geboten sei. Auch hier lag die wichtige und vom Luthertum so gründlich unterscheidende Erklärung für den Glaubenskrieg nicht im Geist und Sinn Calvins und ist doch aus seiner ganzen Glaubenspolitik schließlich hervorgegangen Ueber den Krieg an sich hat Calvin ganz ähnlich wie Luther gedacht ${ }^{397}$ ). Er ist Sache des Staates und diesem für weltliche Zwecke der Verteidigung erlaubt, wenn er nicht im Vertrauen auf die Macht des Fleisches, sondern auf Gottes Hilfe mit aller Demut und christlichen Sittenstrenge geführt wird. Glaubensinteressep dagegen müssen ohne die Macht des Schwertes, rein durch Vertrauen zur Vorsehung, durch Leiden und Dulden durchgesetzt und dürfen nicht mit weltlichen Machtmitteln vermengt werden. Aber der reichliche Gebrauch der Diplomatie war doch auch bereits ein Gebrauch weltlicher Machtmittel, und es liegt nur in der Natur der Sache, daß diese Diplomatie gelegentlich auch zu ihrem letzten Mittel, zur bewaffneten Hilfe und Intervention, schreiten mußte. Wie Calvins Lehre von der Gehorsamspflicht der Untertanen durch das Kontroll- und Widerstandsrecht der unteren Magistrate durchbrochen wurde, so wurde auch seine Lehre von der unblutigen Intervention schließlich bei Gelegenheit zur Anerkennung der bewaffneten. Freilich mußte dann immer für einen Rechtsgrund gesorgt werden, genau wie beim Widerstandsrecht. Es ergab sich, daß, sobald die Staatsgewalt zum Tyrannen geworden war und die unteren Magistrate dadurch an deren Stelle traten, dann diese auch berechtigt wurden, auswärtige Bündnisse zu schließen. So glitt auch die Lehre von der Ausbreitung und Be-

396) Davon geben die Briefe zahlreichste Beispiele, sein Ideal ist, diplomatisch die Machtstellung stärken, ohne daß ein Tropfen Blut fließt, wie er Briefe II 334 betreffs Condés erklärt.

${ }^{397}$ ) Calvins Lehre vom Krieg Inst. IV, 20, I I und I2, wo übrigens die energisch den Krieg.verteidigende Stelle erst aus den späteren Ausgaben stammt. Die Sache Christi ist durch Bekenntnis, Organisation, Bruch mit dem Papismus, Leiden und Dulden, Gottvertrauen allein zu führen. Auf Menschengewalt ist unbedingt zu verzichten; wenn es not ist, wird Gott ein Wunder tun, um seine Kirche zu retten. Das bezeugen zahlreiche Briefstellen. Calvin hat überall vom Waffengebrauch abgeraten und oft bei den für die Reformierten günstigsten oder dringendsten Gelegenheiten. 
hauptung der Christusherrschaft durch rein geistige Mittel hinüber in die Anerkennung des Rechtes der bewaffneten Intervention und des Glaubenskrieges, sobald dabei die legale Ordnung eingehalten wurde ${ }^{398}$ ). Daraus wurde dann das Recht und die Pflichwkriegerischer Unterstützung überhaupt; das, was in realen Fällen dic Not erzwang, wurde so theoretisch gerechtfertigt. Beza hat dementsprechend neben dem Widerstandsrecht der Untertanen auch die Frage des Glaubenskrieges ind der Intervention ausführlich untersucht und die bejahende Antwort biblisch und historisch sowie dogmatisch begründet. Seitdem sind beide Fragen in der monarchomachischen Literatur eng verbunden ${ }^{399}$ ). Welch ungeheure

398) Dieses Hinübergleiten zeigt sich mehrfach in den Briefen. I $34 \mathrm{I}$ bei dem Plan des Bündnisses mit Frankreich, bei dem ein Krieg Frankreichs gegen Karl V zu hoffen war; trotz aller Bedenken meint er sman könnte es mehr einer strấfichen Sicherheit als dem frommen Gottvertrauen zuschreiben, wenn wir Hilfskräfte außer acht lassen, die, wenn auch unerwünscht, doch erlaubt sind \&! II 59 tadelt er die Deutschen, die 1555 durch ihre Trägheit den Schutz Gottes verscherzten und darum so geringes Waffenglück hatten. II 327 an Bullinger: Glaube mir, ich kann es dir gewiß versichern, Aufruhrgefahr besteht von unserer Seite nicht, wenn nicht etwa der König von Navarra offen angegriffen wird. Zu seiner Verteidigung allerdings, hoffe ich, würden sich viele erheben savoyischen Protestanten gegen ihren Herrn. III 442 rät er dem reformierten Kommandanter von Lyon doch nur sehr bedingt, die Waffen niederzulegen : vebrigens wenn sich die beiden auch mit Ihnen verbünden, so müßte doch erst eine rechtliche Grundlage vorhanden sein; denn ohne ihre Hilfe können Sie die Sache, glaube ich, keinesfalls durchführen. Denn etwas angefangen, ohne dazu berufen und berechtigt zu sein, könnte nie gut ausfallen. Ich sage nicht, daß sich vielleicht nicht ein guter Grund finden ließe, aber ich kenne noch keinen, und deshalb wollte ich es nicht wagen, zum Beginn des Krieges zu raten, ohne genauer unterrichtet $z u$ sein. hier ist Calvins Gedanke nicht einheitlich, bei Wahrung eines legitimen Grundes išt auch der Bürger- und der Glaubenskrieg erlaubt. So faßt auch Marcks die Sache auf, Coligny $S .358,36 \mathbf{1}, 380$, besonders 408 ; es kommt dann eben schließlich darauf an, sich einen Rechtsgrund zu verschaffen; da beginnt freilich die Sophistik.

39y) De jure magistratuum 280. Wenn die Stände und Magistratus inferiores nicht stark genug sind, den Tyrannen zu bändigen, dann tritt für diese oder deren sanior pars das Recht der Herbeiziehung auswärtiger Hilfe ein: Licebit etiam saniori parti oppressae auxilia aliunde conquirere, praesertim apud Regni confoederatos et amicos. Beispiel ist der Beistand der israelitischen Stämme gegen die ins Heidentum verfallenen Stämme Ruben und Gad, die Unterstützung der Römer durch Constantin gegen Maxentius, die der italienischen Patrizier durch Carl den Großen gegen die Longobarden. An sich freilich hat das Reich Christi mit Waffen nichts 
Bedeutung das praktisch erlangte und wie dieses reformierte Vorbild schließlich im dreißigjährigen Kriege auch auf die Lutheraner zurückgewirkt hat, die ja bei Gelegenheit des schmalkaldischen Krieges das gleiche Problem bereits erörtert hatten, das ist bekannt. Nach dẹr Beendigung des Zeitalters der Religionskriege, wo Cromwell ein letztes Beispiel protestantischer Politik gegeben hatte, ist das freilich bedeutungslos geworden, aber geblieben ist von alledem bis in die Gegenwart ein mächtiges Gefühl der $\mathrm{Zu}$ -

zu tun: Cum religio ad conscientias pertineat, quibus nullo modo vis inferri potest, non videtur illa ullis armis stabilienda et defendenda, quam ideo praedicatione verbi Dei, precibus ac patientia hactenus potius propagatam conspicimus. Extant praeterea loci permulti in scripturis, quibus ostenditur, quanta sit inter regna hujus mundi et regnum Christi spirituale differentia S. 294. Dazu kommen die Beispiele der Propheten, Christi und der Apostel. Allein damals gab es noch keine christlichen Untermagistrate. Sie standen rein heidnischen Regierungen gegenüber, von denen sie ein Eintreten für die Sache Christi nicht verlangen konnten und denen sie sich leidend unterwerfen mußten. Seit es aber den christlichen Staat mit der göttlichen Verpflichtung der Untermagistrate gibt, steht die Sache anders. At ego contra praecipuum optimi piique Magistratus munus esse dico, ut quidquid mediorum autoritatis et potentiae illi a Deo concessum est, huc totum omnino conferat, ut inter sibi subditos Deus ipse vere agnoscatur agnitusque tanquam summus regum omnium rex colatur et adoretur . So müssen die Regierenden auch mit den Waffen, zunächst bei den eigenen Untertanen, dann aber auch bei fremden, die wahre Religion durchsetzen. Allerdings all das auf legitimem Wege. Die Einführung der wahren Religion in ein Land kann nur mit rein göttlichen Mitteln geschehen. ,Hoc enim proprie Spiritus sancti opus est instrumentis spiritualibus utentis «. Da gelte es nun mit der Predigt die religiöse Erkenntnis zu verbreiten, und nur die starrköpfig Widerstehenden sollen schließlich gezwungen werden! Wo aber die reine Religion bereits gesetzliche Geltung hat, da sind die Regierenden verpflichtet, dieser gesetzlichen Geltung unter Umständen auch mit Waffen zur Wirkung zu verhelfen. Christus und die Apostel waren Privatleute und mußten in den Grenzen ihres Berufes bleiben unter Verzicht auf Waffengebrauch. Aber Magistrate eines christlichen Staates sind zum Waffengebrauch, wenn es nicht mehr anders geht, berechtigt und verpflichtet. Sie sind auch berechtigt, fremde Menschenhilfe anzurufen, wie wieder mit vielen Beispielen belegt wird. Aehnlich ist die Behandlung des Problems bei den »Monarchomachen Elkan S. I 6 und I 68 ff., Cardauns S. 5, S. 104, hier die Stelle aus den Vindiciae „Universam (Ecclesiam) singulis, singulas ejus partes universis commisit Deus; itaque si unam ejus partem princeps religionis illius curet, alteram vero oppressam, si opera ferre possit deserat et negligat, Ecclesiam deseruisse censetur. Die Erlaubtheit der Intervention eines fremden Fürsten zugunsten eines von tyrannischer Obrigkeit bedrückten Volkes, ist einer der feststehenden Rechtsgrundsätze der Zeit . 
sammengehörigkeit aller Calvinisten, eine Internationalität des Calvinismus, der das trotz seiner lutherischen Konferenz heute noch sehr partikularistische Luthertum ein gleiches nicht gegenüberzustellen hat. Mit dem Rückzug von der Theorie des Glaubenskrieges und der allmählichen Lösung des Verhältnisses zum Staate, freilich auch im Zusammenhang mit der Demokratisierung und Kapitalisierung, ist dann dieser internationale Calvinismus in dem für die christliche Ethik so schwierigen Kriegsproblem zu pazifistischen Theorien übergegangen. Der Krieg ist, wie z. B. der Burenkrieg, wohl aus Gründen der nationalen Selbstbehauptung berechtigt, aber christliche Völker sollen andere Völker überhaupt nicht in die Lage bringen, einen solchen Krieg führen zu müssen. Die humanitäre und ethische Bewegung gegen den Krieg und für eine Ersetzung des Kriegsystems durch ein System der Verträge und Schiedsgerichte ist gerade bei den Calvinisten und den Sekten vor allem zu Hause und hier durchaus ernst gemeint in schwerem Kampfe gegen die - übrigens mit der wirtschaftlichen Entwickelung eng zusammenhängenden - imperialistischen Neigungen der Völker, denen sie angehören ${ }^{400}$ ).

Faßt man alles das zusammen, so verstehen sich die eigen-

$\left.{ }^{\iota 0}\right)$ Dieser Pazifismus hervorgehoben bei Hartmann, Engl. Frömmigkeit S. 26. Lehrreich H. Oncken, > Amerika und die großen Mächte*, (Studien und Versuche zur neueren Geschichte, Max Lenz gewidmet 1910) S. $427 \mathrm{f} .:$ Zu den eigentümlichen Folgen der kolonialen Situation dieses Staates gehörte von Hause aus eine relativ größere Unabhängigkeit von der auswärtigen Politik und ihren Gefahren. Und wenigstens unter den puritanischen und täuferischen Elementen verstand es sich von selbst, daß der Krieg, das traurige Privileg der Monarchien und Oligarchien, aus religiösen und demokratischen Gründen zu verwerfen sei ... Der tiefe Einschlag religiöser Stimmungen, die an dem Aufbau dieses Staates in unendlich vielen verborgenen Fäden mitarbeiteten, verlangte gebieterisch, daß das Volk Gottes sich selber genug sei und ohne Waffen auskomme; auf strenge Enthaltsamkeit von der auswärtigen Politik lief auch der rationalistisch-utilitarische Grundzug im amerikanischen Wesen hinaus, der aus naturrechtlichen Quellen entsprang «. Aber S. 469: schon das erste Jahrhundert amerikanischer Geschichte lehrt, daß auch ein Gemeinwesen, bei dessen Entstehung seit den Zeiten der Pilgerväter eher die entgegengesetzten Antriebe mitwirkten, auf die Dauer doch den Lebensgesetzen folgen muß, die dem Wesen des Staates und der Macht als immanente Notwendigkeiten eingeboren sind «. Weiteres dazu bei Oncken, Amerikanischer Imperialismus und europäischer Pacifjsmus, Preuss. Jahrbb. I9II. Ebenso, nur mit der entgegengesetzten Parteinahme und Zukunftsaussicht Masaryk in einem vortrefflichen Artikel über Roosevelt aus s Märze I910 Nr. 12 und 13. 
tüm lichen Soziallehrendes Calvinismus und ihre Entwickelung über den anfänglichen, Luthern scheinbar noch ganz nahe stehenden Stand hinaus. Sie sind ein Erzeugnis der besonderen religiös-ethischen Eigentümlichkeiten des Calvinismus, der in Prädestinationslehre, Voluntarismus, Organisationswille, Aktivität, Heiligungsgemeinde und in seiner aufs Praktisch-Mögliche gerichteten Ethik eine starke Besonderheit darstellte; andererseits aber der politisch-republikanischen, wirtschaftlich-kapitalistischen, diplomatisch-kriegerischen Tendenzen, die aus dem Genfer Boden zunächst in sehr eingeschränkter Weise einströmten, aber mit nahverwandten Elementen der calvinistischen Religion und Ethik sich verbanden und in dieser Verbindung sich immer mächtiger entfalteten, bis sie im Zusammenhang mit der politischen und sozialen wie der kirchlichen Geschichte der einzelnen Länder jenes vom alten Genfer und französischen Calvinismus so verschiedene $\mathrm{Ge}$ präge der religiösen Moral der bürgerlichen Schichten empfingen. Die Ergebnisse dieser Entwickelung faßte die natürlich-philosophische und die theologische Ethik zusammen, die hier ganz anders stark entwickelt ist als im Luthertum und in großem Zuge von Calvin bis auf Jurieu und Lampe heruntergeht ${ }^{401}$ ). Es ist nicht nötig, hier noch einmal zusammenfassend aus dieser Ethik die Soziallehren selbst darzustellen, nachdem sie bereits in der bisherigen Darstellung überall zu charakterisieren gewesen sind. Das soziologische Grundschema des Calvinismus, seine Staats- und Wirtschaftslehre sind klar geworden und bedürfen keiner neuen Zusammenfassung mehr.

Nur bezüglich des Kirchenbegriffes ist noch eine solche nötig. Aus dem Bisherigen ergibt sich seine Stellung zu Staat, Gesellschaft und Wirtschaft. Die Kirche des Calvinismus ist Bekenntnisund Volkskirche, Heiligungsgemeinschaft und Heilsanstalt, Freiwilligkeits- und $Z$ wangskirche zugleich, indem vorausgesetzt wird, daß alle Erwählten bei genügender Belehrung dem Geist der

401) Vgl. Gaß und Luthardt; Alex. Schweizer, Die Entwickelung des Moralsystems in der reformierten Kirche, Theol. Studd. und Kritt. 1850. In all diesen Darstellungen tritt die inhaltliche Entwickelung der Ethik stark zurüek hinter den Fragen des Verhältnisses der philosophischen und theologischen Ethik, der Freiheit und des Gnadenwunders, der Rechtfertigung und des Sittengesetzes, Problemstellungen, die die theologischen Darstellungen der Ethik leider fast ausschließlich zu beherrschen pflegen. Mehr Inhaltlich-Charakteristisches bei Thomas Hall, History of ethics within organized Christianity, New-York 1910. 
Wahrheit ihr Ohr öffnen, und indem gefordert wird, daß alle Nichterwählten Gott zur Ehre und zum Schutze der Erwählten niederzuhalten und an öffentlicher Aeußerung ihres Unglaubens wie ihrer Sittenlosigkeit gehindert werden müssen. Das ist die Vereinigung des Sekten- und des Kirchenideals, ohne Summepiskopat und ohne Patronat. Die Kirche besteht in der Gesamtheit der Erwählten, aber sie ist um deswillen nicht demokratisch verfaßt, sondern geateht der Gemeinde nur stillschweigende $\mathrm{Zu}$ stimmungen und allenfallsige Einsprüche zu. Das Kirchenregiment liegt bei den durch göttliches Kirchenrecht geforderten Amtsstellen der Geistlichen, der Zuchtgerichte, der Doktoren und der Diakonen, deren ordnungsmäßige Besetzung dem Tumult der Volkswahlen entzogen ist und deren Inhaber nicht Vertreter der Gemeinde, sondern Vertreter des Gotteswortes sind. Die Classical- und Synodalverfassung hat diese Genfer Idee den Verhältnissen großer Völker angepaßt, aber ihren Geist nicht verändert. Die letzte Instanz in Glaubens- und Sittenfragen liegt bei der Bibel, deren Einhelligkeit und Durchsichtigkeit aufs strengste vorausgesetzt wird und deren Deutung nötigenfalls durch Befragung und Konsens der angesehensten Kirchen sicher gestellt wird. In der selbständigen Ausübung des Sittengerichtes, in einem System der Ueberwachung und Denunziation, in der Macht des Abendmahlsausschlusses mit der Wirkung des bürgerlichen Boykotts, in der Begutachtung der bürgerlichen Gesetzgebung und gelegentlicher Einwirkung auf sie besitzt diese Kirche eine hohe Selbständigkeit, die auf freiwillige Unterstützung und Zustimmung der gleichfalls aus der Bibel sich belehrenden weltlichen Regierungsgewalt. rechnet, mit dieser aber überall über die Handhabung des Bannes in Konflikt geriet. Reibungen mit der Staatsgewalt sind trotz der auch hier vorausgesetzten Einheit des Corpus Christianum unausbleiblich. Sie sind überall eingetreten und auch in Genf nicht ausgeblieben. In England und den Niederlanden haben sie geradezu zu schweren Kämpfen und großen Katastrophen geführt, deren Wirkungen uns noch beschäftigen werden ${ }^{402}$ ).

402) Vgl. hierzu Rieker, Reformierte Kirchenverfassung; Sohm, Kirchenrecht, S. 642-657; von Hofmann, Kirchenverfassungsrecht der niederländischen Reformierten; Choisy, La théocratie, und L'état chrétien; dazu seine Antrittsvorlesung L'état chrétien calviniste au 16 ème siècle, 1909. Hier eine treffende Hervorhebung der Bedeutung der Kommunion S. 11: La communion est, en effet, dans l'état chrétien un acte obligatoire, imposé, un acte social et civique. Par la participation 
Die Gesells chafts leh re ist bereits mit dem Bisherigen genügend geschildert. Sie trägt in Genf ein ganz überwiegend bürgerlich-geschäftliches und geldwirtschaftliches Gepräge. Wie sie auf die bäuerlichen und auf die seigneuralen Gebiete des Calvinismus gewirkt hat, ist erst noch zu untersuchen. Jedenfalls war die Gesellschaftsidee überhaupt überwiegend bürgerlich bestimmt und wurde das immer mehr. Man sagte dem Calvinismus Adelshaß nach. Die ständischen und zünftigen Gliederungen der Zeit verstehen sich auch hier von selbst, obwohl ein Interesse an der Stabilität nicht bekundet wird wie im Luthertum und der häufige Berufswechsel und die Vermögensumwälzungen in den Refugiantengemeinden überhaupt eine solche Stabilität unmöglich machten. So fehlt die grobe lutherische Dreiständelehre charakteristischerweise ganz. Wo, wie in der Luxusgesetzgebung, Standesunterschiede gemacht wurden, da wird ein ziemlich reich abgestufter Bau ständischer Schichtung klargelegt, aber das Maß der Unterscheidung ist lediglich der Besitz. Gewisse plutokratische Züge, die in den Niederlanden und Amerika bis heute bemerkbar sind, mögen damit zusammenhängen. Vor allem aber ist der Gedanke der religiösen Gleichheit vor Gott viel stärker angespannt als im Luthertum und in der kirchlichen Praxis, inbesondere im Zuchtgericht, nachdrücklich durchgeführt. Hierum gehen in Genf die heißesten Kämpfe. Bekannt ist die Darlegung, die John Knox der Maria Stuart über die Gleichheit auch der Könige vor dem göttlichen Gesetze gab. Auch dem galanten hugenottischen Adel gegenüber hat das Zuchtgericht nicht versagt. Bei aller Festhaltung der äußeren Unterschiede und der dadurch bedingten strengen Loyalität ist doch diese Gleichheit vor Gott unzweifelhaft ein Ferment demokratischer Gedanken, wie das Kuyper mit Recht in seinem à la Sainte Cène, le bourgeois et l'habitant de Genève font profession de croire au seul vrai Dieu et de se soumettre à sa loi. C'est l'hommage rendu par le chrétien au Souverain législateur et protecteur de la Cité, et à. Jesus-Christ, son Fils, le Rédempteur, le Chef suprème de l'Eglise. C'est pourquoi on ne saurait admettre à la sainte table ceux qui violent ouvertement la loi de Dieu et outragent honteusement sa verité. C'est pourquoi on ne saurait non plus admettre que personne s'abstienne de communier sans ávoir été officiellement ou publiquement exclu de la participation de la Sainte Cène. Cependant, tout en étant un acte civique obligatoire, la communion doit être un acte de piété personelle etc.\&. Die Kommunion übt soziologisch für den Calvinismus ähnliche Funktionen aus wie das Bußsakrament für den Katholizismus, dadurch gelangen auch beide zu einer organisatorischen $\mathrm{Kraft}$, die dem Luthertum versagt ist. 
Manifest des modernen Calvinismus ausgeführt und durch die charakteristisch patriarchalen Elemente des Calvinismus freilich wieder eingegrenzt hat. Es ist von Hause aus ein demokratische und aristokratische Elemente mit einander verbindendes und sie gegenseitig eingrenzendes Gesellschaftsideal, das durch die Unterstellung aller Kreise unter die Souveränetät Gottes eine hohe Selbständigkeit gegen die irdischen Machtverhältnisse und zugleich doch eine feste Bindung im Gedanken des Gesetzes und der alleinigen Zweckbestimmung für die Ehre Gottes empfängt. Daher erklärt sich der leidenschaftliche und oft erfolgreiche Angriff geschlossener calvinistischer Minoritäten auf das ganze Volkstum, wie er die französische, niederländische und englische Geschichte erfülltt ${ }^{403}$ ).

Bezüglich der Familien- und Sexualethik ist schließlich noch zu bemerken, daß hier im allgemeinen natürlich die gleichen Grundsätze obwalten wie bei Luther. Aber man wird auch hier wohl eine größere Verselbständigung der Eigenpersönlichkeit der Frau und eine mehr rationell-zweckbestimmte Auffassung der Ehe anerkennen müssen, die von dem scholastisch-dualistischen Gedanken der relativen Anerkennung und wesentlichen Eingrenzung der Konkupiszenz sich zu einem rationellen Familienideal als Mittel der Gesellschaft erhebt. Auch hier sieht der Unterschied lutherischer und calvinistischer Askese durch. Das Luthertum gibt mit der Erbsündenlehre die Konkupiszenz völlig als sündlich preis, läßt aber das triebhaft-sündige Element in der Einschränkung durch die Ehe bestehen, während der Calvinismus jene Sündhaftigkeit weniger betont, dagegen die Eheführung unter die strengste rationelle Kontrolle ihrer Leistung für das Gemeinwesen stellt und die triebhafte Leidenschaft durch sachliche Erwägungen und

408) Hierüber wage ich mich nur mit Zurückhaltung zu äußern, indem es Darstellungen dieser Gesellschaftstheorie nicht gibt. Die Abwesenheit der DreiständeLehre bei Rieker S. 184 betont, die Gliederung nach dem Besitz in den Luxusgesetzen bei Elster S. 190-192, die Fortdauer der Berufskategorien, Zünfte und Gilden bei Choisy S. 118 Anm. 3 und Gierke, Althusius ${ }^{2}$ 24. Hier sind die Berufe alle zugleich als consociationes collegarum behandelt S. 22, zugleich aber hervorgehoben, $\mathrm{daß}$ sie >durchaus frei geschlossene und frei lösliche Verbindungen sind. Ueber die Gleichheit vor Gott s. Choisy, L'état chrétien S. 484-49o. Hierher gehört auch die sorgfältige Vermeidung jeder ${ }^{\prime}$ Amtswürde bei den Geistlichen, die nichts dem lutherischen Amtsbegriff ähnliches aufkommen läßt. Betreffs des Bauernstandes Klagen über seine Vernachlässigung bei Althusius S. 25. Ueber die demokratische Konsequenz der religiösen Gleichheit s. Rieker S. 122. 
Abzweckungen bricht. Es ist ein Unterschied der Nuance, aber er ist wichtig und beleuchtet die innersten Differenzen ${ }^{404}$ ).

Mit diesen bisherigen Charakterisierungen ist wesentlich der alte Calvinismus beschrieben und sind nur einige seine moderne Entfaltung bestimmende Züge hervorgehoben. Der Calvinismus, so wie er heute ist und wie er diese die Gegenwart bestimmenden Züge in den großen Entwicklungen des 17. Jahrhunderts hervorgebracht hat, ist damit noch keineswegs ausreichend verstanden. Noch fehlen $z$ wei wichtige Folgerungen, die aus seinem Wesen mehr oder minder folgerichtig hervorgegangen sind, das Freikirchentum und der innerkirchliche Puritanismus oder Pietismus. Durch das erstere trat er zugleich in eine Art von Verbindung mit der Demokratie, die mit der bisherigen Schilderung seiner Staatsethik noch nicht getroffen ist. Denn diese bezog sich immer nur auf die Aufrichtung von Konstitutionen oder Kontrollen gegenüber einer die Ehre Gottes und das Wohl der Völker verletzenden Staatsgewalt bei übrigens möglichst konservativem und legitimistischem Denken. Das Freikirchentum dagegen ist seinem Wesen nach die Auflösung der mittelalterlichen und altprotestantischen Idee eines einheitlichen staatlich-kirchlichen Lebensganzen und einer die gesamte Kultur einheitlich beherrschenden unfehlbaren Autorität. Es ist damit von vornherein revolutionär gegen die Grundbegriffe der bisherigen Gesellschaft und muß einen religiösen Subjektivismus und Relativismus vertreten, der zwar nur der Verzicht auf die irdische, die absolute Wahrheit anerkennende und durchsetzende Gewalt ist,

404) Ueber Neigung und gegenseitige Klarheit über sich selbst als Voraussetzung der Ehe Briefe I 256, die Bezogenheit auf das Ziel der heiligen Gemeinde I $35 \mathrm{I}$ und 369 , über die Gleichstellung von Mann und Weib in Christo und Pflichten der Frauen wie der größten Helden II I93 (An die gefangenen Frauen in Paris); Gleichheit von Mann und Frau II 268 und 45I; immerhin aber der Mann das Haupt der Frau II 39I; über das Verhalten von Staats- und Zuchtgericht in der Kontrolle des sexuellen Lebens s, zahlreiche Beispiele bei Choisy L'état chrétien, bes. S. $40 \mathrm{I}$; über die Bedeutung der Ehe für die Gesellschaft S. 487 ; zum Ganzen Elster S. $194 \mathrm{f}$. und die schöne Schilderung von v. SchulzeGävernitz, Britischer Imperialismus S. $47-49$ : > Der Puritanismus hat damit einer Betrachtung des sexuellen Verhältnisses die Wege gebahnt, welche die in der Zeugung liegende Verantwortlichkeit in den Vordergrund schiebt und eine ethische Konstruktion des Geschlechtsverhältnisses vom Standpunkt des Kindes aus ermöglicht๔. - Eine Monographie über dieses Thema wäre lohnend. 
der aber eben damit die verschiedenen Religionsgemeinschaften wenigstens als scheinbar gleichberechtigt nebeneinander bestehen lassen muß bis zu der Scheidung beim Kommen Christi. Das bedeutet die Verlegung der formellen Entscheidung der Kirchenzugehörigkeit in de 'Willen des Einzelnen und die wenigstens äußerlich rechtliche Auffassung der Kirche als eines Vereins, wenn auch dogmatisch die so zustande kommende Gemeinschaft nach wie vor als kirchliche Heilsanstalt betrachtet werden kann. Damit ist der Kirchenbegriff im Uebergang zu individualistischdemokratischen Gedanken, und es liegt auf der Hand, daß ein solcher Kirchenbegriff wahlverwandt ist mit der politischen Demokratie, wie umgekehrt, daß die von der Vereinigung der Individuen her den Staat konstruierende Demokratie mit einem solchen Kirchenbegriff leichter arbeiten kann als mit einer uniformen, im Grunde immer den Staat irgendwie absolutistisch beherrschenden staats-kirchlichen Idee. Das Freikirchentum oder die Trennung von Staat und Kirche ist daher im Laufe der Zeit das religionspolitische Prinzip der Demokratie geworden, wie umgekehrt von dem lireikirchentum Antriebe demokratischer Art ausgingen. Es ist klar, daß damit eine neue und über alle bisherigen Grundlagen weit hinausgehende Entwickelung des Calvinismus eintritt, vor allem daß damit eine formell-rechtliche Analogie mit der Sekte entsteht, auch wenn der Kirchenbegriff selbst mit allen dogmatischethischen Konsequenzen gewahrt wird.

Ergibt sich bei dieser ersten Entwicklung schließlich eine mehr formelle Analogie mit dem Sektentypus, so entsteht aus der zweiten eine dauernde sachliche und inhaltliche. Der Pietismus hat nichts unmittelbar mit der kirchlichen Verfassung und mit demoliratischen Neigungen oder Konsequenzen zu tun, sondern geht nur auf die strenge Durchführung des Gedankens der Heiligungsgemeinde und der reinen Abendmahlsgemeinschaft. Er steigert die asketischen Grundzüge des Calvinismus und bricht darüber mit der Welt, und der weltlichen Kultur, soweit sie über das schlechthin utilitarisch Notwendige hinausgeht. Gewiß liegt hierin eine erhebliche Abwendung von der viel freiern und feineren Haltung Calvins, auch von der gerade durch urbane Feinheit und humanistische Bildung ausgezeichneten älteren calvinistischen Kulturidee, die natürlich auch nicht aufhörte fortzudauern, aber von dem aktiveren puritanischen und präzisistischen Calvinismus zurückgedrängt wurde. Damit ergab sich dann aber eine Annähe- 
rung an das Ethos der Sekte, bei der zwar die Unterschiede gegen das alte echte täuferische Ethos immer noch sehr erheblich blieben, aber doch sehr viel schmäler wurden.

Beide Bewegungen, die freikirchliche und die puritanischpietistische, fallen nun aber dabei durchaus nicht überall zusammen. Die erste kann im Sinne des dogmatisch und ethisch korrektesten Calvinismus verstanden werden und kann, wenn sie will, die freiere Haltung zur Welt durchaus behaupten oder steigern. Die zweite umgekehrt braucht nicht auf Auflösung der staats-kirchlichen Lebenseinheit zu dringen, sondern kann entweder hoffen, die ganze Gesellschaft unter das Joch des Zuchtgerichtes und des strengen Ideals zu bringen, oder kleinere Kreise innerhalb der Kirche zu bilden, wobei dann eine religiöse Gemeinschaft im weiteren, mehr pädagogischen und relativen, und im engeren, mehr perfektionistischen und absoluten, Sinne zu unterscheiden wären. Freilich können aber auch beide Richtungen in einander übergehen. Das Motiv der Freikirche kann außer der Verwerfung des Religionszwanges auch das der Heiligungsgemeinde sein, und die pietistische Bildung engerer Kreise kann zur Freikirche führen, wie beides mehrfach geschehen ist und wie es vor allem am Anfang beider Entwickelungen gewesen ist.

Es ist nun die Frage, wie weit beides aus der inneren Konsequenz des Calvinismus zu verstehen ist und wie weit etwa dabei fremcle Einflüsse von außen her mitgewirkt haben. Beide Umformungen haben sich vor allem in den großen englischen und niederländischen Kämpfen zwischen dem Staat und der Souveränität der Kirche, zwischen dem Heiligkeitsideal, der Renaissance und der Volkssitte vollzogen. Tritt hierbei die reine Folgerichtigkeit des Calvinismus hervor oder sind noch besondere Einflüsse der Lage beteiligt?

Zunächst und in erster Linie freilich sind beide Entwickelungen trotz der starken Neuerungen doch verständlich von den Genfer Grundlagen her, allerdings diesmal nicht positiv als Folgen der Genfer Umwelt, sondern gegensätzlich ais Folgen einer andersartigen Umwelt. Sie traten ein, wo die Verhältnisse eines kleinen Staates wegfielen und damit das Problem der Zahl und der Masse und die damit steigende Notwendigkeit gewaltsamen Zwanges in den Vordergrund rückte. Genf war ein kleiner Staat und machte die Durchdringung dieser verhältnismäßig beschränkten Masse mit christlichen Heiligungsmaßstäben möglich. 
Auch blieb seine schwache Staatsgewalt lange Zeit den kirchlichen Interessen untertan. Es blieb in beiden Hinsichten einzigartig und unerreichbar. Aber auch anderwärts, wo der Calvinismus sich in diesem Sinne organisierte, war er zunächst noch die Religion kämpfender Minoritäten. In den kleineren Verhältnissen war es möglich, das Ideal der heiligen Gemeinde als Volkskirche, als die ganze Gesellschaft umfassende christliche Gesittung, aufzurichten, und bei dem Gegensatz gegen die Staatsgewalt fiel das staatskirchliche Problem praktisch weg. Sobald es aber um die Beugung wirklicher Großstaaten unter das calvinistische Staatsund Gesellschaftsideal sich handelte oder sobald die calvinistischen Gemeinden in einer allgemeinen weltlichen Massenkultur standen, da entstand das Problem, wie die Staatsgewalt mit dem für sie sehr schwierigen Uebergewicht der kirchlich-theologischen Interessen sich abfinden würde, und wie die Heiligungsgemeinde streng persönlich überzeugter und bewährter Christen zugleich als Massengemeinde möglich sei. Der Druck des Calvinismus erzeugte den Gegendruck der politischen Interessen, die den „Erastianismus \& d. h. die staatliche Kontrolle über die Kirche forderten, und den Gegendruck der weltlichen Interessen, die sich in den harten und einseitigen Rigorismus nicht finden wollten. Dieser Gegendruck aber verwandelte den Calvinismus, indem er ihn zu neuer Stellungnahme nötigte. War die heilige Gemeinde und die Herrschaft von Gottes Ehre in der Welt überhaupt möglich? Die Frage, welche die Täufer verneint hatten und die Calvin in entschlossenem Vertrauen darauf, daß die Nichterwählten in der Minderheit seien und der christlichen Gemeinde wenigstens äußerlich unterworfen werden könnten und müßten, bejaht hatte, tauchte wieder auf. Mit ihr aber zeigte sich auch nun deutlich die anfänglich ganz verdeckte, relative Wahlverwandtschaft des calvinistischen Ideals mit dem täuferischen. Wie sie fing man das Staatskirchentum überhaupt zu bestreiten und durch eine vom Staat unantastbare Freiwilligkeitskirche zu ersetzen. Wie sie unternahm man es, sich gegen die Welt durch eine puritanisch strenge Lebensnormierung abzugrenzen. Es ist nur eine Annäherung, kein Zusammenfallen. Denn die Kirche blieb auch als Freikirche eine Kirche mit der Richtung auf möglichst breites Volkskirchentum, und auch der Puritanismus hat weltliche Aemter, Macht, Krieg, Recht und Eid nie prinzipiell bekämpft. Aber eine Annäherung liegt vor, und es ist klar, wie sehr sie in dem 
durch den Calvinismus überhaupt gestellten Problem der wirklich aktiv heiligen und Gottes Souveränetät vertretenden Gemeinde begründet ist ${ }^{405}$ ).

406) Diesen Zusammenhang mit dem Problem der Zahl, der Masse und der christlichen Volkskultur hat Göbel richtig 'erkannt und in beiden Richtungen, inbezug auf das Freikirchentum wie inbezug auf den Pietismus, in seiner Bedeutung hervorgehoben; auch hat er die Analogie mit dem Täufertum klar gesehen. Das Problem begann mit den exilierten Fremdengemeinden, der Gemeinde Laskis in London, der evangelisch-calvinistischen Gemeinde in Frankfurt, den niederländischen Exulantengemeinden am Niederrhein Göbel I 326. Hier vollzog sich auch bereits die Demokratisierung der Gemeinden (I $340 \mathrm{f}$ ), die nun ihre Organe selbst wählen mußten und keine Delegationen aus den Behörden in ihren Körperschaften hatten. Entscheidend war hier die Londoner Gemeinde Laskis. Göbel nennt sie seine heilsame Vermittelung $z$ wischen den verfassungslosen Lutheranern und den separatistischen Wiedertäufern, und so hat er die Gründung einer reformierten Kirche, welche zwischen beiden die Mitte hält, auf deutschem Boden möglich gemacht , S. 326. »Unter ihren frei gewählten Predigern und Vorstehern richtete sie sich unabhängig. von dem Bischof und dem Pfarrzwang ganz frei nach ihren eigenen Grundsätzen, bekam aber dadurch auch einen von den übrigen weltlichen und bürgerlichen Verhältnissen und Verbindungen unabhängigen, scharf ausgeprägten, teilweise separatistischen Charakter, welcher nach ihrer Uebersiedelung nach Emden, Wésel, Frankfurt und Straßburg und ihrer weiteren Ausbreitung in den Main- und namentlich in den Rheingegenden der durch sie dort gegründeten reformierten Kirche natürlicherweise denselben scharfen kirchlichen und christlichen Charakter und dem in ihr blühenden, christlichen Leben das Gepräge der Entschiedenheit und Schroffheit, der Weltentsagung und der Weltfeindlichheit aufdrïckte * (336). Aehnliches gilt von den älteren niederländischen Gemeinden vor der - übrigens immer nur relativen - Herstellung ihres staatskirchlichen Charakters, wie v. Hoffmann zeigt; auch von den englischen Puritanern, sobald sie seit 1567 durch die: schroffe Elisabethanische Konformität in die Opposition gedrängt waren, siehe Kattenbusch Art. Puritanismus in PRE ${ }^{3}$ : sie bildeten $>$ Privatvereine, die gewöhnlich Prophecyings genannt wurden. Der Name gründete sich auf I Cor 14, 13. Es waren Vereine zur gemeinsamen Erbauung und zur Förderung eines christlichen Lebens und hatten ihren Ursprung in Laskis Gemeindes; damit trat der Zug zum Presbyterianismus hervor: $D$ Die weltliche Obrigkeit habe keine Gewalt über die Kirche«; sie verlangen die volle Autonomie der Kirche«, was vorläufig nur in Gestalt der Separation möglich ist. - Vgl. weiterhin die Charakterisierung der wichtigen Beschlüsse der Emdener Synode 1571 bei Göbel I 418: >So war denn in Emden eine Kirchenordnung nicht für ein ganzes Land, nicht für eine ganze Stadt oder ein ganzes Volk, sondern nur für diejenigen festgestellt, welche ihr freiwillig beitraten und sich ihrer Ordnung und Kirchenzucht unterwarfen und darum auch jeden Augenblick wieder austreten konnten«. Sie galt vorerst mit für die niederländischen Gemeinden. Der Zusammenhang dieses neuen Kirchenprinzips 
Dabei ist klar, daß der Puritanismus und Pietismus jedenfalls geradliniger aus den reformierten Grundideen hervorgehen konnte als das Freikir che n t u m, zugleich, daß das letztere das welthistorisch dauerhaftere und wichtigere Prinzip ist. Man hat es als s subsidiäres Kirchenideal des Calvinismus bezeichnet, das er hervorholt, wo er mit dem sprimären * nicht ausreicht oder nicht durchkommen kann. Auf der andern Seite hat man von einer naturrechtlichen Tendenz des calvinistischen Kirchenbegriffs gesprochen, die hierin erst $z u$ ihrem folgerichtigen Ausdruck komme. Moderne Calvinisten wie Kuyper deuten das Freikirchentum ohne weiteres in das Wesen von Calvins Gedanken zurück und bezeichnen seine staatskirchliche Idee einer christlichen $Z$ wangskultur als eine leicht wegfallen-könnende mittelalterliche Schranke. Andere vermuten Einflüsse oder wenigstens Analogien des täuferischen Gemeindegedankens, bei dem ja die Spättaufe nur ein Symptom,

- der (jlaubens- und Bekenntniskirche * mit der Feindseligkeit der Staatsgewalten einerseits, mit den Schwierigkeiten des Massen- und Volkschristentums andererseits ist entwickelt 1 423. Ueber die Analogie dieser Gestaltung mit dem Sektentypus I $+\hat{j}$ : $>$ Ueberhaupt würde die ganze (niederrheinische) Kirche . . allmählich in die Gefahr geraten sein eine Sekte zu bleiben oder wieder zu werden, wenn sie nicht einerseits immer im Zusammenhang mit der äußerlich wenigstens mächtig aufblühenden niederländischen Nationalkirche und ihrer zunächst auf den Universitäten Leyden (seit 1575) und Franeker (seit 1585) großartig sich entwickelnden Theologie geblieben wäre und andererseits der Synodalverband und seit 1609 ihre unerwartete Befreiung und außerordentliche Ausbreitung sie vor solcher Verkümmerung bewahrt und auch ihr wenigstens teilweise die Aufgabe gestellt hätte, National- oder gar Landeskirche zu werden und demnach mit ihrem Sauerteig das gramze Volk und das ganze Land $z u$ durchdringen. Dennoch aber konnte unsere Ieformierte Kirche ihren separatistischen Ursprung nie völlig verleugnen, und es blieb d.her in ihr der Gegensatz zwischen Welt und Christentum, Weltmensch und Christ, Mencchensatzung und Wort Gottes, Papsttum und Evangelium, sodaß bei zunehmender Firschlaffung der Kirchenzucht und dadurch veranlaßter Verweltlichung der Kirche uild des christlichen Lebens immer aufs neue von außen und von innen her V'crsuche zur Wiederherstellung der alten Strenge und Schärfe, sei es durch eine Sammlung der eimzelnen Erweckten in den Gemeinden, sei es durch Trennung dieser letzteren von der verweltlichten großen Kirche und Bildung besonderer Gemeinden gumacht wurden. Das erklärt bis heute den Charakter des Wuppertals, Jen Pietismus von Elberfeld und Barmen. Das gilt aber auch mutatis mutandis vun allen (iebicten des Calvinismus vermöge des Gedankens der Heiligungsgemeinde und der kirchlichen Autonomie gegenüber dem Staate. 
aber nicht. das Wesen der Sache ist. Es fragt sich also sehr, wie diese Entwickelung zu verstehen ist ${ }^{406}$ ).

Erwägt man, daß in dem primitiven Calvinismus hierfür auch nicht der leiseste Ansatz ist, sondern daß eine Duldung mehrerer Kirchen neben einander, sowie die Entziehung der Staatsgewalt von ihrer christlichen Pflicht als das höchste Verbrechen erscheint, daß die Absolutheit und Ungebrochenheit des Wahrheitsbegriffs so gut die Einheit der Kultur und die alleinige Herrschaft der Wahrheit wie die Intoleranz gegen die Unwahrheit verlangt; erwägt man ferner, daß der calvinistische Gemeindegedanke von Hause aus eben gerade nicht demokratisch konstruiert ist, sondern die demokratischen Konsequenzen sorgfältig fernhält, daß die Prädestination wohl einen ungeheuren Individualismus der Persönlichkeit, aber keinerlei enthusiastische Mannigfaltigkeit und Unmittelbarkeit der religiösen Ideen gestattet, vielmehr bei der Bindung an die Heilsmittel von Kirche, Wort und Sakrament ihre ganze Furchtbarkeit auch auf diese alleinigen Heilsmittel ausbreitet: dann wird man eine solche Ableitung überhaupt gar nicht versuchen. Dazu kommt, daß der Calvinismus in den Fällen, wo er zum Nebeneinanderbestehen mit fremden Konfessionen gezwungen war, dies als etwas nur Vorläufiges und nur Erzwungenes betrachtet hat, daß er da, wo er im Anfang zu wirklich freikirchlicher und geheimer Existenz genötigt war, dies ausdrücklich als schweren Mangel bezeichnete, daß er in England und Nordamerika von den Duldungsgrundsätzen infolge presbyterianischer Nachschübe zum Prinzip der Theokratie zurückkehrte, sobald er wieder die Macht dazu hatte, daß er den Independentismus und

406) Ueber diese Herausbildung des subsidiären calvinistischen Kirchenbegriffes $\star$ vgl. Rieker S. I90-205; Kuyper, S. 52-60, 7 I-100 erkennt darin die eigentliche, von den Vätern noch nicht ganz enthüllte, Grundtendenz des Calvinismus; das ausgezeichnete Buch von Rothenbücher, die Trennung von Staat und Kirche 1908 zeichnet Entstehung und Wesen des Prinzips; die begeistertste religiöse Verherrlichung des Prinzips als des modernen Religions- und Kirchenprinzips überhaupt bei Al. Vinet, Essai sur la manifestation des convictions religieuses et sur la séparation de l'église de l'état I842, vgl. Deutsch v. Spengler 1845, sowie La liberté des cultes ${ }^{2}$ 1 852 . S. auch Troeltsch >Trennung von Staat und Kirche, der staatliche Religionsunterricht und die theologischen Fakultäten 1907; zu meiner Freude stimmt Rothenbücher mit dem hier von mir gegebenen Aufriß und der Herleitung vom Täufertum wesentlich überein. Den naturrechtlichen Charakter des reformierten Kirchenbegriffes s. bei Sohm, Kirchenrecht I 655 f. 697 f. 
Kongregationalismus in der französischen Kirche geradezu feierlich auf der Synode von Charenton verdammt hat. Auch die anfänglichen separierten Puritanergemeinden Englands wurden bei günstigeren Umständen zu der großen Presbyterianerpartei, die eine presbyterianische Konformität an Stelle der anglikanischen setzen wollte. Selbst die niederrheinischen Gemeinden betrachteten ihre freikirchliche Existenz als Provisorium und strebten nach dem Staatskirchentum, wie ein solches die Niederländer Calvinisten erreichten. Auch die Idee eines Church-Covenant ist nicht calvinistischen Ursprungs, denn die schottischen Covenants sind nicht Kirchenstiftungen, sondern Schutzvereinigungen für die Kirche ${ }^{407}$ ).

${ }^{407}$ ) Es ist aller Nachdruck darauf zu legen, daß dem alten Calvinismus der Wahrheitsbegriff fehlte. von dem aus allein nicht bloß derVerzicht auf das brachium saeculare, sondern die Freigebung verschiedener Kirchenbildungen möglich wird; vgl. Troeltsch -Trennung usw.a. Als die Niederländer sich auf ein derartiges Nebeneinander einrichten wollten, bezeichneten die Genfer das als das fluchwürdige. Castelliosche Toleranzprinzip Rachfahl II 737-731. Die niederrheinischen Kirchen unter dem Kreuz, die faktisch Freikirchen waren, behielten doch ausdrücklich die staatskirchliche Lebenseinheit als das Normale vor, s. Simons, Freikirche, Volkskirche, Landeskirche 1895 S. 12. Wo inan sich unter katholischer Landesherrschaft zunächst freikirchlich organisierte, geschah es als etwas vorläufiges in der Hoffnung auf den Sieg der Wahrheit und in der Behauptung einer Pflicht des Landesherrn, der Wahrheit sich zu unterwerfen Rachfahl II 881, Rothenbücher 20. Wo man ohne Hoffnung des Sieges sich auf andere Konfessionen einrichtete, da wollte man doch keine allgemeine Freigebung der Kirchenbildung, sondern die Beschränkung der Toleranz auf Katholizismus, Luthertum und Calvinismus; es ist die Minoritätentoleranz, wo nichts anders zu erreichen ist, aber nicht das Prinzip der Kultus- und Gewissensfreiheit s. Rachfahl II 728, Frank Puaux, Les précurseurs français de la tolérance au 17 siècle Paris 1881 , Rothenbücher 63. Die Pilgerväter kehrten zur strengen Theokratie mit Todesstrafe gegen die Täufer als Vertreter des Toleranzgedankens zurück, Rothenbücher 120-123. Auch von einer vereinskirchlichen Struktur des Calvinismus kann nicht die Rede sein. Das hat Rieker gegen Sohm, der eine Verwandtschaft des Calvinismus mit dem Naturrecht behauptet, gezeigt und hätte es noch stärker betonen dürfen, siche $\therefore$ I 33. Der Independentismus ist ausdrücklich verworfen, s. S. 82 und Simons, Niederrheinisches Synodal- und Gemeindeleben 1897 S. 15. Der vom Calvinismus so stark gepflegte Vertragsgedanke gilt für den Staat und das Verhältnis zum Staat, aber nicht für die Entstehung der Kirche selbst, wie Rieker selber feststellt S. 73. Bei den unter andersgläubiger Oberhoheit lebenden Fremdlingskirchen Laskis und dann bei den niederländischen Kirchen stellt H. v. Hoffmann (Das Kirchenverfassungsrecht der niederländischen Reformierten, 1902) zwar fest, daß die Kirchenmitgliedschaft sowohl von bisher Andersgläubigen als von bereits Getauften nur >durch Vertrag e erworben wurde, und daß demgemäß hier zum ersten Male die 
In der Tat findet sich der geschichtliche Ausgangspunkt des Freikirchentums als eines normalen Prinzips nicht in diesen von der

Kirche im Sinne des modernen Rechts als Korporation erscheine S. 86. Allein der Ausdruck ist aus der modernen Rechtssprache ergänzt und trifft die Sache nicht, da das Korrelat eines >Austrittsrechtes nicht besteht S. 83. Es handelt sich in Wahrheit" nur um die Form der persönlichen Anteilnahme an einem an sich durch göttliche Stiftung (S. 88 f.) bestehenden und durch die göttlich eingesetzten Aemter (S. 87 f.) sich fortsetzenden Institut, bei dem jedesmal der Kirchenrat oder die Aemter als die geordneten Mittel für die Ausübung der Königsherrschaft Christi das Primäre sind (S. 87 und 96); auch besteht überall, wo ein solches Zentrum ist, die religiöse Pflicht sich dieser einen und alleinigen Anstalt der Wahrheit und Erlösung anzugliedern S. 75, 84 und 87 ! Die Freigebung kirchlicher Vereinsbildung stammt also so wenig wie der Vereinsgedanke selbst aus dem Calvinismus, sondern aus dem Vereinskirchentum der Kongregationalisten und der Täufer s. Rothenbücher S. 30. Der Calvinismus hat ihn daher sich immer auch nur für die äußere rechtliche Form aneignen können, nie für sein Wesen; s. Rieker 130-174. - Der naturrechtliche Kirchenbegriff vollends ist ein rein aus der juristischen Konstruktion erwachsenes begriffliches Mittel, dessen sich alle Gemeinschaften bedient haben und das durch die Einführung der stillschweigenden Zustimmung beliebig in anstaltliche, staatskirchliche und zwangskirchliche Ideen umgebogen werden konnte. Mit der calvinistischen Idee von der Kirche hat er m. E. überhaupt nichts zu tun; siehe Rothenbücher 68-72. - Ueber die schottischen Covenants und teilweise ihre Texte siehe bei Champlin Burrage, The Church Covenant Idea, its origin and development, Philadelphia 1904. - Daß im Freikirchentum ein gegenüber dem alten Calvinismus (auch Katholizismus und Luthertum) neuer Wahrheitsbegriff zu Grunde liegt, zeigt charakteristisch Vinet, Darlegungen S. 276 ,Wenn das Nationalkirchensystem allen Sekten ein Ende oder ihr Entstehen unmöglich machte, so würde es dieser Triumph nicht loben, sondern verklagen. Denn es liegt am Tage, daß es ihn nur auf Kosten der menschlichen Natur und der Religionerringen könnte, die beide eine solche Einheit nicht wollen. Leben und Mannigfaltigkeit sind auf diesem Gebiete ganzkorrelat. Es gibt kein $\mathrm{L}$ eben, woes keine Sekten gibt, Einförmigkeit ist ein Zeichen des Todes* S. 278 , Die Einheit des Glaubens war vor dem Sündenfall, seit dem Sündenfall ist der Mensch individualisiertauch inder Religion und zwaruna uheblich* S. 206. Was ein anderer vom Suchen der Wahrheit gesagt hat, daß es wichtiger sei, als die Wahriheit selbst, läßt sich auch auf die Religion verwenden, wenn es, wie wir glauben, heißen soll: die erste aller Wahrheiten ist die, die Wahrheit wollen und suchen. Die Wahrheit ist nur eine halbe, wenn man sie nicht sucht. Das Suchen ist hier ebensowichtigals das Besitzen.. Dasist wirgeben es zu, die Schlagader und das HerzunsererTheorie S. 293. Das eigentliche Staatskirchentum stammt nach V. erst von der Reformation und ist ihre beklagenswerte Fehlgeburt S. 273. Historisch beruft sich Vinet 
Not erzeugten Freikirchen, sondern in dem Kongregationalismus, dessen. Ursprünge nahe neben denen des Puritanismus lagen, aber mit diesem nicht identisch waren. Robert Browne, der Vater des Kongregationalismus, war im Anfang mit den strengen Puritanern verbunden, entwickelte aber dann die Grundsätze einer Separation, die sich im Gedanken der Fernhaltung von aller weltlichen Gewalt und der Begründung bloß auf die Macht des inneren Geistes, in der biblischen Strenge des Kultus, in der Forderung wiedergeborener Prediger, dem Ideal der Reinheit der Abendmahlsgemeinde, dem Prinzip der Autonomie der Einzelgemeinden und schließlich in dem Covenant- und Vereinscharakter der Gemeinde aussprachen. Hierin ist nur dẹr Zug zur Heiligungsgemeinde puritanisch und calvinistisch. Alle andern Züge sind täuferisch, teilweise spiritualistisch, insbesondere die Idee des Church-Covenant ist ausgesprochen täuferisch. Daß Browne selbst, durch Leiden gebrochen, seinen äußeren Frieden unter Mentalreservationen mit der Konformität machte, tut nichts zur Sache; übrigens waren seine Vorbehalte spiritualistischer Natur, daß es nämlich bei der alleinigen Bedeutung des Geistes auf das Aeußere nicht ankomme. Auch bedeutete die Festhaltung der Kindertaufe und die Anerkennung der anglikanischen Taufe allerdings, daß diese nicht auf erneuter Taufe, sondern auf einem Bund mit Gott und untereinander beruhenden Heiligungsgemeinden sich als reinere und engere Gruppen innerhalb der allgemeinen Kirche empfanden, nicht als neue Kirchenstiftungen. Las zeigt die Polemik mit den General Baptists, die gemeinsam mit der Leydener Kirche Robinsons von einer brownistischen Gemeinde zu Gainsborough ausgegangen waren, aber unter dem Einfluß der holländischen Mennoniten zu dem Prinzip der Spättaufe übergingen. Auch blieben die Brownisten im Dogma völlig calvini-

vor allem auf Amerika 356, das auch den Zusammenhang des Freikirchen-Prinzips mit der Demokratie veranschaulicht s Ueberall, wo man die Demokratie ihr Haupt erheben läßt, wird man es auch die Religion erheben lassen müssen; sie kann es ohne fremde Hilfe, aber sie wird nie populär, national und mächtig werden, als wenn sie aufgehört hat Staatsreligion zu sein S. 366. Doch bedeutet diese Demokratie nur das Selbstbestimmungsrecht des Volkes, nicht eine demokratische Kirchenverfassung und keine egalitäre Aufhebung jedes Patriarchalismus in der Gesellschaft oder im soziologischen Grundschema S. 377. Vinet hält das für ächten Calvinismus, aber es ist in Wahrheit ein subjektivierender und relativierender Spiritualismus. 
stisch orthodox ${ }^{408}$ ). Aehnlich lauteten die Sätze des zweiten Vaters des Kongregationalismus, Henry Barrows, eines zum Puritanismus bekehrten Gentleman und Laien, der als die allein richtige Konsequenz des Puritanismus und des Ideals der Heiligungsgemeinde die Separation ansah. Darum bekämpfte er die Puritaner der Cartwrightschen Richtung als inkonsequent ebenso bitter wie die Hochkirchlichen, welche ihrerseits in den Brownisten und Barrowisten dem Puritanismus die Folgen seines eigenen Tuns entgegenhalten zu dürfen meinten. Er starb mit vielen der Seinen als Märtyrer und Opfer der grausamen Elisabethanischen Konformität, welche in diesen Separationen die Prinzipien des Anarchismus Kirche,

$\left.{ }^{408}\right)$ Zum ganzen s. den vortrefflichen Artikel in PRE ${ }^{3}$ von Loofs sKongregationalismus*. Das große Werk Dexters, Congregationalism of the last 300 years New-York ISSO ist vergriffen und mir nicht zugänglich gewesen. Außerdem s. das hochinteressante Buch von Burrage, The Church-Covenant Idea, das zahireiche Texte dieser Covenants vorlegt, ihre Entwicklung verfolgt und Analogie und Zusammenhang mit dem Täufertum eingehend behandelt, s. S. 46: In the same year isso, it is now generally admitted, Browne very likely came into contact with furreign Anabaptists and doutless learned their simple ideas of formins their brotherhood churches or societies, by a Bund or a Covenant with God. Their idea was that a church may be composed only of believers. Browne accepted this vicw, but following the opinion of his time in general, added vand their seed . . . It may be added that neither Browne nor any of his earlier followers seem to have been influenced to any great extent by the Scothish covenantsa. Uebrigens ist der Covenant der Brownisten und aller späteren nicht bloß ein covenant mit Got, sondern zugleich ein solcher mit den Kirchgenossen, s. die Stelle aus Browiles wrundlegendem Book which sherreth life and manners of all true christians S. 37: How must the church be first planted and gathered under one kind of governement ? First by a covenant and condicion made in Gods behalfe. Secondly by a covenant and condicion made or our behalfe. Thirdly by using the sacraments of baptismc to seale thoses condicions and covenants. A Außerdem s. Burrage, The true story of Robert Browne (1550?-1633) Oxford 1906. Hier die wich!igen spiritualistischen Stellen S. 56: "There (im Gegensalz gegen das äußere Kirchentum der Anglikaner) is no duty, law, deed, cause, question or plea etc., which ought not to be spiritual or is not determined by the divine and spiritual right, law and word of God.\& S. 20: gegen Anglikaner, Presbyterianer die Losung: the Kingdom of (jod should be within you. S. 2r: gegen den Gebrauch des Latein: They spake the languages, saieth the scripture, as the spirit gave them utterance.. Diese Bcrührungen mit dem Spiritualismus sind noch wichtiger als die mit dem Tïufertum: über den Unterschied beider s. unten. Burrage verdanken wir die Entdeckung mehrerer Schriften Brownes, auf denen die neue Darstellung beruht: The retractation of R. B. 1907 und A neiv years gift 190.t, deren Mitteilung ich der (;itle des Herrn Herausgebers verdanke. 
Staat und Gesellschaft bedrohen sah. Seine Gedanken entwickelten sich aus der Bibel und dem calvinistischen Heiligungsgedanken heraus, nicht ohne mittelbaren Einfluß des Brownismus, und in weitgehender tatsächlicher, von ihm selbst freilich bestrittener Analogie mit dem Täufertum. Auch der Einfluß spiritualistischer Literatur fehlte bei ihm so wenig, wie bei Browne, wenn er auch das innere Wort nicht, wie angeblich die Spiritualisten, über die Bibel stellen wollte. Seine Anerkennung der Laienpredigt und der Geistbegabung, die spontan aus der Bibel entstanden sein kann, weist in die gleiche Richtung. So ist sein Ideal eine vom Staat geschiedene reine Gemeinde, die als Einzelgemeinde völlig selbständig sich auf Grund eines Church-Covenant konstituiert und in den Sakramenten lediglich die Siegel dieses Bundes hat, ihre Beamten, Geistliche, Aelteste, Diakone selbständig und in rein demokratischem Verfahren - doch ohne Egalität - beruft, Kirchenzucht und Bann selbständig ausübt, sich und ihre Beamten aus frèien Liebesgaben unterhält und in allen Stücken die urchristliche Heiligkeit und Liebe bei allen ihren Gliedern bewährt. Synoden der Gesamtkirche sollen nur beratende Bedeutung haben, die Einzelgemeinde völlig independent sein; für die Einigkeit wird der Geist sorgen. Das Dogma ist streng calvinistisch-prädestinatianisch. Der Staat soll nur falsche Lehren beseitigen, den Aufbau der Gemeinde aber dieser selbst und dem Geiste nach den Grundsätzen des biblischen Kirchenrechtes überlassen. Trauung und Beerdigung sind bürgerliche Funktionen. Die staatlichen Gewalten sind mit allem konservativen Respekt zu behandeln, doch kann die Exkommunikation auch gegen Fürsten gerichtet werden ohne Beeinträchtigung ihrer bürgerlichen Hoheitsstellung. Die Kindertaufe bleibt in Kraft und auch die Taufe falscher Kirchen wird anerkannt, da ja die Erwählung und die Wirkung des Wortes nicht an die Grenzen der reinen sichtbaren Kirche gebunden ist. Bei aller Analogie mit der täuferischen Vereinskirche und dem täuferischen Heiligkeitsideal bleibt in diesem Letzten ein Rest des calvinistischen Volkskirchentums, von dem aus diese «reinen independenten Gemeinden* bloß als eine perfektionistische Sondergruppierung erscheinen. Trotz aller Polemik ist so der mit dem Puritanismus verbindende Faden nicht völlig zerrissen ${ }^{409}$ ).

409) Hierüber s. Powicke, Henry Barrow Separatist (I 550 ?-I 593), London 1900, ein sehr lehrreiches und für die ganze Kirchengeschichte der Zeit erleuch- 
Von hier aus war eine doppelte Entwickelung des Kongregationalismus möglich, einmal die subjektivistische Entwickelung $\mathrm{zu}$ bloßen heiligeren Sonderkreisen und zur Gewissensfreiheit ohne bestimmte kirchliche Verfassungsideale, auf der andern Seite die zu einer neuen Kirchenbildung des Bundes autonomer Einzelgemeinden, deren jede auf dem Freiwilligkeitsprinzip beruht. In der ersteren Richtung entwickelte sich der englische Independentismus des Cromwell'schen Heeres. In der zweiten ging der eigentliche, bis heute sich behauptende Kongregationalismus. So oder so ist er ein Mittelding zwischen calvinistischem Kirchentypus

tendes Buch. Hier S. $215 \mathrm{f}$ : On the whole it may be said that Barrow was far nearer to the Anabaptists than he knew ... Indead, apart from a number of comparatively superficial differences due partly to circumstances and partly to a more scrupulous fidelity to their common principle of reverence for Scripture - there was nothing in the sphere of church practice which need have held Barrow and the Baptists apart, except the doctrine of baptisme ... But this refers only to his ecclesiastical position. As to theological difference the case is not the same. Here what meets us is diametrical opposition rather than developement. Barrow was a Calvinist, and accepted all the implications of his creed with full consenta. Die Festhaltung der Kindertaufe führt Powicke lediglich auf die Ablehnung des gefürchteten Vorwurfs des Anabaptismus zurück; ich glaube darin doch die oben angeführten tieferen Gründe sehen zu sollen. Er verwirft mit der täuferischen Lehre vom freien Willen auch die Beschränkung der Erlösten auf die der Vereinskirche freiwillig Beitretenden; das bedeutet den Zusammenhang mit noch einem anderen Kirchenbegriff S. 123; gegen die Egalität fast mit den oben gebrauchten Worten 94, die Askese 149; notiert seien Vorausnahmen des Quäkertums: S. 118: B. anticipated George Fox in some points, e. g., in his refusal to take an oath on the Bible; in his objection to naming the days of the week Sunday, Monday etc.; and here in his dislike of titles. Die separatistisch-täuferische Konsequenz des Puritanismus S. 153 ff.; es ist ein Hauptargument Whitgifts, und die einzelnen Puritaner zeigen sich in der Tat Barrow gegenüber in Verlegenheit. Ueber die spiritualistischen Züge s. besonders das Verhör S. $92-93$; B. beruft sich in der Bibelauslegung auf den Geist, der die Frucht des Wortes ist und wiederum das Wort deutet: >Andrews (der Inquirent). This savoureth of a private spirit. - Barrow. This is the spirit of Christ and his Apostles, and most publicly they submitted their doctrines to the trial of all men. So do I - A. What, are you an apostle? B. No, but I have the spirit of the Apostles. - A. What ! the spirit of the Apostles? B. Yes, the spirit of the Apostles. - A. What? in that measure? - B. In that measure that God has imparted unto me, though not in that measure that the Apostles had, by any comparison. Yet the same spirit. There is but one spirit . Das scheint mir noch wichtiger als die auch von Loofs stark betonte Analogie zum Täufertum. Sollte vielleicht Schwenkfeld hier im Hintergrunde stehen? 
und Sektentypus, das durch die jenem von Hause aus innewohnende Beruihrung mit dem Sektentypus nahegelegt war, aber aus ihm doch nur unter dem Einfluß des Täufertums und vor allem des, wie später zu zeigren, davon verschiedenen Spiritualismus hervorging. Wie naheliegend hierbei die sektenhaften Folgerungen lagen, zeigt nicht nur der Uebergang der bereits genannten General Baptists zu den Täufern, sondern die davon ganz unabhängige Entwickelung der Particular laptists, die gleichfalls aus ursprünglich independenten Gemeinden sich ausschieden, zur Spättaufe als Folge des Freikirchenprinzips übergingen, im übrigen jedoch streng calvinistisch blieben und mit den Täufern keine weitere Beziehung hatten. Uebcrgänge von Kongregationalisten-Gemeinden zum Baptismus sind überhaupt nicht selten, ja es gab Gemeinden, die aus beidem gemischt waren. So haben auch Baptistengemeinden den grundlegenden Church-Covenant betätigt, eine ausdrückliche Bundschließung der Gemeindeglieder mit einander und mit Gott, die feierlich von jedem einzelnen unterschrieben und beschworen werden mußte. Das ist ein ganz und gar täuferischer Gedanke. Aber wie leicht für den Kongregationalismus andererseits doch wieder der Anschluß an das calvinistische Kirchentum war, zeigt dic Unterscheidungr eben dieses grundlegenden Church-Covenant als eines bald nur stillschweigenden, bald ausdrücklichen. Im ersteren Fall wird er als in dem Kincler-Taufbündnis und der Existenz der calvinistischen Volkskirche implicite schon enthalten bezeichnet; er bedeutet dann nur eine Auffassung dieser als streng verpflichtender Heilignungsgemeinde und beläßt ihr ihre volkspädagogische Bedeutung. Im zweiten Fall ist es die Konstitution einer Sondergemeinde auf Grund freier Willenserklärung und strenger Bewährung, die das Volkskirchentum aufhebt. So sind die Uebergänge zwischen Kongregationalismus, Pietismus und Presbyterianismus, sogar ein weiteres Verbleiben in der Staasthirche verständlich. Aber das der ganzen Idee zugrundeliegende Element ist doch das unkirchliche des Sektentypus; er hat sich nur von dem calvinistischen Dogma und der calvinistischen Heiligungsidee nicht gelöst und bedarf daher der Konstitution durch einen eigenen Taufritus nicht. Von da aus verstehen sich vor allem die Widersprüche in dem kongregationalistischen Kirchentum Neu-Englands ${ }^{410}$ ).

410) Hierzu vor allem Burrage, Church Covenant Idea; die Entwicklungsmöglichkeiten zum Baptismus, zum Independentismus und zum neuen Volkskirchenprinzip 
Folgen wir zunächst der Entwickelungslinie, die zum sog. kongregationalistischen Kirchenprinzip führte. Ihr gehörten die Exulanten- oder Pilgergemeinden an, die aus den oben geschilderten Ansätzen entsprangen und zuerst nach Holland und dann zur Bewahrung ihrer Nationalitat und im Interesse ihrer Mission für eine »reine demokratische Kirche « nach Neu-England auswanderten. Iie englische Regierung milderte ihre Verfolgungsgesetze dahin, daß sie den Separatisten dic Auswanderung - bei Verlust ihrer Güter und unter Todesstrafe im Fall der Rückkehr -- gestattete. Hatte schon Browne eine rasch wieder verfallende Gemcinde in Middelburg begrründet, so entstand nun aus den Anhängern Barrows eine solche in Amsterdam. Die soziale Stellungs der Gemeinde war unter diesen Umständen eine sehr gedrückte. Farmer und gelehrt Erzogene mußten zum Handwerk oder Handel übergehen. In der Gemeinde zeigten sich bald dic von Whitgift prophezeiten Folgen der Anarchie. Der demokratische Grundzug, das Majoritätsprinzip, die Laienpredigt oder Prophezeiung brachten allerhand Streitereien, Wortklaubereien und Rivalitäten mit sich. Man stritt um eine mehr aristokratisch-presbyterianische oder eine mehr demokratische Handhabung der Verfassung. Die Auskunft, daß überhaupt nicht Menschen, sondern der Geist Christi die Gemeinde regiere, zeigt auch jetzt den spiritualistischen Einschlag des Ganzen, war aber praktisch wertlos. Aus diesen Wirren führte Robinson einen Teil der Gemeinde heraus nach Leyden; er löste das Problem durch Unterscheidung der Kirchenregierung, die die Aeltesten haben, und der Kirchengewalt, die die

S. 167-169. -Yel certainly they would not turn for rescue to the Baptists whose baptisme on faith they had spurnt, and thus lay open their ful indebtedness to Anabaptist principles. \& Die gleichen verschiedenen Entwickelungsmöglichkeiten zeigt Powicke, der sehr richtig das Schwanken der Puritaner zwischen calvinistischer Volkskirche und separatistischer Freiwilligkeitskirche zeigt; charakteristisch ist der Gegensatz Whitegifts, der ohne feste Autorität in Staat und Kirche und ohne das Zusammenfallen beider das Prinzip der Einheit der Gesellschaft bedroht sah. Uebergänge von der Staatskirche zum Separatismus waren den Puritanern ermöglicht durch Kauf des Patronats, wo sie dann ihren Pfarrer sich selbst wählen und als Gemeinde sich $2 \mathrm{u}$ ihm halten konnten; solche Fälle gab es schon vor Rob. Browne, s. Burrage, New facts concerning Robinson I9Io S. 2 I, 34 f. Auch war es häufig, daß puritanische Geistliche, denen die Predigtlizenz entzogen wurde, nun in Privathäusern oder im freien Feld predigten und Personalgemeinden sammelten Dexter, The England and Holland of the pilgrims, Boston I906 S. 125. 
Gemeinde hat, was auf cine Erledigung der minder wichtigen Dinge durch die Aeltesten, der wichtigen durch die Gemeindemajoritäten hinauskam. Zugleich erkannte er eine Church-fellowship, eine beratende Gemeinschaft der an sich independenten Gemeinden, an. Diese Grundsätze nahmen die Pilgerväter in ihren verschiedenen Abwanderungen mit hinüber nach Neu-England. Dort gelang es ihnen, auch die zahlreichen presbyterianischen Nachschübe in ihrem Geiste zu bestimmen. Freilich bedeutete das noch keine Freigebung der Kirchenbildung überhaupt. Nur kongregationalistische Calvinisten wurden dort anerkannt und mit der Kirchenzugehörigkeit sogar auch die wichtigsten politischen Rechte verknüpft. Zur engeren Abendmahlsgemeinde gehörten nur die ausdrücklich als wiedergeboren Anerkannten und den Covenant Beschwörenden. Aber alle Kinder wurden getauft und als weiterer Kreis der Gemeinde betrachtet, der, ohne zur engeren Abendmahlsgemeinde zu gehören, doch als christlich im weiteren Sinne betrachtet wurde und die Kirchensteuern mit bezahlen mußte. Für sie bildete man einen von den Gegnern sog. half way covenant aus, der sie nur zur allgemeinen Christlichkeit verpflichtete. So wurde der Kongregationalismus Staatsreligion in den Kolonialstaaten Neu-Englands und traten dort die Gemeinden untereinander in Beziehung. Von da ging dann der amerikanische Kongregationalismus aus, der von der methodistischen Einwirkung neu belebt einen Teil an die Presbyterianer, einen andern an die Unitarier verlor, aber immerhin bis heute eine starke und einflußreiche Gemeinschaft bildet, deren Verfassungsprinzipien von einer Reihe anderer Denominationen, den Baptisten, Adventisten, Unitariern geteilt werden ${ }^{411}$ ).

111) S. Loofs, Kongregationalismus; vor allem das eben erwähnte nachgelassene Werk von Dexter mit vielem kultur- und sozialgeschichtlichem Detail, auch der Abschnitt bei Powicke über die Amsterdam church, sowie der bei Burrage, Church Covenant, über den half-way-covenant 169-174. Dort auch die Uebernahme des Covenant-Prinzips durch die Baptisten. Die kirchliche Demokratie der Barrowisten war nicht eigentlich demokratisch gemeint, sondern, ähnlich wie bei Luther die Idee der ernsten Gemeinden, als die durch den Geist Christi erzeugte und darum übernatürlich gewirkte Uebereinstimmung, weshalb man Wert darauf legte, alle Beschlüsse aus Gebet und Andacht hervorgehen zu lassen. S. Powicke S. 27 I die Erklärung von Ainsworth: "Christs ruling power, which the papists says is in the Pope, we say not (as this man calumnateth us) that it is in the body of the congregation.; nor that it is in the prelates..., nor (as the Puritans) that it is in the presbytery, ... but that it is in Christ himself... The Word of God is given to all 
Ganz anders stellt sich die andere vorhin genannte Entwickelungsreihe, der Independentismus des Cromwellschen Zeitalters, dar. Er fällt nicht zusammen mit den englischen Kongregationalisten, die gleichfalls in Leyden ihren Ursprung haben und von der nach London zurückgekehrten Gemeinde Jakobs ausgingen, um dann später mit den Presbyterianern und Baptisten zusammen

and every member of the church to read and exercise privately; but publicly in the church - there is a double use of it in prophecy and in office.e Dexter formuliert: The mainspring of power for people and officers alike is in the $\mathrm{living}$ presence of Christ.c Das ist unverkennbar spiritualistisch gedacht; es sind dieselben Sätze wie die Schwenkfelds, s. Sippel, Schwenkfeld ChW. 191 I, S. 869: Das Organisieren misst er nach apostolischem Vorbild nicht den Gläubigen, sondern dem h. Geiste zu. Die praktische Oberleitung ist nicht Sache eines oder mehrerer gewählter oder sich aufwerfender Repräsentanten, sondern des lebendigen regierenden Christus. Dieser allein repräsentiert das Kirchenregiment. Jesus regiert im Geiste durch seine charismatisch begabten Organe sowohl die Gesamtheit der Kirche als auch die Einzelversammlung. In dieser erzeigen sich zum gemeinen Nutzen die charismatischen Aemter und Gaben nach I Cor. 12. Die berühmte Abschiedsrede Robinsons (Weingarten 33, Dexter 587) mit ihrer Ermahnung, sich nicht an seine (Robinsons) Autorität zu binden, sondern sich neue Erleuchtungen offen $z u$ halten, ist gleichfalls spiritualistisch gedacht, aber eben deshalb nicht $z \mathbf{u}$ überschätzen, da ein solcher Spiritualismus sich stets aus der calvinistisch verstandenen Bibel nährt und nur eine feste kirchliche Orthodoxie gleich der lutherischen und Genferischen abgelehnt werden soll. Von hier aus sind auch Robinsons spätere Konzessionen der Geistesgemeinschaft mit Angehörigen fremder Kirchen, ja sogar die Bereitwilligkeit, bei Ansiedelung in Virginia eine äußere, zivile Autorität der Bischöfe anzuerkennen (Dexter $568 \mathrm{f}$, ), zu verstehen; auch die Laienpredigt und Laienzensur gegen die Prediger sind so zu verstehen. Das schließt nicht aus, daß es im Idealfall nur kongregationalistische Gemeinden geben soll, wie das dann auch in Neu-England geschah. Als Motiv der Auswanderung bezeichnet Dexter 567 : $>$ Nor could they bring themselves to abandon the missionary purpose which they had cherished from the first, that they might demonstrate somewhere the value to mankind of a pure and democratic church.<- Ueber die Geschicke und Entwickelung in Neu-England s. das wichtige Werk von Doyle, The Englisch in America, London 1887 und H. K. Caroll, The religious forces of the United States, New-York 1893. Viel Licht gibt auch Roger Williams' später zu besprechender Bloudy Tenent; die kongregationalistischen Kirchen dulden keine andern Kirchen, aber zwingen nicht alle Ansiedler, ihnen voll beizutreten; im ersteren wahren sie die calvinistische Einheitsidee, im letzteren die subjektive Gewissensfreiheit; von allen fordern sie die äußere Entsprechung mit dem Naturgesetz und christlichen Sittengesetz; es gibt also einen Teil der Bevölkerung ohne Kirche überhaupt, doch sollen diese wenigstens das Wort Gottes hören; s. Bl. Ten. S. 250 ! 
den englischen Dissent zu bilden. Diescr englische Kongregationalismus war im Parlament und in der Westminstersynode, auch in dem Klerus, nur in einer sehr kleinen Minorität vertreten und war hier bereit zur Fortsetzung der Staatskirche, nur mit Independenz, Exkommunikationsgewalt und Wahlrecht der Einzelgemeinde; Kontrollen durch staatliche Behörden lehnte er nicht völlig ab. Aber nicht dieser Independentismus der Dissenting Brethren, sondern der der Cromwell'schen Armee wurde der Träger der Bewegung. Das war aber hier erst recht nicht einfach Brownismus oder Barrowismus und war überdies durch den Gang der politischen Dinge vielfach zufällig von außen bestimmt. Vielmehr war es ein im Verhältnis zur Staatskirche überhaupt nicht klares und prinzipielles Drängen auf innerliche Erleuchtung und Erfahrung, auf das Recht der Laienpredigt, die von Offizieren und Soldaten geübt wurde, ein Begehren nach wiedergeborenen Geistlichen und die Berufung auf das Recht freier Gemeindebildung um das Zentrum eines frei berufenen Predigers. Es war ein viel stärkerer, oft mit Luthers Anfangslehren sich berührender, Spiritualismus als bei den Brownisten und Barrowisten; auch an Schwenkfelds dem Urchristentum nachgebildeten engeren Gemeinden kann man denken. Man beanspruchte die Toleranz für sich um der Zartheit des Gewissensund der Selbstbezeugung des Geistes willen, mußte sie dann aber auch den "anderen Sekten * gewähren, weshalb die Independenten den Presbyterianern als Anabaptisten und Antinomisten erschienen; freilich fanden sie in diesem Punkte der unbegrenzten Toleranz bald selbst Schwierigkeiten. Man ließ sich auch die von der Parlamentskommission eingesetzten Geistlichen gefallen, wenn sie Wiedergeborene waren. Vor allem forderte man das Recht der Laienpredigt, weitergehend als Browne, womit man sich dem Enthusiasmus näherte. Der kirchliche Zustand selbst und die Theorie von der Kirche blieben dabei in großer Unklarheit. Insofern Cromwell sich dem Einfluß Harrisons, des eigentlichen Patrons der Sekten in der Armee und des späteren Quintomonarchisten hingab, mochten auch eigentlich täuferische Ideen auf ihn einwirken. Aber er blieb immer bei der Idee einer Verbindung von Toleranz aller Protestanten und von christlicher Einheit und Regierung der Nation ohne Beseitigung der technischen Ordnungen der Nationalkirche. Erst die Majorität des BareboneParlaments machte durch die Beseitigung des Zehnten, womit Pfarreien und Universitäten ihre Grundlagen verloren hätten und 
der Freiwilligkeit anheimgefallen sein würden, den Versuch einer prinzipiellen Neu-Regelung. Gerade dieser Versuch aber veranlaßte Cromwell, dieses Notabelnparlament zu stürzen. Seine eigene Kirchenpolitik war dann, durch eine parlamentarische Prüfungskommission, die Tryers, möglichst tüchtige Leute anstellen zu lassen aus allen Richtungen und Gruppen, auch Presbyterianer und Anglikaner. Nur die Katholiken waren ausgeschlossen aus politischen Gründen, und aus gleichen Gründen wurden nach einem Aufstandsversuch die Anglikaner ausgeschlossen. Daneben waren natürlich die separierten Gemeinden der Baptisten, Kongregationalisten und Quäker usw. geduldet. Auf diese Weise war der Independentismus faktisch Staatsreligion, indem hauptsächlich seine Anhänger, übrigens meist pietistisch ernste Männer, in die Aemter eingesetzt wurden. Wunsch und Wahl der Gemeinden konnte dabei berücksichtigt werden. Das ganze Verfahren und die mit ihm verbundene Toleranz war wesentlich spiritualistisch empfunden; die Kapläne Cromwells waren, wie wir sehen werden, erklärte Spiritualisten. Trotz alledem aber ist doch in Cromwells Gedanken die calvinistische Idee der Grundzug geblieben. Auch er wollte einen christlichen Staat. Er steckte nur die Grenzen der Christlichkeit weiter: Sündenerkenntnis, Rechtfertigungsgewißheit, Gnadentheologie, das sind die Kennzeichen der Christlichkeit. Auch er übte eine moralische Volksüberwachung; nur nicht durch kirchliche Zuchtgerichte, sondern durch die staatlichen Generalmajore. Auch er hielt fest an der Theokratie, betrachtete sein und der Armee Vorgehen als das Vorgehen der magistrats inférieurs bei Versagen der legitimen Obrigkeit, sah sein eigenes Amt als durch Vorsehung und faktische Fügung Gottes geheiligt und darum als Gottesgnadentum an. Seine religiöse Ueberzeugung blieb calvinistisch-prädestinatianisch. So war er und der Independentismus seiner Armee grundsätzlich geschieden von allem Täufertum, trotz zahlreicher Berührungen mit ihm. Seine Lehre von der Salus publica und der Volkssouveränetät ist die reformierte von der Pflicht des Volkes für eine Gottes Willen gemäße Kegierung zu sorgen, und den Willen Gottes sieht er aus dem faktischen Verlauf. In Fragen des Eigentums, des Rechtes, der Regierung ist er darum prinzipiell konservativ; von den demokratischen, kommunistischen und chiliastischen Radikalen grenzt er sich immer schärfer ab. Sein Independentismus war schon von Anfang an von ihnen verschieden; 
er war noch viel weniger als der Brownismus dem täuferischen anolog, daneben noch viel mehr als jener dem Spiritualismus zugeneigt, aber auch dem letztern nicht ohne die feste Begrenzung, die in dem calvinistischen Gedanken eines Gott dienenden und verherrlichenden Staatswesens liegt. Von hier aus hat er dann als Lord-Protektor auch die universale calvinistische Politik der Union und des Schutzes der Protestanten aufgenommen, eine protestantische internationale Politik, die letzte große Aeußerung einer protestantisch-konfessionellen Weltpolitik im Stile Butzers, Zwinglis, Calvins und des hessischen Landgrafen. Mit alledem aber blieb der Cromwellsche Independentismus ein Intermezzo. Ije endgültige Revolution von 1688 griff auf die Ideen vor Cromwell zurück, und der Independentismus gab seine treu bleibenden Anhänger an den Dissent ab, teils an Quäker, teils an Baptisten, teils an Kongregationalisten und Presbyterianer ${ }^{412}$.

412) Hierzu s. Carlyle, Cromwells Letters and Speeches ${ }^{2}$ I846; Gooch, History of English democratic ideas, Cambridge 1898 ; Shaw, History of the English Church 1640-1660, London 1900; Glass, The Barebone Parliament 1653, London 1899; Firth, Cromwells Army, London 1902; Gardiner, Cromwell, 1899: alles sehr wichtige Werke, durch die Weingartens klassisches Buch ,Die Revolutionskirchen Englands c, 1868 vielfach veraltet ist. Weingarten hat die Gruppen innerhalb des Indepedentismus zu wenig unterschieden und den Unterschied des Täufertums vom kirchlichen Protestantismus überhaupt nicht recht erkannt. - Mit Weingartens übrigens trefflichem Bild Cromwells stimmt überein Koldes Artikel C. im PR.8. Die religiöse Bildungsgeschichte Cromwells, sein Verhältnis zu Harrison, seine Aneignung spiritualistischer Ideen bedürfen noch vielfach der Aufklärung. Der Spiritualismus ist von seinen beiden Kaplänen Dell und Saltmarsh im höchsten Grade vertreten, wie später zu zeigen. Auch das ist ein Punkt, der bei Weingarten noch keine Beachtung gefunden hat und der Cromwell vom eigentlichen Täufertum scheidet. Spiritualistische Atußerungen: The true succession is through the spirit given in its measure Kolde IV. 34I; pietistisch ist die Formulierung des alleinigen Kennzeichens wirklicher Christlichkeit: who believe the remission of sins trough the blood of Christ and free justification trough the blood of Christ, who live upon the grace of God, Kolde 342 ; spiritualistisch sind die Kennzeichen eines wahren Geistlichen für die Prüfungskommission: they must not admit a man unless they were able to discerne something of the Grace of God in him; grace of God, which was to be so inquired for, as not foolishly or senslessly, but so far as man could judge according to the rules of charity, Glass 133; spiritualistisch und nicht täuferisch ist sein ganzes Kirchenprinzip der comprehension mit freiem Gewährenlassen der verschiedenen Gruppen innerhalb einer lediglich äußerlich verwaltenden Kirche : a system of State aid and regulation of parishes, leaving to individual churches a free hand for va- 
Kongregationalismus und Independentismus waren zunächst räumlich sehr beschränkte Erscheinungen; der letztere überdies eine

riety of doctrine and freedom in forms of worship, Glass 131; Cromwells Rede -1657: I think, if there be freedom of judgement, it is here. Here are three sorts of godly men whom you are, to take care for, for whom you bave provided for in your settlement, And how could you put the selection upon the Presbyterians, without by possibility excluding all those Anabaptists, all those Independents! As you have put it in this way, that, though a man be any of those three judgements, if he have the ro ot of the matter in him, he may be admitted a, Glass 133. Von gleich spiritualistischen Prinzipien ist Francis Rous erfüllt, der unermüdliche Vorsteher und Mitarbeiter aller kirchlichen Kommissionen des langen Parlaments und Cromwells; dessen Erklärung bei Glass 48: $\rightarrow$ From Christs time place is approved by truth and not truth by place. He that freed true worship from being tied to Jerusalem and tied it to the service inspirit which may be in all places, gave true religion a large scope, even as large as the world itself. « Uebrigens ist Rous ein bekannter Mystiker, den Ritschl, Gesch. d. Prot. I I28-130 denn auch auf das smittelalterliche Vorbilda zurückgehen läßt. ,Wie in der englischen Kirche der independentistische Calvinișmus sich der Wiedertäuferei annähert, so beweist diese Schrift (von Rous), daß man in jener Richtung auch auf das unentbehrliche Vorbild der Mystik wieder zurückgegriffen hat la Auch sonst in der ganzen Church comprehension spiritualistische Begründungen und Motive: siehe bei Shaw II 75 die auf Iretons Bericht den Schotten gegebene Erklärung: 'For the toleration of all religions and forms of worship that their letter objects we know not whom they entend in that charge: as for the truth and power of religion it being a thing intrinsical between God and the soul, and the matters of faith in the Gospel being such as no natural light doth reach unto we conceive their is no human power of coercion thereunto nor to restrain man from believing what God suffers their judgement'to be persuaded of. A Andeutungen über Beziehungen zu Schweńkfeld bei Sippell ChW. 1911 S. 966 und William Dells. Programm S. 8I, wo statt auf Osiander besser auf Schwenkfeld verwiesen wäre. Sofern, wie später zu zeigen, Schwerikfelds Lehre bereits eine Kombination spiritualistischer und täuferischer Gedanken ist, stecken darin natürlich indirekt täuferische Einflüsse. - Das Verhältnis Cromwells zu Harrison s. Glass 61 u. 64, Firth 318,34 I f., 370. - Ueber die independentistischen Feldprediger Dell, Saltmarsh, Sedgwick, Hugh Peters s. Firth $320 \mathrm{f}$, in Lilburnes Regiment John Canne; bei Cromwell ferner John Owen, Thomas Patient, Robert Stapylton s. Firth 324, weitere genannt S. 325-327. Ueber John Owen, den Vertrauten Cromwells, als einen über allen Richtungen stehenden und bei allen geachteten Pietisten s. Heppe, Gesch. des Pietismus I879 S. 43 f.; Dell und Saltmarsch sind Spiritualisten; Hugh Peters, ursprünglich Puritaner, entwickelte sich zum demokratischen Radikalismus Gooch 134-136, 175; Canne, erst Baptistenprediger, wurde gleichfalls täuferisch radikal Gooch I74 f.; John Goodwin ist ursprünglich anglikanischer Geistlicher, dann aber immer mehr zum Spiritualismus fortgeschritten Gooch $132 \mathrm{f}$. - Crom-

Troeltsch, Gesammelte Schriften. I. 
vorübergehende. Aber sie haben große Wirkungen hinterlassen. Von allgemeiner welthistorischer Bedeutung war erstlich der Uebergang der independenten Theorie in die Lockesche Staatslehre, wo sie zu einer mit dem politischen Liberalismus eng verbundienen Theorie der Freistellung der Kirchenbildung und der Trennung von Staat und Kirche wurde. Das wurde bereits oben angedeutet und erklärt sich jetzt aus dem geschichtlichen $\mathrm{Zu}$ sammenhang. Von Locke aus hat sich dann diese Theorie ausgrebreitet und staatsphilosophisch fortentwickelt bis heute. Sie ist die Kirchenpolitik des Liberalismus und der Demokratie geworden. Das zweite noch wichtigere Ergebnis ist, daß die Ordnung der well selbi hat eine stark. calvinistisch-konservative Ader. Seine Auffassung des Naturrechtes blieb ständisch: „Ein Adeliger, ein Gentleman, ein Yeoman (Bauer nder Handwerker), die Unterscheidung dieser ist ein richtiges und großes Interesse ler Nation. Ward die natürliche Verfassung der Nation nicht von Leuten int gleichmacherischen (levelling) Prinzipien mit Hohn und Verachtung, beinahe mit libien getreten : Bernstein 630. Wie er dogmatisch prädestinationsgläubiger Calimist wewesen ist, so war seine Auffassung der Revolution und des Bürgerkriegs zunïchst die calvinistisch-hugenottische. Aber je mehr Voraussetzung und Ziele einer solchen Auffassung bei der anarchischen Gestaltung der Lage sich verflichtigten, um so mehr deutete er Tatsachen und innere Entschlüsse als Offenbarungen und Winke Gottes über den von Gott gewollten Gang der Dinge. Das ist enthusiastisch. Auch der Erwartung der baldigen Wiederkunft Christi hat er sich zugeneigt und im Zusammenhange damit dem unbestimmten Gedanken einer allgemeinen Neuordung der Dinge im. Sinne des christlichen Ideals. Aber die Aufrechtcrhaltung der bürgerlichen und staatlichen Ordnung, die Verwerfung aller reinen I)cmokratie und alles Kommunismus, die Berufung auf die Armee als a lawful power called by God, die Berufung auf die salus populi als die rationelle Rechtwrundlage des Staates, all das sind doch calvinistische Züge im vollen (jegensalz zu der chiliastischen Reformidee, deren Vertreter er zuerst als sich unter cimander widersprechend und darum schwerlich Gottes Willen kundgebend bezeichnete unl die er schlieflich als frevelhafte Zerstörer aller Ordnung betrachtete. Seit der Auflüsung des Parlaments der Heiligen trat er immer entschlossener zu der alten calvini«ischen Theorie der Autorität zurück, indem er sich selbst als die durch das Vulk in Ermangelung aller andern gesetzlichen Autoritäten berufene gesetzliche Autorität betrachtete. Vom Independentismus bleibt ihm nichts als die Gewissensfreiheit, indem er sowohl Sonderorganisationen als Besetzungen der Staatspfarren mit Geistlichen aller Richtungen zuließ, sowie eine starke ethische Kontrolle der Nation. In übrigen trieb er eine Realpolitik, wie sie nur auf Grund des calvinistischen relativen Naturrechts denkbar war, immer noch gewiß, daß s die Sache Christi und die rach de Volkes gut zusammengehen". S. meinen Artikel \$oralisten. Englische PRE. ${ }^{3}$ XIII $445--448$. 
kirchlichen Verhältnisse bei der Konstitution des nordamerikanischen Bundesstaates und in den Verfassungen der nordamerikanischen Einzelstaaten in diesem Sinne praktisch gestaltet wurde, zum Teil eine Folge des tatsächlichen Nebeneinanderbestehens verschiedener. Kirchen in den verschiedenen Staaten, zum andern Teil aber der' Ausdruck des kongregationalistisch-calvinistischen Gedankens von der dem Staate unzugänglichen Majestät der Kirche und der Gewissensfreiheit. Bei einer im allgemeinen festgehaltenen Christlichkeit des Staates sollte er doch gegenüber den Kirchen keine Macht und keine Pflicht besitzen, sondern das religiöse Gewissen sich selbst überlassen, ein scharfer Gegensatz gegen die in den lateinischen Ländern seit der französischen Revolution versuchte Trennung von Staat und Kirche, die in Wahrheit ein Kampf der freidenkerischen Gesellschaft gegen die Macht der Kirchen, vor allem des Katholizismus, ist. Von jenen Theorien und diesem amerikanischen Beispiel werden die kirchenpolitischen Ideen der Gegenwart mit jedem Tage heute mehr bestimmt ${ }^{413}$ ).

Nach allem bisher Ausgeführten kann man das nicht als Wirkung des Calvinismus schlechthin, sondern nur als Wirkung eines täuferisch und spiritualistisch zersetzten Calvinismus bezeichnen. Immerhin ist es Tatsache, daß a u ch die e cht calvinisti-

413) Ueber Locke s. Bastide und Lezius, bes. Rothenbücher, wo auch die weitere rechts- und staatsphilosophische Entwickelung geschildert ist S. 46-II2. Es ist dabei charakteristisch, wie überall der Unterschied zwischen den stärker oder schwächer indepedentistisch-amerikanisch bestimmten Theoretikern und den die moderne Aufklärung gegen die Kirche schützenden und auf den Thron setzenden durchgeht. R. findet die letztere vor allem auf katholischem Gebiet vertreten, wo man die Einheitsreligion gewöhnt ist und nur die katholische Einheit durç die der Aufklärung ersetzt. Dem letzteren Typus folgt auch die deistische Staatsreligion Rousseaus, neben der er private Sonderüberzeugungen freigibt. Auch von dieser Seite her ist Rousseau nichts weniger als ein Ablömmling calvinistischer oder gar neucalvinistischer Ideen; s. auch Jellinek, Erklärung der Menschen- und Bürgerrechte 21904 ; auch meine * Trennung von Staat und Kirche 1905. - Ueber die amerikanische praktische Gestaltung s. außer den S. 749 genannten Arbeiten gleichfalls Rothenbücher 116-I70. Wenn Hägermann auf das Naturrecht und auf Locke hinweist, so verkennt er das christliche Naturrecht, das darin steckt, und die Bestimmtheit Lockes durch den Independentismus. Naturrechtliche und christliche Begründung sind kein Gegensatz, wie er meint S. 151. Daher hat der Methodismus in Amerika so starken Anklang gefunden und herrscht dort heute noch sozial eine sehr massive Orthodoxie und rigorose Moralität. Das pflegt der aufgeklärte Europäer nie recht $z u$ verstehen. 


\section{$\mathrm{schen} \mathrm{Kirchen}$ diesem Beispiel angesichts der modernen} konfessionellen Bevölkerungsmischung und angesichts der zunehmenden Laicisierung des Staates gefolgt sind ${ }^{414}$ ). Diese

114) Ueber den Uebergang großer Teile des heutigen Calvinismus zum Freikirchenprinzip s. Vinet und Kuyper, und die große Uebersicnt Rothenbüchers über die heute bestehenden Freikirchen. - Ueber die Verbindung dieses Kirchenprinzips mit der politischen Demokratie s. Rothenbücher 472. - Die Pilgerväter der Mayflower bildeten schon auf dem Schiff einen politischen Covenant nach Vorbild des kirchlichen, s. Burrage, Church Covenant S. 86 und 93 :. $>$ By 1639 the covenant idea had become so popular in the minds of the Massachusset and New Haven colonists, that even towns were organized by covenante. S. auch Jellinek, Erklärung usw. S. 36-39. Die Verbindung von Calvinismus und Demokratie ist in der modernen calvinistischen Literatur fast etwas Selbstverständliches, sei es in der Form, daß das Christentum und die Bibel als mit der Demokratie identisch erklärt wird, sei es in der, daß der Calvinismus als die endgültige Entwickelungsform des Christentums bezeichnet wird, in der Demokratie und Religion eins geworden sind für immer und die daher zum Sieg über die. Welt bestimmt ist. Das findet man bei Vinet, Kuyper, Rauschenbusch. Die Franzosen betonen die Koinzidenz von Christentum und Demokratie, s. die schon erwähnte Schrift Méalys, überdies P. Sabatier A propos de la séparation ${ }^{2}$. 900 und R. Allier, Une révolution 1806. Der treffliche Calvinforscher Choisy schließt seine Genfer Antrittsvorlesung L'état chrétien calviniste 1909 mit den Worten: ${ }$ En somme le régime théocratique en vigeur dans l'état chrétien de Genève a été pour l'époque une rude, mais salutaire école de justice, de moralité et virile piété. Il a préparé l'avènement de la liberté de conscience dans l'avenir, il a frayé la voie au développement de l'esprit de fraternité et solidarité dans la démocratie chrétienne s. 32. Ueber den englischen Dissent s. v. d. Goltz, ,Staat und Kirche in Großbritannien«, Preuß. Jahrbb. 84, 1896. Ursprünglich vollzogen ist diese Einigung von Calvinismus und Demokratie nur bedingt in England, wo die calvinistisch gesinnten Independenten, wie vor allem Ireton und Cromwell, auch politisch nach Möglichkeit konservativ und legitim blieben und nur die tiufurisch beeinflußten Gruppen der Leveller und ähnlicher die reine Demokratie vertrațen, s. Rothschild, Der Gedanke einer geschriebenen Verfassung in der englischen Revolution 1903, auch Gooch, English democratic ideas. Cromwell erklärte wohl 1654 (Carlyle III 29) »Liberty of conscience and liberty of the subject - two as glorious things to be contended for, as any God has given use, aber fügt sofort hinzu: syhet both these abused for the patronising of villaniese. Damit weist er die radikale Demokratie von seinem relativ konservativen Standpunkt aus zurück. Die bei ihm vorhandene Verbindung von Freikirchentum und Demokratie enthält sowohl das erstere als das letztere in einer eigentümlichen Unklarheit. - Sie ist in ihrem klaren, von alicalvinist. Vorstellungen freien Sinne erst in Amerika vollzogen worden, hierüber $s$. das heute noch großartige Buch von Tocqueville, La démocratie en Amírique ${ }^{3}$ 1850. In England ist sie erst das Werk des 19. Jahrhunderts, wo der Dissent seit den Reformen von 1832 der Träger des Liberalismus und der 
Tatsache aber ist entscheidend für die moderne Gestaltung des Calvinismus. Beinahe überall haben sich neben den Staatskirchen: calvinistische Freikirchen gebildet. In Genf selbst herrscht heute die Trennung. Das durch die Princeton-University fast offiziell gemachte mehrfach erwähnte Manifest Kuypers lehrt das Freikirchentum geradezu als grundlegende calvinistische Theorie. Damit ist denn auch überall die Neigung zu liberalen oder demokratischen Verfassungen verbunden, welche jeder konfessionellen Partei und jeder Kirche freie Bewegung und Geltendmachung in der öffentlichen Meinung ermöglichẹn. Auf dem Wege über das Freikirchentum ist der Calvinismus in seinen Hauptmassen politisch liberalisiert worden und teilt er die Neigung der Sekten zu einer individualistischen und rein utilitarischen Auffassung des Staates so sehr, daß zwischen ihm und ihnen in dieser Hinsicht heute kaum mehr ein Unterschied ist. Es ist bereits oben in anderem Zusammenhang auf die Neigung des Calvinismus zu konstitutionellen Staatstheorien hingewiesen worden. Der freikirchliche Calvinismus wurde aber noch darüber hinaus dem demokratischen Gedanken selbst zugänglich. Erst in dieser Amalgamierung von Freikirchentum und Demokratie empfing er sein heutiges Verhältnis zum politischen Individualismus. So steht der Calvinismus im Verein mit den Sekten heute dem lutherischen Staatskirchentum geradezu diametral gegenüber und bezeichnet er sich mit Hochgefühl als die dem modernen Wesen allein entsprechende Form des Christentums. Er hat natürlich die Demokratie nicht erst erzeugt, aber in seiner freikirchlichen Gestalt sie begünstigt. Wo, wie in den Neu-England-Kolonien, die natürlichen Verhältnisse der Demokratie sehr entgegenkamen, da hat er sie entscheidend gefördert, sich ihr angepaßt und ihren Ideen das Pathos der Unabhängigkeit des Individuums von allen irdischen Gewalten eingeflößt ${ }^{414^{\prime}}$ ).

Demokratie ist und diese Gedanken zugleich mit religiöser Begeisterung durchdringt, s. Ostrogorski, La démocratie et l'organisation des partis politiques I 1903 S. $21-26$; auch Held S. 48 .

414a) Ueber das Hochgefühl des Calvinismus in dieser Hinsicht s. Kuyper S. 15: Das Luthertum ist kirchlich und theologisch geblieben, nur der Calvinismus hat in und außer der Kirche seinen Stempel auf alle Aeußerungen des menschlichen Lebens gedrückt. Vom Luthertum spricht denn auch niemand als von der Schöpfung einer eigenen Lebensform; selbst der Name kommt kaum vor, während die Kenner der Geschichte immer einstimmiger dem Calvinismus als Schöpfer einer eigenen Welt menschlichen Lebens huldigen. S. 26: „Es ist klar wie der Tag, 
Eine logische Folge des Kongregationalismus und des Freikirchentums ist die Tole ranz verschiedener KirchengemeindaB die Hauptmacht in der Entwickelung des Menschengeschlechtes sich nacheinander der Reihe nach von Babylonien und Aegypten nach Griechenland und dem römischen Reich, darauf nach dem Hauptgebiet der päpstlichen Herrschaft und zum Schluß zu den calvinistischen Völkern von Westeuropa verlegte «; S. 37: - Unter Calvinismus ist die vollendete Evolution des Protestantismus zu verstehen, die im 16. Jahrhundert die Lebensentwickelung unseres Geschlechtes in eine neue und höhere Phase geführt hat, ... weshalb ein jeder, der sich weigert, den Atheismus oder Antitheismus als Ausgangspunkt zu wählen, auf den Calvinismus zurückzugehen hat, um aus dem calvinistischen Prinzip, natürlich in einer unserer Zeit entsprechend entwickelten Form, denken und leben zu lernen. S. $594 \mathrm{f}$ : : In the Plymouth colonie and, later, in that of Massachussets the free church system flourished. It had a large part in shaping the thought and life of the colonists. It tinctured their political ideas and aided powerfully in preparing the way for American independence, and ever since their day it has continued a potent factor for good in our national life. In the mother country also, although hampered by many hostile conditions and not wholly free, even yet, to do its best work, it has become conspicuous and effective, and during the 19th cent. it has accomplished much of what it could not bring to pass in the 17 th .. It would be a mistake to regard the Pilgrim colony in American . . . as merely ecclesiastical in origin and developement ... It was one of the earliest manifestations of that resistless impulse of expansion and conquest... which changed the whole face of the globe. It opened a fresh and vitally important era in human history. It was practically the beginning of the civilized, permanent settlement of on almost unknown continent. It prepared the way for the birth of a new and mighty nation. The worlds debt to the Pilgrims is not limited by any denominational lines. It is universal. The adherents of the free church systems fairly may claim to possess special justifications for pride in the Pilgrim history, but nobody can monopolise it. All lovers of intelligence, and civil as well as religious liberty have the right to share it.. Das ist der Amerikanismus in seinem relativen Zusammenhang mit Calvinismus und Sektentum. - Vom entgegengesetzten Standpunkt aus beklagt Shaw, English Church I 316 die Sache: The carliest Reformation had never proclaimed such a separation of the civil from the ecclesiastical governement. It was the fatal and malignant heritage of the genius and life of Calvin, and how adversely it has affected the later history of European progress can hardly yet be estimated. " Ueber die Sonderart der puritanisch-angelsächsischen Demokratie gegenüber der national-französischen s. die zahlreichen feinen Bemerkungen Tocquevilles. Er führt dafür I 5 I als Leitmotiv mit Recht die Worte aus des alten Mathiew Magnalia Americana an: sTäuschen wir uns nicht über das, was wir unsere Unabhängigkeit nennen. Es gibt in der Tat eine Art verderbter Freiheit, deren Gebrauch Menschen und Tieren gemeinsam ist und der darin bestehț, zu tun, was einem gefällt. Diese Freiheit ist der Feind jeder Autorität, sie erträgt ungern die Regeln; mit ihr stei- 
schaften gegen einander und die Möglichkeit ihres Nebeneinanderbestehens in einem Staatswesen. Doch hat es ziemlich lange gedauert, bis diese Folgerungen sich gegen das in jenem enthalten gebliebene calvinistische Prinzip der Alleinwahrheit der eigenen Religionsgemeinschaft und der Christlichkeit des Staates durchgearbeitet hatten, vollends bis auch der reine Calvinismus das Prinzip der. Toleranz übernahm. Die alten Kongregationalisten wollten freie, independente Gemeinden und keinen Staatszwang zur Religion, aber Ausschluß aller häretischen Religion vom Staatsgebiete. Die kongregationalistischen Neu-EnglandPuritaner setzten dieses Prinzip fort, zwangen niemand zur Kirchenzugehörigkeit, duldeten aber keine andere Kirche und verknüpften wichtige Bürgerrechte mit der Kirchenzugehörigkeit; also auch hier das rein negative Prinzip der Beseitigung des Staatszwanges, aber keine positive Einräumung der Bestandsmöglichkeit für verschiedene Religionsgemeinschaften neben einander. Erst die Ermattung des religiösen Geistes und allerhand profane Handelsrücksichten haben dann im I8. Jahrhundert zur Duldung geführt. In England hat das lange Parlament nur den verschiedenen Gruppierungen innerhalb des calvinistischen Protestantismus Duldung gewährt und die Christlichkeit des Staa'tes durch die Aufrechterhaltung der Elisabethanischen Akte, daß jeder "assistence“" beim Gottesdienst zu leisten und nachzuweisen habe, gesichert; man durfte sich nur jetzt die Gruppe aussuchen, bei der man "assistence" leisten wollte. Brownisten und Independenten haben dann gelegentlich auch auf Baptisten, Socinianer, Arminianer, sogar auf Juden und Mohammedaner die Duldung auszudehnen gefordert; die Gründe waren dabei jedesmal spiritualistische, die die äußere Form für die innere Offenbarung als relativ gleich-

gen wir unter uns selbst herab; sie ist der Feind der Wahrheit und des Friedens und Gott hat selbst gegen sie sich zu erklären für nötig gehalten. Aber es gibt eine bürgerliche und moralische Freiheit, die ihre Kraft hat in der Einheit und die zu schützen selbst erst das Wesen aller Macht ist: das ist die Freiheit, furchtlos alles zu thun, was recht und gut ist. Diese heilige Freiheit wollen wir in allen Schicksalslagen verteidigen und dieser nötigenfalls das Leben opfern. : Vgl. auch das oben über das soziologische Grundschema des Calvinismus Bemerkte; auch Ostrogorski I 93 ఎDès le moment où l'âme individuelle se fut réveillée pour s'affirmer en face de Dieu et de la société, ,l'homme‘ etait entré sur a la scène sociale et politique de l'Angleterre pour ne plus la quitter. Il est entré en Angleterre par l'ouverture de la morale, comme il a pénétré en France par celle de la logịuer. Ebenso Morley, Gladstones Life I 163. 
gültig bezcichneten. Am weitesten ging Milton, der freilich seinen puritanisch-spiritualistischen Gedanken mit einer starken Dosis ron intellektualistischer Renaissancestimmung versetzte. Cromwell erklärte die Gewissensfreiheit für ein natürliches Menschenrecht, mußte aber doch Katholiken, Anglikaner und radikale Täufer aus politischen Gründen zuletzt ausschließen; auch hielt er sowohl an der Christlichkeit des Staates als an einem wenigstens formellen und verwaltungsmäßigen Staatskirchentum fest. Nur die Täufer, Quäker und Roger Williams behaupteten die gegenseitige Anerkennung aller Kultgenossenschaften auf spiritualistischer Grundlage und die Indifferenz des nur die zweite Tafel des Dekalogs verwaltenden, auf das Naturrecht erbauten Staates gegen die religiösen $Z$ wecke der Gesellschaft; in demselben Maße wurde hier dann der Staat rein utilitarisch aufgefaßt. Williams trat geradezu zu den Täufern über; aber auch von ihnen rasch abgestoßen, ergab er sich einem konfessionslosen Spiritualismus, von dem aus er in Rhode-Island die Duldung bei allgemeiner Christlichkeit des Staates durchführte. Zum wirklichen Prinzip geworden ist die gegenseitige Toleranz erst durch Lockes Kirchenund Staatstheorie und praktisch durch die Konstitutionen der amerikanischen Staaten, wo das Gewissens- und Menschenrecht der Kultfreiheit aus Hochachtung vor der Majestät des Gewissens zur Verfassungsgrundlage der Einzelstaaten gemacht wurde, übrigens aber die allyemeine Christlichleit des Staates bis heute in verschiedenen Einrichtungen und vor allem in der Volksanschauung als selbstverständlich sich erhalten hat. J)aß diese Firmulicrung der Kultusfreiheit als eines verfassungsmäßig zu garantierenden Menschenrechtes zugleich die vom Naturrecht der Aufklärung längst gelehrten Menschenrechte überhaupt in die juristische Formulierung mit hindurchriß und diese Formulierung dann auch auf die europäischen Verfassungen übertragen wurde, hat Jellinck gezeigt: ähnlich, wie die Berufsidee, ein Beispiel dafür, wie wichtige, heute jeder religiösen Begründung entbehrende und selbstrcrständlich gewordene Begriffe auf dem Boden des religiösen Lebens ursprünglich erwachsen sind. Dem Puritanismus aber kann diese Tat, vor allem die Proklamation der Kultusfreiheit als cines unantastbaren Menschenrechtes, nur insofern zugeschricben werden, als man unter ihm zugleich Quäker und Baptisten mitverstcht, ror allem als man die spiritualistische Erweichung. die Relativierung der äußeren dogmatischen Formen, 
mit in ihn einrechnet. Erst der individualisierende und alle äußeren Formen relativierende Spiritualismus ist der Vater wirklicher Toleranz ; calvinistisch ist nur das Pathos der staatlichen Unantastbarkeit der Religion. Im übrigen aber ist nicht zu vergessen, daß neben diesen religiösen Mächten auch allerhand äußere Gründe, insbesondere auch rationalistisch-aufklärerische Ideen, mit zu jenen Verfassungserklärungen gewirkt haben. In den eigentlichen Calvinismus selbst ist das Prinzip erst mit den pietistischen Separationskirchen und der konfessionellen Gemischtheit der Bevölkerungen übergegangen. Heute hat er gelernt, den altcalvinistischen Gedarken der Souveränetät der Religion und Kirche als Staatsfreiheit und damit auch als Prinzip der Kultusfreiheit zu verstehen. Dabei bleibt er meist orthodox oder evangelical. Die Toleranz ist eine lediglich politische, auf die Unabhängigkeit der Kirche vom Staat hinzielende, aber keine innerkirchliche, soweit es sich noch um echten Calvinismus handelt. Er denkt das Nebeneinander als ein von Menschen nicht zu schlichtendes Provisorium, das erst beim jüngsten Tage zu Gunsten der reinen Wahrheit aufgelöst wird. Gottes Gericht, nicht Staat und Menschen, sollen die Sichtung vollziehen. Ueberdies ist dabei immer noch die Christlichkeit des Staates und der Gesellschaft im allgemeinen auf Grundlage des Naturrechts und des Gewissens der Regierenden vorausgesetzt. Immerhin aber empfindet der Neucalvinismus sich auch in dieser Hinsicht als Träger des modernen Fortschritts; Freikirchentum und Toleranz unterscheiden vor allem ihn vom Altcalvinismus ${ }^{415}$ ).

415) Ueber die Geschichte der Toleranz und der über das bloße Tolerieren hinausgehenden Kultusfreiheit s. den Artikel "Toleranz" von Friedberg in PRE. ${ }^{3}$; Rothenbücher $74 \mathrm{f}$., I16-131; Jellinek, Die Erklärung der Menschen- und Bürgerrechte $^{2}$ 1904; bes. Ruffini, La libertà religiosa, I, Storia della idea, 1900. Ueber die sehr relative Toleranz der Brownisten, Barrowisten und Pilgergemeinden s. die oben genannten Arbeiten von Burrage, Powicke und Dexter; in Neu-England s. Jellinek S. $39-45$; Toleranz des Langen Parlamentes Shaw II 33-97; bei den Independenten Jellinek 36 , Shaw II $46-52$; besonders weit gingen Goodwin und eine Eingabe der Brownisten bei Glass S. 2 I f. (hier die spiritualistische Begründung slet every spirit praise the Lord •); über Cromwells Toleranz s. Glass und Kolde ; Speech III (Carlyle III 68) behandelt die Frage der Grundgesetze, die jede Gesetzgebung als natürliche Rechte berücksichtigen muß. AAgain is not Liberty of conscience a fundamental ?... Liberty of conscience is a natural right; and he that would have it, ought to give it ... Liberty of conscience, truly that is a thing ought to be very reciprocal I... This, I say, is a fundamental. It is for us 
Damit aber hat der Neucalvinismus das ursprüngliche stark konservative, wenn auch dem Luthertum gegenüber viel rationaand the generations to come. Im übrigen war dann doch diese Duldurg eme nur beschränkte, wie Glass ausführlich zeigt. Am weitesten ging Milton, der die puritanisch-independenten und spiritualistischen Motive noch erweiterte durch die Toleranzmotive des Rationalismus, aber auch seinerseits in den Grenzen des christlichen Staates blieb. Das Ergebnis dieser Kämpfe übernahm Locke. - Völlige Unabbängigkeit und Freiheit forderten nur die Täufer und die Spiritualisten. Betreffs der ersteren s. Tracts on Liberty of Conscience and Persecution 1614-I66I, Publikation der Hanserd Knollys Society 1846. Am wichtigsten ist Roger Williams, den das heutige Amerika als einen seiner größten Geister ehrt; s. sThe bloudy tenent of persecution for cause of conscience von 1644 , publiziert mit einer biographischen Einleitung von der gleichen Society 1848 . R. W. war strenger HeiligungsPuritaner und als solcher gegen jede Vermischung von Staat und Kirche, wie sie auch im Neu-England-Kongregationalismus wieder eingetreten war; in engem $\mathrm{Zu}$ sammenhang damit streng demokratisch und für moralische Politik, wie er denn gleich dem späteren Penn mit den Indianern auf dem Fuß der Gerechtigkeit und Güte verkehren wollte und Indianermission betrieb; von da aus bekämpfte er die Kolonial-Charters, die fremdes (indianisches) Land ohne weiteres vergaben. Dies und Proteste gegen die Vermischung von staatlichen und kirchlichen Rechten führte zu seiner Bannung. Er gründete in Providence einen rein demokratischen Staat mit voller Gewissensfreiheit (über dessen Schicksale s. Doyle) und trat zum Baptismus über 1639 (die Biographie bemerkt: infant baptism and persecution, as in other churches, in sisterly embrace together XXVI und erwähnt S. XXXIII a baptist asserting as one of the results of infant baptism that shence also collaterally have been brought the power of the civil magistrate into the churche, eine richtige Empfindung dafür, daß Kindertaufe Volks- und Massenkirche und die letztere Herrschaft des Staates in der Kirche bedeuten muß). Er blieb nicht lange Baptist, sondern gab jede Konfessionszugehörigkeit auf, der Ueberzeugung (wie Schwenkfeld, Coornheert, Seb. Franck und die Kollegianten), daß die echte alte Kirchenverfassung der apostolischen Zeit längst erloschen sei, und daß es jetzt überhaupt keine göttlich eingesetzte Kirche mehr gebe. Damit ging er zum konfessionslosen Individualismus über XXVII. Sein Bloudy Tenent 1644 knüpfte an eine täuferische Schrift für die Gewisserısfreiheit verteidigend an XXX. Erst im gleichen Jahre trat der Independent John Goodwin hervor. Den Independenten ging R. W. zu weit : they are willing to grant liberty only to those sound in fundamentals, the identical views of their brother Congregationalists of America XXXV. Der Sinn des bloudy tenent ist radikal individualistisch, obwohl die Argumentation im ganzen die täuferische ist und mit dieser nur das spezifisch puritanische Pathos der weltüberlegenen Souveränität und siegreichen Mission der Wahrheit verbindet. Spiritualistische Züge sind nicht besonders betont, obwohl Kenntnis und Einfluß spiritualistischer Literatur wahrscheinlich ist. Der Relativismus der Gesinnungsmäßigkeit spricht dafür. S. $8 \mathrm{f}$ : $>$ Whatever worship, ministry, ministration, the best and pu- 
listischere. relative Naturrecht des Sündenstandes dem mo d e r n e n $\mathrm{klassisch-rationalistischen} \mathrm{Naturrecht} \mathrm{des} \mathrm{Li-}$ rest, are practised without faith and true persuasion that they are the true institution of God, they are $\sin$, sinful worships; ministres etc. ... Without search and trial no man attains this faith and right persuasion... Having tried we must hold fast upon the loss of a crown.* Sein Spiritualismus erinnert oft an Luthers Frühzeit $S .118: \gg I$ hence observe, that here being in this Scripture (II Kor 10,4) held forth a twofold state, a civil state and a spiritual, civil officers and spiritual, civil weapons and spiritual weapons, civil vengeance and punishement and a spiritual vengeance and punishement ... These states being of different natures and considerations, as far differing as spirit from flesh, I first observe, that civil weapons are most improper and unfitting in matters of the spiritual state and kingdom, though in the civil state most proper and suitable. Die Fxegese ist oft ausdrücklich mystisch-spiritualistisch. Berufung auf die sfamuus Waldensian wi1nesses « S. 159, Berufung auf Luther S. 17I, gegen Calvin Berufung auf Gal I, $\mathrm{S}$ S. 181. Bemerkenswert ist, daß die zugrunde gelegte täuferische Schrift sich ausführlich auf Luthers spiritualistischen Kirchenbegriff beruft $S$. 15 f. Roger selbst begründet überdies seinen Individualismus auf die Prädestinationslehre S. 82: - The church or spiritual state, city or kingdom has laws orders and armories .... to defend itself against the very gates of earth or hell .... The Lord himself knows who are his and his foundation remaineth sure; his elect or chosen can not perish nor be finally deceived. * Aelinliche Beziehungen auf Luthers spiritualistische Frühzeit werden uns bei den englischen Mystikern des Cromwellschen Zeitalters begegnen. Eine Monographie über R. W. wäre sehr interessant; er ist in vieler Hinsicht sehr originell. - Die Aufnahme der Kultusfreiheit unter die Prinzipien des Neucalvinismus veranschaulicht - freilich etwas sophistisch - Kuyper. Wie er sehr gegen Calvin behauptet, daß »die Regierung der Kirche auf Erden demokratisch in Mark und Bein seic S. 56, so bezeichnet er vollends auch noch die Kultusfreiheit und Toleranz als $\triangleright$ wesentlichen Zug des Calvinismus S. 92. Dabei nähert sich Kuyper auch der mit dem Toleranzprinzip unvermeidlich verbundenen Einsicht in die Relativität aller religiösen Erkenntnis, somit einen Urgrundsatz des Calvinismus aufgebend. Der Calvinismus gab durch sein lautes Eintreten für die Gewissensfreiheit die Einheit der sichtbaren Kirche preis» S. 94. sIndem gerade das Zerbrechen der Einheit der Kirche von selbst den rela ti ve n Charakter eines jeden besonderen Bekenntnisses ans Licht bringen mußte, hat der Calvinismus dadurch, daß er eine Mehrsinnigkeit der Kirchenbildung möglich machte, die Beschränktheit unserer Einsicht auch beim Bekenntnis der Wahrheit ans Licht gebracht !* Der Staat hat in kirchliche Dinge nichts dreinzureden, snicht aus einem falschen Neutralitätsbegriff, . noch als ob ihm das Wahre und Falsche gleichgültig sein könnte, sondern sofern er als Obrigkeit die Voraussetzungen entbehrt, um ein Urteil abzugeben und jedes Urteil hierüber der Souveränität der Kirche zu nahe tritts S. 97. Daher darf der Staat die Aufrichtung der strengsten Orthodoxie im Innern einer Kirche nicht hindern, aber jede Kirche muß auch andere neben 
beralismus angenähert. Dieses selbst ist natürlich kein Erzeugnis des Calvinismus. Es ist - nach seiner theoretischen sich dulden und darf den Staat nicht zu deren Vernichtung in Anspruch nehmen. -Nichts kann die Grundregel brechen, daß die Obrigkeit den Komplex christlicher Kirchen als die vielgestaltige Offenbarung der Kirche Christi auf Erden zu ehren hate S. 98. 'Sie hat die Gewissensfreiheit jedem Bürger als ursprüngliches, jedem Menschen zukommendes Recht anzuerkennene S. 99. Das ist genau der Sinn der Verfassung vón New Hampshire, die Jellinek S. 2 I anführt. Allerdings ist calvinistisch daran nur die Behauptung der Souveränetät der Kirche gegenüber dem Staat. Das relativistische Element in diesen Sätzen stammt aus täuferischen, spiritualistischen und rationalistischen Motiven, wie denn Kuyper selbst sich nicht sder unleugbaren Tatsache entziehen kann, >daß es nicht selten (!) Baptisten und Remonstranten waren, die vor nun drei Jahrhunderten das System der freien Kirche gegen den Calvinismus verteidigtene S. 92،. Wirklich tolerant in Wahrheit denkt nur der Spiritualismus, der ja auch oft genug in Rationalismus übergeht. Das Täufertum ist bei seinem absoluten Wahrheitsbegriff im Grunde nur auf dem Standpunkt der Staatsunabhängigkeit und folgert nun erst daraus die dann unvermeidliche Kultusfreiheit. All diese Einflüsse vereinigen sich im Neucalvinismus. Ueber die daneben bestehenden profanen Wurzeln der Toleranz s. Max Weber, Archiv XXI 42 f. - Die von Jellinek behauptete Bedeutung dieser Formulierung und praktischen Durchsetzung der Gewissensfreiheit für die gesetzliche Formulierung einer noch sehr viel umfassenderen Liste von natürlichen Menschenrechten und damit die Einführung des Begriffs in die Verfassungen des modernen Staates überhaupt ist vielfach bestritten oder eingeschränkt worden. Auf einiges nimmt die zweite Auflage bereits Rücksicht. Der Katholik Paulus (Kölnische Volkszeitung, Literarische Beilage 1906 Nr. 39) sucht die Menschenrechte ausschließlich auf die naturrechtliche Staatstheorie und die Aufklärungsphilosophie zurückzuführen; Wahl ,Zur Geschichte der Menschenrechte (H. Z. 103 S. 79-85) betont neben den religiösen Einflüssen die allgemeine politische Lage der sich vereinigenden Staaten mit ihren grundverschiedenen Kirchenbildungen und den Einfluß der Aufklärungsideen. Das wird wohl zutreffen. Hägermann, Die Erklärungen der Menschen- und Bürgerrechte, I910 (Eberings Hist. Studd. 78) betont gleichfalls auf klärerisch-literarische Einflüsse und reduziert die religiösen Einflüsse auf ein Minimum, hat aber von den letzteren nur sehr verworrene Vorstellungen. Den Sinn und die Meinung von Roger Williams hat er mißverstanden, das christliche Naturrecht ist ihm unbekannt, der von ihm mit Recht betonte Einfluß von Milton und Locke ist nicht im Zusammenhang mit ihrer religiösen Unterlage verstanden. Aber vieles ist auch sehr lehrreich und interessant; in der Hervorhebung der Gleichheit als eines rein rationalistischen Gewächses hat er recht, und die Betonung der wirtschaftlichen, politischen, persönlichen Einflüsse ist sehr berechtigt. Uebrigens hat Jellinek nie die amerikanische Revolution aus dem Puritanismus hergeleitet, sondern nur Formulierung und Begründung der Menschenrechte. Das bleibt m. E. richtig, wenn auch die Aufklärung bei ihm etwas zu kurz gekommen ist. Für jeden Kenner der religiösen 
Seite - ein solches humanistisch gesinnter Juristen, die auf den von den christlichen Färbungen befreiten Stoizismus und das römische Recht zurückgingen, sowie der modernen psychologisch-empiristisch deduzierenden Philosophen ${ }^{416}$ ). Allein wie es

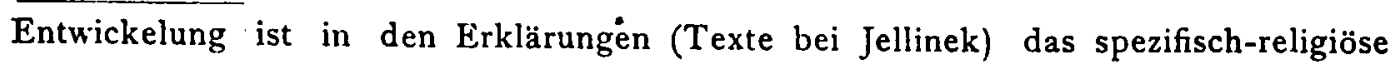
Pathos der Unantastbarkeit der Gewissensüberzeugung und des religiösen Elementes durch die dazu nicht berechtigten Hände des Staates klar und eben damit die calvinistisch-täuferische Herkunft di i ser Wendung des Gedankens. - Neuerdings s. Klövecorn, Die Entstehung der Erklärung der Menschen- und Bürgerrechte I9r1.

416) Daß das klassische Naturrecht die Emanzipation der stoischen Elemente von ihrer Verbindung mit der kirchlichen Dogmatik und Ethik und von dem kirchlichen Mythos der Urgeschichte ist, zeigt jeder Blick in die Masse der durchschnittlichen Literatur des Naturrechts, wie Glafey, Gesch. des Rechts der Vernunft, I739 (s. besonders S. 54, III, I93 f.), und Hinrichs, Gesch. der Rechts- und Staatsprinzipien, 1848-52 (s. besonders I 227, II 13) schildern. Aristoteles, dessen Lehre von der organischen Bildung des Staates in der überhaupt sehr gemischten kirchlichen Naturrechtslehre mit der Vertragslehre und der Lehre von der göttlichen Einsetzung der Obrigkeit verkoppelt worden war, wird gänzlich ausgeschieden, und der gesteigerte Individualismus arbeitet rein mit den stoischen Lehren von der - wirklich oder nur virtuell vorhandenen - ursprünglichen Freiheit, Gleichheit und Güte der Menschen des goldenen Zeitalters, woraus durch den Egoismus und die unsozialen Eigenschaften der Menschen die Nötigung eines Aufbaues der staatlichen Gesellschaft entsteht zum Zwecke des Schutzes der ursprünglichen, von der Natur verliehenen Güter. Damit werden aber nicht nur die stoischen Gedanken herausgelöst, sondern sie werden bei solcher Emanzipation auch ihrer christlichen Färbung beraubt, indem I, das Naturrecht rein aus der Natur der Menschen, d. h. aus der Sozialität und dem Vernunftcharakter abgeleitet wird ohne Vermischung des Naturgesetzes mit der Nachahmung der eigenen Gerechtigkeit Gottes und ohne jede Notwendigkeit direkter Heranziehung des Gottesbegriffes ; 2. indem für die Bestimmung des Naturrechtes zunehmend der Unterschied zwischen Urstand und Sündenstand verschwindet und das Naturrecht aus dem Menschen an sich abgeleitet wird; 3. indem die Entstehung von Staat und Recht nicht als ein bloß relatives Naturrecht des Sündenstandes und ein Abfall von der Unvollkommenheit, sondern als ein Kulturfortschritt zur Wahrung der Naturanlage gegen die sie gefährdenden Leidenschaften erscheint. Von da aus verselbständigen sich dann die Anschauungen vom Menschen, von seiner Urgeschichte und von seiner wünschenswerten gesellschaftlichen Organisation zu rein rationellen Wissenschaften, die der Kirche und Offenbarung wohl einen Raum neben sich anweisen, die aber für sich selber prinzipiell selbständig sind. Vgl. meinen Aufsatz $>$ Das stoisch-christliche Naturrecht und das moderne profane Naturrecht* H.Z. IgII, auch »Verhandlungen des I. deutschen Soziologentages 1911. Wenn hier Gothein und Kantorowicz die Bedeutung des römischen Rechtes für àen Uebergang hervorhehın, so ist hierzu zu bemerken, daß das römische Recht schon für die konfessionelle Rechtsphilo- 
auch von dem christlichen Naturrecht des Calvinismus und der Scholastik einen starken Antrieb empfangen und in sich aufgenommen hatte, so ist der Uebergang des freikirchlich und in seinen praktisch-politischen Beziehungen demokratisch-liberal gewordenen Calvinismus $\mathrm{zu} \mathrm{ihm}$ sehr begreiflich. Die Vereinigung von Staat und Kirche im Alt-Calvinismus hatte außer auf der Pflicht der christlichen Obrigkeit gegenüber Gott auch auf der Unfähigkeit aller Bildungen des relativen Naturrechts beruht, die Bedürfnisse der menschlichen Gesellschaft ohne Mithilfe des Gnadeninstitutes zu befriedigen. Wenn nun beides get trennt war und die profanen Institutionen auf sich selbst, d. h. auf ihre naturrechtliche Grundlage allein gestellt waren, so konnte es nicht ausbleiben, daß diese naturrechtliche Grundlage sich von den Schranken des alten, bloß relativen christlichen Naturrechts und damit von der Ergänzungsbedürftigkeit durch die Kirche befreite. Man näherte sich immer mehr einem autonomen rationellen Naturrecht, das die rein utilitarischen Zwecke der profanen Institutionen mit reiner Vernunft und ohne Mitwirkung der Offenbarungsautorität konstruierte und $\mathrm{zu}$ verwirklichen lehrte. Theologisch ausgedrückt: das Gesetz der Natur in der zweiten Tafel kann verwirklicht werden auch ohne gleichzeitige Verwirklichung der ersten Tafel, die im Sündenstande nicht mehr zum Gesetz der Natur gehört. Derart argumentierten schon Milton, Roger Williams und Bayle. So konnte man sich das moderne profane Naturrecht ruhig gefallen lassen, und zwar um so mehr, je mehr es in der Weise der Engländer wesentlich empiristisch-utilitarisch konstruiert war. Aber auch mit dem sophie die ratio scripta und die historisch-positive Ausformung des Naturgesetzes war, im Geist und Sinn identisch mit dem Dekalog. Ganz deutlich ist dieser Hergang in der Entwickelungsgeschichte des Hugo Grotius, der von Hause aus einem innerlich uncalvinistischen Kreise angehört und aus der Stoa heraus, bei der schon utilitarische und idealistische Elemente eigentümlich gemischt sind, seine ethische, geschichtsphilosophische und juristische Theorie entwickelt, ganz unabhängig von allen Konfessionen, vgl. die bald erscheinende Heidelberger Dissertation von W. Geibel über > Ethik und Theologie des H. G.\& Weiteres zum Einzelnen der Emanzipation vgl. Gierke, Althusius ${ }^{2}$ und Figgis, From Gerson to Grotius; zum Ganzen Bluntschli, ,Gesch. des allgemeinen Staatsrechtes und der Politik \& 1864 und die gegen die tiefen ethischen Gehalte des Naturrechtes ganz unempfindliche Kritik desselben bei Bergbohm ?Jurisprudenz und Rechtsphilosophies 1892; es ist doch schwer zu sagen, wie nach der Zersetzung der kirchlichen Gesellschaftslehre die moderne anders hätte einsetzen können und sollen. 
rationalistisch-idealistischen, von der Autonomie und Gleichheit der Einzelvernunft ausgehenden französischen Naturrecht konnte man sich abfinden, wie das die Calvinisten Neu-Englands im 18. Jahrhundert zeigen. So ist es zu begreifen, wenn der Neu-Calvinismus sich stark naturrechtlich gebärdet und das Recht dafür aus den bereits charakterisierten rationalistisch-naturrechtlichen Ansätzen bei Calvin sich dogmengeschichtlich sichert. Der theokratische Geist ist aus ihm völlig verschwunden ${ }^{416}$ ').

Er überträgt das Prinzip der Bildung aller Gemeinschaft durch Association auf alle Lebensverhältnisse und strahlt die Neigung zur Vereinsbildung nach allen Seiten aus für kirchliche und religiöse, sowohl als bürgerliche und kulturelle $Z$ wecke; an Stelle der Stiftungen, Anstalten, Korporationen, der erblich gebundenen ständischen und zünftigen Fideikommisse tritt der Grundsatz der

416 a) Bei Roger Williams ist in seinem Bloudy tenent einer der wichtigsten Gedanken die Möglichkeit eines nach Naturgesetz und zweiter Tafel erfolgenden Aufbaus der Gesellschaft und des Staates ohne Eingriff des Staates in die Majestätsrechte der rein geistlichen Kirche, aber auch. ohne Bedürfnis der bürgerlichen Moralitắt und Zweckmäßigkeit, sich an dem Christentum eine Stütze zu schaffen. Auch Heiden, Juden und Türken sind zu einer ausreichenden politischbürgerlichen Moral befähigt, die mit der christlichen faktisch immer zusammenpassen wird, da ja das Naturgesetz nur die zweite Tafel des Dekalogs ist. Damit verbunden ist bei R. W. die rein äußerlich-utilitarische Auffassung des Staates, wie das aus gleichen Gründen bei Locke (über ihn das schon erwähnte Buch von Bastide) der Fall ist. Werden dem kirchlichen Staatsbegriff die religiösen Pflichten und Inhalte genommen, so fällt er gänzlich dem Utilitarismus anheim. Ueber Bayle s. Jodl, Gesch. der Ethik $\mathrm{I}^{2}$ 420, über Milton, Stern, Milton und seine Zeit 1877 -99. - Den bruchlosen, von innen heraus sich vollziehenden Uebergang des kirchlich-calvinistischen Naturrechts zum rein rationalistischen, zeigen auch die von Hägermann geschilderten Neu-England-Amerikaner, insbesondere der von ihm als eigentlicher Vater des amerikanischen Systems gefeierte Otis, S. 44-58. Wer von der calvinistischen Staatslehre herkommt, sieht hier überall den calvinistischen Stamm und die rationalistisch-naturrechtliche Korrektur und Fortbildung. Hägermann zitiert S. 52: Derjenige, welcher die Lehre des unbegrenzten passiven Gehorsams und der Widerstandslosigkeit bei den Menschen durchsetzen will, ist nicht nur ein Nero oder Schurke, sondern auch ein Rebell gegen den gesunden Menschenverstand wie gegen die Gesetze Gottes, der Natur und seines Landes. \& Damit verbindet er die Freiheit des Gewissens und die Verwerfung der Priester- und Kriegskaste, wie unter Berufung auf Saul auch Roger Williams gelehrt hatte S. 53. So verglich man ihn in Boston mit Jesaja und Hesekiel S. 47. Das ist doch deutlich calvinistische Atmosphäre. Beispiele für diese Entwickelung finden sich bei Hägermann noch mehrere. 
freien Vereinsbildung, wie Staat und Kirche im Grunde ja auch Vereine sind. Er betont auf Grund der Einerleiheit des biblischen und natürlichen Gesetzes die Zusammenwirkung von Christentum und Humanität in einem dem alten Calvinismus unbekannten Sinne. Von da aus entwickelt er eine pazifistische internationale Gesinnung und Propaganda, vertritt die Menschenrechte und begünstigt die Antisklavereibewegung, verbindet sich mit philan. thropischen und humanitären Bewegungen. Auch die Frauenbewegung findet bei ihm Wurzeln, lange ehe die andern Konfessionen auf sie einzugehen wagten. Die christlich ernsten Bestandteile des amerikanischen und englischen Protestantismus in England unter dem Einfluß der Evangelikalen auch ein großer Teil der Staatskirche - vertreten die charakteristische menschenfreundliche, freiheitliche und kosmopolitische Ethik des Liberalismus ${ }^{417}$ ). So hat schon Cromwell die naturrechtliche salus publica mit dem christlichen Heilsgedanken für vereinbar gehalten und eine relativ modern-liberale und utilitarische Politik mit seiner Idee des christlichen Staates verbunden. Vor allem aber interessant

417) Hierzu vgl. den oft angeführten Aufsatz von Max Weber s Kirchen und Sekten in Nordamerika und Antikritisches. S. 202; Tocqueville, Démocratie en Amérique; y. Schulze-Gävernitz, Deutscher Imperialismus und englischer Freihandela S. 42-64; Hartmann, Englische Frömmigkeit . Sehr interessant ist bei Rothenbücher S. 149-165 zu sehen, wie das amerikanische Recht vom Assoziationsgedanken aus dem kirchlichen Anstaltsgedanken durch zweckmäßige Fiktionen gerecht zu werden versucht. Hier stoßen zwei Welten soziologischen Denkens aufeinander. - Dieser Zusammenstoß ist auch hübsch illustriert in dem Referat über Lockes Argumentation gegen den Patriarchalismus und gegen den Anstaltsgedanken bei Bluntschli S. 173 : $>$ Das (gegnerische) Argument heißt, die Nachkommen werden durch ihre Väter gebunden, und dieses Argument ist falsch. Der Vater hat kein Recht, die Freiheit des Sohnes wegzugeben. Wenn dieser zum Manne wird, ist er nicht minder frei als der Vater war. Weil die Staaten da sind und die Kinder als abhängige Familienangehörige geboren und erzogen werden, weil das Land und die Güter dauernd beherrscht werden, weil da nur einer nach dem andern, nicht gleichzeitig die Menge, volljährig und frei wird, so übersieht man den Akt der Freiheit, den der volljährig Gewordene übt, indem er sich dem Staate vereinigt. Es steht ihm frei, einen andern Staat $2 u$ wählen.e Das ist in der Tat der Angelpunkt, und die Analogie zu dem Sektengedanken liegt auf der Hand, dessen Wesen es ist, daß man nicht unmündig in eine Anstalt hineingeboren werde, sondern reif und bewußt einer Freiwilligkeitsgemeinschaft beitrete, daher nicht Kindertaufe, sondern Spättaufe. - Dabei erinnere man sich, wie umgekehrt Gierkc in seinem Genossenschaftsrecht den mittelalterlichen Begriff der Korporation, der Anstalt, der Staatseinheit von der Analogie des kirchlichen Corpus mysticum herleitet. 
ist in dieser Hinsicht der große moderne Vertreter der christlichen Politik, Gladstone. Er war zwar Anglikaner, näherte sich aber immer mehr dem Dissent und war politisch-ethisch von dessen Ideen bestimmt, nicht von anglikanischen. So hat er aus ethischen Gründen den Liberalismus befördert, das Stimmrecht erweitert, schiedsrichterliche Behandlung auswärtiger politischer Fragen für möglich und wünschenswert erklärt. Seine Politik war eine bewußt christliche und legte für das profane Gebiet ebenso bewußt das natürliche Recht zu Grunde. Hält man dem die Idee des christlichen Staates bei Julius Stahl und Bismarck gegenüber, so erhellt der ganze Unterschied der kontinental-lutherischen und der angelsächsischen, calvinistisch bestimmten oder beeinflußten Ideenwelt. Daß aber diese Unterschiede nicht an dem Angelsachsentum liegen, das zeigt der Umstand, daß der holländische Exminister Kuyper eine ähnliche liberal-naturrechtliche Auffassung für die profanen Angelegenheiten vertritt. Der Neu-Calvinismus ist in all diesen Dingen weit von Calvin abgerückt, was Kuyper vergeblich zu verdecken sucht; dabei ist er formell in der Behandlung der weltlichen Dinge dem modernen Liberalismus und Utilitarismus sehr nahe gekommen, und dieser hat an ihm eine der großen moralischen Kräfte, die ihm auf dem Kontinent fehlen. Von der abstrakten französischen Doktrin der Demokratie und des egalitären Naturrechts unterscheidet er sich dabei immer noch tief genug und meistens mit vollem Bewußtsein ${ }^{418}$ ).

${ }^{418}$ ) Sehr lehrreich ist hier die Biographie Gladstones von Morley 1903. Gladstone arbeitete sich vom anglikanischen Toryismus zu einer Verbindung von Calvinismus und Liberalismus durch, die für die innere Gestaltung Englands entscheidend geworden ist und bis heute inre Hauptstütze am Dissent hat. Die bei uns übliche überlegen ironische Behandlung des großen Staásmannes ist charakteristisch für den UAterschied der beiden geistigen Welten. Sein konservativer Nachfolger Salisbury nannte ihn sthe great Christian\&, und der Biograph bemerkt dazu: nothing could be more trie or better worth saying. He not only accepted the doctrines of that faith as be believed them to be held by his own communion; he sedoulously strove to apply the noblest moralities of it to the affairs both of his own nation and of the commonwealth of nations I 4. Eben deshalb nahm er auch wenigstens partiell das Disestablishement in Aussicht. Er trennte die Sphären des Naturrechts und der Kirchen, jene dem Staat und diese der Offenbarung und ihren verschiedenen Deutunger: vorbehaltend; vgl. ein charakteristisches Wort G.s uber sthe higher ground of natural justice : es ist sthat justice which binds man to man; which is older than Christianity, because it was in the world before Christianity; which is broader than Christianity, because it extends to the world beyond 
In der Entwickelung des Calvinismus zum Freikirchentum kam - so darf man beim Ueberblick über diese ganze EntChristianity; and which underlies Christianity, for Christianity itself appeals to ito I 563; es ist ihm z. B. die Regel für den Chinakrieg. Allerdings bemerkt Erich Marcks hierzu, daß diese christlich-moralische Politik nur möglich gewesen sei, weil (jladstones Vorgänger die englische See- und Weltherrschaft bereits unbestreitbar gemacht habe, wodurch der Luxus einer moralischen Politik für Gladstone erst möglich geworden sei, daneben habe er glückliçherweise Disraeli als Vertreter der antgegengesetzten Politik zur Ergänzung gehabt; s. Marcks, Die Einheitlichkeit der englischen Auslandspolitik 19ro. Heute erleben wir wieder die gleiche moralisch-liberale Begründung der inneren englischen Politik. Hierher gehört such die Fahrt englischer Geistlicher nach Leutschland im Interesse des Friedens. Charakteristisch ist die Noriz, die ich in einem Kirchenblatte einst gelesen habe, wo ein deutscher Generalsuperintendent mit höchstem Erstaunen berichtet, daß sein überaus frommer Gastwirt ihn in voller christlicher Gemeinschaft beherbergt habe, ilım aber wie etwas Selbstverständliches mitgeteilt habe, daß in demselben Gastzimmer vor einiger Zeit sein Freund, der radikale Liberale Theodor Barth, gewohnt habe. Das ist allerdings auf dem Boden des Luthertums nicht müglich, und diese Lnmüglichkeit ist eine der großen Schwierigkeit in der geistigen Lage Veutschlands. - Uebrigens ist dabei nicht zu übersehen, daß der englische I.jbcralismus auch eine stark antireligiöse, rein utilitarische Strömung im Sinne Benth:ms und Mills hat. - Typisch ist auch hier Kuyper, der von Gladstone : $: 4$, dafo er sals christlicher Staatsmann Calvinist in Mark und Bein war« (S. 195). Er spicht von einem sheiligen demokratischen Sinn. S. 2 I. $\rightarrow$ Im Calvinismus sieht man zuerst das Volk in seinen breiten Schichten selber zum Vorschein kommen uinl aus cigener Spontaneität sich um eine höhere Form menschlichen Zusammenlebens bewerbene S. 3I. In diesem Weltbezirk waltet die sallgemeine Gnadea, dic sschüpfungsordnung oder die Lex naturae. Wir haben in der Welt die Wirkung von Gottes allgemeiner Gnade zu ehren, haben aus diesem Grunde die Welt win kirchlichen Banden zu befreien und selbst in ihr zu verkehren S. 24. -.1lles, was unter Menschen regelrecht aus der Schöpfung hervorgeht, besitzt alle Viraussctzungen zu e ig e ne $\mathrm{r}$ (d. h. kirchenfreier) Entwickelung in der $\mathrm{Nat}$ u r als solcher... Es ist allzumal Schöpfungsleben nach Schöpfungsordnungen, und zwar in uranischer Entwickelung* S. 84. „So trat die Kirche zurück, um nichts melir und nichts anderes zu sein als die Versammlung der Gläubigen, so wurde das Lelien der Welt auf allen Gebieten nicht von Gott, sondern von der Herrihaft der Kirche emanzipiert... So gewann das häusliche Leben seine Selbtïndigkeit wieder. Handel und Gewerbe sahen sich in Freiheit auf eigene Kraft angewirsen; Kunst und Wissenschaft wurden von den kirchlichen Banden gelöst und ilırer eigenen Inspiration zurückgegeben und die Unterwerfung der ganzen Nitur unter die Menschen, entsprechend der von Gott im Paradies gegebenen Chöpfunrsordnung, verstanden S. 23. ,Grundgesetzliche Rechte S. 90. ,In der Declaration of Indepence spricht John Hancock es mit andern Worten aus, daß 
wickelung sagen - dasjenige Element zur Befreiung, das von Hause aus in dem Gedanken der Heiligungsgemeinde gelegen hatte, das

Amerika kraft ,the law of nature and of natures God' auftrat, daß man als ,endowed by the creator with certain unalienable rights' handelte, ... daß man seine Declaration, with a firm reliance on the protection of Divine Providence' ausgehen ließ. S. 79. Dieses Naturrecht ist rein utilitarisch : "Gerade in $\mathrm{de} \mathrm{m} \mathrm{Woh} \mathrm{le} \mathrm{r-}$ g e h e $\mathrm{n}$ auf Grund seiner (Gottes) Anordnungen muß seine göttliche Weisheit zum Vorschein kommen* S. 74. Das ist freilich amerikanisierter Neucalvinismus: - Dorthin (nach Amerika) hat sich der Calvinismus verpflanzt, um sich in höherer Freiheit zu entfalten S. 30. Das Gesamtbild dieses Neucalvinismus S. 33 : "Denken Sie daran, wie erst durch den Calvinismus der Psalm der Freiheit aus dem beengten Gewissen zu den Lippen sich drängte, wie unsere konstitutionellen Bürgerrechte erst durch den Calvinismus erobert und gesichert worden sind, und wie zugleich gerade von Westeuropa jene mächtige Bewegung ausging, die Kunst und Wissenschaft aufblühen ließ, dem Handel und Gewerbefleiß neue Bahnen erschloß, das häusliche und gesellschaftliche Lében glänzend gestaltete, den Bürgerstand zu Ehren erhob, den Arbeiter als gleichberechtigt neben seinen Patron stellte, die Philanthropie zu reichem Wachstum brachte und über dies alles durch puritanischen Ernst das sittliche Leben der Menschheit erhöht, gereinigt und geadelt hat S. 33. Der Staat ist für Kuyper heute noch eine Stiftung des relativen Naturrechts des Sündenfalls, eine smechanische<, über dem naturrechtlichen Kosmos der Gesellschaft aufgerichtete Autorität zur Repression des Bösen, aber eben darum sorgfältig einzugrenzen, damit er nicht in die Menschenrechte eingreifen könne S. 86. Mit all diesen demokratisch-liberalen, freikirchlich-toleranten, utilitarisch-naturrechtlichen Prinzipien ist Kuyper der Führer der Orthodoxie und der mit den Katholiken verbundenen Reaktion, wie auch die amerikanischen und englischen Calvinisten in der Regel recht orthodox sind und die Kirchen noch immer sehr fest binden. Der Gegensatz gegen das französische Naturrecht der Egalität S. I73 f. - Damit stimmt überein (bis auf die Gleichheit) der Satz der amerikanischen Unabhängigkeitserklärung (nach Jellinek S. 9) : $\gg$ Wir halten die nachfolgenden Wahrheiten für in sich überzeugend, nämlich, daß alle Menschen gleich geboren sind, daß sie von ihrem Schöpfer mit gewissen unveräußerlichen Rechten ausgestattet sind, daß zu diesen Leben, Freiheit und das Streben nach Glückseligkeit gehören, daß, um diese Rechte zu sichern, Regierungen unter den Menschen eingesetzt sind, die ihre gerechten Befugnisse von der Einwilligung der Regierten ableiten; daß, so oft eine Regierungsform gegen diese Ziele zerstörend wirkt, es das Recht des Volkes ist, sie zu ändern oder abzuschaffen, eine neue Regierung einzusetzen und sie auf solche Grundsätze zu bauen und deren Gewalten derart zu ordnen, wie es ihm zu seinem

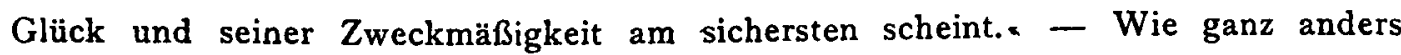
unter dem Einfluß des Luthertums die Staatsauffassung in Deutschland geblieben und wie dieser Begriff vom Kulturstant hier heute noch für viele die Aufnahme der religiösen. Lebenszwecke in die Staatsaufgaben bedeutet, das zeigen insbesondere die Versuche, die Trennung von Staat und Kirche deutsch zu verstehen bei 
aber dort mit dem Gedanken der Einheit der christlichen Gesellschaft und dem Grundsatz ihrer alleinigen Verbürgung durch die Zwangseinheit des Glaubens verbunden gewesen war. Die Lösung beider erfolgte erst unter dem Druck der englischen Revolution und unter Mitwirkung spiritualistischer und täuferischer Einflüsse. Ihre Folge war dann die völlige Beseitigung jenes Gesellschaftsideals der Konformität und die Anheimstellung der profanen Soziallehren an ein gänzlich utilitarisch verstandenes Naturrecht, während die christlichen Maßstäbe unmittelbar lediglich in den Kirchen gepflegt werden und aus der kirchlichen Pflege heraus erst als geistig-soziale Macht in die Gesellschaft hineinwirken. Für die dabei sich ergebende schliëßliche Zusammenstimmung beider bürgt dem Glauben heute noch die Herkunft des Naturrechts von demselben Gott, von dem die Kirche kommt. So können diese calvinistisch bestimmten Völker trotz Preisgabe der äußeren Konformität an eine fortdauernde innere glauben. Wie lange noch, das hängt davon $a b$, wie lange sie von beiden Lebenskreisen die spezifisch moderne Kritik fernzuhalten verstehen und die praktischen Angelegenheiten des Lebens für leicht durch den natürlichen common sense gestaltbar ansehen. Diese Völker kennen bis jetzt noch die moderne Welt wesentlich nur als politisch-sozialwirtschaftlich-technische Entwickelung und haben es verstanden, sich mit ihrer Religion auf diese einzurichten ${ }^{419}$ ). Freilich ist darin seit DarOtto Mayer, Staat und Kirche in $\mathrm{PRE}^{\mathbf{3}}$ und E. Förster, Entwurf eines Gesetzes betr. die Religionsfreiheit I9II, bes. S. 39 und 47 mit Berufung auf den Freiherrn v. Siein und ITegel; hier bleibt der Staat daran interessiert, mit den ihm zustehenden Mitteln äußerer Kirchenpflege die Einheit und den Fortbestand der großen Hauptreligionen zu unterstützen, weil er nicht rein rationell-utilitaristisch verstanden wird. Das gleiche Interesse bei Max Lenz, Nationalität und Religion, Preuß. Jahrbb. 1907, auch hier auf der Grundlage lutherischer Empfindungen.

419) S. 2. B. Kuyper S. 184: J.Der Calvinismus ist der Gipfel des Fortschritts ; der ,Modernismus' ist kein Fortschritt, da er keine eigenen neuen Ideen hat. Der materielle Fortschritt dieses (19.) Jahrhunderts hat nichts mit dem Fortschritt auf dem Gebiete der Prinzipien zu tun.e So hat auch der Pietismus technischen und naturwissenschaftlichen Unterricht als völlig neutral mit der dogmatischen Orthodoxie $2 u$ vereinigen gewußt. Die brauchbare moderne Philosophie sind die $>$ Realien und der $>$ Realunterrichte. Orthodoxie, Naturwissenschaft und Technologie sind hier wohl vereinbar: , Unsere reformierte Konfession spricht von zwei Mitteln, wodurch wir Gott erkennen, der Natur und der Schrift, und noch viel bemerkenswerter ist es, wie Calvin, weit entfernt davon, hierbei die Natur zu vernachlässigen, vielmehr die Schrift nichts anderes als eine Brille nannte, die uns in Stand setat, 
win, Herbert Spencer, Bentham, John Stuart Mill und Ruskin vieles anders geworden und wird es zunehmend anders.werden.

Nun aber konnte dieses dem Calvinismus eingestiftete Element der Heiligungsgemeinde sich auch auf andere Weise auswirken als in dem Kongregationalismus und dem Freikirchentum, die bald auch unitarischen, aufklärerischen und intellektuellen Besonderheiten dienstbar wurden und heute noch sind; insbesondere der moderne Kongregationalismus betont gerne die Verwandtschaft seiner Gewissensfreiheit mit dem wissenschaftlichen Wahrheitssinne $\left.{ }^{420}\right)$. Es konnte sich vielmehr auch als bloße Steigerung der Heiligungsidee und Askese innerhalb der Kirche entwickeln und hat das getan in dem sog. Puritanismus, Präzisismus und Pietismus. Auch diese Entwickelung lag von Hause aus im Wesen des Calvinismus. Pflegt man doch den Calvin stark beeinflussenden Butzer den sPietisten unter den Reformatoren $* \mathrm{zu}$ nennen und Calvin selbst als Rigoristen zu bezeichnen. Aber auch hier mußte diese Tendenz erst durch bestimmte Verhältnisse befreit und vereinseitigt werden. Sie trat die göttliche Schrift der Schöpfung, die verwischt und entstellt war, wieder zu lesen S. II3. „So blieb man ein Pilgrim, aber ein Pilgrim, der auf dem Weg zum ewigen Vaterland noch eine unermeßliche Aufgabe zu erfüllen hatte. Weit breitet sich vor, über und unter dem Menschen der Kosmos mit allen Reichen der Natur aus. Dies ganze unabsehbare Feld mußte bearbeitet werden. Die Erde mit allem, was in ihr ist, mußte dem Menschen unterworfen werden. So erblühten in meinem jetzigen Vaterland Industrie und Landbau, Handel und Schiffahrt wie nie zuvor. Das neue Leben der Bürgerschaft weckte neue Bedürfnisse. Um die Erde sich zu unterwerfen, war die Kenntnis dieser Erde, ihrer Meere, ihrer Natur, der Eigenschaften und Gesetze dieser Natur notwendig* S. 122. So hat man sich die Orthodoxie so vieler großer englischer Naturforscher zu erklären. Auch die ganz andere Stellung der Mission bei diesen Völkern erklärt sich von hier aus nicht bloß aus ihrem kolonialen Bedürfnis und Verständnis, wenn auch Interessen hierbei selbstverständlich mitspielen. Es ist eben hier überall die Möglichkeit sto make the best of both worldse (s. Dowden S. 275).

${ }^{420}$ ) S. Powicke mit starker Betonung des spiritualistischen Elementes im aiten Kongregationalismus S. 218 : A result of hist two first principles working in combination: his faith in the inner light and his reverence for the written word. For faith in the inner light, at least, in the case of the more deeply thoughtful and devout of its disciples, really meant faith in the highest intentions of spirit u a 1 rea s o $n$; and this, when brought to a study of the written Word could not fail to operate selectively, fastening on what was agreeable to the most worthy conception of God and man and tacitly ignoring all else.e So vollzog sich von ihm aus die Abzweigung des Unitarismus. 
hervor erst unter den Bedingungen eines breiten allgemeinen Volkslebens, das den echten Calvinismus mit Verweltlichung bedrohte und das die Ideale Calvins nicht mehr einfach mit dem Zuchtgericht im Genfer Stil lösen konnte oder durfte. In Genf selbst, in dem von dem großen politischen Kampf gänzlich beschäftigten Hugenottentum, in dem nach Genfer Grundsätzen konstituierten Schottland hört man nichts davon. Dagegen hat der Präzisismus in dem von der Staatskirche geleiteten old merry England, in den niemals völlig calvinisierten und vor allem das Zuchtgericht einschränkenden Niederlanden, in den unter niederländischem Einfluß stehenden westdeutschen Landschaften und in dem vom Methodismus aufgerüttelten Amerika sich mächtig entwickelt und von da aus auch das französische und schweizerische Kirchengrebiet im I9. Jahrhundert erfaßt. In Deutschland hat das gleichfalls mit der Gefahr der Verweltlichung und vor allem der dogmatischen Erstarrung ringende Luthertum eine ähnliche Reformbewegung - nicht ohne Anstoß und Beispiel des reformierten Pietismus eröffnet; von da $\mathrm{ab}$ sind überhaupt die Absperrungen zwischen Luthertum und Calvinismus gemildert worden. Heute liegt der ganze Kontinent unter dem stärksten Einfluß angelsächsich-pictistisch-methodistischen Wesens.

Der englische Calvinismus, in der Zeit Eduards VI. begründet, war von Cambridge her, wo Butzer gewirkt hatte ${ }^{421}$ ), und von London her, wo Laskis Fremdengemeinden ein Vorbild gaben ${ }^{422}$ ), von Anfang an im Sinne der Innerlichkeit und der Lebensstrenge becinflußt. Fir wurde dann yon den unter Elisabeth aus Europa zurückkehrenden Exulanten stark dem Genfer Ideal an-

4:1) S. Harrey, Fuzer in England, 1906 (Marburger Diss.) mit interessanten Mitteilungen über Butzers sozialpolitische Vorschläge aus De regno Christi S. 77 bis $S_{5}$ : schon hicr der Kampf gegen Einhegungen, Monopole und schlechte Justiz.

422) Hieriber s. ';öbcl, Christl. Leten I 318-35I. Schon hier begegnen die Demokratisierung der (jemeindeverfassung und die strenge Abhebung gegen die Welt, auch die Prophesyms. Charakteristik der puritanischen Prophesyings bei Heppe 20: Der ganze Akt war won dem Gedanken getragen, daß das Christentum notwendig Leben, und zwar ein ernstes, ganz und gar vom Worte Gottes beherrschtes und streng geregeites Leben sein müsse, in welchem der Christ sich nicht gehen zu lasen, sondern sich unablässig zu üben, sich selbst im Angesichtc des Wortes Gottes zu prüfen und durch anhaltendes (jebet, durch Meditation und Jurch Fasten, überhaupt durch methodische und aszetische Uebung in der Gottseligkeit einer inmer vollkommeneren Heiligung nachzustreben habe.c Man beachte hier auch die Askese. 
genähert und war mit den Schotten in beständigem Austausch begriffen. So teilte er sich allmählich in drei große Hauptströmungen, die oft ineinander übergingen. Es, war einerseits der Presbyterianismus, der von Cartwright zur schärfsten Formulierung gebracht wurde und durch die Hilfe der Schotten in der Zeit des Langen Parlamentes die Hoffnung hatte, Staatsreligion zu werden. Es ist echter, durch die Synodalverfassung über ein großes Volk ausgebreiteter Calvinismus, der einer näheren Schilderung hier nicht bedarf. Es war zweitens der Kongregationalismus, der in den niederländischen, neuenglischen und schlieflich auch in englischen Gemeinden ein ganz neues Prinzip der staatsfreien und die Einzelgemeinden verselbständigenden Kirchenverfassung einführte. Seine Bedeutung haben wir soeben kennen gelernt. Es war schließlich der Puritanismus im engeren Sinne oder der Präzisismus und methodische Rigorismus, kurz der Pietismus, der ohne besondere Kirchenverfassungsplänc eine rein praktische Bewährung des christlichen Glaubens wollte und die calvinistische Theologie in ein "studium pietatis " überführte ${ }^{423}$ ). Diese Gruppe ist es, auf die in unserem Zusammenhang jetzt die Aufmerksamkeit zu richten ist. Ihr gehörten Männer der verschiedensten kirchlichen Gruppierungen an, Presbytcrianer, Anglikaner, Kongregationalisten, Baptisten. Auch in dem Cromwellschen Independentismus war er mit einem starken Zusatz von Mystik und Enthusiasmus in viel höherem Grade die treibende Nacht als die kongregationalistische Kirchentheorie, von der er seinen häreseologischen, sehr wenig besagenden Namen empfangren hat. Cromwell selbst hat wohl vor allen dieser Strömung angchürt

423) Ueber den Namen und seine Geschichte s. Douglas Campbell, The puritan in Holland, England and America ${ }^{4}$ Igoz I S. XXVII; Kattenbusch, Art. Puritmer in PRE. ${ }^{3}$, der den Puritanismus hier geradezu identisch erklärt mit Pietismus; Heppe, Gesch. des Piet., S. 6. Die Titel praxis pietatis u. ä. sind aucl in der englischen Literatur häufig, Heppe S. 23, 30. Die Bezeichnung Precisians or Puritans and now lately Martinists" gebraucht schon Barrow, der letztere Name von den: Marprelate-Briefen hergeleitet Powicke S. 149. Ein anderer unendlich oft wiederkehrender Name int Codliness und Saintlinnes, the godly men oder the saints. Wcingarten hat diese Richtung als solche leider nicht charakterisiert und erkinui, wic Heppe S. 14 mit Recht hervorhebt; so hat er auch ihr Verhältnis zu Presbyterianismus, Kongregationalismus und Täufertum nicht deutlich gemacht; aber erst be: diesen Scheidungen. wirl der Sammelbegriff sIndependentismus einigermaljen durchsichtig. - Die Gegner namnte man nach altem Genfer Gebrauch auch jetzt noc'. gerne $s$ Libertiner. 
und ist nur vorübergehend durch seinen Respekt vor den tatsächlichen göttlichen Führungen der Nation und durch sein abwartendes Zutrauen zu den neuen Offenbarungen von dieser Linie abgedrängt worden. Ihre besten Gedanken und besten Leistungen finden wir bei einem Mann wie Baxter. Aber auch an den Erbauungsbüchern des baptistischen Kesselflickers Bunyan stärkt sich bis heute das ganze pietistische England, wie auch der kontinentale Pietismus.

Die Bewegung begann mit den Angriffen auf die katholischen Elemente des Anglicanismus, den Forderungen des Zuchtgerichtes und der Sammlung reiner Abendmahlsgemeinden. Sie wurde dann aber unter den Stuarts zu einer eigentlichen Erweckungsbewegung, zur Forderung einer zweiten Reformation, die der Reform der Lehre die des Lobens folgen läßt und die persönliche Innerlichkeit und Heiligkeit als das wahre Wesen der Christen verwirklichen will. Charakteristisch für sie sind die Phrophesyings oder Besprechungen der Gemeindeglieder mit ihren Pfarrern über die Predigt und Texte der Bibel; die Hausandachten, in denen der Hausvater die Familie katechisiert und kontrolliert; das Interesse an genauem Jugendunterricht in den Heilswahrheiten, da jeder selbst alle Bedingungen des Heils kennen muß und die Unwissenheit zur Verdammnis führt, wie Bunyan anschaulich zeigt; das freie Gebet an Stelle der toten Liturgien; die strenge methodische Heiligung und Selbstkontrolle, womit die Selbstbiographien und Tagebücher, sowie die Forderung der Meditation zusammenhängen; die Vermeidung aller profanen Lustbarkeiten und die strenge Selbstunterscheidung von den unbekehrten Kindern der Welt oder des Naturstandes; die Forderung asketischer Uebungen und vor allem angestrengtester Arbeitsamkeit als des besten Mittels seelischer und körperlicher Disziplin; die Kasuistik und die sorgfältige Gewissensforschung und -beratung, verbunden mit der eingehendsten Seelsorge; die Volkstümlichkeit und die Fürsorge für Volksschulen und Volkshebung; die äußerste Einfachheit des Lebens in Kleidung und Komfort, die aber eine würdige Gediegenheit nicht ausschloß; die praktische Lebenstüchtigkeit, Zuverlässigkeit und Ehrlichkeit in allen Berufen, die sich in einer sehr erheblichen praktisch-politischen, soziaten und geschäftlichen Tätigkeit zeigt; schließlich die Unions-Gesinnung, die bei der alleinigen Wertlegung auf praktische Erfahrung und heilige Bewährung die Grenzen der protestantischen Denominationen verwischt und alle in der pietistischen saintliness einigt. 
Sie stehen damit in bewußtem Gegensatz zu der Renaissancestimmung und -Literatur der Elisabethanischen und Stuartschen Zeit, auch gegen die Politik und die wirtschaftlichen Maßnahmen der Feudalen, die in den großen Monopolisierungen und den Einhegungen zum Ausdruck kamen. Bekannt ist der Haß Shakespeares gegen diese sinnenfeindlichen Pietisten und der Hohn Buttlers über ihre theologische Enge und Pedanterie. Thr Unterschied gegenüber dem primitiven Calvinismus ist ein viel weiter getriebener Individualismus, der Gott und die Seele trotz aller Gnadenmittel einsam und unmittelbar einander gegenüberstellt; die eingehende Schätzung und Prüfung der guten Werke als Zeichen der Erwählung, womit eine dem echten Calvinismus in diesem Maße unbekannte Gesetzlichkeit und Selbstgerechtigkeit, Methodik und Askese einzieht; damit der Geist der isolierten individuellen Selbstkontrolle und asketischen Disziplin, der die Schätzung der Gaben und Offenbarungen Gottes in der Natur nicht ausschließt, aber doch die Kinder der Erwählung durch die Sprache Kanaans und durch die Strenge der Lebenshaltung von den Kindern der Welt und des Zornes abschließt. In alledem ist die Einwirkung neuer Motive unverkennbar. Die individualisierenden Wirkungen des Pradestinationsdogmas, die Brechung der strengen Kirchlichkeit durch ein Zeitalter kirchlicher Kämpfe, die Spaltung der Gesellschaft in Strenge und Laxe waren inzwischen eingetreten. Das ergab naturgemäß eine andere Lage als in dem strengen und einheitlichen Christenstaate Calvins. Vom lutherischen Pietismus andererseits unterscheidet sich dieser Puritanismus durch seine bei alledem doch ungebrochen kirchliche Haltung, durch die Abwesenheit des Bußkampfes und der momentanen gefühlsmäßigen Gnadenversicherung, durch die methodische Konsequenz der fortschreitenden Heiligung. Wie das Luthertum in der Rechtfertigung mit einem Schlage alles gewinnen läßt und in der Rechtfertigungsseligkeit die allein entscheidende Probe der Begnadigung findet, so sammelte sich die Hauptmasse des lutherischen Pietismus um Bußkampf und Gnadengefühle. Aber im Calvinismus liegt die Gnade in der vorzeitlichen, langsam und stufenweise sich auswirkenden Erwählung. So war im Puritanismus die Bekehrung eine allmählich sich selbst entfaltende Auswirkung der Prädestination und rechnete auf den sorgsam kontrollierten und gepflegten Fortschritt, nicht auf Gefühle, die auch der bloße Zeitglaube haben kann. Damit war dann auch die Kirchlich- 
keit leichter vereinbar, indem serade die Gnadenmittel diesen loortschritt vermitteln und von vorncherein bei ihrer spirituellen IFassun:s die Innerlichkeit des Glaubens nicht hindern. Als Gegengewicht wrsen dic Trockenheit und Strenge der Heiligungsaskese wurcle auch hicr die Mystik herangcholt. Aber, indem sie an den calvinischen Gedanken der insertio in Christum non otiosum anknüpfte, hat dic Mystik hier eine pralitischere und tätigere Richtung erhalten als die lutherische. Chiliastische Gedanken fehlten nicht, aber sic waren verhältnismäßig selten, und es ist dic Fragc, wieweit sic nicht durch Täufertum und Enthusiasmus hereingetracren worden sind. Insofern ist dieser calvinistisch-puritanische Pictismus ctwas anderes als der kontinentale. Fr ist die moralische Schule der (nglischen Mittelklassen gewesen, und hat sich nach den Ermattungen und Neubildungen des grofen englischen Aufklärungszeitalters schon im 18. Jahrhundert wieder erhoben, jetzt freilich in methodistischer Gestalt, die wohl mit den alten puritanischen Ueberlieferungen zusammenhing, aber doch wesentlich neue Elemente zugleich enthielt. Ueber ihn wird später bei der Darstellung der Sckte noch mehr zu sagen sein, da er schließlich zur Separation übergegangen ist. Der von ihm in England und Amerika in immer neuen Instürmen gegen die Aufklärung erzeugte Evangelikalismus bedeutet aber trotz verschiedener Abweichungen bis heute dic Macht puritanisch-calvinistischen Geistes und hat sich auch auf nicht-calvinistische Kirchengemeinschaften übertragen ${ }^{12 t}$ ).

424) Wichtigste Quellen: Works of the English puritan divines, London Is 45 his 48 ro Bb., ron lleppe und Max Weber ausgiebig benïzt. Aulieden Hepp,

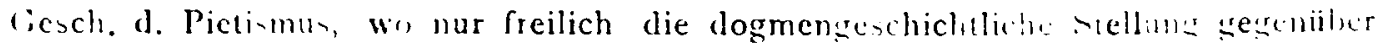

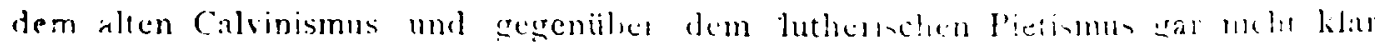

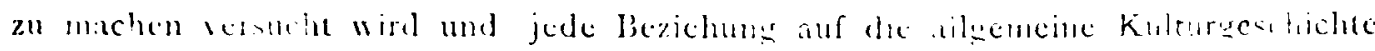

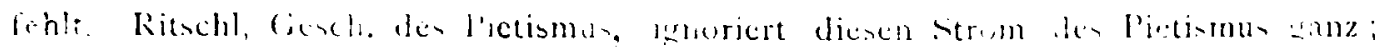

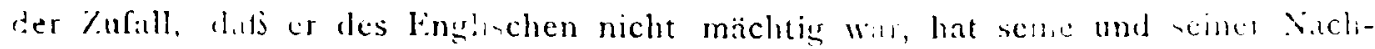

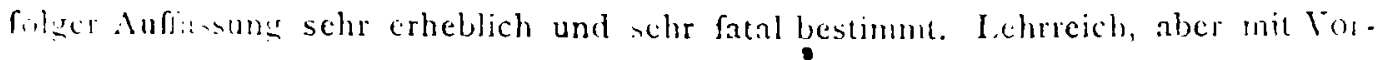
sich zu lemuten ist Douglas Campbell; er versteht unter Puritanismus iuberhaupt len individualistich-1 igonistisch gefaßsten Calvinismus und leitet von ihm fast die sesamte moleme anyclsächsische Welt her, crkennt darin die frundlage der mo-

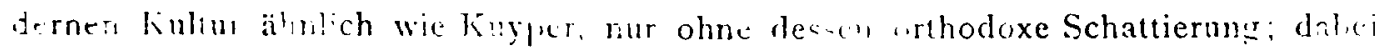
rechnct er auch die chlen mit in den l'usitanismus cin. Das zwcibändisc Werk hat eine vicrte Auflage erlangt, ein Zeichen, welches Echo solche Ansichten fmilu. loler den pictistischen Puritanismus als Conderuruppe gegenüber Presbyterianismus und Kongregationalismus s. auch Shaw, English Church I 6 f., 51-53; die achilderung des Puritanismus der letzten Jahre Elisabeths und der Stuartschen /cit im 
Die soziale \%usammensetzung des Puritanismus umfaßte anfangs Glieder aller Stände. lir ist aber in dem Maße, als er zum eigentlichen Heiligungs-Pietismus wurde, die Religion der Mittelklassen geworden und hat sich seit den Neubelebungen durch den Methodismus in Iingland und Amerika immer mehr als solche befestigt. I)r theologisch-klerikale Charakter wich vor dem I aieninteresse zurück,

Unterschied von dem ilteren, mehr von den Theologen getragenen und vom Genferischen Antikatholizisinus bestimmten bei Class 4-I3; es sci ein nrevivalism\&, vergleichbar dem späteren Methodismus. Ebenso Dexter, The lingland and Flolland of the pilgrims S. I $22 \mathrm{f}$.; es ist eine steformation within the reformation", ein sevangelical purpose $x$ : Diesen Puritanismus in seincm Zusammenfließen mit den Sekten schildert auch Max Weber, der ihn zugleich von dem primitiven (jenfer Calvinismus richtig unterscheidet. - Die Frage nach den Gründen der Eintstehun: dieser pietistischen, die Unterlage der great rebellion und der englischen ncueren Geschichte bildenden Strömung erhebt Douglas Camplell I cap. X; er führt sie auf den Finflufs der niederländischen calvinistischen Exulanten zurück, die 75000 Familienväter betrugen und von lilisabeth aus handels- und gewerl)epolitischen (iründen begünstigt wurden. These Netherlanders helped to make lingland l'rotestant, and this laid a lasting basis for her wealth; but at the same time liey did even a greater work than this; for in helping to make her Protestant they also helped to make her free.\&... It was protestant Ingland, that ultinately controlled the ocean and the markets of the world, colonized America and girled the earth with an empire. S. 429. - Ueber die kulturgeschichtliche Scite der ljewegungs. Taine, Hist. de la littérature.anglaise, II 1863 S. 275-4.35 und vor allem I lowilen, Puritan and Anglican, London 1900. Beide schildern den Weltgegensatz und die incthodische Askese, die aber nicht Zurückzichung, sondern aktive Beherrschung des Weltlebens sein will ; sehr fein ist bei Dowden die Schilderung der Säkularisation des puritanischen Geistes durch den Vergleich von Bunyan und Jefoe $274-78$; hier heilst es vom verweltlichten Puritaner: = To make the best of both worlds was the part of prudence, and of the two worlds that on which our feet are planted is, at least, nearer and the more sulmmissive to our control. Divine providence is doubtless to be acknowledged, but it is highly desirable to supplement Divine providence by self help. . . Alventurer. trader, colonist, missionary, we give him hail as one of our makers of cmpile. a Ueber den moralischen (jegensatz und die Opposition gegen die Jisabcthanisch. I.iterntur s. Campbell Douglas II I14-136. Der Gegensatz war nicht ohne guten (jrund und die literarische Schicht sehr dünn. Ilier auch die Krklärung der von Calvin sich sehr unterscheidenden (S. 15\%) Austerität der Puritaner aus dem Cegensat\% gregen die Weltlichkeit, Immoralitiit und Brutalität der Nalion S. 152-163, wo. bei übrigens das calvinistische Element sehr unterschätzt ist; soziale und politische Reformbestrcbungen S. 17I-176; s. auch die Würdiguug der (jesetzgebung des Barebone-Parlamentes, dessen unterliegende Minoritit aus solchen Pietisten bestand, bei Class; hicr standen Piclisten gegen täuferische linthusiasten. 
die vornehme und höfische Welt wurde durch die Revolution endgültig mit ihm entzweit. Seine Lebensformen paßten nicht für die hohen Beamten und die Seigneurie und konnten auch dem schwer zu brechenden Naturalismus der ländlichen Bevölkerung nur mit großen Einschränkungen aufgezwungen werden. Mit der Konstituierung der ganzen Richtung als Dissent neben der Staatskirche und neben der amtlichen Welt waren daher diese Gruppen von Hause aus auf eine wesentlich geschäftliche Existenz angewiesen. Nach Neu-England war diese bürgerliche Gesinnung des Mittelstandes von Anfang an durch die Pilgerväter übertragen und trotz der wirtschaftlich zunächst überaus primitiven Existenzbedingungen entwickelten sie dort den bürgerlich-kapitalistischen Charakter des vorherrschenden amerikanischen Elements, das schließlich über die aristokratischen Pflanzer- und Sklavenhalter-Kolonien des Südens gesiegt hat. Es ist die Gruppe, die politisch den Liberalismus trägt und die wirtschaftlich aus den schon im allgemeinen günstigen Grundbedingungen des Calvinismus mit besonderer Energie und mit nüchternem Welt- und Wirklichkeitssinn den Geist entwickelte, der dem bürgerlichen Kapitalismus dieser Völker die ideellen Grundlagen seiner breiten Massenentfaltung und Massenerfolge gab ${ }^{425}$ ).

425) Ueber die Klassenbeziehungen Andeutungen bei Glass S. 6 und 23 f., Dowden S. 255 f.; bes. Glass 32 : >Puritanism was a movement of the people, with not a few leaders from among the aristocracy. For a time its temper was high and courageous, hopeful and even andacious in new experiments. His religious spirit tended to abolish or to abate social distinctions : all mortal men were alike sinners before God, and, peer or peasant, if true members of the congregation, were equally saints. Its favoured ecclesiastical schema and plateformes were of a democratie kind. Its political ideal was not a loose and incoherent democracy; it aimed at vigour in government, and was willing to confer immens powers upon chosen individuals; but its political culmination was a Republic. S. 4 : The mundane spirit of the Renaissance (?) in its lower form of commercial interests by degrees allied itself with Puritanisme.s Später S. 275: =The middle classes advanced in wealth, power, and in influence. After the jagged precipices and forlorn valleys - scenes of spiritual exaltation or dispair - a table land was reached - safe, if unheroic - where man might plough and build.ब Energisch ist dem Problem Douglas Campbell nachgegangen, aber er löst das Problem eu äußerlich durch seine Lieblingslehre vom Einfluß der holländischen Immigranten, schildert aber den Sachverhalt selbst als Erhebung der Mittelklassen durch die religiöse Bewegung zu einer bis dahin unbekannten Bedeutung und dauernden Wirkung für die Emporhebung Englands und Amerikas über die übrige Welt, nachdem das Elisabethanische England 
Der niederländische Calvinismus hat eine ähnliche Entwickelung erlebt, freilich aber andere Ergebnisse hervorgebracht. Hier lagen bei der Fortdauer täuferischer Gemeinden und spiritualistisch-mystischer Richtungen, von denen später zu reden sein wird, sowie in der Herausbildung einer starken puritanisch-pietistischen Gruppe innerhalb des staatskirchlichen Calvinismus die gleichen Elemente bereit, die in England zu der Explosion der großen Revolution geführt haben. Allein es fehlte der Gegensatz einer verfolgenden katholisierenden Staatskirche und die innere politische Krisis

mit einer ganz dünnen Oberschicht der Renaissancebildung noch gänzlich hinter der Entwickelung Europas zurückgeblieben war; S. 483 f., 490 f., 492 : No people on earth have a higher order of virtue than the english middle classes. They bare a courage which never falters, an earnstness of purpose which brooks no obstacles, a love of justice and a fair play, a devotion to home and country, and an instinctive morality and real belief in a Higher Power which are not so common among the Latin races ... Their daily life was a sermon on the Christian virtues of industry, temperance and charity \&; 496: The opposition to the arbitrary power of the crown grew with the development of the industrial classes. The tiller of the soil, as Irish history has shown, can exist even when denied almost every human right. But manufactures and commerce require the air of freedom ... The wealth came, but with it the ideas and spirit that in next century (unter Cromwell) bred an revolution. s Die Abdrängung der Mittelklassen des Dissent von der offiziellen Welt und die Zuwendung - wie bei den Juden - zum Geschäft, zu kapitalistischem Betrieb der Landwirtschaft, der Manufaktur, des Handels unter Verstärkung durch Hugenotten II 401 , ihre Bedeutung für den Liberalismus des 19. Jahrhunderts II 404: $\gg$ In 1832 they forced the passage of the Reformbill, widening the suffrage. Then they began to look around for social, legal and other political reforms «. Dabei folgten sie jetzt dem puritanischen Amerika: Rejuvenated England has followed America in her system of popular education, freedom of religion, freedom of the press, the secret ballot, prison reform and the entire reformation of her legal system.\& Die Herkunft des secret ballot vom holländischen KirchenWahlverfahren s. II 437. Trotz der Herleitung dieser Dinge vom Puritanismus ist nun freilich der innere psychologische Zusammenhang von Campbell nicht aufgehellt. Insbesondere würde die Herleitung vom holländischen $\gg$ Puritanismus die Erklärung des letzteren notwendig machen, aber dort behandelt C. die Sache als Selbstverständlichkeit. In übrigen ist das Verhältnis des englischen und niederländischen Puritanismus ein wechselseitiges, wo die Einflüsse herüber und hinüber gehen. Aehnliche Charakteristiken der englischen Mittelklassen bei Held S. 48. Den bei diesen Autoren nur angedeuteten Zusammenhang hat Weber in seinen of genannten Aufsätzen mit feinster Psychologie erläutert und erklärt. Ueber die Uebertragung dieses Geistes nach Neu-England und durch die Holländer nach New-York s. Douglas Campbell II und Doyle, The English in America. 
des Regierungssystems. Vielmehr hatte hier die bürgerliche Republik sich von vornherein in annühernder Uchereinstimmung befunden mit den profanen Idealen des Calvinismus, und auch seine kirchlichen Ideale fanden schließlich eine leidliche Verwirklichung. So kam es hicr nur zur llerausbildung einer stark asketisch und rigoristisch gefärbten Richtung der Präzisen, Ernstigen, Feinen, die im Kulturgegen:atze gegen den humanistischen Renaissance-Geist und gegen die Begleiterscheinungen eines märchenhaften, alle europäischen Völker überflügelnden wirtschaftlichen Aufschwunges sich zu enger n Kreisen innerhalb der Volks- und Staatskirchen zusammentaten. Eine Neigung dazu brachte der in limden 157 I erstmals einheitlich organisierte und im Exil das Vaterland mit einer kirchlichen Gesamtordnung bedenkende Calvinismus von Hause aus mit. Während in der Heimat zunächst der spanische Druck und dann cin von den Ortsbehörden mühsam geregeltes kirchliches Chaos herrschte, organisierten die Calvinisten von der Fremde her nach hugenottischem Vorbild ihr Kirchentum, das in seiner Sonderung des weiteren getauften und des ausdrücklich in der Konfirmation aufgenommenen engeren Mitglicderkreises, sowie in seiner strengen Sittenzucht zugleich die Merkmale kleiner und strenger Exulantengemeinden an sich trug. Seit der L'trechter Union allmählich zurückkehrend, schufen sie im Bündnis mit den werschiedenen Staatsgewalten der einzelnen Provinzen calvinistische Staatskirchen, die freilich anderssläubige Minoritäten neben sich dulden und eine erhebliche Staatsaufsicht, namentlich betreffs des Zuchtgerichtes, über sich ergehen lassen muften. Auch standen sie überall in Gegensatz gegen die ältere und liberalere niederländische Reformbewegung, sowie gegen die wesentlich an Handel und Toleranz interessierten Großstädte. Schon in Emden machte sich der Gegrensatz der »Prïzisen"d. h. der schroffen Calvinisten gegen die » Rekkelijken $\alpha$ d. h. die verträglichen Vermittler geltend. Der Gegensatz verschärfte sich nach der Ausbildung der Staatskirchen. IIan kämpfte um die strenge calvinistische Verfassung, um das strenge Bekenntnis und um das ethische Ideal der Rigorosität. "Präzise « und "Libertiner " standen sich schon jetzt gegenüber. Das erste Interesse der strengen Calvinisten in dieser Lage war die Ausscheidung der überwiegend humanistisch und erasmisch bestimmten, zugleich für die Kirchenhoheit des Staates und für die selbständige Verschiedenheit der einzelstaatlichen Verhältnisse eintretenden Arminianer und der Kampf gegen die hinter ihnen stehenden Stände. Das 
gelang durch das Bündnis der gleichfalls die nationale Einheit erstrebenden oranischen Statthaltergewalt mit dem strengen Calvinismus auf der Dordrechter Nationalsynode 16i8. Diese Synode beschloß zugleich eine Fülle von Maßregeln, die mit Unterstiitzung der Obrigkeiten einer strengen Calvinisierung der Niederländer dienen sollten. Allein man war sich darüber klar, daß das Ziel mit diesen äußerlichen Mitteln allein nicht zu erreichen war, wie denn auch Arminianismus und Erastianismus bald wieder geduldet werden mußten, je nach dem Verhalten der Einzelstaaten. Es bedurfte vielmehr einer innerlich scelsorgerlichen Arbeit an den Individuen, der inneren Ueberwindung oder, wenn das nịcht gelang, der Ausscheidung der "Libertiner" durch die Kirchenzucht. Die Mittel dazu entlehnte man, nachdem schon Taffin und Udemann vorangegangen waren, vom englischen Puritanismus. Wilhelm Teellinck, der Vater des niederländischen Pietismus, nahm seinen Ausgang von englischpuritanischen Reiseeindrücken. Auch die übrigen Führer, insbesondere Voet, benutzten reichlich englische Literatur. Uebersetzungen aus dem Englischen folgten. Einer der Hauptautoren des niederländischen Pietismus, Amesius, war englischer Exulant, und noch Lodensteyn wollte sich auf seine praktische Tätigkeit durch eine Reise nach England vorbereiten. So ist denn auch hier der Uebergang des Calvinismus in einen mehr individualistischen, konventikelmäßigen, seelsorgerlichen und schließlich stark mystisch gefärbten Pietismus ein beinahe unmerkbarer. Aber mit dem Fortschritt der darin liegenden Folgerungen entfernte sich doch dieser dogmatisch völlig orthodox bleibende und auch die Volkskirche festhaltende Pietismus immer deutlicher von dem primitiven Calvinismus einer durch die Christusherrschaft geheiligten einheitlichen Volksgenossenschaft. Es entstand ein ausgebreitetes Konventikelwesen, eine reiche aszetische Literatur, ein auf die Parole der theologia regenitorum eingeschworener Pfarrstand, die Laienbeteiligung an den Konventikeln, wobei auch Frauen zur Lehre zugelassen wurden. Die Kinder der Gnade und der Erwählung sonderten sich von den Kindern der Welt, sie hielten den strengen Sabbat, pflegten die Kasuistik und die Gewissensforschung, übten die methodische Askese, wobei man auch jesuitische und katholische Anregung nicht verschmähte. Man betrieb innere und äuBere Mission, drang auf Bekehrung und sichtbare Zeichen der Bekehrung: Insbesondere pflegte man auch hier, wie in Fingland, die Lehre von den guten Werken als Zeichen und Erkenntnis- 
mitteln der Erwählung, womit jene strenge methodische Gesetzlichkeit und Selbstdisziplin verbunden war. Auch hier äußerte sich der Individualismus in Tagebüchern, Selbstbiographien, Berichten über erbauliche Sterbestunden, in der Pflege der Hausandacht und der Seelsorge. Angesichts der Schwierigkeit, die verweltlichte Massenkirche zu dieser Strenge zu bringen, nahm man auch hier seine Zuflucht $\mathrm{zu}$ eschatologischen und chiliastischen Gedanken. Insbesondere kompensierte man auch hier die harte, nüchterne und trockene Gesetzlichkeit und Disziplin durch mystische Erbaulichkeiten im Stile der altniederländischen Mystik, des heiligen Bernhard und der mystischen Auslegung des Hohenliedes : der Einbruch einer Gefühligkeit und eines kontemplativen Individualismus, der dem Geiste Calvins völlig ferne lag. Hier kamen alte nationalen Ueberlieferungen wieder zum Durchbruch. Voet nannte seinen Lehrer Teellinck geradezu einen »reformierten Thomas a Kempis «. Der Unterschied dieser erneuerten Aszetik von der alten war nur, daß man mit allem Nachdruck die Durchdringung auch der weltlichen Berufe mit diesem Geiste forderte und jeden Versuch, diese als dadurch nicht regulierbar zu bezeichnen, lebhaft bekämpfte. Es war bewußt innerweltliche Askese. So wollte man auch nicht die Separation, sondern die Heiligung von Volk und Kirche. Die Ungläubigen sollten ausgeschlossen werden und die Frommen herrschen, nicht umgekehrt. Man blieb in echt calvinistischem Geiste immer aufs Ganze gerichtet und suchte auch stets von neuem die Obrigkeiten für seine Heiligungsbestrebungen zu gewinnen. Der Kampf gegen den Patronat, gegen den Luxus, gegen die moderne Philosophie, gegen die Toleranz stand auf ihrer Fahne, freilich ohne großen Erfolg bei den Ständen. Jedoch die Leidenszeit während der Kriege Ludwigs XIV. wurde zu einer Zeit großer populärer Erfolge, womit sich zugleich die gesetzliche Härte zu einem mehr evangelischen, weniger alttestamentlichen Geiste erweichte. Wirklich durchführbar aber war das Programm einer solchen Heiligung an der Gesamtkirche und an den Massen natürlich nicht. So kam es denn schließlich zu separatistischen Erscheinungen; andererseits lösten radikal individualistische Mystiker das Band mit der kirchlichen Rechtgläubigkeit. Mystischer Spiritualismus und Sektengeist, in den Niederlanden nie ausgestorben, bröckelten manchen Frommen von der Kirche ab, wie später zu zeigen. Aber es erhieít sich doch in den Staatskirchen ein starker Stamm pietistischer Heiligungs- 
christen durch die ganze Aufklärung und durch die Wirren der napoleonischen Zeit hindurch. Als die Niederlande zum Einheitsstaate und Königreich wurden, ebendamit aber auch die calvinistische Staatskirche neu geordnet werden mußte, da lösten sich diese Pietisten als »abgeschiedene reformierte Kirche*, d. h. als orthodoxe und pietistische Freikirche ab. Sie spielt bis zum heutigen Tage in den Niederlanden eine wichtige Rolle und hat unter ihrem hier oft angeführten Führer Kuyper durch gemeinsame Politik mit den Katholiken vorübergehend geradezu eine beherrschende Stellung gewonnen. In seinen historischen, theoretischen und programmatischen Schriften hat Kuyper diesen Neucalvinismus glänzend und geistreich charakterisiert, der freilich bei den Angelsachsen stärker vertreten ist als auf dem Kontinent. Immerhin ist diese niederländische Freikirche in vieler Hinsicht eine Parallele des englischen Dissent ${ }^{426}$ ).

426) Vgl. Göbel I; Heppe ; Ritschl I; Knappert, Geschiedenis der nederlandsche hervormde Kerk gedurende de $16^{\mathrm{e}}$ en $17^{\mathrm{e}}$ Euw, Amsterdam I9II; über die Verfassung s. v. Hoffmann, Das Kirchenverfassungsrecht der niederländ. Kirche bis I6I8; über die gegenwärtigen Verhältnisse Rothenbücher 425-429. Auf die kulturgeschichtliche Seite der Sache nehmen Heppe und Ritschl so gut wie gar keine Rücksicht. Den Zusammenhang mit England zeigt Heppe 107-I 10, 140-144, 148, I56, 164, 185. Ritschl nimmt davon kaum Notiz, dafür analysiert er den Gegensatz gegen den primitiven Calvinismus, den Zusammenhang mit dem Grundtrieb des Calvinismus, die Entwickelung dieses Pietismus von der bloßen Verstärkung der seelsorgerlichen Heiligungsmittel zum gesetzlichen Individualismus, zur bernhardinischen Mystik, zur evangelikalen Gefühligkeit. Er sieht darin letztlich die Zersetzung des kirchlichen Calvinismus durch täuferischen und katholisch-mystischen Geist. Daß aber darin doch nur die Uebersteigerung eines nach der Heiligung des Gesamtvolkes strebenden und an dieser Aufgabe schließlich naturgemäß scheiternden Rigorismus - also eine Folge des calvinistischen Prinzips selbst - liegt, sieht er nicht, weil er eine mit den nötigen Abstufungen der Reife sich abfindende, aus der Versöhnungsgewißheit Gottvertrauen und Berufstreue erzeugende kirchliche Volksmoral für das Normale hält, wovon der Calvinismus im Pietismus abgewichen sei. - Interessant ist seine Witterung für die im Pietismus enthaltenen Analogien zum Liberalismus S. 267: Der Geschichtskundige darf behaupten, daß die ... Erwartung der gänzlichen inneren und äußeren Veränderungen der Kirche und der Welt die ev. Kirche nicht minder beschädigt hat, als die wohlgemeinten Hoffnungen der politischen Aufklärung und des doktrinären Liberalismus die Gesundheit des sittlichen Volkslebens auf das Spiel setzen. Die pietistische Frömmigkeit wird an diesem Punkte einer nahen Verwandtschaft mit dem politischen Liberalismus überwiesen, während sie selbst glaubt, zu ihm in möglichst ausschließendem Gegensatz 'Troelts ch, Gesammelte Schriften. I. 
Die soziale Zusammensetzung dieses pietistischen niederländischen Calvinismus, der im 17. Jahrhundert mit dem strengen Calvinismus überhaupt zusammenfiel und durch diesen die Hauptzu stehen. Dieser Schein beruht aber nur darauf, daß der Pietismus sich ursprünglich nicht um den Staat als solchen kümmerl, sondern seine dem Liberalismus analogen Versuche auf dem Gebiete der Kirche vornimmt. Die Anhänger der Aufklärung und des politischen Liberalismus aber wissen, daß der Pietismus ihnen vorgearbeitet hat.\& Der asketische und Erweckungscharakter ist stark betont bei Knappert S. 273. - Ueber die kulturgeschichtlichen Verhältnisse siehe Laspeyres; Douglas Campbell II 287-356; Busken-Huet, Het Land van Rembrand ${ }^{2} 1886$. Nicht zu übersehen ist, daß die Arminianer ähnlich wie die Anglikaner Staatskirchler oder Erastianers sind, wie aus eben diesem Grunde die Theologie der Stuarts arminianisch war oder genannt wurde. In diesem Sinne nannte der Partikularist, Staatskirchler und Humanist Oldenbarnevald die Gomarischen Calvinisten -Puritaner und Doppelpuritaner \&, Campbell 304. Es ist also schon hier nicht bloß der dogmatische Gegensatz der Prädestinationslehre. Daß im weiteren der Gegensatz ein solcher gegen die Weltlichkeit eines politisch, wirtschaftlich und wissenschaftlich fortschrittlichen und der Askese widerstrebenden Volkes ist, geht aus den Klagen der -Ernstigen . hervor. Sie bekämpfen vor allem die Exemtion bestimmter praktischer Berufe von den religiösen Regeln und die Beschränkung der letzteren auf das bloß persönliche und private Leben. Sie streifen dabei of geradezu an die Formel - der innerweltlichen Askese a. Vgl. Ritschl I 123 :, Voet nimmt als Definition der Mystik... den Satz von Gerson an: Vita contemplativa est status hominum extra mu ndum ... Voet (der selbst die mystische und asketische Literatur des Katholizismus stark rezipierte Heppe 15I) erkennt nun in dieser Lebensrichtung die Grundlage des Mönchtums... und wendet dagegen ein: unde ipsos videre est separare invicem primae tabulae praecepta a praeceptis secundae tabula e.\& S. 274 : Es ist freilich sachgemäß, daß, wenn die Kontemplation, deren Heimat das Kloster ist, durchgeführt werden soll, das Gesetz der kanonischen Stunden (d. h. die puritanische Disziplin und Zeiteinteilung bis zur Regelung des erlaubten Schlafes) wieder entdeckt wird. Aber dasselbe soll nurgelten innerhalb dierbürgerlichen Geschäftigkeit, welche in der reformierten Kirche ebenso legitimiert wie dem niederländischen Volke geläufig ist.^ $S .278$ : Hier begegnen uns die Themata von Selbstprüfung und Buße, von Selbstverleugnung und Präzisität, von geistlicher Durchdringung der weltlichen Geschäfte und Streben nach Vollkommenheit, endlich von öffentlichem und Privatgottesdienst<. Busken-Huet gibt nach einem Buche van der Tunks über den Theologen Bogermann II 84 eine Schilderung der asketischen Forderungen init der Zusammenfassung: "Hunne levensbeschouwing was somber en stemmig als hun kleed. Zy geleken monniken, die hunne cel verlate $\mathrm{n} h$ adden, en het boze menschdom wilden overreden om, boete doende, de wereld voorzich toteenkloster te maken. Das ist doch überall dasselbe wie das früher von mir zitierte Wort Sebastian Franks (Kultur d. G. 
massen des Volkes beherrschte, ist aus den bis jetzt vorliegenden Darstellungen nicht zu erkennen. Bekannt ist, daß die reiche Kaufmannschaft, vor allem Amsterdams, arminianisch gesinnt war und daß die Politiker die Toleranz als das Heil der Niederlande schätzten; sie kam freilich wesentlich vertriebenen englischen und französischen Calvinisten, den Mennoniten und Sekten, sowie den spanischen und portugiesischen Juden zugute, also Gruppen, die politisch und wirtschaftlich der calvinistischen Republik homogen waren. Bekannt ist auch, daß die städtische Bevölkerung weit überwog über die ackerbauende, und daß das Bauerntum bereits einem kapitalistisch-technischen Betrieb der Landwirtschaft sich zuwandte, also von dem bürgerlichen Calvinismus nicht allzuweit abstand; trotzdem bekämpften die Pietisten lebhaft das Kirmeßtreiben und wird man auch hier in dem bäuerlichen Wesen manchen Widerstand gegen ihren Rigorismus vermuten dürfen. Der überwiegend bürgerliche und mittelständische Charakter wird also auch hier von diesem strengen Calvinismus angenommen werden dürfen. Er hatte hier nur keinen Anlaß, in einen so scharfen Gegensatz zu dem seigneuralen Lebensstil zu treten wie das englische Puritanertum und sein Nachfolger, der Dissent und die Evangelikalen. Er fühlte sich hier mit dem Geiste der Republik und der bürgerlichen Berufsarbeit einig, so daß man besondere Soziallehren des niederländisch-reformierten Pietismus nicht herausheben kann ${ }^{42 i}$ ).

N. S. 445): $\gg$ Die Weltverleugnung ist allen Christen geboten; hilft nicht, daß du es von dir schiebst auf die Mönch.* Für Rachfahl ist das alles nur »gemein. christliche Moral«. Leider folgt ihm darin auch Knodt S. 26.

${ }^{427}$ ) Eine Richtung auf die niederen Volksklassen behauptet Heppe S. 5 I ; Knappert 172 spricht von demokratischen Neigungen der präzisen Prädikanten, die ihrer mittelständischen Herkunft entsprechen; das Gleiche betont die schon erwähnte Diss. von Geibel, der im Ganzen den Großhandel auf der Seite des Libertiner, das Gewerbe auf der Seite der Präzisen sieht; zum übrigen s. Laspeyres, Busken-Huet und Douglas Campbell. - Charakteristisch sind die Ausführungen des Londoner Kaufmanns Lamb gegenüber Cromwell über die Ueberlegenheit der Holländer, die der letztere mitteilt II 327 : > In Holland when a merchant dies, his property is equally divided among his children and the business is continued and expanded, with all traditions and inherited experience. In England, in the contrary, the property goes to the eldest son, who often sets up for a country gentleman, squanders his patrimony, and neglects the business by which his father has become enriched... The honesty of the Hollanders in their manufacturing and commercial dealings. When goods are made or put up in Holland, they sell everywhere without question; for the purchaser hnows that 
Der Pietismus in den niederrheinisch-reformierten Kirchen, die anfïnglich eng mit dem niederländischen Calvinismus zusammenhingen und auch nach der Aufrichtung der niederländischen Staatskirchen dauernd von ihm aus beeinflußt wurden, bedarf keiner näheren Charakteristik. Es wiederholen sich hier dieselben Züge. 1)er Pietismus blieb hier nur durchgängiger erhalten, da der Calvinismus in diesen Ländern nie zur Staatskirche wurde, sondern immer - erst unter dem Kreuz, dann géduldet und von Brandenburg her gestützt, schließlich in die rheinisch-westfälische Kirche aufgenommen - sein Existenzrecht durch eine gesteigerte praktische Heiligkeit zu beweisen genötigt war und nie mit Volks- und Massenkirchen zu tun hatte. So hat sich hier der Pietismus insbesondere stark erhalten bis heute und bildet bis heute den Boden eines üppig wuchernden Sektentums. Von politischen Wirkungen dieses Pietismus ist nichts zu berichten; er blieb als Minderheitsrcligion von breiteren politischen Wirkungen ausgeschlossen, wenn cr auch bis heute dem preußischen Autoritätswesen nicht hold ist. Die wirtschaftlichen Wirkungen sind bekannt. Sie beschränken cich hier nicht auf einen pietistischen Mittelstand, sondern umfassen gerade die großen und reichen Fabrikanten und Handelsleute, begreiflich genug, da hier eine privilegierte Grundherrenschicht in der Kirche überhaupt fehlt und keine Gesellschaftsgruppe in ihr vertreten ist, mit der pietistische Lebensgrundsätze unverträglich wären ${ }^{428}$ ).

they are exactly as represented in quality, wheight, and measure.* Laspeyres weist zur Frklärung des Hochstandes auf die Toleranz und die Anziehung aller Gewerbetweibenden hin, außerdem auf die smoralischen Vorzüge , bestehend in Sparsamkeit und Ehrlichkeit, ohne aber der letzteren Frage in ihrem Verhältnis zur Konfessionalität nachzugehen S. I22-124. Das hat auch keiner der anderen Autoren gretan, wenn auch sowohl Douglas Campbell als Busken-Huet die Blüte der Republik mit ihrem puritanischen Calvinismus in Verbindung bringen. Im allgemeinen werden auch hier für die nähere Beantwortung dieser Frage die Weberschen AnaIs - en maßgelend sein; Andeutungen bei Weber, Antikritisches usw., S. I86-I88 und sichlußworte $S .570-571$. Er bezeichnet den niederländischen Puritanismus als cinen sin wichtigen - aber nicht in allen Punkten - immer wieder gebrochenene. Die Missionsbestrebungen in den Kolonien z. B. wurden unterdrückt, überhaupt dort das Religionswesen nach reinen Handelsgesichtspunkten geordnet, auch die Sklaverei trotz einiger Bedenken gerechtfertigt Laspeyres I06, I I I.

428. $S$. Göbel, Gesch. des christlichen Lebens. Ein großer Teil der wichtigen villen ist bereits oben angeführt; hier ist vor allem deutlich, wie Calvinismus und Pietisınus ineinander übergehen. S. überdies Ritschl, Gesch. des Pietismus I, 
Ebensowenig bedarf der reformierte Pietismus der Schweiz einer Schilderung. Fr hat seinen Ursprung in Einwirkungen des deutschen Pietismus, ist also nicht von Hause aus vom Calvinismus her zu verstehen. Auch die Erweckungen des 19. Jahrhunderts in der französischen Schweiz erfolgten unter auswärtigen Einwirkungen. Aber hier hat doch der reformierte Boden stark auf den Pietismus abgefärbt und ihm gleichfalls den Charakter eines kirchlichen Präzisismus gegeben. Politisch gehören hier die Pietisten zu den aristokratisch-konservativen Kreisen, freilich ist es eine republikanische Aristokratie. Die wirtschaftlichen und sozialen Wirkungen sind in dem Industrialismus der welschen Schweiz und in dem Reichtum Basels sowie in den großen Leistungen für das Gemeinwohl die auch sonst beobachteten ${ }^{429}$ ).

In Nordamerika vollends sind calvinistische, puritanische und sektenhafte Einflüsse nicht zu scheiden. Alles Einzelne bedürfte hier erst der genaueren Erforschung. Es kann in dieșem Zusammenhang nur auf die allgemein anerkannte Tatsăche hingewiesen werden, daß überall der Puritanismus in der führenden englischen Schicht als ein bis heute wesentliches Element des amerikanischen politischen und sozialen Lebens bezeichnet wird, wenn auch freilich der genauere Zusammenhang bis jetzt meines Wissens nirgends aufgehellt worden ist ${ }^{4: 0}$ ).

Blicken wir von hier auf unsere gesamte Darstellung zurück, so zeigt sich der ganze Unterschied des alten und des modernen

Simons, Synodalbuch, und die $\gg$ Kirchen unter dem Kreuz . Der Pietismus des Wuppertales mit seinen wirtschafts-ethischen Folgen darf im allgemeinen als bekannt gelten.

429) S. Ritschl I; das übrige beruht auf allgemeinen Eindrücken; jedenfalls ist Basel ein Paradigma pietistisch-reformierter Sozialethik.

430) S. Münsterberg, Die Amerikaner, 1904, und W. v. Polenz, Das Land der Zukunft, 1903; beide bieten freilich gerade hierüber wenig Auskunft; auch bei Tocqueville finden sich nur Andeutungen; unergiebig ist W. Müller, Das religiöse Leben in Amerika I9II; mehr bietet Rauschenbusch. Viele Einzelbeispiele gibt Max Weber, dessen Studien überhaupt von der Analogie des niederrheinisch-westfälischen Pietismus mit englischen und amerikanischen puritanischen Gruppen ausgehen. Gerade bei der starken Verschiedenheit dieser Gruppen fallen diese Analogien um so stärker ins Gewicht als Zeugnisse einer bestimmten sozial-ethischen Tendenz und Folge (was beides nicht immer zusammenfällt) des Calvinismus. Weber betont, dass diese Folgen auch auf einem an sich sehr ungünstigen Boden, wie Ostfriesland und in den jungen neuenglischen Kolonien, eingetreten seien. Im übrigen ist selbstverständlich und zeigen schon die gegebenen Beispiele, daß jedesmal außer dem Calvinismus noch andere Mächte mitbestimmend sind. 
Calvinismus. Mit dem Freikirchentum und seinen demokratischliberalen Begleiterscheinungen, sowie mit dem pietistischen Rigorismus eines starken, sich selbst kontrollierenden, in weltlichen Dingen sehr utilitarischen Individualismus ist der Neucalvinismus weit abgerückt von dem alten, sehr aristokratischen und dem L.uthertum noch recht nahe stehenden Calvinismus der Genfer Gründungszeit. Aber eben dadurch ist er zugleich ein großes neues sozialethisches Prinzip auf dem Boden des Christentums geworden.

Die christliche Ethik gewinnt hier ein ganz anderes Gesicht als in den beiden anderen Konfessionen, vor allem als im Luthertum. Hatte bei diesem gerade die Innerlichkeit der christlichen Liebesmoral die Fernhaltung von den äußeren Dingen der Rechtsund Staatsordnung gefordert; hatte es ferner den Ausschluß der Konkurrenz und des Kampfes ums Dasein in der ständisch-zünftigen Gliederung befördert, von da aus den Rückzug des Individuums in die innere Seligkeit und äußerlich die demütige Unterwerfung unter die gegebenen aristokratischen Ordnungen des Lebens befürwortet: so verlangt der Neucalvinismus christlichliberale Ordnung von Staat und Gesellschaft, Selbständigkeit und Befreiung des Individuums, Gleichheit des Rechtes und der Lebensmöglichkeiten, internationale Friedensordnungen und Ueberwindung des Kampfes ums Dasein durch Selbstdisziplin und tätige soziale Vereinshilfe. Dadurch erst glaubt er die christlichen Ideale der Freiheit und der Bruderliebe zu verwirklichen und hierfür beruft er sich auf die Bibel als auf das große soziale Lehrbuch der Menschheit. Die patriarchalisch-konservativen Elemente der christlichen Ethik sind zurückgetreten und die freiheitlich-sozialreformerischen sind dafür in den Vordergrund gestellt ${ }^{431}$ ). Die Ent-

431) Ueber die mit dem Neucalvinismus verbundene Auffassung des christlichen Sozialismus s. Rauschenbusch und Holl, Calvinreden S. 35. - Ueber das Verhältnis zum Luthertum s. die charakteristischen Aeußerungen bei Kuyper S. 15: >In allen lutherischen Landen ist die Reformation mehr von den Fürsten als vom Volke ausgegangen, ist dadurch unter die Macht der Obrigkeit gekommen .... und hat infolgedessen weder das soziale noch das politische Leben in Uebereinstimmung mit ihrem Lebensprinzip umgewandelt. Das Luthertum ist kirchlich und theologisch geblieben, nur der Calvinismus hat in und außer der Kirche seinen Stempel auf alle Aeußerungen des menschlichen Lebens gedrückt. Vom Luthertum spricht denn auch niemand als von der Schöpfung einer eigenen Lebensform, selbst der Name kommt kaum vor; während die Kenner der Geschichte immer einstim- 
Die Ethik d. Neucalvinismus i. Verhältn. zu Luthertum u. Katholizismus.

wicklung der beiden Konfessionen ist so eine geradezu entgegengesetzte geworden. Das Luthertum ist in Preußen-Deutschland zu der Stütze der konservativ-aristokratischen, rechtspositivistischen und gewaltgläubigen Lebensordnung geworden und entfaltet in seinen echten Anhängern die christlichen Tugenden einer weltfreien Innerlichkeit neben denen der Ergebung, Geduld, Pietät, Fürsorge und konservativen Beharrlichkeit. Der Calvinismus dagegen ist zu einer christlichen Akzentuierung des demokratisch-libera-

miger dem Calvinismus als Schöpfer einer eigenen Welt menschlichen Lebens huldigen. \& So fühlt er sich als das einzige große christliche Sozialsystem neben dem Katholizismus S. Io: „Vom Romanismus allein kann man sagen, daß er seinen Lebensgedanken in einer eigenen Welt von Empfindungen und Lebensäußerungen verkörperte. Aber neben und gegenüber diesem Romanismus trat nun der Calvinismus auf, nicht allein um eine andere Kirchenform, sondern um eine ganz andere Form des menschlichen Lebens zu_schaffen der menschlichen Gesellschaft eine andere Weise des Bestehens zu geben und mit anderen Idealen und Vorstellungen die Welt des menschlischen Herzens zu bevöllkern. "Diese ${ }^{*}$ Einheit der Lebenskonzeption gibt nicht der enge Begriff des Protestantismus..., sondern die findet man allein in dem mächtigen geschichtlichen Prozeß, der als Calvinismus sein eigen Bett für den gewaltigen Strom seines Lebens grub. Dank diesem Einheitsbewußtsein des Calvinismus können Sie hier in Amerika, können wir in Europa wieder neben dem Romanismus und gegenüber dem modernen Pantheismus Stellung nehmen.\& - Betreffs des Katholizismus sei hier noch das Kontrastbild erwähnt bei Prezzolini, Wesen, Geschichte und Ziele des Modernismus, S. 58-60: Das katholische Ideal ist ein gut genährtes, wenig denkendes, von einer Theokratie geleitetes Volk. Aber diese Art sozialer Betätigung ist grundverschieden von der, die sich im 19. Jahrhundert gebildet hat, und zwar in zwei Punkten: I. in der Priestervorherrschaft und 2. in der Wohltätigkeit . . . An Stelle der Theokratie tritt eine starke Laicisierung und an Stelle der Karität das neue Recht einer gründlichen Sozialreform ... Gegenüber der Sozialdemokratie ist die Haltung der lateinischen Katholiken geteilt. Die alten Katholiken vertreten den Standpunkt der Nächstenliebe und des Wohlwollens und kritisieren fortgesetzt den ökonomischen Liberalismus ... Sie glauben, daß es genügen würde, Zünfte nach Art der mittelalterlichen Gilden, landwirtschaftliche Kreditkassen, Gesellschaften zu gegenseitiger Unterstützung $z u$ gründen und eine Wahlbewegung in den Gemeinden hervorzurufen . . Ihr höchstes Ideal ist das einer mittelalterlichen Gesellschaft auf theokratischer Grundlage mit Arbeiterkorporationen. Die jungen Katholiken gehen allmählich kühner vor, sie wollen modernere rascher wirkende Methoden und scheuen sich nicht, die Kampfesweise und Werbetätigkeit der Sozialdemokratie nachzuahmen und weisen im Gegensatz zu den alten Katholiken eine Verbindung mit den reaktionären bürgerlichen Parteien zurück. \& Daher sind sie in Italien bekanntlich vom Papst zensuriert worden. 
len Gedankens geworden und entfaltet die Tugenden der Selbständigkeit, Freiheit, Menschenliebe, christlichen Weltverbesserung. Die beiden Grundelemente der ältesten christlichen Ethik haben sich auf beide Konfessionen verteilt, und dabei hat jedes eine außerordentliche Verstärkung erfahren. Demgegenüber ist der Katholizismus bis heute eine Vereinigung beider Elemente geblieben und betont nach Bedarf bald mehr seine demokratisch-naturrechtliche, bald mehr seine aristokratisch-patriarchalische Seite, sicher, jeden Konflikt dieser Richtungen durch die täglich sich stärkende kirchliche Zentralleitung beschwören zu können. Andererseits aber bleibt der Calvinismus in seiner Grundtendenz auf möglichste Volkskirchlichkeit und in seiner Betonung der Ungleichheit der Menschen in allen außerreligiösen Beziehungen doch von dem reinen Vereinskirchentum und der egalitär-kommunistischen Idee der strengen. Sekte innerlich geschieden trotz aller herüber- und hinübergehenden Beziehungen. Der auf die Prädestination begründete Individualismus ist und bleibt ein anderer als der auf die rationalistische Freiheitslehre des Täufertums gestützte.

Nun ist aber freilich der letzte Punkt mit der Betonung des bloßen Unterschiedes nicht erledigt, indem gerade dieser Unterschied in der neueren Zeit stark zurückgetreten ist. Der Calvinismus hat sich formell den Sekten genähert. Andrerseits stehen die nach der Reorganisation der Täufer zum Mennonitentum auftretenden späteren Sekten alle bereits unter größerem oder geringerem Einfluß des Calvinismus. Das Freikirchenprinzip und der Pietismus haben vollends beide Hauptgruppen sich noch mehr nähern lassen. Damit erst ergibt sich die volle heutige Weltstellung und soziale Kulturbedeutung des Calvinismus. Der Calvinismus und das Sektentum der Baptisten, Methodisten, Salutisten gehen heute zu einer großen religiösen Einheit zusammen, die sich zugleich als ein großer soziologischer Gesamttypus der christlichen Idee darstellt. Er ist wesentlich getragen vom Angelsachsentum, aber auf dieses nicht beschränkt, sondern auf allen calvinistischen Gebieten nachweisbar. Er hat aufs stärkste auch die religiös-ethische Ideenwelt und Praxis des heutigen Luthertums beeinflußt, vor allem mit Hilfe des hier gleichfalls entstehenden, wenn auch charakteristisch verschiedenen Pietismus ${ }^{432}$ ).

432) Das ist ein Hauptgedanke von Max Weber; aber auch von Kuyper; außerdem s. Knodt 45-46, auch Holl in Calvinreden S. 26. Auch Held hat das beobachtet S. 303: Die arbeitenden Klassen hatten sich längst von der vornehmen 
Diese Verschmelzung ist einerseits darin begründet, daß das im Calvinismus von Hause aus stark mitberücksichtigte und verarbeitete Sektenmotiv in seiner weiteren Entwickelung immer deutlicher hervortrat und sich seiner bemächtigte. Das hat die ganze bisherige Untersuchung gezeigt. Es fand seine Grenze nur an der positiven Weltbejahung und an der sachlichen Selbstauffassung als Kirchenanstalt trotz aller formellen Vereinskirchlichkeit. Auch ist der ursprünglich vom Täufertum ihn so scharf scheidende dogmatische Prädestinationsgedanke vielfach stark zurückgetreten, ohne daß darum die aus diesem herausgebildeten praktisch-ethischen Folgerungen verschwinden brauchten. Der mit jenem Dogma verbundene Heiligungsgedanke lebt selbständig fort und führt $z u$ dem Ideal sittenstrenger Freikirchen. Aber gerade an diesem Punkte kam andererseits auch die Entwickelung der Sekten ihm entgegen, indem diese mit der Ausbreitung und Festsetzung unter toleranten Staatsverhältnissen zu breiten Massengemeinden wurden und damit sowohl die strenge Abschließuns: der Heiligungsgemeinde wie den politischen und wirtschaftlichen Weltgegensatz aufgaben oder doch ganz bedeutend einschränkten; insbesondere stehen die modernen Sekten schon in ihrer Entstehung zugleich unter dem Einfluß calvinistischer Ideen und unterscheiden sich erheblich vom Waldenser- und Täufertum. Beide Gruppen begegnen sich in der Betonung der Freiwilligkeit und der methodisch-asketischen Strenge der Lebensführung. So wuchsen sie zusammen zu einer Gesamtmacht, die man im Unterschiede von dem weicheren, läßlicheren und prinziploseren Luthertum den - asketischen Protestantismus * genannt hat. Man könnte sie auch den individualistischen und aktiven Heiligungs-Protestantismus nennen, wenn diese Bezeichnung nicht zu umständlich wäre. Dieser asketische Protestantismus ist heute, auf die historische Wirkung und Ausdehnung gesehen, die Hauptmacht des Protestantismus, indem er seinen Einfluß weit über die eigentlich pietistisch-asketisch »ernsten $\star C h r i s t e n k r e i s e$ hinauserstreckt. Er bedeutet neben dem mittelalterlichen Katholizismus den zweiten großen Haupttypus christlicher Soziallehren, hinter dem die feineren aber

Staatskirche abgewendet, und ihr religiöses Bedürfnis wurde insbesondere durch die Sekten befriedigt, in denen auch der demokratische Geist der Puritaner in abgeschwächten Formen forlebte. Auf Webers Sätze hierüber ist am Schluß noch zurückzukommen. 
schwächeren Entwürfe der Soziallehren in der Mystik, im Spiritualismus, im Luthertum und im philosophischem Neuprotestantismus an historischer Wirkung weit zurückstehen. Wenn der Katholizismus die nötige Komplexität und Autorität zugleich hatte, um das Gesamtleben $\mathrm{zu}$ umfassen und $\mathrm{zu}$ leiten, so hat der asketische Protestantismus die nötige Härte und Biegsamkeit, die religiöse Energie und die nüchterne Sachlichkeit, die Anpassung an das ethische Denken des Durchschnitts und die dogmatische Einfachheit, um auf seine Weise ähnlich das Gesamtleben zu bemeistern; und, wie jener mit den mittelalterlichen allgemeinen Landesverhältnissen zusammenhing, so dieser mit den modernen politischwirtschaftlich-sozialen und technischen Entwickelungen.

Um aber das zum vollen Verständnis zu bringen, muß erst die Entwickelung des Sektentypus auf protestantischem Boden nachgeholt werden, wobei sich uns in der Mystik und dem Spiritualismus noch eine weitere für die Soziallehren aller Konfessionen schließlich recht wirksame Macht darstellen wird. Insbesondere wird dabei die Bedeutung der Umbildung des Sektentypus zu großen Massengemeinden, die Ermöglichung ihrer freien Bewegung auf dem Boden des toleranten modernen Staates und die Anpassung der Sekten an die bürgerliche Berufswelt hervortreten. Indem aber hierin jene angedeutete Ausgleichung mit dem Neucalvinismus stattfindet, werden die Soziallehren dieses letzteren erst mit jenen zusammen zu abschließender Darstellung kommen können.

4. Sektentypus und Mystikauf protestantischem B od e n.

Der Protestantismus ist mit den beiden großen Konfessionen nicht erschöpft. In ihnen wirkte sich die kirchlich-anstaltliche Grundidee der Reformatoren aus, durch welche die Reformationskirchen mit dem altchristlichen Grundgedanken, vor allem aber dem mittelalterlichen Katholizismus und seinem Prinzip einer allgemeinen, die Kultur beherrschenden Volkskirche zusammenhingen. Allein wie der mittelalterliche Kulturkatholizismus von der Komplementärbewegung der Sekte und der Mystik stets begleitet war und die Motive beider zum Teil auch in sich selbst eingeschmolzen hatte, so hatte auch der Protestantismus beides sowohl in sich als neben sich. Wie die Motive beider neben denen 
des Kirchentypus schon im Neuen Testament enthalten waren ${ }^{433}$ ), so brachte die Geltendmachung des Neuen Testaments im Protestantismus außer dem Anstaltsgedanken auch jene beiden anderen Ideale zu lebhafter Wirkung. Als er aber dann demgegenüber seinen kirchlich-anstaltlichen Charakter und seine Beziehung auf eine absolute, von außen gegebene, allbeherrschende Offenbarungswahrheit herauszuarbeiten genötigt wurde, zwang er sie zu einer selbständigen Existenz neben sich. Jedoch auch dann noch blieben sie trotz alles schroffen Gegensatzes immer in engster Wechselwirkung mit ihm und erlangten schließlich seit der Mitte des 17. Jahrhunderts eine steigende Rückwirkung auf ihn Insbesondere die zwischen dem Calvinismus und ihnen stattfindende Ausgleichung mußte bereits angedeutet werden. Das ist begreiflich genug. Die protestantische Kirchenreform war ja in ihrer Entstehung durchwirkt von jenen beiden neben dem Kirchentypus herspielenden Tendenzen und verdankte ihren Gegensatz gegen den Katholizismus zum großen Teil der Mitwirkung jener beiden. Durch die Vermittelung der Mystik drang Luther erst zu der persönlichen Heilsgewißheit hindurch, die nicht mehr in dinglichen, die Sündennot nicht stillenden Sakramenten, sondern in inneren seelischen Vorgängen die überwindende und erhebende Macht der Gnade fand. Die Strenge und Reinheit seiner biblischen Gesinnungsethik machte an Stelle des Kompromisses von Natur

433) Vgl. Hegler, Geist und Schrift bei Sebastian Franck, 1892 S. 168 Anm. Die Bedeutung der Bergpredigt dürfte noch schärfer hervorgehoben werden, wie das mit Recht in den gleich $z \mathfrak{u}$ erwähnenden Schriften L. Kellers geschehen ist. Ueber die maßgebende Bedeutung der Bergpredigt bei den Täufern s. Gottfried Arnold, Unparteiische Kirchen- und Ketzerhistorie 1700 II $529 \mathrm{f}$. Ebenso bei Sebastian Franck, Chronica, Zeitbuch und Geschichtsbibel 1536, in der Ketzerchronik S. 146: DDarum gehören hierher (unter die falschen Schriftverehrer) alle die, so die Schrift halbieren und nit ebenso streng ob einem Wort Gottes halten als ob dem anderen und die 5.-7. Kap. Math., 6. Kap. Lucae nit so gern und fleißig predigen als die Epistel zu den Römern und Galatern. Vgl. auch Dilthey in seinem bedeutenden Aufsatz $\gg$ Auffassung und Analyse des Menschen im 15. und 16. Jahrhundert\&, Archiv f. Gesch. d. Philos. V 1892; sehr treffend S. 378 : >In der protestantischen Gemeinde lag das Prinzip des inneren Wortes mit dem der Schrift im Streit: die Evangelien mit Paulus: das apostolische Leben mit den Menschen wie sie sind: das christliche Ideal mit der Staatsraison: vor allem doch das Wort der Bibel mit der in der Reformation fortgeschrittenen Gestalt des religiøsen Lebens. \& 
und Uebernatur die Persönlichkeitsmoral der Bergpredigt und das Priestertum aller Gläubigen zur Regel des Sittlichen und rang nach einer neuen Auseinandersetzung mit den Formen und Werten des natürlichen Lebens, wobei Luther anfangs oft die Grenze der Sekte streifte. Erst als das Bedürfnis nach Unmittelbarkeit der Gnadengewißheit fest und ausschließlich auf das objektive Wort von der Sündenvergebung um Christi Sühntod willen zurückgehen gelernt hatte; als die inneren Vorgänge sich auf die Ergreifung der von außen schlechthin dargebotenen Sündenvergebung konzentriert und alles andere zu einer hieraus fließenden Folge gemacht hatten, als von jener objektiven Heilsgrundlage aus die Heilsanstalt der Vermittelung der erlösenden Gewißheit durch Wort und Sakrament sicher konstruiert war; schließlich als von der göttlichen Heilsanstalt aus die Gesinnungsethik der Bergpredigt in die festen Formen des Berufs- und Gesellschaftslebens hineingeleitet war: erst da vollzog sich die Scheidung von den Geburtshelfern und ihre immer schroffer werdende Abstoßung ${ }^{434}$ ). Diese Scheidung hat aber nicht gehindert, daß das ursprünglich Zusammengehörige sich immer wieder suchte, daß die ausgeschiedenen Motive der Sekte und der Mystik sich als relativ zum Protestantismus gehörig empfanden. Sie haben auch in der Tat auf seinem Boden eine eigentümliche, von der älteren sehr verschiedene Entwickelung erlebt und unterscheiden sich wesentlich von der Fortbildung der gleichen Motive auf dem Boden des nachtridentinischen Katholizismus.

Von beiden Motiven hat nun der Sektentypus bereits früher

434) Das ist mit grausamem Witz, aber mit einleuchtender Klarheit von Luther in der Schrift, Wider die himmlischen Propheten von den Bildern und Sakramente von 1525 (B. A. Ergänzungsband I) geschehen. Sofern die Gegner mit ihm die ganze Bibel, vor allem auch den Paulus, als inspirierte Autorität anerkannten, ist Luthers Angriff unzweifelhaft im Recht und sicher vertritt er die Konsequenz seiner eigenen Grundgedanken. Vortrefflich ist diese Sachlage charakterisiert bei Erbkam, Gesch. d. prot. Sekten, 1848 S. 167-171, 483-488. Die Herausarbeitung aus der Mystik ist sehr gut dargestellt in Brauns schon erwähntem Buch, Bedeutung der Konkupiszenz in Luthers Leben und Lehre 1908. Die neueste, auf die nea gefundenen Früharbeiten Luthers eingehende Untersuchung von Scheel, Entwickelung L.s bis zum Abschluß der Vorlesung über den Römerbrief (Schriften des Vereins für Ref.-Gesch. 1910) unterschätzt die Bedeutung der Mystik außerordentlich, s. bes. S. $192 \mathrm{f}$. u. $201 \mathrm{f}$. Ueber Luthers Verhältnis zur Mystik s. auch die treffliche Arbeit von H. Hering, Die Mystik Luthers 1879. Außerdem s. oben S. $473-482$. 
beim Abschluß der Darstellung des Mittelalters seine prinzipielle Charakteristik gefunden ${ }^{435}$ ). Es bedarf daher hier nur der Hervorhebung des Zusammenhangs der protestantischen Sekte oder des Täufertums mit jenem mittelalterlichen Sektenwesen und der Verdeutlichung der besonderen Eigentümlichkeiten, die es nun auf protestantischem Boden angenommen hat. Anders steht es mit der Mystik. Sie ist bei Gelegenheit des Spätmittelalters wohl berührt ${ }^{436}$ ), aber noch nicht in ihrem religiösen Wesen und dem damit zusammenhängenden religiös-soziologischen Charakter analysiert worden. Das war dort nicht nötig, weil bei aller theologischen, religionsphilosophischen, kulturhistorischen und psychologischen Bedeutung, die auch damals schon der Mystik zukam, doch gerade die religiös-soziologischen Eigentümlichkeiten und Folgen noch kaum hervortraten. Sie bedeutete die Entstehung einer Laienreligion innerhalb der Kirche und hatte großen Einfluß auf die Individualisierung der bürgerlichen Welt. Aber für die Gestaltung des religiösen Gemeinschaftslebens und die Kritik des Kirchenbegriffes wie des Dogmas hatte sie noch keine Bedeutung. Die Mystik barg sich noch unter dem Schutz der Kirche oder fand Anschluß an die Orden. Sie stellte sich niemals auf sich selbst. Die protestantische Mystik dagegen lernte sich als Konsequenz des allgemeinen Priestertums und der persönlichen Ueberzeugungsreligion betrachten und sich damit auf eigene Füße stellen. Es wird vor allem darauf ankommen, ihre hierbei sich ergebenden soziologischen Folgerungen deutlich zu machen. Dabei wird sich zeigen, daß sie ein überaus wichtiges, heute geradezu vorherrschendes Prinzip in die Geschichte des Christentums einführt.

Es handelt sich also zunächst um die protestantische Sekte oder das sog. Tä ufertum. Wie tiefe Wurzeln der Sektengedanke in den Ideen und Schöpfungen der großen Reformatoren selbst schon hatte, ist oben bereits gezeigt worden. Luther hatte die Moral der Bergpredigt oder der Person gegen die Moral des Weltlebens oder des Amtes oder des relativen Naturrechtes des Sündenstandes als die eigentlich christliche abgegrenzt und im Grunde damit nur den Bedürfnissen der Volkskirche wie den von

$\left.{ }^{433}\right)$ S. oben S. $358-383$.

${ }^{436)}$ S. oben S. 419-420. 
Gott zugelassenen. und eingesetzten Stiftungen des Sündenstandes Zugeständnisse gemacht ${ }^{437}$ ). Hier blieb immer eine nie ganz verdeckte Naht, die erst in der Gedankenlosigkeit der Orthodoxie unsichtbar wurde. Im engen Zusammenhange damit hatte Luther anfangs innerhalb der allgemeinen Volks- und Zwangschristlichkeit der Landeskirche engere Kreise wahrhafter und ernster Christen in Aussicht genommen, die als Herde echter und reiner Christlichkeit allmählich die Volkskirche von innen durchdringen sollten. Erst die Gefahr des Subjektivismus hat diese Pläne beseitigt und in der uniformen Landeskirche der Visitationen untergehen lassen ${ }^{438}$ ). Die Opposition innerhalb des Protestantismus hat es nie unterlassen, sich auf solche Aeußerungen des jungen Luther zu berufen; solche Berufungen gehen von den alten Täufern bis $z u$ den englischen Independenten und den deutschen Pietisten ${ }^{439}$ ). Von einer anderen Stelle her, aber noch stärker,

437) Vgl. Harnack, Dogmengeschichte $\mathrm{III}^{*}$ S. 904: ,Was im Katholizismus in Kloster und Welt geteilt war, wollten die Reff. in einheitlicher Arbeit verbinden. Auch das ist doch wieder nichts anderes als die sinnerweltliche Askese.

13a) Vgl Karl Müller, Kirche, Gemeinde und Obrigkeit nach Luther, 19ı0, bes. S. 32-40, 84. Ich halte die Darstellung Müllers für völlig zutreffend; sie stimmt auch mit meiner Auffassung überein, s. oben S. 463-472. Luther hat auch bei diesen engeren Gemeinden den allgemeinen Kirchenbegriff der durch das Wort erzeugten Heilsanstalt festgehalten. Sie sollten nur engere Kreise innerhalb derselben sein und von diesen Kreisen die Wirkung des Wortes allmählich in die Massenund Volkskirchen hinaustragen. Auch was sie haben, ist nur vom Wort gewirkt, aber es ist die wirklich starke und erkennbare Wirkung des Wortes, die hier konzentriert wird und sich von hier über das Ganze schließlich ergießen soll. So ist der allgemeine Kirchengedanke behauptet, aber innerhalb seiner doch eine Annäherung an die Sekte vollzogen. Freilich ist der Kirchengedanke dabei der Stärkere und Luthers Entwickelung infolgedessen im Ganzen eine wesentlich geradlinige, wie ich oben es ausgeführt habe. Es ist kein plötzliches Abbíegen zur Sekte und dann ein Wiederzurückbiegen zur Kirche, sondern nur der Versuch, dem Sektenmotiv innerhalb der Kirche gerecht zu werden. Das ist aber sehr schwierig, und darum ist hier Luther bei bloßen Entwürfen geblieben. Das Entscheidende ist der Kirchengedanke, der denn auch alles bestimmt. Das ist auch bereits richtig von Erbkam S. 9-13 erkannt. - Ich meine also nicht mit Rieker und Achelis, daß diese Annäherung an die Sekre eine vorübergehende und prinzipwidrige Beeinflussung durch die Täufer gewesen sei, sondern daß in ihr eine aus der Bibel selbst stammende innere Spannung seines Gedankens liegt.

439) Berufungen auf den jungen Luther, der angeblich seine Anfangsideen verleugnet habe, sind bei den Dissentern allgemein. Beispiele gibt Hochhuth in seiner großen Artikelreihe von Aktenpublikationen aus den hess. Archiven, Z. f. hist. Theol. 
hatte der Sektentypus auf den Calvinismus seinen Einfluß ausgeübt. Calvin hat das Ideal der Sekte, dic heilige Gemeinde, XXVIII--XXXII; bes. XXVIII S. 542, 631, XXIX S. 179. Hier der Brief eines Täufers: Es hat auch ihr eigen Prophet Martinus Luther von solchen geschrieben (in einem kleinen Büchlein also lautend: eine Weise christlich Maß zu halten), daß man in einem versperrten Haus zusammenkommen muß und Ordnung handeln. Abermals spricht er: Ich bin noch nit kühn, solches anzufangen, auf daß solches nit vor ein Rotterei angesehen werde. \& Hier überall die Klagen als Motiv der Täuferei, daß die neue Kirche moralisch nichts leiste, und daß Luther den ersten Anlauf fortzusetzen wegen Mangels an ernsten Christen nicht gewagt habe. - In diesen Zusammenhang gehört auch die Deutung, die W. Köhler der reformatio Hassiaca als einer Ausführung der gleichen lutherischen Gedanken gegeben hat (Entstehung der ref. eccles. Hassiae von 1526, Deutsche Z. f. Kirchenrecht 1906 S. 199-232). Wenn man sie früher mit Lambert auf Franziskanerideale zurückführte, so hatte man den richtigen Instinkt, daß es Sektenideale sind; aber man übersah, daß Luther selbst diese mit seinem weiteren Kirchenbegriff früher zu verbinden gesucht hatte; vgl. W. Köhler, Zu Luthers Kirchenbegriff, Chr. W. 1907.Unter den Independenten hat sich der bereits genannte und später noch genauer zu besprechende William Dell für seine originelle Verbindung mystischer, kongregationalistischer und staatskirchlicher Ideen nachdrücklich auf Luther bezogen; s. Sippell, William Dells Programm einer lutherischen Gemeinschaftsbewegung, I911. Bezüglich Schwenkfelds haben Ecke, Schwenkfeld, Luther und der Gedanke eine: apostolischen Reformation, I9I I und dazu Sippell, Caspar Schwenkfeld, Chr. W. 191 I Nr. 37-4I die Herleitung von Luther gezeigt. - Franck in dem großartig objektiven Artikel Martin Luther seiner Ketzerchronik hebt die Idee der engeren Christengemeinde mit eigener Sakramentsfeier (II I 73 b) hervor. Hegler weist allenthalben auf die Anknüpfungen Francks und der Täufer an die ursprünglichen reformatischen Ideen hin. - Aber auch bei Gottfried Arnold herrscht das volle Bewußtsein darum. So beruft sich Arnold auf Luthers ursprüngliche, mit den Täufern übereinstimmende Ablehnung des Krieges, vgl. auch Francks "Kriegbüchlein*. \$Worauf Luther seine zuvor nach Christi Willen eingerichtete Meinung geändert aus Ursachen, weil das Evangelium das natürliche Recht nicht eben aufhebe Arnold II I I u. 19. L. sei svon den Juristen übertäubet worden II 20. Das anfängliche Drängen auf wirkliche Heiligung, bei dem Luthers Mönchstand noch nachwirkte II 46, das er aber dann leider fallen ließ II 93. Die Idee der besonderen engeren Gemeinden als guter Ansatz betont II 132, die Prediger als Gewählte der Gemeinde leider aufgegeben II I6I, ebenso Zinsverbot leider aufgegeben II 162. - Speners Pia desideria berufen sich zwar für die collegia biblica nicht auf Luthers Ideal echter Christengemeinden, aber auf sein Ideal des allgemeinen Priestertums ( $\$$ Weswegen hier $n$ auch weiter zu gedenken wäre, weswegen nit nur solche Materi, die fast nach Luthers Zeiten nicht so viel mehr getrieben worden, den Leuten bekannter gemacht werde Ausgabe von 1706 S. 109), ferner auf Luthers Empfehlungen von Tauler, Thomas a Kempis und Theologia Deutsch 
und das Mittel der Sekte hierfür, den Bann und die Kirchenzucht, übernommen und dieses Ideal auf eine ganze Landes- und Volkskirche statt auf die engeren Kreise der wirklichen Christen bezogen. Die Nicht-Erwählten und Gottlosen sollten zur Ehre Gottes mit den gleichen Mitteln in äußere Zucht genommen werden, mit denen die Erwählten und Frommen in einer wahrhaften und innerlichen Christlichkeit befestigt und entwickelt wurden. Das Sektenideal der heiligen Gemeinde wurde hier zum allgemeinen Volks- und Kulturideal und die darin liegende innere Spannung hat dann auch später den Calvinismus gesprengt.

Es ist begreiflich, daß der Sektentypus im Protestantismus ${ }^{40}$ )

(S. 140); auch betont er die christlich-utopischen Züge der lutherischen Ethik, Vermeidung der Prozesse S. $4 \mathrm{I}$; Gemeinschaft der Güter in anderem, aber analogem Sinne wie in der jerusalemischen Urgemeinde S. 43 ; überhaupt allenthalben der Rekurs auf die apostolische Gemeinde und die Versicherung, daß das keine res publica Platonica sei. Ueber das Verhältnis der pietistischen Collegia biblica zu Luthers sengeren Gemeindekreisen s. K. Müller, Kirche, Gemeinde usw. S. 83 f. $\left.{ }^{40}\right)$ Die wichtigste Darstellung gibt G ottfried Arnolds Kirchen- und Ketzergeschichte, eine heute noch nicht veraltete und neben den modernen Kirchengeschichten immer noch zu vergleichende Kirchengeschichte. Sie verarbeitet ein unglaublich reiches Urkundenmaterial und versetzit in die Atmosplı̈re des außerkirchlichen Protestantismus wie kein anderes Buch. Außerdem Sebastian Francks berühmte "Geschichtsbibelø, in welche die Ketzerchronik einverleibt ist; hier werden die Täufer mit besonderem Nachdruck und ersichtlich aus vielfacher eigener Erfahrung und Umfrage geschildert. B ullinger, der Wiedertäufer L'rsprung, Fürgang, Sekten, Wesen, Zürich I560, versetzt in die gegenteilige Stimmung des Kirchentums und in das relative Recht der Abwehr; eine Volkskirche konnte mit diesen Leuten nicht paktieren. - Die modernen Darstellungen leiden vor allem daran, daß dies täuferische Sektentum und die Mystik nicht unterschieden werden, die freilich tatsächlich sich vielfach verbanden, aber in der inneren Struktur des Gedankens verschieden sind. Die Gewohnheit der alten Häreseologie, alle Ketzer schwenkfeldiani, Anabaptistae et alii id genuss in einen Topf zu werfen und die schon von Luther vorgenommene Reduktion aller dieser sSchwärmere auf die kath. Häresie der Werkheiligkeit, Gesetzlichkeit und Möncherei hat hier das Verständnis sehr erschwert. Mit Recht hat der sachkundigste und feinsinnigste modernc Forscher, $\mathrm{Hegler}$, beide zu unterscheiden ermahnt und dabei vor allem schon auf die soziologischen Unterschiede verwiesen (Anzeige von Harnacks Dogmengeschichte Theol. Litztg. 1908 S. 253-258. - Der Spur Luthers und Bullingers folgt auch Ritschl (Gesch. d. Pietismus I), der sich sals evangelischer Theologes und Kirchenmann verpfichtet fühlt, san dem Urteil der Reformatoren festzuhaltene (S. 7). Er leitet daher Täufertum und Mystik aus dem Katholizismus, 
sich über dieses von der kirchlichen Reformation selbst zugelassene und verarbeitete $\mathrm{Ma} B$ hinaus geltend machte. In dieser Rich-

und zwar aus den populären und darum urkundlich nicht bekannten Verbreitungen des Franziskanertums, ab. Dabei erkannte er. wohl den Unterschied der Sekte und der Mystik als san sich gänzlich gleichgültig gegeneinander (S. 28 u. 35); aber die Verkuppelung beider stamme schon aus dem Mönchtum, das einerseits das apostolische weltferne Leben erneuern will und andererseits bei seiner Berufs- und Beschäftigungslosigkeit sehr natürlich auf mystische Gefühlsschwelgerei gekommen sei! - Den unprotestantischen Charakter der Täufer hat auch Lud. Keller (Reformat. d. älteren Reformparteien 1885, Staupitz und Anfänge d. Reform. 1888, Anfänge d. Reform. u. Ketzerschulen 1897) behauptet, allein er führt sie nun seinerseits nicht auf den Katholizismus zurück, sondern auf die vom konstantinischen Zeitalter her separierten und die reine urchristliche Freiwilligkeitskirche, Sozialmoral und Toleranz festhaltenden sog. altevangelischen Gemeinden, die mit Petrus Waldus und mit den sog. Wiedertäufern nur Umgestaltungen erfahren hätten und die echt christliche Tradition gegenüber Katholizismus und Protestantismus darstellen sollen. Sind auch die saltevangelíschen Gemeinden* in dieser Weise ein Phantasiegebilde, so sind die Untersuchungen Kellers doch lehrreich und anregend genug. Sein Hauptmangel ist, daß er das Wesen der Sekte im Unterschied von der Kirche nicht scharf genug analysiert, und daß er für seine Sekte alle Oppositionen, die Mystik, den Humanismus usw. reklamiert. Namentlich die Nichtunterscheidung der Mystik und die Aufnahme des Gottesfreundes, Taulers usw. unter die Sekte verhindert jedes klare Bild. Er deutet überall die Mystik und Sekte auseinanider; die Theologie der letzteren müsse als Ergänzung der deutschen Mystik an allen den Stellen herangezogen werden, wo die letztere eine Abgabe des Urteils zu vermeiden pflege!c Staupitz 143, die Mystik sei nur »das halbe Lehrgebäude der älteren Evangelischen. (ebd. 224). Wenn nun das Täufertum diesem aus Mystik und toleranter Freiwilligkeitskirche gemischten Ideal nicht ganz entspreche, so komme das davon her, daß die Täufer die in älterer Zeit nur für Apostel geltende asketische Lehre und Weltablehnung auf die ganze Gemeinde übertragen hätten (ebd. 32r), eine durch nichts bewiesene Behauptung. Alles das weist darauf hin, daß diese von Keller kombinierten Bestandteile $z u$ scheiden sind und für jeden besonders die Frage nach seiner Herkunft aus dem Mittelalter und nach ihrem Verhältnis zum reformatorischen Prinzip zu stellen ist. Dann aber verschwindet das Phantom der altevangelischen Gemeinden, und die von Keller m. E. nachgewiesenen Beziehungen der Täufer zu älteren Sekten verlieren die pikante Bedeutung, die sie bei Keller als dem Apologeten der saltevangelischen Gemeinden mation von ihnen durch Vermittelung von Staupitz herleitet. - Ganz in den Bah. nen von Keller geht $\mathrm{T}$ h u d i ch u m, Die deutsche Reformat. 1517-37, 1907/09: die Unterscheidung von Sekte und Mystik tut er mit den Worten ab II I14: Die von den neueren prot. Theologen beliebte Bezeichnung Mystiker, d. h. Geheimtuer, paßt sehr schlecht und es wäre endlich an der Zeit, dies Fremdwort -zu ver- 
802 III. Protestantismus. 4. Sektentypus und Mystik auf protestantischem Boden.

tung wirkte schon ganz von selbst die Bibel mit der Bergpredigt, die sich in die von den Reformatoren vollzogenen Kompromisse

meiden.\& - Wieder anders erscheint der Sachverhalt bei denen, die Täufer und Spiritualisten für die konsequente Auswirkung des Gemeindeprinzips und der Gewissensautonomie der Reformation halten, wie Weingarten, Revolutionskirchen Englands I868 S. 442 und A. Dorner, Grundriß der Dogmengeschichte 1899 S. 253 ff. Hier pflegt übersehen zu werden, daß auch die Dissenter Fortsetzer der m.a.lichen Entwickelung sind, nur einer andern, als diejenige ist, welche die Reff. fortsetzen. Aber richtig ist hier die Betonung einer vielfachen Verwandtschaft mit den Ideen der noch nicht kirchlich befestigten Reformation. - Beachtung verdient heute noch das geistreiche Buch von $\mathrm{Erbkam}$, das viele gute Einsichten enthält, aber den Sachverhalt schließlich doch ganz schief konstruiert. Die Täufer seien ethische Mystik, die Spiritualisten aber intellektualistiscbe Mystik. Beide zusammen seien eine vom MA. her fortwirkende Ergänzung der kirchlichen Objektivität und Anstalt, die auch den Protestantismus hätten ergänzen sollen. So aber hätten sie sich von ihm ungesund geschieden und sich deshalb in Wunderphantastik und Pantheismus aufgelöst; man scheide sich eben nicht ungestraft von der kirchlichen Heilsanstalt. Sehr reichhaltige Urkunden und eine Beleuchtung der ganzen Bewegung unter lokalen Gesichtspunkten bei $\mathrm{Hochh} \mathrm{uth}$, Protestant. Sektengeschichte in Hessen, Z. f. hist. Theologie XXVIII-XXXII. Auch hier geht alles von der Reformation und der Kritik an ihren mangelhaften moralischen Leistungen aus. - Eine treffliche Schilderung des deưtschen Täufertums bei Cornelius, Gesch. d. Münsterschen Aufruhrs 1855/60, eine sozialistisch gefärbte Gesamtschilderung bei E. Belfort $\mathrm{Bax}$, Rise and fall of the anabaptists, London 1903, besonders bedeutsam das Schlußkapitel mit seinen Hinweisen auf Fortleitungen in der englischen Revolution; vom baptistischen Standpunkt A. H. N e w m a n, History of Antipedabaptism, Philadelphia $I_{\$ 97}$, die eingehendste Gesamtdarstellung, leider nur bis 1609 : schließlich der Artikel = Täufere von Kramer PRE ${ }^{3}$. - Viel Wichtiges findet sich auch bei Göbel, Gesch. des christl. Lebens. Ueber den Zusammenhang der Bewegung bis in die pietistisch-separatistischen Gruppen hinein mit der Weberei und Tuchmacherei, die schon den Waldensern sich vorzugsweise anschloß, s. I 37-39; über den Zusammenhang mit den zahlreichen Waldensern des Rheinlandes I 40-42. Göbel bringt hiermit auch den Sieg des Calvinismus über das Luthertum in diesen Ländern in Verbindung, da jener den Waldensischen asketischen Christen näher stehe. Sehr gute Charakteristik der Täufer als Sektentypus I 134-139. Hier auch eine billige Auffassung: eine ganz bestimmte Richtung des christlichen Lebens, welche in ihrer fanatischen Ausartung wohl bekämpft und auch wohl gewaltsam ausgerottet, in ihrer Wah rheit und Notwendigkeit aber nie völlig unterdrückt und überwunden werden konnte «, sauch christlich berechtigt und anzuerkennen I 135. Im Pietismus sieht er nur die Wiederkehr dieser Richtung, I I 57 und öfter. Freilich hat er hierbei Sektentypus und Mystik nicht scharf genug begrifflich geschieden. 
nur schwer fügte. Gerade die Bergpredigt trieb immer von neuem zur Bildung von strengen Christengemeinden an, welche nach diesen Maßstäben leben wollten und welche dann mit einer Volkskirche und der allgemeinen Kulturgesellschaft sith nicht mehr decken konnten. Diese Wirkung ist um so begreiflicher, als in dem religiösen Leben der Zeit schon zahlreiche Gedankenzusammenhänge und wohl auch Organisationen bereit lagen, die unter waldensischem oder böhmischem Einfluß von den gleichen Ideen erfüllt waren und in der Reformation nur die Entfaltung ihres eigenen Programms, in ihren Siegen die Möglichkeit freier, antihierarchischer und völlig laienhafter Gemeindebildung sahen. In der Tat schossen unter dem Anhauch der Reformation allenthalben die kleinen Gemeindebildungen von ernsten, weltabgeschiedenen Christen mit der Forderung der Freiheit von staatlichem und hierarchischem $Z_{w a n g}$ und mit dem Ideal des freien Zusammentretens der Wiedergeborenen zu Freiwilligkeitsgemeinden in erstaunlicher Masse empor. Ihr äußerlich erkennbares Wabrzeichen war die Spättaufe, d. h. die Bildung der Gemeinden bloß aus Wiedergeborenen und freiwillig ihr Zugehörigen, sowie die Verwerfung der Kindertaufe, d.h. die Bestreitung der objektiven, die Massen von Hause aus einschließenden und von ihrer ethischen Würdigkeit unabhängigen universalen Heilsanstalt. Ebenso trat als äußeres Kennzeichen hervor die Forderung der Gemeindezucht und des Gemeindebannes, die sich vor allem an die Forderung der Reinheit der Abendmahlsgemeinde anschloß. Damit war dann auch die Auffassung des Abendmahles als einer Gemeinde- und Bekenntnisfeier verbunden und der Gegensatz gegen die kirchliche Abendmahlslehre. So wurden sie mit den "Sakramentierern " zusammengeworfen. Ihr wirkliches und eigentliches Wesen aber war die Heiligkeitsgemeinde im Sinne der Bergpredigt und im Sinne der Freiwilligkeitsgemeinde gereifter Christen; die Zurückhaltung von Staat, Amt, Recht, Gewalt, Eid, Krieg, Blut und Todesstrafe; die stille Duldung des Leidens und Unrechtes als des Kreuzes Christi; die enge soziale Verbundenheit der Glieder durch Armenpflege und Hilfskassen, so daß in diesen Gemeinden niemand betteln und hungern mußte; die strenge Kontrolle der Würdigkeit der Gemeindeglieder durch Bann und Gemeindezucht; ein schlichter Kultus rein biblischer Erbauung durch gewählte Prediger und Seelsorger, die unter Handauflegung und Gebet von den Synoden der Ge- 
So4 III. Protestantismus. 4. Sektentypus und Mystik auf protestantischem Boden. meinden verordnet wurden ${ }^{441}$ ). Das sittliche Naturgesetz erkannten auch sie an, aber sie bekämpften dessen von den Kirchen ange-

+11) Vgl. die Schilderung bei G. Arnold II $264 \mathrm{f}$. und $524 \mathrm{ff}$., der sich jedoch selbst von ihnen scharf unterscheidet: , Wiewohl aber viel menschliche Torheit, Blindheit und Schwachheit bei manchen mit unterlief, so war doch bei vielen auch daraus eine große Einfalt und Treue des Gehorsams zu sehen, weil sie dem Buchstaben der Schrift so genau nachzukommen trachteten, daß sie auch darüber in die anderen unzeitigen Urteile verfielen (d. h. exklusiv und intolerant wurden) und sclbst in Schande und Schaden kamen. * Arnold selbst hält es mit den Mystikern. Das Urteil Luthers bei Arnold II 266: Man kann diese Ungeheuer weder durch Schwert noch Feuer bändigen. Sie verlassen Weib, Kind, Haus und Hof und alles was sic haben.: Ebd. Melanchthons Urteil : Es sollte sich niemand ärgern, wenn er die Wiedertäufer so getrost in den Tod gehen und alles leiden sähe, weil sie der Satan verhärtet hätte.» Etwas milder der reformierte Polemiker Hornbeck : ×Daß die Wiedertäufer nicht sowohl durch ihre Lehre der Orthodoxen ihre widerfochten durch den Beisatz einer anderen oder neuen, als daß sie diese nicht recht fasseten und verstünden. Ein späteres orthodoxes Urteil bei Arnold II 524 : Sehe ich die Wiedertäufer und Mennonisten an, so führen sie traun einen $\mathrm{s} c \mathrm{~h}$ e in he ili:̈ e n Wandel, hüten sich für Kleiderpracht, Schwören, Lügen, Fressen, Saufen, Huren, Buben, Zank und Hader wie für dem Teufel, daß, wer in ihre Commun o der Gesell lschaf t kommt, fast erstaunen muß und denken, er komme nicht unter Menschen, sondern eingefleischte Engel, zum wenigsten unter eitel lebendige Heilige und auserlesene Kernchristen. - Grundlegend ist auch die Schilderung bei Seb. Franck (Ketzerchronik 193-201), den Keller sehr mit Unrecht einen sechten Täufer nennt (Ref. S. 462) und der jedenfalls von Kellers altevangelischen Gemeinden nichts weiß. Franck sagt über den Ursprung einfach: :Anno 1526 gleich in und nach dem Aufruhr der Bauern entstand a u s de m B u chstaben der Schrift cin neue Sekt und sundere Kirch, die nannten etliche Wiedertäufer, etlich Täufer, die fiengen an mit einem sunderen Tauff sich*von den anderen zu sündern und alle andern Gemein als unchristlich zu erachten, auch kein selig oder für kein Bruder zu zählen, der nit ihrer Sekt oder Partei war. Fiengen an die, so zu ihnen traten, widerzutauffen oder vielmehr, wie sies fürgaben, zu tauffen nach dem Befehl Christi... Deren Vorsteher und Bischof waren erstlich der Ba!thasar Hübner, Melchior Rink, Joh. Hut, Joh. Denck, Ludwig Hetzer . . . Sic lehreten im Schein nichts denn Lieb, Glauben und Kreuz, erzeigten sich in viel Leiden geduldig und demütig, brachen das Brot miteinander zum Zeichen der Einigkeit und Lieb, halfen einander treulich mit Fürsatz, Leihen, Borgen, Schenken, und lehreten alle Dinge gemein haben; hießen einander Brüder. Wer aber ihrer Sekt nit war, den grußten sie kaum, boten auch dem kein Hand, hielten sich zusammen und nahmen so jährigs zu, also daß die Welt sich einen Aufruhr von ihnen besorgt. Die furchtbare Verfolgung und ihr Märtyrertum habe die Massen überzeugt, daß hier die wahren Christen seien und das habe ihnen wieder großen Anhang verschafft. Da hätten sich viele Täufer des in ihnen vorhandenen guten 
nommene relative Fassung, den Kompromiß des Naturgesetzes mit der Erbsünde. Sie verstanden es wie ihre mittelalterlichen Vorgänger als absolutes Naturgesetz des Urstandes, woraus dann auch gelegentlich ähnlich revolutionäre Folgerungen gezogen wurden wie bei den Wiklifiten und Hussiten. Im allgemeinen freilich galt das Naturgesetz und das mit ihm identische Christusgesetz als in der Welt nicht durchführbar, daher die Welt als Stätte des Teufels, des Leidens und Duldens bis zur Wiederkunft Christi, auf die sich die Frommen durch Scheidung von der Welt bereiteten. Wir erkennen darin alle Grundzüge der Sekte wieder, wie wir sie bereits kennen gelernt haben.

Unter diesen Umständen ist es begreiflich, daß man sich die Frage gestellt hat, ob diese täuferischen Sekten nicht etwa bloß das durch die Reformation ermöglichte Wiederhervortreten der mittelalterlichen, waldensischen Sekte sei. Allein weder ist der Fortbestand einer solchen Sekte als einheitliche internationale Organisation nachgewiesen, noch der Hervorgang der Führer der Täufer aus diesen Sektenkreisen. Sie kamen alle aus der reliKernes überhoben. „Wurden etwas im Geist hoffärtiger, fiengen an jedermann zu urteilen und auch in viel Stücken untereinander uneins $z \mathfrak{u}$ werden und schier so viel Lehr zu treiben als sie Vorsteher hatten... Wiewohl ich für wahr acht uncl gänzlich halt, daß viel frommer einfältiger Leute in dieser Sekte gewesen und noch sind und viele auch ihrer Vorsteher nach Gott geeifert haben, aber meines Bedünkens nit nach der Kunst. Jedoch sollte man nit also mit ihnen tyrannisiren, wo sle gleich hartnäckig sich nit wollten weisen lassen, sondern sie allein Gott befehlen, der allein Glauben geben, Ketzerei austilgen und der Sach, wie gehört, Rat schaffen mag.\& Fs sind die charakteristischen Züge des Sektenwesens bis heute. $₫$ Es ist des Bannens in ihren Gemeinden viel, also daß schier eine jede Gemein die andere in Bann thut, und ist schier eine solche Freiheit zu glauben als im Bapsttumo. Wer in ihren Gemeinden nit zu allen Dingen ja spricht, dem hat Gott die Ohren verstopft und heben an kläglich für ihn zu bitten. Will er nit bald umkehren, so schließen sie ihn aus S. I93 a. Daher auch eine große Unübersichtlichkeit: "Wiewohl alle Sekten in ihnen selbst zerspalten sind, so sind doch sonderlich die Täufer also unter einander uneinig und zerrissen, daß ich nichts Gewisses und Endliches von ihnen zu schreiben weiß \& 193 b. Mustert man die von Franck beschriebenen Schattierungen, so sind es 2 Hauptgruppen: die, welche festen Organisationen angeschlossen sind und an das Schriftgesetz sich halten, und die, welche mehr mit dem Enthusiasmus und der Mystik gehen und dadurch zu gemeinschaftslosen Individualisten werden, aber doch ihr Publikum wesentlich in Täuferkreisen haben. Ueber diesen Unterschied später mehr. Die seit Bullinger sog. »freien Täufer sind keine Täufer, sondern Spiritualisten. - Mit Francks Schilderungen stimmen die Schwenkfelds überein, vgl. Ecke 89, 204-212. 


\section{III. Protestantismus. 4. Sektentypus und Mystik auf protestantischem Boden.}

giösen Bewegung der Zeit, bald mehr aus der lutherischen, zwinglischen oder humanistischen, bald mehr aus einem laienhaften Biblizismus. Auch charakterisiert sie neben der positiven Anknüpfung an das allgemeine Priestertum, den Biblizismus und die Persönlichkeitsreligion der Reformation ein negativer Zug des Gegensatzes, der Enttäuschung durch die Reformation, der radikaleren Betonung ihrer Grundelemente. Das tritt schon in der Hervorkehrung der Spättaufe oder der Wiedertaufe als des neuen Schlagwortes der Bewegung zutage; es bekundet sich noch mehr in der Bekämpfung der moralischen Unfruchtbarkeit der reformatorischen Massen- und Zwangskirchen und in der bitteren Verhöhnung ihrer Welt- und Fürstenfreundschaft. Dies letztere sind bekannte Tatsachen, doch ist deren tiefere Bedeutung weniger allgemein anerkannt. In ihnen kommt nur die innere Schwierigkeit der Reformationskirchen zum Ausdruck. Sie hatten ein äußerst hochgespanntes, beinahe utopisches ethisches Ideal. Unter Verzicht auf die katholische Stufenteilung und unter Preisgebung der hierarchisch-autoritativen Seelenleitung wollten sie die gesamte Bevölkerung mit dem Wunder der strengen christlichen Liebessittlichkeit gleichmäßig durchdringen und das Weltleben zum direkten Organ der religiösen Liebe machen, das Luthertum völlig idealistisch rein im Vertrauen auf die wunderwirkende Macht des Wortes, der Calvinismus mehr praktisch unter Heranziehung eines biblisch-begründeten, göttlich gestifteten Kontrollapparates. Es ist kein Wunder, daß dieser ungeheuere Idealismus schwere Enttäuschungen erlitt, und daß diese praktische Reform nicht gelang. Das Ideal war gegenüber dem Katholizismus verallgemeinert, vertieft und verschärft, und zugleich waren die katholischen Zwangsmittel preisgegeben. So ist namentlich auf dem Boden des Luthertums eine praktische Verwilderung eingetreten, die aus Luthers und seiner Genossen eigenen Zeugnissen wohl bekannt ist und die von der katholischen Polemik bis heute reichlich ausgenützt wird ${ }^{42}$ ). Sie hat vor allem den Einsatz für die Kritik der

442) Vgl. die bekannten Sammlungen von Zeugnissen des Luthertums wider sich selbst bei Döllinger und Janssen. Noch erschütternder ist die Darstellung bei dem ehrlichen Gottfr. Arnold, und beherrschend ist dieser Gesichtspunkt auch in Francks Geschichtsbibel. Hegler hat mit Recht Franck überhaupt von hier aus zu verstehen gesucht, ebenso Ecke den Schwenkfeld. Auch in dem prächtigen Buche von Paul Drews, Der evang. Geistliche i. d. deutsch. Vergangenheit, 1905, ist die Schilderung des moralischen Standes von Geistlichkeit und Gemeinden sehr trüb. Es reicht nicht aus, 
täuferischen Oppositionsparteien gebildet. Auch der Calıinismus hat sich auf seiner Höhe auch nicht einmal in Genf länger als ein halbes Jahrhundert $z u$ halten vermocht. Das Herabsinken auf das Niveau eines selbstgerechten und im irdischen Geschäftssegen den Lohn Gottes für Rechtgläubigkeit und Sittenstrenge preisenden Puritanismus ist eine sehr begreifliche Entartung und Entspannung des calvinistischen Ideals. In demselben Maße aber als die praktisch-ethischen Leistungen hinter dem ldeal zurück-blieben, konzentrierten sich die Kirchen nach echter Kirchenweise auf den objektiven Heilsbesitz, auf das von menschlicher Werkgerechtigkeit unabhängige, göttliche Stiftungskapital. Das aber war für den Protestantismus das bibelgerechte Dogma und die Herrschaft der reinen Predigt des Amtes am Worte. So verfielen sie einer Orthodoxie, die bei ihrer Beschränkung auf das Wort, die Lehre und die Glaubenserkenntnis viel enger und härter war, als die katholische, welche ja neben und unter dem Dogma das Heil zugleich im Kult und in mystischen Devotionen, also in undoktrinären, phantasiemäßigen Elementen, besitzt. Damit war dann aber zugleich ein immer stärkerer Anschluß an die weltliche Macht gegeben, die allein jene Herrschaft des rechten Glaubens wenigstens äußerlich schützen konnte, und mit einem solchen Anschluß an die weltliche Macht wurde naturgemäß auch die feine lutherische Grenzbestimmung zwischen eigentlich christlicher Liebesmoral und naturgesetzlich weltlicher Moral immer mehr verwischt und damit die Moral selbst verweltlicht ${ }^{443}$ ). Das in Krieg, Macht, Gewalt, Recht liegende Problem der christlichen Ethik wurde bald gar nicht mehr empfunden. Statt dessen wurde es umgekehrt als Vorzug der reinen reformatorischen Lehre gerühmt, daß

für diese geringen Erfolge die Nachwirkungen der früheren katholischen Erziehung verantwortlich $\mathrm{zu}$ machen oder auf die späteren wilden Kriegszeiten hinzuweisen. Der nur bedingte moralische Erfolg der Reform liegt sicherlich in ihrem Wesen selbst; s. Ecke 88. Die Ideale waren zu hoch, und die Erziehungsmittel waren eingeschränkt. Hier hat erst die Seelsorge des Pietismus und dann die humanere Moral der Aufklärung und Volksbildung durchgegriffen. Mit welchen Einschränkungen aber auch dies der Fall ist, zeigt z. B. die bekannte Selbstbiographie des berüchtigten Magisters Lauckhardt. Die Hebung der Durchschnittsmoral der Massen ist wohl überhaupt erst das Werk der Volksschule und des modernen Staates, wobei dann die Ideale freilich nicht dem hochidealistischen Luthertum in erster Linie entnommen sind.

149) Hier reden die bekannten Bücher von Tholuck und Hundeshagen eine sehr deutliche Sprache. 
sie für alle diese Dinge Raum und göttliches Recht habe, die von Möncherei und Schwärmerei mit der naturgemäßen Uebereinstimmung aller Gegner Christi geleugnet würden.

An dieser Stelle liegt vor allem der Einsatzpunkt der täuferischen Bewegung. Sie kehrte sich gegen den neuen theologischen Dogmatismus, gegen das Zwangs- und Staatschristentum und gegen die Verweltlichung ${ }^{44}$ ). Sie lebte von der Opposition und machte gegen die Entwickelung der Reformation Elemente geltend, die diese selbst mitenthalten hatte, die sie aber sehr rasch mit den Aufgaben einer die weltliche Kultur rezipierenden Volkskirche hatte verschmelzen lernen. Gegen die Folgen dieser Verschmelzung und damit gegen den Kirchenbegriff und die kirchliche Kultur wandte sich das Täufertum. Dieser stark oppositionelle Zug aber spricht vor allem dafür, daß es in der Tat von der Reformation selbst in Bewegung gesetzt worden ist. Dafür spricht weiter seine apokalyptisch-eschatologische Stimmung, die den älteren evangelischen Sekten gefehlt hat. Es hatte sie mit Luther gemein, der sich schon seinerseits eine solche Auflösung aller kirchlichen Tradition nur aus dem bevorstehenden Ende und aus der Weissagung des Antichrist erklären konnte. Für die Täufer mit ihrem Prinzip der kleinen weltabgeschiedenen Freiwilligkeitsgemeinden verstand sich diese Stimmung erst recht von selbst. Denn die Aufösung der Christenheit in solche kleine, die entartete Massenkirche verlassende Gemeinden war mit dem Gedanken einer Herrschaft Christi über die Welt nur unter der Voraussetzung vereinbar, daß der große, von der Apokalypse gew issagte Massenabfall und der Rückzug der Christenheit auf wenige Getreue jetzt eingetreten sei. Erst von diesen eschatologischen Stimmungen aus gingen dann einzelne Gruppen zur gewaltsamen Aufrichtung des himmlischen Jerusalem über. Außerdem gaben sie in der Erregung dieser Erwartung zugleich mystisch-enthusiastischen Einflüssen Raum, die von den reinen Täufern mennonitischer Observanz später wieder ausgeschieden wurden, die aber auch mit der von der Reformation geschaffenen Erregung zusammenhingen und sie mit den mystischen Abzweigungen mannigfach verbanden. Auch das ist dem echten Waldensertum fremd. Alles das spricht dafür, daß wir im Täufertum

444) Das lehrt jede Lektüre der bei Seb. Franck, Schwenkfeld und Gottfried Anold ge:ammelten Zeugnisse mit unmittelbarer Lebendigkeit. 
einen Seitentrieb der reformatorischen Bewegung vor uns haben, der mit der biblizistischen Reinigung und dem sittlichen Ernst der Reformation eng zusammenhängt, dessen ticfer innerer Gegensatz gegen die kirchliche Idee der Reformatoren aber freilich auch nicht zu verkennen ist. Dabei ist es dann aber sehr wohl möglich, ja wahrscheinlich, daß dic starke Ausbreitung des Täufertums überall von den Nachwirkungen und Resten waldensischer und ähnlicher Sekten begünstigt war, vielleicht nur daraus erklärlich ist. Auch auf einzelne Führer mögen durch unkontrollierbare Verbindungen derartige Ueberlieferungen hier und dort schon eingewirkt haben ${ }^{445}$ ). Der Anstoß und die Ausgestaltung gingen aber sicherlich von der Reformation und von den durch sie geweckten Gegensätzlichkeiten aus. So gehört die ganze lewegung im Grunde doch $z$ u ihr. Sie ist von ihr in Gang gesetzt, beruft sich auf sic und bleibt mit ihr in engster Wechselwirkung, während der Katholizismus sie völlig von sich abzustoßen verstand.

So zeigt die Geschichte des Christentums das eigentümliche Schauspiel, daß die reiche Sektenbildung, die den Katholizismus begleitet hatte, auf dem Boden des letzteren beinahe ganz versiegte und völlig auf den des Protestantismus übersiedelte. Der tridentinische Katholizismus schloß die unbegrenzten Möglichkeiten aus, die noch der mittelalterliche in sich enthalten hatte und organisierte sich derartig straff und zentralistisch, daß an besondere Sekten- und Gruppenbildungen auf seinem Boden nicht mehr zu denken war. Die in den Sektenbildungen sich entladenden Motive fielen natürlich darum auch bei ihm nicht plötzlich aus. Aber sie wurden abgelenkt auf die Bildung neuer Orden und kirchlicher Vereine. So erlebte der tridentinische Reformkatholizismus eine neue Periode glänzender Ordensstiftungen, aber die Sekte hat seitdem bei ihm ausgespielt. Die Bibel ist unter den strengen Verschluß der Kirche genommen und alles Vereinswesen kirch-

445) So scheint Münzer aus dem Einflußkreis Luthers in den von Zwickauer Brüderkonventikeln übergegangen zu sein, Thudichum I 215, auch hat Keller (Reformation $38 \mathrm{I}-388$ ) Beziehungen Grebels $z \mathrm{u}$ Waldensern wahrscheinlich gemacht. Auch sind offenbar manche Prediger der Täufer schon vor Einführung der Spättaufe Konventikelleiter gewesen (Ketzerschulen 52). In den bei Wappler, Inquisition und Ketzerprozeß in Zwickau, 1908, mitgeteilten Protokollen von Täuferprozessen finden sich mehrfach Bezugnahmen auf waldensische Herkunft $S$. I21, 123 f. Dagegen scheinen die ketzerischen Nürnberger Maler, denen Denck nahe gestanden hat, doch anderen Charakters gewesen zu sein. 
licher Autoritiat unterstellt worden ${ }^{4+1}$ ). Das ist so geblicben bis zum heutigen Tage und nur immer mehr verschärft worden. Dahingegen hat die protestantische Bibelkirche mit ihrem Mangel hierarchischer Zentralisation und ihrer Möglichkeit stets neuer Bibeldeutungen von da ab den Sekten cinen fruchtbaren Boden regeben. Sie hat sie zwar zunächst gleichwie die Katholiken mit blutiger Strenge verfolgt und unterdrückt, aber sie vermochte das Prinzip nicht völlig auszurotten, aus dem sie immer wieder hervorsingen, weil sie Elemente dieses Prinzips in sich selber trug. Aus diesem Sachverhalt stammt das eigentümlich verwickelte $\checkmark$ crhältnis der Sekte zu beiden Konfessionskirchen. Mit der Strenge ihres weltindifferenten Ideals und mit ihrer Betonung aktiver Leistungen paßt sie besser auf den Boden des. Katholizismus, der im Mönchtum gewisse Analogien zu ihr hat und im mönchischen Leben ihr Ideal wenigstens relativ anerkennt. Mit der Forderung biblischer Normierung, persönlich-innerlicher Gewißheit und antihierarchischer Freiheit fügt sie sich besser in den Rahmen des Protestantismus. Sie hat auch mit seiner Gnadenlehre und seiner Berufsmoral sich schließlich innerlich vereinigen gelernt. Das verwickelte Verhältnis ist aber im Grunde doch leicht zu verstehen. In beiden Konfessionen nämlich wirkte aus dem christlichen Ur- und Grundbestand her das Sektenmotiv, aber in jeder völlig anders. Der Katholizismus bewältigte es in Orden und Vereinen und vernichtete schließlich jede Existenz der Sekte neben sich. Der Protestantismus dagegen konnte den Versuch der Vernichtung nicht zu Ende führen, sondern mußte die Sekte neben sich als Dissent anerkennen und ihr in sich selber als Pietismus schließlich Raum geben. Der Katholizismus ist biegsamer und kompromißreicher. Wie er in seiner Stufenmoral die weltliche Kultur anerkennt und gerade jetzt in der tridentinischen Reform die Renaissance gründlichst in sich aufnahm, so nahm er auch das Sektenmotiv in seinen neuen Orden und Vereinen elastisch auf. Dafür vernichtete er freilich nach Vermögen Kultur und Sekte, soweit sie selbständig neben ihm existieren wollten. Der Protestantismus ist einfacher, biblischer und enger und darum stieß er sowohl die unkirchlich-weltliche Bildung wie die Sekten von sich aus. Aber bei seinem unaustilgbaren Prinzip persönlicher Ueberzeugungsgewißheit und biblischer Rein-

440) Vgl. Gothein, Staat und Gesellschaft des Zeitalters der Gegenreformation S. $139-145,161-176$. 
heit mußte er sie schließlich neben sich dulden und erfuhr er von ihnen die stärksten Rückwirkungen. die nun ihn in einen Reichtum der Entwickelungen hineinrissen, demgegenüber die katholische elastische Synthese als harte Engigkeit erscheint.

In letzten Grunde freilich ist die Sekte von dem kirchlichen Geiste des Protestantismus und des Katholizismus gleich verschieden, ein neben dem Kirchentypus hergehender, in gewissen Elementen des Neuen Testaments begründeter, selbständiger Zweig der christlichen Idee. Die großen Volkskirchen vertraten die Gnadenidee und die Idee eines die Einzelnen aus sich hervorbringenden Gemeingeistes, und damit nahmen sie auch die Voraussetzungen des allgemeinen Kulturlebens in sich auf. Denn für sie kommt es auf Massenwirkungen an. Das Heil und die Gnade sind ebenso unabhängig von dem Maße der subjektiven Verwirklichung der strengen ethischen Maßstäbe als beweglich in der Anpassung an die durch die Sünde notwendig gewordenen, heilenden und disziplinierenden, aber freilich nicht eigentlich christlichen ethischen Institutionen des Naturgesetzes. Damit machen sie alle die christliche Ethik zu einem die Welt irgendwie aufnehmenden Kompromi ${ }^{447}$ ). Darum sind sie - auf den welthistorischen Einfluß gesehen - die Hauptverkörperungen der christlichen Idee, die grossen historischen Mächte und die Fortbildner der christlichen Ethik. Sie waren das erste große Ergebnis der altchristlichen Weltmission. Aber einmal durchgesetzt waren sie der Stoff und das Widerspiel, denen gegenüber die Kritik und Opposition einer individualistischpersönlichen, streng urchristlich-ethischen und die Massen bei Seite schiebenden Christlichkeit einsetzte. In dieser Kritik aber kommt allerdings ein Grundtrieb der echten altchristlichen Ethik immer wieder zum Vorschein. Sie bildet die engeren Kreise einer strengen ethischen Beurteilung der Welt nach dem Evangelium. Diese Kreise aber nehmen naturgemäß die der Volks- und Gnaden-

${ }^{447}$ ) Sehr treffend, wenn auch unter charakteristischer Mißbilligung Arnolds, sagt ein Gegner Joh. Arndts : >Diejenigen täten Unrecht, die aus Arndts Büchern oder Taulers auf a 11 e applizierten, da doch das gemeine Leben gar andere mores erfordert G. Arnold II 458. Das ist auch der Nerv der Kritik Bullingers an den Täufern; sie sind gegen die die Gesamtheit umfassende christliche Liebe und Duldung der gott->gewollten. Verhältnisse, vgl. Sebastian Franck, Ketzerchronik S. 153. Andererseits richtet sich die Kritik Schwenkfelds gerade gegen die Massenkirche und erkennt deren Zusammenhang mit dem , volkstümlichen Sakramentalismuse Ecke 103. 
812 III. Protestantismus. 4. Sektentypus und Mystik auf protestantischem Boden.

kirche entgegengesetzte soziologische Struktur des Vereins individuell Bewährter an. Das geschah auf dem Boden aller christlichen Kirchen, weil alle mit der Bibel zugleich neben dem Motiv der Gnadenstiftung das Motiv der Sekte in sich tragen. Es sind nur die Saugfäden verschieden, mit denen sich die Sekte auf dem Boden der jeweiligen Kirchen festsaugt. Auf katholischem Boden ist es überwiegend die Weltabgeschiedenheit, die an der oberen mönchischen Moralstufe ihre Analogie findet; auf protestantischem Boden ist es der Individualismus und Subjektivismus der Bibeldeutung und des persönlichen Heilsbesitzes ohne Priestertum und Hierarchie. Es ist kein 'Zweifel, da13 der Protestantismus sich schließlich als der fruchtbarere Boden der Sekte erwiesen hat. Seine ganze lintwickelung ist von einer mächtigen Sektenbewegung begleitet und durchsetzt. Die außerorientlichen soziologischen Konsequenzen dieser Entfaltung des Sektentypus auf protestantischem Boden hat uns schon sein Einbruch in den Calvinismus gezeigt, und das wird sich uns noch weiterhin in diesem Abschnitt verdeutlichen.

Eine Einzeldarstellung der Bewegung ist hier nicht möglich. Es sei nur an die wichtigsten Tatsachen erinnert und der allsemeine Gang der Bewegung gezeichnet, wic das oben auch in bezug auf das Mittelalter geschehen ist.

Die liewegung brach 1525 in $Z$ ü ri $\mathrm{ch}$ aus Kreisen radikaler Reformer hervor, denen $Z$ winglis Durchführung des Schriftprinzips nicht genügte. Die Gläubigentaufe, die Freiwilligkeitskirche, die Vorschriften der Bergpredigt, die Zurückhaltung von Eid, Krieg, Recht und Obrigkeit, schließlich die weitestgehende gegenseitige materielle Hilfe und die Gleichheit aller Gemeindeglieder, die Aeltẹsten- und Predigerwahl durch die Gemeinde und meist auch die Unbezahltheit des geistlichen Amtes: das waren ihre Grundsätze, die mit den Neigungen der demokratischen Mlassen sehr übereinstimmten. Die ganze Bewegung war in der Hauptsache eine solche der Unterschicht, vor allem des Handwerkertums, der Minen- und Bergarbeiter und ähnlicher Gruppen. Die Führer waren meist Theologen, bei denen zunächst die Konsequenz des Schriftprinzips und der Ernst der Gemeindezucht entscheidend waren, aber sie verstanden nach und nach auch an die demokratischen Masseninstinkte zu appellieren. Die ersten gemäßigten Forderungen der Bauern hat man - wohl mit Recht - mit ihren Lehren in Verbindung gebracht, soweit sie sich auf die Wiederherstellung des Ge- 
setzes Christi und der apostolischen Kirche bezogen; der spätere Radikalismus der Bauernrevolution hing dagegen mit den hussitischtaboritischen Ideen von absolutem Gottes- und Naturrecht zusammen, nicht mit dem leidenden und duldenden Täufertum ${ }^{448}$ ). Dieses letztere aber war die eigentliche Hauptmasse. Aufruhr und Gewaltgebrauch lag ihnen völlig fern. Nur die von Hut geführten mährischen Gruppen pflegten den Kommunismus, lehnten jedc Berührung mit der herrschenden Obrigkeit ab und ergaben sich einem joachimitischen Chiliasmus.

Von Zürich aus verbreitete sich die Bewegung ungeheuer rasch und intensiv, indem sie überall die von der Reformation nicht Befriedigten und die Reste der mittelalterlich-evangelischen Gruppen an sich zog. Ganz Mitteleuropa wurde überdeckt mit täuferischen Gemeinden von loser gegenseitiger Verbindung und mit streng schriftmäßiger Kultübung. Augsburg, Mähren und Straßburg, schließlich Friesland und die Niederlande waren die Hauptzentren. Es war ein erster vorzeitiger Triumph des sektenhaften Freikirchenprinzips. Dieses ganze Prinzip aber stand - auch abgesehen von der ablehnenden oder zurückhaltenden Stellung der Täufer gegenüber allen obrigkeitlichen, mit Recht, Gewalt und Eid in Verbindung bringenden Aemtern - der noch alles beherrschenden mittelalterlichen Idee von der staatskirchlichen Einheit der Gesellschaft so schroff entgegen, daß Katholiken und Protestanten darin nur die Leugnung der Grundlagen aller Gesellschaft erblicken konnten. Sie beantworteten die Bewegung mit einer grauenvollen und blutigen Verfolgung, die erst alle Häupter dem Feuer oder Schwert oder Wasser überantwortete und dann auch die Massen schonungslos dezimierte ${ }^{449}$ ). In den noch ungeordneten kirchlichen Verhältnissen vor 1526, wo die örtlichen Einzelgemeinden vielfach selbständig ihr Religionswesen zu ordnen begannen und un-

48) Hierzu s. den Art. Bauernkrieg von Sommerlad in Schieles Lexikon., Er hebt mit Recht das Naturgesetz in seiner absoluten taboritischen Bedeutung hervor und bringt die radikalen Forderungen mit dem Hussitismus in Verbindung. Die gemäßigten Anfangsforderungen der I 2 Artikel bringt Berens, Digger Movement mit dem Täufertum in Verbindung; Stolze, Zur Vorgeschichte des Bauernkrieges, 1908 nennt den Täufer Hubmeier als einen der Mitverfasser.

${ }^{449}$ ) S. die Verhandlungen Philipps von Hessen mit den andern Ständen wegen der gegen die Täufer zu befolgenden Politik bei Hochhuth, Z. f. hist. Theol. Nur der Landgraf ist für eine relativ humane Praxis, kann sie aber gegen die »staatsund gesellschaftserhaltendene Ordnungsmänner nicht durchsetzen. 
begrenzte Möglichkeiten kirchlicher Gestaltung offen zu stehen schienen, da hatte diese Bewegung Boden und Zukunft. Aber eben deshalb beseitigten auch alle herrschenden Mächte die provisorischen Zustände und schufen entschlossen diè kirchliche Einheit von oben, wenn sie von unten und aus der Kraft des Geistes nicht kommen wollte. Nur da, wo eine solche endgültige Ordnung noch unmöglich war, wie in den Niederlanden vor 1572 blieb ihr eine verlängerte und schließlich dauernde, wenn auch eingeschränkte, Lebensmöglichkeit. Ueberall sonst herrschte die Verfolgung. Dieser furchtbare Druck der Verfolgung trieb nun aber die Täufergemeinden einem aufgeregten Enthusiasmus und Chiliasmus entgegen, und so zogen einige Schwärmer in den Niederlanden, wie einst die Taboriten, die Folgerung, daß in der Endzeit nach alttestamentlichem und apokalyptischem Vorbild die gewaltsame Aufrichtung des himmlischen Jerusalem geboten sei. Die Folge davon waren die Greuel von Münster, die sich zu einer Katastrophe des gesamten Täufertums auswuchsen und von allen Verfolgern als Bestätigung ihrer Auffassung betrachtet wurden.

Aus den damit hereinbrechenden Wirren sammelte dann Me n no Simons das Täufertum zu einer stillen evangelischen Gemeinde, schied den taboritisch-joachimitischen Typus aus und brachte den von Anfang an überwiegenden Züricher Typus wie der zur Herrschaft, wobei er sich zugleich auf die mittelalterlichen evangelischen Sekten berief. Es sollten Gemeinden im Sinne der Bergpredigt, mit Bann und Gemeindezucht, Gleichheit der Gemeindeglieder und freier Wahl der übrigens im bürgerlichen Leben bleibenden Vorsteher sein. Der Eid und die Teilnahme an Kries und Rechtsprechung blieben verboten. Die Abschließung gegen nicht-täuferische Christen wurde stark betont, ja sogar die Trennung der Ehen im Falle der Lngläubigkeit oder Bannung eines I ciles gefordert. Die niederländischen Verhältnisse, wo die Einz:Istaaten das Kirchenwesen selbständig und verschieden orcneten, gewährten ihnen die Existenzmöglichkeit, wenn auch ohne bürgerliche Rechte und unter vielfachem Druck des orthodoxen Calvinismus. Sie haben schließlich zunehmend unter dem Einfluß des umgebenden Calvinismus die protestantische Berufsmoral übernommen und von da aus auch Staat, Recht und Amt nicht bloß dulden, sondern selbst mit vertreten lernen. Für Kriege leisteten sie schließlich wenigstens Beisteuern und erhielten für solche Bei- 
steuer am Ende die vollen bürgerlichen Rechte. Die nach 1650 wieder auftauchenden Radikalen sahen in ihnen mit Recht den Kompromiß mit der Welt. Sie verbürgerlichten und gediehen ökonomisch in hohem Grade ${ }^{450}$ ). Aber auch so gelang es nicht, das Täufertum einheitlich $\mathrm{zu}$ organisieren. Es zerfiel auch dann noch in allerhand größere oder kleinere Gruppen freikirchlicher Gemeinden. Unter diesen zeigten die Waterländer und die friesischen Täufer im Gegensatz zu den verfassungsmäßig zentralisierten und den Bann streng handhabenden Gruppen eine Neigung zur Independenz der Einzelgemeinde und zur Betonung der individuellen Freiheit überhaupt. Die Independenz hat sich von da aus immer weiter verbreitet und die Regierung durch ein der ganzen Täuferkirche übergeordnetes Aeltestenkollegium aufgehoben oder auf Scheinrechte beschränkt ${ }^{451}$ ).

Eine außerordentlich wichtige Verzweigung fand nun dieses Täufertum nach England. Dort trat es seit ungefähr $\mathrm{r} 530$ auf durch Vermittelung der massenhaften holländischen Emigranten und mischte sich mit den Resten der Lollarden, erst von chiliastisch-Hofmannschem, dann von mennonitischem Typus. Auch hier wurden sie als separatistische Leugner der Grundlagen aller einheitlichen Gesellschaft grausam verfolgt. Trotzdem behaupteten sie sich auch hier bis in die Zeiten der englischen Revolution, wo wir weiteres von ihnen hören werden.

$\left.{ }^{450}\right)$ Vgl. die Skizze bei Barclay, The inner life S. 79-89. Die Annahme der calvinistischen Berufsmoral, bei der die alte täuferische Askese nur in Vermeidung alles äußeren Luxus und äußerer Ehrenbezeugungen fortdauert, mit Recht hervorgehoben von Max Weber, Archiv f. Soz. XXI S. 69. Die Kritik der Radikalen vom Standpunkt spiritualistischer Askese allenthalben bei Hylkema, Reformateurs; außerdem s. Kramer PRE. ${ }^{3}$ Art. Menno und Mennoniten; auch Göbel II 690-697. Hier aus einem Brief Wilhelms III. von Oranien: »On m'a donné toujours des assurances de l'esprit soumis et pacifique des Ménnonites, qui se comportent avec une resignation et obéissance parfaite envers leurs supérieurs, menant une vie pacifique et laborieuse et contribuant volontiers aux charges de l'état et du pays, où ils demeurent, auquel ils se rendent utiles par leur industrie et leur travail. \& Hier auch Mitteilungen über ihren industriell-kapitalistischen Charakter.

451) Ten Cate, Gemeente of oudsten souverein? Doopgezinde Bijdragen, 46, I906 S. I4I-I5I: „Bij een karakteristiek van de innerlijke ontwikkeling der gemeenten van hun ortstaan c. I650, mag deze trek van overgang der suvereiniteit uit de handen der oudsten in die der gemeente niet worden vergeten: De oudsten verloren hunne macht en te gemeende ontwikkelde zich tot een geheel democratische independente instelling S. $5 \mathrm{I}$. 


\section{III. I'rotestantismus 4. Sektentypus und Mystik auf protestantischen Boden.}

Umgekehrt vollzog sich von England her auch eine Annäherung des pietistisch beeinflußten Calvinismus an das Täufertum. Wir haben das bereits bei Gelegenheit des Kongregationalismus gesehen. Aber die Annäherung ging darüber noch weit hinaus. Von der gegen 1602 in Gainsborough begründeten kongregationalistischen Gemeinde des John Smyth nämlich ging die große, heute weitverbreitete Kirche der General Baptists aus. Die Ausgangspunkte waren puritanisch und calvinistisch; aber während Browne und Robinson ihren Kongregationalismus in vielfacher Analogie mit der täuferischen Independenz ohne Aufnahme der spezifisch täuferischen Lehren ausbildeten, so wurde Smyth, der seine Gemeinde nach Amsterdam als Exulantengemeinde überführte, weiter und weiter in die täuferische Ideenwelt hineingezogen. Schließlich erkannte er die Gläubigentaufe als die Konsequenz des Separatismus und der heiligen Gemeinde an. Er taulte sich selbst und dann seine Gemeindeglieder und begründete damit die Gemeinde neu als Gemeinde der Gläubigentaufe. Nun erklärte er auch ausdrücklich seine Verwandtschaft mit den Täufern und Mennoniten und vereinigte sich mit ihnen. Ein Teil seiner Gemeinde machte bei allem brüderlichen Verhältnis zu den Mennoniten die Fusion nicht mit und lichrte unter der Führung von Helwys und Murton I6II nach England zurück. Dort wurde ihre Kirche die Mutter der großen. Kirche der Ge neral Baptists, die die Prädestination verwerfen, dic Freiheit der Kirche vom Staate fordern, die Gemeinschaft auf den freien Entschluß der Teilnahme, auf Würdigkeit und Immersionstaufe begründen, die dogmatischen Irrtümer der alten Täufer abstellen, Eid, Krieg und staatliche Aemter für bürgerliche Zwecke zulassen, den Kommunismus verwerfen und eine alle Klassen umfassende Körperschaft ohne soziale Einseitigkeit sein wollen ${ }^{452}$ ). Im übrigen halten sie ihren Zusammenhang mit dem Täufertum der Reformationszeit fest, wenn sie auch aus ihrer Entstehungsgeschichte und ihrer dauernden Umgebung einen starken Einschuß calvinistischen Geistes empfangen haben. Sie haben sich durch die Wirren der englischen Revolution hindurchgerettet

452) Newman S. 392. Ueber spiritualistische Züge, die die Gründung von Smyth trug und die die ursprünglich nahestehenden Kongregationalisten schroff verwarfen, s. Barcley 106-109; sie liegen bei den Täufern immer näher als bei Leuten der dogmatischen Autorität. Doch verlangte er Bindung an das äußere Wort als Mittel des Geistes, Behauptung des biblischen Sittengesetzes und strenge Gemeindeordnung. 
und seitdem in England, Amerika und auch auf dem Kontinent zu einer großen Gemeinschaft entfaltet ${ }^{453}$ ). In Wahrheit haben sie vom Täufertum nur das Freikirchen- und Vereinsprinzip, sowie die Forderungen der Sittenzurht festgehalten, im übrigen aber, weit über Menno Simons hinausgehend, die allgemein protestantische Berufsmoral und die Anerkennung von Staat, Recht und Wirtschaft übernommen. Damit sind sie auch von der einseitigen Bindung an die soziale Unterschicht gelöst worden und haben die verschiedensten sozialen Schichtungen in sich aufgenommen. Man spricht heute besser von baptistischen Freikirchen als von baptistischen Sekten. Das in der Welt leidende, duldende und hoffende Täufertum hat, wie schon Menno Simons darin vorangegangen war, in diesem Baptismus seinen Frieden mit der Welt gemacht, nicht viel anders als es die protestantischen Konfessionen auch getan haben. Es blieb nur die Vereinskirche, die Sittenstrenge und ein weitgehender Individualismus, der sich - gleich dem religiösen, übrigens auch sachlich und geschichtlich nahe verwandten, aus dem Calvinismus entbundenen Individualismus der Kongregationalisten und Independenten dem ganzen politischen und sozialen Leben Amerikas und auch der englischen Mittelklassen mitteilte und mit den andern in dieser Richtung wirkenden Motiven verband.

Aber auch das radikale Täufertum blieb nicht ausgestorben. Es erlebte seine Erneuerung in der englischen Revolution. Bereits früher išt gezeigt worden, wie der Kongregationalismus in der Struktur der Gemeinde dem Täufertum folgte und wie die Cromwellschen Puritaner und Independenten mit dem Enthusiasmus der Laienpredigt und der Freigebung der Gemeindebildung täuferische Prinzipien mitvertraten, die dann auch Täufern, Quäkern u. a. mit zugute gekommen sind. Allein der Grundzug dieser

453) Nicht in Verbindung hiermit zu bringen sind die Particular (d. h. prädestina tianischen) Baptists. Die letzteren sind reine Calvinisten, die aus dem Prinzip der Freikirche die Spättaufe folgerten, wie umgekehrt die Freikirche aus dem Ideal der Gläubigentaufe seinerzeit entstanden war. Das zeigt uns den schon bei Gelegenheit des Calvinismus eben erörterten formellen Zusammenhang zwischen Freikirchenund Sektenideal, Newman S. 393. Barclay S. 318: They consisted of little companies of respectable godly people, gathered from Presbyterian worship, into what they deemed a more scriptural form of church discipline, and gradually became convinced of the importance and scriptural sanction of immersion.

Troelts ch, Gesammelte Schriften. I. 
81 II IIl. Protestantismus. 4. Sektentypus und $M_{y}$ stik auf protestantischem Boden.

Independenten war doch mehr spiritualistisch-pietistisch auf der cinen Seite und calvinistisch-puritanisch-theokratisch auf der andern Seite. Gerade in der Verbindung der Tolerierung freier protestantischer Gemeindebildung, der strengen christlichen Sittenpolizei, des heiligen Kriegs für die Sache Gottes und der Aufrichtungr eines christlich-bürgerlichen Gemeinwesens lag der eigentümliche Zus: jenes Cromwellschen Independentismus; er hing mit dem Täufertum doch mehr durch die von Calvinismus überhaupt aufgenommenen täuferischen Ideale und durch die formelle Gemeindefreiheit zusammen als durch den charakteristisch täuferischen Radikalismus eines Neubaus des Gottesreiches auf den Trümmern der weltlichen und bürgerlichen Ordnung. Der täuferische Geist in diesem Sinne lebte dagegen in Harrison und seinem Anhange und wurde durch den neubelebten Chiliasmus geschürt. Schon in der Armee bildete Harrisons Regiment den eigentlichen Sammelpunkt der Sektierer, während Cromwells Regimenter der Sitz des Puritanertums waren. Im Bareboneparlament vollends wollte Harrison und sein Anhang alles Recht und alle Gerichtshöfe beseitigen, um für die Wiederkunft Christi ein von allem weltlichen Wesen befreites Volk vorzubereiten; ja sie tasteten das Privateigentum an und wollten die kirchliche Ordnung durch Beseitigung ihrer finanziellen Grundlage in den Zehnten völlig aufösen; alle irdische Autorität sollte zertrümmert werden zugunsten des himmlischen Königs und des kommenden Gottesreiches. Wie viele solche Ideen im Lande und in der Armee folgten und wie weit in ihnen ein tatsächlicher Zusammenhang mit dem alten radikalen Täufer- und Sektentum genetisch vorliegt, ist schwer zu sagen. Jedenfalls wurde die alte täuferische Literatur viel gelesen. Kein Geringerer als Bunyan hat in seinem Holy War das Münstersche Ideal vor Augen gehabt, während man seinen Pilgrims Progress mit der Geschichte des Tobias von Heinrich Nikläs Wanderungen in Verbindung bringt. Im Barebone-Parlament trafen beide Gruppen aufeinander, und es war die schmerz. liche Trennung Cromwells von seinen alten Genossen, die in der Aufösung des Parlamentes der Heiligen zum Ausdruck kam. Die Tätigkeit des Parlamentes war durch dieses radikale Sektentum unmöglich geworden, nachdem es im übrigen in ernster politischer Arbeit das Gemeinwesen gefördert hatte. Es brach in eine Cromwellsche gemäßigte Majorität und eine Harrisonsche schwärmerischradikale Minorität auseinander und legte daher seine Mission in Cromwells Hände zurück. Von da ab waren die radikalen Heiligen 
die Gegner Cromwells; sie hingen mit populär-demokratischen Bewegungen zusammen, die in der allgemeinen Erschütterung der Verhältnisse in die Höhe kamen. Damit aber geriet die Republik zwischen die Scylla der diktatorischen Autorität und die Charybdis des doktrinären Schwärmertums. Die Männer der Energie und der politischen Verantwortung, wie der General Monk, haben nicht gezögert, sich für die erstere zu entscheiden; und die Masse ist, wie es zu geschehen pflegt, dann nachgefolgt. Damit war die letzte große Erhebung des Täufertums zu Ende, die doch nur im Gefolge der sehr viel weniger vom Täufertum berührten und mehr puritanisch bestimmten Bewegung der Independenten hatte in die Höhe kommen können. Es war die letzte politisch bedeutsame Welle des Chiliasmus, die letzte Wiederkehr des Geistes der Hussiten- und Bauernkriege, der letzte Versuch der christlichen Welterneuerung, das Reich Gottes mit dem Schwerte vorzubereiten ${ }^{454}$ ).

$\left.{ }^{434}\right)$ S. Glass, The Barebone Parliament. Weingarten hielt Täufer und Independenten zu wenig auseinander; sein Satz S. 158: ,In Cromwell erreicht der Anabaptismus seinen Höhe- und Gipfelpunkt, aber es ist ebensosehr auch seine Tat, daß der Anabaptısmus aufhört, eine Macht zu sein «, ist nur sehr bedingt richtig. Ferner Gooch, The history of English democratie ideas in the $17^{\text {th }}$ cent Cambridge 1898, ein sehr stoff- und lehrreiches Buch, das W.eingarten ergänzt und fortführt. Für die ökonomische und sozialgeschichtliche Seite der Sache vgl. die wichtige Arbeit von E. Bernstein, Kommunistische und sozialistische Strömungen während der englischen Revolution des 18 . Jahrh., in $>$ Geschichte des Sozialismus in Einzeldarstellungen I I 895 S. 507-718; natürlich ist hier dann wieder nach sozialistischer Geschichtsdogmatik alles Religiöse nur durchsichtige Hülle für ökonomisch-soziale Bestrebungen, die sich hier noch in ihrem vormarxistischen, d. h. ideologischen und zwar christl.-täuferischen Stadium befinden; außerdem Belfort Bax, Rise and fall of the Anabaptists, London 1903, wo das Ganze mittelbar auf das Täufertum zurückgeführt wird. - Der wesentlich täuferische Charakter der späteren radikalisierten Bewegung, der den presbyterianischen und calvin.-independenten Charakter ablöst, ist in allen Darstellungen anerkannt; auf starke Bestände radikaler Täufer nehmen sowohl die Darstellungen als die Quellen überall Bezug, vgl. Weingarten S. 103-105, das Zeugnis Baillies Weingarten S. 127, S. 179 Anm. 2, 265. Ferner Gooch 73-75, 128-129, 174 f., 267-70, Bernstein 509, 522 Vorspiel im Jahre 1549, 525-527 Lollharden und Täufer. Ueber das Verhältnis zu Luther s. eine Flugschrift bei Weingarten S. II4 : > Jeromes of Prague or Luthers time was but a little bether than the darkest time of popery.* Das ist die Sprache der Täufer und Spiritualisten. Vielfache Bezüge auf radikale, von den friedlichen General Baptists unterschiedene Täufer bei Barclay, The inner life, und in dem wichtigen 
Einige Gruppen die in den letzten Jahren des Kriegs und dann vor allem nach Cromwells *Abfalle hervortraten, zeigen die Buch von Firth, Cromwells Army 1902, das nur leider diesen Beziehungen nicht prinzipiell nachgeht: Disputation der Feldprediger über Kindertaufe S. 325 ; Vertrctung der Laienpredigt durch Leutnant Chillandon in dem Traktat Preaching without ordination; der Leutnant wurde Anabaptisten-Prediger. S. 336: Die Laienpredigt, namentl. der Offiziere, erhielt ihren Anlaß durch die Zurückziehung der presbyterianischen Geistlichen von der Armee, Firth $334 \mathrm{f}$, ebenso Bernstein 546. Sie hing mit dem Chiliasmus zusammen, indem bei dem Kommen des Reiches das geordnete Amt hinfällig wird. Aus dieser Laienpredigt der Offiziere und ${ }^{*}$ ihren relig. Besprechungen entstanden dann auch leicht religiös-politische Theorien, .Firth S. 337. Doch war das Recht der freien Predigt nie unbeschränkt und unkontrolliert; es endete mit der Säuberung der Armee von allen sanabaptistischen Elementen, wobei jedoch Cromwell die milderen A Anabaptistene ausdrücklich der Armee erhalten wollte. Ein Pamphlet von 1655 (Firth $342 \mathrm{f}$.) redet Cromwell an: And so were you at Dunbar in Scotland or at least you seemed so by your words and your actions; for you spake as pure Independency as any of us all then and made this an argument, why we should fight stoutley, because we had the prayers of the Independents and Baptist Churches. So highly did you seem to love the Anabaptists then, that you did not only invite them into the Army but entertain them in your family. \& Bei Firth auch Darstellung der geistlichen Versorgung der Armee, die wichtigsten Feldprediger Dell, Saltmarsh, Hugh Peters, Canne, zum Teil reine Spiritualisten, über die später zu sprechen ist, zum Teil Radikale im Sinne des Täufertums. - Die ethische religiöse Begründung des Krieges gegen die bisherige Autorität war zunächst die hugenotisch-schottisch-calvinistische, s. den Soldatenkatechismus bei Firth 330 und den Traktat von Bridge über das Recht des bewaffneten Widerstandes bei Hanbury, Historical memorials relating to the independents II $189 \mathrm{ff}$. Mit dem Eindringen des Chiliasmu wird die Begründung eine andere: es gilt Christi Reich vorzubereiten. Hierfür besonders lehrreich ein Traktat von Archer, The personal reign of Christ upon earth 1642, den mir Herr Sippell freundlichst mitgeteilt hat. Damit geht dann die Auffassung vom Recht des Krieges in die Analogie des täuferischen über oder ist direkt von ihr abhängig. - Im übrigen ist die Politisierung der Armec dic Folge des Bruches mit dem Parlament und bedeutet das Auf kommen einer bestimmten politischen und sozialen Schicht in der Armee Firth 318, 35I-354. Ursprünglich meist aus gepreßten Leuten bestehend, hatte sie kein eigenes Interesse. Seit $165 \mathrm{I}$ besteht sie nur aus Freiwilligen, weil es nur dieser Sache sei, für Nation und Religion zu streiten. Der eigentliche Sitz dieser Freiwilligen ist von Anfang an Cromwells Kavallerie. - Ueber das damit zugleich auftauchende absolute Naturgesetz der Sekte im Gegensatz gegen das relative der Kirche, auch gegen das immer noch ständisch gedachte hugenottisch-schottische Naturrecht des Staatsvertrages siehe Gooch: S. $108 \mathrm{f}$. schottisch-hugenottisch, ebenso S. $11 ;$ U. 133-162 (Ireton); der Uebergang zum Radikalismus S. 176 (Godwin) und ISo (Milton); das radikale Naturrecht des Urstands, der Vernunft und Christi 
täuferischen Züge mit besonderen Eigentümlichkeiten. Es sind bei der ganzen Lage der Dinge und bei der die Atmosphäre erfüllenden spiritualistischen Vergleichgültigung des Kultus und der Organisation jetzt keine besonderen kultischen Gruppen mehr, eher politisch-soziale Parteien. Aber in diesen treten dann die politischsozialen Folgerungen als solche der religiösen Idee umso deutlicher hervor. Die wichtigste und zahlreichste Gruppe waren die Leveller. Sie waren stark politisch interessiert und setzten sich in Gegensatz gegen die Armeeleitung, aber auch sie begründeten ihre Forderungen religiös. Sie sind die Vertreter des radikalen Natur-, Gottesund Christusgesetzes, das von keinem Kompromiß mit den Ordnungen der Sünde weiß, sondern von Grund aus das christliche, soziale und politische Ideal verwirklichen will. Ihr Führer John Lilburn stammte aus Puritanerkreisen, war ein Opfer der Sternkammer, Exulant in Holland, dann Offizier der Parlamentsarmee. Bald auch mit dem Parlament zerfallen, setzte er durch seine Agitation die Armee in Brand und regte sie zu den berühmten Vorstellungen an die Gemeinen und das Parlament auf, die als Agreements of the people bekannt sind. Der Geist des Ganzen war eine aus dem christlichen Spiritualismus gefolgerte völlige Entstaatlichung der Kirche und ihre Auflösung in freie, sich selbst erhaltende Gemeinden, zugleich die Folgerung einer radikalen Demokratie aus der christlichen Gleichheit.und Freiheit der Erlösten. Nicht Vermögensgleichheit, aber volle Rechtsgleichheit und wirkliche Beteiligung des gesamten Volkes, soweit es christlich fromm ist, an der Leitung der Regierung sollte gefordert werden, das Rechtswesen vereinfacht, die Todesstrafe beschränkt werden. In diesem Sinne sei Jesus der erste Leveller gewesen. Durch den Widerstand der Generale und schließlich durch Cromwells Protektorat zurückgewiesen, gingen sie in eine leidenschaftliche Opposition über, die Attentate, Verschwörungen und sogar Verbindungen mit den Royalisten nicht scheute, bis sie schließlich gewaltsam unterdrückt wurden. John Lilburn selbst rettete sich schließlich in den stillen Hafen des Quäkertums ${ }^{455}$ ).

ohne Kompromiß mit der Sünde S. $184 \mathrm{f}$., 199, 328. Besonders in der gleich zu nennenden Schrift von Berens über die Diggers: First we demand, yea or no, whether the earth with her fruits was made to be bought and sold from one to another? and whether one part of mankind was made to be a Lord of the land and another part a servant by the 1 a w of creation.before the fallis Ueber Bunyan s. Belfort Lax S. 379-381.

455) Ueber die Leveller am besten Gooch S. 139-157, 195-206, 256-259. 
822 III. Protestantismus. 4. Sektentypus und Mystik auf protestantischem Boden.

Viel wirkungsloser sind die Soz a lis te $\mathrm{n}$ und $\mathrm{K}$ o m m un i sten der Revolution. Während die Leveller das dem radikalen Bürgertum und den Arbeitern gemeinsame politische Freiheitsinteresse aus den religiösen Voraussetzungen folgern und begründen, vertreten diese Gruppen das Interesse des Landproletariates, das gleichfalls durch das Reich der Heiligen zu seinem Recht und zu dem

Hier ist die Auffassung Weingartens am befremdlichsten; er sieht in ihnen verkappte Rationalisten und gar die Anfänge des Deismus, weil er das absolute Naturrecht in seiner Identität mit der Vernunft und dem Christusgesetz als alte Sektenidee nicht kennt. Das absolute Naturrecht erscheint ihm als moderner Rationalismus, was es nicht ist. Noch weiter geht Bernstein, der hier nur eine dünne, überall zerreißende Decke im Religiösen erkennen will. Die Schrift von Overton Mans mortalityc, auf die er sich beruft S. $579 \mathrm{f}$., leugnet doch nur. den sog. Zwischenzustand und lehrt eine vollkörperliche Auferstehung. Mehr beweisen die - freilich von Gegnern berichteten - epikuräischen Aeußerungen Walwyns S. 58 I f. Allein bei Lilburn selbst und bei der ganzen Bewegung kann an der wesentlich spiritual.-religiösen Wurzel nicht gezweifelt werden. Die Verwerfung des Dogmas und der Heilsgeschichte sowie die Allegorisierungen sind Spiritualismus im Stil Seb. Francks, aber nicht eine verdeckte Preisgabe der religiösen Grundlage. Die von Weingarten S. 307 zitierte, mit der zur Verteidigung Walwyns geschriebenen Schrift The charity of churchmen vermutlich den gleichen Verfasser besitzende Schrift = The craftmans craft 1649 * (s. auch Weingarten 304) ist mir von Herrn Sippell gütigst zur Kenntnis gegeben. Sie enthält an religiösen Elementen mehr als das bloße von W. zitierte Bekenntnis zur Existenz Gottes. Sie verteidigt einmal Overtons oben berührte Aeußerung über die Sterblichkeit des Leibes als die Auferstehung des Geistes und seine Wiederverkörperung ausdrücklich behauptend; sie verwahrt sich ferner mit charakteristischer Einschränkung gegen den Vorwurf Münsterschen Täufertums Where proofs are wanting, there are resemblances insinuated in their stead; and comparisions made either in such things as are true of neither; or else the Party, that is to be made odious, is likened to such as are already, in some particulars not material; and yet thereby is suggesteda similitude in all therest.e Das ist doch das runde Bekenntnis zum täuferischen Ideal, abgesehen von some particulars not material. Vor allem aber die Begründung der levellistischen Forderung selbst: We answer, that we cannot suppose nor do we think, any rational man to belive the thing unlawful in itself; for then the primitive Christians did unlawful.s Das Prinzip an sich ist christlich und vernünftig; es darf nur nicht mit Gewalt aufgezwungen werden: to make it lawful there must be an unanimous and individual consent of every man unto. Das zeigt auch, wo die mißbilligten particulars der Münsteriten liege : in der dem christlichen Geist widersprechenden Gewaltsamkeit. Die von Weingarten S. 304 zitierte Aeußerung zeigt doch nur den Spiritualismus der Leute, dessen nicht rationalistische Natur wir noch kennen lernen werden. 
Lohn seiner Opfer für den Krieg zu kommen hoffte. Die Bewegung blieb auf dieses beschränkt, da es ein Industrieproletariat noch kaum gab. Sie traten hervor als "Diggers" d. h. als eine kommunistisch organisierte kleine Gruppe, die das Gemeinland und Krongut unter Grabscheit und Pflugschar zu nehmen für ihr christliches Recht hielt. Ihr Wortführer war Gerard Winstanley, von dem unter dem Titel "The law of Freedom " ein christlichsoziales Reformprogramm, Cromwell gewidmet, nebst vielen Flugschriften auf uns gekommen ist: Winstanley war in seinen Ausgangspunkten reiner Spiritualist, ähnlich wie Hans Denk, Sebastian Franck und die Familisten. Aber die aus diesem Spiritualismus des inneren Lichtes und des einwohnenden ewigen Christus, der zusammenfällt mit der schaffenden Gottesvernunft, gefolgerte christlich-soziale Idee ist das alte Sektenideal des absoluten Naturrechts, wie es vor dem Sündenfall war, das Ideal der Freiheit, Gleichheit und Brüderlichkeit, welches Recht, Gewalt und Herrschaft nur soweit kennt, als all das aus der freiwilligen Zustimmung der Individuen abgeleitet ist und der Aufrechterhaltung des Gesamtwohls willig dient. Alles darüber hinausgehende historische Recht, das von der Kirche und dem monarchisch-aristokratischen Prinzip als relatives Naturrecht gefeiert und durch den Sündenfall begründet wird, ist ein Erzeugnis des Fleisches, der Selbstsucht und der Aeußerlichkeit; es wird nur von der falschen Priester- und Professorentheologie im Klasseninteresse mit sophistischen Gründen gedeckt. Christus, das innere I icht, die Vernunft, das absolute Naturrecht, all das ist identisch; es soll mit dem Siege Christi jetzt in England ein neues Zeitalter begründet und auch auf den Kontinent übertragen werden. Durchgeführt werden soll dieses christliche Naturrecht zunächst in der Auflassung des Gemeinlands und der herrenlos gewordenen Güter für eine kommunistische Bearbeitung durch die Verarmten und Kapitallosen. Dabei soll die Familie und der Privathaushalt erhalten bleiben. Auch soll das Ganze nicht mit Gewalt verwirklicht werden. Die älteren Brüder, wie er die Landbesitzer und Kapitalisten nannte, sollen in ihrem Besitz und Gewinn bleiben, nur das freigewordene Land soll den »jüngeren Brüdern* oder den Kapitallosen überlassen werden. Der Geist müsse dann die neue Ordnung selbst durchführen, die Winstanley als eine absolut demokratische, durch jährlichen Wechsel der Wahlbeamten zu leitende Gesellschaft dachte und in der er das Geld sowie Mietung und Verwertung von Arbeitskräften 
ausschloß. Das Vorbild des Gesetzes Israels, geistig gedeutet, schwebte ihm dabei vor. Cromwell stellte er vor die Wahl, die neue Ordnung aufzurichten und so ein wahrer Christ zu bleiben oder bloß unter neuem Namen die alte fortzuführen und dämit den inwendigen Christus zu verraten. Es ist eine Vorausnahme von Ideen über das Eigentum, wie sie später Locke vertreten hat, und von einer Bodenreform, wie sie heute Henry George vertritt, freilich zunächst völlig wirkungslos, da die nächste Entwicklung gerade im Gegenteil die Aufteilung des Gemeinbesitzes und die Verdrängung der freien Bauern zugunsten der Enclosures brachte. Kurz nach Winstanley begegnen wir im Jahre 1659 in London zwei Pamphleten des Holländers Peter Cornelius Plockboy, der der gemäßigt täuferischen Bewegung angehörte und, von den mährischen Täufern, vielleicht auch den Labadisten angeregt, das Programm einer im großen Stil organisierten Kooperativ-Genossenschaft aus christlichen Grundsätzen entwickelte; damit wollte er die bürgerliche Wirtschaft zur Nachfolge zwingen; von praktischen Wirkungen erfahren wir nichts. Immerhin aber haben Winstanleys Ideen dann auf den christlichen Sozialismus des Quäkers Bellers und dieser auf Richard Owen gewirkt, sodaß von ihm unmittelbare Fäden zum modernen Sozialismus hinüberlaufen. Er selbst hat, ähnlich enttäuscht wie Lilburn, mit vielen seiner Anhänger schließlich den Anschluß bei den Quäkern gefunden ${ }^{465}$.

468) Vgl. Gooch S. 214-225, Bernstein S. 583-608; vor allem das die wichtigsten Auszüge darbietende Buch von Berens, The digger movement in the days of the commonwealth, London 1906. Dadurch, daß W. Gott als Vernunft oder creative reason bezeichnet, haben sich viele verleiten lassen, diese Ideen als wesentlich rationalistisch zu betrachten. Allein W. beginnt bei den Familisten und endet bei den Quäkern. Die Creative Reason ist der Logos, identisch mit dem inwendigen Christus: This Spirit of reason is not without a man, but within every man; hence he need not to run after others to tell him or to teach him; for this Spirit is his maker, he dwells in him, and if the flesh were subject thereunto, he would daily find teaching therefrom, though he dwelt alone and saw the face of no other man. S. 45. Even so Christ, which is the spreading power, is now beginning to fill every man and woman with himself. He will dwell and rule in everyone: and the law of reason and equity shall be Christ in them ... This is the Church, the great congregation, that, when the mystery is completed, shall be the mystical body of Christ, all set at liberty from inward and outward straits and bondage. And this is called the holy breathing, that made all new by Himself and for Himself S. 67. The golden Rule, do not to another as thou wouldst have another to do thee, which God, 
Am engsten ist der Zusammenhang mit dem radikalen Täufertum festgehalten bei den Millenariern, einer Partei, die die vier danielischen Weltreiche der kirchlichen Geschichtsphilosophie bis auf Cromwells Protektorat ausdehnte und nach dessen Zusammenbruch das fünfte Weltreich der vollendeten Christusherrschaft erwartete. Sie hofften auf die Wiederkunft Christi und die Aufrichtung des wahren Reiches der Heiligen ohne Priester, Sakramente, Recht, Eid, König und Obrigkeit, auf das Reich des vollendeten christlichen Liebes-Anarchismus. Die einen harrten dieser Zukunft in stillem Dulden und Ertragen der Welt, die andern griffen wie die Taboriten und Münsteraner zur Revolution. $\mathrm{Zu}$ dieser Gruppe gehörten die eigentlichen religiösen Schwärmer; ihr Geist beherrschte die Linke des Barebone-Parlamentes, mit dem Cromwell daher nicht regieren konnte. Sie bildeten eine wirkliche Gefahr für das Protektorat. Ein engerer und stillerer Kreis sonderte sich von ihnen ab unter der Führung von John Pordage, der, zu mystischen und asketischen Ideen übergehend, das Reich der Heiligen zu einer philadelphischen Gesellschaft verinnerlichte, ähnlich wie die späteren Quäker und die kontinentalen Labadisten. Aber viele verharrten auch im erbitterten Kampfe gegen Cromwell. Nahe verbunden mit ihnen waren die radikalen Baptisten, die namentlich in der irischen Armee vertreten waren und dort einen anabaptistischen General auf den Schild heben wollten, bis Monk sie aus der Armee heraussäuberte. Bei der Restauration waren diese Chiliasten die einzigen, die sich nicht fügten oder zu den Innerlichkeitsgruppen übergingen. Sie machten den Versuch einer Auflehnung, der blutig niedergeschlagen wurde. Ihr Führer Harrison starb in der Ueberzeugung, daß er bald wiederkommen werde zur Rechten Christi bei der

Christ and scripture have enacted for a lawe S. 171. "The law of creation and equity of the scriptures 158 . That their intent is to restore the Creation to its former condition* S. 37. In diesem Sinne ist auch stets von dem birth right, dem angeborenen Recht oder den Menschenrechten die Rede. Bereits hier tritt uns dieser wichtige Gedanke, und zwar als ein religiös begründeter, entgegen. Das birth right ist zugleich das vornormannische englische Volksrecht, wie einst in der Wikliffie; vor der Eroberung galt das Naturrecht. Solche Stellen sind zahllos, es ist das uns wohlbekannte christliche Naturrecht in der Sektengestaltung, außerdem verbunden mit dem mystischen Spiritualismus. W. über sein Verhältnis zu den Täufern S.65, sie sind ihm zu äußerlich. - Ueber Plockboy Bernstein S. 685-694 and Laspeyres S. 105 f. - Ueber Bellers Bernstein 694-728. 
826 III. Protestantismus. 4. Sektentypus und Mystik auf protestantischem Boden.

Aufrichtung des Reiches. Von da ab war es mit dem revolutionären Täufertum bis heute zu Ende ${ }^{457}$ ).

Die übrigen religiösen Gruppen der Revolution gehörten der mystisch-spiritualistischen Bewegung an und sind im Zusammenhang mit dieser später zu nennen. Das religiöse Endergebnis von allem aber, die Quäker-Sekte, war ein Mischgebilde aus Sektengeist und Spiritualismus und ist daher gleichfalls erst später zu schildern. Hier war nur das in der Great Rebellion mitspielende sektenhafte Element hervorzuheben, wie im vorigen Kapitel das calvinistisch-schottisch-hugenottische im Zusammenhang des Calvinismus erläutert werden mußte. Was über diese letztere Linie hinausging, war enthusiastisch, mystisch-spiritualistisch und vor allem radikal-naturrechtlich im Sinne des aggressiven chiliastischen Täufertums. Dieses letztere Moment der höchst komplizierten Bewegung gehört in den gegenwärtigen Zusammenhang. Es war nicht das beherrschende, aber es hat tiefe Wirkungen hinterlassen. Wie immer hat auch hier der idealistische Radikalismus zunächst allerdings bloß der Reaktion den Weg bereitet. Aber die Folgen blieben doch unaustilgbar. Teils gebrochen in der Verbindung mit der puritanisch-independenten Bewegung, teils unmittelbar in den radikalen Gruppen hat der Geist des Täufertums dazu gewirkt, die Einheit von Staat und Kirche aufzulösen, die Kirchenbildung frei zu stellen und die Verchristlichung des Volkes auf ethisch-soziale Interessen ohne dogmatischen $Z$ wang hinzuleiten. All das geschah noch im Geist utopischer Schwärmerei, aber es wurde in den nächsten Generationen zum politischen und wirtschaftlichen, nüchternen Programm. Es ist das letzte Mal, daß eine politisch-soziale Revolution sich im Zeichen der christlichen Ideen vollzog, aber diesen Ideen verdankte sie einen großen Teil ihrer Macht und von ihnen her erst ist ihre säkularisierte Gestalt in die moderne Welt eingeführt worden. Hier zeigt sich aufs stärkste die nicht bloß kirchen- und religionsgeschichtliche, sondern die allgemeine politisch-soziale Bedeutung der im Sinne des Sektentypus ausgestalteten christlichen Idee ${ }^{4.58}$ ).

4ii) L'eber die Quintomonarchisten s. Gooch 260-267, 324 und Glass.

453) Hierzu vgl. meine den Independentismus und die Bedeutung des Cromwellschen Zeitalters zusammenfassende Darstellung in Kultur d. G. IV. I ${ }^{2}$ S. 588 bis 600. Das dort Vereinigte ist hier in seine verschiedenen Komponenten aufge- 
Die Entfesselung des Sektengeistes in der englischen Revolution hing mit der pietistisch-puritanischen Gestaltung des englischen Calvinismus zusammen. Diese Gestaltung fehlte auch dem kontinentalen Calvinismus nicht, wie wir gesehen haben. So viel friedlicher und ruhiger dieser verlief, so haben daher doch auch bei ihm die Uebergänge in das erklärte Sektenwesen nicht gefehlt, und die ganze Bewegung griff auch auf das Luthertum über. Hier pflegt man die Erscheinungen unter dem Namen $P$ iet is m u s zusammenzufassen.

Der Pietismus ist im allgemeinen nichts anderes als der innerhalb der Kirchen sich auswirkende und durch die Grundgedanken des Kirchentums eingegrenzte Drang des Sektenideals, wie es aus dem neutestamentlichen Sittengesetz, dem Gedanken des Gottesreiches und dem Gegensatz gegen die kirchlich-sakramentale Veräußerlichung sich auch innerhalb der Kirchen selbst immer wieder erhebt. In diesem Sinne gehört der Pietismus, ebenso wie das Sektenideal selbst, allen Kirchen an. Auch der Katholizismus hatte gerade damals aus verwandten Gründen seine pietistische Erscheinung im Janssenismus; da er eine solche jedoch nur ertragen kann, soweit sie in Orden und Bruderschaften sich kirchlich regeln läßt, so hat er den Janssenismus rundweg vernichtet. Die entsprechenden Bewegungen des Calvinismus, soweit sie innerkirchlich blieben, haben wir bereits als Puritanismus und Präzisismus kennen gelernt. Aber bei dieser Innerkirchlichkeit blieb es nicht, es vollzog sich vielmehr überall der nahe liegende Uebergang zur Separation und zur Sekte. In den Niederlanden begann damit der Labadismus, in England erhob sich mit dem Methodismus eine neue große Welle der Sektenbildung. Aber auch im Luthertum zeigten sich die gleichen Erscheinungen und traten in Berührung mit den calvinistischen, welche Berührung bis zum heutigen Tage immer nur zugenommen hat. Freilich fehlt bei diesem späteren englischen'Pietismus und dem kontinentalen jene welthistorische Aufgipfelung zum Abbruch eines alten und zum Auf-

löst und jede im Zusammenhang ihrer Entwickelungsreihe dargestellt. Der sIndependentismus « ist eben eine völlig komplexe Größe, in der Verschiedenartigstes sich vereinigt. Meine dort sehr allgemein gehaltene. Darstellung von dem Einfluß des täuferischen Elementes, die übrigens dort noch zu sehr unter dem Einfluß Weingartens stand, ist jetzt genauer bestimmt. Damit erledigen sich die teilweise berechtigten Bedenken, die Loofs, Luther und Mittelalter, S. 15 erhoben hat. 
828 III. Protestantismus. 4. Sektentypus und Mystik auf protestantischem Boden.

bau eines neuen Staatswesens, die in der englischen Revolution stattgrefunden hatte. Dort war die religiöse Bewegung durch den Gang der Dinge für einen Moment in den Brennpunlit der politischen und sozialen Kämpfe versetzt, und daraus erklärte sich die gewaltige Umwälzung, in der das Christentum das Haupt eines Königs gefällt hat. Auf dem Kontinent fehlen dem Pietismus derartig große Zusammenhänge. Daher behält er hier und vor allem in Deutschland ein mehr partei- und winkelhaftes, in theologischen und kirchlichen Kreisen sich erschöpfendes, im ganzen mattes und zahmes Wesen. Er zeigt viel echtes, warmes und opferwilliges Christentum, aber auch die ganze Kleinlichkeit geistlicher Gruppen, die für ihre Weltabgeschiedenheit durch einen um so gründlicheren Hochmut sich entschädigen. den scheinbar verschmähten weltlichen Einfluß durch allerhand persönliche Beziehungen dann doch wieder hinten herum gewinnen wollen und ihre Leidenschaften in allerhand geistlichem Krakehl austoben, genau wie das schon die Schattenseite des Täufertums gebildet hatte. In Deutschland ergab sich seit der Erholung aus dem 30jährigen Krieg eine Gegenbewegung gegen das dogmatisch erstarrte, im Amtswesen verknöcherte und moralisch nur allzu duldsame Massen- und Landeskirchentum. Ihr Führer wurde Spener, der dabei außer an seine lutherischen Vorgänger vor allem an Luthers Anfangsprogramm der engeren Gemeinden »ernster Christen $<$ anknüpfte, aber auch von dem englisch-niederländischen Pietismus starke Eindrücke empfangen hatte. Insbesondere führte er das dortige Konventikelwesen ein als ein Mittel der geistlichen und ethischen Reform der Kirche, die zur bisher allein streng durchgeführten dogmatischen Reform nun noch hinzukommen solle. Freilich sollte es eine völlig innerkirchliche Reform sein. Aber der Perfektionismus, die Sammlung bekehrter, d. h. reifer und bewußter Christen zu engeren Kreisen eigentlicher Christlichkeit, die Forderung wiedergeborener Prediger, die Betonung des Laienchristentums und der reinen apostolischen Urkirche bedeutete doch etwas dem kirchlichen Geiste innerlich Entgegengesetztes. Auch glaubte er als stärksten Ansporn für die Reform den Hinweis auf das kommende Gottesreich und die baldige Weltverwandelung gebrauchen zu sollen. Die von hier aus entwickelte Ethik der berufstätigen, aber von der Welt sich scheidenden Askese und die methodisch-rationelle Disziplinierung der Selbstheiligung für das Jenseits stand der lutherischen Ethik der Mit- 
teldinge, der Läßlichkeit und der freien Auswirkung des Geistes, schroff gegenüber. Bei aller Anerkennung des kirchlichen Dogmas, der Sakramente und der Landeskirche schlug eben doch die Verwandtschaft mit dem Geiste der Sekte vor. Das haben denn auch die Gegner genügend hervorgehoben, indem sie den Pietismus mit der Wiedertäuferei, den Weigelianern, Rosenkreuzern und Quäkern immer von neuem in Verbindung brachten. In der Tat ist auch das entscheidende Motiv ein verwandtes gewesen. Nur haben seine Gegner die Anknüpfungspunkte im eigenen Kirchentum nicht sehen oder nicht gelten lassen wollen. Aus der Bibel, den älteren Idealen Luthers, der Veräußerlichung des absolutistischen Staatskirchentums ging die Bewegung mit innerem Recht hervor. Ihre Stellung zur Welt und Kultur war doch erst die konsequente Folgerung aus Luthers Erbsündenund Bekehrungslehre, sobald die lutherische Tauflehre und die lutherische freiere, aber unklare Stellung zur Welt minder betont wurden. Auch war die Nachahmung der reformierten Konventikel und der Anschluß an die reformierte Askese und Moraldisziplin nicht ein zufälliger, fremder Einfluß des Calvinismus, sondern ein Ergreifen der wahlverwandten, aus ähnlichen Motiven erwachsenen Mittel, die der deutschen Bewegung aus der Not helfen sollten. Damit traten dann auch alle anderen Folgeerscheinungen dieses sektenhaft asketischen Geistes ein: die Betonung der Mittätigkeit der Laien, die selbständige Bibelforschung ohne kirchliche Auslegungskontrolle, die Geringschätzung des Staatskirchentums und der »subsidia " religionis, die Forderung des Bannes und der Kirchenzucht als Tätigkeit der Kirche und nicht bloß als solche der Polizei; das Drängen auf eigene, persönlich gefühlte und erfahrene Religion; die Zurückführung aller weltlichen Kultur lediglich auf das Praktisch-Nützliche und die Verwerfung aller Philosophie und Theologie; die Missionierung und Erziehung bei den zwar getauften aber noch nicht eigentlich bekehrten Kindern; die Einführung der Konfirmation als Ersatz für die Spättaufe; das neue pietistische Kirchenrecht des Kollegialismus, der die Kirche aus dem Zusammentreten der Individuen $\mathrm{zu}$ Vereinen hervorgehen ließ, aber freilich die stillschweigende Uebergabe der Vereinsgewalt an die Obrigkeit zugleich behauptete und damit die praktischen Folgerungen vorerst abschnitt. $\mathrm{Zu}$ bedeutenden Separaționen, die überdies im Unterschied von England und den Niederlanden das Reichsrecht nicht zuließ, ist es in Deutschland nicht 
gekommen. Der Pietismus blieb innerkirchlich, ja im Aufklärungszeitalter verband er sich aufs innirste mit den Resten der alten dogmatischen Kirchlichkeit, und aus seiner Wiedererweckung in dem Beginn des 19. Jahrhunderts ist die große orthodoxe Restauration dieses Jahrhunderts hervorgegangen, wodurch freilich das heutige Kirchentum mit einer Masse pietistischer Sprengstoffe durchsetzt worden ist.

Es ist alles in allem das Sektenmotiv auf kirchlichem Boden; von den mystischen Bcimengungen wird später noch zu handeln sein. Die kirchliche Gebundenheit des Sektenmotivs zeigt sich in allen Stücken, nicht nur in Dogma und Organisationsideen, sondern vor allem in seinen sozialen Ideen. Ihm fehlte, wie auch dem Puritanismus und dem späteren Baptistentum, jeder Zug der Sekte zum sozialen und politischen Radikalismus. Er brauchte nicht erst zu verbürgerlichen, wie das alte läufertum, er war von Anfang an bürgerlich und loyal. Er nahm im Sinne des Luthertums die gegebenen Ordnungen in Staat und Gesellschaft hin, wie sie waren, und dachte nicht an eine Christianisierung der Gesellschaftsordnung. Im Gegenteil, er liebte den Anschluß an regierende Gewalten, an den Adel und die höheren Stände und christianisierte nur die Herzen, aber nicht die allgemeinen Verhältnisse. Er trieb innere Mission und heilte soziale Schäden durch eine neue, auf die freie Initiative des Vereins gestellte Art der Karität, aber er tastete nirgends die Grundlagen des Gegebenen an. Auch dem leidenden und duldenden Täufertum ähnelt er nur sehr bedingt. Askese und Weltentsagung vollzieht sich vielmehr, wie im Puritanismus und im späteren Mennonitentum, in der Form der Bejahung aller gegebenen Berufsverhältnisse. So schließt er sich auch der reformierten Geschäftsmoral an. Er lehrt die Beseitigung jedes selbständigen Eigenwertes der weltlichen Interessen und Geschäfte, die er sämtlich nur als "Rentmeister Gottes " zum Nutzen des bürgerlichen Uaseins und zur Verwendung für die *Reichs-Gottes-Arbeit « betreibt. Aber er reformiert nicht die Welt, sondern sammelt die ernsten Christen zu einer Partei in der Kirche und bekehrt die Heiden, auch das ein Zeichen seiner Uninteressiertheit an der Reform des Weltlebens. Seine Aufgaben liegen überall nur in der Bekehrung und in der Sammlung der wiedergeborenen Seelen. Sein Interesse an der Befreiung des dritten Standes, d. h. der Laien ist rein religiös und kirchlich gemeint, als Verselbständigung der persönlichen Innerlichkeit und als Recht der Konventikelbildung. Dabei 
ist ein charakteristischer Unterschied des deutschen gegenüber dem reformierten Pietismus gerade in diesem Punkte hervorzuheben. Während der von Hause aus auf die heilige Gemeinde abzielende Calvinismus bei pietistischer Steigerung gerade in der Unter- und Mittelschicht seine Träger hat, gehen beim deutschen Pietismus diese Schichten gerne in die Separation über, während der kirchliche Pietismus Sache nur allein der Theologen und des Adels ist. Das lutherische Kirchentum ist eben innerlich auf den Pietismus und seine Ethik nicht eingestellt, wenn auch die lutherische Sünden- 'und Bekehrungslehre ihm sehr entgegrenkommt.

Auch so sind natürlich starke kulturgeschichtliche Wirkungen der Individualisierung und Verinnerlichung des Lebens, der gesellschaftlichen Nivellierung, der Verpersönlichung des gesellschaftlichen Daseins nicht ausgeblieben; aber sie sind durch seine Neigung zum Adel, zu Sonderkreisen und Parteiwesen, oft auch ins Gegenteil verkehrt worden. Er ist in Wahrheit ein auf kleinere Kreise zugeschnittenes Bekehrungschristentum, das seinen Halt an den Landeskirchen hat und sucht, und das die Welt und die Kultur liegen läßt, wie sie ist. Kulturwirkungen, vor allem politischer und sozialer Art übt er nur gegen den eigenen Sinn und Willen aus. Wir stehen hier wieder auf dem Standpunkt der leidenden und duldenden Sekte, die überdies mit der kirchlichen und weltlich-staatlichen Ordnung sich abfindet. Daher auch die relative Beliebtheit des Pietismus bei den herrschenden Mächten, nachdem man sich in die Unmöglichkeit der Aufrechterhaltung der alten reinen Staatsreligion - schwer genug - finden gelernt hatte. Er liefert treue, die Unterordnung als Berufsaskese betätigende Diener, tastet die Verhältnisse nicht an, verpflichtet die Herrschenden nur zu patriarchaler Güte und Fürsorge und löscht die Standesunterschiede nur im eigentlich religiösen Verkehr aus; übrigens ist auch das von ihm nur sehr wenig durchgeführt worden $\left.{ }^{459}\right)$.

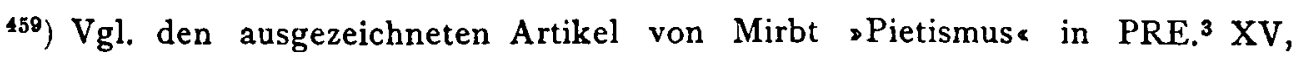
ferner Ritschl; Heppe; Grünberg, Spener 1893, 1905, 1906; Göbel, Geschichte d. christlichen Lebens in der rheinisch-westphälischen ev. Kirche 1849, 1852, 1860. Stephan, Pietismus als Träger des Fortschritts 1908; W. Köhler, Anfänge des Pietismus in Gießen 1689-1695 in der Gießener Festschrift von 1907. Ueber die sozialen Beziehungen s. Gustav Freytag in seinen Bildern aus der deutschen Vergangenheit; Bertholdt, Die Erweckten im prot. Deutschland (Raumers historisches Taschenbuch 1852 und 1853 ), hier ist der reformierte, nicht-Spenersche Charakter 
832 III. Protestantismus. 4. Sektentypus und Mystik auf protestantischem Boden

Bei dieser kirchlichen Gebundenheit des Sektenmotivs im Pietismus ist es verständlich, daß dic wenigen bedeutenden Sepader geschilderten Erscheinungen nicht beachtet; Drews, Einfluß der Kirche auf die gesellschaftlichen Zustănde, Z. f. Th. u. K. I905; Uhlhorn, Liebestätigkeit III 236-26I; bes. Ritschl II 500-505; Max Weber, Archiv XXI S. 39-56. Weingarten, der die verschiedenen Strömungen überhaupt nicht recht unterscheidet, hat leider der pietistischen Strömung in ihrem Unterschied von Kongregationalismus und Täufertum in England keine Aufmerksamkeit geschenkt, wenn er sie auch tatsächlich gelegentlich treffend schildert. - Das in seiner Weise großartige Werk Ritschls beruht auf der scharfen Erkenntnis des sektenhaften Charakters des Pietismus und eröffnet aus diesem Grunde vom Standpunkt des vollendeten Bourgeois und Kirchenmannes gegen ihn eine Polemik, die wegen ihres geradezu inquisitorischen Scharfsinnes von höchster Bedeutung ist. Hier ist es nun höchsı interessant und lehrreich, daß bei Ritschl diese Verwerfung diktiert ist durch seine klare Einsicht darein, daß nur das auf die' anstaltliche Sündenvergebungsgnade aufgebaute Landeskirchentum den für ein Volks- und Massenchristentum nötigen moralischen Relativismus und nur eine durch das objektive Amt geleitete Kirche den relativen gemäßigten Rationalismus einer wissenschaftlichen Theologie ertragen kann. Das Christentum in Gestalt einer Volkskirche ist darauf angewiesen, in einem Mittelmaß von öffentlicher Sitte und in manigfacher Abstufung des religiösen Interesses des Einzelnen aufrechterhalten zu werden I 178. Aller Separatismus wurzelt aber darin, daß die relative Art der kirchlichen Beziehungen nicht zugestanden wird \& I 450. sUrsprünglich richtet sich der Pietismus auf die (moralischen) Burgschaften der Seligkeit jedes Einzelnen im Gegensatz zur Welt und auf die Ablehnung aller der Rücksichten, welche die Kirche auf die Welt zu nehmen pflegt $\alpha$ I 450. *Das auf die reine Lehre sich zurückziehende Luthertum blieb außer direktem Zusammenhang mit den ethischen und ästhetischen Bedürfnissen, die einem Vulk auf Grund der religiösen Bildung erfüllt werden sollen๙. Insofern sei der Pietismus schon durch die Kirche selbst vorbereitet II 88. ,Wer an seinem Orte scine Schuldigkeit als Christ thut, hat aus dem Glauben zu urteilen, daß, wo das Evangelium rein und lauter gepredigt wird, Gott seine Gemeinde hat; und man darf den Wert dieses Glaubens nicht durch die Sorge durchkreuzen, daß die (echte) Gemeinde Gottes umfangreicher sein und mehr in die sinnliche Wahrnehmung fallen müge, als man es beobachtet. Sonst tritt man eben auf den der Kirche entgegengesetzten Boden der Sekte" II I5I. "Ein Leben, welches auf Bußkampf und Durchbruch zum Glauben gestellt wird, mag poch so viele Proben christlicher Vollkommenheit mit sich führen; es ist aber vom Boden des geschlossenen kirchlichen Zusammenhangs weggerückl; und wo es einen entsprechenden Boden der Gemeinschaft findet, in der Sekte oder in der Clique oder in der Aufklärung, das ist bei jenem Grundsatz nicht vorgesehen II I94. Diese Sätze beleuchten ausgezeichnet den Sinn des Kirchentypus. Daß demgegenüber freilich Sekte und Mystik dem Urchristentum näher stehen als die Kirche und jene Berufung auf die jerusalemische Urkirche relativ berechtigt ist, bedarf keines Wortes. - Das letztere 
rationen nicht freiwillige, sondern erzwungene waren. Das gilt von der einzigen größeren deutschen Separation, der Herrnhutergemeinde.

wird denn auch von Göbel viel richtiger eingesehen: „Alle diese Orgien und gefährlichen Ausartungen (des Pietismus) hängen mit den (biblisch) wohlberechtigten Arten des christlichen Lebens so eng zusammen, daß sie immer noch als Erscheinungen desselben angesehen werden müssen, ja daß sogar häufig die rechte Art sich erst aus ihrer ursprünglich mit sündiger Einseitigkeit und Verkehrtheit auftretenden Ausartung herausentwickelt, wie z. B. erst durch den Mystizismus und Separatismus die rechte Mystik und Askese sowohl in den einzelnen Gläubigen und in besonderen Gemeinden als auch - durch Rückwirkung - in der herrschenden Kirche selbst zu der ihr gebührenden Geltung gelangt I 3 . Eine vortreffliche Gesamtcharakteristik, die mit meiner Auffassung völlig zusammentrifft II 617-62 r. Mirbt erklärt die pietistische Askese aus oder Beschäftigung mit der hl. Schrift, deren asketischen Elementen der pietistisch-gerichtete Bibelleser jener Zeit schon unter dem Einfluß eschatologischer Neigungen Verständnis entgegenbrachte XV 804. - Das Urteil Uhlhorns S. 260: „Die richtige Stellung zu den weltlichen Dingen überhaupt zum Staat, zur Wissenschaft, zur Kunst, hat der Pietismus doch nicht gefunden. Er sieht sie nur von seinem subjektiven (d. h. dem unkirchlichen, nur an Bekehrung und Reife der Einzelchristen interessierten) Standpunkte als berechtigt an, soweit sie ihm nützen; nicht wie das Luthertum sie beurteilt an sich, ihrer Substanz nach berechtigt. (Das ist schief und dunkel formuliert; es bedeutet, daß gegenüber der besonderen Mischung von Weltverneinung und Weltbejahung des Luthertums die pietistische Ethik die asketische Konsequenz vollendet durch Anschluß an die reformierte Ethik (s. Max Weber, Archiv XXI S. 46-50), die alles Weltliche des Eigenwertes entḳleidet, aber es rein utilitarisch als Mittel zum Zweck rationell und methodisch gestaltet; daher auch die Bildungsideale des Pietismu genau dieselben wie des Puritanismus). Die Frömmigkeit ist ihm nicht das alles durchdringende Lebensprinzip, sondern der einzige Inhalt des Lebens. Deshalb hat er für die sozialen Lebensinteressen keinen Sinn. Es ist das alles für ihn ein Stück Welt, dem er kühl gegenübersteht. Trotz der Neigung, überall einzugreifen, bleibt er doch auf allen diesen Gebieten unfruchtbar. Der Pietismus hat stark dazu beigetragen, die Bedeutung der. Kirche für diese Lebensgebiete abzuschwächen und auch die Liebestätigkeit, speziell die Armengemeindepflege, in die Hände des Staates zu bringen๔. - Wichtig ist, zu heachten, daß Ritschl den englischen, überall in Pietismus übergehenden Puritanismus ganz beiseite gelassen hat. Er konnte kein Englisch, und dieser Zufall hat für die ihm nacheifernde Auffassung des Pietismus sehr vereinseitigende Folgen gehabt. Hier müssen Heppe und Barclay ergänzen. - Ueber die sozialen und wirtschaftlichen Wirkungen Weber S. $55 \mathrm{f}$ :, Ganz offenbar enthielt also (im deutsch-lutherischen Pietismus) die Ausrichtung des religiösen Bedürfnisses auf eine gegenwärtige innere Gefühlsaffektion ein Minus an Antrieb zur Rationalisierung des innerweltlichen $\mathrm{H}$ a n d elns gegenüber dem nur auf das Jenseits ausgerichteten Bewährungsbedürfnis der reTroelts ch, Gesammelte Schriften. I. 
834 III. Protestantismus. 4. Sektentypus und Mystik auf protestantischem Boden.

Diese Gemeinde ist freilich so wenig wie die Quäkergemeinde ein einfacher Ausdruck des, wenn auch kirchlich gebundenen, Sektengedankens. Sie ist von Hause aus ein Mischgebilde aus der lutherischen Innerlichkeit des Grafen, der, ein sieghafter Menschenbezauberer und ein in das Zeitalter der Sentimentalität verschlagener Kreuzritter, nach dem Vorbilde der engeren Christengemeinden Luthers und der Spenerschen Konventikel die wahrhaft'n Liebhaber Christi sammeln wollte und an der Vereinbarkeit dieser überkirchlich-philadelphischen Kreise mit dem Luthertum nie zweifelte; andererseits aus dem sektenhaften Drang der mährischen Brüder, die, zufällig auf seinem Gute angesiedelt, ihm -zum Streitwagen und Bataille-Pferd * für die Erfechtung seines Sieges wurden, aber auch seine Konventikelidee in die einer organiformierten ,Heiligen', während sie freilich gegenüber der traditionalistischen an Wort und Sakrament haftenden Gläubigkeit des orthodoxen Lutheraners immerhin ein Plus von $m e t h o d i s c h e r$ religiöser Durchdringung der Lebensführung zu entwickeln geeignet war. Die zunehmende Entwickelung in der Richtung auf bloßes Gefühl hängt auch mit der sozialen Verschiebung der Bewegung zu Geistlichkeit und Adel zusammen. Wenn eine praktische Konsequenz des Unterschiedes . . hier charakterisiert werden soll, so kann man die Tugenden, welche der Pietismus. züchtete, mehr als solche bezeichnen, wie sie einerseits der ,berufstreue' Angestellte, Arbeiter und Hausindustrielle und andererseits der vorwiegend patriarchal gestimmte Arbeitgeber in Gott wohlgefälliger Herablassung entfalten konnten. Der Calvinismus scheint im Vergleich damit dem harten rechtlichen und aktiven Sinne bürgerlich-kapitalistischer Unternehmer wahlverwandter. - Die Eigentümlichkeiten des württembergischen Pietismus, der in Deutschland allein wirklich populär geworden ist. hängen mit der Geringfügigkeit des dortigen Adels, "der Disposition einer freien Bauernschaft für religiösen Individualismus und der frühzeitigen Verkirchlichung des dortigen Pietismus zusammen, wogegen aber bis heute separatistische Bauernbewegungen reagieren; siehe Mirbt und Ritschl; auch Kalbe, Kirchen und Sekten der Gegenwart ${ }^{2}$ 1910. - Ueber die soziale Zugehörigkeit des kirchlichen Pietismus zu Adel, Pastorentum, Beamtentum und die des radikalen zu den Unterschichten als Folge der sozialen Umwälzungen der Religionskriege s. Becker, Zinzendorf S. 240-243; es ist das jedenfalls die Auffassung des Grafen. - Ueber den wahren inneren Zusammenhang des Calvinismus mit dem Pietismus, demgemäß dort die Konventikel die Kirchenidee gar nicht stören, und seine innere Gegensätzlichkeit und zerstörende Wirkung auf das Luthertum s. sehr richtige Einsichten Zinzendorfs ebd. S. 246-25\%. - Ueber die Schattenseiten pietistisch-sektiererischen Wesens s. Harnack, Alte Bekannte, Aus Wissenschaft und Leben II 277-288. - Ganz zuletzt kommt mir noch zu Gesicht Göters, Vorbereit. d. Piet. in den Niederlanden 1911, offenbar eine Anknüpfung der-deutschen Entwickelung an die niederländische. 
satorisch geschlossenen, auf Freiwilligkeit und Glaubensreife beruhenden, Zucht und Bann verwaltenden, von Laien geistlich bedienten Sekte hinüberzogen. Aus den Spannungen und Reibungen beider Motive wurde schließlich infolge der Ablehnung seiner Konventikelidee durch die offizielle lutherische Kirche eine neue Kirche, deren Bestand allmählich ein erblicher wurde wie der der Quäkergemeinde; sie nahm an der Kindertaufe keinen Anstoß, sondern suchte nur eine möglichste Innerlichkeit des Gefühls und der Christusmystik durch Kult, Organisation und Erziehung zu erreichen. Trotzdem verblieben doch auch wichtige Züge des Sektenideals. Die Abendmahlsgemeinde sollte möglichst rein sein und die Zucht dafür sorgen. Die Kleinheit der Gemeinde, die gegenseitige Kontrolle, die Staatsunabhängigkeit und der rechtliche Vereinscharakter, die für die Existenz der Gemeinde aufkommenden geschäftlichen Unternehmungen der Gemeinde, der auf die Heidenmission abgeleitete Drang nach Gewinnung frei zustimmender echter Christenseelen, vor allem das Hinarbeiten auf eine von den Kindern der Welt unterscheidende Aktivität und Reinheit der christlichen Ethik: all das gab der Brüdergemeinde teils mit, teils gegen ihren Willen eine Aehnlichkeit mit den Sekten, wie sie sich denn auch gerne auf die böhmischen Brüder, die Waldenser und durch diese auf die Urkirche zurïckführte. Auch fehlen die Spuren ähnlicher Befolgung der Bergpredigt, wie bei den Täufern, nicht. Schließlich ist ihre Ethik, wenn auch in der von dem Grafen erteilten Art und Begründung lutherisch kindlich und fröhlich, relativ weltoffen und systemlos, doch durch den Willen zur Darstellung einer weltunterschiedenen tätigen Christlichkeit und durch calvinistische Zuflüsse zur Gemeinde in mancher Hinsicht wieder der puritanischen verwandt. Die Mähren jedenfalls fühlten sich dem Calvinismus näher als dem Luthertum. Auch sind die unter solchen Verhältnissen eintretenden ökonomischen Folgen, ein durch Reellität und sparsamen Konsum ausgezeichnetes und dadurch sich selbst erfolgreich steigerndes Geschäftsleben, nicht ausgeblieben, um so mehr, als die aus den beweglichen Elementen der Bevölkerung sich erst sammelnde Gemeinde wesentlich auf gewerblich tätige Mitglieder beschränkt war und bei der Nötigung, ihre Kosten, namentlich auch die der Mission, selbst zu bestreiten, auf geschäftliche Unternehmungen der Gesamtgemeinde angewiesen war und ist ${ }^{\mathbf{4 6 0}}$ ).

${ }^{460}$ Vgl. Ritschl, Gesch. d. Piet. III, wo freilich die schulmeisterliche Behandlung, 
836 III. Protestantismus. 4. Sektentypus und Mystik auf protestantischem Boden.

Viel bedeutender ist die Stiftung des Methodismus. eines der wichtigsten Ereignisse in der Geschichte des neueren Christentums und in der modernen geistigen Entwickelung, die Wiederbelebung des altgläubigen Christentums in einer ganz in-

die Herleitung aller sgefahrlichen Fehlere des stheologischen Dilettantens Zinzendorf von einer $\rightarrow$ fahrlässigen . Deutung des lutherischen Kirchenbegriffes, unerträglich ist. Neben Ritschl unentbehrlich Jos. Th. Müller, Z. als Erneuerer der alten Brüderkirche, 1900. In der Hauptsache, der Erkenntnis der Spannung zwischen des Grafen mystisch-überkirchlichem Ideal und dem sektenhaften Ideal der Mähren, hat freilich Ritschl ganz richtig gesehen und auch die Gefahr für das Kirchentum richtig erkannt. Vgl. auch Müller S. 40: Wo eine annähernde geschichtliche Verwirklichung dieses Begriffes (einer ,offenbaren Gemeinde Christi') versucht wird, da wird das so entstehende Gebilde, eine ,offenbare Gemeinde Christi oder wie man es sonst nennen will, immer befähigter sein, das christliche Ideal zu verwirklichenals die Volks-und Staatskirchen, in deren Mitte es sich befindet... Zugleich aber folgt aus dem Begriff einer offenbaren Gemeinde Christi mit Notwendigkeit, daß dieser Charakter nicht einer geschichtlich entstandenen Gemeinschaft als unveräußerlicher Besitz anhaften, gleichsam ihr angeboren seinkann, weil er vonderpersönlichen Christlichkeit der jedesmaligen Mitgliederabhängig is t.: Das ist eben der Unterschied von Kirche und Sekte, auf dessen Verständnis alles ankommt. - Von hier aus beantwortet sich auch die Frage, die Loofs mir einmal brieflich vorgelegt hat, ob nicht das Luthertum - bei anderen äußeren Verhältnissen - eine dem Herrnhutertum ganz analoge Ethik hätte hervorbringen können. Die Frage ist sehr lehrreich, da die prinzipielle Begründung der Ethik hier unzweifelhaft lutherisch gehalten ist in Sinn und Wort. Allein die Ethik einer Sekte und einer Volkskirche ist eben doch grundverschieden. Die Sekte ist mit staatlichen Aemtern, Politik, Recht, Krieg wenig verworren und braucht nicht wie Luther all das aus dem christlichen Naturrecht abzuleiten und in die christliche Ethik als grundlegend wichtig hineinzunehmen. Der Unterschied der Moral des Amtes und der Person, der für das Luthertum so wichtig ist, tritt hier ganz zurück und es bleibt die Ethik der Person. Diese aber wird durch die gegenseitige Kontrolle, durch die Wirkungen der Kleinheit und Enge des Kreises, sowie durch die Messung an der Bibel in die Richtung einer von der Welt sich unterscheidenden Strenge gedrängt. Bedenken gegen Eid, Amt und Krieg wie bei den Täufern bei Müller 27, 92, Ritschl III 244, Annäherungen an den Kommunismus III 296, Verzicht auf das staatliche Recht und innergemeindliche Schiedsprüche III $346-348$; es ist der Geist der Bergpredigt, den Ritschl freilich so wenig wiedererkennt, daß er in dem allem nur sEinfälle sieht. Aber auch die Bewährungsethik und aktive Heiligkeit spielt hier eine viel größere Rolle (Ritschl III 398, 439, 247) als im kirchlichen Luthertum, wie Ritschl und Müller beide richtig anerkennen. Auf lediglich äußere Verhältnisse ließe sich der agrarische Charakter von Luthers Wirtschaftsethik und der überwiegend gewerbliche 
dividualistisch zugespitzten Form, die Vorausnahme der kontinentalen Restaurationsbewegung des 19. Jahrhunderts und eines der Mittel, wodurch die englische Welt gegen den Geist der französischen Revolution immunisiert wurde, der radikale Gegensatz gegen allen Geist moderner Wissenschaft und Kultur. Der Methodismus war zunächst ähnlich wie die Brüdergemeinde - übrigens von dieser selbst angeregt und wie diese durch pietistisches Konventikelwesen vorbereitet - ein Versuch, durch engere erweckte Kreise das Salz der Landeskirche zu werden und ist äußerlich nur durch die Verschließung der landeskirchlichen Kanzeln zur Verselbständigung gedrängt worden. Innerlich freilich war diese Scheidung unumgänglich. Denn seine ganze Struktur war, wie die der Brüdergemeinde, dem Sektentypus und nicht dem Kirchentypus zugehörig trotz des ernsten Willens, in der Kirche zu verbleiben. Ja sein Wesen trieb ihn noch viel mehr zur Verselbständigung, als jene durch das ihre genötigt wurde. Denn sein Absehen war (s. Ritschl III 347, Müller 79, 84) der Herrnhuter allerdings zurückführen. Allein auch das hängt mit dem Unterschied von freiem und beweglichem kirchlichen Verein (Müller 24-27, 36, 40) und Staatskirche zusammen. Der erste ist auf die bewegliche und von dem damaligen Merkantilismus begehrte gewerbliche Bevölkerung zugeschnitten, während die Staatskirche das schollengebundene Bauerntum und den Grundadel berïcksichtigen mußte. Auch folgt der gemeindliche Geschäftsbetrieb aus dem Wesen der Sekte, die sich selbst erhalten muß und nicht von Pfründen und Staatszuschüssen lebt. Es ist also doch ein wesentlicher, innerlich begründeter Unterschied, der gerade bei der Gleichheit der prinzipiellen Grundlagen der Ethik und bei der Gebròchenheit des Sektencharakters im Herrnhutertum höchst charakteristisch ist für die von allem Kirchentum so verschiedene soziologische Wirkung des Sektentums. Außerdem vgl. Max Weber, Archiv XXI 50-57. - Wie weit reformierte Geschäftsmoral im Einzelnen herübergewirkt haben mag, wäre erst zu untersuchen. Es ist doch bezeichnend, wie der Graf gerne seine Gleichnisse aus der Geschäftswelt nimmt; für die Innerlichkeit, mit der der Gnadenschatz der Kirche Herzenseigentum wird : Ich will Gemeinschaft haben, so muß ich einen Schatz haben, eine Aktie in der Sozietät, zu der ich gehören will ... Und wo kann man das besser suchen als unmittelbar bei Ihm* Becker, Zinzendorf S. 20; über die Berechtigung der Konventikel in der lutherischen Kirche: - Welcher vernünftige Mensch wird sagen, daß, wenn zwölf Bürger eine Maskopey einführten zur Beförderung des Commercii, sie sich eo ipso von der ganzen Bürgerschaft und Landschaft trennen müssen< S. I34. Bedeutsam ist auch der in diesen Worten liegende Anschluß an das unlutherische Grotianisch-Pufendorfsche : Naturrecht (auch sonst ausdrücklich s. Becker S. 117), wie auch schon Spener das calvinistische Naturrecht bevorzugt hatte. Das hängt instinktiv mit dem Sektengedanken oder dem der bloßen religiösen Geselligkeit zusammen. Auch mit Bayle hatte der Graf viele Sympathie. 
838 III. Protestantismus. 4. Sektentypus und Mystik auf protestantischem Boden.

nicht auf die Sammlung inniger Christusliebhaber in engen Brüderkreisen gerichtet, sondern auf die Erweckung der Massen, die in einem aufgeklärten Kirchentum lau und unter dem Druck des industriellen Kapitalismus roh und stumpf geworden waren. $\mathrm{Er}$ hat bereits die Verhältnisse der breiten Entfaltung moderner Wissenschaft und die soziale Lage vor sich, die auf dem Kontinent erst im 19. Jahrhundert eingetreten sind. Die Erweckung betrieb er durch die äußerste Verlebendigung des Erbsündendogmas und durch die Eröffnung des Rettungsweges in einer unmittelbar fühlbaren Gewißwerdung von der Rechtfertigung durch Christi Blut. Nicht das träge Beruhen auf der Taufgnade und auf einer leidlichen Korrektheit und Vernünftigkeit der Lebensführung, sondern die radikale und fühlbare Versetzung aus dem Zustand der Verdammnis in den der Vergebung und Seligkeit samt den erst daraus sich ergebenden wahrhaft ethischen Kräften rettet von Hölle, Tod und Verdammnis. Diese Erweckung, welche die methodistischen Missionare unter Gefahren und Mühen, wie einst die Urapostel, und schließlich mit Hilfe großer Feldpredigten in die Mittel- und Unterschichten hineintrugen, mußte aber in ihren Ergebnissen gesichert und gesammelt werden. Hier griff die Organisation ein, in der Wesley, ein unermüdlicher und unerschütterlicher Missionar wie Paulus und ein herrschgewaltiger Organisator wie Ignatius von Loyola, Meíster war. In dieser Organisation aber traten nun die Züge des Sektentypus, die schon in dem Dringen auf die Bekehrung der Erwachsenen und in dem ethischen Perfektionismus mit enthalten waren, deutlich zutage. Das gefühlsmäßige Element der unmittelbaren Versiegelung und Heilsgewißheit, worin sich der Methodismus mit dem Herrnhutertum und dem Luthertum berührt, wurde ergänzt durch eine strenge Sammlung und Kontrolle, in der Wesley dem puritanischen Calvinismus treublieb. Die Gewinnung echter, versöhnter, seliger und in der Heiligung möglichst bis zur Vollkommenheit fortschreitender Christen war das Ziel, ihre Sammlung zu einem organisierten Verein das Mittel. Der Verein bestand zunächst in der Ursprungszeit aus beitretenden Erwachsenen; an die Kindertaufe brauchte nicht gerührt zu werden, da man ja innerhalb der die Kindertaufe überall bewirkenden Landeskirche stand. Der endgültigen Aufnahme ging eine halbjährige Probezeit . voran. Die Beitretenden erhielten ihr vierteljährlich zu erneuerndes society-ticket und wurden innerhalb der society in einzelne 
Klassen von etwa Io Personen eingeteilt, die zu gegenseitiger Herzensöffnung, Kontrolle und Bibelbetrachtung unter einem Laienleiter sich wöchentlich versammelten; von dem Bericht des Leiters war die Weitererteilung des Tickets und die endgültige Aufnahme des Novizen abhängig. Die Gesellschaften wurden ihrerseits zusammengefaßt in Bezirke, die von einem reisenden ordinierten Kleriker pastoriert und visitiert wurden; der letztere hatte zugleich die Aufgabe der Erweckungs- und Missionspredigt nach außen. Die Bezirke standen wieder unter der Oberleitung der Generalkonferenz, der berühmten Hundert, die zunächst lediglich durch Wesleys Willkür, dann nach der Anciennetät, dann unter Zuziehung gewählter Geistlicher und schließlich auch gewählter Laien zusammengesetzt wurden. Auf die Entwickelung dieser Verfassung, deren Grundzüge bis heute geblieben sind, kann hier nicht näher eingegangen werden. Der Gesamtcharakter ist klar. Es ist ein Mittelding zwischen einem auf unbedingten Gehorsam und auf eingehende gegenseitige Kontrolle aufgebauten Orden, wie etwa der Jesuitenorden, mit dem der Methodismus frühzeitig verglichen wurde, und einem auf voller Freiwilligkeit des Anschlusses und dauernder Mitbeteiligung der Mitglieder beruhenden Verein ernster, praktisch sich bewährender Christen, wie die Täuferorganisationen es waren. Die beiden soziologischen Formen des Sektentypus, der Orden und der Verein, sind hier kombiniert; sie sind zugleich für die Aufnahme steigender Massen elastisch gemacht, ohne daß doch der Gegensatz gegen die bloßen Massen- und Kirchenchristen verschwinden sollte. Die Kindertaufe ist in Wahrheit durch das in der Bekehrung eintretende Wiedergeburtsgefühl und dessen Anerkennung durch den Verein ersetzt. Am kirchlichen Dogma wurde nichts geändert, sein Supranaturalismus wurde nur gesteigert und sein Sinn auf die Bekehrung und ihre Voraussetzungen, auf die Heiligung und ihre himmlischen Folgen zusammengedrängt. Die Fortdauer der Kirche wurde vorausgesetzt, aber ihr Geist wurde mit alledem geleugnet. Das führte notwendig auch zur äußeren Trennung, am spätesten in England selbst. Seit dieser Trennung und Verselbständigung aber widerfuhr schließlich dem Methodismus, was den Baptisten, der Brüdergemeinde und den Quäkern widerfahren ist. Mit der Ausbildung eines erblichen Bestandes, wo die Kinder der Gemeindeglieder von selbst zur Gemeinde sich zu halten pflegen; mit der Aufnahme steigender Massen, die sich - in den verschiedenen $Z$ weigen des Methodismus zusam- 
840 III. Protestantismus. 4. Sektentypus und Mystik auf protestantischem Boden.

men - heute auf ca. 30 Millionen belaufen; mit der Steigerung des klerikalen Elementes, die unter solchen Umständen unausbleiblich ist, und mit der Einführung der theologischen Wissenschaft und Bildung; mit den tausendfachen Milderungen des ursprünglichen Welt- und Kulturgegensatzes: mit alledem wurde der Methodismus schließlich immer mehr aus einer Sekte zu einer Kirche oder zu einer Mehrzahl von Kirchen. Wie er von der Kirche ausging, artete er zurück zur Kirche. Von dem ursprünglichen Sektengeiste blieb ihm nur die Empfindlichkeit in Organisationsfragen, die allem Vereinswesen eigentümlich ist, die Rivalität von Laien und Klerikern, wobei die Laien zu einer zunehmenden, aber in den verschiedenen Denominationen verschiedenen Beteiligung an der Leitung gelangt sind. Daraus ergaben sich die zahlreichen Trennungen und Wiedervereinigungen. Damit ist auch, ähnlich wie bei den Baptisten, die ursprüngliche Klassenbedingtheit zurückgetreten. Ursprünglich feierte der Methodismus seine Triumphe in den Mittel- und Unterschichten, bei den Arbeitern der Kohlendistrikte und der Industriestädte. Ihnen brachte er Frhebung der geistigen Persönlichkeit, den ihnen verständlichen Appell an die populäre Phantasie und eine zu ungeheueren Opfern bereite Liebestätigkeit. Den adeligen und ländlichen Schichten, den wissenschaftlich Gebildeten blieb er im Ganzen fern. Er hat den Persönlichkeits- und Individualitätsdrang in die stumpfen, eben der Industrialisierung verfallenden Massen geleitet und der Not mit seiner Liebestätigkeit geholfen. Im übrigen aber war seine Ethik, die den Gefühlscharakter der Bekehrung durch eine um so strengere methodisch disziplinierte Heiligungsethik und eine weitgehende $\mathrm{Ar}$ beitsaskese kompensierte, durchaus staats- und gesellschaftserhaltend. Verbesserungen des Wahlrechtes, Befreiung der Sklaven, philantropische Werke, aber auch strenge Sabbatheiligung, Kampf gegen die moderne Bildung, Wissenschaft und Kunst bezeichnen seine Stellung zu dem Gesellschaftsproblem; und dieser Grundsatz ist im modernen Methodismus nur abgeblaßt, nicht beseitigt ${ }^{161}$ ).

461) Vgl. die glänzende Darstellung von W. C. H. Lecky, History of England in the I 8 th cent. II $52 \mathrm{I}-642$, sehr gerecht und unparteiisch; hier auch der Kulturgegensatz betont, von dem aber, wie immer bei solchen Gruppen, die rein praktischen Wissenschaften ausgenommen sind. Im übrigen aber besteht der Glaulse an Teufel, Dämonen und Hexen, an unmittelbare Erleuchtungen und Wunder, Heilungen und Eingebungen, eine besondere beständig zugunsten der Gläubigen die Natur durchbrechende Vorsehung. 
Auch in den durch den Präzisismus bearbeiteten Niederlanden ist die Sektenbildung nicht ausgeblieben, wenn sie auch dort zu keinen so dauernden Ergebnissen gelangte, weil der Rigorismus schon in den Staatskirchen sich ziemlich frei bewegen konnte. Dort hat ein Mann wie Lodensteyn den Gedanken der Reinheit der Abendmahlsgemeinde so weit getrieben, daß er die Spendung des Abendmahls einstellte. Andere bildeten

Ueber die Askese $589 \mathrm{f}$. Nach Besichtigung des brit. Museums meint Wesley: , What account will a man give to the Judge of quick and dead for a life spent in collecting all these? " Für die Verfassung siehe den vortrefflichen Artikel von Loofs - Meth. \& PRE. ${ }^{3}$ XII und Nuelsen, $>$ Meth. in Amerika \& PRE. ${ }^{3}$ XIII; für die Ethik s. den feinen Abschnitt bei Schneckenburger, Lehrbegriffe der kleineren prot. Kirchenparteien, 1863 S. 103-151 und Max Weber, Archiv XXI 57-61. - Bezüglich der Taufe s. Loofs XII 779; in Wesleys Verkürzung der 39 A. ist die Tauf-Wiedergeburt beiseite geschoben; er handelt nicht de peccatis post ba ptismum, sondern of sin after justification; zu Art. 15 ist der Satz Nos reliqui (neben Christus), etiam baptisati et in Christo regenerati, in multis tamen offendimus et, si dixerimus, quia peccatum non habemus, nos ipos seducimuse beseitigt; wie Loofs meint, zugunsten des Perfektionismus, aber auch, was damit eng zusammenhängt, zu ungunsten der Kindertaufe. Nuelsen zitiert aus dem Katechismus von Nast : Die Wiedergeburt sgeschieht nicht durch die Taufe, sondern sie wird von Gott zu gleicher Zeit mit der durch den Glauben erlangten Rechtfertigung gewirkte XIII 14. An Stelle der Taufe tritt daher die Erweckungsbearbeitung von Kinderklassen, die intensive Arbeit der Kinderschule. Bei der Aufnahme wird zur Probezeit zugelassen auf Grund aufrichtig bekundeten Erlösungsverlangens, die endgültige Aufnahme stellt als erste Frage: ¿Erneuert ihr in der Gegenwart Gottes und dieser Gemeinde das feierliche Versprechen, welches im Taufbund enthalten ist a XIII 18 . Hier ist doch überall die Taufe tatsächlich eliminiert. Schneckenburger S. 148 : >Beide Sakramente fallen daher mehr unter den Begriff der Gebote Christi, denen man sich zu unterziehen hat. Ganz konsequent hat sich daher bei einem Teil der Methodisten der Baptismus entwickelt. Bei den amerik. Methodisten ist die Kindertaufe fast ganz abgekommen (?). - - Die Verkirchlichung zeigt sich allenthalben. Die südamerik. Methodisten haben die Probezeit ganz abgeschafft. XIII I8: ,Die getauften Kinder von Gliedern der Kirche sind den Probemitgliedern gleichgestellt und können, wenn sie ein hinreichendes Alter erreicht haben, die Verbindlichkeiten der Religion zu verstehen und Beweise von Herzensfrömmigkeit geben, auf Empfehlung eines Führers, dessen Klasse sie mindestens sechs Monate besucht haben, als volle Glieder in die Kirche aufgenommen werden, indem sie öffentlich vor der Gemeinde zu dem Taufbunde sich bekennen und die Fragen über Lehre und Kirchenordnung bejahend beantworten. Konfirmationspraxis ist dem Meth. nicht bekannt, doch sind die Prediger angewiesen, die getauften Kinder, sobald sie zehn Jahre alt sind, in besondere Klassen einzuteilen und dieselben über diejenigen Wahrheiten zu unterrichten, welche notwendig sind, um weise zu machen zur Seligkeit * 
842 III. Protestantismus. 4. Sektentypus und Mystik auf protestantischem Boden.

die Taufformel so um, daß sie die Kinder nicht als Christen, sondern als bloß zum Glauben bestimmt bezeichneten, beides starke Anzeichen sektiererischer Folgerungen aus dem Präzisismus. Eine eigentliche Sektenstiftung unternahm nur Labadie, der damit andern die Anregung zur Separation gab. Seine Stiftung ähnelte einem Kloster. Aber da das Motiv hier nicht bloß der Heiligkeitsgedanke, sondern vor allem die Mystik gewesen ist, so soll davon erst später ausführlicher die Rede sein. Ueberdies ist seine Stiftung schon in der nächsten Generation nach ihm eingegangen. Aber sie ist für die Niederlande und für die niederrheinische Kirche das Wahrzeichen für eine starke Entfaltung sektirierischen Geistes geworden ${ }^{462}$ ).

Fast alle bisher genannten Sekten erstrecken sich bis in dịe Gegenwart. Manche neue von ähnlichem Typus sind dazu gekommen, die Heilsarmee, die Adventisten, die Irvingianer,

XIII 19. sIn manchen Gemeinden ist, seitdem die Amtszeit der Prediger (an einer Station) verlängert worden ist, das Klassensystem eingezogen und an Stelle der einzelnen Klassen ist eine sonntägl. a $11 \mathrm{~g}$ e $\mathrm{m}$ e in e Klassenversammlung (Bekenntnisstunde) oder die wöchentliche Bet- und Erfahrungsstunde bzw. Bekenntnisstunde des Jugendbundes getretene ebd. 17. Zusammenfassend Loofs XII 810: ,Einst nahm man als Mitglieder nur solche auf, die mindestens 2 Monate auf Probe in einer Klasse gewesen waren. Jetzt gilt die Mitgliedschaft in den junior society classes als Probezeit, d. h. die Methodistenkinder wachsen in die society hinein wie in Volkslirchen. Wie die Menschen einmal sind, müssen unter diesen zugewachsenen Mitgliedern nicht wenige sein, die innerlich nicht in die Methodistenkirche hineinpassen. Eine methodistische Volkskirche ist eine Unmöglichkeit. Die Schwierigkeiten, die auf der Spannung zwischen seiner wachsenden Ausbreitung und seinem nicht ganz auszutilgenden Society-Charakter beruhen, wird der Methodismus nie überwinden, er hörte denn auf zu sein, was er ist c. - Im übrigen läßt gerade Loofs in seiner Darstellung die sektenhaften Züge, die schon bet dem Methodisten Nuelsen viel deutlicher sind, merkwürdig zurücktreten. Er wünscht eine ähnliche Erweckung für Deutschland, wo alles für einen Wesley reif sei und wo man dann die Bewegung nicht von der Kirche ausscheiden solle Allein einer solchen Erweckung steht bei uns die Tatsache entgegen, daß die Funktionen, die der Methodismus damals ausgeübt hat, bei uns längst von der Sozialdemokratie übernommen sind, an der eine Wesleysche Predigt ganz abprallen dürfte. Auch unterschätzt Loofs den Unterschied der inneren Struktur, wenn er an eine Vereinbarkeit von Landeskirche und Methodismus denkt. Würde bei uns die Gemeinschaftsbewegung zu ähnlicher Größe anwachsen, dann wäre auch bei uns die Vereinbarkeit zu Ende. Solche Dinge sind Fragen der Zahl.

- Leber die Klassenbedingtheit des Methodismus s. Lecky 600-602.

+62) Hierüber s. Göbel II, Ritschl I und Heppe. 
die Darbysten, der württembergische Tempel und andere. Ueberall unterwühlt ihre Mission die kontinentalen Landeskirchen, und in deren eigenem Inneren erzeugt die sog. Gemeinschaftsbewegung immer neue Analogien zu den Anfängen jener Sekten. Sie alle tragen in ihren Soziallehren das gleiche Gepräge der staatsfreien Vereins- und Freiwilligkeitsgemeinschaft, des Perfektionismus, der im Beruf tätigen Askese, der konservativ-bürgerlichen Haltung, auch wo sie an politisch bürgerlich-liberale Ideen sich anschließen. Es ist die Entwickelung, welche die duldende und leidende und die innerkirchlich-pietistische Sekte naturgemäß genommen hat in eirier Zeit, in der die Sekte nicht mehr verfolgt wird und die Unentbehrlichkeit staatlicher und gesellschaftlicher Ordnung für den ungeheuer kompliziert gewordenen wirtschaftlichen Organismus jedermann klar und fühlbar geworden ist. Das Ideal der alten leidenden Waldenser- und Täufergemeinden ist in dem Zeitalter des Kapitalismus unmöglich geworden. Hier muß man entweder radikal verneinen und einen ersetzenden Neubau vorschlagen, oder man macht in noch so welt- und kulturfeindlichen Gruppen doch die gegebene Gesellschaftsordnung mit und kann dann nur die unchristlichen Begleiterscheinungen mildern oder beseitigen ${ }^{463}$ ).

Dieser Gegensatz hat daher doch auch die alten welterneuernden Ideen der a g gressive $\mathrm{n}$ Sekte in der modernen Welt wieder belebt. Sie sind aus der Bibel, der Bergpredigt und dem Reich-Gottes-Gedanken wieder neu aufgestiegen. Hussitenkriege und Armeen der Heiligen hat es zwar nicht wieder gegeben; auch ist die Absicht jetzt nicht mehr in erster Linie, durch eine heilige Gemeinde, eine kultisch und religiös organisierte Gemeinschaft, die Weltverhältnisse unmittelbar umzuwandeln. Dazu weiß oder empfindet man zu deutlich, welche verwickelte Probleme des Gesamtlebens und der Kultur in diesen großen Fragen zusammenlaufen. Mit dem Aufkommen der modernen, bis in die Kleinigkeiten des Lebens eingreifenden Riesenstaaten und der Enthüllung des Wesens

463) Zur modernen Sektengeschichte s. sKirchen und Sekten der Gegenwarte, hrsg. von Kalbe ${ }^{2} 1907$; ferner die Sammlung Kerke en Secte, Baarn, Hollandia Druckerij. Zur sog. Gemeinschaftsbewegung s. den Artikel von Benser in Schieles Lexikon. Ueber den Zusammenhang mit dem allgemeinen Volksleben s. Tischhauser, Gesch. d. ev. Kirche in der ersten Häifte des 19. Jahrh., 1900. Das sind Dinge, die der moderne Bildungsdeutsche nicht kennt, die aber eine wichtige Rolle im wirklichen Leben spielen. 
844 III. Protestantismus. 4. Sektentypus und Mystik auf protestantischem Boden.

der kapitalistischen Gesellschaftsordnung ist das Ideal naturgemäß ein anderes geworden. Das Ideal der christlichen Revolution ist innerlicher und verwickelter geworden. Nun verlangt man von der Allgemeinheit eine Aenderung des Geistes und der Gesinnung als Wirkung des Evangeliums, welche unter Mitbeteiligung aller sozialtechnisch Verständigen erst eine der christlichen Persönlichkeits- und Reich-Gottesidee entsprechende Verfassung der allgemeinen Verhältnisse schaffen soll. Ein grundsätzlicher Bruch mit der in den zwei letzten Jahrhunderten ausgebildeten individualistischen Gesellschaftsordnung, die gleichmäßige Hingabe nicht bloß Einzelner, sondern Aller an das Ganze, die Schaffung gerechter und zweckmäßiger Voraussetzungen, eines für alle ausreichenden materiellen Daseins, als Unterlage für die Entwickelung geistiger Werte: das erscheint als die Forderung gerade einer aufrichtigen christlichen Liebe und Persönlichkeitsschätzung. So enthielt in seinen Anfängen der Sozialismus bei Owen und bei St. Simon derart abgeänderte christliche Impulse; bei Owen stellte die Berufung auf den Quäker Bellers die Kontinuität mit der Sekte direkt her. In Deutschland stellte Weitling diesen Zusammenhang dar. Seit der endgültigen Abwendung des Sozialismus von allen religiösen Ideen und seit der marxistischen Entwickelung zum Klassenkampf und zum Evangelium des Naturalismus hat freilich der Sozialismus aufgehört, diese Entwickelungslinie fortzusetzen. Dafür ist aber an seine Stelle der christliche Sozialismus getreten, der die Forderung des Evangeliums von der Bruderliebe und vom kommenden Gottesreich in ihrer unverhüllten Klarheit und Strenge zu vertreten gewiß ist, nach dem ihm die Sozialdemokratie die Augen über die Folgerungen des Evangeliums geöffnet hat. Der christliche Sozialismus verwirft die Vergötterungen der herrschenden bürgerlichen Ordnung als eines relativen Naturrechts, das von der Sünde her seine Notwendigkeit und von der göttlichen Zulassung her seinen göttlichen Einsetzungscharakter erhalten habe. Was noch der am meisten in der Richtung auf einen christlichen Sozialismus vorgeschrittene Calvinismus nicht gesehen hatte, erkennt er, belehrt von der modernen Staats- und Gesellschaftswissenschaft und von den Erfahrungen des täglichen Lebens: wie abhängig die Möglichkeit einer geistig-ethischen Entwickelung ist von dem Unterbau einer gesunden sozialen Gesamtverfassung, wie eng alles Geistige an physische und materielle Voraussetzungen gebunden ist. Er hat sich überzeugt, daß mit der bisherigen alleinigen Betonung des sIdeologischenc 
nicht durchzukommen ist. Das ist das Neue an ihm. So verwirft er auch den pietistischen Rückzug aus der Welt in das Reich der Innerlichkeit und der Seelenrettung, da das eine Verzweiflung an der Welt und eine Beruhigung bei der Gewinnung weniger - und das sind oft nicht die Besten - darstellt. Auch die Vereinerieiung des Gottesreiches mit der Kirche oder seine Verlegung in das Jenseits scheint ihm weder der Bibel noch den Forderungen der Wirklichkeit zu entsprechen, die beide einen irdischen Zustand verlangen, in dem es möglich ist, über den bloßen Kampf um das nackte Dasein und über das Evangelium vom Konkurrenzkampf und vom Rechte des Stärkeren hinauszukommen. Aber in alledem finden wir doch die vertrauten Züge der alten christlichen Richtung, die Züge der aggressiven an eine wirkliche Weltreform glaubenden Sekte, wieder. Das Reich Gottes und der Vernunft, die Diesseitigkeit des Gottesreiches, der unbesiegliche Glaube an den Sieg des Guten und an die Ueberwindung jeder bloß auf den Kampf ums Dasein begründeten Menschheitsverfassung, die christliche Revolution: es ist das alte große Sektenideal. Es ist nur der ins Menschliche und Verständige übersetzte chiliastische Glaube. Es ist der Gedanke des kompromißlosen Christentums, wie er auf dem Boden moderner sozialer Einsichten sich gestalten mußte, wie er auf dem Boden des Evangeliums mit seinem Vertrauen auf das Wunder der Wiederkunft Christi sich noch nicht hatte gestalten können. Dieser christliche Sozialismus erst hat die alten, seit der Patristik fortgeschleppten christlichen Gesellschaftstheorien, die - mit den geschilderten Veränderungen - - in allen Konfessionen bis heute herrschen und mit einer rührenden Weltfremdheit trotz der inzwischen gänzlich veränderten praktischen Lage in den christlichen Ethiken bis heute fast durchgängig wiederholt werden, zerrissen und zu einem neuen Denken über die Sozialethik des Christentums und über ihr Verhältnis zu den tatsächlichen sozialen Wandelungen genötigt. Er hat die Wurmstichigkeit der bisherigen konventionellen christlichen Ethik geoffenbart, die im günstigen Falle für die Individualethik und für die Familie etwas bot, dagegen in der Sozialethik nur die Beruhigung bei allen bestehenden Institutionen und Verhältnissen zu lehren wußte, sehr zur Befriedigung aller herrschenden Gewalten. Er hat der christlichen Ethik ihren utopischen und revolutionären Charakter zurückerobert und ihren Verkündern die Schmach Christi wieder zugezogen, die für allen Humanitätsdusel, 
846 III. Protestantismus. 4. Sektentypus und Mystik auf protestantischem Boden.

alle ideologische Träumerei, alle frevelhafte Verkennung der Unüberwindlichkeit der Sünde und der Unentbehrlichkeit ihrer Unterdrückungsmittel bei Leviten und Landpflegern bereit liegt. Die sehr gründlichen Verschiedenheiten innerhalb der Bewegung, die auf katholischem, calvinischem, lutherischem und freiprotestantischem Boden sehr eigene Wege geht und die vor allem das Luthertum ganz aus der Fassung gebracht hat, können hier nicht geschildert werden. Nur darauf muß hingewiesen werden, daß mit dieser Bewegung auch alle inneren Probleme der christlichen Ethik und des mit ihr so eng. verwachsenen stoischen Idealismus wieder aufgegangen sind, die Frage, wie weit überhaupt die Kraft der Idee und des Ethos, des Glaubens und der Weltanschauung den natürlichen Prozessen sozialer Entwickelungen gegenübertreten und sie innerlich und äußerlich überwinden und gestalten könne, ob Idealgesetze des Ethos und der göttlichen "Natur des Menschen* die gemeinen Naturgesetze sozialer Entwickelungen überwinden oder wenigstens lenken können, ob nicht auch hier das Mögliche die Grenze des Ideal-Notwendigen bildet, ob es eine Massenchristlichkeit überhaupt geben könne ${ }^{464}$ ).

48) Zum >Christlichen Sozialismus s. außer den bereils angefihrten Schriften von Theod. Mayer, Ratzinger, Uhlhorn, Naumann, Göhre, Wenk, v. Schulze-Gävernitz, Rauscherbusch, Wernle, Traub, Ragaz und Kutter noch die Biographie des Bischofs von Ketteler Pfülf 1899 und die Art. >Christlich-Sozial ^, Evangelisch-Sozial ^, Katholisch-Soziale in Schieles Lexikon, sowie den Aufsatz von Ragaz ,Zur gegenwärtigen Umgestaltung des Clristentumss (Neue Wege, Basel I909) und von Liechtenhahn, Die religiös-soziale Bewegung in der Schweiz (Christl. Welt r911), sowie die gesammelten Reden des Berliner Weltkongresses für freies Christentum, Religion und Sozialismus, hrsg. von Schneemelcher 1911. -- Ueber die schwärmerischen Vorstufen des marxistischen Sozialismus s. Sombart, Sozialismus und soziale Bewegung ${ }^{5}, 1905$; er betont mit Recht den stark rationalistischen und egalitären Einschlag, den die Religion der Aufklärung in diesen Chiliasmus gebracht hat. Die Schweizerischen Religiös-Sozialen setzen das Problem des christlichen Sozialismus am innerlichsten auseinander und lassen die wesentlich christlichen Motive der ganzen Gedankengruppe am deutlichsten erkennen. Der Evangelisch-soziale Kongreß steht auf einem vermittelnden Standpunkt. Die ,Kirchlich-Sozialen k katholischer und lutherischer Observanz sind keine Sozialisten überhaupt. - Zur praktischen Beurteilung der Dinge ist nicht zu übersehen, daß die wirkliche soziale Entwickelung eher sich Analogien mittelalterlicher Festlegungen des Kampfes ums Dasein nähert. Vor unseren Augen entsteht in den - Wohlfahrtseinrichtungen die Schollenpflichtigkeit und Hörigkeit in moderner Form, in den Trusts und Syndikaten die Verteilung der Absatzgebiete und das Prinzip des Nahrungsschutzes, in Genossenschaften und Gewerkschaften 
Es trifft sich merkwürdig, daß, während die abendländische Christenheit derart an eine wirklich christliche Gesellschaftserneuerung im modernen Staate denkt, gleichzeitig das alte radikale Sektenmotiv von Rußland her einen Propheten gefunden hat, der nun seinerseits umgekehrt mit dem Staate und der ganzen technischrechtlichen Kultur überhaupt brechen will, um ein neues Menschentum aufzurichten. Es ist das alte christlich-radikale Ideal ohne auf apokalyptische Gewalt zurückzugreifen, aber auch ohne den modernen technischen Rationalismus zu Hilfe zu nehmen. Bricht die Gesinnung mit der Ordnung der Welt, so wird aus der Liebesgesinnung selbst eine neue Welt entstehen; eine Welt ohne Staat, ohne Recht und Gewalt, ohne Technik und materielle Genußsucht. Tolsto i ist ganz nur aus der russischen Welt und vermutlich auch aus der Entwickelung des russischen Sektenwesens zu begreifen. Aber für das Abendland hat er die Bedeutung, das alte radikale Sektenmotiv einer Verwirklichung der Bergpredigt in den künstlerischen Formen zu verkündigen, die allein die Aufmerksamkeit des modernen Bildungsmenschen auf solche Dinge zu lenken imstande ist. Es ist das Motiv der Bergpredigt ohne die urchristliche Spannung auf das kommende Gottesreich, aber auch ohne die Einbettung in eine kirchliche Kompromißmoral und ohne die Verschmelzung mit der schaffenden Aktivität des Abendlandes. Daß dem Ganzen bei Tolstoi ein Gottesbegriff zugrunde gelegt ist, der stark von abendländischem Pantheismus angesteckt ist und der die hellen Gesinnungsmotive der Bergpredigt mit einer modernen Müdigkeit überhaucht, kann hier außer Betracht bleiben. Welches auch immer die Schranken von Tolstois Verständnis des Fvangeliums sein mögen, es ist doch wie die radikale Sekte und der christliche Sozialismus eine Erinnerung an wesentliche Grundgedanken des Evangeliums, die im relativen Naturrecht des Sündenstandes untergegangen waren und die im

eine Analogie der Zunft, im Staate eine Bureaukratisierung der ganzen Gesellschaft und eine Pensionsanstalt für die halbe Bevölkerung. Der Individualismus wird überall gebunden, und bald wird es nicht mehr zu viel, sondern zu wenig geben. Dann wird sich vielleicht wieder in der Religion neben der bei alledem fortschreitenden formellen politischen Demokratisierung das Asyl des Individualismus öffnen. Siehe hierzu das ausgezeichnete Buch von Joh. Plenge, Marx und Hegel I9II. Das Buch ist völlig aus dem Geiste gedacht, aus dem auch meine ganze Darstellung hervorgegangen ist. $\mathrm{Zu}$ den Zukunftsmöglichkeiten unserer sozialen Entwickelung s. vor allem S. $178-182$. 
III. Protestantismus. 4. Sektentypus und Mystik auf protestantischem Boden.

klassischen Naturrecht des Liberalismus wie in dem modernsten des Sozialismus ihre ursprünglichen Zusammenhänge vergessen und verwischt haben ${ }^{465}$ ).

Diesen Fragen kann hier nicht weiter nachgegangen werden. Sie gehören der systematischen Fthik, nicht der Geschichte der Ethik und der Soziallehren an.

Die Darstellung muß sich vielmehr zurückwenden zu dem zweiten Nebenstrom, der neben dem kirchliehen Hauptstrom des Protestantismus hergeht, zu dem Spiritualismus und der Mystik: Er wurde bereits mehrfach sichtbar in seinen Vermischungen mit dem Sektenwesen und ist in den durchschnittlichen Darstellungen auch überall mit diesem ohne weiteres vermischt. "Täufer und Spiritualisten ist zu einer stehenden Formel geworden, als ob beides im wesentlichen dasselbe bedeute. Das ist aber durchaus nicht der Fall. Es sind zwei getrennte Ströme, die nur gelegentlich sich mischen und die einen sehr verschiedenen geschichtlichen Quellpunkt und Verlauf haben. Der Betrachtung dieser I)inge gilt es nun zuletzt sich zuzuwenden.

Es ist die christliche Mystik und ihre Bedeutung a ufprotestantis che m B ode $n$, um die es sich hier handelt. Auch diese protestantische Mystik setzt vorreformatorische Gedan-

163) Ueber Tolstoi ist unendlich viel, aber wenig Gutes geschrieben worden. Trefflich ist der Artikel von Johannes Nuller, Chr. Welt IgIt S. 218-224: "Das neue Wesen, das Jesus darstellte und weckte, war ihm fremd. Dieses quellende, erfiillende, wiederherstellende, schöpferische Leben aus hthtersinnlichen Tiefen, die feste und freie Ueberlegenheit über alle Dinge auf dem Punkte außerhalb der Welt, der in uns liegt, das göttliche Ja zu allem, was existiert, das in allem das zugrunde liegende Gute, die nach Leben ringende Wahrheit, die durchschimmernde Herrlichkeit sieht und es deshalb fiir Gott in Anspruch nimmt; die Liebe, die überströmendes Leben und Hingabe der Seele ohne Wahl und Grenzen ist, die Ehrfurcht und Güte, Ringen nach unmittelbarer Fühlung im Innersten ist, kannte er nicht. Das ist ein gutes Wort zur christlichen Ethik, aber freilich bleibt die Ausformung dieses Lebens in den konkreten Daseinsverhälınissen schwierig genug. Müller denkt denn auch seinerseits an eine Weltverwandelung, die aus der Einstellung in Jes Empfindungsweise folgen soll, und betrachtet Tolstoi wenigstens als einen Wegweiser zum vergessenen Radikalismus des Christentums: ,Er öffnete mir die Augen dafür, daß das Christentum weltförmig geworden, und die Behauptıng von theologischer Seite, daß es verweltlichen mußte, um Weltreligion werden zu können, konnte das erwachte Mißtrauen nur erhöhen. Wäre es doch der Weg zum Leben geblieben, densie eine Sekteheißén. 
ken und Richtungen fort wie die Sekte, aber sie steht in einem noch engeren Zusammenhang mit den ursprünglichsten Grundgedanken Luthers als diese und hat daher einen noch stärkeren Halt im Protestantismus ${ }^{4 * 6}$ ).

Dabei ist es nun aber sehr schwer, diese Mystik gegen die Sekte richtig abzugrenzen, umsomehr, als die alte häreseologische Ueberlieferung die Unterschiede überall verwischt und unter ihrem Einflusse auch die moderne Forschung nur sehr langsam beides zu trennen gelernt hat. Der Unterschied wird am deutlichsten von der Betrachtung der soziologischen Konsequenzen aus, von denen aus ja auch der $z$ wischen Kirche und Sekte sich erst ergeben hatte ${ }^{467}$ ). Um nun aber die soziologischen Konsequen-

466) Berufungen auf Luthers Geistlehre: bei Seb. Franck, Ketzerchronik II 199 b; Hegler, Geist und Schrift S. 269; Gottfried Arnold II $229>$ Allermaßen aus Luthers Schriften sattsam bekannt ist, daß er in seinen ersten Schriften von dieser Gnade (der Eingebung des Geistes) sehr frei und oftmals viel anstößiger als immer mehr die vermeinten Enthusiasten geschrieben, auch sich allein auf den Geist bezogene; bei den Quäkern, Arnold II 661, 671, 673. - Otto, Anschauung vom hl. Geiste bei Luther 1898, zeigt gleichfalls die Ansätze, nur daß er, den Gegensatz gegen die "Schwärmer am falschen Orte suchend, selbst Luther zu sehr im Sinne der Spiritualisten deutet. - Ueber das Maß des Spiritualismus bei Luther, Zwingli, Calvin, Capito, Oekolampad und Butzer s. die interessanten Ausführungen bei Rich. Grützmacher, Wort und Geist, 1902. Auch die Prädestinationslehre kommt bei Luther und Zwingli in diesem Sinne in Betracht als Ausdruck der Unmittelbarkeit der Erfahrung. Capito greift sogar auf die alte mystische Lehre zurück, daß die innere Erleuchtung nur den in Menschen lebenden Gottesfunken bei den Prädestinierten belebe. Oekolampad hat geradezu Schriften Schwenkfelds herausgegeben. Butzer ist geradezu ein Prediger der Unmittelbarkeit des Geistes im Zusammenhang mit der Prädestination. In dem Maße, als Luther die Wirkung des Geistes nicht bloß mit der Schrift koordinierte, sondern diese zum alleinigen Mittel jener machte, trat auch die Prälestinationslehre zurück und die Kirchlichkeit und Objektivität des Heils in den Vordergrund. Calvin hat durch die vorneherein festgelegte Bindung der Auswirkung der Prädestination an Schrift, Amt und Kirche all das vermieden. Es ist deutlich, wie viel Spiritualismus in den Kreisen der Reformatoren selber lebte. So wuchs er auch aus ihren Schriften selbst immer neu empor. Ein besonders interessantes Beispiel zeigt Sippell in $>W$. Dells Programma. Die mir in einer Ausgabe seiner Works von 1817 (I) zugänglichen Predigten zeigen überall bewußten Anschluß an Luthers spiritualistische Elemente. Das gleiche wird von den Lutheran antinomians gelten, die den Abscheu der puritanischen P'räzisisten und der Männer des jus divinum in der Kirche bildeten s. Sippell S. 2-4.

467) Ueber den Unterschied beider treffende Bemerkungen bei Hegler, Anzeige in Harnacks Dogmengeschichte, ThLZ. 1898 Nr. 9 und Luthardt, Gesch. d. christl, 
850 III. Protestaniismus. 4. Sektentypus und Mystik auf protestantischem Boden.

zen der Mystik richtig zu verstehen, ist es vorerst nötig, diese aus ihrem religiösen Wesen herzuleiten. Es handelt sich daher zuerst um eine allgemeine Analyse des religiösen Wesens der Mystik, für welche im Zusammenhang unserer Untersuchung erst hier der Ort gekommen ist, obwohl die Mystik selbst schon auf die ältesten christlichen Zeiten zurückgeht und insbesondere das für die protestantische Mystik grundlegende Gedankenkapital bereits teils in der Bernhardinischen und Viktorinischen Mystik teils in der großartig gedankentiefen sog. deutschen Mystik des Spätmittelalters ausgebildet worden ist.

Die Mystik im weitesten Sinne des Wortes ist nichts anderes als das Drängen auf Unmittelbarkeit, Innerlichkeit und Gegenwärtigkeit des religiösen Erlebnisses. Sie setzt die Objektivierung des religiösen Lebens in Kulten, Riten, Mythen oder Dogmen bereits voraus und ist entweder eine Reaktion gegen diese Objektivierungen, die sie in den lebendigen Prozeß wieder zurückzunehmen sucht, oder eine Ergänzung der herkömmlichen Kulte durch die persönliche und lebendige Erregung. Sie ist also immer etwas Sekundäres und etwas Absichtlich-Reflektiertes, ein absichtlich herbeigeführter Erregungszustand in charakteristischer gleichzeitiger Verbundenheit mit einer dem ganz entgegengesetzten Unmittelbarkeit des Gefühls selbst. Sie enthält dadurch immer ein Stück Paradoxie, eine Gegensätzlichkeit gegen die Massen und deren Durchschnitt, eine künstliche und doch ihre eigene Künstlichkeit im Unmittelbaren auslöschende Steigerung. Die religiöse Urproduktion selbst, für die Erlebnis und Ausdruck des Erlebnisses schlechthin zusammenfallen, ist daher nie mystisch ${ }^{468}$ ). Wohl aber wird die Lebendigkeit der religiösen Produktion gegenüber der objektivierten Religion leicht und oft $\mathrm{zu}$ mystischen Erscheinungen. Sie äußert sich als Enthusiasmus und Orgiasmus, als Vision und Halluzination, als religiöser Subjektivismus und Spiritualismus, als Konzentration auf das rein Innerliche und Gefühlsmäßige. Ihre Visionen sind freilich selten schöpferische neue Erkenntnisse, sondern fast immer Ausmalungen, Ausdeutungen des gemeinsamen Besitzes, der hier nur eine Belebung und Fortsetzung erfährt, wie dies in den Geistesgaben der alten Christen Ethik II 249 f; auch Sippell, Chr. W. I9 I S. 955-957, zeigt wichtige Einsichten im Anschluß an meine Bestimmung des Sektenbegriffes.

488) $\therefore$ meine Artikel über Offenbarung, Glaube, Glaube und Geschichte in Schieles Lexikon. 
und in den unzähligen Visionen und Prophetien mittelalterlicher Mönche, Nonnen und Heiligen der Fall war und bis heute sich wiederholt. Sie schafft neben oder innerhalb der geltenden Kulte besondere engere Mysterien, in denen das Heil auf eine besonders innerliche Weise angeeignet wird und alte Kulte der Göttermahlzeit, des Opfers, der Neugeburt aus der Gottheit zu einem unmittelbaren mystischen Essen und Trinken der Gottheit, zu einer wirklichen Neugeburt und Vergottung intensiviert und verinnerlicht werden. Sie schafft Prophetien und Ekstasen ebenso wie allegorisierende Grübelei und das Objektive vergeistigende Deutung. Aber sie schafft auch einen leidenschaftlichen Realismus des Verkehrs mit den Gottheiten, der alte Kulte oder geltende Riten zu Mitteln unmittelbarer, substanzieller Einigung macht. Die hellenistischen Mysterien verwandten bald die rohesten fast materialistischen Verstellungen, bald spiritualisierten sie alles zu einem Symbol, das doch immer noch wunderbar wirkte. Das christliche Herrenmahl in der Deutung des Paulus war selbst eine Schöpfung der Mystik, und als die Eucharistie zu einem objektiven Kirchenritus wurde, machte die eucharistische Mystik daraus zum zweitenmal ein mystisches Erlebnis. Vor allem spielt hier das Erotische eine große Rolle, indem entweder die sexuelle Erregung benutzt wird zur Miterregung des religiösen Enthusiasmus oder der letztere sich in sexuellen Reizungen verstärkt und entladet. Die Liebes- und Trinkpoesie der Sufis und die christlichen Deutungen des hohen Liedes spielen auf derselben Saite der Seele. Andererseits überfliegt diese Unmittelbarkeit gerne die sinnlich-endliche Welt durch einen Spiritualismus, der sie gleichgültig macht und ignoriert oder auch sie durch asketische Mortifikation aus dem Wege räumt. Damit ist ihr sowohl ein spiritualistischer Pantheismus als ein radikaler Dualismus von Fleisch und Geist, von Sinnlichkeit und Ewigkeit nahegelegt und im $\mathrm{Zu}-$ sammenhange damit eine alle Endlichkeit vernichtende Askese oder ein sie vergleichgültigender Libertinismus. Die Mystik in diesen verschiedenen Spielarten ist eine allgemeine Erscheinung auf allen Religionsgebieten und besonders in Indien, Persien und Griechenland, Kleinasien und Syrien hochentwickelt. Sie ist auch der urchristlichen Bewegung begreiflicherweise nicht fremd geblieben, teils aus ihr selbst erwachsen teils in sie von außen hereingetragen und begierig ergriffen ${ }^{469}$ ).

169) Zum Allgemeinen s. Edv. Lehmann, Mystik in Heidentum und Christen- 
852 III. Protestantismus. 4. Sektentypus und Mystik auf protestantischem Boden.

Hierher gehört der sogenannte urchristliche Enthusiasmus, ein großer Teil der Geistesgaben, die Glossalalie, der Exorzismus, das ganze pneumatische Wesen, eine bis heute in der christlichen Sektenbewegung immer wiederkehrende Erscheinung, in der die Heilsschätze verlebendigt, subjektiviert und gewaltsam zur Wirkung und Aeußerung gebracht werden. Hierher gehört aber insbesondere auch Paulus nach seiner mystischen Richtung, die mit seiner kirchlichen in einer fortwährenden, wenn auch freilich nicht als Gegensatz empfundenen Spannung, stand. Paulus überkam den Christuskult der Urgemeinde als eine bereits in den ersten Grundzügen durch Kult, Legende und Gemeinderegel objektivierte Religion. Aber er belebte sie durch eine tiefsinnige und leidenschaftliche Mystik, die daher auch die antike Mysteriensprache mitbenützt. Erst hier lag seine religiöse Originalität gegenüber der Urgemeinde, und erst dadurch wurde sein antijüdischer Universalismus möglich. So wurde das Herrenmahl, das Zentrum des neuen Kultus, bei ihm zu einem mystischen Essen und Trinken, einer substanziellen Einigung. So wurde die Taufe zu einem realen Mitsterben und Mitauferstehen mit dem Christus. So wurde der Christus für ihn eine reale Lebenssphäre übersinnlicher Art, in der der Gläubige lebt, empfindet und denkt und zu einem neuen pneumatischen Wesen wird. So wurde alles Zeremonielle und alles bloß Ueberlieferte zum Fleisch und Element dieser Welt, wurde der Christus nach dem Fleisch beiseite geschoben. So wurde die israelitische Heilsgeschichte allegorisiert und spiritualisiert zu unmittelbarer Anwendung auf den Christusgläubigen und wurde die Gemeinde zu einem spiritualen Christusleib. Ekstasen und Visionen fehlten nicht, die Geistesgaben wurden gerühmt und gepflegt und in das Lebenssystem des Pneumatikers eingefügt. Hier in dem urchristlichen pneumatischen Enthusiasmus und in der paulinischen Christusmystik liegen die unversieglichen Quellen einer christlichen Mystik. Im vierten Evangelium ist diese Mystik bereits beruhigt und gefaßt und wieder mit dem Historischen und Objektiven ausgeglichen. Aber hier hat sie nun erst recht ihre charakteristischen Formeln von Fleisch und Geist, von Finsternis und Licht, von Allegorese und buchstäblichem Verständnis, erzeugt oder gefunden.

tum 1901; A. Merx, Ideen und Grundlinien einer allgemeinen Gesch. der Mystik 1903; vor allem Erwin Rohdes Psyche, auch James, Varieties of religious experience. 
Andere altchristliche Schriften enthalten Aehnliches. Durch das Neue Testament sind der pneumatische Enthusiasmus und die paulinische Mystik zu einer dauernden, immer wieder verwandte Bedürfnisse anregenden und ihnen die Formeln gebenden Kraft geworden, die in allen Perioden der Kirchengeschichte, und sonderlich in allen Perioden der Kritik am Ueberkommenen, der religiösen Ermattung und der religiösen Neubildung, sich lebendig geäußert hat.

Im Urchristentum liegen die Keime des Kirchen- und Anstaltsgedankens, der mit dem Gedanken der Gnade, der fertigen Heilsstiftung und Welterlösung, der von allem Subjekt unabhängigen prinzipiellen Neuschaffung der Welt, gegeben ist. In ihm liegen die Keime der Sekte, die die Bergpredigt ihres Meisters als ihr Sittengesetz verehrt und seine Hoffnung auf das zur Erde kommende Reich fortsetzt, die Reinen und Heiligen sammelt zu der des Gottesreiches und der Wiederkunft Christi harrenden Gemeinde. In ihr liegen aber auch die Keime einer Mystik, der alles Vergängliche nur ein Gleichnis, alles Sinnlich-Irdische nur eine Schranke, aller Kult nur ein Mittel substanzieller Einigung und aller Glaube nur eine unmittelbare Versetzung in das unsichtbare Gottes- und Christusleben ist ${ }^{470}$ ).

Von dieser Mystik im weiteren Sinne und in ihrer protëischen Mannigfaltigkeit ist nun aber die Mystik im engeren und technischen, religionsphilosophisch zugespitzten Sinne des

$\left.{ }^{470}\right)$ Ueber den urchristlichen Enthusiasmus s. Gunkel, Wirkungen des hl. Geistes nach der populären Anschauung der apostol. Zeit und nach der Lehre des Apostels Paulus ${ }^{3}$ 1909; Weinel, Geist und Geister im nachapostol. Zeitalter 1899; Taufe und Abendmahl bei Paulus I903; über die Mystik des. Paulus höchst lehrreiche Ausführungen bei Reitzenstein, Die bellenistischen Mysterienreligionen 1910. Von hier aus erklärt sich auch die heute so vielfach zum Ausgangspunkt phantastischer Schlüsse gemachte Opposition des Paulus gegen den Christus nach dem Fleisch. So haben auch nach ihm alle Mystiker gegenüber dem Dogma gedacht. Reitzenstein betont mit Recht auch bei Paulus >den Gegensatz von Autonomie des religiösen Empfindens und Gebundenheit der Traditione S. 58; die smystischen Gedanken befreiten sich unmerklich zunächst von der Tradition, die sich in der Gemeinde auf jüdischem Boden zu bilden begonnen hatte, und der Kampf, der bald folgte, brachte ihm das Bewußtsein der Freiheit, die für ihn nun überall ist wo der Geist des Herrn iste S. 60. - Auch Deissmann, Paulus 19xx, hebt das nervor, ohne freilich den Gegensatz gegen die Urgemeinde und den Ansatzpunkt für alle spiritualistische Mystik hierin genügend zu erkennen. Treffend ist die Betonung der Verbindung des Historischen und Spiritualistischen S. 154: Das erste führt zur Sekte, das zweite zum Spiritualismus. 


\section{III. Protestantismus. 4. Sektentypus und Mystik auf protestantischem Boden.}

Wortes zu unterscheiden. Die bisher geschilderten Erscheinungen gehen aus dem unmittelbaren Gefühlsdrang hervor, sind ebendamit verhältnismäßig instinktiv und spontan und vertragen sich mit jeder Gestaltung der objektiven Religion, mit den üblichen Kulten, Mythen und Dogmen. Sie enthalten keinerlei Doktrin und Theorie über sich selbst, höchstens eine primitive Technik der religiösen Selbstbearbeitung und Stimmungserzeugung. Auch sind ihre verschiedenen Aeußerungen, der Enthusiasmus und Orgiasmus, die Kontemplation und Gnosis, die Allegorisierung und Vergeistigung, die Belebung oder Erzeugung von Kulten unter sich ganz verschieden und enthalten sehr mannigfache, oft sich gegenseitig auf hebende Folgerungen. Sie berühren auch den vorgefundenen soziologischen Zusammenhang der Religion nicht wesentlich, indem sie bloß eine Steigerung seiner Kräfte oder eine Heraushebung Einzelner bedeuten oder etwa neue Kulte hinzufügen, aber die konkrete Religion nicht verneinen. Die Sache kann aber auch ein ganz anderes, viel eindeutigeres Gesicht gewinnen, und dann stellen sich erhebliche soziologische Folgen ein. Die in solcher Mystik wirksamen Kräfte können nämlich auch gegen die konkrete Religion sich prinzipiell verselbständigen, von ihr lösen und eine Theorie ihrer selbst aufstellen, die an Stelle der konkreten Religion und ihres Mythus oder Dogmas tritt, sei es mit offener Verneinung, sei es mit allegorisierender Umdeutung. Damit empfindet die Mystik sich dann als selbständiges religiöses Prinzip, als eigentlichen allgemeinen Kern aller religiösen Vorgänge, der sich in den verschiedenen mythischen Aeußerungen nur verkleidet. Sie empfindet sich als Herstellung einer unmittelbaren Gotteinigung, fühlt sich selbständig gegenüber aller konkreten Religion und hat eine völlig individuelle innere Gewißheit, die sie gegen jede religiöse Gemeinschaft gleichgültig macht, einerlei ob sie äußerlich sie mitmacht oder ob sie eine solche radikal verwirft. Dann wird die Gotteinigung, die Vergottung, die Entwerdung das eigentliche und einzige Thema der Religion. Dies Thema wird als abstrakter Gehalt der mystischen Erlebnisse herausgeholt und zum allgemeinen, universalen Wesen aller innerlichen und echten religiösen Vorgänge gemacht. Eine solche Gotteinigung fordert nun aber weiterhin eine allgemeine kosmische Theorie, in der die Möglichkeit und die Verwirklichungsweise dieses Heilsvorganges begründet ist. Sie fordert zugleich eine aus dieser Theorie sich ergebende Technik der Herbeiführung und Vollendung des mystischen Er- 
lebnisses. Eine solche Theorie muß zeigen, wie es in Gott zu einer Scheidung zwischen Gott und den endlichen Geistern kommen konnte und wie diese Scheidung vermöge des Enthaltenseins der endlichen Geister in Gott wieder überwunden werden kann. Sie zeigt den Ausgang des Endlichen aus Gott und den Rückgang des Endlichen in Gott, die bei aller Scheidung verbleibende Identität, vermöge deren die Wiederaufhebung der Scheidung möglich wird. Sie bezeichnet die Stufen des Herabsteigens und die des Wiederhinaufsteigens der Kreatur zu Gott; sie macht schließlich klar, wie im Denken und Erkennen dieses Prozesses der religiöse Vorgang sich über sich selbst verdeutlicht und zu seinem eigentlichen Kerngehalt kommt. Das reine Denken dieses Zusammenhanges, meint man, ist, wo es wirklich echtes und eigenes Denken ist, das religiöse Erlebnis selbst und dieses wiederum verdeutlicht und erläutert sich vor sich selbst durch dieses Denken. Daraus ergeben sich auch die Stufen dieses Erlebnisses, die nichts anderes sind als die zugleich in inneres Handeln umgesetzten Stufen dieses Denkens bis zur Erreichung und Fühlung des vollen Identitätsgedankens. Eine solche Mystik wird zur selbständigen Religionsphilosophie, welche den religiösen Vorgang als die allgemeine überall gleiche Aeußerung und Bewußtwerdung des metaphysischen Zusammenhangs von absolutem und endlichem Sein erkennt und unter allen konkreten Religionsformen überall den gleichen Kern entdeckt, der aber doch erst unter ihrer Pflege die volle und reine Reife erfährt. Damit wird sie unabhängig von der konkreten Volksreligion, zeitlos und geschichtslos, höchstens unter geschichtlichen Symbolen verhüllt, die allein richtige Deutung des religiösen Vorgangs, unter welchen besonderen Vorstellungen er sich immer verkleide. Sie wird antipersonalistisch und asketisch, indem sie die Persönlichkeit untergehen läßt in Gott, indem sie das Sinnlich-Endliche als die Scheidewand zwischen dem absoluten Gott und dem in der endlichen Kreatur enthaltenen Gott betrachtet. Sie prägt jenen Pantheismus aus, der doch im philosophischen Sinn kein Pantheismus ist, weil in ihm die Trennung des endlichen Ich von Gott so wichtig ist wie die Wiedervereinigung, der daher immerfort umschlägt in den schroffsten Dualismus oder in einen allerhand. Zwischenglieder einlegenden Emanatismus. Sie wird ein Intellektualismus eigener Art, der die Maßstäbe des sinnlich gebundenen Intellekts verachtet und eine nur dem Religiösen verständliche 
856 III. Protestantismus. 4. Sektentypus und Mystik auf protestantischem Boden.

religiöse I.ogik an Stelle des gemeinen, fleischlichen und ungeweihten Denkens setzt. Sie kann aber auch zum reinen Voluntarismus werden, sobald sie die Gefahren des Denkens für die religiöse Innigkeit spürt und den Nachdruck auf die W'illenseinigung mit Gott oder auf den Untergang des endlichen Lebenswillens legt. So gehen die brahmanische spekulative und die buddhistische voluntaristische Mystik. die dominikanische Erkenntnis- und die franziskanische Willens- und Liebesmystik nebeneinander her.

Auch diese technische, religionsphilosophische Mystik im engeren Sinne ist in einer erstaunlichen Analogie auf verschiedenen Religionsgebieten hervorgetreten, im indischen Brahmanismus und seinem Gegenschlag, dem Buddhismus, im Sufismus der Parsen und der persischen Mohammedaner, im Neuplatonismus der Griechen, in dem bunten Synkretismus der Spätantike, den man Gnosis nennt. Im platonischen, neuplatonischen und gnostischen Gewande hat sie sich den alten Christen dargeboten, die nach ihr als einer wissenschaftlichen Grundlegung ihrer eigenen religiösen Lehre begierig griffen, wie sie die Stoa als eine wissenschaftlich durchgebildete Analogie ihrer Ethik für ihre Moral- und Gesellschaftslehre in Beschlag genommen haben. Der Stufengang dieser Entwickelung im Christentum liegt deutlich vor. Jesus ist kein Mystiker. Er lebt nur in der Anschauung Gottes, dringt auf die praktische Heiligung des Lebens und verkündet die bevorstehende Verwirklichung des Ideals. Paulus und die Pneumatiker verinnerlichen, vergeistigen, verlebendigen den in der Urgemeinde gebildeten Christuskult und die Christusüberlieferung ohne Philosophie und Spekulation in freier Benützung der antiken mystischen Kultsprache. Die Gnostiker und religionsphilosophischen Theologen der alten Kirche öffnen sich der religionsphilosophischen Mystik, die konkrete Anlehnung an die christliche Geschichte bald mehr bale weniger betonend und die praktisch-ethische Persönlichkeitsidee bald mehr bald weniger behauptend.

So entwickelte auch die religionsphilosphische Mystik, die Mystik im engeren und technischen Sinne, ihre ungeheure Bedeutung innerhalb des Christentums. Sie half der wissenschaftlichen Theologie der alten Christen ihren Glauben an eine Verkörperung und Menschwerdung Gottes in ihrem Kultheros, dem Christus, auf die wissenschaftlichen Formeln der erst emanatistisch und dann homousianisch verstandenen Trinitätslehre bringen. Sie half ihr das im christlichen Kult zu gewinnende Heilsgut der 
Gotteinigung definieren und ihren Sakramenten einen religionsphilosophischen Sinn zu geben. Auch für ihre Apologetik erwies sie sich als wertvoll, indem die Mystik das natürliche allgemein religiöse Bewußtsein darstellte, das in der Menschwerdung des Logos und in den Sakramenten der Kirche zur Vollendung kommt. Doch ist das in unserem jetzigen Zusammenhang nur insofern von Bedeutung, als die damalige relative Rezeption der Mystik immer den Ausgangspunkt und den Rechtstitel für ein jedesmal neues und volleres Einströmen der Mystik bildete. Die für uns bedeutsamen Wirkungen der Mystik treten vielmehr erst da hervor, wo das Bedürfnis nach Verinnerlichung und Verlebendigung des religiösen Prozesses zu den Mitteln der von der Mystik erarbeiteten Technik des Stufenganges griff, wo man beschrieb, wie die Seele von der Betrachtung und Selbstverleugnung durch reifende Erkenntnis und Einigung bis zum seligen verzückten Genuß gelangen und so die christliche Vereinigung mit Gott und Christus erwirken und erleben könne. Hier bildet der Areopagite nicht die einzige, aber die vornehmste Brücke der Verbindung mit dem Neuplatonismus, der diese Lehre grundlegend ausgebildet hatte. Auch die alexandrinischen Theologen und Augustin hatten bereits das Ihrige getan. Aber entscheidend ist erst die Art, wie die mittelalterliche Frömmigkeit das dem Germanentum fremde, von der Antike als Kult, Dogma und Hierarchie überlieferte christliche System durch die Mystik sich aneignete und persönlich erwärmte. So haben Bernhard und die Viktoriner den Christusglauben aus dogmatischer Verhärtung heraus neubelebt, und so reden auch die Mystiker der Reformationszeit vom Stufengang der Gelassenheit und Entgröbung bis zur Höhe der Seligkeit und Gotteinigung. Weiter kommt für uns in Betracht die Lehre von der mystischen Gotteinigung oder der Einwohnung Christi als dem Kern und Grund aller praktisch-religiösen Leistung und dem Ausstrahlungszentrum aller religiösen Ethik. Damit haben die christlichen Mystiker eine substantielle Verbindung mit Christus erstrebt und gefunden, in welcher das Christusleben zum Prinzip aller religiösen Betätigung und Kraft wurde und wiederum die praktische Weltüberwindung zur Probe auf die Wirklichkeit der Christuseinigung. Hierdurch wurde die Kluft zwischen Geschichte und Gegenwart, Dogma und religiöser Praxis überwunden und der Glaube zum Prinzip unmittelbarer praktischer Leistung. So hat die Christusdevotion des Mittelalters die Unmittelbarkeit der Wirkung 
Christi auf die Gläubigen hergestellt, aus dem Felsen des byzantinischen Dogmas das Wasser des Lebens herausgeschlagen. So hat auch Luther gelegentlich geredet und empfunden. So haben Karlstadt, Schwenkfeld und Osiander den Glauben an eine bloße Rechtfertigung zur Kraft eines sich unmittelbar praktisch äußernden Lebens gemacht. In dieser Richtung ging die Christuslehre aller Spiritualisten, wobei sie dann den geschichtlichen und in der Mystik uns gegenwärtig gemachten Christus gerne durch das allgemeinere Prinzip des in Christus verkörperten Logos verdeutlichten und den Anschluß an die zeitlose Lebensfülle Gottes gewannen.

Vor allem kommt für uns dies letztere in Betracht als Mittel, den mystischen Drang nach Verinnerlichung und Verlebendigung der objektiven Religion zugleich auf eine prinzipielle und allgemeine Grundlage wissenschaftlicher Einsicht zu stellen. Da wird als letzter Untergrund auch der christlichen Heilserfahrung jener allgemeine kosmische Prozeß der Herabsenkung des Absoluten in die Endlichkeit und Sinnlichkeit geschildert, wobei Gott der Lebensgrund, Same und Funke auch der in Selbstsucht und Sünde sich isolierenden und verselbständigenden Kreatur bleibt. Es ist die wichtige Lehre vom Samen und Funken, der in jeder Seele und jeder Vernunft steckt, erstickt von Endlichkeit und Sünde, aber in der Berührung mit dem an uns und in uns arbeitenden göttlichen Geiste der Aktualisierung fähig. Dieser Same wirkt in aller religiösen Sehnsucht und Ahnung und wird durch die rein innere, von der geschichtlichen Offenbarung nur belebte, entzündete und gekräftigte Bewegung des Geistes entwickelt zur vollen Ueberwindung der Welt und zur Rückkehr in Gott. Hier fällt alles Gewicht auf die gegenwärtige unmittelbare, innere, religiöse Bewegung des Gefühls und des Gedankens im Gegensatz gegen jede'äußere Autorität, jeden Buchstabenglauben, jede Abhängigmachung der Seligkeit von geschichtlichen Tatsachen und von deren Kenntnis und Bejahung. Hier fällt die seligmachende Wirkung Gottes zusammen mit der Bewegung des momentanen religiösen Gefühls und ist der Glaube gewiß, die Regung des göttlichen Geistes von der des bloß menschlichen, Meinens und Begehrens unterscheiden zu können durch Selbstprüfung und Selbstlosigkeit. Alles Kirchliche, Historische, Dogmatische, Objektive und Autoritative verwandelt sich in bloße Anregungsmittel und Erreger des allein wertvollen und allein heilsbegründenden persönlichen Erlebens. Es ist eine Theclogie des Heilsbewußtseins, und nicht 
mehr der bloßen Heilstatsachen. Das Verhältnis zwischen dem Geist oder dem gegenwärtigen lebendigen Heilsbewußtsein und den Tatsachen der Geschichte und des Kultus wird neu geordnet. Das Kirchliche, die Lehre, das Dogma erscheinen schon ihrerseits lediglich als Niederschläge eines solchen persönlich-religiösen Lebens und können in ihrem wahren'Sinn nur verstanden werden von dem ihnen entgegenkommenden innern Wirken des Geistes oder der Bewegung Gottes in der Seele. Der Geist Gottes erkennt in der Schrift und der Kirche nur sich selber wieder und kann nur dadurch Kraft und Nahrung aus ihnen ziehen; für sich allein sind beide tote Buchstaben und Zeremonien. Es ist der mystische Spiritualismus im Dienst der Unmittelbarkeit und Persönlichkeit des religiösen Lebens und in der Bewährung durch das AlleinWertvolle, ein weltüberlegenes und weltüberwindendes Leben aus dem Geist. Diese Theorie hat die deutsche Mystik als Unterlage praktischer Reformen und im Zusammenhang mit der Befreiung des spätmittelalterlichen Laienchristentums aus ihren antiken Vorlagen herausgearbeitet, wobei sie sich zur objektiven kirchlichen Institution bald mehr bald weniger folgerichtig verhielt und die christliche Grundrichtung durch die Behauptung des Personalismus nach Kräften sicherte. Der endliche Geist gewinnt nach ihr im Weltprozeß wirkliche Realität, begeht in seiner selbstsüchtigen Versteifung gegen Gottes Geist wirkliche Sünde und wird durch das im Christentum ihn ergreifende Wirken des göttlichen Geistes zum wahren und gotteinigen Kern der Persönlichkeit erhoben. Freilich ist das letzte Ende, die Einigung mit Gott in der Betrachtung oder in der Willenshingabe der Liebe dann doch immer irgendwie ein Untergehen in Gott. Hier hat schon Dante die Distinktionen nur mühsam aufrecht erhalten. Allein an dem Willen, die Erhebung, Rettung und Vergöttlichung des wahren und echten Kernes der Persönlichkeit zu behaupten, kann kein $Z$ weifel sein. Der ganze mystische Gedanke selbst steht ja im Dienst einer persönlich lebendigen Frömmigkeit und das Heil unmittelbar erlebenden Innerlichkeit. Dies und die immer irgendwie festgehaltene Beziehung der inneren Wirkung des Geistes auf die von der Geschichte her ergehende Anregung, Kräftigung und Erhebung unterscheiden diese christliche Mystik von ihrer alten Unterlage, dem Neuplatonismus, ganz abgesehen davon, daß das trinitarisch-christologische Dogma beibehalten und in diesen Sinn hineingedeutet wurde ${ }^{171}$ ).

471) Hierzu vgl. vor allem Preger, Gesch. d. deutschen Mystik, eines der großen 
Aus dieser alten mystischen Ueberlieferung und ihren sie immer neu belebenden Grundlagen im Neuen Testament ging auch die Mystil der Reformationszeit hervor. Daß Luther selbst einen kräftigen Anstoß von ihr erhielt, ist bekannt. Sehr viel weniger ist das bei Calvin der Fall; auch seine Abendmahlslehre hängt nicht mit ihr, sondern m dem. Antikatholizismus und der Scheidung zwischen Gott und Kreatur zusammen. Der Calvinismus hat Verwandtschaft mit dem Sektentypus, aber nicht mit der Mystik. Gleichwohl aber drang sie auch sogar in ihn aus ihren allgegenwärtigen Quellen ein, wie sie in den Katholizismus der Gegenreformation und in den lutherischen Pietismus eingedrungen ist. Hatte sie mit dem Katholizismus den Zusammenhang, daß sie hier gerne als Ergänzung der überstarken Anspannung der rein objektiven Religion auftrat und mit der katholischen Justifikationslehre als der Lehre von einer inneren substanziellen Wandelung der Gläubigen sich verbinden konnte ${ }^{472}$ ), so hatte sie auf dem Boden

Hauptwerke der Kirchengeschichte. Sehr vieles auch bei Ritschl und Harnack an verschiedensten Orten. Der Nachweis Denifles, daß diese Mystik mit der Scholastik völlig eins geivesen sci, ist dorh sehr apologetisch gedacht und geht nicht in die psychologische Tiefe des Problems. Wenn Ritschl und seine Schüler diesen Nachweis so eifrig aufnabmen, so geschah das nur, um damit die Gleichung von Katholizismus und Mystik ebenso zu vollziehen, wie die von Katholizismus, Täufertum, Sekte und Mönchtum. Damit ist dann auch die Mystik vom Standpunkt eines lutherischen Kirchentums abgetan. - Im übrigen finden sich gerade in Ritschls Geschichte des Pietismus eine Reihe scharfsinnigster Ausführungen, in denen sein kirchlicher Instinkt die wesenhafte Anti-Kirchlichkeit der Mystik aufdeckt, auch in ihren scheinbar noch ganz kirchlichen und dogmenfreundlichen Aeußerungen. Aber eben deshalb kann von einer Identität mit dem Katholizismus nicht die Rede sein. Das bekannte Wort von Harnack, wer Mystiker sei ohne katholisch zu werden, sei Dilettant, kann ich in keinem Sinne für richtig halten. Umgekehrt ist freilich die Gleichsetzung von Mystik und Spiritualismus mit der echten Idee des Protestantismus, wozu Weingarten, A. Dorner. Barge, auch Dilthey neigen, sicherlich unrichtig, so wenig die starke spiritualistische Ader bei Luther verkannt werden darf. Sie ist dasjenige an Luther, was der moderne Mensch an ihm vor allem versteht. Das Wormser Lutherdenkmal trägt nicht umsonst lauter spiritualistische Sprüche. - Sehr wertvoll ist auch das große Werk v $\sim$ F. v. Hügel, einem der Führer des sog. Modernismus : - The mystical element of religion as studied in St. Catharine of Genoa and her friendse London 1908; hier sieht man in den Reichtum der die christliche Ideenwelt schaffende Komponenten hinein, wie in wenig anderen Darstellungen; das Christentum ist im Laufe der Zeit $2 u$ einer völlig komplexen Religion geworden.

47') ZLm Ganzen s. vor a.lem auch hier Gottfried Arnold, außerden Ludwig 
des Protestantismus in der Grundrichtung auf individuell-persönliche Heilsgewißheit und besonders im Luthertum in der Lehre von der gegenwärtigen Seligkeit des in Christus Befreiten einen sie anlockenden Reiz. Insbesondere aber gab der spiritualisierte Kirchenbegriff des Protestantismus und die anfängliche Unsicherheit in der Durchsetzung der neuen Kirchenordnungen ihr Raum zu selbständigen Entfaltungen und Festsetzungen. Wo sie, von den Kirchen ausgeschieden, eines anderen gemeindlichen Anhalts bedurfte, da fand sie im erregten Enthusiasmus der Täufer und bei ihrer asketischen Sittlichkeit einen freilich sehr unsicheren Zufluchtsort und Anschlußpunkt. Andere blieben völlig einsam und vertrauten ihre Erkenntnis nur dem Buche an ${ }^{472}$ ). Unter diesen Umständen entfaltete sich eine protestantische Mystik, die nicht wie die katholische eine Kompensation kirchlicher Aeußerlichkeit war, sondern sich als selbständiges Prinzip religiöser Erkenntnis, Innerlichkeit und Ethik fühlte und betätigte. Erst auf dem Grunde des protestantischen Individualismus und Paulinismus kam die spezifisch christliche Mystik zu einer Neues bildenden und unabhängigen Entwickelung, der eine immer tiefere Einwirkung auf den kirchlichen Protestantismus beschieden wai und die doch immer innerlich von ihm geschieden blieb. Die Ergebnisse der modernen, spekulativen und autonomen Religionsphilosophie vorausnehmend, deutete sie die Entwickelung des modernen Protestantismus an und, die Kirchlichkeit in ihrer Verbindung mit dem Pietismus zersetzend, machte sie die kirchliche Geschlossenheit und

Keller, Erbkam; Göbels, Heppes und Ritschls Gesch. d. Picticmus. Vieles bei Hegler, Geist und Schrift bei Seb. Franck, der S. 277 eine Gruppierung versucht; ferner Maronier, Het inwendig word, Amsterdam I89o; Rich. Grützmacher, Wort und Geist 1902, auch die schönen Darstellungen Diltheys im Archiv f. Gesch. d. Philos. Von kirchlichen Theologen standen der Richtung am nächsten Capito und Oekolampad; auch Butzers Verhältnis wäre noch zu untersuchen. S. auch Hegler, Beiträge zur Gesch. d. Mystik in der Reformationszeit, hsg. von W. Köhler 1906; es sind Mitteilungen von Schriftstïcken aus dem Einflußkreise Seb. Francks. Wertvolle Angaben auch bei Sippell, Ueber den Ursprung des Quäkertums; dort eine sehr treffende Bemerkung über den Unterschied von Enthusiasmus und Mystik Chr. W. I910 S. 460. - Eine vortreffliche Gesamtcharakteristik auch dieser Richtung bei Göbel II 680-69o, der auch den Unterschied der sektenhaft-separatistischen (Labadie und Spener) und der mystisch-separatistischen Gruppen (vor allem Gottfried Arnold) sehr scharf erkennt.

${ }^{472}$ ) S. unten S. 860. 
862 III. Protestantismus. 4. Sektentypus und Mystik auf protestantischem Boden.

Anstaltlichkeit des Protestantismus vollends und in zunehmendem Maße unsicher.

Diese eigentlichste Tiefe des Gedankens enthüllte sich freilich nur bei den bedeutendsten Denkern und innerlichsten Persönlichkeiten des protestantischen Spiritualismus wie bei Seb. Franck und Valentin Weigel, Dirck Coornheert und John Saltmarsch. Aber Stücke dieses Gedankenganges kehren in oft unklarer Verbindung mit kirchlichen Sätzen bei allen wieder, wie bei Karlstadt, Schwenkfeld u. a. Auch dem Enthusiasmus, der bei den älteren Täufern, in den Anfängen der Quäker, im Methodismus eine große Rolle spielt, lagen solche Folgerungen nahe; sie wurden auch von einzelnen gezogen, wenn auch freilich der bloße Enthusiasmus an sich mit solcher Begründung in dem dauernden, immer gleichen Gottesfunken der menschlichen Seele nichts zu tun hat, sondern umgekehrt gerade an plötzlichen, außerordentlichen und regellosen Manifestationen Gottes hängt. Aber da er in alledem doch aur die unmittelbare Gegenwart des Geistes oder Gottes in der religiösen Erregung dringt, so ist bei ihm der Uebergang zur Mystik nahe gelegt und vor allem von enthusiastischen und wissenschaftlich gebildeten Täufern oft vollzogen worden. Die englischen Puritaner haben vom Pietismus und Enthusiasmus her wenigstens teilweise - und dann sehr nachdrücklich - sich der Mystik und dem Spiritualismus ergeben; auch bei den kontinentalen Pietisten blieben sie nicht aus; in beiden Fällen wirkte die ältere spiritualistische Literatur nach. Die Kongregationenlisten und Independenten sind, wie wir bereits sahen, ohne sie nicht zu verstehen. Vor allem haben die Quäker geradezu aus dem Enthusiasmus die Theorie des inneren Lichtes klassisch herausentwickelt und darin ihre Ruhe und ihre Klärung gefunden. Erst da aber, wo Enthusiasmus und Verinnerlichung zu solchen Folgerungen gelangen, wird die Mystik zum Spiritualismus; in seiner antihierarchischen Neigung zu einem radikalen allgemeinen Priestertum bekundet dieser Spiritualismus zugleich seinen protestantischen Charakter ${ }^{4: 3}$ ).

473) Vgl. hierzu die sehr verdienstlichen Schriften von H. Heppe, Geschichte. der pietistischen Mystik in der katholischen Kirche 1875, Gesch. des Pietismus und der Mystik in der reformierten Kirche namentlich der Niederlande 1879. Das letztere behält neben Ritschls Gesch. d. Pietismus seinen sehr erheblichen Wert. - Ein. seitige Zuweisung der Mystik zum Katholizismus bei Herrmann, Verkehr des Christen mit Gott S. 16-2I. In der Schule Ritschls wird Mystik und Sektentypus auf den Katholizismus zurückgeführt, um sie um so sicherer vom Protestantismus auszuschließen. 
So ist denn nun auch der Unterschied gegenüber dem Sektenideal und dem Täufertum klar. Für das Täufertum ist entscheidend das Gesetz Christi, die Bergpredigt, und das damit übereinstimmende absolute Gesetz der Natur. Die Spiritualisten dagegen kennen nur den Geist, seine Freiheit und innere Bewegung. Sie sind "Antinomisten « und schöpfen aus dem vom inneren Christus erleuchteten Gewissen. Die Täufer verfechten mit Leidenschaft die Spättaufe als äußeres Bundeszeichen. Den Spiritualisten ist die Taufe überhaupt gleichgültig. Sie kennen nur die Geistestaufe, und nur die Geistbegabten können erkennen, wer zur wahren, rein spirituellen Kirche oder Gemeinschaft des Geistes Christi gehört. Die Täufer haben äußere Ordnungen und Zeremonien, Abendmahl, Fußwaschung, Verfassung. Die Spiritualisten kennen nur den Gottesdienst im Geist und in der Wahrheit, keine äußerlich geschlossene Gemeinde und im Grunde kein Sakrament. Die Täufer haben das äußere Wort als Regel des Buchstabens und als äußere Autorität. Die Spiritualisten haben das inwendige Wort, den Logos, den Gottessamen oder Gottesfunken, in dessen Regungen sie erst das äußere Wort verstehen und das sie bei der auch von ihnen festgehaltenen Inspirationslehre allegorisch deuten. Die Täufer organisieren Gemeinden und verteilen in ihnen verschiedene Aemter, haben Ordination und Mission. Die Spiritualisten wohnen in der unsichtbaren Gemeinde, in der der Geist alles von selbst wirkt und in der man sich nach dem Fleisch nicht zu kennen braucht. Die Täufer sammeln eine vỏn Christus regierte Gemeinde wahrhafter Heiligen. Die Spiritualisten wissen nichts von einer sichtbaren Gemeinde, sondern warten auf das dritte Reich, wo alle vom Geist selbst erleuchtet und geleitet werden; für sie regiert Christus nur durch den mit dem unmittelbaren religiösen Erleben identischen Geist. So nehmen die Täufer auch die Apokalypse beim Wort und berechnen die Wiederkunft und das Kommen des tausendjährigen Reiches. Die Spiritualisten vergeistigen auch das tausendjährige Reich und die Wiederkunft Christi zu einer inneren Wiederkunft in den endlich der Liebe sich öffnenden Gemütern. Die Täufer hängen an der synoptischen Predigt, am geschichtlichen Jesus und an seiner Verkündigung des kommenden Gottesreiches. Die Spiritualisten berufen sich auf Paulus und Johannes, kennen Christum nicht nach dem Fleisch und dringen durch den Geist in immer neue und tiefere Gotteserkenntnis vor, die ihnen allein das wahre Gotteswerk ist. Das sind grundlegende Unter- 
schiede, deren letzte Ursachen schon in der Bibel selbst liegen.

Mit alledem sind dann auch die starken soziologischen Eigentümlichkeiten des Spiritualismus klar. Die Mystik ist ein radikaler Individualismus, der von dem der Sekte sehr verschieden ist. Hebt diese die Individuen durch bewußten Gegensatz und ethische Strenge gegen die Welt $a b$, verbindet sie dieselben zu einer gerade auf gewollter Vereinigung ruhenden und in Kontrolle und Bußzucht sich festigenden Gemeinschaft, knüpft sie die einzelnen an Vorbild und Autorität Christi und steigert sie den Individualismus gerade durch seine leinstellung in die Wechselwirkung des Gemeindeverbandes und Kultus, so drängt die Mystik nicht auf ein Verhältnis von Mensch zu Mensch, sondern auf ein Verhältnis zu Gott. Sie macht alles Historische, Autoritative und Kultische lediglich zu Anregungsmitteln, die sie nötigenfalls auch entbehren kann. Insbesondere der Spiritualismus löscht in seinem Drang nach Unmittelbarkeit in Wahrheit die Geschichte aus und beseitigt damit das Zentrum, um das allein ein christlicher Kult sich sammeln kann. Er wird geschichtslos, kultlos, gemeinschaftslos, allerdings in sehr verschiedenen Graden der Folgerichtigkeit. So lange er bewußt christlich bleibt, spielt die Bibel und das geschichtliche Bild Christi immer noch eine bedeutende Rolle, aber doch nie mit der Kraft, daß daraus eine fest geschlossene, um Kult, Geschichte und Autorität gesammelte Gemeinde würde. Seine Gemeindebildungen sind Provisorien, Zugeständnisse an menschliche Bedürfnisse, ohne innere Notwendigkeit und Göttlichkeit. Es ist somit ein gänzlich anderer Individualismus als der der Sekte. Nicht um handelnde, bekennende und sich in der Wechselwirkung stets neu aus den Einzelwillen erzeugende Gemeinschaft handelt es sich, sondern um einen Parallelismus religiöser Spontaneitäten, die nur verbunden sind durch die Gemeinsamkeit des göttlichen Lebensgrundes, aus dem sie stammen, durch die Gemeinsamkeit der Liebesgesinnung und durch die Verbindung in Gott, die das freie und unsichtbare Werk des göttlichen Geistes ist. Hier bedarf es an sich keines Sakramentes, keines Dogmas, keiner Kirche, keiner Aemter und keiner Organisation. Die Gemeinschaft ist, wie die religiöse Erleuchtung selbst, lediglich das Werk des in allen identischen und in allen sich wieder erkennenden Geistes, aus dem auch in jedem gegebenen Falle die innere Berührung der Seelen und die werktätige Aeußerung christlicher Liebe stammen. In der Lösung von allen Vermittelungen und Organisationen, 
in der Stellung des Glaubens und Gefühls auf sich selbst ist der Individualismus des Täufertums überboten. In der Neigung zu quietistischem Ruhen und Sich-Hingeben, zur Bewährung der Liebesgemeinschaft nur von Fall zu Fall, ist aber umgekehrt dieser Individualismus wiederum viel schwächer als der auf beständige Aktivität gerichtete und gerade durch die aktive Heiligkeit die Gemeinde verknüpfende Individualismus des Täufertums. Auch der Individualismus kann eben sehr Verschiedenes bedeuten und sehr verschiedene Wirkung haben je nach Begründung und Zusammenhang, wie wir das schon bei dem Unterschied des mittelalterlichen auf Differenzierung und Abstufung gerichteten Individualismus gegen den protestantischen auf gleiche Autonomie und Verpflichtung aller gerichteten gesehen haben ${ }^{473}$.

Insofern möchte es scheinen als besitze der Spiritualismus überhaupt keinen positiven soziologischen Charakter, oder als gewinne er die Gemeinschaft immer nur erst durch Inkonsequenz oder Unklarheit. Allein das wäre nicht richtig. Einmal setzt, wie schon bemerkt, der Spiritualismus die Einheit des alle Frömmigkeit hervorbringenden Lebensgrundes und die Einheit des alle verbindenden Zieles voraus. $\mathrm{Er}$ bewirkt bloß die Gemeinschaft und Einheit nicht selbst durch eigenes menschliches Tun, Stiften und Vereinbaren, sondern läßt sie mit dem Geist aus Gott entstehen. Weiter ist es doch christlicher Spiritualismus. Das bedeutet nicht bloß, daß der Geist voll verkörpert und anschaulich ist in Christus und damit die Gläubigen doch zu einer historisch' bestimmten Einheit sammelt, sondern auch daß der ethische Willenscharakter des christlich-prophetischen Gottesgedankens auch ihm die Richtung auf handelnde Liebe und Selbstmitteilung an die Brüder aufdrängt. Von hier aus ergibt sich die ihm spezifisch eigene Gemeinschaftsidee: die Idee der unsichtbaren Kirche, der rein geistigen, nur Gottes Auge erkennbaren Gemeinschaft, für die der Mensch nicht zu sorgen braucht, sondern die unsichtbar ohne äußere Zeichen und Mittel alle überwaltet. Der Gedanke der reinen Geistesgemeinschaft, der sich von selbst durchsetzenden Macht des Geistes, ist der Hintergrund dieses Empfindens, und darum ist der einzelne hier vom Organisieren und Missionieren, von allem Kirchen- und allem Sektentum entlastet. Der geschichtliche Zusammenhang b aucht nicht mühsam behauptet und begründet $z u$ werden. Er stellt sich überall von selber her, wo der Geist den Geist erkennt.

478 a) Vgl. oben S. 624 Anm.

Troeltsch, Gesammelte Schriften. I. 
IS6) III. Mutelantismus. 4. Sektentypus und Mystik auf protestantischem Boden.

1)a alles Christentum im Grunde mit der Regung des Gottessamens in der Seele identisch ist, ist auch Christus allgegenwärtis, ist er nicht bloß in seiner geschichtlichen Erscheinung, sondern in jedem wahrhaft Frommen anschaulich. Auch nichtchristliche liromme können so Offenbarungen des Christus sein. Das bedeutet abcr wiederum, daß alle Religiosität überhaupt, in christlicher Beleuchtung gesehen, als mit dem Christentum identisch betrachtet wird. Praktisch zu betätigen ist daher diese Gemeinschaft vor allem in Toleranz und Vertrauen auf Gottes sich von innen her durchsetzende Geistesmacht. So sucht man sich überall in den Tiefen der Seele zu berühren, wo diese überhaupt zugringlich sind, und betätigt man die christliche Liebe nicht in absichtlichen Ordnungen und Stiftungen, sondern in jedem Irall, wo dic I.icbespflicht praktisch an uns herantritt. Es steckt also doch (in Jilement des Gemeinschaftlichen in diesem christlichen Spiritualismus, grerade ein Luthers anfänglichem Denken verwandtes, demsci.:nüber Luther nur dic feste Bindung des Geistes an Wort, Sakrament und Amt verlangte, während umgekehrt der Spiritualismus dic freic und ungebundene Bewcgung, die wachsende Erkenntnis und dic zunchmende lireiheit gegenüber dem Buchstaben, verkündigte. Mber das soziologische Element der Mystik geht noch weiter. Auch der Mystiker ist ein Mensch und unterliegt dem \%wans der Selbstmitteilung und dem Bedürfnis der Aufnahme tremelen lebens in das eigenc. Auch ist ihm das nicht bloß menchliche Schwäche, sondern ein christliches Gebot, durch das 1 orbild der reinen I.iebe der Urkirche anschaulich als ein Gebot des cieistes. Aber solche Gemeinschaft will sich nicht sckticrerisch an dic Stelle der großen unsichtbaren Kirche setzen und sreift nicht cin in Gottes Werk der Ausbreitung des Geistes, sondern sie ist die rcin persönliche Gemeinschaft der Mitteilung und Erbatum der Seclen im vertrauten Kreise. Sie äußert sich als dic scheime V'crbindung der Gottesfreude, als Philadelphentum, als Grupwenbildung um Seelenleiter und überlegene Virtuosen, fliefsend und frei sich bildend. Oder es sind familienhafte ()rganicationen frommen Zusammenlebens, die an das Kloster erinnern und in ihrem Notis auch mit den mystischen Motiven des Nünchtums übcreinstimmen. Das soll dann aber nicht die wahre Kirche und (jemcinde sein. sondern ist etwas lediglich Persönliches und Zufilliges, cine Gruppenbildung innerhalb der unsichtbaren Lirche, die der (jeist zusammenführt und durch die er in unkontrol- 
lierbarer Weise auf das Ganze wirkt ${ }^{44}$ ). In solchem engeren Kreise kann dann auch der Kultus erst rein und wahrhaftig geübt werden als eine Gemeinschaft der Herzen, die wahrhaft in der Liebe brennen und sich innerlich kennen und verbinden. Hier ist er nicht mehr ein magisches Gnadenmittel und nicht mehr eine gesetzliche Zeremonie, sondern die gegenseitige Erschließung und Mitteilung der Herzen, darstellendes Handeln, wie Schleiermacher - sehr unkirchlich - den Kultus bezeichnet. Hier kann das Herrenmahl oder das Liebesmahl erneuert und spiritualisiert werden zu seinem wirklich mystischen Sinn, der in der Massenkirche und in der zänkischen Zuchtpraxis der Sekten nicht möglich ist. Der Spiritualismus ist überkirchlich, »synkretistisch * oder »indifferentistisch * oder »schwärmerisch $«$, wie die damalige Polemik $\mathrm{zu}$ sagen pflegte. In Wahrheit nimmt er die zum Dogma erstarrte Geschichte in die lebendige Bewegung und Entwickelung des Gei-

474) S. den bei Göbel II 68I mitgeteilten Satz von Ernst Ludwig Gruber: >Die wahren Separatisten fangen keine neue Sekte an, als welches wieder aufbauen hieße, was zuvor abgebrochen, sondern sie gehen in das inwendige Heiligtum, in ihr Herz, und suchen Gott daselbşt in Christo. Jesu durch seine Gnade im Geist und in der Wahrheit zu dienen, auf dessen selige Offenbarung und Erscheinung in und außer ihnen sie dann mit freudiger und glaubensvoller Hoffnung warten und im übrigen einen stillen und exemplarischen Wandel führen, auch ihren Mitgliedern und Nebenmenschen nach Vermögen und Gelege nheit im Geist- und Leiblichen alle schuldige Liebe erweisen. Von ihrem äußerlichen Gottesdienst ist nicht viel zu sagen, weil sie keinen geformten und nach gewissen Regeln, Arten und Zeiten abgemessenen haben, sondern solchen $\mathrm{nach}$ der täglichen, stündlichen und augenblicklichen Anregung Gottes und der ihnen vorkommenden Gelege $n$ heit nit Beten, Singen, Lesen und Behandlung göttlichen Wortes zur Erbauung ihrer und anderer einrichten.\& Dazu s. weiter die Schilderung der mystischen Separatisten in Bd. II und Bd. III ; dort die soziologische Charakteristik des sphiladelphischen Periodus III 7 I -86 , auch die əphiladelphische Einlaclung * III 99. Doch zeigt Göbel nur die Gemeindebildungen des reformierten und lutherischen mystischen Separatismus in Westdeutschland. Die Charakteristik reicht an sich viel weiter. Schon bei Preger findet sich allerhand Material ganz ähnlicher Art für die m.a.liche Mystik, weiteres in Heglers "Schrift und Geista. Göbel u. Ritschl schildern nur die verhältnismäßig kleinlichen pietistischen Konventikel, die die Aktivität einer von allen großen politischen Dingen ausgeschlossenen Bevölkerung in bald rührenden, bald dumpfen und überspannten Grüppchen auf die religiöse Grübelei ablenken. Die großen Gedanken solcher Mystik bei Seb. Franck, Castellio und Coornheert bleiben bei ihnen außer Betracht. Nur die letzteren aber können mit der kirchlichen Denkweise an Größße und prinzipieller Schärfe sich messen. 
stes zurück, sucht er in den psychologischen Vorgängen selbst die wesentliche ()ffenbarung und die gegenwärtige Erlösung. Wie alle Mystik erst an dem Gegensatz des objektivierten Dogmas und Kultes entsteht, so setzt er sehr aristokratisch die Fortdauer des buchstäblichen Gottesdienstes als Massenreligion voraus. Aber seine stille Propaganda sammelt daraus die echten Gotteskinder, um sie zu erheben in das Gottesreich, das rein inwendig ist in uns. Von allen Seiten her sieht er die Seelen in dieses Reich hineinwachsen. Die engeren Gemeinschaften sind ihm lediglich persönliche und wechselnde, die allgemeine Einheit des Geistes in einem besonderen Kreise mit gesteigerter Lebendigkeit auswirkende Gruppen. Daher bleiben die Spiritualisten auch vielfach in den Kirchen, die sie ja nicht durch etwas Neues ersetzen wollen, und halten sie ihre Gruppen für innerhalb der Kirche mögliche Sondergruppierungen. Manche freilich verwerfen die Kirche völlig und leben als einsame Menschen. Aber dann trösten sie sich doch einer besseren Zukunft, einer dritten Offenbarung, wo alle von Gott gelehrt sein werden und ein sunsektisches Christentum der Liebe alle verbinden wird. Zur freiwilligen Separation haben sie nicht entfernt den Trieb wie die Sekten.

Natürlich wirkt diese ganze Denkweise auch auf die dogmatische Vorstellungswelt zurück. Wie das kirchliche Hauptdogma von Christus, der Trinität, dem Erlösungswerke des Sühnetodes und den diese Heilswirkung zueignenden Sakramenten eng mit dem Kirchenbegriff und dem kirchlichen Kultus verbunden ist, so wendet sich der Spiritualismus gegen die kirchliche Erlösungslehre und die Sakramentslehre. Er kennt kein fertiges Heil als Ausstattung der Anstalt, sondern in erster Linie die Offenbarung und Erlösung in dem jedesmal gegenwärtigen religiösen Erlebnis; so bedarf er des Versöhnungsdogmas nicht und findet er in ihm nur die logischen, ethischen und metaphysischen Widersprüche, die es auflösen. Er kennt keine Zueignung des Heilseffektes durch Kult, Sakrament und Kirchenstiftung; so bestreitet er die ganze Lehre von einer objektiven Heilsbeschaffung und -vermittelung und lehrt er nur das Vorbild Christi als die Quelle der von ihm fortwirkenden Geisteskräfte. Er kennt überhaupt Christus nicht in erster Linie nach dem Fleisch und hat kein Interesse an dem Gottmenschheitsdogma, sondern er findet die Gottheit Christi lediglich in dem Geiste Christi, der in dem historischen Jesus nur sein konkretes Symbol besitzt. Er vergottet daher Christus gänzlich bis 
in sein Fleisch oder er lockert die Beziehung des göttlichen und menschlichen Elementes in Christo. Von da aus ergeben sich dann auch gelegentliche Angriffé auf die Trinitätslehre, deren Rückbildung in einen neuplatonischen Emanatismus für ihn nahe genug liegt $\left.{ }^{475}\right)$. Er drängt nicht auf ein Massenchristentum, für das naturgemäß die Sündenvergebung als Freilassung der unüberwindlichen Stufenunterschiede der Heiligung, ohne doch den Heilstrost preiszugeben, im Vordergrunde steht; bei ihm tritt hinter der unmittelbaren Gottesgewißheit und der tatsächlichen Ueberwindung der Sünde in der Vergöttlichung der Seele die Sündenvergebung überhaupt zurück ${ }^{426}$ ).

Nach all diesen Seiten hin steht er aber im Gegensatz auch zur Sekte, die den Gottmenschen als Autorität und Gemeindestifter voraussetzt und des Heilswerks als Ergänzung der Anstrengungen eines doch immer unvollkommenen Heiligungslebens bedarf. Mit ihrem historischen, buchstäblichen Christus und mit ihrer Festhaltung der synoptischen Reich-Gottes-Predigt vermag er nichts anzu-

415) Das hat Veranlassung gegeben, verschiedene Spiritualisten den Antitrinitariern zuzuzählen, einer Gruppe, die in der üblichen Dogmengeschichte immer noch aufgeführt wird, deren Glieder aber ganz verschiedenen Zusammenhängen angehören und in ihr nur unter äußerlich häreseologischen Gesichtspunkten zusammengefaßt werden.

${ }^{476)}$ Sehr lehrreich ist hier der schroffste und scharfsinnigste Bestreiter der $\mathrm{My}$ stik, Ritschl. Wie er sein kirchlich-anstaltliches Interesse in engem Zusammenhang mit dem Volkschristentum entwickelt, so muß er auch die Sündenvergebung als Attribut der Gemeinde oder Kirche lehren, an dem der Einzelne als Glied der Kirche durch die Taufe teil hat. Dementsprechend bekämpft er auch an der Mystik nichts so als ihre Vernachlässigung der beiden Korrelate: objektive Sündenvergebungsgewißheit und Gemeinde als Anstaltskirche. Niemand hat diese Zusammenhänge so scharf erkannt wie er. Darum hat er auch von dieser Erkenntnis aus seine eigene kirchliche Dogmatik auf die Korrelation von Christus-SündenvergebungsgewißheitGemeinde begründet. Interessant ist nun aber seine Lehre besonders, weil er die Begründung der Sündenvergebung auf den Sühnetod bestreitet. Er muß sie daher als Ausstattung der Gemeinde mit einer auf der supranaturalen Autorität Christi ruhenden Gewißheit über Gottes Bereitschaft, Sünde zu vergeben, konstruieren und kommt damit in die Nähe der Sozinianer, bei denen er aber wieder die Korrelation auf die Gemeinde vermißt. So ist höchst interessant, seine ausführliche Auseinandersetzung mit dem Spiritualisten Dippel und mit Zinzendorf (Gesch. d. Pietism. III 429-435), von denen der erste den Sühnetod bestreitet, der andere ihn behauptet und die beide den Kirchengedanken zerstören oder doch auflockern. Durch Betonung der Gemeinde und der objektiven Sündenvergebungsgewißheit in $\mathrm{ihr}$, die nicht des Sühnetodes, sondern nur der Bürgschaft Christi bedürfe, entscheidet er den Streit zwischen beiden in einem $\gg$ höheren Drittens. 
fangen. Nur wo die Sekte in den Spiritualismus hinübergleitet, findet sich auch bei ihr jene dogmatische Kritik, wie bei einigen täuferischen Theologen und den ()uäkern. Umgekehrt nähert sich der Spiritualismus an einigen andern l'unkten dogmatisch der Sekte, aber aus charakteristisch verschiedenen Gründen. 1)as silt vor allem von der Verwerfung des Prädestinationsdogmas. Es schien in seiner Verkoppelung mit der Erbsünden- und Verwerfungslehre sowohl den moralischen Ernst zu :refährden als auch die Grundlage der Mystik, den überall gegenwärtigen und irgendwie wirksamen inneren Gottessamen, aufzuheben. Ebenso näherte er sich der Sekte in der Zusammenziehung des Glaubens auf eine schlichte, erlebbarc und fühlbare Einheit des Gedankens, wic das ursprünglich auch schon Luther gewollt hatte und wie es jedes Bedürfnis nach Innerlichkeit und Unmittelbarkeit wiederholt. Gegen die kirchlich-orthodoxe Entfaltungr dies's praktisch-cinfachen Kerns zur Dogmatik kämpfte daher nicht bloß das moralistische Täufertum, sondern ebensosehr der mystische Spiritualismus ${ }^{4 i}$ ).

Durch diese Kritik arn Dogma und durch die Berufung auf einen immer sleichen ruhenclen göttlichen Lebensgrund in der Seelc, der durch das Zusammentreffen mit der Bibel und der Christusverkündigung nur aktualisiert wird, gewinnt der Spiritualismus nun aber eine andere, im Grunde näher stehende Verwandtschaft, die Verwandtschaft mit dem Rationalismus. Allein es bedarf nur eines Blickes auf die humanistische Theologie, den Sozinianismus und den I)eismus, um den bei alledem bestehenden wichtigen Lnterschied zu bemerken. Vom Humanismus hat manches Motiv herübersewirkt, wie bei Seb. Irank, Castellio und Coornheert deutlich crkennbar ist. Allein es bleibt ein grundsätżlicher Unterschicd. Der mystische Enthusiasmus mit seinen beständigen Erleuchtungen und Handlungen Gottes in der Scele, die spiritualistische Lebersinnlichkeit mit ihrer Askese, ihrer Verwerfung des Buchstabens und des äußerlich sinnlichen Verstandes ist dem ra${ }_{477)}$ Ueber diese Vereinfachung s. Otto, Anschauung Luthers vom hl. Geiste; auch Kant-Friesische Religionsphilosophie S. 18-23; nur ist es irrig, die entsprechenden Vereinfachungsbestrebungen der Aufklärungstheologie an Luther anzuschließen; es ist der Pietismus und Spiritualismus, dem diese hier folgt. Die Entfaltung des > verbum consummatum ac breve Luthers aus dem objektiven Heilsmittel des Wortes zur Dogmatik ist die unumgängliche Folge kirchlicher Theologie, die eine absolute äussere Autorität hat und haben muß im orthodoxen Sinne des Kirchenbegriffes und dann natülich auch diese Autorität bis in Peripherische entfalten muß, um keine Unklarheiten übrig zu lassen, in denen sich die Schwärmerei festsetzen könnte. 
tional-wissenschaftlichen Geiste im Grunde doch entegegenesect:t. Dieser ist eher in der rationellen Apologetik und Scholastik der Kirchen zu Hause, und echte Rationalisten wie die Sozinianer hielten sich lieber an die Kirchen, da die reine kritisch-theologische Wissonschaft ein eigenes Gemeinschaftsprinzip nicht besitzt. Wo sie zur Separation gedrängt wurden, da schufen sic dann freilich eigene Gemeinschaften, die aber mehr Aehnlichkeit mit der Schule als mit einem religiösen Gesinnungs- und Liebesverbande hatten. Trotzdem hat nun aber doch der Spiritualismus mancherlei Berührungen mit dem allgemein begrifflichen Geiste des Rationalismus und geht er beim Verlöschen seiner mystischen Glut leicht in ihn über, wie das bei Spinoza, Edelmann und einem Teil der l) cisten der Fall war. Die unmittelbar aus der Gegenwart Gottes schripfende Mystik ist ein überall und immer gleich sich wiederholender Vorgang und berührt sich so mit der Autonomie und Allgemeingültigkeit des wissenschaftlichen Denkens. Beide assimilieren sich aneinander. Ferner wird in dem Maße als die Mystik nach neuplatonischem Muster ihr Erlebnis auf allgemeine kosmusche Grundlagen zurückführt und es als Aktualisierung des in jeder Vernunft enthaltenen Gottesfunkens betrachtet, die mystische Religion überhaupt zu einem im Denken und Erkennen Gottes sich vollziehenden Vorgang, zur Erlösung des Geistes durch Erkenntnis. Sie führt damit zu einem Universalismus, der in allen konkreten positiven Religionen jenen grundlegenden, aus dem wesentlichen Verhältnis von Gott und Endlichkeit entspringenden Vorgang erkennt. Sie nivelliert bei aller Verehrung der Bibel doch den Unterschied der Religionen und erkennt den Christus in uns auch in den nichtchristlichen Religionen an. Sie setzt dem auf historische Objekte gerichteten, Tat und Vertrauen verlangenden Glauben die universal und allgemein in ihrer inneren Notwendigkeit verstandene religiöse Erkenntnis entgegen. Damit aber geht sie aus der positiven Theologie in die universale Religionsphilosophie über. Mit der Aufhebung oder Abschwächung der Kluft zwischen christlicher und außerchristlicher Welt ist dann weiterhin die religionsgeschichtliche Vergleichung und Kritik nahegelegt, mit der schon Erasmus vorangegangen war. Sie wendet sich zunächst auf diejenigen Elemente der dogmatisch-kultischen Ueberlieferung, die dem Mystiker am meisten im Wege stehen, gegen die der mystischen Unmittelbarkeit feindselige Isolierung und Festlegung der christlichen Heilstatsachen. Gerne wird das Geschichtlich-Zeitliche und 


\section{III. Protestantismus. 4. Sektentypus und Mystik auf protestantischem Boden.}

das Sinnlich-Magische einer mehr oder minder durchgreifenden Kritik ausgeliefert und wird statt dessen das darin liegende Zeitlos-Allgenieine herausgezogen. So entwickelte sich die volle Konsequenz des Spiritualismus erst bei jenen Mystikern, die, wie Franck, Coornheert und Castellio, auch die humanistische Bildung und Kritik mit übernommen hatten. Damit verbindet sich schlicßlich eine Toleranz, die weit über die täuferische Toleranzforderung hinausgeht, die nicht bloß den Verzicht auf Gewalt und Konformität bei Vorbehaltung der eigenen Alleinwahrheit bedeutet, sondern die wirklich jeden bei seinem Glauben beläßt und relativistisch empfindet, weil in allem Relativen das Absolute gegenwärtig ist. Es ist jene Relativierung des Wahrheitsbegriffes, die weder den Kirchen noch den Sekten geläufig ist und die erst völlig die auf Alleinherrschaft drängenden Triebe eines absoluten Wahrheitsbegriffes entwurzelt. Wenn Luthers stark spiritualistische Ansätze zur Toleranz verloren gingen, so kam das davon her, daß er den absolutistischen Wahrheits- und Offenbarungsbegriff nicht aufgeben wollte, sondern mit instinktiver Selbstverständlichkeit beibehielt. In ihm nußten jene Ansätze unvermeidlich untergehen. Dagegen setzte die spiritualistische Toleranz sich durch, weil sie überall Wahrheit und Offenbarung in relativer Annäherung an die eine, letztlich immer crst in der Gegenwart erlebbare, Wahrheit erkannten. Erst bei ihnen gab es Gewissensfreiheit innerhalb der religiösen Gemeinschaft, während Sekte und Freikirche eine solche nur vom Standpunkte des Staates und neben den kirchlichen Organisationen kennen. Aber auch in dieser Hinsicht ist sie vom strengen Rationalismus verschieden, der vielmehr bei der Absolutheit seines Wahrheitsanspruches zur Intoleranz neigt wie die Kirchen und nur aus Geringschätzung und Opportunität zur Duldung bereit ist. Wirkliche Toleranz kannte und kennt nur derjenige Rationalismus, der sich mit mystisch-spiritualistischen Gedanken zugleich durchdrungen hat ${ }^{4 i s}$.

478) Vgl. meine = Trennung von Staat und Kirche« S. 2 If. Die Herleitung des uniformen Kirchentums und der Intoleranz, sowie der gegenteiligen Stellungen von der Art des Wahrheitsbegriffes scheint mir eine sehr wichtige Erkenntnis. Doch habe ich damals den Unterschied von Täufertum und Spiritualismus noch nicht genügend erkannt, wenn ich dort die gegenteiligen Stellungen einfach auf das Täufertum zurückführte. Wie die Kirche mit einem bestimmten Wahrheitsbegriff, so hängt auch die Sekte und der Spiritualismus mit einem solchen zusammen. Die Sekte verzichtet auf Gewalt und Konformität, aber nicht auf die Absolutheit des Wahrheitsbegriffes; 
Aber das sind doch nur die letzten Konsequenzen. So weit sind unter den Spiritualisten des alten Protestantismus nur wenige gegangen. Sie wollten im Grunde nur die christliche Lebenswelt verlebendigen, tätig und wirksam machen und gingen daher meist über eine bloße bernhardinische Christusmystik gar nicht hinaus. Schwenkfeld ist der Führer oder doch der Typus der meisten. Auch wurde das die Kluft zwischen Christentum und Nichtchristentum befestigende Erbsündendogma zwar in den Hintergrund gedrängt durch den Gedanken des Fleisches und der im Aeußern sich verfestigenden Selbstsucht; aber der grundlegende Dualismus wurde doch selten gänzlich aufgelöst. Das alles sind erst moderne Folgerungen aus diesen Gedanken, die in ihnen steckten, aber fast nie $z u$ voller Folgerichtigkeit entwickelt wurden. Seiner spezifischen Christlichkeit ist der alte Spiritualismus immer noch, auch bei den Radikalsten, gewiß, und er beruft sich mit Vorliebe auf die verwandten spiritualistischen Aeußerungen in Luthers Frühzeit, wo auch Luther alles vom Geist erwartet hatte, der im Worte enthalten ist. Alles ist auf das Vertrauen zum Geiste gestellt, der, wo immer er auch ist, der Geist Christi ist und die Christlichkeit der Menschheit bewirken wird. Die konfessionellen Härten sind erweicht oder gar aufgelöst; aber das Christentum selbst ist in diesen Relativismus noch nicht hineingezogen; diese Folgen einer relativen Betrachtung schlummern noch. Die äußere Kirche ist aufgelöst; aber die innere Kirche und der durch sie gegebene Zusammenhalt besteht fort. Das Interesse ist kein intellektualistisches, sondern ein gefühlsmäßiges. Nicht die Kritik am Dogma und an der heiligen Geschichte erzeugt die religiöse Stellung, sondern umgekehrt. Der Ausgangspunkt aller Kritik ist das Unmittelbarkeitsbedürfnis, der ethische Ernst und die soziologische Stellungnahme des Mystikers oder Spiritualisten. Die Dogmen, soweit sie hiermit im Widerspruch sind oder von hier aus gefühlsmäßig überflüssig werden, verfallen freilich der Kritik, wozu dann humanistische und sonstige Kritik herangezogen wird. Das Interesse selbst aber ist ein religiöses, und der ganze Relativismus wird als ein innerhalb der christlichen Position möglicher empfunden. Um diesen religiösen und christlichen Grundzug zu brechen, bedarf es erst der Einwirkung der modernen Naturwissender Spiritualismus relativiert ihn erst $z u$ verschiedenen Ausdrucksformen elher nur geistig-innerlich faßbaren und darum überhaupt nie abschließend und adäquat formulierbaren Wahrheit. 
874 III. Protestantismus. 4. Sektentypus und Mystik auf protestantischem Boden.

schaft und der auf sie aufgebauten neuen philosophischen Systeme. Erst seitdem verschmelzt sich der Spiritualismus mit einem wirklich rationalen , universalen Theismus ${ }^{479}$ ).

179) Die Verwandtschaft des Spiritualismus und des moralistischen Sektentums mit der Aufklärung, die für Orthodoxe wie R. Grützmacher eine Selbstverständlichkeit ist, ist auch ein Hauptgedanke Ritschls, der geradezu die Aufklärung von diesen Zersetzungen des gesunden Kirchentums herleitet. So bildet er die erstaunliche Gleichung von Katholizismus, Mönchtum, Sekte, Mystik und Aufklärung, in der jedes Glied zugleich die Ungesundheit des anderen dartut und der gegenüber dann nur Ritschls rationalistisch ermäßigtes, aher doch wesentlich positiv-supranaturales und auf eine moderne Volksethik zugeschnittenes lutherisches Kirchentum übrig bleibt. So hat, damals noch Ritschl folgend, W. Bender in Dippel, Der Freigeist aus dem Pietismus 1882, die Selbstverwandelung der Mystik in Aufklärung geschildert. Allein diese Behauptungen sind offensichtlich bei Ritschl nichts als Apologetik für sein kirchliches Luthertum, und Benders Behauptung ist positiv falsch. Der Umschlag in Rationalismus, der ebenso bei der Orthodoxie wie bei Pietismus und Mystik eintrat, muß, wie schon dieser Eintritt unter ganz verschiedenen Voraussetzungen zeigt, seinen Grund in etwas haben, was gleichmäßig jenseits aller liegt. Bei der Orthodoxie vollzieht isich der L'ebergang vermöge ihres intellektualistisch-scholastischen Elementes, beim Heiligungspietismus vermöge seines moralistischen und in weltlichwissenschaftlichen Dingen rein utilitaristisch-empiristischen Elementes, bei der Mystik vermöge ihres Gedankens von einem in der Vernunft oder der Seele als solcher enthaltenen zeitlosen religiösen Element. In allen Fällen aber stammt die Aufklärung nicht aus den religiösen Interessen, sondern aus der politisch-sozialen Umwälzung und der Emanzipation der Interessen von den religiösen Leitgedanken der Vergangenheit, die begleitet ist von einer völlig neu, d. h. kausal-naturwissenschaftlich orientierten Philosophie und von einer damit zusammenhängenden Entwickelung neuer technischer Möglichkeiten. Die Aufklärung war die stärkere Bewegung und suchte bei allen Gruppen das jeweils ihr homogene Element; es ist naturgemäß jedesmal ein anderes. Der Umschlag in Aufklärung trat eben deshalb auch nirgends von selbst ein. In England ist der Umschlag durch die whiggistische Revolution erkämpft und durch die Cromwellsche vorbereitet worden. Von den Ergebnissen dieses Kampfes und Sieges her ist erst die Aufklärung auf dem Kontinent durchgedrungen, und sie ist auch in den anderen Ländern nirgends völlig ohne Kampf durchgedrungen. Der Kampf wurde vor allem durch das absolutistische Fürstentum durchgeführt. Daß danı die neue Bewegung überall aus der alten an sich zog, was ihr homogen war, ist ja klar. In diesem Sinne leben viele christliche Ideen -- verändert - auch in der Aufklärung fort, vor allem die hier von mir in ihrer Entwickelung verfolgte Idee des Naturgesetzes und Naturrechtes s. meinen Aufsatz Das stoisch-christliche Naturrecht und das moderne profane Naturrecht, H.Z. 191 I Bd. 106. Auch der ganze Individualismus der Aufklarung hängt mit dem entkirchlichten christlichen Subjektivismus zusammen, wie das Plenge a. a. O. mehrfach treffend ausführt. Ihr letzter Grund aber, die soziale Umwälzung und das entscheidende Emporkommen des Bürgertums 
Eigentümlich ist auch die Ethik des Spiritualismus. Auch sie ist Heiligungs- und Vollkommenheitsethik und wirft den Kirchen nichts so lebhaft vor als ihre ethische Laxheit und ihr "Zechen auf fremde Kreide" d. h. ihre Beruhigung bei der stellvertretenden Tilgung des Sündenfluches im Tode Christi. Gerade hier scheint der Spiritualismus mit der Sekte sich besonders nahe zu berühren und ist er mit ihr oft genug zusammengeflossen. Auch mit der katholischen Ethik berührt er sich, der er daher oft höheres Lob spendet als der protestantischen. Aber diese Heiligungsethik ist hier doch anders verstanden als in der Sekte. Nicht Kontrolle, Gemeindezucht und Strenge des Bergpredigt-Gesetzes

hängt gleichfalls mit der vorangegangenen protestantischen Entwickelung zusammen, aber nur mit deren ungewollter ethisch-sozialen Wirkung, das geschäftliche Bürgertum zu steigern; hierüber s. Max Weber. - Der Zusammenhang des Deismus mit den radikalen Parteien und Spiritualisten der englischen Revolution ist noch nicht aufgeklärt. Bei Lockes Toleranzprinzip ist er klar. Aber Lockes Theologie und ebenso die Tolands weisen auf arminianische und sozinianische Einflüsse hin. Bei den durchschnittlichen Deisten ist die Opposition der Dissenter gegen alles Katholisierende erkennbar, aber kein Umschlag spiritualistischer oder pietistischer Ideen in Rationalismus. In Deutschland sind Edelmann und Lorenz Schmidt, von Spinoza bestimmt, keine Entwickelungsstufe des christl. Spiritualismus. - Auch Dilthey scheint mir das Rationale in dem suniversalen Theismus eines Franck und Coornheert $z \mathbf{u}$ überschätzen. - Der Unterschied des Spiritualismus gegen die rationalistische Theologie der Sozinianer, Arninianer, Deisten ist auch von der soziologischen Seite her nicht uninteressant. Jene liebte es in dem Gefühl, mit der wissenschaftlichen Argumentation auf psychologisch viel schwächere Triebkräfte angewiesen zu sein und nur eine intellektuelle Schicht erreichen zu können, in den Kirchen zu bleiben und sie lediglich zu liberalisieren oder in ihnen wenigstens Duldung zu finden. Ihre eigene kirchenbildende Kraft ist $z u$ gering. Wo sie zur Separation genötigt sind, da haben sie einen Propaganda- und Belehrungstrieb, einen wissenschaftlichen Wahrheitstrieb, der der Mystik und dem Spiritualismus ganz ferne liegt. Es wäre eine anziehende Aufgabe, die rationalistischen Gemeindebildungen bis herab auf die heutigen freireligiösen Gemeindebildungen von der soziologischen Seite her zu betrachten. Sie haben keine Aehnlichkeit mit den mystischen freien Kreisen, aber auch keine mit den Heiligkeitsgemeinden und ebensowenig mit der Kirche. Ritschls für alles Unkirchliche unglaublich scharfer Blick vergleicht sie mit der Schule, Rechtf. und Vers. ${ }^{2}$ I S. 320-323, und leitet aus diesem Charakter die Annäherungen an die Sekte, den intellektuellen Propagandatrieb, das Zurücktreten des Kultus, die Leichtigkeit der Spaltung über Lehrmeinungen, ab. Das verbindende Element ist nur die intellektuelle Zustimmung verbunden mit allen Bedürfnissen der Ausbreitung und Belehrung, aber auch allen Gefahren der Spaltung und dem Mangel der allumfassenden geistigen Substanzialität, welche den aus dem Gemeinbesitz sich fortzeugenden Kirchen zukommt. 
ist ihr Ideal, sondern die gesetzlose lireiheit des Geistes. Gerade hier berührt sie sich mit Luther und hat sie auf seine frühen Aeußerungen gerne sich bezogen. Die Freiheit des Geistes ist auch im Sittlichen alles. Auch hier gibt es keinen Buchstaben und nichts Aeußerliches. So fehlt ihr zwar nicht der tiefe Weltgegensatz, die Ablehnung der fleischlichen und selbstsüchtigen Weltgesinnung; in diesem Sinne befolgt sie das asketische Ideal viel stärker als die Kirchen. Aber ihr fehlt das andere Element der Askese, die methodisch-gesetzliche Einübung und Lebensgestaltung auf das jenseitige Ziel hin. Sie kennt einen Methodismus der Stufen der Gottesgemeinschaft und der Selbstbearbeitung für das Ziel der Vergöttlichung. Aber sie kennt keinen Methodismus der für ein jenseitiges Lebensziel sich bereitenden und den Gnadenstand stufenweise bewährenden sittlichen Heiligung. Sie steht dem nüchternen und gesetzlichen Geist des Calvinismus und Puritanismus so ferne wie dem der Baptisten und Mennoniten. Wo sie im Puritanismus Fuß faßte, da hat sie sich auf Luther und auf die katholische Literatur berufen, wie bei Dell und bei Francis Rous. Immerhin unterscheidet sich in diesem Punkt calvinistische und lutherische Mystik. Tersteegen fand den Grafen Zinzendorf leichtsinnig; der letztere vertrat folgerichtiger die Ethik des Spiritualismus und der Mystik. Ihr Ziel ist ein immanentes, eine freie Seligkeit, die alles Gute aus eigenem Triebe bewirkt und an die Konventionen der Menschen so wenig gebunden ist wie an ein Sittengesetz der Bibel. Auch der Gedanke des natürlichen Sittengesetzes hat daher hier keine große Bedeutung. Lieber spricht man vom inneren Licht, von der erleuchteten Vernunft, vom Gewissen als identisch mit der Christusoffenbarung und durch sie zum vollen Leben erweckt. Diese Ethik der Freiheit zielt in erster Linie auf Genuß und Betätigung des persönlichen Seelenheils ab. Die Ausgießung der Gottesliebe auf die Brüder ist erst ein Anhang, wenn auch ein stark und nachdrücklich betonter Anhang. Es ist die Stellung der Religion über der Ethik. Daß dabei die Fragen der weltlichen Moral, Staat, Gesellschaft, Wirtschaft eine ganz geringe Bedeutung haben und wesentlich der Gleichgültigkeit verfallen ist eine ganz natürliche Folge. Wo man in engerem Kreise diese Probleme zu lösen unternahm, gab man ihm die Form des Familienhaushaltes oder klosterähnlicher Vergesellschaftung, oder man nahm Elemente des Sektentypus in sich auf, mit dem man gerade bei jedem Versuch ethischer Praxis 
zusammenrückte, wie denn überhaupt die Vermischungen nahe genug lag. In der Wirklichkeit geht beides fortwährend durcheinander. Die Sekte strebt hinüber nach der Verinnerlichung der Mystik, die Mystik nach der heiligen Gemeinschaft der Sekte. Der Enthusiasmus, die Folge starker Erregungen und großer Kampfzeiten und der gegen beide gerichtete Druck der Kirchen tut das Seinige dazu, beide Gruppen sich zu nähern. Aber es zeigen sich dann doch auch stets die Gegensätze und Spannungen, die aus solcher Mischung hervorgehen ${ }^{480}$ ).

180) Vieles gibt auch hier Ritschls Geschichte des Pietismus. Im übrigen läßt sich an diesem Punkte gar nicht generalisieren. Das ist gerade der Unterschied der spiritualistischen Ethik von jeder kirchlichen und jeder sektenhaften. Wichtig ist vor allem zu erkennen, daß hier auch die Askese mehr einen metaphysischen und uni mittelbar religiösen, als einen disziplinären Sinn hat, eben deshalb auch leicht umschlagen kann in Libertinismus. Für diese Gruppen trifft daher das, was Weber als Askese geschildert hat, durchaus nicht $z u$, wenn sie nicht etwa, wie z. B. Tersteegen, dèr Zinzendorf leichtsinnig fand, durch reformierte Herkunft die Askese von vornherein reformiert verstanden. - Mitteilungen über die Ethik auch bei Hegler, Geist und Schrift S. 148-150, 166, I70-184. Die Soziallehren sind bei Franck wesentlich dieselben wie bei Luther, nur mit noch größerer Resignation. - Beziehungen auf das absolute Naturgesetz, das hier natürlich mit dem göttlichen Samen und Funken, der höheren im Menschen enthaltenen göttlichen Natur, gleichgesetzt wird, aber auch mit dem natürlichen sittlichen Bewußtsein zusammenfällt und mit den zehn Geboten identisch ist, bei Hegler 209, 243, I16; die ro Gebote im inwendigen Wort enthalten $92 \mathrm{f}$. Das "Naturgesetz der Liebe « bei dem Mystiker Sperber Ritschl I 304 ; ebenso Dippel I 337 ; das Gewissen und natürliche Sittengesetz = ewigem Wort und übernatürlichem Licht I 354, was Ritschl natürlich sofort als Aufklärung nimmt. Bei Barclay S. 225 erklären einige Aelteste den heiligen Geist vermittelt außer durch das Wort durch "his handywork in the whole creation, the law of nature written in the hearts of mankind, the light of conscience $\times$. - Höchst interessant ist Saltmarch, dessen Sparcles of glory 1647 in einer Jubiläumsausgabe von I 847 mir Herr Sippell mitgeteilt hat. Hier liegt eine an Hegel anmutende Lehre vor. Aus der Naturstufe oder dem Naturgesetz bricht, durch deren fühlbare Unfähigkeit zur Erreichung eines letzten Wertes hervorgetrieben, als höhere Stufe das Geistesgesetz hervor: "The christian is one, who should live in an higher region than flesh or nature; and when God sayth, come up hither he shall live there even in the Spirit with him; so as though grace destroys not nature, yet it perfects and glorifies nature, and leads it out into higher and more excellent attainements, than it can find in itself. Nature lives by this law: preserve thyself, thy life, thy lands, thy rights and privileges, avenge thyself, an eye for an eye and a tooth for a tooth and love only thy neighbour. Grace lives by this law : Deny thyself, forsake lands, life, houses, take up the cross, if he take thy cloak let him have thy coat also, love thy enemies, bless them that curse thee. \& Das erinnert an die katholische 
Diese allgemeine Charakteristik ist nun noch an den einzelnen Erscheinungen zu bewähren. Dabei kommt es hier so wenig, wie bei der Sekte, auf eine neue Darstellung des Sachverhaltes an, sondern auf eine Beleuchtung der soziologischen Bedeutung und sozialen Wirkung der einzelnen Gruppen, in der ihr Gegensatz gegen die kirchliche Gemeinschaftsidee und die kirchliche Sozialethik zu Tage tritt.

Der erste starke Gegensatz dieser Art zeigte sich bei Thomas Münzer. Er ging zunächst von Luther aus, aber auch von den durch Luther empfohlenen mystischen Schriften; er kannte auch die joachimitische Literatur. Als Prediger in Zwickau hat er sich überdies aus den dort bestehenden Konventikeln die Idee einer Wiederausgießung der pneumatischen Gnadengaben vor dem bald bevorstehenden Ende angeeignet. Die mystische Lehre von den Stufen der leidentlichen Vergottung, von dem selbständig innerlich sich kundgebenden und vom Wort nur angeregten und geprüften Gottesgeiste, verbunden mit dem Zwickauer Enthusiasmus, bildete seine Theologie. Damit vereinigte sich von Anfang an das Ideal der Aufrichtung einer geschlossenen Gemeinde der mystisch Erleuchteten und Erwählten, das sich dann bis zu kommunistischen Gesellschaftsreformen erweiterte. Das letztere muß ihm durch hussitische-taboritische Ideen nahe gelegt worden sein, wie er denn nach der Vertreibung aus Zwickau zu den Böhmen ging und dort auf die Verwirklichung seines Ideals - freilich vergeblich - rechnete. Von da aus ging er nun immer stärker zu dem Programm über, daß bei Versagung der Obrigkeit in diesen Endzeiten das Ideal der vollkommenen Geistgemeinde mit Gewalt durch die Laien verwirklicht werden dürfe und müsse. Auch die Konsequenz der Verwerfung der Kindertaufe zog er von hier aus, aber nur deshalb, weil überhaupt die äußeren sakramentalen Vornahmen lediglich Fleisch seien, Mit den Täufern selbst hatte Münzer nichts zu tun. Die eben aufgekommenen Züricher Täufer begrüßten ihn zwar, aber sie warnten ihn vor dem

Anwendung der Entwickelungsidee, ist aber anders gedacht. Diewtch im Konkurrenzkampf und der Selbsterhaltung schließlich selber aufhebende Natur wird zu einer Ethik der Liebe in Gott getrieben, disengaged from the love of power, dominion riches, earthly glory. Die neutest. Moral ist nur eine buchstäbliche Vorstufe und Vorschule dieser auf der dritten Stufe aus der Freiheit des Geistes zu betätigenden Liebesethik. Das sind Begriffe vom Naturgesetz und von der Gnade, die mir nirgends sonst begegnet sind und die eine tiefe Wahrheit in sich schließen. 
Gewaltgebrauch und tadelten seine geringe Betonung der Spättaufe. Münzer ist eine Verquickung von mystischen Ideen mit der hussitisch-taboritischen und enthusiastischen Revolution. Das aber ist eine zufällige und nicht innerlich zusammengehörende Verbindung, die bei dem unruhigen, nach besonderen und auffallenden Betätigungen begierigen Manne sich aus dessen Charakter und Schicksal erklärt. Schließlich haben ihn die Wogen des Bauernkrieges verschlungen. Mit Münzer hingen von seinem Zwickauer Aufenthalt her die sog. Zwickauer Schwärmer zusammen, denen aber keine andere Bedeutung zukommt als die, den pneumatischen Enthusiasmus und die damit eng zusammenhängende spiritualistische Kritik der Sakramente im Sinne einer aufgeregten, von mystischen Brocken lebenden Klein-Leute-Religion vertreten zu haben ${ }^{4 s 1}$ ).

Viel bedeutsamer und folgenreicher trat die Mystik bei $\mathrm{K}$ arlstadt hervor. Hier führte sie $z u$ einer leidenschaftlichen Entzweiung mit Luther, der den Gehilfen seiner Anfangszeit erst durch Landesverweisung und dann durch Internierung an einem überwachten Wohnsitz unschädlich machen ließ, bis sich dieser durch die Flucht in die Schweiz befreite. Auch Karlstadt konnte die Verwirklichung des Heils nicht in der bloßen Ergreifung der Sündenvergebungsgewißheit aus dem Wort und aus der kirchlichen Predigt durch den vom Gesetz erschütterten Menschen erkennen. Auch er wollte es in der Weise der Mystik als einen stufenartigen Prozeß verstehen, der von der Entwerdung bis zur Gottförmigkeit führt, und wollte als Mittel dieser Heiligung nicht die bloße Autorität des schriftwortes, sondern vielmehr die von der Schrift lediglich entzündete und an ihr kontrollierte freie innere Bewegung des Geistes anerkennen. Auch er wollte den rein innerlichen Vorgang an seinen praktischen Wirkungen, an der durch die Gottförmigkeit ermöglichten Selbstverleugnungs- und Liebesmoral, erkennbar wissen. Daraus ergab sich ihm mit der ganzen Mystik eine Höherstellung des Geistes über den Buchstaben, eine spiritualistische Kritik der Sakramente, eine Laienreligion von Geisterleuchteten die von besonders Geistbegabten unter Anerkennung dieser Geistträger durch die Gemeinde pastoriert

${ }^{+81)}$ Vgl. den Artikel über Münzer von Kolde PRE. ${ }^{3}$, Gottfr. Arnold II 14-I 7 mit dem charakteristischen Urteil:,$O b$ er wohl anfänglich zweifelsohne zuweilen mag Bevorzugungen von Gott gehabt haben, so hat doch die Natur die Vorhand behalten.e K. Müller, KG. II 310-326. 
wurden, die freie Bildung von Gemeinden durch eigene Wahl eines solchen Geistträgers zum Geistlichen, die starke Betonung der praktischen Wirkungen der Gottförmigkeit, durch die er mit den sozialen Reformbewegungen der Zeit sich berührte. Durch dieses letztere vollzog die Mystik auch hier eine scheinbare Annäherung an die Sekte. Aber in Wahrheit handelte es sich für Karlstadt nicht um die Moral der Bergpredigt, sondern um die Geistigkeit der Entwerdung; nicht um die Spättaufe als Siegel einer festen Gemeindezugehörigkeit, sondern um spiritualistische Verflüchtigung der Sakramente; nicht um die Bildung einer heiligen Gemeinde, sondern um die Sammlung der freien geistbewegten Individuen, für die alle Gemeinschaft nur etwas Aeußerliches ist. So hat er auch von Nünzer sich geschieden und ist er später den Täufern nicht beigetreten. Seiner geistlichen Aemter und Würden sich entledigend hat er in einer Zeit, da noch alle Welt kirchlich experimentierte, zu Orlamünde eine solche Gemeinschaft bilden wollen, was an sich Luthers Anfangsprinzipien nicht unbedingt entgegengestanden hätte. Allein Luther nahm Anstoß an Karlstadts Ersetzung der Rechtfertigungslehre durch die Lehre von den Heilsstufen, an der Verselbständigung des Geistes gegen das Wort, an der Verkoppelung der praktischen Bewährung mit den sozialen Reformforderungen und vor allem auch an der Verletzung des Patronatsrechtes. Sein leidenschaftlicher $\mathrm{Haß}$ sah in ihm nur mehr einen Genossen Münzers und unklaren Wirrkopf. So trieb er ihn ins Elend, aus dem ihn dann die über die Mystik milder denkenden Schweizer Kirchen erretteten. Der Gegensatz selbst aber war nicht ein persönlicher, sondern ein sachlicher: es stand gegen den alles Heil vermittelnden und an objektive Autorität bindenden, dadurch zur Kirchenbildung fähigen Gedanken Luthers die im Grund vermittelungslose und individualistische Mystik, die sich überdies zufällig mit demokratischen Reformströmungen der kleinen Kommunen berührte. Im übrigen aber hat dann doch wieder Karlstadt » Wort * und »Geist « ähnlich wie Luther in seinen Anfängen und wie $Z$ wingli zu verbinden gesucht. Daher ist es zu einer klaren Auseinandersetzung hier nicht gekommen. Es sind nur die für alle Folgezeit entscheidenden polemischen Formeln von Luther geprägt worden ${ }^{482}$ ).

482) Vgl. das große Werk von Barge, der freilich sehr einseitig für Karlstadt Partei nimmt um der doch auch für Karlstadt an der Peripherie liegenden politischsozialen Stellungnahme willen. Die Karlstadtsche Mystik hätte sicher in dieser 
Einen bedeutenden Fortschritt bedeutet die I-ehre und Konventikelbildung $\mathrm{Sch}$ we $\mathrm{n} \mathrm{kelds}$, eines der liebenswürdigsten und innerlich vornehmsten Anhänger und Reformgenossen Luthers, dessen Spiritualismus aber auch immer noch ein gemäßigt kirchlicher blieb. Er war ein Schüler der Anfänge Luthers, zug̣leich von der deutschen Mystik, insbesondere Tauler, bewegt, überdies mit Karlstadt und den dem Spiritualismus sehr zugänglichen Basler und Züricher Reformatoren in Berührung. Ien Ausschlag gaben seine Erfahrungen bei der Evangelisationstätigkeit in Schlesien, die Entdeckung von der Unmöglichkeit der getauften Volks- und Massenkirche, und die Verbindung von Luthers spiritualistischer Gemeindeidee mit dem biblischen Urbild der charismatisch-pneumatischen Kultgenossenschaft. Für all das konnte das bloße objektive "Wort" nicht ausreichen, es bedurfte des vom Wort unterschicdenen lebendigen, fühlbaren und an den Früchten zu bemessenden Geistes. Sein Grundgedanke war demgemäß die gegenwärtige innere Wirksamlseit des bekehrenden und erneuernden Gottesgeistes und die Unentbehrlichkeit der diese Wirksamkeit bekundenden praktischen religiösen und ethischen Früchte. Gegen eine Auflösung in rein menschlich-psychologische Vorgänge schützte er die innere Geistesbewegung, wie schon Iuther getan hatte, durch die energischeste Betonung der Prädestination und der Selbstbezeugung des Geistes als wahr in den Prädestinierten. Mit der Vermittelung der inneren Geisteswirkung durch die objektiven Autoritäten des Wortes und der Predigt behielt er insoferne Fühlung, als er das Wort oder die Bibel ihrerseits nur als einen Niederschlag innerer Geisteswirkungen betrachtete und ihre Bedeutung in der Entzündung einer analogen inneren Geistesbewegung erkannte, wie die war, aus der sie selbst hervorgegangen. Ueberdies diente sie als Prüfungsmittel für die inneren Wirkungen des Geistes. Auch ein von Christus fertig vollzogenes Heilswerk des Sühnetodes, erkannte er an, legte aber allen Wert auf die Zueignung und Nachbildung dieses Sterbens durch das gänzlich reale Einwohnen des erhöhten Christus in den Erwählten. Nicht das Vertrauen auf die Autorität des Kirchen-

Richtung nichts Dauerhaftes schaffen können und wollen. Aber Luthers rïcksichtsloses Verhalten gegen die Gegner seiner kirchlichen Idee ist hier doch richtig und lehrrcich bcleuchtet. Im offiziellen Lutherbild pflegen diese Züge sehr vertuscht $2 u$ "erden. Außerdem Scheel »Individualismus und Gemeinschaftsleben* 7. Th. R. 1907, R. Grützmacher I56-I58; Gottfried Arnold II $231-239$.

Troeltsch, Gesammelte Schriften. I 
evangeliums und den Heilsbesitz der Kirche, sondern die persönliche unmittelbare Christusmystik des Sterbens und Auferstehens mit Christo ist ihm das Heil. Hieraus folgte für ihn eine scharfe Entgegensetzung des Buchstabens, des Fleisches und der Kreatur gegen alles Unmittelbar-Göttliche, gegen den Geist, gegen die innere Auswirkung der Erwählung. Vor allem ergab sich ihm hieraus die mit nichts Kreatürlichem zu befleckende Göttlichkeit Christi, dessen menschlicher Leib gleichfalls schon von Beginn der Schöpfung ein übernatürliches und geistiges Fleisch gewesen sein soll. Dies wunderliche Dogma Schwenkfelds, das mit Spekulationen der alten patristischen Mystik zusammenhängt und den spiritualistischen Heilsvorgang gleichzeitig zu einem substantiellen macht, sollte im Grunde nur die Enthistorisierung Christi ausdrücken unter gleichzeitiger Aufrechterhaltung des christologischen Dogmas. Die weitere Folge davon war die völlige Entwertung der äußeren Sakramente, die höchstens als Bekenntniszeichen für die schon vorhandene Geisterfülltheit in Betracht kommen können. Den Täufern stand er daher trotz der Verwerfung der Kindertaufe und gelegentlicher freundlicher Berührungen innerlich völlig ferne. Für ihn gab es überhaupt keine Taufe als die durch den Geist, kcin Gesetz als das durch den Geist wirkende und keine Gemeinde als die von Christus selbst hervorgebrachten, charismatisch und pncumatisch regierten Konventikel, die als fließende Gemeinschaften innerhalb der äußeren Kirchen deren Salz und Leben bedeuten. Diese Konventikel sind engere und wahrhafte Abendmahlsgremeinden, die durch den Bann nach Möglichlicit rein zu halten sind. Die urapostolische Kirche ist verschwunden; sic ist bald veräußerlicht und seit Konstantin ganz verweltlicht. Die seitdem bestehende äußere, Kirche, die heute in vier Kirchen, eine papistische, lutherische, zwinglische und täuferische zerteilt ist, mag weiter bestehen als Hilfsanstalt für den Kern und Keim der wahren Kirche, die Konventikel der wahrhaft vom Geist Wiedergeborenen. Die Verbindung mit dem Staat ist von Uebel, der Zwang in religiösen Dingen gänzlich unchristlich. Dic Konventikel stehen, als das Widerspiel der Welt, naturgemäß unter der Verfolgung. Erst ein sichtbar von Gott bezeugter Apostel oder die Wiederkunft Christi wird sie zu endgültiger Organisation oder zum Siege bringen. Man sieht: das chiliastische Motiv entspringt stets von neuem aus solchem Zusammenstoß der universalen Hoffnung und des tatsächlichen Mißerfolges. Das 
war nun freilich der schärfste Gegensatz gegen die "Taufwiedergeburtskirche « der lutherischen Prädikanten, die nur auf einen großen Haufen sehen. Es hat daher auch den heftigsten Grimm Luthers erregt, der den "Stenkfeld * in Schlesien und in allen lutherischen Landen unmöglich machte und ihm damit ein ähnliches Schicksal bereitete wie Karlstadt ${ }^{483}$ ). Aus seiner schlesischen Heimat durch Selbstverbannung entfernt hat Schwenkfeld in rastlosem Wanderleben, vor allem unter dem Schutz aristokratischer Standesgenossen, solche Konventikel persönlich verbundener Gläubigen geschaffen, die an den Kirchen sich beteiligten, aber von deren Sakramentsfeier sich enthielten, bis darüber Einigkeit ge-

489) Vgl. Grützmacher, Art. Schw. in PRE. ${ }^{3}$, Wort und Geist, S. 158-173; Gottfried Arnold II 246-26I, der hier sehr ausführlich ist und seine Sympathie nicht verhehlt. Grützmacher verweist mit Preger auf mögliche Einflüsse der böhmisch-mährischen Täufer und ihrer Theorie vom Verbum substantiale und Verbum grammaticale. Jedenfalls ist seine Theorie religionspsychologisch sehr fein, s. Grützmacher, Wort und Geist, S. 165: D Die Schrift ist nur ein Abbild und Gleichnis von dem, was durch die Inspiration in den Herzen der Propheten gewirkt war.a -Dieweil man Geist und Leben nicht kann schreiben noch mündlich aussprechen, sondern allein das Gleichnis, so muß man zwischen der Schrift und Gottes lebendigem (d. h. inwendigem) Wort gebührlich unterscheiden und nit Symbolen geben, was rei et veritatis ist.\& "Denn obwohl Gott durch seinen Geist mit den heiligen Männern, durch welche die Schrift geschrieben ist, geredt und ihnen eingegeben hat, was sie sollen schreiben, so hat er darum nicht Schrift, nicht Syllaben, nicht Buchstaben geredt wie wir Menschen, sondern Geist, Kraft und Leben, welches seiner Natur nach nicht kann ins Buch geschrieben werden, sondern allein nach dem Gleichnis oder Biide, dazu dann ein geistlich Urteil will gehören, durch welches das schriftliche Wort vom lebendigen Gotteswort und das Bild von der Wahrheit wird unterschieden. „Die heiligen Menschen Gottes, welche vom hl. Geist zu schreiben und zu reden sind getrieben, haben ihre Gabe und Reichtum, so sie im Herzen gehabt und lebendig empfunden, nicht mögen in Stein und Schrift fassen und andern geben. Sie habens kaum etlicher Maßen können abmalen und mit Laut, Stimme oder Schrift im hl. Geiste bezeugen. Die Feder hat das Herz nicht mögen gänzlich auf das Papier bringen noch der Mund den Bronnen mit seinen Quellen ausreden, sondern haben also im Dienst durch ihre Stimmen, soviel uns nützlich, das Gleichnis fürgetragen und (dadurch) zu dem einigen Heiland, Brunnen und Licht (d. h. dem in uns sich bezeugenden Christus) geweiset. " Luthern versuchte Schwenkfeld sich mehrfach freundlich zu nähern, stets vergeblich. Beim letzten Versuch gab L. dem Boten einen Zettel mit den Worten: „Der unsinnige Narr vom Teufel besessen verstehet nichts, weiß nichts, was er bellet. Will er aber nicht aufhören, so lasse er mich mit seinen Büchlein, die der Teufel ausgespeiet und geschmeißt, ungeheyet; und habe ihm das mein letztes Urteil und 
schaffen wäre. Man wird in vicler Hinsicht an Zinzendorf erinnert; nur steht Schwenkfeld dereigentlichen Mystik noch näher. Sein Ideal sind cugere Kreise inncrhalb der Kirchen, die von cinem wahrhaft wivelergeborenen unil darum wirksamen Prediger, der auch Laie sin kann, erbaut werden. Die Verfolgung hat sie, wie später Ilornhuter und Mcthodisten, zur Versclbständisung in eigenen (iismeinden genötigt. In dicsen Verfolgungen crhielten sich nur wenige Gemeinden, in sichlesien vereinigten sie sich gegen Ende des 16. Jahrhunderts mit den Täufern. Seit I 720 entwichen die spärlichen Rectr rou dem Druck nach England, Iolland und Amerika.

Antwolt: Ler He!r schelte dich du Satan, und deinen Geist, der dich berufen hat und dein Lauf, darin du laufut, und alle, die deines Teils sind a Arnold II 25 I. Andere Orthodone urteilten gerechter: $\rtimes$ Er wollte neutral, ein Scepticus, cin Sonderling sein. . Hi halte es weder mit l'apisten, noch Lutheranern, noch Sakramentierern, noch Winktitufern, billige bei jeder sekte nur etwas und gehe auf eike 1: a und sonderliche form der Religion $\Lambda$ rnold II 242. Er selbst äußert : ach ahmlich: DIas in hich jetzl keiner Partei oder Sekte untergebe, wie mans hcisi, Wuldr den Papisten, Lutheranern, Zwingrianem noch Täufern mit meinem

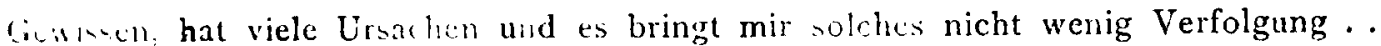
lar . Mssumlerung halber nehme ich keines Hehl und achte es für gewiß . .., daß ler Christ aungelic mit seinem Herzen aits diescr büsen argen Welt, damit er sein Her, immer witder dahin richte, da sein Schatz ist, Jesus Christus, über sich ins himmlische Wesena ibid. Den Gegensatz gegen die auf ihre Objektivität sich steifende Volks- und Massenkirche betont er selbst aufs schärfste 5.242 . In Penn$\because$ Wanien gibt es hcute noch 4 Kongregationen von Schwenkfeldern mit 306 Mit:-1ichein, Ncwinan S. 15b. - Die neueste und reichhaltigste, sehr verdienstliche L)irstellung ist das Buch von Karl Ecke, Schwenkield, Luther und der Gedanke e'mer ap,ostolischen Reformation, IyII. Sie geht vom Standpunkte des pietistischen (acmeinschaftschrivtentlims aus und fciert in schwenkfeld den Kirchenvater dieser Kichtung, der mit Luthers ursprünglichem Ideal der ecclesiolae einverstanden, dagewn 1 .uther, Windung zum Volks- und Massenchristentum und leir damit verbundenen

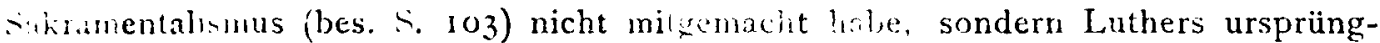
liche like aus dor libel heraus zum fmetmatively-charismatischen Gemeinschaftscliricentum, damil zal wahen the der christichen (jemeinschaft, fortgebildet habe. Trotz schnundus liehandlung Luthers erscheint anch hier Luther ähnlich wie in large surbialte. Gesen die shäretische Mystik z. B. Franck, der »die Höhen refurm:lonicher lentserkenumis nie erklommen hat (96), wie uberhaupt gegen $\mathrm{My}$ stak und Tiutertum arerot E. seinen Ifelden ab, um ihn lediglich aus dem Ur-

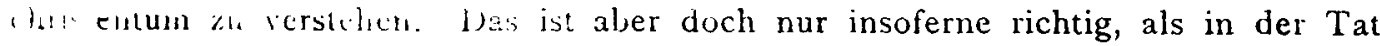
sthm die Bibel lilchinte des Sektentums und der Mystik enthält. Im übrigen riakt $\Sigma$ ing 1.ml der sikte als einc Kombination beider ein. Bemerkenswert ist Schwenkfelds 
Im ganzen ist es eine Verbindung von Sektenprinzip und Mystik, aber weniger aus der sektiererischen und mystischen Tradition als aus lutherischen, biblischen und patristischen Anregungen gewonnen, überkonfessionell und kirchenfrei, aber doch die Kirchen als Vorstufen und äußeres Mittel der Christianisierung neben sich anerkennend und benützend. Die eigentliche Wiedergeburt der Kirche steht erst noch bevor, und die reinen Konventikel sind nur deren Anbahnung. Aber diese Wiedergeburt wird ein Werk göttlicher Wunderkraft und Geistesausgießung vor dem Ende sein. Die Wirkung dieser Gedanken war eine große und breite, wenn auch unkontrollierbare. Fast bei allen Spiritualisten finden sich Spuren ihres Einflusses, und insbesondere sind die englischen Kongregationalisten wohl nur von hier aus zu verstehen, wenn sie auch außerdem einen starken calvinistischen Einschlag haben. Ein das mystische Element einseitig weiter verfolgender Schüler Schwenkfelds war dann später Valentin Weigel, der alles Aeußere so sehr verachtete, daß er sein Leben lang sich für einen orthodox-lutherischen Pfarrer gab und der die völlige Verlegung alles Heils in dic rein inneren, unmittelbar persönlichen Geistesbewegungen erst in seinem literarischen Nachlaß der entsetzten Welt kund tat. Er hat die rein philosophischen Grundlagen der Mystik, den Idealismus der Gott-Menschheitsidee, konsequent entwickelt und ist daher mehr philosophisch als kirchengeschichtlich bedeutsam ${ }^{483}$ a).

Urteil über Luthers Schrift »Himmlische Propheten« Ecke 80: „Wollte Gott, mu sehe gedachtes Büchlein recht und mit aufgetanen Augen an, sche auf Christum unsern Herrn darinnen und auf seine güttliche Wahrheit, vergleichte dieses mit den vorigen Doktor Martini Schriften, und erkennte, wohin und wieferne cr nun kommen, verstünde auch, was für Jammer, Unbestand und Irrungen darin befunden und sich künftig erst daraus wird erbören. \& - Sehr interessante Urteile Schwcnkfelds über die Täufer bei Ecke 204-212, 89. Für die Ethik ist charakteristisch, daß S. klagt, die lutherischen Kaufleute hielten sich gar nicht an Luthers Ethik, sondern nur an Sündenvergebung und Prädestination S. 163. - Die folgenreichicn Gedanken vom Erlöschen der Urkirche, dem seitdem herrschenden äußeren Kirchentum, dem Bevorstehen eines apostolisch beglaubigten Reformators, der zukünftigen Geistesausgießung und dem dann folgenden Ende s. Ecke S. 227, 323--334. Anderer Art, aber gleich begründet, ist der Chiliasmus der Täufer; von hier aus fällt auch ein Licht auf das Auftauchen der eschatologischen Ideen im Independentismus und Pietismu-. Jedes Ernstmachen mit der Heiligungsgemeinde für die Massen führt zum Chiliasmus.

483a) Ueber Weigel siehe Grülzmacher, Wort und Geist, S. 185-195; hier Berufung auf den jungen Luther: „In den Büchern Lutheri suchet besser; da findet 
Blieb die Mystik Schwenkfelds immer noch in kirchlichen Grenzen und suchte sie ein Verhältnis zu geordneten spezifisch christlichen Gemeinschaften, so ging sie bei den bedeutendsten und selbständigsten Vertretern über diese Grenzen hinaus und wurde zu einem völlig individualistischen, mit dem kritischen Rationalismus der Humanisten sich berührenden Prinzip, das den entschlossenen Kampf gegen die kirchlich sich befestigende und objektivierende Reform aufnahm und dafür wieder von ihr als gefährlichste Störung ihrer Ziele tödlich gehaßt und verfolgt wurde. Es sind Sebastian Franck, Sebastian Castellio und Dirck Coornheert, neben Erasmus und den Reformatoren die bedeutendsten Köpfe der Bewegung überhaupt.

Der Eigenartigste ist Luthers Zeitgenosse Se b a s ti a n F r a n ck. Erschüttert von der Fruchtlosigkeit der neuen Predigt, der Unmöglichkeit, mit dem bloßen Amt des Wortes die Menschen zu heiligen, und von dem Widersinn einer auf subjektive Erfolge verzichtenden dinglichen Heiligkeit der Kirche an sich gab er sein lutherisches Predigtamt auf und lebte als literarischer Prophet der alleinigen Erlösungskraft des Geistes und des inneren Wortẹs, wie Paulus daneben vom Handwerk sich nährend. Der feste Punkt alles Christentums wurde ihm im Zusammenhang mit der mittelalterlichen Mystik die in den Stufen der Selbstentsagung und Gelassenheit bis zur Seligkeit und Gottförmigkeit aufsteigende innere Macht des Geistes, die dann herausspringen muß in die praktische Ethik der Selbstheiligung und der Bruderliebe, im übrigen Staat und Gesellschaft der Menschen lassen muß, wie sie durch Gottes Ordnung und Zulassung sind. Wahrhaft persönliche Christen gibt es seiner Erfahrung nach nur wenige, und diese wenigen sind verstreut in aller Welt meist ohne Verbindung und Zusammenhang, verbunden nur in dem sie kennenden Geiste und sich gegenseitig erkennend durch die Stimme des Geistes. Es gibt eine Kirche der vom Geiste wunderbar gewirkten Gottesgemeinschaft, aber nur für den Glauben, ohne äußeren Kult und ihr ebensolche Reden, wie jetzt von mir gehört, sonderlich in seinen ersten Schriften. \& Sein radikaler, erkenntnistheoretischer Subjektivismus ( Alle Erkenntnis kommt von dem Erkenner ) und die Identifikation der psychologischen religiösen Gedankenbewegung mit dem Denken des Logos oder der göttlichen Natur Christi in uns hat ihm auch einen Platz in den Geschichten der Philosophie verschafft s. J. E. Erdmann, Grundriß II ${ }^{3}$ I 878 S. $483-488$ und Windelband, Gesch. der neueren Philosophie ${ }^{3} \mathrm{I}_{48} 8-488$. Es ist die echt neuplatonische Mystik, wobei die Christlichkeit nur gewahrt ist durch die Voraussetzung eines sachlichen Zusammenfallens von Logos und Christentum. 
Zusammenhang und ohne äußerliches Gnadenmittel und ohne buchstäbliche Autorität. Sie ist lediglich gewirkt von Gott. I)er sie hervorbringende Geist selber aber ist eine aus dem Grunde des Gemütes, aus der Immanenz Gottes in der Kreatur, aus dem göttlichen Samen und Funken im Menschen entspringende Be,wegung. der Seele, die überall, wo sie sich aus dem Untergrund des Bewußtseins erhebt, identisch ist und mit dem christlichen Geiste zusammenfällt. Es ist der Logos oder der Christus in uns, der durch alle Kreatur ausgegossen ist und die Identität aller wahren Frömmigkeit mit der christlichen, in der Menschwerdung des Logos anschaúlich dargestellten, bewirkt. Der Vorzug der christlichen Offenbarung ist nur, diese allgemeine unwandelbare Wahrheitssubstanz vollkommen darzubieten, indem sie aus der Geistesęrüllung Jesu und der biblischen Autoren sich in der biblischen Ueberlieferung niedergeschlagen hat und indem von dieser her der Geist in uns entzündet und bewegt wird. Das geschieht freilich nur, wo der innere Geistesfunke der biblischen Verkörperung des Geistes schon suchend und sehnend entgegenkommt. Erst der Geist vermag die Bibel zu deuten, die die ewigen inneren Wahrheiten des Geisterlebnisses als historische Mythen des Sündenfalls und der Erlösung allegorisch vortiägt und die auch sonst in ihrem Buchstaben etwas völlig MenschlichHistorisches, erst durch den Geist zum Leben zu Erweckendes ist. Daraus ergibt sich ein universalhistorisch-religionsgeschichtlich denkender Theismus, der freilich nur eine ewig unveränderliche Wahrheitssubstanz kennt, und eine allegorische Betrachtung der Schrift, die überall in ihr die Umsetzung von Ideen in geschichtliche Mythen wittert. Weiterhin entsteht daraus eine allgemeine Geschichtsphilosophie, die überall in aller Geschichte den sich immer neu wiederholenden Kampf des auf das Unsichtbare, Geistige und Selbstlose gehenden Glaubens gegen den ans Sichtbare, Aeußere und Selbstsüchtige sich haltenden Unglauben sieht. Von Kirchen, Parteien und Sekten hält er unter diesen Umständen gar nichts. Auch eine neue Reformation ist überflüssig, da jede Reformation nur eine neue Kirche ergäbe. Wenn ein von Gott sichtbar beglaubigter Mann des Geistes und der Kraft käme, so möge man sich um ihn scharen. Allein so lange dies nicht der Fall ist, bleibt die Aufgabe ein unsektisches und unabhängiges, rein persönlich-individuelles Christentum der Heiligung und Bruderliebe ohne allen äußeren Kult und ohne alle 
$8 \times 8$ 111. Viotestantismus. 4. Sektentypus und Mystik auf protestantischem Boden.

änfere Autorität. Fr sieht die letzte Stufe der Geschichte des Christentums anbrechen, wo Kirchen und Sekten untergchen und der reine persönliche Glaube und die unsichtbare Gemeinde des Geistes in allen Landen übrig bleiben werden, 'im als wcistliches Salz der Welt zu dienen. lis ist das offenbar eine sehr resignierte Wendung des Schwenkfeldschen Gedankens von ciner bevorstehenden Reformation durch cinen apostolisch beglaubigten Mann und auch für die kommende (ievistesausureßung der Zukunft der völlige Verzicht auf jeden kirchlichen Charakter. Er nähert sich damit der alten mystischen I,chre vom evangelium aeternum oder vom dritten Reich. Diese L,ehren haben ihn freilich bei den Zeitgenossen unmöglich gemacht. Ueberall vertrieben hinterließ er zum.Schluß keine Spur seines Schicksals mehr. In Ilolland und England lebten seine Schriften fort, und dort begegnet man seinen fortwirkenden Ideen ${ }^{4 * 4}$ ).

484) Vgl. das ausgezeichnete Buch von Hogler; Goltried Arnold, der Francks Idee der Ketzergeschichte aufgenommen und fortgesetzt hat und iiberhaupt ihm sehr nahesteht II 281-283; Dilthey, Archiv $V 3 S y-400$. Dilthey betont $m$. E. nicht stark genug den Zusammenhang mit dur mittelalterlichen Mystik und modernisiert zu stark. Die Verwandtschaft mit der modernen Religionsphilosophie seit Lessing, Kant, Schleiermacher und Hegel mit seinen (jedanken ist ja offenbar. Allein bei Franck ist von geschichtlicher Bewegung der Wahrheit'nicht die Rede; er hat einen völlig geschichtslosen und absoluten, nur ganz spiritualisicrten Wahrho it-hegriff; er huldigt einem weltfeindlichen Dualismus, der eine fortschreitende wirl sieghafte allgemeine religiöse Bewegung ausschließt und der modernen l:thik guadeza entgegusteht; er behandelt schließlich die Schrift doch mehr alleguricchokkultintisch als religionsgeschichtlich und psychologisch. Sein kultuoner Individualismus und sein mystischer Immanenzgedanke freilich findet den Beifall der Modernen, wie die im Diems der Religionspolitik des Diederichschen Verlags stehende Neuausgabe seiner slaradoxas mo zeigt. - Luther hat von dem durch seinen Indiviluali-mis sich zur Wranguslusigkeit verdammunden Manne keine Nutiz genummen; erst nach seincm Tode äußert er sich: „Lir hätte wider solchen bösen Mcncchen nichts chivilien wollen, weil or ihn zu hoch verachtet; er wäre ein Lästermaul, les l'eulel- eigen und liebstes Maul gewesen... Sovicl ich dem liench meiner lase nach spüren und uneilen kann, so ist er ein Enthusiast oder Gewrele dem nicht: [- [illt als Geirt, Cieist, Geist, der vom Wort, Sakrament und Predigame nubre häl .... Er set Jurch allen Koth hindurchgewandert und in seinem "renru ersichla Arrold II 2is. So urteilte Luther über einen der edelsten ur.l ireienten Ciriter der Zeit. In Delltschland wurde er bald vergessen ual hatte seine fortinkung in den Niederlanden. Arnold konnte seine Schriften nut Lut an alutreituen! lgl. in ührigul, auch Heglers Prugramm: 2S. Francks lata..minsclie l'araphrase der riellschen Theologie und scine holländisch erhaltenen 
Aehnlich wie das Luthertum von der Kritik Francks, so ist der Calvinismus von derjenigen $\mathrm{C}$ a s telli o s begleitet. Als bedeutendem christlichem Humanisten und Vorsteher des Collège schien ihm bestimmt, der Melanchthon Genfs zu werden. Da hat ihn eine Meinungsverschiedenheit über biblisch-kritische Fragen mit der allgewaltigen dogmatischen Autorität Calvins entzweit. Von da ab blieb der Schutz der persönlichen Ueberzeugungsfreiheit als des Palladiums einer echt christlichen Reformation seine große Lebensaufgabe. Den Hintergrund hierfür gewährte dem mit Occhino und David Joris befreundeten Manne, dem Verehrer der deutschen Theologie «, die spiritualistisch-mystische Lehre von der die Bibel erst richtig deutenden und ihre innere Lebensmacht ohne Vlenschenhilfe durchsetzenden Kraft des heiligen Geistes. Er teilte auch die Lehre von den Heilsstufen, von der Gelassenheit und Selbstabtötung bis zur vollen Herrschaft des Christusgeistes, die Verwerfung der Imputationslehre und die Herleitung der Sündenvergebung aus dem Wesen des im Geist sich kundgebenden Gottes, der als zornig und unversöhnt nur von trotzigen und unerleuchteten Herzen angesehen wird. Dabei war seine Mystik stark moralisch und aktiv gefärbt und im Uebergang zu einem ethischen Rationalismus begriffen. Immerhin aber war er nicht Erasmianer, sondern Spiritualist. Von hier aus behandelte er die Bibel, die sein Bienenfleiß ins Lateinische und Französische übersetzte, völlig im Sinne Sebastian Francks. Obwohl an der Inspiration der Bibel festhaltend, hat er doch durch die Vorbehaltung des Verständnisses an den Geist, der in dem buchstäblichen Niederschlag der innerlichen Inspirationen der Verfasser sich wiedererkennt, eine innerlich freie und erstaunlich kühne philologisch-kritische Stellung zur Bibel eingenommen. Vor allem aber kämpfte er seit der Verbrennung Servets für den Grundsatz der Relativität aller äußern Ausdrucksformen des Geistes, die doch die Identität des Geistes in sich selber nicht aufhebt. Er wurde zum großen Vorkämpfer der spiritualistisch-mystisch begründeten Toleranz. Dabei berief er sich vor allem auf Luthers Anfänge und auf Sebastian Franck, auf die Lehre von der Trennung der weltlichen

Traktates I901; außerdem H. Ziegler, Z. f. wiss. Theol. 1907, auch Heglers Beiträge zur Geschichte der Mystik. Von Francks Schriften in England wird Herr Sippell berichten, der sie in dortigen Archiven aufgefunden. Ein Mann wie Saltmarsh scheint mir ohne Franck unverständlich; es sind überall verwandte Gedanken, zugleich von einer gewinnenden menschlichen Liebenswürdigkeit. 
und geistlichen Gewalt, welche letztere allein durch Wort und Geist und durch das Vertrauen auf ihren schließlichen, rein geistigen Sieg wirken darf. Es ist nicht die Toleranz der Skèpsis oder des Opportunismus, sondern die Toleranz der Mystik, die alle dogmatischen Formulierungen als nur annähernde Erkenntnis preisgibt. Wie den grauenvollen Blutdurst, so hoffte er auch die moralische Unfruchtbarkeit und die dogmatische Aeußerlichkeit der Reform damit überwinden zu können. Wie er sich unter diesen Umständen die Aufrechterhaltung der von ihm nie bestrittenen Volksund Massenkirche dachte, ist nicht mehr zu erkennen. Es scheint, daß er an die Unüberwindlichkeit des Geistes, an die Möglichkeit einer alle vereinigenden dogmatischen Vereinfachung glaubte und daß er den Bann oder die Ausschließung von der $\mathrm{Ge}$ meinde, die auch er im ethischen Interesse wünschte, unter diesen Umständen als eine nur wenige treffende Maßregel ansah. Jedenfalls zeigt er nicht die. Resignation Schwenkfelds für die Gegenwart und daher auch nicht seine eschatologischen Erwartungen; er mochte in dem kleinen Basel eine solche ethische Vereinfachung und spiritualistische Verinnerlichung für die Gesamtkirche für möglich halten; auch war seine Ethik unter humanistischem Einfluß dem praktischen Leben mehr angepaßt als die Schwenkfelds und Francks. Die Genfer Gegner aber erkannten die ganze Gefährlichkeit eines solchen Relativismus für den Gedanken der Volks- und Massenkirche und der für eine solche notwendigen infallibeln Autorität. Sie hielten dem "phantastischen*Vertrauen auf den Sieg des Geistes und des Wortes entgegen, daß auf Wunder nicht zu zählen sei, wie man ja auch das Elend des Hungernden nicht der Dazwischenkunft der Engel, sondern zweckmäßigen Maßregeln empfehlen müsse. Sie suchten den nach Basel Geretteten dort unmöglich zu machen, freilich ohne Erfolg. Nach seinem Tode wurden seine bereits gedruckten und seine ungedruckten Schriften in den Kämpfen der Remonstranten neu verwendet und erlebten ebenso wie die Francks in den Niederlanden eine Wirksamkeit, die sie zu Lebzeiten der Verfasser nicht hatten finden können ${ }^{486}$ ).

485) Vgl. das treffliche Buch von Buisson "Sébastien Castellion, sa vie et son oeuvre Paris I892. Ueber C.s Mystik und Spiritualismus I 310-3I4, II 38, 99, 194-197, 201-213, 259. Das Wesen dieser Toleranż mit ihrer spiritualistischen Begründung, die noch so stark auf die allgemeine Christlichkeit der Atmosphäre rechnet, daß sie nur für innerchristliche Unterschiede an die Toleranz denkt, im 
In den Bahnen Castellios, den er ganz übersetzen wollte und teilweise übersetzt hat, ging der bedeutende niederländische $\mathrm{Hu}$ manist und Politiker Coornhe ert. Seine Wirksamkeit fiel noch, wie die gleichzeitige oben erwähnte Reorganisation der täuferischen Gemeinden, in die Zeit der Unentschiedenheit der kirchlichen Verhältnisse der Niederlande. In diesem Zustande kämpfte er, jede parteiische Konfession und die Aufrichtung jeder neuen

übrigen aber die Selbstdurchsetzung der , geistigen christlichen Wahrheit \& für selbstverständlich hält I 366, 373, II 38, 290, 295. C. vergleicht die Einzeldogmen den mit jedem Land wechselnden Scheidemünzen, die Wahrheit des Geistes mit dem überall angenommenen Gold. So ist es auch zu verstehen, wenn später in England und Amerika die Toleranz nur eine innerchristliche ist und den Atheismus nicht einschließt. Das ist nicht Inkonsequenz, sondern die Folge der spiritualistischen Begründung der Toleranz. Von Luthers Anfangspositionen ist diese Toleranz mit ihrem Vertrauen auf den Sieg des Geistes nur dadurch unterschieden, daß für C. der , Geist bei seinem loseren und oft allegorischen Verhältnis zum Bibelbuchstaben ein einfacheres und gestaltloseres Prinzip ist als Luthers stets mit dem -Worta verbundener Geist. Daher entsteht hier größere Bewegungsfreiheit. Aber man würde sie mißverstehen, hielte man sie für eine völlig unbegrenzte. Mit diesem erweiterten Toleranzbegriff ist dann freilich auch ein anderer Wahrheitsbegriff gegeben als bei den Reformatoren. Die Wahrheit liegt in der im Gewissen sich subjektiv versiegelnden Macht des Geistes, während alles Aeußerlich-Buchstäblich-Zeremonielle und Institutionelle lediglich relativ wertvolle, vom Geist erst zù deutende Hülle ist: Die absolute Wahrheit beschränkt sich auf den Geist, ist aber hier auch klar und unausweichlich. Alles Buchstäbliche, Bibel und Dogma, gehören dagegen dem Gebiet des Relativen an. Zugleich ist. diese Wahrheit eine völlig subjektive, nur vom Subjekt an sich selbst zu erprobende. Es ist also weder der Wahrheitsbegriff der modernen Wissenschaft noch der der kirchlichen Heilsanstalt, sondern der des Spiritualismus und der Mystik. - Das Entsetzen der Gegner, die hierin den Inbegriff satanischer Gefahren, sakademische Skepsis und freche Phantastik * (II 25-39, I22, 249, 255, 258), die Aufhebung aller Möglichkeit einer wahren Kirche und festen Autorität sahen, ist begreiflich. Höchst charakteristisch ist Bezas Einwurf gegen das Vertrauen auf die geistige Selbstdurchsetzung der Wahrheit: „Là-dessus que fera l'église? Qu'elle crie au Seigneur, diras-tu, et il l'exaucera... Qui certes, elle criera au Seigneur... Mais celuy aussi qui a faim criera bien au Seigneur et toutes fois il n'attendra pas qu'un ange luy apporte à manger, mais prendra comme de la main de.Dieu la viande, qu'un autre luy donnera ou qu'il aura luy-mesme acquise par moyens honestes et licites II 27. Hier liegt in der Tat der entscheidende Punkt. Mit dem spiritualistischen Vertrauen auf den Sieg des Geistes und mit dem Relativismus der Duldung verschiedener Buchstäblichkeiten war das Ideal der Einheitskirche und die Selbstbehauptung in den fiebernden Massenkämpfen der Zeit nicht durchzuführen. Der schwache Punkt bei Castellio liegt daher auch in der Unklarheit seiner Begriffe von der Kirche. 
Kirche überhaupt verwerfend, für ein Christentum des inneren Wortes und der praktischen Bewährung dieses inneren Wortes. Er wollte keine Bekenntnisse und keine Dogmen außer der Bibel und dem Apostolikum, aber auch keine täuferisch-buchstäbliche Deutung der Bibel, sondern die freie und innerliche Herrschaft des in Gelassenheit, Selbstverzicht und Bruderliebe sich betätigenden, das Verständnis der Schrift erst erschließenden Geistes. Der Geist und der Christus in uns sollen am praktischen Tun erkannt und bis zur Vollkommenheit verwirklicht werden. Die Sündenvergebung trägt der Geist in sich, und es bedarf keiner Beziehung auf eine angebliche Bewirkung der Sündenvergebung durch den historischen Sühnetod Christi. Dieser Christus in uns reicht auch weit über die eigentliche Christenheit hinaus, indem der Logos auch ohne Schrift zahlreiche Heiden erleuchtet und erneuert hat. In alledem trägt seine Mystik die wesentlich praktisch-rationalistischen Züge wie die Castellios; die tieferen Geheimnisse der Trinität und der Christologie will er nicht untersucht, sondern nur praktisch betätigt sehen. Von Erasmus, auf dessen Vereinfachung des Evangeliums er sich gerne beruft, trennte ihn die entschieden protestantische Gnadenlehre, der spiritualistische Einschlag und der Bruch mit aller und jeder Kirche. Im übrigen aber näherte er wie Erasmus und Castellio die christliche Ethik der stoischen an und milderte dadurch den spiritualistischen Dualismus. Besonders charakteristisch ist unter diesen Umständen seine Stellung zu den kirchlichen Organisationen neben ihm und zu dem ganzen Gedanken einer kultischen Gemeinschaft. Er verwirft wie Franck

Er denkt nirgends an Sekten- und Konventikelbildung, sondern stets an Durchsetzung des Geistes auf geistige Weise für das Ganze II 37, 230: Contentez-vous qu'on accorde aux principaux points de la religion lesquels sont clairs et évidents en la Sainte-Écriture, puis ils sont en tout point d'accord avec vous.\& Die wahren Christen freilich sind selten II 232 : , Ceux qui regardentainsi a nombre (wie Calvin) et pourcela contraignent le s g e ns, ressemblent à un fol qui, moyennant un grand tonneau et un peu de vin dedans, le remplit tout d'eau pour en avoir d'avantage, en quoi faisant tout s'en faut qu'il accroisse son vin, que même il gaste ce qu'il avoit de bon. Par.quoi il ne faut pas esbahire si aujourdhui le vin des Chrétien est tant soit petit et faible, puisqu'on y mêle tant d'eau !s Als Mittel der Reinhaltung der Kirche dient ihm eine Ausschließung ohne alle bürgerlichen Folgen II 235: >Voilà les vrais moyens de résister aux hérétiques :-par parole s'ils usent de parole, et par glaive s'ils usent de glaive. Das alle: ist von modernen Toleranzbegriffen noch sehr viel verschiedener als Buisson meint. 
jede Reformation und Neuaufrichtung der Kirche, da die sichtbare Kirche an sich vom Uebel ist. Doch kann man unter diesen Umständen an dem alten Kult äußerlich teilnehmen, da ein schlechter Kult nicht böse und ein gereinigter Kult nicht gut macht. Man kann alles mitmachen und sich innerlich davon unabhängig halten. Aber man kann auch jede kirchliche Gemeinschaft meiden und ohne Sakrament und Kult leben in reiner innerer Heiligung und bloßer Bruderliebe. Eine neue Kirche will er, wie Schwenkfeld und Franck, nur zulassen, wenn ein von Gott mit Zeichen und Wundern ausgerüsteter Prophet aufstände ${ }^{486}$ ). Aber sich selbst kann er nicht dafür halten, ebensowenig die Reformatoren; und auch in den Visionären neben ihm, wie David Joris und Heinrich Nikläs, kann er solche nicht erkennen. Für den Fall, daß die Christen trotz alledem einer Gemeinschaft $z u$ bedürfen glauben, entwirft er dann freilich ein höchst eigentümliches Gemeindeprogramm. Der Glaube soll auf Bibel und Apostolikum beschränkt und vor allem soll auf praktische Bewährung gedrungen werden. Die sich frei vereinigenden Gemeinden sollen alle als Mitglieder annehmen, die diese einfachste Glaubenssubstanz anerkennen und von groben Sünden sich frei halten. Um der Schwachen willen kann eine Meidung der beharrlichen und verstockten groben Sünder und Bestreiter von Gottes Ehre vorgeschrieben werden, aber ohne Wortklauberei und Konsequenzmacherei. Taufe und Nachtmahl können um der Schwachen willen gebraucht werden als Zeichen der Wiedergeburt, aber in voller Freiheit. Ein autoritatives Lehramt gibt es nicht, sondern nur Vermahnung und Besserung aus der Schrift. Solche Gemeinden sollen frei sein und niemand zur Zugehörigkeit gezwungen sein. Das sieht aus wie eine Ermäßigung und Rationalisierung des Schwenkfeldschen Ideals, an den überhaupt -manches erinnert. Es ist freilich ein höchst utopisches Kirchenprogramm, das in der Durchführung zu einer unabsehbaren Teilung der Gemeinden geführt haben würde, und möglich nur, wie bei Castellio und bei dem jungen Luther, durch das Zutrauen zu der von selbst einigenden Kraft des heiligen Geistes. So hat es denn auch eine praktische Wirkung nur im bescheidensten Maße gehabt und die Konfessionalisierung der Niederlande nicht aufgehalten ${ }^{487}$ ).

${ }^{486}$ ) S. Hegler, S. 256 f. Wie schon bei Franck kehrt sich auch bei Coornheert dieser Gedanke bes. gegen die Täufer.

${ }^{487}$ ) Ueber das Verhältnis von Castellio zu Coornheert s. Buisson II 324 f., die mystische Lehre C.s bei Heppe, Gesch. des Pietismus und der Mystik in der reform. 
Coornheerts Nachwirkungen zeigt deutlich erkennbar nur die Gruppe der Collegianten oder Rijnsburger, die ein eigentümliches Mittelding zwischen Freikirche oder Sekte und lediglich persönlich-verbundener mystischer Gemeinschaft darstellen. Sie mußten sich äußerlich den Täufern anschließen, ohne doch die Aufrichtung einer Täuferkirche zu billigen, und sind durch den Zutritt von Remonstranten sehr rationalistisch gefärbt worden. Aber ihr Grundzug ist der Spiritualismus und die Mystik Coornheerts. Die neunzehn Artikel von Galenus Abrahams und Spruyt c. 1650 erklären die mit erkennbaren Wundergaben ausgerüstete apostolische Kirche für längst erloschen. Sie allein durch das Mittel der nachgelassenen Schriften wieder aufzurichten*, finden sie in der Schrift kein Gebot und in den neuen Kirchen keine Ermunterung, da sie, die Mennoniten nicht am wenigsten, in beständigem Streit sich entzweien. Ein den apostolischen Lehrern vergleichbarer, wunderbeglaubigter Prophet ist nicht erschienen und damit kein Mittel der Wiederaufrichtung von Kirchen vorhanden. Daher erklären sie sich selbst für eine rein menschliche Stiftung ohne göttliches Gebot oder Autorität, die lediglich auf dem Vertrauen beruht, es werde dem großen Hausvater doch wohlgeKirche namentl. d. Niederlande, I879 S. 80-86. ,Diese Heiligen sind und leben in Christo, der das Licht der Welt ist, und sie allein können darum Gott erkennen. Von Gott selbóst mittelst seines lebendigen Wortes, nämlich des Logos, und des Geistes der Wahrheit gelehrt und in alle Wahrheit geführt und durch des Geistes Salbung erleuchtet, bedürfen siè daher keiner Unterweisung durch Menschen mehr S. 84. Christus ist Mensch geworden ... und herrlich auferstanden, daß wir durch seinen tätigen Gehorsam in uns in ihm göttlich sollten werden « S. 88 . Eine Bekanntschaft auch mit Franck und Schwenkfeld ist doch sehr'wahrscheinlich. Dilthey, Archiv V 486-493 rückt ihn viel zu nahe an Erasmus heran, wenn er ihn auch > wenigstens über das, was $E$. in seinen Schriften zu sagen für geraten hielt, entschieden hinausgehen läßt S. 492. Rachfahl, der überhaupt der niederländischliberalen Parole von Erasmus als dem Träger des niederländischen Nationalgeistes folgt, macht ihn zum reinen Erasmianer, Oranien I 45I. Das ist aber falsch. Humanist ist er nur in der Würdigung des $>$ Naturgesetzes und seines stoischen Charakters, worin er ja aber auch mit den Reformatoren, Castellio und Franck, einig ist. Er betont nur diese Unterlage und ihre Identität mit dem Logos allerdings viel stärker. In der Hauptsache aber ist er Spiritualist und Mystiker, der die Stufen der Heiligung von der Gelassenheit bis zur Sündlosigkeit zum Zentrum macht und alles auf das innere Wirken Gottes zurückführt, s. auch Busken-Huet II 47-56. Seine Ideen über die Kirche entnehme ich Exzerpten, die Herr Sippell gesammelt und mir zur Einsicht überlassen hat, deren Veröffentlichung er aber sich selbst vorbehalten hat. 
fallen und er werde es, soweit es aus guter Meinung geschieht, nach seiner gründlichen Barmherzigkeit gnädig ansehen *. Daher haben bei ihnen Aemter, Dienste, Zeremonien, Lehrer, Taufe, Nachtmahl und Bann »nicht den Wert, wie in der ersten Kirche«. >Allerhöchstens sind sie zulässig, wenn sie ohne Anspruch auf Autorität, in aller Niedrigkeit, mit Duldsamkeit und unter Verbesserungen gehandhabt werden, ohne daß man die Gewissen der Menschen an seine Lehre und den Gebrauch derselben genau bindet *. "Die Gläubigen-Taufe und das Abendmahl können auch jetzt noch, wenn sie vorsichtig gehandhabt werden, ihren Gebrauch und Nutzen haben *. Die eigentliche Wahrheit aber liegt in der reinen Innerlichkeit des Gemütes und in der unsichtbaren Kirche. Das sind, wie eine nähere Erklärung von 1659 sagt, »die in der heutigen Zeit des Verfalls der sichtbaren Kirche überall unter vielerlei Völkern zerstreuten Gläubigen, die sich von Herzen abwenden von allem $Z$ wist und aller Sektiererei, die mitten unter allen Zerspaltungen ein ungeteiltes Herz haben und insgesamt beruhen auf einem und demselben Grund, Christus, und völlig eins sind in dem Grund und der Kraft Gottes «. Das sind wie bei Coornheert unverkennbar Nachwirkungen und Umformungen Schwenkfeldscher Gedanken. Es ist nur der schroffe Supranaturalismus, die substantielle Mystik und die Eschatologie weggefallen ${ }^{487 a}$ ).

Bekannt ist, daß auch ein Teil der Täufer spiritualistischen Ideen gehuldigt hat, und man hat um deswillen oft beide Gruppen vereinerleit. Allein es sind doch nur einzelne Theologen des Täufertums und ihr Anhang. Das Täufertum ist an sich untheologisch und bedarf nicht mehr als der Bibel. Bei feinerer theo-

487 a) Ueber die Collegianten ausführlich Hylkema, Reformateurs, und Sippell, Ueber den Ursprung des Quäkertums, Chr. W. I9Io S. 483-487. Ebenso verdanke ich Herrn Sippell die Kenntnis der bei Hylkema vielfach angezogenen >XIX Artikel a und ihrer „Erklärung «, deren Veröffentlichung er sich gleichfalls vorbehalten hat. Ueber den Zusammenhang der Rijnsburger mit den Täufern s. Newman, Antipedobaptism S. 32 I f., über ihren spiritualist. Charakter ganz in der Weise Coornheerts s. Barclay, The inner life S. 9o. Ueber Coornheert und seinen Anhang als Vertreter des inneren Wortes und Genossen Seb. Francks und Schwenkfelds s. auch Maronier S. 307-309, über die Anfänge der Collegianten Barclay S. 89-92, ihre spätere Entwickelung seit 1650 bei Hylkema. Eine Biographie Coornheerts oder wenigstens eine Darstellung seiner Theologie wäre höchst lohnend und würde die Zusammenhänge nach vorwärts und rückwärts sehr erleuchten. Die herrschende einseitig konfessionelle Auffassung der Reformationsgeschichte könnte damit wieder an einem wichtigen Punkte eingeschränkt werden. 
896 III. Protestantismus. 4. Sektentypus und Mystik auf protestantischem Boden.

logischer Beschäftigung ergaben sich allerdings hieraus Bedürfnisse der Begründung und Folgerung, die zum Spiritualismus führen konnten, sobald man dem groben gesetzlichen Buchstaben der Bibel oder ihren Widersprüchen entgehen wollte. Auch hat der in den Verfolgungszeiten auftretende Enthusiasmus, dessen neue Offenbarungen man mit der neuen Lage beim Anbruch des Weltendes rechtfertigte, durch die darin liegende Ueberschreitung des Schriftbuchstabens eine Brücke zum Spiritualismus gebildet. An sich aber sind enthusiastische Täufer und spiritualistische Mystiker noch recht verschieden. Andererseits haben spiritualistische Denker, die gemeindlichen Anschluß suchten, ihn bei den Kirchen nicht finden können, sondern ihn bei der ethischen Laienreligion der Täufer gesucht, wie das auch Karlstadt und Seb. Franck vorübergehend getan haben. Das letztere ist auch der Fall bei einer der menschlich anziehendsten Persönlichkeiten der Reformationszeit, bei $\mathrm{H}$ a ns Denk. Er war ein Schüler Taulers, der deutschen Theologie und des Humanismus; doch entzweite er sich, als Schulrektor in Nürnberg unter die Einflüsse von Karlstadt, Münzer und Staupitz geraten, mit der lutherischen Kirchenlehre, der er ihre ethische Unfruchtbarkeit und ihre das Subjekt entlastende Versteifung auf die der Kirche zukommende Versöhnungsgnade vorwarf. Von da ab führte er das Flucht- und Wanderleben, das allen solchen Geistern beschieden war. Er wandte sich den Täufern zu, um schließlich auch von ihnen sich wieder zu scheiden und sich ganz der Erlösungskraft des inneren Wortes und des ewigen Christus zu befehlen, der überall seine Kirche, bei Beschnittenen und Unbeschnittenen, Katholiken, Zwinglianern und Lutheranern, innerlich hervorbringt, wenn man sich vom Geist zur Gelassenheit und Bruderliebe führen läßt. Christus und die Bibel sind ihm die von Gottes Geist erfüllten Belebungsmittel des inneren Samens oder Funkens. In der Belebung dieses überall enthaltenen, in jeder Seele schlummernden und vom Willen hingebend $\mathrm{zu}$ pflegenden Funkens ist Gott der Erlöser; Christus ist als Erlöser nur zu bezeichnen, sofern er diese inneren Vorgänge in Gang bringt. Allein damit Christus das könne, muß der Geist schon im Menschen sein. Nur indem der göttliche Geist im Menschen sich in dem göttlichen Geist der Bibel wieder erkennt, kommt es zu der Aeußerlichkeit, Fleisch, Selbstsucht und Weltlichkeit überwindenden Erlösung, zur Gottesliebe und zur Bruderliebe als der Wirkung und Probe jeder echten Erlösung. Daher sein Kampf gegen die Aeußerlichkeit des 
widerspruchsvollen Bibelbuchstabens, gegen die Stellvertretungsund Versöhnungslehre, gegen die ausschließliche Bindung des Heils an den geschichtlichen Christus, gegen die den göttlichen Seelengrund verkennende Scheidung der Menschen in Erwählte und Verdammte, gegen die Uebertreibungen der Sündenlehre, gegen die Spaltung des Endschicksals in Himmel und Hölle, gegen die kirchliche Christologie und gegen die mit der Welt sich vertragende kirchliche Ethik. Den Staat erkannte er an, aber den Christen widerriet er die Teilnahme an staatlichen Aemtern. Aehnlich stand es mit Hätzer, Bünderlin, Entfelder. Sie waren Schüler Denks, und haben mit ihm Seb. Franck beeinflußt. Eine ganz eigentümliche Stellung nahm Theobald Thamer ein, der den Geist in das natürliche Gewissen oder sittliche Naturgesetz verwandelt hat, eine merkwürdige Vorausnahme der zwei Jahrhunderte später eintretender Umwandelung der christlichen Ideenwelt in den moralistischen Deismus ${ }^{488}$ ).

Viel weiter in die neuplatonische und naturphilosophische Begründung des Geistes und des Kampfes zwischen Fleisch und Geist führen die mystischen Naturphilosophen der Epoche L u dwig Vives, Campanus und Servet, Agrippa von $\mathrm{Net}$ esheim und $\mathrm{Par}$ a celsus. Sie sind nach der religiösen Seite hin sämtlich Vertreter einer kirchlich gleichgültigen Innerlichkeit der Gesinnung und einer die Selbstsucht überwindenden mystischen Liebe, sind auch größtenteils Katholiken geblieben, üben aber ihre Hauptwirkung auf protestantische Spiritualisten aus. Insbesondere Servet in seiner Wiederbelebung gnostischer Elemente der Bibel und ihrer Verknüpfung mit neuplatonischen Spekulationen war einer der interessantesten und geistvollsten

488) Vgl. hiezu im allgemeinen Hegler, Geist und Schrift, und Keller, Staupitz. Keller nennt diese spiritualistischen Täufer die »besseren Täufer «, wie das auch Maronier tut S. 327, andere nennen sie »freie Täufer «, was eine contradictio in adjecto ist. Ueber Bünderlin s. Hegler S. 5I, Entfelder Hegler 273 und Keller 36o. Ueber Thamer s. Neander, Th. als Repräsentant moderner Geistesrichtung 1842 und Hochhut, Z. f. hist. Theol. 186I. Wie Sebastian Franck, Coornheert und die Kollegianten bestreitet Denk schließlich jedes geistliche Amt, auch das von ihm bei den Täufern selbst bekleidete; ohne supranaturale Berufung, wie die der Apostel war, gibt es kein Amt. Das ist wieder der Satz Schwenkfelds, oder geht schon Schwenkfeld hierin auf eine ältere mystische Theorie zurück? Das kommt der Aufhebung jeder Kirche und Sekte überhaupt gleich s. Keller, Denk 1882 S. 226 ; hier Analysen seiner Schriften. Sein sog. $*$ Widerruf s ist nur die Abrückung von den Täufern zum Spiritualismus.

Troelts ch, Gesammelte Schriften. I. 
Köpfe der Zeit. Von ihnen allen hat auch Seb. Franck nicht. unerhebliche Einflüsse aufgenommen. Auf Eindrücken von Paracelsus, Schwenkfeld und Weigel beruhte dann die Theosophie J a k o b B öhmes, religiös gleichfalls wesentlich Spiritualismus unter gläubiger Schonung der kirchlichen Sakramente. Der gleichen Gedankenwelt gehörten dann weiter die Gichtel, Poiret, van Helmont, Fludd Vater und Sohn an. Sie alle haben nach der Ausrottung der Ketzer in Deutschland und der Schweiz ihre Zuflucht in den Niederlanden und in England gefunden, wo der Spiritualismus der Revolutionsepoche an ihren Büchern zum großen Teil seine Nahrung fand. Böhmes Schriften wurden in Holland gedruckt und ins Englische übersetzt, ähnlich wie Franck seine Weiterwirkung in Holland und England gefunden hat. Unter den großen Naturforschern stand Kepler dieser Richtung nahe, der ja auch sonst bekanntlich mit dem Neuplatonismus, der Unterlage des ganzen prinzipiellen Spiritualismus, sich nahe berührte. Er glich seine neue Naturlehre mit der Bibel durch die Beschränkung der Offenbarung auf die religiösen *Intentionen * des Geistes und durch die "Akkommodation* der buchstäblichen Ausdrucksweise des Geistes an die populäre Denk- und Redeweise aus; auch er hat den heißesten Kampf mit den Theologen führen müssen und seine der Hexerei angeklagte Mutter nur durch eine heftige literarische Polemik vor dem Tode gerettet. Ein anderer der hierher gehörigen bedeutenden Reformer und Propheten der Zukunft war Amos Comenius, der letzte Bischof der böhmischen Brüderkirche, der nach furchtbaren Schicksalen, wie so viele andere, sein Asyl in Amsterdam fand. In den Angelegenheiten der natürlichen Dinge war er, wie später die Pietisten und Quäker, Anhänger einer empirisch-sensualistischutilitarischen Auffassung, von wo aus seine berühmte Reform der Pädagogik ihren Ausgangspunkt nahm. Religiös ist er dagegen Chiliast, Platoniker und Spiritualist. Er hofft auf die Einheit der Menschheit im Geiste und auf das Ende aller Konfessionen. Er gehörte wie Sebastian Franck zu den heimlichen Verschworenen einer bessern Zukunft, die erst heute voll verstanden werden ${ }^{489}$ ).

${ }^{489}$ ) Zum Ganzen vgl. Hegler und Gottfried Arnold. Ueber Servetes Spiritualismus Tollin, Servet und die Bibel, Z. für wiss. Theol. 1875. Ueber Paracelsus den schünen Aufsatz Euckens in den »Beiträgen zur Einführung d. Gcsch. d. Philosophie «. Betreff Bühmes sei in diesem Zusammenhang nur auf Ritschl, Gesch. d. Pietismus II $301-305$ u. R. Grützmacher 195-204 verwicsen. Der religionsphilosophische und metaphysische Gehalt dieser Denker interessiert uns hier nicht; hierüber s. den heute noch unvergleichlichen $\triangleright$ Grundriß der Gesch. der Philosophie ${ }^{3}$ von J. E. Erdmann 
Dem ganz andersartigen Gebiete der orgiastisch-enthusiastischen Mystik gehörten- ursprünglich die Gruppen der Joristen und Familisten an. Der mit der Auflösung der bisherigen Kirche nahegelegte und auch von Luther oft ausgesprochene Gedanke des bevorstehenden Weltendes, die Vorbilder des urchristlichen Enthusiasmus und der Apokalypse legten derartige Schwärmerei nahe, am meisten bei dem täuferischen Biblizismus; dazu kam die von der sadistisch grausamen Verfolgung gesteigerte furchtbare Nervosität. Die beiden Gruppen bedeuteten die Herausarbeitung von festeren mystisch-spiritualistischen Gemeinschaften aus diesem regellosen Enthusiasmus und wurden damit bedeutsame Kräfte in der Ausbildung der großen mystischen Bewegung, die dann in der englischen Revolution und im Pietismus sich auswirkte.

Die Joriste $n$ gehen auf David Joris zurück, einen niederländischen Zeitgenossen Luthers, der in die reformatorische und dann in die täuferische Bewegung hineingeriet; da suchte er die beiden Flügel der letzteren, den radikal-gewaltsamen und den leidenden, zu vereinigen in dem übergeordneten Prinzip der Mystik, deren Ethik er im Sinne der Gelassenheit und Bruderliebe, aber nicht ohne libertinistische und antinomistische Folgerungen aus dem Grundsatz der Freiheit und Vollkommenheit des Geistes lehrte. Seine Besonderheit aber war, daß er aus dieser Mystik eine Gemeinschaft herausbildete, die ohne Kult und Sakramente an seine eigene Person gehunden war, indem er sich in wunderbaren Visionen zum $T$ äger des Christusgeistes oder zum dritten David beim Anbruch der neuen Weltzeit, des dritten Reiches, bezeich-

I 462-502, auch Gottfried Arnold. Hier erscheinen sie lediglich mit ihrer spiritualistisch-mystischenWirkung, die die Bindung an geschichtliche, kirchengründende Heilstatsachen überflüssig oder zu bloßen Hilfsmitteln des eigentlich entscheidenden, ganz individuell-persönlichen Vorgangs macht. Das hat Ritschl mit dem Scharíblick des Hasses richtig erkannt, - Ueber Kepler gleichfalls Eucken S. 38-53; hier das charakteristische Bekenntnis Keplers gegen einen orthodoxen Gegner: $>$ Tibi. Deus in naturam venit; mihi natura ad divinitatem aspirat « $s .43$. Sein Verhältnis zur Schrift bei Deißmann, Kepler und die Bibel 1894 ; dort auch die Analogik Seb. Francks S. 28.f. betont. - Ueber Amos Comenius s. den Artikel von Schiele in seinem Lexikon und die Veröffentlichungen der Comeniusgesellschaft, die ganz koirsequent auch die übrigen Spiritualisten unter ihre Fittiche genommen hat, leider in der oft unkritischen, wenn auch cinem richtigen Instinkt folgenden Weise ihres Leiters, Ludwig Keller. Ueber den Zusammenhang von Askese, Spiritualismus und Pietismus mit einer empirischen Pädagogik und Philosophie s. die sehr erleuchten den Bemerkungen von Max Weber, Archiv XXI S. 53 u. 97. 
nete. Zugleich schuf er einen familienhaft persönlichen Verband um sich herum, für den er in phantastischen Verkündigungen und Botschaften die Anerkennung von staatlichen und kirchlichen Gewalten verlangte. Er bejahte für seine Person, was Schwenkfeld, Franck, Coornheert und die Kollegianten leugneten, den wunderbaren Beruf. Zugleich brachte er ihn mit seiner Lehre von den drei Weltzeiten und von einer besonderen Einwohnung und Erschließung des bisher unvollkommenen offenbaren Christusgeistes in seiner Person in Verbindung. Deshalb griff ihn auch der sonst mit seinen spiritualistischen Grundsätzen einverstandene Coornheert heftig an. Bereit, äußerlich sich allen beliebigen Kulten anzuschließen, lenkte Joris schließlich in Basel als geehrter Bürger heimlich eine große, überall hin verzweigte Gemeinde, die gleichfalls sich nur als geheime Gemeinde verbreitete. Noch radikalen Pietisten wird Ansteckung durch joristisches Gift vorgeworfen, wie denn seine Schriften noch Ende des I6. Jahrhundert neu aufgelegt wurden. Das Ketzerrecht konnte von den entrüsteten Baslern, die in ihm einen vornehmen fremden Herrn von exemplarischer Frömmigkeit gesehen hatten, erst an seiner Leiche ausgeübt werden. Eine interessante Wiederholung ähnlicher Vorgänge ist die moderne Sekte der Nazarener, deren Prophet Wirtz Aehnliches von sich aussagte und deren Gemeinde in ähnlicher Weise heimlich verbunden war, im übrigen eine Trägerin der uralten mystischen Traditionen und Literatur ${ }^{490}$ ).

490) Hierüber Gottfried Arnold, für den der von der Rechtgläubigkeit über jedes Maß gehaßte Erzketzer und Blasphemist ein Lieblingsheiliger ist, ein Zeichen . der Neigung mancher $Z$ weige des Pietismus für ihn; außerdem die mustergültige, das ganze Thema aufarbeitende Untersuchung von Nippold, Z. f. Hist. 1863 u. 1864. Hier die Auseinandersetzung des Joris mit Menno Simons B. 33 S. 14I-I 49 und B. 34 S. 533-557, die den Unterschied von Sekte und Mystik vorzüglich erleuchtet: (jeist gegen Buchstabe, Freiheit gegen Gesetz. Die drei Typen B. 34 S. 554, wo Blesdyk auseinandersetzt: DDie einen (die Sekte) haben eine falsche Zuversicht auf äußerliche Tugenden und opfern alles für buchstäblichen Glauben auf .., die andern (die Kirchen) haben eine falsche Zuversicht auf einen selbsterdachten Gottesdienst ... oder auf den Wahn, den sie Glauben nennen, daß Christus für sie gestorben, ihre Gerechtigkeit und Heiligung geworden ist ... Und diese falsche Zuversicht stützen und unterhalten sie, die einen mit vielen äußerlichen Werken, die andern mit Erzählen und Lesen der hl. Schrift, welche sie nach gelehrten Kommentaren dem Volk erklären, aber Gottes Wort nennen, und mit Gebrauch des Nachtmahles, welches sie für eine Versiegelung der Erlösung und Rechtfertigung halten. Dem gegenüber verkündet Joris die Religion des Geistes als neu erweckter Prophet 
Aber auch schon gleichzeitig erhob sich neben den Joristen ein bedeutendes Seitenstück, das Haus der Liebe * oder die $\mathrm{F} \mathrm{a}$ milia caritatis *. Ihr Stifter war der Kaufmann Heinrich Nikläs, der unmittelbar aus dem Katholizismus heraus ohne Anschluß an eine der Reformparteien sich einem visionären Enthusiasmus und den bekannten Gedanken der deutschen Mystik von der Vergottung und Gelassenheit, vom göttlichen Licht- und Liebesfunken, sowie der Fleisch und Buchstaben überwindenden Ethik der Frommen und Vollkommenen ergab. Seine Wirkung aber hat er doch erst auf protestantischem Boden gefunden, indem er sich als den Propheten der letzten Tage auf Grund seiner visionären Berufung, und seiner Vergottung darstellte und die bekannten drei Stufen der Heilsgeschichte auf sich als den Propheten der letzten Stufe bezog. Auf dieser letzten herrscht die reine Innerlichkeit des Geistes wie einst im Urstand und die reine asketische Heiligkeit und Liebe, zugleich jene völlige Freiheit von Gesetz, Geschichte und Buchstaben, die als vollendete Schwärmerei erscheint. Bedeutsam aber ist, daß dieser Prophet seine Gemeinde nicht bloß im Personenkult mit sich verbunden, sondern eine hierarchisch-kommunistische Organisation geschaffen hat, die nach dem Vorbild der Täufer die reine Gemeinde des neuen Jerusalem hervorbringen und nach dem des Katholizismus zugleich ein heiliges Priestertum darstellen sollte, das letztere freilich nur auf innerer Erwählung beruhend. Auch dieser Gruppe ist Coornheert entgegengetreten, da sie das hierarchische

S. 554. Die Auseinandersetzung mit Coornheert 34, S. 627-64I, besonders S. 635 : - Hierbei wirft der Verteidiger (des David) dem Coornheert vor, er verstehe Davids Meinung (insoferne C. festhält an der Verkörperung des Geistes in der Bibel statt in dem neuen Propheten) nicht, weil er sie mit Francks und Schwenkfelds Ansicht, mit denen er (C.) selbst übereinstimme, verwechsle. Denn David lehrt nicht wie diese, daß in den letzten Zeiten niemand mehr den anderen mündlich und schriftlich belehren wird, sondern Buchstaben oder äußere Lehre nennt er das, was von weltlichen Weisen ohne den Geist gelehrt wird. Dem gegenüber bezeichnet er das, was von dem wahren Gesandten Christi (d. h. durch David selbst) durch den heiligen Geist, zumal in den Zeiten des heiligen Geistes oder der Vollkommenheit gesprochen wird, als Geist und Leben." Das erleuchtet in der Tat den Sachverhalt. Keine Klassenbedingtheit dieser Sekte 34 S. 575, Neue Ausgaben Ende des 16. Jahrh. B. 34 S. 566, 627, 667. Vorwürfe des Jorismus gegen Knutzen 1674: 34 . 672. Den Eindruck auf den radikalen Pietismus bezeugt auch Arnolds Ehrenrettung. - Ueber die Sekte der Nazarener Kalbe S. 275-285. Ein Verwandter von mir, der Anhänger dieser Gruppe war, besaß die ganze übliche mystische Literatur, einschließlich Gottfried Arnold und der Berleburger Bibel. 
Amt erneuere und die einfache Enthaltenheit des Geistes in der Bibel schwärmerisch verunreinige. Aber auch sie hat große Ausbreitung gefunden, vor allem in England, wo Bunyan dic allegorisch-mystische Reise des Propheten zu seinem Pilgrims Progress umgestaltete und wo man fast alle schwärmerischen Erscheinungen mit den Familisten in Verbindung brachte. Insbesondere hat man die sog. Kanters, eine besonders exzentrische spiritualistische Gruppe, von ihnen hergeleitet. Mit der englischen Revolution verschwindet ihre Spur. Eine gewisse Aehnlichkeit mit ihnen bietet in neuerer Zeit die Grundung. Irvings, die apostolische Kirche. Neben ihnen gab es noch manche kleinere Prophetengemeinden von ähnlichem Wesen, aber von geringerer historischer Bedeutung, zum Teil aus abgefallenen Anhängern der beiden Gemeinden bestehend? ${ }^{491}$ )

Gehörten diese Gruppen den kirchlich noch nicht festgelegten Verhältnissen Hollands an, so stellten die $\mathrm{L}$ a b a diste $\mathrm{n}$ eine klösterlich-kommunistische Hausgemeinschaft im Gegensatz zu der reformierten Staatskirchlichkeit der Niederlande dar. Labadie war ursprünglich katholischer Priester und stand dem Jesuitenorden nahe. Von der quietistischen Mystik und der Lehre vom inneren Wort ergriffen, näherte er sich den augustinisch-reformierten Lehren, trat zum Calvinismus über und fand, aus Frankreich vertrieben, begeisterte Aufnahme bei den niederländischen Pietisten. Seine Gemeinde in Middelburg organisiert er aber bald auf.Grund

401) Vgl. Gottfried Arnold und Nippold, Z. f. hist. Theol. 1862. Hier ist freilich die englische Entwickelung der Gruppe nur sehr dürftig behandelt. Ueber die letztere s. Belfort Bax 338-380; er bringt Ranters und Quäker mit ihnen in Zusammenhang; ebenso Barclay, The inner life of the religion societies of the commonwealth $1876,25-35$. Keine Klassenbewegung Nippold 370, Anerkennung der bestehendẻn Gesellschaftsordnung und äußere Fügung in gegebene Verhältnisse, auch kirchliche 377 ; Gegnerschaft Coornheerts 388 und 536 ; die ideale Ethik im Sinne libertinistischer Mystik 516, der Grundsatz der heiligen Gemeinde und Bußzucht aus Täufertum stammend, 539-542, die hierarchisch-kultische Geheimorganisation, aber ohne Sukzession und. Anstalt, lediglich innere Berufung des Geistes und Anerkennung dieser Berufung durch Weihe 549-563. Es ist eine eigentümliche Mischung von spiritualistischer Mystik, visionärem Enthusiasmus, katholischer Hierarciiie und täuferischem Gemeindeideal, zugleich sehr starke Betonung der im dritten Reich wiederherzustellenden Vollkommenheit und Gotteinigkeit des Urstandes. Daher bringt Berens Winstanley in engen Zusammenhang mit den Familisten S. $15 \cdots 18$. - - Ueber den Irvingianismus s. Kalbe S. 439 bis 455 . - Weitere Propiltmenen sind die Ubboniten, Heppe S. 68, andere in den beiden Abhandin $\rightarrow n$ in ippolds. 
des inneren Wortes, des Stufengangs der Gotteinigung und der strengen Askese zu einer neuen Gemeinde des kommenden himmlischen Jerusalems, wurde aber infolgedessen von seinen alten Freunden fallen gelassen. Das spiritualistische Prinzip mit dem klösterlichen und dem täuferisch-chiliastischen verbindend hat er dann seine kommunistische Hausgemeinde geschaffen, die zu einem un: ruhigen Wanderleben verurteilt war, bis sie unterging, nicht ohne nach allen Seiten Keime des mystischen Denkens auszustreuen. So gehört er sowohl der Geschichte des Sektentypus als der der Mystik an, eine Doppelseitigkeit, die wir bereits mehrfach festzustellen hatten, die aber die Getrenntheit beider Typen nicht aufhebt ${ }^{492}$ ).

Auch außerdem wurden die $\mathrm{Nie} d \mathrm{e} \mathrm{rla} \mathrm{nde}$, wo noch alte Ueberlieferungen der Mystik des 15. Jahrhunderts nachwirkten und die in ihrer vorcalvinistischen Reformationsepoche Schauplatz und Zufluchtsort aller möglichen mystischen Bewegungen gewesen waren, um die Mitte des 17. Jahrhunderts von einer neuen Welle der mystischen Bewegung durchflutet, ähnlich wie gleichzeitig England. Der von dorther eindringende puritanische Pietismus bildete, wie wir bereits gesehen haben, die Brücke zu einer die kirchliche Heilslehre, den Kult und die Heilsgeschichte vergleichgültigenden Mystik. Der jüngere Teellinck, Lodensteyn, Brakel im 17. und Schortinghuys im 18. Jahrhundert streiften die Grenze der Aufhebung jedes kirchlichen Heilsgedankens ${ }^{493}$ ). An-

492) Vgl. Heppe S. 240-374, Ritschl I 194-246. Die Doppelheit des Motivs : >die Mystik und der Gedanke, daß der Wiedergeborene mit dem Nicht-Wiedergeborenen keine Gemeinschaft haben dürfe S. 316. Charakteristisch der Gegensatz des reinen Spiritualisten Gichtel, $>$ der mit dem geschlossenen Sektenwesen sich nicht zurechtfinden konnte, indem er selbst durchaus keine Sekte bilden wollte ebd. 317. - Andauernde labadistische Einwirkungen auf die niederländische Kirche Heppe 394-464 die Konventikel waren der Boden, auf dem sich ganz gewöhnlich Pietisten, Labadisten und Hattemisten die Hand reichten 4399 ; in der deutschreformierten Kirche Heppe 482 u. 489 . Dabei fielen die kommunistisch-klösterlichen Bestrebungen zu Boden, aber es blieb die Neigung zur Separation, zur geschichtslosen Mystik, zum Enthusiasmus, zum Chiliasmus, Perfektionismus und gelegentlich auch die sexuell ungebundenen Neigungen eines solchen Perfektionismus. Ueber die Ausläufer dieser Bewegung in den philadelphischen Sozietäten, darunter der sog. Butlarschen Rotte s. Hochhut, Geschichte und Entwickelung der philadelphischen Sozietäten, Z. f. hist. Theol. 1865. - Ueber Analogie und Zusammenhang mit den Waldensern und Täufern s. Maronier S. 316; auf der Reise von Genf. nach Middelburg hat Labadie in der Tat bei pfälzischen Waldensern seine Zuflucht gefunden. $\quad{ }^{493}$ ) Vgl. Heppe S. $169-204,375-489$. 
dere, wie die Verschooristen und Hattemisten, näherten sich dem Pantheismus. Die ganze Atmosphäre ist die Voraussetzung sowohl für die Ethik Spinozas als für die des Geulincx ${ }^{494}$ ). Die Collegianten erwachten aus ihrem stillen Leben und trugen durch Galenus ihren Independentismus, ihr Prophetisieren und ihren Spiritualismus des inneren Lichtes als reformatorische Kraft in die täuferischen Gemeinden hinein, woraus bis ins I8. Jahrhundert hinein tiefe und leidenschaftliche Gegensätze hervorgingen. Neue Propheten des Enthusiasmus und der Heiligkeit standen auf, von der leidenschaftlichen Spannung des neuen großen niederländischen Daseinskampfes gegen Ludwig XIV. ergriffen. Lutherische Mystiker und Anhänger Böhmes neben den Sendboten der quietistischen französischen Mystik machten eifrige Propaganda. Die Missionare der Quäker weckten auch in den Niederlanden den Gedanken einer jetzt erst einsetzenden wirklichen Reformation der Christenheit, nachdem die Reform Calvins und Luthers nur eine Art neuer Katholizismus gewesen sei und die Christenheit innerlich unverändert gelassen habe. Die zweite Hälfte des 17. Jahrhunderts sah so in den Niederlanden die Mystik zu einer großen, breite Volksmassen erfüllenden Bewegung ansteigen. Alle Stände waren daran beteiligt, wenn auch in den verschiedenen Gruppen verschieden. Der nur die Kirche ergänzendc Pietismus blieb von dem unkirchlichen Spiritualismus deutlich geschieden, auch wenn die pietistischen Mystiker sich

494 Veber den Verkehr Spinozas mit Collegianten und Mennoniten s. Kuno Fischcr, Gesch. d. n. Ph. 1 165, 1.37 f.; über seine Verwandtschaft mit dem Spiritualismus ibid. S. 153-155 nach den Briefen : „Zur Seligkeit halte ich es nicht für notwendig, Christum nach dem Fleisch zu kennen; ganz anders dagegen denke ich ron jenem ewigen Sohn Gottes, nämlich der ewigen Weisheit Gottes, welche sich in allen Dingen, am meisten im menschlichen Geist, unter allen Menschen am meisten in Jesus Christus geoffenbart hat; denn ohne diese Weisheit, die allein lehrt, wie sich Wahrheit und Irrtum, Gutes und Büses unterscheiden, kann niemand selig werden.* Das ist die Lehre der Spiritualisten. Auf solche Zusammenhänge verweist auch Windelband, Gesch. d. n. Ph. I 213. Hegler S. 288 wirft mit Recht die Frage auf, ob Sp. den vor allem in Holland fortgepflanzten Seb. Franck gekannt habe. Auch Hylkema, Reformateurs, Haarlem 1900 und 1902 stellt Spinoza in diesen Zusammenhang II $367,473-477$. Das scheint mir überhaupt erst die religiö-ethische seite von Spinozas Denken zum Verständnis zu bringen. Auch feulincx schürt unzweifelhaft nach der religiös-ethischen scite hin in den gleichen allgememer /usammenhang, wic Heppe mit Recht hervorhebt. 
schließlich nur mehr durch ihren Willen zur Kirche von ihm unterschieden. Er setzte sich praktisch zumeist in der Weise fest, daß er zunächst bei den längst mit dem Staat ausgesöhnten täuferischen Gemeinden cindrang, um sie - unter heftiger Bekämpfung der täuferischen Sekte selbst -- als Sprungbrett zur reinen kirchenfreien Mystik zu benützen und dann ihren alten weltverbessernden Radikalismus wiederzu beleben. Dadurch erhielt dieser Spiritualismus von Haus aus zugleich eine praktisch-reformatorische schwärmerische Richtung, die er bei Seb. liranck und Coornheert noch nicht gehabt hatte. So verschiedenartig diese Geister waren, einig waren sie in der Verwerfung der sakramentalen Kirche und der buchstäblichen Sekte, der Massenchristenheit und der äußeren Autorität, der bisherigen Geschichte der Kirche von Konstantin bis Luther und Calvin. Es ist überall der echteste Spiritualismus mit seinem radikalen Individualismus, seiner Kritik an Buchstaben, Autorität und Dogma, seinem Drang nach Unmittelbarkeit und Gefühlsmäßigkeit, seiner Unabhängigkeit des inneren Christus von der äußeren Christenheit und ihren Geschichtswundern. Sehr bunt und verschiedenartig sind frcilich ihre Gemeinschaftsbildungen. Die einen bcnutzten; wic bereits gesagt, die Täufergemeinden, indem sie zugleich deren inneren Daseins grund aufösten. Die anderen hatten rcin persönliche Prophetengemeinden oder geschlossene Hausgemeinden nach Art der Labadisten. Andere suchten neue Vereinigungen oder bestritten auch alle äußere Gemeinschaft überhaupt und erwarteten das völlig freie Wirken des Geistes in einem neuen Zeitalter der rein geistigen Kirche. Ebenso verschiedenartig ist ihre Ethik, die nur überall die Grundzüge der spiritualistischen Askese, der Ueberwindung von Fleisch und Welt trägt. Aber hier gibt es dann im einzelnen rein quietistische Gelassenheit, übersittliche rein geistige Freiheit der Wiedergeborenen mit völliger Unabhängigkeit von allen Konventionen bürgerlicher Moral auch in sexuellen Dingen, puritanisch-pietistische Berufsund Arbeitsaskese verbunden mit größerer oder geringerer $\mathrm{Zu}$ rückhaltung von den Ordnungen des Staates und den Sitten der Gesellschaft, schwärmerische Erwartungen des Weltfriedens und Verzicht auf Recht, Macht und Gewalt in jedem Sinne, vor allem die Gleichgültigkeit einer enthusiastischen Innerlichkeit gegen alle Moral überhaupt und den inneren Drang zur opfervollsten Liebestätigkeit. Toleranz und Gewissensfreiheit, Ausschaltung des Staates aus allen religiösen Dingen, das Ideal eines möglichst auf 
906 III. Protestantismus. 4. Sektentypus und Mystik auf protestantischem Boden.

Liebe, Frieden und Gesamtwohlfahrt aufgebauten Staates verstehen sich dabei von selbst, ebenso wie der heftige Gegensatz gegen den bestehenden Macht- und Gewaltstaat der fleischlichen Selbstsucht. Doch soll alle Reform von innen herauskommen aus der Macht des Geistes, soll ohne Revolution und äußere Gewalttat von selbst sich durchsetzen. So hat denn auch die Staatsregierung diese Leute sehr zum Verdruß der Presbyterien und Geistlichen, im wesentlichen gewähren lassen, so lange sie seine Institutionen und die herrschende Sitte nicht praktisch gefährdeten. Wie aller übermäßig gespannte Idealismus, so ist auch dieser allmählich in sich selbst versickert; wie auch überall sonst, ging sein heiliger Christusgeist, der ja auch ihm mit Gewissen, Vernunft und Naturgesetz einig war, in die rationalistische und philosophische Vernunft über ${ }^{495}$ ).

Eine noch bedeutendere Entfaltung gewann der Geist der Mystik in den durch die englische Revolution geschaffenen Ver-

495) Ueber diese neue Flut mystischer Bewegung s. das hochinteressante Buch von Hylkema. Es ist eine Fundgrube von charakteristischen Eigentümlichkeiten des Spiritualismus und zeigt in überraschender Weise die Parallele zu der englischen Bewegung. Der Name freilich ist nicht glücklich gewählt, auch ist der dogmengeschichtliche Zusammenhang mit dem früheren Spiritualismus und das Verhältnis zu den Täufern nicht genügend klargestellt; die politisch-sozialen sowohl als die theologischen Lehren dieses Spiritualisten sind zu sehr modernen, rationalistischen und politisch-sozialen Erscheinungen angenähert. - Keine Klassenbedingtheit I 80, II 205-208; gemeinsamer Gegensatz gegen Kirche und Täufer I 138, 169, 185, II 7; radikale Unkirchlichkeit I Iooff., Gegensatz auch gegen den innerkirchlichen asketischen Pietismus II $86 \mathrm{f}$., 472 ; Identität des wahren ethischen Gehaltes des Geistes mit Gewissen und Vernunft I 161, 167, 176; die Ethik im Verhältnis zum Staat I 147-I78, nach innen II I-III. Sehr treffend ist die Hervorhebung der prinzipiellen Unabhängigkeit und Fremdheit dieser religiösen Idee gegen alle Moral überhaupt II 83-III; am meisten calvinistisch-puritanische Züge bei den Collegianten, kommunistisch-sektenhaft-demokratische Züge bei den anderen. Sehr interessant ist bei den ersteren auch die Uebereinstimmung mit den von Max Weber charakterisierten ökonomischen Zügen des sasketischen Protestantismusa; van Hoek ruft seinen Collegiantenbrüdern zu: >Vergenoegt $\mathbf{u}$ met een seedig gelat en gemoed, met deftighijd in handel en wandel ! \& II I4; hier findet auch das von Weber so stark betonte systematisch-rationale Element der reformierten Askese seinen klassischen Ausdruck II 49: , Liever dan er ook maar de minste ruimte aan te geven (d. h. dem Fleisch), wil hij het st el sel matig tyraniseeren. Juist omdat het vleesch op gemak gestelld is, zal hij sich zetten tot strengen arbeid etc. \& Bei den eigentlichen Spiritualisten und reinen Mystikern dagegen fällt diese Methodik zugunsten der Freiheit des Geistes weg. Es ist ein starker Unterschied zwischen 
hältnissen. Die E n gl ä n d e r, denen man die praktische Nüchternheit und Verstandesmäßigkeit wie ein anthropologisches Merkmal zuzuschreiben pflegt, hatten ihr großes mystisches Zeitalter. Freilich stand auch hier die entsagende, duldende, alles vom Wirken des inwendigen Christus erwartende Mystik in der unmittelbaren Bedeutung zurück hinter den aggressiveren und praktischer auf die Welt eingerichteten Gestaltungen der christlichen Moral, erst hinter der presbyterianischen politischen Religion und dann hinter den radikal-täuferischen Idealen. Allein neben und unter dem allen war eine starke spiritualistische Strömung, die den Gedanken der vollen Trennung von Staat und Kirche, des radikalen Laienchristentums, der freien Prophetie und Predigt, der von innen heraus erfolgenden ethischen Erneuerung in Opferwilligkeit und Bruderliebe, der frei aus dem Innern quellenden, durch kein schulmäßiges Dogma und keine Gelehrsamkeit verfälschten Lehre in die Massen trug und damit diese Massen teils dem Independentismus, teils dem Täufertum erst geneigt machte. Beide boten für die Mystik allerhand Einsatzpunkte, und umgekehrt konnte die Mystik leicht zu der Folgerung der freien Gemeindebildung und der Bindung der Sakramente an volle Würdigkeit führen, wie sie von jenen vertreten wurde. Auch war es nicht schwer, von dieser Seite her den puritanischen Pietismus zur Preisgebung seiner kirchlichen Denkweise zu verlocken. Und wo sich die Mystik von all diesen Verschmelzungen fernhielt oder aus ihnen sich befreite, da schuf sie die rein der Innerlichkeit zugewandten Gruppen wie die Seekers oder Waiters und die Quäker oder orgiastisch-libertinistische Gruppen wie die Ranters. So wurde sie hier zu einer Macht des allgemeinen Lebens wie nie zuvor und nachher nie wieder. Ihre Wurzeln lagen in der ganzen Vorgeschichte des Cromwellschen Zeitalters. Der Pietismus hatte sich bereits der Mystik geöffnet bei Hall, Francis Rous und James Janaway. Daneben aber gab es auch bereits unter den Stuarts radikale Spiritualisten, so vor allem John Everard, den eine holländische Quelle als Vorläufer der Quäker bezeichnet. Er war, am Anfang des I 7. Jahrhunderts lebend, Prediger und Schriftsteller, übersetzte den Poimandres, den Areopagiten, Schriften Taulers, die deutsche Theo-

der die reformierte Berufsmoral anerkennenden und als Zuchtmittel verwertende und der quietistisch-kontemplativen Mystik. Auch die enthusiastischen Weltreformer haben mit der protestantischen Berufsmoral wenig zu tun; hier dominiert der Geist der radikalen welterneuernden Sekte. 
logie, den Widerruf Hans Denks u. a. ins Englische und trug selbst in seiner Geöffneten Schatzkammer * den verwegensten Spiritualismus des inneren Wortes und der Erlösung durch innerliche Gotteinigung vor. Dabei berief er sich auf Plato, Plotin, Proclus, Origenes, Augustin, Bernhard, auch auf den heiligen Franz. In fortwährendem martyrienreichen Kampf mit der Staatsregierung und Kirche erwarb er einen mächtigen Anhang, mit dem die Familisten und andere Ansätze der Mystik sich verschmolzen zu haben scheinen. Dazu kamen dann weiterhin die Gemeinden von Anhängern Jakob Böhmes, dessen Werke von den Niederlanden herüberdrangen und jetzt ins englische übersetzt wurden; sie haben noch George Fox in seinen Anfängen stark beeinflußt, bis er sich wegren der von den Böhmisten beibehaltenen Sakramente von ihnen wandte. Nicht zu vergessen ist daneben die große Schule englischer Platoniker zu Cambridge, die eigentliche philosophische Leuchte des damaligen England, die in die Finsternis des kirchlichen Aristotelismus hineinschien und eine mystische Ethik im Sinne der Neuplatoniker verkündigte; die rationalistisch-technische Fortschrittsphilosophie des Fürstendieners Baco hatte daneben so gut wie gar keine Bedeutung. Aber es blieb nicht bei dieser in letzter Linie wissenschaftlich und begrifflich begründeten, auf ruhigen und dauernden Geistesprinzipien sich erhebenden Mystik. Neben ihr entfaltete sich, von der täuferischen I iteratur und niederländischen Einflüssen genährt und in den furchtbaren Wirren der Zeit gesteigert, die enthusiastische Mystik der Visionäre, Convulsionäre und Propheten ; sie war stark chiliastisch gefärbt und dogmatisch gänzlich allerhand plötzlichen und wechselnden Einfällen und Liebhabereien preisgegeben, hatte aber auch ihrerseits ihre Bedeutung in der Weckung des religiösen Unmittelbarkeitsdranges und in dem Streben nach ethisch-asketischer Bewährung. Dadurch floß sie mit der ersterwähnten eigentlichen Mystik hund $\epsilon$ tfach zusammen. Zugleich verschloß sie sich nicht auf enge Kreise, sondern ergoß sich über alle. Auch Staatsmänner und Generäle handelten nach Eingebungen und Erleuchtungen und lauschten achtungsvoll den sich darbietenden Propheten, die ja möglicherweise ein wirkliches Wort Gottes haben konnten. Cromwell zum Beispiel meinte bei längerem Austausch mit Fox wohl noch einig mit ihm werden zu können, was dieser freilich mit Grund für einen Irrtum hielt. Dazu kam die anarchische Entwickelung des Independentismus. Ursprünglich rein calvinistisch und nur die Selbständig- 
keit der aus wirklichen Christen bestehenden Gemeinden fordernd, verfielen die Independenten in schwärmerische Willkür. Sie verlangten und übten die freie Predigt von Männern und Frauen, beriefen sich auf unmittelbare Erleuchtung und Geisteszeugnisse und trieben die Folgerungen aus dem Prinzip der Wiedergeborenen-Gemeinde bis zum radikalen Individualismus. Ebenso zeigten die Baptisten neben den streng mennonitisch gefärbten General Baptists die alte Neigung des Täufertums, sich mit Enthusiasmus und Spiritualismus zu verbinden. Aus all diesen Kreisen und Einflüssen setzten sich die »Geisttreiber « zusammen, wie sie die erbitterte Polemik der Puritaner zu nennen pflegte. So ist es zu begreifen, daß die beiden großen Prediger des Cromwellschen Hauptquartiers, John Dell und John Saltmarsh erklärte Spiritualisten gewesen sind. Der erste lehrte, daß die wahre Kirche sich allein auf das Wort und die ihm einwohnende Wundermacht begründen solle, indem das Wort die Gemeinden von selbst um sich schare und hervorbringe: man müsse ihm nur völlig freien Lauf lassen, wie das schon Luther in seinen Anfängen gelehrt habe. Auf die Frage, wie denn dann die Gläubigen die wahre Predigt und die echten Träger des Wortes erkennen sollten, antwortete er mit dem Satze, daß die Gläubigen die Gabe hätten, sich gegenseitig zu erkennen. Freilich ist das Wort, um das es sich hierbei handelt, stets das innere Wort, das dem Bibelwort und dem Wiedergeborenen gleicherweise immanent ist und zeitlos wie der Logos über beiden schwebt. Der andere trug die alte mystische Lehre vor von den drei Stufen der Heilsgeschichte von Adam bis zu Christus, von Christus bis zum Zeitalter des Geistes und von diesem als dem gegenwärtig beginnenden bis zum himmlischen Jerusalem. In dieser dritten Periode gibt es überhaupt keinen Buchstaben und kein Gesetz, kein geistliches Amt und keine äußere Kirche, sondern nur den in der Liebe sich erweisenden inneren Christus. Es sind die Gedanken die man von Seb. Franck, Coornheert und den Collegianten her kennt; auch an Schwenkfeld erinnert manches. Auch hier waren es, wie in der niederländischen Mystik, sehr verschiedene Geister, und doch hatten sie alle etwas Gemeinsames. Sie bildeten teils neue eigene Kultgemeinschaften, teils ließen sie sich in die freigemachten kirchlichen Aemter setzen, teils bekämpften sie jedes Amt und jeden Kultus überhaupt. Die einen erkannten den Zehnten und damit das darauf aufgebaute kirchliche Amt an, die andern verwarfen eines mit dem andern. Die Bewegung ging 
910 III. Protestantismus. 4. Sektentypus und Mystik auf protestantischem Boden.

durch alle Klassen; sie trug überall den asketischen Zug, der bei den extremen Schwärmern in die Freiheit des Fleisches umschlug. Am schwierigsten war für sie das Problem des Krieges und der auf äußerem Rechtszwang beruhenden Obrigkeit. Hier haben die einen den heiligen Krieg für die Endzeit zugegeben, die andern haben ihn auch jetzt verworfen. Die einen wollten Staat und Recht nur bei christlicher Handhabung anerkennen, die andern wollten um der Ordnung willen sich in das Gegebene fügen. So viel Köpfe, so viel Meinungen, in allen aber ein ungeheurer utopischer Idea-, lismus, der von dem Zeitalter des Geistes die Aufrichtung einer Lebensordnung im reinen, kompromißlosen christlichen Sinne erwartete ${ }^{496}$ ).

496) Zum Ganzen vgl. Hylkema, der die Zusammenhänge des holländischen und englischen Spiritualismus, besonders die Bedeutung der Collegianten für die Seekers und Quäker mehrfach beleuchtet; ferner und vor allem Barclay, der außerordentlich viel Material in undurchsichtigster Ordnung gibt; allein seine Darstellung versetzt völlig in die Atmosphäre der Zeit und beleuchtet allenthalben die Unterschiede zwischen Independenten, Baptisten und reinen Spiritualisten, auch die wechselnden Entwickelungen, Annäherungen und Entfernungen dieser Gruppen. Entscheidend ist für ihn mit Recht bei der Aussonderung der echten Spiritualisten das Kriegs- und Resistence-Problem. - Auf dem Material beider und Verfolgung der von ihnen gegebenen Winke beruht die höchst lehrreiche Arbeit Sippells, Ueber den Ursprung des Quäkertums, Chr. W. 1910 und „Dells Programm«. Er hat vor allem die mystischen Traktate und ihren Zusammenhang mit den Collegianten und damit indirekt mit Coornheert aufgehellt und auch die Beziehungen zu Luthers anfänglichem spiritualistischen Gemeindeideal verfolgt. Mehreres verdanke ich mündlichen Mitteilungen Sippells, der mir auch mehrere in seinem Besitz befindliche seltene Traktate der Zeit gütigst zur Verfügung gestellt hat. So habe ich Dells Predigten und Dells Select Works, London 1773 , und den wundervollen kleinen mystischen Traktat von Saltmarsh, Sparkles of glory, London 1847 , sowie Eatons Honey-Combe kennen lernen. Erst aus diesen Traktaten versteht man. die Zeit. Ueber Dell s. nun die interessante . Irbeit Sippells; S. scheint mir freilich die Beziehungen zum Kongregationalismus, der schon seinerseits spiritualistische Elemente enthielt, zu unterschätzen und die zu Luther zu überschätzen. Dells Lehre ist doch in Wahrheit ein mit spiritualistischer Mystik versetzter Kongregationalismus, der überdies eine rein technische Unterstützung des Kirchenwesens durch den Staat akzeptiert, wie da, unter Cromwell nahe lag; auch an Schwenkfeld kann gedacht werden, wie Sippell neuerdings Chr. W. 191 I S. 966 selbst bemerkt. Bei den wesentlich calvinistischpuritanischen Independenten ist eine Entwickelung von ursprünglich reinem dogmatischen Calvinismus zu den enthusiastischen Independenten unter den Einwirkungen von Täufern und Spiritualisten, vor allem auch der Aufregung und Nervosität 
Diese spiritualistischen Hoffnungen scheiterten naturgemäß nicht anders als die radikal-täuferische Welterneuerung an den hartèn politisch-sozialen Notwendigkeiten. Das Ergebnis aller Kämpfe

der Zeit zu konstatieren: Barclay S. 150-159. Aber das ist doch nicht reiner Spiritualismus; vgl. die von Barclay mitgeteilte Stelle C. H. Spurgeons: „It happened that the Puritans were getting into the sere and yellow leafe; and the Independents and Baptists and other sects, who were at times throughly and even remarkably spirituel, were growing worldly, political, and vain glorious. They had.the opportunity of grasping the carnal sword and they embraced this opportunity; and from that very moment very many of them lost the spirituality for which they had been eminent. The danger was, lest the Evangelical sects should quietly settle down into one State Church .... and preach each one after bis fashion... At that very moment God sent into the world George Fox .. He stood up in the face of the christian world and said to it: No, thou shalt not da this. Thou shalt not conform thyself to the world. Thou shalt not go into an unholy alliance with the State; there shall be in the midst of the a spiritual people, who shall bear their protest, that Christ's Kingdom is not of this world, and that religion standeth not in forms and ceremonies, but is a matter connected with the inner man and is the work of Gods spirit in the heart." Das zeigt den ganzen Unterschied des Spiritualismus gegen die oben geschilderten täuferischhussitisch-hugenottisch-calvinistische Stimmung des Kriegs für die Aufrichtung des Königreichs Christi. Der gleiche Unterschied in der Bemerkung Barclays S. 625 : - The christianity of Cromwells soldiers at the commencement of our Civil Wars cannot be doubted, but it is more than doubtful whether it improved in quality by the conflict. They had however seen enough of war to be apt disciples of Fox, and many of them became preachers of the Gospel of peace and good will to men.e - Ueber englische Böhmisten Barclay S. 214, über die Seekers und ihren Zusammenhang mit den Collegianten S. 73 und 4I0-4I3; über die Ranters S. 4 I4 bis 428, B. führt sie bis auf die Libertins Calvins und die mittelalterlichen Brüder vom freien Geist zurück, während das mir eine bloße Analogie, erklärlich aus gemeinsamem Untergrund, scheint. - Die Entwickelung vieler spiegelt sich in dem Bericht über Salmons Traktat S. 428 I : „First he became a Presbyterian; they appeared to him to hover gently and soar sweetly in a more sublime region than the Episcopal people. Then came Independency on the stage, a people far exceeding others in the strictness of their form. Then the doctrine of Believers Baptisme. He became a Baptist preacher, braved persecution and built a tabernacle. Then came that voice from the throne of the Almighty: arise and depart, for this is not your rest. $-\mathrm{S}$. auch die Darstellung bei Firth, Cromwells Army. Hier drang der Spiritualismus durch die Laienpredigt ein und durch die Ersetzung aer presbyterianischen Kapläne, die sich zurückzogen, durch spiritualistische, Dell, Saltmarsh, Sedgwick, Hugh Peters, S. 320. Die allmähliche Zurückdrängung aus der Armee S. 340: A sober congregationalisme became the dominant form of religion. 
912 III. Protestantismus. 4. Sektentypus und Mystik auf protestantischem Boden.

war nach der einen Seite das Protektorat, dann die Restauration und schließlich der whiggistische Liberalismus, nach der andern die gründliche Abwcndung von allem christlichen Ueberidealismus, die Verweltlichung des Geistes zur Vernunft, womit der Deismus die große religionsgeschichtliche und religionsphilosophische Kritik der Neuzeit begann. Alles, was von dem mystischen Aufschwung ubrig blieb, das waren * die Kinder des Lichtes o oder »die Gesellschaft der Freunde , wie die $Q$ u ä k e r sich nannten. Sie sind in ihrer endgültigen Lehre die reinen Abkömmlinge des Spiritualismus der Reformationszeit, die Verkünder des inneren Lichtes, der persönlichen Wiedergeburt durch den ewigen Christus, der Identität des Geistes im Wiedergeborenen und in der Bibel, der Enthaltenheit des göttlichen Lichtes in dem jedem Menschen innewohnenden Lichtfunken, der in der Berührung mit der Bibel lediglich entbunden wird aus der Gefangenschaft durch Fleisch und Finsternis. Aber es wäre doch falsch, sie von hier aus allein verstehen zu wollen. Sie sind in Wahrheit die Verbindung dieser spiritualistischen Lehre mit der täuferischen Idee der reinen und heiligen, auf ernster Bekehrung beruhenden und staatsfreien Freiwilligkeitsgemeinde. Sie haben die natürliche Neigung des Spiritualismus zur Gemeinschaftslosigkeit gebrochen durch den Anschluß an die mennonitische und vor allem collegiantische Gemeindeverfassung.

Cromwell deutet das kommende Gottesreich im Gegensatz gegen die Quintomonarchisten spiritualistisch und will die äußeren Ordnungen daher bestehen lassen S. 341. Monk klagt über militärische Unbrauchbarkeit von Spiritualisten $344 \mathrm{f}$. Kassierung spiritualistisch gesinnter Offiziere $346 \mathrm{f}$. Hier die Charakteristik des Hauptmanns Jackson: In the language of the time, he was one of those who had passed through all forms, and was above all forms and above all ordinances, whose religion was not made up of laws and duties, but all exaltation and inward bliss For such, he said, all external forms of duties and performances are turned into praises and thanksgivings. Now there is nothing but mirth in them, there is a continual singing of birds in them, chirping sweetly, in a sweet harmony of soul-ravishing delightful music.\& Er erlag einem presbyterianisch gesinnten Oberst, war aber militärisch sehr brauchbar, weshalb Fairfax ihn nicht opfern wollte. Daß auch Cromwell hierin nicht zu weit gehen ließ und sozinianische oder antinomistische Folgerungen als derogation to the honour of God bestrafte, zeigt der Fall des Hauptmanns Covell $347 \mathrm{f}$. - Die Bedeutung der Familisten für das Ganze schränkt Sippell S. 2 sehr ein; er leitet Enthusiasmus und Mystik von der eschatologischen Wendung des Puritanismus her S. 5-IO. Doch ist bei Everard, Dell und Saltmarsh die ganze mystisch-spiritualistische literarische Tradition unverkennbar im Hintergrunde Sippell S. 80-88. 
Wie diese haben sie ihren engeren und weiteren Kreis, ihre L,ehrAeltesten und ihre Armenpfleser, ihre Versammlungen und Liebesmahle, dic freie L aienpredigt - dazu kommt hier das schweigende, der Erleuchtung harrende Meeting - , die Gemeindezucht und den J3ann. Nur vollziehen sie die Aufnahme nicht durch die Spättaufe, sondern durch die Anerkennung der Wiedergeborcnheit der Aufnahme Begehrenden, wozu man-wenigstens mit liücksicht auf clas äußere Verhalten - dic Vorsteher für befähigt hält. Die freic Gemeinde des Geistes muß auch hier voraussetzen, daß der Geist in der IVahl der Aeltesten und in der Aufnahme der Bewerber sich selbst erkennt. Insoferne stehen auch sie Luthers ursprünglichem, spiritualistischen Gemeindeideal nahe; sie lösen das damit entstehende Problem, wer denn dann zur Aufnahme und zum Amt berechtist sei, durch das Vertrauen zum Geist. lireilich mußten auch sie erleben, daß praktisch aus dieser frei vom Geist grebildeten Gemeinde durch die Gewöhnung an dic Nacht des Gemeinschaftslebens eine sich von den Eltern auf die Kinder forterbende Gemeinschaft wurde, ein $\gg$ Geburtsrecht statt des freicn Zustrümens aller Bekehrten zur Gemeinde der Gottesfreunde. Aber nicht bloß die Verfassung verband sie mit dem Täufertum. Auch ihre Ethik, die den Antinomismus scheute, band sich, wie die der Täufer, an die Weisungen der Bergpredigt, forderte den Verzicht auf weltliche Ehre, auf Macht, Kriegr, Recht, Eid und obrigkeitliche Aemter und schrieb die schrankenloseste Bruderliebe und Armenpflege vor. Nach dieser Seite hin sind sie, wie man sleichfalls mit Recht oft gesagt hat, die letzte und die reinste ()rganisation des Täufertums. Von da aus haben sie dann freilich auch die verbürgerlichende Entwickelung der ihnen so nahestehenden Mennoniten durchgemacht. Bei der ursprünglichen Weltfremdheit konnte es nicht bleiben; sie haben vielmehr dic reformierte Berufsethik mit ihrer asketischen Lebenshaltung in steigendem Naße verbunden. Gott hat dann auch »ihr Geschäft gesegnet « mit d'n ökonomischen Folgen, die diese Berufslehre des asketischen P'rotestantismus mit sich zu bringen pflegt. Strengste Arbeitspflicht, Beschränkung der Arbeit auf nützliche praktische I,cistungen in Handel, Industrie, Handwerk und I andwirtschaft; Mindesimaß des Luxus und der eigenen Konsumtion, Höchstmaß der Leistungen für die Gemeinde; gemeindliche Ueberwachung der geschäftlichen lihrlichkeit und Kreditwürdigkeit, des Familienlebens, der Kindererziehung; kurz das gleiche Ideal wie im alten calvinistischen 
Genf, nur auf Grund der Freiwilligkeit: das ist schließlich der Charakter der Gemeinde, die mit dem äußersten weltfremden Spiritualismus begann. Sie *verbürgerlichte* gerade auf Grund ihrer asketischen Berufsmoral, wie denn die Askese nach Bernstein (ine bürgerliche d. h. bürgerliche Lebenshaltung hervorbringende Tugend ist.

Besonders bedeutsam aber ist, daß ihnen das Schicksal durch ihren größten und reinsten Gläubigen, durch Penn, die Gelegenheit gegeben hat, auf dem jungfräulichen Boden Amerikas einen Staat und eine Gesellschaft mit Hilfe dieser strengsten und in vieler Hinsicht folgerichtigsten Fassung echt christlicher Ethik aufzubauen. Der Quäkerstaat von Pennsylvanien ist das wheilige Experiment $\ltimes$, die Schaffung eines wirklich christlichen Staates auf (irund der lireiheit des Geistes und der Strenge des Ethos zugleich. Es war cin Staat ohne religiöse $Z$ wangsgemeinschaft und ohne jede Bezichung politischer und religiöser Organisationen auf einander, nur durch dic praktisch infolge der Majorität der Quäker bestehende Christlichkeit bestimmt und durch die vertrauensvoll stets wiederholte Wrahl quäkerischer Vertreter in die Volksvertretung aufrechterhalten. Die Verhältnisse waren günstig in dem erst der Kultur zu erschließenden Kolonialland, wo nur mit Indianern und Nachbarkolonien Konflikte entstehen konnten, wo einfache fromme larmer ohne verwickelte Kulturbedürfnisse und ohne die Schwierigkeiten einer Massenbevölkerung in persönlich bekanntem kleınen Kreise ihre Angelecrenheiten ordnen und schlichten konnten. Es gelang mit den Indianern ohne Blutvergießen auszukommen und nach innen -- wenigstens am Anfang - die meisten Streitigkeiten in brüderlichem Schiedśspruch ohne Gericht und Zwang zu überwinden. Sowcit das nicht gelang, nahm man an einer formell rechtlichen Justiz und auch an der Todesstrafe keinen Anstoß; die Gewalt sesen einzelne unverbesserliche Friedensstörer schien etwas anderes al der Krieg und auch für das christliche Regiment Pflicht. (ié. cheitert ist dieser christliche Staat schließlich nach 7ojähriger Exitenz an dem Kriegsproblem und an der Toleranz. In die Kämpf: zwischen England und Frankreich hineingezogen und vom Nutterland zu kriegerischer Parteinahme genötigt, verlor die KoWnie da quäkerische Gepräge. Die (uäker ließen sich nicht mhe in die Vertretungen wäh!en, um die Kriegssteuern nicht bewilligen zu müssen. Dadurch siwannen die von der quäkerischen Toleranz stets geduldeten und ron ihnen nicht zu sich be- 
kehrten fremden Denominationen die Oberhand; die (Juäker aber verloren mit dem faktischen auch den geisticen Einfluß auf die Kolonie. In dem großen Unabhängigkeitskriege hatten die Quäker das tragische Schicksal, einem Kampfe untätig zusehen zu müssen, der zum großen Teil um ihre eigenen Ideale geführt wurde. Nun erkannten sie, daß das öffentliche Leben überhaupt nichts ist für den Christen und gaben das sheilise Experiment " für immer auf, während umgekehrt ein anderer Teil von ihnen, darunter liranklin, auf das alte christliche Prinzip der non-resistance verzichtete und sich dafür umso eifriger der demokratischen Idee als einer christlichen Forderung in die Arme warf. Die Hauptmasse zog sich, immer mehr in die Minderheit gedrängt, auf die rein gemeindliche Existenz zurück, wo sie ihre Reihen strenger schlossen und eine großartige Liebestätigkeit entfalteten. Aber auch so ließ sich die Verweltlichung nicht aufhalten. Der Ruhm dieser späten Zeit ist die wirkungsvolle Forderung der Sklavenbefreiung und humaner Negererziehung, nachdem sie in der Zeit ihrer Herrschaft bereits mit dem praktischen Beispiel vorangegangen waren und ihrerseits alle Sklaven freigelassen hatten.

Aehnlich ist die Entwickelung der europäischen Quäker verlaufen, die nur sehr viel früher ohne den Umweg über das heilige Experiment bei dem gleichen Ergebnis ankamen. Sie sind hervorragend in ökonomischer Tüchtigkeit, Redlichkeit und christlicher Liebestätigkeit, nehmen aber bei dem Mangel jedes propagandistischen Geistes nicht zu, auch das eine höchst lehrreiche Tatsache für das soziologische Verständnis des religiösen Lcbens: die Toleranz und Innerlichkeit ist, wie sie aus dem Widerspruch gegen das Massen- und $Z$ wangschristentum hervorging, der Behauptung eines organisatorischen Zusammenhangs nicht günstig. Sie begnügten sich in ihrem Kreise, die Aufgaben einer christlichen Gesellschaft zu lösen auf der Grundlage des P'rivateigentums, der strengen und ehrlichen Arbeit und der Armenfürsorge. Ueber ihren Kreis hinaus wirkten sie durch philantropische und hu$m$ anitäre Aufforderungen und Leistun $r e n$. Interessant ist insbesondere, wie einer der ihren, John Bellers ( $\dagger$ I 725 ), die Unzulänglichkeit solcher bürgerlicher Sozialideen erkannte und aus christlichen wie ökonomisch-sozialpolitischen Erwägungen heraus einen Sozialismus der Produktivgenossenschaft erst den lireunden, dann dem P'arlament vorschlug. Er trug dabei freilich der bürgerlich-kapitalistischen Gesamtlage und den Gewohnheiten der Freunde Rechnuns; 
(116 III. Protestantismus. 4. Sektentypus und Mystik auf protestantischem Boden.

faßte aber doch das Problem von Armut und Reichtum an der Wurzel an, indem er mit besserer Organisation der Arbeit zugleich cine gerechtere und gleichmäßigere Verteilung des Airbeitsertrages um des Evangeliums willen vorschlug. Auf ihn hat dann im 19. Jahrhundert Richard Owen zurückgegriffen und unter den (Uäkern einige seiner besten Helfer gefunden ${ }^{497}$ ).

$\left.{ }^{497}\right)$ Ilieruber vor allem Barclay, der die wichtigsten Einzelheiten gibt, aber schtlich das Bestreben hat, das Quäkertum als eine pietistisch-biblizistische Freiwilligkeitskirche erscheinen zu lassen; außerdem Weingarten, der sie von den Täufern, und Sippell, der sie von den Mystikern herleitet, sowie das Tagebuch von George Fox (deutsch 1910) mit der schönen Einleitung von Wernle, die vor allem das Kir.utmachen mit der Moral der Bergpredigt betont. Mir scheint alles Verständnis daran zu liegen, daß man versteht, wie der anfängliche Spiritualiınus und Futhusiasmus orennisations- und haltlos war, wie er zu einer Organisation nur durch den Anschluß an das Vorbild der täuferischen (jemeindebildung kommen konnte und wie diesc (jemcindebildung, einmal vollzogen, zu immer weiterem Kompromiß mit der Welt niilinte, bis die puritanische Berufsmoral und eine fast kirchliche Ordnung und leberdicfertung erreicht war. Das Quäkertum ist eine Synthese von Spiritualismus und liukutum und schließlich nahe an den Puritanismus herangedrängt, den es wn lnfang an so schroff verwarf. - Das ist denn auch das Hauptergebnis von Iinulays Dastellung, der dem entsprechend auch den spiritualistischen und enthusiastisclien Lisprung abschwicht. Der Anschluß an die Verfassung der Mennoniten $\therefore 247:$ Does not this clearly show the way in which the doctrine of the light, assuciaicd with the doctrines and practices of the Mennonites, passed into England and found a powerful and active exponent in George Fox : $*$ Der verbleibende Unter"hlud $\div$ - 4 " : In Friesland, he (ein quäkerischer Missionar) says, that they (die Täufer) liun: exceedingly on their outward visible things, so that I am confident it was as casy for the Aputle taking the sect of the Pharissees off from circumcision, wlicruns, temple and the traditions of the elders, as it is for us to bring these people van het uitwendige l wopgeszinde avendmaal, that is from their ordinances commonly called Baptism and the Lords supper. Der Anschluß an Mennoniten und Collegianten bes. S. 352-35S. - 1'c Spannung zwischen beiden Elementen ist darum auch nicht aunchlicben S. 43 If. Das schwierige Problem der Feststellung der Mitgliedischaft in den spiritualist. Voraussetzungen aus s. $\$$. 359-366, ebenso die bestellung der minister und teaching elders als Anerkennung einer charismatischen Begabung durch dic liemcule $\therefore$. 445. Die Lüsung des Problems der »Infallibilität», d. h. der entscheiclendell, iiber Mitgliedschaft und Amt bestimmenden Instanz ist der Geist, zu dein man das Vertrauen haben inufs $s$. 446: „None ought nor can be accounted to the Church of Christ, but such as are in a measure sanctified or sanctifying by the urace of liod and led by his $S_{p}$ irit; nor get any made officers in the curch, liut ly the srace of (jod and inward revelation of this Spirits. An der Unlösbarkeit denes l'rublems scheiterte scinerzeit Luthers Idec der reinen Christengemeinden. Bei 
.Mit dem Quäkertum ist der christliche Spiritualismus in England zu Ende. Es selbst hat sich zunehmend entspiritualisiert. Von da ab herrscht die moderne bürgerliche Aufklärung im $\mathrm{Zu}-$ sammenhang mit dem Aufschwung der bürgerlichen Klassen oder eine in ihrem besseren Teil pietistisch gesinnte Kirchlichkeit, beide mit dem charakteristisch utilitarischen Zuge, der vom Calvinismus auf die weltlichen Dinge so leicht ausgeht und der auch oft genug die geistlichen ergreift. Die zweite große Erweckungsperiode

den Quäkern wurde freilich der Geist schließlich bezüglich der membership zum birthbrìght, d. h. zur Präsumtion, daß die Quäkerkinder vom Geist erfüllt sein werden und zu einer möglichst intensiven religiösen Erziehung; bezüglich der Beamten zur Stimme der Majorität, die die Beamten ernannte und kontrollierte. Das ist die von Barclay immer neu beklagte Verweltlichung S. 527 und 362. - Die Aufnahme der puritanischen Berufsmoral, die Ueberwachung der Gemeinde durch Laien die Aufsicht und Einmischung in alle Einzelheiten des geschäftlichen und des Familienlebens S. 490-50I ; hier Ueberwachung der Arbeits- und Lohnverhältnisse, strengste Vermeidung jedes Luxus, Ausschluß alles Bettels und Unmöglichkeit eines Armen in der Gemeinde. Nur der Nutzen ist maßgebend für alles Tun; in einer Gemeinde wird verboten, Blumen zu pflanzen; das ist Luxus, statt dessen sind Kartoffeln und Rüben zu pflanzen. Hier auch die ökonomischen Konsequenzen geschildert, übereinstimmend' mit Weber, Archiv XXI S. $6 \mathrm{r}-72$, und besonders Bernstein S. 680-685. - Ueber den Quäkerstaat in Pennsylvanien vgl. das hochinteressante Buch von Sharpless, A Quaker Experiment in governement, Philadelphia 1902. - Barclay klagt über den numerischen Rückgang der Gesellschaft und führt ihn auf den Mangel an Propaganda und die Laxheit der Ausschließung ron Unwürdigen und von nach auswärts. Heiratenden zurück. Aber das liegt an dem soziologischen Prinzip der Gesellschaft, die nur in Zeiten des Enthusiasmus sich stark ausbreiten kann. Den Gewinn von der natürlichen Bevölkerungssteigerung haben nur die Kirchen, die sich durch die Kindertaufe mit der Bevölkerung selbst vermehren und mit ihren Maßstäben die Massenreligion vereinigen können. Aehnliche Klagen sind mir in Amerika bei Unitariern und Kongregationalisten begegnet. Das liegt in der Sache und dem ist nur durch Annäherung an kirchliche Prinzipien zu entgehen, wie schon das birth-right der Quäker eine solche ist, s. Barclay S. 362. - Ueber die Armenpolitik der Quäker mit Unterstützungswohnsit\%, Arbeitsvermittelung und Würdigkeitsprüfung und mit der Wirkung der Aufhebung der Armut im engeren Kreise, aber Fernhaltung der Proletarier und die damit einsetzende Entproletarisierung s. Barclay S. 517-52I und Bernstein 683. - Ueber Bellers die höchst interessanten Mitteilungen bei Bernstein S. 694-718. Es ist das radikal-christliche täuferische Element im Quäkertum, das hier spricht, ververbunden mit puritanischer Schätzung der Arbeit. Die Hauptschrift trägt das charakteristische Motto: „Industry brings plenty. The sluggard shall be cloathed with raggs. He that nill not work, shall not eat, 
des religgiösen Gefühls, der Me thodis mus, hattc denn auch keine mystisch-spiritualistischen Unterlagen mehr. Wohl kannte auch er - und er ganz besonders - den Dran's nach incividueller und persönlicher Unmittelbarkeit. Aber er befriedgte ihn in der Form des Enthusiasmus und der konvulsiven Erweckung. Wie sehr sich das ron der spiritualistischen Mystik unterscheidet und wie ganz anders das auf das Problem der Gemeinschaftsbildun wirkt, haben wir bereits gesehen. Auf diesem Orgiasmus beruht geradezu die immer neue erschütternde Massenwirkung des Methodismus, das Missionarische und Ueberwältigende; durch ihn gelangt er an Individuen und Volksschichten, die anders gar nicht zu erreichen sind. Freilich enthält dieser linthusiasmus dic Gefahr einer anarchischen Individualisierung, aber dieser Gefahr begegnet der Methodismus, wie wir wesehen haben, lurch die um so feiner und wirksamer gerade auf die Verknüpfung des Individuums mit dem Ganzen berechnete Organisation. In ihr ist er ebenso Mcister wie in der Kunst der Erweckung. Dem Enthusiasmus entspricht eine Ethik der Seligkeit und Freiheit, deren Folgen an sich antinomistisch wären. Aber auch hier ist die Konsequenz des mystischen Gedankens gebrochen durch Einführun: der calvinistischen Strenge, die als methodische Bewährung und Erkennunsszeichen des Heilsstandes dicnt; auch davon war bereits oben dic Rede. Nur in der ïußersten Vereinfachung des praktisch-dogmatischen Gehalts cher christlichen Idee kommt die Reduktion auf den $\nsim$ Geist * hier zu einer bedeutenden Wirkung. Freilich geht es dann wie bei den Klüstern. wo auf die Zeiten der Begeisterung die der Sättigun:s folyen und stets neue Reformen notwendig werden. So müssen auch der Methodismus und seine Abzweigungen immer nele stürme der Erweckung entfesseln, um nicht in eine halbe und rerweltlichende Kirchlichkeit zurückzusinken ${ }^{498}$ ).

Nicht unerheblich sind die spiritualistisch-mystischen Beimischungen im kontinentalen Pietismus. Wenner als ein aus schr heterogenen Elementen bestehendes Ding bezeichnet worken ist. so liegt die Hauptursache davon, wie beim Quäkertum

4 (14) Leher diesen Enthusiasmus s. Lecky II 582-589, außerdem James, The variety of religious experience, Lóndon 1902. Das Anschauungsmaterial dieser Religionspsychologie ist fast ganz diesem Gebiet entnommen. - Leber das mystische Element im . Hethodismus, das durch Einflüse des Hermhutertums vermittelt ist, s. Schneckenburger, Kleinere Kirchenparteien S. I50 f.; was Loofs PRE. XII 774 und 7 gu dagesen sagt, scheint mir das nicht aufuheben. 
und manchen Gruppen bereits des Täufertums, in dieser Beimischung. Von dem überwiegend aus den Niederlanden her beeinflußten deutsch-reformierten Pietismus und den mystischen Elementen des englischen Pietismus war bereits die Rede. Hier ist nur noch der innige Poet Tersteegen zu erwähnen, der ähnlich wie Scb. Franck und Coornheert seine Stellung völlig über den Konfessionen nahm und als erwählter Seelenführer Gottesfreunde um sich sammeltc. Ferner ist noch Lavaters und Jung Stillings als reformierter Mystiker zu gedenken, die allerdings beide den Gegensatz von Welt und Heiligkeit, von Fleisch und Geist unter dem Einfluß moderner Immanenzgedanken und moderner Humanität zurücktreten ließen, aber in einer an der Gebetserhörung sich erprobenden Christusmystik das Zentrum einer "lichtvollen «, von allen Konfessionen unabhängigen Christlichkeit und rein persönlichen Gemeinschaft fanden. Im ganzen hat überhaupt der reformierte Pietismus nach dem ersten Anlauf zu einer sektenhaft-asketischen Reform der Gesamtkirche sich vielfach auf eine konfessionell indifferente Mystik zurückgezogen und die strenge Lebensheiligkeit mit stark quietistischen Zügen durchsetzt. Dem lutherischen Pietismus lag eine ähnliche Entwichelung schon von Luthers Hochschätzung der mittelalterlichen Mystik und von der orthodoxen Lehre der Unio mystica her in noch viel höherem Grade nahe. Sehr bald fand zur Belebung der dogmatischen Christologie die bernhardinische Christusmystik Eingang, vor allem bei den auf Innerlichkeit und Wärme dringenden Männern der asketischen Literatur und des Kirchenliedes. Besonders bedeutsam ist hier Joh. Arnd, der nicht in die Linie des rigorosen Konventikelchristentums, sondern in die des Spiritualismus und der Mystik gehört, nur daß er dabei den Anschluß an das lutherische Iogma sorgfältig wahrte und die Vermittelung durch das Wort betonte. Ein Freund Valentin Weigels und Verehrer des Paracelsus, ein Kenner der mystisch-erbaulichen Schriften hat er einen Kompromiß zwischen dem Luthertum des Amts und Wortes und der unmittelbaren inneren Erleuchtung, zwischen Rechtfertigungsdogma und Vergottungsiehre, zwischen radikaler Erbsündenlehre und panentheistischen Immanenzideen instinktiv geschlossen, der reich ist an Widersprüchen, aber bis heute sich sehr erbauungskräftig erweist. $\mathrm{Er}$ ist nicht ohne heftige Anfeindungen geblieben, aber die eingeschlagene Richtung fand ihre Fortsetzung, und vor allem der Pietismus zog daraus mannigfache Nahrung. Boehmistische, niederländische und englische Einflüsse, auch der Rückgang auf die äl- 
tere mystische Literatur haben diese Neigung sesteigert. Doch blicb es im sanzen bei dem Nusbau der Lehre von den Stufen der Heiligung und Gotteinigung, bei einer dem Zeitgeschmack entsprechenden Sentimentalisierung der bernhardinischen Christusmytik und bei einer mystischen Reich-Gottes-Hoffnung, die dr,ch erst mit der geistigen Wicderkehr Christi die völlige Vergleichsuiltigung von Imt, Wort und Sakrament erwartete. Auch konvulsionire Lirscheinungen, visionärer Enthusiasmus und wuncierbegabtes Prophetentum blicben nicht aus. Spener selbst, dessen skrupulöses Wesen der Mystils Wenig verwandt war, liehte Wenigstens die mittelalterlich'n mystischen Schriften und sprach von der Kirche als dem rerborgenen Samen der licben Seelen in jeder Kirche a ein Lieblingsausdruck der englischen Mystik. An sich bedeutete die Betonung der inneren Erfahrung und praktischen Erprobung allerdings auch bei ihm und seinen Schülern eine Konkurrenz für die Rechtfertigung als den Gnadenbesitz der Kirchenanstalt, und von da aus konnte leicht der Uebergang zur Mystik gemacht werden, insbesondere dann, wenn die asketische Heiligkeit nicht mehr calvinistisch, sondern quietistisch-spiritualistisch verstanden und begründet wurde. Immerhin aber vermochte $\mathrm{ihm}$ sein Gegner Dilfeld nur weinen subtilen Enthusiasmus nachzusagen. Franke, der in Wahrheit dic Beschlagnahme des P'ietismus für die Jirzichung der Theologen bedeutet und insoferne die Kirche schlechthin roraussetzt, hat doch dem Enthusiasmus durch die I chre rom Bußkampf und der daticrbaren Bekehruns, die sich schlecht mit der Kindertaufe vertruss, mannigfachen Vorschub getan. Auch hat die unmittelbare * Empfindlichlicit e des Gnadenstandes eine gewisșe Richtung auf den spiritualismus. So hat er Tauler als Beispiel einer praxis interioris Christianismi gefeiert und einen Traktat der Katharina von Genua übersetzt. Jaher konnte auch E. V. I.öscher solchen I'ictisten starke Verstöße gegen die Kirchlichkeit vorhalten, »den fromm scheinenden Indiffercntismus und die Geringschätzung der Gradenmittcl, vor allem des Wortes, Neigung zu Mystizismus, Enthusiasmus und Chiliasmus, das Reden von dem in der Natur und den Menschen ruhenden Ebenbild Gottes, die Vermischung von Natur und Gnade, die Rede von der Vergottung der frommen Venschen, dic Deutung des Glaubens als Erfahrung und geistlicher Empfindung, die Hegung und Entschuldigung der Schwärmer. Mit den litzteren ist der L'ebergang zum eigentliches. spiri- 
tualismus angrebahnt, aber er ist bei der wesentlich kirchlichen Bestimmtheit des deutschen Pietismus und bei der unbegrifflich phantasicmäßigen Natur des Enthusiasmus wic der bernhardinischen Christusmystik im ganzen eine Seltenheit. Sicht man von allerhand krähwinkelhaften Begebenheiten und dunklen Ehrenmännern ab, so kommen hier nur Gottfried Arnold und Dippel, und zwar beide als sehr berieutende Geister, in Betracht. Beide stellten sich echt spiritualistisch aus jeder Konfession und Kirche heraus, fanden die christliche Gemeinschaft vollkommen nur in der Urgemeinde vor Konstantin, erkannten dic Bedeutung Christi und ler I Icilsgeschichte in der Aktualisierung des in jedem Menschen enthaltenen göttlichen Samens, betonten das Verwandte in dem göttlichen Seelengrunde auch der nichtchristlichen Frommen, folgerten aus der Geistnatur und Gotteinigkcit des Menschen dic asketische Heiligung und clie Indifferenz gegen die bestehenden, aus der Natur sich ergebenden gesellschaftlichen ()rdnungen, lehrten die Einerleihcit des inwendigen Wortes mit dem sittlichen Naturgesetz der. Menschenliebe und erwarteten das Gottesreich ohne imt, ohne Glaubenszwang, ohne Staatskirchentum. lis sind dic \%üge des in letzter Iinie durch die neuplatonische Religionsphilosophie unterbauten, aber mit dem Christusgeiste und durch ihn mit der christlichen Geschichte verknüpften Spiritualismus. Der interessante und sarkastische Edelmann ging von da aus zu cinem Monismus über, cler clas geschichtliche Christentum für Trug und Wahn crklärte und ein Entzücken für Arthur J)rews und Genossen bilden müßte. Auch Christian Thomasius gchörte zu denFreunden der mystischen »Indifferentisten mehr als zu denen des eigentlichen Pictismus, mit dem er am Anfans verbunden sewesen war. Auf jenem »Indifferentismus in Selbstverleugnung und Liebe zu einigen bei Jireigabe der religiösen Vereinsbildung, die nur freilich unter geşenwärtigen Vérhältnissen ülscrall mit dem positiven Staatskirchenrecht zu rechnen hat. Von den Mystikern abe: trennte ihn wieder sein antiasketischer Sinn, und so vollzos er den L'ebergang zu einer christlichen Aufklärungr ${ }^{499}$ ).

199, Ueber die lini mystica treffende liemerkungen bei Iupfeld, Jithik Gerhards, S. 204-232; iiber Arnd s. Lasch, Arnds Wahres Christentum, Monatsschrift f. Pastoraltheologic 19on: sehr viel bei (iöbel, der die Mystik überall mit Liebe aufsucht, so lange sie innerkirchlich bleibt; übrigens s. die oben zum Pietismus angefühte Literatur. Ritschl hat den Loterschicd des yludifferentismus " yegen die 
Das mystische Element des eigentlichen Pietismus ist auf den Gipfel gesteigert in der Her $\mathrm{rnh}$ u ter ge me in d e. Hier war der Graf selbst sein eigentlichster Träger und hat ihm die innige, aber auch unerträglich geschmacklose Form gegeben, die in Sprache und Lyrik der älteren Brüdergemeinde den modernen Leser zu

s. Sekte und die Besonderheit ihrer Art von Gemeinschaftsbildung wohl erkannt. Er nennt sie in seiner freundlichen Weise ,Clique II 359-362, I 475, 483, sieht im Seelenführer der Gottesfreunde eine Nachahmung des katholischen Beichtvaters, in der Mystik den Lrgrund des streitbaren Jesuitenordens oder einen Luxus, der darin begründet ist, daß es $\gg$ Menschen genug gibt, die ähnlich gestellt waren (uie Tersteegen), teils Weber, deren mechanische Arbeit ihrer Einbildungskraft und Andacht wenig fürderlich war, teils reiche Leute, die nicht $z u$ arbeiten brauchten, teils Frauen, namentlich unverheiratete, welche immer die Fähigkeit und die Zeit besitzen zu mystischer Kontemplation \& I 478 ! Solche Leute passen nach seiner Meinung nur ins Kloster, und die ganze Lehre stammt aus dem Kloster. Dem gegenüber ist ihm noch die asketische Sekte erträglich: „Denn der Separatismus (der Sekte) verrät gerade, je heftiger er gegen die Unreinheit einer Konfessions kirche auftritt, eine versteckte Anhänglichkeit an dieselbe, wenigstens insofern, als er die Notwendigkeit einer partikularen Kirchenbildung überhaupt voraussetzt « I 483 . Das ist ein vülliges Unverständnis : - Ueber die Stellung zu Staat und Gesellschaft bei Gottfried Arnold und Dippel II 315 und II 327, auch Göbel II 698-735 und III 166-193. Die Auffassung Dippels trägt einige quietistische Züge, ist aber im Ganzen nicht, wie Ritschl meint, in Wahrheit klösterlich und aus Thomas Aquinas stammend, sondern echt lutherisch. Er bevorzugt Ackerbau und Viehzucht, betrachtet die Arbeit als Askese und Mittel der Selbsterhaltung wie der Nächstenliebe, behandelt das Privateigentum als Folge des Sündenfalls usw. Nur hat er gegen staatliche Berufe eine Abneigung, die Luther wohl für die Person, aber nicht für das Amt hatte, und bekämpft er die geistlichen Berufe, was für Luther natürlich auch ausgeschlossen war. Gottfried Arnold ergibt sich echt lutherisch in die bestehenden Verhältnisse wie einst auch Sebastian Franck. Richtig II 365: "Die Praxis der alten Wiedertäufer und der englischen Baptisten lag den Separatisten in Deutschland in dem Maße fern, als ihre Frömmigkeit mit keinen politischen Ansprüchen und keiner Tendenz auf soziale Reform verknüpft war. Ihre vollständige Wellfüchtigkeit und ihre ganz individuelle, vielfach auf Quietismus gestimmte Selbstverleugnung ließ ihnen die Isolierung eines Jeden auf sich selbst als das wünschenswerte erscheinen. \& Diese Begründung gilt freilich nur für die Mystiker; die Gründe für solche Passivität bei den asketischen Pietisten und Kirchenreformern waren andere, denen Ritschl nicht nachgegangen ist. Es war die Unmöglichkeit jeder Sozialreform im Horizont des deutsch-luther. Absolutismus und die Uebernahme einer von vornherein bürgerlich-konservativen Berufsmoral von den Calvinisten. - Ueber Christian Thomasius Ritschl II 552 und R. Kayser, Christian Thomasius und der Pietismus, 1900. Wenn man von radikaler. Pietismus spricht, so ist auch dieser zu unterscheiden 
entsetzen pflegt. Für ihn ist der Pietismus keine Reformation der Kirche mehr, sondern eine freie Verbindung der Persönlichkeiten mit dem innerlich gegenwärtigen, im Wort erkennbaren Heiland, wie ihm schon die Urkirche lediglich eine persönliche Wirkun ein persönlicher Verband der Gläubigen war. Der Spenersche Konventikel wird in seinem Geist zur freien christlichen Geselligkeit, wobci er und die Brüder in dieser Gesclligkeit durch die Vorsehung eine besondere Konnexion mit der Person des Heilands empfangen haben. Es ist kein Spiritualismus, der das Christentum in dem allgegenwärtigen und nur in Christus besonders verkörperten Geiste sieht, sondern eine am kirchlichen Dogma haftende Christusmystik, die ähnlich wie einst Paulus und später der h. Bernhard die objektive Heilstatsache in die unmittelbare Innerlichkeit und Gegenwart des Gefühls zurückschlingt. Hierin hat sich auch Zinzendorf mit den Jansenisten trefflich verstanden. Der Unterschied ist nur, wie Ritschls Spürsinn richtig heraus-

nach der anketisch-sektenhaften und nach der mystisch-indifferéntistischen Richtung: die letztere ist im Luthertum bedeutend wichtiger und folgenreicher als die erstere, während diese umgekeh auf calvinistischem Gebiete bis heute von hüchster Bedeutung ist und immer aus diesem her seine Nachschübe und nachdrängenden Stöße empfängt. Ueber die Mystik in der reformierten Kirche s, oben $\$ .774-789$; außerdem Heppe S. 70; Ritschl I 122-130; Nax Weber, Archiv XXI 44. Bei der holländischen und englischen unkirchlichen Mystik ist oben ihr 7usammenhang mit den spiritualistischen Elementen des Täufertums und dem alten Spiritualismus der Reformationszeit gezeigt worden. - Ueber das Wiederaufkommen mittelalterlich-mystischer Literatur zahlreiche Angaben bei Ritschl, auch Keller, Reformation, S. 470f.; sehr interessant auch Hegler, Sebast. Francks lateinische Paraphrase der deutschen Theologie, I901; hier $\therefore .16: \gg$ Das Urteil über die deutsche Theologie ist bei den Calvinisten in der orthodoxen Periode andauernd ein. schärferes geblieben als bei den Lutheranern. \& - Die andersartige Stellung der Mystiker und Spiritualisten zur praktischen Ethik, d. h. das Ausbleiben des Anschlusses an die calvinistisch-rationelle Askese und Berufssittlichkeit zugunsten einer mehr passiv leidenden und prinziplosen Stellung zur Welt ist von Ritschl und Max Weber (Archiv XXI 4I) mehrfach angedeutel, aber nicht bis in die eigentlichen Gründe verfolgt, die in der andersartigen dogmatischen Grundidẹe und soziologischen Beschaffenheit der Mystik liegen. Hier fehlt denn auch der systematische Utilitarismus und herrscht die Unbefangenheit der Stimmung, des Gefühls und der momentanen Eindrücke. Aber gerade dadurch nähern sie sich wieder dem Luthertum, von dem sie in der Ethik sich nur durch eine stärkere prinzipielle Verwerfung des Fleisches unterscheiden. Aber hier waren ja gerade Luthers Anhänger auch ihrerseits sehr schwankend. 
fühltc, daß diese pietistische, und besonders die Zinzendorfische Christusmystik, jene Unmittelbarkeit als ein jedesmal ganz individuell seartetes l'rivatverhältnis zum lebendigen Heiland faßt, während die ältere Christusmystik die Ansprüche individuellen Gefühls in einer viel allgemeineren, weniger differenzierten un l gattungsmäßigeren Weise befriedigte. Der Pietismus sieht eben auf die ganze Entwicklungsgeschichte des christlichen Individualismus zurück und hat schon einen Einschlag des modernen sentimentalästhetiscben Individualismus. Im übrigen ist aber das Verhältnis zur Kirchlichkeit bei dieser Mystik der Herrnhuter sehr unklar. Zinzendorf hat sich stets für übereinstimmend mit der lutherischen Lehre gehalten. Allein es war in Wahrheit eine Uebereinstimmung nur mit gewissen Teilen des lutherischen Dogmas. Hingegen war es keine Uebereinstimmung, sondern ein Gegensatz geısenüber dem kirchlichsoziologischen Geiste des Luthertums. Wir haben gesehen, wie er mit Hilfe der Mähren zur Ausbildung cincr selitenhaften Organisation genötigt wurde. Aber auch diese ist doch immer wieder durchbrochen von dem letzten (igentlichsten Motiv des Grafen, das in der stark spiritualisierenden Christusmystik liegt. Ilinter jener Gefühlsunmittelbarkeit des gegenwärtigen Christus und der individuellen Differenzierung des Heilandsverhältnisses lauerte cine gewisse Vergleichgültigung des Geschichtlichen und ein gewisser, liebevoll gepflegter Relativismus der individuellen religiösen Besonderheiten. I lic mystisch auflösenden Folgen traten bereits in der sogenannten Sichtungszeit im Herrenhag zutage, in der Ernennung Jesu zum (Oberältesten der Gemeinde, in dem Dringen auf den Gencralycist der Bibel statt auf den Buchstaben, in dem über dic Konfissionen hinausstrebenden "Generellen «, in der Vergleichsültigun Erziehung für die allein wahre Christusliebe. Vor allem aber gelangte der relativierende Individualismus der rein persönlichen lirömmigkeit, wie er in der gegenseitigen Selbstdarstellung, der Einverleibung der Berichte über das innere Leben der Einzelnen ins Gemeindearchiv, der erbaulichen Vorlesung dieser Konfessionen, in dem Interesse für persïnliche Sonderentwickelungen besonders zum turdruck kommt, zu einer starken Wirkung bis weit über die Gemeinde hinaus. In diesem Sinn blicben Schleiermacher und Novalis dauernd 'ëgrlinge der Brüdergemeinde und entwickelten nur die darin licgenden IFolsen. Auch bei Iries ist die Bekleidung cer allyemeinen religiösen Idee mit $\mathrm{dem}$ individualisierenden 


\section{und relativierenden Symbolismus wohl vor allem eine Erinnerung an die Brüdergemeinde ${ }^{500}$ ).}

500) Vgl. Plitt, Zinzendorfs Theologie 1869 f., Becker, Z. und sein Christentum im Verhältnis zum kirchl. und religiösen Leben seiner Zeit I900. Auch hier sehr scharfsichtig Ritschl, der ihn ursprünglich dem Philadelphentum und Indifferentismus im Sinne Arnolds zurechnet und ihn erst durch die Mähren in die Bahnen. des Sektengedankens gezwungen werden läßt. Den Ausdruck hat Becker (Studd. u. Kritt. I89I) bestritten, da Z. immer Lutheraner geblieben sei. Aber das ist doch richtig, daß es ein überkirchliches, interkonfessionelles Luthertum, d. h. lutherische Christusmystik und Gefühlsethik, ist, um die es sich handelt und deren Unterschied vom kirchlichen Sinn des Luthertums nur dem Grafen nicht zum Bewußtsein kam. Hierin war er merkwürdig naiv und unklar. Mystische Züge bei Ritschl III 407, 384, vor allem bei Becker 76-82, 249-262. Seine Bedenken gegen die Mähren beziehen sich auf deren Sektencharakter, sihre Neigung zum Separatismus, ihre Veranlassung und Inkorporation in schädliche Sekten, wenn sie nur etwas hübsch Aeußerliches hatten $\ltimes$; $>$ das ist ein italienischer, waldensischer falscher Genius gewesen (Worte Z.s bei Müller Ioof.). Warum er von seiner Mystik doch zum Anschluß an eine Gemeinde kommt; sagt er' selbst sehr klar: sUns ist die mährische Konstitution... gar sehr zu statten gekommen; wir hätten. sonst doch eine andere Form inventieren müssen. Denn im Grunde ists doch ein fanatisches (d. h. spiritualistisches) Räsonnement, wenn man spricht: Was Sekten, was Menschen! wir wollen Gemeine Jesu Christi sein. Aber was denn für eine ? Die unsichtbare? So müßt ihr wieder Einsiedler werden. Die sichtbare? So wisset, daß es keine gibt ohne eine Religionsform tout courte Müller 99. Diese Worte sind höchst erleuchtend für den Unterschied der Sekte gegen die Mystik und den Spiritualismus. Hierher gehürt auch sein Gegensatz gegen die von den Mähren gewünschte Kirchenzucht und gegen die Ausbildung der Gemeinde zu einem Staat im Staate; s. Becker S. 225-232. - Ueber den von hier aus und viel weniger vom Vereins- und Freiwilligkeitscharakter herzuleitenden gefühlig ästhetisierenden Individualismus vgl. das interessante Programm von Sam. Eck, Ueber die Herkunft des Individualitätsgedankens bei Schleiermacher, Gießen 1908. Ueber die Umwandlung der Spener $\rightarrow$ schen Konventikel in freie religiöse "Geselligkeit als etwas aus der geselligen Natur des Menschen folgendes und darum auch in der Religion berechigtes, sowie andererseits die Fortbildung der Konventikel zu fruen Assoziationen, die die Befruchtung der Landeskirchen durch Konzentrierungen innigeren Christentums um erleuchtete Rüstzeuge Gottes bewirken sollen, s. Becker S. I63-I 78 ; S. I 53 : >Das Zinzendorfsche Brüdertum hat mit dem, was man Kirchenbildung nennt, nichts zu tun, sondern ist lediglich eine in freien Gesellschaftsgruppen und Vereinen sich organisierende religiöse Bewegung innerhalb der Volkskirchen.« Dabei aber hält der Graf die letztere im Grunde doch für erledigt: „Die Zukunft gehört (für Z.) der freien religiösen Assoziation, die lediglich den gekreuzigten Christus zum Grund und zum Zweck hat, und unter diesem allein maßgebenden Gesichtspunkt den Volkskirchen dienen will. $\ltimes$ 
In verschiedenen Formen dauert mit dem gesamten Pietismus und seinen mannigfachen Abzweigungen, auch in der Stiftuncr neuer mystischer oder auch geradezu spiritualistischer Gemeinden, diese ganze Ideenwelt bis heute. Die alten mystischen Traktate werden gelesen und neu aufgelegt bis in die Gegenwart. Es sind das die von der Oeffentlichkeit wenig beachteten Unterströmungen des religiösen Lebens, auch sozial meist der Unterschicht angehörig. Sie haben sich vielfach mit Spiritismus und Theosophie heute verbündet. Ein neuer Anstieg großen Stiles ist nur die Lehre Swedenborgs, der ein in die moderne Naturwissenschaft übersetzter Paracelsus ist und bereits die okkultistischen Phänomene mit seiner Mystik verband ${ }^{501}$ ). Aber das betraf schließlich nur enge Kreise: in Amerika lebt seine Gemeinde fort; ihr stand William James nicht ferne.

Wichtiger für das allgemeine geistige Leben ist nun aber ein anderer Umstand. Es ist die Herauskehrung des letzten spiritualistischen und religionsphilosophischen Sinnes der Mystik, die für die Gesamtheit des heutigen außerkirchlichen oder wenigstens nicht spezifisch kirchlich oder pietistisch religiösen Lebens entscheidend geworden ist. In dem Maße nämlich, als das moderne Denken unter den Einfluß des Begriffes allgemeiner Weltgesetze und einer durchgängigen Welteinheit kam, hiermit auch Moral, Religion und Kunst als allgemeine Grundgesetze der menschlichen Geistesentfaltung zu betrachten genötigt wurde, erwies sich als das einzige Mittel, eine Brücke von diesem Denken zur Religion und zum Christentum zu schlagen, die spiritualistische Mystik. Sie bedeutete ja bereits den überall wesentlich gleichen, im unmittelbaren Lebenszusammenhang mit Gott sich bewegenden religiösen Vorgang, den man in seinem ethisch-religiösen Inhalt der christlichen Idee verwandt fülen konnte und der in den geschichtlichen Elementen des Christentums eine geschichtliche Verkörperung und Symbolisierung, eine bes̀onders lebendige oder urbildliche Darstellung seiner selbst erkennen konnte, soweit er überhaupt an sie sich zu binden fortfuhr. Man brauchte sie nur mit den allgemeinen psychologischen oder erkenntnistheoretischen Gedanken der modernen Philosophie zu verbinden, so ergab sie die allgemeine Grundlage, von der aus man zum Besonderen der positiven

501) Vgl. auch hier Kalbe, Kirchen und Sekten der Gegenwart; auch W. Eruhn, Theosophie und Theologie 1907 . 
Religionen sich den Weg bahnen konnte, nachdem die naive tausendjährige Herrschaft des Positiv-Besonderen d. h. des supranatural verfestigten Christentums erschüttert war. Die ganze moderne Religionsphilosophie geht in dieser Richtung.

Freilich war damit dann das Historisch-Positive aller Religion überhaupt zum Problem gemacht und war die Möglichkeit radikalster Lösungen eröffnet. Da die geschichtlichen Elemente gleichzeitig einer allgemeinen historischen Anschauung einverleibt und damit der Kritik unterworfen wurden, so führte das Bedürfnis der Befreiung von unsichern Geschichtlichkeiten nicht selten vollends zur Forderung der reinen Unmittelbarkeit, Gegenwärtigkeit und Innerlichkeit des evangelium aeternum, zur Aussicht auf das dritte Reich, wo jeder aus eigener Lebenstiefe selbständig und individuell und doch wesentlich übereinstimmend die Erkenntnis Gottes schöpft. Die Gedanken, denen Sebastian Franck den schärfsten und tiefsinnigsten Ausdruck gegeben hat, setzten sich wieder durch. Eine Mystik in diesem Sinne ist der Kern der Leibnizischen Religionsphilosophie, so entschlossen orthodox sich dieser Alles-Vermittler auch gebärdete. Diesen Weg war bereits Spinoza gegangen. Mit einem theistisch-individualistischen Verständnis folgten ihm Herder und Goethe, welcher letztere seine Anschauung von der Kirchengeschichte aus Gottfried Arnold schöpfte. So hat Lessing die Religion unter Berufung auf herrnhutisches Gefühlschristentum vor Verstand und Kritik gerettet. So hat der übrigens rein ethischtheistisch und gar nicht mystisch empfindende, aber doch auch die Religion nur als Geist und Idee anerkennende Kant die Heilsgeschichte behandelt; seine Vergeistigung der Dogmen zu Symbolen ewiger Wahrheiten und immer sich wiederholender Gegenwartsvorgänge ist völlig im Sinne des Spiritualismus. Für Fichte, Schelling und Hegel bedarf es keines weiteren Beweises; die beiden letzteren haben ausdrücklich auf die alte mystische Literatur zurückgegriffen, und auch noch des späten Schelling Gnosis ist ein an Böhme angelehnter Spiritualismus. Vor allem aber ist bei Hamann, Friedrich Heinrich Jacobi und Lavater klar, wie ihre so unendlich anregenden Ideen aus der christlichen Mystik oder auch geradezu aus dem Spiritualismus stammen. Wenn sie die theistischen und dualistischen Gegenspieler gegen den monistischen Zug der Epoche sind, so ist der Gegensatz doch nur ein relativer und innerhalb des gemeinsamen Ganzen. Wie der Mo- 
nismus der andern durchsetzt ist mit dem Irrationalismus dẹs Individucllen und gुekrönt ist mit einem ethisch erfüllten Gottesbegriff, so ist der Dualismus dieser kein solcher bloß von Naturgesetz und christlichem Wunder, sondern von äußerlich-mechanischer Natur und Fülle des Geistes, von niedrigerer und hüherer Natur überhaupt. Der Geist wird bei ihnen zum Genie und das Fleisch wird bei ihnen zu der am Aeußerlichen, Rechnungsmäßigen und Sinnlichen haftenden Verstandesmäßigkeit. Der Glaube wird ihnen zum Gefühl, das der in der Seele gegenwärtige Gott wirkt und in dem er und alle seine ()ffenbarungen allein erlebt werden können. Es liegt aufder Hand, wie sich hier die alten spiritualistischen Ideen nur in neuer Form fortsetzen oder erneuern. Dabei tritt das in die christliche Mystik aufgenommene religionsphilosophischneuplatonische Element immer deutlicher und selbständiger heraus, mit ihm der ästhetische Einschlag des Platonismus, den die Verchristlichung so gründlich beseitigt hatte, und den die moderne ästhetische Kultur in so viel differenzierterer Weise erneuert ${ }^{502}$ ).

502) Das kann in Einzelnen hier nicht belegt werden. Einiges bei lieller, Reformation S. 48 $4-4 \$ 8$; die Monatshefte der Comeniusgesellschaft beschäftigen sich in der Weise Kellers unausgesetzt mit diesem Gegenstand; auch Troeltsch, Das Historische in Kants Religionsphilosophie, I904. Aehnlich führt Kronenberg, Geschichte des deutschen Idealismus I I 909 den Satz durch, daß der deutsche Idealismus der Durchbruch der christlichen Mystik sins Allgemein-Menschlichea sei. Fein sind seine Darstellungen von Hamann und Jacobi. Loch ist die Gleichung von Christentum, Mystik, Protestantismus, Romantik, Platonismus und die Ableitung des geistigen Kampfes aus den Urgegensätzen dieser Richtung gegen Aufklärung, Rationalismus, Scholastik, Kirchentum sehr wenig gecignet, das Richtige an seiner Behauptung mystisch-spiritualistischer Einflüsse auf den deutschen Idealismus erkennbar zu machen. - Lehrreich für die völlige Vernachlässigung aller soziologischen Gesichtspunkte bei solcher Konstruktion ist die Kritik von J. Plenge, Realistische Glossen zu einer Gesch. d. deutschen Idealisrnus, Archiv für Sozialwissenschaft XXXII 1-35: Der kritische Subjektivismus erlebt eine kurze kritische Glanzzeit, "trasen von dem sozialen Optimismus der zur Freiheit gelangenden Bourgeoisie ... Er scheint eine solche Verfrühung (d. h. twegenüber der Aufyabe eines Neubaus der Gesellschaft im Zusammenhang mit der religiösen IItec), die nur durch die auf dem Boden des christl. Subjektivismus gewachsene spezifische Ausbildung d's Vernunftproblems möglich wurdes S. 34. - Veber den sehr intercssanten und einflußreichen Lavater s. die vortreff 1 . Studien von v. Schultheß-Rechberg und Heinr. Naier in J. C. Lavater 1902, dazu m. Anzeige HZ. 93. - Zum Ganzen Sell, Die Religion unserer Klassiker, 1904. Das beste findet man heute noch bei Gelzer, Die deutsche poetische Literatur seit Klopstock und Lessing, I $\$_{4} 6$. Trefferd formuliert Sell S. 175 das Gemeinsame der Klassiker : „Es ist die Leberzeugung von der völli- 
Am wichtigsten wurde hierin die $\mathrm{R}$ om a ntik, deren religiöses Element durch Schleiermacher und Novalis vertreten und über den ganzen Kreis mit größerer oder geringerer Echtheit und Tiefe wirksam gemacht worden ist. Jeder Kenner von Schleiermachers Reden weiß, wie hier geradezu die spiritualistische Idee von einer unmittelbaren Offenbarung des religiösen Gefühls und einem sich gegenseitigen Verstehen aller Geisterfüllten und aller Offenbarungen verkündet ist, wie auch die soziologischen Folgerungen schonungslos gezogen sind: eine fließende Gruppenbildung, um be-

gen Relativität alles dessen, was sich als Offenbarung gibt, unter voller Anerkennung dessen, von wannen alle Offenbarungen kommen, und dessen, was sie empfängt: von Gott und der Seele๔. Goethe ist im Ganzen nicht unchristlich, aber schlechterdings unkirchlich. >Dieser Pietismus (Lavaters, Jungs usw.) konnte und mußte Goethe interessieren, weil er eine Gestalt eigener, selbst erfundener Religion ist, keine auf Autorität oder durch bloße Gewohnheit oder durch Unterwerfung unter irgend eine Obrigkeit angenommene Religion S. 176. >Darnach ist Goethe (abgesehen von der antikisierenden mittleren Periode seines Lebens) ein an die Bibel in freier Weise sich anschließender Autodidakt, ein nur dem Zeugnisse des eigenen Gewissens folgender Gläubiger « 189. Lehrreich ist Goethes Wort: „Es gibt den Standpunkt einer Art Religion, den der reinen Natur und Vernunft, welcher göt tlicher A b$\mathrm{kunft}$. Dieser wird ewig derselbe bleiben und dauern und gelten, so lange gottbegabte Wesen vorhanden. Doch ist er nur für Auserwählte und viel $\mathrm{zu}$ hoch, u mallgeme in $\mathrm{zu}$ werdene S. 206; das ist nicht rationalistisch, sondern spiritualistisch gemeint mit der Goethe eignenden Einbeziehung der Natur in die Offenbarung des Allgeistes. Das bekannte Wort über Christus: „Fragt man mich, ob es in meiner Natur sei, ihm anbetende Ehrfurcht zu erweisen, so sage ich: durchaus. Ich beuge mich vor ihm als der göttlichen Offenbarung des höchsten Prinzips der Sittlichkeit ist ebenfalls ganz im Sinne des Spiritualisınus, nur daß sich Gott gleichzeitig auch in anderen Wirklichkeiten ähnlich mächtig offenbart, wie z. B. in der Sonne als der vorzugsweisen Offenbarung des zeugenden Prinzips; , die Anbetung Christi ist nur bedingte Anerkenntnis von etwas, das er von ihm erfahren hat \& 190. Sehr bedeutsam ist die religiöse Erziehung in der pädagogischen Provinz der Wanderjahre, weil sie einen eigentümlichen, diesen Ideen entsprechenden Kult entwirft, der vom kirchlichen völlig abweicht und das Bedürfnis bekundet, der neuen Fassung des Christentums auch eine Erziehungsgemeinde und einen Kult zu geben; es ist der Gedanke eines an verschiedene Gruppen frei zu gebenden Erziehungssystems und Kultes. - In diesen Zusammenhang gehören auch Björnson und Ibsen, die beide von dem Pietismus ihrer Heimat ausgegangen sind. Das dritte Reich Ibsens ist das Evangelium aeternum Lessings, die Dreiheit dèr Stufen oder das dreifache Evangelium bei den Mystikern, und geht bis auf Joachim von Fiori zurück; hierzu Weinel, Ibsen, Björnson, Nietzsche, 1908. - Das ganze Thema verdiente eine eigene Untersuchung. 
sonders starke Führer und Propheten geschaart, verbindet immer neu und wechselnd die Gläubigen in gegenseitiger Darstellung und Erweckung des ihnen allen einwohnenden Gefühls; der Geist bleibt nicht gebunden an die historische Gemeinschaft des Christentums, sondern kann, über es hinausschreitend, das an sich überall identische religiöse Gefühl zu immer neuen konkreten Gruppen sich vereinigen lassen; die Propheten und Offenbarer, Christus eingeschlossen, sind nur Anreger und Entżünder des bei Jedem eigenen und unmittelbaren religiösen Lebens. Ein gewisser Zusammenhang mit Herrnhut ist hierin unverkennbar, wenn auch die Gesamtanschauung überwiegend von den Grundzügen der modernen Weltanschauung aus bestimmt ist und der Unmittelbarkeits- und Verinnerlichungsdrang mit Schleiermachers ganzem Wesen eng verbunden ist. Gleichviel aber, ob Analogie oder historische Abhängigkeit, das Ganze ist dem protestantischen Spiritualismus aufs allernächste verwandt. Bei Novalis ist überdies noch die herrnhutische Christusmystik in diesen Rahmen eingestellt, worin Schleiermacher später folgte; aber sie ist hier auch wirkliche Christusmystik d. h. Anschauung der alles erfüllenden und in Christus nur konkret verkörperten göttlichen Lebenskraft; das Abendmahl ist die Speisung mit dem im ganzen Universum verdinglichten und konkretisierten göttlichen Geiste, ein Symbol der Einheit von Geist und Natur, von Prophet und Gemeinde. Dieser romantische Spiritualismus hat nun aber nach zwei Seiten hin überaus wichtige neue Züge. Einmal fällt in ihm unter der Einwirkung der modernen Gesetzes- und Alleinheitsbegriffe der dualistische Gegensatz von Fleisch und Geist und damit die asketische Lebensrichtung des älteren protestantischen Spiritualismus wes. Hatte dieser seinen asketischen Dualismus mit dem Gedanken der göttlichen Immanenz durch den neuplatonischen Stufen-Emanatismus notdürftig vermittelt und überdies der Freiheit der Kreatur in diesem Rahmen Platz gemacht, so hat der neue Spiritualismus die Richtung zur Immanenz schlechthin und zum Determinismus. Wo das letztere nicht der Fall ist, da ist doch die Freiheit nur das Prinzip einer aufsteigenden und überwindenden Entwickelung, nicht das einer asketisch-dualistischen Enţ̧egensetzung von erlöstem Geist und Sündenvergiftung des Fleisches. Das macht den heutigen Spiritualismus überall den pantheisierenden Immanenzgedanken verwandt und setzt den alten Gegensatz in aufsteigende Entwickelungsstufen um. Die zweite wichtige Veränderung ist die Verwachsung der vollende- 
ten religiösen Innerlichkeit und Individualität mit der ästhetischen Individualitätsidee, der Differenzierung des ganz individuellen künstlerischen Gefühls. Das geht weit hinaus über den immer noch am Allgemeinen haftenden Aesthetizismus des Platonismus, der bisweilen in der christlichen Mystik des Altertums noch nachklang und in der Renaissance wieder mit heraufgekommen war. Es ist eine unter dem Einfluß der christlichen Idee und des modernen Lebens bis ins äußerste differenzierte Aesthetik ganz persönlichen Empfindens. Damit verbindet sich jetzt nur allzuleicht der ganze ästhetische Relativismus, der alles als an seinem Ort berechtigt und die Harmonie des Ganzen erfüllend betrachtet. So energisch Schleiermacher, Novalis, Fichte, Schelling, Hegel einem solchen Relativismus sich entgegengesetzt haben, er ist bis zum heutigen Tage immer nur gewachsen, verbunden mit dem Wachstum einer prinzipiell ästhetisierenden Weltanschauung und mit dem Eindruck der geschichtlichen Mannigfaltigkeiten. Diese doppelte Fortbildung aber bedeutet eine höchst wichtige Ergänzung der reinen christlichen Innerlichkeit. Hatte der ältere Spiritualismus die neuplatonische Vergottungslehre und die Naturphilosophie an sich herangezogen, so zog er jetzt den modernen Humanitätsbegriff und den ästhetischen Individualismus an sich. Damit aber wurde er fähig auf die praktischen Aufgaben des modernen Lebens einzugehen ${ }^{503}$ ).

In dieser romantischen Religiosität, in dem mit der künstlerischen Differenzierung und dem philosophischen Immanenzgedanken verbundenen Spiritualismus, wurzelt dasjenige, was der moderne Deutsche der Bildungsschicht vom Protestantismus sich aneignen kann, sein Verständnis der Religion überhaupt. Es ist die heimliche Religion der Gebildeten. Die ganze mystisch-spiritualistische Literatur feiert darum heute ihre Auferstehung: Vor allem ist dazu der Boden des Luthertums veranlagt, das von Hause aus auch in seiner echtesten Gestalt damit gewisse Beziehungen hatte. Auf angelsächsischem und calvinistischem Boden begegnet ein solcher Spiritualismus viel geringerem Verständnis, erscheint er als unpraktisch, unsozial, unkirchlich, unethisch. Doch ist mit den Schriften des Emersonschen Kreises und - in einem stark aktiv-ethischen, dem Aesthetizismus entgegengesetzten Sinne mit denjenigen Carlyles auch dort längst dieser Weg betreten:

5v3) S. auch den Aufsatz von Koch, Zur Beurteilung der modernen Persönlichkeitskultur, und die Erwiderung von Joh. Müller, Chr. W. 1908. 
alles Historische ist ein Symbol; ewig unter allen Formen ist die sich überall erkennende, von den Heroen nur mit besonderer Gewalt ausströmende Idee. In England ist schließlich auch der ästhetisch-spiritualistische Geist eingezogen mit Ruskin und seiner Schule, den man mit Recht das Ende des Puritanismus genannt hat.

Mit alledem sind dann auch die soziologischen Folgerungen aus dieser Grundstellung nicht lange in der Verborgenheit geblieben. Die religiöse Gemeinschaft, die Kirche und der Konventikel gleichermaßen, ist völlig zurückgesełzt. Der Kultus hat seine innere Notwendigkeit überhaupt verloren und ist für die Religion bedeutungslos geworden. Das Historische ist zum Symbol, zum Anregungsmittel, zur Veranschaulichung geworden, wenn man nicht gar völlig bedenklich ihm gegenübersteht. Sein Zusammenhang mit dem Kultus ist beinahe völlig verschwunden, es ist zum Thema der wissenschaftlichen Verhandlung, zum Gegenstand der freien Phantasie und beliebigen privaten Stimmungserregung geworden. Die Literatur, die Poesie und das alte Philadelphentum, die Bildung kleiner, von persönlichen Eindrücken geleiteter Kreise, sind an Stelle der alten kultischen Gemeinschaft getreten, ganz so wie es Schleiermachers Reden schildern, nur meist mit geringerem Ernst. Inzwischen sind dann auch der naturalistische Monismus moderner Naturphilosophen und brahmanistische und buddhistische Ideen in diese Mischung eingeflossen; sie haben vollends die Beziehungen zur christlichen Geschichte, ja zu dem christlichen Personalismus überhaupt, gründlich verwirrt oder gar gelöst und leidenschaftlich bekämpft. Aber auch wo diese Ablösung von allem christlichen Geiste nicht eingetreten oder nicht erkannt ist, da verläuft doch oft genug das Verständnis das Christentum in diesen romantischen und neuromantischen Auffassungen eines völlig persönlich differenzierten und gänzlich innerlichen Spiritualismus ${ }^{304}$ ).

504) Hiezu s. die Arbeiten von Dilthey und Haym. Das Anti-Kirchliche in Schleiermachers Reden, die nur der Unverstand gegenüber den gleichzeitigen Predigten für eine exoterische Aeußerung halten kann, hat A. Ritschl richtig gefühlt ; s. Schl.s Reden und ihre Nachwirkungen auf die evangel. Kirche in Deutschland I 874. Außerdem Troeltsch, Schl. und die Kirche (Schl., der Philosoph des Glaubens 1910). - Der ästhetische und der Immanenzcharakter sowie der radikale Individualismus der romantischen Religion sind nirgends besser erkannt als bei Kierkegaard, der die beiden ersten abstößt, um so stärker aber das letztere betont. Die Ergänzung dieses Individualismus durch einen romantisch katholisierenden $Z$ ug, ahnlich wie Novalis, zeigt Paul de Lagarde in seinen deutschen Schriften, die 
Auch die Gedankenbildungen der neueren wissenschaftlichen Theologie, soweit sie mit dem modernen Geiste inneren Zusam-

trotz mancher Schrullen zum Bedeutendsten gehören, was überhaupt über die moderne religiöse Lage geschrieben worden ist; er sieht den 'ganzen Zustand als Auflösung _der bisherigen Kirchen und als Vorbereitung einer neuen Religion durch einen aus dem vorpaulinischen Evangelium erneverten und ethisch vertieften Spiritualismus an. - Charakteristisch für die völlige Auflösung des Kirchengedankens und bezeichnend für unzählige ähnlich Denkende ist A. Bonus, Die Kirche (aus -Die Gesellschafte, hsg. v. Buber XXVI). - Einflußreiche Kreise, wie der von Joh. Müller in Schloß Mainburg, zeigen ganz den Charakter einer ethischen Mystik: Weckung des göttlichen Samens im Menschen durch Christus zu freier persönlicher Ausgestaltung aus dem mit Christus gemeinsamen, aber mit seinem Buchstaben sich nicht deckenden Geiste; die Menschwerding des Menschen durch die Befolgung der von Christus dargelegten und zur Erkenntnis gebrachten Naturgesetze des persönlichen Lebens ist nichts anderes als die spiritualistische Lehre von der Weckung des göttlichen Funkens in der Berührung mit Christus, alles freilich in die Sphäre der Aktivität versetzt. Dieser Kreis zeigt auch typisch den Kirchengegensatz und die soziologische Art eines solchen Spiritualismus, vgl. seine Bergpredigt, verdeutscht und vergegenwärtigt I906. - Spiritualistisch ist auch die Auffassung vom Christentum, die Eucken als die notwendige Fortbildung desselben bezeichnet, vgl. ?Können wir noch Christen seine, 191 I S. 190: "So entspricht es dem Zuge der weltgeschichtlichen Bewegung, wenn wir eine weitere Wendung vom Sichtbaren ins Unsichtbare fordern und wahre Wirklichkeit von sinnlicher Handgreiflichkeit noch schärfer geschieden haben wollen. Daher fällt es nicht aus den Zusammenhängen des Christentums, der Religion des Geistes, heraus, wenn uns die Geschehnisse innerhalb des Geisteslebens als die Hauptsache gelten und als solche behandelt sein sollen.. S. 200: sDie religiöse Gemeinschaft muß sich auf die Wahrheiten stellen..., welche unmittelbar dem Lebensprozesse selbst angehören, nicht ersterhand aus metaphysischer Spekulation oder aus geschichtlicher Ueberlieferung stammen d. h. also Wahrheiten, welche die Tatsachen des Erscheinens einer neuen (inneren) Welt beim Menschen und die Weiterbildung dieser Welt durch Kampf und Erschütterung hindurch betreffen und vertreten, die Tatsachen einer grundlegenden, kämpfenden und überwindenden Geistigkeita. - Eine gegen das Christentum indifferente sehr originelle Mystik entfaltet Maeterlinck, dessen Einfluß auf die Gegenwart gleichfalls aus dieser Homogenität zu verstehen ist, s. Der Schatz der Armen ", deutsch 1906. - Bewußt antichristlich gestaltet sich unter pessimistischem Einfluß die Mystik bei Schopenhauer und Ed. v. Hartmann, noch feindseliger bei dessen Schullern Arthur Drews und v. Schnehen. Hier fällt bei der Auslöschung jedes theistisch-personalistischen Elementes jeder Gemeinschaftstrieb und jeder Kultus völlig weg und wird der Mittelpunkt des christl. Kultus, Jesus, gänzlich beseitigt; gleichwohl glauben diese Religionsphilosophen durch eine solche gemeinschafts-, kult- und geschichtslose Religion der Immanenz des Einzelgeistes im All die unter uns absterbende Religion wieder beleben 
menhang haben und zugleich religiöse Wärme und Lebendigkeit suchen, bewegen sich seit Schleiermacher, Hegel und de Wette in dieser Richtung. Freilich hat man hicr klarer das Bedürfnis, der Geschichte und Offenbarung gerecht zu werden, aber doch nur unter der Grundvoraussetzung, daß die Erlösung nicht eine Ausstattung der Heilsanstalt mit einer fertigen Heilskraft, sondern ein jedesmal neuer Vorgang der inneren linigung der Seele mit Gott ist. Daher ist auch das Problem der Bedeutung der Geschichte für den Glauben in der modernen Theologie das Zentralproblem geworden. Sie ist dem Meister Eckart und Sebastian Franck näher verwandt als Luther und Calvin, und schätzt an L.uther für die Gegenwart wesentlich nur seine spiritualistischen Anfänge. Sie ist auf der ganzen Linie die Erneuerung des alten Spiritualismus. Ihre besten Gedanken hat sie von dort her oder findet sie dort bereits vorgebildet. Sie versetzt sie nur in die inzwischen ausgebildete historisch-kritische Denkweise und in die moderne Welterkenntnis hinein. Sic ist Theologie des Bewußtseins im Gegrensatz zur Theologie der Tatsachen und hat für Jesus nur die Bedeutung der urbildlichen Erregung des frommen Bewußtseins. Aber damit wiederholt sich für sie auch die soziologische Situation und Wirkung jenes Spiritualismus. Sic schafft keine Gemeinschaftsformen und formt weder den dazu nötigen Gemeinsinn und Autoritätsglauben, noch den nicht minder nötigen Fanatismus und Lniformitätsdrang. Sie lebt in Gemeinschaften und von Gemeinschaften, die andere, rücksichtslosere Kräfte gebaut haben und muß sie aus Bekenntniseinheiten in bloße Verwaltungsorganisationen $\mathrm{zu}$ verwandeln trachten, die sehr verschie. denen Geistern und Kräften Behausung gewähren. Sie ist dem kirchlichen Geiste entgegengesetzt durch ihre Toleranz, ihren Subjektivismus und Symbolismus, ihre Betonung der ethischen und religiösen Gesinnungsinnerlichkeit, ihren Nlangel an festen Normen und Autoritäten. Daher muß sie die Organisationsformen mitbenützen, die das robustere Zeitalter des staatskirchlichen

zu können. - Höchst charakteristisch ist auch Simmel, Das Problem der religiösen Lage (in dem Sammelband \& Weltanschauung, Philosophie und Religione I9I1), der die Religion rein als Zuständlichkeit ohne jeden bestimmten Inhalt und Antrieb fafst und daher auch jede geschichtliche und kultische Beziehung ausschließt. Hierher ychürt auch die moderne mystische Lyrik wie die R. M. Rilkes und Achnliches auch die Religionspolitik des Diederichs'schen ־erlages, die ganze moderne Losung snicht unreligiös, aber unkirchlich 
Zwanges geschaffen hat und die ohne Gewalttat nie entstanden wären. Oder sie nimmt überhaupt einen neuen Zustand in Aussicht, wo die Investierung der Religion in den verfallenden Kirchen überhaupt nicht mehr nötig ist. Nicht umsonst hat Richard Rothe mit Hegel das Aufgehen der Kirche im Staat d. h. die volle Autonomie des mit der Gesamtvernunft und ihrer sozialen Organisation unmittelbar einigen religiösen "Geistes \& prophezeit. Er hat damit die letzten Tendenzen und die schwersten Probleme des Spiritualismus klargelegt, diesen selbst aber als das notwendige Ergebnis der Entwickelung des Christentums in einer äußerst lehrreichen und tiefsinnigen Gesamtauffassung. der Kirchengeschichte konstruiert ${ }^{504 a}$ ).

504a) Es ist nicht uninteressant, unter diesem Gesichtspunkt die gegenwärtige protestantische Theologie zu gruppieren. Die heutige Orthodoxie hat ein stark pietistisch-spiritualistisches Element; aber da sie in der inneren Erfahrung des Geistes immer vor allem Bibel, Sakrament und Kirche als das übernatürliche Agens der Gegenwartserfahrung beglaubigt werden läßt, so behält sie einen hinreichenden Rest von Objektivität, Autorität, Maßstab und Wunder, um kirchlici denken und wirken zu können; hier hat man von der Jungfrauengeburt und Auferstehung eine innere Erfahrung; sie ist kirchlich »potente. - Schleiermacher und seine Schüler sind wesentlich spiritualistisch; aber er ist vom Spiritualismus zu einer modernisierten Christusmystik zurückgegangen, womit er einen christlichen. Kult und einen, einigermaßen faßbaren Lehrkanon, die Anerkennung der Erlösung durch den übernatürlichen Eindruck der gotteinigen Christuspersönlichkeit, behält ; dementsprechend behauptet er Kirche und Kultgemeinschaft, freilich mit Freigebung sehr individueller Zurechtlegungen der in die Volkskirche eingekleideten christlichen Lebenssubstanz; von hier aus ist eine feste Kirchlichkeit in alten Sinne nie zu erreichen. - Schleiermacher sind alle $\mathrm{Heg}$ el i a ner gefolgt, soweit sie die Religion aus dem rein intellektualistischen Geiste und dem lediglich partei- und schulmäßigen Zusammenhang heraussetzen wollten; oder sie haben das >Prinzip des Geistes völlig gegen die »Person « Christi verselbständigt und damit für die Kirche nur die völlig anonyme Geistesgemeinschaft übrig behalten. - Ritschl und seine echten Schüler haben die Lehrsubstanz eigentümlich reduziert, aber für sie eine streng autoritativ-kirchliche Geltung verlangt, eben deshalb die Kirchlichkeit aufs stärkste betont und den mystischen Spiritualismus aus jedem Schlupfwinkel vertrieben; es war sein Triumph, den orthodoxen Gegnern ihre pietistisch-spiritualistischen Erweichungen des'Kirchenbegriffes nachzuweisen und kirchlicher zu sein als sie. Sein Dogma ist daher völlig auf die Möglichkeit einer Volks- und Landeskirche zugeschnitten. - Herrmann folgt einer Zinzendorf und Schleiermacher verwandten Christusmystik, die einen Kern der von außen gegebenen, Gewißheit und Zuversicht verbürgenden und dadurch erlösenden Offenbarung behauptet, im übrigen aber alles der persönlich-gewissensmäßigen Ueberführung 
Eben hieraus ist es aber auch zu begreifen, wenn gerade aus der Romantik heraus der soziologische Gegenschlag erfolgt ist, die anheimstellt; daher hält er es kirchlich mit Luthers Vertrauen zu der übernatürlichen, die Bekehrung von sich aus wirkenden Christusverkündigung, die keiner künstlichen Nachhilfe bẹdarf und sich von selbst durchsetzen wird; die kirchenrechtlichen Folgerungen aus einer solchen Positior haben Rudolf Sohm und Erich Förster gezogen; das würde praktisch zu kongregationalistischen Folgerungen führen, bei denen es lediglich eine Sache des Glaubens und Gottvertrauens ist, daß man ihnen keine kirchen-auflösende Wirkung zutraut. - Die sog. religionsgeschichtliche $\mathrm{Schule}$ lenkt völlig zum Spiritualismus zurück und ist daher kirchlich simpotent «. Meine eigene Theologie ist sicherlich spiritualistisch, sucht aber eben deswegen dem historischen und dem damit verbundenen kultisch-soziologischen Moment Raum zu schaffen. Die Schwierigkeiten eines solchen Unternehmens sind mir natürlich wohlbekannt. - Harnack (s. besonders die Aeußerungen über den Weltkongreß für freies Christentum, Aus Wissenschaft und Leben 1911 I 146-152) hält eine prinzipielle Lösung des Problems überhaupt für untunlich und wünscht nur ein verständiges tolerantes Kirchenregiment, das den Geistlichen Bewegungsfreiheit läßt, also eine rein faktische Auflösung des Kirchentums und seine Wahrung lediglich durch Beseitigung ganz extremer Greistlicher, über deren Extremität ein wesentlich die Persönlichkeit in Betracht ziehendes Spruchgericht entscheidet nach bestem Wissen; das mag dann den Uebergang zu späteren glücklicheren Formationen bilden. Eine Auffassung, die durchaus der Mischung von Spiritualismus und Historismus in seiner Theologie (s. ebd. Christus als Erlöser S. 8I-94) entspricht. - Von da aus versteht sich auch eine Schrift, wie die des Generalsuperintendenten Kaftan ,Wo stehen wir ? Eine kirchliche Zeitbetrachtung * I9I I. Er rühmt an den Orthodoxen ihre kirchliche Potenz und verwirft bei den Liberalen ihre kirchliche Impotenz, die er an lauter, den Spiritualismus in Erinnerung bringenden Zügen erläutert. Zur Rettung der Kirche will er die Subjektivisten von ihr abgliedern. Die Charakteristik ist nicht falsch. Aber man muß doch auch hervorheben, daß mit der skirchlichen Potenza wesentlich Eigenschaften verbunden sind, die moralisch sehr schwer zu ertragen sind, und mit der spiritualistischen Impotenz solche, die gerade der Milde, Güte und Innerlichkeit des Christentums entsprechen. Es ist eben die soziologische Antinomie 2wischen den Erfordernissen der Organisationsbildung und denen der freien Persönlichkeitsbildung. Mutatis mutandis steht die Sache bei den politischen Parteien ganz $\ddot{h} h n l i c h$, nur daß diese nicht prinzipiell der Bildung der Persönlichkeit dienen. Steht die Sache aber so, dann wäre doch ein anderer Ausweg als der Kaftans wünschenswert. So würde die Kirche um einen sehr hohen Preis gerettet und dem allgemeinen Geistesleben überdies völlig entfremdet. - Feine Bemerkungen über diese ganze Lage bei Sell in dem Aufsatz, Die zweifache Theologie, ChW 1911; s. auch meine Gedächtnisrede *Richard Rothe 1899 . Rothe hat sich nur durch seine Christologie der letzten Konsequenzen des Spiritualismus erwehrt, schließt sich aber auch in dieser an die Theosophie an; hier erinnert er an Schwenkfeld, Paracelsus, Bơhme, Oetinger, Arnd. - Zum Ganzen s. auch das erwähnte Buch von Bruhn. 
Zurückwendung zum alten Kirchentum. Das ist schon bei Novalis kein aus der Romantik selbst quellender Trieb, sondern im Gegenteil eine Erwehrung gegen ihre relativierenden und radikal individualisierenden Folgen. Ihm geht bei der romantischen Versenkung in die Geschichte die völlige Verarmung der modernen Gesellschaft und der sie erfüllenden Religion an soziologischem Gehalt und gemeinschaftsbildender Kraft auf. Von hier aus erscheint ihm nicht ohne guten Grund das Mittelalter natürlicher und reicher. Aehnliche Einsichten ergaben sich gleichzeitig bei St. Simon, der für seine Entdeckung einer notwendigen sozialen Neugestaltung nach der religiösen Idee griff und hier sich an ein romantisch belebtes Christentum hielt. Auch die französische katholische Romantik ging ähnliche Wege. Das romantische historische Gefühl und das Bedürfnis nach Symbol- und Phantasiebefriedigung ist nur ein Mittel für diese Gegenbewegung gewesen. Der eigentliche Geist der Romantik ging keineswegs in dieser Richtung. Das neue Kirchentum hat sich darum bald genug von diesen untauglichen Mitteln befreit und $z u$ pietistischen oder rein orthodoxen gegriffen. Heute herrscht in katholischem und protestantischem Kirchentum in Wahrheit der der Romantik entgegengesetzte Geist, die Richtung auf Anstalt, Autorität, Uniformität. Von der Romantik ist nichts geblieben als bei Theologen, die gerne geistreich sein und sich modern gebärden wollen, die Phraseologie.

Aber zu einem solchen Gegenschlag nötigte in irgend einer Art doch das eigentliche Wesen des Christentums selbst, das nie lediglich individualistische Mystik, sondern immer zugleich ethische Triebkraft, zur Gemeinschaft yerbindende Anerkennung des göttlichen Willens ist und das als Religion nur von einem lebendigen Kultus genährt werden kann. Der Kultus kann aber kein anderer als die Verehrung Jesu als Gottesoffenbarung in irgend einem Sinne sein. So hat auch Schleiermacher sich von seinen spiritualistisch-individualistischen Jugendidealen zur Kirche zurückgewendet und sie um den Christuskult vereinigt als um die Quelle, von der die religiöse Kraft des Urbildes immer neu ausströmt. Dieser Kult soll - nach ihm in den Landeskirchen, so lange solche bestehen, in einer großen gemeindlichen Selbständigkeit und mit weitgehender individueller Beweglichkeit ausgeübt werden. Er soll innerhalb der landes- und volkskirchlichen Einheit die einzelnen Kultkörperschaften mit christlichem, jedesmal sich individualisierendem Geiste durchdringen. Es ist das Ideal einer Synthese von kirchen- 
artigem Gemeingeist und spiritualistischem Individualismus, von Volliskirche und kongregationalistischer Independenz, von Christusverehrung und Lebensgestaltung aus dem Christusgeist, ein Ideal, das von Gemeinden und Kirchenregierungen die größte Weisheit und W'eitherzigkeit, Besonnenheit und Hingebungsfähigkeit fordert, das ebendeshalb praktisch nur als Karikatur d. h. als landeskirchliche Orthodoxie mit notgedrungener Duldung liberaler Theologen durchgeführt worden ist. Die gebildete Laienwelt hat, sowcit sie am Christentum hängt, daher in Wahrheit eine Religion ohne Kirche und Kultus, ein Christentum des Geistes und der Gesinnung, der humanitären Tat und völlig individueller Zurechtlegung des religiösen Gedankengehaltes ${ }^{505}$ ).

Durch all das ist die Lage des Christentums in der modernen Bildungsschicht bedingt. Die Zugehörigkeit der religiösen Typen zu gewissen sozialen Schichten, die sich überall herausarbeitet und jenen Typen erst dauernde Wurzelung verleiht, ist auch hier nicht zu übersehen. Gewisse Schichten verlangen die Selte, ihre Aufreizung und ihre das Individuum mitbeteiligende und befriedigende soziologische Gestaltung. Andere verlangen die Kirche als das alles ausgleichende und vermittelnde, Autorität und Halt bietende, der Massenleitung günstige soziologische und religiöse Element. Die moderne Bildungsschicht aber versteht im allgemeinen nur den Spiritualismus. Es ist das zugleich ein Reflex des radikalen, atomisierenden Individualismus der modernen Kultur überhaupt, eines Individualismus, der auf den nicht-religiösen Lebensgebieten bereits wieder zu weichen und in sein Gegenteil umzuschlagen beginnt. Es ist mit der Verfüchtigung von Gemeinschaft, Kultus, Geschichte und Sozialethik trotz aller Tiefe und Innerlichkeit des Gedankens zugleich eine Schwächung des religiösen Lebens, das von Kirche und Sekte in seiner konkreten Lebensfülle erhalten werden muß, damit eine ganz individuelle Mystik es überhaupt spiritualisieren kann. So darf man es sich nicht verbergen: diese

505) Treffende Bemerkungen über die Wendung bei Novalis und bei der französ. Romantik bei Windelband, Die Philosophie im deutschen Geistesleben des 19. Jahrhunderts, $1909 \therefore 32-36$; uber St. Simon s. Lorenz Stein, Sozialismus und Kommunismus. Schon Herder hatte in seiner Bückeburger Zeit derartige Anwandelungen. Wie wenig aber solche Wendungen aus dem eigentlichen Geiste der Romantik stammen, zcigt die heutige Neuromantik, welche den alten ästhetisch differenzierenden Geist erneuert und die positiv-historische Tendenz wieder gänzlich ausgeschieden hat, vermutlich nur, um einen ähnlichen Umschlag zu erleben. 
der modernen Bildungsschicht allein zugängliche liassung des Christentums setzt neben sich den Fortbestand anderer und konkreterer Lebensformationen des Christentums voraus und kann nicmals für alle sein. Man wird vielmehr mit Sicherheit sagen können, daß clic Verheißung Lessings, das Lvangelium aeternum und die in allen Individuen gleich ursprüngliche und gleichartige Gotteserkenntnis, niemals eintreten wird. Was aber in Wahrheit kommen wird und welche Bedeutung dieser moderne Spiritualismus für die Zukunft haben wird, das vermag freilich niemand zu sagen. Das Problem der Organisation religiöser Gemeinschaften ist heute dunkler als jemals. Die Lage am Anfang der Reformation ist mit der Erstarkung von Sekte und Spiritualismus und mit der Fraglichkcit des Verhältnisses von Kirche und Staat wiedergekehrt ${ }^{506}$ ).

Damit ist der Ueberblick über die Erscheinungen dess Sektenwesens und der spiritualistischen Mystik gewonnen. Obwohl beide von dem kirchlichen Protestantismus sich sehr wesentlich unterscheiden, so gehören sie doch zum Protestantismus; indem sie die jeden Kirchentypus begleitenden und aus der Bibel sich stets neu erzeugenden Strebungen der Sekte und der Mystik in ihrer spezifisch protestantischen Bestimmtheit zeigen, die Sekte in der schließlichen Erfüllung mit dem protestantischen Berufsideal, die Mystik in ihrer Verschmelzung mit dem protestantischen autonomen Individualismus. So liegen denn auch ihre Ideale schon im protestantischen Kirchentum selbst enthalten, die Sekte mehr im Calvinismus, die Mystik mehr im Luthertum. Sie ergänzen sich mit dem Kirchentum in dem sog. Pietismus immer von neuem, der ein Mittelding zwischen protestantischem Kirchentum und sektenhaft oder spiritualistisch gestimmter Frömmigkeit ist. Die erstmalige Ausscheidung der mit den demokratischen Neigungen der Zeit verknüpften sektenhaften und mystischen Gruppen aus der Reformation hat dereinst die populäre Kraft des Protestantismus stark beeinträchtigt und ihn erst recht den herrschenden Gewalten in die

506) Siehe meine Abhandlung "Die Kirche im Leben der Gegenwart in dem schon erwähnten Sammelwerk Weltanschauung usw., und den Aufsatz \Gewissensfreiheit $\mathrm{ChW}$ 19II; auch meinen Vortrag, Die Bedeutung der Geschichtlichkeit Jesu für den Glauben 1910; ganz ähnlich urteilt Eucken a. a. O. S. 136. S. auch die mit Bonus sich auseinandersetzenden Schlußausführungen in Harnacks Dogmengeschichte 4. Aufl. III 902-908. 
Arme getrieben, wodurch dann wieder die Festigkeit seines Kirchentypus gesteigert wurde. Aber die ausgeschiedenen Motive kamen wieder und erzeugten teils das pietistische Wesen, das den Kirchen bis heute seinen Einfluß tief aufgeprägt hat, teils die verselbständigte Sektenbewegung und die christliche soziale Reformidee sowie den kirchenfreien oder kirchlich gleichgültigen Spiritualismus ${ }^{307}$ ).

Es erübrigt nun bloß noch abschließend die Soziallehren dieser Gruppen und ihre soziologische Bedeutung zu formulieren. Dazu bedarf es nicht mehr als die im einzelnen schon gemachten Beobachtungen kurz zusammenzufassen und das Verhältnis dieser Soziallehren zu denen des Katholizismus, des Luthertums. und des primitiven Genfer Calvinismus zu bestimmen.

Um mit der zuletzt behandelten Richtung zu beginnen, so ist Spiritualismus und Mystik überhaupt ohne Organisationstrieb. Nur in dem Maße, als der ethische christliche Theismus in ihnen erhalten bleibt, und bei den quietistisch-pantheisierenden Gruppen nur unter dem Druck des unausrottbaren natürlichen Gemeinschaftstriebes, ergeben sich hier soziale Selbstgestaltungen der religiösen Idee. Sie pflegen an sich lediglich das Individuum und sein Heilsinteresse und glauben zugleich an die allgemeine Geistes- und Liebesgemeinschaft. Diese letztere betonen sie unter Umständen sehr stark, aber Kirche und religiöse Organisation liegt ihnen ferne. Innerhalb jener geglaubten Geistesgemeinschaft aber bilden sie mit eigenem Tun nur die engeren Kreise des Philadelphentums, der Seelenführer und Virtuosen aus. Kultus und Geschichtsbeziehung, an denen Kirchen und Sekten ihren zusammenhaltenden Organisationspunkt finden, treten hier zurück, werden in ein persönliches unmittelbares Verhältnis zu Gott und Christus oder in die Erhebung des Geistes verwandelt oder verschwinden ganz. Sie bilden ein soziologisches Grundschema wohl aus, eine Einigung aller Geister im gemeinsamen Ziel und eine völlige Toleranz aller Geister nebeneinander, weil, wie Lagarde sagt, s auf dem Wege aufwärts zu Gott die Linien sich nicht schneiden, sondern zusammentreffen $\%$. Allein sie tragen dieses Grundschema nicht planmäßig und tätig in die Gesellschaft hinein. Es gilt nur für

507) Ebenso Göbel I 145. Das ist auch das Richtige in Barges Gesamtanschauung vom Verlauf der Reformation, die nur wenig Verständnis für den Kirchentypus zeigt, aber in den Hauptzilgen richtig ist. 
die Suchenden, Erkennenden und Erleuchteten, und seine Kraft kann sich nur mit der Ausbreitung des Geistes von selbst verbreiten. Hier wird nichts gemacht und organisiert. Die Frage ist nur, wie weit dieser Geist von selber wirken wird, und da unterscheiden sich die einzelnen sehr nach ihrem Temperament. Resignation, bewußter Aristokratismus, Pessimismus, Quietismus und optimistische Hoffnung wechseln hier. Von da aus folgt natürlich erst recht eine völlige Gleichgültigkeit oder Hilfosigkeit gegenüber den außerreligiösen sozialen Problemen. Mit dem Staate und der Wirtschaft weiß diese Denkweise im Grunde nichts anzufangen, das muß alles neu und anders werden. Wann? und wie? das ist freilich schwer zu sagen. Nur auf dem Gebiete der Sexual- und Familienethik hat sie begreiflicherweise eigentümliche Züge aufzuweisen, da diese Dinge mit der ganz persönlich intimen Lebenswürdigung sehr eng zusammenhängen. Hier charakterisiert sie eine große Unabhängigkeit von der Konvention. Die Verinnerlichung und Vergeistigung dieser wichtigsten, das Gefühlsleben so stark beeinflussenden Vorgänge, die Zusammenschmelzung des Erotischen mit dem Ethisch-Religiösen, ist ihr Ziel. Daher stammen die Erscheinungen, die man als Antinomismus und Libertinismus diesen Kreisen immer wieder mit Recht und Unrecht vorwarf. Heute ist gerade von ihnen das Problem der Sexualethik mit großer Feinheit behandelt. Die Gesinnungsmäßigkeit und religiöse Durchdringbarkeit der erotischen Beziehungen oder auch umgekehrt asketische Bedenken gegen die erotische Gefühlskonkurrenz werden hier betont und von da aus die Ideale sehr stark im Gegensatz gegen die konventionelle rechtliche, vermögenspolitische und kirchlich-legitime Anschauung von der Ehe entwickelt. Die sehr schwankenden Einzelheiten lassen sich nur im Rahmen einer Monographie darstellen, würden aber sehr viel des Interessanten darbieten. Wichtig bleibt jedenfalls die Berührung erotischen und religiösen Gefühls, die bei diesen verinnerlichten Subjektivitäten eine gegenseitige Durchdringung beider möglich macht und die grobe kirchliche Lehre von der Konkupiszenz als Folge des Sündenfalls beseitigt. Wo aber in den großen spiritualistischen Denkern der Neuzeit, wie Schleiermacher und Richard Rothe, die Ethik auf die praktischen Aufgaben der Kultur eingeht, da stammen ihre Gedanken offenkundig und eingestandenermaßen aus der modernen Ideenwelt. Die Schwierigkeit ist dann die Einschmelzung dieser Ideenwelt in die christliche Innerlichkeit und Ueberweltlichkeit. Für 
III. Protestantismus. 4. Sektentypus und Mystik auf protestantischem Boden.

die Schwierigkeit und Zwiespältigkeit dieser Aufgabe ist insbesondere Rothe höchst charakteristisch ${ }^{508}$ ).

Was dann weiter die Sekte betrifft, so zerfällt sie wie bereits im Mittelalter in die aggressive welterneuernde und die duldende und leidende, weltindifferente Sekte.

Die e rstere mit ihrem apokalyptisch gewaltsamen Geiste ist seit dem 17. Jahrhundert erschöpft, hat freilich hier in der

508) Einzelheiten s. bei Ritschl und Göbel. Die Geschichte der Ethik von Luthardt II 248-340 und Gaß II I $S .283-325,359-368$ bieten an diesem Punkte so gut wie gar nichts. Dippel hat eine Sozialethik geschrieben : >Christenstadt auf Erden ohne gewöhnlichen Lehr-, Wehr- und Nährstand oder kurze doch eigentliche Abbildung der aus dem Reiche der Natur entstandenen und im Zorn Gottes bestätigten Ordnungen unter den Menschenkindern. Auszüge bei Walch, Religionsstrcitigkeiten 729 f. u 753 f. Die gegebene Gesellschaft des Naturgesetzes gehört nur in die Oekonomie des Gesetzes oder des Vaters. - Aehnliche Gedanken enthält Saltmarsh in seinen Sparcles of glory. Ein völlig neuer aus Geist, Gesinnung und Liebe fließender gesetzesfreier, aber in sich organisch durch die Liebe gegliederter Menschheitszusammenhang soll kommen. Bis dahin ziehen die Christen sich von der Welt in Gelassenheit und Demut zurück. - Sebastian Franck toleriert die gegebenen Verhältnisse im Sinne des lutherischen Naturrechts mit starker Resignation und pessimistischer Menschenbeurteilung, Hegler 260-263, 243, I I6, 179-184; auch Schmoller und Wiskemann berühren Franck. - Aehnlich konservativ und provisorisch für die Gegenwart, aber spiritualistisch-revolutionär für die Zukunft steht Gottfr. Arnold zu dem Problem Ritschl II 311, 315. Winstanley und Lilburne dagegen erwarten die Erneuerung dẹ Gesellschaft im demokrat. und kommunist. Sinne vom Geist und arbeiten bewußt, wenn auch ohne Gewalttat, auf dieses Ziel hin. - Für die Sexualethik ist auf die Zulassung der Frau zum Predigen hinzuweisen, die an sich schon eine Auf hebung des kirchlichen, vor allem lutherischen Patriarchalismus ist. Im übrigen tritt die feinere Sexuatethik erst bei den modernen Spiritualisten zutage, die die religiöse Idee der Persönlichkeit mit einer ästhetischimmanenten Auffassung der Natur verbinden. Hier sind charakteristisch Schleiermachers Briefe über die Lucinde s. Rade, Stellung des Christentums zum Geschlechtsleben S. 6I-89, wo aber die Sache zu nahe an Luther angeschlossen ist statt an die Subjektivierung der Persönlichkeit in Mystik und Spiritualismus. Schleiermachers Gedanken sind völlig unlutherisch. - In diesen Gedankenkreis gehören auch die feinen'Schriften zur Sexualethik von Lhotzky, Das Buch der Ehe 1911, und Joh. Müller, Beruf und Stellung der Frau 1911. Das ist gänzlich uıkirchliche Sexualethik. Joh. Müller ist überhaupt für die Ethik des modernen Spiritualismus sehr charakteristisch: nicht quietistisch, sondern kräftig und entschlossen auf die Neugestaltung der Menschheit durch die Erweckung des in. jeder Seele schlummernden sursprünglichen Wesens a oder Gottesfunkens gerichtet, den der Eindruck Jesu erweckt und zu persönlicher frei gestaltender Gesinnung macht. Es 
Great Rebellion Englands ungeheure welthistorische Wirkungen hervorgebracht. Seitdem besteht sie nur mehr in den christlichsozialen Bestrebungen weiter, die mit sehr verschiedener Folgerichtigkeit und mit sehr verschiedenen Mitteln eine neue gerechte und Gottes Willen wie der Vernunft gemäße Gesellschaftsordnung herbeizuführen bestrebt sind. Im Katholizismus, der übrigens nur auf dem gemischt-konfessionellen Boden sich auf die Sache einläßt, ist der Sektencharakter naturgemäß am meisten abgestreift. Dort gilt es im Grunde nur einen neuen Stand in den von der Kirche geleiteten sozialen Organismus einzufügen, dessen innere Harmonie durch die der Kirche gegebene Gnadenkraft und die sie leitende Autorität damit auch für die Gegenwart wieder hergestellt sein wird; das schließt natürlich eine sehr energische und erfolgreiche sozialpolitische Tätigkeit im einzelnen nicht aus, um so mehr als ihr der ungeheuere kirchliche Einfluß zur Verfügung steht. Auf dem Boden des Calvinismus äußert der christliche Sozialismus sich wesentlich als Vereinsbildung, Beeinflussung der öffentlichen Meinung und Stiftung von Kooperativ-Gemeinschaften. Auf dem Boden des Luthertums, wo gar keine Ansätze in den Kirchen für ihn bereit lagen, hat er sich am prinzipiellsten entwickelt. Aber auch hier teilt er sich in eine bloß im allgemeinen die ethische Gesinnung bearbeitende und auf Versöhnung des Klassenkampfes hinarbeitende Richtung und eine andere, welche eine sozialistische Erneuerung der gesamten Gesellschaftsverfassung für Christenpflicht

ist ein spiritualisierter Chiliasmus. Die hüchsten Wirkungen hat diese Lehre naturgemäß für die rein persönlichen Verhältnisse und damit für das Geschlechtsverhältnis. Ueber Staat, Wirtschaft und Gesellschaft enthält seine Bergpredigt, verdeutscht 1906, freilich sehr vage und unmögliche spiritualistische Reformideen, die der Komplikation des wirklichen Gesellschaftslebens nicht entfernt gerecht werden. Das ist Enthusiasmus. Der Gegensatz gegen die Kirche, die Bildung kleiner, um die Persönlichkeit gescharter Kreise, die Zuwendung zum Empirismus und die Abneigung gegen die theologische Wissenschaft kehren auch hier als charakteristische Grundzüge wieder. Demokratische und kommunistische Züge, alles Egalitäre, liegt dagegen Müller völlig fern. - Im übrigen ist bei alledem aber auch an solche Dinge wie Tolstois sKreuzersonate « zu denken. - Die Soziallehren Weigels angedeutet bei Ritschl, Gesch. d. Piet. I $97: \gg$ Er rechnet auf vollständige Umgestaltung der bürgerlichen Gesellschaft. Nicht mehr Justinians, sondern Christi Gesetz soll gelten. Die Obrigkeit darf keine Steuern nehmen, keine Todesstrafe verhängen, keinen Krieg führen, Gemeinschaft der Güter soll herrschen. Der Handel wird als unchristlich bezeichnet. Die Erzeugung der Kinder, also auch die Ehe, wird als eine Ordnung der Sünde bezeichnet. - Ueber Rothe s. meine Rede S. 3I-35. 
und für Einstellung in den von Gott gewollten, aufwärts führenden Zug der Entwickelung hält. Gegenüber diesen allgemeinen Grundproblemen treten natürlich die sozial-ethischen Einzelprobleme zurück. Sie zersplittern sich entweder in unendliche Einzelfragen oder sie gehen -unter in der Unbestimmtheit der nur in den allgemeinsten Zügen charakterisierten Zukunftsordnung. Die zum Teil recht lehrreichen Besonderheiten können auch hier nur monographisch dargestellt werden ${ }^{5084}$ ).

In unserem Zusammenhang handelt es sich nur um die grundsätzliche Einsicht in die Zusammenhänge. Diese aber ist lehrreich genug für das ganze Verhältnis des Christentums zu dem Gedanken einer Sozialreform und schließt die bereits früher gemachten Beobachtungen über dieses Thema ab. Das Evangelium war in dieser Hinsicht völlig ideologisch und gleichgültig gegen die Welt, deren Verwandelung es erst dem großen Wunder des kommenden Gottesreiches zuschrieb und im Großen wie im Kleinen völlig Gott anheimstellte; nur der Vorzug der Armen und Leidenden als der wärmer und demütiger Gott Fühlenden. war dabei in Aussicht genommen; außerdem betrachtete es jeden Erweis der Liebe, den die Gelegenheit forderte, als Betätigung der Gott gemäßen Gesinnung. Die alte Kirche nahm die Welt mit den notwendigsten Abänderungen und mit innerer Zurückhaltung gegen sie in sich auf und bildete zur Besiegung der materiellen Not die Anfänge der Karität aus. Das Mittelalter hat eine relative Zusammenstimmung der wirklichen Lage mit dem christlichen Ideal hervorgebracht; aber es entwickelte nur die Herrschaft der Kirche über diese natürlichübernatürliche Lebensharmonie und begegnete den Schäden nicht mehr durch kirchliche und gemeindliche, sondern durch anstaltliche, mönchische und stiftungsmäßige Karität. Das Luthertum befahl alle Dinge der weltlichen Lebensordnung einer vom Evangelium geleiteten Obrigkeit und ließ diese sich mit den hier obwaltenden Schwierigkeiten abfinden, gewiß, daß das Evangelium die Naturordnung durch die Liebe zu beseelen und zu ordnen vermag. Der Calvinismus, der das Sektenideal der heiligen Gemeinde in sich aufgenommen und mit dem staatskirchlichen Geiste ausgeglichen hat, betonte zum erstenmal neben den Sekten an leitender Stelle ein christlich-soziales Ideal, aber in dem

\footnotetext{
b08 ) Hierzu die verschiedenen, schon erwähnten Arbeiten von Ragaz und Rauschenbusch, weiteres oben S. $946 \mathrm{f}$.
} 
durchaus konservativen Sinne der Behauptung der gegebenen bürgerlich-staatlichen Ordnung und in der Voraussetzung, daß diese von relativem Naturrecht geleitete Ordnung bei gutem Willen und dem nötigen Heiligungsernst zur Unterlage einer wirklich christlichen Lebensorganisation gemacht werden könne. Eine radikale Sozialreform, die die bestehende Gesellschafts- und Eigentumsordnung als wurzelhaft unfähig betrachtet, die christliche Persönlichkeit und die christliche Liebe allumfassend auszubilden, kannten nur die Sekten, und zwar auch diese nur in dem Maße, als sie vom Dulden und Leiden unter dem Einfluß des eschatologischen Reich-Gottes-Gedankens und in der Erwartung der Nähe seiner Verwirklichung zur grundsätzlichen Reform nach dem Ideal des Gottesreiches und der vollen urständlichen Vernunft übergingen. Je mehr hierbei noch überdies der stoische Naturrechtsgedanke mitklang, wurde diese Reform demokratisch und kommunistisch. Sie waren die alleinigen Träger einer radikalen kompromißlosen und nicht-resignierten christlichen Sozialethik. Die Kirchen setzten dem bis heute den Gedanken der auf Erden unüberwindlichen Sünde oder der Innerlichkeit des Heils entgegen und haben sich auch durch die Not der Zeit und die wachsende Entchristlichung der Massen nur zu einer mehr oder minder tiefgreifenden Mitarbeit an der staatlich-bürgerlichen Sozialreform und überdies zu innerer Mission und breit entfalteter Karität treiben lassen; das letztere ist schon ein Einfluß, den sie dem Calvinismus und Pietismus verdanken. Aber gerade bei diesen Versuchen konnte die Einsicht nicht ausbleiben, daß jede geistig-ethische Emporbildung der Masse an bestimmte politisch-ökonomische Grundlagen gebunden ist und daß die moderne kapitalistische Lebensverfassung diesem Ziel schärfer entgegensteht als irgend eine bisherige. So erhob sich der christliche Sozialismus zu einer innern Kritik der bestehenden bürgerlichen Ordnung und verlangte entweder eine radikale Erneuerung der grundlegenden Gesinnung oder geradezu die Abstellung der gegebenen bürgerlichen Ordnung zugunsten einer neuen Gesellschaftsordnung, wie deren Ideal zugleich die von der Not der Lage hervorgerufenen sozialistischen Reformparteien erfüllt. Damit aber nimmt der christliche Sozialismus den alten Geist der aggressiven Sekte wieder auf, deutet wie sie die Bewegungen der Zeit auf einen von Gott herbeizuführenden grundsätzlichen Wandel der Dinge, macht den Gedanken des Reiches Gottes auf Erden und des inneren Zusammenhangs von Geist und Leib geltend und 
946 III. Protestantismus. 4. Sektentypus und Mystik auf protestantischem Boden.

nähert sich den alten Gedanken des absoluten stoisch-christlichen Naturrechts. Die modernen Immanenzgedanken und die Bedeutung der innerweltlichen Kultur haben auch auf ihn abgefärbt. Er versteht und konstruiert sich als ein Ergebnis der geistigen und kulturell-technischen Entwickelung. Der asketische Enthusiasmus und Dualismus ist daher auch für ihn vorbei. Er ergänzt das Evangelium nicht mehr wie die alte Sekte aus dem Alten Testament und der Apokalypse, sondern aus der modernen sozialwissenschaftlichen und technologischen Fortschrittsstimmung. So hat er auf den apokalyptischen Revolutionsgedanken der Gewalt und auf das weltverwandelnde Wunder verzichtet und erwartet die Revolution nur von innen heraus. Damit aber löst er sich auch heute von der Kirche, nicht sowohl von der tatsächlichen Institution, als von dem Geist und Sinn der Kirche, die die Ergebung der Massen in die gottgeordneten Verhältnisse im ganzen verlangt und, ihrem Begriff nach mit allen Mächten der Ordnung und Autorität verbunden, Sozialreform nur als Karität und als christliche Kontrolle der bürgerlichen Ordnung kennt. Sozialistische Kirchen sind ein Unding. Denn die Kirchen haben einen anderen religiösen Inhalt als die radikal-ethische Leistung und Lebensgestaltung. Aber ein vom kirchlichen Geiste gelöster christlicher Sozalismus kann sich auf das Evangelium berufen. Die christliche Religiosität der Kirchen ist eben eine innerlich anders geartete als die einer freien Gemeinschaft zur Anstrebung des Gottesreiches. Dabei sind natürlich zahlreiche Uebergänge zwischen beiden nicht ausgeschlossen. Aber in dem Gegensatz einer auf die Menschen realistisch eingestellten Kirchenanstalt und einer das Ideal bedingungslos erstrebenden freien Willensgemeinschaft liegt der Kern des Problems.

Die duldende und leidende Sekte stellt sich dar in den Mennoniten, Baptisten, Quäkern, den aus dem Pietismus entstanderen Gemeindebildungen und den modernen Sekten. Auch sie hat einen anderen Charakter angenommen als ihre mittelalterlichen und altprotestantischen Vorfahren, als die Waldenser, Böhmischen Brüder und altprotestantischen Täufer. Sie sind von duldender und partieller Verneinung der Staats-, Gesellschafts- und Wirtschaftsordnung zur Bejahung übergegangen und haben sich alle auf Grund der protestantischen Berufsmoral zu Gruppen entwickelt, die im soziologischen Sinne als bürgerlich gelten müssen und auf die gegebenen Verhältnisse sich einrichten. Die Sozialre- 
form betreiben sie nur als innere Mission, Bekehrung, Erweckung und Karität, auch als gesteigerte Kontrolle der Gesellschaft durch die christliche öffentliche Meinung und Presse. Diese Verbürgerlichung und der Anschluß an die Berufsmoral ist eine natüliche Folge der dauernden Festsetzung, der steigenden Zahl, der Vererbung fester Verhältnisse, der Verflechtung in den allmächtigen Organismus des modernen Staats- und Wirtschaftslebens, das nicht mehr, wie die Anarchie und Einfachheit mittelalterlicher Verhältnisse, unberührte Inseln in seinem Strome bestehen lassen kann. Auch der Einfluß ihrer calvinistischen Umgebung ist ein bedeutender. Dadurch wuchsen und wachsen sie nun aber in ihrer soziologischen Selbstgestaltung wie in ihrer sozialen Ethik eng zusammen mit dem Calvinismus oder besser dem Neucalvinismus, der auch seinerseits die Verbindung mit dem Staate größtenteils gelöst hat und mit ihnen nach der ethischen Seite hin ununterscheidbar zusammengeht. Vor allem die Staatsfreiheit und die Forderung kirchlicher Neutralität des Staates unterscheidet sie noch von den Kirchen, ein Unterschied, der mit der Lösung der Kirchen vom Staate in der Neuzeit auch von der andern Seite her immer mehr verringert wird. Der Grund dieser Entwickelung ist durchsichtig. Die duldende und leidende Sekte ist nur als Provisorium möglich, als Warten auf die göttliche Offenbarung des Reiches. Hört dies Warten auf und gehen sie auf die dauernden Ordnungen der Welt ein, so relativieren auch sie ihre Maßstäbe und schließen ihren Kompromiß. Sie nähern sich mit Notwendigkeit entweder den Kirchen oder der radikalen Sekte oder sie erlöschen. So sind sie verkirchlicht und verbürgerlicht, wie der Calvinismus umgekehrt freikirchlich und gesetzlich geworden ist. Sie sind religiös-soziologisch betrachtet Kirchen geworden, wie die echten Kirchen auf dem Gnaden- und Sündendogma beruhend und fassen nur die Zugehörigkeitsbedingungen formell oder tatsächlich strenger als die Kirchen. Als solche selbständige, staatsunabhängige und die Souveränetät des Religiösen gegenüber der profanen Welt gerade durch diese Trennung bekundende Kirchen, als Organisationen eines sehr gesteigerten Individualismus der persönlichen Ueberzeugung und der bewußten, planmäßigen ethischen Leistung, entwickeln sie von sich aus ein soziologisches Grundschema, das man als Verknüpfung der Individuen in einem Gesamtgeiste bezeichnen kann, der nicht die Summe, sondern das Produkt der sich vereinigenden Einzelwillen ist, der nur durch ihre aktive Arbeit und nur in ihr 
besteht. Er nimmt jeden Einzelwillen von einer bestimmten Seite her in sein Wesen hinein, um ihn hierin von dem Gesamtgeist aus wieder rückwirkend $z u$ bestimmen, nach anderen Seiten hin aber zu beliebiger andersartiger Vergesellschaftung freizulassen. Es ist kein barer Individualismus, aber auch kein die Individuen erst hervorbringender und in sich tragender Anstaltsgeist, sondern eine lebendige Wechselwirkung zwischen den zusammentretenden Individuen und dem aus dieser Vereinigung sich ergebenden Produkt. Nicht vererbte Gefühle und Stimmungen, fertige und durch eigene W'underkraft sich erhaltende Grundgerüste des Lebens, zwischen eigener Anstrengung und vegetativer Zugehörigkeit hin- und hergehende Gemütsrichtungen bestimmen die Gemeinschaftsidee, sondern der klar erkannte, methodisch verwirklichte, jeden einzelnen beanspruchende und doch allen übergeordnete göttliche $Z$ weck des Lebens, die heilige Gemeinde, die Bewährung der Gnade, die Bereitung für das Jenseits. Es ist eine eigentümliche Mischung von Kirchengeist und Sektengeist, wobei der letztere der stärkere ist. An den religiösen Gemeinschaften vor allem betätigt, veranschaulicht und eingeübt überträgt sich dieser Geist auf das Ganze des Lebens als ein soziologisches Grundschema, das ähnlich den Staat, die Kommunen und das ganze unendlich verzweigte Vereinsleben überhaupt bestimmt. Von da aus ergibt sich eine gewisse Wahlverwandtschaft mit Demokratic und Liberalismus, aber ohne die rationalistische Forderung der Gleichheit und ohne den revolutionären Geist, wie er der Demokratie der lateinischen Völker eigentümlich ist. Vielmehr ist ein solcher Individualismus geradezu konservativ, indem ur die sehr zarten Bedingungen des Gleichgewichts zwischen Individuum und Gemeinschaft sorgfältig als Verfassung aufrecht erhält und sie möglichst unantastbar macht. Das sind Dinge, die jedem Beobachter amerikanischen Lebens auffallen und die auch den englischen Dissent charakterisieren. Man pflegt diese Eigentümlichkeiten aus der angelsächsischen Rassennatur herzuleiten, während in Wahrheit diese Rassennatur in der Schule des Calvinismus und der Sekte geschult und erwachsen ist ${ }^{509}$ ).

So ergibt sich aus der puritanischen und freikirchlichen Entwickelung des Calvinismus einerseits, aus der Verbürgerlichung des

$\left.{ }^{509}\right) \mathrm{Vgl}$. die mehrfach angeführte Studie Max Webers über s Kirche und Sekte in Nordamerika๔; einiges auch bei Tocqueville und Bryce, The American Commonwealth ${ }^{3}$ Ig03. 
Täufertums und aus der Verkirchlichung der pietistischen Sekten andererseits jene Gesamtgruppe des Protestantismus, die bereits oben als vasketischer Protestantismus* bezeichnet worden ist, im Unterschiede vom Luthertum und vom Ka.tholizismus. Hier ist der Faden wieder aufzunehmen, den wir am Schluß des vorigen Abschnittes fallen lassen mußten. Das Luthertum hat, wie mehrfach ausgeführt, zwar die Berufserfüllung als Gottesdienst und Betätigung der Liebespflicht gelehrt, aber bei seiner Betonung der reinen Innerlichkeit der Religion, seiner Unsicherheit in der Normierung des sittlichen Handelns und seiner Ergebung in die vom Naturgesetz geschaffenen, oft höchst unchristlichen Lebensbestimmungen und Mächte eine ihm aus eigenem Trieb erwachsene, zusammenhängende und systematisierte Gestaltung sozialer Dinge überhaupt nicht herbeigeführt. Es besitzt weder in der Theorie noch in der Lebensstimmung eine systematische Ethik. Es durchbricht den aus seiner Erbsündenlehre auch bei ihm folgenden Asketismus immer wieder durch das Ausruhen in der Seligkeit göttlicher Gnade, durch dankbares Genießen göttlicher Gaben in allem Guten und Schönen, und zieht sich, wo es bedenklich wird gegen Welt und Sünde, wieder auf seine innere Rechtfertigungs-Seligkeit zurück. Der Katholizismus andererseits schätzt gleichfalls den Kosmos des Berufssystems als das naturgesetzliche Mittel der natürlichen Existenz. Aber er gilt doch eben nur für die natürliche Existenz und ist somit bloß die Unterstufe der höheren übernatürlichen Sittlichkeit, die an die Forderungen des aktiven Lebens nicht mehr innerlich gebunden ist, sondern in dem komtemplativen Leben die höchsten Stufen der Uebernatur oder Gnade erreicht. Der asketische Protestantismus der Gruppen, die in der angegebenen Weise geschichtlich zusammengewachsen sind, behandelt dagegen den Beruf als Mittel der Bewährung und die eifrige Berufserfüllung als Erkenntniszeichen des Gnadenstandes. Er spannt dementsprechend die Berufsarbeit an zu einem zusammenhängenden System der Aufbietung und Konzentration aller Kräfte auf das Berufsziel, das dem einzelnen durch seine vorsehungsmäßige Stellung im beruflichen Kosmos zugewiesen ist. Die innere Lösung des Gefühls und des Genusses von allen Gegenständen der Arbeit, die rastlose Anspannung der Arbeit auf das im Jenseits liegende und darum bis zum Tode Arbeit fordernde Ziel, die Herabsetzung aller irdischen Dinge und Güter zu bloßen Zweckmäßigkeitsmitteln, die methodische Ausbildung 
950 III. Protestantismus. 4. Sektentypus und Mystik auf protestantischem Boden.

der Arbeit zur Unterdrückung aller zerstreuenden und träge machenden Triebe und die opferwillige Verwendung ihres Ertrages für die religiöse Gemeinde und das öffentliche Wohl: das sind seine Grundsätze und Ideale, die im einzelnen verschieden begründet werden, die aber ein gleichartiges Gepräge tragen und auch in erheblichem Maße praktisch verwirklicht wurden und werden $\left.{ }^{510}\right)$.

510) Hier mündet meine Darstellung endgültig ein in die bekannten Untersuchungen Max Webers über Der Geist des Kapitalismus usw. * Webers Untersuchungen gehen von dem Bestreben aus, die Konstitution des modernen, gewerblich-bürgerlichen, vom antiken und spätmittelalterlichen unterschiedenen Kapitalismus aufzufinden. Als eines dieser Konstituentien hat sich ihm auf Grund praktischer Anschauung in Westfalen und am Niederrhein, in Schottland, England und Amerika der sasketische Protestantismus dargestellt, dessen Wesen Weber in dieser wirtschaftsgeschichtlichen oder besser kulturgeschichtlichen Absicht untersucht. Meine Darstellung hat andere Ziele. Sie erstreckt sich nur auf die Klarstellung der protestantischen Sozialethik um ihrer selbst willen. Ich lasse also die weiteren Bezüge Webers beiseite. Seiner Darstellung des sasketischen Protestantismus konnte ich in diesem Punkte genau folgen, weil sie sich mir bei jeder erneuten Durcharbeitùng dieses Gegenstandes neu als glänzend scharfsinnige Beobachtung und Analyse bewährt hat. - Im übrigen aber gehen - was ich bei dieser Gelegenheit bemerken möchte - meine Untersuchungen nicht von denen Webers aus. Sie sind äußerlich veranlaßt durch den Auftrag, für das Archiv das Buch von Nathusius , Die Mitarbeit der Kirche an der Lösung der sozialen Frage anzuzeigen. Ich fand dabei, daß alle Voraussetzungen für die Lösung einer solchen Aufgabe in der Literatur fehlten, und machte mich daran, die Grundlagen mir selbst zu verschaffen. Daraus ist dieses Buch entstanden. In diese Arbeit mündeten aber dann alle Interessen meiner Forschung ein: soziologisch-phänomenologische über Begriff und Wesen der Kirche, die sich mir aus Rothes bekannter Lehre ergaben (s. > Religion u. Kirche ₹reuß. Jahrbb. 1895), die Geschichte der christl, Ethik betreffende (s. $>$ Grundprobleme der christlichen Ethik \& Z. f. Th. u. K. 1902) und vor allem Untersuchungen über die Bedeutung der Lex naturae (sie ziehen sich seit meinem selanchthon und Gerhard durch eine ganzé Reihe von Arbeiten hindurch). Schließlich ist das Buch zur Ausführung des Programms geworden, das ich I90I in meiner Anzeige von Seebergs , Lehrbuch der Dogmengesch. \& Gütt. Gel. Anzz 1902 S. 2 I-30 entworfen habe. Webers Arbeit aber ist erst seit 1903 erschienen. Auf den Begriff des sasketischen Protestantismus wäre ich allerdings ohne Weber nicht in größerer Klarheit gekommen, als dieser Begriff schon bei Schneckenburger und Ritschl vörbereitet ist. Man braucht übrigens die Werke dieser beiden hervorragend scharfsinnigen und kenntnisreichen Gelehrten nur genau zu studieren, um auf den Begriff geführt zu werden. Webers eigene, sehr bedeutende Entdeckung ist die Einstellung in den allgemeinen kultur- und wirtschaftsgeschichtlichen Zusammenhang, wobei übrigens auch die psychologische Fein- 
Von diesen Grundsätzen aus verstehen sich dann auch die das außerreligiöse Gebiet betreffenden Soziallehren des asketischen Protestantismus, wie von nun ab der Kürze wegen immer gesagt werden soll. Der Neucalvinismus, dessen Soziallehren aus diesem Grunde oben nicht für sich dargestellt wurden, ist hierbei mit einbegriffen ${ }^{510 a}$ ).

Die Sexualethik ist natürlich strengste Familienethik. Vorund außerehelicher Geschlechtsverkehr sind verpönt. Das ist gemeinchristlich. Aber die Familienethik selbst ist hier doch eigentümlich gedacht. Die Askese verlangt nämlich die Ausscheidung alles Erotischen und Gefühlsmäßigen, das Katholizismus und Luthertum als die aus der Erbsünde folgende Wollust immerhin dulden zu müssen glaubten. Das Geschlechtsleben der Ehe war ihnen medicina libidinis. Hier aber wird es dem $Z$ weckzusammenhang der zu Gottes Ehre dienenden Gemeinde fest eingegliedert. Das Geschlechtsleben soll nicht dem Genuß, sondern der wohlüberlegten Kinderzeugung dienen. Es hat keinen $Z_{\text {weck }}$ in sich selbst, sondern dient der Fortpflanzung von Gesellschaft und Kirche. Die Kinderzeugung wiederum bedeutet die Pflicht zur Aufzucht von nützlichen Gliedern der Gesellschaft und frommen Gliedern der Gemeinde, setzt sich also unmittelbar fort in der Aufgabe einer zweckmäßigen Erziehung. Der Gedanke einer planmäßigen, nützlich-realistischen Erziehung und entsprechender Schulen gehört den Sekten und dem Pietismus an. Das sehr individualistisch empfundene Verhältnis der Geschlechter in der Ehe mildert den harten Patriarchalismus; die Frau wird insbesondere im Täufertum religiös und damit auch sozial verselbständigt. Die Sekten kennen gelegentlich, wie die Mystiker, weibliche Prediger und Stundenleiter. In den reformierten Prophecyings und Konventikeln Voets durften Frauen mitreden. In der Gemeinde Labadies spielten Frauen, allen voran die berühmte Anna von Schürmann, eine entscheidende und selbständige Rolle. Die bekannte Stellung der Frau in Amerika hängt unter anderem auch mit ihrer religiösen Position zusammen. Es ist nur natürlich, daß bei dem ganzen Streben nach gehaltener, fester und bewußter Lebenserfassung auch die Stellung. der Kinder $\mathrm{zu}$ den Eltern selbständiger wird. Kinderschulen

heit seiner dogmatisch-ethischen Analysen nicht übersehen sein soll. Sie stützt sich auf eindringende Studien von Baxter, Spener, Bailey, Sedgwick, Hoornbeck und die Works of the puritan Divines, London $1845-48$.

B10 a) S. oben S. 794. 
952 III. Protestantismus. 4. Sektentypus und Mystik auf protestantischem Boden.

und Kindergruppen mit der Entwicklung eines selbständigen Korpsgeistes und einer selbständigen Verantwortung bezeichnen das Erziehungsideal dieser Gemeinschaften; in dieser Richtung bewegt sich auch die kirchliche Sonntagsschule, die Christian Young Man Association und Aehnliches. Die durch die demokratischen Lebensgewohnheiten verstärkte Wirkung dieser Erziehung ist etwas vom Auffallendsten, was der Europäer in Amerika wahrnimmt ${ }^{511}$ ).

311) S. Weber, Archiv XXI S. $79 \mathrm{f}$. A sober procreation of childrene ist der Zweck nach Baxter, ähnlich Spener, indessen mit Konzessionen an die grobe lutherische Ansicht ... Nach der Auffassung mancher pietistischer Richtungen ist die höchste Form der christlichen Ehen diejenige mit Bewahrung der Virginität; die nächstschärfste diejenige, in welcher der Geschlechtsverkehr ausschließlich der Kinderzeugung dient, und so fort bis zu denen, die aus rein erotischen oder rein außeren Gründen geschlossen wurden und ethisch betrachtet als Konkubinate gelten. Dabei wird in diesen unteren Stufen die aus rein äußerlichen Gründen geschlossene Ehe (weil immerhin rationaler Erwägung entspringend) der erotisch bedingten vorgezogen. Die Herrnhuter Theorie und Praxis mag hier außer Betracht bleiben.* So begrïndet Whitefield einen Heiratsantrag : >I bless God, if I know anything of my own heart, I am free from that foolish passion which the world calls love ... I trust I love you only for God and desire to be joined to you only by His commands and fur his sake Lecky II 589. Weiterhin Weber S. 79 f. : $\gg$ Wie bei jener rationalen Deutung der geschlechtlichen Beziehungen bei den puritanisch beeinflußten Völkern schliéßlich doch jene Verfeinerung und geistig ethische Durchdringung der ehelichen Beziehungen und die feinen Blüten ehelicher Ritterlichkeit erwachsen sind, - im Gegensatz zu jenem bäurisch-patriarchalen Brodem, der bei uns bis in die Kreise der, Geistesaristokratie' noch in oft sehr fühlbaren Rückständen vorhanden ist - das bleibt hier außer Erörterung; der Schutz der Gewissensfreiheit der Frau und die Ausdehnung des Gedankens des, allgemeinen Priestertums' auf sie waren auch hier die ersten Breschen in den Patriarchalismus. \& W. Köhler verzeichnet im Th. JB. I9II eine Abhandlung von Ellen A. Mc. Arthur, Woman petitions to the Long Parliament, in Ecclesiastical History Review 24, S. 698-709; dazu bemerkt er: $>$ Warum dieses Auftreten der Frauen gerade jetzt am Vorabend der Puritanerherrschaft und des Quäkertums? Aus welchen Kreisen stammen sie, welches sind ihre Motive? Man hört doch deutlich den calvinistischen Einschlag.e Das Parlament antwortet allerdings: ,Good women, we entreat you to repaire to your houses and turne your petitions into prayers at home for us. Ueber die Gründe der Stellung der Frau in Amerika s. Bryce II 742: = The cause is the usage of the Congregationalist, Presbyterian and Baptist Churches, under which a woman who is the member of the congregation has the same rights in choosing a deacon, elder, or pastor, as a man has. - $\mathrm{Zu}$ der oft betonten Neigung des asketischen Protestantismus $z \mathfrak{u}$ einer breiten Volksbildung, aber ohne Philosophie und akademische Theologie, dagegen mit biblischer und 
Die politis c he Ethik betrachtet den Staat gleichfalls vom rein utilitarischen Gesichtspunkt aus. Hierin ging schon das calvinistische Naturrecht voran, das die Sekten und Freikirchen fortsetzen. Der Staat hat sein Existenzrecht nur als Mittel der Ordnung und Zucht, als Voraussetzung der Gesellschaft. Die rein politische Auffassung des Staates als eines ethischen Selbstzweckes, die der Antike selbstverständlich war und die in der modernen Welt sich vielfach erneuert hat, liegt gänzlich außerhalb des Horizontes. Eine solche wesentlich utilitarische und wesentlich soziale, unpolitische Auffassung des Staates ist nun freilich, wie früher mehrfach gezeigt, ebenfalls gemein-christlich. Sie ist die natürliche Folge der Verlegung aller wahrhaften Lebenswerte in das religiöse Gebiet, wobei dann für die übrigen Lebenswerte günstigen Falls nur die Bedeutung eines Mittels zum $Z$ weck übrig bleibt. Allein der asketische Protestantismus geht hier auf Grund des rationalistischen Naturrechts, das er ebenso wie die puritanische Moral instinktiv vom Calvinismus herübernimmt, viel weiter als Luthertum und Katholizismus. Für den Katholizismus ist der Staat ein Stück der Naturstufe, über welcher die gegen den Staat völlig gleichgültige Oberstufe der Gnade sich erhebt; daher wird hier der Staat bald als Mittel gebraucht und verherrlicht, bald als Stoff und Voraussetzung geformt und zurechtgewiesen, bald ganz außer Kraft gesetzt und der Weltorganisation der Kirche zu Füßen gelegt. Im Luthertum ist er auch ein Stück der natürlichen Ordnung, aber als solches eine notwendige Form der Betätigung der christlichen Liebe und Gesinnung; aber indem er doch wesentlich ein Erzeugnis der die Sünde strafender und heilenden natürlichen Vernunftentwickelung ist und als solcher von Gott geleitet ist, gewinnt er, ob dem christlichen Lebenzweck nützlich oder schädlich, doch die übernatürliche Würde einer unmittelbar von Gott eingesetzten Gewalt, die vor allem ertragen

technisch-realistischer Bildung, s. auch das Schulprogramm Dells bei Sippell 63-71, dessen Aehnlichkeit mit dem der Quäker und Pietisten auch Sippell hervorhebt. Er will strenge Zucht der Jugend, allgemeine Volksschule, möglichst viele Hochschulen, aber keine scholastischen, theologisch-philosophischen und privilegierten Universitäten : Besonders müssen die mathematischen Wissenschaften auf den Universitäten hoch in Ehren gehalten werden, wie Arithmetik, Geometrie, Geographie und dergleichen, welche nichts Böses mit sich führen und außerdem sehr nützlich sind für die menschliche Gesellschaft und die Angelegenheiten dieses gegenwärtigen Lebens. 
und respektiert werden muß. Der alte Calvinismus hatte einen gleich starken Autoritätssinn, wie das Luthertum, und nur für den Fall der Unchristlichkeit der Staatsgewalten ein subsidiäres Ideal utilitarisch-rationeller Eingriffe, die aber einem geordneten Autoritätsverhältnis möglichst schnell Platz machen und wieder eine staatskirchliche Lebenseinheit herstellen sollten. Von dem asketischen Protestantismus dagegen wird die Staatsordnung zwar im Prinzip gleichfalls auf das Naturrecht des Sündenstandes zurückgeführt, aber immerdar an ihrem rationellen $Z$ weck gemessen, der Verantwortung nicht bloß vor Gott, sondern auch vor seinen Auftraggebern, dem Volk, unterworfen, sei es rechtlich oder bloß moralisch. Die staatskirchliche Lebenseinheit ist aufgehoben, der Staat nicht mehr direkt an dem christlichen Lebensinteresse der Kirchen und Denominationen beteiligt und damit vollends auf die Stufe reiner

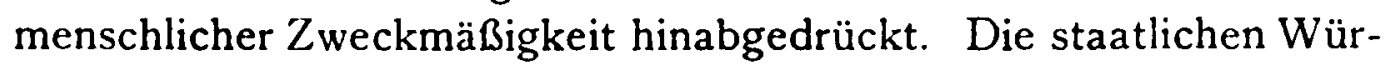
den, Ehren und Aemter bezeichnen von Gott und dem Volk zugewiesene Funktionen, aber nicht eine innerlich und an sich den Gewalthabern innewohnende Göttlichkeit. Keiner Kreatur dürfen Ehren erwiesen werden, die der Ehre Gottes zu nahe träten, und im Grunde sind alle nur Funktionäre der Vorsehung in dem natürlichen Kosmos der Gesellschaft, der durch strenge Lebensführung im christlichen Sinne der Ehre Gottes zu dienen hat. Daher herrscht hier eine Gleichheit aller vor Gott, die in den bekannten Sitten der Quäker nur besonders stark ausgedrückt ist, aber durchaus keine egalitäre Anschauung im Sinne der europäischen Demokratie. Das hindert der Vorsehungsgedanke, der den gesellschaftlichen und politischen Kosmos von Gott mit ausdrücklicher Heilsabsicht in verschiedenen Gruppen, Lebenslagen und Kräfte geteilt weiß. In dieser starken Bedeutung der Vorsehung ist die Prädestination erhalten oder wenigstens nachwirkend. So ist der asketische Protestantismus einer liberalen und demokratischen Staatsauffassung ohne Gleichmacherei geneigt, schiebt den Staat überhaupt gerne auf den Bereich des Unvermeidlichen zurück, verherrlicht das eigene Volkstum mehr um seiner religiösen Mission als um seiner politischen Größe willen und regelt die internationale Beziehung gerne nach den pazifistischen Grundsätzen, die zugleich die vernünftigen und geschäftlich wünschenswerten sind. Den imperialistischen und nationalistischen Bewegungen gegenüber ist der asketische Protestantismus sehr schwankend. Teils verwirft er sie grundsätzlich, teils vermag er sie als Ausbreitung christlicher Zivili- 
sation zu rechtfertigen, als deren alleiniger echter und von Gott auserwählter Vertreter er sich fühlt. Er sieht sich dann im Lichte des Alten Testamentes als Volk der Verheißung und bringt den Imperialismus unter den Gesichtspunkt der Mission ${ }^{511 a}$ ).

Die Wirtschafts ethik schließlich lehrt zunächst gleichfalls gemeinchristlich die Arbeit als Folge des Sündenfalls und als Strafe wie Disziplin der Sünde betrachten. Aber dieser Gedanke wird hier zu dem vor allem im Puritanismus ausgebildeten und von dort mehr oder minder folgerichtig übernommenen Geiste der rationellen, planmäßigen Arbeitsdisziplin, für welche Faulheit und Arbeitslosigkeit der Ursprung alles Uebels und die Versäumung aller Zucht ist. Mit dieser methodischen Anschauung der Arbeit, für welche gelegentlich auch andere Motive als die puritanischen, z. B. bei den Quäkern das Harren und Sich-Bereiten auf die göttliche Erlcuchtung, geltend gemacht werden, ist nun aber ein starker und systematischer Antrieb zur Produktion gegeben, wie umgekehrt mit derselben Askese eine bedeutende Einschränkung der Konsumtion und eine völlige Vermeidung alles Luxus, jedenfalls alles auffallenden, sich eitel oder protzenhaft bemerkbar machenden Luxus, verbunden ist. Erst hier wirkt im vollsten Maße das, was oben als die dem bürgerlichen Kapitalismus günstige ethische Disposition des Calvinismus geschildert worden ist. So wurde diese Wirtschaftsethik bürgerlich-, man wird sagen dürfen, kleinbürgerlich-kapitalistisch und zeigte auch alle Folgen dieses kapitalistischen Lebensstils, die planmäßige Arbeitsteilung, das Fachmenschentum, den Sinn für Nutzen und Profit, die abstrakte Arbeitspflicht, die Verpflichtung gegenüber dem Vermögen als einer um ihrer selbst willen zu erhaltenden und zu steigern-

¿11a) Die Belege hierfür sind durch die ganze obige Darstellung zerstreut; besonders hervorzuheben ist auch hier Tocquevilles und Kuypers Darstellung. Einiges auch bei Bryce, II 6I7-854; er vergleicht charakteristischer Weise die amerikanische Frömmigkeit gerne mit der Schottlands und der englischen Nonkonformisten. Ueber den Staat II 701: The state is not to them, as to Germans or Frenchmen, and even to some English thinkers, an ideal moral power, charged with the duty of forming the characters and guiding the lives of its subjects. It is more like a commercial company, or perhaps a huge municipality created for the management of certain business, in which all who reside within its bounds are interested. That an organisation of this kind should trouble itself, otherwise than as matter of police, with the opinions or conduct of its members, would be as innatural as for a railway company to inquire how many of the shareholders were total abstainers. \& Vl. auch Veit sEnglische und deutsche Frömmigkeit ChW 1906. 
den Größe. Der Besitzer ist * Rentmeister * Gottes und verwaltet eine anvertraute Gottesgabe. Eine solche Ethik stellte dem begin. nenden modernen bürgerlichen Kapitalismus, der sich gerade durch diese Züge von dem antiken und spätmittelalterlichen Kapitalismus unterscheidet und neben dem die andern immerdar vorhandenen Arten des Kapitalismus scibstverständlich nicht zu übersehen sind, energische und mutige Unternehmer sowie Arbeitswillige und der Ausbeutung sich fügende Arbeitnehmer zur Verfügun:. Sein besonderes christliches Gepräge aber behält dieser Kapitalisim c curch die Verpönung der Genußsucht und der Selbstverherrlichurig, die sich im Dienst der Vorsehung wissende Pflichttreue der Arbeit, die strenge Ehrlichkeit und Zuverlässigkeit, die humane Verpflichtung der Fürsorge für den Arbeitnehmer und der Pietiit gegen die Arbeitgeber, die ausgedehnte karitative Verwendung des Besitzes. Das System der festen Preise, die Standardisierung fester Qualitätsgruppen, der Aufbau des Geschäftes auf strengste formalistische Ehrlichkeit, der Grundsatz shonesty is the best policy *; all das hat hier seine Ausgangspunkte. Es ist ein geistig-moralischer Gegensatz gegen das System der zünftlerischen Regulierung und gegen das des übervorteilenden Handelns von Fall zu Fall, ein Aufbau des Geschäftslebens auf die Kalkulation des Individuums gegenüber einem abstrakten Abnehmerkreis und auf die hierfür unentbehrliche Korrektheit und Ehrlichkeit der Angaben und Lieferungen. Die Inschrift der Bremer Börse, daß der Kaufmann der ehrlichste Mann sei, ist von hier aus zu verstehen. Die Berechtigung des Wirtschaftslebens ist seine $Z$ weckmäßigkeit für die Gemeinschaft, und in diesem Sinne kann es als Segen gelten, während an sich die völlige innere Unabhängigkeit des Gemütes vom Besitz das Ideal ist. Daher kann man auch fortfahren gerade die Armut zu preisen. Sie bewahrt vor den Gefahren des Reichtums, wie umgekehrt der letztere, christlich verwendet, die Gemeinde vor Elend bewahrt. So ist auch hier kein Gedanke von Gleichheit. Das verhindert der ganze Vorsehungsgedanke und vor allem der Prädestinationsgedanke, wo er lebendig geblieben ist. Es ist immer ein von Gott geleiteter Kosmos, in dessen Wechselwirkung, Arbeitsteilung und Anlageverschiedenheit das christliche Ethos erst sich auswirkt. Wie Calvinismus und Sekten sich begegnen in der Herausbildung der Freiwilligkeitskirche und in der Lösung des Verhältnisses zum Staate, so begegnen sie sich auch in der die Wirtschaftsethik des asketischen Protestantismus bestim- 
menden Fassung der innerweltlichen Askese ; der Calvinismus, indem er aus seiner ursprünglich größeren Freiheit unter dem $Z$ wang des Bewährungsgedankens die methodische'Arbeitsaskese erzeugt, die leidende Sekte, indem sie ihren Weltgegensatz aufgibt und ihre weltabgewandte Askese mit der protestantischen Berufsmoral verschmilzt. Zudem begegnen sich beide in dem gemeinsamen Schicksal, daß sie, auf Grund ihrer Staatsfreiheit und Nonkonformität von den staatlichen Aemtern und Ehren und damit von den seigneuralen Klassen abgedrängt, den Mittelklassen des Bürgertums zugewiesen werden. Dadurch befestigt sich dieser bürgerlich-kapitalistische Charakter noch mehr. Die Landwirtschaft ist nicht ausgeschlossen, doch ist sie an diesen Schichten nur mit den Farmen und den bürgerlich-kaufmännischen Verwertungen des Landbesitzes, aber nicht mit dem feudalen Grundbesitzertum beteiligt. Damit ergeben sich die Unterschiede gegen die früher geschilderte prinzipiell traditionalistische Wirtschaftsethik des Katholizismus von selbst, welche Arbeit und Besitz nur der natürlichen Unterstufe zuweist und auch hier die Motive des Erwerbs nicht unmittelbar in die religiöse Ethik hineinzieht, sondern im Erwerb nur ein Mittel standesgemäßer Existenz und, soweit entbehrlich, der Karität sieht; die eigentlichste Karität wird hier gerade von den Besitzlosen, außerhalb der Weltarbeit Stehenden geleistet. Ebenso sind gegenüber dem Luthertum die Unterschiede deutlich. Es nimmt zwar den Erwerbsberuf auf in den Berufsdienst der Liebe am Nächsten, bevorzugt aber hier die mit einer feststehenden agrarisch-handwerkerlich-amtlichen Gliederung der Gesellschaft gegebenen Berufe und ist gerade gegen den Kapitalismus und die Arbeit der kalkulierenden Erwerbssteigerung höchst mißtrauisch und ablehnend. Aber auch gegenüber dem primitiven Calvinismus, der mit seinem staatskirchlichen Horizont auf die Gesamtheit der Erwerbe mit gleichem Interesse gerichtet war, die Arbeitsaskese nicht entfernt in diesem Maße ausgebildet hatte und überhaupt nicht den kleinbürgerlichen Horizont besaß, ist das etwas Neues. Es ist die Wirkung der Askese, in der der puritanisch sich vergesetzlichende und methodisierende Calvinismus mit den der Welt sich relativ öffnenden Sekten zusammentraf, und zugleich die Folge der sozialen und politischen Situation, in der beide sich der offziellen Welt gegenüber befanden ${ }^{512}$ ).

512) Ich gebe hier den die kapitalistischen Bezüge des Calvinismus und der Sekten betreffenden Gedankengang Webers wieder, nachdem ich ihn oben bereits 
958 III. Protestantismus. 4. Sektentypus und Mystik auf protestantischem Boden.

Ueberblickt man dies alles mit einem Blick, so stellt sich die christliche Sozialphilosophie des puritanischen Calvinismus, des Pietismus und der Sekten, teilweise sogar auch der mystischen Gruppen, als eine große Einheit dar, die an historischer Bedeutung nur mit der Sozialphilosophie des Mittelalters verglichen

angedeutet habe. Es ist erst hier der Ort, ihn in seinem vollen Umfang einzufügen, weil es nicht sowohl auf den Calvinismus als aut den puritanisch-pietistischasketischen Calvinismus und den Zusammenschluß der Sekten mit ihm in dieser Hinsicht ankommt. Das hat Rachfahl nicht beachtet, obwohl es Weber stark genug betont hat und seine Arbeit geradezu sämtliche Sekten umfaßt. - Ein Beispiel für die Sache rein von der letzteren Seite her ist die Schilderung des Quäkertums bei Weingarten 397-405. Der charakteristische Ausdruck von den Rentmeistern Gottese finden sich bei Heppe 188, hier auch Lodensteyns Betrachtung über - Die Darbringung der zeitlichen Güter eines Christen an ihren Eigentümer^. In der Form eines Gespräches mit Gott läßt er in dieser Meditation den Christen in aller Form den Akt der Uebergabe all seiner Güter an Gott, dessen Rentmeister er sein will, vollziehen. - Alles weitere sehe man bei Weber nach, außerdem s. die teilweise vorausgreifenden Mitteilungen oben S. 709-723. Ich glaube nur durch meine Darstellung der Sekten und besonders durch die Abgrenzung der Mystik gegen den Sektentypus Webers Auffassung noch im Einzelnen deutlicher, auch durch den Aufweis der sektenhaften Elemente in Urcalvinismus die Verschmelzung des Calvinismus mit der Sekte verständlicher gemacht zu haben. - Das glänzend geschriebene Buch Sombarts Die Juden und das Wirtschaftsleben entkräftet m. E. die Weberschen Sätze durchaus nicht. Es rechtfertigt vor allem die ganze Fragestellung, nach der Genesis des das >kapitalistische System * tragenden skapitalistischen Geistes zu suchen, der für dessen moderne Massengestaltung die unentbehrliche Voraussetzung ist und sich nichts weniger als von selbst versteht. Ferner zeigt es eine der von Weber immer anerkannten und betonten, aber in seinem $\mathrm{Zu}$ sammenhange nicht zu untersuchenden Komponenten des modernen kapitalistischen Geistes. Vor allem aber wird durch Sombarts Untersuchungen diejenige Richtung des kapitalistischen Geistes nicht getroffen, auf die es Weber vor allem ankam und die auch für das Verständnis der modernen Kultur noch wichtiger ist, die auf den bürgerlichen Massenkapitalismus mit der modernen Berufs- und Fachmenschenidee gerichtete. Es galt den bürgerlichen Geist der modernen Kultur zu erklären neben der vom Altertum her immer fortwirkenden, nicht spezifisch bürgerlichen Handhabung des Kapitalismus und neben den technischen, politischen, kolonialen und metallischen Anregungen. Außerdem s. oben S. 720 . Uebrigens wiederhole ich, daß mit alledem von mir nicht ein Beitrag zur Geschichte des Kapitalismus beabsichtigt ist, was ich den Beherrschern dieses sehr schwierigen Gebietes überlassen muß. Es handelt sich nur um das Verständnis der protestantischen Soziallehren, neben dem hier alles außer Betracht bleiben kann, was sonst in die Geschichte des , Kapitalismus gehört. 
werden kann. Es handelt sich für uns hier, wie beim Mittelalter, wesentlich um die Theorie, um die gedankliche und stimmungsmäßige Orientierung einer chsistlichen Kulturarbeit und Gesellschaftsorganisation. Die wirklich lebendigen, überzeugten und praktisch vollen Ernst machenden Träger des Systems werden hier wie dort in der Minorität sein. Aber sie schaffen die Selbstverständlichkeiten und die Gedankengeleise, auf denen sich das Bewußtsein einer allgemeinen Christlichkeit und eine einheitliche Lebensstimmung bewegen kann, einerlei wieviel wirklich innerlicher Ernst mit ihr jedesmal gemacht wird. Das große Problem der christlichen Ueberweltlichkeit, sich mit dem praktischen Leben der Gesellschaft zu verbinden und auszugleichen, ist beide Male auf eine große und populär wirksame Weise gelöst: im Katholizismus durch eine Universalkirche, die den Aufstieg der Natur zur Gnade regelt, beaufsichtigt und schließlich selbst bewirkt; im asketischen Protestantismus durch ein stark individualistisches Gemeindewesen, das mit dem modernen Individualismus im Einklang ist, und durch die asketische Selbstkontrolle der einzelnen Individuen, die alles Weltlich-Soziale zum reinen Mittel der Verherrlichung Gottes und der Bewährung des Gnadenstandes herabsetzt. So fehlt es nicht an Berührungen zwischen beiden Systemen, indem beide den Weltgegensatz des Christentums in einer methodischen Disziplin und Askese zum Ausdruck bringen ${ }^{513}$ ). Aber ihr Unterschied ist dann doch wieder fundamental, indem der Katholizismus seine Askese gegen die Unterstufe des Weltlebens in Gegensatz stellt, damit die Konsequenzen dieser Unterstufe überall durchbricht und den eigentlichen Höchstleistungen der Askese geradezu einen gegensätzlichen, mortifikatorischen Charakter verleiht. Die protestantische Askese dagegen zieht den ganzen natürlichen Lebensstoff in die überweltliche $Z$ wecksetzung unmittelbar hinein, wodurch sie hier den mortifikatorischen und dualistischen Charakter verliert und zu einer methodischen Arbeit für das Seelenheil und das Reich Gottes innerhalb der weltlichen Berufsformen wird. Das Luthertum freilich vollzog diese feste Schließung des Ringes nicht, und die ihm vielfach verwandte spiritualistische Mystik fiel sehr häufig in die mortifikatorische und rein dualistische Askese zurück.

513) Ueber Analogien zur protestantischen Askese bei den Klöstern, soweit sie die Arbeit aufnehmen und die Systematik der Selbstdisziplin dabei entwickeln s. Max Weber, Archiv XXI $28 \mathrm{ff}$; über gelegentliche Verbindung der Mystik mit der Berufssittlichkeit als Mittel der Disziplin ebd. XX 50 und XXI 22. 
Dagegen ist der Ring dieser Betrachtung geschlossen im puritanischen Calvinismus und den Heiligungsgemeinden der Sekten. Wie weit sie damit dauernd die moderne Kulturwelt christlich zu bemeistern vermögen, ist eine Frage für sich. Noch ist diese Ideenwelt eine welthistorische Macht. Aber daß Staat, Gesellschaft und Wirtschaftsleben sich von ihr vielfach nicht mehr beherrschen lassen und bei ihrem heutigen Wesen von ihr gar nicht mehr beherrscht werden können, das ist überall erkennbar.

All dem gegenüber erhebt sich auch hier die 1 e $\mathrm{t} z \mathrm{te}$, über unseren unmittelbaren Gegenstand hinausgehende $\mathrm{Fr}$ a ge nach dem Zusammenhang dieser Anschauungen mit den allgemeinen sozialen Verhäitnissen und nach ihrer Wirkung auf das Ganze der Kultur. Sie kann auch hier nur mit äußerster Zurückhaltung beantwortet werden, da erstlich hier die Tatsachen bis jetzt nur sehr teilweise bekannt sind, und da zweitens die Wechselseitigkeit des Beeinflussungsverhältnisses jede sichere Deutung der Tatsachen sehr erschwert ${ }^{614}$ ).

Der Spiritualismus ist kein Erzeugnis besonderer sozialer Verhältnisse. Es sind andere Gründe, aus denen er hervorgeht: die Erfahrung der Unfähigkeit der Kirchen, ihr Ideal zu verwirklichen, der Ueberdruß am Kampf und Streit der religiösen Parteien, die rein innere Dialektik des auf seine letzten Wurzeln zurückgehenden religiösen Gefühls, die kritische Zersetzung der Dogmen und Kulte, der Ueberdruß an den Täuschungen und Wirrsalen des äußerlichen Lebens überhaupt. So hat er auch von sich aus keine soziale Wirkungen auf die Allgemeinheit. Seine innigen Kreise dringen nicht in die Masse und seine rein betrachtenden Gedanken greifen nicht ins Gesamtleben ein, sondern wirken rein persönlich oder schweben literarisch über dem Ganzen. In den modernen Zeiten beruht seine Ausdehnung allerdings auf der Existenz von Klassen, die dem groben Kampf ums Dasein entnommen sind und eine geistige Verfeinerung um ihrer selbst willen suchen können, sofern er nicht in Klein-Leute-Sekten sich versteckt, die aber immer dann auch einen besonderen sektenhaften Zug zugleich haben. Außerdem ist er verschwistert mit der modernen wissenschaftlichen Bildung der autonomen Vernunft,

514) Zum Ganzen s. die alle seine früheren Gedanken (in Archiv XX u. XXI und dem Artikel der Chr. W.) zusammenfassenden und fortsetzenden Ausführungen Webers im "Schlußwort XXXI 584-598. S. auch oben die Ausführungen über die Askese S. 645-647. 
sofern diese religiöse Wendung nimmt. Er spiegelt insoferne heute den allgemeinen Individualismus der Neuzeit und befestigt ihn wiederum seinerseits. Er begleitet die sozialen Zustände, aber geht nicht aus ihnen hervor und beeinflußt sie nicht unmittelbar. Die Beeinträchtigung der Kraft und Gesctlossenheit der Kirchen durch ihn ist dann freilich indirekt eine sehr wichtige soziale Wirkung.

Das radikale Sektenideal umgekehrt ist niemals aus der reinen inneren Dialektik des christlichen Gedankens hervorgegangen. Dieser verlegte in seiner Urgestalt derartige Dinge zu sehr in die $z$ war baldige, aber doch von Gott allein herbeizuführende Zukunft und stellte alle Einzelheiten der Tat Gottes, nicht der Ueberlegung und Organisation durch Menschen anheim. Nachdem der Christusglaube sich auf die dauernde Welt eingerichtet und als Kirche gestaltet hatte, konnte die Hoffnung auf eine völlige ethische Welterneuerung immer nur von außen her durch den Eindruck unhaltbarer Zustände in das Christentum hineingetragen werden und mußte sie auch irgendwie stets menschliche Organisation und Ueberlegung bedeuten. Man verstand dann besonders drohende soziale und politische Situationen als Anzeichen bevorstehender Welterneuerungen, als Aufforderung zur Anbahnung des Gottesreiches, eine Mischung von gläubiger Erwartung des Reiches und eigener Herbeiführung der neuen Zustände. Nur, wo die gegebenen Verhältnisse eine Reform verlangten, wo die Zeitgeschichte die Deutung auf eine von Gott herbeizuführende baldige Katastrophe irgendwelcher Art nahe legte und damit die Erwartung des Gottesreiches neu belebte, erhob sich daher das Sektenideal zu seiner vollen Energie. Es ist also stets vom Gang der allgemeinen sozialen Entwickelungen erst mit in Bewegung gesetzt. Das gilt auch von dem modernen christlichen Sozialismus, der erst durch die Aufdeckung der Folgen des kapitalistischen Systems und vor allem durch die große sozialistische Bewegung geweckt ist und in seinen radikalen Gruppen diese Bewegung in der Tat als Zeichen einer von Gott gewollten Weltumwällzung deutet. Eben deshalb stehen auch seine Wirkungen in zweiter Linie neben diesen allgemeineren, von ihm nur gedeuteten, angeeigneten und berichtigten Bewegungen. Die soziale Revolution steckt dem Christentum nicht im Blute. Es kann sich auch zu der modernen, nicht gewaltsamen, aber doch grund. sätzlichen sozialen Revolution nur mit einer gewissen Anstrengung bekennen. Seine Sache ist die Revolution der Geister und der Gesinnungen nicht in der Richtung auf die Weltangelegenheiten, 
sondern in der Richtung auf Gott. Es muß die moderne Erkenntnis ron dem inneren Zusammenhang aller geistigen Werte mit.der materiellen sozialen Grundlage schon sehr stark angespannt werden, um es einer tiefgehenden Reform oder gar der Revolution auch der Gesellschaft zuzuführen. Welche Wirkung seine Bemühungen, den modernen Klassenkampf durch Erziehung der Besitzenden zur Erkenntnis ihrer sozialen Pflichten und der Proletarier zu Vertrauen und Mäßigung tatsächlich ausgeübt hat, ist vorerst noch schwer zu sagen. Bekannt ist der bedeutende Einfluß der christlichen Sozialisten in England. In den übrigen Ländern ist die Bedeutung schwerer einzuschätzen. Vorhanden ist sie jedenfalls. In diesen Dingen reden die materiellen Umstände lauter als die Ideen; aber das Bedürfnis nach Erfüllung mit idealem Gehalt ist vorhanden. In dieser Hinsicht hat der christliche Sozialismus sicherlich eine Mission, wenn er auch die neue Gesellschaft schwerlich erbauen wird ${ }^{514}$ ).

Durchgreifend und umfassend ist dagegen, wie schon mehrfach im einzelnen hervorgehoben, die sozial- und kulturgeschichtliche Wirkung des asketischen Protestantismus ${ }^{515}$ ). Sein zum Frei-

514 ) S. Sombart, Sozialismus und soziale Bewegung, S. 19, 100, 252, 262.

515) Hierzu vgl. die verschiedenen Angaben bes Max Weber, dessen Interessen gerade bei diesem Problem liegen. Er hat hier das Programm der Forschung formuliert S. 109: >Die Aufgabe ist.., die Bedeutung des asketischen Rationalismus (d. i. des a:littischen Protestantismus mit seinem utilitarischen und die Arbeit systematisicrenden Charakter) nun auch für den Inhalt der s o z i a l-ökonomischen Ethik, also für die Art der Organisation und das Funktionieren der sozialen Gemeinschaften rom Konventikel bis zum Staate aufzuzeigen. Alsdann muß seine Beziehung zu dem humanistischen Rationalismus und dessen Lebensidealen und Kultureinflüssen, ferner zur Entwickelung des philosophischen und wissenschaftlichen Empirismus, zu der technischen Entwickelung und zu den geistigen Kulturgütern analysiert werden. Dann endlich ist sein geschichtliches Werden von den mittelalterlichen Ansätzen einer innerweltlichen Askese aus und seine Auflösung in den reinen Utilitarismus h is to $\mathrm{r}$ is $\mathrm{ch}$ und durch die einzelnen Verbreitungsgebiete der asketischen Religiosität hindurch zu vifolgen. Daraus erst kann sich die Kulturbedeutung des asketischen Protestantismus im Verhältnis $z u$ anderen plastischen Elementen der modernen Kultur erzeben. Das Programm ist sehr schwer durchzuführen, so lange nicht die Geschichte des Humanismus, der humanistischen Bildung und der sie tragenden Stände, sowie die Geschichte der modernen Philosophie in ihren sozialen Beziigen aufgehellt ist. Daran fehlt es in den Spezialwerken bis jetzt noch ebenso wie in den kirchengeschichtlichen. Auch die Geschichte der Technik, die keineswess wit der der Naturwissenschaften zusammenfällt, müßte erst klargestellt sein. 
kirchenideal übergehender Kirchenbegriff, seine demokratische Gestaltung der Einzelgemeinde und des Aufbaus der Kirchenverfas. sung, sein autonomer, in Gottes Wille und Erlösun sstat gefestigter Individualismus, seine planmäßige und sachliche Arbeitsamkeit haben eine der Unterlagen gebildet für die ungeheuren Umformungen der modernen Gesellschaft, die in katholische und lutherische Gebiete erst von außen her hereingetragen worden ist, die aber andererseits doch auch durch die wirtschaftlichen, politischen und technischen Neubedingungen der modernen Welt allein nicht geschatf $(n$ worden wäre. Das darf als ein Ergebnis unserer Untersuchung b:zeichnet werden. Die Verrechnung der einzelnen Bildkräfte der modernen Gesellschaft gegeneinander ist hier nicht $\mathrm{zu}$ vollzich. $\mathrm{n}$ Genug, daß dem asketischen Protestantismus ein sehr erheblicher Anteil zukommt. Man kann natürlich auch hier die Fragc umdrehen, ob diese Leistung dem asketischen Protestantismus nicht erst durch die Anpassung an die Umwelt des fortgeschrittenen Westeuropa möglich geworden oder aufgedrungen sei. Auch das ist in unserer Untersuchung vielfach erörtert worden. Schon die Genfer Umwelt enthielt solche Richtung gebende Antriebe ; der französische, niederländische und englische Boden unzweifelhaft noch mehr. Auch die Abdrängung seiner Angehörigen von der offiziellen Welt in vielen Ländern hat seine Physiognomie mit bestimmt. Allein im ganzen wird man bei den übereinstimmenden Entwickelungen in so vielen ganz

Das Programm Webers ist also m. E. noch nicht ausführbar. Aber es ist äußerst anregend, wie übrigens auch ähnliche Andeutungen Plenges a. a. O. - Insbesondere ist ein solches Programm der Kulturgeschichte lehrreich durch seinen Unterschied gegenüber Lamprecht, der ein ähnliches wissenschaftliches Erkenntnisziel mit ganz anderen Methoden erstrebt. Lamprechts Methoden beruhen auf psychologischen \& Gesetzen, die ihm die Anordnung der Tatsachen in bestimmten Reihen von vornherein ermüglichen und vorschreiben, während meine Methode wesentlich auf die Analyse des konkreten individuellen Zusammenhangs gerichtet ist in Bezug auf seinen Inhalt und seine nur mit diesem besonderen Bestand gegebenen besonderen kausalen Bezüge. Insofern möchte ich mit dieser Arbeit auch meinen Gegensalz gegen die Lamprechtsche Methode erleuchtet haben, wo ein hüchst wertvolles Erkenntnisziel mit unmöglichen Mitteln zu erreichen versucht wird. - Vüllig zustimmen kann ich den methodischen Betrachtungen über den Zusammenhang von Geschichte des Christentums und Kulturgeschichte, die Harnack in dem Vortrag wLeber das Verhältnis der Kirchengeschichte zur Universalyeschichte *, Aus Wissenschaft und Leben II 41-62, entwickelt hat. Ich glaube nur in dieser Arbeit gezeigt zu haben, daß die religiöse Entwickelung eine festere und eigenständigere Haltung zeigt, inshesondere in Verhältnis zu den politischen Verfassungsentwickelungen, als Harnack annimnt. 
rerschicdenen Kulturzusammenhängen und auf manchmal so wenig günstigem. Boden hier von der führenden Bedeutung der religiösethischen ldee sprechen dürfen, die ja von Hause aus eine starke Anpassung an die praktischen und durchschnittlichen Bedürfnisse in sich truy $\left.{ }^{515}\right)$. Heute ist aus dem, was sie wesentlich mitgeschaffen hat, freilich ihr Geist großenteils entwichen. Die von ihr mit geformten Schöpfungen sind in andere Hände übergegangen und werden von diesen ihren $Z$ wecken gemäß gestaltet. Insbesondere gilt dies von den Umwandelungen der Ergebnisse der englischen puritanischen Revolution durch die ranzösische Revolution und ihre geistig-litcrarischen Tricbkräfte. Allein gegen diese von den lateinischen und katholischen Völkern geschaffene und die Welt überallhin überflutende rationalistische und abstrakte Aufklärung lämpft bis heute überall die in der Schule des asketischen Protestantismus sebildete Auffassung der menschlichen Gesellschaft und ihrer $Z$ wecke. Sie ist ror allem im Angelsachsentum verkör$\mu r$ r. Soweit der gesellschaftliche Kampf der Gegenwart ein geistiger und prinzipieller ist, dreht er sich vor allem um diesen Gegensatz zuiuchen angelsächsisch-calvinistischer Korporationsidee und französisch-rationalistischer Demokratie; der katholische und der lutherische Patriarchalismus sind in den Hintergrund getreten. l)ie Gruppenunterschiede des Protestantismus verringern sich zusehends in diesem Gegensatze. Calvinismus und Sektentum haben sich gefundicn. Aber auch das Luthertum wird langsam in diesen Aufmarsch der protestantischen Soziallehren hineingezogen und rom asketischen Protestantismus beeinflußt. Es wird das noch mehr geschehen, wenn einmal, wie sicher zu erwarten, seine Staatsstützen zerbrochen sind.

Das protestantische Kirchentum, das als Reform des Katholizismus begonnen und sich als neue Einheits- und Zwangskultur des Christentums ausgebildet hatte, wurde in steigendem Maßse zu einer Ablösung seiner Soziallehren von diesen kirchlich-universalen Anfangsbildungen geführt. Das erste große Gebilde in diesem Ablösungsprozeßs ist der asketische Protestantismus. Er hat die Hauptmasse protestantischer Kultur begründet und durchgesetzt. Aber auch er ist im Verblassen begriffen, und damit steht der Protestantismus vor neuen Aufgaben sowohl seiner eigenen soziologischen Selbstgestaltung als seiner sämtlichen Kulturbeziehungen.

515 a) ミ. oben S. 690. 
Schluls.

Die Darstellung ist am Ende. Sie konnte in erschöpfender Breite nur bis zum 18. Jahrhundert geführt werden. Die von da aus bis auf die Gegenwart sich erstreckenden Entwickelungen konnten, nur angedeutet werden. Wie die ganze Kirchengeschichte mit jenem Jahrhundert unter neue Bedingungen tritt und infolge der Auflösung der staatskirchlichen Lebenseinheit wie der Verselbständigung des modernen Denkens seitdem überhaupt keinen einheitlich geschlossenen Gegenstand mehr vor sich hat, so unterliegt auch die Sozialphilosophie der christlichen Gruppen einer unübersehbaren Zerteilung und einer immer wechselnden Abhängigkeit. Der Boden, auf dem sie sich bewegen, ist ein neuer geworden, der Boden der modernen bürgerlich-kapitalistischen Gesellschaft und der bureaukratischen Militärstaaten. Das Verhältnis von Staat und Religion ist gelockert oder gar aufgehoben. Die Sozialtheorie ist aus ihrer lediglich mit der Antike, der Bibel und der Theologie arbeitenden Kindlichkeit zu einer selbständigen Wissenschaft herangereift, die die Beziehungen von Boden und Bevölkerung, das Verhältnis des wirtschaftlichen Unterbaus und des geistigen Ueberbaus, die soziologischen Gesetze und Verhältnisse aller Gemeinschaftsbildung völlig neu untersucht und die Sózialphilosophie der Kirchen weit überholt hat. Vor allem haben die moderne Bourgeoisie, das Naturrecht, die Emanzipation des vierten Standes, schließlich der wissenschaftliche Rationalismus ein neues soziologisches Grundschema des rationalistischen Individualismus geschaffen, das mit den älteren Ideen des christlichen Individualismus zwar zusammenhängt, aber durch den optimistischen und esalitären Geist ihm wiederum scharf gegenübersteht. Die Gegenschläge, die gegen diesen atomistischen und auch im Kommunismus und Sozialismus noch wesentlich individualistisch denkenden demokratischen Geist sich erhoben haben, sind nur teilweise von der kirchlichen Sozialphilosophie bestimmt, zum andern Teil aber vom naturwissenschaftlich-biologischen oder vom platonisch-organischen Geiste; beide bedeuten einen scharfen Gegensatz gegen die Grundgedanken der christlichen Sozialphilosophie. Die wirklichen praktischen Einschränkungen des modernen Individualismus, die Stillstellung des vom bürgerlichen Individualismus für ein paar Jahrhunderte entfesselten und über die Erde sich ergießenden Konkurrenzkampfes scheint überdies ein Werk rein wirtschaftlicher und 
politischer Machtverhältnisse werden zu sollen, wo die Verteilung der Absatz- und Einflußsphären der Produltion sichere Kontingentierıngen bringt und mit dieser Festlègung auch die Beweglichkeit der Bevölkerung wie die Produktion der Yachkommenschaft in feste Grenzen eingeengt werden wird. Der radikale Individualismus wird vermutlich bald ein $Z$ wischenakt sein zwischen einer alten und einer neuen Kultur der Gebundenheit. Er ist die Zerlegung eines abgerissenen Hauses in seine einzelnen Steine, aus denen dann wieder ein neues aufgebaut wird. Wie das neue Haus aussehen wird und welche Möglichkeiten es der Entfaltung der christlichen Ethik und der christlichen Sozialphilosophie bringen wird, weik heute noch niemand. Sie wird sowohl mit ihrem Gemeinsinn wie mit ihrem metaphysischen Individualismus an ihm bauen. Aber sie wird sich mit anderen Bauherren zu teilen haben und gleich diesen an die Besonderheiten des Bodens und Materials gebunden sein.

Lnter diesen Umständen ist eine Schilderung der gegenwärtigen Lage und eine Ableitung von Grundsätzen für die $\mathrm{Zu}$ kunft aus ihr untunlich. Wollte man sich aber auf'die bloße Darstellung der verschiedenen gegenwärtigen christlichen Bestrebungen, Programme und Gruppenbildungen beschränken, so wäre auch das bei der Verwickeltheit der ganzen Lage die Aufgabe eines eigenen Werkes. So bleibt zum Abschluß der bisherigen Darstellung nur übrig, ihre Ergebnisse ohne näheres Eingehen auf diese besonderen Gegenwartsfragen in einigen kurzen allgemeinen Sätzen zu formulieren. 'Unsere Untersuchung ging aus von den sozialethischen Aufgaben und Möglichkeiten des Christentums in der Gegenwart. "Sie ging dann zurück auf die Scheidung der sozialen Selbstgestaltung $d e r$ religiösen Idee von ihren Beziehungen auf die profanen sozialen Bildungen. " Sie entdeckte, daß diese Beziehungen sich sehr verschieden gestalten je nach der besonderen Fassung der christlichen Idee und der dieser Fassung entsprechenden or-

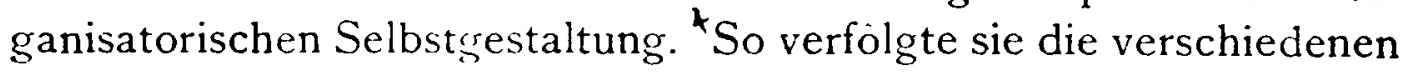
Kirchen- und Gruppenbildungen und die ihnen jedesmal. entsprechende Sozialethik. ${ }^{5}$ Sie stieß schließlich auf die Bedingtheit all dieser Bildungen durch die allgemeinen Kulturverhältnisse und ${ }^{6}$ mußte überall die Frage nach dem jeweils vorliegenden wechselseitigen Beeinflußungsierhältnis aufwerfen. Só kommt es, daß die Ergebnisse sich über die gesamte Auffassung von Wesen und Geschichte des Christentums überhaupt erstrecken.

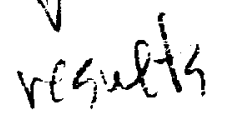


Es sind folgende:

I. Es ist klar geworden, wie wenig eindeutig bestimmt das Evangelium und das Urchristentum in der Gestaltung der religiösen Gemeinschaft selbst war. Das Evangelium Jesu war freie personalistische Religiosität mit dem Drang nach innerstem Verstehen und Verbinden der Seelen, aber ohne jede Richtung auf kultische Organisation, auf Schaffung einer Religionsgemeinschaft. Erst in dem Glauben an Jesus, in der Erhöhung des Auferstandenen zu dem Kultmittelpunkt einer neuen Gemeinde trat die Notwendigkeit hierzu ein. Dabei zeigten sich von Anfang an die drei Haupttypen der soziologischen Selbstgestaltung der christlichen Idee: die Kirche, die Sekte und die Mystik. Die Kirche ist die mit dem Ergebnis des Erlösungswerkes ausgestattete Heils- und Gnadenanstalt, die Massen aufnehmen und der Welt sich anpassen kann, weil sie von der subjektiven Heiligkeit um des objektiven Gnaden- und Erlösungsschatzes willen bis zu einem gewissen Grade absehen kann. Die Sekte ist die freie Vereinigung strenger und bewußter Christen, die als wahrhaft Widergeborene zusammentreten, von der Welt sich scheiden, auf kleine Kreise beschränkt bleiben, statt der Gnade das Gesetz betonen und in ihrem Kreise mit größerem oder geringerem Radikalismus die christliche Lebensordnung der Liebe aufrichten, alles zur Anbahnung und in der Erwartung des kommenden Gottesreiches. Die Mystik ist die Verinnerlichung und Unmittelbarmachung der in Kult und Lehre verfestigten Ideenwelt zu einem rein persönlich-innerlichen Gemütsbesitz, wobei nur fließende und ganz persönlich bedingte Gruppenbildungen sich sammeln können, im übrigen Kultus, Dogma und Geschichtsbeziehung zur Verflüssigung neigen. Diese drei Formen sind schon in den Anfängen vorgebildet und treten bis heute auf jedem Konfessionsgebiet nebeneinander auf mit allerhand Verschlingungen und Uebergängen untereinander. $Z u$ einer großen Massenwirkung sind nur die Kirchen befähigt. Die Sekten nähern im Fall der Massenausbreitung sich den Kirchen an. Die Mystik hat Wahlverwandtschaft zur Autonomie der Wissenschaft und bildet das Asyl für die Religiosität wissenschaftlich gebildeter Schichten; in wisscnschaftlich unberührten Schichten wird sie zum Orgiasmus und zur gefühlsmäßigen Devotion, mit alledem eine gern gepflegte Ergänzung von Kirchen und Sekten.

2. Es erhellt die Abhängigskeit der ganzen christlichen Vorstellungswelt und des Dogmas von den soziologischen Grundbe- 
dingungen, von der jeweiligen Gemeinschaftsidee. Das einzige besondere christliche Ur-Dogma, das Dogma von der Göttlichkeit des Christus, entsprang erst aus dem Christuskult und dieser wiederum aus der Notwendigkeit der Zusammenscharung der Gemeinde des neuen Geistes. Der Christuskult ist der Organisationspunkt einer christlichen Gemeinschaft und der Schöpfer des christlichen Dogmas. 1)a der Kultgott der Christen, nicht wie ein anderer Mysteriengott polytheistisch zu verstehen ist, sondern die erlösende Offenbarung des monotheistischen Gottes der Propheten darstellt, so wird aus dem Christusdogma das Trinitätsdogma. Alle philosophischen und mythologischen E.ntlehnungen sind nur Mittel für diesen aus der inneren Notwendigkeit der christlichen Kultgemeinschaft sich bildenden Gedanken. Dieses Christusdogma gewinnt nun aber auf dem Boden der Kirche, der Sekte und der Mystik eine sehr verschiedene Bedeutung. Der Christus der Kirche ist der Erlöser, der in seinem Heilswerk die Erlösung und Begnadigung ein für allemal vollbracht hat und, durch Amt, Wort und Sakramente in der Kirche wunderbar wirkend, sein Heilswerk den einzelnen zueignet. Der Christus der Sekte ist der Herr, das Vorbild und der Gesetzgeber von göttlicher Würde und Autorität, der seine Gemeinde in der irdischen Pilgerschaft durch Schmach und Elend gehen läßt, aber die eigentliche Erlösung bei seiner Wiederkunft und der Aufrichtung des Gottesreiches vollziehen wird. Der Christus der Mystik ist ein innerlich geistiges, in jeder Erregung frommen Gefühls, jeder Wirkung des Samens und Funkens gegenviärtiges Prinzip, das in dem geschichtlichen Christus göttlich verkörpert war, aber nur in innerer Geisteswirkung erkannt und bejaht werden kann und das daher mit dem göttlichen verborgenen Lebensgrunde des Menschen überhaupt zusammenfällt. Wie mit dem Ur-Dogma, so geht es auch mit allen anderen. Wie das Christusdogma die ursprüngliche Jesus-Verkündigung vom Gottesreich in sich aufgezehrt hat, so ist mit den Wandelungen des Christusdogmas auf den verschiedenen Gebieten auch das Schicksal dieses zweiten christlichen Hauptgedankens bestimmt. Die Kirche ist das Christusreich und daher mit dem Gottesreich in der Welt identisch oder doch das Mittel seiner beständigen Erzeugung. In der Sekte bleibt Jesus der Verkündiger und Bringer des kommenden Gottesreiches und sie neigt zum Chiliasmus. In der Mystik ist die Christusherrschaft die Herrschaft des göttlichen Geistes und daher ist hier das Gottesreich lediglich inwendig in uns. Ganz analog 
steht es mit dem Erlösungsgedanken. Für die Kirche ist das Erlösungswerk fertig im Sühnetod des Christus; es stattet die Kirche mit der Kraft der Sündenvergebung und Heiligung aus. Für die Sekte liegt die eigentliche Erlösung in der Wiederkunft Christi und der Aufrichtung des Reiches, wofür alles andere nur Vorbereitung war. Für die Mystik ist die Erlösung der immer neu sich wiederholende Vorgang der Einswerdung der Seele mit Gott, . wofür Christus nur Anreger und Symbol ist. Die verschiedenen Typen mischen und verbinden sich in Wirklichkeit natürlich ebenso wie die Typen der christlichen Gemeinschaftsidee. Aber von dieser Abstraktion aus versteht man doch die Dogmengeschichte sehr viel klarer und einfacher, als das bisher der Fall war. Sie ist weder eine immanente Entwickelung der christlichen Gottesidee, noch ein Amalgam antiker Mysterienmythologie und spekulativer Philosophie, noch eine Anhäufung kirchlicher Lehrbestimmungen, noch ein unmittelbarer Ausdruck der jeweiligen christlichen Lebensstimmung. Die religiöse Lehre ist der Ausdruck der zunächst im Kultus sich sammelnden und ausströmenden religiösen Lebendigkeit und die Ausbildung des Gedankens, soweit Gedanken überhaupt zu diesem $Z$ wecke nötig waren. Alles Philosophische und rein Dogmatische ist sekundär. Die hinter dem Kultus und der jeweiligen Gemeinschaftsidee liegende instinktive Fassung der Gottesidee selbst hat man sich dialektisch klar zu machen nie das Bedürfnis empfunden. Man hat nur die Einzelheiten verkettet und systematisiert. Die eigentlich religiöse Grundidee selbst liegt im Unbewußten und hier wiederum eingebettet in die instinktiv damit gegebene Gemeinschafts- und Kultusidee. Daß einzelne. Denker in die Tiefen dringen und theologisch und religionsphilosophisch sich in die christliche Gotteserkenntnis hineinbohren, ist dabei nur selbstverständlich; aber solange sie an irgendwelche Gemeinschaft gebunden bleiben, kehrt auch bei ihnen diese Bedingtheit durch den soziologischen Charakter des ihnen vorschwebenden Gemeinschaftsgedankens wieder. Umgekehrt bringt eine wesentliche dogmatische Kritik auch eine Verschiebung in der soziologischen Grundempfindung mit sich. Das bedeutet dann aber auch einen erleuchtenden Aufschluß über Wesen und Schicksal der Theologie, der wissenschaftlichen Bearbeitung der christlichen Vorstellungswelt. Die Theologie des Katholizismus, der durch und durch kultisch und sakramental bedingten Entwickelung der christlichen Ideenwelt, ist die formelhafte Fixie- 
rung und dic Einstellung des depositum fidei der Erlösungsanstalt in den Rahmen der spätantilien idealistischen Entwickelungsmetaphysik. Dic Theologie des Protestantismus, des Kult und Saliament verinncrlichenden und ver yeistiyenden Kirchenprinzips, hat das gereiniute Dogma zu einem Gedankensystem gemacht, das aber auf die kultische Predigt und auf den autoritativen Gnaden- und Lehrfond bezogen bleibt; infolgedessen bewegt sie sich hin und her zwischen einem System ron durch sich selbst gültigen Gedanken und einem historisch-autoritativen, wunderheglaubigten Dogmenkreis, ein Schwanken, das mit der zunehmenden Beeinflussung durch moderne Wissenschaft nur immer heftiger scworden ist. Die Sekte, die ihrem ganzen Wesen nach der Lnterschicht angchört und der Vermittelungen mit dem allgemeinen Denken nicht bcdarf, geht auf den vorkirchlichen und rorwissenschaftlichen Standpunkt zurück und hat überhaupt keine Theologie, sondern eine gtrenge Ethik, einen lebendigen Mythos und eine leidenschaftliche Zukunftshoffnung. Der Spiritualismus allein faßt die christliche Religiosität als lebendig fortzeugende Gegenwartsbewegung und als Moment in der allgemeinen Bewegung des religiösen Bewußtseins überhaupt. Daher hat er allein (in: eigentlich wissenschaftliche, auf das Allgemeine zurückgchende, rclisionsphilosophische Theologie erzeugt und eine wirkliche Fortbildung eröffnet. Daher ist auch er allein unter allen christlichen Gedankenbildungen von den großen Denkern des modernen Idcalismus übernommen und fortgebildet worden. Aber wie er aus der Brechung des eigentlich kirchlichen Geistes entstanden ist, so findet er nur schwer ein Verhältnis zu den Kirchen und den Bedingungen fester und dauernder Organisation. An diesem Punkte liegt das schwere Problem der heutigen Christlichkeit in der modernen Bildungsschicht.

3. Es tritt die Verschiedenheit des christlichen Wahrheitsbegriffes in den drei verschiedenen Typen zutage, und von ihm aus klärt sich das verwickelte und widerspruchsvolle Verhältnis des Christentums zur Staatsgewalt und zur. Toleranzidee. Die Kirche will Massen- und Volkskirche sein und verlegt daher die Götthchkeit und Heiligkeit aus den Subjekten in die objektive Heilsanstalt und ihre göttliche Gnaden- und Wahrheitsausstattung. Sie besitzt, wie eine schlechthin wunderbare, aller sonstigen menschlichen Kraft entgegengcsetzte Erlösungsgnade, so eine absolute, unmittelbar göttliche, aller menschlichen Subjektivität 
entgegengesetzte Wahrheit und Lehrautorität. Solche Wahrheit muß ihrem Wesen nach uniform und allbeherrschend sein. So wird sie in der Kirche selbst gegen Geistliche und Lehrer, aber auch gegen Gläubige und Laien diese unwandelbare Wahrheit mit $Z$ wang aufrecht zu erhalten berechtigt und verpflichtet sein. Jeder idealistische Versuch, diese Durchsetzung der Wahrheit der inneren Wunderkraft der Kirche selbst ohne Zwang zuzuschreiben, scheitert an der praktischen Undurchführbarkeit und hat die Rückkehr zum $Z$ wang zur Folge. Aber auch nach außen wird dieser Zwang sich schließlich äußern müssen, indem volksverderbende, Gottes Ehre schmähende Irrtümer und Sitten nicht geduldet werden dürfen und das in die Kirche hineingeborene Volk nicht der Versuchung schutzlos ausgeliefert werden darf. Schließlich muß dafür gesorgt werden, daß das ganze Volk zur Kenntnis der Heilspredigt komme und jedermann wenigstens mit dem göttlichen Heil in Berührung gebracht werde. Das verlangt die Barmherzigkeit, und dazu berechtigt die absolute Göttlichkeit der Heilswahrheit. Hier darf man die Menschen zu ihrem Wohle zwingen. Das aber verlangt die Mitwirkung der materiellen Gewalt oder des Staates, ohne welchen weder, die Uniformität der Kirche nach innen noch die Ausbildung von Volks- und Landeskirchen jemals zustande gekommen wäre. Er tut damit nur seine Pflicht gegen die göttliche Wahrheit. Damit entsteht das verwickelte Konformitätsverhältnis zum Staate. Ganz anders aber denken hier die Sekten. Sie wollen nicht Massenkirchen, sondern Bekenntnisgemeinden heiliger Christen sein. Das sind kleine Gemeinden, die neben dem Staate und der Gesellschaft stehen. Auch sie behaupten die absolute Wahrheit des Evangeliums zu haben, aber sie erheben sie hoch über jede Erkenntniskompetenz der Masse und des Staates und verlangen daher die Freiheit vom Staate; da überdies gerade dieses absolute Evangelium ihnen Gewalt, Nacht und Recht verbietet, so müssen sie auch auf die gewálttätige Durchsetzung nach innen und außen verzichten. So fordern sie die Toleranz nach außen, die religiöse Neutralität des Staates. Nach innen aber betätigen sie eine geistliche Lehr- und Sittenzucht. Sie haben die Toleranz des an seine eigene Sache glaubenden Idealismus und verbieten es, aus der Absolutheit der Wahrheit deren gewaltsame Durchsetzung zu folgern, erwarten überhaupt vor dem jüngsten Tage keine Massendurchsetzung. Bei verschiedenen Sektenbildungen nebeneinander können sie es auf den rein geistigen Kampf und den bloß ethischen 
Wetteifer ankommen lassen, ohne an der Absolutheit ihrer Wahrheit irre zu werden. Sie ist keine Wahrheit für die Masse und Allgemeinheit und wird erst am jüngsten Tage in ihr herrschendes Recht eingesetzt werden. Sie kennen die Toleranz und Gewissensfreiheit als eine solche neben den Kirchen und als den Standpunkt der herrschenden Gewalten. Nach innen kennen sie keine oder nur sehr wenig Toleranz, da hier das biblische Gesetz herrscht. Aber indem sie auf die Mitwirkung der Staatsgewalt für die Aufrechterhaltung dieser Einheit verzichten und höchstens auf das Mittel des sozialen Boykotts angewiesen sind, entstehen hier unendliche Spaltungen; wirkliche Konformität gibt es eben nur mit Hilfe des Staates und der materiellen $Z$ wangsgewalt. Wieder anders schließlich denkt die spiritualistische Mystik. Sie verinnerlicht und relativiert die Heilswahrheit zu einem individuellen persönlichen Besitz, der unaussprechlich hinter den buchstäblichen Formen liegt. Die bloß relative Bedeutung der biblischen, dogmatischen, kultischen Form macht sie von jeder geschichtlichen Form unabhängig, und die innere Einheit des Geistes eint ganz von selbst alle Seelen in der gemeinsamen rein geistigen, doch nicht formulierbaren Wahrheit. Auf diesem Standpunkt und auf diesem allein ist Toleranz und Gewissensfreiheit auch innerhalb der religiösen Gemeinschaft möglich, indem die Organisation lediglich zu einem Mittel der Kirchenpflege wird, das religiöse Leben selbst aber unter den verschiedenen relativ berechtigten Ausdrucksformen sich frei bewegen kann. Freilich entstehen dann auch hier Schwierigkeiten, mit welcher Entscheidungsinstanz und nach welchem Maßstabe hier die Christlichkeit überhaupt noch festgestellt werden kann. Die gewöhnliche Antwort, daß der Geist den Geist erkennt, ist praktisch wertlos. Darum ergibt sich von diesem Standpunkt aus leicht der Verzicht auf alle und jede organisierte Gemeinschaft oder der Rückzug auf private Gesinnungsgemeinschaften rein persönlicher Art. Die Mystik droht mit der Konformität alle Gemeinschaft überhaupt aufzuopfern und verfällt leicht einem relativistischen Individualismus. In diesem Zirkel bewegt sich das Problem der christlichen Toleranz und Gewissensfreiheit im Verhältnis zu den Bedingungen der religiösen Gemeinschaftsbildung. Aus ihm gibt es kein Entrinnen. Es gibt nur wechselnde praktische Auskünfte von annähernder Brauchbarkeit aus diesem tragischen Widerspiel der Kräfte heraus.

4. Es erleuchtet sich die Geschichte des christlichen Ethos, 
deren Darstellung bekanntlich außerordentliche Schwierigkeiten hat. Das Ethos des Evangeliums ist von einer unendlichen Erhabenheit und kindlichen Innigkeit : einerseits die Selbstheiligung für Gott durch Fernhaltung alles dessen, was die innere Gemeinschaft mit Gott stört und durch Betätigung alles dessen, was mit seinem Willen innerlich verbindet, und andrerseits die Bruderliebe, die in Gott alle Spannungen und Härten des Kampfes ums Dasein, des Rechtes, der bloß äußerlichen Ordnung auföst und die Seelen zu innigstem Verstehn wie zu opferwilligster Liebe verbindet, die auch schon in ihren einfachsten Aeußerungen eine Ahnung des wahren göttlichen Wesens ist. Es ist ein Ideal, das zu seiner vollen Durchführung eine neue Welt verlangt, die dementsprechend auch Jesus in dem Gottesreich verkündet hat. Aber es ist ein Ideal, das in der dauernden irdischen Welt ohne Kompromiß nicht durchführbar ist. Daher wird die Geschichte des christlichen Ethos zu einem immer neuen Suchen nach diesem Kompromiß und. zu immer neuen Bekämpfungen der Kompromißgesinnung. Als Volks- und Massenanstalt ist nun aber vor allem die Kirche zum Kompromiß genötigt, und durch ihre Verlegung der Heiligkeit in die Anstalt und die ihr eignende Vergebungsgnade ist sie befähigt, ihn zu finden. Sie hat ihn gefunden durch das Bündnis mit der stoischen Idee von dem relativen Naturrecht des Sündenfalls, die für die Dauer des irdischen Lebens Recht, Macht, Gewalt, Krieg, Privateigentum, Besitzstreben als Folgen wie als Heilungsmittel der Sünde anerkennt. Mit diesem Kompromiß trat dann freilich in der Kirche die durchschnittliche Weltmoral und die strenge Heiligkeitsmoral auseinander. Die letztere floß mit der spätantiken dualistischen Askese zusammen und organisierte sich in den Klöstern, um aus diesen immer wieder in die Welt hineinzudringen. So ergab sich eine Moral der Doppelstufigkeit, die die klassische katholische Theorie in ein sinnreiches Entwickelungssystem des Aufstiegs von der Natur zur Gnade gebracht hat. Der kirchliche Protestantismus hat diese Doppelstufigkeit aufgelöst und beides in seiner Berufsmoral ineinander gezogen, das Luthertum mit läßlicher Ergebung in die gegebenen und mit der Sünde gesetzten Weltverhältnisse, der Calvinismus und der asketische Protestantismus mit dem Versuch, rationell innerhalb des Weltlebens die heilige Gemeinde herzustellen. Neben diesen kirchlichen Kompromissen aber stand von Anfang an die Sekte, die das reine Ideal der Bergpredigt ohne Kompromiß durchführen 
wollte und damit in einen scharfen Weltgegensatz gedrängrt wurde. Sic hat ihn als leidende und duldende Sekte mit dem möglichen Mindestmaß von Zugeständnissen in engen und stillen Kreisen durchgeführt und sich des kommenden Gottesreiches getröstet, bis auch sie durch den Anschluß an den asketischen Protestantismus einen Weg zur Eingliederung in die dauernde Welt gefunden hat. Als aggressive und welterneuernde Sekte hat sie, wenn ihr das klar bevorstehende Weltende das Recht zum Gebrauch der Gewalt zu geben schien, die christliche Lebensordnung mit Gewalt durchzusetzen gesucht, selbstverständlich nie mit dauerndem Erfolg und immer unter I'reisgabe ihrer eigentlichen Christlichkeit; anstelle des Livangeliums traten dann für sie die Apokalypse und das Alte Testament. Unbekümmert aber schließlich um beides, um Kompromiß und Kompromißlosigkeit, lebt die spiritualistische Mystik in der Irreiheit des Geistes und des Gewissens, antinomistisch im guten und gelegentlich auch im bösen Sinn; auch wo sie streng asketisch ist, ist sie es im Sinne der Freiheit. Sie tut und unterläßt, wie die Quäker sagen, alles, was dem Gefühl einer innigen Gemeinschaft mit dem lebendigen und heiligen Gott entspricht oder entgegensteht, und ergießt sich in eine rein innere persönliche Seelengemeinschaft. Damit verlicrt sie freilich die Möglichkeit zur Massenwirkung und zu jeder Gesamtorganisation des lebens. Aber nach der strebt sie uberhaupt von Hause aus nicht oder sie erwartet sie erst von der inneren Macht des Geistes. Sie läßt es darauf ankommen, was von ihrem Geiste in die Allgemeinheit fließen und dort auf eine innerliche Weise sie umgestalten mag. In allen diesen ethischen Bildungen aber steckt als die treibende Kraft der christliche Weltgegensatz. Iiese Grundrichtung des Christentums ist heute von der modernen Lebensbewegung mit ihrem Utilitarismus, ihrem Optimismus, ihrer Immanenz, ihrem Naturalismus und ihrer ästhetischen Naturverherrlichung empfindlich gebrochen, oft bis zum völligen Unverständnis ihrer selbst gebracht worden. Aber sie bricht aus den religiösen Grundgedanken und aus der Selbstauflösung jedes rein innerweltlichen Optimismus immer neu hervor. Sie stellt heute der christlichen Ethik wiederum von neuem inmitten aller Kulturseligkeit und alles bloß skeptischen Pessimismus ihre Aufgabe. Das Problem der Ceberweltlichkeit und ihrer unvermeidlichen Folge, der Askese im metaphysisch-dualistischen oder im disziplinär-rigorosen Sinne, ist daher noch heute das Grundproblem des christlichen Ethos, 
das doch zugleich keine einfache Welt- und Selbstverneinung ist. Andererseits ist sein zweites Grundproblem die Ergänzung dieser religiösen Einseitigkeit durch eine mit ihr vereinbare Kulturethik. Die Kirche hat diese Ergänzung aus der spätantiken Philosophie als sittliches Naturgesetz aufgenommen. Die Sekte, sofern sie auf die Ergänzung verzichtet hat, verfiel in Kulturlosigkeit und Bedeutungslosigkeit, die Mystik in völlig einsame Resignation. Wo beide zu Bedeutung sich erhoben, haben sie jede auf ihre Weise gleichfalls Ergänzungen herangeholt. Die alten Ergänzungen aber sind heute bei einer völlig neuen Kulturlage unmöglich geworden. Eine neue Ergänzung ist also nötig. Das christliche Ethos kann für sich allein nicht lcben und genügen in einer dauernden Welt. Die Frage ist nur, wie diese Ergänzung heute gestaltet werden kann. Hier liegen die Aufgaben einer neuen christlichen Ethik.

5. Die letzte wichtige historische Einsicht ist diejenige in Recht und Grenzen der Anwendung einer sozialgeschichtlichen Methode auf das Christentum. Die "Marxistische * Methode formt mit demjenigen an ihr, was sich als klar berechtigt erweist, nach und nach all unsere geschichtlichen Auffassungen und damit natürlich auch die Auffassungen von Gegenwart und Zukunft um. Die Gelehrten des Klassenkampfes haben es unternommen, das ganze Christentum als ideologisches Spiegelbild ökonomischer Entwickelungen darzustellen und damit nicht bloß bei den Parteigenossen Eindruck gemacht. In feinerer und lehrreicher Weise hat erst jüngst Maurenbrecher diese Auffassung an der Geschichte der Entstehung des Christentums durchgeführt. Gegenüber jeder ausschließlichen und doktrinären Durchführung dieser Methode hat nun aber die bisherige Darstellung gezeigt, daß alles spezifisch Religiöse und vor allem die großen Knotenpunkte religiöser Entwickelungen eine selbständige Aeußerung des religiösen Lebens sind. Jesus, Paulus, Origenes, Augustin, der hl. Thomas, der hl. Franz, der hl. Bonaventura, Luther, Calvin, sie können in ihrem Fühlen und Denken nicht aus Klassenkämpfen und ökonomischen Interessen hergeleitet werden. Aber auf der andern Seite ist doch klar, daß in dem Kausalzusammenhang, aus dem heraus ihr eigentümlich religiöses Denken Anstoß, Form, Bewegung und Ziel konkret gewinnt, immer in größerer oder geringerer Stärke, in mittelbarer oder unmittelbarer Weise soziale und durch diese vermittelt schließlich auch ökonomische Kräfte wirken. Wie auf allen Ge- 
bieten, so ist auch auf dem religionsgeschichtlichen die Auffassung des Kausalzusammenhangs durch die neue Rücksicht auf dieses mitwirkende Element erheblich erweitert und verändert. Wie man bereits bisher politische, wissenschaftsgeschichtliche, philosophische, rassentheoretisch-biologische Kausalitäten in den Zusammenhang einstellte, aus dem und in dem die konkreten religionsgeschichtlichen Bildungen sich erheben, so muß man auch diese neu enthüllte Kausalität in ihrer vollen Bedeutung aufnehmen. Das bedeutet prinzipiell nichts Neues, wenn man überhaupt einmal sich daran gewöhnt hat, die religiösen Offenbarungen aus dem Zusammenhang der Kausalitäten erwachsen zu sehen, wobei von ihrer angeblichen Notwendigkeit und von sangeblichen Gesetzen der Geschichte hier nicht weiter die Rede sein soll. $Z$ wischen den Kausalitäten besteht kein Rangunterschied größerer oder geringerer Vornehmheit, und so ist es keinerlei Entwürdigung, wie viele meinen, wenn man dieser neu erkannten Kausalität dasselbe Recht einräumt, wie den bisher beachteten. Aber praktisch bedeutet es doch eine recht erhebliche Verschiebung des Bildes. Es zeigt sich dann, wie das Christentum und die verwandten idealistischen Bestrebungen ethisch-religiöser Art in der Spätantike mit dem Ergebnis der antiken Sozialgeschichte allerdings zusammenhängen und daher auch sich treffen und verbinden als die neue Welt; wie das Mittelalter sein Wesen durch Aufpfropfung der Kirche und des christlichen Ethos auf eine relativ einfache und unentwickelte soziale Welt erhält und dadurch erst eine christliche Kultur möglich wird; wie der Individualismus der Reformation die Auflösung der mittelalterlichen Gesellschaft voraussetzt und die siegreiche Durchsetzung der Reformation nur aus den politischen und sozialen Verhältnissen erklärbar wird; wie der Unterschied der beiden protestantischen Konfessionen durch den politischen und sozialen Boden aufs stärkste mitbedingt ist; wie der moderne Protestantismus mit der modernen bürgerlichen Gesellschaft und ihren Bildunysidealen verknüpft ist, und wie schließlich der Kapitalismus, der moderne nationalistische und imperialistische Staat und die ungeheure Bevölkerungssteigerung eine Krisis der bisherigen christlichen Ethik bedeuten. Es zeigen.sich die Klassenzusammenhänge der Sekten, die verborgenen Gründe von plötzlichen Wendungen des religiösen Gedankens, die aus seiner bloßen gedanklichen Dialektik nicht begreiflich wären. Freilich wird damit die Religionsgeschichte noch tiefer in den Strom 
des Geschehens und in die Wechselbedingtheit der Grundelemente des I, ebens hineingezogen. Es wird noch weniger möglich, auch nur in der christlichen Ethik einen unwandelbaren und absoluten Punkt zu finden, da auch diese stets nur die Bemeisterung ciner gegebenen, vor allem durch soziale Verhältnisse bedingten Lage und die Aufstellung eines dieser Lage entsprechenden Ideals ist. Allein auf dem Weg zu einer solchen Auffassung ist die Religionsgeschichte und die Geschichte des Christentums längst, seit sie das religiöse Leben in die allgemeine Entwickelung einstellen gelernt hat. Die relative Bedingtheit jedes Momentes als einer unwiederholbaren Synthese und als einer ihm entsprechenden geistig-ethischen Bemeisterung, die im Instinktiven oft viel klarer sieht als in der vieles übersehenden und vieles bemäntelnden Theorie, wird dadurch nur noch eindringlicher vor Augen gestellt. Das macht die Unart, ganze Zeiten und Gruppen nur als Vorbereitungsstufen für ein in der Historie doch nie auffindbares Absolutes zu betrachten, endgültig unmöglich. Dafür aber tritt Rankes tiefsinniges Wort, auf das schon öfter hingewiesen wurde, in sein Recht, daß jede Epoche - nicht mit ihrer groben Wirklichkeit, aber mit ihren von ihr selbst instinktiv gebildeten Idealen und Ziclen - unmittelbar ist zu Gott. Sie ist es auch in der Bemeisterung der aus der Naturgrundlage, der wirtschaftlich-sozialen Lage, den politischen Machtverhältnissen folgenden Aufgaben durch die Idee, wobei die Idee von dem von ihr bemeisterten Stoffe nie unabhängig sein kann und oft genug von ihm in Bewegung gesetzt ist. Dagegen aber sind alle Versuche, das Chrístentum zu einem wechselnden Spiegelbild der Wirtschafts- und Sozialgeschichte zu machen, eine Modetorheit oder ein unter der Firma der neuesten Wissenschaftlichkeit versteckter Angriff auf seine religiöse Geltung.

6. Alle diese Erkenntnisse sind historischer Art. Aber es erhebt sich natürlich die Frage, ob eine so ausgedehnte Untersuchung über die Ideen- und Lebenswelt des Christentums wirklich nichts zu bringen vermag als historische Einsichten in Gewesenes und in dessen Nachwirkung auf die Gegenwart. Lehrt sie nicht auch etwas Bleibendes und Ewiges als Gehalt des christlichen Sozialethos kennen, das ein Leitstern wäre für die Gegenwart und für die Zukunft, etwas, was nicht bloß dem Begreifen, sondern auch dem Gestalten der Lage dient? Sie ist nun gewiß imstande, auch etwas derartiges zu lehren. Aber Erkenntnisse ewiger ethischer Werte sind keine wissenschaftlichen Erkenntnisse und sind Troeltsch, Gesammelte Schriften. I. 
nicht wissenschaftlich beweisbar. Sie sind Herausgreifungen aus dem geschichtlichen Leben, die die lebendige Ucberzeugung und der handelnde Wille vollzieht in der Gewißheit, hier die absolute Vernunft in ihrer uns zugewandten und im gegenwärtigen Zusammenhang geformten Offenbarung zu erkennen. Nur in diesem Sinne sei es nun noch versucht, die bleibenden ethischen Werte herauszuheben, die in der bunten Geschichte der christlichen Soziallehren enthalten sind. Erstlich: Das christliche Ethos allein auf Grund seines personalistischen Theismus hat einen metaphysisch begründeten, durch keinen Naturalismus und keinen Pessimismus zerstörbaren Persönlichkeits- und Individualitätsgedanken. Die Persönlichkeit, die aus dem Naturwesen durch Willens- und Wesenseinigung mit Gott erst entsteht, ist allein über die Endlichkeit erhaben und kann allein ihr trotzen. Ohne diesen Halt aber verflüchtigt sich in Wahrheit jeder Individualismus. $\mathrm{Z}$ we i te $\mathrm{ns}$ : Der christliche Ethos allein hat auf Grund seines Gedankens von einer allen zugewandten und alle in sich vereinigenden göttlichen Liebe einen wirklich unerschütterlichen Sozialismus. Erst in dem Medium des Göttlichen versinken die Trennungen und Sprödigkeiten, die Kämpfe und Ausschließlichkeiten, die dem Menschen als Naturwesen zugehören und in denen sein natürliches Dasein sich formt. Erst in ihm gewinnen die Vereinigungen, die $Z$ wang und Gewalt, Sympathie und Hilfsbedürfnis, Geschlechtstrieb und Neigung, Arbeit und Organisation stiften, einen ihnen allen übergeordneten und unzerstörbaren, weil metaphysischen Zusammenhang. D ritte ns: Nur das christliche Ethos überwindet das Gleichheits- und Ungleichheitsproblem, indem es weder im Sinne der Auslese die Gewalt und den Zufall verherrlicht, noch im Sinne der egalitären Doktrin die Wirklichkeit vergewaltigt. Es nimmt die Verschiedenheit der Lebenslagen, der Kräfte und der Fähigkeiten als einen von Gottes unerforschlichen Willen gestifteten Zusammenhang hin, den die innere Hebung der Persönlichkeit und die gegenseitigen Verbundenheitsgefühle in einen ethischen Kosmos verwandeln. Die ethischen Werte der willigen Ein- und Unterordnung nach der einen Seite, der Fürsorge und der Verantwortung nach der andern Seite stellen jeden in Verhältnisse, wo er die natürlichen Lnterschiede in ethische Werte der gegenseitigen Ancrkennung, des Vertrauens und der Fürsorge umwandeln kann und soll. Viertens: Das christliche Ethos leistet kraft der christlichen Persönlichkeitsschätzung und Liebe etwas, was keine 
noch so gerechte und rationelle'Gesellschaftsordnung völlig entbehren kann, weil in ihr immer unberechenbare Leiden, Nöte und Krankheiten übrig bleiben, die Karität. Sie ist aus dem christlichen Geiste entsprungen und kann nur durch ihn sich behaupten. Alle Kleinlichkeit und Bekehrungslust, die sich mit ihr verbinden mag, ist doch nur eine menschliche Beschränktheit an einer groBen und edlen Sache. Schließlich: Das christliche Ethos stellt allem sozialen Leben und Streben ein Ziel vor Augen, das über allen Relativiuäten des irdischen Lebens hinausliegt und im Verhältnis zu dem alles nur Annäherungswerte darstellt. Der Gedanke des Gottesreiches der Zukunft, der nichts anderes ist als der Gedanke der endgültigen Verwirklichung des Absoluten, wie immer man sie denken mag, entwertet nicht, wie kurzsichtige Gegner meinen, Welt und Weltleben, sondern strafft die Kräfte und macht durch alle Durchgangsstufen hindurch die Seele stark in ihrer Gewißheit eines letzten, zukünftigen absoluten Sinnes und Zieles menschlicher Arbeit. Er erhebt über die Welt, ohne die Welt zu verneinen. Dieser tiefste Gedanke und Sinn aller christlichen Askese ist das einzige Mittel, Kraft und Heldentum zu behalten in einer geistigen Gesamtlage, die dàs Gefühlsleben so unendlich vertieft und verfeinert und die natürlichen Motive des Heroismus rettungslos zerbricht oder lediglich aus den Instinkten der Brutalität wieder zu erwecken versucht. Er ist eine Quelle der angespannten Aktivität und der Zielsicherheit zugleich und damit der schlichten Gesundheit. Alle Gesellschaftsutopien werden dann überflüssig; die immer wieder von- der Erfahrung gepredigte Unmöglichkeit, das Ideal voll zu begreifen und zu verwirklichen, braucht dann den Suchenden nicht zu beirren und nicht in die Skepsis zurückzuwerfen, die so leicht die Folge geráde ernsten Wahrheitssinnes ist und die feineren Geister der Gegenwart überall erfüllt. Das Jenseits ist die Kraft des Diesseits.

7. Diese sozialethischen Gedanken und Kräfte quellen aus der christlichen Religiosität. Damit sie es können, ist die Lebendighaltung und Fortpflanzung dieser religiösen Kräfte notwendig und für beides wieder eine sie fortleitende und beständig neu erzeugende Organisation. Es ist daher die Frage: was lehrt unsere Darstellung über dieses gerade in der Gegenwart so brennende Problem, über die Bildung der religiösen Gemeinschaft selbst und deren Einfügung in die anderen großen Gemeinschaften? Lernen wir aus einem dicken Bande, der von den Ge- 
meinschaftstheorien des Christentums handelt, nicht etwas zur Ueberwindung unseres täglich schlimmer werdenden Kirchenelends? Auch hier ist der Ertrag ein reicher, freilich auch hier mehr eine Sache freier Zweckmäßigkeitseinsicht als wissenschaftlicher Beweisführung. Die e rste Lehre ist, daß das religiöse Leben auf der Stufe der Geistesreligion einer selbständigen, von den naturgegebenen Gliederungen unterschiedenen Organisation bedarf. Darnach strebt es im ersten Augenblick seiner seibställdigen Selbsterfassung, und das bleibt immer eines seiner wichtigsten Probleme. Das Zentrum solcher Organisationen ist der Kultus; die Herleitung der zusammenfassenden Kräfte von ihm oder die Angliederung an ihn ist das große Problem. Ohne Gemeindeorganisation und ohne Kultus ist das Christentum nicht fortpflanzungs- und zeugungsfähig. Jeder Rückzug auf den bloßen freischwebenden Geist und seine organisationslose Selbstdurchsetzung ist eine L topie, die die wirklichen Bedingungen des Lebens verkennt und nur die Verflüchtigung und Enthräftung des Ganzen zur Folge hat. Bezüglich der Formen dieser Organisation zeigte sich $z$ weit c n s die Ueberlegenheit des Kirchentypus über den Sektentypus und die Mystik. Er hält an dem vollen Heils- und Gnadencharakter der Religion fest, ermöglicht die Unabhängigkeit des Gnadenbesitzes von den Leistungen der Individuen, kann die verschiedensten Stufen der Reife und Verchristlichung umfassen und ist darum allein fähig, eine Volksreligion mit den unumgänglichen verschiedenen Abstufungen der Mitglieder zu umhegen. Darin i $\downarrow$ er der Sekte überlegen und vollends der Mystik. Darum rerliuft die eigentliche Hauptmasse der christlichen Religionsgeschichte als Kirchengeschichte und ist die »allgemeine christliche Kirche* das nächste Ergebnis der urchristlichen Missionsarbeit. Er ist aber allerdings zugleich eine Herabminderung der christlichen ldee auf das Niveau praktischer Möglichkeiten und Durchschnittlichliciten, ein Prinzip der weitestgehenden Anpassungen und Kompromisse. Der Kirchentypus selber aber hat dritte ns gerade wegen der in ihm enthaltenen Spannungen zwischen reiner Christlichkeit und Weltanpassung eine sehr wechselreiche Geschichte gehabt und ist heute in voller Wandelung begriffen. Die reine und konsequente Ausprägung des Kirchentypus ist der römische Katholizismus, der in steigendem Maße die Innerlichkeit, Persönlichkeit und Beweglichkeit der Religion der festen Objektivierung in Dogma, Sakrament, Hierarchie, 
Papsttum und Infallibilität geopfert und den sektenhaften wie den mystischen Motiven nur im Ordenswesen und den l)evotionen ein Ventil geöffnet hat. Seit seiner Krisis im 15. Jahrhundert, wo die naive Selbstverständlichkeit seiner Herrschaft aufzuhören anfing, hat er darum sich immer mehr objektiviert und zentralisiert. Im Gegensatze dazu suchte der Protestantismus den Gedanken der kirchlichen Heilsanstalt wieder mehr zu subjektivieren und zu verinnerlichen, indem er das objektive organisierende Element in die heilige Schrift und die ihr innewohnende Geisteskraft, sowie in das sie auslegende Predigtamt verlegte, Luther mit einem bald enttäuschten. Vertrauen zu der Alle bekehrenden Macht des Geistes und Wortes, Calvin mit der Nachhilfe einer festen und zur Kontrolle der Gläubigen fähigen Kirchenverfassung. Alle Kirchentümer haben zu ihrer Aufrechterhaltung und Durchsetzung mit der rein moralischen Macht nicht ausgereicht, sondern den weltlichen Arm in Anspruch nehmen müssen. Ohne seine Hilfe gibt es kein, dauerndes, konformes und unzertrennbares Kirchentum. Es ist ohne Zwang nicht denkbar, und der Zwang ist wicderum nicht denkbar ohne Hilfe des Staates. In Zeiten einer allgemeinen naiven Gläubigkeit wirkt ein solcher $Z$ wang auch nicht schädlich oder unreligiös. Weiß man die Wahrheit schlechthin sicher und sind die allgemeinen Instinkte der Völker in ihr einig, so ist die Bewahrung vor Torheit, Irrtum und Verführung nur verständig und gesund, die Voraussetzung für die Aufrechterhaltung der geistigen Einheit der Gesellschaft überhaupt, die man nicht dem doktrinären und überidealistischen Ideal einer freien Selbstgesetzgebung des Einzelnen opfern darf. Aber eben wegen dieses $\mathrm{Zu}$ sammenhanges des Kirchentypus mit der ungebrochenen Einheit der Weltanschauungs-Instinkte großer Völkergruppen ist vierten s der ungebrochene Kirchentypus nur solchen Zeiten innerlich angemessen. Unsere Darstellung zeigt, wie er seit der Auflösung dieser Voraussetzungen im Einschrumpfen oder in der Zersetzung begriffen ist. Die Tage des reinen Kirchentypus in unserer Kultur sind gezählt. Die Selbstverständlichkeiten der modernen Lebensanschauung fallen mit denen der Kirche nicht mehr zusammen. Der $Z$ wang ist nicht mehr eine Bewahrung des Ganzen vor Einzelstörungen, sondern eine Vergewaltigung der wirklichen Lebensströmungen. Der weltliche Arm hat sich zurückgezogen, ganz oder teilweise, und wird bald nur mehr überall den kleinen Finger geben oder gar nichts. Die verschiedenen Kirchentümer stehen in konfessionell gemischten 
Bevölkerungen als eine sich selbst aufhebende Vielzahl absoluter Alleinwahrheiten gegenüber. Die Seelen der Völker entgleiten den Kirchen, und ein guter Teil ihrer Funktionen ist an Schule, Literatur, Staat und Vereinswesen übergegangen. Unter diesen Umständen ist der Kirchentypus des Katholizismus zu einer immer gewaltsameren und äußerlicheren Gewissensherrschaft gezwungen. Das protestantische Kirchentum aber ist zu einer ähnlichen Entwickelung teils zu schwach fundiert, teils enthält es in seiner Subjektivierung des Kirchentums starke, ihr entgegenwirkende Kräfte. So hat es dem mit der modernen Welt wahlverwandten Sektentum und der Mystik nicht widerstehen können. Es hat sich mit Sektenmotiven und mystisch-spiritualistischem Relativismus durchsetzt. Es ist kein reines Kirchentum mehr, wenn auch der kirchliche Konformitätsgeist leidenschaftlich genug gegen diese unaufhaltsame Entwickelung sich empört und verschämt oder unverschämt nach katholischen Idealen hinüberschielt. Seine stark hervortretenden Entwickelungsrichtungen sind die Ablösung vom Staate, die Freigebung der Kirchenbildung, die Independenz der Einzelgemeinde, die Verwandelung der Staatskirchen in Volkskirchen, die zusammenhalten in der gemeinsamen Verwaltung, aber den Einzelgemeinden freie Hand lassen, eben damit aber einen ihren $\mathrm{Zu}$ sammenhalt beständig bedrohenden Konfliktsstoff in sich tragen. Auch unter der Hülle einer scheinbar noch fortbestehenden einheitlichen Bekenntniskirche hat die Bekenntnislosigkeit der ungeheueren Mehrzahl der Kirchenglieder diesen Zustand erzwungen. Es ist eine immer zunehmende Durchdringung der Lebensgehalte des Kirchentypus mit denen der Sekte und der Mystik, die uns die Geschichte des Protestantismus gezeigt hat. Während der Katholizismus beide immer unwirksamer macht, werden im Protestantismus beide immer mächtiger. In der gegenseitigen Durchdringung der drei soziologischen Grundformen und ihrer Vereinigung zu einem all diese Motive versöhnenden Gebilde liegen seine Zukunftsaufgaben, Aufgaben soziologisch-organisatorischer Natur, die dringender sind als alle Aufgaben der Dogmatik. Die Anstrengungen, durch diese eine vermittelnde Einheit zu schaffen, sind gescheitert. Es gibt keine »protestantisch-kirchliche Dogmatik * mehr. So wird auch Einigung und Zusammenhalt auf einem anderen Boden als dem der Dogmatik gesucht werden müssen. Es wird nur möglich sein unter der Voraussetzung, daß die von $\mathrm{Zwang}$, Gewalt, Staatsreligion und Konformität geschaffenen Kirchen zu Gehäusen werden, in 
in diesen llirrsalen nur die Unmöglichkeit, daß die Welt den Frieden rebe, der über alle Vernunft ist. Die Kirchen aller Konfessionen - am wenigsten freilich die lutherischen - entfalten Programme zur I inclcrung dieser schweren, allen Greist und alles Gemüt bedrohenden Nöte und arbeiten an ihrem Teile rührig und aufopfernd. Aber sic gehen dabei im wesentlichen nur auf die alten grofìn Hau,ttypen ihrer Sozialphilosophie zurück, die sie für die grandiocen Kïmpfic der Gegenwart von neuem mobil zu machen versuchen. Wir haben nun gesehen, daß es nur zwei solcher großer Haupttypen gibt, die eine umfassende historische Bedeutung und Kraft erlangt haben. J)er eine ist die ständisch-zünftig-patriarchalische Sozialphilosophie des mittelalterlichen Katholizismus, der die relative Gebundenheit des Kampfes' ums Dasein, die Begründung aller Gemeinschaft auf persönliche Autoritäts- und Pictätsbeziehungen, die relativ einfachen Wirtschaftsformen und Bedürfnisse der vorkapitalistischen Periode, die Reste alter Solidaritäten in Bluts- und Bodengcbundenheit mit dem christlichen Ethos des individuell-persönlichen Wertes und der universalen I.iebesgemeinschaft in der kirchlichen Lebensorganisation $z \mathrm{u}$ verbinden wußte. Der andere ist die Sozialphilosophie des asketischen Protestantismus, der aus dem freikirchlich und pietistisch gefärbten Calvinismus und den der Verkirchlichung angenäherten asketischen Sekten emporwuchs, der mit dem modernen Utilitarismus und Rationalismus, der Betriebsamkeit des Berufes und der Verherrlichung der Arbeit um ihrer selbst willen, mit der politischen Demokratie und dem Liberalismus, mit der freien Bewegung des Individuums und dem alles beherrschenden Vereinsgedanken innerlich verwandt ist, der aber die ethisch gefährlichen Folgen dieses modernen Lebens durch die religiösen Ideen der Verantwortung des Individuums und der Liebespflicht des Einzelnen wie der Gemeinschaft, durch die Verpönung von Luxus, Mammonismus und Genußstimmung, schließlich durch einen überall der Sache Christi dienenden Heroismus zu neutralisieren weiß. Was neben diesen beiden Haupttypen an christlichen Sozialidealen sich gebildet hatte, vermochte schon seinerzeit nicht den harten Stoff der sozialen Wirklichkeit aufzulösen; es prallt heute vollends an diesem Felsen ab. Aber auch jene beiden mächtigen Typen haben sich - trotz großer bis heute dauernder Leistungen erschöpft. Was der zünftig-patriarchalische Katholizismus will, das ist teils überhaupt nicht wieder möglich, teils kann es mit 
den geschwächten religiösen Kräften des Katholizismus nicht durchgeführt werden, die überdies die unerträglichsten Nebenwirkungen mit sich führen. Was der asketische Protestantismus als rationêlles Mittel für die Aufrichtung der Christusherrschaft dem religiösen Gedanken unterordnete, das ist diesem längst über den Kopf gewachsen und hat die religiösen, ja überhaupt die gedanklichen und metaphysischen Eingrenzungen und Richtpunkte von sich geworfen; andererseits fordert seine kühle Härte, nüchterne Sachlichkeit und betriebsame Bekehrungslust, sein unkünstlerischer und puritanischer Charakter alle Instinkte der modernen Kultur zur Gegnerschaft heraus; und auch vom rein religiösen Standpunkte aus ist seine Neigung zur Gesetzlichkeit und zum Pharisäismus, zur Treiberei und Schablonisierung nichts weniger als in voller Uebereinstimmung mit den tiefsten christlichen Ideen. Unter diesen Umständen ist das Ergebnis unserer Untersuchung die Einsicht in die problematische Lage aller christlich-sozialen Arbeit. Sie ist problematisch überhaupt, weil die Fähigkeit der Idee zur Bemeisterung der brutalen Wirklichkeit immer eine dunkle und schwierige Sache bleibt, problematisch insbesondere weil die geschichtlichen Hauptformen der christlichen Gesellschaftslehre und -gestaltung gegenüber den bestehenden Aufgaben aus vorschiedenen Gründen heute versagen. Soll es eine christlich-soziale Bemeisterung der Lage geben, so werden hier neue Gedanken nötig sein, die noch nicht gedacht sind und die dieser Lage entsprechen, wie die älteren Formen älteren Lagen entsprochen haben. Sie werden aus der inneren Triebkraft der christlichen Idee und ihrer lebendig-gegenwärtigen Neugestaltung herausgeholt werden müssen und nicht lediglich aus dem Neuen Testament, wie ja auch jene beiden großen Hauptformen nicht aus dem Neuen Testament, sondern aus der jeweiligen Gegenwartsbewegung der religiösen Idee herausgeholt worden sind. Und sie werden das Schicksal haben, das alles Schaffen der religiös-ethischen Idee hat: sie werden unentbehrliche Dienste leisten und innerlichste Kräfte entfalten, aber sie werden ihren eigentlichen idealen Willen nie voll verwirklichen in dem Bereiche der irdischen Lebenskämpfe. Das Reich Gottes auf Erden als einen vollendeten sozialethischen Organismus werden sie so wenig schaffen, als irgend eine andere Macht der Erde. Es ist eine der ernstesten und wichtigsten Einsichten unserer Untersuchung, daß aller Idee die brutale Tatsächlichkeit und aller Emporentwickelung die inneren und äußeren Hemmnisse entgegen- 
stehen. Es gibt keine absolute christliche Ethik, die jetzt erst zu entdecken wäre, sondern nur Bemeisterungen der wechselnden Weltlagen, wie das auch die frühere auf ihre Weise gewesen ist. Es gibt auch keine absolute Ethisierung, sondern nur das Ringen mit der materiellen und der menschlichen Natur. So wird auch die jetzige und kommende christliche Ethik eine Anpassung an die Lage sein und nur das Mögliche wollen. Darin ist die unaufhörlich vorwärts treibende Spannung und ebenso die'Unvollendbarkeit der ethischen Arbeit begründet. Das können nur ideologische Doktrinäre oder im Glauben alles Irdische überfliegende Schwärmer verkennen. Der Glaube ist die Kraft des Lebenskampfes, aber das Leben bleibt ein auf immer neuen Fronten sich immer neu erzeugender Kampf. Für jede bedrohliche Kluft, die sich schließt, geht eine neue auf.

Es bleibt dabei - und das ist das alles zusammenfassende Ergebnis - das Reich Gottes ist inwendig in uns. Aber wir sollen unser Licht in vertrauender und rastloser Arbeit leuchten lassen vor den Leuten, daß sie unsere Werke sehen und unseren himmlischen Vatér preisen. Die letzten Ziele aber alles Menschentums sind verborgen in seinen Händen. 


\section{Sachregister *}

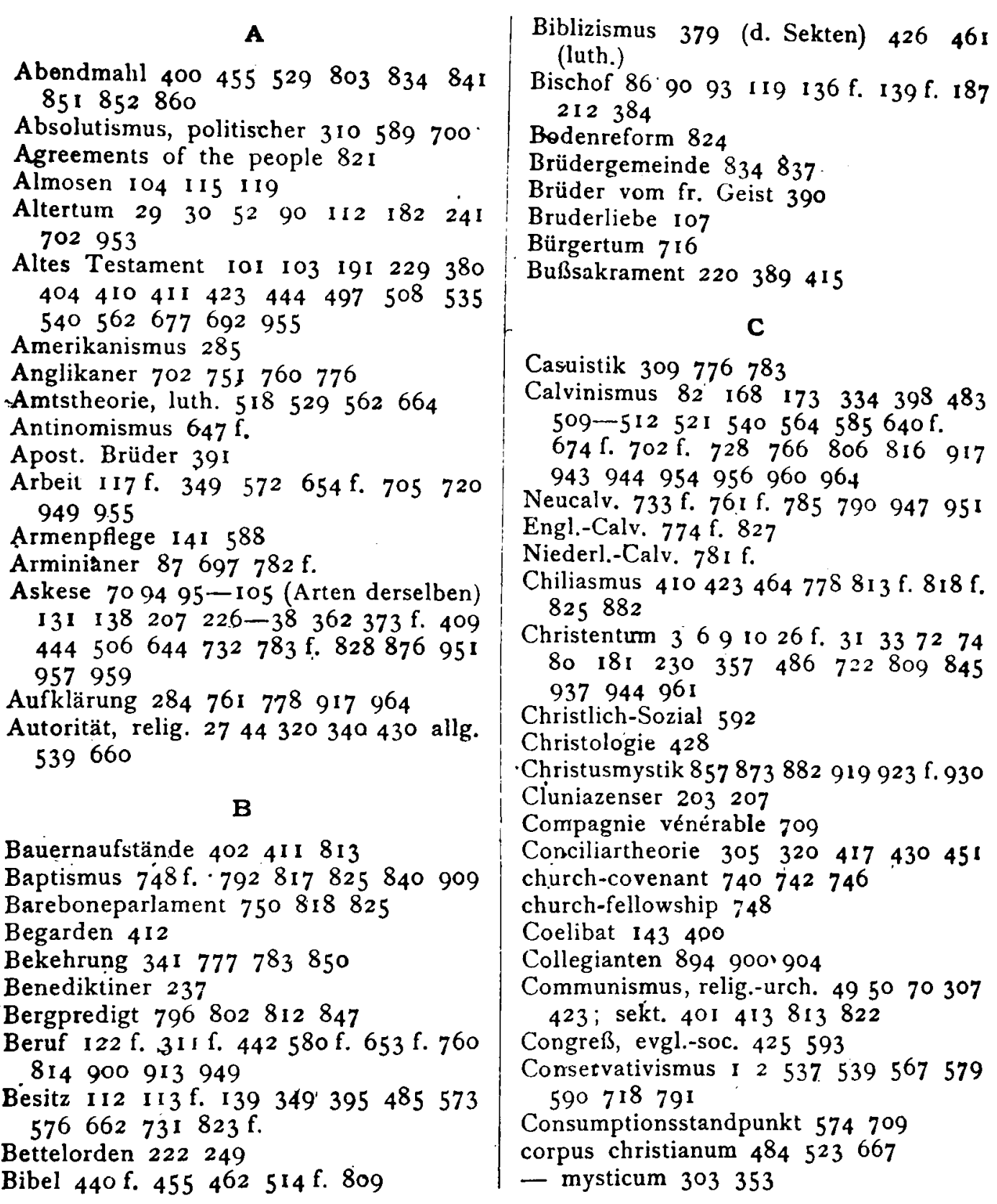

*) Die Register verdankt der Leser der Freundlichkeit des Herrn stud. theol. et philos. Herbert Link. 


\section{D}

Darbisten 843

Deismus $87 \mathrm{I} 897912$

Dekalog $145 \quad 158 \quad 261264269271289$ $380+41494 \quad 498$ f. $506 \quad 529543643$ 65 . $\mathrm{f}$.

Demokratie 702734948

Deutsche Theologie $420 \quad 850889896$ 907

Dissenter $420 \quad 7.557 S_{7} 810948$

Dogma 172 200 $462 \quad \$ 73$

Dominikaner 856

$\begin{array}{lllll}\text { Donatisten I } 89 & 359 & 367 & 385\end{array}$

Dordrechter Synode 783

\section{E}

Ehe $48 \quad 53 \quad 126 \quad 3.35557$

Eherecht 90 I $3055^{8}$

Enthusiasmus, urch. 852 ; sekt. 862918

Entwicklungsgedanke $270 \quad 276$ 291 381 $44^{t}, 9.30$

Erastianismus $736 \quad 783$

$\begin{array}{llllllll}\text { Erbsünde } & 97 & 217 & 483 & 558 & 646 & 648 & 732\end{array}$ $\begin{array}{llll}829 & 838 & 873 & 949\end{array}$

Erlüsungslehre und -hoffnung I 695267 $445 \quad 446 \quad 648$

Erweckung $237 \quad 776 \quad 838917$

Eschatolorie $97 \quad 105 \quad$ I $10 \quad 121 \quad 216 \quad 359$ $\begin{array}{lllllll}368 & 373 & 391 & 392 & 424 & 466 & 808\end{array}$

Episkopat $\mathrm{S}_{4}-87$ IST $189 \mathrm{f} .203218$

Evangelikalismus 778787

Evangelium 14 f. $36-424752$ f. 8996 $\begin{array}{lllllllll}107 & 174 & 176 & 227 & 232 & 295 & 311 & 369\end{array}$ $375+226478$ II 847944946

\section{$\mathbf{F}$}

Familisten 823899901908

Feudalismus $93 \quad 121 \quad 377$

Flagellanten 391

Franziskaner 214 2I6 $227 \quad 238 \quad 386 \quad 390$ $394 \quad 415 \quad 856$

Frauenbewegung 768951

Freikirchentum $733 \quad 738$ f. $757 \quad 761 \quad 785$ 792 f. 8 I 3963

Frciwilligkeitskirche $\begin{array}{lllll}375 & 383 & 803 & 808\end{array}$ 812912

\section{G}

Gegenreformation 5 I 2679

Geldwirtschaft $204243 \mathrm{f}$.

Geistlehre 377873879887889892

Gemeindeprinzip, luth. 464 f. 467587 913 ; calv. 682739742

Gemeinschaftsbewegung 843

Gemeinschaft, relig. $86 \quad 8792 \quad 187216$ 354427679948

General Baptists 742746812909

Genossenschaft 2.4824
Gesetz I56f. $824 \quad 382 \quad$ (Sekte); 436 kath.; 437 prot.

Geschichtsphilosophie, kirchl. I30 163

Geschäftsleben 709830

Glaubensbegriff 438 prot.

Glaubenskrieg 725

Gleichheit-Ungleichheit $495360-65$ 127 I75 $308 \quad 314$ f. 41067173 I 812 954

$\begin{array}{llllllll}\text { Gnade } & 271 & 427 & 436 & 449 & 485 & 508 & 644\end{array}$ 8 I I

Gnosis I9 $20 \quad 98 \mathrm{f}$. IOI 153856897

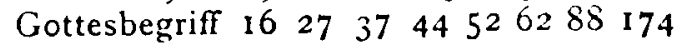
$\begin{array}{lllllllll}185 & 264 & 283 & 381 & 382 & 440 & 446 \text { f. } & 649\end{array}$ $\begin{array}{lll}672 & 847 & \$ 65\end{array}$

Cotteinigung $\} 857$ f. 859878919

Gottesgesetz 378 4I0f. 416

Gottesgnadentum I68f. 31031675 I

\section{$\mathbf{H}$}

Handel I27f. 346577 705 f. 9 I 3956

Hattemisten 904

Hausgemeinde 903905

Heiligung 490793

Heilsarmee $\mathrm{S}_{42}$

Herrenhuter 833 f. 884922 f.

Hugenotten $656 \quad 724 \quad 731 \quad 774$

Humanismus $283 \quad 420 \quad 43$ I $697 \quad 870$

Humanität 76893 I

Hussitismus 39039340 If. 409 f. 813 878

Jansenismus 827923

Idee, christl. 7 I 7487 I 0413725 I 282 $\begin{array}{lllllll}310 & 352 & 356 & 408 & 4 \text { II } & 420 \text { f. } 429\end{array}$ $\begin{array}{llllllll}43 & 452 & 683 & 792 & 8 \text { II } & 826 & 918\end{array}$

$\begin{array}{llllllllll}\text { Jesus } & \text { I } 5 & \text { I } 6 & 27 & 28 & 34 & 40 & 41 & 44 & 49\end{array}$ 93 f. $104 \quad 296 \quad 373 \quad 376 \quad 855 ;$ als Messias 58 ; als Christus 585960 636883 f. $376 \quad 440455$ 5I 4 f. 852 856 f. 868 f. 896

Immanenzidee 531 (des Luthertums) 919 930946 (modern)

$\begin{array}{lllllll}\text { Individualismus } & 68 & 72 & 83 & 86 & 90 & 107\end{array}$ $\begin{array}{lllllllll}150 & \text { I } 7 \text { I } & 232 & 244 & 306 & 322 & 354 & 357 & f\end{array}$ $\begin{array}{lllllllll}376 & 392 & 421 & 424 & 440 & 671 & 717 & 757\end{array}$ $\begin{array}{llllllll}777 & 792 & 812 & 864 & 865 & 93 & 961 & 965\end{array}$ Independentismus 405410512739745 $749759775798817-819862908 \mathrm{f}$. Interventionspolitik 724

Institutio Calvini 684

Joachimiten 390405410

Joristen 893899

Irvingianer 842902

Judentum 715

Jugendunterricht 776

Jurisdiktionsgewalt 2 I $9515 \mathrm{f}$. 
$\mathbf{K}$

Kaiserzeit, rümische 2 I f. 273 I $20 \mathrm{f}$. 126

Kaisertum 167 f. I89 f. I93 I95 342

Kalixtiner 402

Kapitalismus 354421708 f. 7 II f. 718 $780955 \mathrm{f}$.

Kastenordnung, wittenbergische 537

Karolinger I95 I98 $207 \quad 240$

Karität $575 \quad 589830$

$\begin{array}{llll}\text { Katharer } & 238 & 385 & 389\end{array}$

Katholizismus $173 \quad 187 \quad 208 \quad 227334438$ $\begin{array}{llllllll}452 & 462 & 507 \text { f. } 5 \text { I } 9550 & 555 & 585 & 642\end{array}$ $647 \quad 7 \times 8721792-794806 \quad 809-813$ 860943949959

- mod. 179344431 Sog

Katechismus, luth. 552 calv. 663

Ketzerrecht 223388

Kirche $92 \mathrm{f}$. I05 I09 I I 6 II $9136 \quad 175$ $\begin{array}{llllllllll}178 & 182 & 188 & 213 & \text { f. } & 230 & 241 & 254 & 272\end{array}$

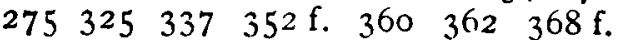
398413423 Wicl. ; 448472484 Prot.; 5I3 luth.; 588590677683 Calv. ; 700 Sekten; $734 \quad 738 \quad 747 \quad 795806$

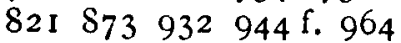

- unsichtbare 865895

Kirchengut 204 f. 222

Kirchenreform 383 Greg.; 398 Wicl. : 795 prot. ; 828 Spener

Kirchenrecht $87 \quad 89$ g0 f. I35 $172 \quad 196$ 341388516 f. 683829

Kirchenväter 50 IOI II 7 I I 8 I2 I 147 $\begin{array}{llllllll}I 56 & \text { I } 59 & \text { I } 62 & 165 & 167 & \text { I 68 } & \text { I75 } & 20 \text { I }\end{array}$ 359406410

Kirchenzucht I $34 \quad$ I $88 \quad 829$

Klassenkampf $962 \quad 964$

Klerus 88 f. $92 \quad$ IO4 I3I I39 I9I 205 $\begin{array}{lllll}231 & 337 & 384 & 388\end{array}$

$\begin{array}{lllllll}\text { Kloster I4I } & 177 & \text { I } 88 & 203 & \text { f. } 9 \text { I } 8\end{array}$

Konfessionalismus 873893

Konfirmation 829

Konformität, Elisabeths $742 \mathrm{f} .772$

Kongregationalismus $740 \quad 742$ f. 745 f. 775816 f. 862885

Konkupiszenz 732941

Konsistorium 517588

Konventikel $828 \quad 834882885932$

$\begin{array}{lllll}\text { Kreuzzüge } 205 \quad 230 & 249 & 387\end{array}$

Kriegsproblem 725728807814910914

Kult $83 \quad 220 \quad 388867932937$

Kultfreiheit 760

Kultur, christl. $126 \quad$ I 72 f. $177 \quad$ I 79 I8I 222272275357408422426667959

- mod. 229357432717

Kyniker 118

\section{L}

Labadisten $825827842902 \mathrm{f}$. Laienpredigt 720
Laientum 384 f. 413417418 f. 461829 840907

Landeskirchentum $195 \quad 197 \quad 206 \quad 240 \quad 384$ 459466516 f. $798 \quad 828$

Lehnswesen 196206

Leveller $82 \mathrm{I}$

Liberalismus $3 \quad 310 \quad 335 \quad 354 \quad 537 \quad 754$ $\begin{array}{lllll}763 & 768 & 769 & 791 & 848\end{array}$

Liebesidee II 5 I I 6539720866

Liebestätigkeit I34 f. $247 \quad 304 \quad 720$ s. Karität

Loliharden 400815

Lutheraner 503530680702

$\begin{array}{lllllll}\text { Luthertum } & \text { 105 } & 173 & 334 & 455 & 506 & 509\end{array}$ 5II 5 I 2 f. 5 I 5 f. 549 f. $555 \quad 589590$ $\begin{array}{lllllllll}642 & 648 & 652 & 667 & 706 & 718 & 721 & 728\end{array}$ $\begin{array}{llllllll}751 & 774 & 777 & 790 & 792 & 794 & 806 & 827\end{array}$ $\begin{array}{llllllll}831 & 860 & 924 & 931 & 943 & 944 & 949 & 953\end{array}$ 959964

- mod. 555

\section{M.}

Mährische Brüder 407 f. 834 f. 924

Manchestertum 7 I 7

Menschenrechte 355760768

Mennoniten $742 \quad 787808913$

Merkantilismus 584589

Merowinger 204

$\begin{array}{llllll}\text { Methodisten } & 748 & 779 & 792 & 827 & 836 f \text {. }\end{array}$ $\begin{array}{llll}862 & 884 & 918\end{array}$

Millenarier 825

Mission $205 \quad 368 \quad 389 \quad 590 \quad 783 \quad 830 \quad 945$

Mittelalter $122 \quad 126 \quad 140 \quad 174 \quad 179 \quad 182 \mathrm{f}$. $\begin{array}{lllllllll}193 & 194 & 230 & 233 & 241 & 332 & 381 & 420\end{array}$ $\begin{array}{llll}429 & 448 \quad 470 & 944\end{array}$

Modernismus 270285328

Monarchomachen 69I 720

Mönchsregel I97 203

Mönchtum $94 \quad 107$ I 16 £. I22 I $26 \quad$ I 3 I $\begin{array}{llllllll}143 & 156 & 176 & 179 & 188 & 228 & 23 & \text { I f. } 349\end{array}$ $\begin{array}{llllllll}359 & 360 & 410 & 427 & 442 & 507 & 810 & 812\end{array}$

Monogamie $129 \mathrm{f}$.

Montanismus IO5 I55 359

Moral, kath. $276 \quad 526807$

— prot. 476501 f. $509 \quad 529647654$ 797807

— antike 332

Mysterien I9 $5988 \quad 85$ I

Mystik $96 \quad$ I $44 \quad 281 \quad 383 \quad 390 \quad 392 \quad 420 \mathrm{f}$. $\begin{array}{lllllll}778 & 783 & 794 & 797 & 842 & 848 & 849\end{array}$ (Arten derselben) $864 \quad 866 \quad 868 \quad 87$ I f. 886 899903 f. 9 I9 920 f. 939940 f.

N

Natur - Uebernatur 264 f. 271442

Naturalwirtschaft 20424 I $242 \mathrm{f}$.

Naturgesetz, sittliches $5^{2} \quad 144 \quad 146 \quad$ I 58 164228253261264 f. $289290410 \mathrm{f}$. $\begin{array}{llllllll}416 & 417 & 442 & 444 & 494 & 499 & 508 & 530\end{array}$ 657804811821 
Naturrechtslehre $5154 \quad 164 \quad 167 \quad 170173$ $\begin{array}{llllllll}253 & 272 & 329 & 332 & 359 & 378 & 404 & 459\end{array}$ $\begin{array}{llllllll}532 & 544 & 578 & 585 & 688 & 691 & 700 & 763\end{array}$

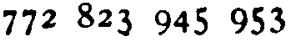

Nazarener 960

Nestorianer 188

Neues Jerusalem 901903

$\begin{array}{llllll}\text { Neuplatonismus } & 56 & 229 & 271 & 274 & 277\end{array}$ $\begin{array}{lllllllll}359 & 382 & 856 & 857^{\circ} & 869 & 898 & 908 & 921\end{array}$ 928

$\begin{array}{llllll}\text { Neues Testament } & 16 & 29 & 377 & 387 & 441\end{array}$ 811853860

Nominalismus 283430

Obrigkeit 588

- Occamismus 283430

Orden $227 \quad 237 \quad 387 \quad 551809$

Orthodoxie $\begin{array}{llll}555 & 798 & 807 & 935\end{array}$

Ortlibarier 390

Ostrom 194

Ottonen 195

\section{$\mathbf{P}$}

Papalidee 195207210211310320342

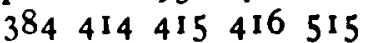

Particular Baptists 817

Patarie 384

Patriarchalismus, christl. 67 f. 93109 296299314344551

Pauperismus 4867

Perfektionismus 828838

Persönlichkeitsideal $354 \quad 421450668 \mathrm{f}$. 856

Philosophie, mod. 765

Pietismus 512589733734773775776 $777 \quad 783785788$ f. 79279881082.7 f. 83 I 860898899903904907918 f. 939

Pilgerväter $747 \quad 748 \quad 780$

Platonismus $26 \quad 31 \quad 5698144145181 \mathrm{f}$. 216236254

Polis 30 II $239243 \quad 251 \quad 312$

Prädestination $62 \mathrm{f}$. I $21289398 \mathrm{f} .404$ $\begin{array}{lllllllll}438 & 643 & 650 & 669 & 739 & 793 & 870 & 881\end{array}$ 956

Präzisismus $773 \quad 827 \quad 84$ I

Preistheorie $127346 \quad 574706956$.

Presbyterianer $695739748 \quad 749775$

Proletariat 22 f. 822

Prophesyings 776 95 I

Protestantismus $180 \quad 352 \quad 420 \quad 426 \quad 429$ $\begin{array}{lllllllll}434 & 438 & 462 & 507 & 508 & 512 & 531 & 648\end{array}$ $\begin{array}{lllllllll}679 & 793 & 794 & 810 & 812 & 813 & 86 \text { I } & 939\end{array}$ 964

- mod. 180794

- asket. $793 \quad 949$ f. 954959962964

Puritanismus 405557652733736740

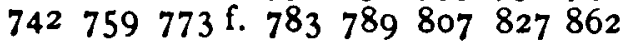
932
Q

Quäker $760824 \quad 825826835862870$

898904907912 f. 955

Quäkerstaat Pennsylvanien 915

Quietismus 649

\section{$\mathbf{R}$}

Räte, evgl. 145380

Radikalismus, christl. 359376406409 511815817826

Ranters 902907

Rationalismus 76 701 $87087 \mathrm{I}$

Rechtslehre, kath. 206 f. 2 II $32834^{I}$

Rechtfertigung 648

Reformation I94 $358 \quad 425 \quad 429 \quad 431 \quad 433$ 512808809

Reich Gottes $35 \quad 36 \quad 42 \quad 47 \quad 48$ 1 10 422 945

Reichskirche 197

Rekkeljiken 782

Relativismus 873889924931

Religionsgeschichtliche Schule 936

Religionsphilosophie 871 927

Remonstranten 890

Renaissance 19423751277793 I

Restauration 555 (pr.-deutsch) 830 orth.

Revolution, engl. 702780781815817 828899

- christl. $379 \quad 4$ IO 4 4I 844845946 $96 \mathbf{r}$

Revolutionsrecht $340 \quad 535 \quad 561 \quad 665 \quad 687$

Rijnsburger 894

Romantik 929936

\section{$\mathbf{S}$}

Sakramentsidee 84 f. 892 I 7 f. 388400 439449455

Salier 195198

Salutisten 792

Seekers 907

$\begin{array}{lllllll}\text { Sekte } & 184 & 358 & 360 & 382 & 423 & 424\end{array}$ $\begin{array}{lllllllll}426 & 427 & 433 & 507 & 511 & 677 & 703 & 787\end{array}$ 792794 f. 8 Iof. 812827839843 853869876939942944946 f. 956 960961964

Separatisten 747

Severer 153

Sexualethik $100 \quad 104 \quad 131 \quad 132353 \quad 556$ 73294 I 95 I

Sittengesetz, christl. 263 f. 528

Sklaverei $1922 \mathrm{f}$. 2453 I20 I 30 I $32 \mathrm{f}$. $\begin{array}{lllllllll}142 & 162 & 313 & 355 & 581 & 768 & 840 & 915\end{array}$

Skotismus 283

$\begin{array}{lllllll}\text { Sozialdemokratie } & 2 & 754 & 757 & 769 & 82 \text { I }\end{array}$ 844

Sozialismus $381 \quad 405 \quad 406$ f. 64267772 I $\begin{array}{llllllll}822 & 824 & 844 & 848 & 915 & 943 & 945 & 961\end{array}$ 
Sozialphilosophie, kath. 282 284 f. 325 330335350510511 ; prot. 475510 524 ; luth. 556 ; ask. Pr. 958 f.

Sozialpolitik I 26655

Sozialproblem I i I 355

Sozialreform $126 \quad 326 \quad 334 \quad 585 \quad 945$

Sozinianer 871

Spiritismus 926

Spiritualismus $390 \quad 391 \quad 744 \quad 746 \quad 747$ $\begin{array}{lllllllll}756 & 760 & 761 & 794 & 821 & 848 & 858 \cdot f . & 863\end{array}$ 864898905917 f. 927930934940 f. 960

Sünde $427 \mathrm{f}$.

Supranaturalismus $92 \quad 104 \quad 450$

Synodalverfassung 730

\section{Sch}

Schisma 397

Schmalkalder Bund $53 \mathrm{~S}$

Scholastik 279530

Schule 177776951

Schwärmer 814825879

\section{St}

Staatsidee 10 I 24570 ; Paulus 73 I $48 \mathrm{f}$; germ.-rom. r95; Kirchenväter 20I; Greg. 213 f.; Thomas 253336339353 414 ; luth. 48552 I 540543556560 ; calv. 66I 683; Hobbes 702 : Sekten 729744754760906953

$\begin{array}{lllll}\text { Staatskirchentum } & 193 & 195 & 196 f . & 736\end{array}$ $\begin{array}{llllll}760 & 782 & 784 & 785 & 954\end{array}$

Stadt 12 I 250 f. 3 I2 $344 \quad 377 \quad 384 \quad 386$ $433 \quad 578 \quad 588$

Ständegliederupg I $20 \quad 332 \quad 442 \quad 522 \quad 582$

Stellvertretung Christi $232 \quad 322 \quad 447$

Stoicismus 2 I $26 \quad 3$ I $32 \quad 4452$ f. IO5 I 44 I $46 \mathrm{f} .158 \quad 162 \quad 165 \quad 167 \quad$ I8I f. 216 229251254359410502765846856

T

Taboriten 403813878

Taufe 34 I 40045549 I 742744842863

- Spättaufe 803806816

- Kindertaufe 455465742803

Täufertum $402 \quad 4$ IO $\quad 450 \quad 47$ I 5 II 664 $\begin{array}{llllllll}682 & 702 & 736 & 738 & 742 & 744 & 746 & 750\end{array}$ 760797 f. $814 \quad 815 \quad 817818843860$ 863870895913

Tempel, württembg. 843

Tertiarier 232

Theokratie I70 I72 214216229240 $42356675 \mathrm{I}$

Theologie, moderne 935

Theismus 874887

Theosophie 926

Thomismus 182 f. $252290293 \quad 315347$ $\begin{array}{llllllll}369 & 427 & 429 & 430 & 508 & 512 & 525 & 551\end{array}$ $\begin{array}{lllllll}\text { Toleranz } & 750 & 758 \text { f. } & 76 \mathrm{I} & 787 & 866 & 872\end{array}$ 889890905914915940

Traditionalismus, dogmatischer 848586 88298

Trennung von St. u. K. 754 f.

Trinitat(dogma) 462856868

Unabhängigkeitskrieg, amerik. 915

Union 776

Unitarier 748

Universalepiskopat des Papstes 209210 214

Universalismus, religiöser $\begin{array}{llll}68 & 72 & 83 & 86\end{array}$ $90107 \quad 195 \quad 221871$

Urgemeinde 429853

Urkirche, Ideal der 391393

Urstandslehre $\begin{array}{llllll}53 & 162 & 445 & 499 & 535 & 67 \text { I }\end{array}$ 700

Utilitarismus 769

Utraquisten s. Calixtiner

V

Vaticanum 209

Vereinskirche 812817

Verschooristen 904

Vertragstheorie 696

$\begin{array}{llll}\text { Viktoriner } 222 & 237 & 857\end{array}$

Virginität I00 IOI I3 I 208557

Volkskirche $736 \quad 783 \quad 792 \quad 800 \quad 8$ II

Volkssouveränität 684 f. 694

Vollkommenheitsideal $232 \quad 233 \quad 282 \quad 322$ 381 Sekt.; 442 Prot.; 484 Luth.; 491 644 Cal.; 838 Meth.

\section{W}

Wahrheitsbegriff 4.72 Luth.; 739 Calv.; 872 myst.-spirit.

Waiters 907

Waldenser $226 \quad 386 \quad 389$ f. $394 \quad 405 \quad 808$ 843

Waterländer 815

$\begin{array}{lllll}\text { Werke, gute } & 138 & 276 & 777 & 783\end{array}$

Wiklifie 38 I 393 f. 4 I 7

Wirtschaftstheorie 4673 Alte Kirche; 24I f. 346 Mittelalt. 957; 571957 Luth.; 704957 Calv.; 955 ask. Prot. Wohlfahrtspflege $588 \mathrm{f}$.

Wort, das bibl. $449463 \mathrm{f}$.

Wucher I28 $346 \quad 572574$

\section{$z$}

Zentrum 12

Zinswesen $708 \mathrm{f} .720 \mathrm{f}$.

Zuchtgericht 776

Zunft 25 I $333 \quad 343 \quad 580677$ 


\section{Namenregister.}

Abaelard 222

Agrippa v. Nettesheim 897

Althusius 696

Ambrosius 105

Amerika $355 \quad 721 \quad 731739748 \quad 755 \quad 760$ $\begin{array}{llllllll}768 & 774 & 789 & 817 & 884 & 914 & 926 & 948\end{array}$ 952

Amesius 783

Amsterdam $747 \quad 816898$

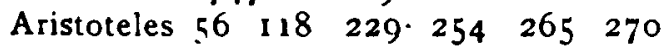
274 f. 309315317344359410499 $502525530542 \mathrm{f}$.

Arnold von Brescia $226 \quad 386$

Arnold, Gottried $36880492 \mathrm{I}$

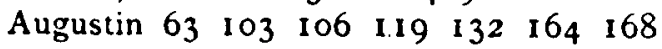
$\begin{array}{lllllllll}170 & 191 & 215 & 229 & 236 & 254 & 268 & 289\end{array}$ 359367410562857

Baco 908

Barclay 910916

Barge 434681880

Barrow 743747

Basel 890900

Baxter 776

Bayle 766

Bentham 717

Bern 682

Bernhard von Clairvaux $222 \quad 226 \quad 237$ 784850857919923

Bernstein 914

Beza 607688709724726

$\begin{array}{llllll}\text { Biegelmaier } 90 & 112 \mathrm{f} \text {. II } 5 & \text { I20 } & 125 & 127\end{array}$ 152

Bismarck 2537769

Boehme, Jakob 898908927

Boehmer I $90200216223 \quad 234 \quad 438458$

Bonaventura 386

Bonifacius 197

Bonus 933

$\begin{array}{lllllll}\text { Brentano } & 46 & 51 & \text { II } 3 & 127 & \text { I } 28 & 132\end{array}$

Browne 742 f. 747759816

Buddensieg 395

Buddeus 526

Bünderlin 896

Bunyan 776818902

Burkhardt, J. 4767791

Butzer $682752773 \quad 774$
Eckart 934

Ecke 884

Edelmann 87 I 921

Eger 497504

Ehrhard 180

Eicken, von I 81200223 f. 226287363

Emerson 931

Emden 782

Endemann 127

England $393 \quad 4$ II 512694701709721 $\begin{array}{llllllll}730 & 732 & 735 & 739 & 759 & 766 & 768 & 774\end{array}$ $815816 \quad 817837884888902907 \mathrm{f}$. 962963

Epiktet 54

Erasmus 69787 I 886892

Estienne 690

Eucken 933

Everard, John 907

Feuguerąy $256 \quad 267273$ f. 316

Fichte 927931

Filmer 700

Fludd 898

Fox, George 908

Frank, Seb. $368 \quad 458 \quad 823 \quad 862870872$ 886 f. $889 \quad 896 \quad 897$ f. $900 \quad 905 \quad 927$ 934

Francke, Aug. Herm. 920

Franklin 915

Frankreich $384 \quad 386 \quad 4$ II $\quad 414 \quad 512 \quad 709$ $\begin{array}{lllll}732 & 767 & 774 & 963\end{array}$

Franz von Assisi 390400

Fries 924

Galenus Abrahams 894904

Gaß $390 \quad 102 \quad 106 \quad 125$

Genf 655 68I f. 706 f. 720731735757 774807963

Gentillet 690

Geulinx 904

$\begin{array}{lllllll}\text { Gierke 90 1. I } 47 & \text { I I I } & \text { I } 73 & 216 & 288 & 297\end{array}$ 697

Gladstone 769

Goebel 73780283386 I 867

Gothein 284 339765

von der Goltz $459 \mathbf{4 6 2}$

Gottschick $365398 \quad 400 \quad 402$ f. 438456 
Gregor der Gr. $133 \quad 165 \quad 191 \quad 198 \quad 208$ f. 213 f. $219222 \quad 236254368$

Grotius 545697

Grützmacher, R. 874883

Haegermann 764

Haetzer 897

Hall 907

Hamann 927

$\begin{array}{lllllllll}\text { Harnack } & 42 & 51 & 75 & 81 & 96 & \text { III } & \text { I } 80 & 209\end{array}$ $\begin{array}{lllll}237 & 268 & 860 & 936 & 963\end{array}$

Harrison 750818825

Hartmann, Ed. von 933

Hauck I92 $202 \quad 216 \quad 23$ I

Hegel $92793 \mathrm{I} 934 \mathrm{f}$.

Heinrich von Toulouse 386

Helmont, van 898

Helwys 8 I 6

Herder 927

Hermas 157

Hermelink 431475

Heumann 44I 502506935

Hobbes 702

Hoensbroech 216218

Hofmann, von 524 f. 533554

Holland $384 \quad 386 \quad 388902$

Hotmann 690

Huegel, F. von 860

Huß 401 f. 408

Hut 813

Hylkema 900910

Jacobi, F. H. 927

James, W. 98296

Janaway 907

Jellinek $760 \quad 764$

Innocenz III 209

Jodl $3 \quad 30 \quad 56$

Irenaeus 165

Isidorus Hisp. 165

Italien $\mathbf{3 8 4} 386 \quad 391 \quad \mathbf{4 2 0}$

Jung-Stilling 919

Jurieu 69I 729

Justinian $131 \quad 168$

Kant $284 \quad 555669927$

Karl d. Gr. I97 20I $204222 \quad 236 \quad 240$

Karlstadt $858 \quad 862 \quad 879896$

Katharina von Genua 920

Kautsky 17433

Kierkegaard 932

Knox, John 693731

Kuyper 73I 738 f. 763769

Labadie 84.2

Lagarde 940

Lampe 729

Lamprecht 199 f. 963

Laski 774

Lavater 919927

Troeltsch, Gesammelte Schriften. I.
Leibniz 698927

Lessing 927939

Leyden $\begin{array}{llll}742 & 747 & 749\end{array}$

Lilburn 821 824

Locke $699717 \quad 754 \quad 760824$

Loening 143 I 88

Lodensteyn 783841903

Lombardei 384386

Loofs $225.470 \quad 827836842$

Luthardt 3255486 f. 645

Luther 420430 f. 434 f. 448450 f. 452 f. $\begin{array}{lllllllll}481 & 512 & 524 & 532 & 541 & 552 & 555 & 578\end{array}$

$\begin{array}{llllllll}586 & 643 & 654 & 660 & 663 & \text { f. } 669 & 750 & 795\end{array}$

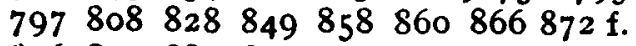

$\begin{array}{llllll}876 & 879 & 881 & 899 & 919 & 934\end{array}$

Macchiavelli 536578

Maeterlinck 933

Major, John 694

Masius 546

Marsilius von Padua 414

Marx 844

Maurenbrecher $291338 \quad 345$

Mausbach I8I

Melanchthon 47 I 52453054 If. 66I

Methodius I3 I

Meyer, Th. I73 294317

Middelburg 747902

Milton 760766

Monk 819 825

Morus, Th. 28342 I

Müller, Joh. 848932942

Müller, K. I $98 \quad 260 \quad 406 \quad 798$

Münzer, Th. 878880

Nathusius $5 \quad 6 \quad$ I2 13

Naumann $13 \quad 47 \quad 592$

Neu-England $746 \quad 747 \quad 748 \quad 757 \quad 780$

Niederlande 512709721724730 f. 735 $740774 \quad 784$ f. 813 f. 84 I 891902 919963

Niclaes, Heinr. 893901

Nicolaus von Kues 283

Novalis 470924929931937

Occam $416 \quad 430 \quad 451$

Oldenbarneveld 697

Origenes I 58

Overbeck $4 \quad 146$

Owen, R. 8248449 I 6

Paracelsus 897926

Paulus $28 \quad 29 \quad 51 \quad 5963 \quad 66 \quad 67 \quad 68 \quad 9498$ $\begin{array}{llllllll}13 & 147 & \text { I } 55 & 296 & 358 & 368 & 429 & 447\end{array}$ $\begin{array}{llllllll}45^{2} & 455 & 851 & 852 & 856 & 863 & 923\end{array}$

Pelagius 100

Penn $914 \mathrm{f}$.

Peter von Bruys 386

Peter von Chelzic 407

Peutinger 578 
Philipp v. Hessen 752

Pirkheimer 578

Plato $54 \quad 56 \quad 131 \quad 233 \quad 317$

Plenge 847

Plinius $25 \quad 123$

Plockboy 824

Poimandres 907

Pufendorf 545702

Rachfahl 650704

Rade 560

Ragaz 365

Ranke I\$6

Ratzinger 143294327

$\therefore$ Ritschl $4374 \quad 454645647669778785$

$\begin{array}{llllllll}800 & 836 & 860 & 867 & \$ 69 & 874 & 920 & 935\end{array}$

Rodbertus 8

Rothe, Rich. 935941

Rousseau 29698

Saltmarsh 909

v. Seckendorf $569 \quad 584$

Segalleli, Gerh. 39r

Sencca $54 \quad 163 \quad 165$

Servet 889 init

St. Simon is 844937

Simons, Nienno 814

Sohm 85 192 509513520

Spener $\$ 2 \$ 920$

Spinoza tolis 871904927

Spruyt 894

Swedenborg 926

Schelling 927931

Schlejermacher $867 \quad 924 \quad 929 \quad 931 \quad 932$ 934935 137941

Schopenhaner 933

Schottland $51269474077+775$

Schortinghays 903

Schweiz 771774789

Schwenkfeld 750858862873881 f. 886 895900
Stahl, Jul. $76 \quad 245 \quad 536 \quad 545 \quad 590 \quad 769$

Stella, Eudo von 386

Stuarts $695731 \quad 776$

Taffin 783

Tanchelm 386

Tauler 889896907920

Teellinck 783903

Tersteegen 876919

Thamer 897

Thomas von Aquino 183215219253 $\begin{array}{lllllllll}277 & 312 & 316 & 318 & 337 & 340 & 343 & 344\end{array}$ $\begin{array}{lllll}358 & 369 & 406 \quad 416\end{array}$

Thomasius 546941

Tryers $75^{\mathrm{I}}$

Udemann 783

$\begin{array}{lllllll}\text { Uhlhorn } 81 & 105 & 113 & 128 & 132 & 134 & 174\end{array}$

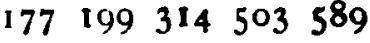

Victoriner 850

Vinet $741 \mathrm{f}$.

Vives, L. 578588897

Voetius $783 \quad 784951$

Weber, M. 251346355656715 f. 718 877950962

Weigel, V. 862885

Weinel $28 \quad 157$

Weingarten 822827832860

Weilling 844

Weber 858

Wesley 858

Whitgift 747

Wichern 590

Wiclif 404 f. 406408414

Williams, Roger 760766

Winstanley 823

Wirtz 900

Ziegler, Th. 3 ro 225

Vinzendorf 834 f. $884922 \mathrm{f}$

Zürich 68I 812814

/wingli 681752812880 

denen jetzt friedlich die verschiedenen christlichen Geister wohnen und wirken können. Die kirchlichen Organisationen behaupten sich durch ihr eigenes geschichtliches Schwergewicht, und können, einmal geschaffen, anderen Zwecken dienen als denen, fuir die sie ursprünglich gebaut worden sind. Die Schmerzen und Qualen, die das Staatskirchentum seinerzeit gekostet hat, mögen als das Opfer betrachtet werden, das die Erbauung gekostet hat, das aber nicht ewig wiederholt zu werden braucht. Was $Z_{\text {wang, }}$ Härte und starknervige Uniformität erbaut hat, kann von feineren und vor allem von sehr verschiedenen Geistern bewohnt werden, die dann freilich gegenseitig für Verträglichkeit sorgen müssen. Während das bloße Freikirchen-System oder System der Trennung von Kirche und Staat nur eine Gewissensfreiheit neben und außer den Kirchen gewährt, in ihnen selbst aber erst recht die Intoleranz aufrichtet, kann ein solches System die Volkskirche behaupten und die heiß ersehnte Gewissensfreiheit in der Kirche gewähren, soweit sie überhaupt möglich ist. Vom Geiste des Kirchentypus aber behauptet sich dann der große Gedanke einer gemeinsamen historischen Lebenssubstanz, die in allen individuellen Gemeindebildungen und Verkündigungen nur besondert und verflüssigt wird. Wir behalten Gemeingefühl und Vererbungsbewußtsein, ein $*$ Minimum von Kirche $\varangle$, wie Richard Rothe sagte.

8. Wo aber bleibt die Frage, von der wir ứsprünglich ausgegangen sind, die Frage nach der Bedeutung des Christentums für die Lösung des heutigen sozialen Problems, das das Problem der kapitalistischen Wirtschaftsperiode und des von ihm geschaffenen industriellen Proletariats, der militärisch-bureaukratischen Riesenstaaten, der in Welt- und Kolonialpolitik auslaufenden ungeheuren Bevölkerungssteigerung, der unermeßliche Lebensstoffe erzeugenden, im Weltverkehr alles mobilisierenden und verknüpfenden, aber auch Menschen und Arbeit mechanisierenden Technik ist? Man braucht die Frage nur so zu formulieren, um nach allem Bisherigen als wichtigste Antwort zu erkennen, daß das überhaupt ein neues, für die christliche Sozialarbeit bisher überhaupt nicht vorhandenes Problem ist. Die radikalen sozialreformerischen Ideale der chiliastischen Sekte sind dem ungeheuren Ernst dieses Problems gegenüber Kinderspiel und Kindertraum; ehrenwert und edel, aber utopisch auch in ihrer modernen Gestalt eines radikalen welterneuernden christlichen Sozialismus. Die Mystik verzichtet von vornherein auf jede Lösung und sieht 